\title{
The Hurricane Hill Site (41HP106) The Archaeology of a Late Archaic/Early Ceramic and Early-Middle Caddoan Settlement in Northeast Texas, Vol. I
}

Timothy K. Perttula

Heritage Research Center, Stephen F. Austin State University

Follow this and additional works at: https://scholarworks.sfasu.edu/ita

Part of the American Material Culture Commons, Archaeological Anthropology Commons, Environmental Studies Commons, Other American Studies Commons, Other Arts and Humanities Commons, Other History of Art, Architecture, and Archaeology Commons, and the United States History Commons

Tell us how this article helped you.

This Article is brought to you for free and open access by the Center for Regional Heritage Research at SFA ScholarWorks. It has been accepted for inclusion in Index of Texas Archaeology: Open Access Gray Literature from the Lone Star State by an authorized editor of SFA ScholarWorks. For more information, please contact cdsscholarworks@sfasu.edu. 


\section{The Hurricane Hill Site (41HP106) The Archaeology of a Late Archaic/Early Ceramic and Early-Middle Caddoan Settlement in Northeast Texas, Vol. I}

\section{Creative Commons License}

\section{c) (1)@ $\Theta$}

This work is licensed under a Creative Commons Attribution-NonCommercial-No Derivative Works 4.0 International License. 


\section{THE HURRICANE HILL SITE (41HP106): THE ARCHAEOLOGY OF A LATE ARCHAIC/EARLY CERAMIC AND EARLY- MIDDLE CADDOAN SETTLEMENT IN NORTHEAST TEXAS, VOL. I}

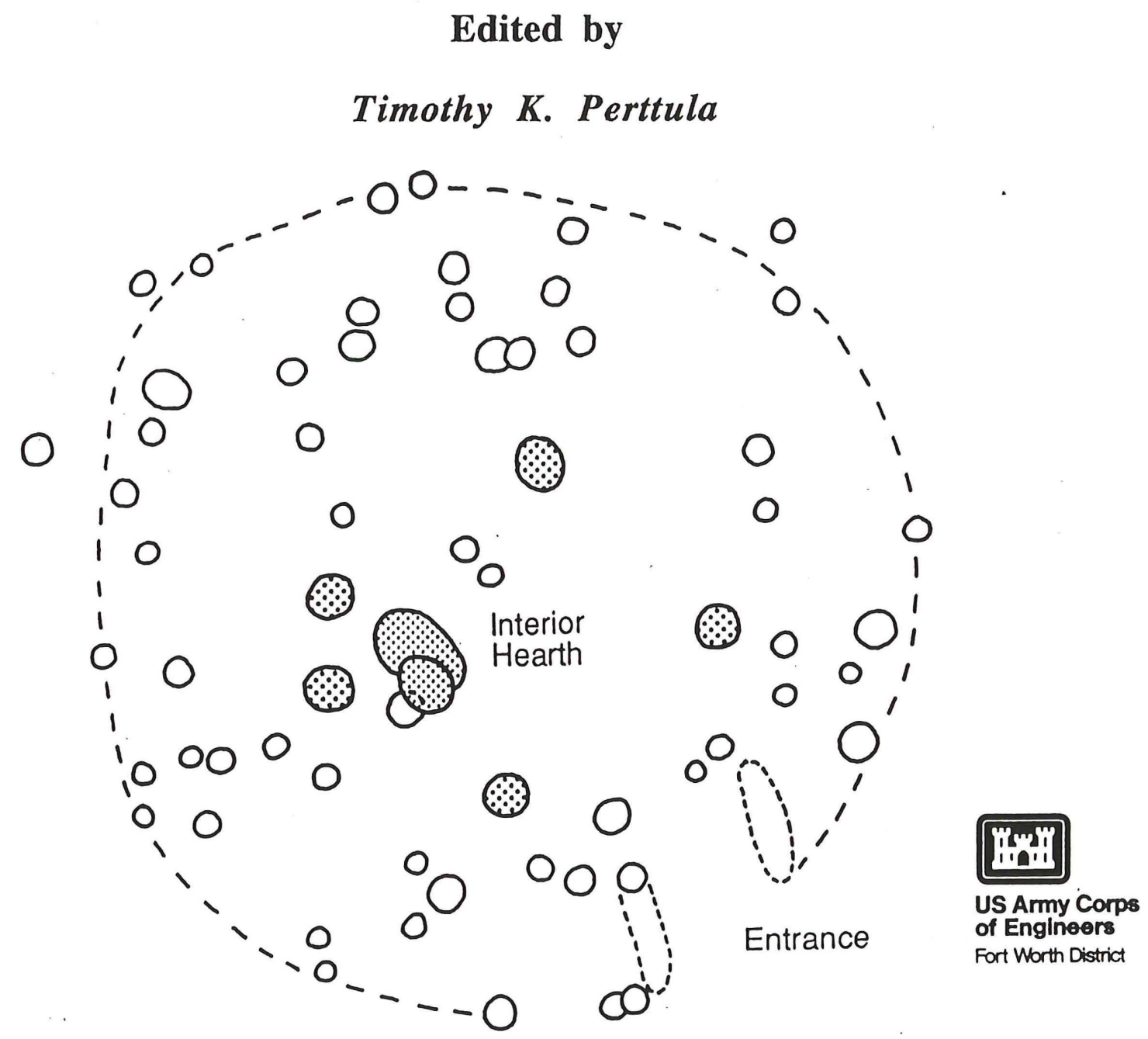

Special Publication No. 4, Friends of Northeast Texas Archaeology 


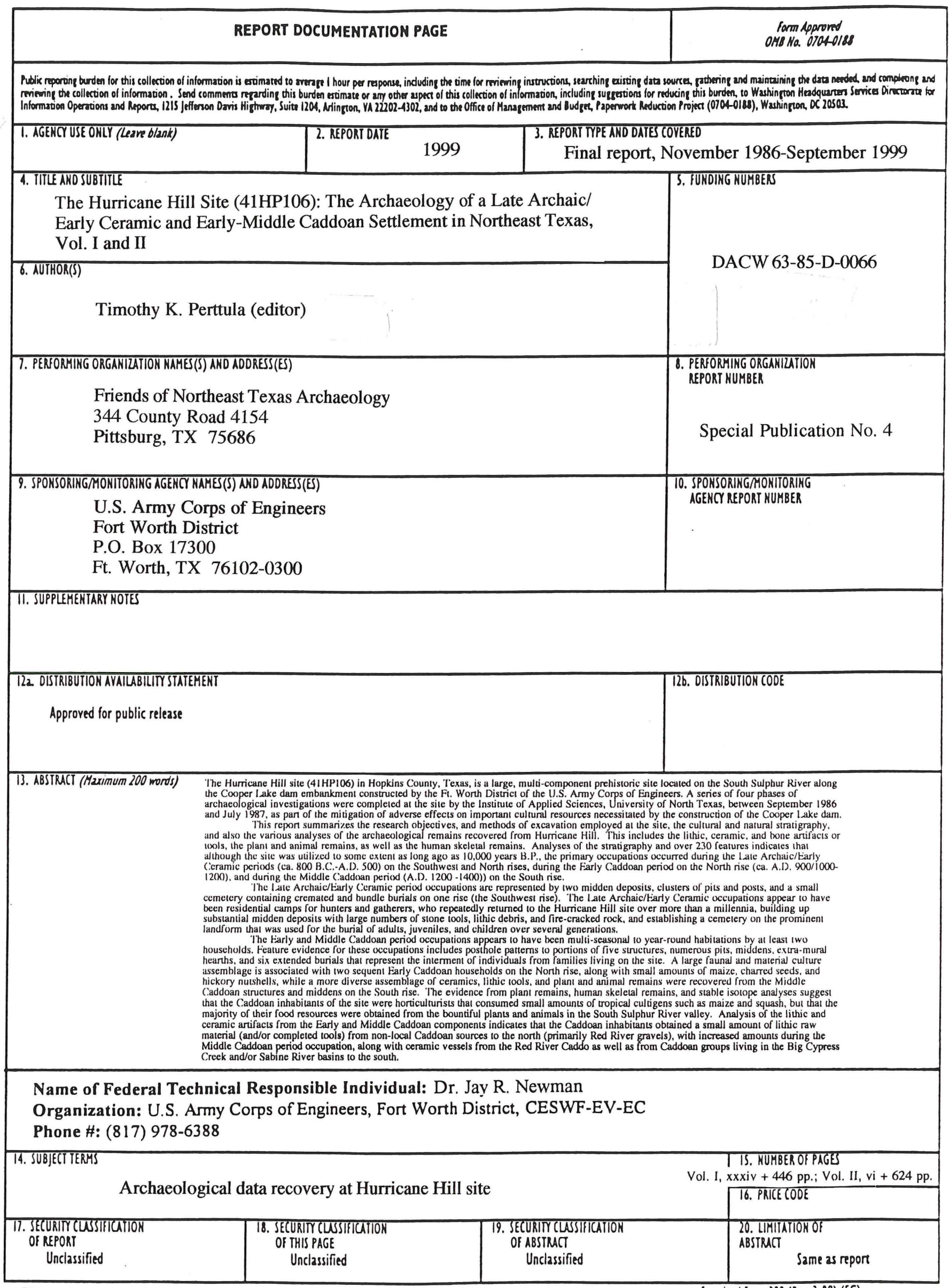


Cover Illustration: Posthole Patterns from Structures A and B, Middle Caddoan period houses at the Hurricane Hill Site (41HP106) 


\title{
THE HURRICANE HILL SITE (41HP106): THE ARCHAEOLOGY OF A LATE ARCHAIC/ EARLY CERAMIC AND EARLY-MIDDLE CADDOAN SETTLEMENT IN NORTHEAST TEXAS, VOL.I
}

\author{
Edited by \\ Timothy K. Perttula \\ with contributions \\ by \\ Heather Brown \\ Marie Brown \\ James W. Cogswell \\ Gary M. Crites \\ C. Reid Ferring \\ Michael D. Glascock \\ S. Eileen Goldborer \\ H. Gill-King \\ Sergio A. Iruegas \\ Hector Neff \\ Bo Nelson \\ Cecily A. Pegues \\ Timothy K. Perttula \\ Bonnie C. Yates \\ and \\ Laurie Zimmerman
}

Special Publication No. 4, Friends of Northeast Texas Archaeology

1999 
The archaeologist squatted at the edge of the excavation and looked down...All day, sorting bone from stone, joints from shafts, flakes from cores, over and over again, until the past resonates its obvious message:

"We are here: we ate shellfish, we ate crabs, we hunted possum, we chipped stone, we were here."

It's not a job for everyone.

Carmel Schrire (1995), Digging Through Darkness: Chronicles of an Archaeologist, p. 202 


\section{TABLE OF CONTENTS, VOLUME I}

Abstract $\quad$ xii

Acknowledgments $\quad$ xiii

Contract Data $\quad$ XV

List of Figures xvi

List of Tables $\quad$ xxx

Chapter $\mathbb{1}$, Introduction, by Timothy K. Perttula 1

Report Organization 1

Cooper Lake Project Dam Embankment Investigations 4

Chapter 2, Environmental and Cultural Setting, by Timothy K. Perttula 9

Environmental Setting $\quad 10$

Climate 10

Geology 10

Soils 12

\begin{tabular}{lr} 
Vegetation & 12 \\
\hline
\end{tabular}

$\begin{array}{ll}\text { Fauna } & 14\end{array}$

Holocene Environmental Change 15

Cultural Setting $\quad 19$

Prehistoric and Early Historic Archaeological Research 19

Cooper Lake Research Investigations $\quad 22$

Prehistoric Archaeological Record 24

Paleoindian period 24

Early, Middle, and Late Archaic period 25

Early Ceramic period $\quad 27$

Formative-Middle Caddoan periods $\quad 28$

Late Caddoan Archaeological period $\quad 30$

Historic Native American record 31

Chapter 3, Research Orientation, by Timothy K. Perttula 33

SMU Research Design $\quad 34$

IAS/UNT Framework 34

Summary $\quad 36$

Chapter 4, Field and Laboratory Methods, by Timothy K. Perttula 39

Field Excavation Strategies $\quad 39$

$\begin{array}{ll}\text { Laboratory Procedures } & 57\end{array}$ 

Site, C. Reid Ferring

Cultural and Natural Stratigraphic Record $\quad 60$

North Rise $\quad 61$

South Rise $\quad 71$

$\begin{array}{ll}\text { Southwest Rise } & 77\end{array}$

Chapter 6, Cultural Features, by Timothy K. Perttula 81

Features on the North Rise $\quad 82$

Features on the South Rise $\quad 98$

Summary of the South Rise Features $\quad 111$

$\begin{array}{ll}\text { Features on the Southwest Rise } & 111\end{array}$

General Comments Concerning Features at the Hurricane Hill Site 118

Chapter 7, Overview of the Prehistoric Components at the 121

Hurricane Hill Site, and Intra-Site Spatial Analyses of

Artifacts and Features, by Timothy K. Perttula

Age and Definition of Prehistoric Components 121

North Rise $\quad 123$

South Rise $\quad 126$

$\begin{array}{ll}\text { Southwest Rise } & 128\end{array}$

Components without Radiocarbon Dates or Features 128

Late Archaic and Early Ceramic Period Components 131

$\begin{array}{ll}\text { Early Caddoan Period Component } & 134\end{array}$

Middle Caddoan Period Component 135

Intra-Site Analyses: Spatial Structure of the Hurricane 135

Hill Site

North Rise $\quad 136$

South Rise $\quad 142$

Chapter 8, Lithic Artifacts from the Hurricane Hill Site, 155 by Timothy K. Perttula

$\begin{array}{ll}\text { Introduction } & 155\end{array}$

Overview of the Hurricane Hill Lithic Artifacts 156

Projectile Points 161

$\begin{array}{ll}\text { Arrowpoints } & 171\end{array}$

Lithic Debris 


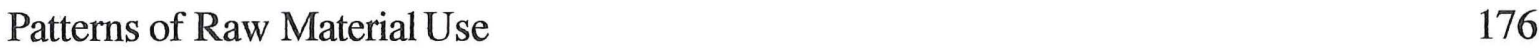

North Rise Assemblages, Blocks D and E 182

$\begin{array}{ll}\text { North Rise Assemblages, Block A } & 201\end{array}$

South Rise Assemblages, Blocks B/C and F 219

$\begin{array}{ll}\text { Southwest Rise } & 235\end{array}$

$\begin{array}{ll}\text { Other Lithic Artifacts } & 239\end{array}$

$\begin{array}{ll}\text { Summary of the Lithic Assemblages } & 239\end{array}$

Chapter 9, The Caddoan Ceramic Artifacts from Hurricane Hill, 243

by Timothy K. Perttula, with a contribution by Sergio A. Iruegas

Overview of the Hurricane Hill Ceramics 245

North Rise Assemblages, Blocks D and E 261

$\begin{array}{ll}\text { North Rise Assemblages, Block A } & 267\end{array}$

$\begin{array}{ll}\text { South Rise Assemblage, Blocks B and C } & 270\end{array}$

$\begin{array}{ll}\text { Southwest Rise } & 277\end{array}$

Summary of the Ceramic Assemblages $\quad 277$

The Petrographic Analysis of Caddoan Ceramics from the Hurricane 279

Hill Site (41HP106), Hopkins County, Texas, Sergio Iruegas

$\begin{array}{ll}\text { Introduction } & 279\end{array}$

$\begin{array}{ll}\text { Methodology } & 280\end{array}$

Results of the Petrographic Analysis $\quad 280$ Group 1

Group 2

$\begin{array}{ll}\text { Summary } & 289\end{array}$

Regional Comparisons in Paste Composition from Petrographic 291

Analyses

$\begin{array}{ll}\text { Ceramic Pipes } & 296\end{array}$

Miscellaneous Clay Items 300

Chapter 10, Compositional Analysis of Caddoan Ceramics from 303

Northeast Texas, by Hector Neff, James W. Cogswell, and

Michael D. Glascock

$\begin{array}{ll}\text { Introduction } & 303\end{array}$

$\begin{array}{ll}\text { Background } & 303\end{array}$ 
Sample Preparation

Irradiation and Gamma-Ray Spectroscopy 304

QuantitativeAnalysis of the Chemical Data 304

Results 306

1. Compositional Groups · 309

2. Production Zones $\quad 312$

3. Association of Chemical Composition with other Attributes 316

$\begin{array}{ll}\text { Conclusions } & 319\end{array}$

$\begin{array}{ll}\text { Acknowledgments } & 319\end{array}$

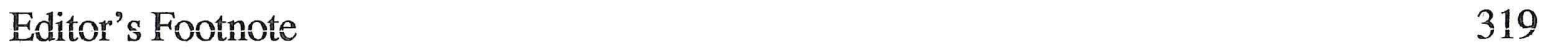

Chapter 11 , Bone Tools from Hurnoicane Hill, by Bonnie C. Yates 321

$\begin{array}{ll}\text { Awls } & 324\end{array}$

Ornament/Special Function $\quad 324$

Hunting/Fishing Implements 324

Stone-Knapping/Hide-Working Tools

$\begin{array}{ll}\text { Miscellaneous } & 324\end{array}$

Bone Artifact Descriptions $\quad 324$

$\begin{array}{ll}\text { Discussion } & 327\end{array}$

Chapter 12, Human Skeletal Remains: Pathological and Dietary= 329

Nutritional Aspects, by H. Gill-King

$\begin{array}{ll}\text { Introduction } & 329\end{array}$

Condition of the Human Materials $\quad 329$

$\begin{array}{ll}\text { Morphological Considerations } & 329\end{array}$

Skeletal and Dental Pathology 331

$\begin{array}{ll}\text { Infection } & 331\end{array}$

Metabolism/Nutrition $\quad 333$

Neoplasia $\quad 334$

Degeneration/Trauma $\quad 334$

Dental Pathology $\quad 337$

Dietary and Nutritional Features 338

$\begin{array}{ll}\text { Cremations } & 342\end{array}$

$\begin{array}{ll}\text { Summary } & 343\end{array}$ 
Chapter 1 3, Vertebrate Fauma from Hurricame Hill, by Bonnie C. Yates 345

Introduction 345

$\begin{array}{ll}\text { Environmental Reconstruction } & 347\end{array}$

Distribution of Faunal Remains 349

Behavioral Inferences $\quad 349$

Seasonality $\quad 349$

Hunting/Fishing Practices 350

Dog Burial 352

Conclusions and Inter-Site Comparisons 352

Chapter 14, Amalysis of the Molluscan Remains from the 355

Hurricane Hill Site, by Laurie S. Zimmerman

$\begin{array}{ll}\text { Introduction } & 355\end{array}$

Methods $\quad 355$

Faunal Identification $\quad 355$

Computer Coding $\quad 355$

Quantitative Techniques 355

Structure of the Assemblage 356

$\begin{array}{ll}\text { Burned Shell } & 358\end{array}$

$\begin{array}{ll}\text { Modified Shell } & 358\end{array}$

$\begin{array}{ll}\text { Glochida } & 358\end{array}$

$\begin{array}{ll}\text { Harvesting Patterns } & 359\end{array}$

The South Sulphur River Habitat 360

Taxonomy 361

Phylum Mollusca (Molluscs) 361

Chapter 15, Macrobotanical Remains from a Northeast Texas 365

Late Archaic to Middle Caddoan Site: Hurricane Hill (41HP106),

Hopkins County, by Eileen Goldborer and Timothy K. Perttula,

with contributions by Marie Brown and Gary M. Crites

$\begin{array}{ll}\text { Introduction } & 365\end{array}$

Laboratory Methods 366

Results of the Paleobotanical Analyses 366

Wood Charcoal 366

Nutshells 366

$\begin{array}{ll}\text { Cultigens } & 368\end{array}$ 
Distribution of Maize across the Hurricane Hill Site 371

Charred Seeds

Uncharred Seeds

Discussion

Late Archaic and Early Ceramic components

375

Early Caddoan component

376

Wild Plant Resources

376

Resource Areas and Seasonality

377

Cultivated Plants

378

Middle Caddoan period

Summary

381

Chapter 16, Prehistoric Settlement and Cultural Lifeways

383 at the Hurricane Hill Site: Summary and Conclusions, by Timothy K. Perttula

References Cited 


\section{TABLE OF CONTENTS, VOLUME II}

Appendix $\mathbb{I}$, Test Excavations at Area $B$, 41HP106,

by Timothy K. Perttula

I-1 to $\mathbb{I}-13$

Appendix II, Historic Cultural Materials from the Hurricane Hill Site by Heather Brown and Cecily A. Pegues

III-1 to III-8

Appendix III, Chemical Elemental Concentration Values for INAA Analysis of Hurricane Hill Ceramics

IIII-1 to IIII-13

Appendix IV, Radiocarbon Dating Results from the Hurricane Hill Site (41HP106)

Appendix V, Decorated Sherds, 41HP106, by Timothy K. Perttula

$\mathrm{V}=1$ to $\mathrm{V}-\mathbf{2 1}$

Appendix VI, Plain Rim Sherds, by Timothy K. Perttula

VI-1 to VI-13

Appendlix VII, Plain Ceramic Body and Base Sherds, 41HP106

VII-1 to VII-36

Appendix VIII, Projectile Points, 41HP106, by Timothy K. Perttula

VIII-1 to VIII-29

Appendix IX, Chipped Stone Tools and Cores, 41HP106

IX $\mathbf{1}$ to IX-30

Appendix X, Groundstone Implements, 41HP106

$X-1$ to $X-3$

Appendix XI, Lithic Debris, 41HP106, by Timothy K. Perttula

XI-1 to XI-142

Appendix XII, Daub, Burned Clay, Fire-cracked Rocks, and

XIII-1 to XIII-59

Natural Gravels

Appendix XIII, Bone Tools, by Bonnie C. Yates

XIIII-1 to XIIII-6

Appendix XIV, Unidentified Faunal Remains

XIV-1 to XIV-15

Appendix XV, Provenience Information from the Hurricane Hill Site 106

Appendix XVI, Artifact Counts from Select Fine-Screen Samples, 41HP106, by Timothy K. Perttula and Bo Nelson

$\mathrm{XV}-1$ to $\mathrm{XV}-$

XVI-1 to XVI-6

Appendix XVII, Soil Samples, 41HP106

XVII-1 to XVII-2

Appendix XVIII, Bioarchaeological Data Forms for the Hurricane Hilli Site, compiled by Timothy K. Perttula

XVIIII-1 to XVIIII-78

Appendix XIX, Hurricane Hill Site Molluscan Remains Data

$X I X-1$ to $X I I X-10$

Base, by Laurie Zimmerman

Appendix XX: Summary of Plant Remains from Flotation

Samples, by S. Eileen Goldborer, Gary D. Crites, and

Timothy K. Perttula

$X X-1$ to $X X-11$ 


\begin{abstract}
The Hurricane Hill site (41HP106) in Hopkins County, Texas, is a large, multi-component prehistoric site located on the South Sulphur River along the Cooper Lake dam embankment constructed by the Ft. Worth District of the U.S. Army Corps of Engineers. A series of four phases of archaeological investigations were completed at the site by the Institute of Applied Sciences, University of North Texas, between September 1986 and July 1987, as part of the mitigation of adverse effects on important cultural resources necessitated by the construction of the Cooper Lake dam.
\end{abstract}

This report summarizes the research objectives, and methods of excavation employed at the site, the cultural and natural stratigraphy, and also the various analyses of the archaeological remains recovered from Hurricane Hill. This includes the lithic, ceramic, and bone artifacts or tools, the plant and animal remains, as well as the human skeletal remains. Analyses of the stratigraphy and over 230 features indicates that although the site was utilized to some extent as long ago as 10,000 years B.P., the primary occupations occurred during the Late Archaic/Early Ceramic periods (ca. 800 B.C.-A.D. 500) on the Southwest and North rises, during the Early Caddoan period on the North rise (ca. A.D. 900/1000-1200), and during the Middle Caddoan period (A.D. 1200 -1400)) on the South rise.

The Late Archaic/Early Ceramic period occupations are represented by two midden deposits, clusters of pits and posts, and a small cemetery containing cremated and bundle burials on one rise (the Southwest rise). The Late Archaic/Early Ceramic occupations appear to have been residential camps for hunters and gatherers, who repeatedly returned to the Hurricane Hill site over more than a millennia, building up substantial midden deposits with large numbers of stone tools, lithic debris, and fire-cracked rock, and establishing a cemetery on the prominent landform that was used for the burial of adults, juveniles, and children over several generations.

The Early and Middle Caddoan period occupations appears to have been multi-seasonal to year-round habitations by at least two households. Feature evidence for these occupations includes posthole patterns to portions of five structures, numerous pits, middens, extra-mural hearths, and six extended burials that represent the interment of individuals from families living on the site. A large faunal and material culture assemblage is associated with two sequent Early Caddoan households on the North rise, along with small amounts of maize, charred seeds, and hickory nutshells, while a more diverse assemblage of ceramics, lithic tools, and plant and animal remains were recovered from the Middle Caddoan structures and middens on the South rise. The evidence from plant remains, human skeletal remains, and stable isotope analyses suggest that the Caddoan inhabitants of the site were horticulturists that consumed small amounts of tropical cultigens such as maize and squash, but that the majority of their food resources were obtained from the bountiful plants and animals in the South Sulphur River valley. Analysis of the lithic and ceramic artifacts from the Early and Middle Caddoan components indicates that the Caddoan inhabitants obtained a small amount of lithic raw material (and/or completed tools) from non-local Caddoan sources to the north (primarily Red River gravels), with increased amounts during the Middle Caddoan period occupation, along with ceramic vessels from the Red River Caddo as well as from Caddoan groups living in the Big Cypress Creek and/or Sabine River basins to the south. 


\section{Acknowledgments}

This project has been a long road to haul, and I for one am surprised that it is now finished. Five years ago, there was not much chance of that. It all began more than a decade ago with my participation as Project Archaeologist during the archaeological survey of the Cooper Lake dam embankment in the Fall of 1986, then reached a temporary crescendo when I was the Project Archaeologist responsible for the direction of the excavations in 1986-1987 at Hurricane Hill while construction rapidly proceeded on the Cooper Lake dam. Two hurried and interim drafts were prepared, provided at the behest of the Corps of Engineers, then they languished (deservedly so) in 1990. There was a long hiatus between 1990-1995, brought on by a lack of funding from the Corps of Engineers, other archaeological commitments at the University of North Texas, and different commitments by myself and Dr. C. Reid Ferring, the Principal Investigator. The document before you represents the completed report, such as it is, the manuscript being prepared in offhours, during weekends, and during "vacation." Thus, there are many people I want to thank for their assistance (and patience) along the way.

First, the Ft. Worth District of the U.S. Army Corps of Engineers (COE) is acknowledged for their continuing concern for and support of cultural resources in Texas. For their help with the 1986-1987 fieldwork, then COE archaeologists Karen Scott and Erwin Roemer, and Steve Helfert, Environmental Division, are thanked for everything they did to facilitate the completion of this project. Jerry Spraggins, Cooper Lake COE Headquarters, helped in logistics and coordination of field work (and lent his name [e.g., "scrogged"] as a descriptive term for some of the construction-related disturbance that had taken place at the Hurricane Hill site before my involvement in the project began). Dan McGregor (now with Operations) and Jay R. Newman of the Planning Division of the COE-Ft. Worth District picked up the pieces years later, and greatly assisted with obtaining additional funds to finish the report. Dan also provided advice and knowledge concerning the archaeology at Cooper Lake which proved quite helpful, and provided copies of Hurricane Hill burial documentation forms completed by Geo-Marine, Inc. and the University of Arkansas. Jay was also there to continually remind and prod me that the report did need to be finished one of these days. He also provided detailed comments on the final draft report.

Second, I want to thank Dr. C. Reid Ferring, the Principal Investigator for the project, for the initial opportunity to participate in the Hurricane Hill project. While trying to complete the report has been an albatross to carry around 'lo these many years, I would do it again (although not exactly in the same way) in a heartbeat, because how often does one have the opportunity to work on the archaeological site such as Hurricane Hill.

Backhoe work was accomplished by Gary Cheatwood and Porterfield Construction Co. Gary also shared with me his knowledge (which is considerable) of the archaeology of the Sulphur River basin. I would also like to thank Dr. LaVerne Herrington and Dr. Nancy A. Kenmotsu, then of the Texas Historical Commission, for their comments during a site visit in 1986 regarding the overall significance of the site.

Dr. Dee Ann Story, Dr. James E. Bruseth, Ross C. Fields, Jan A. Guy, and Dan J. Prikryl have offered insightful comments on the archaeology as the work was being done, and/or provided comments on the various versions of the Hurricane Hill manuscripts, over the years, and I thank them. I, of course, blame no one but myself for any misuse and abuse of those comments.

Ross, in particular, graciously shared with me his wide and varied knowledge of Cooper Lake archaeology, and provided copies of pertinent Cooper Lake manuscripts and reports. He also contributed immeasurably to the success of the investigations by having Prewitt and Associates, Inc. pay for 15 radiocarbon dates from Hurricane Hill during their synthesis effort.

I am particularly indebted to Bo Nelson for his efforts in 1995-1996 in sorting out the artifact collections and radiocarbon samples, assisting with the analysis of the lithic debris and other remains from the myriad fine-screen samples, and taking charge of the artifact photographs for Chapter 8 . Without his help, the project would have hopelessly floundered before it really got off the ground (for the final time). $\mathrm{He}$, along with the other original Friends of Northeast Texas Archaeology (Mike Turner, Bob Skiles, and Tom Middlebrook), supported the eventual publication of this report as a Special Publication of the Friends of Northeast Texas Archaeology. included:

The efforts of the dedicated and lab crew members are greatly appreciated. Project personnel

\section{Survey Crew}

Tim Perttula

\section{Testing/Mitigation Crew}

George Brown 


$\begin{array}{ll}\text { Robert Cast } & \text { Heather Brown } \\ \text { Gemma Mehalchick } & \text { Jeff Cutter } \\ \text { Randy Nathan } & \text { Arlan Kalina } \\ & \text { Marge Dryden } \\ & \text { Michael Dryden } \\ \text { Thomas A. Nelson } & \text { Nancy Edens } \\ \text { Leonard Allen } & \text { Steve Gaither } \\ \text { Sylvia Kooren } & \text { Bob Howell } \\ & \text { Karl Kleinbach } \\ \text { Lab Crew } & \text { Andre Lelievre } \\ \text { George Brown } & \text { Gemma Mehalchick } \\ \text { Janet Barry Enos } & \text { (Crew Chief, Phase I-II) } \\ \text { Wanda Cast } & \text { Pat Neel } \\ \text { Steve Gaither } & \text { (Crew Chief, Phase II) } \\ \text { Lynn Mitchell } & \text { Randy Nathan } \\ \text { Cecily Pegues } & \text { (Crew Chief, Phase II) } \\ \text { Leon Price } & \text { Cindy Parish } \\ \text { LeeAnna Schniebs } & \text { Dana Robinson } \\ & \text { Jim Ross } \\ & \text { Bob Skiles } \\ & \text { Bryan Small } \\ & \text { David Susice }\end{array}$

Steve Gaither in particular assisted me in the detailed analysis of the many decorated and rim sherds and projectile points, and I thank him for a job well-done.

Consultants have also provided important information towards my understanding (limited though it may be) of the archaeological record at the Hurricane Hill site. Specialists at the University of North Texas included: Dr. H. Gill King, who conducted the initial bioarchaeological analyses; Bonnie C. Yates (now of the U.S. Fish and Wildlife Service) analyzed the faunal materials and bone tools, and helped mightily with the initial draft report preparation; Dr. C. Reid Ferring completed some soil descriptions, and Tom Nelson managed and processed the voluminous computerized data base from the site. Dr. King would like to thank Ms. Bonnie Yates, then-Curator of Zooarchaeology (University of North Texas) and her assistants, Ms. Marie Brown and Ms. LeeAnna Schniebs, for preparation of materials and editorial comments; Dr. Henri Petit, Baylor College of Dentistry, for consultation on dental samples; Mr. Hamo Meguerditchian, Southwestern Institute of Forensic Sciences (SWIFS), for radiography; Dr. I .C. Stone, also of SWIFS, for trace element analysis; and Mr. Harold Krueger of Geochron Laboratories for stable isotope analysis. Radiographs and photographs [although not provided to the volume editor, unfortunately] are on file at the Laboratory of Forensic Anthropology, University of North Texas, Denton.

Dr. Gary Crites of the University of Tennessee was responsible for the initial paleobotanical analyses, along with Marie Brown, and Eileen Goldborer completed more recently the more substantial analyses of the remaining flotation and fine-screen samples. Laurie Zimmerman took on the mussel shell analyses. I thank Sergio Iruegas for his petrographic study of the Hurricane Hill ceramics, and Dr. Hector Neff, along with James Cogswell and Michael Glascock, of the University of Missouri Reactor Center for agreeing to do the instrumental neutron activation analyses. Thanks also to Dr. Jerome C. Rose for permission to publish the bioarchaeological data forms from the Hurricane Hill skeletal remains analyzed by the University of Arkansas, and for providing me with a copy of the Standardized Osteological Database manual and software. Diane Wilson provided me with copies of the bioarchaeological data forms to include in this publication.

Project management at the University of North Texas between 1986-1990 was the responsibility of Jan Hansen, Business Manager. Draft report preparation (in 1988 and 1990) would have been impossible without the dedicated efforts of the Institute's support staff: Wanda Cast, Denise Sellars, Cecily Pegues, Cathy Gray, and Kathy Henson, word processing; Pam Carmichael and Tamie J. Green, graphic artists. Stepping into the breach with illustrating assistance was Gerald Blow.

Finally, the final figures and report preparation was completed with the considerable assistance of Nancy Reese and Terry Sherrell at Morgan Printing (Austin, Texas).

A heartfelt thanks is extended to all of these people for their assistance. Todo se acaba.

Timothy K. Perttula, September 1999 


\section{CONTRACT DATA}

This report is submitted to the Fort Worth District, Corps of Engineers, P.O. Box 17300, Fort Worth, Texas, 76102, in partial fulfillment of Delivery Order No. 13 (issued September 1986), Modification No. 1 to Delivery Order No. 13 (issued October 21, 1986), Delivery Order No. 17 (issued October 28, 1986), Delivery Order No. 19 (issued December 19, 1986), Delivery Order No. 21 (issued January 28, 1987), Delivery Order No. 23 (issued March 16, 1987), Delivery Order No. 24 (issued May 4, 1987), and Modification No. 1 to Delivery Order No. 24 (issued July 6, 1987), under Contract DACW 63-85-D-0066 to Alan Plummer and Associates, Inc., Arlington, Texas, and subcontracted to the University of North Texas, in September, 1986. 


\section{LIST OF FIGURES}

Figure 1-1. South Sulphur River and Hurricane Hill: a, South Sulphur River

channel near Hurricane Hill; b, looking west at the Hurricane Hill site.

Note Area B in lower right of hill, and North rise in upper left center

Figure 1-2. General location of the Cooper Lake dam embankment, Delta and

Figure 1-3. Hurricane Hill and vicinity, showing landforms and distribution

of known prehistoric sites

Figure 1-4a. Contour map of the Hurricane Hill site

Figure 1-4b. Contour map of the western end of Hurricane Hill, with East, North,

South, and Southwest rises

Figure 2-1. Hurricane Hill within Northeast Texas (source map adapted from

Erwin Raisz, Landforms of the United States, 1957)

Figure 2-2. Geological map of the Three Forks of the Sulphur River

Figure 2-3. Biotic communities in the vicinity of Hurricane Hill (after Moir et al. 1997)

Figure 2-4. Stable isotope results from humate samples, Cooper Lake, White Oak Creek Mitigation Area, and Red River Army Depot (Sources: Cliff and Peter 1992; Fields et al. 1997).

Figure 2-5. Dendrochronological sequence, Big Cypress State Park, Louisiana, A.D. $997-1651$.

Figure 2-6. Archaeological investigations and important known prehistoric sites in the Sulphur River basin of Northeast Texas

Figure 2-7. Temporal affiliation of prehistoric sites recorded across the Sulphur River basin of Northeast Texas: $a$, Wright Patman Lake; $b$, White Oak Creek Drainage, Titus County, including White Oak Creek Mitigation Area; c, Cooper Lake Surveys; d, Red River Army Depot/Lone Star Army Ammunition Plant; e, Cooper Lake, 1972-1976 excavated sites

Figure 4-1. Phase I investigations at Hurricane Hill

Figure 4-2. Block and unit layout for Block A on the North rise at Hurricane Hill, and South and East axis coordinates

Figure 4-3. Phase II investigations at Hurricane Hill

Figure 4-4. Block and unit layout for Blocks B, C, B/C, and F at Hurricane Hill, including South and East axis coordinates

Figure 4-5. Phase III block investigations at Hurricane Hill 
Figure 4-6. Block D and E layout, showing South and East axis coordinates: a, Block D; b, Block E

Figure 4-7. Phase IV gradall investigations at Hurricane Hill 55

Figure 5-1. Distribution of Midden deposits on the North rise: PrimaryMidden and 62 Middens 1 and 2

Figure 5-2. $\quad$ Profiles \#1-\#6, Block A 63

Figure 5-3. Profiles of the north and east walls of Block A extension 65

Figure 5-4. Block D profiles \#1-7 66

$\begin{array}{lll}\text { Figure 5-5. } & \text { Block D, profiles \#8-10 }\end{array}$

$\begin{array}{lll}\text { Figure 5-6. } & \text { Block E profiles \#1-5 }\end{array}$

Figure 5-7. Profiles of BHTs 31/32/33, A-A', B-B', and C-C' $\quad 70$

Figure 5-8. Plan of South rise depicting topography and location of major features 72

Figure 5-9. Outer wall profiles, Block B/C $\quad 72$

Figure 5-10. Profiles in Block B/C in the vicinity of Structures A and B 73

Figure 5-11. Profile A-A' and B-B', Feature 9, Blocks B/C and F 76

$\begin{array}{lll}\text { Figure 5-12. Southwest rise, plan of excavations and location of profiles 1-8 } & 77\end{array}$

$\begin{array}{lll}\text { Figure 5-13. Southwest rise, profiles of backhoe trenches and Unit } 96 & 78\end{array}$

$\begin{array}{lll}\text { Figure 5-14. } & \text { Profiles of Units } 284 \text { and } 285 & 79\end{array}$

Figure 6-1. Distribution of middens and features at Hurricane Hill 83

$\begin{array}{lll}\text { Figure 6-2. } & \text { Feature plan of Blocks A, D, and E } & 84\end{array}$

Figure 6-3. Midden 1 Excavations in progress $\quad 85$

$\begin{array}{lll}\text { Figure 6-4. } & \text { Feature 1, Burial } 1 & 86\end{array}$

$\begin{array}{lll}\text { Figure 6-5. } & \text { Feature 2, Burial 2, Unit } 47 & 87\end{array}$

$\begin{array}{llr}\text { Figure 6-6a. } & \text { Profile of Feature 25, Burial } 5 & 89\end{array}$

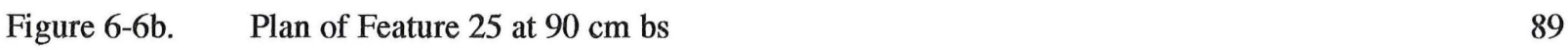

Figure 6-7. North rise features: a, Feature 34; b, Feature 25 at $90 \mathrm{~cm}$ bs 90

Figure 6-8. Cremations and pits with burned and unburned bone $\quad 91$

Figure 6-9. $\quad$ Pits and other features in Midden 1 92 
Figure 6-10. Plan and profile of Feature 24

Figure 6-11. $\quad$ Plan of Feature $4 \quad 94$

Figure 6-12. Plan and profile of Feature 31, Block D 95

Figure 6-13. Plan of House D and other features in the northernmost part of Block D 97

Figure 6-14. Features and structures on and in the vicinity of the South rise 99

Figure 6-15. Plan of excavations, depicting clusters of posts and pits around and 100

Figure 6-16. Feature 5: a, top of Feature 5, Units 172-173, looking north; b, northern 102 half of Feature 5A, and underlying Feature 5B ash lens

$\begin{array}{lll}\text { Figure 6-17. Feature 5A, Block B/C } & 103\end{array}$

Figure 6-18. Location of central hearths and large pits in Structures A and B 104

Figure 6-19. Posthole patterns, Block B/C 104

$\begin{array}{lll}\text { Figure 6-20. } & \text { Profiles of selected postholes and small pits } & 105\end{array}$

Figure 6-21. Plan of postholes for Structure B 106

$\begin{array}{lll}\text { Figure 6-22. Plan of postholes for Structure A } & 109\end{array}$

Figure 6-23. Plan of features, Southwest rise 112

Figure 6-24. Southwest rise features: a, Feature 60; b, Feature 71

Figure 6-25. Plan and profile of Feature 77, Scrape Area 6

Figure 6-26. Feature 68, an extended Middle Caddoan burial on the Southwest rise 116

$\begin{array}{lll}\text { Figure 6-27. Feature 70, Southwest rise } & 117\end{array}$

Figure 7-1. Radiocarbon and thermoluminescence Dates from the North rise 121

Figure 7-2. Radiocarbon, thermoluminescence, and archaeomagnetic Dates 122

$\begin{array}{lll}\text { Figure 7-3. Radiocarbon dates from the Southwest rise } & 123\end{array}$

$\begin{array}{lll}\text { Figure 7-4. Relative frequency of temporally diagnostic dart projectile points by } & 129\end{array}$ period, block, and naturai rise

$\begin{array}{lll}\text { Figure 7-5. } & \text { Relative frequency of temporally diagnostic arrowpoints by period, } & 130\end{array}$

Figure 7-6. Vertical Distribution of arrowpoints and dart points in Block A, 132 Block D/E, and Block D/C 
Figure 7-7. Vertical distribution of daub, burned clay, and fire-cracked rock in Block A and Block D/E

Figure 7-8. Vertical distribution of dart points inside and outside the structures on the South rise

Figure 7-9. Vertical Distribution of daub, burned clay, and fire-cracked rock in Block B/C

Figure 7-10. Distribution of ceramics on the North rise

Figure 7-11. Distribution of decorated and rim sherds in Block A

Figure 7-12. Distribution of decorated and rim sherds in Blocks D and E

Figure 7-13. Distribution of stone tools on the North rise

Figure 7-14. Distribution of complete and broken arrowpoints in Block A

Figure 7-15. Distribution of complete and broken arrowpoints in Blocks D and E

Figure 7-16. Distribution of faunal remains in Block A on the North rise

Figure 7-17. Distribution of faunal remains in Blocks D and E on the North rise

Figure 7-18. Distribution of Shell umbos in Block A

Figure 7-19. Distribution of ceramics in Blocks B/C and F on the South rise

Figure 7-20. Distribution of rim and decorated sherds in Blocks B/C

Figure 7-21. Distribution of faunal remains in Blocks B/C

Figure 7-22. Distribution of maize within Structures A and B

Figure 7-23. Distribution of charred nutshells in Blocks B/C

Figure 7-24. Spatial distribution of bone tools, Blocks B/C

Figure 7-25. Distribution of complete and broken arrowpoints, Blocks B/C

Figure 7-26. Distribution of select Middle Caddoan chipped and ground stone

Figure 7-27. Distribution of daub in Blocks B/C

Figure 7-28. Distribution of burned clay in Blocks B/C

Figure 7-29. Distribution of fire-cracked rock, all levels, Blocks B/C 150

Figure 7-30. Distribution of fire-cracked rock, Level 6+, Blocks B/C 150

Figure 7-31. Distribution of dart points in Blocks B/C 151 
Figure 7-32. Distribution of lithic debris in Blocks B/C

Figure 7-33. Distribution of cores, levels 1-3 and levels 4-6, in Blocks B/C

Figure 7-34. Spatial distribution of selected chipped stone tools in Blocks B/C

Figure 7-35. Distribution of utilized flakes in Blocks B/C on the South rise

Figure 8-1. Lithic classification scheme

Figure 8-2. Projectile point classes: $a$, dart points; $b$, arrow points

Figure 8-3. Distributions of dart points in Texas (after Prewitt 1995): a, classes

$06,09,12,14,17,18,21$, and 24 ; b, classes $01,02,03,04,05,07,10,11,12$, $13,15,16,19,20$, and 22

Figure 8-4. Distribution of arrow points in Texas (after Prewitt 1995)

172

Figure 8-5. Use of non-local lithic raw materials in the lithic debris and tools

177 at Hurricane Hill

Figure 8-6. Use of probably non-local and non-local lithic raw materials in the lithic debris, depicting the nine most common non-local materials

Figure 8-7. Use of probably non-local and non-local lithic raw materials in the tools from the North and South rises

Figure 8-8. $\quad$ Dart points, Block D: a, Class 01 (No. 3, 5-7), Class 02 (No. 1), Class 03 (No. 4), Class 09 (No. 2); b, Class 02 (No. 1, 3), Class 03 (No. 2, 4-5), and Class 08 (No. 6). Provenience: a-1 (81-1), a-2 (S38E26, 55-60 cm), a-3 (S26E27, $54 \mathrm{~cm})$, a-4 (S32E27, $40 \mathrm{~cm})$, a-5 (S35E25, $40 \mathrm{~cm})$, a-6 (80-5B), a-7 (87-2), b-1 (87-2), b-2 $(\mathrm{S} 36 \mathrm{E} 29,29 \mathrm{~cm}), \mathrm{b}-3$ (S36E25, $40 \mathrm{~cm}), \mathrm{b}-4$ (87-5), b-5 (S39E29, $30 \mathrm{~cm}), \mathrm{b}-6$ (S29E27, $30-35 \mathrm{~cm}$ )

Figure 8-9. Dart points, Block E: a, Class 01 (No. 12, 13), Class 02 (No. 2, 9), Class 03 (No. 1, 3-8, 13), Class 05 (No. 10), and Class 09 (No. 11); b, Class 08 (No. 2), Class 12 (No. 1), Class 17 (No. 4), Class 18 (No. 5), and Class 23 (No. 3). Provenience: a-1 (S33E22, $50 \mathrm{~cm})$, a-2 (S30E21, $60 \mathrm{~cm})$, a-3 (90-5A), a-4 (S35E20, 34-36 cm), a-5 (24-6), a-6 (S29E20, $52 \mathrm{~cm})$, a-7 (24-6), a-8 (S33E20, $45 \mathrm{~cm})$, a-9 (92-1), a-10 (S27E17, $15 \mathrm{~cm})$, a-11 (91-4), a-12 (S36E20, $38 \mathrm{~cm})$, a-13 (S36E21, $10 \mathrm{~cm})$, a-14 (93-4), b-1 (S24E17, $32 \mathrm{~cm})$, b-2 (S29E18, $30 \mathrm{~cm})$, b-3 (S32E20, $70 \mathrm{~cm}), \mathrm{b}-4$ (S29E16, $45 \mathrm{~cm}), \mathrm{b}-5$ (S32E20, $70 \mathrm{~cm})$

Figure 8-10. Late Archaic style dart points, Block D: a, Class 07 (No. 5), Class 09365 (No. 2-4), Class 20 (No. 1); b, Class 12 (No. 1-2, 5), Class 18 (No. 3-4). Provenience: a-1 (S35E27, $60 \mathrm{~cm})$, a-2 (88-4), a-3 (87-2A), a-4 (S36E28, $43 \mathrm{~cm})$, a-5 (S36E26, $53 \mathrm{~cm})$, b-1 (S36E27, $20 \mathrm{~cm}), \mathrm{b}-2$ (S39E29, $35 \mathrm{~cm}), \mathrm{b}-3$ (S35E28/29, $52 \mathrm{~cm}), \mathrm{b}-4(\mathrm{~S} 30 \mathrm{E} 29,38 \mathrm{~cm}), \mathrm{b}-5(\mathrm{~S} 28 \mathrm{E} 30,54 \mathrm{~cm})$ 
Figure 8-11. Arrowpoints and flake tools, Block D: a, Class 01 (No. 5), Class 02 (No. 7-8),

Class 05 (No. 1, 6), Class 07 (No. 3), Class 09 (No. 4), Class 10 (No. 2); b, utilized flake (No. 1-2, 4, 6, 8), distal/lateral utilized flake (No. 3, 7), bilateral utilized flake (No. 5), indeterminate bifacial tool (No. 9). Provenience: a-1 (78-3), a-2 (83-2A), a-3 (S34E25, $15 \mathrm{~cm}), a-4$ (77-2), a-5 (80-5A), a-6 (79-3), a-7 (75-2), a-8 (S30E26, profile 40), b-1 (79-4), b-2 (S34E26, $50 \mathrm{~cm}), \mathrm{b}-3$ (87-3), b-4 (87-3), b-5 (75-UID), b-6 (S34E26, $40 \mathrm{~cm}$ ), b-7 (S34E26, $60 \mathrm{~cm})$, b-8 (87-4), b-9 (81-5).

Figure 8-12. Arrowpoints and groundstone tools, Block E; 1, mano; 2, bifacial mano, 3, 5-6, Class 06; 4, Class 02; 7, Class 07; 8, Class 05; 9, Class 01. Provenience: 1 (S27E18, $20 \mathrm{~cm}$ ), 2 (S24E20, $38 \mathrm{~cm}), 3$ (94-3A), 4 (92-1), 5 (24-4), 6 (23-2), 7 (S36E19, $17 \mathrm{~cm}$ ), 8 (92-2), 9 (BHT 39).

Figure 8-13. Cores, blank-preforms, and groundstone, Block D: a, opposed platform core (No. 1, 3-4), multiple platform core (No. 5-6), blank-preform (No. 2); b, pitted stone (No. 1). Provenience: a-1 (82-2), a-2 (82-1), a-3 (87-4), a-4 (79-2), a-5 (87-5), a-6 (85-2), b-1 (S27E27, $25 \mathrm{~cm})$

Figure 8-14. Cores, blank-Preforms, and hammerstones, Block E: a, blank-preforms (No. 1-2, 4-6), multiple platform core (No. 3); b, hammerstones (No. 1-2), bifacial core (No. 3). Provenience: a-1 (92-1), a-2 (S29E20, 55-60 cm), a-3 (94-4), a-4 (91-3A), a-5 (24-6), a-6 (S24E21, $30 \mathrm{~cm}), b-1$ (S37E21, $30 \mathrm{~cm})$, b-2 (S32E18, $35 \mathrm{~cm}), b-3(91-2)$

Figure 8-15. Blank-Preform thickness categories

Figure 8-16. Distribution of non-local tools by depth in blocks

Figure 8-17. Percentage of large flakes and non-cortical flakes in 1/4-inch and finescreen and flotation samples (see Tables 8-8 and 8-9). Group I, 1/4-inch screen sample, and Groups II and III, fine-screen and flotation samples

Figure 8-18. Percentage of large flakes by level in Blocks A, E, and B/C from finescreen samples (see Appendix XVI). Block A, $n=2848$; Block $E, n=469$; Block B/C, $n=1699$

Figure 8-19. Dart points, bifaces, and cores, Block A, levels 1 and 2: a, Class 01 (No. 1-2, 8-9), Class 02 (No. 6, 10), Class 03 (No. 4), Class 04 (No. 7), Class 11 (No. 3), unidentified expanding stem (No. 5); b, indeterminate bifacial tool (No. 2), knive (No. 4), multiple platform core (No. 5), core fragments (No. 1, 3). Provenience: a-1 (34-1), a-2 (36-1), a-3 (31-1), a-4, a-8 (35-1), a-5 (43-1), a-6 (41-2), a-7, a-10 (44-1), a-9 (25-1), b-1, b-4 (26-1), b-2, b-5 (32-1), b-3 (43-1)

Figure 8-20. Dart points, Block A, level 2: Class 01 (No. 3-4, 9, 11-12), Class 02 (No. 7, 13), Class 03 (No. 5-6, 15-16), Class 08 (No. 10, 14), Class 12 (No. 2), Class 13 (No. 8), Class 18 (No. 1). Provenience: 1, 4 (252-2A), 2, 6 (246-2), 3 (242-5A), 5 (249-2B), 7 (244-2B), 8 (256-2B), 9 (248-2A), 10 (255-2A), 11 (34-2), 12 (32-2), 13 (43-2), 14 (35-2), 15 (29-2), 16 (42-2) 
Figure 8-21. Dart Points, Block A, level 3: Class 01 (No. 3, 5, 9, 15-17), Class 02

(No. 1-2), Class 03 (No. 4, 8, 12, 14), Class 05 (No. 10), Class 07 (No. 11), Class 10 (No. 6-7), Class 12 (No. 13). Provenience: 1 (257-3B), 2 (240-3A), 3 (249-3A), 4 (136-141, 4), 5 (244-3B), 6 (108-113, 5A), 7 (256-3B), 8 (39-3), 9 (44-3), $10,12(37-3), 11(42-3), 13(38-3), 14(30-3), 15,17$ (34-3), 16 (41-3)

Figure 8-22. Blank-Preforms, and dart points, Block A and E, level 5: a, blank-preforms (No. 1-4); b, Class 01 (No. 3, 5), Class 03 (No. 1, 6, 8), Class 05 (No. 4), Class 06 (No. 10), Class 13 (No. 7), Class 17 (No. 2, 9). Provenience: a-1, a-2 (38-5), a-3 (23-5), a-4 (37-5), b-1, b-3, b-5, b-7 (27-5), b-2 (29-5), b-4, b-6 (31-5), b-8 (26-5), b-9 (37-5), b-10 (45-5)

Figure 8-23. Blank-Preforms and dart points, Block A and E: blank-preforms (No. 1-3), Class 01 (No. 6), Class 03 (No. 7, 10, 13), Class 04 (No. 4), Class 07 (No. 11), Class 09 (No. 9), Class 12 (No. 12), Class 14 (No. 5), Class 15 (No. 8). Provenience: 1 (43-4), 2 (34-4), 3 (41-4), 4 (31-4), 5, 13 (34-4), 6, 12 (32-4), 7, 11 (29-4), 8-9 (45-4), 10 (24-4)

Figure 8-24. Arrowpoints and flake tools, Block A, levels 1-2: a, Class 01 (No. 1, 6), Class 02 (No. 3), Class 03 (No. 2), unidentified (No. 5), preform (No. 4); b, unilateral retouched piece (No. 3), alternate retouched piece (No. 1), distal retouched piece (No. 2, 4), distal/lateral retouched piece (No. 5). Provenience: a-1, 4 (29-1), a- 2 (41-2), a-3 (39-1), a-5 (32-1), a-6 (26-1), b-1 (36-2), b-3 (36-1), b-4 (30-1), b-5 (25-1)

Figure 8-25. Arrowpoints and flake tools, Block A, level 2: a, Class 01 (No. 3, 5, 7, 14), Class 02 (No. 1-2, 8, 10, 12), Class 04 (No. 6), Class 05 (No. 4, 13), Class 06 (No. 11), unidentified (No. 9); b, distal utilized flake (No. 1, 3), distal retouched piece (No. 2), bilateral utilized flake (No. 4-5), arrowpoint preform (No. 6). Provenience: a-1 (252-2A), a-2 (249-2A), a-3 (257-2A), a-4 (246-2), a-5 (244-2B), a-6 (38-2), a-7, a-10 (45-2), a-8, a-11 (27-2), a-9 (32-2), a-12 (39-2), a-13 (40-2), a-14 (36-2), b-1 (257-2), b-2 (242-2), b-3 (253-2), b-4 (250-2), b-5 (35-2), b-6 (40-Fea. 4)

Figure 8-26. Arrowpoints and flake tools, Block A, level 3: Class 01 (No. 5), Class 02 (No. 4), Class 03 (No. 3), Class 05 (No. 6, 8), Class 06 (No. 1-2, 7), bilateral utilized blade (No. 9, 13), distal/lateral utilized flake (No. 10, 16), unilateral retouched piece (No. 11, 12, 18-19), end-side scraper (No. 14), utilized bifacial thinning flake (No. 15, 17). Provenience: 1 (UID unit-3), 2 , 19 (37-3), 3 (28-3), 4 (44-2), 5 (40-Fea. 4), 6 (32-3), 7 (27-3), 8 (36-3), 9 (243-3), 10 (239-3), 11 (256-3), 12 (241-3), 13 (249-3), 14 (240-3), 15 (30-3), 16-17, 19 (40-3)

Figure 8-27. Flake tools, Block A, level 4: distal/lateral utilized flake (No. 1, 2), unilateral retouched piece (No. 3, 5, 9), bilateral retouched piece (No. 10), end-side scraper (No. 4), small adze (No. 6), distal retouched piece (No. 7), side scraper (No. 8). Provenience: 1 (238-4), 2 (239-4), 3 (244-4), 4-5 (28-4), 6 (37-4), 7-8 (31-4), 9 (45-4), 10 (41-4)

Figure 8-28. Flake tools and blank-preforms, Block A, level 5: blank-preforms (No. 3-4), indeterminate bifacial tool (No. 2), bilateral utilized flake (No. 1), unilateral retouched piece (No. 5-6, 9), distal utilized flake (No. 7), distal/lateral retouched piece (No. 8). Provenience: 1-2 (242-5), 3 (241-5), 4 (257-5), 5-7 (29-5), 8 (26-5), 9 (41-5). 
Figure 8-29. Cores and blank-preforms, Block A, level 2: blank-preforms (No. 1-2, 4-6, 8-9), multiple platform core (No. 7), core fragment (No. 3). Provenience: 1 (25-2), 2 (36-2), 3 (30-2), 4 (38-2), 5 (248-2), 6 (243-2), 7, 9 (253-2), 8 (257-2)

Figure 8-30. Cores, blank-preforms, and bifacial tools, Block A, level 3: blank-preforms (No. 2, 4, 6-7, 10), indeterminate bifacial tool (No. 1), bifacial knive (No. 5), adze (No. 8), opposed platform core (No. 3, 9). Provenience: 1 (32-3), 2 (29-3), 3-4 (37-3), 5 (36-3), 6 (255-3), 7, 10 (256-3), 8 (238-3), 9 (251-3)

Figure 8-31. Cores and blank-preforms, Block A, levels 4 and 7: blank-preforms

(No. 5-6, 8), tested cobble (No. 7), multiple platform core (No. 1, 3-4), single platform core (No. 2). Provenience: 1 (36-4), 2 (40-4), 3 (43-4), 4 (32-4), 5 (257-4), 6 (240-4), 7 (247-7A), 8 (245-4).

Figure 8-32. Celts and cores, Block A: celt (No. 1), opposed platform core (No. 2), multiple platform core (No. 3). Provenience: 1 (244-3), 2 (35-4), 3 (40-2)

Figure 8-33. Dart points, Block B/C, level 3: Class 01 (No. 12), Class 02 (No. 3, 7-8, 10-11, 15, 17), Class 03 (No. 4-6, 9, 13-14), Class 10 (No. 2), Class 15 (No. 16), Class 20 (No. 1). Provenience: 1 (133-3B), 2 (106-3B), 3 (110-3B), 4 (124-3B), 5 (175-3B), 6 (112-3B), 7 (143-3B), 8 (62-3B), 9 (149-3B), 10 (120-3B), 11 (156-3B), 12 (105-3B), 13 (163-3A), 14 (133-3A), 15 (136-3A), 16 (134-3A), 17 (109-3A)

Figure 8-34. Dart points, Block B/C, level 4: Class 02 (No. 1-3, 8), Class 03 (No. 7, 10-11), Class 06 (No. 4-5), Class 09 (No. 12), Class 13 (No. 6), Class 15 (No. 9), Class 17 (No. 13). Provenience: 1 (142-4A), 2 (105-4A), 3 (158-4A), 4 (144-4A), 5 (171-4A), 6 (67-4A), 7 (65-4B), 8, 10 (108-113-4A/4B), 9 (205-4B), 11 (169-4B), 12 (52-4B), 13 (Zone 2/3)

Figure 8-35. Dart points, Block B/C, level 5: Class 01 (No. 8, 18), Class 03 (No. 1-3, 7, 12), Class 06 (No. 5), Class 08 (No. 4), Class 09 (No. 13, 17), Class 12 (No. 6, 9 , 16, 19), Class 15 (No. 11, 14-15), Class 18 (No. 10), Class 20 (No. 20). Provenience: 1 (65-5B), 2 (173-5B), 3 (57-5B), 4 (55-5B), 5, 16 (59-5B), 6 (48-5A), 7 (57-5A), 8 (192-5A), 9 (59-5A), 10 (55-5A), 11 (56-5A), 12 (133-5A), 13 (116-5A), 14 (174-5B), 15 (101-5B), 17 (143-5B), 18 (55-5B), 19 (175-5B), 20 (49-5B)

Figure 8-36. Flake tools, arrowpoints, and dart points, Block B/C, level 2: notch (No. 1), distal utilized flake (No. 2), distal/lateral retouched piece (No. 3), unifacial perforator (No. 4), arrowpoints: Class 01 (No. 5, 11-12, 14, 17), Class 02 (6-7, 9-10), Class 03 (No. 13), Class 05 (No. 8), Class 07 (No. 19), unidentified (No. 15-16, 18), dart points: Class 01 (No. 21, 26-27), Class 03 (No. 23-24), Class 13 (No. 25), Class 17 (No. 28), Class 20 (No. 20). Provenience: 1 (167-2), 2, 7 (174-2), 3, 18, 22 (234-2), 4 (71-2), 5 (99-2), 6 (68-2), 8 (184-2), 9 (136-2), 10 (137-2B), 11 (187-2B), 12 (105-2), 13 (231-2), 14 (58-2), 15 (176-2B), 16, 20 (141-2), 17 (120-2B), 19 (188-2), 21 (197-2), 23 (59-2), 24 (113-2A), 25, 28 (55-2), 26 (133-2), 27 (111-2A) 
Figure 8-37. Arrowpoints and flake tools, Block B/C, Surface and level 1: a, Class 01

(No. 6, 8), Class 02 (No. 2, 12-14), Class 03 (No. 4, 10, 17), Class 04 (No.

11, 15), Class 05 (No. 1, 5, 7, 16), Class 08 (No. 3), Class 09 (No. 9), unidentified (No. 18); b, bilateral retouched piece (No. 1, 3), drill (No. 2), side scraper (No. 4). Provenience: a-1 (106-1), a-2, a-9, a-15 (213-1), a-3, a-14 (51-1), a-4 (123-1), a-5 (109-1), a-6 (116-1), a-7 (49-1), a-8 (135-1), a-10 (53-1), a-11 (148-1), a-12 (48-1), a-13, a-17 (115-1), a-16 (50-1), a-18 (56-1), b-1, b-2, b-3, b-4

(Surface, South rise)

Figure 8-38. Flake tools and arrowpoints, Block B/C, level 3: a, utilized flake (No. $1,5)$, unilateral retouched piece (No. 2, 6), distal/lateral utilized flake (No. 3), bilateral utilized flake (No. 4, 7), end scraper (No. 8); b, Class 02 (No. 2), Class 03 (No. 1, 4, 7), Class 05 (No. 3, 5-6). Provenience: a-1 (106-3B), a-2 (170-3B), a-3 (114-3B), a-4 (126-3A), a-5 (114-3A), a-6 (222-3A), a-7, a-8 (112-3A), b-1 (60-3A), b-2 (192-3A), b-3 (68-3A), b-4 (140-3A), b-5 (133-3A), b-6 (58-3A), b-7 (97-3A)

Figure 8-39. Cores, blank-preforms, and flake tools, Block B/C: a, distal/lateral utilized flake (No. 1, 4), utilized flake (No. 2), end-side scraper (No. 3), unilateral retouched piece (No. 5); b, blank-preform (No. 2-3, 6), multiple platform core (No. 1, 5), core fragment (No. 4). Provenience: a-1 (114-4B), a-2 (120-4B), a-3 (52-4), a-4 (106-4B), a-5 (51-4), b-1 (116-4A), b-2 (160-4A), b-3 (133-4A), b-4 (173-4A), b-5 (105-4A), b-6 (48-4A)

Figure 8-40. Flake tools and pigment stone, Block B/C, level 5: pigment stone (No. 5), utilized flake (No. 3), bilateral utilized flake (No. 1), composite uniface (No. 2), bifacial thinning flake with used edge (No. 4), distal/lateral utilized flake (No. 6). Provenience: 1 (142-5B), 2 (174-5A), 3 (63-5B), 4 (55-5A), 5 (107-5A), 6 (243-2B)

Figure 8-41. Cores, blank-preforms, and flake tools, Block B/C, level 3: blank-preform (No. 4, 6-7), opposed platform core (No. 1), core fragments (No. 2-3), bilateral utilized flake (No. 5), distal/lateral utilized flake (No. 8). Provenience: 1 (182-3A), 2 (123-3A), 3 (101-3A), 4, 8 (126-3B), 5 (196-3B), $6(133-3 \mathrm{~B}), 7$ (68-3B)

Figure 8-42. Cores, blank-preforms, and knife, Block B/C, level 5: blank-preforms (No. 1, 3, 5-11), knife (No. 2), core fragments (No. 4, 12). Provenience: 1 (63-5B), 2 (186-5B), 3 (136-141-5B), 4 (129-5B), 5 (134-5B), 6 (105-5B), 7 (52-5A), 8 (192-5A), 9-10 (106-5A), 11 (116-5A), 12 (54-5A)

Figure 8-43. Cores, blank-preforms, biface, and flake tool, Block B/C, levels 1-2: multiple platform core (No. 6, 8), opposed platform core (No. 2, 10), core fragment (No. 4), blank-preform (No. 1, 7, 9, 11), bifacial gouge (No. 3), unilateral retouched piece (No. 5). Provenience: 1 (163-1), 2 (121-1), 3 (57-1), 4 (51-1), 5 (98-1), 6 (129-1), 7 (221-2), 8 (142-2), 9 (55-2), 10 (127-2), $11(222-2), 12(124-2)$

Figure 8-44. Groundstone tools, South rise and Block F: hammerstone (No. 1), mano/pitted stone (No. 2), celt (No. 3-4). Provenience: 1-3 (surface), 4 (276-1) 
Figure 8-45. Southwest rise tools: adze (No. 1), indeterminate biface (No. 2-4, 7), end-side scraper (No. 5), dart point base (No. 6, 9), blank-preform (No. $8,10)$, unilateral retouched piece (No. 11), axe (No. 12). Provenience: 1 (Fea. 59), 2-4 (Fea. 62), 5 (Fea. 67), 6 (Fea. 75), 7-11 (Fea. 76), 12 (BHT 46)

Figure 9-1 Vessel and pipe forms represented at Hurricane Hill: a, simple bowl; b, carinated bowl; c, wide-mouthed bottle; d, narrow-mouth bottle; e, scalloped rim bowl; f, everted rim jar; g, vertical rim jar; h, barrelshaped bowl; i, long-stemmed Red River pipe

Figure 9-2 Engraved ceramic decorative elements \#010-\#014, \#021, \#022, \#025, \#026, \#028, \#034, \#036-\#039, \#041, \#045, \#053, \#066-\#068, \#070-\#072, \#074, \#091, and \#094.

Figure 9-3 Incised, incised-brushed, and incised-appliqued ceramic decorative elements: a, Incised: \#001, \#002, \#017, \#023, \#040, \#042, \#043, \#044, \#046, \#047, \#048, \#073, \#075, \#076, \#079, \#080, and \#090; b, Incised-Brushed: \#086, \#093; c, Incised-Appliqued: \#003

Figure 9-4 Punctated ceramic decorative elements \#004, \#005, \#015, \#019, \#031, 248 \#052, \#054, \#059, \#060, \#061, \#062, \#082, \#083, and \#089

Figure 9-5 Punctated-appliqued, punctated and noded, brushed-punctated, impressed-punctated, and incised-punctated-brushed ceramic decorative elements: a, punctated-appliqued (\#055); b, punctated-noded (\#077); c, brushed-punctated (\#081); d, impressed-punctated (\#063); e, incised-punctated-brushed (\#085).

Figure 9-6 Incised-punctated ceramic decorative elements \#006, \#008, \#016, \#018, \#020, \#024, \#027, \#032, \#049, \#050, \#051, \#056, \#057, \#058, \#064, \#065, $\# 078, \# 087$, and \#088

Figure 9-7 Brushed, brushed-trailed, impressed, and trailed ceramic decorative elements: a, brushed: \#007, \#029, \#030, \#033, and \#084; b, brushed-trailed: \#069 and \#095; c, impressed: \#035; d, trailed, \#009.

Figure 9-8 Frequency of decorated sherds and rim sherds by block and level

$\begin{array}{lll}\text { Figure 9-9 Rim shape and rim-lip profile. } & 260\end{array}$

Figure 9-10. Punctated, engraved-impressed triangle, and incised-punctated sherds from the North rise: $a-b$, punctated, $c-d$, engraved-impressed triangle (\#025); e-f, incised-punctated. Provenience: a, 32-2; b, 32-5; c, S34E20, $37 \mathrm{~cm}$; d, 257-6A; e, Fea. 2; f, 257-4B.

Figure 9-11. Plain and engraved rims from the North rise: a-e, plain rims; $f$, engraved rim, element \#026. Provenience: a, ST 4, North rise; b, 29-1; c, 34-3; d, 31-2; e, BHT 32; f, S36E33.

Figure 9-12. Engraved sherds from the North rise, Element \#026. Provenience: a, 25-6; b, 81-2.

Figure 9-13. Plain vessel section from Feature 53, Scrape Area 3. 
Figure 9-14. Incised-punctated and engraved sherds from the North rise:

a-d, incised-punctated; e-i, engraved. Provenience: a, 29-2/44-2; b, 259-6A;

c, 32-3; d, 257-5B; e, 32-1; f, 38-1; g, 37-3; h, 29-4; I, ST 11, historic locality 1.

Figure 9-15. Distribution of refitted sherds from Block A on the North rise 270

Figure 9-16. Punctated-noded, engraved, and engraved-punctated sherds from the 272

South rise: a, Maxey Noded Redware; b-e, g-j, engraved;

f, engraved-punctated. Provenience: a, 173-4A; b, 59-1; c, 115-2; d, 63-2;

e, 184-2; f, 174-2; g, 68-3A; h, 223-3A; I, 68-3B; j, 60-5B, Feature 12.

Figure 9-17. Incised, incised-punctated, and punctated sherds from the South rise:

a-d, incised; e-g, incised-punctated; $h-j$, punctated. Provenience: a, 192-5A;

b, 111-2; c, 113-3B; d, 66-2; e, BHT 38; f, 196-2B; g, 109-1; h, 66-1; i, 52-3B;

j, 168-2.

Figure 9-18. Plain rims from the South rise. Provenience: a, 134-3A; b, Surface; c, 170-5A;

Figure 9-19. Distribution of refitted sherds from Block B/C on the South rise

Figure 9-20 Differences and similarities between the blocks in ceramic decorative elements. Block A: a, cross-hatched incised; b, hachured incised; c-d, fingernail punctated; e, engraved with impressed triangles; $f$, diagonal engraved; $g$, parallel brushed; $h$, horizontal engraved; $I$, curvilinear incised-punctated; $\mathrm{j}, 1$, zoned incised-punctated; $\mathrm{k}$, corncob-impressed. Block B/C: a, cross-hatched incised; b, diagonal incised; c, e, cane punctated; d, fingernail punctated; $f, n$, Maxey Noded Redware; $g$, diagonal engraved; $h$, horizontal engraved; $i$, engraved pendant triangles; j, engraved ladder; k, overlapping brushed; $1-m$, zoned incisedpunctated. Block D/E: a, cane punctation; $b$, horizontal engraved; c, incised-punctated.

Figure 9-21. Photomicrograph of Group 1 sherds: a, Sample 8; b, Sample 30.

Figure 9-22. Photomicrograph of Group 1 sherds: a, Sample 9; b, Sample 20.

Figure 9-23. Photomicrograph of Group 2 sherds: a, Sample 4; b, Sample 31.

Figure 9-24. Photomicrograph of Group 2 sherd Sample 7.

Figure 9-25. Photomicrograph of Group 2 sherds: a, Sample 10; b, Sample 22.

Figure 9-26. Location of Caddoan sites with ceramic petrographic data.

Figure 9-27. Pipe sherds from Hurricane Hill: a, c, h, stem; b, butt end; d-g, bowls. Provenience: a, 252-3A; b, 148-2; c, 142-3B; d, 68-2; e, 62-3B; f, surface, South rise; g, 173-3A; h, 108-2A.

Figure 9-28. Distribution of pipe sherds in Block A

Figure 9-29. Large section of long-stemmed Red River pipe, Block B/C, Unit 144, $20 \mathrm{~cm}$ below surface. 
Figure 9-31. Miscellaneous clay items: a, clay lump/coil; b, clay ball; c, basketry impression on fired clay; d, sherd with drilled hole. Provenience: a, 242-3A; b, 91-2; c, 50-3A; d, Shovel Test 4, North rise.

Figure 10-1. PCA biplot of principal components 1 and 2 of the Northeast Texas data set. Ellipses represent 90 percent confidence level for membership in the four reference groups. Vectors connect the origin with the coordinates of each element

Figure 10-2. PCA biplot of principal components 1 and 3 of the Northeast Texas data set. Ellipses represent 90 percent confidence level for membership in the four reference groups. Vectors connect the origin with the coordinates of each element

Figure 10-3. Plot of logged elemental concentrations of lanthanum and chromium in the four reference groups. Ellipses represent 90 percent confidence level for membership in the four reference groups

Figure 10-4. Plot of logged elemental concentrations of antimony and tantalum in the Great Bend and Hurricane-2 reference groups. Ellipses represent 90 percent confidence level for membership in the groups

Figure 10-5. Plot of logged elemental concentrations of sodium and rubidium in the Titus and Hurricane-1 reference groups. Ellipses represent 90 percent confidence level for membership in the groups

Figure 10-6. Principal components 1 and 2 of the Northeast Texas data set (same as Figure 10-1) showing the unassigned, Natchitoches, and Spiro region specimens plotted along with 90 percent confidence ellipses for the four reference groups

Figure 10-7. Principal components 1 and 3 of the Northeast Texas data set (same as Figure 10-2) showing the unassigned, Natchitoches, and Spiro region specimens plotted along with 90 percent confidence ellipses for the four reference groups

Figure 10-8. Bivariate plot of lanthanum and chromium concentrations (same as Figure 10-3) showing the unassigned, Natchitoches, and Spiro region specimens plotted along with 90 percent confidence ellipses for the four reference groups

Figure 11-1. Landmarks on right deer ulna

Figure 11-2. Bone tools from Hurricane Hill: a, deer metapodial blank/preform (Type A); b, worked beaver incisor (Type X); c, ring-and-snap platform (Type G); d, metapodial tool (Type D); e, deer ulna platform (Type G).

Figure 11-3. Fishhook fragments: a-c, bone fishhooks (Type Q); d, fishhook fragment (Type P); e, incised bone fragment (Type M); f-h, fishhook fragments (Type P)

Figure 11-4. Distribution of bone tools in Block A on the North rise 
Figure 12-1. Burial 4, individual (B) from Feature 35. Six-year molar is fully occluded

Figure 12-2. Burial 3, Feature 3

Figure 12-3. Burial 3, note excessive cortical thickening and hyperactive endosteum

Figure 12-4. Burial 3, Feature 3: long bone with endosteal nodules and

Figure 12-5. Growth arrest lines from bone of Burial 4B. Several growth

Figure 12-6. Enamel lines in dentition of Burial 4B. Note six or seven enamel lines in

Figure 12-7. Dietary nomogram

Figure 12-8. Isotopic probability zones of dietary sources

Figure 13-1. Types of aboriginal fishing apparatus (from Stewart 1977)

Figure 15-1. General seasonal availability for charred wild plants

Figure 16-1. Principal components at Hurricane Hill and paleoenvironmental conditions

Figure A-I-1. Location of Area B within the Hurricane Hill site: a, Area B at the western end of the site; $b$, Area B, showing Backhoe trenches 50 and 51, Shovel Test 1, Unit 95, and trench profiles 1-9.

Figure A-I-2. Area B trench profiles 1-9.

Figure A-I-3. Unit 95: a, east wall profile (see key for Figure A-1-2); b, plan of floor at $34-40 \mathrm{~cm}$ bs, showing burned rock and Gary point (elevation in $\mathrm{cm} \mathrm{bs}$ ).

Figure A-I-4. Area B projectile points and tools: dart points (No. 1-4), cores (No. 5, 7-8), blank-preform (No. 6), indeterminate bifacial tool fragment (No. 9)

Figure A-

VI-1.

Rim shapes and rim/lip profiles.

Figure A-

VIII-1

Dart projectile point classes (1-24).

VIIII-2

Figure A-

VIII-2

Arrowpoint classes $(1-10,12)$.

VIII-2

Figure A-

XI-1

Block A, showing unit numbers and South and East coordinates.

Figure A- 
Figure A-

Figure A-

Figure A$\mathrm{XV}-2$

Phase II archaeological investigations at the Hurricane Hil site.

$\mathrm{XV}-4$

Figure AXV-3

Figure AXV-4

Figure AXV-5

Block $\mathrm{A}$ and Block A extension.

Figure AXV-6a

Block D excavations.

$\mathrm{XV}-8$

Figure A$\mathrm{XV}-6 \mathrm{~b}$

Block E excavations.

XV-8

Figure AXV-7

Block B, C, and F excavations. 


\section{Líst of Tables}

Table 4-1. Frequencies of cultural materials recovered from Phase I shovel tests 40

Table 4-2. Summary of excavations $\quad 42$

Table 4-3. Volume of flotation samples $\quad 44$

Table 4-4. Frequencies of cultural materials recovered from 1xI-m units during 47 Phase II and IV investigations

Table 5-1. Soil profile description, Profile 1, North rise $\quad 60$

Table 5-2. Gravel densities in the A-horizon of selected excavation areas $\quad 79$ on the North, South, and Southwest rises

Table 6-1. Classes, locations and frequencies of features 82

Table 6-2. Cultural affiliation of burials $\quad 85$

$\begin{array}{lll}\text { Table 6-3. } & \text { Frequencies of cultural materials recovered from burials } & 88\end{array}$

Table 6-4. Frequencies of cultural materials recovered from pits 93

Table 6-5. Frequencies of cultural materials recovered from hearths 95

Table 6-6. Posthole data for structures on the North rise 96

Table 6-7. Frequencies of cultural materials recovered from postholes 97

$\begin{array}{lll}\text { Table 6-8. } & \text { Summary statistics for posthole sizes } & 98\end{array}$

$\begin{array}{lll}\text { Table 6-9. } & \text { Posthole data for Structure A } & 107\end{array}$

$\begin{array}{llr}\text { Table 6-10. } & \text { Posthole data for Structure B } & 108\end{array}$

$\begin{array}{lll}\text { Table 6-11. Posthole data for Structure C } & 110\end{array}$

Table 6-12. Estimated inhabitants for structures on the South rise 111

Table 6-13. Data for cremations on the Southwest rise 112

Table 6-14. Data for other burials on the Southwest rise $\quad 114$

Table 6-15. Frequencies of cultural materials recovered from pits with organic-rich fill 117

$\begin{array}{lll}\text { Table 6-16. } & \text { Mean frequencies of cultural materials by feature class } & 118\end{array}$

Table 6-17. Relative frequencies of feature classes for selected Cooper Lake sites 119

$\begin{array}{lll}\text { Table 7-1 } & \text { Radiocarbon assays from the Hurricane Hill site } & 124\end{array}$

$\begin{array}{lll}\text { Table 7-2. } & \text { Archaeomagnetic and thermoluminescence (TL) dates } & 126\end{array}$ 
Table 7-3. Cultural periods represented in different areas of the Hurricane Hill site

Table 8-1. Lithic tool and debris frequencies for Block A 156

Table 8-2. Lithic tool and debris frequencies for Block D 156

Table 8-3. Lithic tool and debris frequencies for Block E 157

Table 8-4. Lithic tool and debris frequencies for Block B/C 157

Table 8-5. Lithic tool and debris frequencies for the Southwest rise 161

Table 8-6. $\quad$ Relative frequencies of dart point classes 163

$\begin{array}{lll}\text { Table 8-7. } & \text { Relative frequencies of arrowpoint classes } & 163\end{array}$

Table 8-8. Dart point measurements $\quad 164$

Table 8-9. Relative frequency of drinding, resharpening, serrating, beveling, and 166

Table 8-10. Arrowpoint measurements $\quad 171$

$\begin{array}{lll}\text { Table 8-11. Frequencies of coarse-screened lithic debris by size and cortex } & 174\end{array}$

Table 8-12. Relative frequencies of cortex and size data for a selected sample 175

Table 8-13. Identified lithic raw material types 176

$\begin{array}{lll}\text { Table 8-14. } & \text { Frequencies of local and non-local raw material types for a } & 178\end{array}$

Table 8-15. Relative frequencies of local and non-local lithic raw materials 180 for tools

Table 8-16. $\quad$ Relative frequencies of tools manufactured from non-local lithic 182 raw materials

$\begin{array}{lll}\text { Table 8-17. Distribution of arrow and dart points in Block D } & 183\end{array}$

Table 8-18. Distribution of arrow and dart points in Block E $\quad 183$

Table 8-19. Dart point beveling, resharpening, drinding, and impact fractures $\quad 188$

$\begin{array}{lll}\text { Table 8-20. } & \text { Distribution of shaped flake tools } & 190\end{array}$

Table 8-21. Distribution of unifacial and retouched flake tools 191

Table 8-22. Distribution of cores $\quad 196$

Table 8-23. Weight and frequency of daub, burned clay, and fire-cracked rock, 200 Block D 
Table 8-24. Weight and frequency of daub, burned clay, and fire-cracked rock, Block E

Table 8-25. Distribution of arrow and dart points in Block A

Table 8-26. Weight and frequency of daub, burned clay, and fire-cracked rock,

Table 8-27. Distribution of arrow and dart points in Block B/C

Table 8-28. Weight and frequency of daub, burned clay, and fire-cracked rock,

Block B/C

Table 8-29. Weight and frequency of daub, burned clay, and fire-cracked rock,

Southwest rise

Table 9-1. Ceramic attributes

Table 9-2. Relative frequencies and densities for the ceramic assemblages from the North, South, and Southwest rises

Table 9-3. Temper data for base and body sherds

Table 9-4. Relative frequencies of temper types for plain base and body sherds

Table 9-5. Ceramic attribute data for a selected sample of base sherds by

Table 9-6. Relative frequencies of surface treatments for sherd samples from Blocks $\mathrm{A}$ and $\mathrm{B} / \mathrm{C}$

Table 9-7. Relative frequencies for ceramic decorative types 255

Table 9-8. Frequencies of decorative elements 256

Table 9-9. Relative frequencies of rim shapes for Block A and Block B/C 259

Table 9-10. Relative frequencies of rim-lip profiles from the North and South rises

Table 9-11. Ceramic attributes of decoration, voids, matrix, and temper

$\begin{array}{lll}\text { Table 9-12. Grain characteristics } & 281\end{array}$

Table 9-13. Available petrographic data from Caddoan sites 292

Table 9-14. Paste composition of sherds from selected Caddoan sites in 294

Table 9-15. Frequencies of pipe fragments from Blocks $\mathrm{B} / \mathrm{C}$ and $\mathrm{F}$ on the

Table 9-16. Frequencies of pipe fragments from Block A on the North rise 
Table 9-17. Frequencies of Miscellaneous Clay Items

Table 10-1. Principal Components Analysis of correlation matrix of Caddo

Table 10-2. Hurricane Hill and Titus County analyses

Table 10-3. Other compositional analyses from the Caddo Area

Table 11-1. Bone artifacts from Hurricane Hill

Table 12-1. Human remains by age, sex, and feature

Table 12-2. Dentition available by feature

Table 12-3. Instances of observed pathologies by category and location

Table 12-4. Dental pathology by feature and tooth

Table 12-5. Stable isotope ratios from Bone Gel and Hydroxyapatite

Table 12-6. Frequencies of Zinc and Copper in selected human skeletal remains

Table 12-7. Cremations 343

Table 13-1. Vertebrate fauna recovered from Hurricane Hill $\quad 345$

Table 13-2. Number of identified animal bones in each excavation block 349

Table 13-3. Dietary contribution of major species 352

Table 13-4. Intersite comparison of minimum number of individual vertebrates, 353

Table 14-1. Number of identified specimens (NISP) and minimum number 356 of individuals (MNI) for each taxon recovered from the Hurricane Hill site, 41HP106

Table 14-2. Number of Identified Specimens (NISP) and Minimum Number of Individuals (MNI) for each taxon recovered from Block A of individuals (MNI) for each taxon recovered from Block B/C

Table 14-5. Number of identified specimens (NISP) and minimum number of individuals (MNI) for each taxon recovered from Block D

Table 14-6. Provenience information and measurements for modified freshwater mollusc taxa recovered from the Hurricane Hill site 
Table 14-7. Reported fish hosts for freshwater mussels recovered from the Hurricane Hill site

Table 15-1. List of initial sample contexts analyzed by Crites 365

Table 15-2. Weights of identified nut remains 367

Table 15-3. Maize cupule measurements 369

Table 15-4. Charredseeds $\quad 372$

Table 15-5. Uncharred seed types 374

Table 15-6. Summary of plant remains by component 375

Table A-1-1. Cultural materials from Area B, Hurricane Hill Site I-5

$\begin{array}{lll}\text { Table A-I-2. Projectile points, Area B } & \text { I-7 }\end{array}$

Table A-II-1. Frequency of historic period artifacts from the Hurricane Hill site II-3 


\title{
CHAPTER 1 , INTRODUCTION
}

\author{
Timothy K. Perttula
}

In September 1986, the Institute of Applied Sciences at the University or North Texas (IAS/UNT), began archaeological investigations in the Cooper Lake project dam embankment area. One component of that research effort was the intensive excavations completed at the Hurricane Hill site (41HP106), a large prehistoric site on a hill overlooking the South Sulphur River that was occupied from the Paleoindian to the Late Caddoan periods, that sat astride the dam axis (Figure 1-1). This research, long overdue in reporting, was one component of a much larger archaeological effort funded by the U.S. Army Corps of Engineers (COE), Fort Worth District, beginning in 1986 that dealt with the inventory, assessment and evaluation, and data recovery of the archaeological and cultural resources present in the proposed Cooper Lake construction areas and floodpools (e.g., Bousman et al. 1988; Jurney and Bohlin 1993; Jurney et al. 1993; Cliff et al. 1995; Green et al. 1996; McGregor et al. 1997; Fields et al. 1997).

The Cooper Lake dam and project area is located in Delta and Hopkins counties, Texas, about 160 $\mathrm{km}$ northeast of Dallas, Texas. The 2.6-mile long dam is located at river mile 23.2 on the South Sulphur River about 5 miles $(8 \mathrm{~km})$ southeast of the town of Cooper, Texas (Figure 1-2). The lake will inundate 22,740 acres at the flood control pool elevation of 446.2 feet above mean sea level and will extend upstream along the Middle and South Sulphur River valleys for a distance of approximately 14 miles to just east of the Hunt County line.

The Principal Investigator for the IAS/UNT embankment project was Dr. C. Reid Ferring, and Dr. Timothy K. Perttula was the Project Director responsible for the supervision of the fieldwork, laboratory analyses, and report preparation (as editor and main author) while at IAS/UNT. Field and laboratory crew size ranged from five to 30 persons, and a total of 1148 person-days was expended to complete the four phases of field investigations at the site. All records, files, and artifacts generated during the course of the project are presently curated at IAS/UNT in Denton, Texas.

\section{Report Organization}

The information presented in the remainder of this technical report of the findings on the archaeological investigations at the Hurricane Hill site (the name of the hill used by local residents of the Cooper Lake area) is prepared in accordance with the terms and conditions specified in the various delivery order scopes of works formulated by the COE. Recommendations for data recovery or mitigation-level report organization and guidelines developed by the Council of Texas Archeologists (1987) are also followed in the preparation of this technical report.

Following this introductory chapter, the cultural and environmental setting of the project area is presented in Chapter 2. The cultural setting is primarily a discussion of the history of archaeological research in the Sulphur River basin and Cooper Lake, as well as a general summary of the nature of prehistoric settlement and lifeways relevant to the past use of the Hurricane Hill site. The environmental setting reviews the modern characters of the climate, geology, soils, vegetation, and fauna, as well as provides an overview of the evidence for Late Holocene environmental change in northeastern Texas, particularly recent dendrochronological data from the Red River basin (see Stahle and Cleaveland 1994, 1995).

Chapter 3 presents the research orientation and overall perspective of the project at the time work began at Hurricane Hill. The primary concern of the research investigations is to address the formation, occupational character, and intrasite spatial structure of the Late Archaic/Early Ceramic and Early-Middle Caddoan period components at the site. Specific research problems to be addressed include: (1) intrasite spatial patterning of structures, features, artifacts, and ecofacts (i.e., faunal and floral remains), (2) subsistence strategies, (3) lithic and ceramic technology, (4) cultural chronology, (5) the exchange and importation of ceramic and lithic raw materials, and (6) the site's paleoenvironmental context. A discussion of the methods, techniques, and approaches utilized in field and laboratory settings for the Hurricane Hill investigations is presented in Chapter 4. 

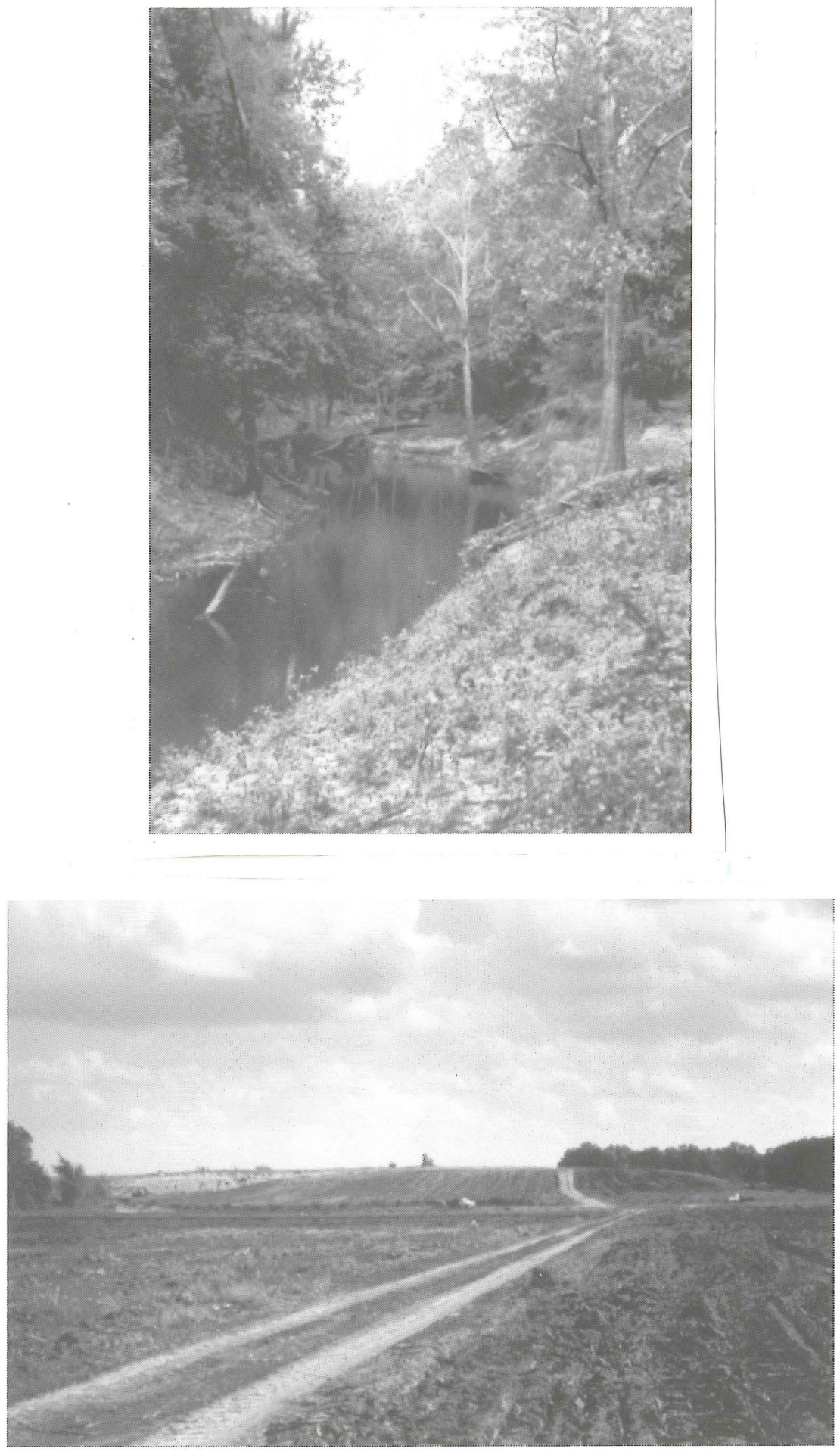

Figure 1-1. South Sulphur River and Hurricane Hill: a, South Sulphur River channel near Hurricane Hill; b, looking west at the Hurricane Hill site. Note Area B in lower right of hill, and North rise in upper left center. 


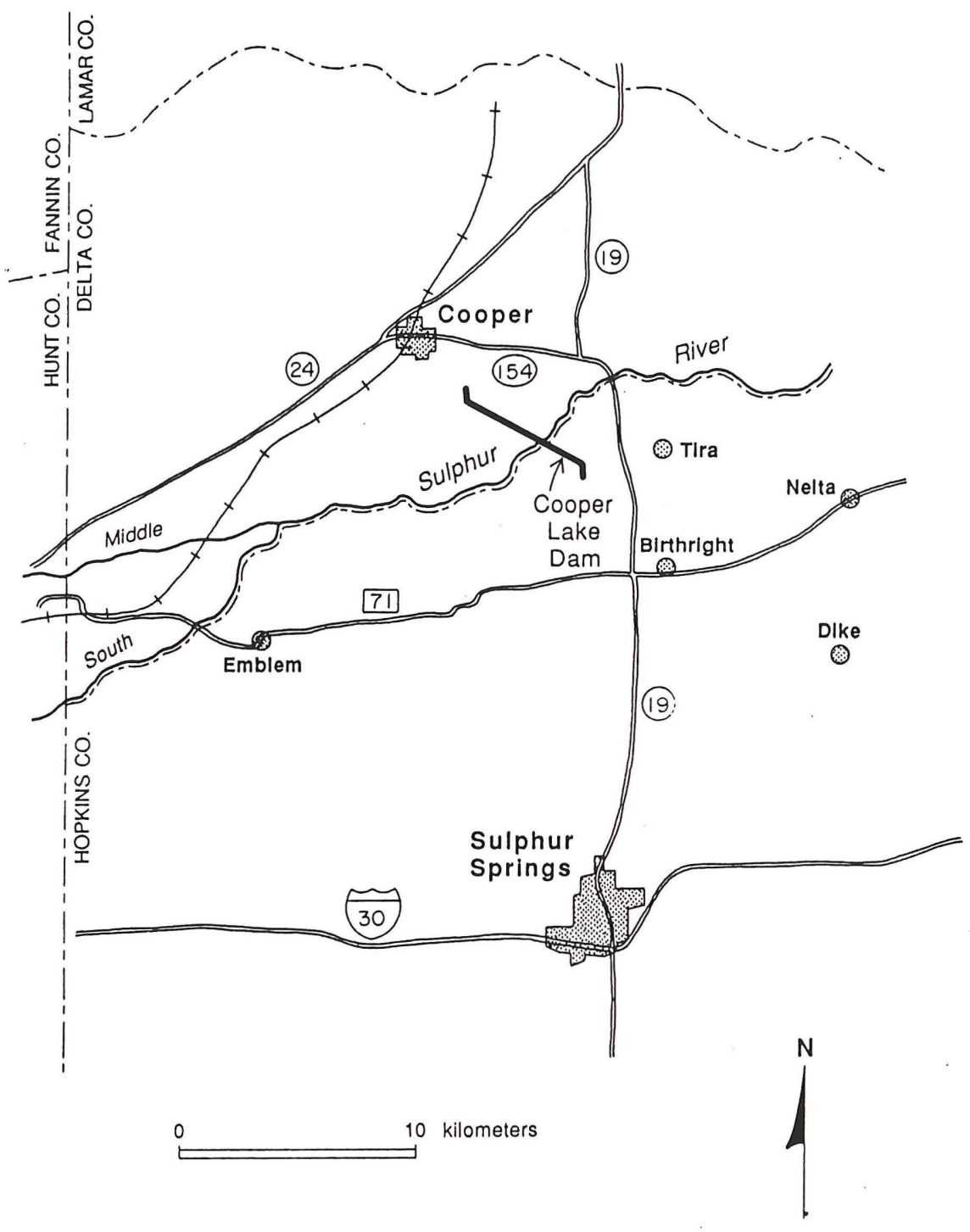

Figure 1-2. General location of the Cooper Lake dam embankment, Delta and Hopkins counties, Texas.

Chapters 5 and 6 present the basic building blocks of the site analyses and provide the cultural and chronological framework for all subsequent discussions in the report. The cultural and natural stratigraphy, types and distributions of features, and defined archaeological components (e.g., Johnson 1987:2), are discussed for each major provenience/topographic context at the site, leading up to an overview of the nature of each prehistoric occupation at Hurricane Hill.

Following the definition of the primary components and occupations in Chapter 7, including a discussion of the numerous radiocarbon, archaeomagnetic, and thermoluminescence dates from Hurricane Hill, the intrasite spatial structure of the Early Ceramic and Early-Middle Caddoan period components is reviewed. The focus of the spatial analysis is the distribution and density of the material culture and ecofactual remains and on their spatial relationship with the $200+$ features recorded at the site. Chapters 8 15 present more detailed discussions of the analytical findings resulting from the examination of the human skeletal remains, the molluscan fauna, zooarchaeological analyses, and paleobotanical remains, as well as the material culture remains from the different analytical units at the site. 
A synthesis of the archaeological record from the Hurricane Hill site is presented in Chapter 16, along with an overall project summary. The concern in this chapter is a comparison between Hurricane Hill, other contemporaneous and/or partially contemporaneous sites at Cooper Lake, as well as related sites in the Sulphur River basin and Northeast Texas (and elsewhere in the Caddoan Area), with respect to changes or continuities in settlement-subsistence strategies and lifeways between ca. 800 B.C. and A.D. 1400 .

Test excavations in Area B at Hurricane Hill, conducted during Delivery Order No. 13, are summarized in Appendix I. Appendix II provides a summary of the historic nineteenth and twentieth century cultural materials recovered during investigations at Hurricane Hill (see also Perttula 1989b). Appendix III presents the chemical concentration values from the sherds subjected to instrumental neutron activation analysis, and Appendix IV provides the radiocarbon dating results forms. Finally, more detailed and specific analytical information on key artifact and ecofactual remains and mechanical and chemical data from soil samples are provided in Appendices IV-XX, and are maintained on file at the Fort Worth District $(\mathrm{COE})$ and will be curated with the excavated materials.

\section{Cooper Lake Project Dam Embankment Investigations}

Initial archaeological investigations in the Cooper Lake project dam embankment area by IAS/UNT consisted of historic cemetery relocation studies. These investigations were conducted at the Tucker (41DT104) and Sinclair (41DT105) sites, two Anglo-American family cemeteries dating between 1860 and 1940. Results of these studies may be found in Lebo (1988) and Perttula and Lebo (1987). Concurrently, the Cooper Lake dam embankment, spillway, borrow pits, and diversion channels (totaling 865 acres) were intensively surveyed (Perttula 1988a) in late September 1986 under Delivery Order No. 13 of contract DACW 63-85-D-0066.

Preliminary assessments of all identified sites were to be made relative to eligibility for inclusion in the National Register of Historic Places following the criteria specified in 36 CFR Part 60, and subsurface backhoe trenching was to be done in areas designated for early construction, including the borrow pits and diversion channels. This latter task was proposed to follow up the encouraging geoarchaeological investigations carried out by Prewitt and Associates, Inc. at Cooper Lake from May through July 1986 (Bousman et al. 1988). Additionally, two prehistoric sites known in the dam embankment, one recorded in 1970 by Southern Methodist University (SMU) (Hyatt and Skinner 1971) as X41HP38 (referred to, herein, as Area B of 41HP106 [see Appendix I]), and the other thought then to be unrecorded but subsequently included as 41HP106 in the revised site forms submitted by IAS/UNT to the Texas Archeological Research Laboratory (TARL), were to be tested and evaluated for their eligibility for inclusion in the National Register of Historic Places. Test excavations were to consist of shovel tests, auger holes, and controlled excavation units measuring at least $50 \times 50 \mathrm{~cm}$.

The intensive survey and test excavations under Delivery Order No. 13 were completed on October 9, 1986. A total of 27 prehistoric and historic sites were recorded or re-recorded in the project area, 10 with prehistoric components (seven solely of prehistoric affiliation and three with prehistoric and historic components) and 17 with historic period components. Site assessments, based on the eligibility criteria specified in 36 CFR 60.4 for the National Register of Historic Places, as well as their integrity, context, and archaeological content, indicated that a number of prehistoric and historic sites in the dam embankment project area had the potential to contain important archaeological deposits that would necessitate additional test excavations to evaluate their research significance prior to the initiation and/or completion of the dam embankment construction activities (Perttula 1988a). Prehistoric sites recommended for additional work included Hurricane Hill (41HP106), the subject of the present report (Figure 1-3).

Initial test excavations at Hurricane Hill, referred to as Phase I investigations (see Chapter 4, this volume), were completed in 25 person-days. An additional 3 person-days were spent at Area B at Hurricane Hill (see Appendix I). Two historic period localities at the far eastern edge of the Hurricane Hill site were tested in November 1986 under Delivery Order No. 13, modification 1 (see Perttula 1988a:Figure 5-11), and Delivery Order No. 17 (Perttula 1989b). 


\section{Figure Redacted}

Figure 1-3. Hurricane Hill and vicinity, showing landforms and distribution of known prehistoric sites.

At the conclusion of the initial test excavations at the Hurricane Hill site, it was known that the prehistoric and historic archaeological deposits, although disturbed by bulldozer grubbing (see Figure 1-1b), covered an area of about 21 acres (88,440 square meters) in several different depositional and stratigraphic contexts. Shovel testing had identified a large and very well-preserved midden on one sandy rise (the North rise) that contained abundant faunal remains and lithic and ceramic artifacts. The midden appeared to be primarily of Early to Middle Caddoan period age (ca. A.D. 1000-1400), based on the recovered ceramics and arrow points, but the recovery of Late Archaic/Early Ceramic period diagnostics (primarily Gary points) exclusively in the lower depths of the midden suggested that the Early and Middle Caddoan archaeological deposits were stratigraphically overlying the Late Archaic/Early Ceramic period deposits. The earlier Late Archaic/Early Ceramic archaeological materials also appeared to be concentrated on several other rises at the site, but their unequivocal stratigraphic association in the North rise midden could not be determined on the basis of the limited Phase I investigations. Vertical and horizontal concentrations of burned rock in the lower depths of the midden did suggest, however, that the Late Archaic/Early Ceramic period component(s) contained preserved and discrete cultural features. This was considered not only of particular significance in the further investigation of intra-site spatial patterning at Hurricane Hill, but also increased the possibility of acquiring substantial new information on the character of Early Ceramic period settlements in the Cooper Lake area (e.g., Bousman et al. 1988; Story 1990; Fields et al. 1997).

The Early and Middle Caddoan period midden deposits were considered to be the most significant aspect of the Hurricane Hill archaeological record at the time the work began because of the preserved faunal and floral remains in the anthropogenic soils. The recovery and study of these remains was considered likely 
to be able to contribute important data in the development of a more comprehensive understanding of the prehistoric subsistence record in the Cooper Lake area as it was then known (subsequent excavations between 1991-1994 have added considerable prehistoric subsistence information for the aboriginal groups living in the South Sulphur River basin [see Cliff et al. 1995; Fields et al. 1997]). Furthermore, such subsistence information would help further the understanding of Caddoan subsistence strategies in the upper Sulphur River drainage, as well as northeastern Texas in general (e.g., Crane 1982; Perttula and Bruseth 1983; Perttula et al. 1983).

The overall topographic setting of the Hurricane Hill site, which is quite different from that of other Caddoan occupations in the Cooper Lake basin (see Bousman et al. 1988:Tables 3, 4, and 9; Fields et al. 1997), and the content of its archaeological deposits, were additional measures which suggested (Perttula 1988a:123) the preservation of significant information on changing temporal and spatial patterns of settlement at Cooper Lake. The investigation of settlement patterns and settlement system relationships is an important topic that received renewed efforts in the Cooper Lake area after the conclusion of the Hurricane Hill investigations (e.g., McGregor et al. 1997; Fields et al. 1997).

Excavations at the Hurricane Hill site were thought to not only complement the available prehistoric settlement evidence from Cooper Lake, but to contribute new and important information on changes in prehistoric locational choices for settlement over time. Horizontally and/or vertically stratified archaeological deposits were apparently preserved at Hurricane Hill. The functional, technological, and stylistic analyses of the prehistoric material culture assemblages from the site's different archaeological components, combined with certain intra-site characteristics (such as the presence or absence of features, middens, and burials, etc.), hopefully would lead to an assessment of settlement changes as well as differences in the intensity of use occurring on the site through time. These changes would be expected to relate to broader cultural changes occurring in the region during the Late Archaic/Early Ceramic, Early Caddoan, and Middle Caddoan periods.

Phase III excavations at Hurricane Hill were initiated on November 11, 1986, and continued through December 19, 1986, under Delivery Order No. 13 (Modification 1) and Delivery Order No. 17 issued by the COE. During this phase of investigations, additional work consisted of completing three small block excavations in two areas (the North and South rises) of the site (Figure 1-4a). A number of backhoe trenches were also excavated along the upland edge between the blocks and then south, across other areas of the site where sub-surface archaeological deposits seemed likely (see Chapter 4, this volume). The thrust of these investigations was to systematically recover a larger assemblage of faunal and paleobotanical remains from the midden deposits on the North rise, and to determine if other features, middens, or burials were preserved on different, but related, parts of the site. A total of 248 person-days were expended during the Phase III investigations.

Investigations were confined to a 2-acre area along the western edge of the Hurricane Hill site, primarily on the North, South, Southwest, and East rises (see Figure 1-4a). Outside these areas, prehistoric archaeological materials apparently occurred in shallow, plow- or bulldozer-disturbed contexts that lacked subsurface contextual integrity, middens, or preserved faunal/floral remains, or else were thoroughly mixed with late nineteenth and twentieth century trash deposits or structural debris (Perttula 1989b:117-132). Archaeological deposits along the eastern edge of the Hurricane Hill site are only a maximum of $40 \mathrm{~cm}$ in thickness, and are strewn with a surface mantle of Ogallala quartzite gravels.

The small block excavations on the North and South rises, in combination with the extensive site backhoe trenching, demonstrated that in situ, well-preserved archaeological deposits with features, faunal/floral remains, and human burials were present in three different parts of the Hurricane Hill site. Fine-screen and flotation samples were taken consistently from controlled proveniences within the excavation blocks to insure the systematic recovery of microfaunal and paleobotanical remains. However, at this phase of the investigations, it was recommended to the COE by IAS/UNT that a larger sample of these remains should be recovered from the North rise before concluding the archaeological fieldwork. The presence of human burials in the construction zone (i.e., the Hurricane Hill site lies entirely within the right-of-way of the dam embankment), and the probability that Middle Caddoan period house remains were preserved on the South rise, were primary and critical factors in recommending to the Fort Worth District of the COE that additional excavations be undertaken at the site. 


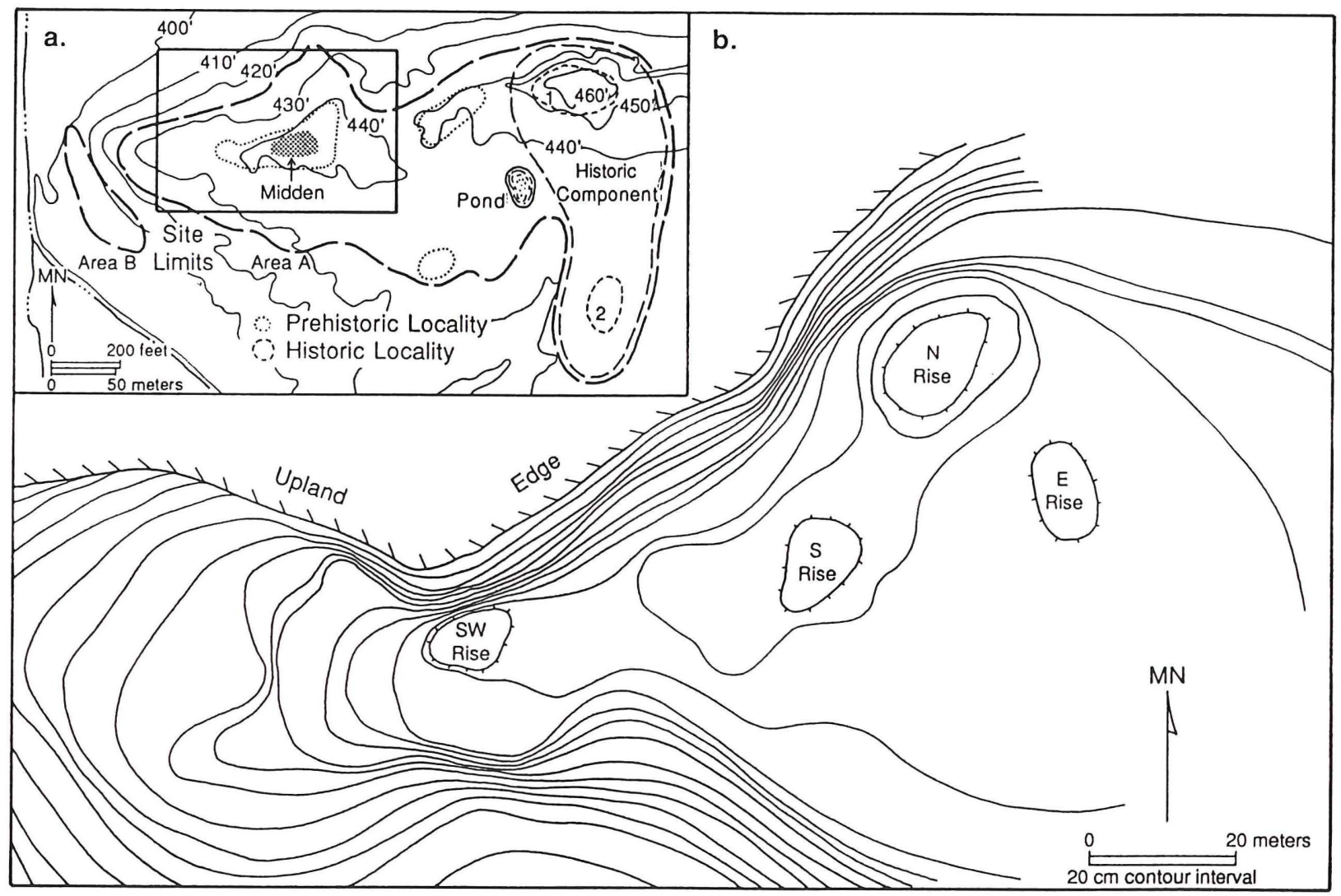

Figure 1-4. Hurricane Hill countour map: a, Hurricane Hill site; b, western end of Hurricane Hill, with East, North, South, and Southwest rises.

The COE concurred with the IAS/UNT recommendations, and continued excavations at Hurricane Hill concentrated on the intensive investigation of the North rise midden and the house/midden archaeological remains on the South rise. Phase III excavations included the areal expansion of the original three blocks, and the completion of three additional block excavation units on the two rises. These investigations ran from December 22, 1986, to March 25, 1987. Over $460 \mathrm{~m}^{2}$ were hand-excavated in a controlled manner during the intensive excavation effort at Hurricane Hill, with a total of 818 person-days spent during Phase III activities. In addition to exposing portions of five Caddoan houses or structures and excavating over 100 cultural features, a wide variety of prehistoric material culture remains were recovered from the Late Archaic/Early Ceramic and Early to Middle Caddoan period components at the site.

The distribution of human burials on the rises at Hurricane Hill, and the extent of the excavations conducted to date, strongly indicated that additional human remains were present on the site that had yet to be exposed or recovered during these investigations. The COE was of the opinion, to which the IAS/UNT archaeologists concurred, that an effort should be made to examine these areas, as well as other parts of the site (i.e., the Southwest rise), where human remains were expected to be encountered, and to properly record and remove them prior to the initiation of dam construction activities at Cooper Lake in August 1987. Because of the potentially large surface area involved--about $5000 \mathrm{~m}^{2}(1.25$ acres)--and COE scheduling considerations in completing the dam construction, a gradall was employed to selectively strip certain areas within the site in a final effort to locate human remains and other important cultural features.

During Phase IV investigations, the controlled site stripping was completed in two stages, the first on June 2-3, 1987, and the second between July 8-20, 1987. Fifty-four person days were spent in the grading operations. 
The initial grading in June 1987 on the North, South, and Southwest rises was to determine not only the feasibility of the grading at the site, but also to rapidly establish whether human remains and other kinds of important cultural features were indeed present in these locations. Delivery Order No. 24 restricted the initial grading effort to two days, and it was important, therefore, to examine a sample of topographic settings and archaeological deposits at the site should it become necessary to expand the grading effort. Approximately $500 \mathrm{~m}^{2}$ were graded in June 1987, exposing a limited number of features on the North and South rises, but at least 14 separate cultural features--including six possible burial features--were exposed late in the second day of the initial grading operations on the Southwest rise. The features could only be cursorily recorded and mapped, and none were completely excavated at the time. They were covered with plastic and soil until they could be fully examined.

It was the opinion of IAS/UNT archaeologists that additional investigations would be warranted at the Hurricane Hill site to record, map, and excavate all human skeletal remains and burial features exposed in the graded areas before it would be possible to consider the excavation effort to be completed at the site. One concern was the strong probability that unexposed human remains were present outside the scraped areas on the Southwest rise (based on the spatial extent of the known and probable burials exposed in June 1987), and that those exposed previously had not been examined by archaeologists in any comprehensive fashion. Additional grading was also recommended because of the potential for cultural features for the areas south of the South rise blocks, and between the South rise block and the North rise, that were then covered with backdirt from the hand excavations and backhoe trenching conducted in Phases I-III.

The COE issued Modification 1 to Delivery Order No. 24 on June 29,1987 . The final mitigation effort at the Hurricane Hill site was to include: (1) the excavation of all exposed human remains and burial features on the Southwest rise, (2) additional grading around the periphery of the burials in order to assure the controlled recovery and excavation of as many human burial features still existing at the site as possible, and (3) more grading in the vicinity of the Middle Caddoan period houses on the South rise. An additional $1100 \mathrm{~m}^{2}$ were stripped during July 1987 , and all features exposed in previous and final gradall operations were recorded and excavated (see Chapters 5 and 6, this volume). Final fieldwork activities at Hurricane Hill concluded July 20, 1987. At that point, it was agreed between the COE and IAS/UNT archaeologists that sufficient work had been accomplished in the data recovery effort to mitigate the adverse effects of dam construction on the site. 


\title{
CHAPTER 2, ENVIRONMENTAL AND CULTURAL SETTING
}

\author{
Timothy K. Perttula
}

The Hurricane Hill site is at the far western margins of a great expanse of deciduous forest and woodlands that reaches to the Atlantic ocean (Brown et al. 1998:Figure 5). More specifically, this prehistoric site appears to have been situated within the Trans-Mississippi South, a biographic concept proposed by Schambach (1998:xi-xii) in 1970, an area whose "culture history appears to have been dominated by...Eastern Woodland-oriented peoples from the early Archaic period on" (Schambach 1998:xii). Just to the west of the Trans-Mississippi South lie bands of grassland prairie that extend across the broad interfluves between the South and North Sulphur rivers, and between the North Sulphur and the Red River to the north (Figure 2-1).

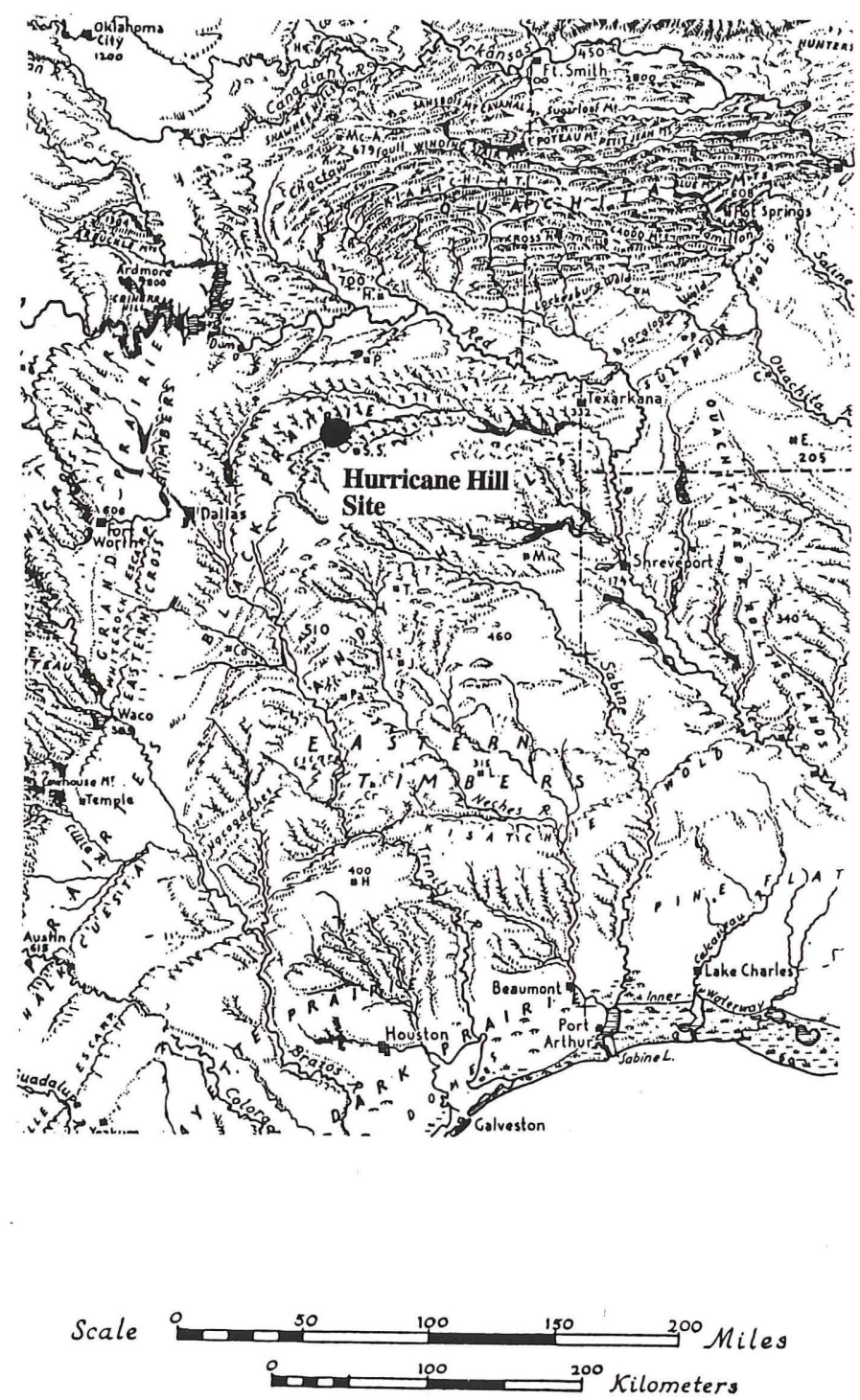

Figure 2-1. Hurricane Hill within Northeast Texas (source map adapted from Erwin Raisz, Landforms of the United States, 1957). 


\section{Environmental Setting}

The Cooper Lake project area lies in the Upper Sulphur River basin, within the valley of the South Sulphur River. The Sulphur River, including the North, Middle, and South Sulphur rivers, is a major eastward-flowing tributary to the Red River, and at the time of initial Anglo-American and European settlement in the 1820s and 1830s, was commonly referred to as the Sulphur Fork of the Red River (Flores 1985:41; Strickland 1937:206).

The Middle and South Sulphur rivers join about $15 \mathrm{~km}$ above the dam axis, while the South and North Sulphur rivers merge $25 \mathrm{~km}$ downstream from the dam, at the Hopkins and Franklin county lines, to form the main branch of the Sulphur River (see Figure 2-1). The three forks of the Sulphur River, which originate in the Blackland Prairie between Bonham and Greenville, Texas, flow roughly east-northeast through the West Gulf Coastal Plain, then turn to the east-southeast crossing the more resistant Eocene-age Wilcox Group formations in Titus, Morris, and Cass counties. The Sulphur River empties into the Red River at the southern end of the Great Bend of the Red River in Southwest Arkansas. In the project area, the South Sulphur River trends northeast to southwest, with a broad floodplain and a well-developed meander system. At least four temporally different channel sets are known in the South Sulphur River valley for the Late Pleistocene/Late Holocene period (Bousman et al. 1988).

Delta and Hopkins counties lie near the western margins of the Gulf Coastal Plain, a physiographic province that is related to ancestral marine and deltaic processes of the ancestral Gulf of Mexico (Sellards et al. 1932). The present land surface has a generally southeasterly dip, with sedimentary bedrock formations of Cretaceous and Eocene deposits laid down paralleling the margins of the ancient receding coastline. The regional topographic trends control drainage and major valley configurations within the Sulphur River basin; this restricts most drainage into the three Sulphur River forks to tributaries that enter from the north (Bousman et al. 1988), such as Big Creek and Doctors Creek in the vicinity of the Cooper Lake dam axis. In general, the land surface in the project area is undulating to gently rounded, with low hills and flat uplands representing the long-term erosion and weathering of limestone, sandstone, and marl bedrock (Bureau of Economic Geology 1979).

Hurricane Hill, and the archaeological deposits located upon it, is one of the larger hills in the Cooper Lake project area, and it dominates the local topography because of its size, prominent escarpments to the north and west, and the fact that it projects into the floodplain of the South Sulphur River. The crest of Hurricane Hill is 441 feet amsl, approximately 51 feet $(15.6 \mathrm{~m})$ above the floodplain of the river. An abandoned channel of the South Sulphur River ran, apparently, at the base of the hill at one time, but based on the inspection of $\mathrm{COE}$ trenches along the dam embankment and spillway right-of-ways, the channel has been buried by alluvial and colluvial deposits.

\section{Climate}

The modern climate of the Cooper Lake area is humid mesothermal with average winter temperatures of $45^{\circ} \mathrm{F}$ and average summer temperatures of $81^{\circ} \mathrm{F}$. The first freeze in winter typically occurs in mid-November, and the last freeze is in late March. The growing season averages 228-238 days (Lane 1977; Ressel 1979).

Mean annual precipitation currently averages about $115 \mathrm{~cm}$ for this part of northeastern Texas. Periods of maximum rainfall occur in the spring and fall seasons, with periods of lower precipitation occurring during the months of July and August. Rainfall frequently occurs in the form of local thunderstorms, and droughts are common phenomena in the summer months. Less than 23 percent of the total annual precipitation falls during July-September.

\section{Geollogy}

Midway Eocene and Upper Cretaceous formations are exposed throughout the Cooper Lake project area (Figure 2-2). The undifferentiated Midway Group is of Lower Eocene age (60-70 million years ago) and is a 50 to 150-meter thick deposit of sandstone, shale, and limestone with thin beds of clay, silt, and glauconitic sand. The Navarro Group is composed of calcareous, clayey, and glauconitic shale, sandstone, and marl deposits with marine megafossils abundant locally. The Navarro Group is exposed in a broad band 
at the Cooper Lake dam and parallels the South and Middle Sulphur valley walls through the project area. Hurricane Hill is situated on an outcrop of the Navarro Group which, locally, is composed primarily of sandstone grading to a marl deposit with marine megafossils. Calcareous, clayey, and sandy deposits characterize the Upper Cretaceous Neylandville formation present along the north valley wall of the Middle and South Sulphur rivers (Bureau of Economic Geology 1979).

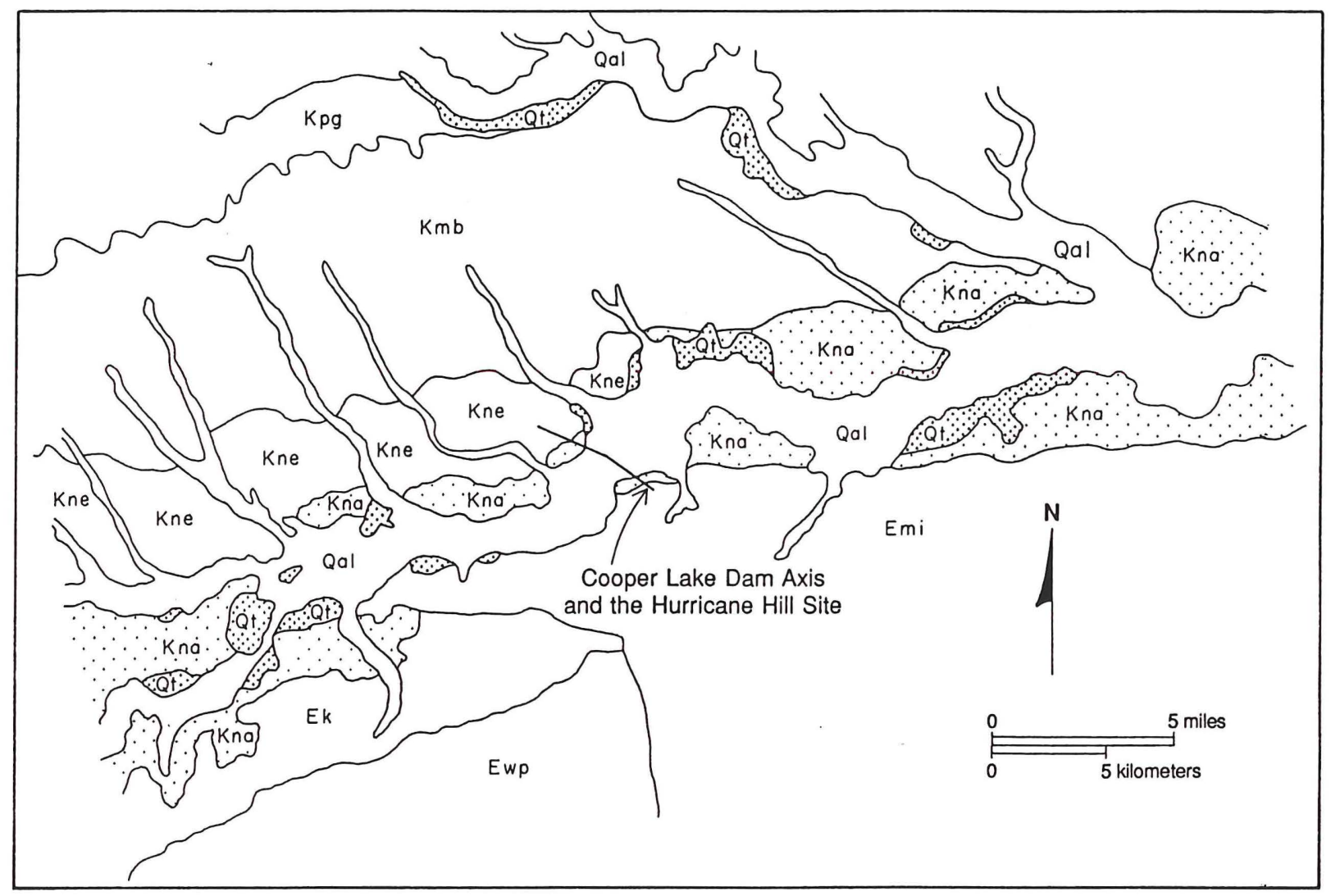

Figure 2-2. Geologic map of the Three Forks of the Sulphur River.

More recent fluvial deposits, including Pleistocene and Holocene age alluvial terraces, are present along the forks of the Sulphur River and its largest tributaries (see Figure 2-2). The radiocarbon dating of the humates in buried soil horizons at a series of localities at Cooper Lake has shown that these deposits range in age from 13,300-640 B.P. (Bousman et al. 1988). The alluvial deposits are clearly associated with distinct paleo-channels and meander beds, noted from surface and aerial photo reconnaissance techniques. These probably represent different fluvial systems in the evolution of the South Sulphur River valley (Bousman et al. 1988:Figure 14).

Present at Cooper Lake are extensive upland lag deposits of Uvalde gravels (Banks 1990; Byrd 1971). These deposits contain pebble and cobble-sized chert, quartzite, and silicified wood gravels that prehistoric inhabitants of the area used in the production of stone tools. Bedrock sources of knappable lithic raw materials are unknown in the South Sulphur River, and sources of stone would have only been available locally in the upland gravels or in stream gravels reworked in fluvial deposits. Hurricane Hill has one of the larger upland gravel deposits in the project area, being concentrated on the crest of the hill in the vicinity of historical locality \#1 (see Figure 1-4; see also Perttula 1989b), but extending east 1 kilometer or more towards Vaden Creek. 
Soils within the Cooper Lake project area are loamy, silt loam, clay loam, and clay deposits with a moderately high alkaline content. They derive primarily from underlying bedrock facies of the Eocene and Upper Cretaceous groups (Fisher 1965).

Upland soils in the project area are divided into prairie or woodland series and/or associations. While, in general, prairie soils are more extensive at Cooper Lake (see Doehner et al. 1978), forested loam and silt loam soils are present on certain upland landforms adjacent to the South Sulphur River and Doctors Creek. Prairie soils are usually restricted to broad interstream divides, ridgetops, and along upper ridgeslopes. Forested soils occur in more dissected settings, as well as on alluvial terraces and certain narrow ridgetops, such as Hurricane Hill.

Prairie soils are included within the Crockett loam, Wilson silt loam, Normangee clay loam, Heiden clay, Leson clay, Ellis clay, Bazette clay loam, and Ferris clay series and/or associations (Lane 1977; Ressel 1979). These soils are deep, clayey to loamy soils formed in calcareous, shaly, and clayey deposits. With the exception of soils that formed on ridge slopes (i.e., Normangee clay loam, Ellis clay, and Ferris clay), these prairie soils are arable soils suitable for the modern cultivation of corn, cotton, and sorghum once the thick tall-grass prairie sod is broken up during tilling. Corn yields of 40-60 bushels per acre and cotton yields of 300-400 pounds of lint per acre are estimated for these soils using modern cultivation techniques (Lane 1977:Table 2; Ressel 1979:Table 4). The most fertile prairie soil in the immediate area is the Heiden clay. This vertisolic soil is restricted to a small patch near the South Sulphur River (see Perttula 1988a:Figure 2-2).

Woodland soils probably include the Annona loam, Benklin silt loam, Freestone-Hicota complex, and Woodtell loam series and/or associations. These soils have relatively shallow A-horizons covering argillic clay B-horizon subsoils. They are only moderately acidic, and if not subject to erosion, deflation, or the severe leaching of nutrients, are arable soils where corn and/or cotton can be cultivated. Corn yields of 45-60 bushels per acre are estimated for the Annona, Freestone-Hicota, and Woodtell soils. Benklin silt loam, formed in alluvial deposits preserved in terraces along Doctors Creek and the South Sulphur River (Ressel 1979:10, 50), is a much deeper and fertile woodland soil. It is estimated that corn yields of 85 bushels per acre and cotton yields of 650 pounds of lint per acre are obtainable from Benklin silt loam soils (Ressel 1979:Table 4).

Soils atop Hurricane Hill have been classified as Woodtell loam, 2-5 percent slope (Lane 1977:24). These soils are deep, gently sloping and well-drained upland soils formed under a plant community of hardwoods (oak-hickory) and native tall grasses. The typical profile, as described by Lane (1977:23), is a 9inch $(23 \mathrm{~cm})$ thick acidic loam A-horizon overlying a 49-inch $(128 \mathrm{~cm})$ thick, red and gray clay B-horizon. A clay loam and shale C-horizon is exposed 58 inches $(151 \mathrm{~cm})$ below the surface.

Since the relatively unconsolidated loam woodland soils are found primarily on sloping to gently sloping upland landforms, colluvial deposits may be expected on lower ridgeslopes and toe-slopes at the base of upland settings (Bousman et al. 1988). While Middle to Late Holocene period colluvial deposition has been documented at several sandy mantle localities in eastern Texas and Northwest Louisiana (Heinrich 1986; Perttula et al. 1986; Fields 1987, 1989, 1990; Thoms 1993), it is likely that the majority of the colluvium deposited at Cooper Lake probably dates to historic times (after 1840), following the forest clearance and cultivation of these upland soils. Sites 41HP116 (W. S. Long \#2) (Perttula 1988a:51-58; McGregor and Martin 1997:93-102) and 41HP106-B (Hurricane Hill Area B) (see Appendix I) have been buried by colluvial deposits that probably eroded from Hurricane Hill in historic times. A combination of colluvial and alluvial deposition also appears to be responsible for the roughly stratified archaeological deposits noted at W. S. Long \#2 that date from ca. 200 B.C.-A.D. 1400.

\section{Vegetation}

The Upper Sulphur River basin lies within the modern distribution of the Blackland Prairie and Post Oak Savannah (Kuchler 1964; Vines 1982). Within the major stream valleys is a riparian floodplain forest (Figure 2-3). 


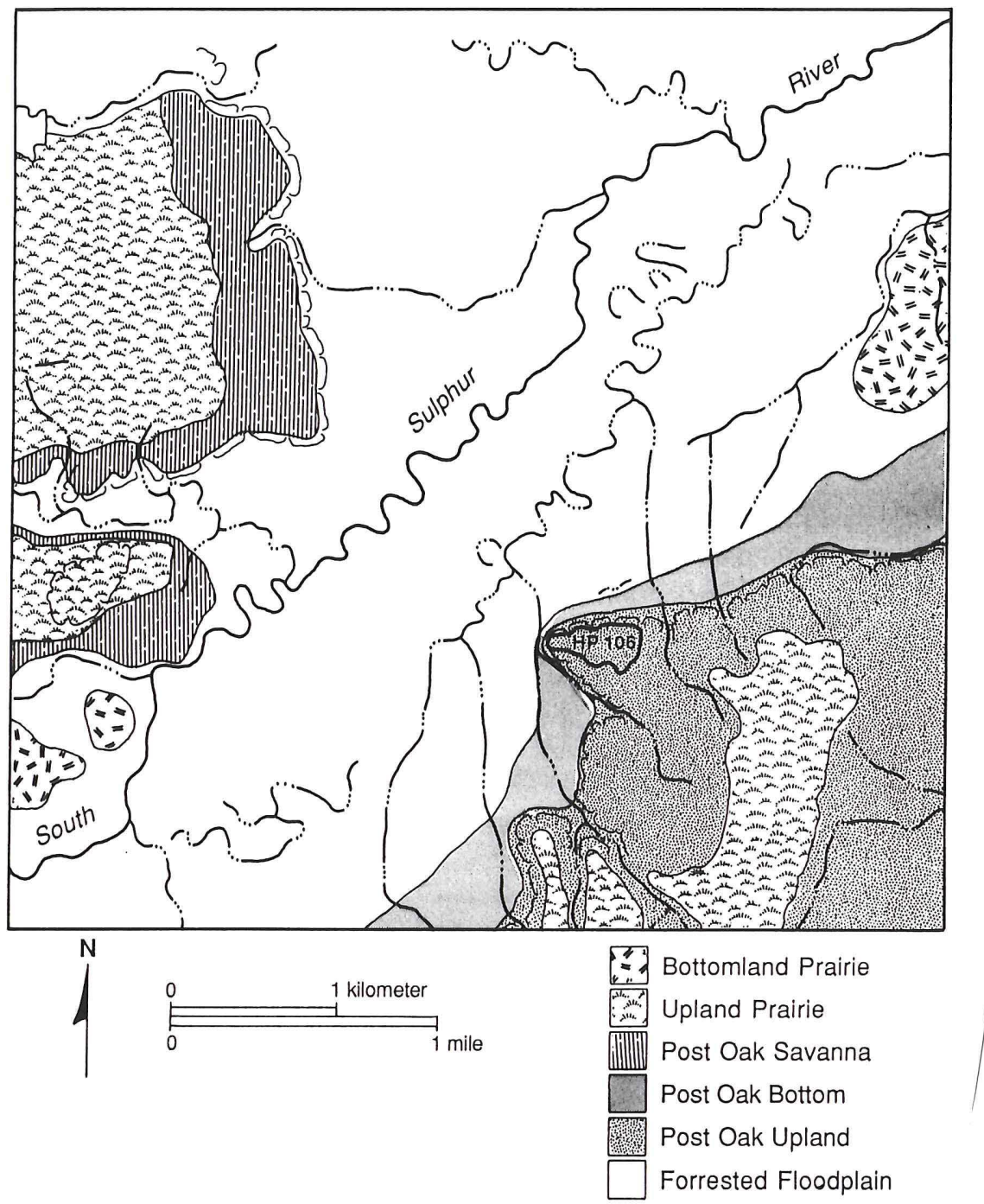

Figure 2-3. Biotic communities in the vicinity of Hurricane Hill (after Moir et al. 1997).

The Blackland Prairie is a tall-grass prairie community formed in association with the clayey soils found in the Upper Sulphur River basin. It is composed primarily of big bluestem (Andropogongerardi), little bluestem (A. Furcatus), switchgrass (Panicum virgatum), and Indiangrass (Sorghastrum nutans) (Gould 1975). The tall-grass prairie is generally restricted to upland topographic settings, but as Jordan (1973) has pointed out, the distribution of prairie and woodland along the margins of the Blackland Prairie and Post Oak Savannah is an intricate mosaic of biotic communities. In a letter written in 1833, the tallgrass prairie habitat in the vicinity of Clarksville (in Red River County) was described in these terms:

...A few miles south of this place [Pecan Point in northeastern Red River County] is the beginning of a prairie country, or rather a country of prairie and timber interspersed in about equal proportions...The prairies are situated between these creeks [draining south into the Sulphur River]. The creeks are skirted by narrow bottoms, with all the growths common to bottom land, oak, walnut, cane, etc., ascending from these you meet 1st, Post oak land, generally of very little value except for the Timber, and then come the prairies, which are the most elevated part of the country, with black, rich soils well 
adapted to the cultivation of corn or cotton and producing fine pastures. The prairies are of various sizes, from 1,000 to 100,000 acres...its boundaries are much more extensive -- it imbraces [sic] the head waters of the Sulphur Fork which has its source 80 miles above the point which I have seen [Letter from George W. Smythe to Samuel Gregg, quoted in Strickland 1937:206-207; brackets added].

In the immediate Cooper Lake area, the Post Oak Savannah is confined primarily to a discontinuous band of loam and silty loam upland soils of the Annona-Freestone-Woodtell association (see Figure 2-3). It is analogous, however, to the broader belt of Post Oak Savannah formed in the sandy Eocene Wilcox Group soils covering southern Hopkins County, the headwaters of White Oak Bayou, and the upper portions of the Sabine River basin (Kuchler 1964). The Post Oak Savannah community is an open-canopy woodland with a tall-grass understory that appears to mark a natural biotic transition zone between the Blackland Prairie to the north and west, and the more mesic Oak-Hickory-Pine Forest to the east and south. It is a medium-tall to tall broadleaf deciduous forest with widely spaced post oak (Quercusstellata), blackjack oak (Q.marilandica) and hickory (Carya spp.). Cedar (Juniperus virginiana), Bois d'arc (Maclura pomifera), a variety of oak species, cedar elm (Ulmus crassifolia), and hackberry (Celtis laevigata) are additional overstory species expected in the modern Post Oak Savannah, although it is likely that Bois d'arc is a modern introduction to the area. The cessation of natural firing in the grasslands has encouraged the expansion of cedar in the Cooper Lake area. General Land Office (GLO) survey field notes from the Cooper Lake area, summarized by Moir et al. (1997:6-9 and Figure 1-4), indicate that Hurricane Hill is located in the post oak uplands, dominated by post oak, hickory, and ash (Moir et al. 1997:Table 1-1). Slopes leading to the overflow areas of the South Sulphur River were also covered with post oak. Upland prairies were apparently located on more clayey soils on linear, dissected ridgecrests to the east and south of Hurricane Hill (see Figure 2-3).

The riparian floodplain forest is the more complex woodland habitat in the modern Blackland Prairie/Post Oak Savannah ecotone. Its composition is conditioned by both hydrological factors and periods of overflow along the Sulphur River and its tributaries. Bottomland communities include hardwood forests, wetlands, and aquatic habitats, with the latter two being restricted primarily to sloughs, channel lakes, old channels, and other patchy settings within the South Sulphur River floodplain. Most portions of this habitat have been drained or altered as a result of channelization and levee construction on the forks of the Sulphur River, but historic-era descriptions are available that provide a cursory depiction of the climax riparian forests in the valley (e.g., Flores 1985:41-43). Common species represented in these riparian floodplain forests include water oak ( $Q$. nigra), pecan (Carya illinoensis), ash (Fraxinus spp.), hickory, hackberry, elm, cottonwood (Populus deltoides), overcup oak (Q. lyrata), sycamore (Plantanus occidentalis), and willow (Salix nigra) (see Doehner et al. 1978). Jurney (1987) provides a thorough description of the riparian forests in the Trinity River basin, which should also be analogous to the Cooper Lake area bottomland forests. Herbs, ferns, shrubs, cane (Arundinariagigantea), forbs, successional weeds, and sedges are common components of the understory vegetation in riparian floodplain forests.

GLO records (Moir et al. 1997:Table 1-1) indicate that in the mid-nineteenth century the riparian floodplain forest was dominated by elm, post oak, ash, hickory, hackberry, and pin oak, as well as a variety of other oaks. Small bottomland prairies covered with tall grasses were present, apparently, in the South Sulphur River valley on elevated sandy knolls near present and/or old channels of the river (see Figure 2-3). A post oak bottom was distributed along the valley wall of the south side of the South Sulphur River (Moir et al. 1997:Figure 1-5), in an area where colluvial deposits may be expected to have been common.

\section{Fauna}

The Cooper Lake area is within the Texan biotic province defined by Blair (1950). The biotic province includes a wide variety of mammals, reptiles, and amphibians. Many of these species reach their western or eastern range limits within the boundaries of East Texas, although the character of the fauna along the eastern edge of the Texan province is not significantly different from that occurring throughout the more southeastern Austroriparian province.

Common vertebrate species exploited by prehistoric and historic inhabitants of the Sulphur River basin include deer, cottontail rabbit, box turtle, turkey, raccoon, and fox squirrel (Bousman et al. 1988:37). Archaeological excavations in Early Caddoan period deposits at Cooper Lake also suggest that freshwater 
fish and mussels were commonly eaten (Henderson 1978a; McKinley and Bruseth 1978). Even though extensive prairies were nearby, only limited evidence for hunting activities there is demonstrated in the Cooper Lake zooarchaeological assemblages. Prairie exploitation is restricted to a few individuals of pronghorn and bison (see Henderson 1978a). Historical accounts, however, suggest that bison (and wild horses or mustangs) were abundant on the Sulphur River in the early nineteenth century (Flores 1985:43, 114).

\section{Holocene Environmental Change}

At present, the nature of Holocene environmental changes in northeastern Texas is poorly understood because of the lack of study, and the absence of substantial amounts of primary paleoenvironmental evidence from buried soils, pollen, faunas, and stable isotope analyses (e.g., Bryant and Holloway 1985; Collins and Bousman 1993; Ferring 1995). Much of the paleoenvironmental research completed in Texas over the last twenty years has been in Central Texas, the High Plains, and the southern Plains (Bousman and Brown 1998:105-107), although important evidence of Late Pleistocene and Holocene climatic change has been obtained by Ferring (1995; see also Humphrey and Ferring 1994) from the multidisciplinary investigations of the Aubrey Clovis site on the Elm Fork of the Trinity River in Denton County, Texas.

An early attempt at paleoenvironmental reconstruction for the last 5000 years in the Tall-Grass Prairie/Post Oak Savannah habitats in eastern Texas was completed at Richland-Chambers Creek in Navarro and Freestone counties (Bruseth et al. 1987). Generally comparable settings exist between Cooper Lake and Richland-Chambers Creek in that both areas along the eastern edge of the Blackland Prairie and along the margins of the Post Oak Savannah.

Bruseth et al. (1987:47) outlined three basic environmental periods at Richland-Chambers Creek covering the periods between 3000 B.C. and A.D. 1820. Environmental Period I (3000 B.C.-A.D. 500) was suggested to have been wetter than present, although how much moister was not specified. Increased effective moisture would have led to an expansion of the open-canopy Post Oak Savannah throughout the upland habitats now oocupied by tall-grass prairie. The riverine habitat would have comprised a complex successional mosaic, rather than a mature climax forest, due to increased flooding and alluvial deposition (Bruseth et al. 1987:47).

Conditions during Environmental Period II (A.D. 500-1200) were thought to be warmer and drier than during the previous three millennia, leading to a recession of the Post Oak Savannah eastward and the formation of a prairie habitat in the Trinity River basin. However, Bruseth et al. (1987:47) point out that since the woodland recession would have been from west to east, the prairie environment may not have reached the eastern margins of the present Blackland Prairie until "late in this, or even into the next, period." The riparian floodplain environment would have maintained its overall complexity through the period, and, in terms of exploitable resources, Environmental Period II would not have differed significantly from Environmental Period I.

Bruseth et al. (1987:47) also suggested that much drier conditions characterized Environmental Period III (A.D. 1200-1820), and that the tall-grass prairie of the Historic period was probably established at this time. Upland grassland habitats would have dominated the regional vegetational composition, although upland slope forests and mosaics of forest and prairie were documented by pioneer settlers (Jordan 1973, 1981). These environmental conditions were considered prime habitats for early pioneer settlement in the Sulphur Fork country of Northeast Texas (Jordan 1973:240, 251). The riverine habitat may have become less complex due to the development of a climax forest, but it is likely that, because of their size and stream dynamics, the South and Middle Sulphur rivers were less susceptible to reduction in environmental potential than smaller streams, such as Richland and Chambers creeks.

More recent paleoenvironmental research has substantially modified and refined our understanding of paleoenvironmental changes in this part of Texas, and extended the record of climatic change back to ca. 14,000 years ago or more. In particular, pollen data from Ferndale Bog (Holloway 1994; see also Ferring 1995) in the Ouachita Mountains of southeastern Oklahoma, and from several bogs in Central Texas (Bousman 1998), indicate that the Late Pleistocene climate (ca. 11,000-14,000 years ago) was cool and dry, and probably supported a grassland steppe. By 11,000 years ago, as the climate became warmer and wetter, 
oak woodlands or oak savanna habitats would likely have been present throughout much of eastern Texas (and north into Oklahoma). These woodlands were maintained for several thousand years--perhaps until 7500 years ago, although Bousman (1998:Figure 4) notes a period of open, grassland vegetation in Central Texas between 9500-8750 B.P. The Ferndale Bog pollen diagram (see Ferring 1994:Figure 4.5) also points to a more open and grassy setting, based on decreasing oak pollen and lower pollen influx between ca. 80009200 years ago.

Between ca. 7500-5000/4000 years ago, the Middle Holocene climate was quite warm and dry, and Ferring (1995:24) suggests this was a period of significant reduction in available biomass for Native American hunter-gatherers in the region. In the Ferndale Bog area of southeastern Oklahoma, the vegetation was an oak-hickory-pine woodland, while farther to the south and west in Central Texas, grasslands were dominant. Given Cooper Lake's transitional setting, it is likely that grasslands were expanding at the expense of upland woodlands (cf. Ferring 1995:26), and would have comprised a larger component of the local ecology. Bousman's (1998:210) palynological analyses led him to conclude that the grass cover was greatest--and the climate the driest--between 5500-4500 B.P., while Ferring (1995:24) places the very dry and warm episode between ca. 6500-5000 B.P. This is the same temporal period as there are grasslandenriched (C4 grasses) stable isotope values from humate samples in the Sulphur River basin (Figure 2-4).

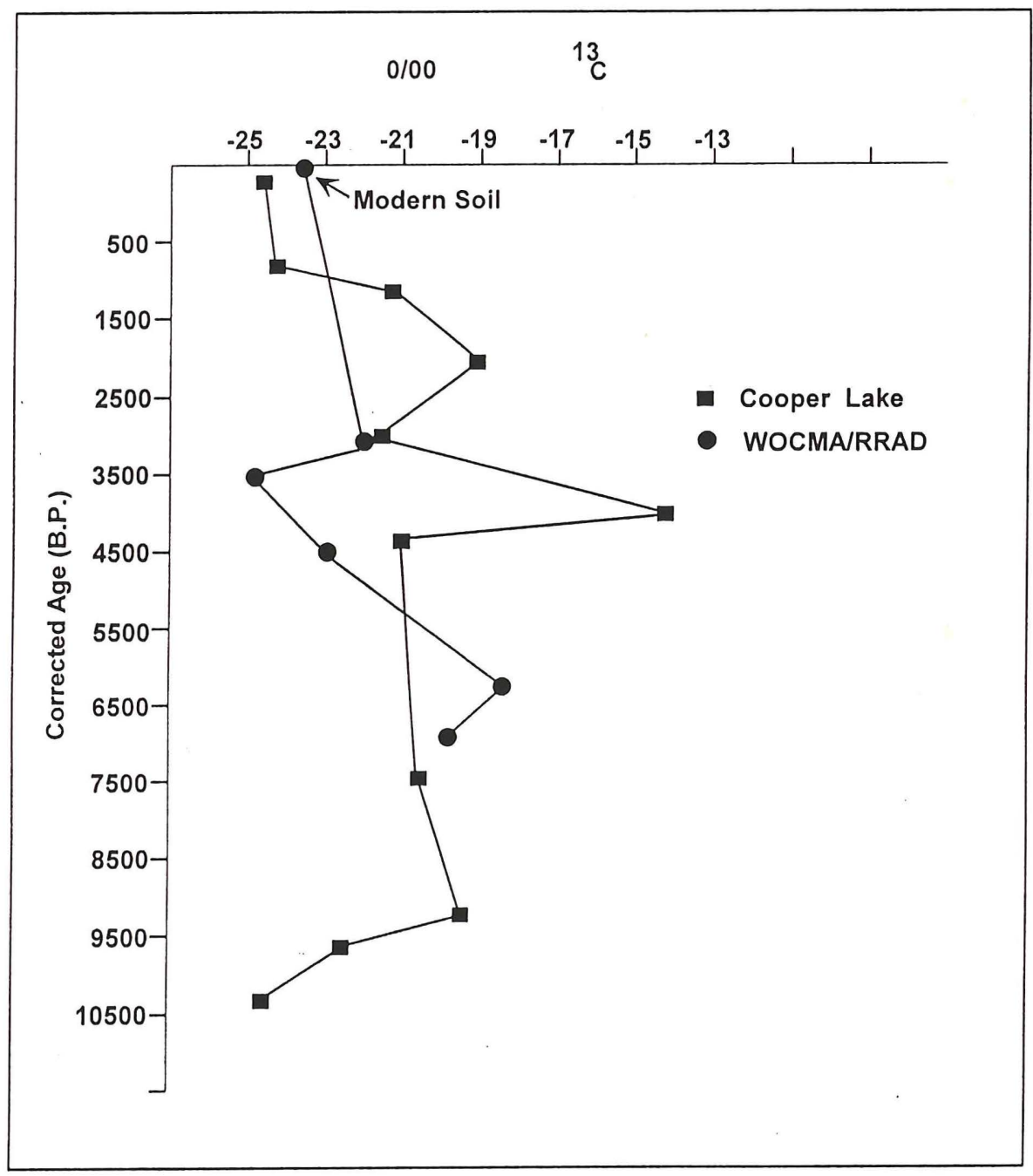

Figure 2-4. Stable isotope results from humate samples, Cooper Lake, White Oak Creek Mitigation Area, and Red River Army Depot (sources: Cliff and Peter 1992; Fields et al. 1997). 
The Late Holocene period after ca. 5000 years ago appears to have been that of fluctuating climates--moist or dry cycles--that were generally wetter than during the preceding Middle Holocene. Ferring and Yates (1996:Figure 7.5) propose that there were wetter years between ca. 5000-2000 B.P. and after 1000 B.P., with a drier cycle between 1000-2000 years ago. With these climatic and rainfall conditions, Oakhickory woodlands were probably the principal vegetation in upland habitats in the upper Sulphur River basin, with a well-developed riverine forest, but tall grass prairies would have existed (and fluctuated in extent) on the upland clayey soils within the basin. Supporting the drier and warmer cycle in the middle portion of the Late Holocene, the Ferndale Bog pollen record indicates that the peak in pine pollen was between ca. 800-1800 B.P. (Holloway 1994:Table I.2), while Bousman (1998:207) notes one grass spike or peak in the Weakly Bog in Central Texas that dates about 1500-1600 years, with another between 400-500 B.P.. Stable carbon and oxygen isotopes from mussel shells along Denton Creek in North Texas, however, point to a warm/dry peak at ca. 2850 B.P., and then after 1500 B.P. (Brown 1998:164). Stable carbon isotope values from humate samples in the Cooper Lake area of the upper Sulphur River basin have C4enriched peaks (i.e., higher C4 grasses in the biomass) around 2000 B.P. and 4000 B.P. (see Figure 2-4).

For the last 1000 years or more, dendrochronological records of paleoenvironmental change are the most accurate and temporally sensitive data available on Late Holocene environmental change (e.g., Stahle 1996). Fortunately, recent dendrochronological research in Texas, Arkansas, and Louisiana, as well as the Southeast U.S., by Stahle and Cleaveland $(1988,1992,1993,1994,1995)$ has compiled significant new information on subtle but changing climatic and rainfall conditions and trends for the general TransMississippi South region.

Droughts are not uncommon in the region in modern times, and dendrochronological analysis suggests there were numerous wet and dry spells between ca. A.D. 1000-1700, just as there were between 5000-1000 years ago, as well as after the Caddoan peoples vacated much of the Sulphur River basin in Northeast Texas (see Stahle and Cleaveland 1988, 1994). Some of the worse droughts may have occurred around A.D. 1555, 1570, 1595, and 1670, and the period between A.D. 1549-1577 has been suggested to have had the worse droughts in the past 450 years (Stahle et al. 1985).

More detailed dendrochronological analyses from bald cypress tree-ring chronologies on spring rainfall between A.D. 1002-1988 from Big Cypress State Park in northwestern Louisiana indicate the seven sets of wettest years were between A.D. 1053-1057, 1168-1176, 1178-1180, 1265-1268, 1323-1328, 15531555, and 1584-1586 (Figure 2-5; standard ring width indices data provided by the Department of Geography, University of Arkansas, on file with the author); the wettest years were about a decade from 1168-1176 and 1178-1180. These years would likely have been optimal growing years for Caddoan horticultural groups, assuming a correlation between crop production and spring precipitation values (cf. Anderson et al. 1995:265). The wetter rainfall conditions would also likely have led to an increase in the extent of woodland and forested habitats in the upper Sulphur River basin at the expense of tall-grass prairie, and a concomitant expansion in the carrying capacity of woodland plants and animals around the Hurricane Hill site.

Conversely, the driest years--between A.D. 1014-1016, 1215-1217, 1444-1447, 1455-1460, and 1529-1533--may well have stressed food supplies, the ability of the Early and Middle Caddoan groups to produce sufficient food reserves from the cultivation of tropical cultigens, and the success of any maize harvests during these extended periods. The very dry years between A.D. 1444 and 1460 detected by the dendrochronological record correlate well with the grass spike/drier episode noted by Bousman (1998) from the Weakly Bog pollen record. These droughts probably also affected the constancy of flow in the numerous upland springs in the area, as well as the volume of flow in the South Sulphur River, which would have influenced the relative quantity of animal and plant foods in floodplain and upland forested habitats. 
Figure 2-5. Dendrochronological sequence, Big Cypress State Park, Louisiana, A.D. 997-1651.

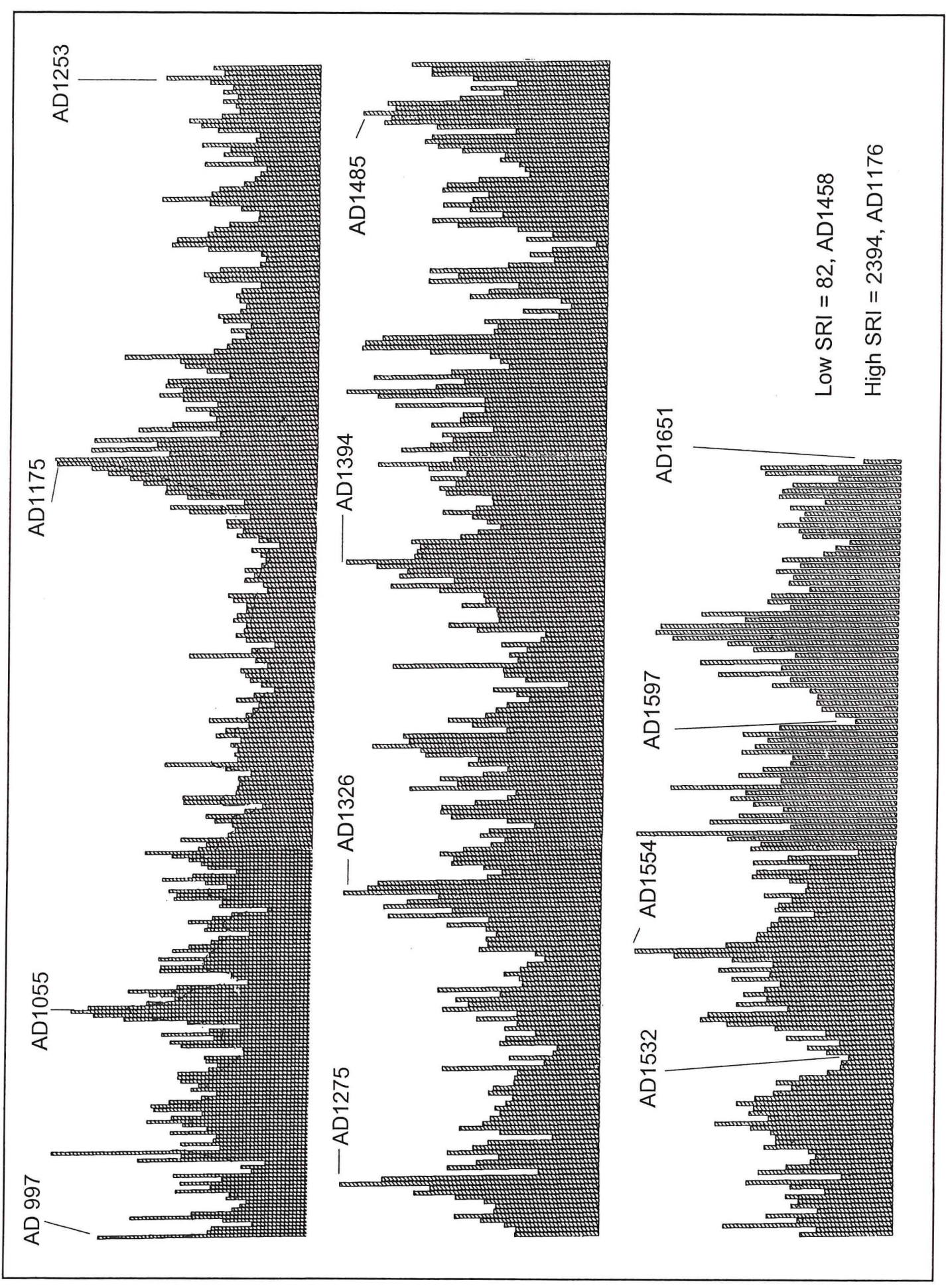


Looking at the period of wet and dry spells from ca. A.D. 1000-1600, the wetter years $(>1400$ standard ring width indices [sri]) were more than two times as frequent as the driest and droughty ( $<560 \mathrm{sri}$ ) years (see Figure 2-5). After ca. A.D. 1430, the wetter years occurred less often, some 55 percent less between A.D. 1600-1700 than in the ca. A.D. 1200-1400 period when Caddoan structures were built on the South rise at the Hurricane Hill site. The frequency of very dry years remained rather constant after ca. A.D. 1430, but were conversely quite rare between A.D. 1000-1400 (see Figure 2-5). Clearly, then, if the dendrochronological data from Big Cypress State Park are relevant to understanding local climatic conditions in the upper Sulphur River basin, the primary Caddoan settlement of the Hurricane Hill site took place during an equitable climatic episode when floodplain and upland forests were expanding at the expense of tall-grass prairie. There were comparable spring rainfall amounts during most of a 400 -year period. It is only after the mid-15th century, and a major drought between A.D. 1444-1447 and 1455-1460, that more xeric conditions probably existed in the upper Sulphur River basin.

\section{Cultural Setting}

\section{Prehistoric and Early Historic Archaeological Research}

Professional archaeological research in the South Sulphur River basin, and the Sulphur River basin in general, began in earnest in the early 1930s as part of the Laura Spelman Foundation-funded University of Texas reconnaissance and excavations at Caddoan sites throughout East Texas (Pearce 1932). Field parties from the University of Texas concentrated primarily on excavations of Caddoan cemeteries in the Cypress, Sabine, and Neches River basins, but did record and investigate a few sites on the Sulphur River and its tributaries in Hopkins, Franklin, Titus, and Red River counties (Guy 1988, 1990). Important sites investigated or visited at that time include Culpepper (41HP1), Jonas C. Atkinson (41FK1), W. A. Ford (41TT2), Farrar (41TT1), and T. M. Coles (also known as Mustang Creek, 41RR3), located 30-50 km east to southeast of Cooper Lake (Goldschmidt 1935; Jackson 1931; Scurlock 1962) (Figure 2-6).

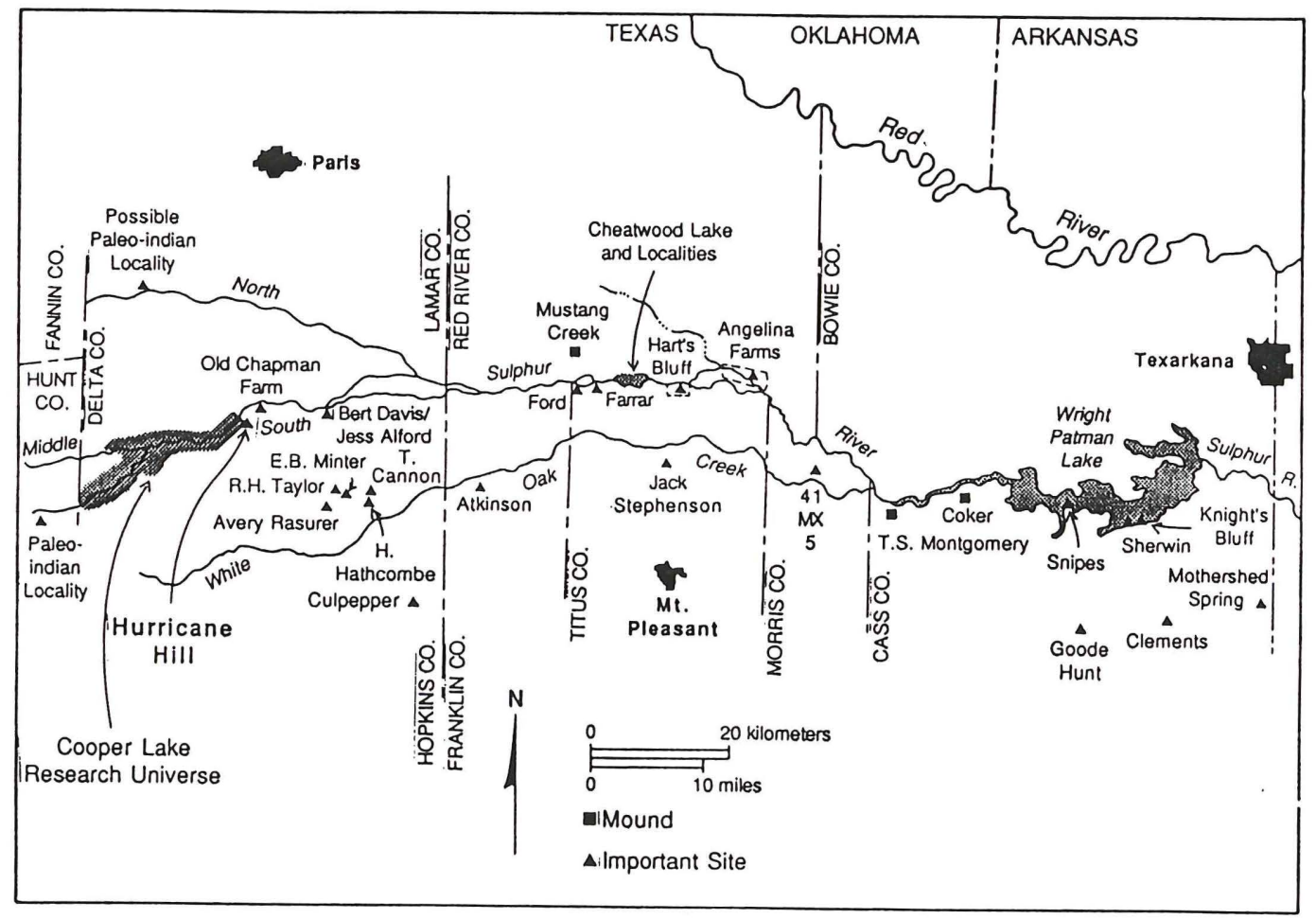

Figure 2-6. Archaeological investigations and important known prehistoric sites in the Sulphur River basin of Northeast Texas. 
In the 1930s, University of Texas archaeologists visited five prehistoric sites in the White Oak Bayou drainage of the Sulphur River basin, in the vicinity of Dike, Texas, and obtained small collections of artifacts from them. These sites are approximately 13-20 km southeast of the Cooper Lake project dam embankment (see Figure 2-6). The five sites--E. B. Minter (41HP2), R. H. Taylor (41HP4), Hilman Hathcoat (41HP9), Avery Rasurer (41HP10), and Tom Cannon (41HP11)--contain archaeological materials demonstrating the general occupations of the area between ca. 8000 B.C. and A.D. 1400. All appear to have Caddoan components roughly contemporaneous with the main periods of Caddoan occupations documented at Cooper Lake (Fields et al. 1997), with possibly their principal use during the Early Caddoan period.

In 1919, Pearce made a preliminary reconnaissance of East Texas sponsored by the Bureau of American Ethnology (Davis 1979). He visited the Bert W. Davis farm (41HP3), about $10 \mathrm{~km}$ east of Hurricane Hill, to see excavations conducted by the landowner in a midden-capped sandy knoll about a mile from the South Sulphur River. Ten burials had been removed at that time, and four ceramic vessels and two chipped stone axes had been recovered. One of the vessels was apparently a plain water bottle (Pearce 1920). In 1934, A.T. Jackson (1934) returned to the site, excavating 510 feet of trenches in the midden mound which covered 3,465 square meters and had 36-110 cm thick deposits. Recovered in the midden were primarily Early Ceramic period materials, including Gary points, Kent points, possible thick grog-tempered Williams Plain pottery, and Marksville Stamped and Marksville Incised ceramics (TARL n.d.). Jackson (1934) reported that the landowner had also removed 16-18 skeletons, from depths of 12-15 inches (30-39 $\mathrm{cm}$ ), which had been placed in "extended positions, on their backs, with the head to the southwest and feet to the northeast." Apparently after the midden was deposited in Early Ceramic times, it was then utilized as a cemetery by Caddoan groups that left the extended burials.

While working at the Bert W. Davis farm, Jackson (1934a) also trenched the Jess Alford Plantation site (41HP5) a short distance away on an old channel of the South Sulphur River. He encountered only extensive gravel deposits, chipping debris, and Late Archaic/Early Ceramic diagnostic projectile points. He did report that a burial had been found at the site in 1933 that had a conch shell gorget similar to those recovered in Middle Caddoan period (apparent Sanders focus or phase contexts) at the Sanders site on the Red River (e.g., Hamilton 1997; Krieger 1946).

The next phase of archaeological research in the Sulphur River basin began in the late 1940s and 1950s at two federally sponsored reservoir salvage projects. This archaeological research included excavations at the Knight's Bluff, Sherwin, and Snipe sites at Texarkana Reservoir on the lower Sulphur River (Jelks 1961), and the initial survey and test excavations at Cooper Lake (Moorman and Jelks 1952; Duffield 1959; Johnson 1962). The work was initiated by the Austin Office of the River Basin Surveys of the Smithsonian Institution and then, by the Texas Archeological Salvage Project (TASP) at The University of Texas. Twenty-six sites were recorded in the 1950s surveys at Cooper Lake. One site, Manton Miller (41DT2), was subsequently tested by TASP (Johnson 1962:234-268) in October and November 1959.

Avocational archaeologists of the Dallas Archeological Society began archaeological research in the Cooper Lake area at this time. Hatzenbuehler (1953) and Harris (1955) excavated human burials of probable Early Caddoan period affiliation at the Tick (41DT6) and Spike (41DT16) sites. Gilmore and Hoffrichter (1964) excavated at the L. O. Ray site (41DT21) in 1963. The primary component at the site appears to be an Early Caddoan one that dates between ca. A.D. 1000 and 1300 (see Fields et al. 1997), but a Late Archaic/Early Ceramic occupation was also present in the midden deposits at the site.

Hatzenbuehler $(1949,1950,1951)$ conducted limited investigations at a series of midden mounds 1-2 km northeast of Hurricane Hill that were situated in the floodplain of the South Sulphur River. Each of the midden mounds contained burials that had been disturbed by plowing, abundant animal bones and mussel shell, bone tools, and an assortment of archaeological remains dating from the Late Archaic through the Middle Caddoan period. These remains included projectile points, fire-cracked rock, lithic debris, burned clay, arrow points, and ceramics. At the Chapman Farm and site 19C3-5 (see Figure 2-4), the recovery of triangular arrowpoints and Avery Engraved ceramics (Hatzenbuehler 1950:26) indicated that a Late Caddoan (post A.D. 1300-1400) occupation had occurred as well on these floodplain localities. Long (n.d.) apparently also collected at these sites, but their exact locations are not known. 
Since ca. 1970, professional archaeological research in the Sulphur River basin has been based on the passage of environmental and cultural legislation, such as the National Historic Preservation Act of 1966 (P.L. 96-515, as amended), the National Environmental Policy Act of 1969 (P.L. 91-190), and the Archaeological and Historic Preservation Act of 1974 (P.L. 93-291). Archaeological research in these instances is an integral part of Federal and State legislative responsibilities to identify, evaluate, protect, and preserve important cultural resources on federal and state lands, and to treat important historic properties affected by a federal undertaking.

In addition to the intensive investigations at Cooper Lake conducted by Southern Methodist University (SMU) from 1970 to 1976, and then later by IAS/UNT in 1986-1987 and SMU in 1987-1989, as well as Prewitt and Associates, Inc. and Geo-Marine, Inc. after that (Cliff et al. 1995; Green et al. 1996; Fields et al. 1997), there have been many other professional archaeological research projects carried out in the Sulphur River basin, in response to cultural resource management legislation (see recent summary by Hunt and Cliff 1998:16-18). This included surveys at the Texarkana or Wright Patman Lake (Briggs and Malone 1970; Cliff and Hunt 1998; Cliff et al. 1996a; Hunt and Cliff 1998; Linder-Linsley and Lindsay 1997; White et al. 1995); various investigations from intensive survey to excavations at the White Oak Creek Mitigation Area (WOCMA) on the middle Sulphur (Peter et al. 1990; Cliff and Peter 1992; Cliff, ed. 1994; Cliff and Hunt 1995; Cliff et al. 1996b, 1996c; Largent et al. 1997; Cliff and Beene 1997); archaeological survey and historic archival research at the Red River Army Depot-Lone Star Army Ammunition Plant west of Texarkana (Cliff and Peter 1988; Peter and Cliff 1990a, 1990b; Peter et al. 1991; Cliff and Peter 1994; Cliff et al. 1996d); excavations of a Late Caddoan hamlet and cemetery at 41MX5 (Brewington et al. 1995) and an Archaic encampment at 41BW422 on Barkman Creek (Tucker 1994); surveys at Harts Bluff Ranch, Angelina Farms (Heartfield, Price and Greene, Inc. 1982a, 1982b), and a 1971 survey by East Texas State University in portions of Franklin, Morris, Red River, and Titus counties (East Texas State University 1971:50-84). More than 530 archaeological sites were recorded in these surveys, principally Archaic (mainly Late Archaic), Early Ceramic, and Caddoan (mainly dating before A.D. 1200/1300) sites (Figure 2-7), several of which contained significant archaeological deposits dating to the Early and Late Caddoan periods.
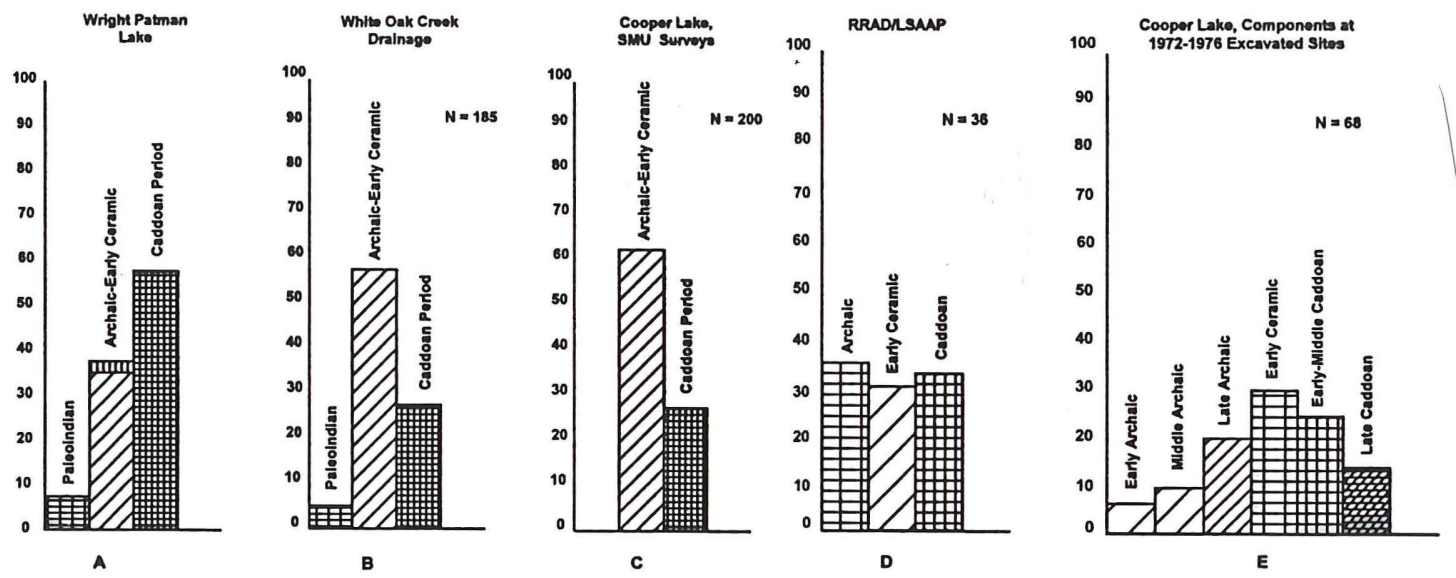

Figure 2-7. Temporal affiliation of prehistoric sites recorded across the Sulphur River basin of Northeast Texas: a, Wright Patman Lake; b, White Oak Creek Drainage, Titus County, including White Oak Creek Mitigation Area; c, Cooper Lake Surveys; d, Red River Army Depot/Lone Star Army Ammunition Plant; e, Cooper Lake, 1972-1976 excavated sites.

Only in the WOCMA and Wright Patman Lake areas are Middle and Late Caddoan components present in any number among the Caddoan tradition sites, a point discussed later in this report. At WOCMA, for instance, Middle and Late Caddoan period components comprise 36 percent of the Caddoan components ( $n=31$; see Cliff and Beene 1997), and 20 percent at Wright Patman Lake ( $n=20$; sample from Cliff and Hunt 1998; Cliff et al. 1996a; Hunt and Cliff 1998; White et al. 1995). By contrast, Middle to Late Caddoan components at Cooper Lake are sparse (cf. Fields et al. 1997:90), and the most recent 
extensive surveys by Jurney and Bohlin (1993) and Jurney et al. (1993) there identified only a single Late Caddoan component from the 37 Caddoan components.

Bear Ridge (41TT5) and Post Oak Mound (41TT40) were tested by Heartfield, Price and Greene, Inc. (1982a). At the Angelina Farms, Heartfield, Price and Greene, Inc. (1982b) tested several Caddoan occupations on floodplain knolls along the middle reaches of the Sulphur River, documenting the EarlyLate Caddoan settlement of the Sulphur bottom area. At site 41RR65 (see Figure 2-6), archaeological deposits associated with a Middle Caddoan settlement were examined, and a human burial was exposed at the base of the midden deposits (Heartfield, Price, and Greene, Inc. 1982b:A.84-A.107).

Bell (n.d.) recorded over 50 prehistoric sites in the White Oak Creek drainage of the Sulphur River basin during the 1970s. Most of the recorded sites date to the prehistoric Caddoan tradition (ca. A.D. 8001680), but Paleoindian, Archaic, and Early Ceramic period components were also recognized (see Figure 27). Some of the more significant sites recorded by Bell (n.d.) include Jack Stephenson (41TT64), an Early to Middle Caddoan period cemetery; Covey (41TT320), an apparent Late Caddoan Texarkana phase cemetery with shaft burials; and Big Slough Borrow Pit (41TT69), a multicomponent Paleoindian and Late Archaic site with a Late Caddoan cemetery on White Oak Creek.

Just upstream from WOCMA, an Early Caddoan (ca. A.D. 1000-1200) cemetery and mound site has been documented at the Morris Mounds site (41TT724). The site has two mounds, one of which had burials with large numbers of ceramic vessels, and the other mound (about 1 meter in height) was constructed of different layers of soil or mound fill, probably capping structures within the mound (Nelson and Perttula 1997:4). In the same vicinity in the White Oak Creek valley, the Jack Morris Titus phase cemetery (41TT723) was identified on an alluvial fan landform. The Late Caddoan cemetery contained more than 40 burials, and was probably a community cemetery for Titus phase groups in this part of the White Oak Creek basin.

\section{Cooper Lake Research Investigations}

SMU's Archaeology Research Program completed the survey of the 34,000-acre reservoir at Cooper Lake in 1970, recording 105 prehistoric sites (Hyatt and Skinner 1971); an additional five sites were recorded in later investigations by SMU at Cooper Lake (Doehner et al. 1978). Research in 1972 (Hyatt et al. 1974), 1973 (Hyatt and Doehner 1975), 1974 and 1975 (Doehner and Larson 1978), and 1976 (Doehner et al. 1978) included excavations at 33 prehistoric sites.

Historical archaeological sites and cultural materials were noted during the survey and excavation phases of the project, but no specific attempt was made to develop a historic research design applicable to Cooper Lake or to address these types of archaeological resources (see discussion in Moir et al. 1997). The Cooper Lake survey was much like most of the cultural resource management projects being conducted in East Texas in the early and mid-1970s in that historic sites and standing structures were not considered of research significance (see Fox 1983).

While Bousman et al. (1988:13-36) have considered in detail the results of SMU's 1970-1976 research at Cooper Lake and have assessed specific conclusions of the project in light of current knowledge about the archaeological record in East Texas, it is important to briefly summarize here the overall approach of that research because it bears on some of the research problems posed in the later SMU and IAS/UNT research designs (see Chapter 3, this volume). Prehistoric sites excavated from 1972-1976 were chosen specifically to test the subsistence-settlement models presented in the survey report (Hyatt and Skinner 1971; Hyatt et al. 1974:19-20).

The basic model of seasonal exploitation at Cooper Lake proposed by Hyatt and Skinner (1971:46) had been expanded, refined, and ultimately discarded as the research progressed, although the testing of other subsistence-settlement models continued to guide the Southern Methodist University research (Hyatt and Doehner 1975:71, 72; Doehner and Larson 1978:153-156; Doehner et al. 1978:209-211). Other themes of the prehistoric archaeological research at Cooper Lake were designed to provide an empirical focus whereby expectations of the contrasting settlement-subsistence models could be tested from excavation data acquired in the project area. These subsidiary themes included: (1) site types and functions: (2) intrasite and intersite activity patterning, (3) lithic technology and artifact assemblages, (4) chronology, (5) subsistence change 
and faunal exploitation, (6) seasonality, (7) paleodemography and mortuary programs, and (8) environmental reconstruction (e.g., Bousman et al. 1988:13-36).

Other research activities at Cooper Lake included a geoarchaeological study of the Late PleistoceneHolocene alluvial deposits along the Middle and South Sulphur river valleys (Bousman et al. 1988; Darwin et al. 1990; Ferring 1997). A primary goal of these studies was to reconstruct a Quaternary depositional history of the Cooper basin (the Cooper Lake project area). An understanding of the depositional history of the area would not only be a significant contribution to the geological and paleoenvironmental record for northeastern Texas but would, when completed, provide the context necessary to locate preserved, in situ buried archaeological deposits spanning this period. Despite considerable efforts and numerous deep backhoe trenching, few buried archaeological deposits were ever identified and documented in the Cooper Lake basin prior to its inundation (Fields et al. 1997:3-5).

Only recently in eastern Texas had the geological, geoarchaeological, and paleoenvironmental records been studied along the lines proposed for the Cooper basin (see Ferring 1986, 1987; McGregor 1988; Collins 1988; Mandel 1987). This was of special importance in northeastern Texas because archaeological deposits older than ca. 3000 B.P. had not been found in good depositional or geological context. Previous research by Slaughter and Hoover $(1963,1965)$ at several localities on the North Sulphur River had suggested an association between extinct fauna and cultural remains in buried Late Pleistocene alluvium (the Sulphur River formation). This association indicated that depositional contexts existed in the Sulphur River basin where early occupations may be preserved. Dates of 11,135 \pm 450 B.P. (on shell) and 9,550 \pm 375 B.P. (on charcoal) were obtained from Delta County bone quarries 4 and 5, respectively. Archaeological evidence presented by Preston (1972, 1974), Carley (n.d.), and Cheatwood (1988) is a relatively clear demonstration that there was the potential for finding archaeological sites in good context (within the Sulphur River basin) that predate the Late Archaic. The discovery of the Finley Fan site (41HP159) at Cooper Lake, buried in an alluvial fan (Gadus et al. 1992), later documented deeply buried Middle Holocene components within the basin.

The Bousman et al. (1988) study examined existing exposures, profiles, and natural cuts, and then placed numerous backhoe trenches where Late Quaternary deposits were expected to be preserved. The possibility that archaeological materials would also be buried within this alluvium added an important cultural context to the geomorphological perspective. In situ buried cultural materials were uncovered at several localities (Bousman et al. 1988:94). In particular, significant alluvial deposits containing buried archaeological materials were found at the Ragland North and Finley Branch localities (Bousman et al. 1988:50-51, 63-67), located on the Middle and South Sulphur rivers, respectively. A series of soil humate dates ranging from ca. 14,435 to 550 years B.P. were obtained from intact floodplain alluvial deposits at Cooper Lake. The dates on these alluvial deposits suggested that a relatively complete record of Late Pleistocene and Holocene deposits was preserved in the project area that will be worthy of intensive geomorphological and archaeological research.

In 1986, UNT completed an 865-acre survey of the proposed Cooper Lake dam embankment, locating the Hurricane Hill site, nine other prehistoric sites, and 17 sites with historic cultural materials (Perttula 1988a). Following this, test excavations were conducted at four late nineteenth-early twentieth century sites along the embankment right-of-way (Perttula 1989b), and mitigation activities were initiated at the James Franks site (41DT97), an 1850s farmstead along the Doctors Creek valley (see Perttula 1989a; Parish and Perttula 1996). Early Caddoan components were excavated at this site as well and at historical locality \#1 at the Hurricane Hill site (Perttula 1989a:129-137, 1989b:117-130).

Beginning in February 1987 and lasting several years, SMU conducted prehistoric and historic archaeological investigations at Cooper Lake (Jurney and Bohlin 1993; Jurney et al. 1993; McGregor et al. 1997). A 4,700-acre area adjacent to the dam embankment was surveyed, and 102 new sites were recorded. Limited testing was then initiated at 58 sites, including nine previously reported by SMU in the 1970s (see McGregor and Jurney 1997:Table 2-1) and three sites, recommended by Perttula (1988a:123-124), that had been found in the embankment survey. Four sites of prehistoric age--Thomas (41DT80), Doctors Creek (41DT124), 41HP137, and Lawson (41HP78)--were subsequently excavated in 1987 (see McGregor 1997a, $1997 \mathrm{~b}$ for a summary of these Early Ceramic and Early Caddoan sites). Five historic sites were also excavated during the field season (Jurney 1997), and the historic Sinclair cemetery was excavated prior to its relocation (Winchell et al. 1992, 1995). Additional archaeological survey of more than 17,700 acres was 
also completed by SMU in 1989 at Cooper Lake (Jurney and Bohlin 1993; Jurney et al. 1993), and 134 new sites were recorded, and an additional 69 previously known sites were re-recorded.

Prewitt and Associates, Inc. completed the archaeological investigations at Cooper Lake between 1990-1995, along with prehistoric and historic archaeological and archival/oral historical research by GeoMarine, Inc. at three historic sites (Green et al. 1996) and two prehistoric sites (Cliff et al. 1995). The work by Prewitt and Associates, Inc. included an evaluation of the project research design (Fields et al. 1991) and the preparation of a mitigation plan for the treatment of the remaining important archaeological sites to be affected by construction/inundation (Fields and Gardner 1991); archaeological survey (Bailey et al. 1991); test excavations at eight prehistoric sites (Gadus et al. 1991, 1992), and intensive excavations at five prehistoric sites in 1991 and 1992 (Fields et al. 1993, 1994). The results of these investigations of the prehistoric and historic archaeological sites has been synthesized in an excellent volume (Fields et al. 1997), which we will draw upon extensively in this technical report.

More than 240 sites at Cooper Lake have prehistoric archaeological deposits, and over the years some 57 of these sites have been tested to determine their research potential (Fields et al. 1997:Table 2). Including the work accomplished by Prewitt and Associates, Inc. since 1986, extensive excavations have been conducted at Hurricane Hill (the subject of this report), Lawson (41HP78), Thomas (41DT80), Doctors Creek (41DT124), 41HP137, Finley Fan (41HP159), Tick (41DT6), Spike (41DT16), Johns Creek (41DT62), Peerless Bottoms (41HP175), and Spider Knoll (41DT11) (see Fields et al. 1997; McGregor et al. 1997). Significant new data on Archaic (primarily Late Archaic), Early Ceramic, and post-A.D. 800 Caddoan period settlement patterns, ranges of activities, use intensity, subsistence, sociocultural interaction, material culture, and mortuary patterns have been recovered from these sites that have shed new light on the nature of prehistoric lifeways in the upper Sulphur River basin of Northeast Texas (Fields et al. 1997:3793).

\section{Prehistoric Archaeological Record}

The discussion of the prehistoric archaeological record for the Cooper Lake area is organized in terms of the chronological framework, and estimated dates, employed by Story (1990; see also Perttula. 1988b), namely:

\begin{tabular}{ll} 
Paleoindian & $10,000-6000$ B.C. \\
Early Archaic & $6000-4000$ B.C. \\
Middle Archaic & $4000-2000$ B.C. \\
Late Archaic & $2000-200$ B.C. \\
Early Ceramic & 200 B.C.-A.D. 800 \\
Formative Caddoan & A.D. $800-1000$ \\
Early Caddoan & A.D. $1000-1200$ \\
Middle Caddoan & A.D. $1200-1400$ \\
Late Caddoan & A.D. $1400-1680$ \\
\multicolumn{1}{c}{ Texarkana Phase } & A.D. $1400-1700$ \\
Titus Phase & A.D. $1430-1680$ \\
Historic Caddoan & A.D. $1680-1840+$
\end{tabular}

\section{Palleoindian period}

Discrete and preserved Paleoindian occupations are as rare as hen's teeth in East Texas, although the Forrest Murphey Site (41MR62) at Lake O' the Pines on Big Cypress Creek may represent a horizontally stratified Paleoindian encampment (Johnson 1989a; Story 1990). The previously mentioned Delta Bone Quarry 5 (41DT86) site on the North Sulphur river may also represent a Paleoindian context (Slaughter and Hoover 1963, 1965). The calibrated one-sigma charcoal date of 8082-9170 BC is broadly contemporaneous with Clovis, Folsom, and Dalton complexes in the region.

The earliest Paleoindian archaeological materials (ca. 11500-9500 years B.P.) include Clovis and Folsom fluted lanceolate points, commonly manufactured on high-quality non-local lithic raw materials, along with scraping tools (Story 1990:Table 44). Unfluted lanceolates--commonly resharpened and beveled-dominate the latest Paleoindian components, including Dalton (Johnson 1989a:Figure 7), Plainview, San 
Patrice, and Scottsbluff points (see Perttula 1989c, as well as early side-notched points, Albany beveled bifaces or knives, and Cody knives (Webb et al. 1971; Johnson 1989a:Figure 13), Quince-style scrapers (Story 1990: Perttula 1994a), and bifacial adzes.

Sites of this age throughout the Trans-Mississippi South tend to occur near major drainages (such as the Red and Sulphur rivers) or in resource-rich areas, such as along the Ouachita Mountains and Ozark Mountains escarpments (Anderson 1996a). Anderson (1996b:Figure 3.2) has postulated that the initial and most intensive Paleoindian settlement of the Southeast U.S. took place in the resource-rich valleys of the Mississippi, Ohio, Tennessee, and Cumberland rivers. From there, Paleoindian groups settled throughout the wooded Southeast and East, with concentrations at $250-400 \mathrm{~km}$ intervals, indicating the scale of movement of these highly mobile foragers. As with much of the Southeast, the distribution of Paleoindian artifacts within the major Northeast Texas basins suggests that these early occupations were principally situated within the major stream valleys (see Thurmond 1990:Tables 54-54; Perttula 1995a). However, the relatively sparse Paleoindian archaeological record, as well as the dispersion of Paleoindian artifacts on many landforms (but especially alluvial terraces and upland projections) and different settings within the region, seems to indicate that the Paleoindian groups occupying this part of Northeast Texas were very mobile hunters and gatherers of a variety of resources rather than specialized hunters of extinct megafauna (Fields and Tomka 1993:82). Johnson (1989a:53-54) also suggests that some of the Paleoindian archaeological remains (particularly Plainview and Scottsbluff projectile points and Cody knives) from the region are a result of Plains Late Paleoindian (ca. 10000-9000 years ago) groups that moved into (or "invaded" according to Johnson [1989a:53] in the case of the Cody "people") parts of Northeast Texas during periods when grassland habitats spread eastward to exploit the plains resources (such as bison) found there. However, recent paleoenvironmental research (see above) suggests that oak woodlands were the principal vegetational community in the region by that time, with grassland communities more regionally extensive before 11,000 B.P. and after 7500 B.P.

Components of this period throughout Northeast Texas typically consist of isolated finds of diagnostic points in surface and/or multicomponent contexts (e.g., Story 1990; Fields and Tomka 1993). Carley (n.d.) and Preston $(1972,1974)$ have documented an extensive Paleoindian presence in the Sulphur River basin of East Texas, although as yet, no Paleoindian materials have been recovered in situ unless the association of extinct fauna and cultural remains at the Delta Bone Quarry can be substantiated.

One of the larger assemblages of Paleoindian remains has been described by Preston $(1972,1974)$ from a site in Hunt County south of Commerce, Texas. More than 35 Plainview, Dalton, and Scottsbluff points made primarily from non-local lithic raw materials, were recovered from depths of 4-6 feet in sand deposits excavated by a sand and gravel company (Preston 1972:7). Plainview, Dalton, and Scottsbluff point types, dating from ca. 8000-6000 BC, were the most common forms in the large sample described by Carley (n.d.) from the North and South Sulphur rivers.

\section{Early, Middle, and Late Archaic period}

Excavated Archaic components in northeastern Texas are still poorly known (Story 1985, 1990), even in the Cooper Lake area, one of the more extensively investigated areas within the region. Moreover, research on this time period is critically hindered by the lack of stratigraphic or chronological data from stratified and/or single component occupations. Story (1990:Figure 32) and Thurmond (1990:Table 8) provide the most current chronological classifications of Archaic-age dart points, with straight and expanding stem forms characteristic of the Early and Middle Archaic periods, and the contracting stem darts particularly diagnostic of the Late Archaic (and much of the Early Ceramic period as well [Schambach 1982, 1998]).

Ferring (1995:26) suggests that much of the Early and Middle Archaic periods were drier than today, with apparent reductions or shifts in biomass as well as the local expansion of prairie habitats along the western margins of Northeast Texas. Nevertheless, drier conditions and changing vegetation conditions "clearly did not preclude occupations" (Ferring 1995:33) during these periods. Early Archaic settlements appear to be small and widely distributed, located primarily on terrace and upland projections within major stream basins, although this may well be an illusion of biased research interests (e.g., Story 1985:31). Story $(1985: 35,39,1990)$ has also suggested that group mobility was still high, within large and poorly defined territories, during the Early Archaic. Most sites appear to be "heavy" and "limited-use" areas (cf. 
Thurmond 1990:41), that is to say, evidence repeated and recurrent occupations by small groups.

Generalized subsistence economies may have continued to characterize these hunting-gathering groups (e.g., Meltzer and Smith 1986). Anderson (1996b) suggests that such Archaic groups had highly mobile foraging adaptations along the Red River, the central Sabine River, and in interior uplands away from major drainages, with expedient lithic technologies. Most sites of this age were briefly used, but tended to concentrate in the larger drainages within the region.

Like the Paleoindian period, artifactual remains of the Early Archaic era are generally limited to a few isolated diagnostic projectile points found in multicomponent sites. Early Archaic materials have been noted at 41HP2 in the White Oak Bayou drainage in just such a situation, and other sites in the Cooper Lake area have a minimal Early Archaic presence (Bousman et al. 1988:34). Cheatwood (1988), however, has recovered Early Archaic materials in a buried context on the Sulphur River near Talco, Texas, and Bousman et al. (1988) reported possible Middle Archaic materials from Finley Branch that may have eroded from a soil horizon dated 6790 B.P. Subsequent excavations at the Finley Fan site (41HP159) recovered buried Middle and Late Archaic burned rock features and lithic tools from this vicinity (Gadus et al. 1992). The Middle Archaic component at Finley Fan dates between 3152-4410 B.C. (Fields et al. 1997:42).

Sites of the Middle and Late Archaic comprise the record for the first well-known archaeological units in northeastern Texas. In general, throughout this period of time the trend is for the development of more complex settlement systems and evidence for some degree of sedentary occupation by ca. 200 B.C. Story (1985:52) argues that by the Late Archaic, settlements were within distinct territories of compact and stable distribution. By the Middle Archaic period, fairly substantial and extensive occupations are recognized within the major basins, with a rather limited use of smaller tributaries and stream headwater areas. The overall distribution of sites dating to this period may indicate a settlement system concentrated within major basin systems, such as the Sulphur River and its primary tributaries.

Burned rock features (possible hearths, ovens, and cooking pits; see Black et al. 1997) and burned rock concentrations are present in dated Middle Archaic contexts at a few sites (see Gadus et al. 1992; Cliff et al. 1996b), suggesting that the cooking and processing of plant foods was an important activity by this time, but mainly by small groups for short-term use (Fields et al. 1997:90). Lithic raw materials from a possible Middle Archaic assemblage at Lake Fork Reservoir suggested that the exchange of non-local materials (particularly finished tools) was commonplace (Perttula 1984), although "patterns in raw material use were not uniform across Northeast Texas" (Fields and Tomka 1993:92). In the upper Sulphur River basin, however, the use of non-local raw materials was not common, and the non-local lithics that are present primarily originated to the north in the Red River basin (Fields 1995a; Fields et al. 1997). The relatively high use of local lithic raw materials (typically upland gravel sources) during the Late Archaic further confirms the limited inter-regional interactions that took place at the time (Fields and Tomka 1993; Perttula and Bruseth 1995).

Late Archaic sites are widely distributed in the Sulphur River basin, occurring along the major streams, near springs, on spring-fed branches, upland ridges, and on tributary drainages of all sizes (cf. Cliff and Peter 1992; Cliff and Hunt 1995; Cliff et al. 1996b). Indeed, the distribution of Late Archaic sites across Northeast Texas suggests that these Native American groups used in a moderate to extensive way almost every part or habitat of the region, which was now primarily forested after ca. 5000 B.P. Anderson (1996b) notes major site concentrations of Late Archaic sites along the Red and Little rivers in Arkansas and Louisiana, as well as in the Ozarks and Ouachita Mountains. These settlement data are compatible with higher population densities, limited group mobility but a wide dispersion of camp and foraging areas, the possible establishment of definable territorial ranges, and a well-developed foraging economy based on the hunting and gathering of local food resources.

A few Late Archaic occupations in the Pineywoods and Post Oak Savanna of Northeast Texas are known that contain earthen middens (i.e., the Yarbrough site along the Sabine River; see Johnson 1962). In general, however, sites of this period contain burned rock features, and/or concentrations of burned rock, as well as small pits. The Late Archaic occupation in area $\mathrm{C}$ at the Unionville site had a buried anthrosol or buried surface that had been darkened or stained by cultural activities (Cliff et al. 1996b); within the anthrosol were two clusters of burned rock features. 
No paleobotanical evidence is available that indicates the Late Archaic populations in Northeast Texas cultivated native plant species (i.e., such as sumpweed, sunflower, or chenopod), as was the case by the first millenium B.C. in many parts of Eastern North America, including the Arkansas Ozarks (Fritz 1990b, 1994:24-27, 1997). Nutshells and tubers are documented in Late Archaic components at the Unionville site (Cliff and Hunt 1995; Cliff et al. 1996b).

Middle and/or Late Archaic components have been identified at almost all of the prehistoric sites excavated to date at Cooper Lake, and in other project areas within the Sulphur River basin (see Figure 2-7) although they are not the components responsible for the majority of the prehistoric cultural features and archaeological remains recorded there (e.g., Bousman et al. 1988:30). Based on the topographic settings chosen for Middle and Late Archaic settlement at Cooper Lake, and the presence of extensive buried Holocene alluvial deposits on the South Sulphur River, considerations of settlement frequency, location, and occupational intensity are probably skewed by the fact that many Archaic occupations are buried in floodplain settings. Only a few sites of the Middle and Late Archaic periods have been investigated and well-dated (e.g. Cliff et al. 1995, 1996b; McGregor et al. 1997), particularly 41DT59, Finley Fan, and the Unionville site (41CS151).

\section{Early Ceramic period}

The Early Ceramic or Woodland period in this part of Northeast Texas is recognized primarily by plain and relatively thick ceramic bowls and "flower-pot"-shaped jars, although ceramics are not abundant on Early Ceramic period sites outside of the Red River and lower Sulphur River areas (see Bruseth 1998; Story 1990). Other distinctive material culture attributes include double-bitted axes, small and thin Gary projectile points (cf. variety Camden defined by Schambach [1998]), and later in the period (ca. A.D. 600-700) by small corner-notched arrowpoints (Thurmond 1990; McGregor 1997b). In several instances, as at the Bert Davis site near Hurricane Hill, Lower Mississippi Valley related ceramics (such as Churupa Incised, Marksville Incised, and Marksville Stamped) occur in Early Ceramic period components.

It is apparent that Early Ceramic populations in Northeast Texas lived in increasingly larger groups and resided for longer periods of time at certain sites. The fact that some Early Ceramic period sites in the area have relatively substantial midden deposits, and some evidence for structures (probably daubed pole and thatch houses), suggests more intensive occupations and a decreased residential mobility; the degree of settlement permanence, however, is still less than that documented in the subsequent long-term Caddo settlement of Northeast Texas (Perttula et al. 1993:99). On the basis of available information, Early Ceramic period groups may have cultivated squash or gourds (possibly also using them as net floats; see Fritz 1999), and used seeds and tubers/roots, as well as a wide variety of woodland and aquatic animal resources.

There is, apparently, a major expression of Early Ceramic period archaeology in the Sulphur River basin, although the recognition, and formal definition of the archaeological character of this period are still not adequately developed (Story 1981, 1990; Jelks 1961). Southern Methodist University's excavations at Cooper Lake seem to indicate that the ceramic materials from Early Ceramic components, such as 41HP137 and Lawson, are not characterized by the thick Williams Plain wares that are common in Early Ceramic contexts along the Red River, the lower Sulphur (Jelks 1961), and in southeastern Oklahoma (Brown 1971; McGregor 1997b; Bruseth 1998).

One such Early Ceramic site (41TT372) on an upland ridge at the headwaters of Piney Creek, in the White Oak Creek basin, had extensive burned rock features, as did 41TT409, where the burned rock concentrations (covering ca. 120 square meters) date from about 1650-1800 years B.P. (Kotter et al. 1993). At Wright Patman Lake and Cooper Lake, Early Ceramic components are quite common (see Figure 2-7), and the better-known archaeological components have been recognized at the Snipes, Arnold (41HP102), Tick, Thomas, Luna, Johns Creek, and Lawson sites, as well as other midden sites on the Sulphur and South Sulphur rivers (including Hurricane Hill), primarily on the basis of large numbers of radiocarbon dates from selected sites at Cooper Lake (Doehner and Larson 1978; Fields et al. 1997; Perttula 1998a). Spike, Tick, and Hurricane Hill have middens (those at Spike and Tick were 60-100 cm thick), while burials were found (flexed, bundle, and cremation) in a small cemetery on the Southwest rise at Hurricane Hill (Fields et al. 1997:91-92; Perttula 1997a). The Tick and Spike sites have calibrated dates from AD 
192-986 and BC 195-AD 891, respectively, while the calibrated dates from Early Ceramic contexts at Hurricane Hill range from AD 59-449 (see Chapter 7, this volume).

Important paleobotanical remains found in Early Ceramic components at Cooper Lake include hickory, acorn, tubers (probably the prairie turnip, Psoralea sp.), and cultivated squash or gourd. The squash was recovered from a feature at 41HP137 whose calibrated 1-sigma date is 122-46 BC (McGregor 1997b; Perttula 1998a:Table 1).

The presence of Early Ceramic period burial mounds along the Middle Sabine, Angelina, Neches, and Red rivers in East Texas, Louisiana, and Arkansas (Schambach 1997a) suggests that regional social hierarchies were being developed at that time, and that more complexly-organized local groups existed in these localities. Along the Red River, the mounds are found in blufftop and alluvial valley settings (Webb 1984; Schambach 1997a). The construction and use of these mounds also reflect the existence of specialized controls in the procurement and dispersal of non-local raw materials and artifacts, such as cherts, copper, and ceramic vessels that were included as grave goods in the burial mounds. Currently, however, there is no evidence that Early Ceramic populations in the Sulphur River basin were involved in these social developments or participated in the interregional exchange systems operative in these other areas.

Both sedentary and seasonal habitation sites are apparent for this period. The full emergence of the sedentary life, however, did not take place in the Sulphur River basin until ca. A.D. 800. Although extensive midden deposits are present at some sites, most of the occupations are relatively small in size and homogeneous in character.

\section{Formative-Middle Caddoan Periods}

The Early and Middle Caddoan periods in much of northeastern Texas are characterized by a number of cultural innovations that contributed to an expansion in population and the increased complexity of Native American socio-political organization. The bow and arrow led to the development of more efficient hunting strategies, while the evolution of more productive varieties of maize and other tropical cultigens ensured that these horticultural resources were an important, if not essential, part of the economy. The existence of dispersed sedentary communities, small villages, farmsteads, salt-making sites, and logistical camps (see Binford 1980) reflects a broad distribution of the Caddoan populations throughout most of the forested habitats in northeastern Texas, including much of the Sulphur River basin.

Caddoan archaeological sites are quite common throughout Northeast Texas. Indeed, the Cooper Lake area appears to have been "used most intensively by Native Americans" between ca. A.D. 800-1300 (Fields et al. 1997:75). The same may be said for other parts of the Sulphur River basin (see Figure 2-7). Formative to Middle Caddoan period sites are situated primarily on elevated landforms (alluvial terraces, natural levees, and upland edges) adjacent to the major streams, or in the stream valleys themselves, as well as along minor tributaries and spring-fed branches. Proximity to arable soils were preferred for settlement locations, probably because of good drainage for habitation, and for cultivation purposes. The majority of these Caddo sites are:

permanent settlements that have evidence of the structures, including posts, pits, and features marking their residency, along with the cemeteries and graves where the dead were buried; the middens where the animal and plant food refuse was discarded amidst broken stone tools and pottery vessels; and the material remains of tools and ceramics used in the procurement and processing of the bountiful resources of the region. They represent the settlements of Caddoan communities and sociopolitical entities, and the civic-ceremonial centers that were their focus (Perttula 1993a:125).

The most common types of Caddoan settlements in the region during Formative-Middle Caddoan periods appear to be small hamlets and farmsteads (Cliff 1997; Cliff et al. 1996c; Largent et al. 1997), sometimes with small cemeteries (Goldschmidt 1935). Larger communities (covering 10 or more acres) have also been recognized--principally in the Middle Caddoan period (Middlebrook and Perttula 1997; Nelson and Turner 1997; Perttula and Cruse 1997)--and they may occur in association with mound centers. One such larger community is the ca. A.D. 1150-1400 Oak Hill Village (41RK214) in the Sabine River drainage, where the 3.5 acre village consisted of a central plaza with 42 circular and rectangular structures 
(including several small structures that may be granaries), several midden deposits, and a single small substructural mound (Cruse 1994, 1995).

The Formative to Middle Caddoan groups generally seem to have been horticulturists, cultivating some maize and squash, along with several kinds of native seeds (Perttula and Bruseth 1983), gathered nuts and tubers/storage roots, and were proficient hunters of deer. fish, and many other animal species. The available paleobotanical and bioarchaeological evidence from Northeast Texas (and elsewhere in the Caddoan area) does not indicate, however, that Caddoan groups became dependent upon maize and other domesticated plants until after about ca. A.D. 1300; by ca. A.D. 1450, maize probably comprised more than 50 percent of the diet of many Caddoan groups (see Burnett 1990; Perttula 1996; Rose et al. 1998). Caries data and stable isotope analyses of human remains from the ca. A.D. 1100-1300 component at the Sanders site on the Red River indicate that these Caddoan peoples were consuming significant amounts of carbohydrate-rich maize crops (Wilson 1997; Wilson and Cargill 1993).

The presence of the Early Caddoan mound centers on the Sulphur River at the T. M. Coles site (Jackson 1931), and several Early to Middle Caddoan mounds at Wright Patman Lake (Stephenson 1950), including Coker (Perttula et al. 1997), is good evidence that social and settlement hierarchical differences existed among the Caddoan groups in the basin during the latter part of the prehistoric record of the region (see also Miller 1986; Perttula 1993b, 1994b). These mound sites-important civic-ceremonial centers--had temple and/or burial mounds, although single mounds appear to be common in the lower Sulphur River basin (see Cliff 1997). The Coker (41CS1) site apparently has four mounds, including one with an extensive mortuary deposit with burials adorned with Gulf Coast shell artifacts and ornaments (Perttula et al. 1997).

The Formative to Middle Caddoan groups had a rich material culture, including well-made cornernotched and rectangular-stemmed arrowpoints, siltstone and greenstone celts, flake perforators and drills, large Gahagan bifaces, and more expedient flake tools. Long-stemmed Red River (Hoffman 1967) and cigarshaped pipes were made by the Caddo at this time, along with platform pipes (Turner 1997), ceramic earspools, and figurines (see Newell and Krieger 1949).

They made ceramic vessels (carinated bowls, compound bowls, simple bowls, bottles, and jars) for cooking, storage, and serving needs (see Perttula et al. 1995). Most of the ceramics were made locally, but petrographic and chemical studies suggest that ceramics may have been traded between Caddoan groups from the Sabine River to the Red River (Reese-Taylor 1995a:23-25; Neff 1998). Utility wares were commonly plain, but those that were decorated had incised, punctated, fingernail-impressed, appliqued, and brushed decorative treatments; brushing, in particular was a form of vessel surface treatment that is notable after ca. A.D. 1300 in the middle and lower portions of the Sulphur River basin (Cliff 1997; Gaither et al. 1991; Jelks 1961). Finewares usually had well-done incised or engraved decorative motifs, such as curvilinear, scroll, ladder, pendant triangle (solid and cross-hatched), and horizontal and/or diagonal elements. Incised and incised-punctated decorated ceramics, including Crockett Curvilinear Incised and Crockett and Pennington Punctated-Incised "hybrids," dominate the Formative and Early Caddoan ceramic assemblages at Caddoan sites in the upper Sulphur River basin (Fields et al. 1997:81 and Figure 29).

Whether any or all of these innovations characterize the post-A.D. 800 archaeological record at Cooper Lake is still a matter of some debate, however. The excavations at the Thomas, Lawson, Doctors Creek, Spider Knoll, and 41DT59 sites recovered primarily wild plant remains (hickory, acorn, tuber [Psoralea sp?]), with only a limited amount of maize and squash from components dated from ca. A.D. 9001200. Thus, it is appears to be the case that the use of tropical cultigens did not play a major role in local subsistence economies at that time (e.g., Fields et al. 1997; McGregor 1997a), and probably never.

The most common manifestations of Caddoan period settlements in the Sulphur River basin are dense midden deposits resembling midden mounds (e.g., Heartfield, Price and Greene, Inc. 1982a, 1982b; Doehner and Larson 1978). These middens appear to represent a long-term use of particular settings, such as floodplain remnant knolls or upland edges, by a series of sedentary groups, as postholes, structure remnants, hearths, burials, and pits are present along with a substantial material culture assemblage of lithic tools and ceramics. Singly, the occupations, might represent small habitation areas of fairly brief occupational span, but in aggregate comprise a major palimpsest of Caddoan settlement trends in these places. 
Significant excavations of Caddoan period habitation sites in the general Cooper area include older work at the E. B. Minter, Arnold, Spike, L. O. Ray, and Manton Miller sites (Bousman et al. 1988; Gilmore and Hoffrichter 1964; Johnson 1962), as well as extensive excavations in the 1980s-1990s at Spike, Thomas, Doctors Creek, Spider Knoll, and Hurricane Hill sites. At Spider Knoll, the Caddoan archaeological deposits had numerous postholes (from two possible structures and drying racks or arbors), pits, and a large midden deposit (Fields et al. 1997:93-96). The many dates from Spider Knoll (Fields et al. 1994) suggest it was used a number of times over a period of ca. 400 years, from AD 880-1287. Recently studied Formative to Middle Caddoan components at the Unionville site, Area C, 41CS150, 41CS155/156, Area B, 41BW553, Knight's Bluff (41CS14) and 41TT670 along White Oak Creek and the lower Sulphur had well-preserved middens, hearths, postholes, and other features, including small cemeteries (Cliff et al. 1996b; Cliff and Hunt 1995; Jelks 1961; Largent et al. 1997).

\section{Late Caddoan Archaeological Period}

In the Great Bend area of the Red River, Late Caddoan archaeological sites are included in the contemporaneous Belcher and Texarkana phases (Schambach 1983). Texarkana phase sites occur on the Red River northwest of Texarkana to the Arkansas/Oklahoma state lines, as well as on the lower Sulphur River (Jelks 1961), while Belcher phase sites are distributed from about Fulton, Arkansas, to below Shreveport, Louisiana (Webb 1959; Schambach 1983; Kelley 1997). Upstream from the Texarkana phase, the McCurtain phase represents another Late Caddoan archaeological complex (Bruseth 1998).

In the Texarkana phase area, sites include large, permanent settlements with mounds and cemeteries, hamlets, and farmsteads. The mound centers were marked by the construction of earthen mounds that were used as temples, burial mounds, or ceremonial fire mounds. These settlements were inhabited by sedentary Caddo agricultural communities with complex societies led by individuals with high status who lived at the mound centers (e.g., Story 1990). Sites such as Hatchel (41BW3), Moore/Higginbotham (3MI3/30), and Cabe Mounds (41BW14) represent the larger villages or towns (Creel 1996; Sierzchula et al. 1995; Perttula et al. 1995), while known Texarkana phase hamlets or farmsteads have been investigated at the Sherwin, Atlanta State Park (Harris et al. 1980), and 41MX5 (Brewington et al. 1995) sites. These settlements--both the larger communities and the smaller hamlets/farmsteads--had pole and grass structures, outdoor ramadas or arbors, household cemeteries, and midden deposits from household refuse. The 1691 Teran de los Rios map of the Nasoni village on the Red River documented the likely character of individual farmstead compounds (see Perttula et al. 1995:Figure 3) and the layout of a dispersed village.

The Texarkana phase Caddoan sites appear to date from ca. A.D. 1300-1700, and mound construction seems to coincide with the main period of settlement at the Hatchel site, from about A.D. 1400-1700 (Creel 1996). Both archaeological and historical information suggests that the main platform mound at the Hatchel site may be the templo or temple mound shown on the Teran map (Wedel 1978:8). The Cabe mound may also have been occupied at this time, and Sierzchula et al. (1995) suggest that the Moore/Higginbotham mound center and community represents the upper Kadohadacho village that was eventually abandoned in 1788 (see Smith 1995:77).

Bruseth (1998) provides the most current discussion of the archeological character of the Late Caddoan McCurtain phase. From stable isotope and bioarcheological evidence, the McCurtain phase Caddo were agricultural peoples, depending heavily on the cultivation of maize as the main staple of the diet (Rose et al. 1998; Colby 1997). Like other Late Caddoan groups on the Red River, the McCurtain phase settlement pattern includes numerous habitation sites (with household cemeteries) and mound centers, though the mounds appear to have mainly been constructed between ca. A.D. 1300-1500. Bruseth (1998) suggests that the Caddo settlements along this stretch of the Red River resembled the Teran-Soule model (i.e., Schambach et al. 1983; Trubowitz 1984) in that Caddo villages were composed of individual compounds of houses and other structures associated with mounds and the residence of a caddi or chief. The density of McCurtain phase sites indicates that "greater numbers of people are living in closer proximity than before" (Bruseth 1998:90). At the Roitsch site (41RR16), the mound in McCurtain phase times was used as a place for the burial of the social elite, as a shaft tomb with $\mathbf{1 0}$ individuals and many grave goods was located near the center of the mound (Skinner et al. 1969). Special purpose salt-processing sites (such as the Salt Well Slough site [41RR204]) are also common in the vicinity of the Roitsch site. One of the most distinctive archaeological attributes of the McCurtain phase was the adoption of shell-tempering for both the utility and fine-ware ceramics, along with the manufacture and use of triangular arrowpoints. 
The Titus phase (dated from ca. A.D. 1430-1680) represents the archaeological remains of a number of Caddoan groups that lived in the Big Cypress Creek valley, parts of the Little Cypress Creek valley, the middle portions of the Sulphur River, the middle and upper portions of the White Oak Creek drainage, and the upper and middle reaches of the Sabine River drainage (Thurmond 1990:Figure 35; Perttula 1998b:Figure 4-3). These agricultural Caddoan peoples lived in dispersed year-round settlements where they farmed and hunted, and buried their dead in planned family and community cemeteries (Perttula and Nelson 1998). Regional Caddoan populations were apparently extensive throughout much of the Northeast Texas Pineywoods after ca. A.D. 1350/1400 (Thurmond 1990:Table 63).

Titus phase ceramics were generally tempered with finely crushed grog and bone, and were decorated with engraved lines. Scrolls, scrolls and circles, pendant triangles, and other curvilinear motifs were the most common decorative elements on a variety of vessel forms (Thurmond 1990:Figure 6; Perttula 1998b:Figure 4-4). Utility wares were usually large jars and bowls decorated with neck-banding, brushing, applique, punctation, and incised lines. Other ceramic artifacts manufactured by the Titus phase Caddo included earspools as well as biconical and elbow pipes (see Jackson 1933).

Tool diversity is low among this Late Caddoan culture, consisting primarily of triangular and corner-notched arrowpoints, flake tools, and various groundstone implements. These include celts, metates and manos, pigment stones, and abrading slabs (Turner 1978, 1992). Deer mandibles, beamers, and punches have also been noted, along with antler tines.

In the Sulphur River basin, Late Caddoan archaeological sites have been excavated that have been included within the Titus and Texarkana phases (Brewington et al. 1995; Thurmond 1985; Schambach 1983). Texarkana phase sites on the lower Sulphur appear to be closely related culturally to Caddoan entities on the Great Bend of the Red River, and are exemplified by large, permanent settlements at the Hatchel, Tilson (or Horace Cabe), and Mitchell sites in Bowie County, Texas, as well as smaller hamlets and farmsteads. Late Caddoan sites in the middle reaches of the Sulphur basin may be affiliated with the defined Cypress cluster of the Titus phase (Thurmond 1985:193, 1990), and sites such as Culpepper and W. A. Ford in Hopkins and Titus counties have been included within the Three Basins subcluster.

Thurmond (1985:193) noted that the SMU investigations at Cooper Lake (e.g., Doehner et al. 1978) failed to identify a single Titus phase component, but a reconsideration of the occupational history at Cooper Lake sites--and the excavations at the 15th century Peerless Bottoms site (41HP175; see Fields, Gadus, and Klement 1994)--indicates that there is, indeed, a transitory Late Caddoan exploitation of floodplain habitats at Cooper Lake (Bousman et al. 1988:30) by Late Caddoan groups populations. The Peerless Bottoms site has virtually the same variety of Caddoan ceramics as early (ca. A.D. 1300-1500) McCurtain phase sites on the Red River, and calibrated dates range from AD 1330-1524 (Fields, Gadus, and Klement 1994b). This is also a period of increased interaction between Pineywoods groups and Caddoan populations living some $100 \mathrm{~km}$ or more to the north on the Red River (Bruseth 1998; Perttula 1992:249).

Changes in the intensity of settlement after ca. A.D. 1400 at Cooper Lake suggest that permanent, sedentary settlements are uncommon in the South Sulphur River basin. Instead, the types of settlement represented are more indicative of mobile and functionally specific occupations probably relating to seasonal hunting activities. Thus, the upper portions of the Sulphur River basin were not apparently occupied on a permanent basis by Late Caddoan groups, and Fields et al. (1997:115) suggest that after ca. A.D. 1400, the upper Sulphur River basin area was the scene of "nonintensive, presumably limited-purpose use." It is likely that this later utilization of the South Sulphur River included forays by Caddoan hunting parties from the Red River, the lower Sulphur River, and the Cypress Creek drainages.

\section{Historic Native American Record}

No historic or post-A.D. 1700 Native American components have been recorded on the Sulphur River west of Bowie and Cass counties, Texas (Harris et al. 1980; Dickinson 1941). There is no ethnographic or archival information available that suggests that Caddoan or Wichita groups lived in the Upper Sulphur River basin during the eighteenth or early nineteenth centuries. The region north of the Sabine River is virtually unknown from an ethnographic perspective, having apparently been abandoned by Caddoan groups after ca. 1680, and by the time of sustained European or Anglo-American contact ca. A.D. 
1790-1800 (e.g., Flores 1985:3-30), most Indian populations in the area may well have been adversely affected by exposure to acute European diseases, and may have died or left the area.

The introduction of European diseases severely reduced the population sizes of Caddoan and Wichita groups, perhaps reducing populations as much as 95 percent between initial exposure (possibly in the 16th century [see Ramenofsky and Galloway 1997]) and the time of sustained European observations (e.g., Dobyns 1983; Perttula 1992). If Caddoan populations lived throughout much of the Sulphur River basin at the time of initial contact (ca. A.D. 1520), it is likely that drastic population losses, following the continued introduction of European diseases, would have resulted in: (1) the abandonment or emptying of the Sulphur River and/or (2) the retention of settlements as enclaves along major trails and portages (such as the Nasoni portage), rather than a continuous distribution of settlements and populations throughout the region.

Historical documents from the 1542 DeSoto-Moscoso entrada into East Texas from the lower Mississippi River Valley suggest that the "Nissohone" of the chronicles are probably the Nasoni of the eighteenth century (e.g., Hudson 1986; Swanton 1939) who were living on the lower Sulphur River (Hudson 1997:Map 8). It appears that the "Nissohone" lived in the same areas of the Sulphur River in 1542 as did population remnants approximately 150 to 200 years later (Perttula 1989d, 1992). Other Nasoni moved south into the Neches-Angelina River drainage after initial European contact and were eventually introduced to the Catholic faith when Spanish colonial religious and political policy dictated that Caddoan populations be missionized. The Mission San Jose de Nazones (1716-1719, 1721-1730) was built for these Nasoni at the same time other Spanish missions were built for the Neche, Tejas, Nacogdoches, Ais, and Adaes Caddoan groups (Swanton 1942).

Long after the Spanish mission system had failed in East Texas, Caddoan groups still continued to live in their native territories. However, in the 1790s, changes in Spanish policy regarding the colonization of Spanish Texas, led to the movement into Caddo territory along the Red River of Anglo-Americans and Immigrant Indians who had originally lived east of the Mississippi River (such as the Choctaw, Delaware, Cherokee, and Alabama tribes). Competition for land and resources, and the limited access to European trade goods, caused continual enmity between Caddoan groups (primarily living on the Red River and near Caddo Lake) and these intrusive groups. Several such Native American groups, including the Delaware, Quapaw, and Shawnee, moved into the lower Sulphur River valley in the early 1800s (Bollaert 1850; Ewers 1969). The Shawnee, for instance, numbered 300 families in 1830 (Ewers 1969:142), while the Delaware and Quapaw were estimated to number 150 families apiece in their East Texas settlements.

It is likely that the choice of the Sulphur River (then known as the Sulphur Fork of the Red River) as the area to settle was based on two related factors. The first was its proximity to Anglo-American settlements and trading establishments on the Red River at Sulphur Fork (at the mouth of the Sulphur River), Jonesborough, and Pecan Point (Steely 1986; Strickland 1937). Second was the historic trace that ran from the Red River (in Louisiana) across the Sulphur River towards the Taovayas-Wichita Indian villages on the upper Red River (Flores 1985:4). This trace was used by Anglo-American and Spanish traders in the 1790s to hunt deer and bison for their hides, and to procure wild horses for eventual sale in Natchitoches and New Orleans. The trace crossed the Sulphur River in the vicinity of Mustang Creek (Flores 1985:38, 113), not more than 30 miles $(50 \mathrm{~km})$ downstream from Cooper Lake. Mobile hunting parties of Caddoan groups, as well as more recent Immigrant Indian groups exploiting the same area, could very well have ranged into the prairie habitats of the South Sulphur River valley as late as the mid-1830s. 


\title{
CHAPTER 3, RESEARCH ORIENTATION
}

\author{
Timothy K. Perttula
}

As discussed in Chapter 1, archaeological investigations at the Hurricane Hill site (41HP106) were initiated in September 1986 when the Institute of Applied Sciences at the University of North Texas (IAS/UNT) conducted a reconnaissance survey of the dam embankment area at Cooper Lake. The site was well-known to avocational archaeologists and local residents, but had been overlooked in previous Cooper Lake surveys (e.g., Hyatt and Skinner 1971). The IAS/UNT team was called upon to fully record the boundaries of the site, as it had already been subjected to fairly extensive bulldozer disturbance by $\mathrm{COE}$ construction contractors, and to begin a testing program to evaluate its National Register of Historic Places eligibility.

That work identified relatively undisturbed subsurface archaeological deposits of prehistoric age over an approximately $6,000 \mathrm{~m}^{2}$ (1.5 acres) area near the western end of the 21-acre site. A large, wellpreserved midden deposit was encountered during shovel testing on the North rise. Test excavations indicated that the midden contained abundant faunal, floral, and archaeological remains in a 30- to 60-cm thick undisturbed deposit below the bulldozer grubbing or "scrogged" deposit. An initial assessment of the archaeological deposits suggested that it was an accretional midden "mound" with the potential to contain superimposed Late Archaic, Early Ceramic, and Early/Middle Caddoan period occupation zones or horizons. The Early/Middle Caddoan component (ca. A.D. 1000 to A.D. 1400) contained the overwhelming majority of the subsistence remains and ceramics, while the Late Archaic and Early Ceramic components (ca. 800 B.C. to A.D. 700) had a wide assortment of lithic tools and burned rock accumulations. Caddoan ceramics were recovered from shovel tests on other rises at the western end of the site. However, the overall nature of the subsurface deposits there remained unknown at the conclusion of Delivery Order 13 (see Chapter 1, this volume).

Based on the character of the North rise midden, our overall impression of the character of the Hurricane Hill site at that time was that regionally significant archaeological deposits were present, but additional test excavations were warranted to fully explore and assess other parts of the site. In particular, it was considered necessary to determine if structural features, human burials, or other cultural features could be located that would then be contextually associated with the Late Archaic/Early Ceramic and Early/Middle Caddoan period components. Obviously, if these types of features could be located in further testing, then the overall research significance of the site would be increased commensurably. At the same time, it was agreed by the $\mathrm{COE}$ that additional units would be excavated in the North rise midden to acquire more comprehensive information on the content and stratigraphic context of the remains preserved there.

Other likely occupational areas on different rises were investigated by excavating bisecting sets of backhoe trenches across each rise. The effort was successful in that cultural features and middens were also discerned on the South and Southwest rises. It became clear that the North rise midden was only an aspect of a more complex settlement occupied by Caddoan peoples. The presence of human burials on the North and South rises--and the possibility of preserved Middle Caddoan period structural remains on the South rise--meant that the scope of investigations had to be expanded to address the recovery of these more significant site features.

When it was clear that extensive excavations for data recovery purposes were necessary to mitigate the adverse effects of dam construction on the archaeological deposits, an excavation strategy was formulated that addressed specific aspects of the overall effort (i.e., the efficient recovery of human remains on the North rise and the exposure and documentation of suspected structures on the South rise). Since this strategy was devised in the absence of a formal research design, due to the emergency nature of the work, IAS/UNT and COE archaeologists agreed that the preparation of a research design at this point in the field work effort: (1) would be helpful in providing a clearer set of directions for future excavation requirements, and (2) would stand as the explicit rationale for pursuing certain excavation strategies over other options. 


\section{SMU Research Design}

The COE archaeologist suggested that the site-specific research design for the Hurricane Hill investigations be prepared in consultation with the Archaeology Research Program, Southern Methodist University, the archaeological contractor hired by the COE in 1987 to complete the cultural resources investigations at Cooper Lake (the COE subsequently hired Prewitt and Associates, Inc. to complete these investigations in 1991; see Fields et al. 1997). SMU's preliminary research design (SMU 1987) was provided to IAS/UNT archaeologists on 21 January 1987. The final SMU research design was not reviewed by the IAS/UNT because it was not available at the time the Hurricane Hill research design was written. While it was not intended that the SMU research design provide the research framework for the Hurricane Hill site research document, it was considered important that a certain comparability in research orientation and focus be maintained between the two. That is, important research themes defined by SMU that were applicable to the on-going and future archaeological investigations at Hurricane Hill were pursued in a systematic manner where possible.

The major orientation of the SMU preliminary research design is to:

systematically investigate processes of culture change from an ecological and behavioral perspective. The research design aims to understand how the settlement-subsistence patterns of the prehistoric and historic occupants of the Sulphur River drainage articulated with Holocene environmental changes and cultural developments in surrounding areas (SMU 1987:2-1).

Specific prehistoric research problems addressed by SMU include: (1) intrasite and intersite patterning, (2) subsistence resources, (3) technology, and (4) cultural chronology.

\section{IAS/UNT Framework}

A most important point in the effective consideration of settlement-subsistence systems, which was directly relevant to the additional intensive investigations at Hurricane Hill by the IAS/UNT, was that work should be directed towards those sites, or components within sites, that possess the optimal contextual integrity. Only in this way was it possible, or warranted, to obtain representative archaeological data sets with interpretable stratigraphic and temporal associations. The IAS/UNT testing approach concluded that only the North and South rises contained this kind of contextual integrity. Accordingly, these were the two areas in which it was decided to continue the intensive excavation effort.

The primary concern of the IAS/UNT research investigations at the Hurricane Hill site was to address the formation, character, and intrasite spatial structure of the Early Ceramic and Early/Middle Caddoan period occupations. In order to do this, the decision was made to restrict investigations to a relatively small part of the site area. Prior research at prehistoric sites in East Texas has been greatly hindered by an inability to relate any archaeological excavations to interpretable community or settlementscale cultural phenomena (e.g., Story 1990). The Hurricane Hill site appeared to possess a degree of spatial context not previously suspected at Cooper Lake prehistoric sites, and hence, it provided a unique opportunity to investigate intrasite spatial patterning in detail at one such site.

A field strategy used to facilitate the archaeological study of community or single settlement-scale problems was the excavation of large blocks in areas known, or suspected, to contain patterned associations of features and artifactual remains. Large block areas on the South rise were designed to acquire spatial information on the distribution of structural features, extramural features, and activity areas associated with the Early or Middle Caddoan occupations (see Chapter 4 for more specific information on the size and placement of block excavations on the North and South rises).

Outside the areas known to contain structural features, a modified block excavation strategy was implemented. Modifications consisted of: (1) shovel skimming archaeological deposits in two blocks (Blocks D and E) to rapidly expose cultural features, such as human burials, pits, and hearths, within the North rise midden, and (2) manually excavating and screening the matrix of a selected sample of 1x1-m units (this sampling approach had been suggested by Dr. Dee Ann Story during a site visit in the fall of 
1986) within the two blocks (estimated to be 10 percent of the 220 square meter block areas). This strategy produced stratigraphic data on the density and character of the midden's material remains, particularly the Early Ceramic occupational debris comprising the lower levels of the midden.

The limited controlled excavations of units in Blocks $\mathrm{D}$ and $\mathrm{E}$ were balanced by the expansion of Block A excavations from 20 square meters to 42 square meters. The block was placed in that part of the North rise midden known to contain well-preserved faunal and floral remains dating primarily to the Early Caddoan period. The expansion of Block A was considered necessary to obtain an adequate and representative sample of subsistence remains from these contexts. Approximately 9.5 percent of the total North rise midden was excavated by hand during the data recovery effort.

The comprehensive investigation of prehistoric subsistence strategies at Hurricane Hill was predicated upon the systematic recovery of the total faunal and macrobotanical assemblages preserved within those areas of the site selected for excavation. This necessitated use of fine-screen (1/8-inch and 1/16-inch mesh) and flotation recovery techniques at Hurricane Hill to ensure that small faunal remains (e.g., rodents and fish) and most macrofloral remains were not underrepresented or overlooked. These recovery techniques were employed most intensively in Block A excavations. More extensive fine-screen and/or flotation samples were obtained from the Block A expansion, amounting to approximately 90 percent of the expansion, and fine-screen and flotation samples were also routinely obtained during the excavations on the South rise.

It was extremely important that the faunal and floral samples from this well-dated context were large enough that interpretations of subsistence diversity, taxonomic richness, and overall species composition were not unduly affected by variations in sample size (e.g., Grayson 1984; Jones et al. 1983; Jones and Leonard 1989). A concerted effort to acquire a statistically adequate sample was, therefore, of primary concern behind determinations of the size of the Block A excavations. The extent of excavations in Block A was small relative to Blocks B through E, but the level of significant information contained in Block A deposits was considered superior, in a qualitative sense, because of the preserved subsistence remains. Well-preserved faunal and floral assemblages from excavated Caddoan and Early Ceramic period sites were rare in Northeast Texas at the time of our work (cf. Perttula et al. 1983), although more recent investigations at Cooper Lake has also obtained significant subsistence data from sites occupied at those times (Fields et al. 1997). Therefore, it was imperative that the opportunity presented by the middens for the recovery of subsistence remains be realized before the Hurricane Hill site was totally destroyed.

More general research themes pursued in the investigations were designed to enhance understanding of the site's paleo-environmental context, Early Ceramic to Early/Middle Caddoan lithic and ceramic technology, the exchange and importation of ceramics and lithic raw materials, and overall site formation processes. Studying these aspects of the archaeological record at Hurricane Hill, in combination with significant new data on subsistence and site layout, was aimed at formulating a cultural-ecological synthesis of the changing prehistoric utilization of the Hurricane Hill site in particular, as well as the Cooper Lake area in general.

Potential paleoenvironmental data from the site were to be acquired in several ways. Most important was the information collected from the faunal and paleobotanical resources utilized by the site inhabitants, as this data helps to characterize local resource availability and zones of exploitation at the time of the occupation(s). In addition, terrestrial gastropods and molluscs were preserved in the North rise midden. Sedimentological and pedological studies, of particular importance for discerning site formation processes (e.g., Ferring 1986; Ferring and Peter 1987), in certain contexts can contribute to a better understanding of the paleoenvironmental record. It is likely, however, that the site's paleoenvironmental context must await more systematic paleoenvironmental research across Northeast Texas.

Beyond the overall characterization of tool assemblage variability between components and from intrasite dimensions, other parameters of lithic analysis included how frequently raw materials were procured from local or non-local sources. Methods of cobble reduction, tool production, and maintenance were to be studied using attributes of percentage of cortex present, blank form, and other variables compatible with the SMU analytical schemes (e.g., Peter and McGregor 1987; McGregor 1997c) and with then-current IAS/UNT analyses at Lake Ray Roberts in North Central Texas (cf. Ferring and Allen 1987; Ferring and Yates 1996). 
One part of the ceramic analytical efforts follow those outlined in Ferring and Perttula (1987), since significant provenance and technological data on Caddoan ceramic assemblages from northeastern Texas and southern Oklahoma have already been accumulated that may be directly comparable to Hurricane Hill. Additional ceramic analysis is directed towards establishing temporal and formal frameworks for the recognition of Caddoan cultural constructs in the Cooper Lake area. Decorative style design, vessel morphological attributes, and choices in tempering materials are considered to be the most useful elements for these purposes.

Thurmond's $(1985,1990)$ discussion of the stylistic variability in the Late Caddoan ceramic type, Ripley Engraved, that has distinct decorative rim motifs with specified spatial and temporal distributions, illustrates an important point in current Caddoan ceramic classifications (Schambach and Miller 1984). Namely, stylistic change is more than simply an iconographic one or only reflective of temporal differences. Rather, the analysis of systemic assemblage-scale variability in style may help not only to differentiate the style of communities and the spread of ideas and symbols but also to ascertain the movement of pots as a consequence of economic exchange (Rice 1987, 1996). The analyses of attributes such as vessel form, thickness, and temper, and the co-association of morphological, technological, and functional attributes, are appropriate to the study of local and regional ceramic variability. If patterned technological and functional changes can be related to diachronic trends in Caddoan lifeways, functional and behavioral differences through time in the use of ceramics may be identified that are specifically informative about Caddoan cultural change (cf. Braun 1985, 1988).

At the time of the investigations at Hurricane Hill, no clear ceramic chronological framework existed for the upper Sulphur River basin that was applicable to accurately determining the temporal periods when the presumed Caddoan utilization of Hurricane Hill, and the Cooper Lake area in general, took place. Insufficient research near the project area precluded the reliability of the rather gross level of temporal classification then available in the northeastern Texas portion of the Caddoan area (e.g., Schambach 1983; Bruseth and Perttula 1981; Miller 1986). The development of a local ceramic chronology was, therefore, considered to be an essential and basic pursuit of ceramic studies in the Cooper Lake area, and the large Hurricane Hill ceramic assemblage was an ideal place to begin in the construction of such a chronology (see also Cliff and Perttula 1995; Fields et al. 1997).

An important question concerning the archaeological deposits at Hurricane Hill is how did the middens form? Are they accretional features or midden "mounds," and if so, how rapidly were they deposited? Are distinct occupational surfaces discernible in the North rise midden? Does the midden represent a more homogenous, less structured depositional event with no distinct occupational episodes preserved in its fill? The answers to these questions have implications not only for interpreting the character of the cultural assemblages and features preserved therein, but also for relating distinct occupational events with specific temporal and functional aspects of the site occupation.

These site formation processes can be studied from several perspectives once the temporal context has been well-established. Thermoluminescence (TL) samples from apparent occupational surfaces and associated features were processed, along with numerous radiocarbon dates from a number of contexts, and the resulting dates provide the framework for discussing rates of deposition and differential preservation within the midden(s). Patterns of refuse disposal and the duration's of occupation were to be investigated once the depositional environment of the site deposits had been ascertained, as this was a necessary step for adequately comparing areas within the site in terms of their archaeological content.

\section{Summary}

The primary rationale of the IAS/UNT work at the Hurricane Hill site was to implement a diversified excavation strategy for mitigating the adverse effects to the site caused by destruction of significant archaeological resources in the Cooper Lake dam right-of-way. In trying to understand the intrasite spatial structure of Late Archaic/Early Ceramic and Early/Middle Caddoan period occupations dispersed across the dam axis right-of-way, our excavation strategy was based on the manual excavation of large blocks of contiguous units and the mechanical grading of several areas on the North and South rises where abundant cultural features and structural remains were preserved. 
Controlled excavations were necessary to insure that contextually associated material remains and features (i.e., structures, pits, and burials) could be defined that relate to each occupational episode preserved on the rises. Block A was expanded to enhance the recovery of the well-preserved subsistence remains present in the North Rise middens. These date primarily between A.D. 1000 and A.D. 1400 and provide an excellent sample for consideration of changes in Caddoan subsistence. Large block excavations on the South rise were necessitated to document the Middle Caddoan structures preserved there. 


\title{
CHAPTER 4, FIELD AND LABORATORY METHODS
}

\author{
Timothy K. Perttula
}

This chapter reviews first the methods of testing and excavation employed during the four different phases of archaeological research at the Hurricane Hill site. The discussion is presented sequentially, so that the history of work and the reasons for the chosen excavation strategies may be clearly understood. The second part of the chapter concerns the laboratory methods used to inventory, process, and analyze all material classes of artifacts (i.e., stone, ceramic, faunal, floral, or historic) recovered during the project.

\section{Field Excavation Strategies}

Once the overall limits of the site had been established during the surface reconnaissance of the dam construction area, it was necessary to assess the subsurface context, integrity, and character of the archaeological deposits in certain areas of the site. Because the surface inspection had indicated that the thickest, densest, and best-preserved archaeological deposits at the site were located at its western end, near the edge of the upland overlooking the South Sulphur River floodplain, Phase I investigations consisted, initially, of the excavation of 24 shovel tests across this portion of the site (Figure 4-1). A number of other shovel tests were placed at the eastern end of the site to examine a different set of prehistoric/historic deposits (Perttula 1989b). The shovel tests were spaced at 10 to 20 -m intervals along the upland edge, across the four sandy rises, and east or southeast of the rises, in an attempt to rapidly, but efficiently, locate preserved subsurface archaeological deposits and to assess the overall condition of the archaeological record in this part of the site.

$\circ 6$

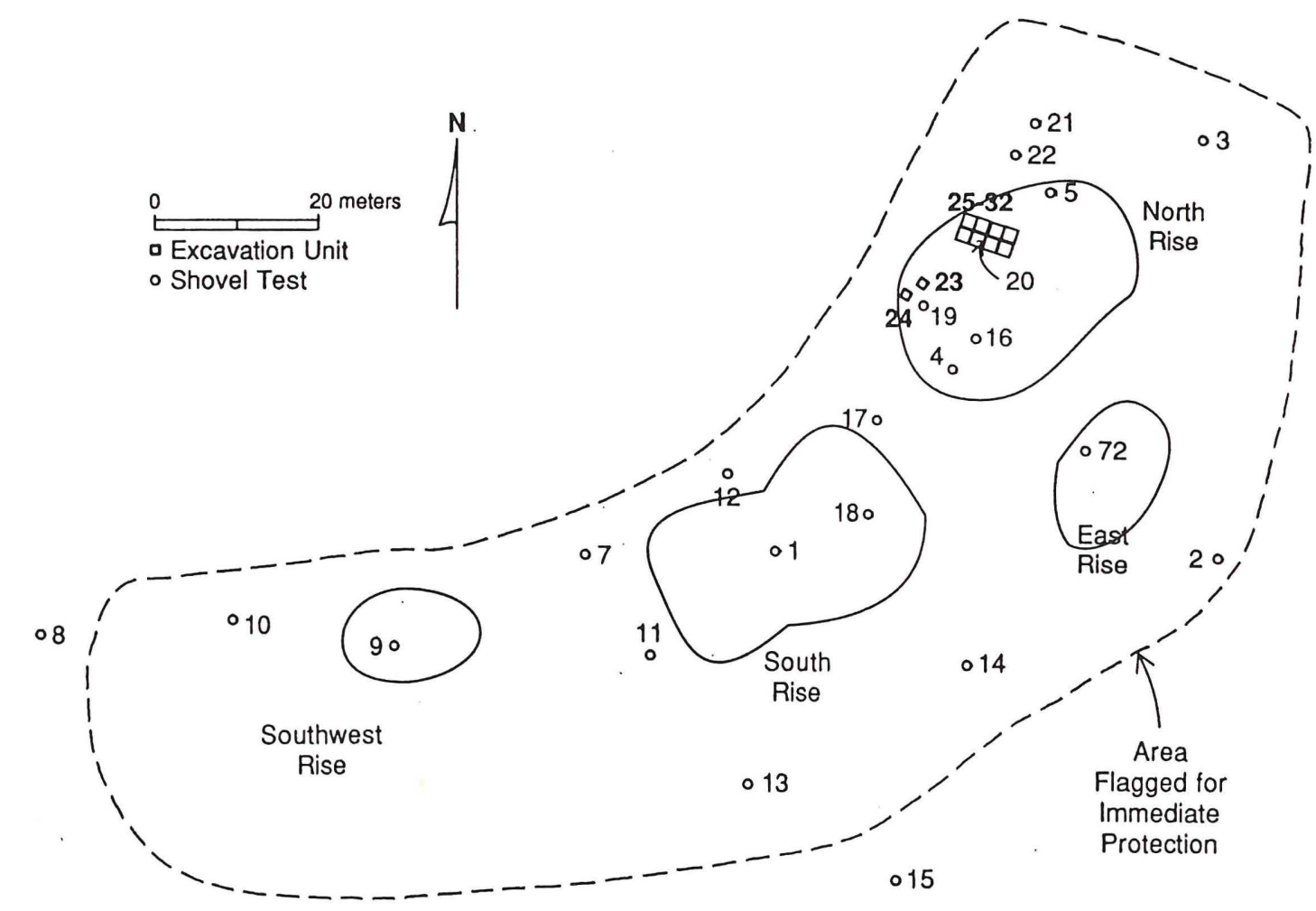

Figure 4-1. Phase I investigations at Hurricane Hill. 
Only shovel test \#14 contained no archaeological remains. The remainder of the shovel tests documented that prehistoric archaeological materials covered the entire area of the upland landform within the right-of-way; were present to depths of 60-70+ cm; were basically undisturbed below $10-20 \mathrm{~cm}$ below surface (bs), the depth of plowing, bulldozing or grubbing; and were concentrated on the North, South, and Southwest rises (Table 4-1). On the North rise, 20 to 40-cm thick midden deposits were noted in Shovel Tests \#5 and \#20, and a concentration of burned clay that was recorded in Shovel Test \#19 (see Table 4-1) was considered to be an indication that a preserved cultural feature of undetermined function was preserved on the rise. Although midden deposits were not noted in shovel tests on the South, East, and Southwest rises, subsurface deposits upwards of $40-70 \mathrm{~cm}$ in thickness were recorded on these landforms. The presence of relatively abundant Caddoan sherds on the North and South rises was also noted during the shovel testing operations.

Table 4-1. Frequencies of cultural materials recovered from Phase I shovel tests.

\begin{tabular}{|c|c|c|c|c|c|c|}
\hline $\begin{array}{l}\text { Shovel } \\
\text { Test \# }\end{array}$ & Tools & $\begin{array}{l}\text { Lithic } \\
\text { Debris }\end{array}$ & Sherds & $\begin{array}{l}\text { Daub } \\
\text { (g) }\end{array}$ & $\begin{array}{l}\text { Burned } \\
\text { Clay (g) }\end{array}$ & FCR \\
\hline
\end{tabular}

\section{NORTH RISE}

$\begin{array}{lllllll}4 & 1 & 11 & 4 & - & 1.5 & 1 \\ 5 & 5 & 35 & 2 & - & - & 5 \\ 16 & 7 & 174 & 2 & - & - & 60 \\ 19 & 13 & 192 & 9 & - & 45.5 & 51 \\ 20 & 27 & 421 & 47 & 6.7 & 37.1 & 65 \\ 21 & - & 15 & - & - & - & 1 \\ 22 & 3 & 12 & 1 & - & - & - \\ \text { Subtotal } & 56 & 860 & 65 & 6.7 & 84.1 & 183\end{array}$

\section{SOUTH RISE}

$\begin{array}{lll}1 & - & - \\ 7 & 15 & 88 \\ 11 & 1 & 23 \\ 12 & 5 & 28 \\ 18 & 15 & 99\end{array}$

$\begin{array}{lll}\text { Subtotal } \quad 36 & 238\end{array}$

3

$-$

$-$

1

5

\section{SOUTHWEST RISE}

9

10

Subtotal
7

7
73

13

86
0.0

7.4

22

-
-
-

7.4

2

7

$-$

13

EAST RISE 
Table 4-1. Frequencies of cultural materials recovered from Phase II shovel tests, cont.

\begin{tabular}{|c|c|c|c|c|c|c|}
\hline $\begin{array}{l}\text { Shovel } \\
\text { Test \# }\end{array}$ & Tools & $\begin{array}{l}\text { Lithic } \\
\text { Debris }\end{array}$ & Sherds & $\begin{array}{l}\text { Daub } \\
\text { (g) }\end{array}$ & $\begin{array}{l}\text { Burned } \\
\text { Clay (g) }\end{array}$ & FCR \\
\hline
\end{tabular}

\section{OTHERS}

\begin{tabular}{|c|c|c|c|c|c|c|}
\hline 2 & - & 1 & - & - & - & 1 \\
\hline 3 & - & 5 & 2 & - & - & 3 \\
\hline 6 & 9 & 94 & 1 & - & - & 9 \\
\hline 8 & 2 & 50 & - & - & - & 12 \\
\hline 13 & 4 & 27 & 2 & - & 1.3 & 5 \\
\hline 14 & - & - & - & - & - & - \\
\hline 15 & - & 3 & - & - & - & - \\
\hline 17 & 5 & 49 & - & - & - & 2 \\
\hline 33 & - & 4 & - & - & - & - \\
\hline Subtotal & 20 & 233 & 5 & 0.0 & 1.3 & 32 \\
\hline SITE TOTAL & 119 & 1438 & 75 & 6.7 & 92.8 & 239 \\
\hline
\end{tabular}

Shovel tests were $30 \times 30 \mathrm{~cm}$ in size, and all fill from the shovel tests was screened through $1 / 4$ inch hardware cloth to recover cultural materials. With the exception of Shovel Test \#20, which was excavated in 20-cm thick arbitrary levels to assess the vertical character of the midden on the North rise, shovel tests were excavated in one vertical provenience to the base of cultural deposits. Notes were taken on the nature and thickness of the soil matrix and the underlying B-horizon when it was encountered. When a temporally diagnostic artifact was recovered in situ, information was recorded on its depth and associated soil matrix. All artifacts recovered from the shovel tests were retained for laboratory analyses. A magnetic strip was placed at the bottom of each shovel test prior to backfilling to aid in relocating shovel tests, should that prove necessary.

After the shovel tests were backfilled, a red pin flag was placed in the backfill of the shovel tests for mapping their location during the production of the site contour map. A temporary site datum, a wooden stake, was placed southeast of the South rise. This stake was tied in to the main site datum, CE Benchmark P.C. 31 + 07.8 (see Figure 1-4), a short distance away. However, a formal site grid had not been established yet. Instead, shovel tests were numbered consecutively beginning with \#1.

Surface collections were made at the Hurricane Hill site to recover temporally and functionally diagnostic prehistoric artifacts from different parts of the site. Surface collections were also made periodically during all phases of the project due to the excellent surface exposure caused by the bulldozer clearing of the site. Notes were maintained on the collections that specified the location and extent of surface-exposed artifacts relative to the different natural rises, as well as to landmarks and shovel tests. In at least one instance after a heavy rain, a more thorough surface collection was taken on the North rise to recover a broader range of artifacts, to obtain information on the frequency of fire-cracked rock (FCR), and to assess the relative frequency of non-local lithic raw materials on this part of the site. Lithic debris, FCR, fired clay, plain body sherds, faunal remains, and mussel shell were collected in addition to the lithic tools and decorated ceramics that had also been collected on several previous occasions.

Ten $1 \times 1$-m excavation units were placed on the North rise as part of the Phase I investigations (see Figure 4-1). As previously mentioned (see Chapter 1), the intent of the test excavations was to quickly gather more data on the character of the archaeological deposits than was possible from surface collections and shovel tests. Instead of dispersing 1 x 1-m units randomly across the site, work was concentrated on the North rise--where the presence of midden deposits was already known--in order to maximize the recovery of datable remains and faunal materials before this part of the site was destroyed by construction activities. 
This work was done with the expectation that, at the conclusion of the two week field investigations, the site would be bulldozed again and destroyed.

Because of the nature of the scope of work for the Phase I investigations specified by the COE archeologists, it was not possible to systematically excavate $50 \times 50-\mathrm{cm}$ or 1 x $1-\mathrm{m}$ units across the site, although this sort of sampling approach certainly would have been helpful in planning a comprehensive excavation strategy (cf. Bruseth and Martin 1987). Consequently, the effort was decidedly ad hoc. In any event, it was decided that excavations on the North rise would be most advantageous from an archaeological perspective because of the preserved midden deposits. A total of 6.5 cubic meters of archaeological deposits was excavated on the North rise during Phase I (Table 4-2).

Table 4-2. Summary of Phase I-IV excavations.

\begin{tabular}{|c|c|c|c|c|c|c|}
\hline \multirow[t]{2}{*}{ Phases } & \multicolumn{2}{|c|}{$\begin{array}{l}\text { Manual } \\
\text { Excavations }\end{array}$} & \multicolumn{2}{|c|}{$\begin{array}{l}\text { Machine } \\
\text { Excavations }\end{array}$} & \multicolumn{2}{|c|}{ Total Excavations } \\
\hline & sq. m & cu. m & sq. m & cu. m & sq. m & cu. $m$ \\
\hline Phase II & & & & & 12.4 & 6.5 \\
\hline Shovel tests & 2.4 & 0.9 & - & - & & \\
\hline $1 \times 1-\mathrm{m}$ Units & 10.0 & 5.6 & - & - & & \\
\hline Phase II & & & & & 269.5 & 179.8 \\
\hline Block Excavations & 36.0 & 17.8 & - & - & & \\
\hline $1 \times 1$-m Units & 4.0 & 2.0 & - & - & & \\
\hline Backhoe Trenches & - & - & 229.5 & 160.0 & & \\
\hline Phase III & & & & & 353.0 & 150.5 \\
\hline Block Excavations & 353.0 & 150.5 & - & - & & \\
\hline Phase IV & & & & & 1606.0 & 962.2 \\
\hline ScrapedAreas & - & - & 1600 & 960.0 & & \\
\hline $1 \times 1$-m Units & 6.0 & 2.2 & - & - & & \\
\hline TOTALS & 411.4 & 179.0 & 1829.5 & 1120.0 & 2240.9 & 1299.0 \\
\hline
\end{tabular}

Two of the 1 x 1-m units (Units 23 and 24) were located near Shovel Test \#19 to provide more information on the fired clay concentration exposed by that shovel test (see Figure 4-1). The remaining units (Units 25-32) were placed next to Shovel Test \#20, in the approximate center of the well-preserved midden on the North rise. They were arranged as three connected trenches 3-4 $\mathrm{m}$ in length (Figure 4-2).

Each 1 x 1-m unit was excavated in 10-cm arbitrary levels, and all matrix was dry-screened through 1/4-inch hardware cloth. The units were not oriented to magnetic north, but to $33^{\circ} \mathrm{E}$ of true North so that they were aligned with the topographic trend of the North rise (see Figure 1-4). Excavations were terminated at the base of the cultural deposits, which extended a few centimeters into the clay or sandy clay loam B-horizon of the Woodtell soil series. Documentation of excavation efforts included daily journals completed by the Project Director and Crew Chief, excavation unit level forms, photo logs, and measured profile drawings and accompanying stratigraphic descriptions of one or two walls of each excavation unit. The soil matrix was described using the concept of zones, which consists of defined "layers" in the profile that can be distinguished on the basis of color, particle size, cohesiveness, structure, geomorphic features, and sorting from adjacent zones (Bousman et al. 1988:49). Zones were designated numerically (from I-IV 
etc.), and an alphabetical subset was employed to denote that the zone was not continuous across the excavated area of the inspected profiles (see Chapter 5, this volume).

\begin{tabular}{|c|c|c|c|c|c|c|c|c|}
\hline \multicolumn{8}{|c|}{ East Axis } & \multirow{9}{*}{$\begin{array}{c}\text { Block A extent } \\
\text { Phase III }\end{array}$} \\
\hline & 20 & 21 & 22 & 23 & 24 & 25 & 26 & \\
\hline - 18 & 248 & 249 & 250 & 251 & 252 & 253 & 254 & \\
\hline 19 & 238 & 239 & 240 & 241 & 242 & 243 & 255 & \\
\hline $\begin{array}{l}\text { South } \\
\text { Axis }\end{array}$ & 34 & 35 & 36 & 37 & 38 & 244 & 256 & \\
\hline 21 & 31 & 31 & 29 & 32 & 39 & 245 & 257 & \\
\hline 22 & 26 & 42 & 43 & 25 & 40 & 246 & 258 & \\
\hline \multirow[t]{3}{*}{23} & 28 & 44 & 45 & 27 & 41 & 249 & 259 & \\
\hline & Phase I & \multicolumn{2}{|c|}{ Block A } & \multicolumn{3}{|c|}{ Phase II } & & \\
\hline & & & 是 & \multicolumn{3}{|c|}{2 meters } & & $\begin{array}{l}\text { Numbered } \\
\text { Excavation } \\
\text { Unit }\end{array}$ \\
\hline
\end{tabular}

Figure 4-2. Block and unit layout for Block A on the North rise at Hurricane Hill, and South and East axis coordinates.

All zones were described by color utilizing a Munsell Soil Color Chart, and textural designations were based on guidelines enumerated by the U.S. Dept. of Agriculture (1975). Using a clean trowel, 100 to 200-g soil samples were obtained from each defined soil zone for further mechanical and chemical analyses. Photographs were taken of excavation activities throughout the course of Phase I investigations, and color slides were also taken of each measured profile for overall comparability between different excavation units.

At the conclusion of Phase I activities, magnetic strips were placed at the bottoms of the pits and all $1 \times 1-m$ units were backfilled. The area of excavations was flagged and marked with stakes, and a conservatively-based estimate of the extent of well-preserved archaeological deposits located at the western end of the site was also flagged to mark the part of the site to be avoided by the CE contractors during renewed bulldozing and grubbing activities. The flagged area covered ca. 10,000 square meters (see Figure 4-1).

Phase II investigations at Hurricane Hill were more expansive spatially, as well as more intensive locally, than the preceding work (Figure 4-3). Block A, on the North rise, was expanded to 20 square meters (see Figure 4-2) to recover a larger and more representative sample of the cultural, faunal, and floral remains preserved in the midden. At this time, 50 x 50-cm fine-screen units were excavated within each $1 \times$ 1-m unit of the Phase II extension, usually taken from Quad 3 (the southwest quadrant of the $1 \times 1-\mathrm{m}$ unit), and beginning below the plowzone and bulldozer disturbance (generally below $10-20 \mathrm{~cm} \mathrm{bs}$ ). For the finescreen units, a 1/16-inch mesh screen was employed to recover macrofaunal/floral remains, as well as to assess and quantify each level's population of artifacts less than 1/4-inch in size (e.g., Fladmark 1982). A 
flotation sample was taken from the fine-screen unit for each level; the average flotation sample size was 7.0 liters (Table 4-3).
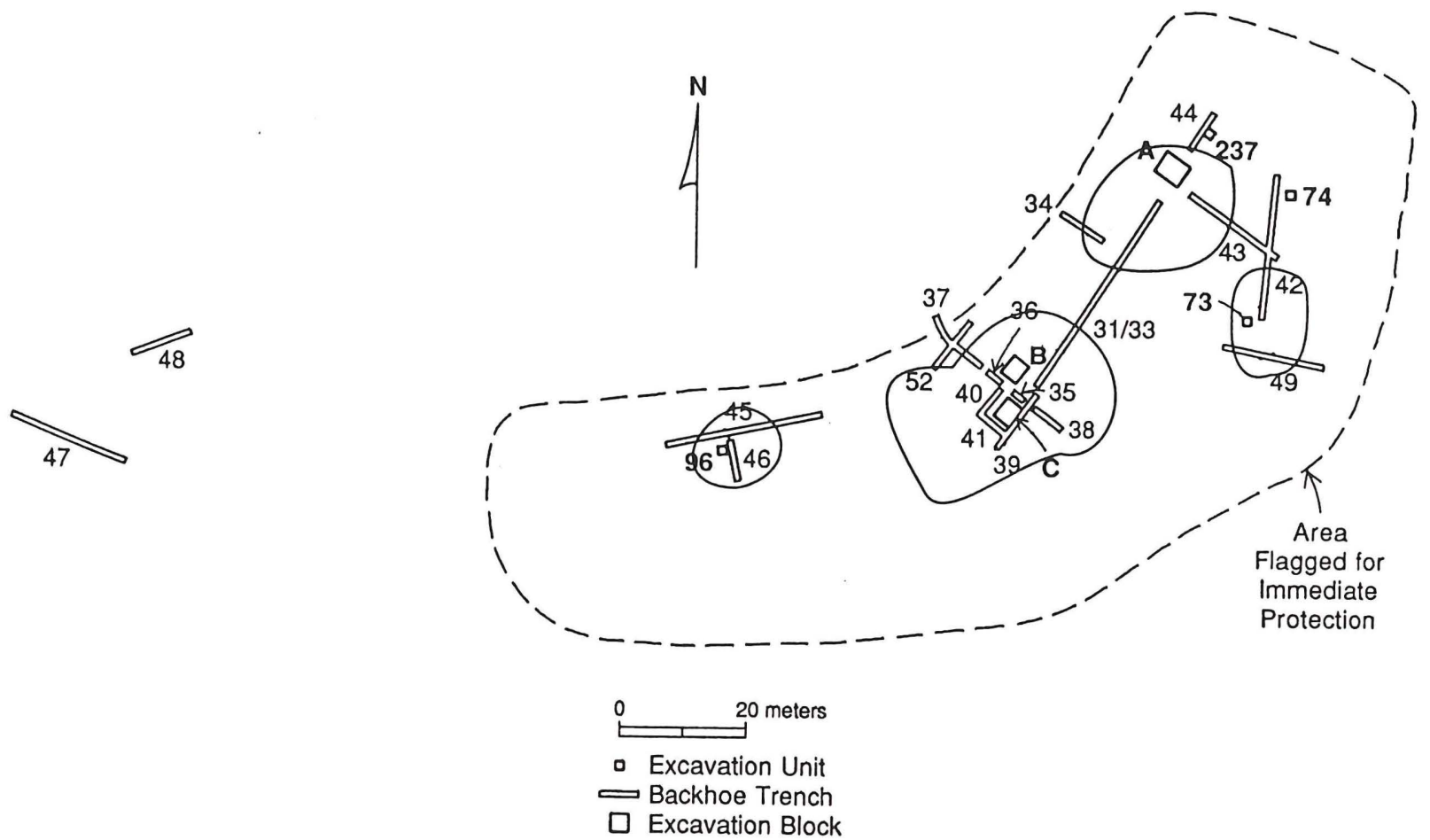

Figure 4-3. Phase II investigations at Hurricane Hill.

Table 4-3. Volume of flotation samples.

\begin{tabular}{llll}
\hline Provenience & Samples & $\begin{array}{l}\text { Volume } \\
\text { (liters) }\end{array}$ & $\begin{array}{c}\text { Mean } \\
\text { (liters/sample) }\end{array}$ \\
\hline North Rise: & 48 & 336 & 7.0 \\
Block A & 491 & 3050 & 6.2 \\
Block A-extension & 126 & 892 & 7.1 \\
Block D & 47 & 329 & 7.0 \\
Block E & & & \\
South Rise: & 83 & 498 & 6.0 \\
Block B & 80 & 480 & 6.0 \\
Block C & 513 & 3100 & 6.0 \\
Block B/C & 8 & 59 & 4.4 \\
Block F & 191 & 8923 & \\
Features & & & 11.2 \\
\hline
\end{tabular}


The fine-screen samples were initially processed at a large stock pond several hundred meters east of the site excavations, but the flotation samples were simply bagged in resealable, airtight plastic bags and stored in Cooper, Texas, until they were taken to the off-campus laboratory of the IAS/UNT. A frothflotation device was constructed for the project, using the same design employed by Southern Methodist University during archaeological investigations at Richland-Chambers Creek Reservoir (Peter 1987). The samples were air-dried, then processed through a series of four nested screens. The heavy fraction $(6.4-\mathrm{mm}$ screen), and three light fraction (1.70-mm-0.25-mm screen) residues, were placed on newspapers to air-dry, and then the samples were labeled with the provenience code and stored in cardboard boxes at the off-campus field laboratory until they were sorted or shipped to consultants for further examination.

The next aspect of the Phase II investigations was the excavation of 18 backhoe trenches (\#31-46, \#52) across the four rises at the west end of the site, along with two backhoe trenches at the far west end of the site (see Figure 4-3). A total of 229.5 square meters of backhoe trenches was excavated (see Table 4-2), with an average depth of $70 \mathrm{~cm}$. (The numbering system for the backhoe trenches was a continuation of that begun with the buried site reconnaissance carried out in the dam embankment [Perttula 1988a:85-90]). Backhoe Trenches \#50 and \#51 were excavated in Area B of the Hurricane Hill site (see Appendix I, Volume II).

The main purpose of the backhoe trenching was to rapidly assess the character of subsurface archaeological deposits in other areas of the site besides the North rise midden, and to explore the site for the presence of preserved features. The trenches were oriented parallel to the edge of the landform so that they cross-cut each of the sandy knolls or rises in an effort to expose more informative profiles of the stratigraphic, pedologic, and cultural deposits (see Figure 4-3). Backhoe Trenches \#47 and \#48 were placed at the extreme edge of the landform (see Figure 4-3) to examine a possible midden exposed on the surface in a bulldozed area, as well as to evaluate an informant lead that two human burials had been previously disturbed a few meters north of Backhoe Trench \#48 (Banks 1986).

Both walls and the floor of each trench were cleaned and scraped with a trowel to: (1) examine the cultural or natural stratigraphy, and (2) look for preserved features bisected by the backhoe. Possible features and stains (see Chapter 6, this volume) were located in the trench, marked with a pin flag, and the origin and total depth of the feature or stain were also recorded. Features and stains were numbered consecutively, beginning with \#1, and any exposed artifacts in clear association with features or stains were collected at the time of initial cleaning. Features and stains were not excavated upon immediate exposure, but upon the completion of the backhoe trench.

The fill of the trenches was described according to color and texture, as mentioned above, and zones (or zone subsets) designated numerically and/or alphabetically, depending upon the horizontal continuity of the zone. In most trenches, one entire wall profile was measured and drawn, with soil samples taken at various sections along the trench within each designated zone. Photographs were taken of each measured profile. Only measured sections were completed for some of the trenches when it was evident that cultural deposits were sparse, and features or stains were lacking in the trench.

Archaeological materials from a non-feature or non-stain context were collected in a few instances from a backhoe trench to document the occurrence of certain types of temporally or functionally diagnostic artifacts within designated soil zones. Horizontal location within the trench, the absolute depth below surface, and the zone designation were the types of information routinely recorded for such diagnostics. Non-diagnostic lithic debris, bone, burned clay, and daub were mapped in the measured trench profiles, but they were not collected from the trenches unless they occurred in direct association with a feature or stain. Temporally or functionally diagnostic artifacts were collected from backhoe backdirt only when the artifact could be associated with a particular trench, regardless of its specific horizontal or vertical provenience.

Backhoe trench excavations were initiated in the vicinity of Block A on the North rise midden and were oriented northeast-southwest towards the South rise and the vicinity of Shovel Test \#1 (see Figure 41), because of a surface concentration of sherds, novaculite arrowpoint fragments and debris, as well as burned clay exposed on the South rise. These artifacts denoted a possibly significant Caddoan occupation that warranted investigations at the same time the area between the North and South rises was explored. 
Backhoe Trenches \#31-33 exposed the southern edge of the North rise midden and encountered evidence for human burials in three different sections of the 36-m long trench (see Chapter 5, this volume). The first two burials had been placed in the North rise midden along the lower slopes of the rise. However, the third burial, an adult in a pit with limited amounts of midden fill, occurred on the margins of the South rise and was thought to probably have been located outside a structure (e.g., Rose 1984).

If a Caddoan structure was present on the South rise, it would have been near the crest of the rise some meters away from the third burial. Accordingly, a series of short backhoe trenches (\#35-41) were oriented parallel or perpendicular to Backhoe Trench \#33, where the third burial had been found, bisecting South rise (see Figure 4-3). The trenches were excavated in limited increments until either the B-horizon clay was exposed, or stains and features were apparent in plan view in the floor of the trench. Previous experience in northeastern Texas Caddoan sites by Prewitt (1975), Story (1982), and Bruseth and Perttula (1981), among others, had suggested that backhoe trenching was an expedient technique for locating stains or features associated with Caddoan wood structures. The cultural origin of a stain cross-sectioned by a backhoe trench is more readily interpreted than a stain exposed in a small test unit. In addition, these trenches provided a long exposure to examine spatial variation in the character and extent of different depositional zones. These zones could relate to house fill and/or extramural middens, or could be natural zones with no discernible cultural deposits.

A number of stains, possible pits, and features were initially noted and marked in the floors and walls of the backhoe trenches on the South rise, clearly indicating intensive Caddoan use of the rise. Also, at the intersection of Backhoe Trenches \#35, \#36, and \#40, circular and probable posthole stains were noted in proximity to, and under, a large clay-lined hearth basin (Feature 5). This hearth was exposed at a relatively shallow depth. Thus, these particular backhoe trenches were discontinued. While it was possible that the hearth was not located within a Caddoan structure, the presence of a large posthole immediately below the hearth and of other postholes or stains in a radius around the hearth, where they had been intersected by backhoe trenches, appeared to be substantive evidence for the presence of a structure. The occurrence of a center post under the central hearth of a Caddoan house is a common phenomenon in northeastern Texas archaeological sites (Story 1981 (ed.), 1982; Newell and Krieger 1949), and this was believed to be the case on the South rise of the Hurricane Hill site. Based on Caddoan house construction activities observed ethnographically, the large central post probably helped support the superstructure of the house while it was being erected, and after the other posts and crossbeams had been lashed together, the central post was cut out. A hearth was then placed at its location to complete the house (e.g., Swanton 1942:148-153; Bolton 1987:112).

Following the initial identification of probable Caddoan structural remains on the South rise, Backhoe Trench \#37 was extended west towards the edge of the upland landform to search for associated middens, and Backhoe Trench \#38 was excavated for a similar purpose along the eastern slope of the rise (see Figure 4-3). Backhoe Trench \#37 was later bisected by Trench \#52, which was excavated to further delimit the midden deposits that were located on the western part of the rise.

Similar goals were pursed for the excavation of additional backhoe trenches on the North rise. Namely, Backhoe Trenches \#34, \#43, and \#44 were excavated to delimit the boundaries of the North rise midden.

To expand the site investigations beyond the North and South rises, additional trenches were excavated on the East and Southwest rises (see Figure 4-3). Midden deposits and features were located on the Southwest rise, but no discrete cultural zones or features were detected in backhoe trenches cutting across the East rise. To be sure that important cultural deposits were not overlooked on the East rise, two 1 x 1-m units (Units 73 and 74) were excavated to ascertain the vertical character of the subsurface record and to obtain a broader sample of archaeological remains (Table 4-4). 
Table 4-4. Cultural materials recovered from $1 \times 1 \mathrm{~m}$ units excavated across the site.

\begin{tabular}{|c|c|c|c|c|c|c|}
\hline Provenience & Tools & Debris & Sherds & $\begin{array}{l}\text { Daub } \\
\text { (g) }\end{array}$ & $\begin{array}{l}\text { Burned } \\
\text { Clay (g) }\end{array}$ & FCR \\
\hline \multicolumn{7}{|c|}{ East Rise } \\
\hline $73-1$ & & 91 & 3 & & & 6 \\
\hline $73-2$ & 3 & 49 & 1 & & & 10 \\
\hline $73-3$ & 3 & 90 & 2 & 0.7 & & 7 \\
\hline $73-4$ & 2 & 66 & & & & 11 \\
\hline $73-5$ & & 59 & & & & 11 \\
\hline $73-6 A$ & 5 & 31 & & & 5.9 & 27 \\
\hline Sub-total & 13 & 386 & 6 & 0.7 & 5.9 & 72 \\
\hline \multicolumn{7}{|c|}{ South Rise } \\
\hline 283-1 & & 41 & 4 & & 4.9 & 13 \\
\hline 283-2 & 1 & 52 & 7 & & 0.4 & 7 \\
\hline $283-3$ & 2 & 58 & 4 & & & 19 \\
\hline $283-4$ & 2 & 100 & & & 17.8 & 26 \\
\hline $283-5$ & 4 & 82 & & & & 11 \\
\hline $283-6$ & 4 & 8 & & & & \\
\hline $283-7$ & & 13 & & & & 4 \\
\hline Sub-total & 13 & 354 & 15 & 0.0 & 23.1 & 70 \\
\hline $284-1$ & 1 & 72 & 6 & & & 8 \\
\hline $284-2$ & & 99 & 9 & & 2.1 & 8 \\
\hline $284-3$ & & 46 & & & & 5 \\
\hline $284-4$ & 1 & 33 & & & . & 3 \\
\hline $284-5$ & & 24 & & & & 3 \\
\hline Sub-total & 2 & 274 & 15 & 0.0 & 2.1 & 27 \\
\hline $285-1$ & 1 & 23 & 1 & & 2.1 & 7 \\
\hline $285-2$ & 1 & 11 & & & & 4 \\
\hline $285-3$ & 1 & 18 & & & & 2 \\
\hline $285-4$ & 1 & 13 & & & & 1 \\
\hline Sub-total & 4 & 65 & 1 & & 2.1 & 14 \\
\hline S. Rise $\sum$ & 19 & 693 & 31 & 0.0 & 27.3 & 111 \\
\hline
\end{tabular}


Table 4-4. Cultural materials recovered from $1 \times 1 \mathrm{~m}$ units excavated across the site, cont.

\begin{tabular}{|c|c|c|c|c|c|c|}
\hline Provenience & Tools & Debris & Sherds & $\begin{array}{l}\text { Daub } \\
\text { (g) }\end{array}$ & $\begin{array}{l}\text { Burned } \\
\text { Clay (g) }\end{array}$ & FCR \\
\hline \multicolumn{7}{|c|}{ Southwest Rise } \\
\hline $96-1$ & 1 & 362 & 10 & 0.8 & 5.1 & 57 \\
\hline $96-2$ & 3 & 371 & 1 & 0.2 & 4.8 & 44 \\
\hline $96-3$ & 4 & 283 & & & 8.8 & 13 \\
\hline $96-4$ & 1 & 62 & & & 114.1 & 7 \\
\hline $96-5$ & 1 & 60 & & & & 13 \\
\hline Sub-total & 10 & 1138 & 11 & 1.0 & 132.8 & 134 \\
\hline $280-1$ & 6 & 201 & & & 24.7 & 19 \\
\hline Sub-total & 6 & 201 & & & 24.7 & 19 \\
\hline $282-1$ & 6 & 223 & 1 & & 3.8 & 50 \\
\hline $282-2$ & 3 & 143 & 1 & & & 28 \\
\hline Sub-total & 9 & 366 & 2 & & 3.8 & 78 \\
\hline \multirow[t]{2}{*}{ SW Rise $\Sigma$} & 25 & 1705 & 13 & 1.0 & 161.3 & 231 \\
\hline & & & Other & & & \\
\hline $74-1$ & 15 & 419 & 10 & & 8.0 & 126 \\
\hline $74-2$ & 2 & 64 & & & & 21 \\
\hline Sub-total & 17 & 483 & 10 & & 8.0 & 147 \\
\hline TOTAL & 74 & 3267 & 60 & 1.7 & 202.5 & 5619 \\
\hline
\end{tabular}

Shallow, eroded, and dense archaeological deposits were encountered in Unit 74 at the north end of Backhoe Trench \#42, but no middens or features were evident along the trench. In the vicinity of the center of the East rise, deeper sandy loam deposits had been exposed in the trenching, and the inspection of the profiles suggested that leached midden deposits were preserved on the rise. Unit 73, however, placed in that area, did not detect any midden deposits per se, although evidence of Caddoan use of the rise was documented in the upper $30 \mathrm{~cm}$ (see Table 4-4). Thus, the staining apparent in Backhoe Trench \#42 was probably a result of wetter soils encountered in the trench rather than a product of cultural deposition. 
Unit 237 was excavated adjacent to Backhoe Trench \#44 to record and document a large pit exposed in the floor and east wall of the trench (see Figure 4-3). Similarly, Unit 96 on the Southwest rise was excavated to examine a possible cultural feature identified in Backhoe Trench \#46, as well as to recover archaeological remains in a controlled context from the midden deposits on the rise. In hindsight, more extensive manual excavations on the Southwest rise would undoubtedly have produced significant and substantial data on Late Archaic/Early Ceramic use of the Hurricane Hill site earlier in the investigations (cf. Perttula 1995b). At the time, however, efforts were concentrated on delimiting the Early/Middle Caddoan deposits on the North and South rises. These deposits were clearly significant, and additional work there was already being contemplated before the Phase II investigations were completed (see Chapters 1 and 3 , this volume). As a consequence, archaeological remains on the Southwest rise were essentially overlooked until the Phase IV work was undertaken.

Two small block excavation units ( $4 \times 3 \mathrm{~m}$ in size) were placed on the South rise, adjacent to the hearth and the exposed postholes or stains. This initiated the controlled excavation of the Caddoan house remains encountered during backhoe trenching (see Figure 4-3). These blocks were labeled B and C, respectively (Figure 4-4). The small size of the two blocks was recognized as probably ill-suited to the exposure and documentation of structural remains and house posthole patterns. However, Phase II investigations were still being considered as nothing more than test excavations by the COE. Available resources did not permit the excavation of a large block on the South rise unless it was determined by the COE that extensive excavations were necessary, and if so, the work would be done during a subsequent phase of investigations. Essentially, Phase II test excavations on the South rise were designed to assess whether or not Caddoan house remains were preserved, and if they were preserved, then to determine the area that would have to be excavated to uncover house midden debris, possible floors or living surfaces, and posthole patterns.

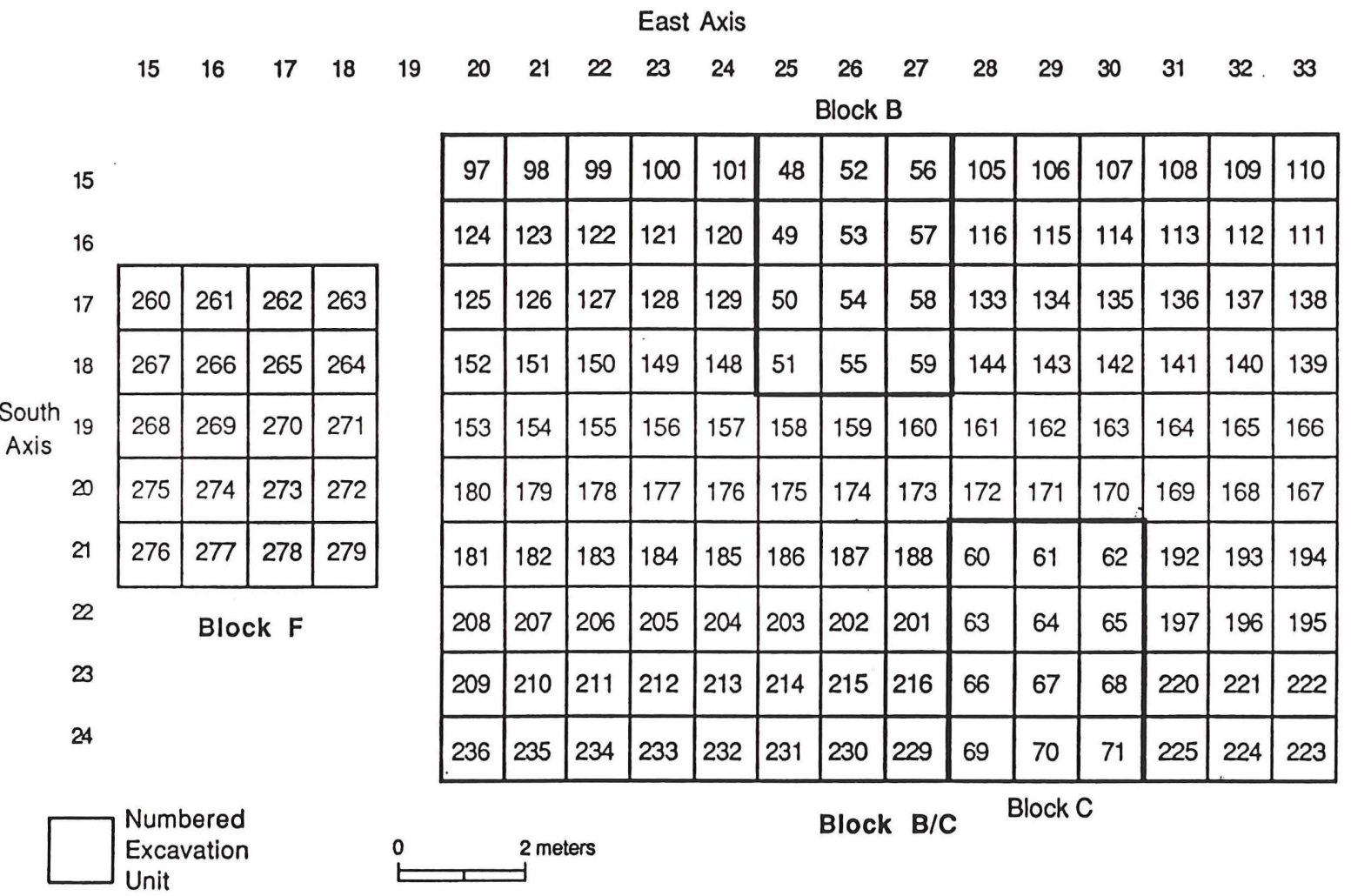

Figure 4-4. Block and unit layout for Blocks B, C, B/C, and F at Hurricane Hill, including South and East axis coordinates. 
The Block B and C Phase II investigations utilized the same recovery techniques as those previously described for the Block A excavations. That is, the blocks were divided into a series of contiguous $1 \times 1-\mathrm{m}$ units that were excavated in arbitrary levels. Below the plowzone or the grubbed/disturbed zone, one quad of each $1 \times 1-\mathrm{m}$ unit was excavated as a fine-screen unit. A 6 to 7 -liter flotation sample (see Table 4-2) was removed from each level of this quad to systematically assess the preservation of microfaunal/floral remains in the house area and the distribution of small artifacts that had been discarded, swept, and trampled into the floor(s) of the possible house.

Levels of 5 and $10 \mathrm{~cm}$ thickness were excavated in Blocks $B$ and $C$ to attempt to vertically isolate possible floors or occupational surfaces not discerned in the plan or profile inspections. Levels were designated as follows: Level 1, 0-10 cm bs; Level 2, 10-20 cm bs; Level 3a, 20-25 cm bs; Level 3b, 25$30 \mathrm{~cm}$ bs; Level 4a, 30-35 cm bs; Level 4b, 35-40 cm bs; Level 5a, 40-45 cm bs; Level 5b, $45-50 \mathrm{~cm}$ bs; Level 6a, 50-55 cm bs; Level 6b, 55-60 cm bs; Level 7a, 60-65 cm bs.

The floors of each unit were troweled at the bottom of each level, and all stains, disturbances, and artifacts visible in the floor were mapped in situ on large-scale block maps. Stains and features were numbered and recorded consecutively, and the fill from each stain or feature was then removed from the general matrix. Before excavation, the stain or feature was mapped on either the unit level form or a feature form, its top elevation determined, and a general description of the matrix completed. Then the stain or feature was cross-sectioned, usually in one dimension, and photographed, but in a few cases the stain or feature was cross-sectioned in several dimensions because of its size or due to the complexity of the feature or stain fill. In some cases the stain was given a feature number, but this was not a uniform practice. If the stain was determined to be of cultural origin, the cross-section was profiled, and the remaining stain matrix was collected as a flotation sample. All matrix from the individual features was retained for flotation.

Excavations in Blocks B and C did not proceed to the base of the archaeological deposits, as they did in Block A, because the primary goal of the Phase II excavations was to uncover stains, features, and associated archaeological remains relevant to understanding the Caddoan use of the South rise. Features and stains tended to originate between 20 and $30 \mathrm{~cm}$ bs and extend to between 50 and $70 \mathrm{~cm}$ bs. The deeper excavations were conducted solely to expose the lower levels and bottoms of features and stains. If a feature or stain had not been encountered as of $50 \mathrm{~cm}$ bs, the unit was discontinued.

Excavations carried below the level of the house "floors," ca. 20-30 cm bs, were not only important for systematically exposing posts, pits, and stains whose fill contrasted with the lighter loam Ahorizon underlying the house, but they were also important in recovering relatively undisturbed Late Archaic/Early Ceramic period occupational debris from the lower levels of the A-horizon on the sandy South rise. It had been contemplated that a sample of the units in Blocks B and C would be excavated to the base of the cultural deposits (ca. 70-80 cm bs) once the house excavations were completed, but for a variety of reasons this was never done. The primary reason was that more significant Late Archaic/Early Ceramic period deposits had been located on the North and Southwest rises, and these deposits received the bulk of attention in later phases of the investigations at the Hurricane Hill site.

The strategy of Phase III excavations at the Hurricane Hill site was based on two primary considerations. The first consideration was the recognition of intrasite spatial patterning of the separate occupations, while the second was the definition of each occupation's stratigraphic and temporal context within the deposits. Consequently, block excavations, consisting of a series of contiguous equal-sized excavation units, were utilized instead of noncontiguous excavation units of smaller scale.

Only through the examination of patterns of artifacts and features in a spatially contiguous manner is it possible to accurately arrive at an understanding of intrasite spatial activities (e.g., Hietala 1984; Carr 1985; Kroll and Price 1991; Wandsnider 1996). Excavation units dispersed over a wide area do not have the same potential to accurately examine occupational spatial patterning simply because the scale of investigation is limited in the horizontal dimension, and vertical stratigraphic correlations are difficult to make. Even the use of a small set of contiguous excavation units (as in the original Blocks B and C) is of limited utility in this respect because of the possible different scales at which spatial patterning may be detectable inside and outside of Caddoan structures. The larger the scale of intrasite spatial patterning being investigated, the larger the excavation block must be to satisfactorily detect and analyze such spatial 
structure. Therefore, the goal of the Phase III block excavations at Hurricane Hill was to realistically select, given time and budgetary constraints, block sizes of sufficient scope to permit the detection of large-scale spatial patterning on the different rises, while at the same time retaining sufficient detail to investigate small-scale spatial events. The block size was, additionally, a compromise between the expected depth of cultural deposits and the need to obtain comparable records of intrasite structure in these different areas through time.

The level of investigations at the Hurricane Hill site, from survey through testing and excavation, can be conceptualized as increasing in scope while decreasing in scale. At the survey level, effort was concerned with defining the limits and basic character of the site; therefore, little information was gathered concerning possible intrasite differences. However, with test investigations, not only was more detail added to what was known of the basic site character, but substantive data on intrasite variation in the distribution of artifacts and clusters of artifacts became available.

Only during excavation could intensive investigations focus primarily on only one or a few small parts of the total site. The choice of particular areas for detailed examination over others was ultimately dependent upon the general project research goals (see Chapter 3 , this volume). The explicit decision therefore, to focus on one or two areas of the site in order to recognize and define specific Caddoan or Late Archaic/Early Ceramic periods of use, during one or several particular phases of occupation, was determined by the overall focus of the research design.

Prior to the initiation of the Phase IIII investigations, a metric grid was laid out across the western part of the site area. The grid was aligned parallel to the edge of the upland landform at $30^{\circ}$ East of magnetic north. Grid coordinates and grid north were arbitrarily defined so that the area of the site investigated would lie in the southeastern grid quadrant. The orientation of block grids on the North and South rises was not the same (Figure 4-5). The South rise blocks were oriented $30^{\circ} \mathrm{E}$ of magnetic north to accommodate the backhoe trenches excavated during the Phase II investigations. The North rise block grid was oriented at 28 degrees east of magnetic north.

Block A was expanded to a $7 \times 6$-m rectangle along those sides of the original Phase II block that appeared to have the highest densities of faunal remains as well as the thickest midden deposits (see Figure 4-2). Blocks $B$ and $C$ were enclosed within a larger block (Block B/C) (see Figure 4-4), large enough (140 square meters) to expose Caddoan house remains, extramural features, and localized trash deposits and human burials around the house(s). A small midden on the slope west of Block B/C was examined in Block F, a $5 \times$ 4-m excavation unit encompassing the approximate center of these midden deposits (see Figure 4-4). Blocks D and E were located on the North rise, a short distance grid south of Block A (see Figure 4-5). Blocks $D$ and $E$ were placed on this part of the rise to investigate the spatial and vertical character of the Caddoan and Late Archaic/Early Ceramic period occupations adjacent to the "midden" mound deposits in Block A, and to attempt the exposure of features and structural remains relating to the Caddoan use of this part of the site. The presence of human burials in Backhoe Trenches \#31-33 suggested that additional burials would be encountered in these two blocks. The two blocks encompassed 248 square meters (Figures 4-6a and 4-6b), but only $221 \times 1-\mathrm{m}$ units (22 square meters) were actually hand-excavated and the deposits screened through 1/4-inch mesh cloth. The remainder were either left as balks or were shovel-skimmed to expose cultural features or artifact concentrations.

In terms of the overall site grid, the original grid coordinates (at the northwest corner) for the different blocks were as follows: Block A, S103/E106; Block B/C, S144.5/E102; Block D, S109/E112; Block E, S109/E102; Block F, S146.5/E97. Vertical provenience control was maintained in the block excavations. The surface at the northwest corner of each $1 \times 1-\mathrm{m}$ unit was used for measurements of below surface depth.

The blocks were divided into $1 \times 1-\mathrm{m}$ units, and each unit was numbered consecutively, beginning with Unit 75 and continuing to Unit 279 (see Figures 4-2, 4-4, and 4-6). However, Units 95, 96, and 237 were not in blocks. Each unit within the separate blocks was excavated in arbitrary 5- to 10-cm levels. Horizontal provenience control and mapping of artifact locations and features were based on this minimum unit size. 


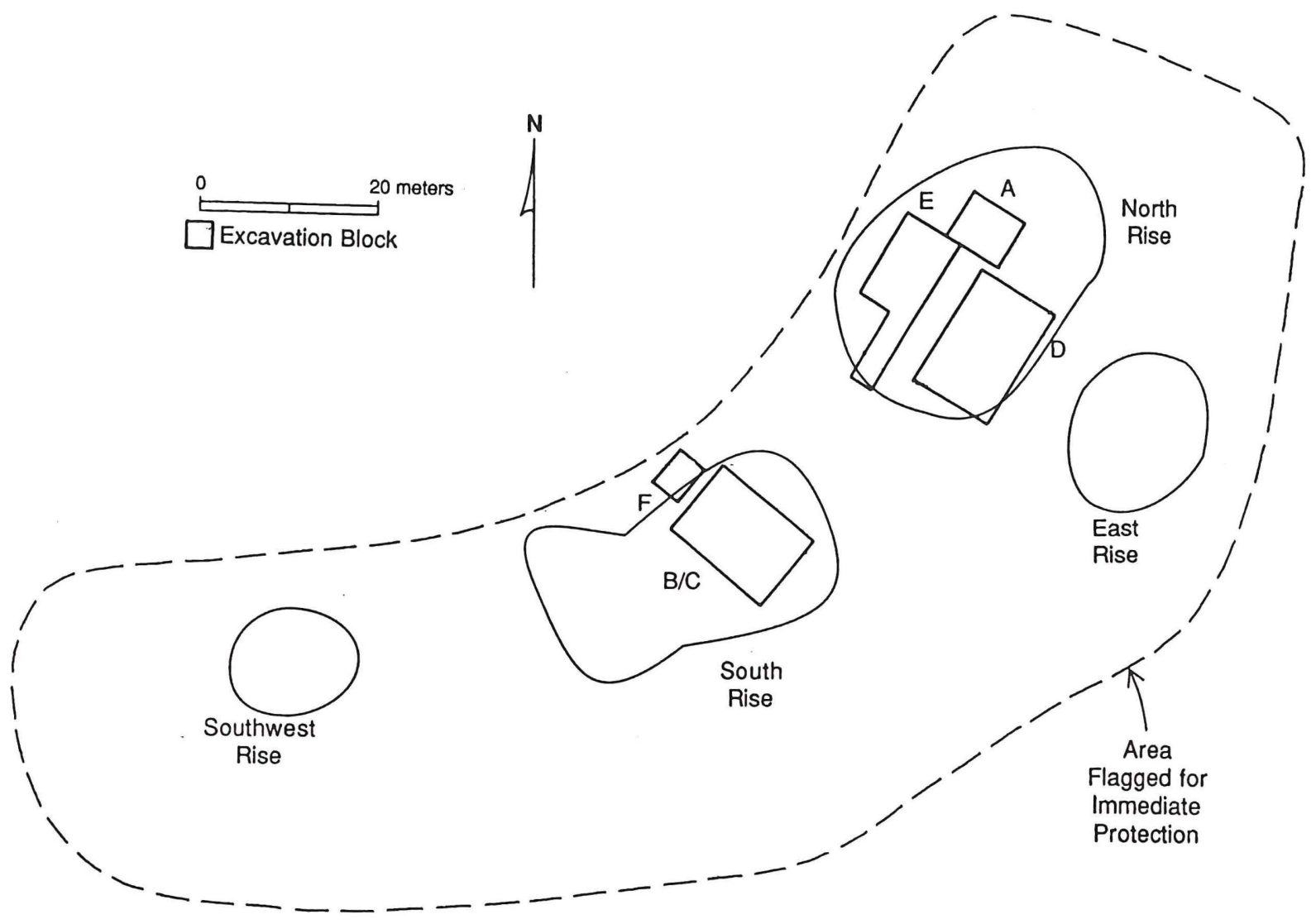

Figure 4-5. Phase III block investigations at Hurricane Hill.

No attempt was made to record all lithic tools or ceramic sherds in situ. The overall volume of soil to be excavated, in combination with the tool and ceramic densities commonly encountered, prohibited implementation of three-dimensional mapping. Horizontal provenience information is thus based almost exclusively on the 5- and 10-cm levels within each square. Exceptions were usually the result of more detailed provenience information gathered from features, floor scrapings, securing of radiocarbon and thermoluminescence samples, and block or unit profiles.

Because of the homogenous nature of the soil deposits, whether midden or natural soil zones, the three-dimensional plotting of certain artifacts, particularly fire-cracked rocks (FCR), proved to be of considerable utility in enabling the reconstruction of occupation horizons or surfaces in Blocks A-E. Consistent three-dimensional plotting of larger visible FCR within each arbitrary level was done in the absence of heterogeneous or differentiated stratigraphic contexts.

Basal elevations were taken on flat-lying rocks, sherds, and stone tools. When rocks or other artifacts dipped, information on the dip direction was taken, as well as top and bottom elevations, in case the artifacts had been deposited in a pit or depression. Artifacts usually did not overlap except in certain feature contexts; more varied dips in artifact orientation were characteristic in these cases (e.g., Schiffer 1983:681). 


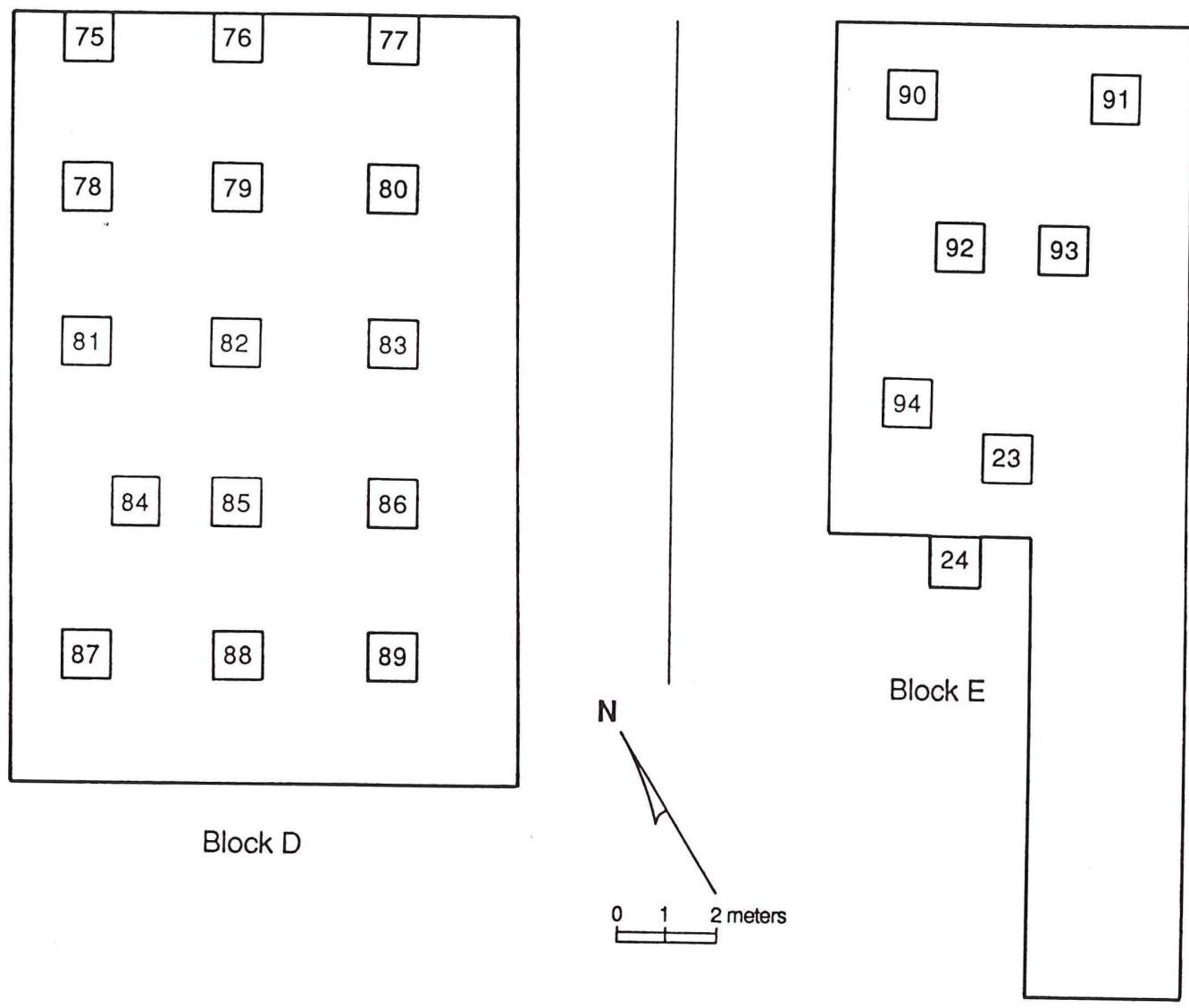

Figure 4-6. Block D and E layout, showing South and East axis coordinates: a, Block D; b, Block E.

Elevation data sets, along with pertinent FCR weights and/or feature distributions, were projected onto different vertical planes and actual stratigraphic horizons within continuous sections across all block grid lines. Associated elevations were initially defined for tentative occupation horizons, subject to additional examination by related data sets, feature associations, and temporal information.

Four our purposes, cccupation horizons should have consistent vertical and horizontal associations of artifacts and features and to be manifestations of one occupational unit (e.g., Binford 1983:367). Analyses of spatial and temporal variables within these occupation horizons can be employed to help determine whether they are the product of single or multiple occupational episodes.

These types of analyses should not be taken to suggest that there have not been any postdepositional movements or alteration of the site deposits. Non-cultural formation processes (e.g., Schiffer 1983 , 1987) certainly played a role in the ability to interpret the existence of postulated cultural horizons, although little specific evidence of artifact movement or pedoturbation processes was obtained at Hurricane Hill. Lithic refitting studies have demonstrated that there can be significant post-depositional movements of artifacts (Cahen et al. 1979; Hofman 1986; Villa 1982), but the large lithic assemblage from Hurricane Hill prohibited a comprehensive attempt to conjoin or refit tools to aid in the identification of cultural stratigraphy. Ceramic refits were limited, but did prove useful in associating particular levels within the Blocks $\mathrm{A}$ and $\mathrm{B} / \mathrm{C}$ deposits that appear to be the product of habitation in and around Early and Middle Caddoan structures (see Chapter 9, this volume). Instead, the combination of different classes of associated data (elevations on larger items such as FCR and sandstone slabs, feature plans, plan maps of rock, daub, 
and burned clay weights, and horizontally defined artifact clusters), are informative about cultural activities and the presence of occupation horizons, despite non-cultural formation and bioturbative processes.

The level of "noise" in associating cultural remains to postulated occupation horizons is apparently dependent upon the rapidity of cultural deposition across the site, as well as the periodicity and intensity of occupation over the occupational sequence. In situations where occupations were taking place at the same time that rapid deposition in midden mounds (for instance, at $>0.5 \mathrm{~cm} / \mathrm{yr}$ ) was occurring, the possibility of recognizing discrete and separable occupations increases commensurably (e.g., Ferring 1986). In general, the different and pre-Caddoan occupations at Hurricane Hill are not separated from one another by relatively sterile deposits, but cultural materials are present in varying amounts below Caddoan occupation horizons recognized by distinctive midden deposits and concentrations of charcoal, daub, and burned clay (in the case of the Southwest rise, midden deposits dating to the Early Ceramic period overlie Late Archaic occupational materials); the former and earlier archeological deposits can be defined somewhat by the mapping technique. This is probably the result of the limited span of time that generally separates each occupation horizon, as well as the overall low rates of deposition of cultural and non-cultural deposits. Consequently, the discrete cultural deposition of Caddoan middens and structural features in several areas at the Hurricane Hill site has aided in the recognition of stratigraphically deeper and earlier Early Ceramic and Late Archaic archeological deposits.

In order to gain a finer measure of vertical and horizontal control within the Caddoan midden deposits in Block A, special collections and fine-screen procedures were changed between the Phase II and Phase III investigations. All 1 x 1-m units in Block A extension (see Figure 4-2) were divided into 50 x $50-\mathrm{cm}$ units or quads and excavated in 5-cm levels, beginning below $10 \mathrm{~cm}$ bs. All soil matrix within the quads was screened through 1/16-inch mesh, and an average of 7 liters was removed from each quad for flotation. As a result, roughly nine times as much matrix from Block A extension was processed from flotation samples as had been completed during the Phase II investigations (see Table 4-3).

For the other blocks, fine-screen and flotation samples were taken by arbitrary level only from one quad of each $1 \times 1-\mathrm{m}$ unit once the excavations had penetrated below the plowzone or disturbed grubbing areas. However, in Block F, the midden deposits were removed in one arbitrary $15-\mathrm{cm}$ level $(10-25 \mathrm{~cm}$ bs) from the squares that were excavated (Unit 276 and 279 [see Figure 4-4]), rather than as parts of two arbitrary 10-cm levels. Because of the seemingly low density of cultural and ecofactual remains in the Block F midden, flotation samples were taken from each quad within that level.

Over 100 radiocarbon and thermoluminescence (TL) samples were taken from the different blocks and trenches excavated across the site. In the case of the TL samples, the sherd was collected from a soil zone believed to be undisturbed by bulldozer grubbing or recent fires, and they were collected with an associated soil sample (50-100 g). For both the radiocarbon and TL samples, the entire sample area was plotted in three dimensions. Radiocarbon assays from Hurricane Hill were obtained by Beta Analytic, Inc. (see Fields et al. 1997; Perttula 1997a). Only a small sample of TL dates were secured for Hurricane Hill before Alpha Analytic, Inc., the only North American firm then conducting TL dating, closed the TL laboratory. TL analyses of ceramics have proven to be less precise than provided by radiocarbon dating, and most archaeologists today do "not see TL of ceramics as worth either the effort or the money" (Feathers 1997:2-3). Because of the large number of both radiocarbon and TL dates obtained from Hurricane Hill, we are in the position to evaluate and compare the accuracy of the TL samples to the preferred radiocarbon results (see Chapter 7, this volume).

The final phase of investigations (Phase IV) at the Hurricane Hill site consisted of the controlled stripping of the A-horizon in twelve separate areas on the Southwest, South, and North rises (Figure 4-7). This was done to locate additional human burials and to recover further intrasite information on the density and patterning of cultural features in the Late Archaic/Early Ceramic and Early/Middle Caddoan period components. About $1,600 \mathrm{~m}^{2}$ were stripped (see Table 4-2) using a road grader with a 3 -ft-wide bucket. 


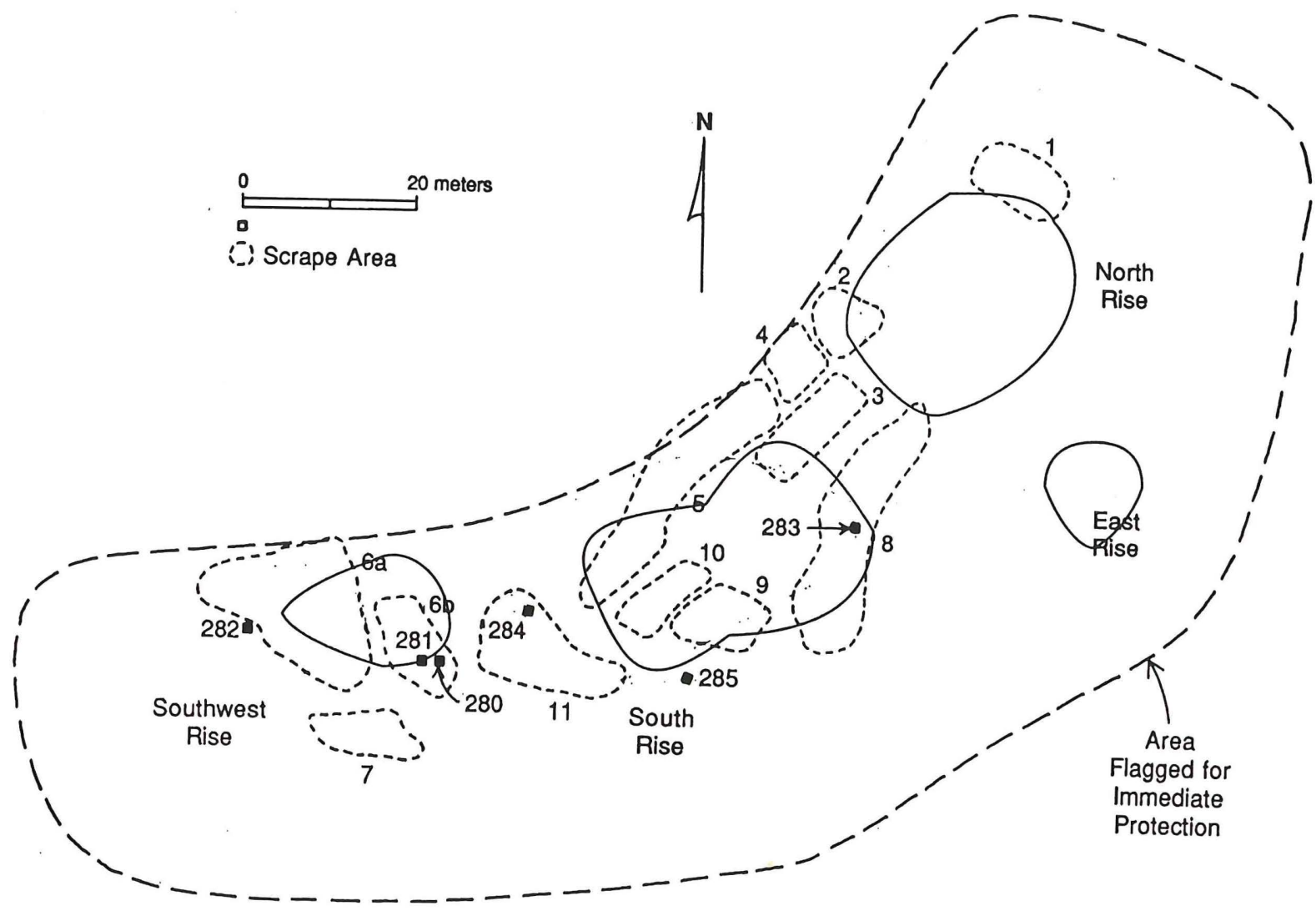

Figure 4-7. Phase IV gradall investigations at Hurricane Hill.

The road grader stripped away thin slices of the A-horizon in designated areas (see Figure 4-7) until the B-horizon clay was exposed. After each strip was removed, the area was traversed by one or two members of the archaeological team, and possible cultural stains or features were marked with pin flags. When a designated area was completely graded, flat shovels and trowels were used to clean (sometimes several times to improve visibility) the exposed surface to identify and define posts, pits, or burial pits that had penetrated into the B-horizon. These types of cultural disturbances, as well as other likely looking stains, were also marked with pin flags.

All features or stains exposed in the scraped areas were treated in the same manner. First, they were completely exposed and mapped. Their location within the site was mapped relative to one of the temporary site datums. Then the depth at which they were exposed below the surface was determined. Because the thickness of the A-horizon was generally known, a feature's likely depth of origin and total depth could be estimated. Many of the cremation pits and the one extended burial exposed by the grading, had been identified by their distinctive fill above the B-horizon; thus, more accurate estimates of feature origin could be made in these cases.

After these tasks had been completed, the feature or stain was cross-sectioned along the longest axis, and the fill was set aside for flotation. The cross-section profile was drawn as a measured section, photographed, and if the profile cross-section indicated a cultural origin for the disturbance, a feature number was assigned, and a feature form was completed. The remaining fill was collected for flotation. If the 
disturbance was determined to be natural (e.g., rodent hole, tree root, etc.), the fill from the cross-sectioned half was screened through 1/4-inch mesh, and artifacts were retained from that provenience.

Due to the nature of the features or stains exposed in the grading operations (i.e., primarily small pits or posts), all fill from the cultural disturbances was collected for flotation to recover paleobotanical or faunal remains in association with cultural materials of definite temporal affiliations. In the case of cremation pits, some of which contained over 200 liters of cultural fill (see Chapter 6, this volume), all of the feature fill was collected to ensure that preserved human osteological remains were retained for analysis (see Chapter 12, this volume). This allowed an accurate assessment of the probable number and age of the individuals cremated, and whose remains were deposited in the pit. More than 90 percent of the feature fill that was floated was derived from the features exposed during the grading operations (see Table 4-3).

As mentioned in Chapters 1 and 3, areas were selected for grading on the basis of patterns in the spatial distribution of human burials already noted from the Phase II and IIII investigations and the location of structural remains identified in Block B/C. Grading around Block B/C (see Figure 4-7) was designed to recover further information on the distribution of postholes and extramural features in the vicinity of Houses A and B, and to determine if a small family cemetery was present east of the block. On the North rise, grading activities were simply an extension of the manually excavated units and backhoe trenching already completed at Block A and vicinity. An area north of Block A, where the midden deposits thinned considerably and structural remains were expected, was also examined during the work (see Figure 4-7).

Grading on the Southwest rise (Scraped Areas 6,6B, and 7) was conducted initially to determine the character and range of features or stains preserved in the midden there, and also to acquire a larger sample of temporal diagnostics since Caddoan ceramics were uncommon, and it seemed likely that the midden was deposited almost exclusively during the Late Archaic/Early Ceramic period. After it became apparent that a large number of pits, many containing burned human bone, were present in the Southwest rise midden, additional scraping (Scraped Area 11) was done to delimit the spatial boundaries of the pits and to look for evidence of structural remains in proximity.

Grading operations proceeded smoothly, and were completed in four days. However, some difficulties were experienced in maintaining a smooth, unrutted level surface because of the undulating nature of the top of the B-horizon clay and the variable depth and thickness of the A-horizon sandy loam above the subsoil. During grading on the South rise, and between the South and Southwest rises, it is likely that some posts and pits were undetected because they did not extend into the B-horizon and, thus, were unobserved in the homogenous A-horizon loam matrix. The B-horizon not only was deeper on the South rise, but varied from a clay loam to a clay and did not provide the uniform contrast necessary to detect all manners of stains or features. Realistically, manual excavations in the blocks on the South rise, although more time-consuming, were more useful for the detection of the complete range of posts, pits, and stains than were the grading operations. Therefore, reconstructions based on the results of the grading should be considered less precise for this area. Nevertheless, this did not preclude the identification of several Middle Caddoan structures and associated intra- and extra-mural features (middens, pits, and burials) on the South rise, and the difficulties in feature detection were overcome by repeated troweling and scraping of the block excavations and grading surfaces.

An additional six $1 \times 1-\mathrm{m}$ units were excavated at the Hurricane Hill site during Phase IV investigations (see Figure 4-7). Units 283, 284, and 285 were placed in areas to be graded on the South rise to gather controlled information on the subsurface archaeological deposits some distance from the Caddoan house structures in Block B/C (see Table 4-4). Because the frequency of Caddoan ceramics appeared to be quite variable on this part of the site and extremely low on the Southwest rise, information that we could retrieve about the spatial distribution and number of Caddoan ceramic sherds was thought to be useful in more accurately delimiting the Middle Caddoan period component on the South rise. Units 280 and 281 were excavated to sample the contents of a large disturbance (Feature 70) exposed on the Southwest rise in Scraped Area 6B. Unit 282, south of Scraped Area 6 (see Figure 4-7), was excavated to acquire a larger sample of artifacts from the possible discrete Late Archaic/Early Ceramic component on the Southwest rise than had been obtained previously (see Table 4-4). 
These 1 x 1-m units were excavated in arbitrary 10-cm levels with the matrix screened through $1 / 4$ inch mesh hardware cloth. Fine-screen and flotation samples were obtained only from stains or possible cultural disturbances.

\section{Laboratory Procedures}

The washing, cataloguing, and analyses of cultural materials recovered during the four phases of investigations at the Hurricane Hill site were completed in the laboratories of the Institute of Applied Sciences at the University of North Texas (IAS/UNT). In the field, samples collected from each distinct site provenience were assigned a separate lot number. That is, for example, materials collected from the 1/4-inch mesh screening of matrix from one level of an excavation unit were assigned a different lot number than the fine-screen or flotation samples from the same unit and level. Lot numbers were assigned consecutively from 1 through 5839, except for Lot Numbers 5000-5399 that were assigned to provenience samples from the James Franks site (41DT97; see Perttula 1989a).

The lot number tag was retained during all stages of sorting and artifact processing to keep track of the provenience, and the lot number catalogues were updated in the field and lab at the end of each day, or week (in the case of the IAS/UNT lab), to ensure that the correct provenience information had been entered in the catalogue. This information was also entered into the computer system at the IAS/UNT for a permanent record, and to aid in the sorting of multiple provenience-level information from the excavations.

Cultural materials from the 1/4-inch screening of matrix were initially sorted into constituent groups (i.e., lithic, ceramic, faunal, floral, or historic). Temporally or functionally diagnostic lithic tools were labeled with the Texas Archeological Research Laboratory site number, tool number (consecutively from 1), and lot provenience information, but the lithic debris was placed in plastic bags with the lot number tag and the analyses were tabulated on unit coding analysis sheets. All rim or decorated sherds were processed in the same manner as the lithic tools, but the 7,000+ plain body sherds were not labeled. Faunal and floral remains were retained as discrete lots for transmittal to consultants, but because of the extensive number of fine-screen and flotation samples that required initial processing in the laboratory (primarily to remove for further analysis all cultural materials larger than 1/8-inch in size), only a sample of these lots were chosen for sorting and analysis (see Chapters 13 and 15, this volume). Similar sampling strategies were employed in the analysis of lithic debris from the fine-screened units, particularly in the treatment of raw material and size variability (see Chapter 8, this volume). Screen size was entered on lithic debris/raw material computer coding forms.

All fine-screen and flotation samples collected in the field were processed, and those which were not selected for further processing or analysis are stored at the curatorial facility for IAS/UNT. Unprocessed TL and charcoal samples have also been retained for permanent curation.

All photographs and slides taken during the investigations have been catalogued in preparation for final curation. Materials, notes, photographs, and computer records were curated at IAS/UNT during the course of the project. The final curation of materials from the Hurricane Hill site, pursuant to 36 CFR 79, has not been resolved with the U.S. Army Corps of Engineers, Fort Worth District. 


\title{
CHAPTER 5, DESCRIPTION AND ANALYSES OF THE CULTURALANDNATURALSTRATIGRAPHY
}

\author{
Timothy K. Perttula, with a contribution by C. Reid Ferring
}

Archaeological excavations in different areas of the Hurricane Hill site encountered a diversity of pedological and depositional features that reflected a varying prehistoric use of the upland landform over at least two to three thousand years. The upland landform itself is not composed of a unitary deposit, but these deposits tend to vary depending upon the slope and microtopographic changes across the site; local erosion; and disturbances caused by historic-era plowing or bulldozing done by the COE contractors.

Although bioturbative processes have been active on this long-stable landform, as discussed by Ferring in the next section of Chapter 5, both horizontally and vertically discrete archeological deposits are present at Hurricane Hill, particularly on the North, South, and Southwest rises. In these areas, discrete cultural midden deposits created micro-scale areas with cultural stratigraphy on the rises, as in (a) the burial of eroded and scoured Pleistocene gravel deposits below the Late Archaic/Early Ceramic midden on the Southwest rise; (b) the deposition of two Caddoan midden deposits atop an earlier Primary Midden on the North rise; and (c) the discrete occupational deposits associated with the construction and use of two Middle Caddoan structures on the South rise, with these being created over a ca. 40-125 year period in a small area previously used during the Late Archaic and Early Ceramic periods. Following Ferring's short discussion of the geology and depsoitional character of the Hurricane Hill site, and because of the considerable variability in the cultural and natural stratigraphy at the site, the descriptions and analyses of site stratigraphy are presented according to natural rise and block. Blocks $\mathrm{A}, \mathrm{D}$, and $\mathrm{E}$ are located on the North rise; Blocks $\mathrm{B}$, $\mathrm{C}$, and $\mathrm{F}$ are on the South rise; and the majority of the non-block excavations (gradall scraping) were conducted on the Southwest rise (see Figures 4-5 to 4-7).

\section{Geology and Depositional Character of the Hurricane Hill Site, by C. Reid Ferring}

The Hurricane Hill site is located on a bedrock strath terrace on the south side of the South Sulphur River near the dam access for Cooper Lake. The site area is a relatively flat surface that has been dissected in recent times, and influenced severely by historic and modern land use activities. At its crest, Hurricane Hill is about 50 feet (15 meters) above the South Sulphur River floodplain, and it is surrounded on three sides (to the east, north, and west) by alluvial surfaces that are the same approximate elevation as the floodplain. A paleo-meander belt is located several hundred meters north of the site. Radiocarbon dates from a buried soil and archaeological horizons at site 41HP118 (Ferring 1997; McGregor and Martin 1997) suggest that this meander belt was active at least until ca. 2000 years B.P. It is likely that this was the active meander belt during much, if not all, of the prehistoric occupations at Hurricane Hill. Therefore, the site situation was ideal in that it afforded high sandy ground near the active river.

The stratigraphy of the site includes Cretaceous bedrock, the Natchitoches sandstone, that has been eroded into a strath surface. Quaternary or possible Late Tertiary age gravels occur at the surface of the bedrock, reflecting an ancient channel of the South Sulphur River. These gravels in turn are overlain by Pleistocene-age alluvial deposits. A very mature soil had formed on these deposits long prior to the prehistoric occupations at the Hurricane Hill site.

A profile in the midden area on the North rise (Table 5-1) indicates that the midden deposits overlie the truncated B-horizon of the Pleistocene deposits. Slightly west of this locality, but also near the North rise, another profile showed a thin gravel deposit separating the midden deposits from the underlying Bhorizon. This suggests that local erosion, scouring, and reworking of Pleistocene gravels occurred prior to the prehistoric occupation at Hurricane Hill, and the deposition of the Late Archaic/Early Ceramic period midden deposits (referred to below as the "Primary Midden"). Many of these gravels are Ogallala quartzite cobbles (cf. Banks 1990) that were suitable for use for lithic tool manufacture and for hearth lining. In profile, the North rise midden deposits are loamy. These sandy deposits probably reflect an A/E horizon of the mature soil that was in place prior to the prehistoric settlement at the site. 
Table 5-1. Soil profile descriptions.

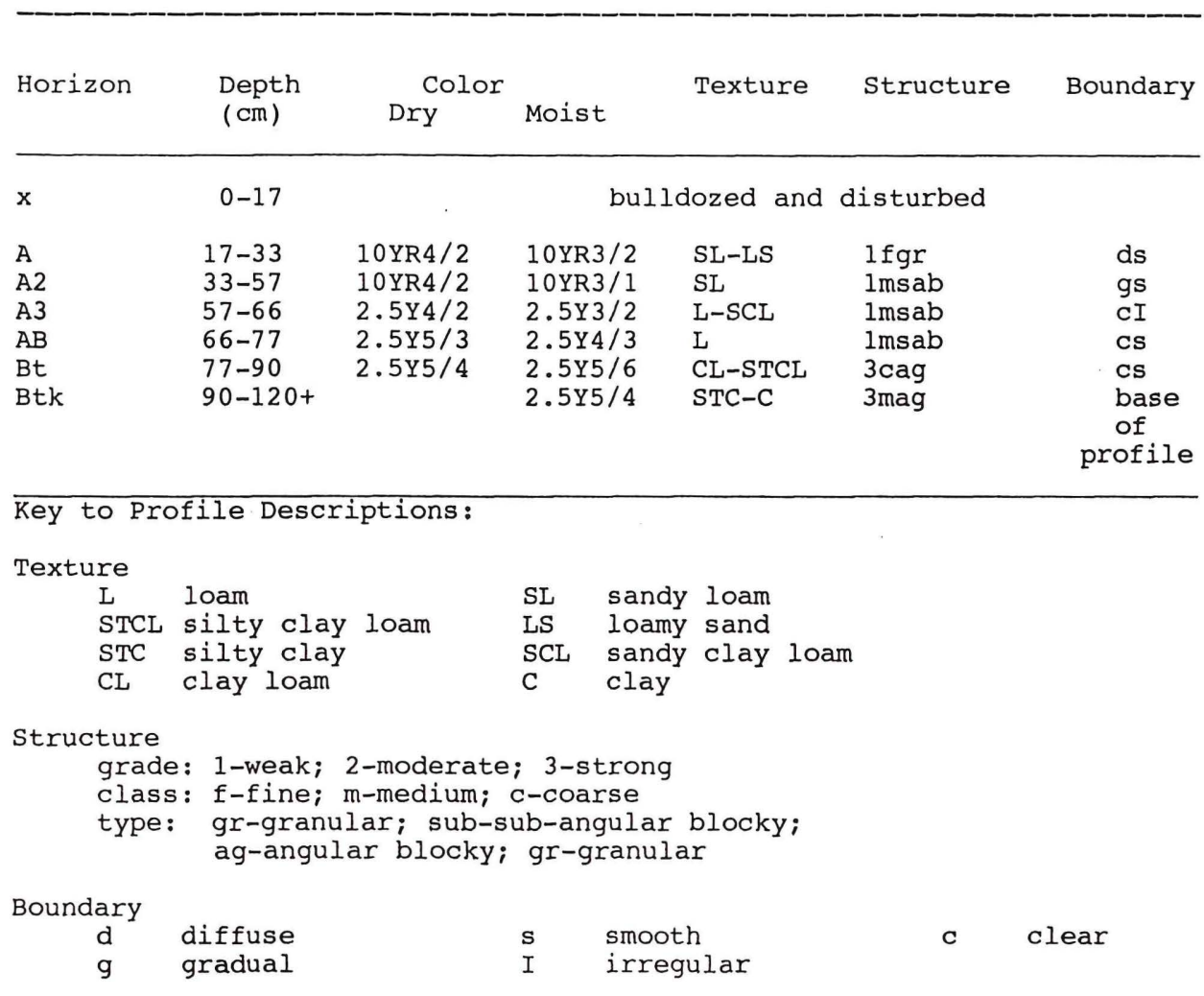

Bioturbation and the cultural reworking of artifacts into these coarser deposits probably account for much of the vertical distribution of artifacts over the main part of the Hurricane Hill site, while the cultural introduction and reworking of sediments and discarded trash accounts for the thicker deposits in the area of the North rise midden. Calcareous horizons occur below the North rise midden deposits, indicating the leaching of bone and shell carbonates into the soil sub-horizons. Overall, the intensive occupation of the site--including the construction of houses, excavation of pits, and the formation of trash middens--accounts for extensive human disturbance of artifacts within the Hurricane Hill site.

\section{Cultural and Natural Stratigraphic Record}

Outside the areas of intensive investigations and proceeding east towards Historic Localities 1 and 2 (see Figure 1-4), the natural stratigraphy at the Hurricane Hill site corresponds closely with the descriptions of the Woodtell loam soil series provided by Lane (1977). This soil series has a relatively thin, very dark grayish-brown (10YR3/2) to yellowish-brown (10YR5/4) A1 and A2 horizon loam that is 0-23 $\mathrm{cm}$ thick overlying a yellowish-red (5YR4/8) to red (2.5YR4/6) clay B-horizon. Due to the accumulation of midden deposits, the A-horizon on the western end of the site has been considerably thickened, and in certain cases appears to be a "midden mound" that overlies a buried A-horizon representing the original surface of the knolls. On the other knolls or rises, however, the loam-A-horizon, in the absence of clear midden deposits, is still two or three times thicker than the typical natural profile. The B-horizon also varies from a sandy clay to a clay depending upon where the profile was described.

Stratigraphic information and profile descriptions were obtained from all blocks and manual excavations, as well as from selected backhoe trenches or graded areas. The initial descriptions of the cultural and natural stratigraphy, obtained at the completion of Phase I investigations, were based on profiles of the $8 \mathrm{~m}^{2}$ test excavations on the North rise. More comprehensive stratigraphic data were 
obtained as information from the site excavations was synthesized, and different or deeper deposits were exposed in the blocks. Finally, Dr. C. Reid Ferring described several profiles on the North rise (see Table 5-1), and examined in more detail the depositional and pedogenic character of the archaeological materials in Block A, the potential "midden mound" (see above).

As previously mentioned, different deposits at the Hurricane Hill site are described using the concept of "zone" (Bousman et al. 1988:39). Zones are differentiated on the basis of color, particle size, cohesiveness, structure, and texture. Hence, a zone is any perceived layer in a profile that can be readily distinguished from adjacent zones. Zone differentiation is thus made independently of interpretations concerning whether it is a product of pedogenesis, deposition, intensive cultural activities, or some unidentifiable process. All zones discerned in the block excavations were described by color utilizing a Munsell Soil Color Chart. Textural designations were based on guidelines presented by the Soil Survey Staff (1975).

Zones that extended across described profiles in a continuous manner were assigned Roman numerals from top to bottom. Lenses or discontinuous sections of distinct soil deposits were given Roman numeral and alpha or alphanumeric designation (i.e., Ia, IIlb, Illb1, etc.).

\section{North Rise}

The primary archaeological deposits on the North rise are a series of horizontally and/or vertically discrete midden deposit covering most of the knoll (Figure 5-1). The most prominent midden deposits, in terms of overall thickness and preservation of vertebrate animal remains, is Midden 1 (see Figure 5-1). While the thermoluminesence dates on sherds from Midden 1 suggested that it was a Middle Caddoan period accumulation of refuse dating between ca. A.D. 1210 and 1370, the more reliable radiocarbon dates (see Chapter 7) indicate that it was deposited in the Early Caddoan period, between ca. A.D. 1000-1200. A smaller but concentrated Caddoan midden deposit (Midden 2) is located a few meters south of Midden 1, near the crest of the knoll (see Figure 5-1). Stratigraphic and cultural data indicate that both middens were deposited atop the Primary Midden, which was an earlier cultural strata or zone. This deposit appears to represent an organic-rich A-horizon of the original soil on the North rise. This earlier midden, which covers approximately 460 square meters of the North rise (see Figure 5-1), dates primarily to the Late Archaic/Early Ceramic period, between ca. 200 B.C.-A.D. 800; radiocarbon dates indicate the midden dates between A.D. 100 and A.D. 500 (see Chapter 7, this volume).

Four soil zones have been defined in the 50 to $80-\mathrm{cm}$ thick archaeological deposits exposed in Block A and Block A extension. Continuous north and east wall profiles of Block A and Block A extension are illustrated in Figure 5-2 and Figure 5-3. The top deposit is a reworked and disturbed zone caused by bulldozer activities associated with site clearing prior to initiation of the archaeological investigations. This disturbed zone is apparently composed of Zone I and II deposits intermixed with burned trees and other debris. The contact between the disturbed zone and Zone I or II is abrupt and distinct because of the recent formation of the deposits. The extent of bulldozer operations on the North rise was such that Zone I was totally removed from some portions or was present only in pockets (see Figure 5-2: profiles 1 and 5).

Zone I is a very dark grayish-brown (10YR3/2) sandy loam plowzone overlying the undisturbed Zone II midden deposits, and was partially buried by redeposited soils from construction activities. Based on the color of the zone, the presence of abundant ceramic and lithic remains, and the occurrence of deteriorated or poorly preserved faunal remains, zone I represents the plowed portions of Zone II in Midden 1. Zone I is a maximum thickness of $16 \mathrm{~cm}$ below the disturbed zone, but its absolute thickness is not known because of the disturbances.

As previously noted, Midden 1 deposits comprise Zone II in Block A. This midden deposit is a very dark gray sandy loam, $16-28 \mathrm{~cm}$ in thickness. Exposed in the profiles were a number of burned clay fragments, charcoal flecks, mussel shell, animal bone, and fire-cracked rocks that testify to its accumulation as a trash dump. Trends in the slope of the midden indicate that it formed on a relatively level surface. The thickest deposits are at the southern end of the block, near the crest of the rise. The midden gradually thins across the block. As a separate midden from the underlying Zone III midden (part of the PrimaryMidden), Zone III is distinguishable by color, texture, and preservation quality only in the Block A excavations (see Figure 5-2). Outside this area (i.e., along the margins of Midden 1) the two middens may have become 
compressed, or the accretion of Zone II contributed little to the depositional sequence farther removed from the crest of the knoll.

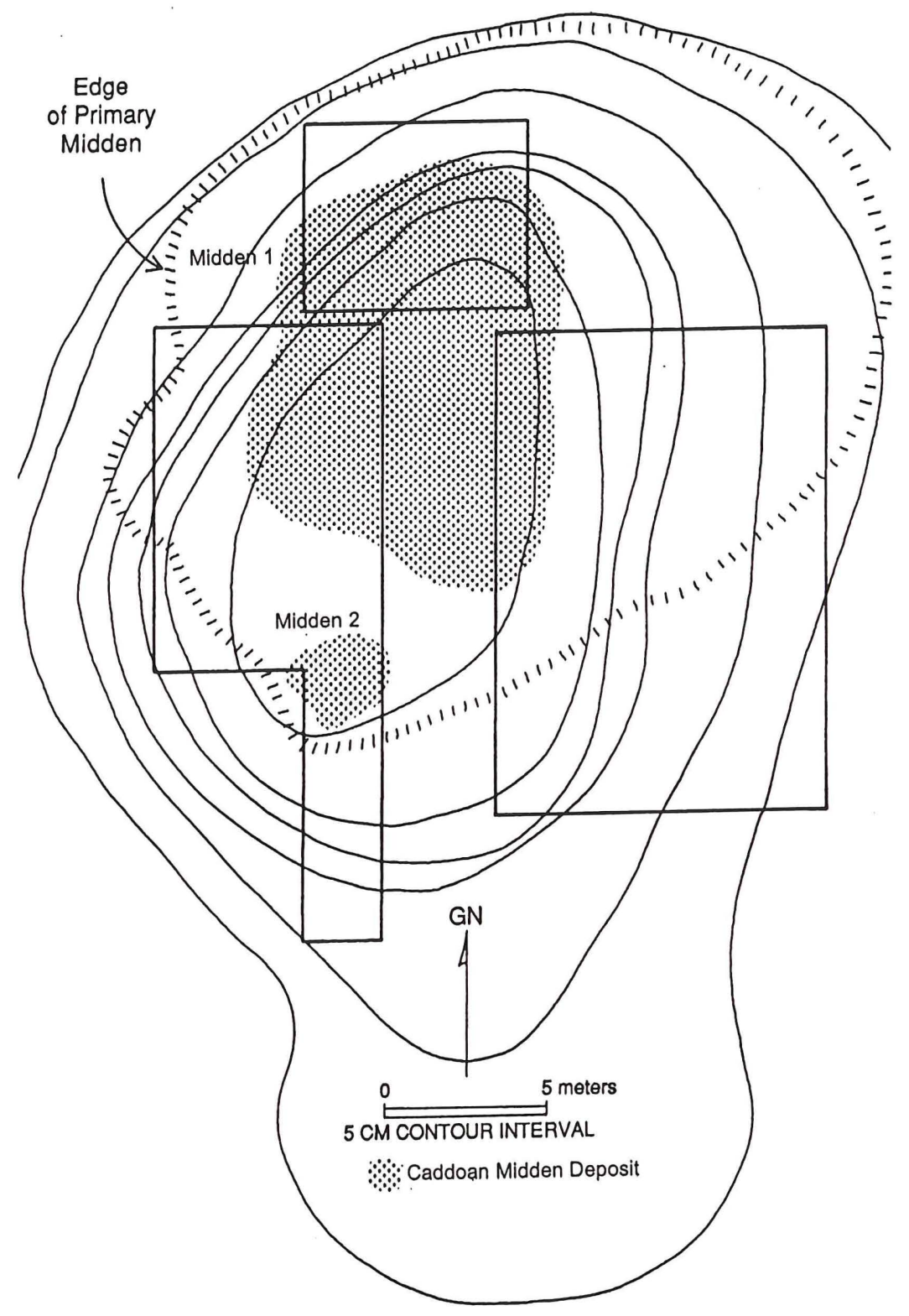

Figure 5-1. Distribution of midden deposits on the North rise: Primary midden and Middens 1 and 2. 
Profile 1

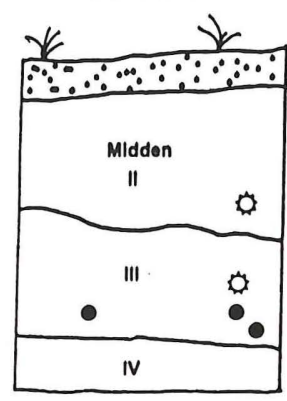

Profile 2
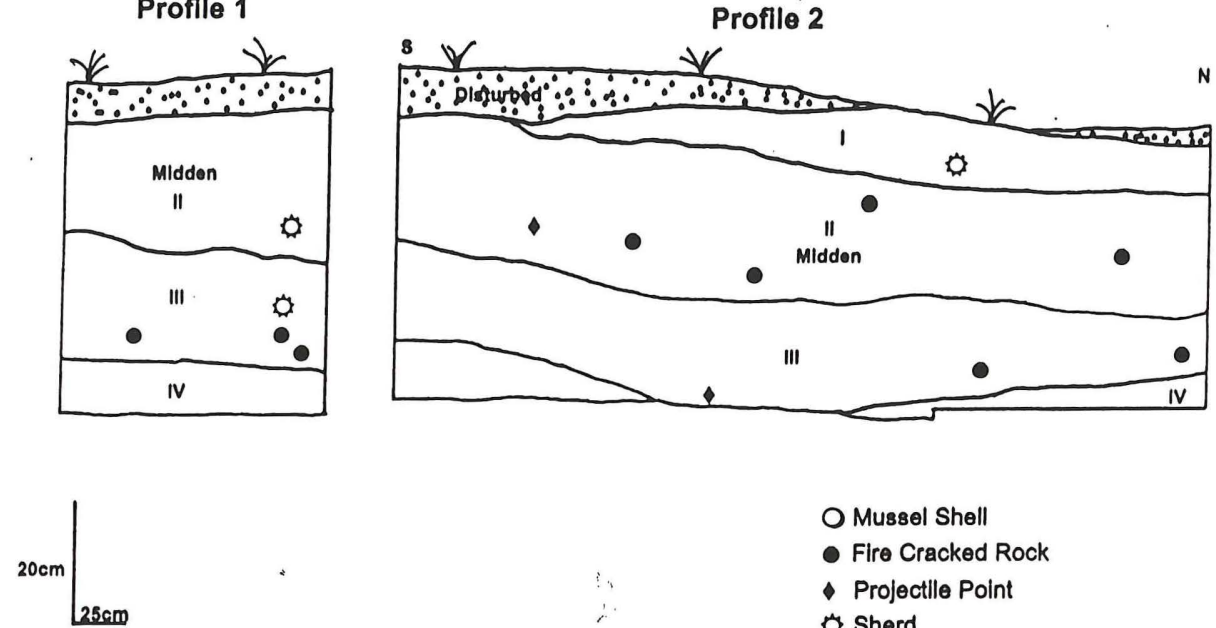

O Mussel Shell

- Fire Cracked Rock

- Projectlle Point

Sherd

Profilo 3
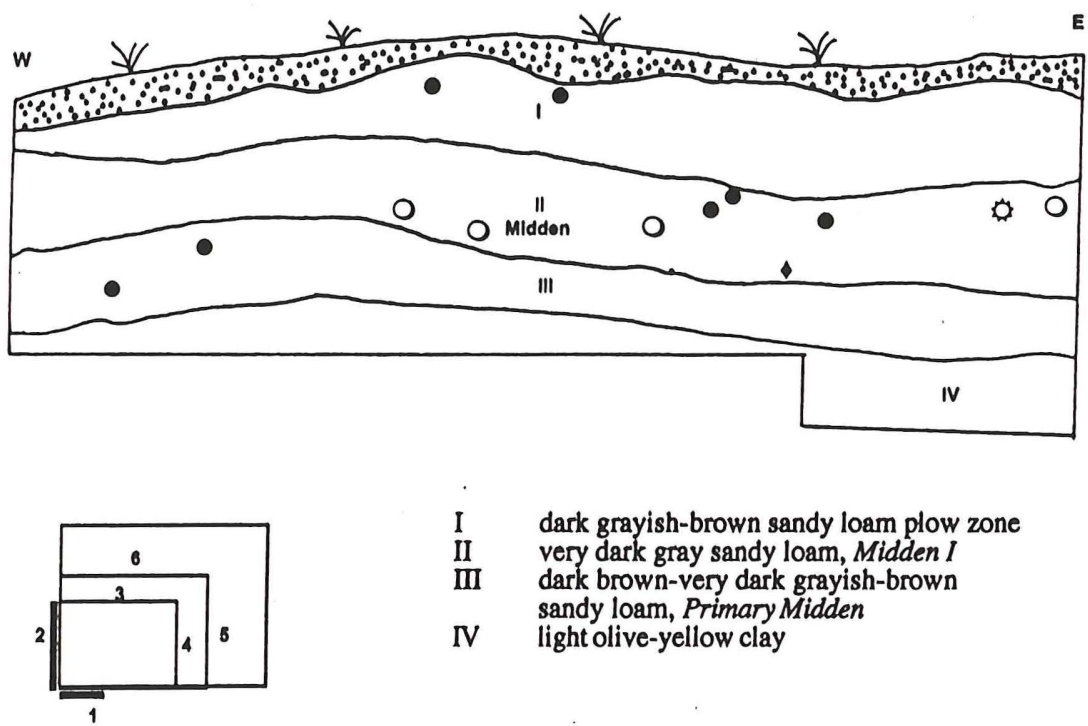

I dark grayish-brown sandy loam plow zone

II very dark gray sandy loam, Midden I

III dark brown-very dark grayish-brown

IV light olive-yellow clay

Figure 5-2. Profiles 1-6 in Block A. 


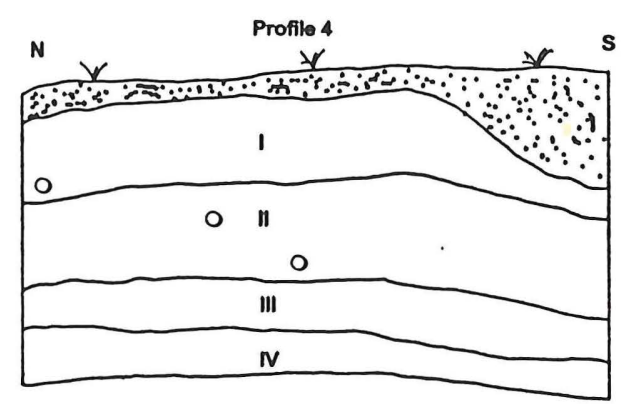

O Mussel Sholl

- Fire Cracked Rock

- Projoctio Point

O Sherd

I dark grayish-brown sandy loam plow zone

II very dart gray sandy loam, Midden I

III dark brown-very dark grayish-brown

sandy loam, Primary Midden

IV light olive-yellow clay

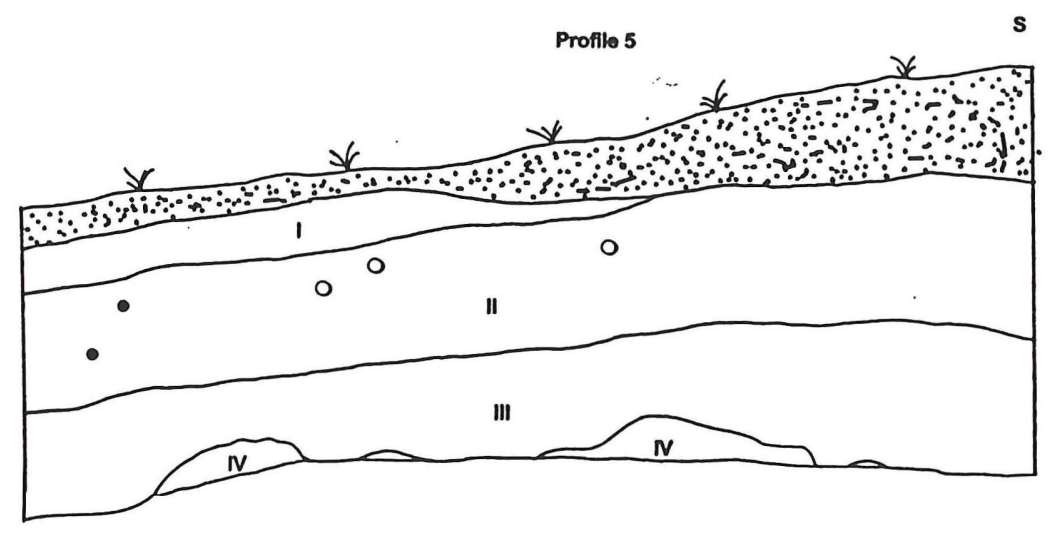

Profile 6

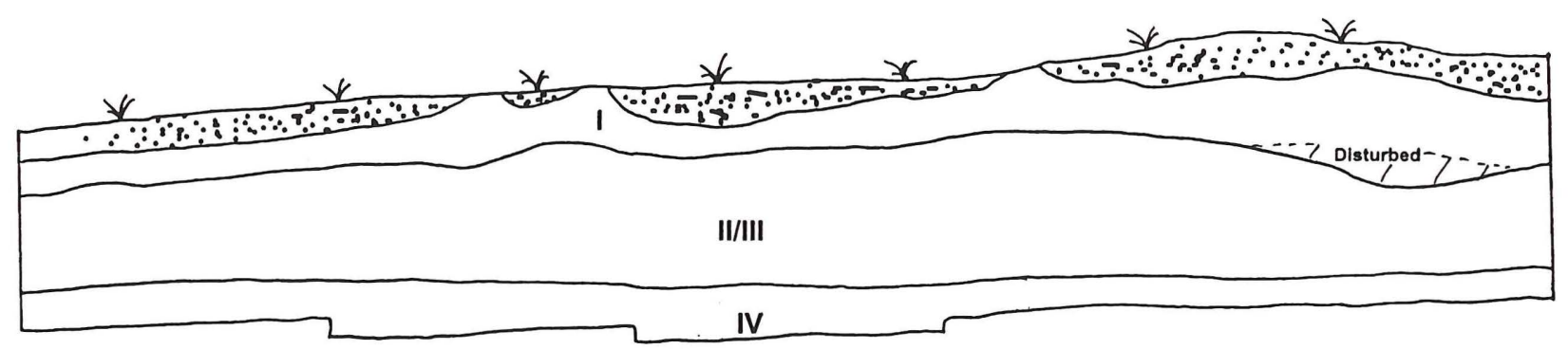

$\square$ Backdirt and Disturbed Zone

1 Sandy Loam, 10YR 3/2

II Midden, 10YR3/1, Sandy Loam

III Lower Midden, 10YR3/2-3/3, Sandy Loam

IV Clay, 2.5Y7/6-6/6

Figure 5-2. Profiles 1-6 in Block A, cont. 

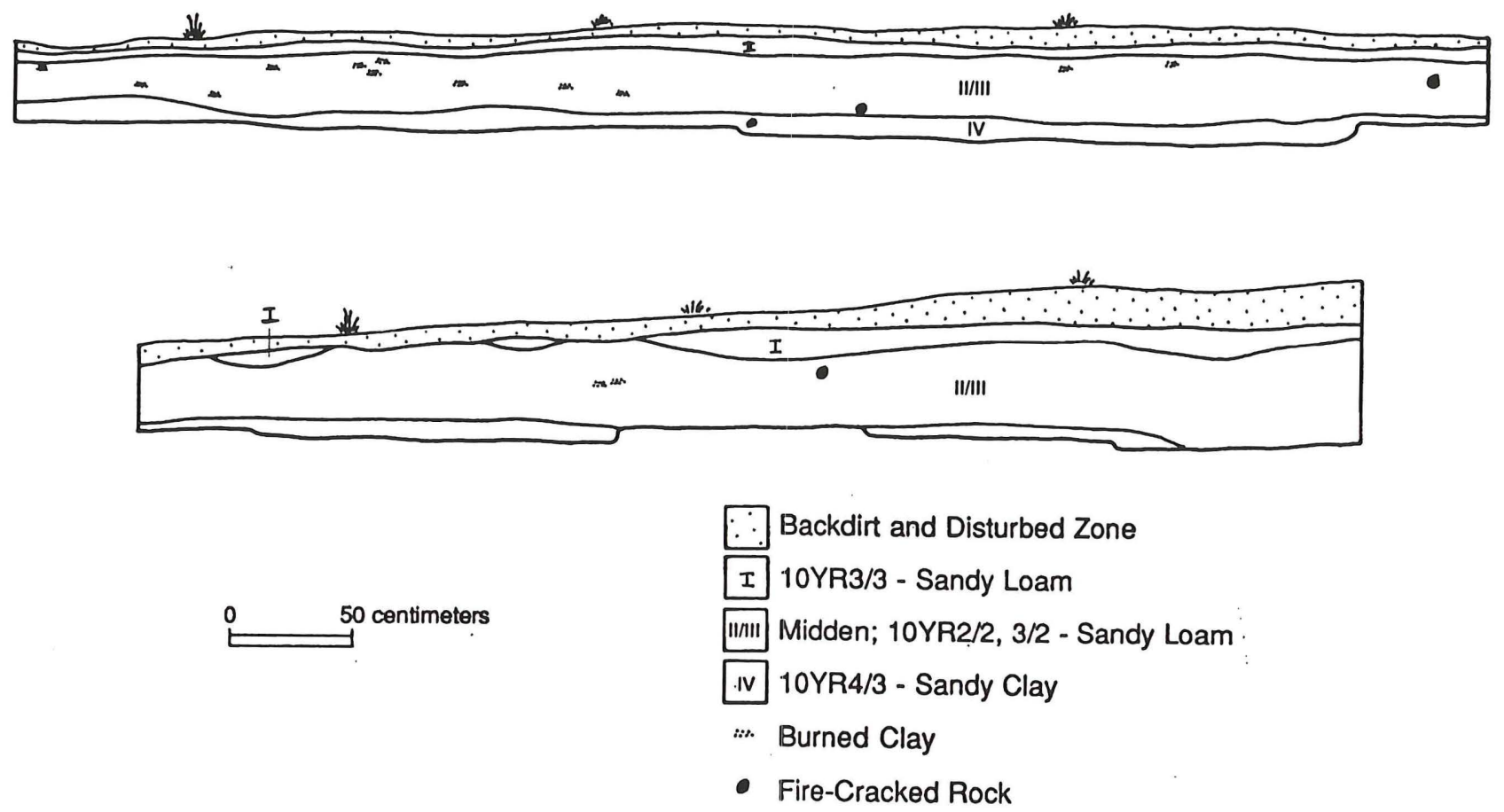

Figure 5-3. Profiles of the north and east walls of Block A extension.

Zone III is a dark brown (10YR3/3) to very dark grayish-brown sandy loam midden deposit associated with the Primary Midden. One of the principal artifactual constituents of Zone III is fire-cracked rock. Zone III is conformable with the underlying B-horizon clay (see Figure 5-2) and ranges from ca. 8-28 $\mathrm{cm}$ in thickness, being thickest along the slopes of the original knoll where the midden accumulated over an undulating and sloping B-horizon.

The B-horizon (Zone IV) is a light olive-yellow clay (2.5Y6/6-7/6) with minimal mottling or iron concretions in the exposed profiles. It contains cultural materials only at the contact with Zone III where materials have become compressed or bioturbated into the zone. Along the slopes of the knoll, the Bhorizon is brown (10YR4/3) and has a sandier texture than on the crest of the knoll (see Table 5-1); this is designated Zone IVa (see Figure 5-3).

In areas outside the main portion of Midden 1, Zones II and III cannot be visually distinguished or stratigraphically separated. Consequently, the midden deposits are referred to as Zone II/II in those areas (see Figure 5-3). Faunal remains are well-preserved in the top 10-15 cm of Zone II/III in Block A and Block A extension, but in few other places across the site. Thus, the upper part of the Zone II/III soils, where present, is apparently a Caddoan deposit relating only to Zone II.

In Block D, stratigraphic zones have been defined that correspond directly with those on the crest and slopes of the knoll in Block A (Figures 5-4 and 5-5). The midden deposit, designated Zone II/III, is thickest near the western edge of the block, along the crest of the North rise, and thins considerably down slope. Although the midden is roughly conformable to the present disturbed ground surface, it does have a "mounded" appearance in the area referred to as Midden 1 (see Figure 5-4: profiles 3 and 4). Proceeding grid south in Block D along the knoll, the midden pinches out and is replaced by Zone IIIa, a dark yellowishbrown (10YR4/4) to yellowish-brown (10YR4/6) sandy loam containing minimal amounts of charcoal flecks and burned clay. This zone ranges in thickness from 10-60 $\mathrm{cm}$ (see Figure 5-5, profile 10), also pinching out along the edges of the North rise. In other parts of the block, Zone IIIa underlies the midden (see Figure 5-4, profile 3), demonstrating the depositional nature of the Zone II/III midden. 


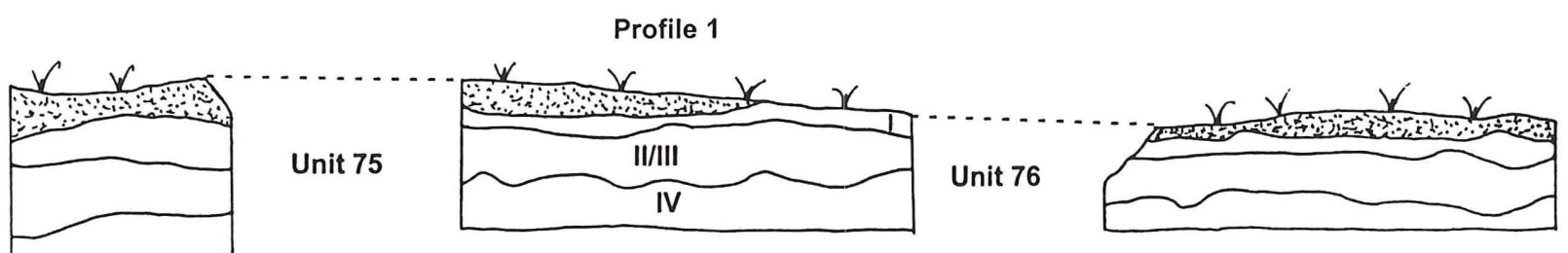

Profile 1, con't.
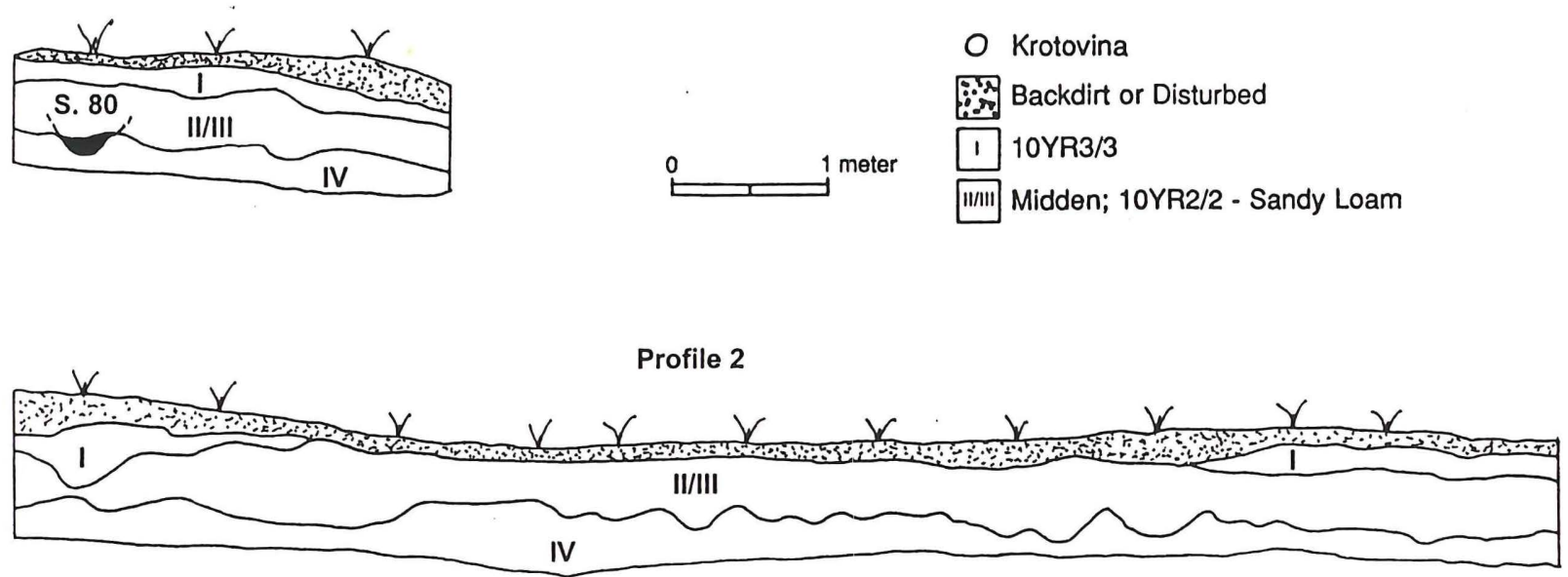

Profile 3

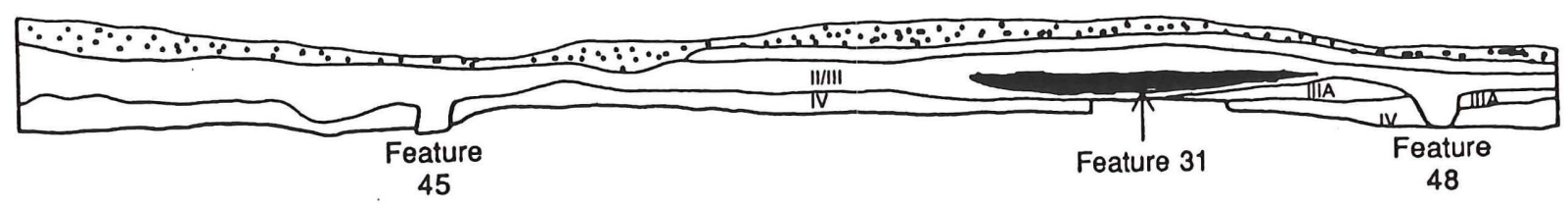

Profile 4
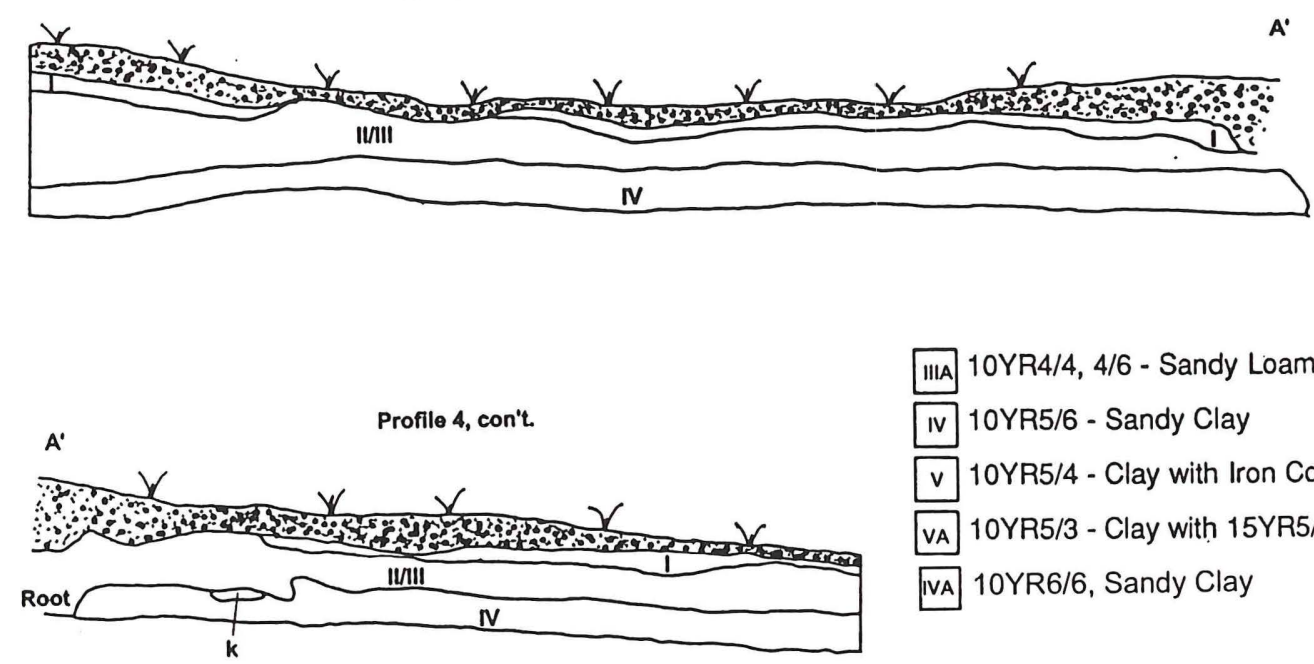

IIIA 10YR4/4, 4/6 - Sandy Loam

IV 10YR5/6 - Sandy Clay

v 10YR5/4 - Clay with Iron Concretions

VA 10YR5/3 - Clay with 15YR5/6 Mottle

IVA 10YR6/6, Sandy Clay

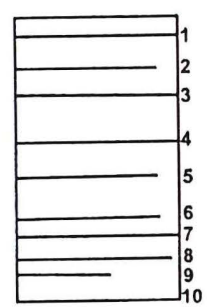

Figure 5-4. Block D profiles 1-7. 


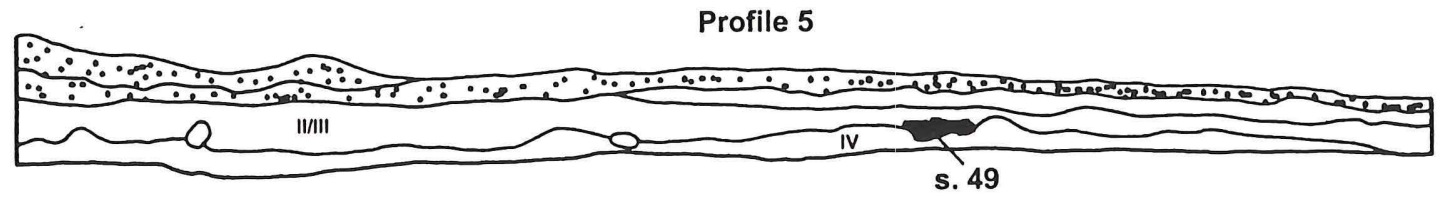

Profile 6

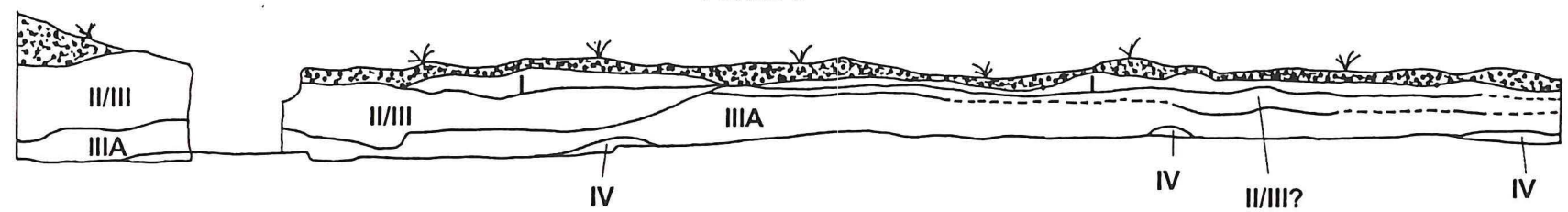

Profile 7

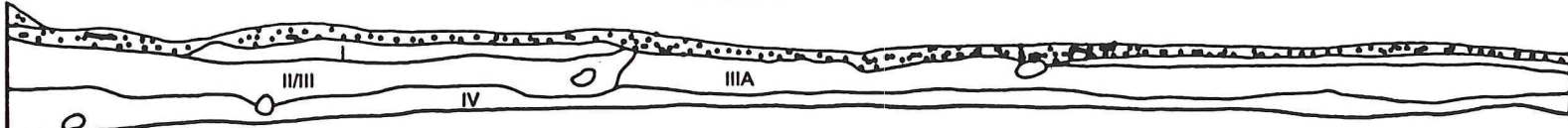

Figure 5-4. Block D profiles 1-7, cont.

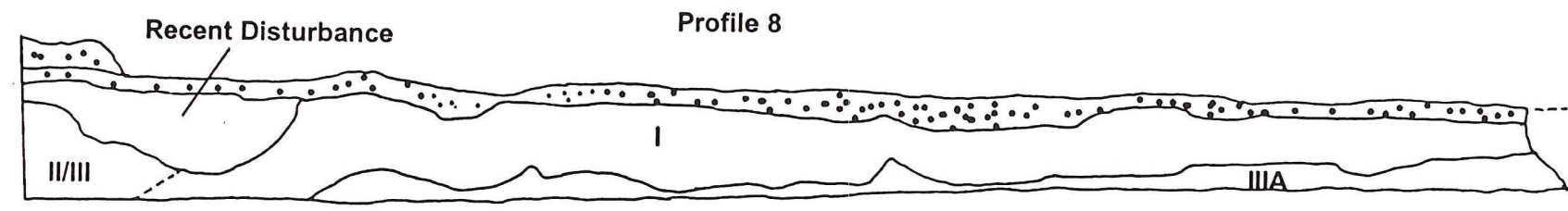

Profile 8, cont.

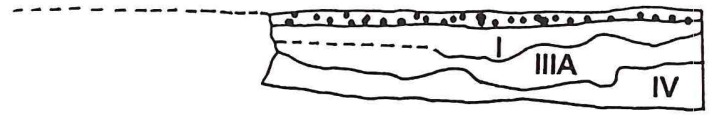

Profile 9

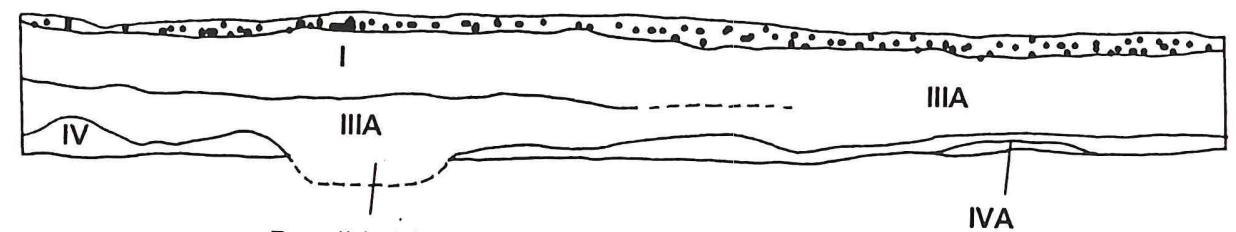

Possible Pit Feature

Profile 10

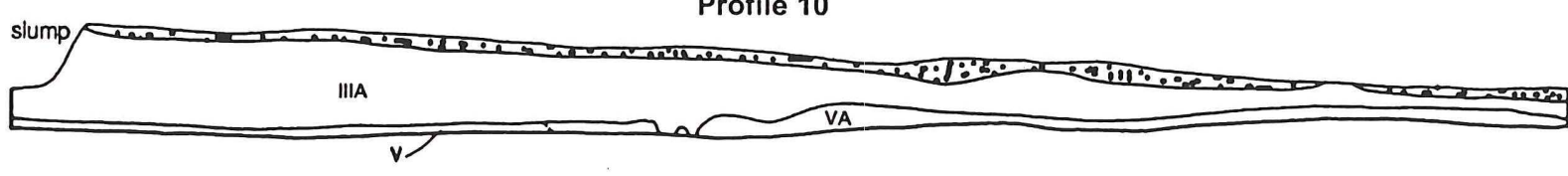

Figure 5-5. Block D profiles 8-10. 
The B-horizon ranges in color and texture from a yellowish-brown (10YR5/6) sandy clay (Zone IV) to a more plastic brown and yellowish-brown clay along the southeastern margins of the North rise. The Bhorizon clay is very mottled and contains abundant hematite concretions.

Because of the contrasts in color between the midden and the underlying soil zones, all cultural features observed in the profiles appeared to have originated in Zone II/III, with the exception of a possible pit feature originating in Zone IIIIa (see Figure 5-5, profile 9). The vertical origin of the Zone II/III features is uncertain because of the difficulty in detecting the tops of the features (pits and stains) in the dark gray midden. One feature, Feature 31 (see Figure 5-4, profile 3), consisting of a thick deposit of burned rock, originated at the base of the Zone II/III midden and was subsequently buried by it.

The profiles in Block E complement the information already discussed for Block D. The Zone II/III midden is lens-like in appearance, thickening considerably from west to east across this part of the North rise (Figure 5-6). Midden 2 can be detected in profile (see Figure 5-6, profile 5) because its very dark brown color (10YR2/2) contrasts with the very dark grayish-brown color of the Primary Midden. However, the two middens merge stratigraphically, and unlike in Block A, the Midden 2 zone cannot be demonstrated to overlie the Primary Midden. The contents of these deposits are, on the other hand, completely compatible with Midden 1, and represent, therefore, another localized "midden mound" deposit that dates to the Early Caddoan period. Caddoan burials were placed in this midden (see Chapter 6, this volume), and other features of Caddoan affiliation originate near the top of the midden where they have been truncated by plowing.

The midden is about $45 \mathrm{~cm}$ in thickness along the crest of the knoll at the eastern end of Block E. At the western end of the block, it is $20-25 \mathrm{~cm}$ thick (see Figure 5-6, profiles 2 and 3). The Primary Midden is overlain by the Zone I plowzone and merges with Zone IIIa along the slope of the knoll (see Figure 5-6, profile 5). A dark yellowish-brown (10YR3/4) sandy loam, Zone IIa, is sandwiched between the plowzone and the midden (see Figure 5-6, profile 2). Whether this is a depositional feature or an earlier plowzone has not been determined.

The Zone II/III deposits are conformable to the slope of the underlying B-horizon clay, clearly reflecting the cultural alteration of the A-horizon through the deposition of plant and animal remains, and other trash. These activities increased the organic content of the A-horizon, as well as caused the soil to darken. The appreciable thickness and "mound-like" appearance of the Zone II/III midden deposits also indicate a localized aggradation or build-up of sediments on this part of the North rise through cultural activities.

Underlying the midden zone throughout Block $\mathrm{E}$ is a brown to yellowish-brown (10YR5/6) sandy clay-clay argillic B-horizon. The clay content increases with depth in Zones IV and V (see Figure 5-6, profiles 2 and 4).

Backhoe Trench \#31-32-33 was $36 \mathrm{~m}$ long and extended from the North rise to the South rise (see Figure 4-3). The trench was excavated to provide a continuous profile between the North and South rise blocks for correlating natural and cultural zones between the two areas. Additionally, it was a relatively rapid method for examining the nature of the archaeological deposits between the two rises. Shovel tests in these slightly lower portions of the site indicated that archaeological materials were abundant, but the depositional or pedogenic context had not been established in any comprehensive manner.

Deep A-horizon sandy loams are present on the North and South rises, but between the rises the Ahorizon is considerably thinner and generally lighter (10YR3/2-3/3) in color (Figure 5-7). Midden 1 deposits were exposed below the plowzone at the north end of Backhoe Trench \#31/32/33 as a dark grayishbrown (5YR2.5/2) sandy loam (Zone II) that was $25-30 \mathrm{~cm}$ in thickness. A brown (10YR5/3) sandy loam A-horizon, designated Zone III, underlies the midden across the central extent of the rise but pinches out along the southern slope (see section B-B' on Figure 5-7). This zone correlates with Zone IIIIa, a strong brown (7.5YR5/6) sandy loam, on the South rise (see below) and in the intervening area between the rises. This zone contains archaeological materials relating primarily to Early Ceramic and/or Late Archaic occupations. 

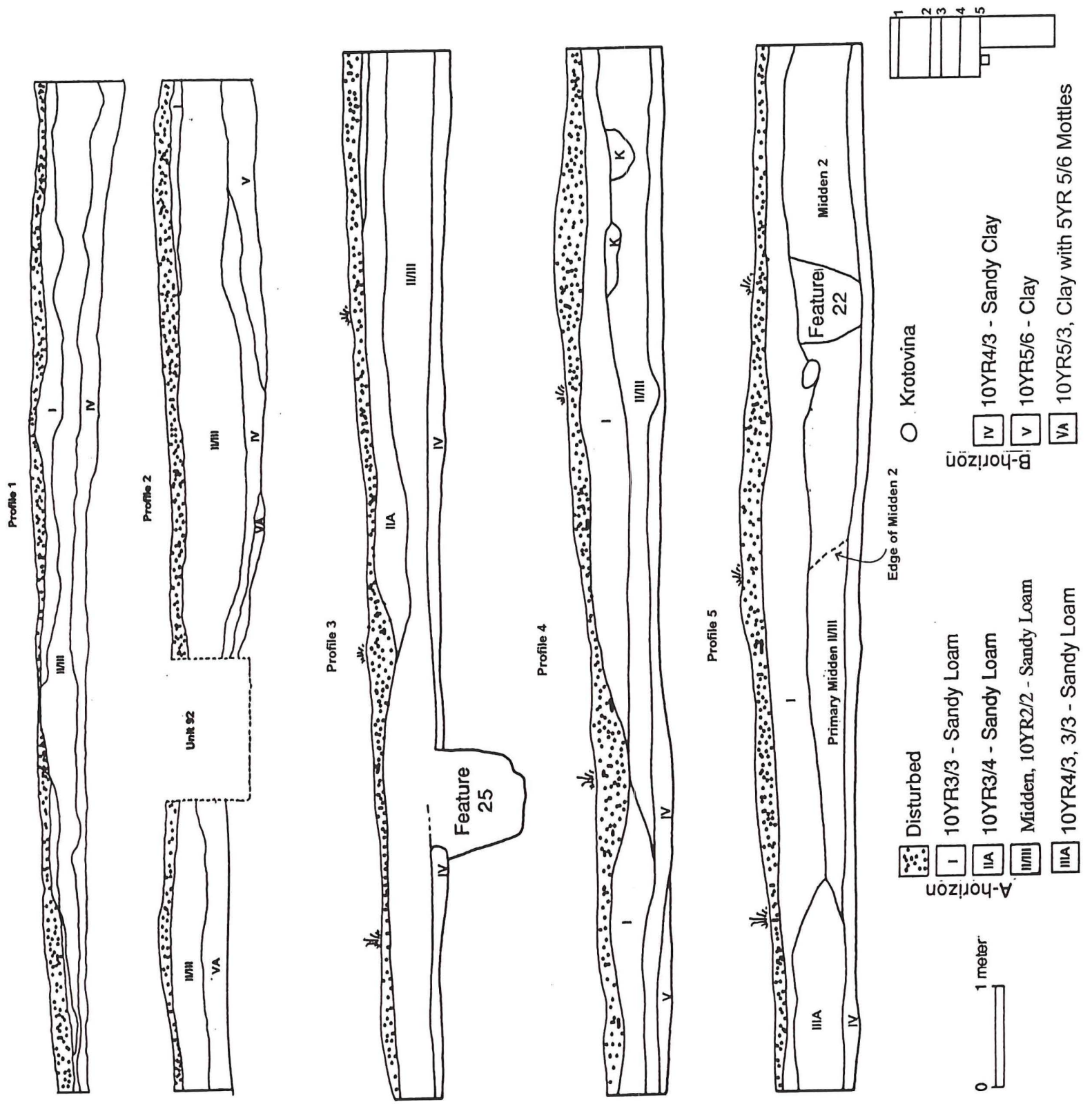

Figure 5-6. Block E profiles 1-5. 


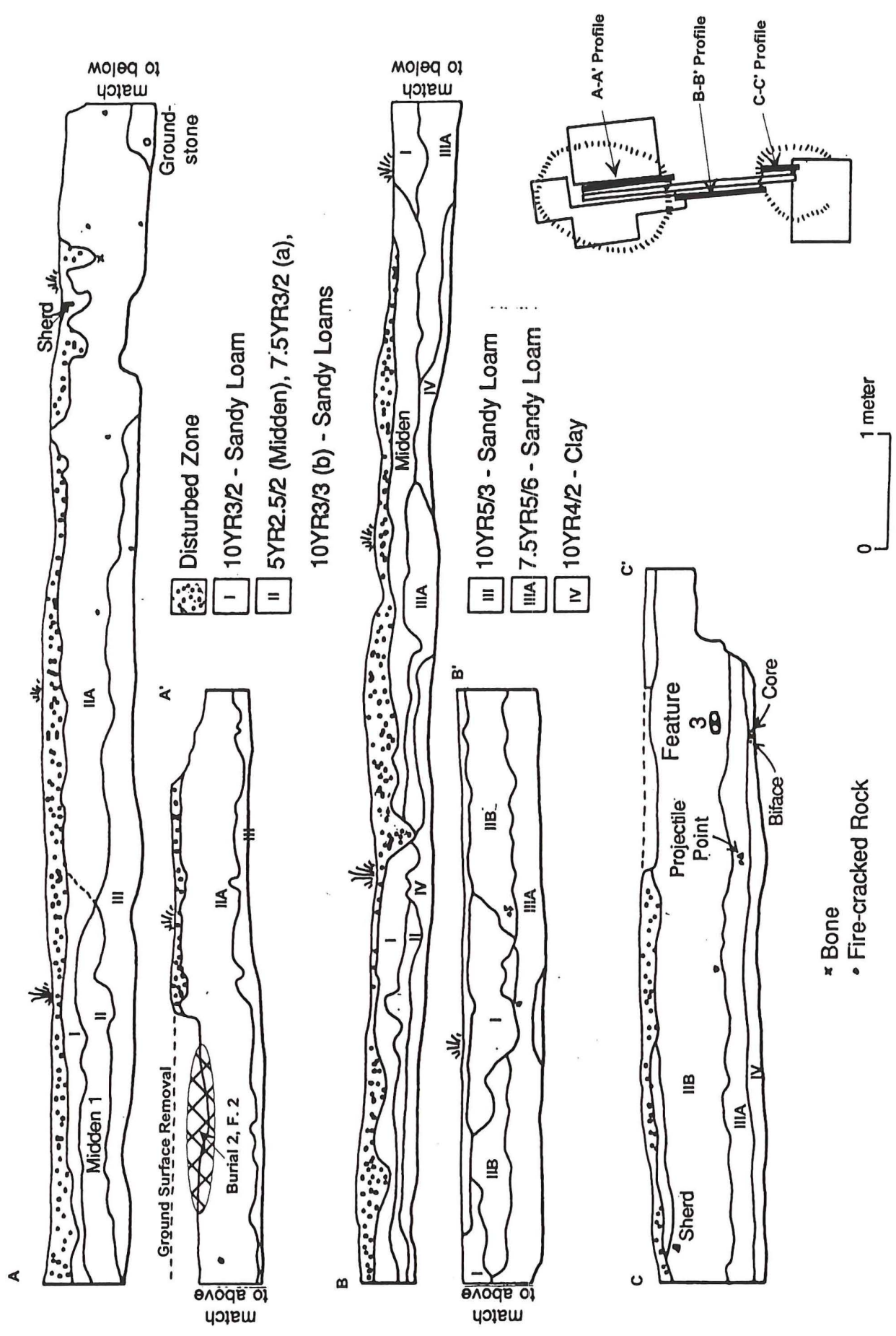

Figure 5-7. Profiles of BHTs 31/32/33, A-A', B-B', and C-C'. 
In the approximate center of the lower landform elevations between the crest of the North and South rises is another midden deposit (see section B-B' on Figure 5-7). This midden is $5.2 \mathrm{~m}$ in length, but its width is undetermined. The area around this midden had been extensively disturbed by bulldozing, as well as by the miring of the backhoe, and it was not feasible to conduct additional mechanical explorations at the time because of the difficulty involved in maneuvering heavy equipment in the saturated soils. After the sediments had an opportunity to drain and dry out, the area was scraped with a gradall (see Chapter 4 , this volume). The midden is exposed between $12-20 \mathrm{~cm}$ bs and has a maximum thickness of $25 \mathrm{~cm}$ (see Figure 5-7). It has the same color and texture as Midden 1 on the North rise, but it does not have the excellent preservation of vertebrate faunal remains noted for portions of the North rise middens.

At the same stratigraphic level as Zone II on the North rise, but south of Midden 1, is a very dark brown sandy loam designated Zone IIa. This zone has lesser amounts of organic content and a slightly lighter color than Midden 1, and it is not considered an anthropogenic zone. It does, however, contain pockets of midden that occur in association with cultural features, such as Features 1 (Burial 1) and 2 (Burial 2), two extended burials located in Backhoe Trench \#31/32/33 (see Chapter 6, this volume). Both individuals had been placed in shallow pits excavated into Zone IIa, and midden sediments had been incorporated into the fill to a sufficient extent that the pit outlines could be discerned a few centimeters above the pit floors.

The top of the argillic B-horizon is a dark grayish-brown (10YR4/2) clay (Zone IV). It is exposed at only $30-35 \mathrm{~cm}$ bs in the lower areas between the two rises. Otherwise, it is encountered ca. $60-80 \mathrm{~cm}$ bs on the North and South rises (see Figure 5-7).

The sequence of soil zones identified in the short section of Backhoe Trench \#31/32/33 profiled on the South rise is similar to that of North rise outside the main extent of the midden deposits. The top 10$15 \mathrm{~cm}$ have been disturbed by bulldozing, which removed a significant portion of the Zone I plowzone in the process. Underlying this are two A-horizon zones--Zone III and Zone IIIa--that have a combined thickness of $60-65 \mathrm{~cm}$. The upper zone is a dark brown sandy loam that grades into Zone IIIIa, a strong brown (7.5YR5/6) sandy loam. Both zones contain archaeological materials, although the Caddoan period remains are confined primarily to Zone IIIb, except where bioturbation, root disturbances, or undetected stains or pits penetrated the underlying Zone IIIla. Beneath the two A-horizon zones is the B-horizon clay, Zone IV, which is located below the depth at which most of the expected Caddoan structural remains would likely extend. Consequently, the contrasts between zones are not considered optimal for the detection of pits and stains, such as occurred at the Bird Point Island site (Bruseth and Martin 1987) and Oak Hill Village (Cruse 1994, 1995), where features penetrated the argillic horizon and were readily distinguished by color, texture, and compactness. The South rise exhibits more of a gradation in color and texture with depth. Changes in these variables were more subtle to detect stratigraphically and in plan view, particularly micro-changes in color and texture that had possible cultural significance. As discussed below, the detection of postholes and other cultural stains on this rise was aided by cloudy conditions, moist soil, large horizontal exposures, and the fortuitous knowledge gained from backhoe trenching concerning the location of the central hearths (and underlying central post) relative to the structure outlines in Block B/C.

\section{South Rise}

Descriptions and analysis of the soil zones on the South rise have already been mentioned above in connection with Backhoe Trench \#31/32/33, as this lengthy trench provided an initial view of the cultural and natural stratigraphic sequence on this landform. More extensive profiles, however, have been obtained from described and measured sections in Blocks B, C, and F where Caddoan midden and structural remains were recognized and defined (Figure 5-8).

On the crest of the knoll, the plowzone is designated Zone I. It is a brown (10YR4/3) sandy loam, and except where it has been disturbed by bulldozing, it is continuous across the blocks (Figures 5-9 and 510). A minimal amount of backdirt covered the original ground surface in some portions of the South rise excavations, but more frequently, a few centimeters of the plowzone had been scraped away and used to fill recent pits excavated by the $\mathrm{COE}$ contractors for burning slash and tree stumps. 


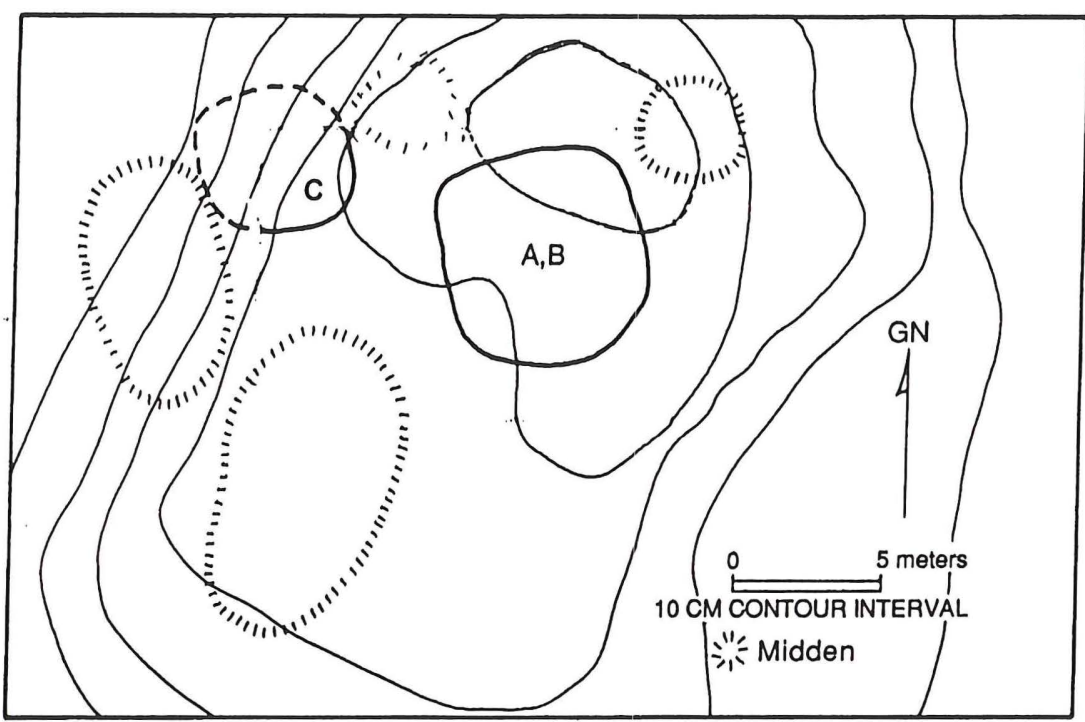

Figure 5-8. Plan of South rise depicting topography and location of major features.
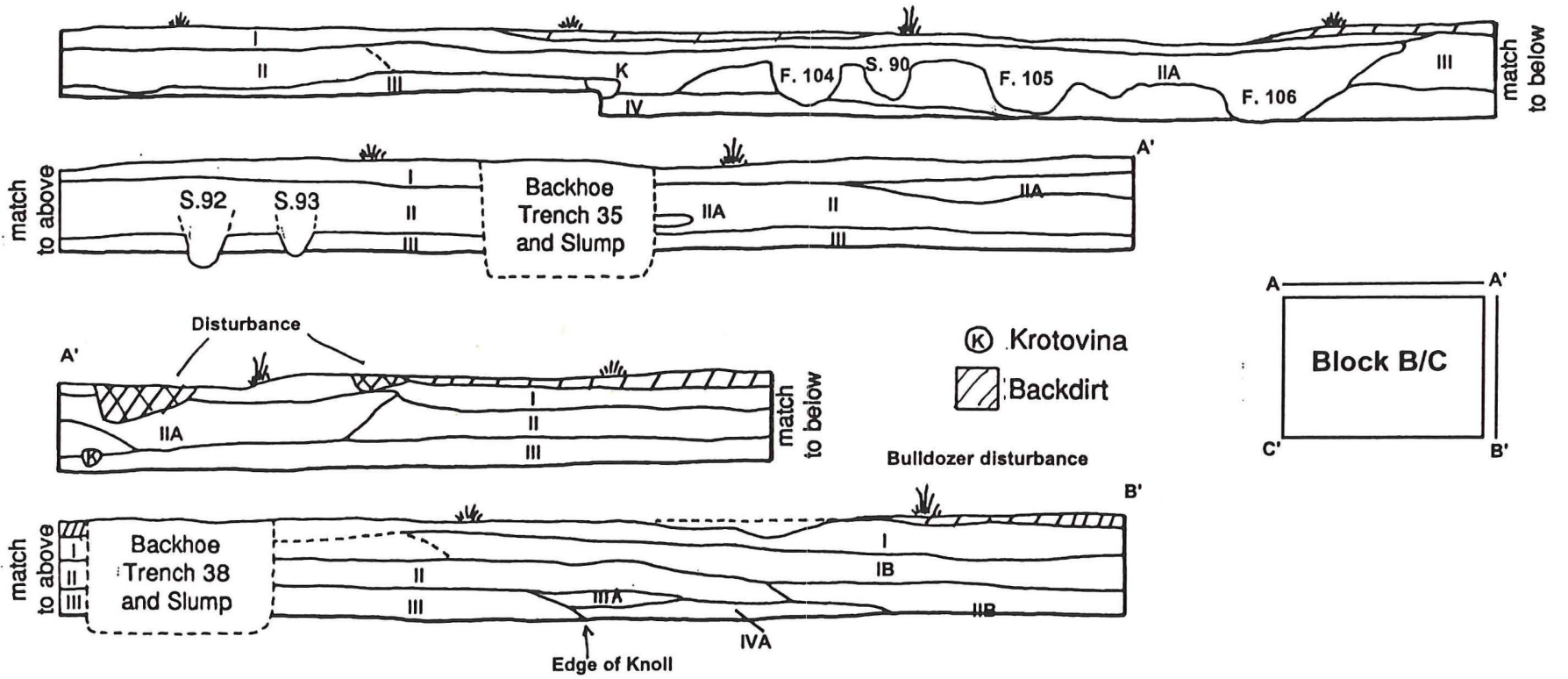

1 10YR3/3, 4/3 - Plowzone

18 10YR3/3 - Mottled Sandy Loam

11 10YR3/3, 2/1 - Sandy Loam

IIA 10YR3/2 - Sandy Loam with Charcoal Flecks

$118,10 Y R 5 / 4$ - Sandy Loam

III. 10YR4/3,3/4 - Sandy Loam

Figure 5-9. Outer wall profiles, Block B/C.
IIIA : 10YR4/4 - Sandy Loam

Iv 10 YR 4/4,5/4 - Sandy Loam

IVA 10YR5/8 - Sandy Clay

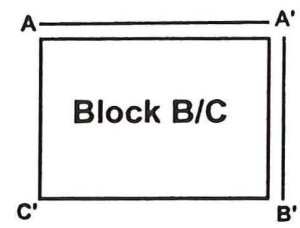

. 


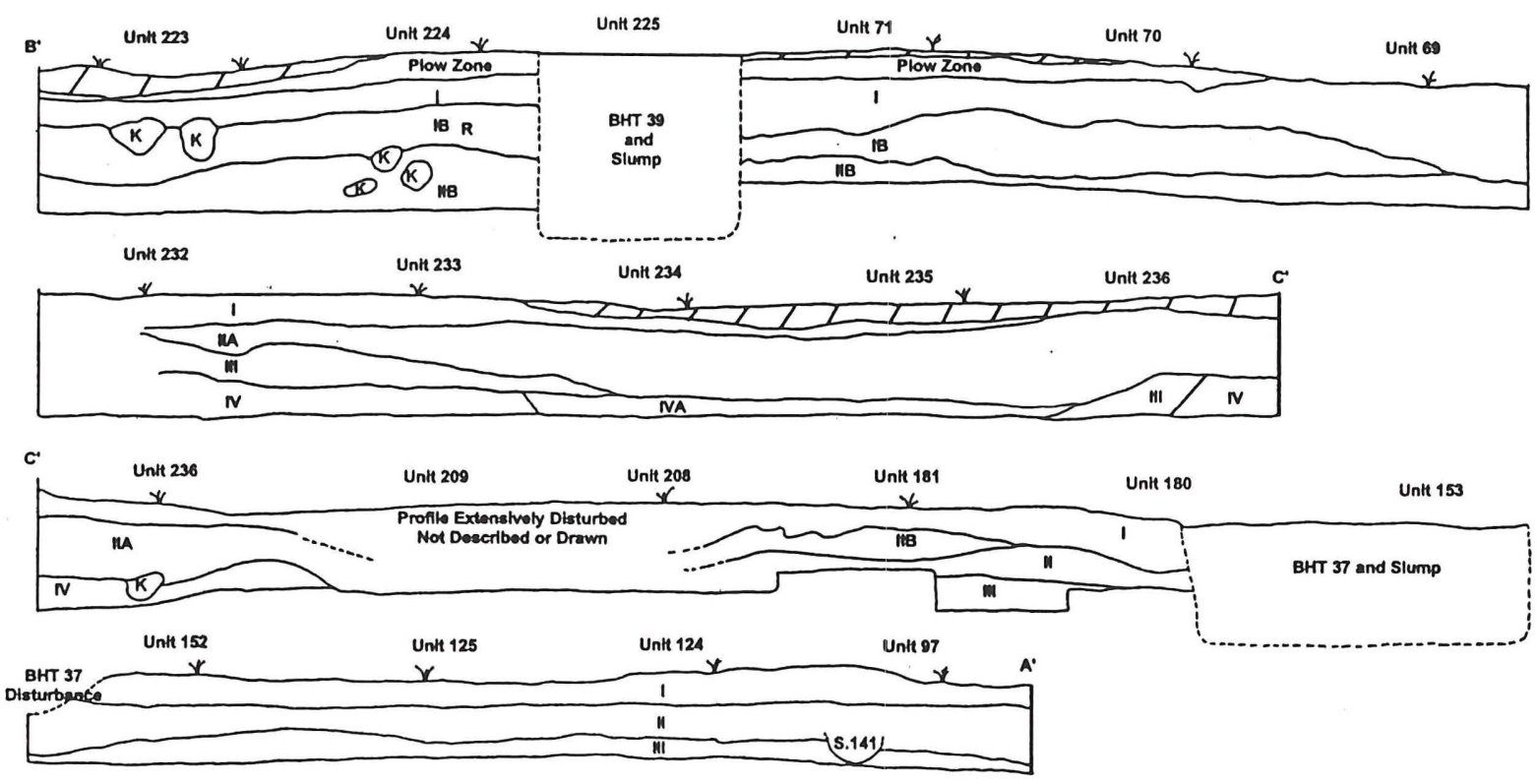

Figure 5-9. Outer wall profiles, Block B/C, cont.
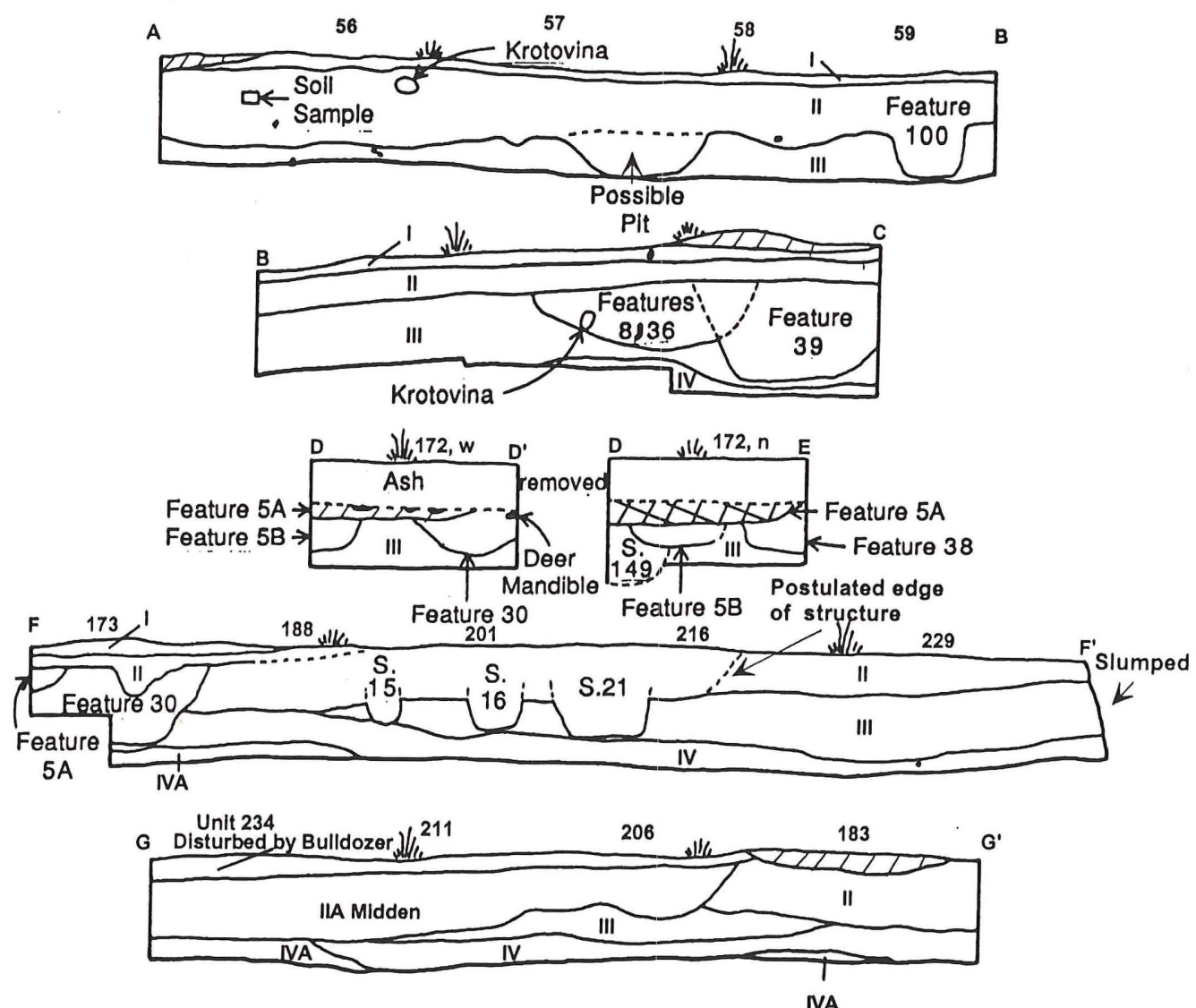

Figure 5-10. Profiles in Block B/C in the vicinity of Structures A and B. 

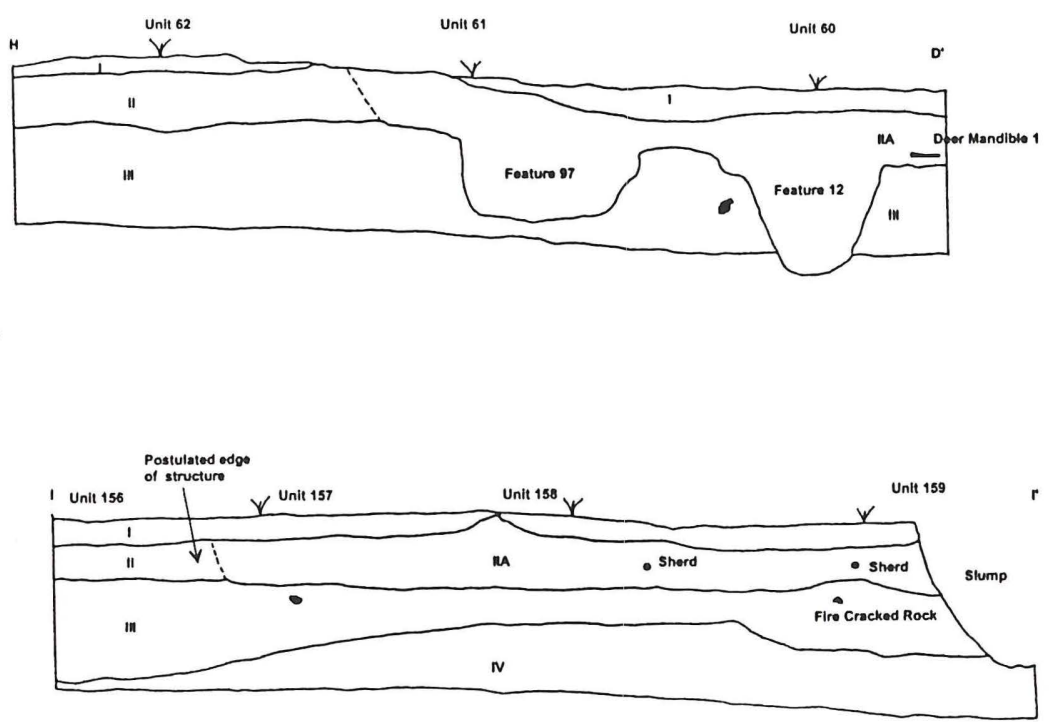

$0 \quad 50$ centimeters

- Fire-cracked Rock

ZBackdirt

1 10YR3/3, 4/3 - Plowzone

11 10YR3/3. - Sandy-Loam

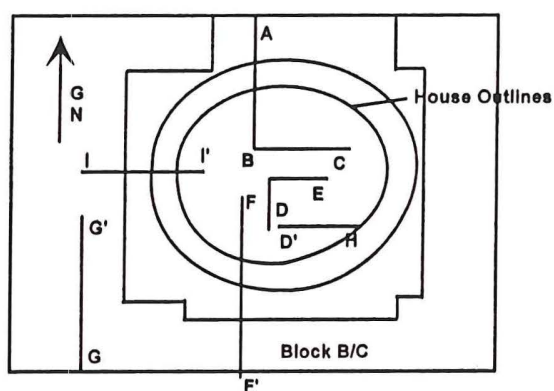

IIA 10YR3/2 - Sandy Loam with Charcoal Flecks

III 10YR4/3, 3/4 - Sandy Loam

IV 10YR4/4, 5/4 - Sandy Loam

INA 10 YR5/8 - Sandy Clay

Figure 5-10. Profiles in Block B/C in the vicinity of Structures A and B, cont.

Below the plowzone is a dark brown (10YR3/3) sandy loam A1 deposit about $15-30 \mathrm{~cm}$ in thickness that is designated Zone II. Archaeological materials are abundant in this zone, and many Midden Caddoan period cultural features, primarily postholes and pits (sees Figure 5-9 and 5-10), originate in this zone (see also Chapter 6). Along certain sections of the profiles the A1 deposit increases in organic content, becomes darker in color (a very dark grayish-brown to black, 10YR 3/2-2/1), and is characterized by charcoal flecking. These sections have been designated Zone IIa, and this zone appears to consist of middens and/or portions of a living surface (or "floor"?) associated with the occupation of one of the Middle Caddoan structures on the South rise.

This zone is present in two small deposits along the north edge of the block (see Figure 5-8), and as a much larger midden at the southwest corner of Block B/C. Additionally, a small section of Zone IIa was recognized adjacent to, and at the same level as, Feature 5a, the central hearth for Structure A (see Profiles C-D', E, and E-E' in Figure 5-10). Postholes and pits originate in Zone IIa within the houses and 
in middens along the north end of the block excavations (see Profile A-A' in Figure 5-9). The extramural middens are $8-15 \mathrm{~cm}$ thick below the plowzone, and Zone IIa is a maximum of $5 \mathrm{~cm}$ thick within the house.

Zone IIa midden deposits along the southwestern edge of Block B/C have a lens-like appearance in profile. Based on the basal slope of the midden and the underlying A12 and B-horizon zones, these midden deposits appear to have been dumped in a shallow (15 to 20-cm deep) basin adjacent to the crest of the South rise (see profile $B^{\prime}-C^{\prime}$, and $C^{\prime}-A$ in Figure 5-9). The shallow depression was completely filled with midden debris that was probably also augmented by slope wash. Consequently, Zone IIa deposits extend a short distance out from the sides of the depression. The midden has a maximum thickness of $28 \mathrm{~cm}$.

Zone III, an A12 horizon, is a brown to dark yellowish-brown sandy loam that underlies the midden (Zone IIa) or Zone II across the crest of the knoll. Since excavations in Block B/C generally terminated at $50 \mathrm{~cm}$ bs (the base of level 5) except where necessary to expose and define cultural features, the total depth of Zone III was not uniformly established except where backhoe trenching penetrated to the B-horizon clay (see above). In a few sections of the block, Zone IV, an A13 horizon, was identified below Zone III. Both Zones III and IV in Block B/C comprise part of what was designated Zone IIIa on the North rise in Backhoe Trench \#31/32/33 (see Figure 5-7). Zone IV is a dark yellowish-brown to yellowish-brown sandy loam. No in situ features or stains originating in Zones III and IV were noted in the excavations. However, Early Ceramic and Late Archaic period archaeological materials were relatively common in both zones.

Along the slopes of the South rise below the plowzone, the A-horizon is composed of Zones Ib and IIb, mottled sandy loams ranging in color from dark brown to yellowish-brown. Krotovinas and root disturbances are more apparent in these zones, although this may simply be due to the lighter-colored deposits along the slope. Each zone averages about $15-20 \mathrm{~cm}$ in thickness and overlies, at relatively shallow depths, a B-horizon of yellow sandy clay, Zone IVa (see Figures 5-9 and 5-10). The top of the argillic horizon is only exposed in only a few sections of the profile on the crest of the knoll where it is 70$80+\mathrm{cm}$ bs, but it is exposed at $35-40 \mathrm{~cm}$ bs along the slopes of the knoll where the overlying sandy loam zones are much shallower. The Zone IVa deposits are culturally sterile except for archaeological material from overlying zones that occur at the top of the argillic horizon due to pedoturbation.

Excavations in Block F exposed a midden that had been deposited along the slope of the South rise south-southwest of Structure C, a Caddoan building (see Figure 5-8). The midden, designated Zone IIa, underlies, and is partially truncated by, the plowzone (Zone I), However, Zone IIa is stratigraphically above Zone II, a very dark grayish-brown sandy loam (Figure 5-11). Zone II in Block F is a pedogenic unit comparable to Zone II in Block B/C (see above). Middle Caddoan middens in Block B/C, however, originate in Zone II, not above it as in Block F. Thus, the Block F midden may contain slightly younger Caddoan archaeological deposit than the bulk of the archaeological materials associated with Structures A and B in Block $B / C$, or perhaps is associated with the youngest Middle Caddoan structure, estimated to date from the first to the third-quarter of the 14th century (see Chapter 7, this volume). Unfortunately, no radiocarbon dates were obtained from either Structure $\mathrm{C}$ or the midden deposit.

The Block F midden (referred to as Feature 9; see Chapter 6, this volume) is a very dark brown (10YR2/2) sandy loam with a maximum thickness of $20 \mathrm{~cm}$, but an average thickness of $10 \mathrm{~cm}$. No features, posts, or pits were identified within the midden; therefore, it probably constitutes only a trash deposit that accumulated rather rapidly. Along the southern margins of the midden, the color of Zone IIa changes distinctly to a very dark grayish-brown (10YR3/2). This subset of the midden is designated Zone IIa1 (see Figure 5-11).

Underlying the midden are two A-horizon zones, Zone II and III, consisting of brown to dark brown sandy loams; a mottled and possibly eroded Zone IIb, and a dark yellowish-brown (10YR4/4) clayey B-horizon (Zone IV). This B-horizon clay is exposed between $34-45 \mathrm{~cm}$ bs only along the southern extent of the midden (see Figure 5-11). 

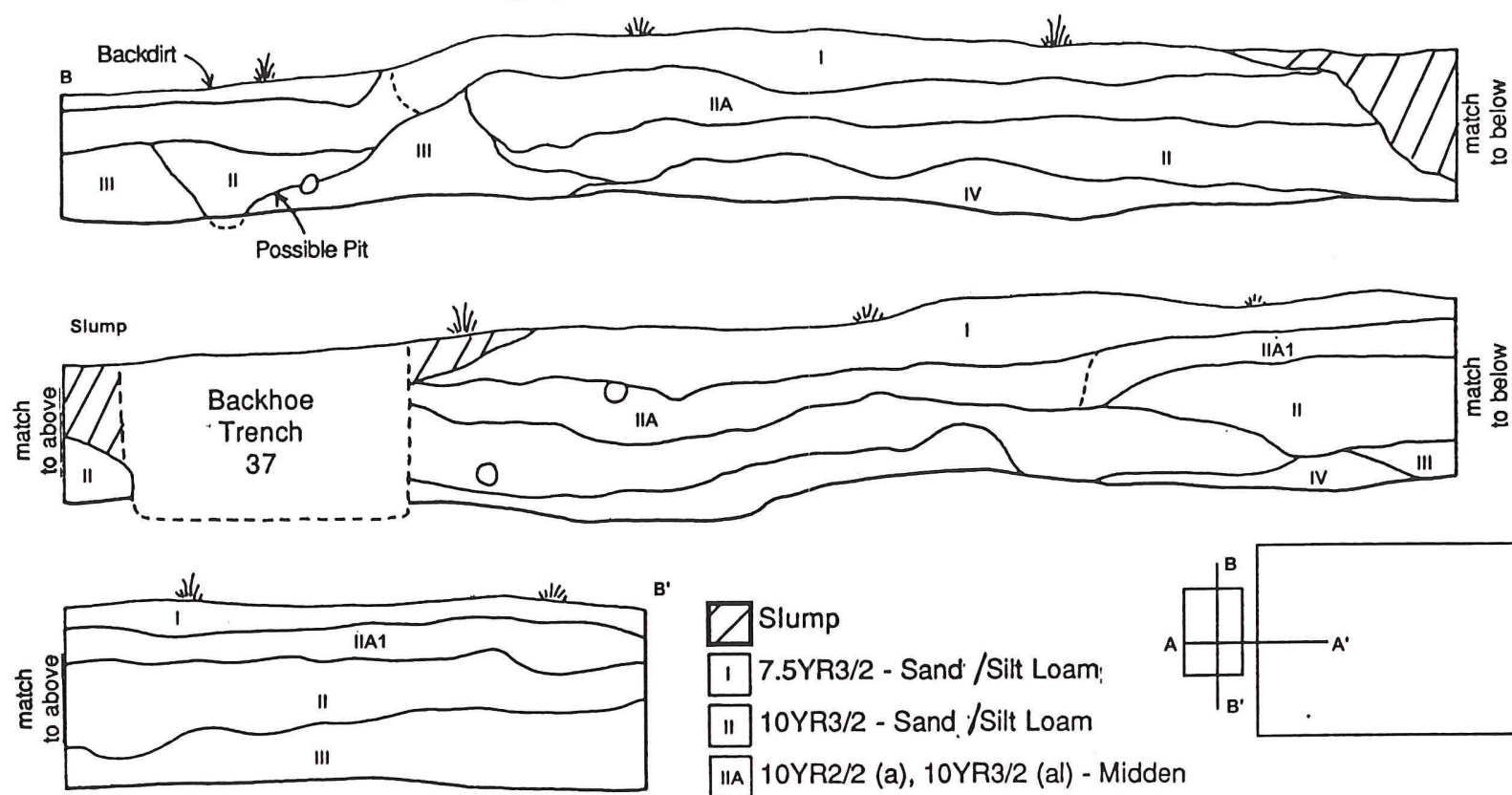

DSlump

17 7.5YR3/2 - Sand /Silt Loam:

11 10YR3/2 - Sand /Silt Loam

IIA 10YR2/2 (a), 10YR3/2 (al) - Midden

III 10YR3/2, 4/3 - Mottled Sand/Silt Loam

III) 10YR4/3 - Sand /Silt Loam

IV 10YR4/4 - Silty Clay

$\overbrace{}^{0} \underbrace{50}$ centimeters

O Krotovina
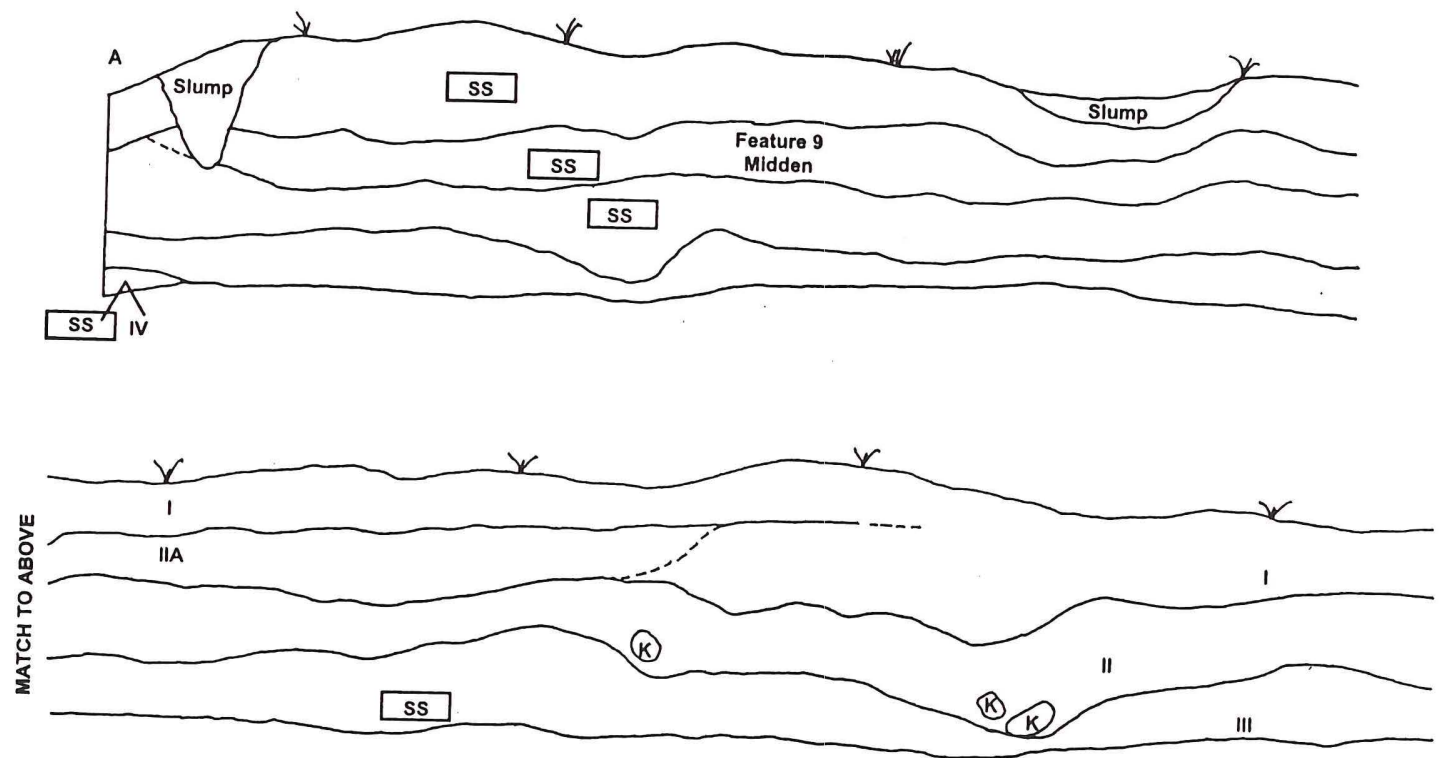

$A^{*}$

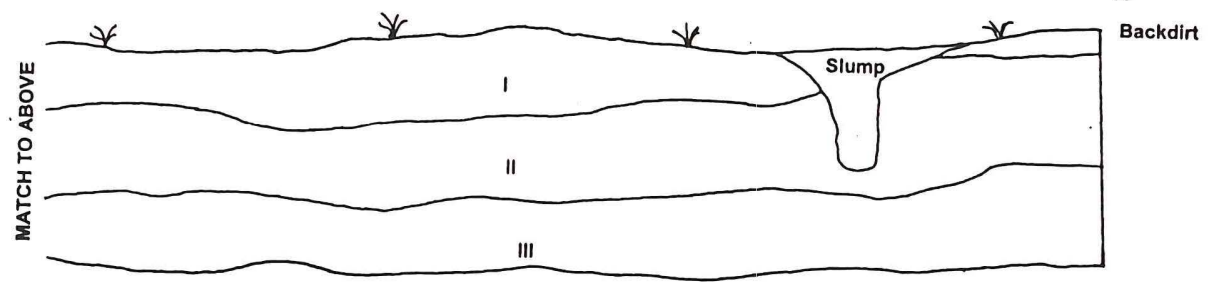

Figure 5-11. Profile A-A' and B-B', Feature 9, Blocks B/C and F. 
Excavations in Block F were limited to the shovel skimming of Zone $\mathrm{I}$, the exposure of the Zone IIa midden, and the fine screening and flotation of midden matrix from two units at the southern end of the block (see Chapter 4, this volume). Consequently, although it was established that Zone I and Zone IIa contain Caddoan materials, it is not known if earlier cultural remains are preserved in underlying zones along this portion of the South rise slope.

\section{Southwest Rise}

Information on the natural and cultural stratigraphy of the Southwest rise at the Hurricane Hill site derives from a series of measured profiles along Backhoe trenches \#45 and \#46, in several scraped areas, and selected 1 x $1 \mathrm{~m}$ units dispersed across the rise (Figure 5-12).

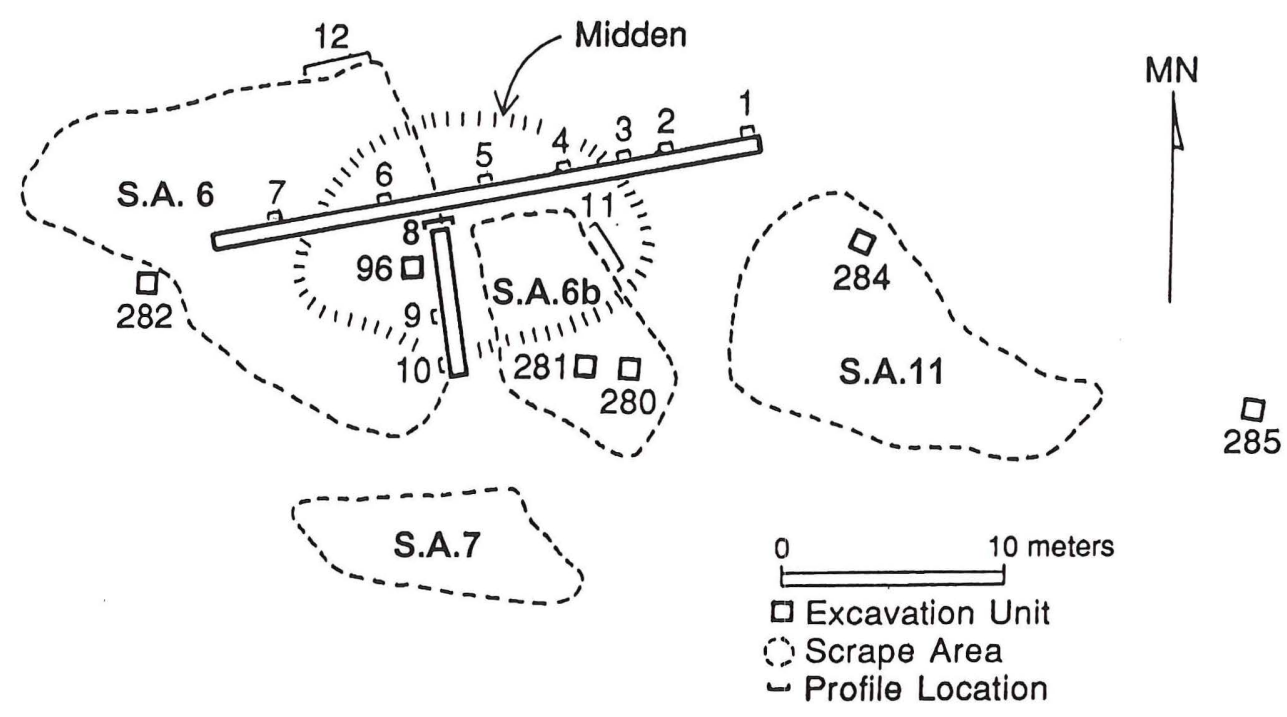

Figure 5-12. Southwest rise, plan of excavations and location of profiles 1-8.

On the crest of the rise, the A-horizon sediments average about $50-55 \mathrm{~cm}$ in thickness. These sandy loam deposits increase to $70 \mathrm{~cm}$ in thickness along the edge of the upland landform away from the crest and nearest the South rise. It thins to about $20 \mathrm{~cm}$ thick on the west, southeast, and south where the A-horizon has been eroded or disturbed by bulldozer activities (Figures 5-13 and 5-14). A midden is preserved on the crest of the Southwest rise. A few low spots or depressions off the crest were apparently buried by the midden. The Southwest rise appears to have been dissected by eroded swales that exposed the B-horizon clay in some areas, prior to the deposition of the midden. These swales were convenient trash disposal areas when the rise was occupied.

The stratigraphy of the Southwest rise differs substantially from that of the north and South rises in one critical detail: the amount of naturally occurring gravel in the A-horizon on the Southwest rise (Table 5-2). The gravel underlies the midden and occurs in a lens about $30-40 \mathrm{~cm}$ bs in several profiles on the crest of the rise and in excavation areas trending north down the slope. The gravels are composed of Ogallala quartzite cobbles, petrified wood, and small pieces of locally occurring chert nodules, and appear to be part of the much larger surface gravel sheet of Uvalde gravels noted across the eastern half of the site (see Chapter 2, this volume). The gravel lens is best preserved below the midden deposits on the rise crest (see Figure 5-13, profiles 5-6, 8, and Unit 96). The gravel lens probably helped to maintain the character of the rise and reduce the extent of local erosion. This "preservation" was further aided by the accumulation of midden deposits atop the rise. 

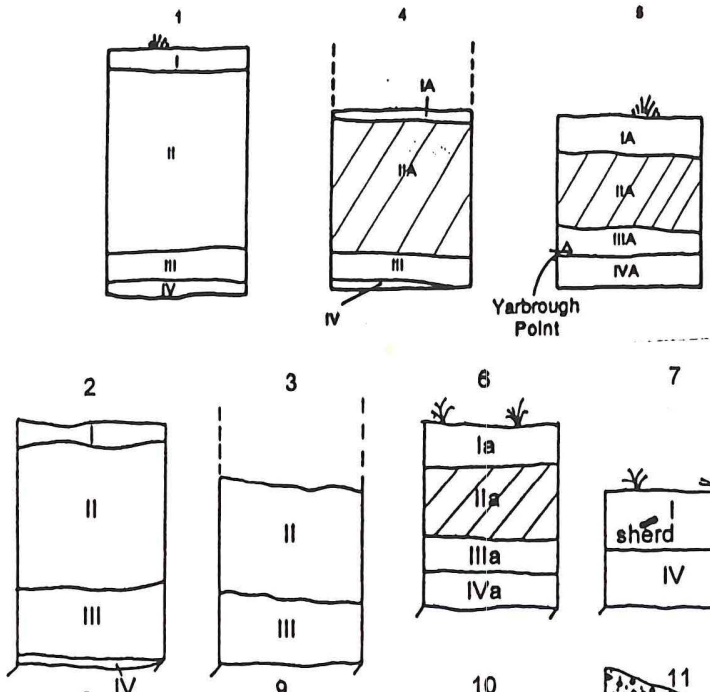

7
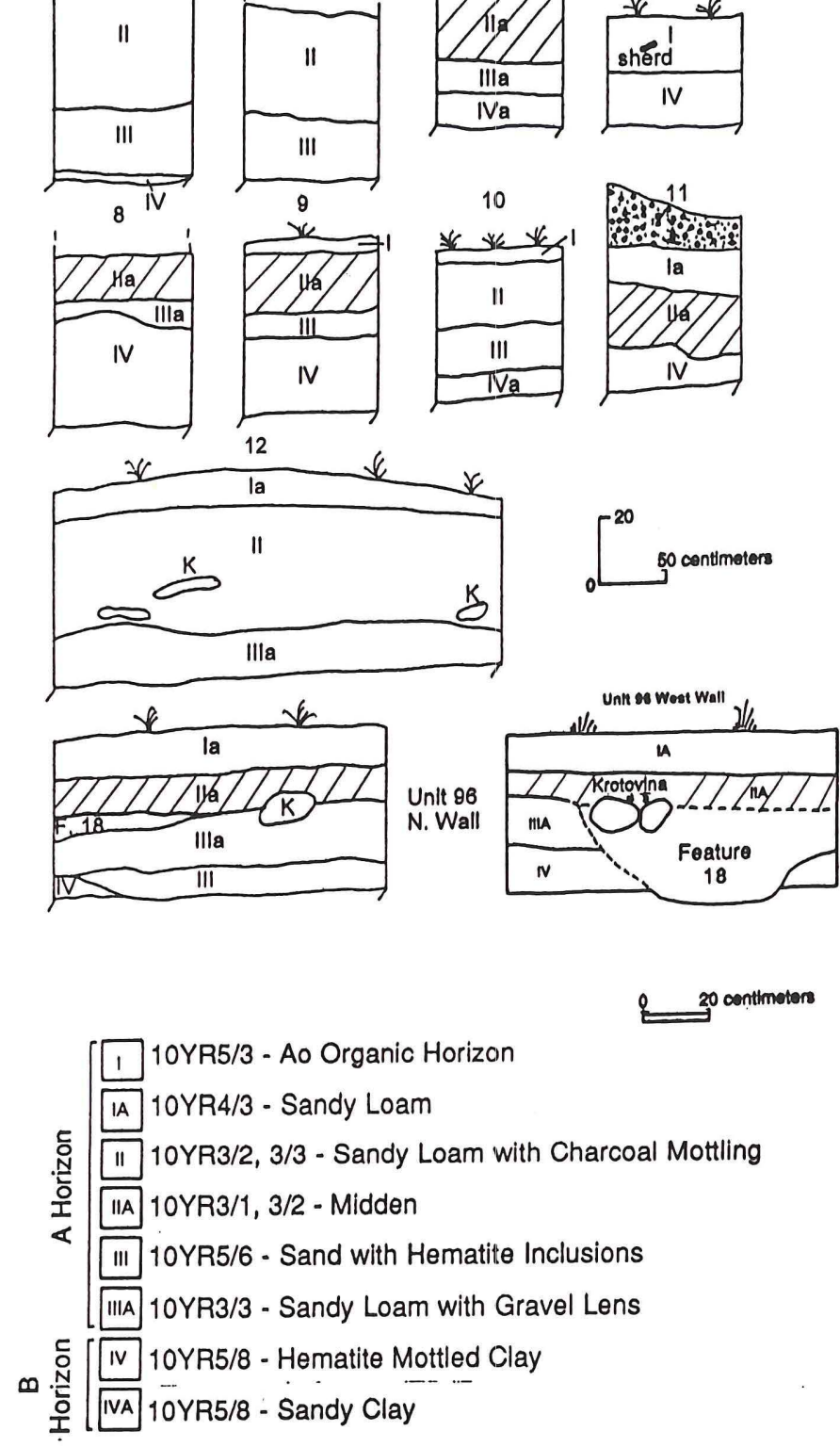

Figure 5-13. Southwest rise, profiles of backhoe trenches and Unit 96. 

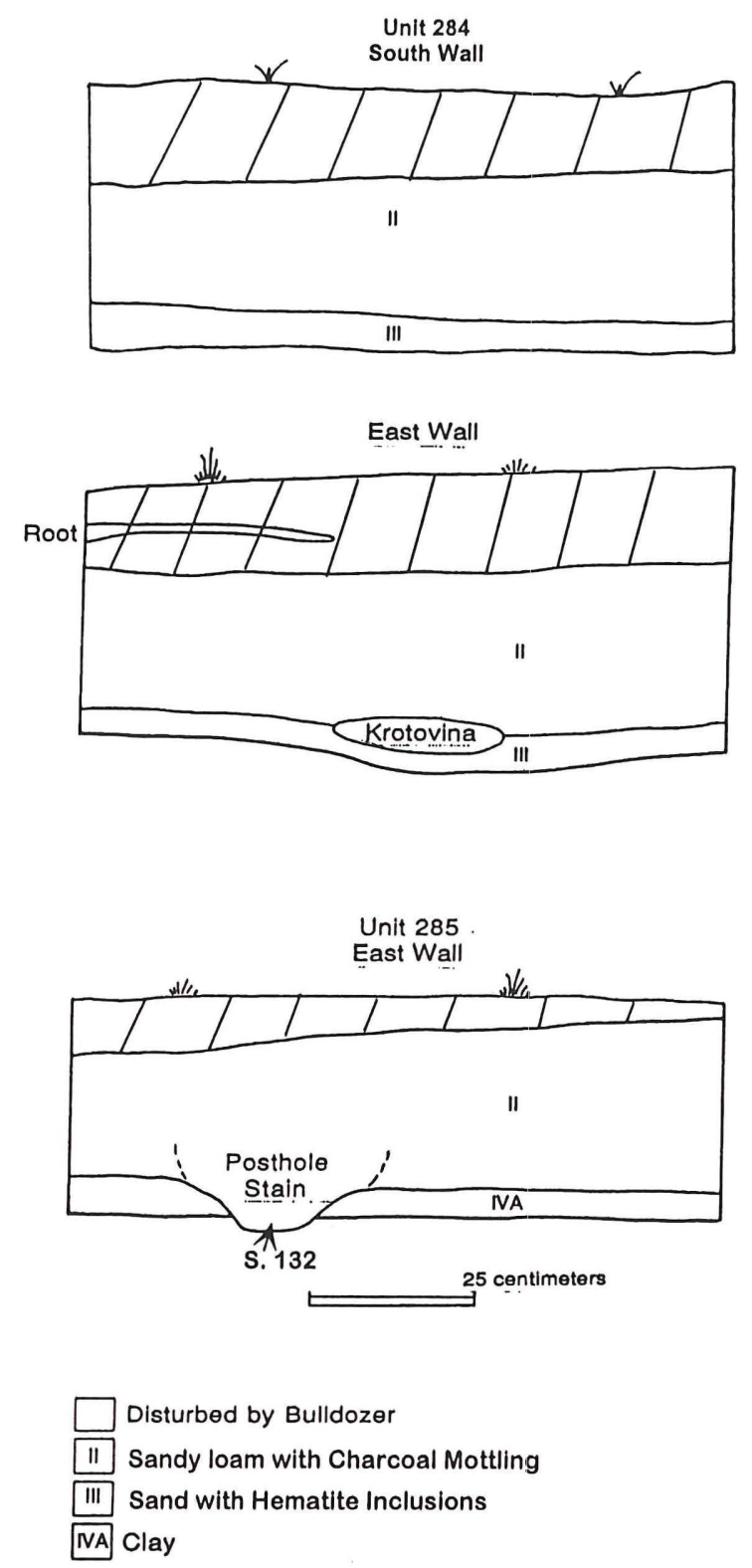

Figure 5-14. Profiles of Units 284 and 285.

Table 5-2. Gravel densities in the A-horizon of selected excavation areas on the North, South, and Southwest rises.

\begin{tabular}{lcc} 
Location & No. ${\text { per } \mathrm{m}^{2}}^{2}$ & $\mathrm{Kg} \mathrm{per} \mathrm{m}^{2}$ \\
\hline Southwest Rise & 374 & 2.23 \\
Block A, North Rise & 147 & 1.00 \\
Block B/C, South Rise & 88 & 0.25
\end{tabular}


A number of A-horizon zones were defined on the Southwest rise. They include the organic

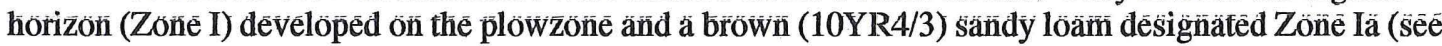
Figure 5-13). Due to bulldozer disturbances, Zones I and Ia were not present in all measured profile sections. Below the plowzone is a $18-50 \mathrm{~cm}$ thick A1 horizon, designated Zone II, which is a very dark grayish-brown (10YR3/2) to dark brown (10YR3/3) sandy loam with charcoal flecking. This zone is outside the boundaries of the midden. (see Figure 5-13, profile 7).

The midden, Zone IIa, is a very dark gray (10YR3/1) to very dark grayish-brown (10YR3/2) sandy loam. It varièes in thickness from 10 to 36 crin and appears to be thickest on the northeastern part of the rìise (see Figure 5-12). The midden has been extensively bioturbated by rodents and roots (see Figure 5-13, profile 8). An abundance of archaeological remains (e.g. lithic debris, fire-cracked rock, burned claỳ, añd stone tools), that appears to be associated with a Late Archaic/Early Ceramic period occupation of the Southwest rise, is contained in the midden. A number of cultural pits and stains originate in the Zone IIa deposit (see Figure 5-13, Unit 96 west wall profile and Chapter 6, this volume) and generally extend into the argillic horizon.

Between the midden and the argillic horizon, is a dark brown sandy loam A-horizon, designated Zöne IIIä, thàt contains appreciable anomounts of gravel. This giravel-rich zone is $\mathbf{8}$ to 18 cim thick where it could be measured. Along the periphery of the midden and the Southwest rise, Zone IIIIa is replaced by a 8$20 \mathrm{~cm}$ thick yellowish-brown (10YR5/6) sandy loam (Zone III) with hematite inclusions. This zone, however, stratigraphically underlies Zone MIIa in Unit 96 on the crest of the rise (see Figure 5-13). Both zones contain archaeological materials. Whether they represent in situ deposits or have been introduced by pedoturbation has not been ascertained because of the limited controlled excavations on the Southwest rise. Temporally diagnostic artifacts collected from Zone IIIIa exposures in Backhoe Trench \#45 date to the Middle and Late Archaic periods, however (see Chapters 7 and 8, this volume).

The argillic horizon is divided into two zones. Zone IVa is a yellow (10YR5/8) sandy clay, exposed along the eastern half of the rise, and Zone IV is a yellow, hematite-mottled clay deposit. They lack archaeological remains except at the contact with the overlying A-horizon deposits.

The stratigraphy on the Southwest rise represents a mature, natural soil profile that has been enriched and altered to an anthropic epipedon by the formation of a discrete midden deposit. Differences in soil character across the rise, and along the slopes of the rise, record micro-topographic changes, periods of erosion and gravel deposition, and spatial variability in the density of artifácts and featuires, rèläte tó severeal periods of use over approximately the last 4,000-6,000 years. The primary soil zone with archaeological significance is the Zone IIa midden, a relatively intact and discrete Late Archaic/Early Ceramic period deposit. 


\title{
CHAPTER 6, CULTURAL FEATURES
}

\author{
Timothy K. Perttula
}

This chapter discusses the kinds and character of the more than 225 archaeological features documented from the different site areas at Hurricane Hill. Also reviewed is the origin or stratigraphic context of the different features, and their contents. The features are associated with the Late Archaic, Early Ceramic, Early Caddoan, and Middle Caddoan period use of the site, and at least one feature may date to the late 19 th or early 20 th century.

Features are spatially discrete remains of specific activities localized in space and time (e.g., Dunnell 1983). Features often times contrast with the surrounding matrix in which they occur. However, feature boundaries may be expected to vary depending upon the degree of cultural or natural disruptions that occurred after the feature was abandoned and no longer used. It is important to consider, then, that feature contents are not necessarily reliable for ascertaining the original function of a feature. Limited aggradation or sedimentation at the Hurricane Hill site provided considerable opportunities for mixing feature contents from different, possibly unrelated occupations or use episodes. Non-portable aspects of the features (see below) provide a more stable context for discerning similar classes of features (e.g., Schiffer 1972). However, materials recovered from features are certainly important in developing an understanding of the secondary use and abandonment of features, and below we will discuss the artifact characteristics of the different kinds of features.

The contents of features may be altered by processes of bioturbation via roots, rodents, and insects. The softer, less compact matrix of many features encouraged rodent and insect disturbances. Most of the features had rodent holes (krotovinas). Another disturbance factor was the bulldozing and grubbing associated with COE clearing and construction activities at the site. Upon initial exposure and inspection, root stains and burned tap roots had plan views consistent with pits or postholes, and it was only after the stains had been cross-sectioned that their natural origin became apparent. Concentrations of ash and burned clay, caused by the clearing operations, could be separated from cultural features with similar characteristics by recognizing their association with a burned stump or larger roots.

In certain cases, cultural evidence suggested that features were left exposed or repeatedly altered during their use. Cremations on the North and Southwest rises of the site often occurred in small, overlapping pits within a larger undercut pit, suggesting that the original cremation pit was re-opened or expanded to accommodate the interment of additional burned human remains. Consequently, the original contents of the small, once discrete pits became mixed. Therefore, even though the pit maintained a unitary function, specific associated artifacts could only be considered in aggregate because the pit had been used repeatedly.

One final contextual problem is the fact that pits and other features were often placed in preexisting middens, and these deposits were used as backfill for the later pits. In the case of burial pits dug into existing middens, the midden fill was probably replaced shortly after interment, but non-burial pits probably remained open for more lengthy periods. In both instances, a midden related to earlier, or different, occupations was the primary constituent of the feature fill. This obscured evidence of the types of material remains, if any, that were placed in the pits and could be considered contemporaneous with the pits. In the absence of intentional grave good associations (see below), determining the absolute age of burials solely on the basis of material remains found in the fill was not practical. Relative estimates are appropriate based upon terminus post quem dating.

Key criteria used to initially categorize the types of features present at the Hurricane Hill site include: (1) whether the feature was a surface manifestation or a pit/depression excavated through a living surface; (2) whether there was evidence of in situ burning (i.e., oxidization of the feature walls or the structural association of burning by-products, such as ash or charcoal concentrations, into the feature); (3) whether the feature had well-defined spatial boundaries; and (4) whether there was a consistent arrangement of within-feature components, such as burned soil strata, rock-lined pit walls, and/or concentrations of 
burned bone or other animal and plant remains. The next step was assigning descriptive labels to features as an aid for comparisons with other Late Archaic/Early Ceramic to Early Caddoan period sites that have been excavated at Cooper Lake (e.g., Cliff et al. 1995; Gadus et al. 1992; Fields et al. 1993, 1994, 1997; Martin 1997a, 1997b). Feature classes identified at Hurricane Hill include large and small pits, burials, hearths, stains/postholes, surficial concentrations of cultural material, organically-stained pits, middens, and possible historic features (Table 6-1). A total of 230 features was recorded in the Phase I-IV investigations, with most of the features located on, or in the near vicinity of the North, South, and Southwest rises (Figure 6$1)$.

Table 6-1. Classes, locations, and frequencies of features at Hurricane Hill.

\begin{tabular}{|c|c|c|c|c|c|c|c|c|c|c|c|c|c|c|c|}
\hline \multicolumn{2}{|c|}{ Blocks } & \multicolumn{5}{|c|}{ Scraped Area } & \multirow[b]{2}{*}{5} & \multirow[b]{2}{*}{6} & \multirow[b]{2}{*}{7} & \multirow[b]{2}{*}{8} & \multirow[b]{2}{*}{9} & \multirow[b]{2}{*}{10} & \multirow[b]{2}{*}{11} & \multirow[b]{2}{*}{ BHT $|x|-m$} & \\
\hline$A / D / E$ & $\mathrm{~B} / \mathrm{C}$ & $\mathrm{F}$ & 1 & 2 & 3 & 4 & & & & & & & & & TOTAL \\
\hline
\end{tabular}

\begin{tabular}{|c|c|c|c|c|c|c|c|c|c|c|c|c|c|c|c|c|c|}
\hline $\begin{array}{l}\text { Pit: } \\
\text { large } \\
\text { small }\end{array}$ & $\begin{array}{r}11 \\
6 \\
\end{array}$ & $\begin{array}{r}11 \\
8 \\
\end{array}$ & 1 & & 1 & 1 & & & $\begin{array}{l}6 \\
1 \\
\end{array}$ & & $\begin{array}{l}1 \\
1\end{array}$ & 1 & & 2 & 1 & & $\begin{array}{l}33 \\
19\end{array}$ \\
\hline $\begin{array}{l}\text { Burial: } \\
\text { cremation } \\
\text { extended } \\
\text { other }\end{array}$ & $\begin{array}{l}1 \\
3\end{array}$ & $\begin{array}{r}2 \\
2^{\mathrm{c}} \\
\end{array}$ & & & & & 1 & & $\begin{array}{l}6 \\
1 \\
6 \\
\end{array}$ & & & & & & & & $\begin{array}{l}8 \\
6 \\
9 \\
\end{array}$ \\
\hline $\begin{array}{l}\text { Hearth: } \\
\text { burned clay' } \\
\text { FCR } \\
\end{array}$ & $\begin{array}{l}2 \\
1 \\
\end{array}$ & 2 & & & & & & & & 1 & & & & & & & $\begin{array}{l}4 \\
2 \\
\end{array}$ \\
\hline $\begin{array}{l}\text { Stains/Postholes } \\
\text { Organic-Rich Pits } \\
\text { Midden }^{\text {a }} \\
\text { Other } \\
\text { Historic? }\end{array}$ & $\begin{array}{r}32 \\
\times \\
2\end{array}$ & $\begin{array}{r}87 \\
\times\end{array}$ & $\mathrm{x}$ & $\begin{array}{r}3 \\
\times\end{array}$ & $x$ & & & $\begin{array}{l}2 \\
x\end{array}$ & $\begin{array}{r}1 \\
4 \\
X \\
1\end{array}$ & & $\begin{array}{r}4 \\
x\end{array}$ & 1 & $\begin{array}{r}3 \\
\times\end{array}$ & 8 & & 1 & $\begin{array}{r}142 \\
4 \\
- \\
2 \\
1\end{array}$ \\
\hline TOTALFEATURES & 58 & 112 & 1 & 3 & 1 & 1 & 1 & 2 & 26 & 1 & 6 & 2 & 3 & 10 & 1 & 1 & 230 \\
\hline
\end{tabular}

a Not included in totals

c One is a dogburial

Note:

Blocks A/D/E, Scraped Areas 1 through 4, and the backhoe trench (BHT) are onor included with the North Rise.

B/C and F, Scraped Areas 5, 8, 9, 10, and 11 and the $1 \times 1-\mathrm{m}$ unit are on or included with the South Rise.

Scraped Areas $6 a, 6 b$, and 7 are on or included with the Southwest Rise.

\section{Features on the North Rise}

Including features exposed in Scraped Areas 1 through 4, 66 features were recorded on the North rise (see Table 6-1 and Figure 6-1). The most frequent types of features are stains/postholes (53.0 percent); large pits (18.2 percent), those with length and width dimensions greater than $50 \mathrm{~cm}$; and small pits (12.1 percent), those with an area of only between 0.09-0.20 square meters. Larger features are represented by the large North rise midden (referred to below as the Primary Midden) and two smaller, more recent Early Caddoan midden deposits referred to as Midden 1 and Midden 2 (Figure 6-2). Midden 1 covers 96 square meters (Figure 6-3) and Midden 2 covers approximately 14 square meters. Calibrated radiocarbon dates from Midden 1 deposits range from AD 882-1213; a pit feature containing maize in the Block A extension has a calibrated date of AD 1249-1285 (see Chapter 7, this volume). One sigma calibrated radiocarbon dates from Primary Midden contexts range from AD 59-493, indicating its deposition during the Early Ceramic period. 

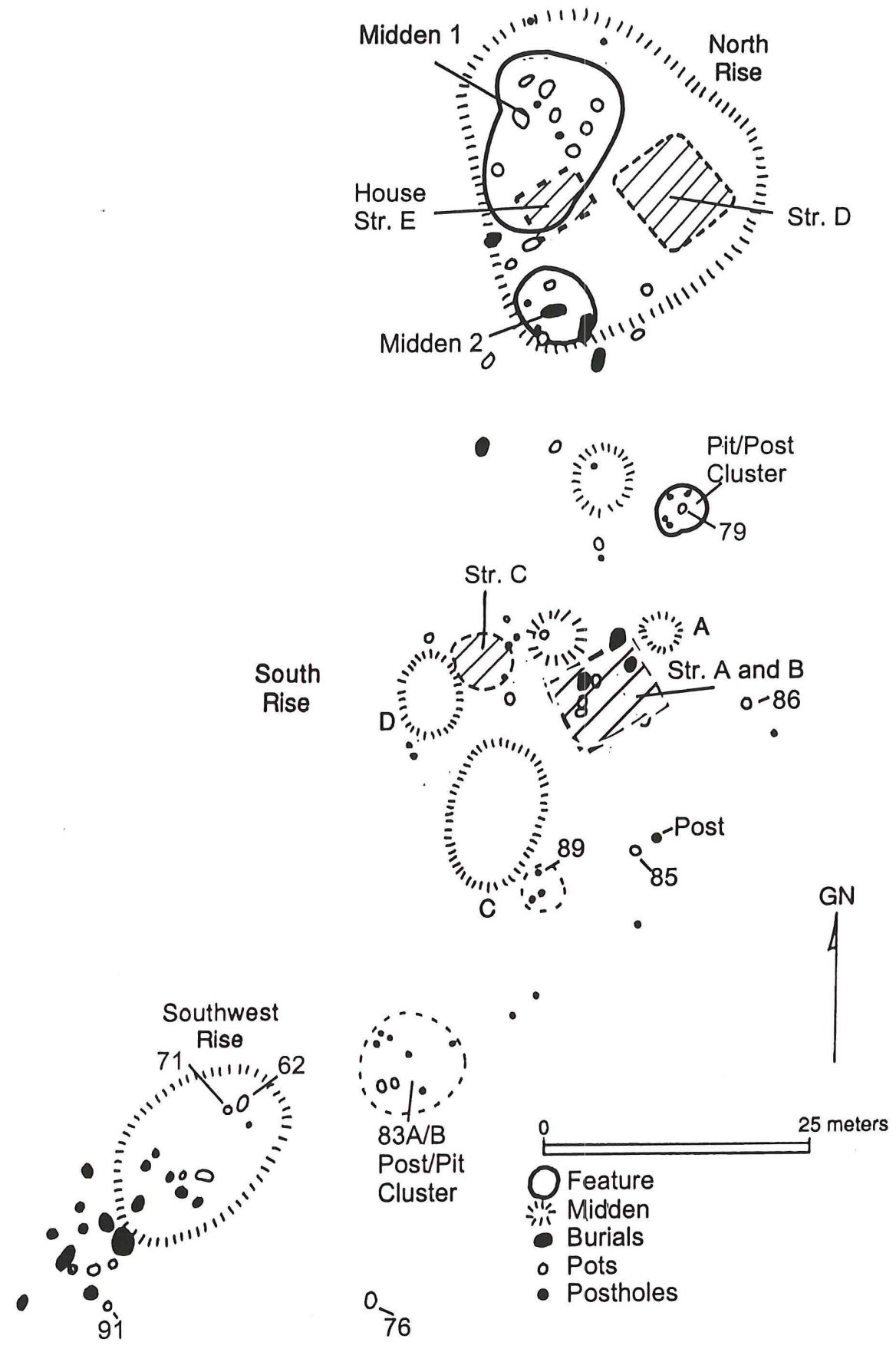

Figure 6-1. Distribution of middens and features at Hurricane Hill. 


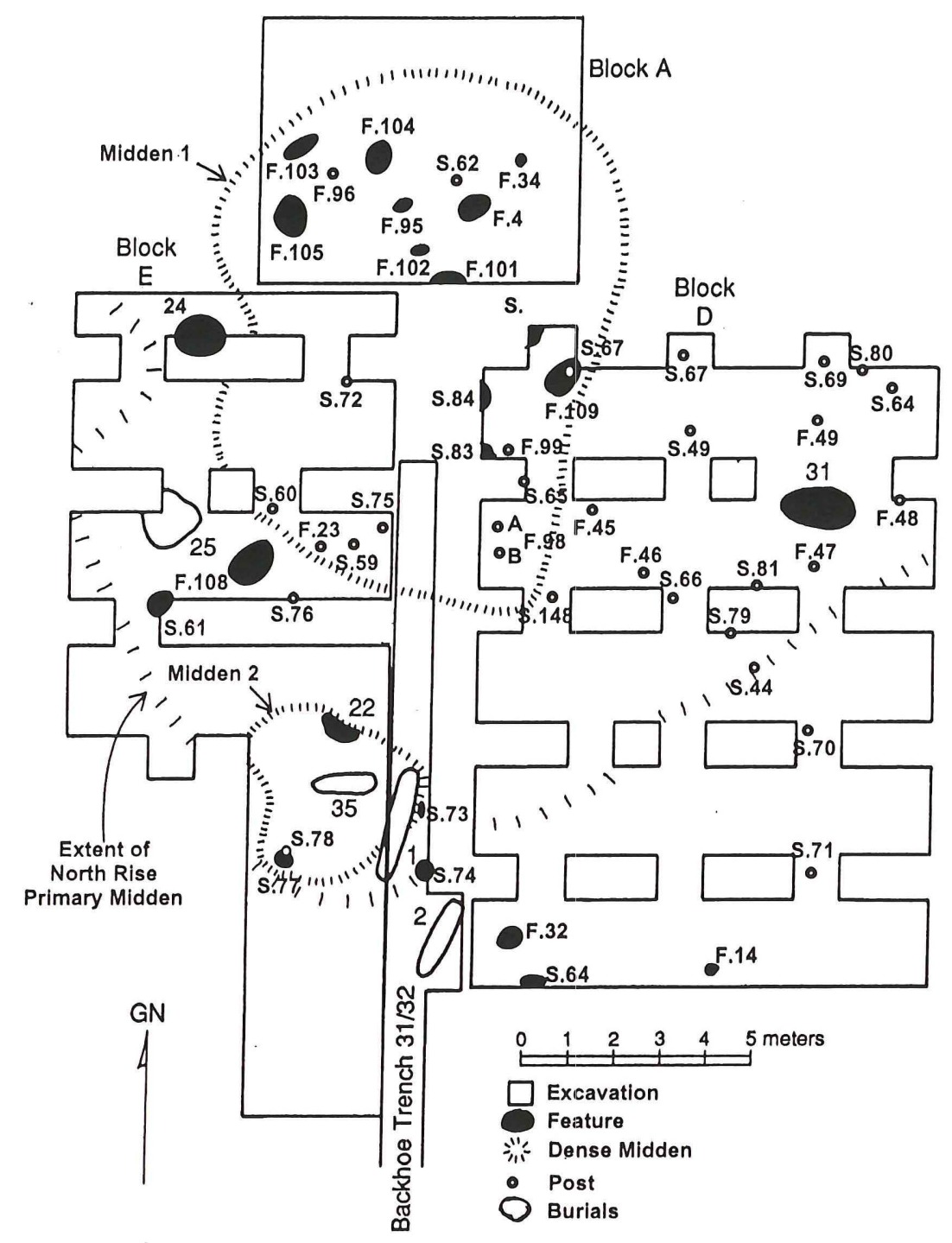

Figure 6-2. Feature plan of Blocks A, D, and E.

The majority of features on the North rise were located in Midden 1 and Midden 2. Exceptions to this are the Early Caddoan period Structure D, some of the larger pits, and Burial 7 (Feature 25), a deep cremation pit; these features were located in the PrimaryMidden. Several small pits (Feature 53 and 54) and another cremation pit, Burial 8 (Feature 55), were also located outside the North rise middens.

Several extended burials, Burial 1 (Feature 1) and Burial 4 (Feature 35), were excavated in Midden 2 (see Figure 6-2). Another possible burial feature was detected a short distance west of Burial 4, but also in Midden 2. It had been disturbed by pothunters and no human remains or associated grave goods were located during our investigations, and this area was not given a feature number (Editor's Note: In Perttula [1990a], this pothunter disturbance was erroneously identified as Burial 18; Burial 18 actually refers to a set of human remains donated by an avocational archaeologist from an unknown part of the Hurricane Hill site). An additional extended burial, Burial 2 (Feature 2), was found outside but near Midden 2 (see Figure 6-2). These Caddoan burials (Table 6-2) were placed on their backs in an extended position, with the forearms either flexed and pulled up towards the head or folded across the abdomen. 


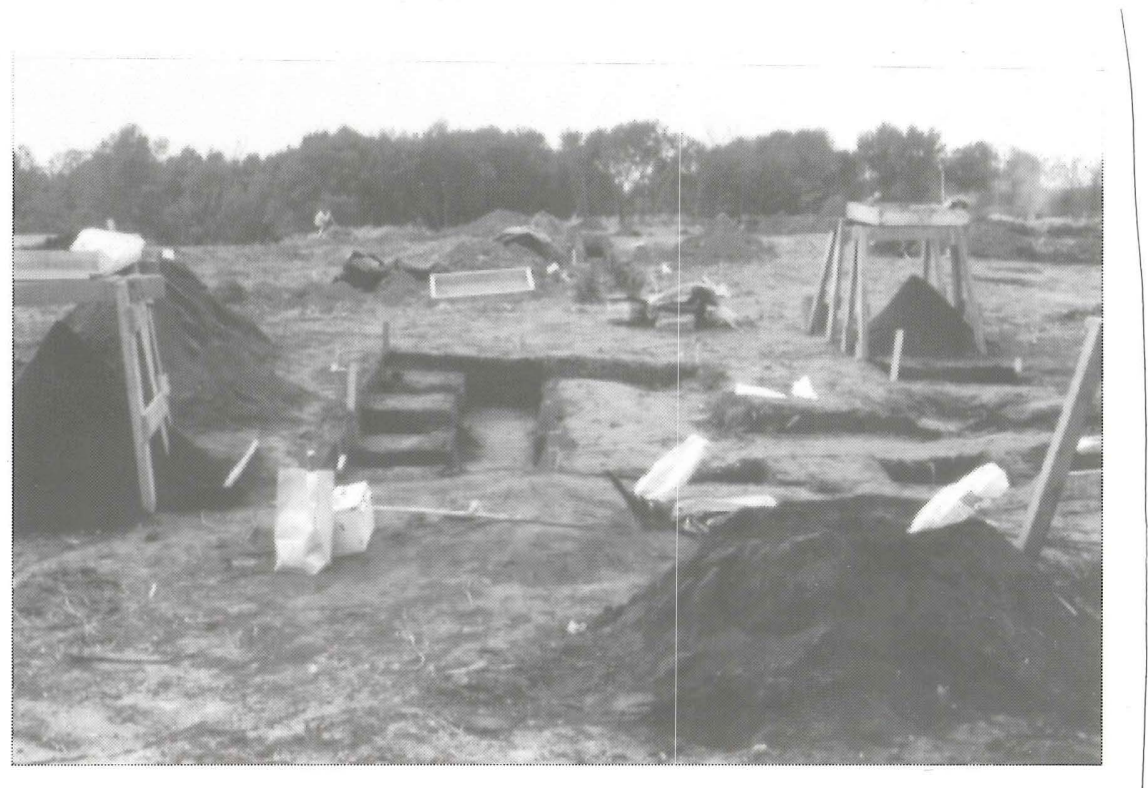

Figure $\overline{6}-\overline{3}$. $\bar{M} i \bar{d} \bar{d} e n \underline{I}$ excavations in progress.

Table 6-2. Cullural Affiliation of the Burials.

\begin{tabular}{|c|c|c|c|}
\hline Buriaí \# & Feature \# & Affiliation & Likelihood of Ássignment* \\
\hline i & 1 & Early Caddoan & 1 \\
\hline 2 & 2 & Early Caddoan & 1 \\
\hline 3 & 3 & Middile Caddoan & 1 \\
\hline 4 & 35 & MiddleCaddoan & 1 \\
\hline 5 & 36 & MiddileCaddoan & 1 \\
\hline 6 & 7 & MiddleCaddoan & 2 \\
\hline 7 & 25 & Eariy Ceramic & $\hat{2}$ \\
\hline 8 & 55 & Early Ceramic & 2 \\
\hline 9 & 60 & Early Ceramic & 2 \\
\hline 10 & 63 & Early Ceramic & 2 \\
\hline 11 & 64 & Late Ȧrchaic & 2 \\
\hline 12 & 65 & Early Ceramic & 2 \\
\hline 13 & 68 & MiddíeCaddoan & 1 \\
\hline 14 & 73 & Early Ceramic & 2 \\
\hline 15 & 77 & Eariy Ceramic & $\overline{2}$ \\
\hline 16 & 81 & Early Ceramic & 2 \\
\hline i'7 & 90 & Early Ceramic & $\overline{2}$ \\
\hline $18^{* * *}$ & - & Early Caddoan & 3 \\
\hline i⿳⺈ & $1 \overline{8}$ & Eariy Ceramic & $\overline{2}$ \\
\hline 20 & 59 & Early Ceramic & 2 \\
\hline 21 & 66 & Early Ceramic & 2 \\
\hline 22 & 69 & Early Ceramic & 2 \\
\hline
\end{tabular}

* 1=strong; $2=$ probable; $3=$ uncertain

** These remains were donated by $\mathrm{J}$. Banks, and their provenience and context is uncertain 
With the exception of Burials 1 and 4, they were single interments of adults (see H. Gill-King, Chapter 12, this volume and Appendix XVIII). Burial 1 and Burial 2 were disturbed by backhoe trenching that crushed the skulls (Figures 6-4 and 6-5). Preservation of the skeletal remains was good, however, although articular ends of the feet and hands, as well as the ribs were missing. In addition, a few rib fragments were preserved in Burial 1. Bioarchaeological analyses by Rose (see Appendix XVIII) indicates that there were human remains from at least six individuals in Burial 1, and it is probable these represent the skeletal parts from burials that were already present in either Midden 2 or the Primary Midden that became incorporated in the fill of Burial 1 since no other intact or even partially intact burials were noted in the burial pit (see Figure 6-4).

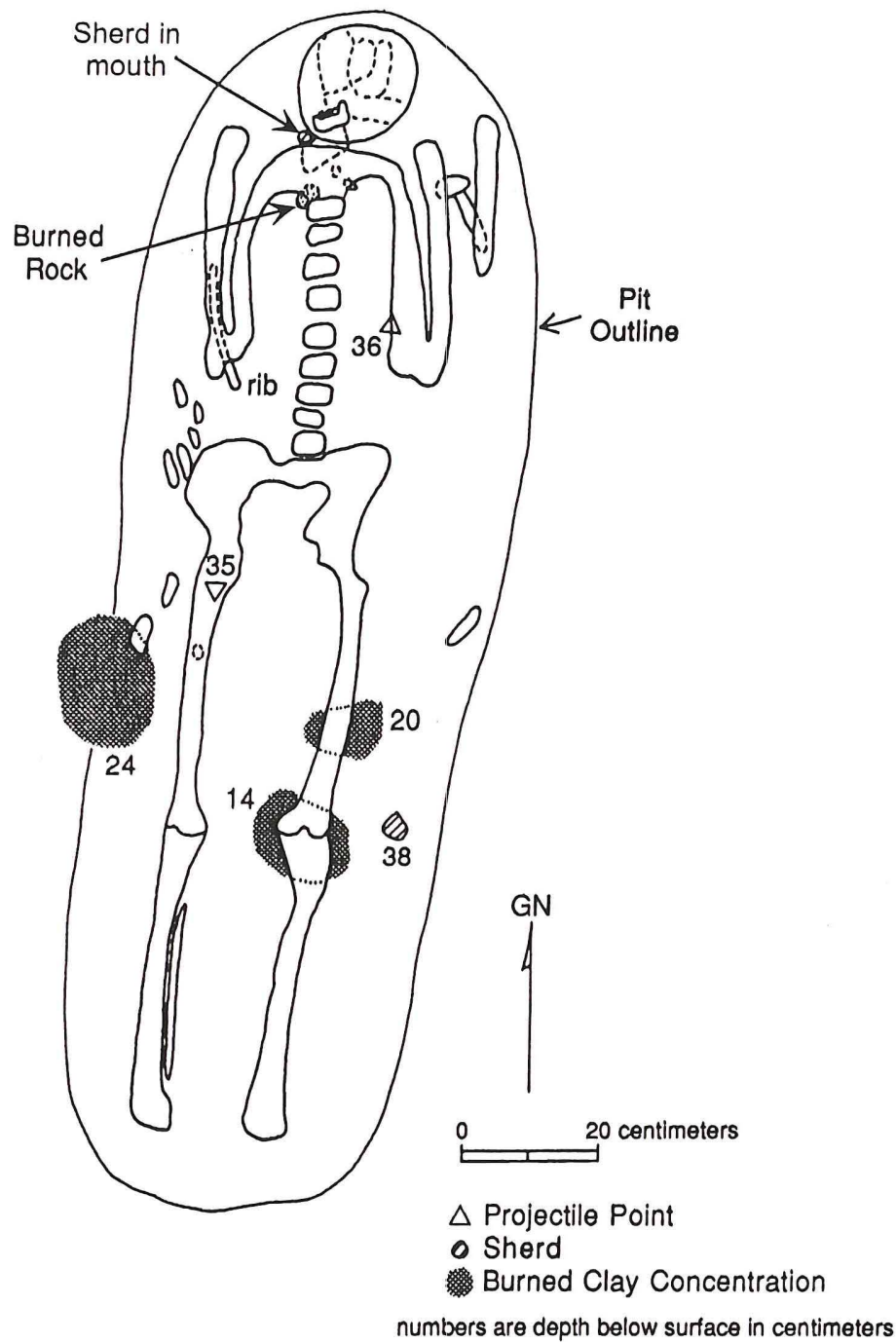

Figure 6-4. Feature 1, Burial 1. 


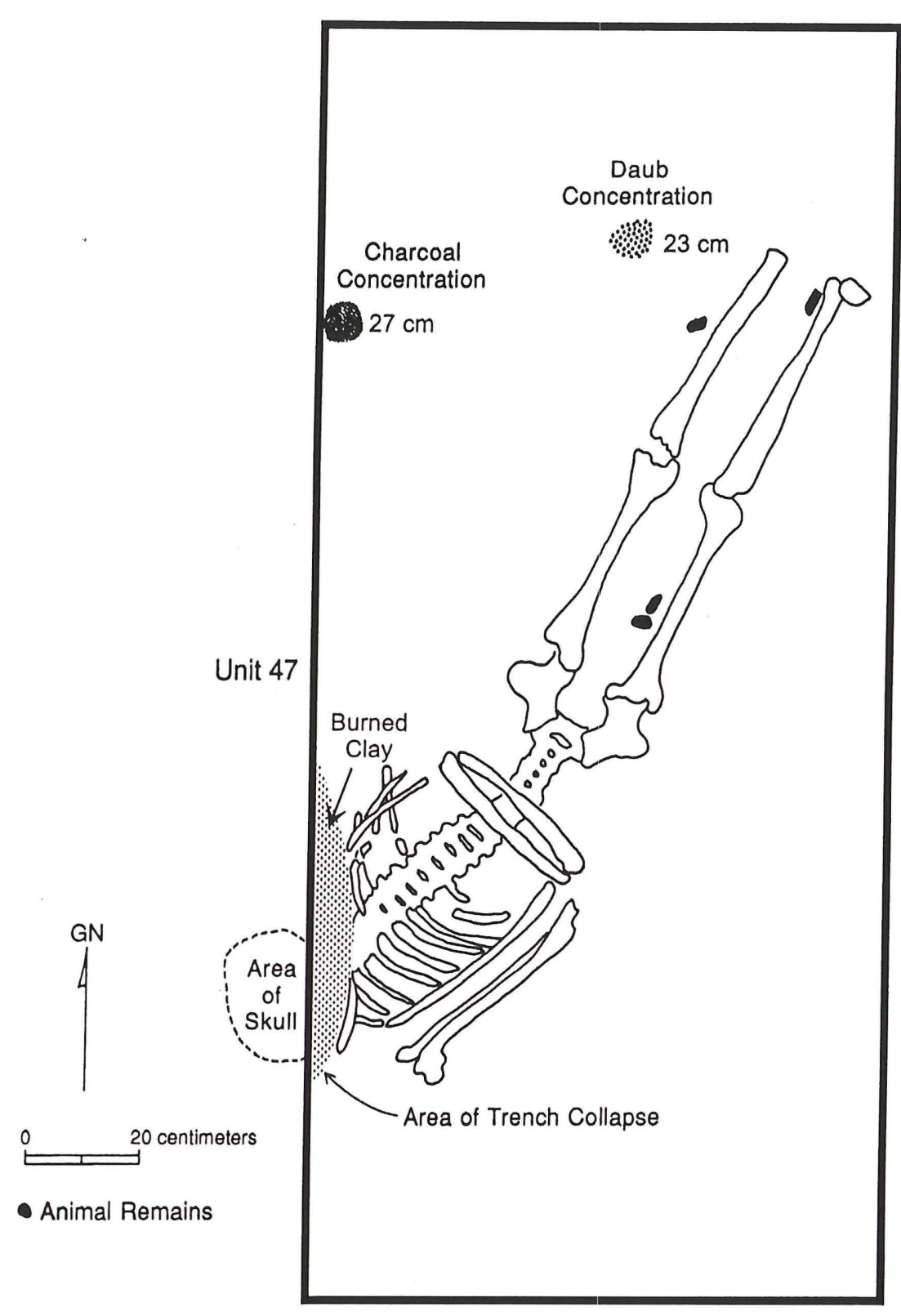

Figure 6-5. Feature 2, Burial 2, Unit 47.

Although these extended burials occurred in or near the same midden, differences in orientation of the head and body suggest that the interments were not necessarily contemporaneous, assuming that such shared mortuary practices were more likely between contemporaneous graves than burials separated in time. The abundant material remains present in the fill of the extended burials (Table 6-3) not only testify to the fact that these burials were placed in or near a dense midden, but that they are Caddoan burials (see Table 62) since Midden 2 deposits appear to date ca. A.D. 1000-1200. The recovery of a Maud arrowpoint from the general fill of Burial 2, located outside the midden, however, suggests that this interment may have occurred later in the occupation of the site, given the occurrence of Maud points in Late Caddoan contexts in Northeast Texas and at Cooper Lake (see Fields, Gadus, and Klement 1994). More precise dating techniques, such as the radiocarbon dating of the skeletal remains themselves, were not implemented 
because the COE policy in effect on the treatment of human skeletal remains (K. Scott, 1988 personal communication) prohibited destructive analyses. A one-sigma calibrated date on charcoal from the burial fill of Feature 2 is AD 959-1020 (0.91 relative area under probability distribution; hereafter this will be referred to as "RA"), indicating that the formation of Midden 2, not necessarily the interment of the individuals, dates to the Early Caddoan period.

Table 6-3. Frequencies of cultural materials recovered from burials ${ }^{\mathrm{a}}$

\begin{tabular}{|c|c|c|c|c|c|c|c|c|c|c|}
\hline Feature \# & Burial \# & Rise & Tools & $\begin{array}{l}\text { Lithic } \\
\text { Debris }\end{array}$ & Sherds & $\begin{array}{r}\text { Daub } \\
(\mathrm{g})\end{array}$ & $\begin{array}{r}\text { Burned } \\
\text { Clay } \\
(\mathrm{g}) \\
\end{array}$ & $\begin{array}{l}\text { FCR } \\
(\mathrm{N}) \\
\end{array}$ & $\begin{array}{r}\text { FCR } \\
(\mathrm{kg})\end{array}$ & Fauna \\
\hline $\begin{array}{r}\text { Extended } \\
1 \\
2 \\
3 \\
35 \\
36 \\
68 \\
\end{array}$ & $\begin{array}{r}1 \\
2 \\
3 \\
4 \\
5 \\
13\end{array}$ & $\begin{array}{r}\mathrm{N} \\
\mathrm{N} \\
\mathrm{S} \\
\mathrm{N} \\
\mathrm{S} \\
\mathrm{SW}\end{array}$ & $\begin{array}{r}13 \\
71 \\
16 \\
17 \\
2 \\
7 \\
\end{array}$ & $\begin{array}{r}83 \\
1,730 \\
193 \\
391 \\
45 \\
973 \\
\end{array}$ & $\begin{array}{r}33 \\
200 \\
40 \\
34 \\
3 \\
2\end{array}$ & $\begin{array}{r}0.9 \\
17.3 \\
12.7 \\
23.5 \\
1.7 \\
1.5 \\
\end{array}$ & $\begin{array}{r}78.6 \\
241.2 \\
39.5 \\
26.5 \\
8.2 \\
95.6 \\
\end{array}$ & $\begin{array}{r}26 \\
432 \\
38 \\
127 \\
7 \\
46 \\
\end{array}$ & $\begin{array}{l}1.0 \\
5.7 \\
0.2 \\
1.2 \\
0.2 \\
0.2 \\
\end{array}$ & $\begin{array}{r}9 \\
11 \\
3 \\
1\end{array}$ \\
\hline $\begin{array}{r}\text { Cremation } \\
25 \\
55 \\
60 \\
63 \\
64 \\
65 \\
90 \\
\end{array}$ & $\begin{array}{r}7 \\
8 \\
9 \\
10 \\
11 \\
12 \\
17 \\
\end{array}$ & $\begin{array}{r}N \\
N \\
\text { SW } \\
\text { SW } \\
\text { SW } \\
\text { SW } \\
\text { SW } \\
\end{array}$ & $\begin{array}{l}8 \\
2 \\
1 \\
1 \\
2\end{array}$ & $\begin{array}{r}196 \\
41 \\
13 \\
94 \\
655 \\
13 \\
55 \\
\end{array}$ & 1 & $\begin{array}{l}7.5 \\
0.4 \\
\end{array}$ & $\begin{array}{r}3.5 \\
\\
\\
5.9 \\
11.0 \\
123.1 \\
4.1 \\
\end{array}$ & $\begin{array}{l}14 \\
59 \\
12 \\
\end{array}$ & $\begin{array}{r}+ \\
\infty 0.1 \\
0.8 \\
\varnothing 0.5\end{array}$ & 52 \\
\hline $\begin{array}{r}\text { Other } \\
7 \\
59 \\
66 \\
69 \\
73 \\
77 \\
81 \\
\end{array}$ & $\begin{array}{r}6 \\
20 \\
21 \\
22 \\
14 \\
15 \\
16\end{array}$ & $\begin{array}{l}\text { S } \\
\text { SW } \\
\text { SW } \\
\text { SW } \\
\text { SW } \\
\text { SW } \\
\text { SW }\end{array}$ & $\begin{array}{l}1 \\
1 \\
2 \\
1 \\
\end{array}$ & $\begin{array}{r}140 \\
30 \\
11 \\
17 \\
15 \\
58 \\
\end{array}$ & 2 & 0.1 & 1.6 & $\begin{array}{r}21 \\
1 \\
13 \\
5 \\
2\end{array}$ & $\begin{array}{r}0.5 \\
\\
405 \\
+ \\
+\end{array}$ & \\
\hline TOTAL & & & 145 & 4,753 & & 65.6 & 638.8 & 813 & $9.8+$ & 76 \\
\hline $\begin{array}{r}\text { Mean } \\
\text { Numbers } \\
\text { Extended } \\
\text { Cremation } \\
\text { Other }\end{array}$ & & & $\begin{array}{r}21.0 \\
2.0 \\
0.7\end{array}$ & $\begin{array}{r}569.2 \\
152.4 \\
38.7\end{array}$ & $\begin{array}{r}52.0 \\
0.1 \\
0.3\end{array}$ & $\begin{array}{r}9.6 \\
1.1 \\
+\end{array}$ & $\begin{array}{r}81.6 \\
21.1 \\
0.2\end{array}$ & $\begin{array}{r}112.7 \\
13.6 \\
6.0\end{array}$ & $\begin{array}{l}1.4 \\
0.2 \\
0.1\end{array}$ & $\begin{array}{l}4.0 \\
7.4 \\
0.0\end{array}$ \\
\hline
\end{tabular}

a Only burials with cultural materials are listed

Burial 1 was oriented with its head toward the northeast (facing southwest). The head of Burial 2 was oriented toward the southwest (see Figures 6-4 and 6-5). No grave goods were associated with either burial, and the distribution of archaeological materials in the fill probably reflects random backfilling of the graves. Initially, concentrations of burned clay noted above the legs of Burial 1 (see Figure 6-4) were thought to relate to a burning episode associated with the interment (e.g., Jackson 1938), but the long bones have not been burned or charred, and there was no evidence of grave fill oxidation.

Cremations, the other type of burial treatment noted on the North rise, have been reported from a number of Late Archaic, Early Ceramic, and/or Early Caddoan contexts in eastern Texas, and in Arkansas (Schambach 1997a; Stewart 1993) and Louisiana (Webb 1984). For instance, cremations dating between A.D. 580-860, A.D. 1000-1200, and A.D. 1300-1650 have been documented at Bird Point Island (Bruseth and Martin 1987:54-55, 68-69) in the Trinity River basin, a cremation at the Boxed Springs site (41UR30) dates to ca. A.D. 800-1000 (notes on file at the Archeology Division, Texas Historical Commission), and one cremation (Feature 20) on Rise I may date to ca. A.D. 1000-1200 at the Lawson site (Martin 1997a:424-426) at Cooper Lake; the feature is not directly dated, however, and Early Ceramic period materials are also present on Rise I. Other well-studied cremations from the Cottonwood Springs site at the Jewett Mine in east central Texas apparently date between ca. 1000 B.C.-A.D. 100 (Fields and Klement 1995:100). None of the skeletal remains from the North rise cremations at the Hurricane Hill site have been directly dated, but based on their contents (see Table 6-3), radiocarbon dates from the Primary Midden, 
and investigations of several cremations on the Southwest rise, they are considered to date to the Late Archaic and Early Ceramic periods (between ca. 1000 B.C.-A.D. 500).

Feature 25 (Burial 7), was a large deep pit used as a cremation basin on at least two occasions (Figure 6-6). The feature appeared to originate at the base of the Primary Midden (ca. $48 \mathrm{~cm} \mathrm{bs}$ ), and extended to $105 \mathrm{~cm}$ bs (see Figure 6-6a). The pit had been expanded and undercut as it was reutilized. Initially, Feature 25 may have also functioned as a crematory basin because the walls at the base of the pit had been oxidized from exposure to fire. The upper pit walls (i.e., the surface associated with the second, higher cremation in Stratum 1) had not been exposed to fire.
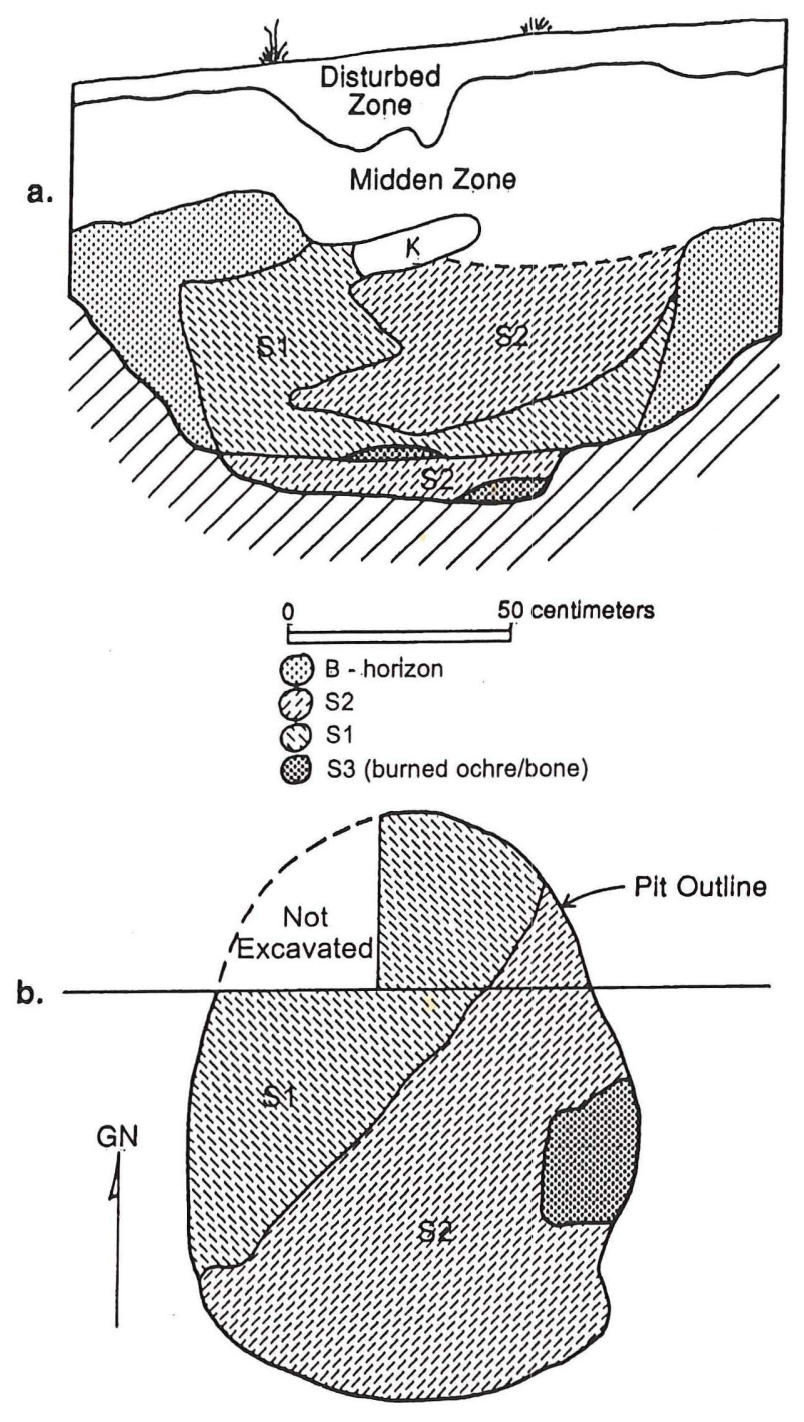

Figure 6-6. Feature 25, Burial 5: a, profile; b, plan at $90 \mathrm{~cm}$ bs.

Burned and/or deposited at the base of the pit was a black (10YR2/1) to very dark grayish-brown (10YR3/2) loam (Stratum 2) containing charcoal flecks and burned bone fragments, probably from several individuals (see Chapter 12 and Appendix XVIII). One side of the pit contained the main cremation deposit, 
consisting of burned human bone smeared with burned ochre that had a dark red (10R3/6) color (Figure 67b). The deposit covered about 0.06 square meters at the base of the pit (see Figure 6-6b). A second cremation deposit, also smeared with burned ochre, was about $10 \mathrm{~cm}$ higher in the pit itself, and incorporated Stratum 1 sediments, a very dark grayish-brown (10YR3/2) sandy clay. These sediments probably represent backdirt removed from the B-horizon when the pit feature was initially dug. The second cremation was placed in a small mounded pile atop the Stratum 2 deposits that had covered the earlier cremation (see Figure 6-6a). The weight of the burned human bone, as well as the identifiable fragments, strongly suggests that each cremation deposit was composed of multiple individuals (see Chapter 12, this volume and Appendix XVIII).
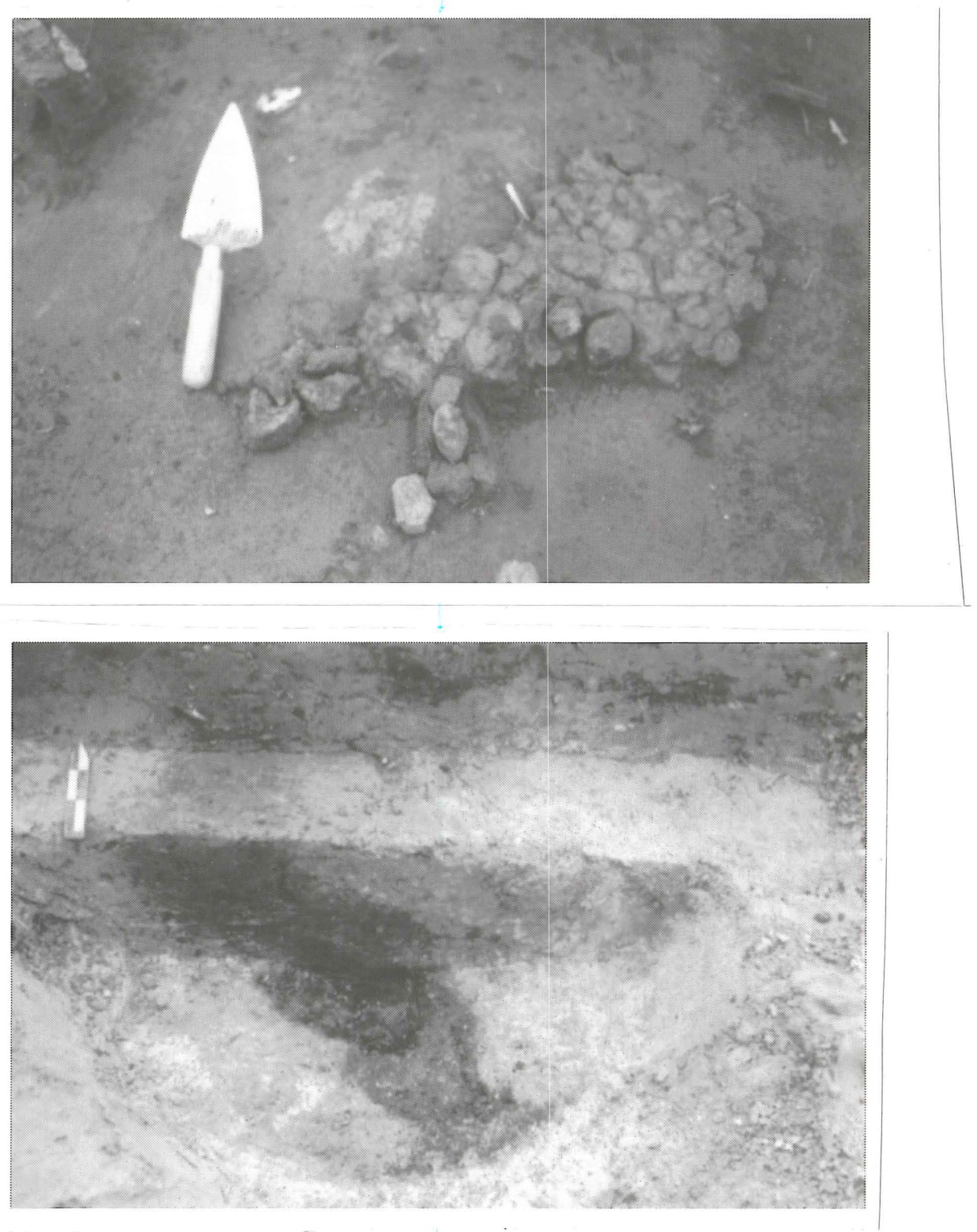

Figure 6-7. North rise features: a, Feature 34; b, Feature 25 at $90 \mathrm{~cm}$ bs.

The other North Rise cremation, Feature 55 (Burial 8), also consisted of a large pit used on multiple occasions (Figure 6-8). Unlike Feature 25, however, no evidence of in situ burning was observed in the basin. Therefore, this cremation pit probably represents the secondary inhumation of cremated human 
remains. Within the larger pit were six posthole-sized smaller pits (pits 1-6) containing burned human bone (see Figure 6-8a). The bone weights from these smaller pits suggest that each pit contained the cremated remains of a single individual. The varying depths of the smaller pits may be indicative of the fact that not all were contemporaneous; certainly, the small pits along the outside of the basin (pits 3,4, and 6) were excavated twice as deep as the shallower pits 1 and 2, but which pits came first is unknown.

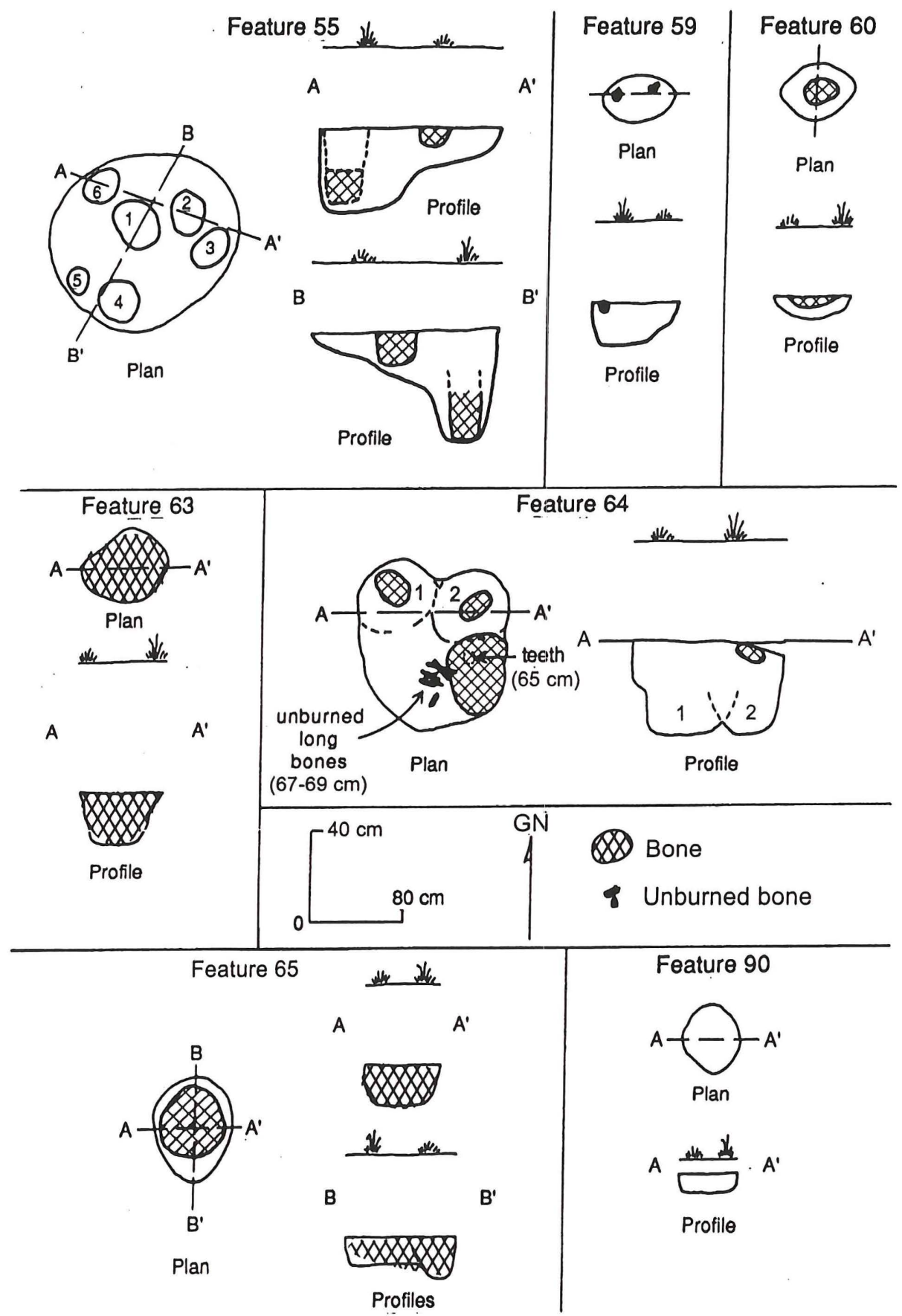

Figure 6-8. Cremations and pits with burned and unburned bone.

Large and small pits on the North rise clearly cluster in Middens 1 and 2 (Figure 6-9; see also Figure 6-2). The pits contained an assortment of refuse (Table 6-4), including fire-cracked rock, small 
amounts of animal bone, charred plant remains (see Appendix XX), burned clay, lithic debris, and a few sherds. In most cases, the pits appeared to have originated in the middens (Figure 6-10), and all are considered to be Early Caddoan in age. Pits outside Middens 1 and 2 may have either Early Ceramic or Early Caddoan affiliations, with the former considered the most likely possibility.

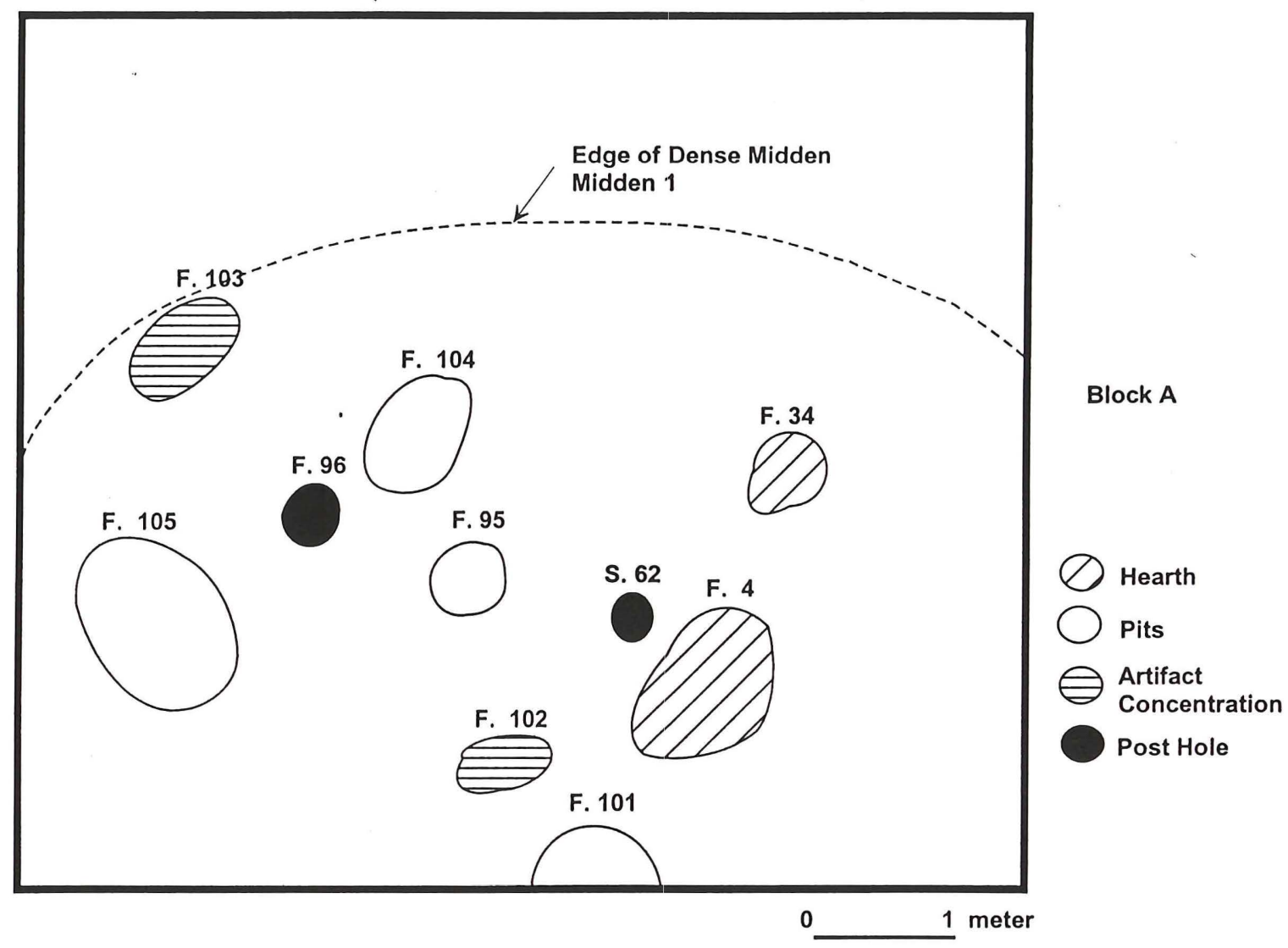

Figure 6-9. Pits and other features in Midden 1.

Three hearths were identified on the North rise (see Table 6-1). Feature 4 and Feature 34 were in Block A, Midden 1, and Feature 31 was located along the edge of the Primary Midden in Block D (see Figure 6-2).

The Midden 1 hearths, designated as Type A hearths at Hurricane Hill, were circular, shallow basin-shaped pits with evidence of in situ burning and clay-lined walls (Figure 6-11). Both Features 4 and 34 originated at $16 \mathrm{~cm}$ bs, near the top of the Early Caddoan Midden 1 in Block A, and probably represent extramural cooking and heating features. They contained considerable quantities of daub and burned clay (see Figure 6-7a), sherds, and faunal remains. Large amounts of archaeological materials and bone tools (see Yates, Chapter 11) also occurred on a possible living surface or occupation horizon associated with the hearths in Midden 1. 
Table 6-4. Frequencies of cultural materials recovered from pits.

\begin{tabular}{|c|c|c|c|c|c|c|c|c|c|}
\hline Feature \# & Rise & Tools & $\begin{array}{l}\text { Lithic } \\
\text { Debris }\end{array}$ & Shetds & $\begin{array}{l}\text { Daub } \\
\text { (g) }\end{array}$ & $\begin{array}{l}\text { Burned } \\
\text { Clay } \\
\text { (g) }\end{array}$ & $\begin{array}{l}\text { FCR } \\
\text { (n) }\end{array}$ & $\begin{array}{l}\text { FCR } \\
(\mathrm{kg})\end{array}$ & Fauna \\
\hline $\begin{array}{c}12 \\
13 \\
15 \\
16 \\
22 \\
24 \\
29 \\
30 \\
32 \\
38 \\
39 \\
53 \\
54 \\
57 \\
74 \\
75 \\
79 \\
82 \\
83 \mathrm{~A} \\
83 \mathrm{~B} \\
85 \\
91 \\
94 \\
95 \\
104\end{array}$ & $\begin{array}{c}S \\
N \\
\text { SW } \\
\text { SW } \\
\text { N } \\
N \\
\text { S } \\
\text { S } \\
N \\
\text { S } \\
\text { S } \\
N \\
N \\
\text { S } \\
\text { SW } \\
\text { SW } \\
\text { N/S } \\
\text { SW } \\
\text { S } \\
\text { S } \\
\text { S } \\
\text { SW } \\
\text { SW } \\
N \\
N\end{array}$ & $\begin{array}{l}8 \\
5 \\
1 \\
3 \\
5 \\
2 \\
1 \\
3 \\
1\end{array}$ & $\begin{array}{c}19 \\
19 \\
\\
8 \\
68 \\
12 \\
106 \\
59 \\
\\
47 \\
17 \\
24 \\
\\
101\end{array}$ & $\begin{array}{l}1 \\
1\end{array}$ & $\begin{array}{l}0.1 \\
1.4\end{array}$ & $\begin{array}{l}3.0 \\
3.9 \\
0.6\end{array}$ & $\begin{array}{c}1 \\
18 \\
4 \\
2 \\
9 \\
24 \\
8\end{array}$ & $\begin{array}{r}+ \\
<0.5 \\
<0.5 \\
+ \\
<0.5 \\
0.5 \\
+\end{array}$ & $\begin{array}{c}34 \\
4 \\
1 \\
14 \\
3 \\
4 \\
7\end{array}$ \\
\hline Total & & 34 & 988 & 24 & 1.9 & 62.8 & 103 & $3.0+$ & 91 \\
\hline
\end{tabular}

$+=$ present in trace amounts
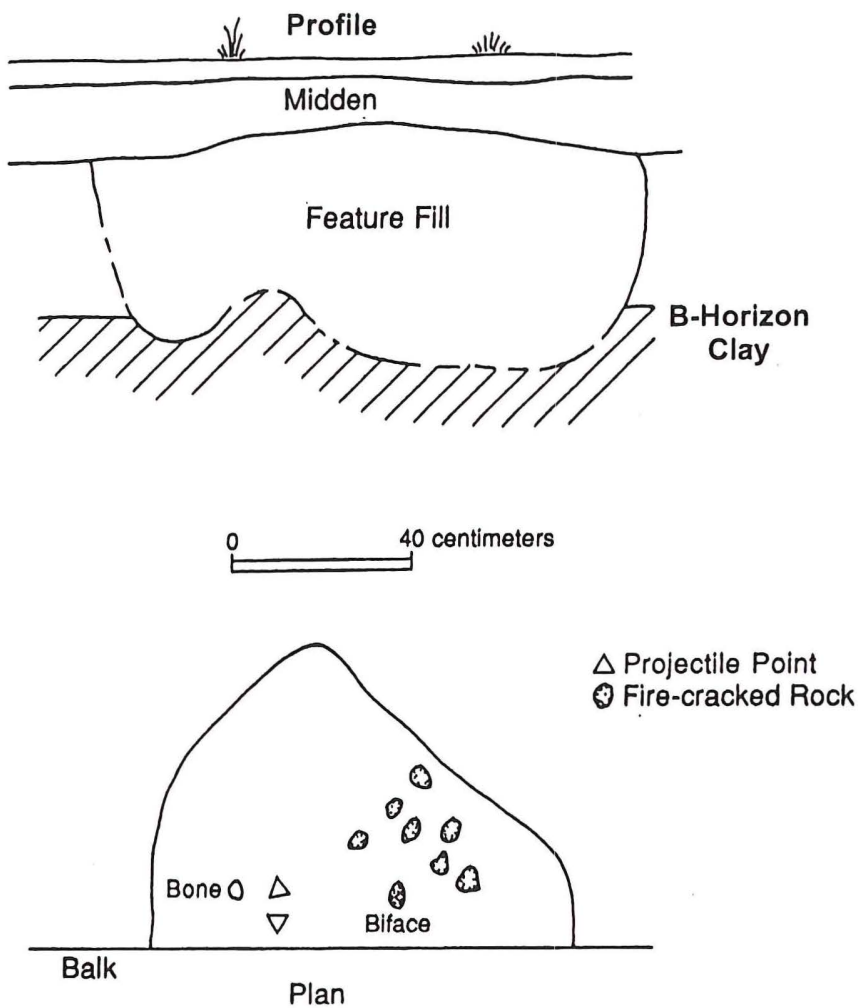

Figure 6-10. Plan and profile of Feature 24. 


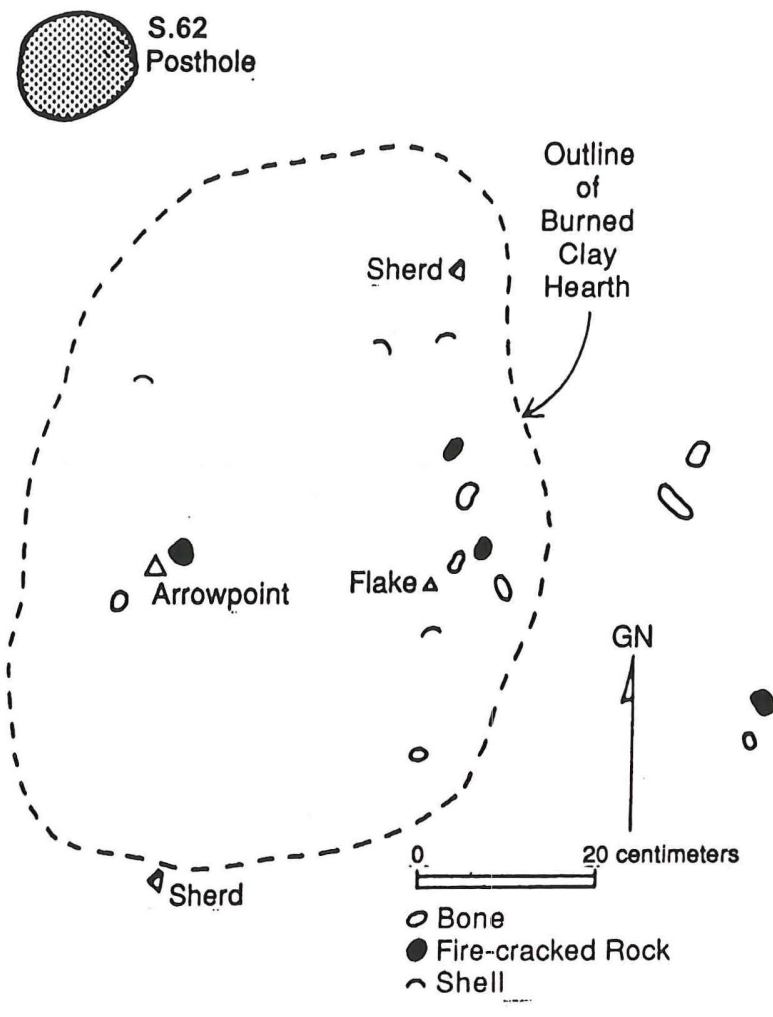

Figure 6-11. Plan of Feature 4.

The Type B hearth, Feature, 31, was basin-shaped and was located within Structure D (see Figure 6-2). However, except for concentrations of fire-cracked rocks (39 kg), Feature 31 exhibited no evidence for in situ burning. Fire-cracked rock occurred in a broad oval depression (Figure 6-12) that was about $16 \mathrm{~cm}$ deep, and originated about $39 \mathrm{~cm}$ bs, midway in the Zone II/III Primary Midden. It contained large quantities of fire-cracked rock (Table 6-5). This type of feature was probably used more as a source of radiating heat rather than as a means of containing and storing heat within the basin for cooking. The latter activity, functionally, is best demonstrated by the Type A clay-lined hearths in Midden 1 .

Partial posthole patterns were defined on the North rise in Block D and Block E. Based on the possible alignment and location of the postholes, two separate structures stood on the rise. The structures were not completely exposed, due to difficulties in discerning posthole stains in the dark midden soils and to the fact that portions of the blocks were left unexcavated because of the sampling scheme utilized for these blocks (see Chapters 3 and 4, this volume).

Both structures appear to be of Early Caddoan affiliations, based on the archaeological content of the soil zones and midden deposits in proximity to the posthole patterns. However, Structure E (see Figure 6-2) is earlier than Structure D (how much earlier is not known) since it was covered by Midden 1.

Although Midden 1 overlies Structure E, it clearly did not accumulate within the structure until it had been abandoned, since it seems to be a trash midden, and it also extends well to the north (see Figure 6-2). Structure D is probably contemporaneous with the deposition of the Early Caddoan Midden 1. 

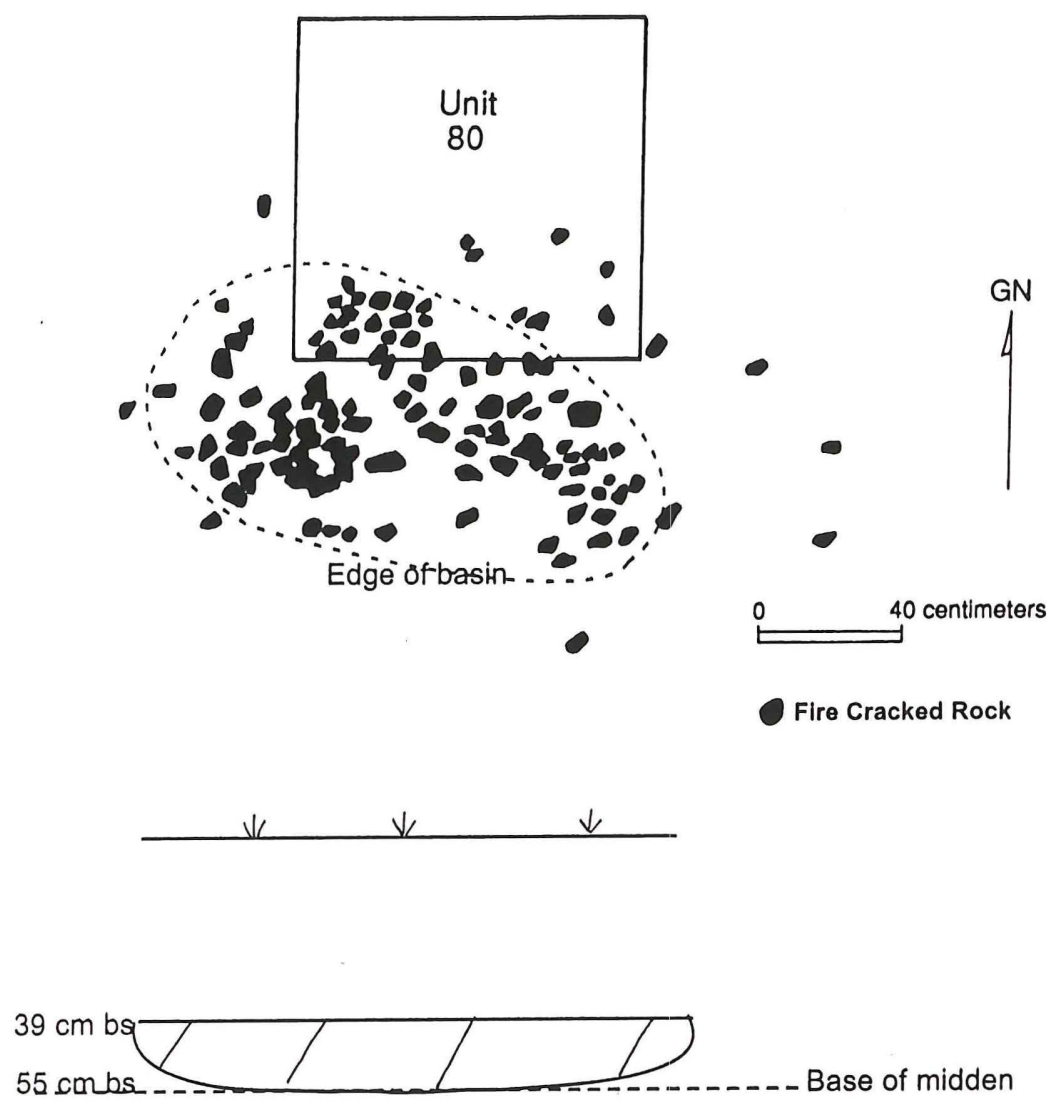

Figure 6-12. Plan and profile of Feature 31, Block D.

Table 6-5. Cultural materials from Type $A$ and $B$ hearths.

\begin{tabular}{|c|c|c|c|c|c|c|c|c|c|}
\hline Feature \# & Rise & Tools & $\begin{array}{l}\text { Lithic } \\
\text { Debris }\end{array}$ & Sherds & $\begin{array}{l}\text { Daub } \\
\text { (g) }\end{array}$ & $\begin{array}{l}\text { Burned } \\
\text { Clay } \\
\text { (g) }\end{array}$ & $\begin{array}{l}\mathrm{FCR} \\
(\mathrm{N})\end{array}$ & $\begin{array}{l}\text { FCR } \\
(\mathrm{kg})\end{array}$ & Fauna \\
\hline \multicolumn{10}{|l|}{ Type A } \\
\hline 4 & $\mathrm{~N}$ & 4 & 176 & 32 & 42.6 & 482.1 & 64 & 0.5 & 191 \\
\hline $5 \mathrm{~A} / \mathrm{B}$ & $S$ & 2 & 50 & 8 & & 569.8 & 10 & + & 60 \\
\hline 34 & $\mathrm{~N}$ & & & 2 & 148.2 & 206.8 & 7 & 3.7 & 523 \\
\hline \multicolumn{10}{|l|}{ Type B } \\
\hline 31 & $\mathrm{~N}$ & 2 & 24 & & & & 194 & 39.0 & \\
\hline 76 & sw & 10 & 539 & 9 & & 460.3 & 157 & 2.0 & \\
\hline Total & & 18 & 789 & 51 & 190.8 & $1,719.0$ & 432 & $45.2+$ & 774 \\
\hline
\end{tabular}


Structure D was delineated by 15 postholes that averaged $23 \mathrm{~cm}$ in length and $20 \mathrm{~cm}$ in width (Table 6-6). Because there was little variation in their dimensions, all were classified as outside wall support posts; few of the postholes contained any archaeological materials (Table 6-7). Partial wall alignments, based on the distribution of postholes, seemed to indicate a rectangular structure oriented with magnetic north (Figure 6-13). No definite center postholes were identified; however, a Type B rock hearth (Feature 31) was present near the probable south and eastern walls of the structure. No other internal features were recognized within Structure D.

Table 6-6. Posthole Data for Early Caddoan structures on the North rise.

\begin{tabular}{|c|c|c|c|c|}
\hline Stain \# & Feature \# & $\begin{array}{l}\text { Length } \\
(\mathrm{cm})\end{array}$ & $\begin{array}{l}\text { Width } \\
\text { (cm) }\end{array}$ & $\begin{array}{l}\text { Depth } \\
\text { (cm) }\end{array}$ \\
\hline \multicolumn{5}{|c|}{ Structure D - Block D } \\
\hline 34 & & 23 & 20 & \\
\hline 37 & 47 & 28 & 22 & $30-38$ \\
\hline 41 & 45 & 23 & 22 & $23-45$ \\
\hline 43 & 46 & 27 & 21 & $23-31$ \\
\hline 44 & & 27 & 25 & \\
\hline 49 & & 16 & 15 & \\
\hline 52 & 49 & 18 & 17 & \\
\hline 56 & 48 & 28 & 24 & $15-53$ \\
\hline 66 & & 21 & 20 & \\
\hline 67 & & 19 & 18 & \\
\hline 68 & & 18 & 17 & \\
\hline 69 & & 22 & 20 & \\
\hline 79 & & 27 & 22 & \\
\hline 80 & & 22 & 21 & $37-50$ \\
\hline 81 & & 22 & 21 & $50-65$ \\
\hline \multicolumn{5}{|c|}{ Structure $\mathbb{E}=$ Block $\mathbb{D} / \mathbb{E}$} \\
\hline 40 & 99 & 29 & 21 & $35-50+$ \\
\hline 59 & & 26 & 24 & \\
\hline 60 & & 23 & 21 & \\
\hline 65 & & 22 & 22 & \\
\hline $72 *$ & & 38 & 34 & \\
\hline 75 & & 25 & 23 & \\
\hline 85 & & 27 & 21 & \\
\hline- & 23 & 23 & 23 & $37-51$ \\
\hline- & $98 \mathrm{~A}$ & 24 & 24 & $35-53$ \\
\hline- & $98 \mathrm{~B}$ & 22 & 22 & $35-45$ \\
\hline
\end{tabular}

The floor of the structure was apparently about $35 \mathrm{~cm} \mathrm{bs,} \mathrm{but} \mathrm{approximately} 25 \mathrm{~cm}$ below what would have been the original ground surface if the backdirt and disturbed zone are discounted. The Caddoan inhabitants of Structure D are considered to be primarily responsible for the accumulation of Midden 1, estimated to date primarily between A.D. 1000 and 1200, situated to the north-northwest, and immediately outside the walls of the structure. 
Table 6-7. Frequencies of cultural materials recovered from postholes.

\begin{tabular}{|c|c|c|c|c|c|c|c|c|}
\hline Feature \# & Rise & $\begin{array}{l}\text { Lithic } \\
\text { Tools }\end{array}$ & Debris & Sherds & $\begin{array}{l}\text { Burned } \\
\text { Clay } \\
\text { (g) }\end{array}$ & $\begin{array}{l}\text { FCR } \\
(\mathrm{N})\end{array}$ & $\begin{array}{l}\text { FCR } \\
(\mathrm{kg})\end{array}$ & Fauna \\
\hline $6^{a}$ & S & & & 1 & & & & \\
\hline $20^{a}$ & $\mathrm{~s}$ & 1 & 16 & & 16.8 & 3 & + & 1 \\
\hline $46^{b}$ & $\mathrm{~N}$ & 1 & 3 & & & & & \\
\hline $49^{b}$ & $\mathrm{~N}$ & . & & & & 1 & + & \\
\hline 50 & $\mathrm{~N}$ & & 8 & & & & & \\
\hline 52 & $\mathrm{~N}$ & & 2 & & & & & \\
\hline 56 & $\mathrm{~S}$ & & 7 & & & & & \\
\hline 58 & $\mathrm{~S}$ & & 8 & & & & & \\
\hline 72 & SW & & 13 & & & & & \\
\hline 87 & $\mathrm{~s}$ & & 4 & & & & & \\
\hline 92 & SW & & 2 & & & & & \\
\hline 93 & SW & & 4 & & & & & \\
\hline 96 & $\mathrm{~N}$ & 1 & 4 & & & 1 & + & \\
\hline $98 \mathrm{~A} / \mathrm{B}^{\mathrm{C}}$ & ${ }^{c} \mathrm{~N}$ & 2 & 16 & 2 & & 1 & + & \\
\hline $99^{c}$ & $\mathrm{~N}$ & 5 & 22 & & & 10 & 0.2 & \\
\hline Total & & 10 & 109 & 3 & 16.8 & 16 & $0.2+$ & 1 \\
\hline
\end{tabular}

a Structure A

b Structure D

cStructure E

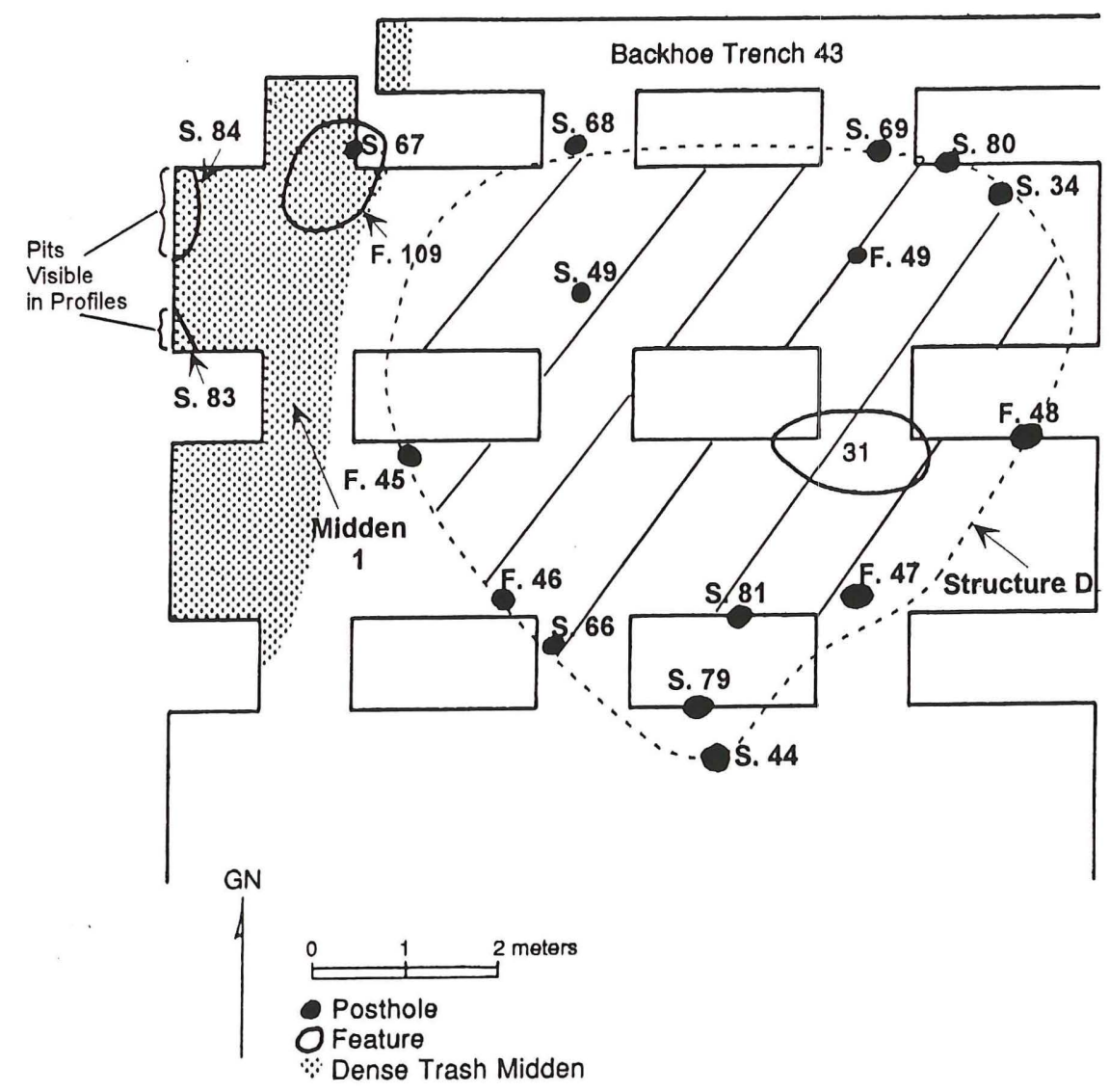

Figure 6-13. Plan of House D and other features in the northernmost part of Block D. 
A total of 10 postholes were associated with Structure E (see Table 6-6), and only Features $98 \mathrm{~A} / \mathrm{B}$ and 99 contained any archaeological materials (see Table 6-7). The range in posthole sizes and the alignment of posts suggest that nine posts were wall supports, and one (Stain 72; see Figure 6-2) was probably a center post or a small pit (Table 6-8). It was smaller in size, however, than the center support posts associated with Structures A and B on the South rise (see Table 6-8). The limited spatial information on the wall support posts for Structure E suggest it was also a rectangular structure. A 5-m portion of at least one wall and a shorter section of an intersecting wall (see Figure 6-2) show that the structure was aligned parallel to the crest of the North rise (ca. $30^{\circ} \mathrm{E}$ of $\mathrm{N}$ ).

Table 6-8. Summary Statistics for Posthole Sizes.

\begin{tabular}{llllll}
\hline & $\begin{array}{c}- \\
\text { Post Type }\end{array}$ & $\mathrm{N}^{\mathrm{a}}$ & $\mathrm{X}^{\mathrm{b}}(\mathrm{L} \mathrm{x} \mathrm{W})$ & $\mathrm{SD}^{\mathrm{c}}$ & $\mathrm{CV}^{\mathrm{d}}$ \\
\hline South Rise & & & & \\
A & support & 25 & 583.6 & 188.2 & 32.2 \\
A & central & 4 & 1983.8 & 383.3 & 19.3 \\
B & support & 26 & 736.1 & 295.1 & 40.1 \\
B & central & 4 & 1971.5 & 388.8 & 19.7 \\
B & other & 3 & 1233.3 & 190.3 & 15.4 \\
C & support & 9 & 618.4 & 127.6 & 20.6 \\
North Rise & & & & & \\
D & support & 14 & 456.6 & 123.2 & 27.0 \\
E & support & 9 & 547.9 & 51.8 & 9.5 \\
E & other & 1 & 1292.0 & - & - \\
\hline
\end{tabular}

\footnotetext{
${ }^{a}$ Number of measurable posts

b Mean

$\mathrm{c}_{\text {Standard deviation }}$

${ }^{d}$ Coefficient of variation: $100 \mathrm{x}$ SD/X

e Possible small pits or posts underinterior hearths
}

Within Midden 1, besides two postholes, clay-lined hearths, and pits, there were two "surficial" concentrations (Features 102 and 103) of archaeological materials between ca. $25-28 \mathrm{~cm}$ bs. These appear to represent debris on a possible occupational surface preserved in the midden. Feature 102 included a $40 \mathrm{x}$ $40 \mathrm{~cm}$ concentration of burned rock lying flat on a "surface," ash, sherds, faunal materials, and a bone tool (see Figure 6-9). The other debris concentration (Feature 103) was comprised of sherds, bone fragments (primarily deer-sized), and mussel shell.

\section{Features on the South Rise}

A total of 137 features were recorded during Phase I-IV investigations of the South rise at the Hurricane Hill site. Over 81 percent of the features identified were in Block B/C, and another 7 percent were recorded in Scrape Area \#11, south of the two blocks (see Table 6-1). Three other small clusters of features were recorded in Scrape Area \#8 (Features 78-80, 84, 86) and Scrape Area \#10 (Features 87-89) north, east, and west of Block B/C (Figure 6-14). These clusters were composed of postholes and large and small pits, and probably relate to poorly defined exterior post features such as work areas, ramadas, drying racks, or arbors (e.g., Kelley 1997; Kelley et al. 1996). Based on previous archaeological investigations at numerous Caddoan residential sites throughout the Caddoan area, and ethnographic information (see Swanton 1942; Bolton 1987), it was expected that these types of post features would occur in close proximity to the Caddoan house structures on both the South and North rises. 


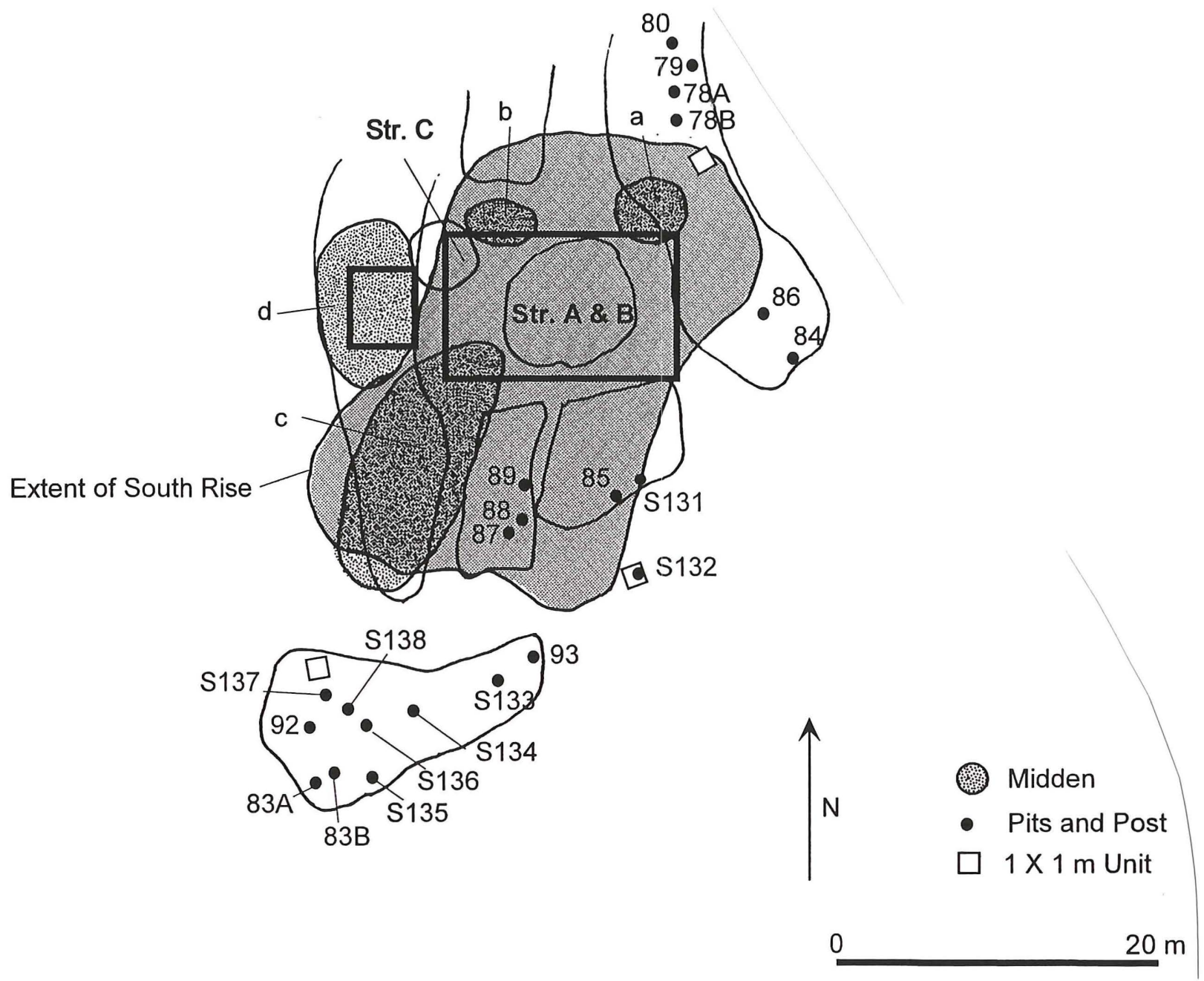

Figure 6-14. Features and structures on and in the vicinity of the South rise.

In addition to extra-mural post features, four areas of trash midden accumulation (middens A-D) are present on the South rise that clearly relate to the Middle Caddoan period settlement on this part of the Hurricane Hill site (see Figure 6-14; see also Figure 5-8). The association of each midden with the different periods of house construction on the South rise, however, has not been established beyond question (see below), but there is little doubt that they each relate to the intensive Middle Caddoan settlement of the South rise. Calibrated radiocarbon dates from the South rise and associated features range from AD 11591402 (see Chapter 7), but the most reliable dates fall between ca. A.D. 1250-1400.

Three human burials of apparent Middle Caddoan period affiliation were excavated in Block B/C on the South rise: Features 3, 7, and 8 (Figure 6-15). Burials 3 (Feature 3) and 5 (Feature 36) are extended inhumations, but the context of Burial 6 (Feature 7) is unclear because only a limited amount of skeletal material was recovered in the pit. A calibrated radiocarbon age range of $A D 1248-1319(\mathrm{RA}=0.62)$ was obtained from charred nutshells in the Burial 5 grave. 


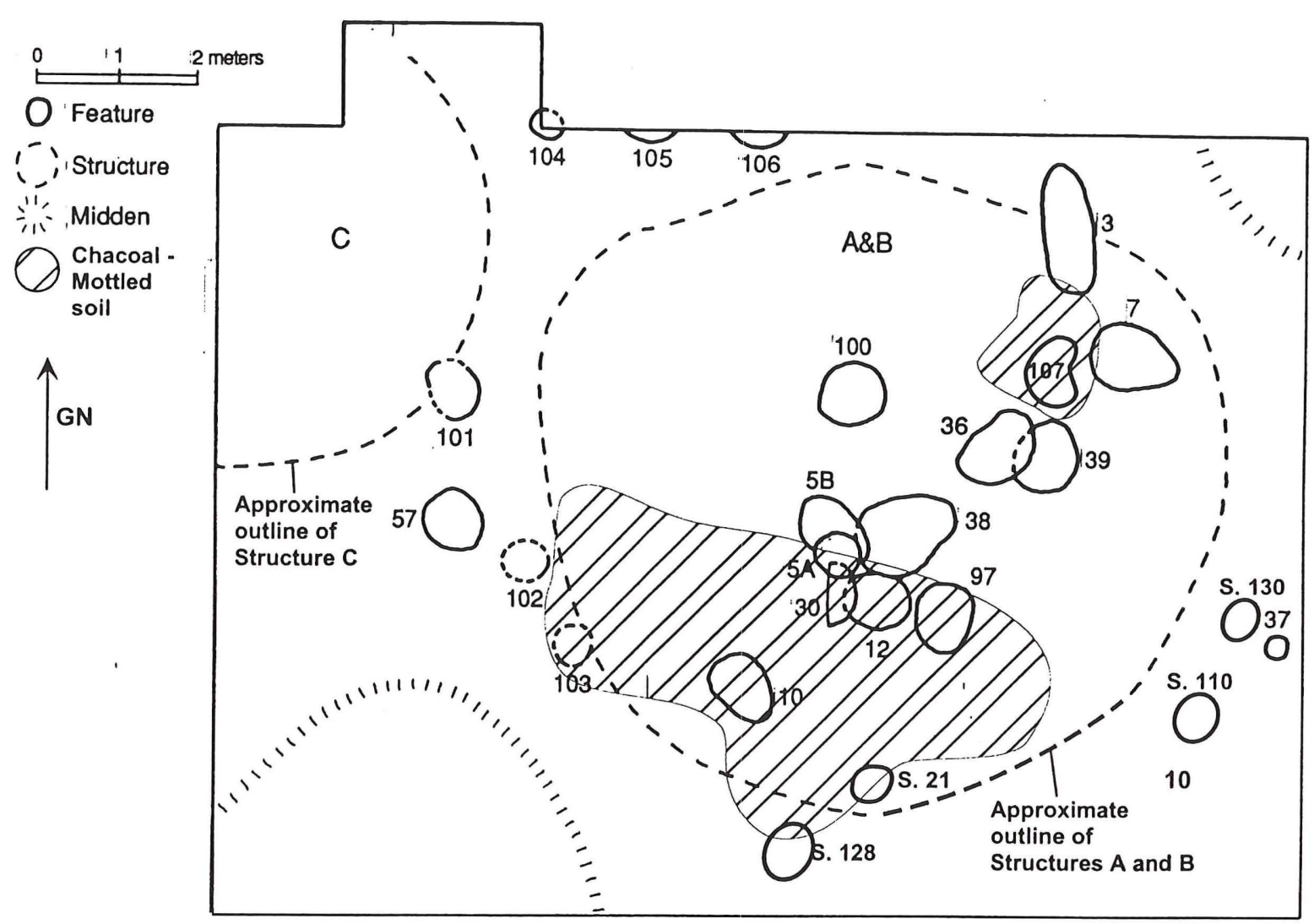

Figure 6-15. Plan of excavations, depicting clusters of posts and pits around and within the structures on the South rise.

The Burial 3 pit is oriented northeast-southwest (see Figure 6-15), with the head of the burial facing to the northeast, as was the case with Burial 2 on the North rise (see above). The individual had been placed in a pit that extended to $63 \mathrm{~cm}$ bs, and quantities of midden debris had been dumped in the burial pit (see Table 6-3). Based on its position relative to Structure A and B, it is probably associated with Structure $\mathrm{B}$, the earlier house on the south rise--since the posthole pattern of the later Structure A cuts across the burial pit--and it was placed just outside the northeastern wall of the house (see Figure 6-15). Except for the skull, preservation of the skeletal remains was poor, as only portions of the pelvis, arms, legs, and hands were present with Burial 3 (see Chapter 12, this volume).

Burial 5 was placed in a pit that extended from ca. $32-50 \mathrm{~cm}$ bs. The burial pit had been detected during the backhoe trenching carried out in Phase II investigations, but it was not until intensive excavations were carried out in Block $\mathrm{B} / \mathrm{C}$ that the burial feature was exposed. What portions of the burial that remained in the pit were fairly well-preserved, although the excavation of BHT \#35 removed the area below the mid-section of the body. The burial was extended on its back, with its head facing to the southwest. Feature 39, a later pit, disturbed the burial as well (see Figure 6-15; there are older fractures visible on the left humerus that probably reflect the disturbance caused by the excavation of this later pit. Burial 5 originates at a depth that is compatible with a Structure B association. This house is the earlier Middle Caddoan structure on the rise, and the individual was apparently buried in a sub-floor pit.

Burial 6 (Feature 7) appears to pre-date the first house constructed on the South rise because the pit in which it was interred was intersected by Stain 4, one of the support posts associated with Structure B (see below). No clear arrangement of skeletal materials was observed in the grave pit, which extended from 
ca. $36-78 \mathrm{~cm}$ bs, but the unburned human bones were concentrated between $50-65 \mathrm{~cm}$ bs; presumably the remainder of the bone had deteriorated in the sandy loam matrix. No artifacts were recovered in the burial pit.

The extended burials on the South rise had midden fill placed in the burial pits, and the fact that Middle Caddoan period artifacts occurred in abundance in these midden deposits rather clearly indicates that the burials post-date the initial accumulation of Caddoan midden on the South rise (which would date them after ca. A.D. 1250; see below). Burial 6, on the other hand, has a dark, organic fill in the grave, but no archaeological materials were present in the pit; it may be the earliest of the Caddoan burials on the South rise. As with the burials recorded on the North rise, none of the burials on the South rise had intentionally placed grave offerings.

A dog burial (Feature 37) was located outside the structures, but near the southeast corners of the two houses (see Figure 6-15). It had been placed in a shallow pit (18-22 cm bs), with its legs flexed, and its head facing south (see Chapter 13, this volume).

A number of large and small pits were recorded on the South rise (see Table 6-1). The larger pits contained only limited amounts of archaeological material other than lithic debris and burned clay (see Table 6-4). They are distributed primarily within Structure A and B, particularly in proximity to the central hearths (Features 5A and 5B) (see Figure 6-15).

One of the pits, Feature 83B, with a calibrated radiocarbon age range of $A D 1307-1360$ ( $R A=0.71$ ), contains only a few undecorated pottery sherds. Eight postholes/stains and the two adjacent pits (Features $83 \mathrm{~A}$ and $83 \mathrm{~B}$ ) were recorded about 20 meters south of Structures $\mathrm{A}$ and $\mathrm{B}$, and about 7-13 m east of the Southwest rise midden (see Figure 6-14). All of the postholes/stains are the size of support posts for a structure, but there is no clear alignment of posts indicating a wall or arc of posts. The stains/postholes originate in Zone III deposits, but they terminate above the B-horizon, and thus are difficult to detect. Since the postholes were exposed in the gradall scraping, the irregular distribution of the posts may indicate that other postholes/stains were overlooked or scraped away before they could be observed in plain view. All eight postholes/stains had a dark gray charcoal-flecked sandy loam matrix, but no evidence of firing was noted in the area. The association of the postholes/stains and the two pits--one of which dates to the Middle Caddoan period (see above)--suggests a second Middle Caddoan post/pit cluster. The pits contain lithic debris, fire-cracked rock, and a few plain sherds (see Table 6-4).

The smaller pits, including Feature 57 and Feature 101 (see Figure 6-15), are located in extra-mural contexts, but they are within 1-2 meters of the exterior walls of both of the structures. Archaeological materials are sparse within the small pits, as was also the case at the Thomas site (cf. Cliff 1995:Table 615). Differences in the distributional pattern of the two sizes of pits probably relate to varying functional uses, whether it be as storage facilities, smudge pits, or more specialized heating and cooking features. It is likely, considering evidence gathered from other contexts (e.g. Bruseth and Martin 1987; Good 1982; Kelley et al. 1996) that the large pits within the house structures are below ground storage facilities placed in close proximity to the household heating and cooking facilities (the central hearths).

There are two burned clay hearth basins (Features 5A and 5B) near the center of Structures A and B (see Figure 6-15). The hearths are superimposed (Figure 6-16b; see also Figure 5-10, including profiles of two walls from Unit 172 in Block B/C), which apparently is a reflection of the rebuilding and succeeding use of two structures on the South rise. Feature $5 \mathrm{~A}$, the latest hearth, originates about $16 \mathrm{~cm} \mathrm{bs,} \mathrm{and} \mathrm{the}$ basin extends to $28 \mathrm{~cm}$ bs. The basin is a yellowish-red (5YR5/8) oxidized clay that has become broken up into chunks (Figure 6-16a), and the basin fill is a charcoal-flecked sandy loam with a large pocket of ash in the center of the basin (Figure 6-17). A thin $(25 \mathrm{~cm})$ lens of Zone IIa midden covers a $3 \mathrm{~m}^{2}$ area around the hearth, but mainly to its east. On this occupational surface were found two deer mandibles, a Maxey Noded Redware bottle sherd, and most of a clay elbow pipe (see Chapter 9). An archaeomagnetic date of A.D. 1300 \pm 50 was obtained by Dr. Brooks Elwood (The University of Texas at Arlington) from the walls of the burned clay hearth basin. 

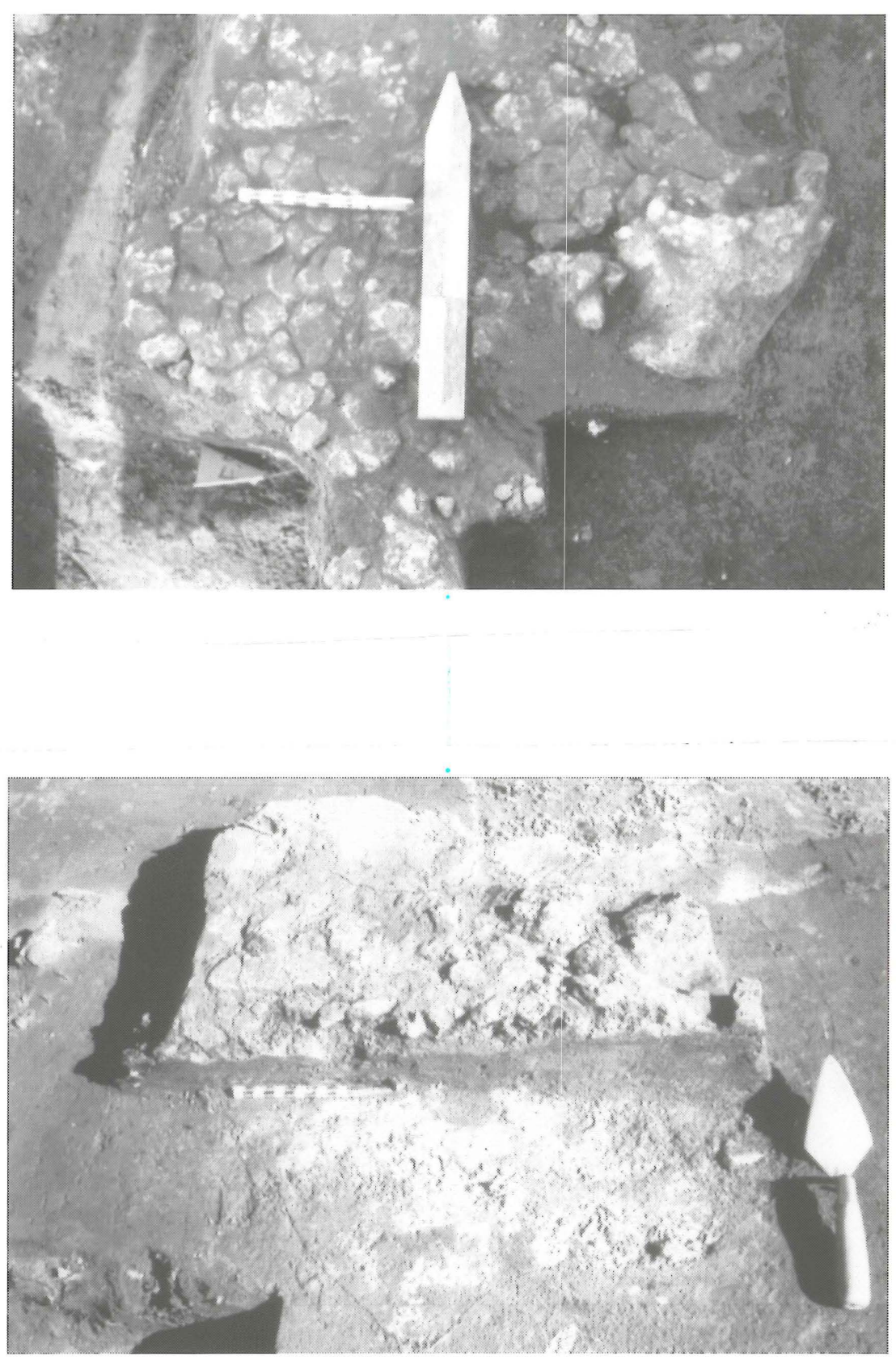

Figure 6-16. Feature 5: a, top of Feature 5, units 172-173, looking north; b, northern half of Feature 5A, and underlying Feature 5B ash lens. 


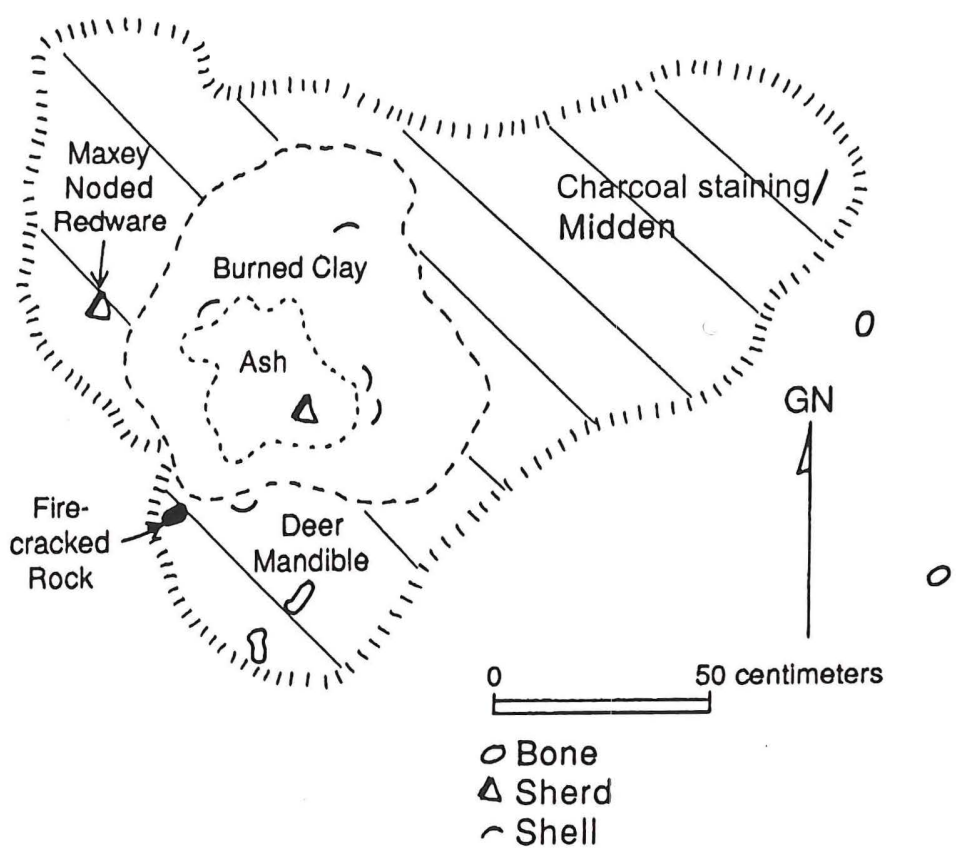

Figure 6-17. Feature 5A, Block B/C.

Hearth 5B, the earlier burned clay hearth (see Figure 6-16b), originates at $31 \mathrm{~cm}$ bs, and the basin extends to $42 \mathrm{~cm}$ bs. It overlies a posthole stain that probably represents the original central post that was cut out after the superstructure had been erected, with the hearth being placed over it (see Figure 5-10). A similar fill deposit accumulated in the hearth 5B basin as was noted for Feature 5A.

Three large pits--Features 12,30 , and 38--occur in immediate proximity to the central hearths (Figure 6-18). Based on their depths and apparent origins in the profiles, Feature 12,15 cm thick, was associated with Structure B, the earlier Middle Caddoan structure. The other two pit features are associated with the later structure, Structure A. Hearth 5A partially overlies Feature 30 (see Figures 5-10 and 6-18). Another set of large pits are situated from 1-2 meters away from the central hearths (see Figure 6-15).

The contents of Hearth 5A/5B are listed in Table 6-5. Burned clay fragments are the primary constituent of the fill, along with faunal remains, lithic debris, and a small number of fire-cracked rock and sherds.

More than 85 postholes were recorded in the Block B/C excavations (see Table 6-1). They tend to cluster in two broad areas within the block (Figure 6-19), and apparently they represent the decayed remnants of support and super-structural posts from three separate structures.

Since there were limited posthole super-positioning, other means of associating posthole patterns with the two structures (and the two superpositioned hearths) had to be attempted to unravel the use of the area. The one good example of superpositioning indicated that stain 140, a relatively small and shallow post ( $35 \mathrm{~cm}$ is its bottom depth), intersected stain 11, part of an entrance trench, and clearly post-dated the trench (see Figure 6-19). On this basis, the depths and sizes of all pits, posts, and stains were examined in Block B/C. A consistent pattern was noted that the smaller and shallower support posts were distributed differently than the larger and deeper support posts, and the former originated at a level consistent with the base of Zone IIa deposits, an occupational surface associated with the upper central hearth (Feature 5A). The deeper posts originated at a depth of ca. $30-35 \mathrm{~cm}$ bs (Figure 6-20) and extended generally to $56-59 \mathrm{~cm}$ bs, and appeared to be associated with the earlier interior hearth, Feature 5B, of Structure B. 


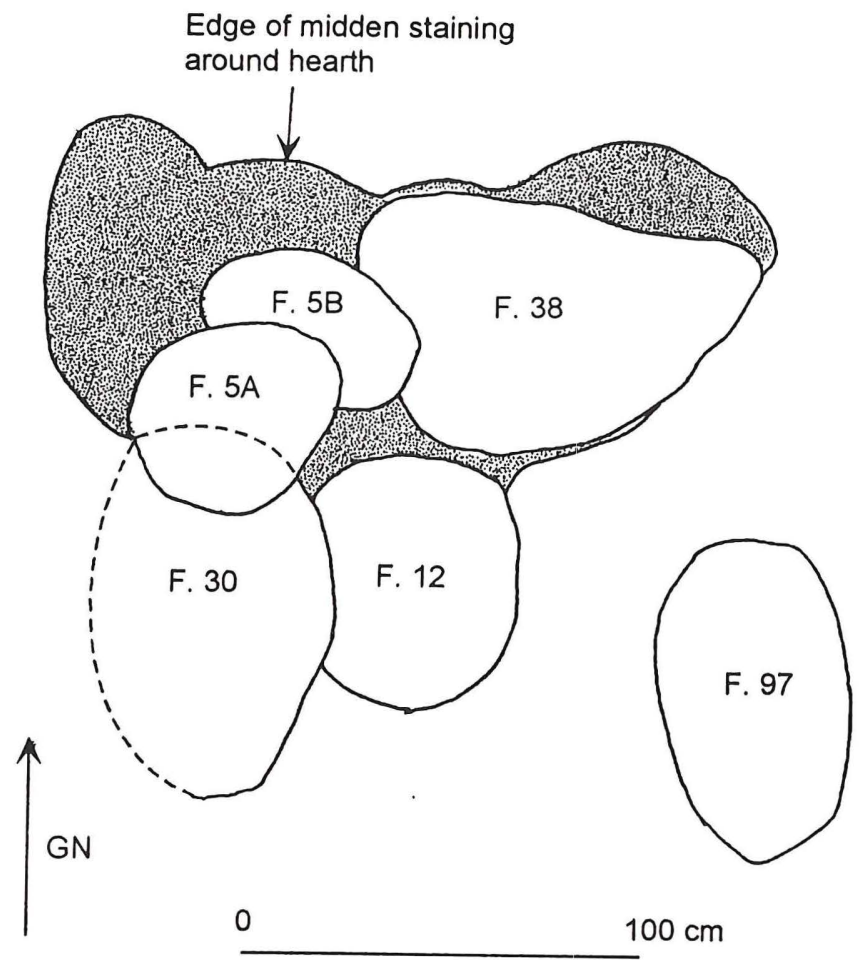

Figure 6-18. Location of central hearths and large pits in Structures A and B.

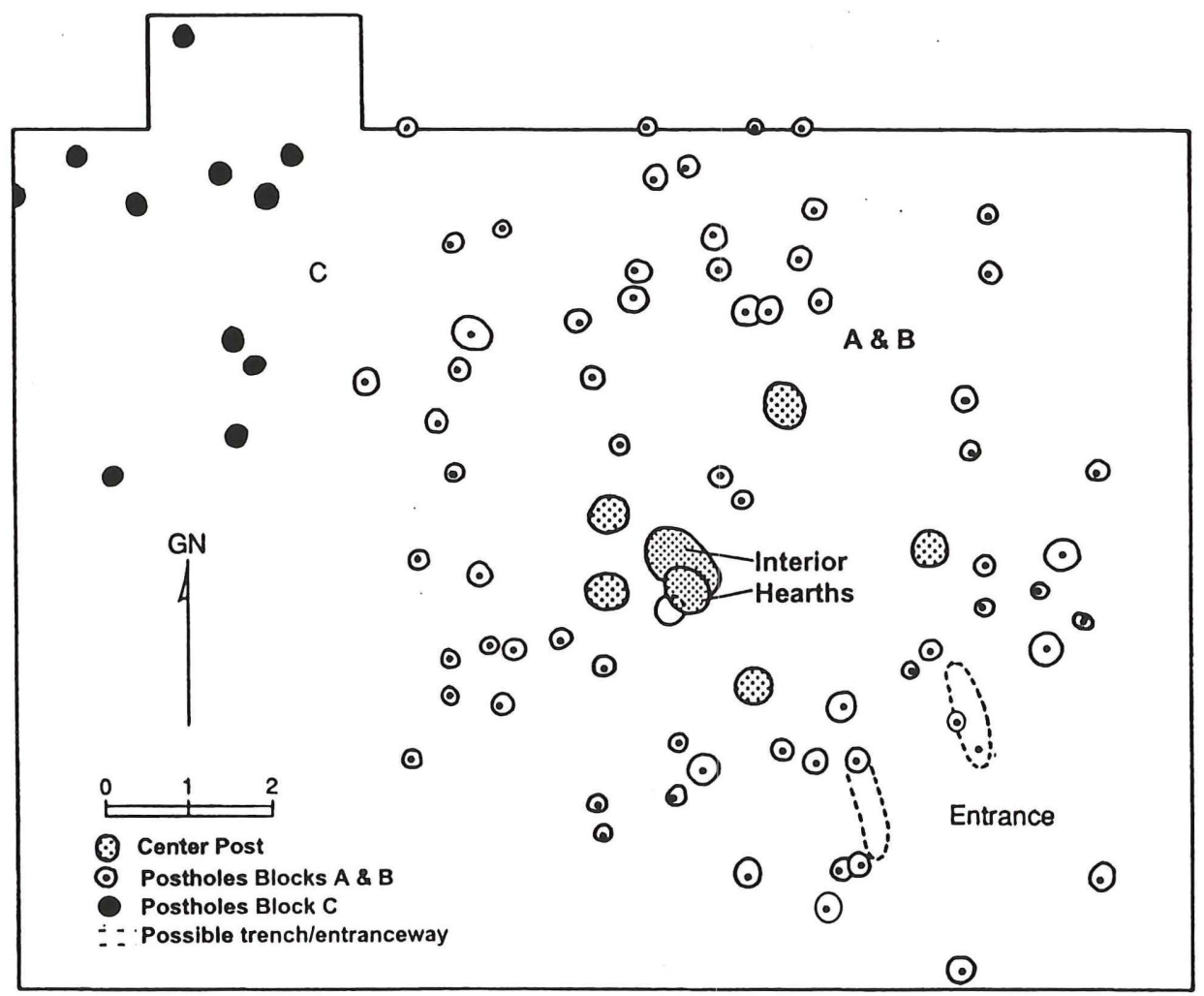

Figure 6-19. Posthole patterns, Block B/C. 

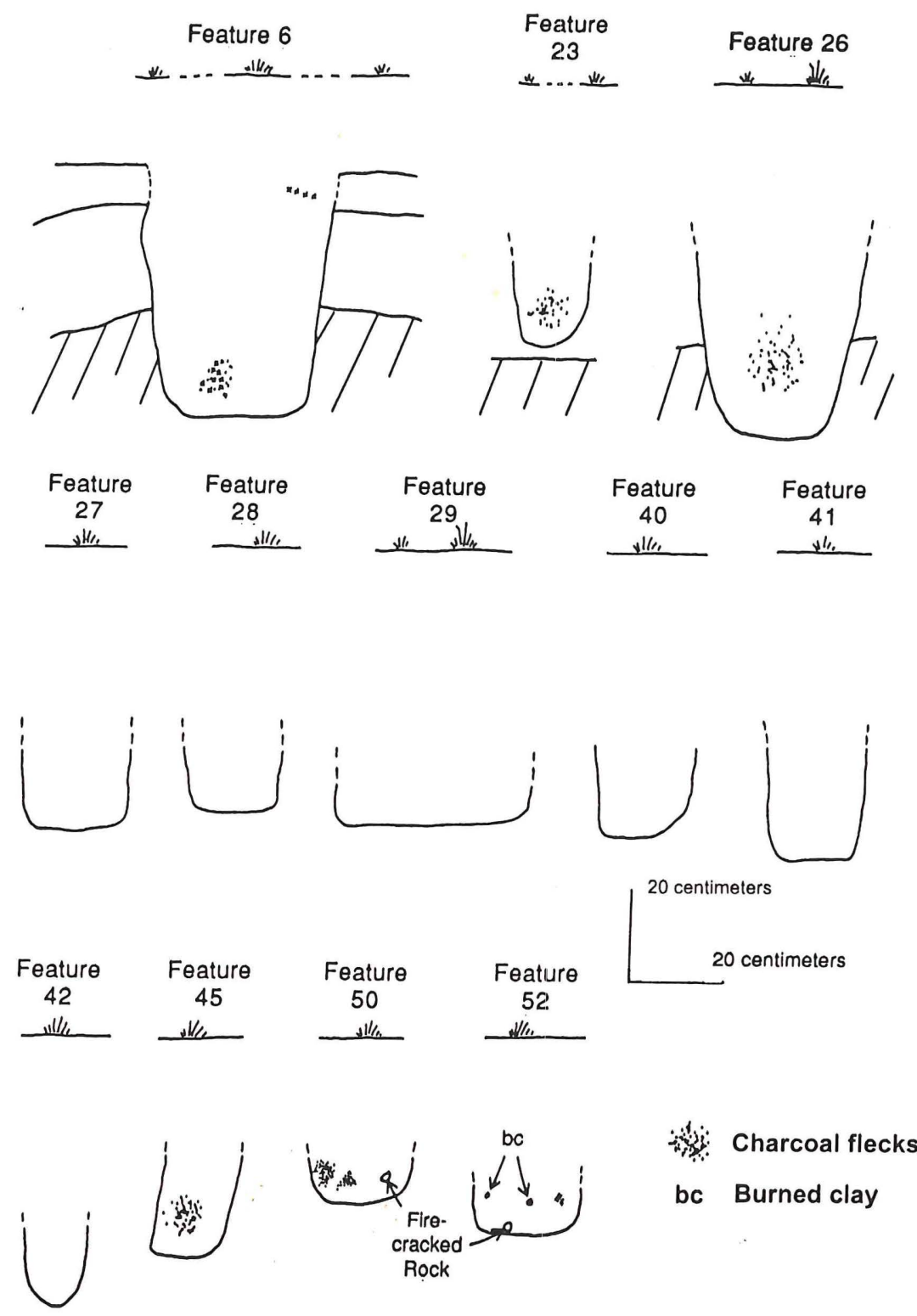

Figure 6-20. Profiles of selected postholes and small pits.

The plotting of the two different types of postholes, and the patterns of Structures A and B are illustrated in Figures 6-21 and 6-22. Although it is clear that not all the posts for either structure were detected, and some could have been removed by the backhoe trenching (see Figure 6-19), the majority of the respective posthole patterns had been preserved on the South rise.

Typical wall support postholes for Structure B average about $27 \mathrm{~cm}$ in diameter, while those for Structure A average $24 \mathrm{~cm}$ in diameter, there is a limited range in the size or depth of the posts within either structure (Table 6-9 and Table 6-10). The center posts are correspondingly larger (45 $\mathrm{cm}$ in diameter) and deeper, extending $40-50 \mathrm{~cm}$ below the "floor" of the structures. They are more standardized in size than the support posts, with coefficients of variation (CV) ranging from 19.3-19.7, while the CV for wall support posts ranged from 32.2 to 40.1 for Structures A and B, respectively (see Table 6-8). This statistical relationship makes sense given that the central posts are more critical to insuring that the superstructure remain stable and standing than are any individual wall support post. 


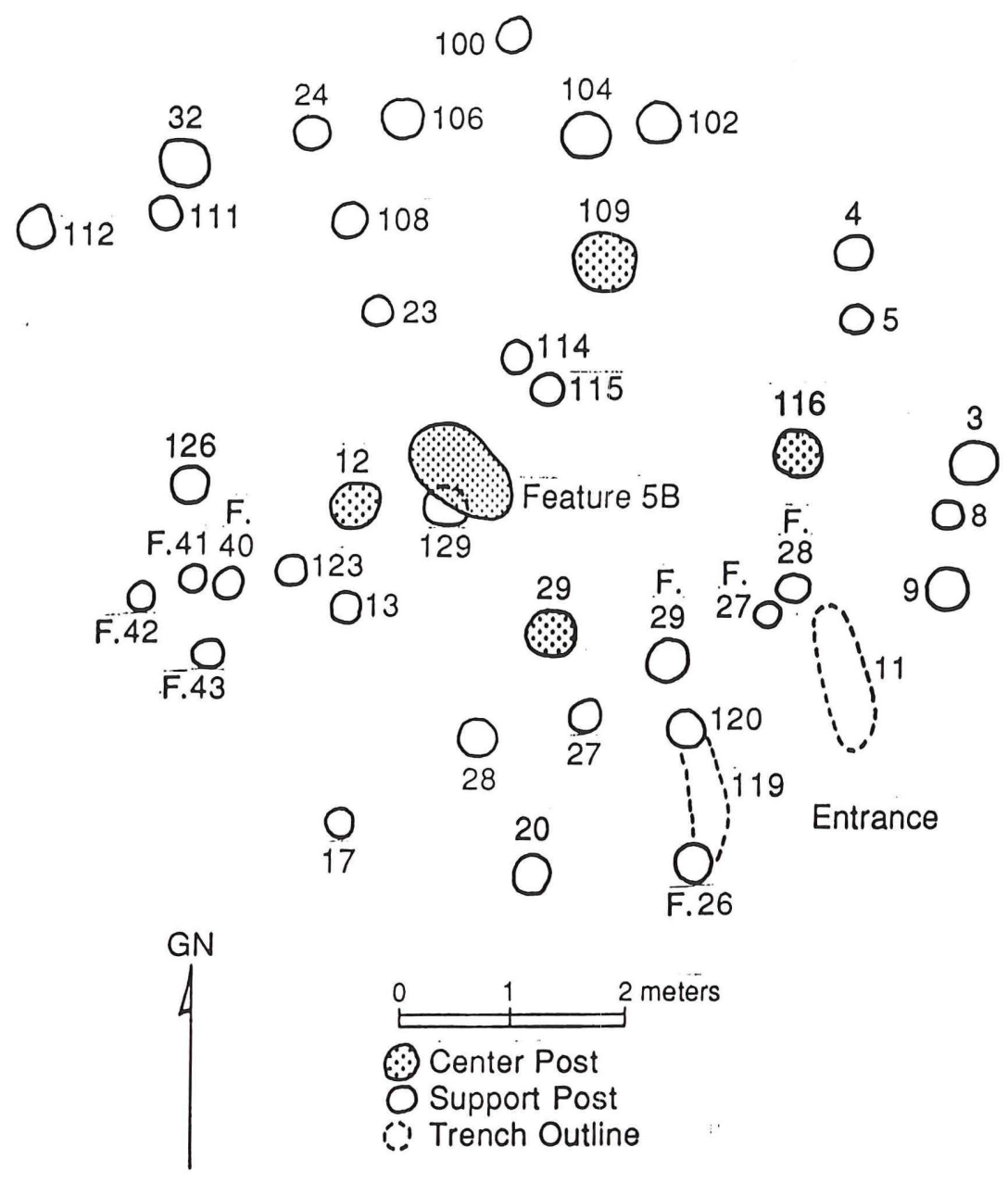

Figure 6-21. Plan of postholes for Structure B.

House B is circular to sub-rectangular in shape, $7.1 \times 7.6 \mathrm{~m}$ in length and width, covering a surface area of $53.96 \mathrm{~m}^{2}$ (see Figure 6-21). It has four center posts, situated between 0.2-2 meters distance on four sides of the central hearth. Interior posts may mark dividers within the house, elevated sleeping platforms, or other types of walls, but any arc of interior posts is not well defined. Similarly, the pattern of exterior wall supports, spaced about $90 \mathrm{~cm}$ apart, is not complete, but there are gaps in the area of BHT \#33 and 36 (see Figure 6-15).

The Structure B entrance is located at the southern end of the structure, and is aligned approximately to magnetic north. The entrance is marked by two parallel stains or trenches, $140-150 \mathrm{~cm}$ in length, that define an entranceway about $110 \mathrm{~cm}$ in width (see Figure 6-21). Although the eastern trench lacks postholes, the fact that the western trench (Stain 119) has postholes at either end strongly suggests that both trenches did have wooden posts in them to make a covered entranceway. Similar entranceways were noted on two of the Caddoan structures at the Hines site (41WD450) at Lake Fork Reservoir in Wood County, Texas, one of which has a calibrated radiocarbon age range of AD 1042-1189 (Bruseth and Perttula 1981:Figure 3-16; Perttula 1998a:Table 1). Circular Middle Caddoan structures with extended entranceways have also been excavated at the Oak Hill Village (41RK214), principally in the final era (post-ca. A.D. 1350) village (Robert Rogers, 1998 personal communication). 
Table 6-9. Posthole data for Structure A.

\begin{tabular}{|c|c|c|c|c|c|c|}
\hline Stain \# & Feature \# & Unit & $\begin{array}{l}\text { Length } \\
(\mathrm{cm})\end{array}$ & $\begin{array}{l}\text { Width } \\
(\mathrm{cm})\end{array}$ & Level & Contents \\
\hline 1 & & 158 & 20 & $?$ & $?$ & \\
\hline 6 & . & 169 & 25 & $?$ & $5 \mathrm{~A}$ & \\
\hline 7 & & 169 & 21 & $?$ & $5 \mathrm{~A}$ & \\
\hline 15 & & 201 & 20 & 19 & $4 B$ & \\
\hline 16 & & 201 & 21 & 19 & $5 \mathrm{~A}$ & \\
\hline 19 & 20 & 54 & 20 & 20 & $?$ & \\
\hline 22 & 26 & 56 & 25 & 25 & $4 \mathrm{~B}$ & \\
\hline $29 a$ & & 60 & 46 & 42 & $6 \mathrm{~B}$ & \\
\hline 30 & & $148 / 51$ & 26 & 26 & $4 B$ & pottery, pipe \\
\hline 94 & & 108 & 16 & 16 & $3 B$ & bone \\
\hline 95 & & 113 & 25 & 25 & $3 \mathrm{~B}$ & \\
\hline 96 & & 106 & 27 & 22 & $5 \mathrm{~A}$ & bone \\
\hline 97 & & 56 & 25 & 22 & $4 \mathrm{~B}$ & \\
\hline 98 & & 49 & 23 & 21 & $4 \mathrm{~A}$ & FCR \\
\hline 99 & & 49 & 27 & 25 & $4 \mathrm{~A}$ & \\
\hline $101^{b}$ & & 115 & 40 & 32 & $4 \mathrm{~A}$ & FCR \\
\hline 103 & & 116 & 30 & 27 & $4 \mathrm{~A}$ & \\
\hline 105 & & 57 & 30 & 25 & $4 \mathrm{~A}$ & pottery \\
\hline 107 & & 192 & 20 & 20 & $4 \mathrm{~A}$ & \\
\hline \multirow[t]{2}{*}{$109^{a}$} & & $143 /$ & & & & \\
\hline & & 144 & 55 & 50 & $6 B$ & $\begin{array}{l}\text { pottery, FCR, } \\
\text { bone }\end{array}$ \\
\hline 110 & & 140 & 25 & $?$ & $3 B$ & \\
\hline \multirow[t]{2}{*}{$116^{a}$} & & $163 /$ & & & & \\
\hline & & 170 & 39 & 36 & $7 \mathrm{~A}$ & \\
\hline 121 & & 64 & 32 & 25 & $5 \mathrm{~A}$ & \\
\hline 122 & & 202 & 20 & 19 & $5 \mathrm{~A}$ & \\
\hline 124 & & 204 & 20 & 16 & $5 \mathrm{~A}$ & \\
\hline 125 & & 186 & 18 & 17 & $5 B$ & \\
\hline 127 & & 176 & 22 & 22 & $4 \mathrm{~B}$ & pottery \\
\hline \multirow[t]{2}{*}{139} & & $168 /$ & & & & \\
\hline & & 193 & 25 & 23 & $4 \mathrm{~A}$ & \\
\hline $140^{b}$ & & $62 / 192$ & 37 & 34 & $4 \mathrm{~A}$ & \\
\hline 141 & & 203 & 18 & 17 & $4 \mathrm{~B}$ & \\
\hline 143 & & 54 & 28 & 24 & $5 \mathrm{~A}$ & \\
\hline 144 & & 50 & 25 & 23 & $4 \mathrm{~A}$ & \\
\hline \multirow[t]{2}{*}{ - } & $6^{a}$ & $159 /$ & & & & \\
\hline & & 160 & 43 & 43 & $6 \mathrm{~B}$ & pottery \\
\hline
\end{tabular}

$?=$ undetermined

a Center post

b Possible small pit 
Table 6-10. Posthole data for Structure B

\begin{tabular}{|c|c|c|c|c|c|}
\hline Stain & Feature \# & Unit & $\begin{array}{l}\text { Length } \\
(\mathrm{cm}) \quad(\mathrm{cm})\end{array}$ & Width & Contents \\
\hline 3 & & $165 / 168$ & 40 & 38 & \\
\hline 4 & & 141 & 25 & 25 & \\
\hline 5 & . & 141 & 22 & 20 & \\
\hline 8 & & 168 & 22 & 20 & pottery \\
\hline $9^{b}$ & & $168 / 193$ & 52 & $?$ & \\
\hline $11^{\mathrm{C}}$ & & $192 / 197$ & 130 & 35 & pottery, FCR \\
\hline $12^{d}$ & & $173 / 174$ & 45 & 40 & \\
\hline 13 & & 187 & 25 & $?$ & \\
\hline 17 & & 215 & 25 & $?$ & \\
\hline 20 & & 66 & 35 & 35 & \\
\hline 23 & & 59 & 24 & 20 & \\
\hline 24 & & 54 & 20 & 18 & bone \\
\hline 27 & & 64 & 28 & 24 & FCR \\
\hline 28 & & 63 & 35 & 32 & \\
\hline $29 d$ & & 60 & 46 & 42 & \\
\hline $32^{b}$ & & 50 & 42 & 35 & \\
\hline 100 & & 116 & 29 & 26 & pipe fragment \\
\hline 102 & & 115 & 30 & 30 & \\
\hline 104 & & 133 & 32 & 30 & \\
\hline 106 & & 57 & 35 & 30 & \\
\hline 108 & & 54 & 28 & 28 & pottery \\
\hline $109 d$ & & $143 / 144$ & 55 & 50 & pottery, FCR, bone \\
\hline 111 & & 50 & 22 & 20 & FCR \\
\hline $112^{b}$ & & 129 & 40 & 32 & FCR \\
\hline 114 & & 161 & 34 & $?$ & \\
\hline 115 & & 161 & 26 & 24 & \\
\hline $116^{d}$ & & $163 / 170$ & 39 & 36 & \\
\hline $119^{c}$ & & $64 / 65 / 67 / 68$ & 130 & 40 & FCR \\
\hline 120 & & $64 / 65$ & 33 & 31 & \\
\hline 123 & & 174 & 26 & 25 & \\
\hline 126 & & 175 & 29 & 28 & \\
\hline $129 e$ & & 173 & 40 & 38 & $\therefore$ \\
\hline & 26 & $67 / 68$ & 35 & 30 & \\
\hline & 27 & 62 & 22 & 20 & FCR \\
\hline & 28 & 62 & 30 & 25 & FCR, bone \\
\hline & 40 & 186 & 27 & 27 & bone \\
\hline & 41 & 186 & 20 & 20 & FCR \\
\hline & 42 & 186 & 20 & 17 & \\
\hline & 43 & 186 & 25 & 22 & \\
\hline
\end{tabular}

$?=$ undetermined

a The posts uniformly extended into level $6 \mathrm{~B}(56-60 \mathrm{~cm}$ bs), except for Stain 116 , which extended into level 7A (61-65 cmbs).

b Possible small pit

cEntranceway trench

d Center post

e Posthole underinterior hearth 


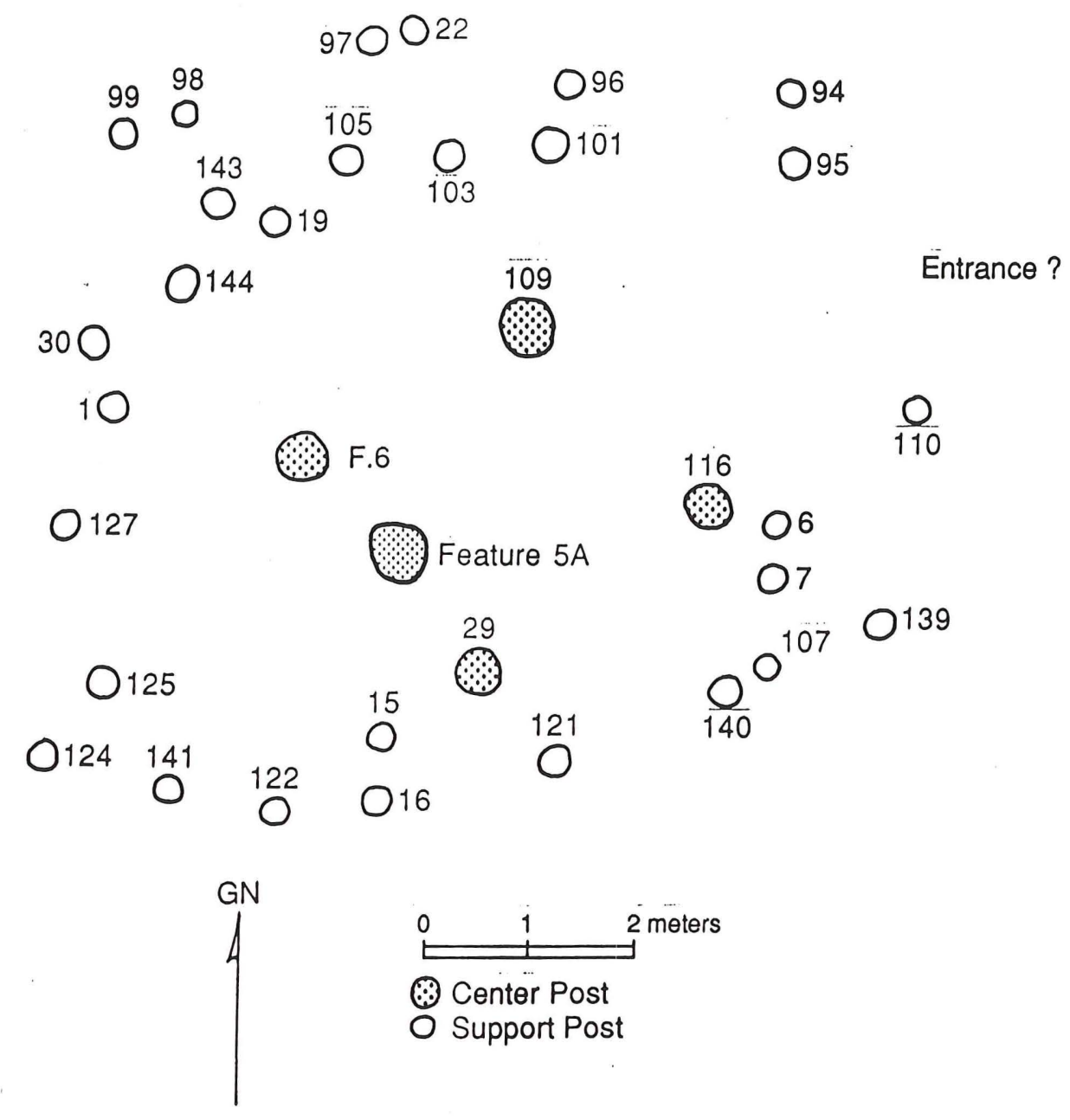

Figure 6-22. Plan of postholes for Structure A.

The later house structure, Structure A, is perhaps better defined than Structure B, but even so, a complete posthole pattern is not represented among the 32 postholes assigned to it (see Table 6-10). A conspicuous gap along the eastern wall of the structure may perhaps represent the entrance to the structure (see Figure 6-22). This would suggest that the midden A deposits (see Figure 6-12) on the South rise, about 1 to 5 meters east-northeast of the postulated entrance, accumulated as refuse tossed out the entrance of Structure A. Middens B and C are located in a similar relationship with the entranceway of Structure B (see Figure 6-14).

Structure $\mathrm{A}$ is also circular to sub-rectangular in shape, $6.0 \times 7.5 \mathrm{~m}$ in length and width, covering an area of $45.5 \mathrm{~m}^{2}$. The wall support posts are more evenly spaced than they are with Structure B, and average about $50-70 \mathrm{~cm}$ in separation along the better preserved sections of the walls (see Figure 6-22). The close spacing of some of the posts, almost as if they were double posts, along the walls (e.g., Stain 22/97 or Stain 107/140) suggests that part of the structure was probably rebuilt or repaired on at least one occasion. These are four center posts to Structure A. The westernmost posts (Feature 6 and Stain 29) are set about a meter away from, and on either side of, the central hearth (see Figure 6-22), while the eastern two posts are 2.2-2.4 meters northeast and southeast of the hearth, and roughly equidistant from the other two "central" posts. A possible interior divide, or elevated sleeping or storage platform, may be marked by 
several stains in the southeastern quadrant of the structure, but otherwise the interior area away from the central hearth, and adjacent large pits (see above), is free of interior posts (see Figure 6-22).

The third structure on the South rise in Block B/C is represented by an arc and cluster of eleven postholes in the northwest quadrant of the block (Table 6-11; see also Figure 6-19). No interior center posts or pits could be identified in the area, but several larger pits were recorded along the eastern margins of what is designated Structure C. If the arc and cluster represent a circular or sub-rectangular structure such as Structure $A$ and $B$, extrapolating the arc suggests the structure is about $6 \times 6 \mathrm{~m}$ in length and width; less than half of Structure C is represented in the block excavations, however. Since the majority of the posts are relatively shallow, with bottom depths only between $30-40 \mathrm{~cm}$ (see Table 6-11), the gradall of Scrape area \#5 (see Figure 4-7) may have removed evidence for the remaining posts since they do not penetrate into the underlying B-horizon.

Table 6-11. Posthole data for Structure $\mathbb{C}$.

\begin{tabular}{|c|c|c|c|c|c|c|}
\hline Stain \# & Feature \# & Unit & $\begin{array}{l}\text { Length } \\
(\mathrm{cm})\end{array}$ & $\begin{array}{l}\text { Width } \\
\text { (cm) }\end{array}$ & Level & Contents \\
\hline 2 & & 154 & 21 & $?$ & $4 \mathrm{~B}$ & \\
\hline 86 & & 97 & 21 & 20 & $3 B+$ & \\
\hline 87 & & 99 & 28 & 26 & $3 \mathrm{~B}+$ & \\
\hline 88 & & 100 & 29 & 26 & $5 \mathrm{~A}$ & FCR \\
\hline \multirow[t]{2}{*}{$89^{a}$} & & 99/ & & & & \\
\hline & & 100 & 30 & 28 & $5 \mathrm{~A}$ & \\
\hline 113 & & 127 & 27 & 22 & $3 \mathrm{~B}$ & \\
\hline 141 & & 97 & 34 & $?$ & $3 \mathrm{~B}+$ & \\
\hline 142 & & 150 & 23 & 22 & $?$ & \\
\hline 145 & & 127 & 26 & 24 & $?$ & \\
\hline 147 & & 98 & 25 & 20 & $3 B$ & \\
\hline - & $56^{b}$ & - & 25 & 24 & - & \\
\hline
\end{tabular}

$?=$ Undetermined

a Possible small pit

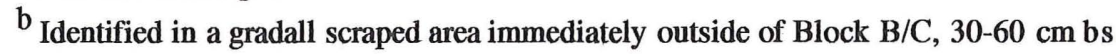

Another possibility is that Structure $C$ represents an arbor or ramada, rather than a residential structure, situated in proximity to one of the two other South rise structures. This would be consistent with both the absence of interior post and pit features, the shallow depth and wide spacing of the postholes (see Figure 6-19), and the low density of archaeological materials in this part of Block B/C (see Chapter 7, this volume). Possible ramadas have been excavated at the Cedar Grove (Trubowitz 1984:91-92 and Figure 9-14) and McLelland (Kelley 1997:32 and Figure 20) sites along the Red River, and they have widely-spaced posts (1.2-3 meters apart). A late 1860s-early 1870s Soule photograph of the Caddo Long Hat's village in western Oklahoma (Swanton 1942:Plate 14) shows a rectangular ramada in use near the village's residential structures. It consisted of six main posts about 1.5 meters apart, and cross poles to create a flat roof, and six smaller posts that made a low elevated platform within the ramada.

Based on the relative positioning of midden deposits on the South rise, Structure $C$ may be associated with the Midden D feature (Feature 9) situated along the slopes of the rise (see Figure 6-14). If so, then Structure C may have been used towards the latter part of the Middle Caddoan period occupation (thus, roughly contemporaneous with Structure A) since from stratigraphic grounds Midden D appears to be slightly younger in age than the other middens. The presence of a few pieces of shell-tempered pottery in Midden D also supports this suggestion since the use of shell-tempered pottery seems to date after ca. A.D. 1400 (Bousman et al 1988:29; Fields, Gadus, and Klement 1994; Cliff 1995) in the Cooper Lake area. 


\section{Summary of the South Rise Features}

The posthole and feature evidence summarized for the South rise indicates that three separate Middle Caddoan structures stood on the rise at one time or another. One or several episodes of midden deposition can also be associated with each of the structures. On these grounds, the archaeological evidence clearly suggests that an intensive, if individually short-term, Caddoan occupation occurred on this part of the Hurricane Hill site in the thirteenth and fourteenth centuries.

The stratigraphic, feature, and material culture data obtained in these investigations, however, seem to indicate that each structure was occupied at a different time than the others, or that Structures A and C may have been contemporaneous. Nevertheless, the structures are not part of a larger hamlet on the South rise. They are instead considered to represent two (or three, if Structure $\mathrm{C}$ is assumed to have a residential function) individual households. They are probably not related to the households investigated on the North rise of Hurricane Hill, because they date from at least 50-150+ years later than the Early Caddoan structures on that rise.

Using population estimates that are based on the amount of living area per person suggested by Cook (1972), and assuming that each structure had a residential function for the purposes of this discussion, Structures A, B, and C contained between 8-11 persons each, either as multiple nuclear families or extended families (Table 6-12). Cook's (1972) estimate works out to $4.5-5 \mathrm{~m}^{2}$ per person at the Hurricane Hill site.

\section{Table 6-12. Estimated Inhabitants for Structures on the South Rise.}

\begin{tabular}{llll}
\hline Structure & $\begin{array}{l}\text { Surface Area } \\
\left(\mathrm{m}^{2}\right)\end{array}$ & $\begin{array}{l}\text { Associated Midden } \\
\left(\mathrm{m}^{2}\right)\end{array}$ & $\begin{array}{c}\text { Estimated Inhabitants } \\
\mathrm{a}\end{array}$ \\
\hline & & $<20$ & 9 \\
$\mathrm{~A}$ & 45.5 & 80 & $10-11$ \\
B & 53.96 & $<30$ & 8 \\
C & 36.00 & & \\
\hline
\end{tabular}

\footnotetext{
a Based on Cook (1972), summarized in Good (1982: 93-94 and Table 13)
}

Kelley (1997:Table 46) also employed a series of population estimates based on Naroll (1962), Smith (1978), and Casselberry (1974) of $10 \mathrm{~m}^{2}, 4.74 \mathrm{~m}^{2}$, and $6 \mathrm{~m}^{2}$ per person, respectively, for population estimates for two 17th century Caddo sites in northwestern Louisiana, and found that Cook's, Smith's, and Casselberry's population estimates were the most reasonable. Applying the two latter population estimates to the South rise structures suggests that between 6-11 individuals lived in each of the structures. Bruseth and Martin (1987:60-61), on the other hand, used an estimate of 4-6 $\mathrm{m}^{2}$ per person, based on Wichita ethnographic accounts, to derive population estimates for the houses at Bird Point Island in Navarro County, Texas. The houses at that site were estimated to contain between 5-8 people.

\section{Features on the Southwest Rise}

Twenty-seven cultural features were recorded on the Southwest rise, located about 25-30 meters south-southwest of the South rise (Figure 6-23; see also Figure 6-1). Many of the features are within the dense midden deposits atop the crest of the Southwest rise, but pits and burial internments do occur to the west of the midden along the slope of the rise (see Figure 6-23). The most frequent types of features are extended and probably bundle burials ( 26 percent), cremations ( 22.2 percent), large pits (22.2 percent), and organically-filled pits (14.8 percent). 


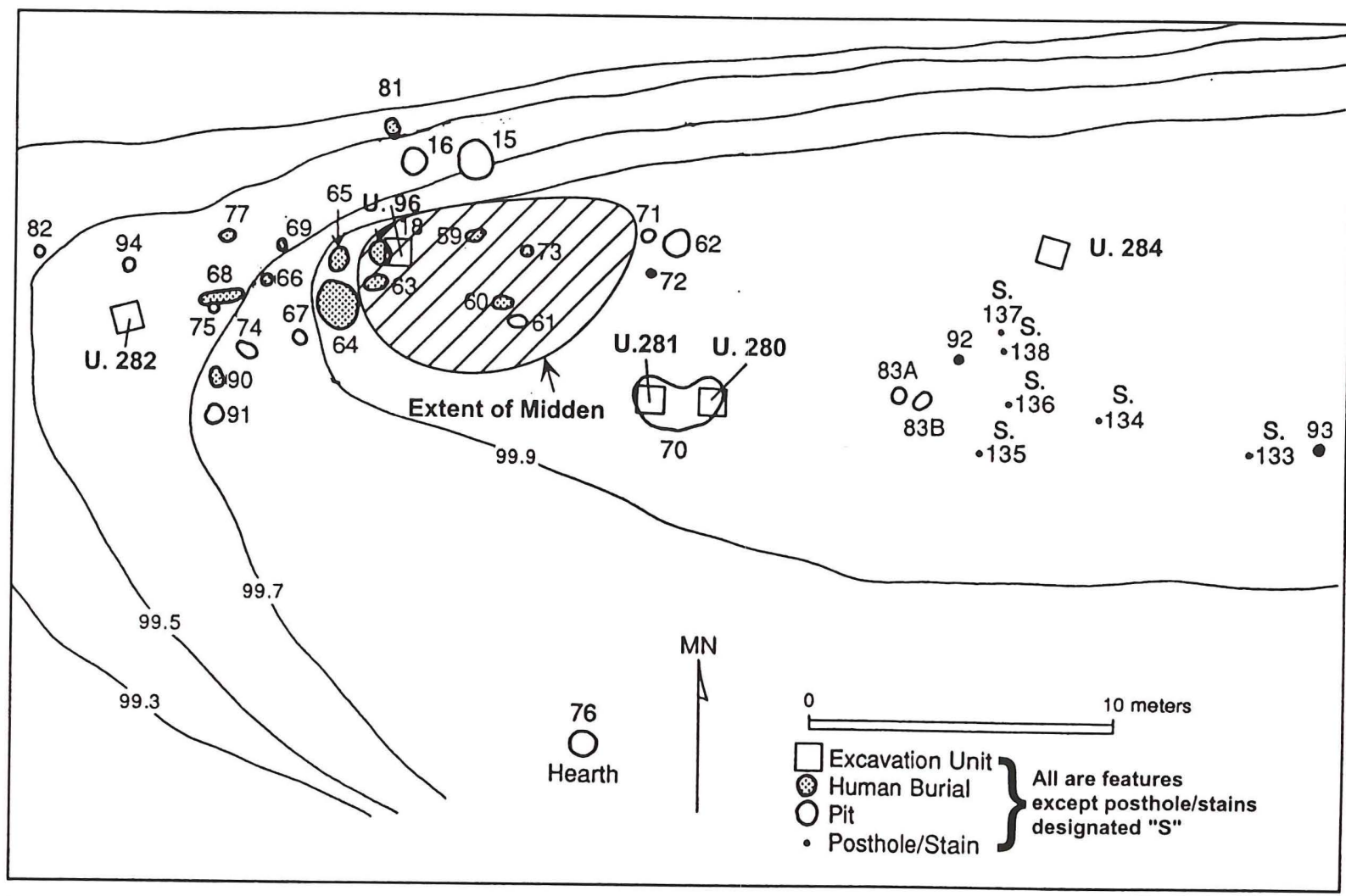

Figure 6-23. Plan of features, Southwest rise.

The cremations on the Southwest rise range in size from $0.30 \mathrm{~m}^{2}$ to $1.88 \mathrm{~m}^{2}$ (Table 6-13). When they were initially exposed in the gradall excavations, they were marked by circular and streaky concentrations of burned bone (Figure 6-24a).

Table 6-13. Data for Cremations on the Southwest Rise.

\begin{tabular}{cccc} 
Feature \# & $\begin{array}{l}\text { Area } \\
\left(\mathrm{m}^{2}\right)\end{array}$ & $\begin{array}{l}\text { Depth } \\
(\mathrm{cm} \text { bs })\end{array}$ & Multiple/Single $^{\mathrm{a}}$ \\
\hline & & & \\
18 & 0.30 & $20-51$ & $\mathrm{~S}$ \\
60 & 0.30 & $30-40$ & $\mathrm{~S}$ \\
63 & 0.46 & $56-78$ & $\mathrm{~S}$ \\
64 & 1.88 & $42-84$ & $\mathrm{M}$ \\
65 & 0.54 & $35-52$ & $\mathrm{M}$ \\
90 & 0.31 & $6-16$ & $\mathrm{~S}$
\end{tabular}

\footnotetext{
${ }^{\mathrm{a}} \mathrm{M}=$ multiple; $\mathrm{S}=$ single
} 

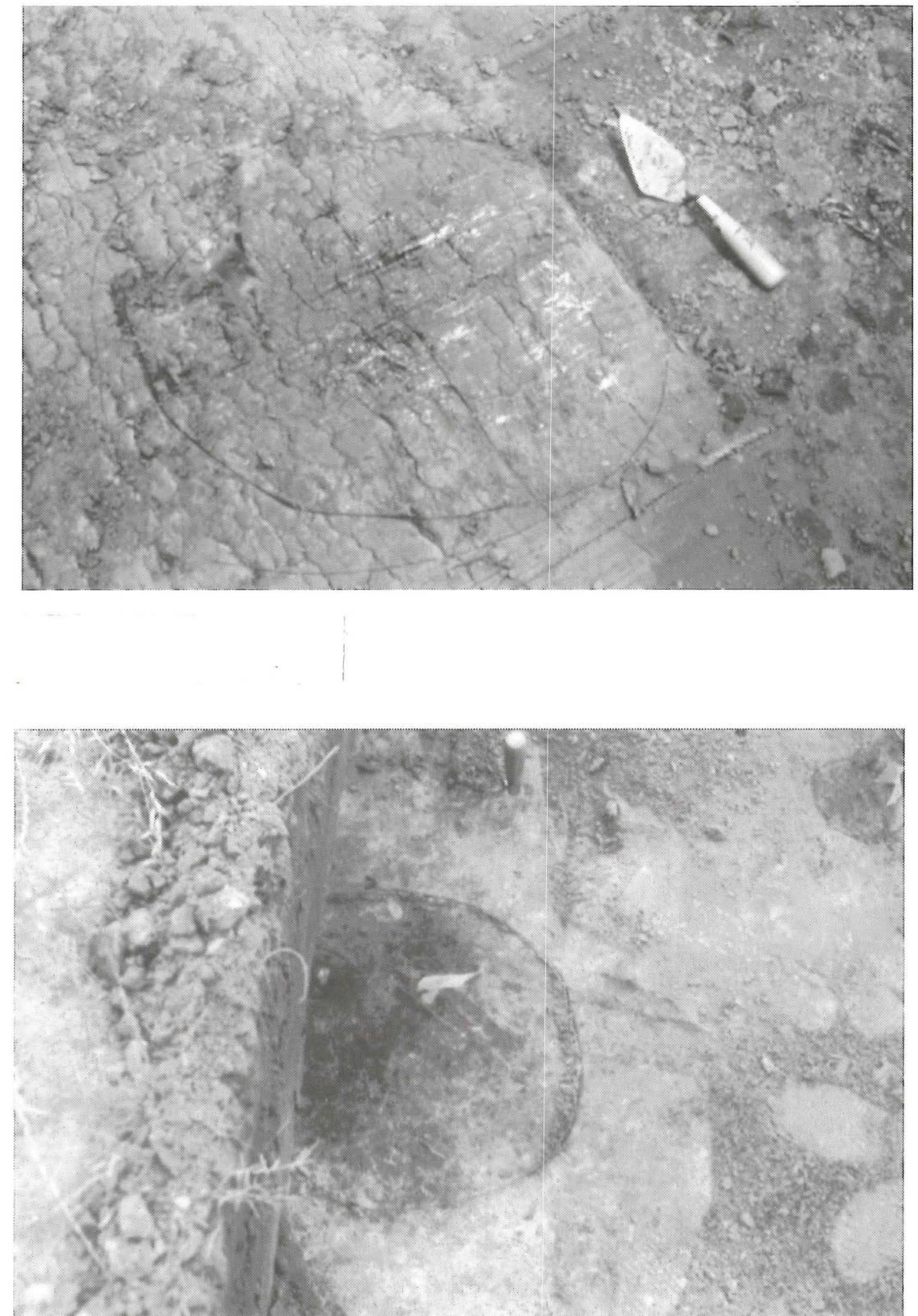

Figure 6-24. Southwest rise features: a, Feature 60; b, Feature 71. 
The larger cremation pits, such as Feature 64 and 65, evidence multiple periods of use, based on the internal stratigraphy of the features (see Figure 6-8b, f) and the weight of the human bone (see Chapter 12, this volume, and Appendix XVIII). In Feature 64 (Burial 11), a stack of seven unburned but poorly preserved long bones was present in the pit fill, along with a pile of teeth fragments, and at least three, but possibly four, separate episodes of pit re-use were recorded. It appears that a large pit was initially dug that had diffusely scattered human bone, along with the stack of unburned long bones, placed in the pit with midden fill. A calibrated one-sigma radiocarbon date on charred nutshells from the midden fill ranges from 1007-890 BC ( $R A=0.77)$, and the deposition of the long bones and teeth must post-date that age.

Subsequently, three separate pits (see Figure 6-8b)--about the size of other single secondary cremations (see Table 6-13)--were then excavated within the larger pit to contain compact deposits of cremated human bone.

The multiple cremations are located in the center of the area where burial internments were made on the Southwest rise (see Figure 6-23), and Feature 64 clearly sits in the middle of the cemetery. A total of 13 burial pits are present in the $90 \mathrm{~m}^{2}$ cemetery area. Single cremations occur in all directions from the center of the cemetery, but otherwise exhibit no clear intra-cemetery spatial patterning. Cremations that are present in the midden itself are not intrusive into it, but clearly originate in the midden deposits. The cremations contain few archaeological materials (see Table 6-3), with the exception of Feature 64, primarily burned clay, fire-cracked rock, and lithic debris. Feature 64 contained 667 pieces of lithic debris, $11 \mathrm{~g}$ of burned clay, 59 fire-cracked rocks, and a broken bifacially worked lithic tool There is no evidence of in situ burning associated with any cremation on the Southwest rise, thus the presence of a crematory basin can be inferred for the Hurricane Hill site (possibly the Feature 25 cremation on the North rise?), even though its location is unknown.

The cremations are temporally associated with the Southwest rise midden and pit features. Calibrated radiocarbon dates from three features on the rise (Feature 62, Feature 71, and Feature 91; see Figure 6-23) range from 307-207 $\mathrm{BC}(\mathrm{RA}=0.79)$ to $\mathrm{AD} 118-232(\mathrm{RA}=1.00)$. This dating evidence, and the circumstantial link between the midden, pit features, and cremations indicate that the cremations date to the earlier part of the Early Ceramic period, slightly overlapping with the Early Ceramic period midden and features on the North rise.

Other types of human remains of the Southwest rise were composed of poorly preserved, disarticulated remains of unburned individuals, as with Burial 15 or Feature 77 (Figure 6-25). This particular burial feature contained remains from two individuals, an adult and a sub-adult (see Chapter 12, this volume). These burials are in small pits that range in size from only $0.13-0.23 \mathrm{~m}^{2}$, at the lower end of the size of burial pits with flexed individuals from other sites at Cooper Lake (e.g., Martin 1997a; Cliff 1995:Table 6-22), and are interpreted as bundle burials of remains that had been previously buried or left exposed until the flesh and ligaments had fallen away. These burials contained very low amounts of archaeological material, primarily fire-cracked rock and lithic debris (see Table 6-3). The locations and depths of these burials (Table 6-14) also indicate that they originated in the Early Ceramic period midden.

Table 6-14. Data for Other Burials ${ }^{\text {a }}$ on the Southwest Rise.

$\begin{array}{lll}\text { Feature \# } & \begin{array}{l}\text { Area } \\ (\mathrm{sq} \mathrm{m})\end{array} & \begin{array}{l}\text { Depth } \\ (\mathrm{cm} \mathrm{bs})\end{array}\end{array}$

\begin{tabular}{lll}
\hline & & \\
69 & 0.23 & $35-55$ \\
69 & 0.17 & $41-45$ \\
73 & 0.13 & $48-61$ \\
77 & 0.15 & $14-20$ \\
81 & 0.16 & $38-50$ \\
& 0.20 & $43-48$ \\
\hline
\end{tabular}

\footnotetext{
${ }^{\mathrm{a}}$ Probable secondary bundle burials
} 


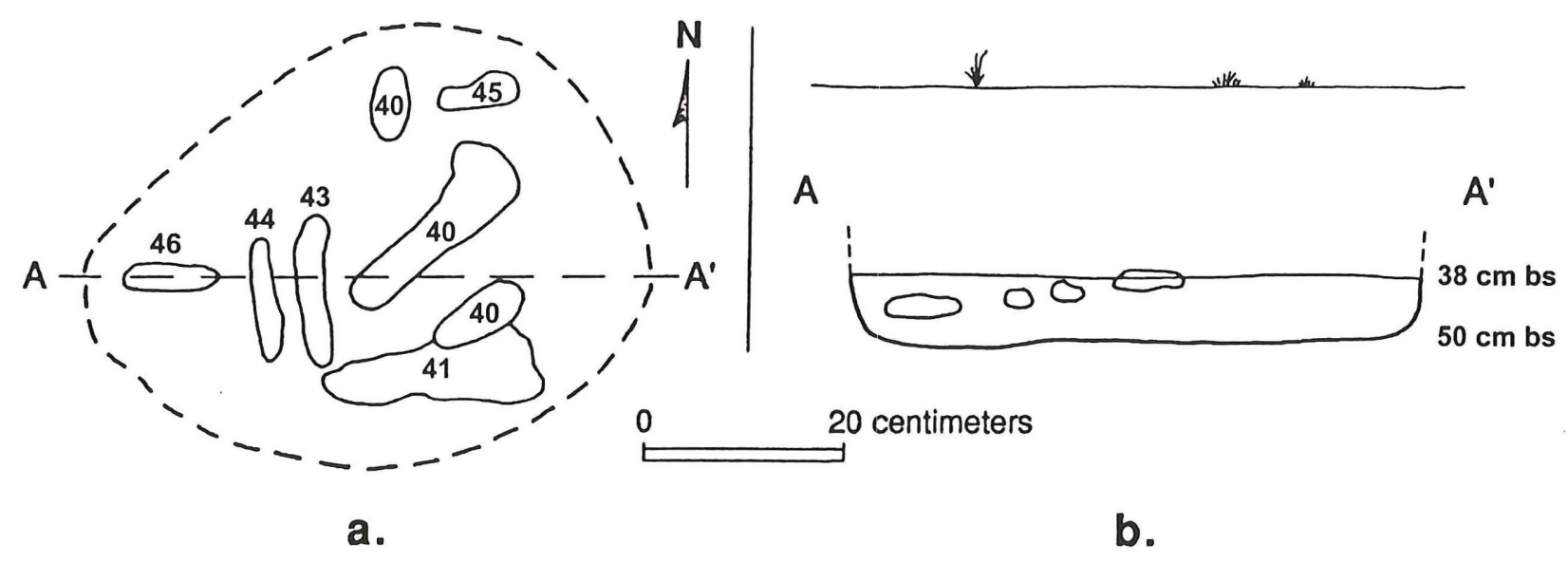

Figure 6-25. Plan and profile of Feature 77, Scrape area 6.

A single Southwest rise burial--Burial 13 (Feature 68)--dates to the Middle Caddoan period. The burial is a single, extended inhumation placed in a $1.86 \mathrm{~m}$ long x $0.60 \mathrm{~m}$ wide pit, excavated from $25-45$ $\mathrm{cm}$ bs (Figure 6-26). The burial pit had not been placed in the midden deposit, and it was the westernmost of the burials found on the rise (see Figure 6-23), but the fill of the pit was a dark brown charcoal-flecked sandy loam containing significant amounts of burned clay and fire-cracked rocks, as did the other Caddoan extended burials (see Table 6-3). The adult individual (see Chapter 12, this volume) was oriented northeastsouthwest, with the head turned to the side and facing to the southeast (see Figure 6-26). The skeletal material was very poorly preserved, with most of the ribs, articular endings, or feet and hand bones lacking, and probably disintegrated due to the acidic matrix of the burial fill. There were no intentionally-placed grave goods in the feature fill, but the recovery of a red-slipped sherd in the pelvic area, as well as two Steiner arrowpoints and a single Bassett arrowpoint in the fill, indicate that the burial must have been interred after around ca. A.D. 1200. This interment is thus contemporaneous with the Caddoan settlement on the South rise.

Only one other feature on the Southwest rise appears to be associated with a Caddoan use, Feature 75. This is a small pit that is intrusive into Burial 13 (Feature 68), the Middle Caddoan extended burial (see Figure 6-26). The feature itself contains only burned clay, fire-cracked rock, and lithic debris (see Table 6-4).

The other pits on the Southwest rise also contain relatively low densities of archaeological materials (see Table 6-4), including lithic debris, daub, burned clay, and fire-cracked rocks. Two pits (Feature 62 and Feature 94) have diagnostic Early Ceramic period varieties of Gary points in the fill, and a calibrated date on nutshells from Feature 62 has an age range of AD 78-148 (RA=0.64). These pits are distributed throughout the midden, as well as up to 5 meters east and west of the midden (see Figure 6-23).

A distinct class of pit that is represented at the Hurricane Hill site only on the Southwest rise is the organically-filled pits: Feature 61, the previously mentioned Feature 62, Feature 67, and Feature 71 (see Figure 6-23). Feature 71 has a calibrated radiocarbon age of 307-207 BC $(R A=0.79)$. These pits have a distinct organic-rich matrix (see Figure 6-24b), but contain almost no charcoal (see Cliff 1995:Table 6-18), and there is no evidence of in situ burning. They are small pits, ranging between $0.12-0.40 \mathrm{~m}^{2}$, and have very limited amounts of archaeological remains (Table 6-15). Feature 62 contains the majority of the artifacts from the organically filled pits on the Southwest rise, primarily lithic debris, fire-cracked rock, and burned clay. Cliff (1995:6-98) suggests that these organically-rich pits may be either the charcoal-stained bases of posts or small, shallow pits in which something was burned or decayed. Using the additional evidence from the features on the Southwest rise, it seems reasonable to conclude that they represent pits in 
which something was burned elsewhere, the contents winnowed in some manner, and then dumped into the small pits.

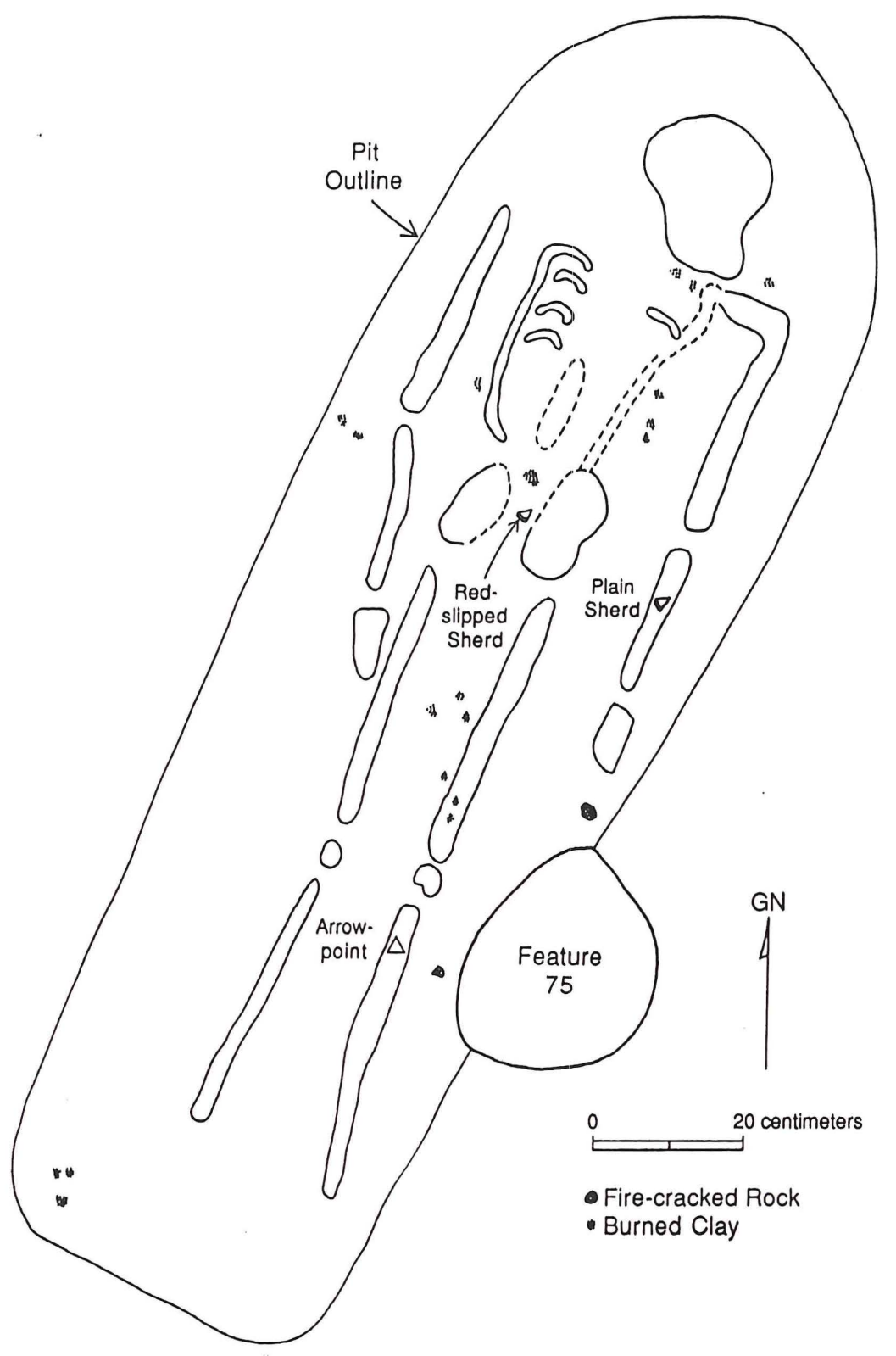

Figure 6-26. Feature 68, an extended Middle Caddoan burial on the Southwest rise.

Only a single posthole was recorded in the Southwest rise, Feature. 72 (see Figure 6-23). It is a small post, $0.021 \mathrm{~m}^{2}$ in area, that extends from $46-68 \mathrm{~cm}$ bs, originating in the midden. No cultural materials were recovered in association with the post except lithic debris (see Table 6-7). 
Table 6-15. Frequencies of cultural materials recovered from pits with organic-rich fill.

$\begin{array}{llll} & & \text { Lithic } & \text { Burned } \\ \text { Feature \# } & \text { Tools } & \text { Debris } & \text { Clay }\end{array}$

(g)
FCR

$(\mathrm{N})$
FCR

$(\mathrm{kg})$

\begin{tabular}{llllll}
\hline & & & & 7 & + \\
61 & & 72 & 5.2 & 32 & 0.4 \\
62 & 5 & 407 & & 1 & + \\
67 & 1 & 29 & & & + \\
71 & & 593 & 5.2 & 40 & $0.4+$ \\
\hline Total & 6 & & & & \\
\hline
\end{tabular}

A type B or rock hearth, Feature 76, was uncovered in Scrape Area \#7 on the Southwest rise (see Figure 6-23). The hearth basin extended from $7-38 \mathrm{~cm}$ bs, and is estimated at $85 \mathrm{~cm}$ in diameter. The feature contained large amounts of fire-cracked rock, burned clay, lithic debris, and stone tools (see Table 6-5). Represented among the stone tools were three Gary var. Camden and var. LeFlore projectile points, temporal diagnostics of the Early Ceramic period (e.g.,. Schambach 1982). The few ceramic sherds from the hearth include only one decorated piece, a diagonal incised/zoned punctated rim sherd (see Appendix V). Based on the internal stratification of the feature contents, and the fact that there were two vertically distinct lens of fire-cracked rock in the fill, the hearth had probably been reutilized on at least one occasion after the feature basin had been initially dug out.

An unusual charcoal and ash-stained feature was exposed in the gradall scraping on the Southwest rise. This feature, Feature 70, is located a few meters to the south of the midden (see Figure 6-23). The feature is a $3.0 \mathrm{~m} \mathrm{x} 1.8 \mathrm{~m}$ oblong stain that was uncovered at a depth of $10 \mathrm{~cm}$ bs (Figure 6-27). Within the larger stain are two areas of oxidized soil, burned clay, and ash, and around the two areas of burning are several areas of stains and possible burned posts. The 15 possible burned posts (1-6 on Figure 6-27 are stains without wood, while A-I are stains with wood) also originate at $10 \mathrm{~cm} \mathrm{bs}$, and extend to a depth of only $25 \mathrm{~cm}$ bs. Upon further exposure, the tops of the burned posts usually gave way to unburned sections of the same post at the base of the posthole, and several portions of unburned posts were also recorded.

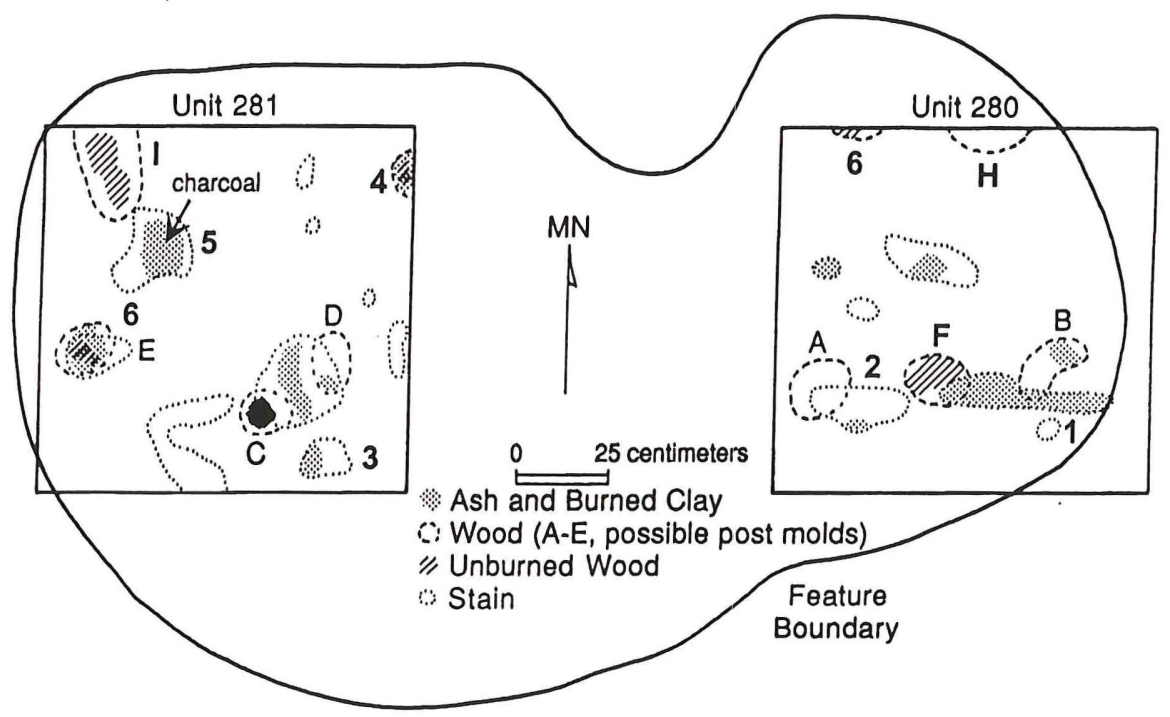

Figure 6-27. Feature 70, Southwest rise. 
The shallow depth of the feature stains and posts, as well as the presence of unburned wood (unlikely to have been preserved for long in the acidic soil conditions) suggests that this feature is of recent historic age. Upon excavation of the feature fill in two adjacent 1 x 1-m units (Unit 280 and 281), however, no historic period artifacts were noted in association with the feature, but a large quantity of prehistoric materials were recovered. Nevertheless, the overall character of the feature is more suitably considered to be of late 19 th or early 20 th century age, perhaps associated with the farmsteads at Historic locality 1 or 2 (Perttula 1989e), than it is with the Early Ceramic occupation on the Southwest rise at the Hurricane Hill site. A small amount of post- 1890s materials have been recovered in the Phase I-IV investigations at the site, especially from the South rise (see Appendix II), but no obvious features were uncovered that permit an accurate assessment of the type of use that occurred there. Feature 70 is equally equivocal, if not more so, than the data obtained in the intensive investigations, unfortunately. Clearly, because of the large amounts of charcoal and ash concentrated in two areas of the feature, an intense surface fire was in use, and the fire locations were partially encircled by small $(8-13 \mathrm{~cm}$ in diameter) wood posts. Perhaps the feature is an outdoor smoker built during historic times atop prehistoric deposits on the Southwest rise.

\section{General Comments Concerning Features at the Hurricane Hill Site}

The large number of cultural features at the Hurricane Hill site has provided a wealth of useful information on the intensity and intra-site distribution of the different primary occupations at the site, namely the Late Archaic/Early Ceramic, Early Caddoan, and Middle Caddoan period settlements/components. Of particular significance are: (1) the cremations, bundle burials, and extensive midden deposits associated with the Late Archaic/Early Ceramic components on the North and Southwest rises, and (2) the Early and Middle Caddoan structures and associated middens.

Even with respect to the contents of the features themselves, the relative densities of cultural materials (Table 6-16) provide an indication of the composition of the midden deposits, variations in the intensity and extent of refuse disposal, and an idea about the kinds of material culture remains typically found in conjunction with certain features. Tabulating the relative frequency of the various kinds of features present on the North, South, and Southwest rises (Table 6-17) illustrates rather clearly, however, differences in the nature of settlement between the Late Archaic/Early Ceramic and Caddoan components.

Table 6-16. Mean frequencies of cultural materials by feature class.a

\begin{tabular}{|c|c|c|c|c|c|c|c|c|}
\hline Feature Class & $\begin{array}{l}\text { Lithic } \\
\text { Tools }\end{array}$ & $\begin{array}{l}\text { Lithic } \\
\text { Debris }\end{array}$ & Sherds & $\begin{array}{l}\text { Daub } \\
\text { (g) }\end{array}$ & $\begin{array}{l}\text { Burned } \\
\text { Clay } \\
\text { (g) }\end{array}$ & $\begin{array}{l}\text { FCR } \\
(N)\end{array}$ & $\begin{array}{l}\text { FCR } \\
(\mathrm{kg})\end{array}$ & Fauna \\
\hline \multicolumn{9}{|l|}{ Burials: } \\
\hline Extended $(n=6)$ & 21.0 & 569.2 & 52.0 & 9.6 & 81.6 & 112.7 & 1.4 & 4.0 \\
\hline Cremation $(n==7)$ & 2.0 & 152.4 & 0.1 & 1.1 & 21.1 & 13.6 & 0.2 & 7.4 \\
\hline Other $(n=7)$ & 0.7 & 38.7 & 0.3 & + & 0.2 & 6.0 & 0.1 & -- \\
\hline Pits $(n=25)$ & 1.4 & 39.5 & 1.0 & 0.1 & 2.6 & 4.3 & 0.1 & 3.8 \\
\hline \multicolumn{9}{|l|}{ Hearths: } \\
\hline$A(n=3)$ & 2.0 & 75.3 & 14.0 & 63.6 & 419.6 & 27.0 & 1.4 & 258.0 \\
\hline$B(n=2)$ & 6.0 & 281.5 & 4.5 & -- & 230.2 & 175.5 & 20.5 & -- \\
\hline \multicolumn{9}{|l|}{ Stains / } \\
\hline Postholes(n=15) & 0.7 & 7.3 & 0.2 & -- & 1.1 & 1.1 & + & 0.1 \\
\hline \multicolumn{9}{|l|}{ Organic- } \\
\hline Rich Pits $(n=4)$ & 1.5 & 148.3 & -- & - & 1.3 & 10.0 & 0.1 & - \\
\hline
\end{tabular}

a The frequency data was calculated only for features that contained cultural materials 


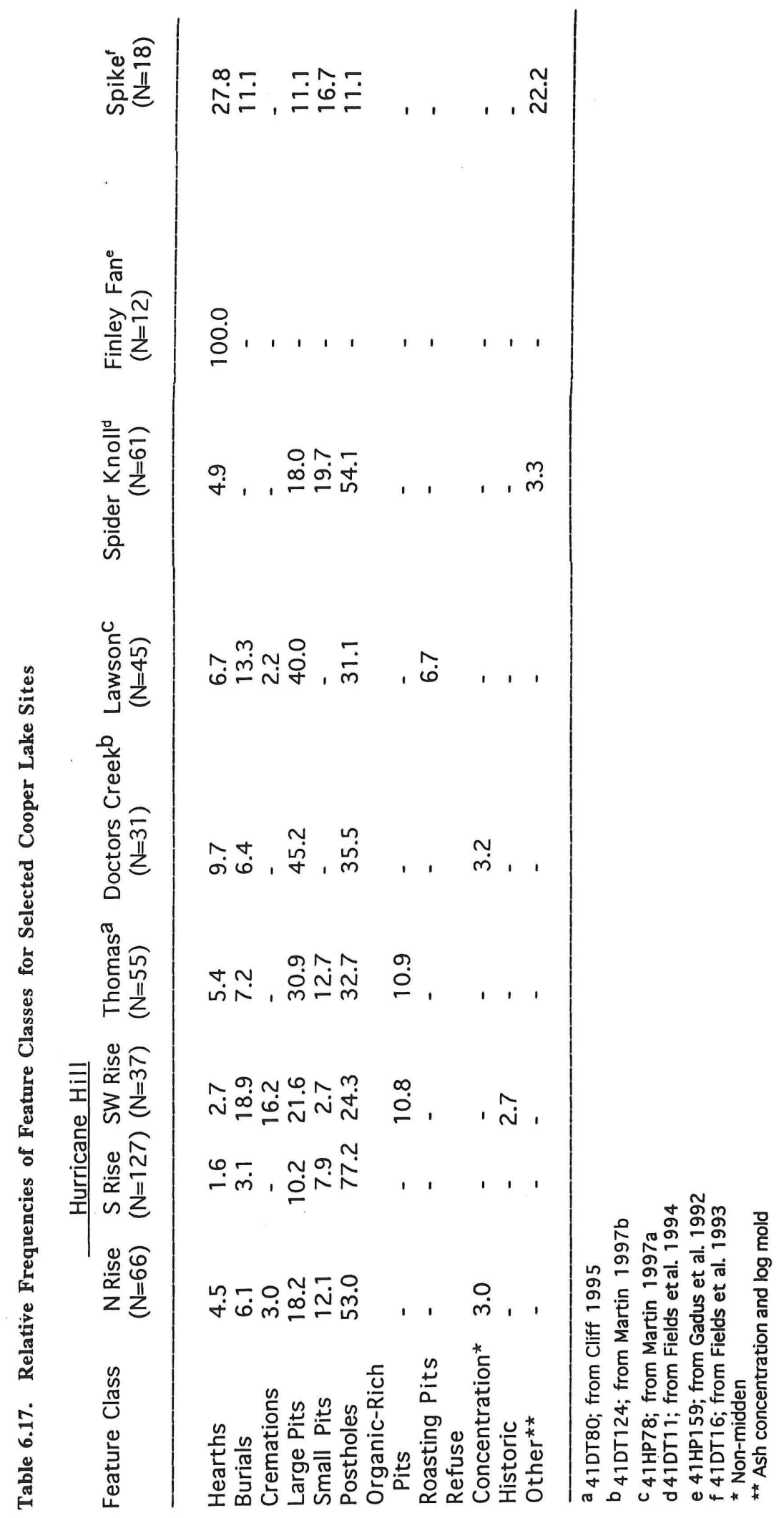


The Late Archaic and Early Ceramic period features (dating between ca. 1000 B.C. and A.D. 500) are restricted to the Southwest rise and the North rise, and include substantial midden deposits on both rises. The other features are represented primarily by human internments--including bundle burials and cremated burials containing one to several individuals--large and small pits of uncertain function, and organicallyfilled pits utilized for burning unknown substances (see Table 6-17). The few postholes/stains that may be of Late Archaic/Early Ceramic age may represent remnants of a structure of some kind, but clearly does not constitute evidence for a multi-seasonal or sedentary occupation during those periods. Instead, the midden deposits probably represent a periodic but concentrated accumulation of refuse from a number of different occupations during the Late Archaic/Early Ceramic period, the locale being apparently revisited for habitation purposes. The use and maintenance of a cemetery on the Southwest rise was also an important aspect of the Late Archaic/Early Ceramic occupation at the site, and may imply a relatively intensive occupation (i.e., Fields et al. 1997:58).

Midden deposition and a substantial material culture record from Early Ceramic period use of the North and South rise also suggests they were the location of intensive seasonal occupations, probably foraging camps as well as places of lithic tool manufacture and maintenance, and the scene of at least two cremations. The majority of information available about the Early Ceramic period settlement on the North and South rises comes from the North rise, particularly the Primary Midden archaeological deposits. Substantial Block D and Block E excavations in those deposits produced an abundance of material culture remains relating to that period, particularly lithic tools and debris, but the absence of features probably indicates the intermittent and short-term nature of the occupations.

On the North and South rises, much of the feature evidence, and the substantial midden deposits with ceramics, animal bones, and tropical cultigens (maize and squash), clearly point to the fact that permanent habitations were built and maintained by Caddoan peoples there between ca. A.D. 1000-1200, and A.D. 1250-1400, respectively. Based on the estimated sizes (in $\mathrm{m}^{2}$ ) of the structures, the five different structures contained between 6-11 individuals each. As only two of the structures (Structures A and C on the South rise) may have been occupied contemporaneously, the various Caddoan components at Hurricane Hill appear to be small farmsteads rather than the product of a hamlet or small village.

The Caddoan settlement of the two rises is represented by an abundance of postholes and pits (see Table 6-17), the latter probably serving as storage and cooking facilities before they were filled with trash and midden, arranged in clear association within structures, or in extra-mural contexts. Extended burials were placed outside the structures (as was a dog burial) in or near discrete Caddoan midden deposits, but away from yard areas where other pits, refuse concentrations, and activity areas probably took place. One burial was placed in a sub-floor pit. None of the burials contained grave goods.

The relative frequency of Caddoan features on the North and South rises contrasts with the types of features recorded at earlier Archaic, Early Ceramic, and Early Caddoan settlements excavated at Cooper Lake where features were well-preserved (see Table 6-17). Burials, hearths (located outside of houses, as well as rock hearths in Archaic contexts at Finley Fan), ash concentrations, and large pits were in general much more frequent than they were at Hurricane Hill. At Spider Knoll, the proportions of postholes and pits are quite comparable to the North and South rises, and constitute good evidence for the residential nature of the two areas at Hurricane Hill and Spider Knoll. Nevertheless, the excavations at Spider Knoll did not uncover well-defined posthole patterns or structural remains (Fields et all. 1997:Figure 35) in the Early Caddoan component, while more substantial house remains are present at least on the South rise at Hurricane Hill in Middle Caddoan times. It is likely that these differences relate to local and temporal variability in Caddoan occupational intensity and settlement permanence within the Cooper Basin area (e.g., Bousman et al. 1988:23, 29; Fields et al. 1997:91) between ca. A.D. 900-1400. Trends in the permanence of settlement, differences in use intensity, and population dynamics before and after ca. A.D. 1200-1300 suggested by Fields et al. (1997), and hinted here in the comparison of the feature data probably have a regional significance in Caddoan native history (see also Chapter 16, this volume). 


\title{
CHAPTER 7, \\ OVERVIEW OF THE PREHISTORIC COMPONENTS AT THE HURRICANE HILL SITE, AND INTRA-SITE SPATIAL ANALYSES OF ARTIFACTS AND FEATURES
}

\author{
Timothy K. Perttula
}

\begin{abstract}
The material remains recovered from the Hurricane Hill site have provided diverse sources of information (e.g., features, tool types, ceramics, etc.) concerning the settlement and occupational history of the site. Although the evidence summarized in Chapters 5 and 6 indicates that the vast majority of the features and anthropogenic midden deposits identified at the site belong to either Late Archaic/Early Ceramic period, Early Caddoan period, and Middle Caddoan period occupations, the recovered archaeological materials document a lengthy use of each different landform, extending back in certain cases to as much as 10,000 years B.P. during the Late Paleoindian era. However, the primary evidence for delineating other occupations or components, besides the three main components that contain many features, midden deposits, and a wide assortment of material culture remains, is projectile point types and their vertical and horizontal distribution across the site (see Chapter 8, this volume).
\end{abstract}

\section{Age and Definition of Prehistoric Components}

A total of 29 radiocarbon, thermoluminescence (TL), and archaeomagnetic dates are in hand from the Hurricane Hill site, one of the larger samples of absolute dates available from a prehistoric archaeological site in Northeast Texas (see Perttula 1998a, 1998e; Story 1990). These include eight radiocarbon dates and two TL dates from the North rise (Figure 7-1); seven radiocarbon dates, six TL dates, and a single archaeomagnetic date from the South rise (Figure 7-2); and five radiocarbon dates from the Southwest rise (Figure 7-3).

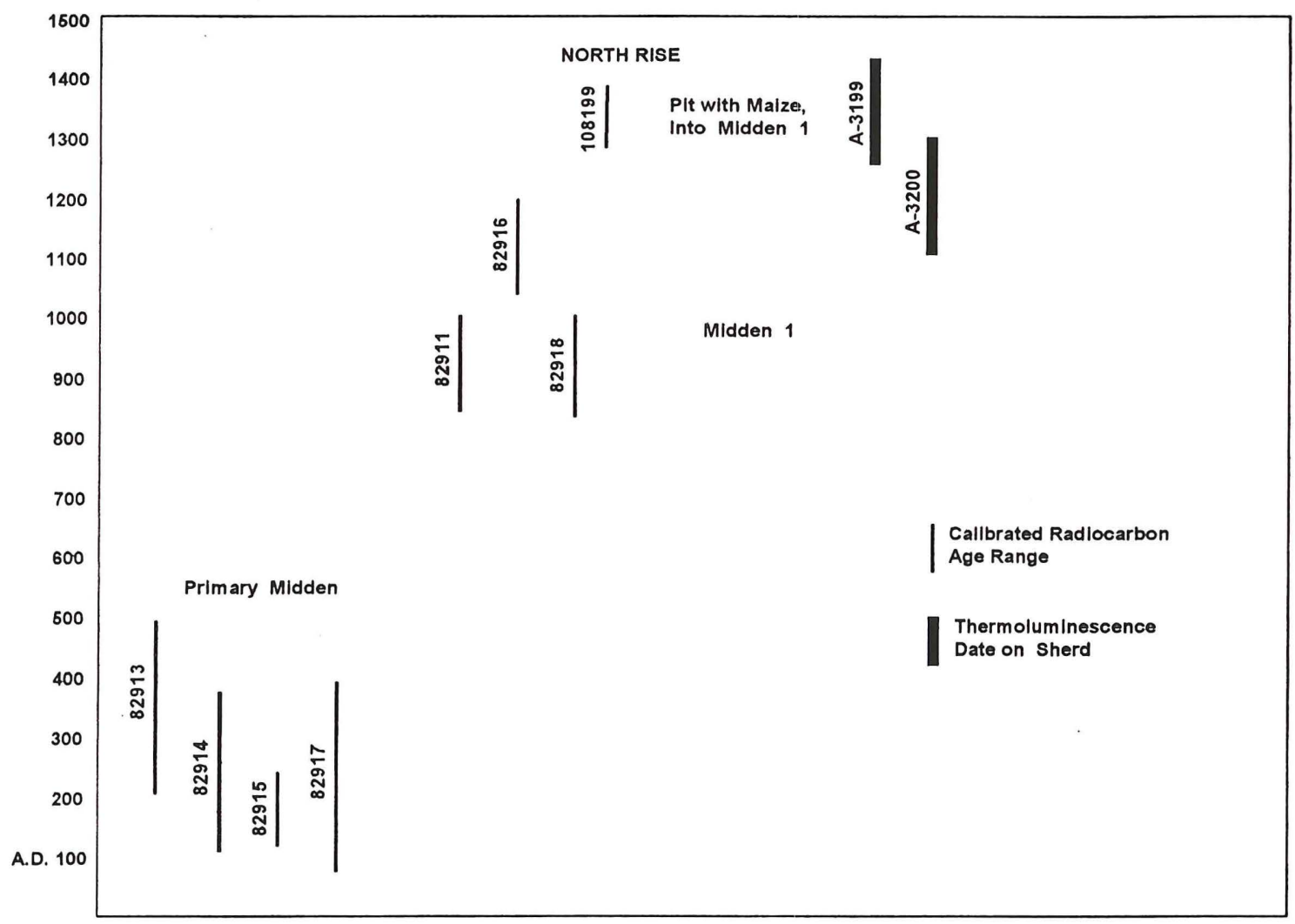

Figure 7-1. Radiocarbon and thermoluminescence dates from the North rise. 


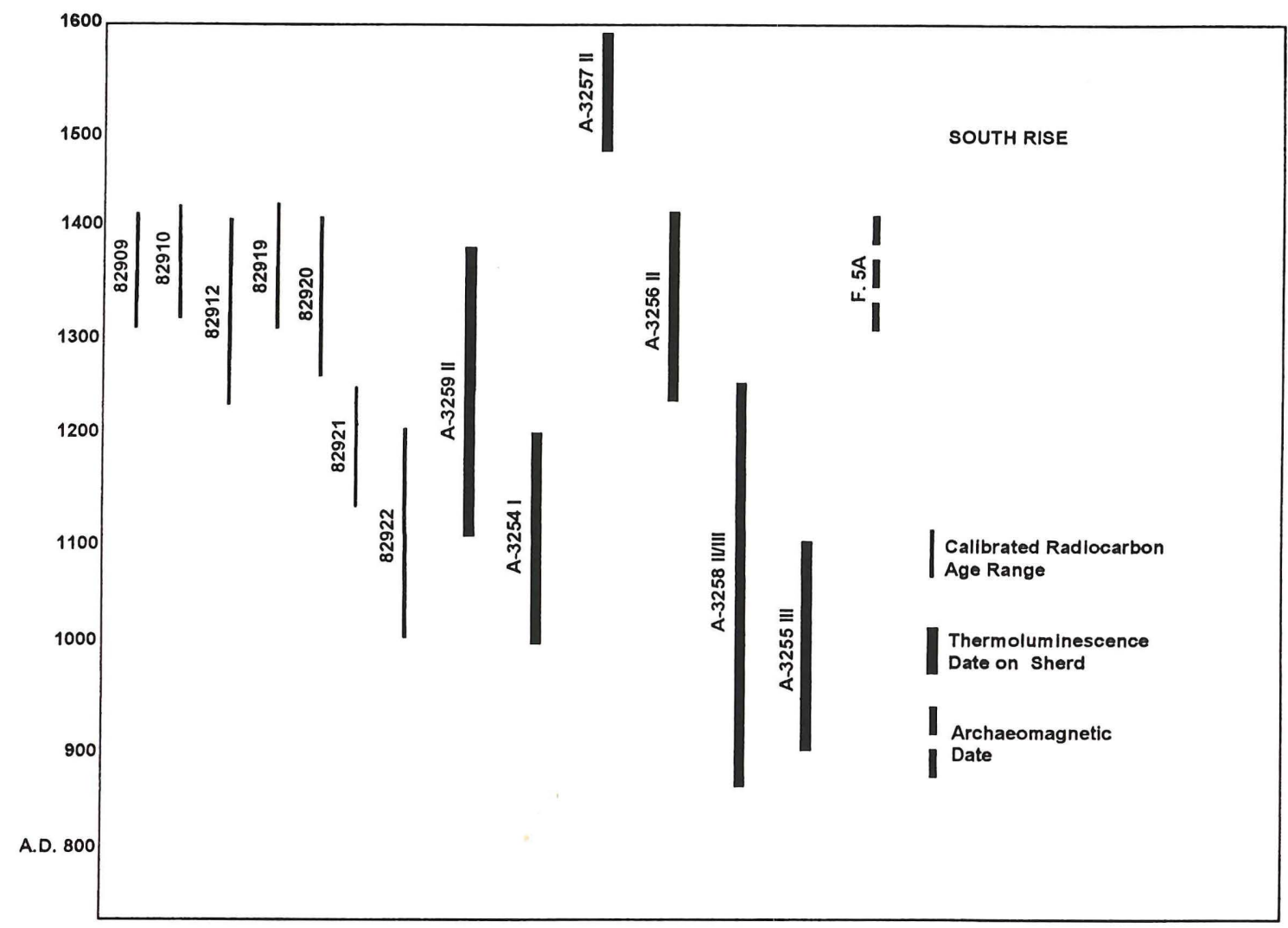

Figure 7-2. Radiocarbon, thermoluminescence, and archaeomagnetic dates from the South rise.

Twenty radiocarbon dates have been obtained from various midden and feature contexts at the Hurricane Hill site (Table 7-1). The results of the radiocarbon assays are presented first, and in conjunction with archeomagnetic and TL dates, these dates will be used to offer age estimates for the major occupations at the site (see also Perttula 1997a). The interpretations offered herein of the radiocarbon dates are based on: (1) the intra-site provenience and context of the radiocarbon samples, particularly midden and feature relationships, and (2) artifact associations. I discuss the results by natural rise, because each rise appears to have had a different occupational history. After considering the absolute age ranges of the principal archaeological components at the site, and estimating their temporal span, other classes of data (i.e., the vertical and horizontal distribution of projectile points, ceramics, daub, burned clay, and fire-cracked rocks in midden, feature, and natural rise contexts) are reviewed to establish the depositional context and archaeological content of the Late Archaic, Early Ceramic, Early Caddoan, and Middle Caddoan components at the Hurricane Hill site. 


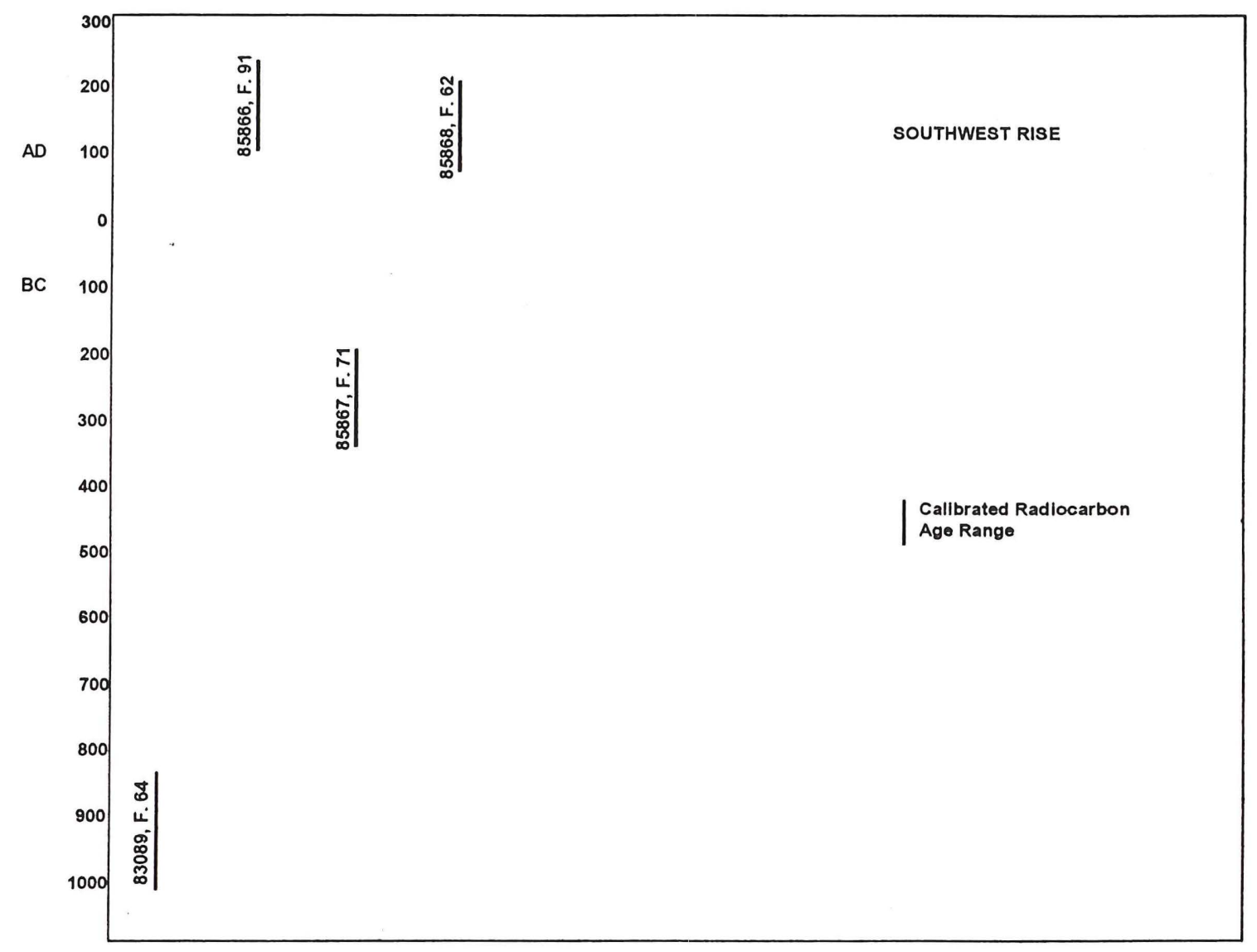

Figure 7-3. Radiocarbon dates from the Southwest rise.

\section{North Rise}

Assays Beta-82913, 82914, 82915, and 82917 are from midden contexts in Blocks A, D, and E on the North rise (see Figure 7-1). They date the Primary Midden, an Early Ceramic or Woodland period deposit that covered the entire North rise (see Chapter 5). In terms of probabilities at one sigma, the calibrated age span of the Primary Midden is cal A.D. 59-449 (see Table 7-1). The most common diagnostic Early Ceramic period artifacts on the North rise are the Gary var. LeFlore and var. Camden dart point forms, which Schambach $(1982,1998)$ estimates date to 450 B.C.-A.D. 250 and A.D. 250-700, respectively.

Overlying the Primary Midden in two areas of the North rise are two small Caddoan middens labeled Midden 1 and Midden 2 (see Chapter 6, this volume). Much of Block A is within the Caddoan Midden 1, and the two calibrated radiocarbon dates from this context (Beta-82916 and 82918) are AD 1154 1213 (relative area under probability distribution $[\mathrm{RA}]=0.45$, but the $\mathrm{RA}$ is 0.65 for the calibrated $\mathrm{AD}$ 1117-1213 range) and $A D$ 882-1039 $(R A=1.00)$. Feature 2, an extended Caddoan burial at the south edge of the North rise (with no grave goods but abundant sherds from Midden 2 fill), has a calibrated radiocarbon date of AD 959-1029; this is contemporaneous with Beta-82918. A more recent use of the North rise, presumably contemporaneous with the Middle Caddoan occupation on the South rise (specifically Structure $\mathrm{B})$, is indicated by the calibrated date of AD 1249-1285 from charred maize cupules in an apparently deep pit in Unit 259, 60-65 cm, excavated into Midden 1 (see Figure 7-1). 


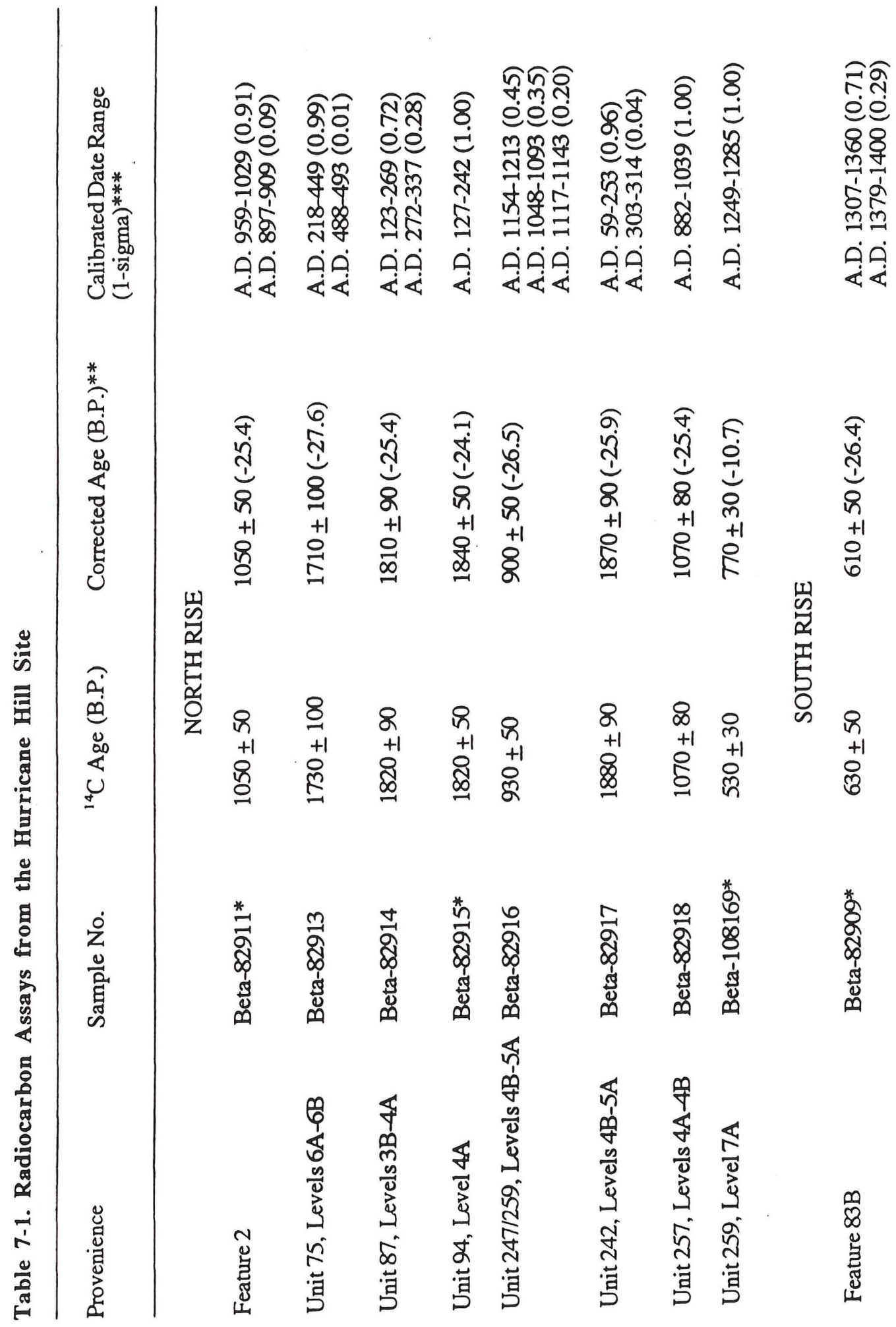




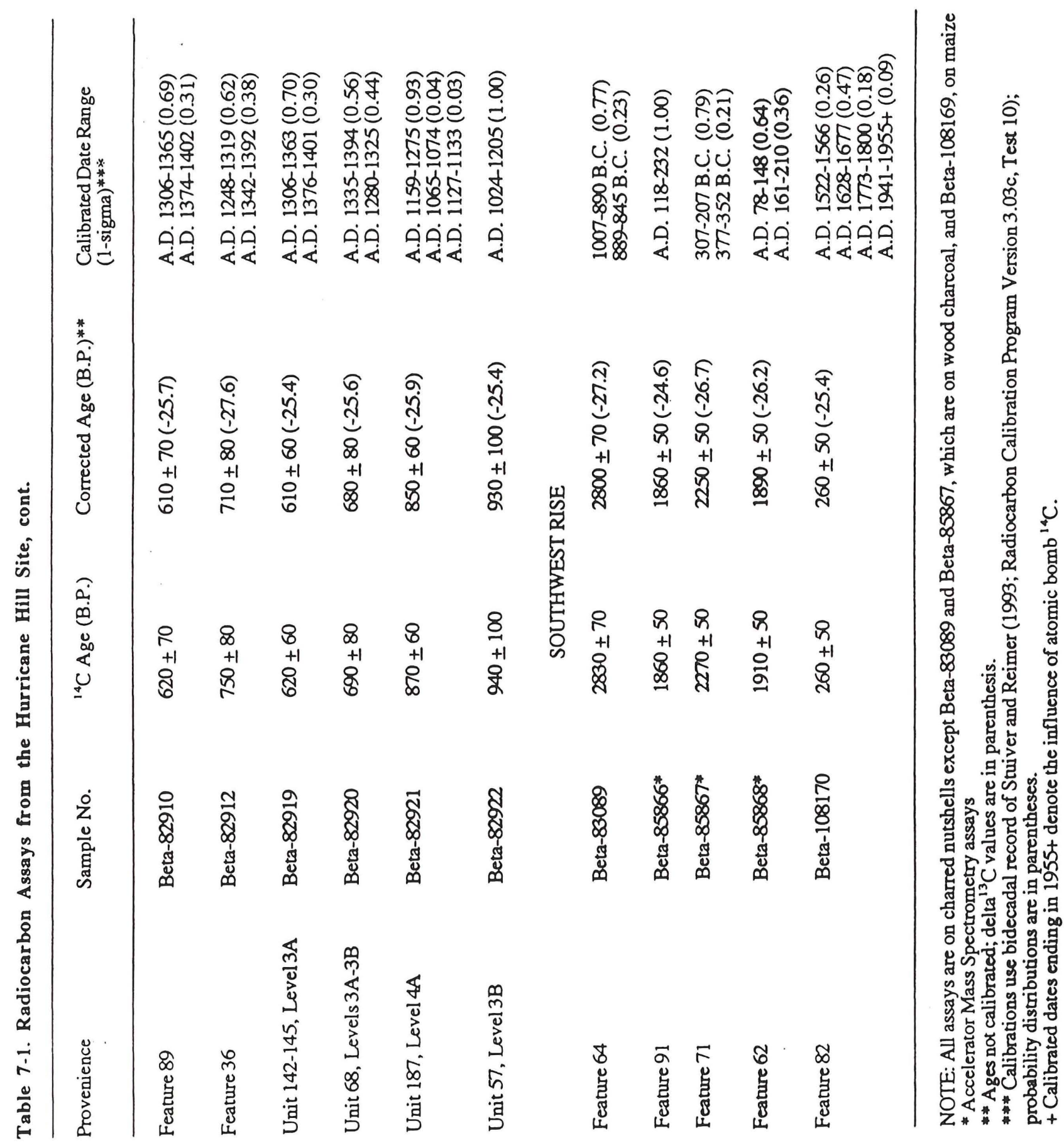


Based on the three dates from Midden 1, and the abundance of Alba, Scallorn, and Steiner arrowpoints and Crockett Curvilinear Incised and other distinctive decorated ceramics on the North rise (see Chapter 8, this volume), these radiocarbon assays clearly pertain to an Early Caddoan period (ca. A.D. 900/1000-1200) use of this part of the Hurricane Hill site. Presumably, the two sequential structures there (Structures D and E) also date to this period, with Structure E being the earlier structure since Midden 1 overlays it.

Thermoluminescence (TL) dates were obtained from two grog-tempered sherds of common utility wares in Midden 1 on the North rise (Table 7-2): A.D. $1210 \pm 90$ (45 cm below the surface) and A.D. 1370 \pm 100 ( $25 \mathrm{~cm}$ below the surface). Four other sherds from other contexts in Midden 1 were also submitted for TL dating, but each of the sherds exhibited anomalous fading (e.g., Aitken 1985), and accurate estimates of the dates could not be obtained. The 95 percent confidence intervals for the two TL dates from the Caddoan midden on the North rise, which are in stratigraphic order, overlap between A.D. 1170 and 1390, which appear to be too recent given the calibrated radiocarbon dates from Midden 1.

Table 7-2. Archaeomagnetic and Thermoluminescence (TL) dates.

$\begin{array}{lllll}\text { Provenience } & \begin{array}{l}\text { Depth } \\ (\mathrm{cm} \mathrm{bs})\end{array} & \begin{array}{l}\text { Stratigraphic } \\ \text { Zone }\end{array} & \text { Date Lab \# } & \text { Type of Sherd }\end{array}$

\begin{tabular}{|c|c|c|c|c|}
\hline \multicolumn{5}{|c|}{ North Rose, Block A } \\
\hline Unit 40, F.4 & 19 & II & (Alpha-3252) & \multirow{2}{*}{$\begin{array}{l}\text { grog-tempered, plain } \\
\text { body sherd }(7.0 \mathrm{~mm}) \\
\text { grog-tempered, plain } \\
\text { body sherd }\end{array}$} \\
\hline Unit 27 & 25 & II & AD $1370 \pm 100$ (Alpha-3199) & \\
\hline Unit 29 & 26 & II & (Alpha-3201) & $\begin{array}{l}\text { grog-tempered, plain } \\
\text { body sherd }(9.0 \mathrm{~mm})\end{array}$ \\
\hline Unit 30 & 26 & II & (Alpha-3251) & $\begin{array}{l}\text { grog-tempered, plain rim } \\
(8.9 \mathrm{~mm})\end{array}$ \\
\hline Unit 42 & 37 & II / III & (Alpha-3253) & $\begin{array}{l}\text { grit-tempered, LeFlore } \\
\text { Plain sherd }(8.0 \mathrm{~mm})\end{array}$ \\
\hline Unit 32 & 45 & II/ III & $\mathrm{AD} 1210 \pm 90$ (Alpha-3200) & $\begin{array}{l}\text { grog-tempered, base sherd } \\
(12.0 \mathrm{~mm})\end{array}$ \\
\hline \multicolumn{5}{|c|}{ South Rise, Block B/C } \\
\hline Unit 61 & 17 & II & AD $1250 \pm 170$ (Alpha-3259) & \multirow{5}{*}{$\begin{array}{l}\text { grog-tempered, plain } \\
\text { body sherd ( } 7.9 \mathrm{~mm}) \\
\text { archaeomagnetic date } \\
\text { LeFlore Plain ( } 6.2 \mathrm{~mm}) \\
\text { grog-tempered, plain } \\
\text { body sherd ( } 9.7 \mathrm{~mm}) \\
\text { grog-tempered, plain } \\
\text { body sherd ( } 9.5 \mathrm{~mm})\end{array}$} \\
\hline Unit $172, F .5 A$ & 20 & II & $\mathrm{AD} 1300 \pm 50$ & \\
\hline Unit 57 & 20 & II & AD $1090 \mp 100$ (Alpha-3254) & \\
\hline Unit 61 & 22 & II & AD $1540 \pm 60$ (Alpha-3257) & \\
\hline Unit 58 & 25 & II & $\mathrm{AD} 1320 \pm 90($ Alpha-3256) & \\
\hline Unit 62 & 29 & II/ III & AD $1050 \pm 200($ Alpha-3258) & \multirow{2}{*}{$\begin{array}{l}\text { grog / grit-tempered, plain } \\
\text { body sherd ( } 8.0 \mathrm{~mm}) \\
\text { grog-tempered, plain } \\
\text { body sherd }(10.5 \mathrm{~mm})\end{array}$} \\
\hline Unit 58 & 30 & III & AD $1020 \pm 120($ Alpha-3255) & \\
\hline
\end{tabular}

a Anomalous TL date

\section{South Rise}

The South rise radiocarbon dates (see Table 7-1) are from the following contexts: two small pits (Features 83B and 89) some 10-20 m from two overlapping Caddoan structures (Structures A and B); Feature 36 (Burial 5), an extended Caddoan burial (without grave goods) in a pit associated with the earlier structure (Structure B); nutshells thought to be associated with floor trash deposits of Structure A (Beta- 
82919 and 82920); and nutshells from contexts associated with Structure B (Beta-82921 and 82922). The artifacts (such as Hayes, Bonham, and Perdiz arrowpoints and plain grog-tempered and red-slipped ceramics, Sanders Engraved, other distinctive engraved decorative elements, non-shell-tempered brushed pottery, and several Maxey Noded Redware sherds) and an archeomagnetic date of A.D. $1300 \pm 50$ on the central hearth of Structure A suggest that the main Caddoan component on the South rise dates to the Middle Caddoan period (ca. A.D. 1200-1400).

The South rise dates readily cluster into two groups. The first group of calibrated dates (Beta-82921 and 82922), thought to be associated with Structure B, span the period from cal. AD 1024-1275. The other date from a Structure B context is cal. AD 1248-1319, the Feature 36 burial. The Beta-82922 assay does not appear to be a useful radiocarbon assay, for it implies that Structure B predates Structure A (see below) by at least 100 years (and possibly as many as 280 years), when the archaeological evidence of central hearth and posthole pattern superpositioning (see Chapter 6, this volume), as well as the spatial distribution of artifacts within the structures (see below) is much more consistent with Structures A and B dating to within one or two generations of each other. With the radiocarbon and archaeomagnetic dates at hand, it is suggested that Structure B dates from the mid-13th century to the beginning of the 14th century.

The second South rise group of four dates ranges from cal. A.D. 1306-1394; three cluster between cal. A.D. 1306 and 1365 (see Figure 7-2). They include the two extramural pits and the nutshells from the floor of Structure A. These calibrated radiocarbon assays indicate that the Caddoan Structure A on the South rise, and associated extramural work areas, was probably built and used through the first half to threequarters of the 14th century.

On the South Rise, the six TL dates range from A.D. $1020 \pm 120$ to A.D. $1540 \pm 60$, but actually cluster into three groups: (a) three dates between A.D. 1020 and A.D. 1090; (b) another three dates which range from A.D. 1250-1320; and (c) a single date of A.D. $1540 \pm 60$ (see Table 7-2). Because of the age range apparent in the TL dates, and the fact that the Caddoan ceramics submitted for TL dating were suspected to derive from sequent houses, and not separated by a significant span of time, there are incongruities. There is no clear difference in the age of the sherds that correlates with depth, and thus with possible "surfaces" or floors associated with the two houses. However, the close superpositioning of hearths and posts seems to strongly indicate that the two episodes of house construction were not separated by much of a time interval. Nevertheless, the clustering of the TL dates into two non-overlapping (at the 67 percent confidence interval) groups suggests the possibility that there was an Early Caddoan period occupation on the South rise prior to the construction of Structure $B$, the first house on the rise. The possibility is considered likely, given some of the types of arrowpoints (e.g., Scallorn, Steiner, and Alba) recovered on the South rise in Block B/C, as these forms have been documented in ca. A.D. 900-1300 contexts at various Cooper Lake sites (Fields et al. 1997).

Given the interpretation from the radiocarbon dates and the artifacts that the South rise was occupied primarily by Caddoan peoples between ca. A.D. 1250-1375 and the fact that only two of the TL dates (both probably associated with Structure A, see below) fall within this range, it seems reasonable to conclude that the TL dates are less reliable than the calibrated radiocarbon dates on charred nutshells. They may be as much as 200-300 years too young or too old.

The two TL dates of A.D. $1250 \pm 170$ and A. D. $1320 \pm 90$ may be associated with Structure A on the South rise, as these dated sherds were found between $17-25 \mathrm{~cm}$ below the surface. An archaeomagnetic date, A.D. $1300 \pm 50$, was also obtained (by Dr. Brooks Elwood, The University of Texas at Arlington) from the wall of the upper (later) interior hearth (Feature 5A) at this same approximate depth, further dating the use of this structure.

The TL date of A.D. $1540 \pm 60$ from Block B/C was from a plain grog-tempered sherd recovered near the "floor" of Structure A (see Table 7-2), at $22 \mathrm{~cm}$ below the surface. The ceramic stylistic data discussed in Chapter 8, and the radiocarbon dates from the South rise, however, indicate this TL date is again too young for the vast majority of the Middle Caddoan ceramics from Blocks B/C. Nevertheless, there is a small amount of data suggestive of a later occupation in this part of the Hurricane Hill site with which this date could conceivably be associated. This is a small amount of plain and brushed shell-tempered wares from Blocks B/C and Block F, and several triangular arrowpoints. Ceramic tempering information reviewed by Bousman et al. (1988), Cliff (1995), and Fields et al. (1997) suggest that the use of shell-tempered 
pottery, in conjunction with some grit- and fine grog-tempered wares, was more frequent in the Cooper Basin during the Late Caddoan period (ca. A.D. 1400-1680). Thus, the presence of shell-tempered pottery, and certain types of Late Caddoan triangular arrowpoints (discussed below), does suggest that the South rise at the Hurricane Hill site was lightly occupied during the period (A.D. 1480-1600) indicated by the TL date.

\section{Southwest Rise}

Five radiocarbon dates have been obtained from the Southwest rise (see Table 7-1 and Figure 7-3); one of the dates (Beta-108170) is much too young and appears to have been contaminated, and will not be discussed further. This area of the Hurricane Hill site contained substantial Late Archaic and Early Ceramic period midden deposits, pit and hearth features, and a small cemetery with cremations and bundle burials (see Chapter 6; see also Perttula 1995b). The most common diagnostic artifact in the Southwest rise archaeological deposits is the Gary var. Gary dart point, estimated to date from ca. 850-450 B.C. (Schambach 1982), followed by the Gary var. LeFlore point type.

The oldest radiocarbon date (Beta-83089) is from wood charcoal in the fill of Feature 64, a large pit with more than $2,500 \mathrm{~g}$ of cremated human bone (from several individuals), seven stacked unburned long bones, a small pile of unburned teeth, 667 pieces of lithic debris, $11 \mathrm{~g}$ of burned clay, 59 fire-cracked rocks, and a broken bifacially worked lithic tool. At one or two standard deviations using Stuiver and Reimer's (1993) Method B (cal. 1007-890 B.C. and 1121-813 B.C., respectively), and given the estimated dates of the two most common Gary point types on the Southwest rise, the Feature 64 calibrated date seems to be too old. Of course it is possible, however, that the charcoal originated in older Late Archaic midden deposits, but this seems unlikely given the calibrated ages of Features 62, 71, and 91, also in the Southwest rise midden, which indicate that midden deposition and feature use occurred during two periods, from cal. 307-207 B.C. (Feature 71) and cal. A.D. 78-232 (Features 62 and 91) (see Figure 7-3). This latter period of use on the Southwest rise is contemporaneous with the calibrated ages of the PrimaryMidden deposits on the North rise (see Figure 7-1).

These Southwest pit features contained midden deposits and/or organically-rich fill, and two of the three pits are within the midden while the third (Feature 91) is $3 \mathrm{~m}$ to the south (see Chapter 6, this volume; see also Perttula 1995b:Figure 3). All three of the features contain some amounts of lithic debris, burned clay, and fire-cracked rock, and a Gary var. LeFlore dart point was recovered in Feature 62.

The four dates from the Southwest rise indicate a lengthy, but apparently only periodic, use of the landform during the Late Archaic and Early Ceramic periods. Three of the dates fall within a span of time when fairly substantial midden and feature deposits are known to occur widely throughout the Cooper Lake basin (e.g., at sites 41DT6, 41DT16, 41DT62, 41HP78, 41HP102, and 41HP137; see Fields et al. 1997), but only the prehistoric occupation at 41DT59 (Cliff et al. 1995) is contemporaneous with the cal. 1007890 B.C. age for the Feature 64 cremation (see Fields et al. 1997). Unfortunately, the radiocarbon dates obtained from the Southwest rise at Hurricane Hill do not fully clarify the age and span of use of the prehistoric cemetery, and additional radiocarbon samples in the collections should be submitted from burial contexts to better resolve their chronological context.

\section{Components without Radiocarbon Dates or Features}

The Late Archaic, Early Ceramic, Early Caddoan, and Middle Caddoan components on the North, South, and Southwest rises were defined primarily on the basis of contextual relationships between features, material remains, and calibrated radiocarbon dates from features and midden deposits from these different areas of the site. The Hurricane Hill site was used periodically during other times, and there are earlier archaeological materials underlying the Early and Middle Caddoan period components on the North and South rises.

With these materials from areas and deposits withou features and/or radiocarbon dates, in particular the Late Archaic and Early Ceramic period assemblages outside of the Southwest rise, it is difficult to define clear archaeological components because of the lack of good primary associations. This is due both to the limited number of features from these deeper components and the few diagnostic artifacts associated with features. As previously mentioned, differences in the types of projectile points found in certain areas, or from distinct soil zones, play a larger role in the recognition of earlier components than do selected aspects 
of the site archaeological record which are directly informative about contextual associations (i.e., a feature with radiocarbon dates and temporally diagnostic lithic or ceramic artifacts). Consequently, the definition of these earlier components at Hurricane Hill, even as tentative as these definitions are, runs the risk of associating materials that are more properly considered to represent secondary associations (Johnson 1987:4). That is, materials made by different groups, or by the same group at different periods of time that "have come to lie together through human agency such as pit digging, by deposition on a living surface stable for many years, or from joint redeposition by some natural agency such as slope wash" (Johnson 1987:4), would be improperly associated. It does the negate the recognition of the primary Early Ceramic, Early Caddoan, and Middle Caddoan components on the North, South, and Southwest rises discussed in detail above, because they are based on a large suite of radiocarbon dates and an abundance of features in good context.

Figures 7-4 and 7-5 depict the relative frequency of temporally diagnostic projectile points, beginning with the Paleoindian period, in different areas of the site, including the North rise (Blocks A, D, and E), the South rise (Block B/C), and the Southwest rise. Identified projectile point types or classes (see Chapter 8) that appear to date to relatively restricted temporal periods or a single period (see Schambach 1982, 1998; Prikryl 1990; McGregor and Bruseth 1987a:171-184; Story 1990; Perttula 1994a) were utilized to determine the different periods of use across the various landforms and blocks. The following temporal intervals include the following: Paleoindian, Middle-Late Archaic, Late Archaic, Late Archaic-Early Ceramic, Early Ceramic, Early Ceramic-Early Caddoan, Early-Middle Caddoan, Middle-Late Caddoan, and Late Caddoan (see Figures 7-4 and 7-5). Based on more than 680 classifiable projectile points, associated absolute dates from middens and features, the large Early and Middle Caddoan period ceramic assemblage, features, and feature contents it is possible to develop a tabulation of the components present across the site (Table 7-3).
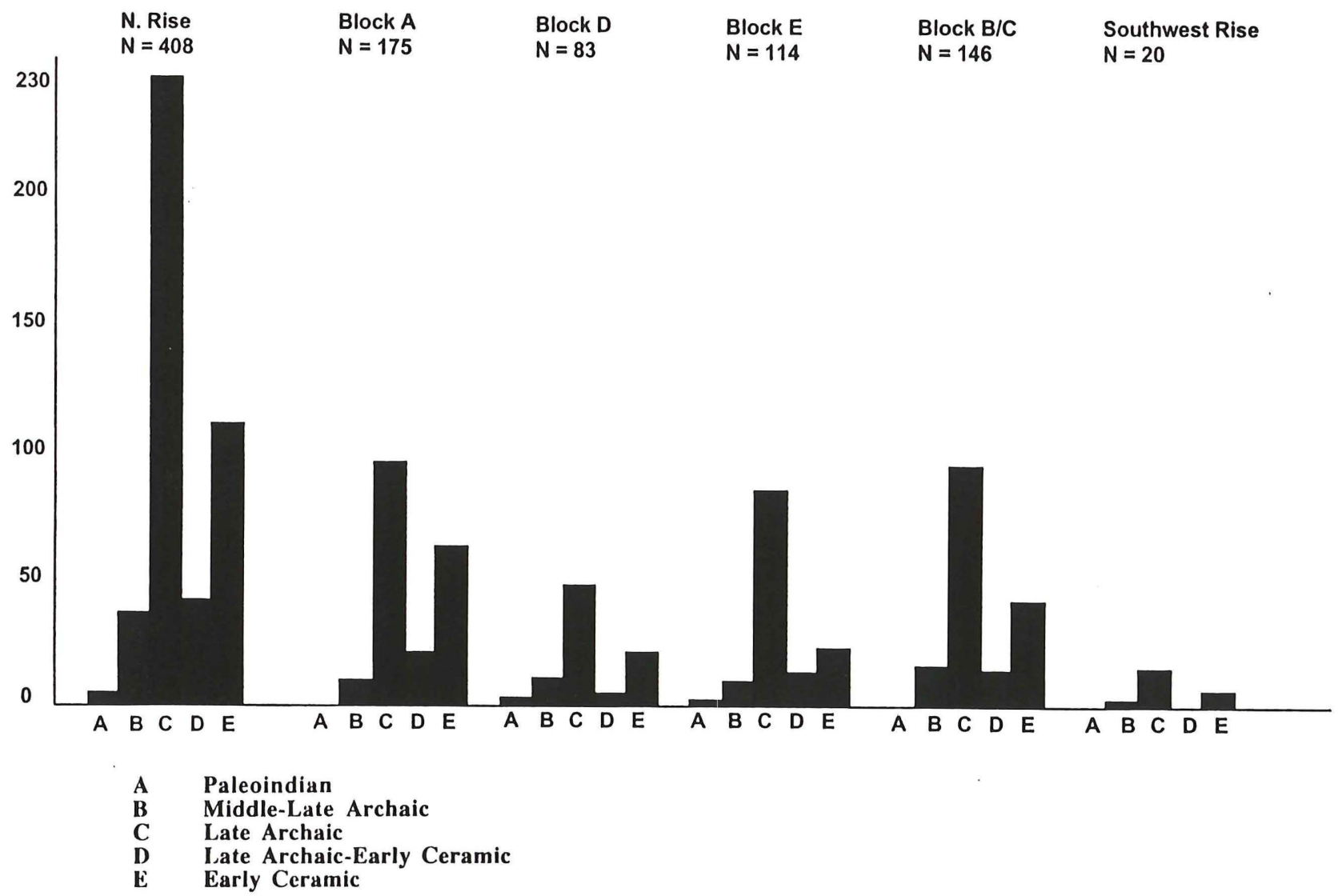

Figure 7-4. Relative frequency of temporally diagnostic dart projectile points by period, block, and natural rise. 


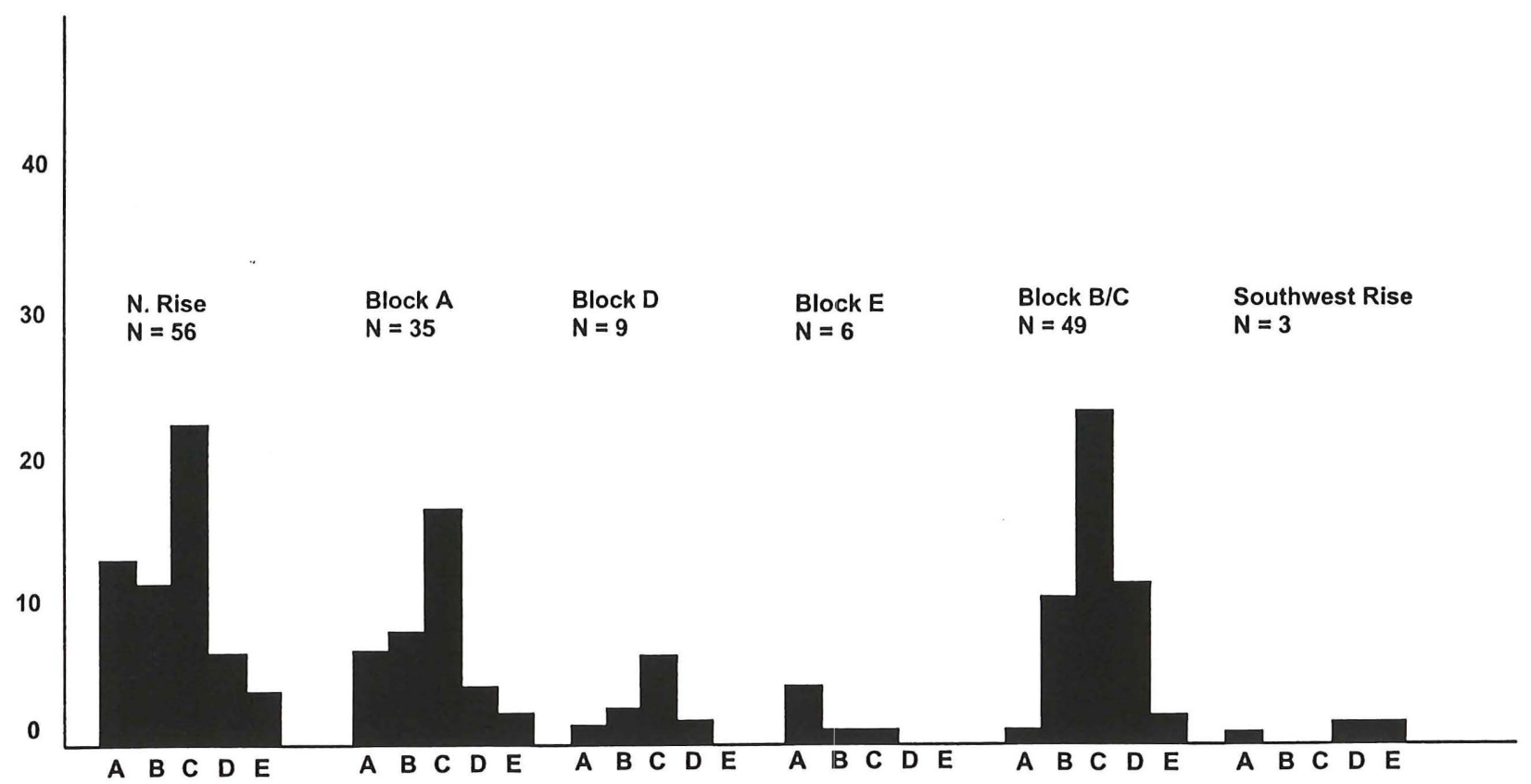
A Early Ceramic - Early Caddoan
B Early Caddoan
C Early - Middle Caddoan
D Middle - Late Caddoan
E Late Caddoan

Figure 7-5. Relative frequency of temporally diagnostic arrowpoints by period, block, and natural rise.

As used here, a primary component is one in which the majority of the cultural features and material culture remains can be assigned together by contextual association (see Bousman et al. 1988:21,29). The presence of a component, but not a primary component, at a certain provenience means simply that an assemblage of cultural materials can be defined which in aggregate (i.e., are associated with at least one feature and/or a distinct cultural or natural deposit, such as a midden or recognized soil zone) represent an occupation of some substance. A minimal presence (see Table 7-3) indicates that temporally diagnostic materials have been identified in a particular site area, but they cannot be definitely associated with any cultural features or a distinct cultural or natural soil deposit, and/or they are isolated horizontally from the remainder of the site's cultural assemblage that may date to that time period.

Figure 7-4 indicates the site had been utilized periodically since the Paleoindian period, and the aboriginal use of the Hurricane Hill site extended up to as recently as about A.D. 1400-1680, based on a few triangular arrowpoints on the three rises (see Figure 7-5). Paleoindian period lanceolates have been recovered only on the North rise (see Figure 7-4), specifically in Blocks D and E, but they were not found in features or good stratigraphic contexts, being instead mixed in with the abundant Late Archaic and Early Ceramic archaeological materials. Dart points that are thought to date from Middle to Late Archaic period contexts are present in archaeological deposits on the North, South, and Southwest rises (see Figure 7-4), but again, their associational context is generally problematic; that is, there was no consistent association of Middle-Late Archaic projectile points with discrete midden deposits or soil zones. One exception is where two expanding stem dart points and a fragmentary hematite axe were found stratigraphically below the Southwest rise midden, which may have begun to be formed as early as 1000 B.C. 
Table 7-3. Cultural periods represented in different areas of the Hurricane Hill site.

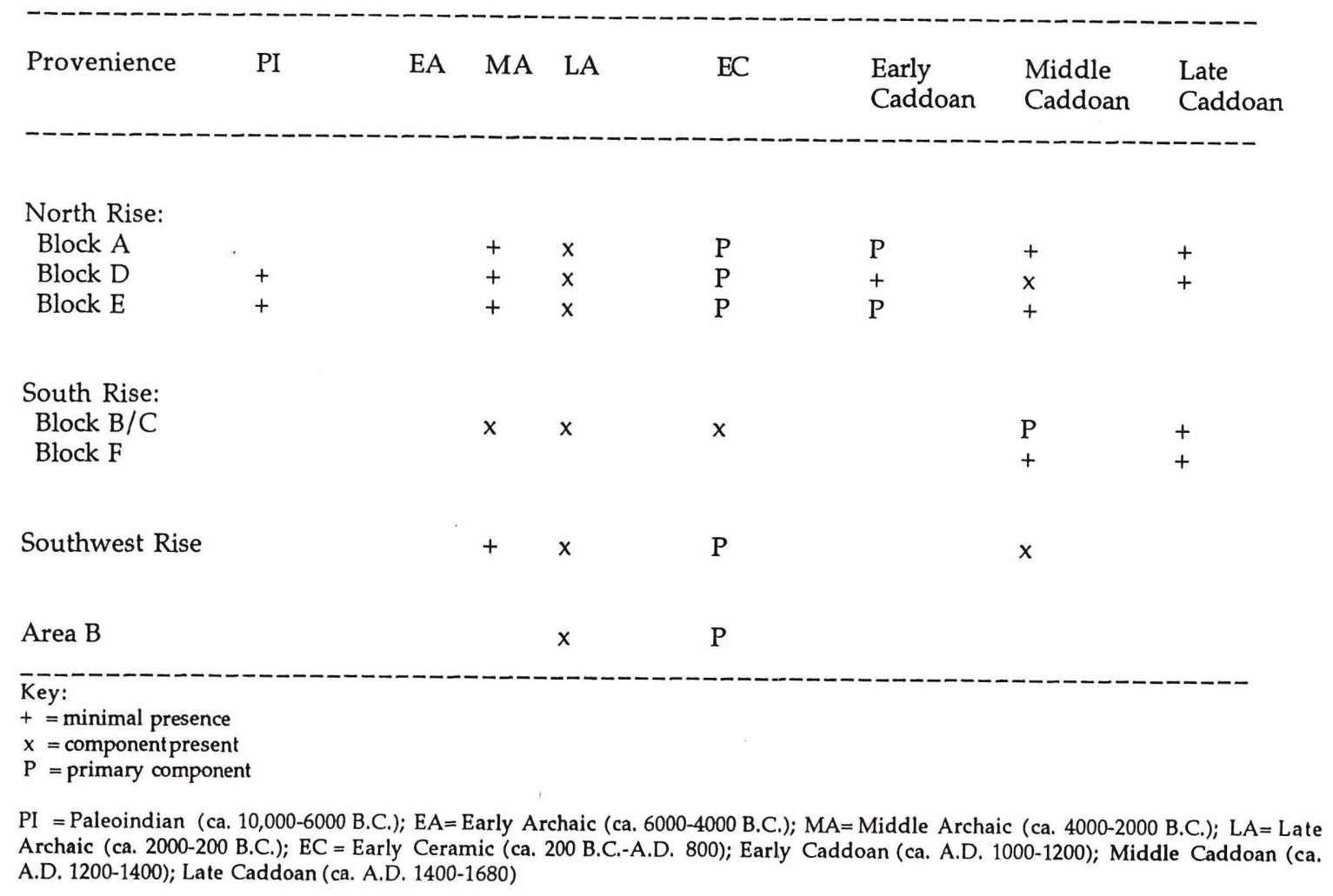

In general, the lower depths of the North rise and Southwest rise middens, and in soil zones below the Middle Caddoan structures on the South rise, are dominated by Late Archaic and Early Ceramic period temporal diagnostics (Figure 7-6; see also Figure 7-4). Conversely, the Caddoan arrowpoints occur primarily in the upper $30 \mathrm{~cm}$ of the midden and soil deposits on the North and South rises; on the Southwest rise, arrowpoints were found only in a single burial feature (Feature 68). With respect to the Early and Middle Caddoan ceramic assemblages (see Chapter 9, this volume) on the North and South rises, respectively, more than 80 percent of the rim and decorated sherds on those rises were also recovered in the upper $30 \mathrm{~cm}$, with the highest numbers being found between $10-20 \mathrm{~cm}$ below surface.

Its prominent topographic setting, the presence of abundant knappable gravels, the site's position relative to the South Sulphur River with its aquatic and riparian habitats, as well as the availability of loose and easily tillable, fertile sandy loam soils, were all attractions that contributed to the intensity of the prehistoric occupations at Hurricane Hill over many millennia. Even so, the more intensive occupations, at least over the short term, occurred during four relatively restricted periods: portions of the Late Archaic (ca. 2200-2800 B.P.), the Early Ceramic (ca. 1500-2000 B.P.), the Early Caddoan (ca. A.D. 900/1000-1200), and the Middle Caddoan (ca. A.D. 1250-1375) periods, and we turn to a further consideration of the archaeological content of these components.

\section{Late Archaic and Early Ceramic Period Components}

Primary components dating to the Late Archaic and Early Ceramic periods are present on the North rise, the Southwest rise, and Area B (see Table 7-3). In most cases, the archaeological deposits cannot be separated into discrete Late Archaic and Early Ceramic period assemblages or contexts, which is why they are considered together. There is also a fairly substantial component of these periods on the South rise (see Figure 7-4), but it does not have midden deposits or features of Late Archaic or Early Ceramic period age. 


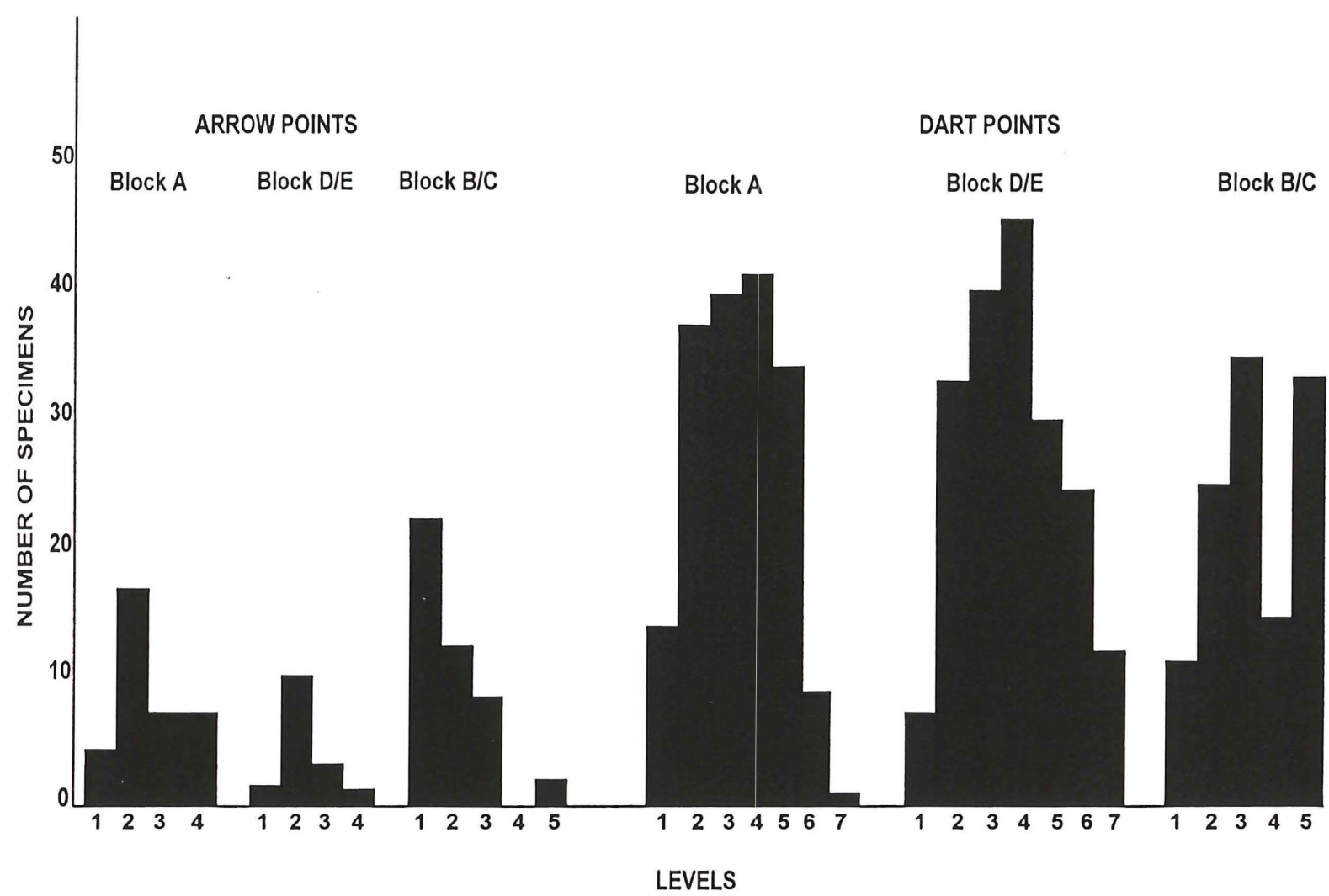

Figure 7-6. Vertical distribution of arrowpoints and dart points in Blocks A, D/E, and B/C.

On the North rise, these components are represented by a large PrimaryMidden deposit, several cremations, pits, and burned rock features, while on the Southwest rise the components include a smaller midden, a few pits and burned rock features, and a cemetery with cremations and bundle burials (see Chapter 6). The radiocarbon dates from the North and South rises indicate the Late Archaic/Early Ceramic period occupations began ca. 1000 B.C. and lasted to ca. A.D. 450, with the main period of use between ca. 300 B.C.-A.D. 450 . More than 90 percent of the dart points on the North rise are considered to date to the Late Archaic/Early Ceramic periods (see Figure 7-4), and Figure 7-6 indicates that the archaeological deposits below $40 \mathrm{~cm}$ bs in both Blocks A, D, and E contain exclusively dart points, and there is little evidence of the Early Caddoan period component below $30 \mathrm{~cm}$ bs in Blocks D and E.

The density of burned rock in Block A peaks between $30-40 \mathrm{~cm}$ bs, but it is also abundant between $40-50 \mathrm{~cm}$ bs (Figure 7-7). The vertical distribution of the burned rock is very different than either the daub or burned clay, and likely marks the depths at which the Late Archaic and Early Ceramic period deposits predominate in the Primary Midden and below the Caddoan Middens 1 and 2. 

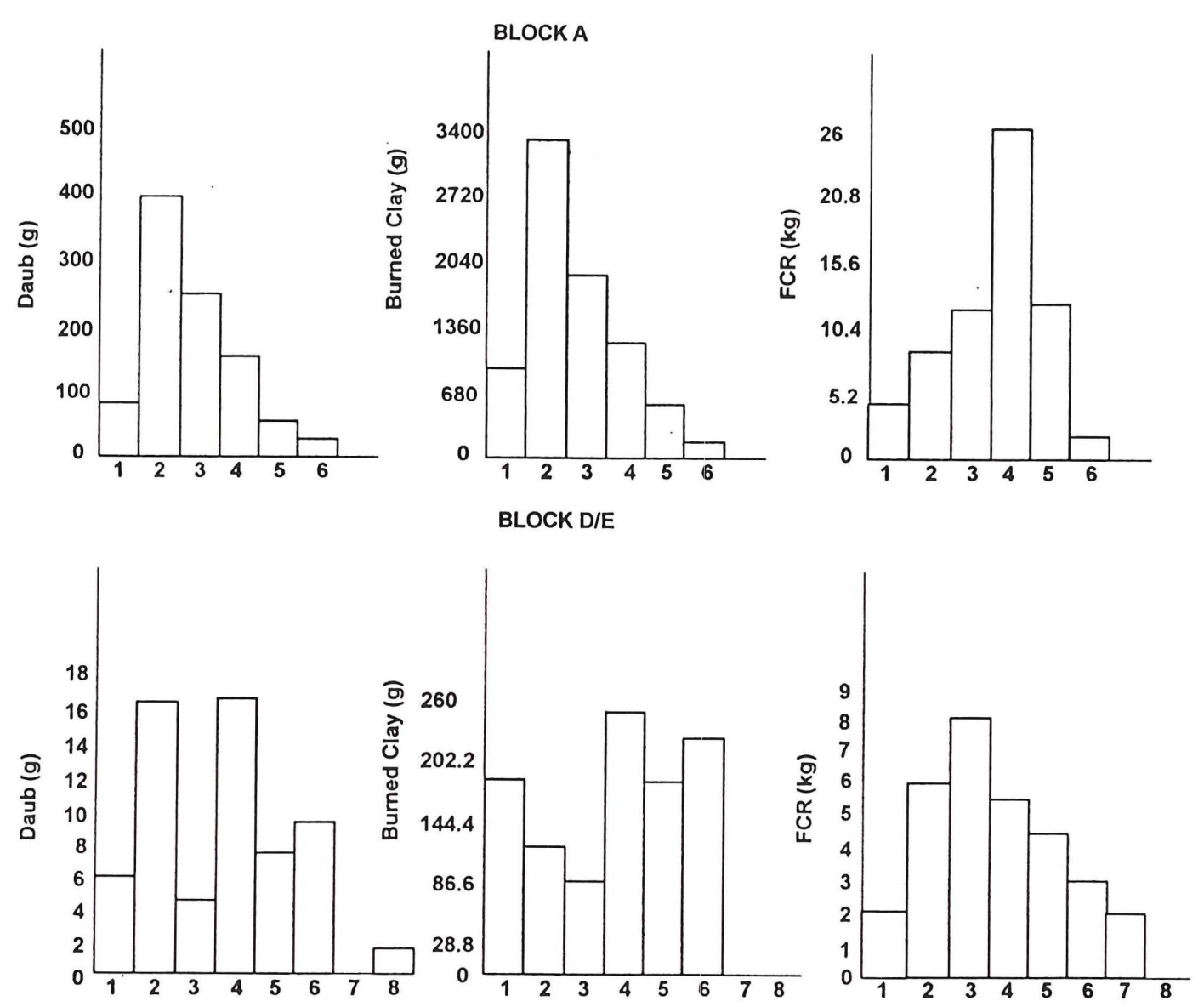

Figure 7-7. Vertical distribution of daub, burned clay, and fire-cracked rock in Blocks A and D/E.

On the South rise, Middle Archaic, Late Archaic, and Early Ceramic period dart points vs. arrowpoints and ceramics are predominant in deposits below $30 \mathrm{~cm}$ bs, particularly between $40-50 \mathrm{~cm}$ bs (see Figure 7-6). As with the North rise projectile point assemblage, typolgically more than 90 percent of the dart points appear to date to the Late Archaic/Early Ceramic period (see Figure 7-4). Dart points are equally abundant in arbitrary levels $3(20-30 \mathrm{~cm}$ bs) and $5(40-50 \mathrm{~cm}$ bs) inside and outside of the structure excavations (Figure 7-8), suggesting a relatively intensive Late Archaic/Early Ceramic occupation across much of the South rise, but one that was concentrated on the crest of the rise (see discussion below), not too coincidentally the same place selected for the construction of two structures by Middle Caddoan period families many generations later. As the natural rise was not aggrading, and there were no midden deposits of Late Archaic/Early Ceramic age, the Late Archaic/Early Ceramic artifacts became incorporated over time into the sandy sediments through bioturbation and translocation, as did the later Middle Caddoan period artifacts that were discarded inside and outside the structures. The aboriginal excavation of pits and postholes during the Middle Caddoan period probably also contributed to the movement of earlier artifacts upwards and downwards in the sandy loam sediments. Nevertheless, the later Middle Caddoan period occupation contributed to some vertical separation in the archeological deposits.

The density of burned rock on the South rise includes comparable amounts between $10-40 \mathrm{~cm}$ bs, with a substantial peak between $40-50 \mathrm{~cm}$ (Figure 7-9). The deeper peak is associated with a peak in the frequency of Late Archaic/Early Ceramic period projectile points, and their vertical co-association indicates that the archaeological deposits found below $30-40 \mathrm{~cm}$ on the South rise are Late Archaic/Early Ceramic in age Conversely, daub and burned clay amounts are much more abundant between 0-30 $\mathrm{cm}$ bs, where they are clearly associated with the Middle Caddoan period structures and this later use of the rise. 


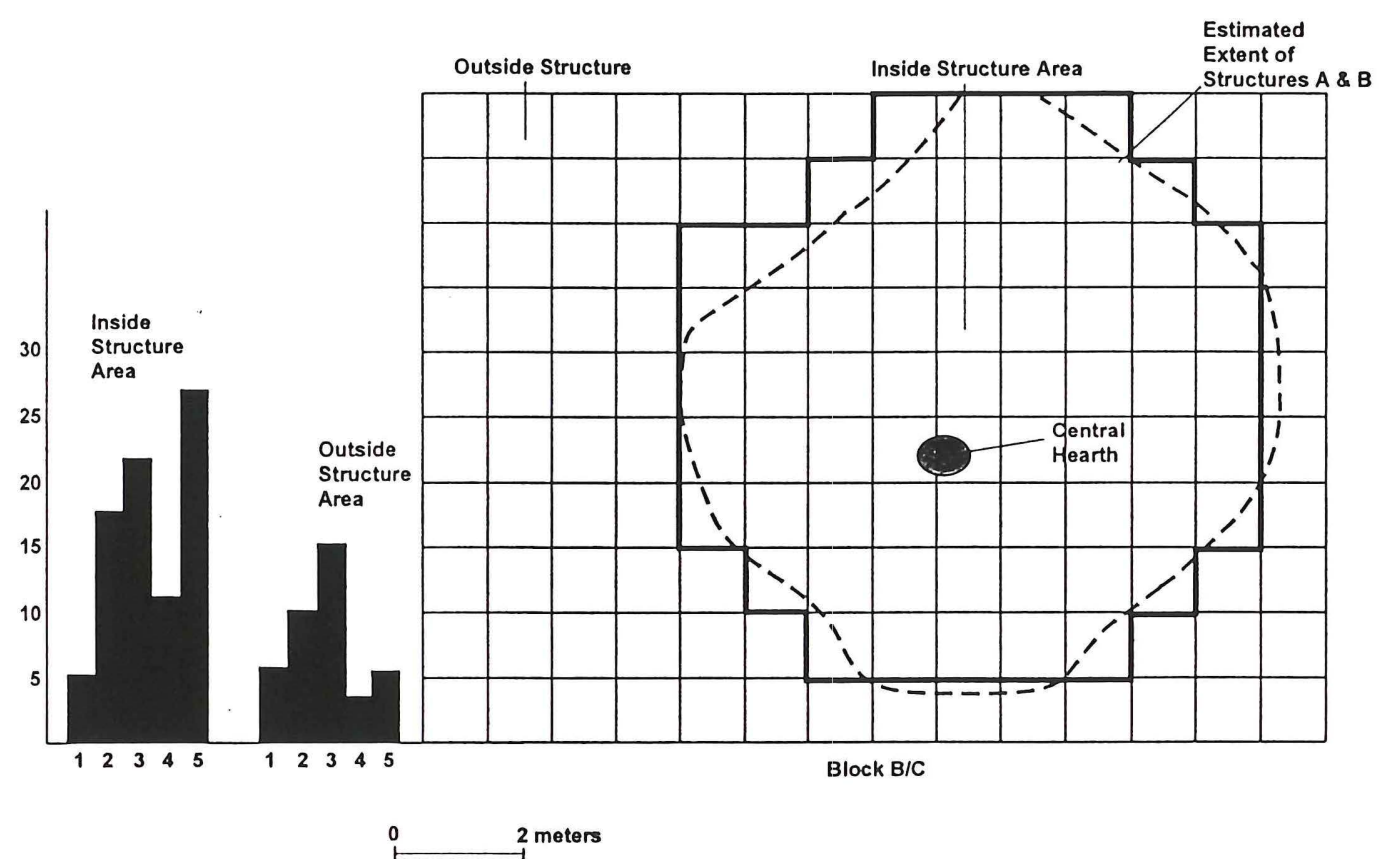

Figure 7-8. Vertical distribution of dart points inside and outside the structure on the South rise.

BLOCK B/C
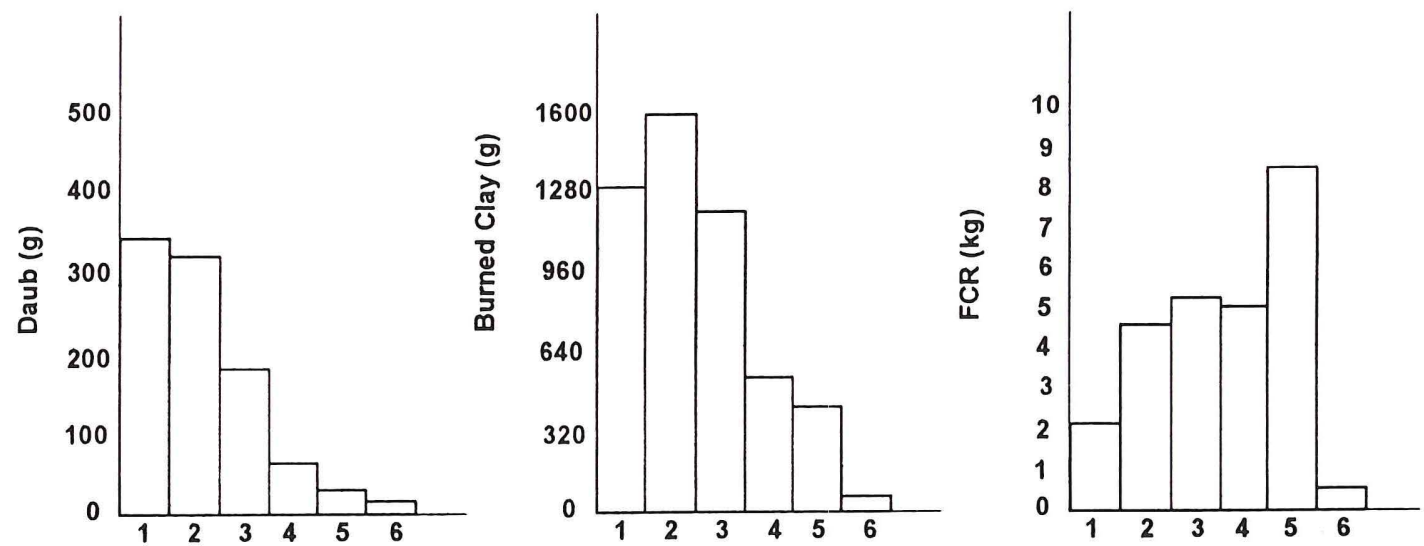

Figure 7-9. Vertical distribution of daub, burned clay, and fire-cracked rock in Block B/C.

\section{Early Caddoan Period Component}

Radiocarbon dates, the decorated ceramics, and an assortment of arrowpoint styles, indicate that there is an Early Caddoan period component (estimated to date from ca. A.D. 900/1000-1200) on the North rise. The relatively shallow (30-40 cm thick) Midden 1 and Midden 2 deposits on the rise were formed by 
the Caddoan occupants during this temporal interval (apparently developing atop the earlier Primary Midden), along with several burial features and two Caddoan structures (Structures D and E). The midden features overlie the PrimaryMidden, a Late Archaic/Early Ceramic deposit that covers most of the North rise and extends to ca. $60-70 \mathrm{~cm}$ below the surface (see Figures 7-6 and 7-7). Much of the daub and burned clay, along with the ceramics and arrowpoints, are from $0-30 \mathrm{~cm} \mathrm{bs}$, and they peak between $10-20 \mathrm{~cm}$ bs in Block A (see Figure 7-7). In Block D and E archaeological deposits, there are two peaks in the daub (between 10-20 cm and 30-40 cm bs) and three peaks in the burned clay (between 0-10,30-40 cm, and 50$60 \mathrm{~cm} \mathrm{bs}$ ), but only the uppermost peaks appear to be associated with the Early Caddoan component, with the lower peaks, along with dart points and fire-cracked rock (see Figures 7-6 and 7-7), part of the Late Archaic/Early Ceramic deposits in the North rise PrimaryMidden.

\section{Middle Caddoan Period Component}

The primary Middle Caddoan period component is present in the upper $30 \mathrm{~cm}$ of the archaeological deposits on the South rise, specifically in Blocks B/C and F, and a variety of pit and burial features inside and outside Structures A and B on the rise. As previously mentioned, both the ceramics and arrowpoints are clearly concentrated at these depths (see Figure 7-6; see also Chapter 9, this volume), as are daub and burned clay from clay-lined wall thatching and basin hearths associated with the two structures (see Figure 7-9). Radiocarbon and archaeomagnetic dates indicate the Middle Caddoan period component dates from ca. A.D. 1250-1375. Although a few Middle Caddoan arrowpoints and ceramic sherds (see Chapter 8, this volume) have been found on the North and Southwest rises, and one radiocarbon date from the North rise dates to the earlier part of this period, they at best represent an occasional use of these rises by the few Middle Caddoan occupants on the South rise.

\section{INTRA-SITE ANALYSES: SPATIAL STRUCTURE OF THE HURRICANE HIILL SITE}

A concern with interpreting the internal site structure and the spatial patterning of certain activities at the Hurricane Hill site is the focus of this part of Chapter 7. The intra-site spatial analyses will include the consideration of relative density patterning and compositional patterning (e.g., Whallon 1984) of selected tool, ceramic, and debris classes. Ferring (1984:116-117) defines density patterning as "the absolute and relative spatial density of things on or within the minimally dated horizon," while compositional patterning is the "density-free differential spatial distribution of selected categories of artifacts or ecofacts within the minimally dated horizon." As O'Connell (1987) has suggested, spatial analyses in archaeological settings are best conducted in situations where large block excavations of contiguous units have been excavated, as is the case at Hurricane Hill; furthermore, the excavations have also documented multiple features with associated artifacts of diverse character in contexts that have not been deeply buried, which should allow for the identification of intra-site patterns in features and artifacts that can be related to different sets of activities and depositional contexts.

Understanding the intra-site spatial organization of the Late Archaic/Early Ceramic, Early Caddoan, and Middle Caddoan period occupations at Hurricane Hill is important in relating the overall site structure to broader questions of regional settlement-subsistence changes in Northeast Texas (cf. Story 1981 (ed.), 1985, 1990; Fields et al. 1997; Perttula 1996), specifically contrasts in settlement permanence between Late Archaic/Early Ceramic hunters and gatherers and Early and Middle Caddoan horticulturists. The spatial analyses can provide critical evidence in detecting differences in the overall organization of the huntergatherers and horticulturists in terms of their mobility and foraging ranges (cf. Kelly 1995), the length and intensity of the occupations, and the range of activities that took place there through time. However, because of the complex, multi-component nature of the occupations on the North and South rises (see above), and the apparently repetitive use of the rises during the Late Archaic and Early Ceramic periods, the consideration of intra-site spatial patterning here does not necessarily presume that they represent analytically useful entities in each case; that it is to say, that the spatial patterns can differentiate between single, multiple, and/or palimpsest occupations (e.g., Binford 1982, 1983a, 1983b). Rather, the association of features, tools, and clusters of debris classes are examined to define spatial patterns in the different defined components, each of which has different ranges in contextual integrity. If these spatial patterns are significant relative to fundamental notions of activity structure, refuse disposal, and their technological- 
functional context (e.g., Carr 1985; Kroll and Price 1991; Wandsnider 1996)--which appears to be the case for the Caddoan occupations with numerous features and midden deposits as well as associated artifacts-conclusions may be drawn about the spatial patterning of material culture remains that relate to specific kinds of behaviors or component activities during the Late Archaic/Early Ceramic, Early Caddoan, and Middle Caddoan occupations. In essence, then, the analysis of spatial pattern discussed here is pattrendriven in nature, aiming to define and discuss any such recognizable patterns of spatial variability in features and material culture within the site. The spatial analyses will focus primarily on the distribution of ceramics, chipped stone tools, lithic debris, and faunal remains (including mussel shells) on the North and South rises, along with a variety of other material culture remains on the South rise.

\section{North Rise}

On the North rise, patterns of artifact spatial density, particularly the ceramics and faunal remains, correlate with the locations of the Early Caddoan period trash middens, Midden 1 and Midden 2 on the crest and slopes of the rise (see Figure 6-2). On the South rise, however, prominent density and compositional patterns of artifact distributions primarily relate to the use and/or discard of materials within two Middle Caddoan structures (Structures A and B). The trash deposit around the structures were only minimally investigated, but they apparently do not contain a comparable array of faunal remains, sherds, and tools that were so abundantly documented in Block A and parts of Blocks D and E.

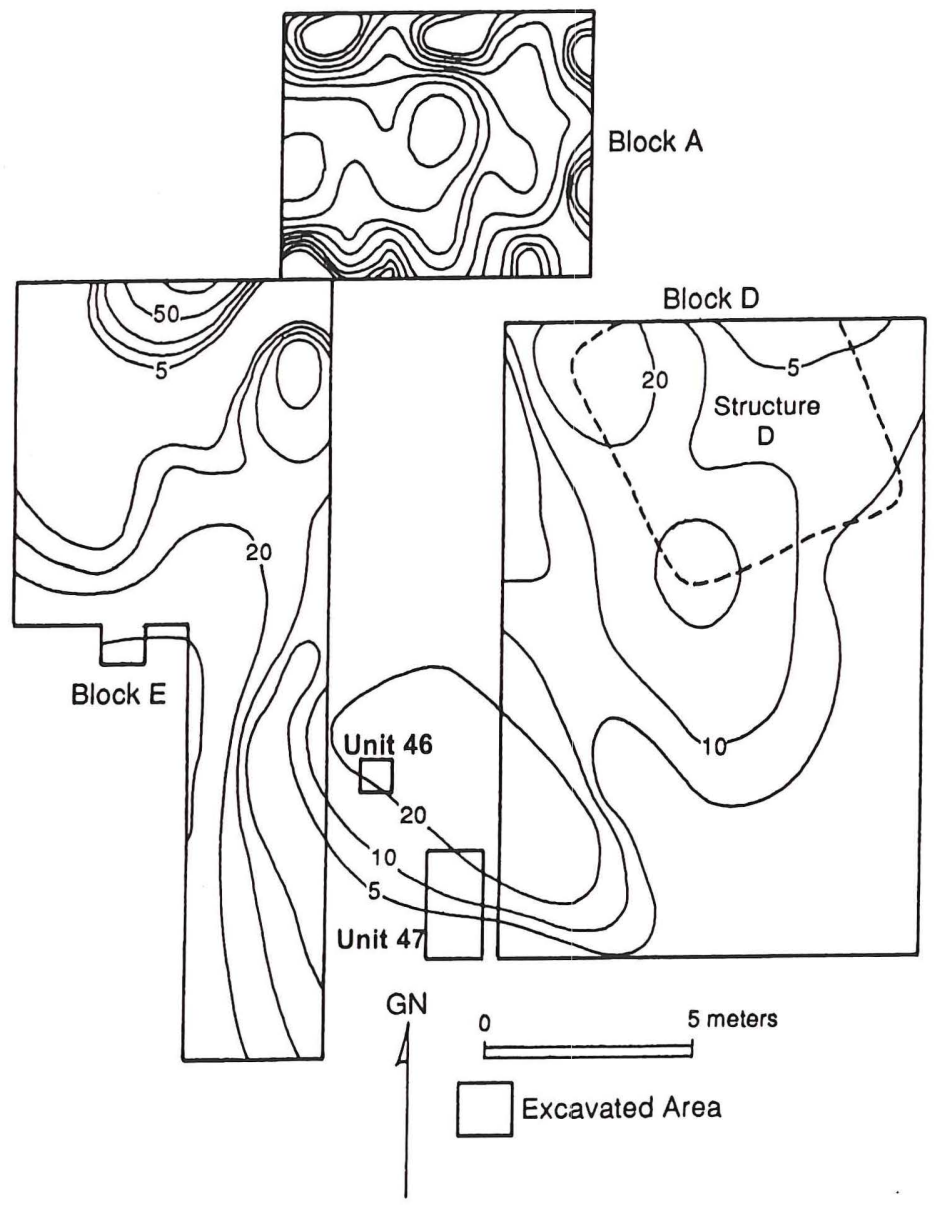

Figure 7-10. Distribution of ceramics on the North rise. 

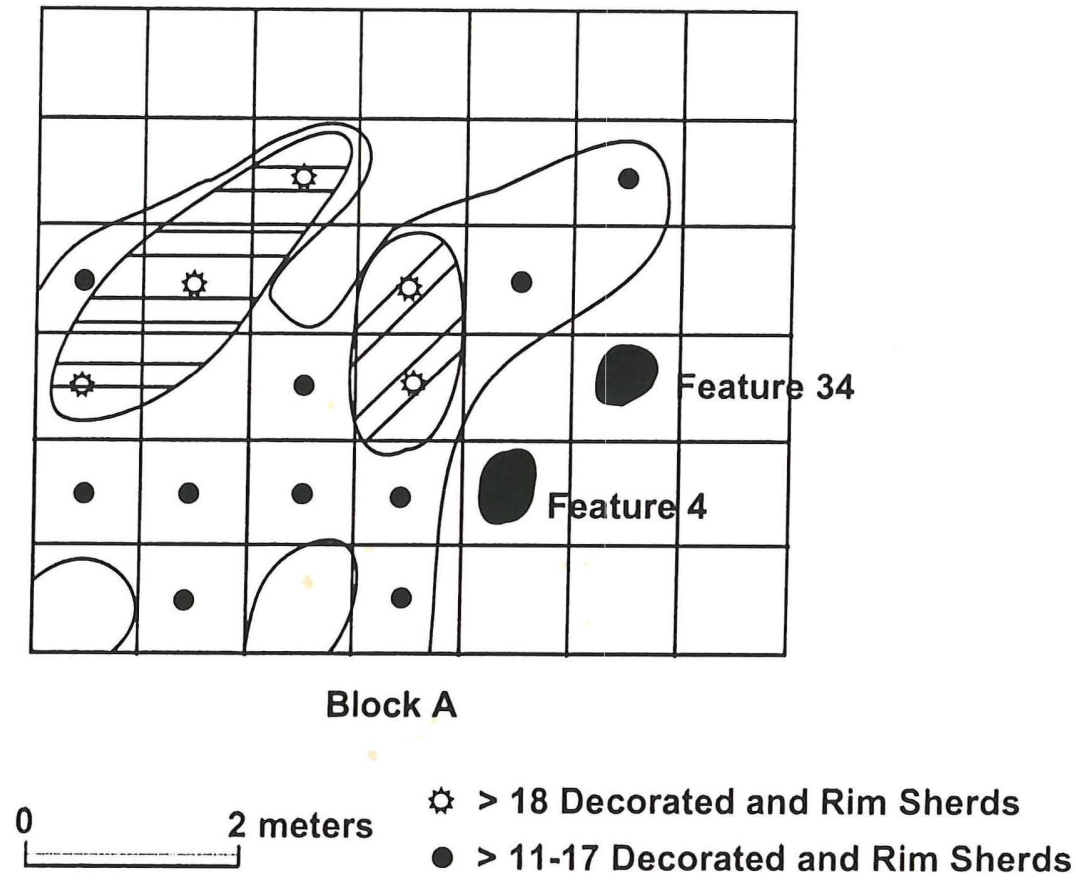

Figure 7-11. Distribution of decorated and rim sherds in Block A.

Early Caddoan ceramics on the North rise were highly concentrated in Midden 1 (with densities above 100 per $\mathrm{m}^{2}$ ), with two smaller clusters in a corner of Structure D (along the edge of Midden 1), and at the northern edges of Block D and Block E (Figure 7-10). Another cluster is present along the southern slopes of the North rise in the vicinity of Midden 2 (see Figure 7-10). Within Midden 1, the overall ceramic density is relatively homogenous, due probably to the rapid accumulation o the midden deposits, but the distribution of rim and decorated sherds suggests one or two smaller clusters (covering together about $20 \mathrm{~m}^{2}$ ) in the southwestern part of Midden 1, where densities range from more than 11-18 rim and decorated sherds per $\mathrm{m}^{2}$ (Figure 7-11). Both clusters are situated to the west of the two clay-lined hearths, and 4-8 meters northwest from the northern wall of Structure D, and a similar distance from Structure E in the northeastern part of Block E. Within Blocks D and E, plain rims and decorated sherds occur in close association with the Early Caddoan midden deposits, in the vicinity of Feature 35 (an extended Early Caddoan burial feature), and inside and just outside Structure D (Figure 7-12). Except for an area located immediately grid west of Block A, the major portion of Midden 1 containing large numbers of Early Caddoan sherds was excavated during our investigations.

Tools, however, have a broader distribution across the North rise (Figure 7-13), because the spatial distribution of dart and arrow projectile points and various other chipped stone tools appear to relate to the density of material culture remains within both Midden 1 and 2 and the Late Archaic/Early Ceramic Primary Midden across most of the rise. The highest tool density $\left(>30-45\right.$ tools per $\mathrm{m}^{2}$ ) is in Midden 1, specifically the western half of Block A--as was the case with the rim and decorated sherds--with secondary clusters with between 10-30 tools per $\mathrm{m}^{2}$ in Midden 2 in the vicinity of Feature 2 (another extended Early Caddoan burial), and in the northern half of Block E (see Figure 7-13). Apparently the Late Archaic/Early Ceramic period occupation concentrated in Block E, as this was also the location of two Late Archaic/Early Ceramic period cremations containing multiple individuals (Features 25 and 55 ). 


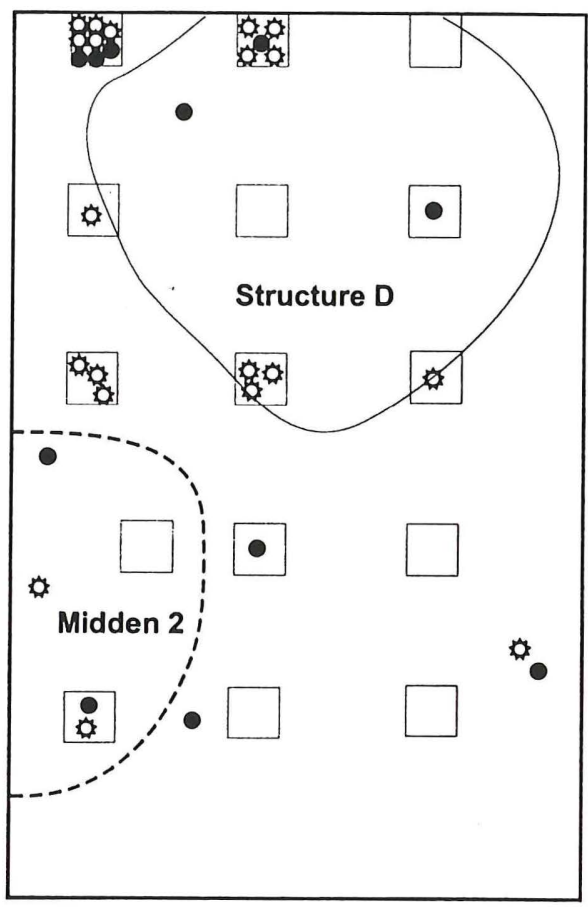

Block D

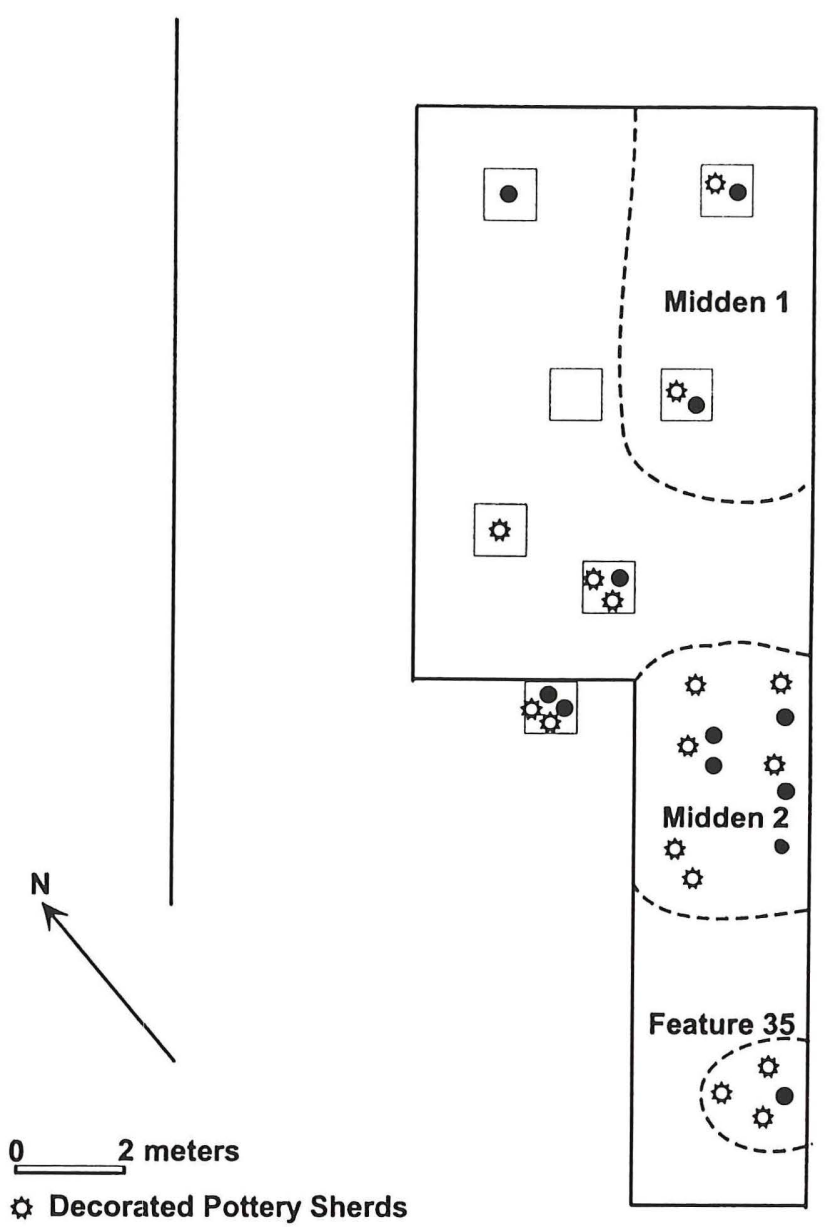

- Plain Rim Sherds

Block E

Figure 7-12. Distribution of decorated and rim sherds in Blocks D and E.

The majority of the Early Caddoan period arrowpoints in Midden 1 were broken and then discarded in the midden deposits. Their distribution is apparently different than the ceramics or stone tools as an aggregate because they are primarily found within 1-2 $\mathrm{m}$ of the clay-lined hearths outside of Structure D (Figure 7-14). Within Block D, the arrowpoints (89 percent broken) are distributed either within Structure D or Midden 2, while the six arrowpoints in Block E (50 percent of which were broken before being discarded) are within or near Middens 1 and 2 (Figure 7-15).

Faunal remains have a broadly similar pattern to the Caddoan ceramics, in that they are clearly associated with the Early Caddoan midden deposits on the North rise; this is to be expected since the vast majority of these remains were recovered from Middens 1 and 2 (see also Yates, Chapter 13, this volume). The only apparent difference between these classes of remains is that the faunal remains are more restricted spatially and are less well preserved outside Midden 1 (Figure 7-16). In Midden 1, faunal remains occur in densities between $1500-5000+$ specimens per $\mathrm{m}^{2}$ in the southeastern part of Block A, particularly to the north of the extramural clay-lined hearths (Features 4 and 34), with much lower densities in the western part of the block excavations compared to the densities of ceramics (both plain and decorated sherds) and stone tools (see Figure 7-16). This suggests, not too surprisingly, a clear spatial differentiation in the use and discarding of ceramics and tools, compared to the disposal and butchering of animal refuse, in the Early Caddoan midden deposits. 


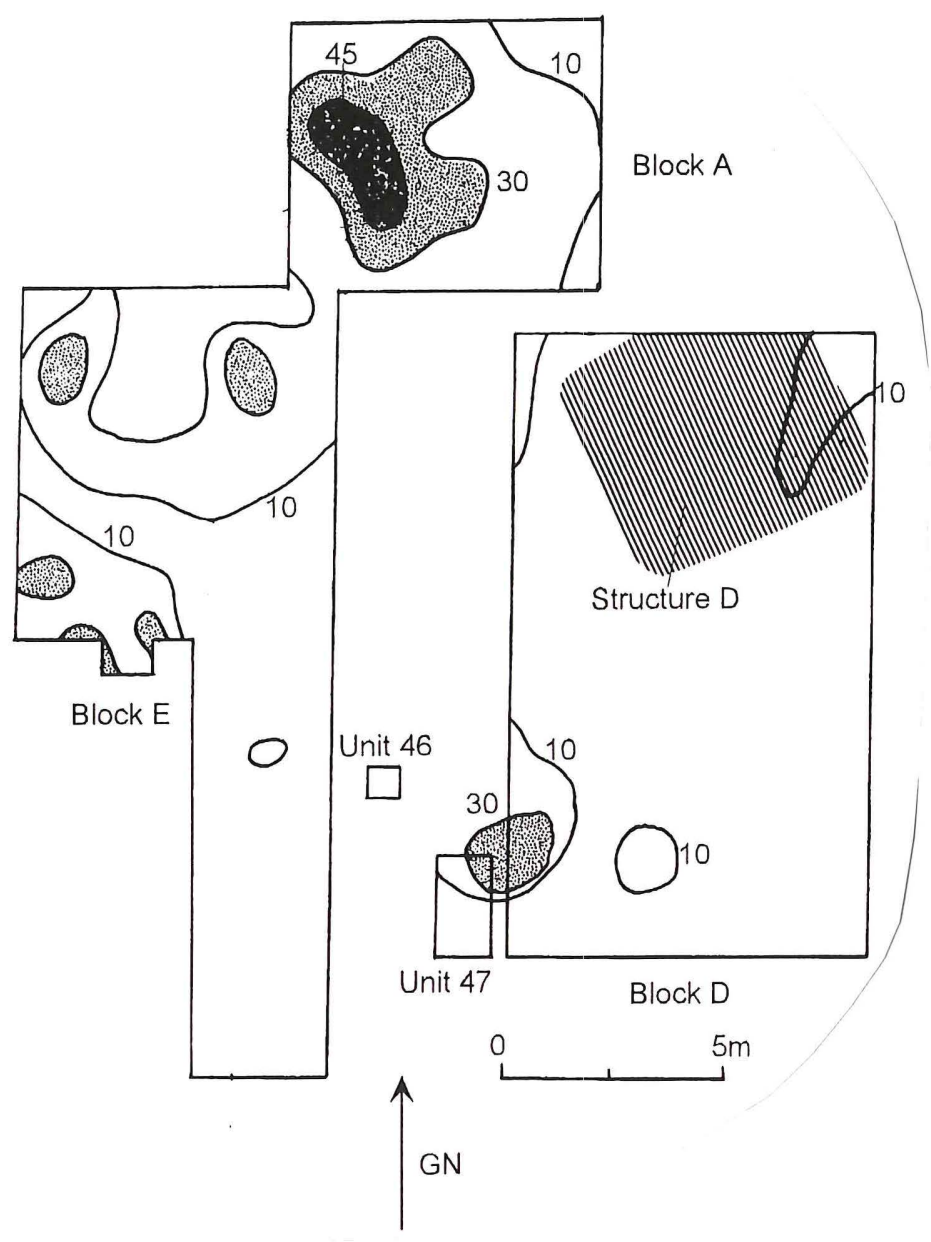

Figure 7-13. Distribution of stone tools on the North rise.

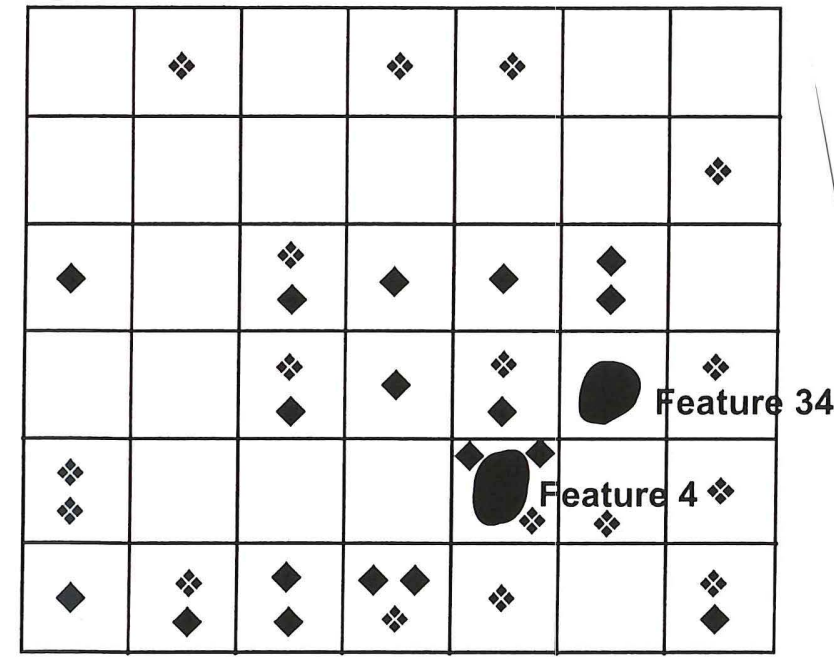

Block A

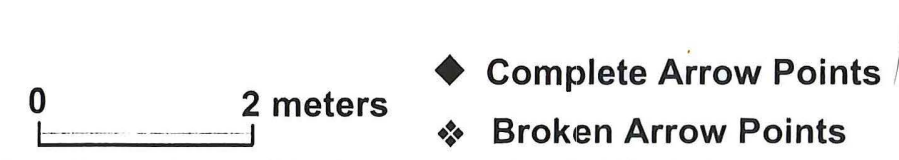

Figure 7-14. Distribution of complete and broken arrowpoints in Block A. 


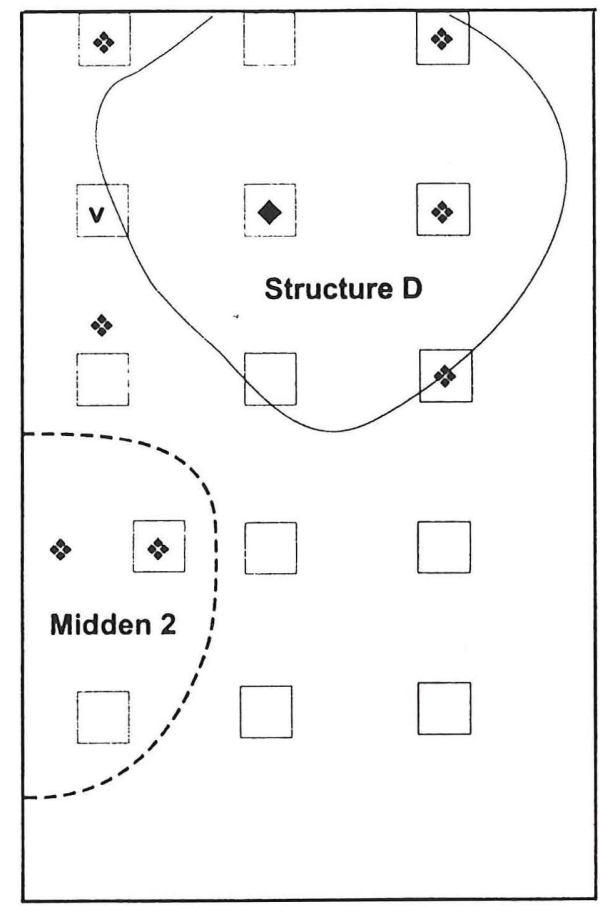

Block D
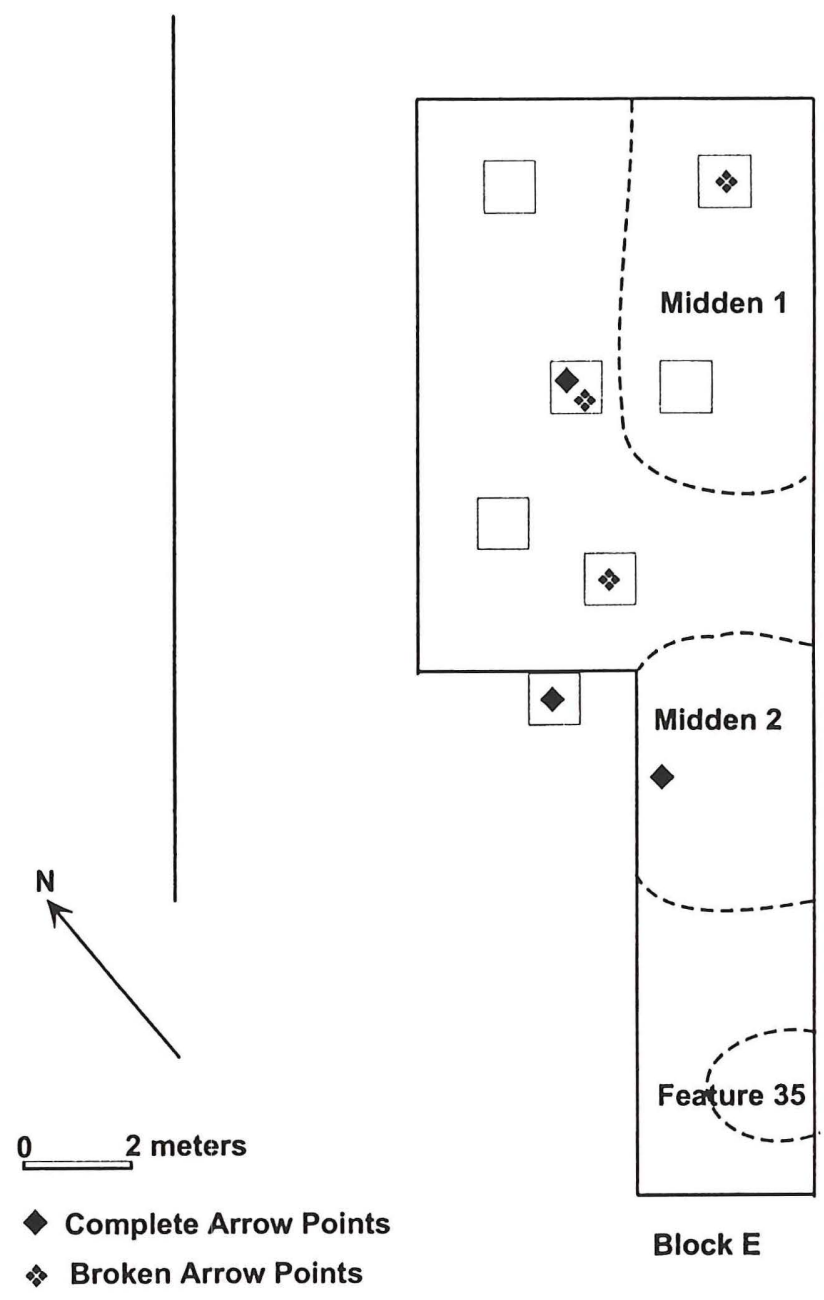

Block E

Figure 7-15. Distribution of complete and broken arrowpoints in Blocks D and E.
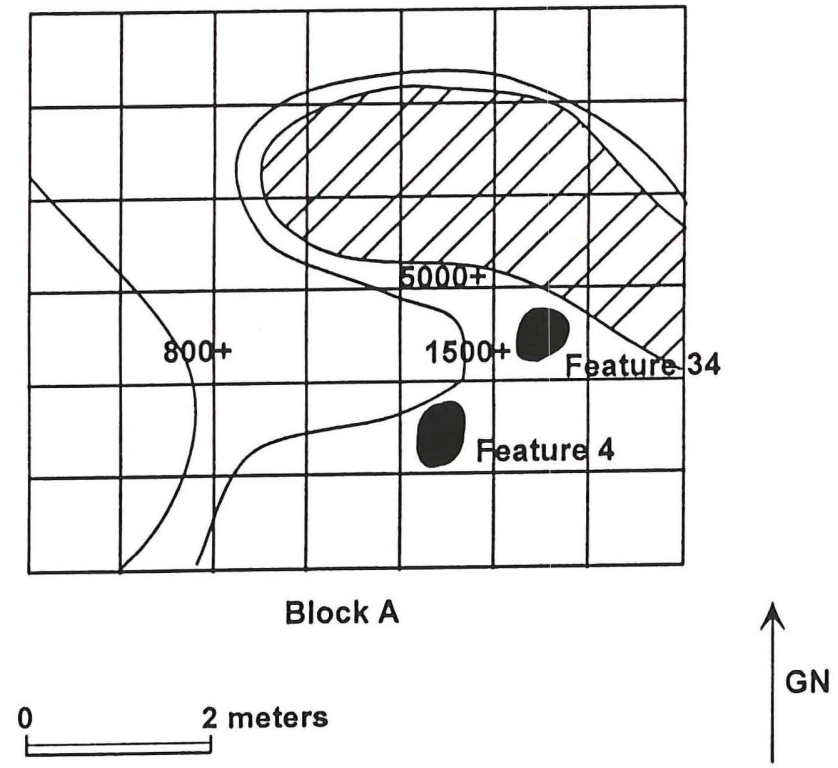

Figure 7-16. Distribution of faunal remains in Block A on the North rise. 
Midden 2 has a discrete faunal cluster, estimated to cover about $60-70$ square meters, although it was only partially delineated in Blocks D and E. The density of faunal remains in Midden 2 ranges from 50$250+$ specimens per $\mathrm{m}^{2}$ One faunal spatial cluster also occurs in the vicinity of Structure D, being located outside the northwestern corner of the structure (Figure 7-17), and is apparently part of Midden 1, which was formed to the west and northwest of Structure D.

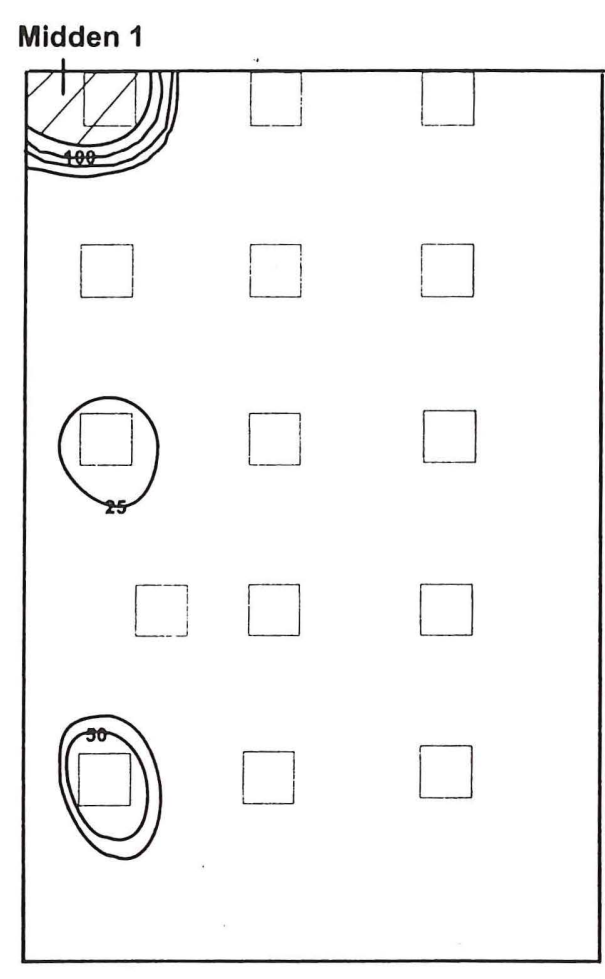

Block D

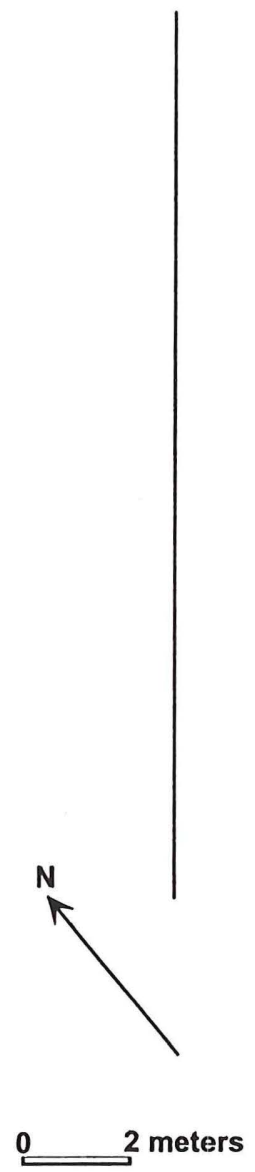

meters

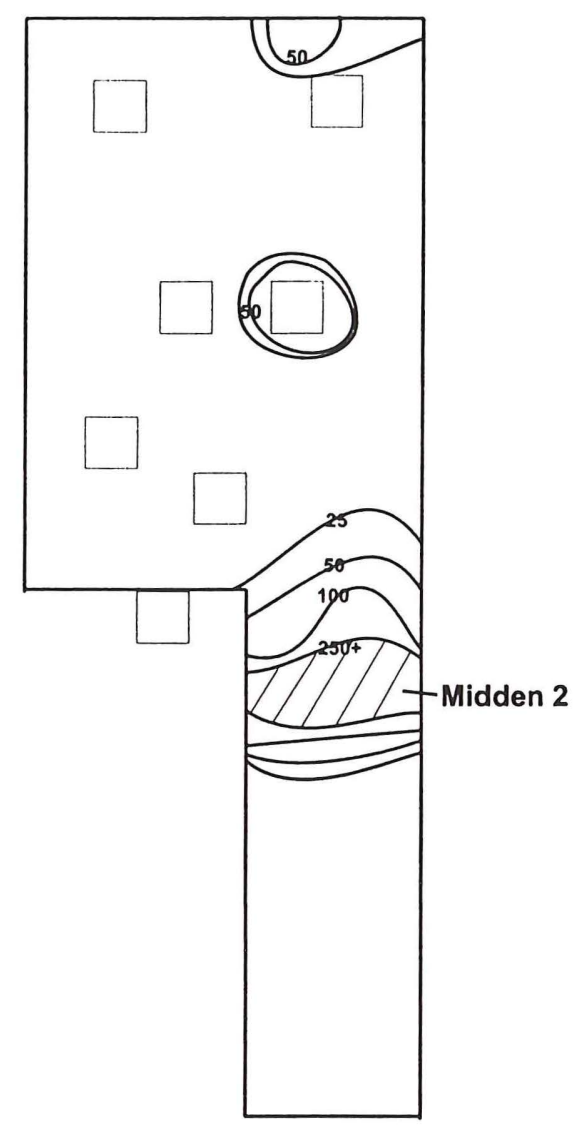

Block E

Figure 7-17. Distribution of faunal remains in Blocks D and E on the North rise.

Burned and unburned mussel shells were also discarded in the eastern part of the Early Caddoan Midden 1 deposits, and in proximity to the two clay-lined hearths in the midden itself (Figure 7-18). In particular, the highest concentrations of mussel shell umbos $\left(>10-20\right.$ umbos per $\mathrm{m}^{2}$ ) occur immediately to the east and northwest of the hearths, probably where they were raked out and the shells discarded after they had been cooked. 


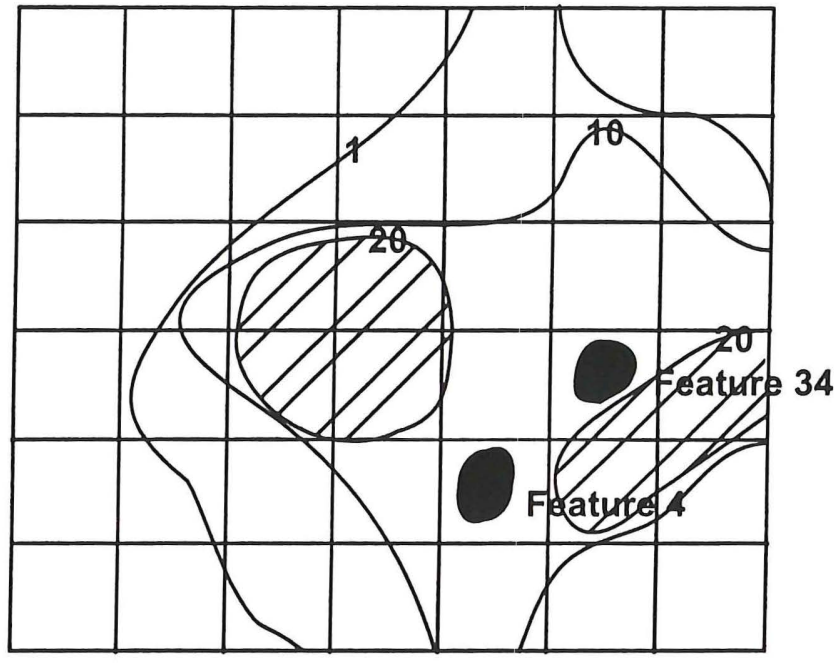

Block A

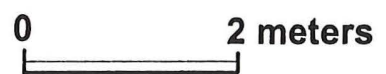

Figure 7-18. Distribution of shell umbos in Block A.

\section{South Rise}

The spatial record of features and artifacts on the South Rise is much different than what has been documented on the North rise in earlier components. This is partially because of differences in context between the two areas (i.e., primarily midden deposits versus primarily structural deposits; in the case of the Late Archaic/Early Ceramic remains from the South rise, they do not occur in association with a midden), as previously mentioned, and as a consequence of the much lower densities of remains for both the Late Archaic/Early Ceramic and Middle Caddoan occupations on this part of the site.

Middle Caddoan ceramics, both plain and decorated sherds, cluster both north and south of the interior hearths (Feature 5A and 5B) within and/or just outside of Structures A and B (Figures 7-19 and 720). The larger cluster north of the interior hearth covers about $12-15 \mathrm{~m}^{2}$, with sherd densities between 100 300 sherds per $\mathrm{m}^{2}$, with three smaller clusters (ca. $2-5 \mathrm{~m}^{2}$ ) to the south and west of the interior hearths with densities between 100-200 sherds per $\mathrm{m}^{2}$ (see Figure 7-19). The densest numbers of rim and decorated sherds (with $>10$ sherds per $\mathrm{m}^{2}$ ) also occur within the structures, but between $2-4 \mathrm{~m}$ from the interior hearths (see Figure 7-20).

Other clusters of sherds occur in proximity to the entrances of the houses. However, these clusters do not have as high a density as either the main cluster north of the hearths, or the two smaller clusters south and southeast of the hearths. This is probably because of several factors, including that (1) the majority of the excavations occurred within the structures; (2) the ceramic sherds are small pieces from broken vessels, with apparently other larger pieces of the broken vessels discarded elsewhere (see the discussion of the sherd refitting analyses in Chapter 9, this volume) outside the structures, and (3) only the peripheries of the exterior middens were sampled during the present investigations. Midden D, in Block F, on the other hand, contains a very low density of ceramic remains. 


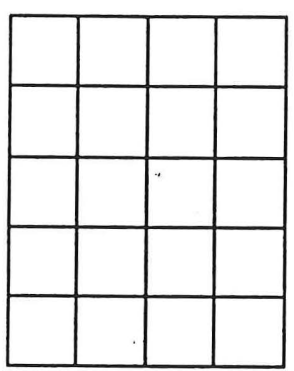

Block F
Structure $\mathrm{C}$

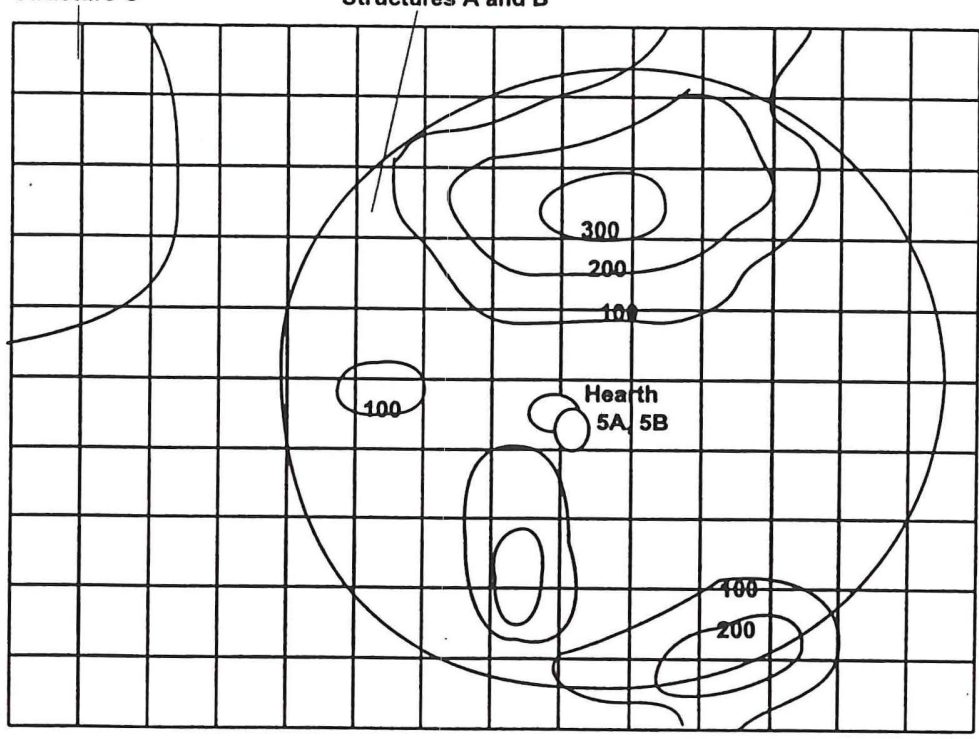

Block B/C

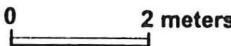

Figure 7-19. Distribution of ceramics in Blocks $\mathrm{B} / \mathrm{C}$ and $\mathrm{F}$ on the South rise.

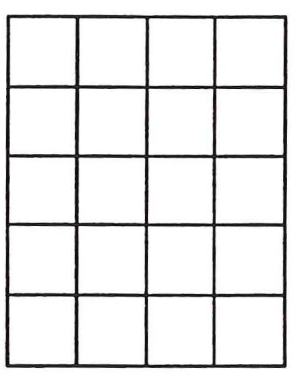

Block F

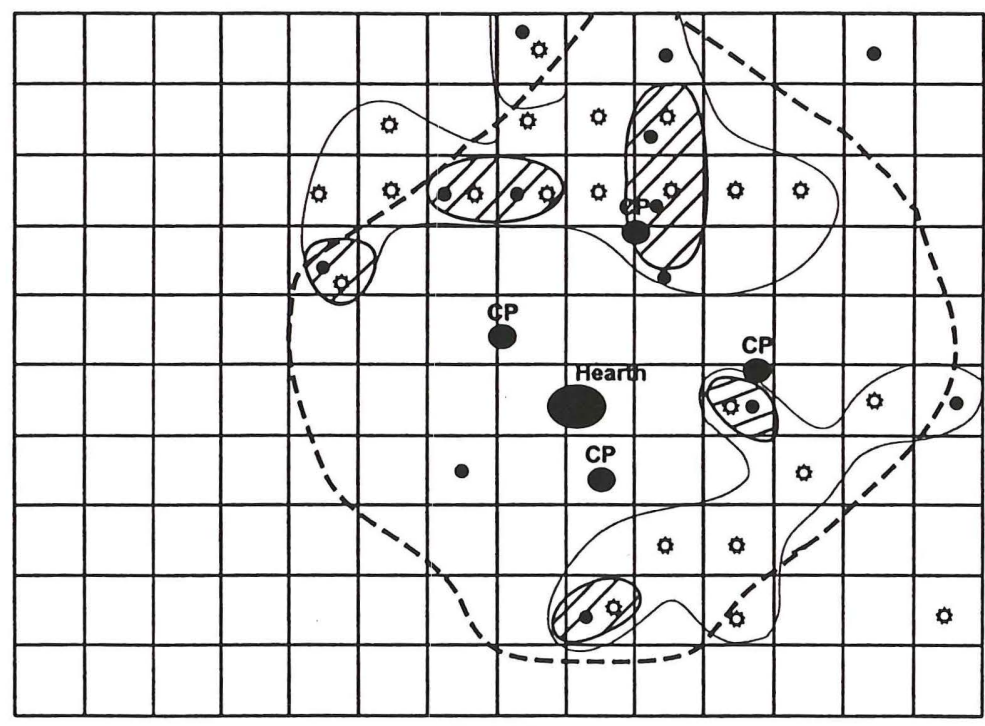

Block B/C

2 meters $>5$ Decorated Pottery Sherds

- >5 Plain Rim Sherds

Figure 7-20. Distribution of rim and decorated sherds in Block B/C. 
The clusters of ceramic sherds inside Structures A and B lie generally between the four central posts and the exterior wall posts (see Figures 7-19 and 7-20), not between the interior hearths and the central posts. This distinctive spatial patterning in the ceramic sherds is also duplicated in other select artifacts classes discussed below--highlighting a common pattern of use and artifact discard within the Middle Caddoan structures--and interestingly, Bruseth and Martin (1987:Figures 13-16 and 13-17) illustrate similar distribution of artifacts, including sherds, within House 1 at the Bird Point Island site. It appears to be the case that this central area around the hearth and between the hearth and the central posts was kept very clean of broken sherds and discarded lithic tools, primarily to increase access for cooking and heating activities associated with the use of the structures by its several occupants (including the placement of an assortment of wholle vessels near the hearths), and also to be able to easily reach pits near to the hearths that may have contained storable plant foods.

Animal bone is more tightly clustered than either the ceramics or tools in Block B/C, and almost all of it was distributed within Structures A and B; the middens contained few bones. The highest density of bone (greater than 75-460 g per $\mathrm{m}^{2}$ ) is clustered within 1-2 $\mathrm{m}$ of the interior hearths (Figure 7-21), inside the four interior center posts, except for a $3 \mathrm{~m}^{2}$ area northeast of the hearth, near the apparent entrance to Structure A, the latest Middle Caddoan structure (see Figure 7-21). The animal bone clusters south, southeast, and northeast of the hearths represent the faunal remains that were discarded into nearby large pits. The density of bone along the walls of the structures is quite low, and this is probably where sleeping platforms (such as were described among the Hasinai Caddo by Henri Joutel in 1687 [Foster 1998:208-209] or other internal structural features were situated. The $3 \mathrm{~m}^{2}$ area northeast of the hearth appears to represent a small midden deposited on the occupation surface or floor of the mid-14th century Structure A, at 16-20 cm bs. Larger sherds, most of a complete ceramic pipe (see Chapter 9, this volume), a piece of galena, and other items were recovered at this level in this part of the house.

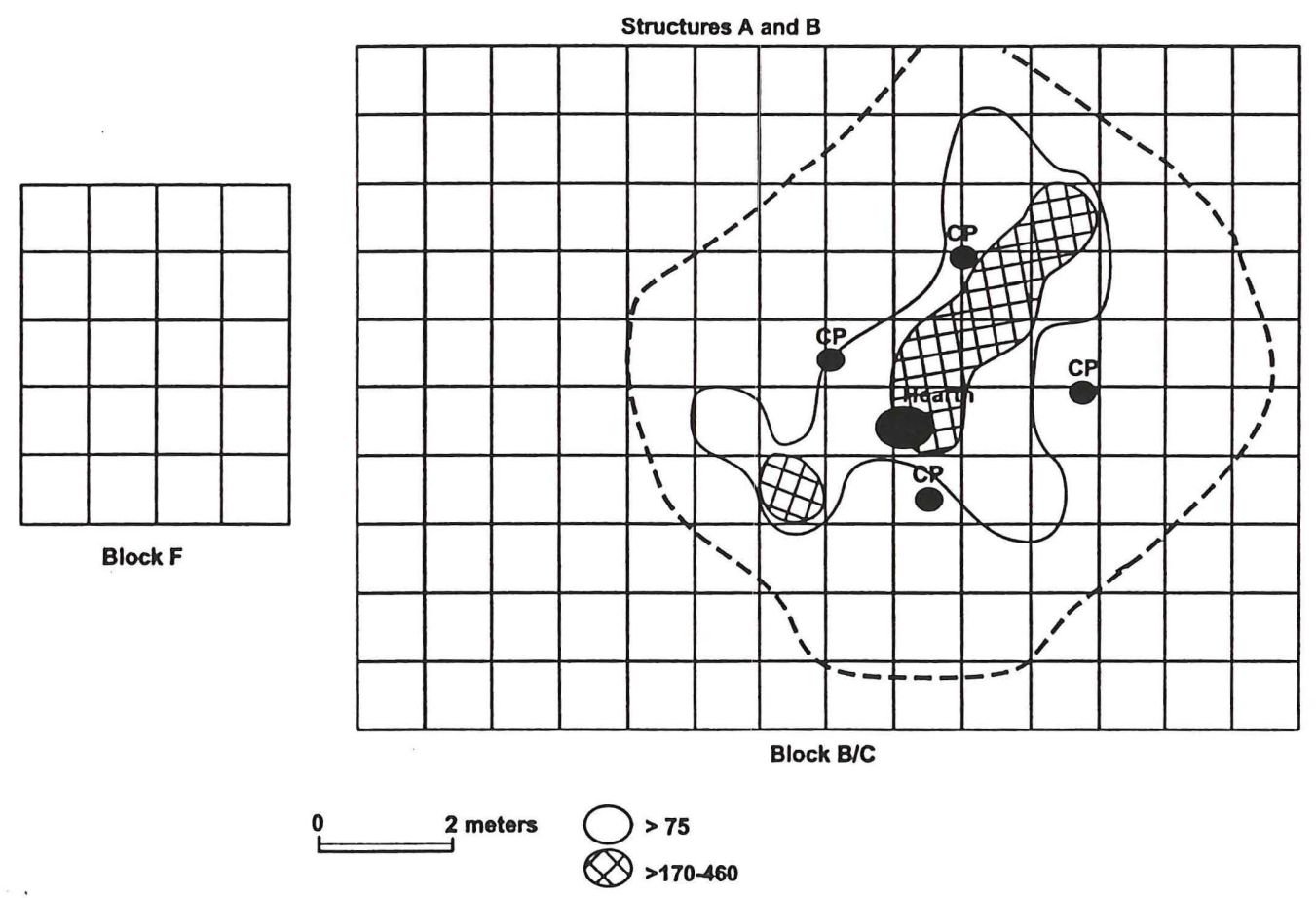

Figure 7-21. Distribution of faunal remains in Block B/C.

As with the animal bones from Structures A and B, charred maize cupules were only recovered inside the structure and principally in the hearth and four pits between the interior hearth and the four central posts (Figure 7-22). Clearly, the use of maize in Middle Caddoan times is represented by charred pieces of 


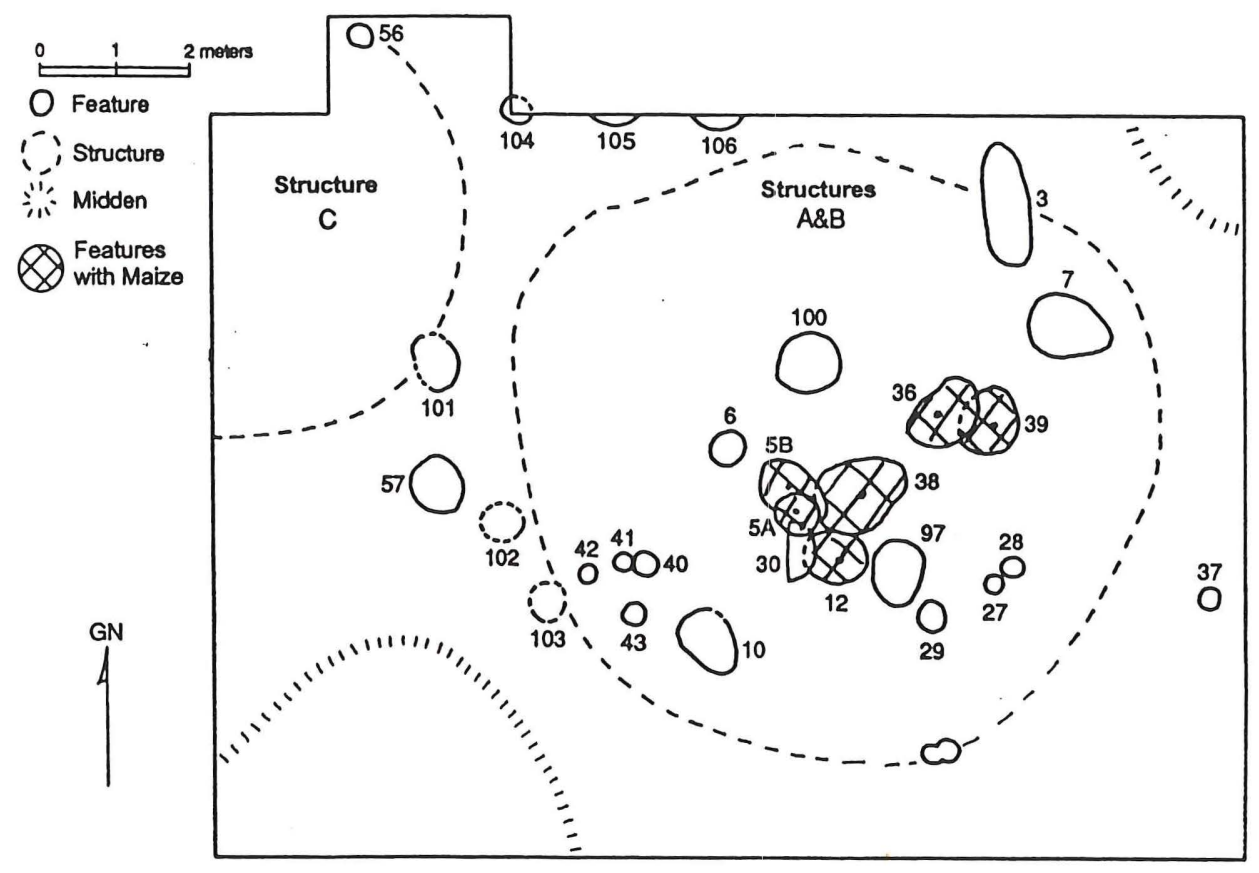

Figure 7-22. Distribution of maize within Structures A and B.
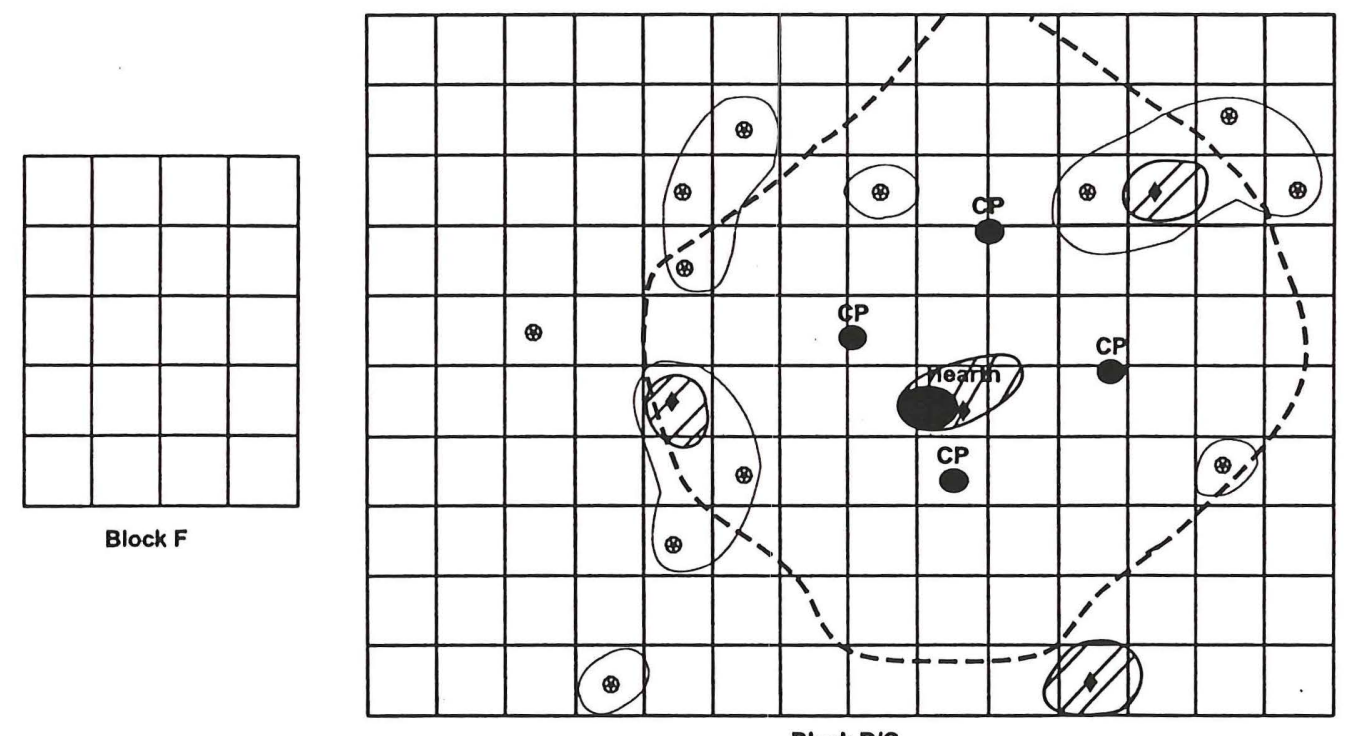

Block B/C

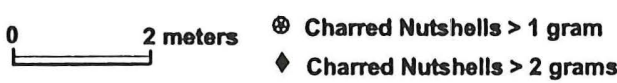

Figure 7-23. Distribution of charred nutshells in Block B/C. 
cobs and kernels that were discarded into nearby large pits, and the processing and discarding of maize elsewhere on the South rise was very limited; on the North rise, maize cupules and kernels were common in trash midden contexts outside of Structure D (see Appendix XX for provenience data). Charred nutshells-principally hickory, but also including acorn and hazelnut--were more broadly distributed within Structures $\mathrm{A}$ and $\mathrm{B}$, and also occur in small clusters (with more than $2 \mathrm{~g}$ of charred nutshells) along the exterior structure walls as well as immediately outside the structures on the east, south, and west (Figure 7-23). The latter nutshells may have been discarded in general midden deposits, while the small clusters to the south and west appear to represent nutshells tossed out the structure entrance(s). Only one of the nine charred nutshell clusters occurs in the house floor space between the interior hearths and the four center posts, totally opposite to the disposal patterns of faunal remains and maize pieces.

The distribution of bone tools and arrowpoints also highlights the restricted use of the floor space in and around the interior clay hearths within Structures A and B. The five bone tools are only 1-2 m from the interior hearths, but along and outside the central floor area demarcated by the four center posts (Figure 7-24). The arrowpoints, although much more common than the bone tools, were also discarded or lost inside and outside the structures, but none of the 45 arrowpoints (62 percent of which were broken; more than 70 percent of the arrowpoints found within the structures were broken) with provenience data occur within the central hearth/center post space (Figure 7-25). Rather, within the structures they cluster along its northern half and almost all the arrowpoints in this area are broken (see Figure 7-25), while outside the structures the arrowpoint clusters are present to the northwest of the interior hearths, northeast (by the entrance to Structure A?), southeast (by the entrance to the earlier Structure B?), or to the southwest (in midden deposits).

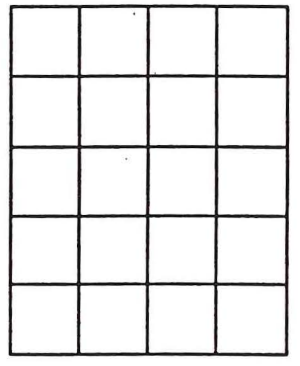

Block F

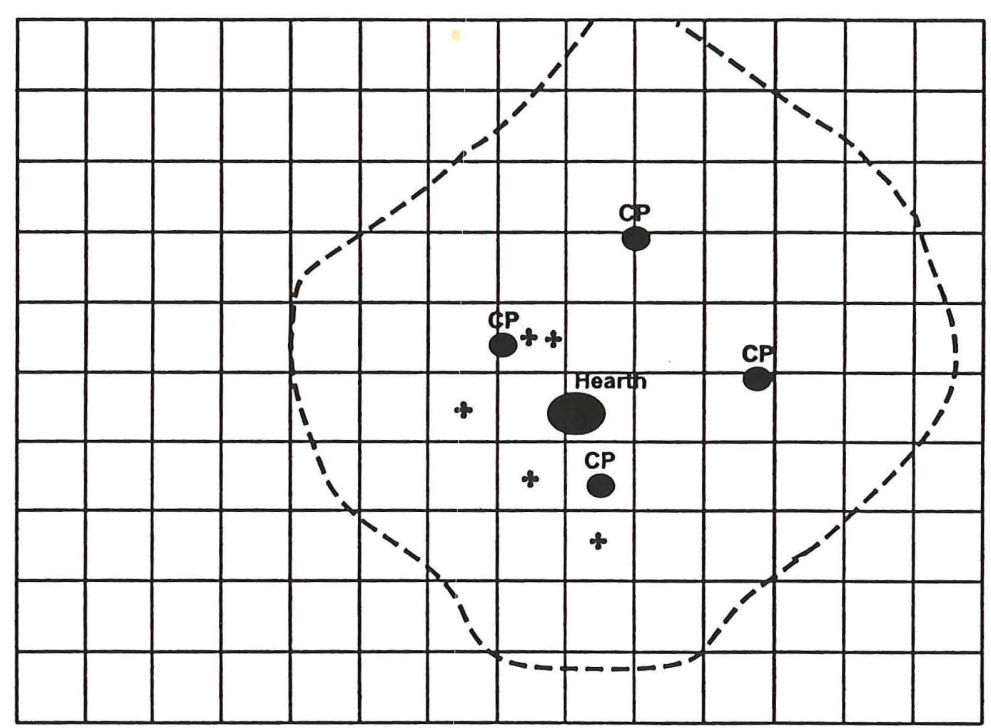

Block B/C

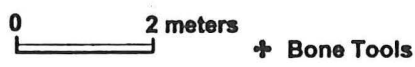

Figure 7-24. Spatial distribution of bone tools, Block B/C. 

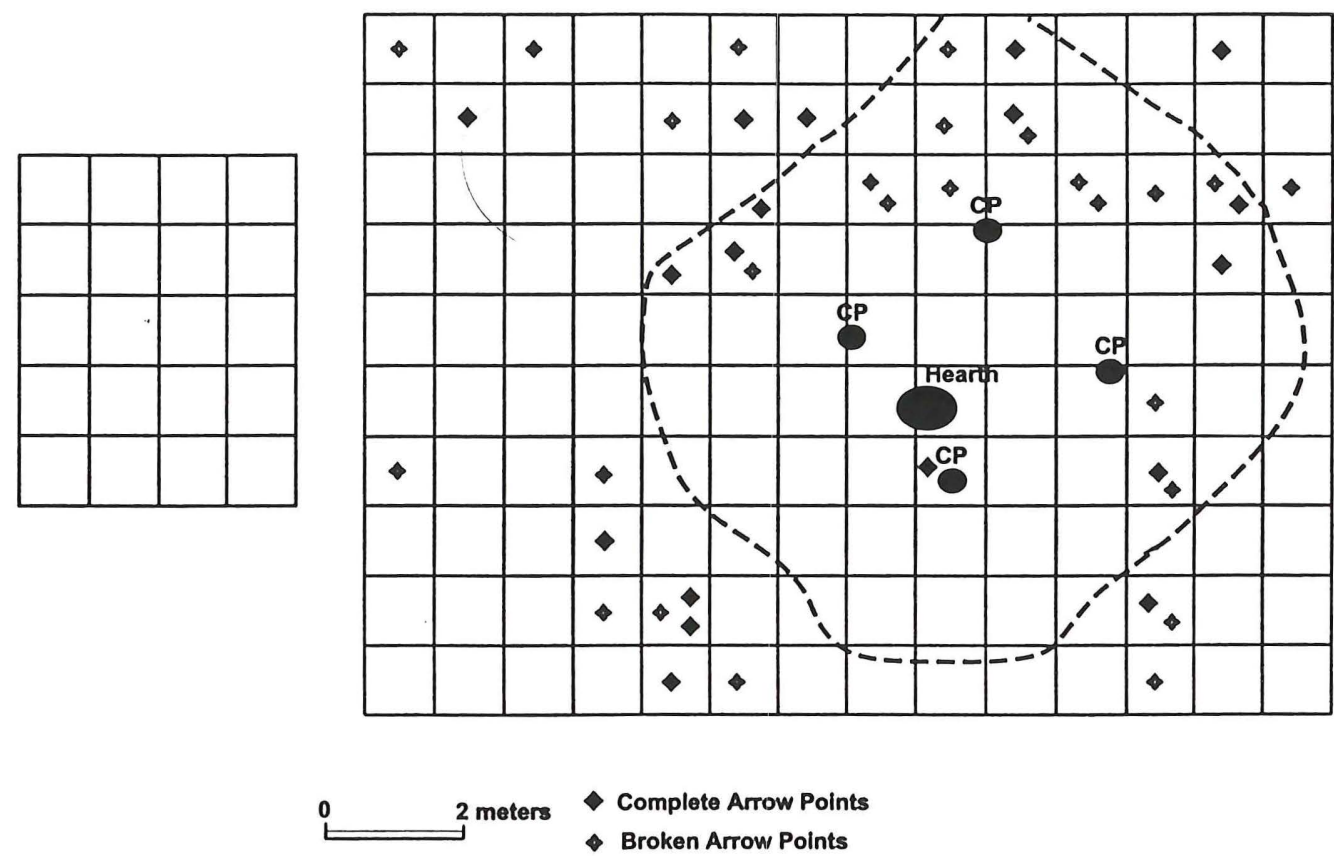

Figure 7-25. Distribution of complete and broken arrowpoints, Block B/C.

Middle Caddoan period chipped and groundstone tools are also distributed spatially outside of the central structure hearth/post area, but within the structures themselves there is a more even spread of discarded tools to the north and south of the hearths (Figure 7-26). These groups of tools include scrapers, drills/perforators, and hammerstones, while an abrader and a metate fragment were found southwest of the interior hearths and near the structure walls. Outside the structures, chipped and groundstone tools-particularly scrapers--are found almost exclusively along and near their northern walls or in Midden D in Block F, downslope to the west of Structures A and B (see Figure 7-26).

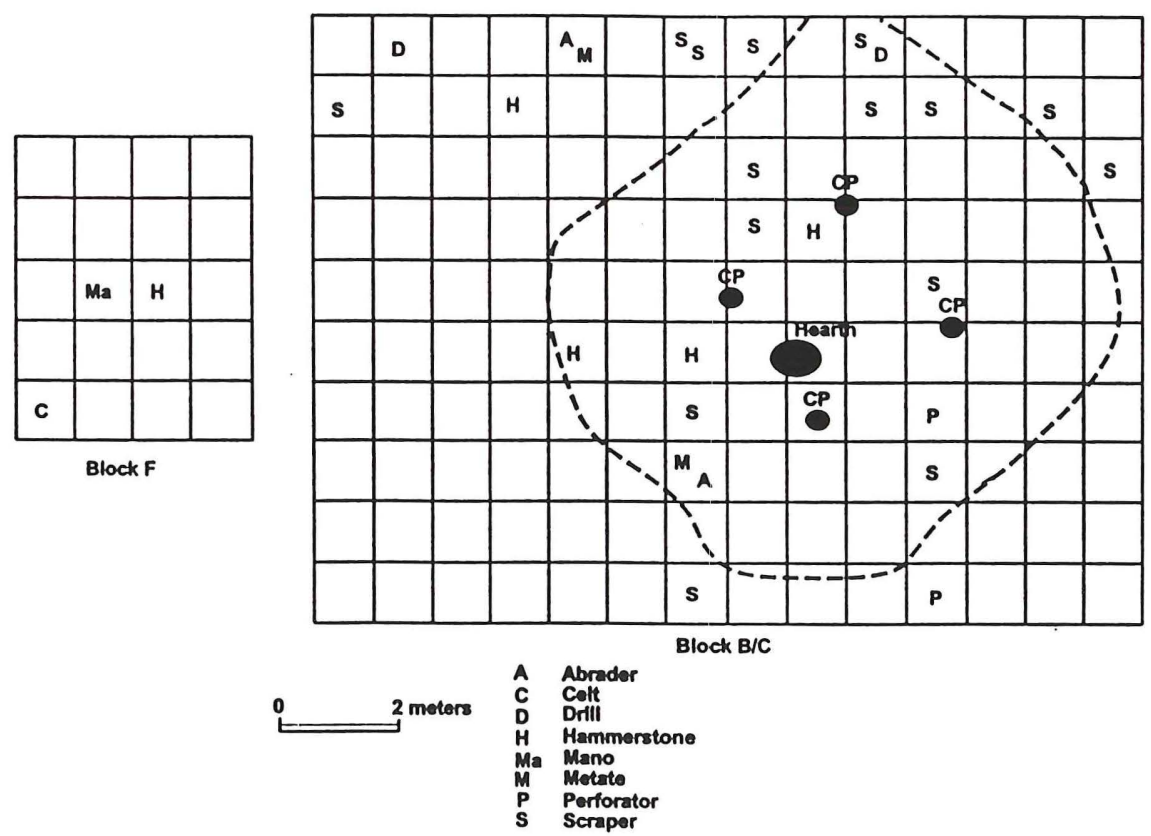

Figure 7-26. Distribution of select Middle Caddoan chipped and groundstone tools in Block B/C. 
The spatial distribution of daub and burned clay, most of which appears to be associated with the later Structure A (see Figure 7-9) suggests that when Structure A collapsed, it fell to the northeast, away from the interior hearths but towards the entrance on the northeastern side of the structure. The highest densities of daub (>5 g per level in a $1 \times 1 \mathrm{~m}$ unit) and burned clay ( $>20-50 \mathrm{~g}$ per level in a $1 \times 1 \mathrm{~m}$ unit) are in the northeastern quadrant of the block excavations, both inside and outside the structures (Figures 727 and 7-28), and in the area of the postulated entrance for Structure A. The highest densities of burned clay $(>100 \mathrm{~g}$ per level) clearly define Features $5 \mathrm{~A}$ and $5 \mathrm{~B}$, the interior hearths for the two structures (see Figure 728). It is interesting that other than in the hearths themselves, little daub or burned clay was found in the floor space defined by the four center posts. Why this should be the case is not clear if it is accurate that most of the daub and burned clay represent small remnants of clay-lined wall thatching that fell to the ground when the structure collapsed, unless the strength of the four center posts was such that the walls fell straight out; there was a covered interior partition; or the clay-lined thatching was not uniformly applied on the structure walls. The daub found near the center posts (see Figure 7-27) may represent pieces that fell from a smokehole that would have been made over the interior hearth and cut through the grass lining on the top of the structure (cf. Foster 1998:208). Such a daub mass has been reported from a 15th century rectangular Caddo structure at the Standridge site in southwestern Arkansas (Early 1988:50).

The spatial distributions of FCR, cores, lithic debris, other chipped stone tools (including utilized flakes), and dart projectile points on the South rise are quite different than the Middle Caddoan period ceramics, plant and animal remains, bone tools, and arrowpoints. In general terms, it is reasonable to suggest that the majority of these lithic remains are part of the Late Archaic/Early Ceramic period occupation that occurred on the crest of the South rise many generations prior to the Middle Caddoan occupation, and bear no co-associational relationship with the interior hearths and four center posts of Structures A and B.

Although because of the intensive use of ceramics by the Middle Caddoan peoples at Hurricane Hill it is suspected that the FCR is not part of the Middle Caddoan material culture assemblage, FCR (in levels with $>0.5 \mathrm{~kg}$ of FCR) is present in several areas inside and outside the structures (Figure 7-29). Levels between $0-60 \mathrm{~cm}$ bs with more than $0.5 \mathrm{~kg}$ of FCR are concentrated north of the interior hearths. In fact, much of this FCR is from levels below the floor of the Middle Caddoan structures, particularly from deeper than $50 \mathrm{~cm}$ bs (Figure 7-30). This distribution suggests that at least one buried Late Archaic/Early Ceramic cluster of FCR (either discarded from hearths and pits or the disarticulated remnants of the features themselves) was present on the crest of the South rise at the time the Middle Caddoan structures were built, and that it was further buried by Middle Caddoan refuse and trash deposits. Outside the structures, the Late Archaic/Early Ceramic period deposits are more shallowly buried.

Additional information bearing on the extent of the Late Archaic/Early Ceramic occupation on the South rise is the distribution of dart points and lithic debris across Block B/C (Figures 7-31 and 7-32). Dart points are abundant both inside and outside the two Middle Caddoan period structures, but as discussed above, are particularly common in contexts underlying the floors of these structures, especially in level 5 (40-50 cm bs). The distribution of dart points in the north central portions of the block excavations (see Figure 7-31) is quite comparable to that of the FCR, and indicates that the Late Archaic/Early Ceramic cluster covers at least $50 \mathrm{~m}^{2}$ on the South rise. The relatively high but homogeneous density of projectile points--ranging between at least 2-4 dart points per $\mathrm{m}^{2}$--on the South rise further suggests that the Late Archaic/Early Ceramic period component is a product of multiple, repeated occupations over perhaps a millennia. The highest frequencies of lithic debris occur both inside and outside of the Middle Caddoan structures, but only 25 percent of the units with more than 90 pieces of lithic debris in any one level are within the boundaries of the structures (see Figure 7-32). Like the FCR and dart points, the largest amounts of lithic debris are distributed across the northern part of the Block B/C excavations, again on the higher parts of the South rise, but over a larger area than either the FCR or the dart points. 


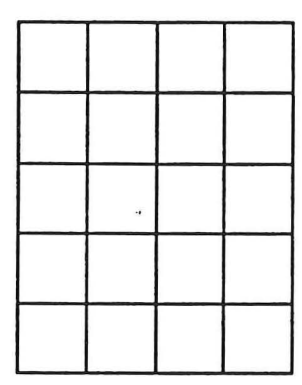

Block F

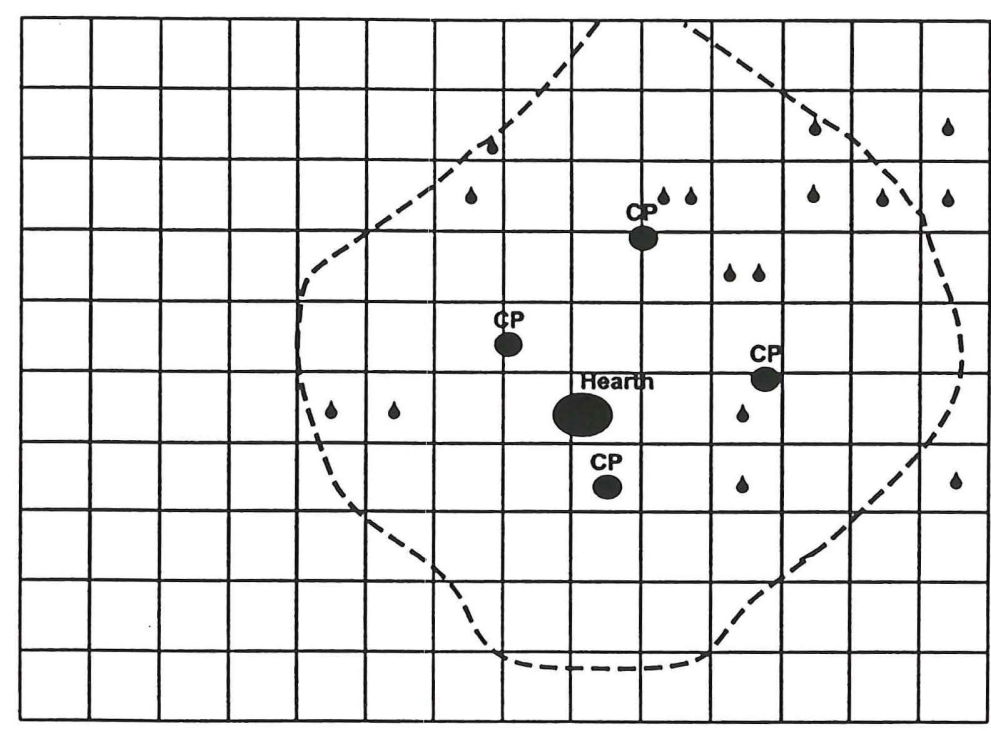

Block B/C

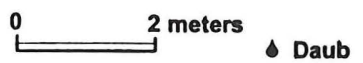

Figure 7-27. Distribution of daub in Block B/C.

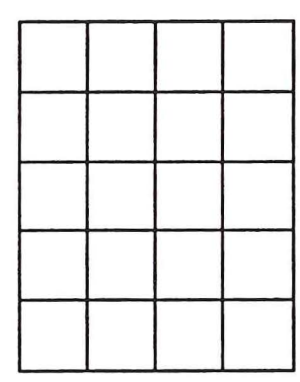

Block F

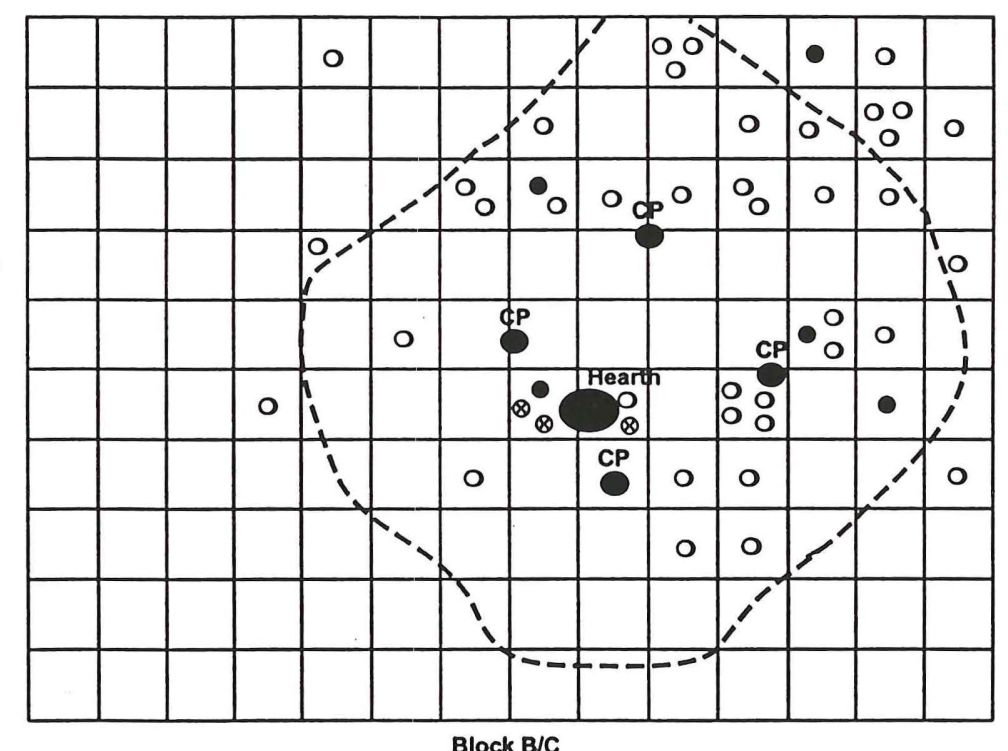

Block B/C

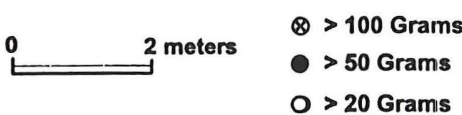

Figure 7-28. Distribution of burned clay in Block B/C. 

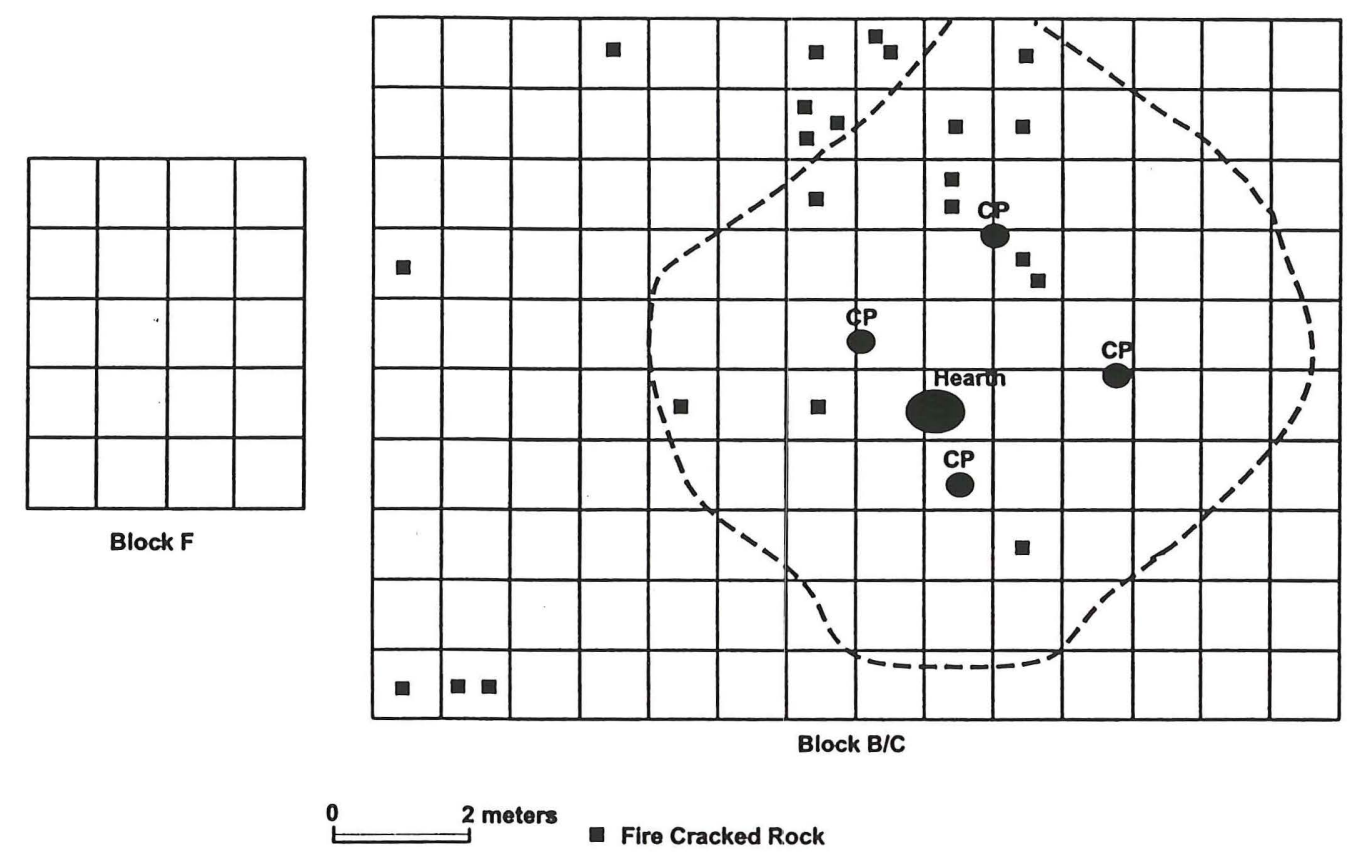

Figure 7-29. Distribution of fire-cracked rock, all levels, Block B/C.

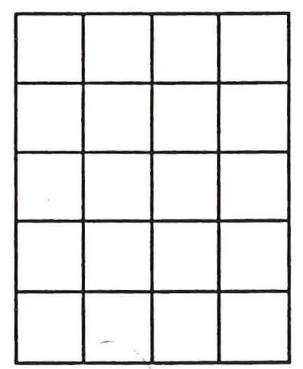

Block F

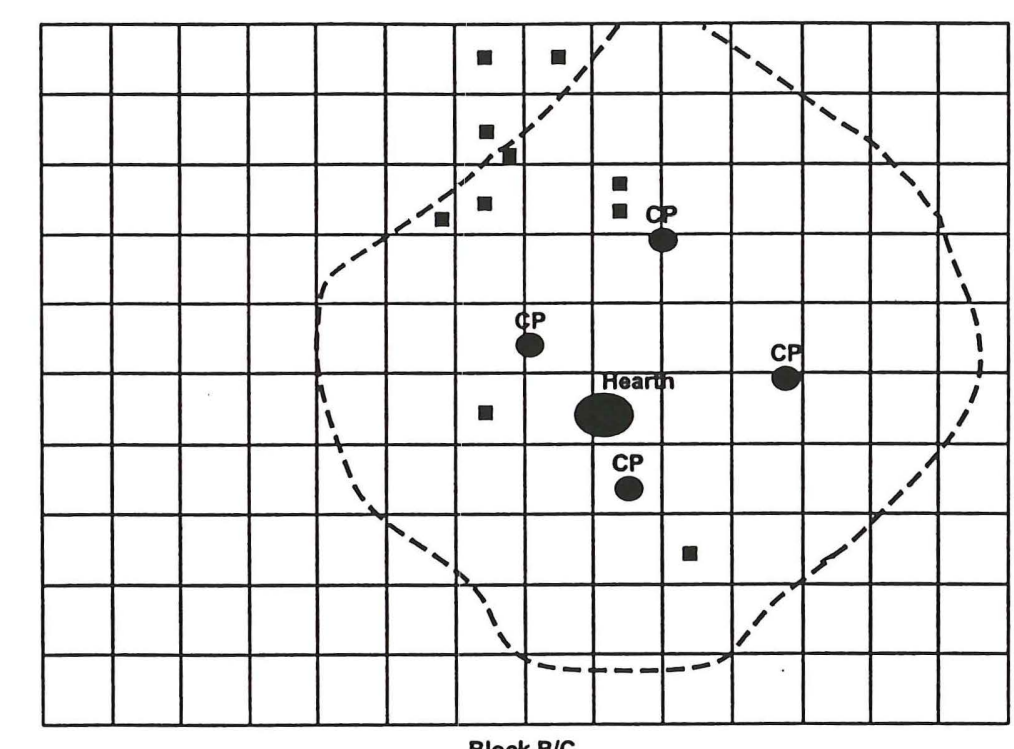

Block B/C

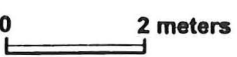

Fire Cracked Rock

Figure 7-30. Distribution of fire-cracked rock, level 6+, Block B/C. 


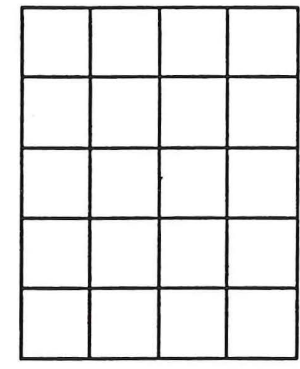

Block F

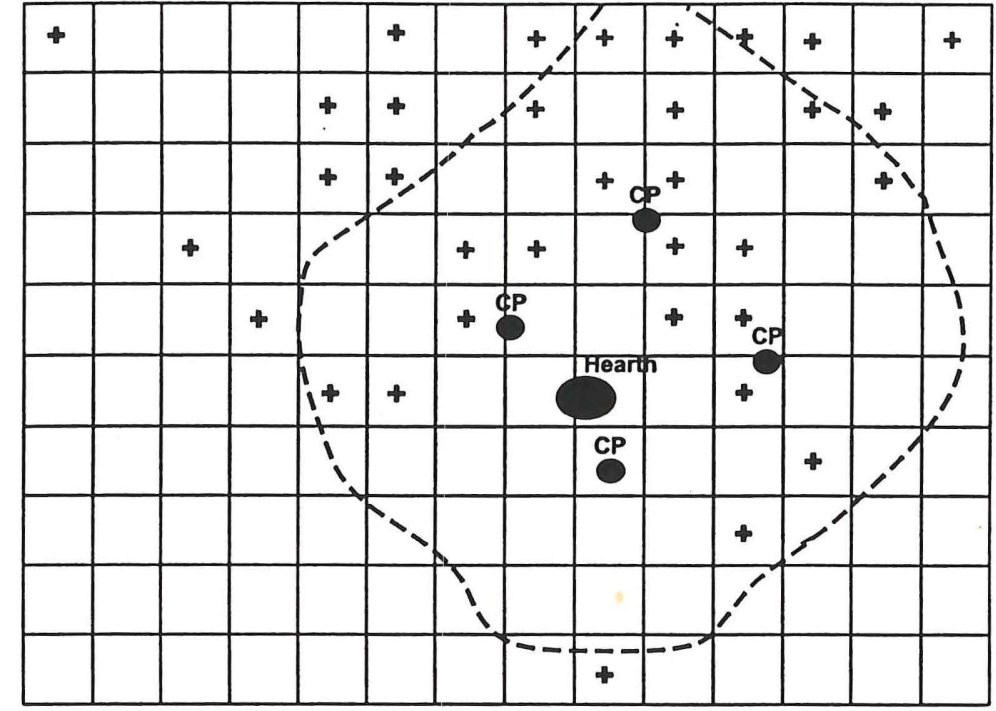

Block B/C

Figure 7-31. Distribution of dart points in Block B/C.

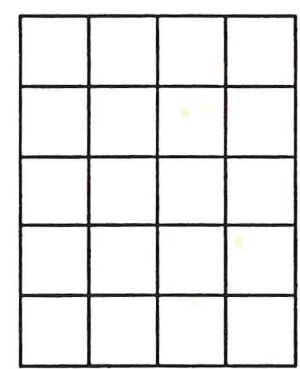

Block F

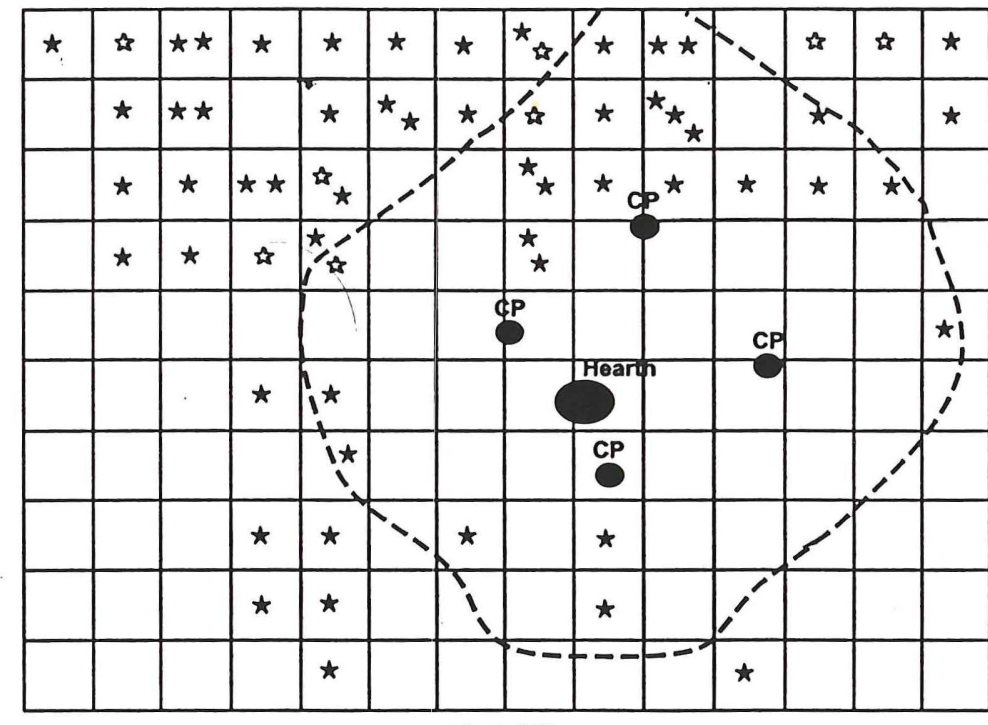

Block B/C

2 meters Lithic Debris Levels with $>90$
Lithic Debris Levels with $>50$

Figure 7-32. Distribution of lithic debris in Block B/C. 
Cores and a variety of other chipped stone tool classes (including utilized flakes, arrowpoint preforms, gravers, notch/spokeshave, unifacial tools, retouched pieces, and knives) are found throughout the Block B/C excavations, but clearly recognizable local clusters are not apparent. Within the structures, the cores probably associated with the Middle Caddoan structures (present between 0-30 cm bs) are found in and around the central interior hearth and four center post area, with the majority of the cores to the north and east nearer the structure walls (Figure 7-33). Cores are also common outside the structures at shallow depths, including near the entrances of the two structures, as well as to the west in the area of Structure C, the possible Middle Caddoan period ramada or arbor (see Figure 7-33). Cores from deeper contexts--assuredly Late Archaic/Early Ceramic in age--are widely distributed across the block, but excavation units with more than $2-4$ cores are found only in the northern portion of the block, in immediate proximity to the units with the highest densities of FCR (see Figure 7-29), and several of the units where dart points are abundant (see Figure 7-31). Furthermore, a number of cores in the deeper deposits were recovered in units in the special area defined by the Middle Caddoan period interior hearths and the four central posts, which was a special floor space where few Middle Caddoan period artifacts of any kind (primarily maize cupules, animal bone, bone tools, and charred nutshells; see discussion above) were distributed, again indicating that the preexisting Late Archaic/Early Ceramic period archaeological deposits were distributed over the same part of the South rise later used by the Middle Caddoan period occupants. The same spatial patterning identified in the distribution of cores, lithic debris, and projectile points is apparent with the utilized flakes and other chipped stone tools, in that they are well distributed across the block excavations, clustering primarily in the northern part of the block, although the retouched pieces are more abundant in the central part of the block, south of the FCR clusters, than are the utilized flakes (Figures 7-34 and 7-35). A number of the retouched pieces and utilized flakes are found in deeper Late Archaic/Early Ceramic deposits underneath the interior hearths and four central posts, while the utilized flakes recovered between $0-30 \mathrm{~cm}$ bs are distributed in all cardinal directions from the interior hearths, but occur in low densities ( 10.8 percent of the 83 utilized flakes from these depths) in proximity to the interior hearths and the four central posts (see Figure 7-35). Most of the utilized flakes in probable Middle Caddoan period contexts are within the northeastern portion of Structures A and B; in the area of the Structure A entrance.

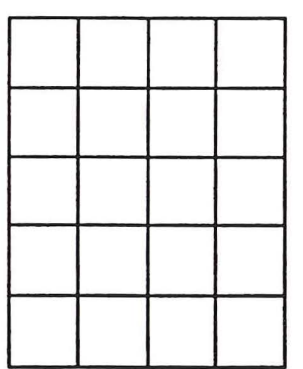

Block F

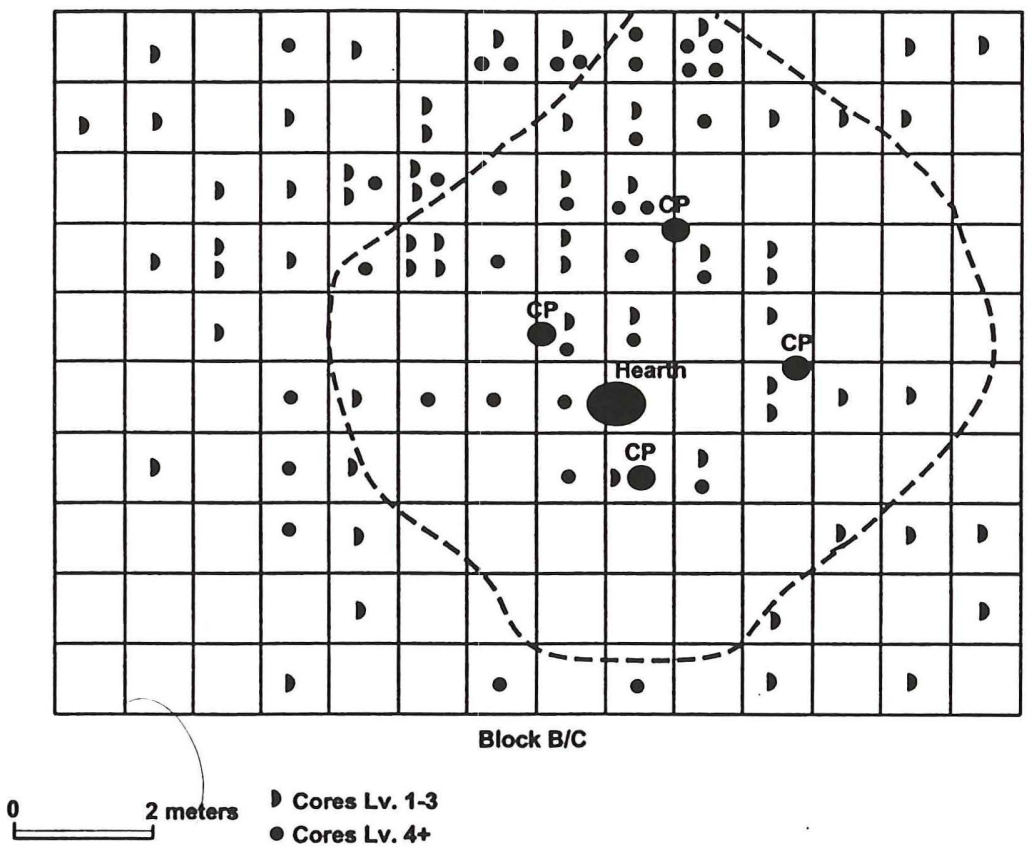

Figure 7-33. Distribution of cores, levels 1-3 and levels 4-6, in Block B/C. 


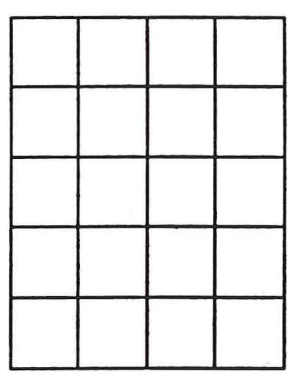

Block F

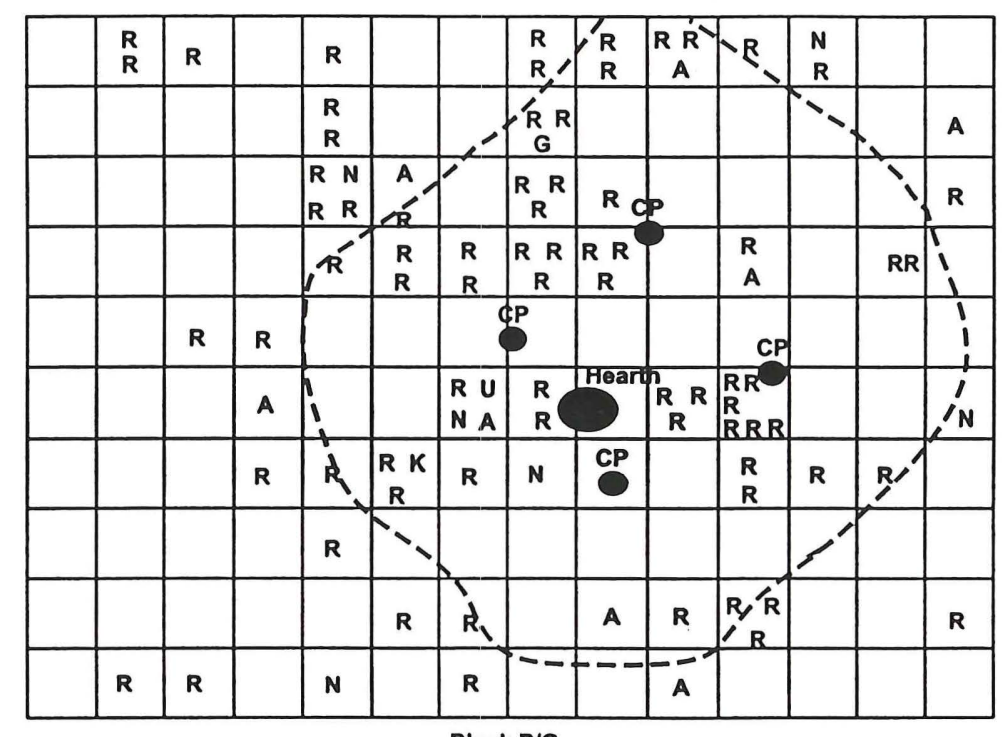

Block B/C

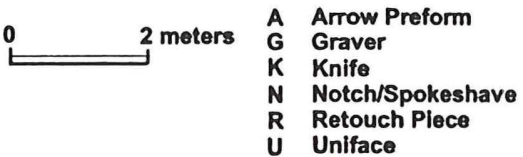

Figure 7-34. Spatial distribution of selected chipped stone tools in Block B/C.

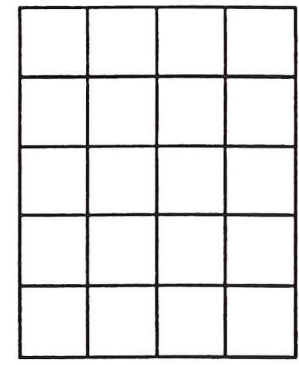

Block F

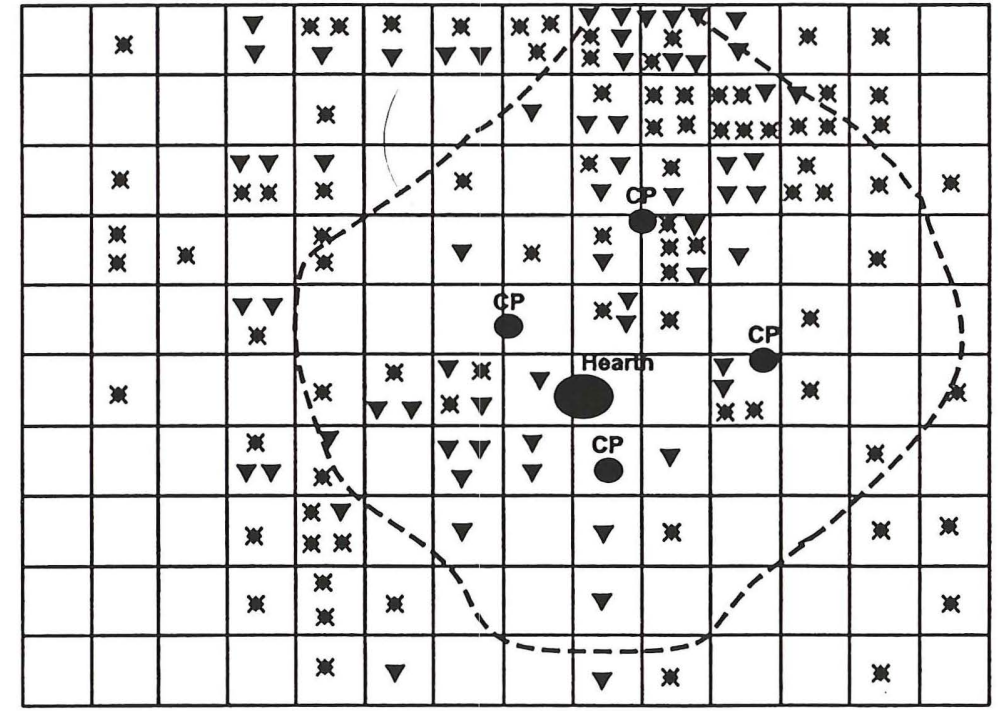

Block B/C

Utilized Flakes Lv. 1-3

$\nabla$ Utilized Flakes LV. 4t

Figure 7-35. Distribution of utilized flakes in Block B/C on the South rise. 
The overlapping distributions of lithic debris, dart points, and FCR (and indeed, other stone tool and debris classes also discussed above) in the northern part of Block B/C are reasonably interpreted as the overall amalgamation of repeated occupations on the South rise, once localized in space, but that through time have become a complex mixture of different and probably repetitive events involving the use of hot rocks for cooking and heating and the manufacture and maintenance of stone tools. As tool debris, discarded tools, and burned rock distributions began to overlap on the essentially non-aggrading surface of the South rise, what is left in the archaeological record is "that over time, there is a statistical tendency for given activities to be repeatedly localized in the same places, although these loci would not be reserved exclusively for a single activity" (Binford 1978:348).

Archaeological remains in this context have gross density-based spatial patterns that appear to correlate more with topography (i.e., the crest of the rise) than they do with overall site structure in a cultural sense, in part because of the limited aggradation that occurred during the Late Archaic/Early Ceramic use of the rise, and the accumulation of palimpsests of overlapping artifact clusters. As Stafford (1985:233) has pointed out:

The longer the duration of an occupation or the greater the degree of reoccupation, the less resolution likely between observed patterns and events. Either local patterns become more obscure or, conversely, global trends emerge to dominate the patterning; that is, from place to place in an occupation similar artifact relationships are exhibited. When local patterning is evident, observable relationships may vary across the site depending on location. 


\title{
CHAPTER 8, LITHIC ARTIFACTS FROM THE HURRICANE HILL SITE
}

\author{
Timothy K. Perttula
}

\section{Introduction}

Over 3,500 lithic tools and 130,000 pieces of lithic debris, as well as more than 13,000 pieces of fire-cracked rock (FCR), were recovered from the Phase I-IV archaeological investigations at the Hurricane Hill site (see Appendices VIII, IX, X, XI, and XII in Volume II of this report). This chapter presents descriptive and summary information on the analysis of the Archaic, Early Ceramic, and Caddoan lithic assemblages from the different areas of the site (i.e., the North, South, and Southwest rises). The classification of the lithic artifacts is based on the general approach utilized for the Lake Ray Roberts and McGee Creek projects in north central Texas and southeastern Oklahoma, respectively (e.g., Ferring and Allen 1987; Ferring and Yates 1996; Perttula 1994a), in that these artifacts are separated into categories of unmodified debris, chipped stone, ground stone, and FCR (Figure 8-1). Within these basic categories, then, are a number of further analytical subdivisions based on the presence of cortex (for the lithic debris), whether it was unifacial, bifacial, or a parent stone mass (for chipped stone tools and cores), or whether the tool was shaped by the chipping or grinding of the lithic raw material.

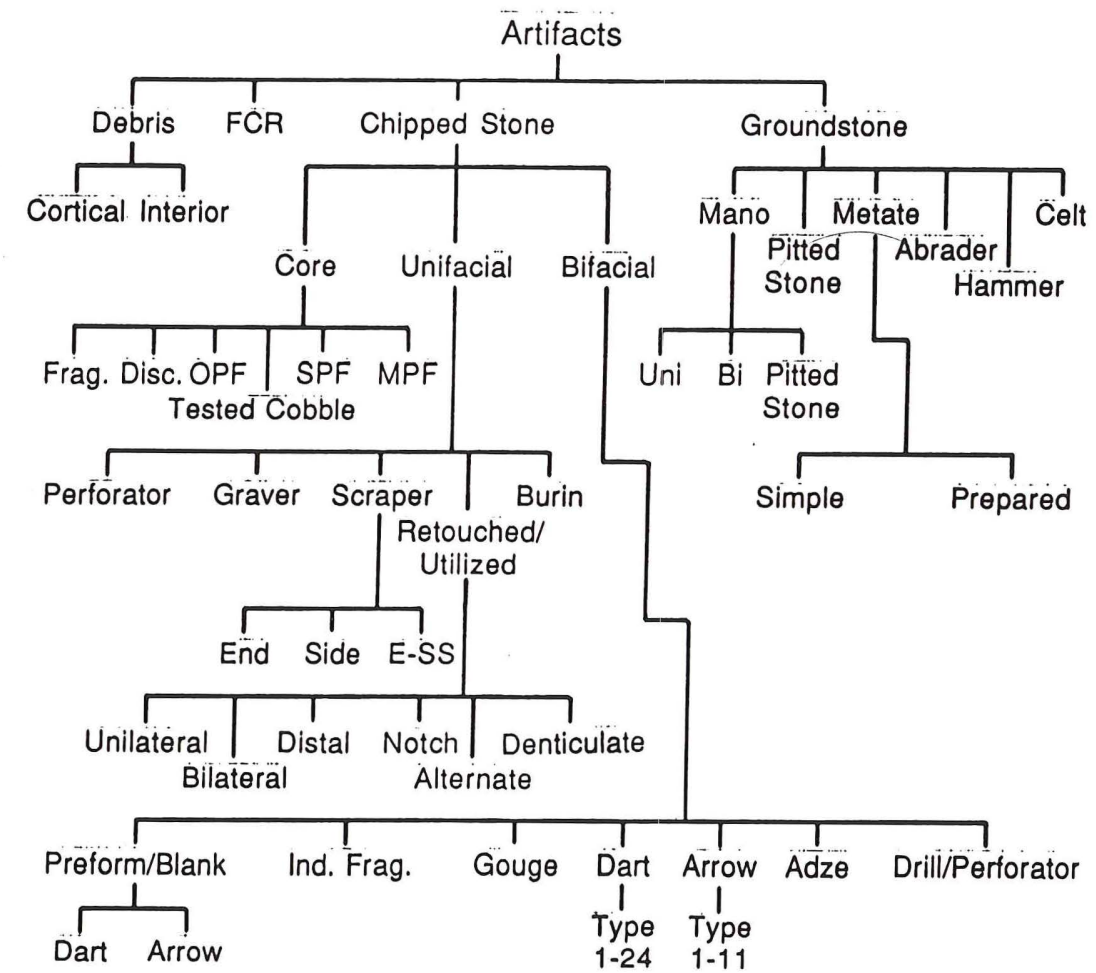

Figure 8-1. Lithic classification scheme. 


\section{Overview of the Hurricane Hill Lithic Artifacts}

Total counts for tools and lithic debris are presented by each block excavation or site area in Tables 8-1 thru 8-4. Block F had only six tools (see Appendix IX and X). The remainder of the lithic tools were collected from general surface contexts, from miscellaneous $1 \times 1 \mathrm{~m}$ units excavated during several phases of work that were not in blocks, from backhoe trenches, and from shovel tests (see Appendix VII, IX, and $\mathrm{X})$.

Table 8-1. Lithic tool and debris frequencies for Block A.

\begin{tabular}{|c|c|c|c|c|c|c|c|c|c|c|}
\hline \multirow[b]{2}{*}{ Level } & \multirow[b]{2}{*}{2} & \multirow[b]{2}{*}{3} & \multirow[b]{2}{*}{4} & \multicolumn{3}{|c|}{ Tool Class $^{\mathrm{a}}$} & \multirow[b]{2}{*}{8} & \multirow{2}{*}{$\begin{array}{l}\text { Tool } \\
\text { Total }\end{array}$} & \multicolumn{2}{|c|}{ Lithic Debris } \\
\hline & & & & 5 & 6 & 7 & & & $1 / 4^{n b}$ & $\mathrm{FS} / \mathrm{F}^{\mathrm{C}}$ \\
\hline 1 & 10 & 4 & 1 & 17 & 17 & 41 & - & 90 & 3,073 & 1,256 \\
\hline 2 & 37 & 37 & 4 & 55 & 34 & 64 & 3 & 234 & 4,464 & 14,866 \\
\hline 3 & 31 & 57 & - & 49 & 38 & 79 & 4 & 258 & 3,607 & 11,549 \\
\hline 4 & 45 & 49 & 1 & 50 & 42 & 107 & 4 & 298 & 4,005 & 8,212 \\
\hline 5 & 42 & 33 & - & 36 & 25 & 44 & 1 & 181 & 2,430 & 4,916 \\
\hline 6 & 10 & 9 & - & 8 & 4 & 17 & - & 48 & 533 & 1,048 \\
\hline 7 & 2 & 2 & - & 1 & 1 & - & - & 6 & - & - \\
\hline Surface & 4 & 7 & - & 10 & 8 & 9 & 1 & 39 & 120 & - \\
\hline $99^{d}$ & 2 & 5 & - & 3 & 1 & 1 & - & 12 & - & - \\
\hline Total & 183 & 203 & 6 & 229 & 170 & 362 & 13 & 1,166 & 18,232 & $41,847^{e}$ \\
\hline
\end{tabular}

a 2 = core; 3 = blank/preform, dart point; $4=$ blank/preform, arrowpoint; $5=$ bifacial tool; $6=$ indeterminate biface fragments, completed tools; 7 = retouched pieces; $8=$ groundstone tools

b Screen size used in recovery

c Recovery from fine screen or flotation

d Feature or unknown provenience

e This total is large because approximately 90 percent of Block A Extension was fine screened.

Table 8-2. Lithic tool and debris frequencies for Block D.

\begin{tabular}{|c|c|c|c|c|c|c|c|c|c|c|}
\hline \multirow[b]{2}{*}{ Level } & \multirow[b]{2}{*}{2} & \multirow[b]{2}{*}{3} & \multicolumn{4}{|c|}{ Tool Class $^{\mathrm{a}}$} & \multirow[b]{2}{*}{8} & \multirow{2}{*}{$\begin{array}{l}\text { Tool } \\
\text { Total }\end{array}$} & \multicolumn{2}{|c|}{ Lithic Debris } \\
\hline & & & 4 & 5 & 6 & 7 & & & $1 / 4^{\prime \prime b}$ & $\mathrm{FS} / \mathrm{F}^{\mathrm{c}}$ \\
\hline 1 & 6 & 8 & - & 2 & 3 & 9 & - & 28 & 1,004 & 403 \\
\hline 2 & 4 & 7 & 2 & 16 & 13 & 14 & 1 & 57 & 1,475 & 1,342 \\
\hline 3 & 2 & 2 & 2 & 8 & 3 & 6 & 1 & 24 & 1,147 & 970 \\
\hline 4 & 7 & 12 & $=$ & 28 & 10 & 14 & - & 71 & 1,386 & 1,784 \\
\hline 5 & 4 & 4 & 1 & 13 & 10 & 7 & - & 39 & 931 & 927 \\
\hline 6 & 4 & 11 & - & 15 & 4 & 3 & 2 & 39 & 335 & 438 \\
\hline 7 & - & 1 & - & 7 & 1 & 1 & - & 10 & 113 & 219 \\
\hline 8 & - & $\hat{1}$ & - & - & 2 & $\hat{1}$ & - & 4 & 37 & 46 \\
\hline 9 & - & - & - & - & - & - & - & - & 1 & - \\
\hline $99^{d}$ & 4 & 5 & 2 & 5 & 5 & 25 & 1 & 47 & 522 & 388 \\
\hline Total & 31 & 51 & 7 & 94 & 51 & 80 & 5 & 319 & 6,951 & 6,517 \\
\hline
\end{tabular}

\footnotetext{
a Tool classes are the same as for Table 8-1.

b Screen size used in recovery

${ }^{c}$ Recovery from fine screen or flotation

${ }^{d}$ Feature or unknown subsurface provenience
} 
Table 8-3. Lithic tool and debris frequencies for Block $E$.

\begin{tabular}{|c|c|c|c|c|c|c|c|c|c|c|}
\hline \multirow[b]{2}{*}{ Level } & \multicolumn{6}{|c|}{ Tool Class ${ }^{\mathbf{a}}$} & & \multirow{2}{*}{$\begin{array}{l}\text { Tool } \\
\text { Total }\end{array}$} & \multicolumn{2}{|c|}{ Lithic Debris } \\
\hline & 2 & 3 & 4 & 5 & 6 & 7 & 8. & & $1 / 4^{\prime \prime b}$ & $\mathrm{FS} / \mathrm{F}^{\mathrm{C}}$ \\
\hline 1 & - & 5 & 2 & 5 & 5 & 12 & 1 & 30 & 728 & 426 \\
\hline 2 & 6 & 7 & 2 & 24 & 6 & 23 & 7 & 75 & 1,569 & 2,423 \\
\hline 3 & 6 & 21 & - & 32 & 6 & 19 & 3 & 87 & 1,393 & 2,054 \\
\hline 4 & 14 & 18 & - & 20 & 11 & 19 & 2 & 84 & 1,187 & 1,266 \\
\hline 5 & 7 & 7 & - & 17 & 6 & 9 & - & 46 & 849 & 1,060 \\
\hline 6 & 9 & 4 & - & 10 & 3 & 6 & 1 & 33 & 607 & 188 \\
\hline 7 & - & 2 & - & 7 & 2 & - & - & 11 & 51 & 6 \\
\hline 8 & - & 1 & - & - & - & - & - & 1 & 29 & 29 \\
\hline 9 & - & - & - & - & 1 & 2 & - & 3 & 33 & - \\
\hline $99^{d}$ & - & 1 & - & 7 & 1 & 7 & - & 16 & 40 & - \\
\hline Total & 42 & 66 & 4 & 122 & 41 & 99 & 14 & 384 & 6,486 & 7,452 \\
\hline
\end{tabular}

a Tool classes are the same as for Table 8-1.

b Screen size used in recovery

${ }^{c}$ Recover; from fine screen (FS) or flotation (F)

$\mathrm{d}_{\text {Feature provenience }}$

Table 8-4. Lithic tool and debris frequencies for Block $B / C$.

\begin{tabular}{|c|c|c|c|c|c|c|c|c|c|c|}
\hline \multirow[b]{2}{*}{ Level } & \multirow[b]{2}{*}{2} & \multirow[b]{2}{*}{3} & \multirow[b]{2}{*}{4} & \multicolumn{2}{|c|}{ Tool Class ${ }^{a}$} & \multirow[b]{2}{*}{7} & \multirow[b]{2}{*}{8.} & \multirow{2}{*}{$\begin{array}{l}\text { Tool } \\
\text { Total }\end{array}$} & \multicolumn{2}{|c|}{ Lithic Debris } \\
\hline & & & & 5 & 6 & & & & $1 / 4^{n b}$ & $\mathrm{FS} / \mathrm{F}^{\mathrm{c}}$ \\
\hline 1 & 16 & 24 & 5 & 33 & 30 & 67 & 1 & 176 & 7,035 & 956 \\
\hline 2 & 19 & 32 & 1 & 40 & 25 & 38 & - & 155 & 5,320 & 3,262 \\
\hline $\begin{array}{l}3 \mathrm{~A} \\
3 \mathrm{~B}\end{array}$ & $\begin{array}{l}14 \\
11\end{array}$ & $\begin{array}{l}19 \\
13\end{array}$ & $\overline{1}$ & $\begin{array}{l}23 \\
24\end{array}$ & $\begin{array}{l}18 \\
19\end{array}$ & $\begin{array}{l}37 \\
38\end{array}$ & $\overline{2}$ & $\begin{array}{l}111 \\
108\end{array}$ & $\begin{array}{l}2,814 \\
2,523\end{array}$ & $\begin{array}{l}1,421 \\
1,335\end{array}$ \\
\hline $\begin{array}{l}4 A \\
4 B\end{array}$ & $\begin{array}{l}10 \\
9\end{array}$ & $\begin{array}{l}17 \\
17\end{array}$ & $\overline{1}$ & $\begin{array}{l}9 \\
7\end{array}$ & $\begin{array}{l}11 \\
12\end{array}$ & $\begin{array}{l}31 \\
29\end{array}$ & $\overline{2}$ & $\begin{array}{l}78 \\
77\end{array}$ & $\begin{array}{l}2,259 \\
2,035\end{array}$ & $\begin{array}{l}1,017 \\
896\end{array}$ \\
\hline $\begin{array}{l}5 \mathrm{~A} \\
5 \mathrm{~B}\end{array}$ & $\begin{array}{l}9 \\
11\end{array}$ & $\begin{array}{l}31 \\
20\end{array}$ & - & $\begin{array}{l}19 \\
16\end{array}$ & $\begin{array}{l}17 \\
10\end{array}$ & $\begin{array}{l}32 \\
25\end{array}$ & $\overline{3}$ & $\begin{array}{l}108 \\
85\end{array}$ & $\begin{array}{l}1,859 \\
1,920\end{array}$ & $\begin{array}{l}761 \\
883\end{array}$ \\
\hline $\begin{array}{l}6 \mathrm{~A} \\
6 \mathrm{~B}\end{array}$ & - & 1 & - & - & $\begin{array}{l}1 \\
-\end{array}$ & - & - & $\begin{array}{l}2 \\
-\end{array}$ & $\begin{array}{l}45 \\
15\end{array}$ & $\begin{array}{l}19 \\
-\end{array}$ \\
\hline $\begin{array}{l}7 \mathrm{~A} \\
\text { Surface } \\
99^{d}\end{array}$ & $\begin{array}{l}- \\
1 \\
4\end{array}$ & $\begin{array}{l}- \\
4 \\
20\end{array}$ & - & $\overline{9}$ & $\begin{array}{l}- \\
2 \\
6\end{array}$ & $\begin{array}{l}- \\
7\end{array}$ & $\overline{2}$ & $\overline{21}$ & $\begin{array}{l}45 \\
7 \\
331\end{array}$ & $\begin{array}{l}- \\
- \\
49\end{array}$ \\
\hline $99^{d}$ & 4 & 20 & - & 4 & 6 & 7 & - & 41 & 331 & 49 \\
\hline Total & 104 & 198 & 8 & 184 & 151 & 307 & 10 & 962 & 26,208 & 10,599 \\
\hline
\end{tabular}

a Tool classes are the same as for Table 8-1.

${ }^{b}$ Screen size used in recovery

c Recovery from fine screen or flotation

${ }^{d}$ Feature or Unknown subsurface provenience (i.e., found in the backdirt of backhoe trench) 
In these comparisons, there are seven tool classes: core; blank/preform for dart points; arrow point preforms; bifacial tools (including arrow points and dart points, as well as gouges, adzes, and knives); indeterminate bifacial tool fragments; retouched pieces and utilized flakes; and groundstone (although cores and blank/preforms are included here as tools in the IAS/UNT classification scheme, it is understood that cores and blank/preforms represent manufacture-related lithics rather than a completed and useful tool). For our purposes, these lithic classes are defined as follows:

Core: Cores are pebbles or cobbles of lithic raw material that have flake scars and evidence of platform preparation from the removal of flakes, or the reduction of pebble/cobble masses, for the production of tools. The following core types are present: (a) tested cobble; (b) bifacial core; (c) single platform flake; (d) opposed platform flake; (e) multiple platform flake; (f) discoidal; (g) globular; and (h) core fragment.

Blank/preform: These are bifacially worked items that were broken or discarded before the completion of manufacture, and they are generally thick, ovate and non-symmetrical specimens lacking edge retouching and shaped tips.

Arrow point preform: Unifacially and/or bifacially worked preform of arrowpoint dimensions (in thickness and width), with fine edge retouching, but lacking evidence of hafting.

Bifacial tool: These are apparently finished or completed lithic items that have been bifacially retouched, and also have fine edge retouching and straightening, evidence of a haft, stem, and/or notching. Among the bifacial tools in the Hurricane Hill assemblage are arrow points, dart points, gouges, adzes, stemmed knives with hafts, and knives without a discernible haft.

Indeterminate bifacial tool fragment: This tool class consists of fragments of completed bifacially chipped and retouched tools, but because they are fragments, their morphology or function is indeterminate.

Retouched and utilized piece: Retouched pieces are tools made on flakes that have been deliberately shaped through retouching modification, while utilized flakes have evidence of small, discontinuous, and abrupt and macroscopically visible step fractures along the flake edge that probably are from use wear, rather than deliberate retouching modification. Among the retouched tools, the following classes are recognized: (a) drill, (b) unifacial and bifacially-worked perforator, (c) graver, (d) end scraper, (e) thumbnail scraper, (f) side scraper, (g) end and side scraper; (h) denticulate; (i) notch/spokeshave, (j) burin, (k) composite uniface, and (l) unilateral, bilateral, distal, distal-lateral, and alternate retouched pieces. The utilized pieces are characterized by the location of the use wear on the flake, or the type of flake: (a) unilateral, (b) bilateral, (c) distal, (d) distal/lateral, (e) rejuvenation flake, end scraper, and (f) utilized bifacial thinning flake.

Groundstone: Groundstone artifacts include tools that were formed by chipping, grinding, pecking, pounding, and polishing of large masses of lithic raw material, including coarsegrained quartzite, sandstone, quartzitic sandstone, siltstone, and hematite. The following groundstone tool categories are recognized: mano (unifacial or bifacial), pitted stone, pitted stone and mano, metate, hammerstone, axe, and celt.

Fields et al. (1993:30-36) and Largent et al. (1997:C-1 to C-10) also provide applicable definitions of lithic tool classes from Sulphur River basin sites in Northeast Texas.

Other attributes that have been recorded for individual specimens within each of the lithic tool classes include raw material (of which there are 30 different types; see below); platform (missing, unfaceted, faceted, cortex, crushed); presence and amount of dorsal cortex $(0,1-25,26-50,51-75$, and $76-100$ percent); length, width, and thickness; tool number; and blank form (i.e., indeterminate chunk, stream cobble, nodule, tabular piece, reworked piece, or flake). In the case of the dart and arrow points, other attributes were also noted and measured, namely: (1) maximum thickness, (2) blade length, (3) blade width, (4) haft length, 
(5) haft width, (6) neck width, (7) depth of basal concavity, (8) presence of basal and lateral grinding, (9) presence of resharpening, (10) serration, (11) beveling, (12) tip configuration, (13) blade breakage pattern, and (14) extent of lateral grinding.

In Block A on the North rise, utilized flakes, scrapers, and intentionally retouched pieces (Tool Class 7) comprise the most frequent tool class in either the Caddoan or Early Ceramic/Late Archaic components, accounting for 31 percent of the total tool assemblage, and also accounting for between 24-46 percent of the assemblage by level through the deposit. In the upper levels (i.e., levels 1-3 or 0-30 cm bs) in Early Caddoan period contexts, retouched pieces and utilized flakes comprise 27-46 percent of the tools compared to 24-36 percent of the tools (see Table 8-1). The comparable frequencies of retouched tools and utilized pieces suggest these are functionally stochastic (cf. Odell 1998); that is, these are multi-functional tools whose popularity for domestic tasks (such as food processing, subsistence activities, and construction of facilities and structures) did not substantially vary during the prehistoric occupation of the Hurricane Hill site.

Other types of flake tools are better represented in the Early Caddoan component, including perforators, drills, denticulates, and notches/spokeshaves. All are common implements in prehistoric Early Caddoan lithic assemblages in Northeast Texas. As with the scraping tools and utilized pieces, these flake tools were probably used for a variety of tasks associated with the cutting, sharpening, scraping, or other modification of bone, wood, and leather items.

Projectile points account for about 20 percent of the tools, and they are relatively common in all levels of the North rise midden deposits in Block A, ranging from 17-23 percent (see Table 8-1). Only 17 percent of the projectile points are arrowpoints. The remainder are dart points that were either attached to spears for thrusting, attached to darts thrown with an atlatl (e.g., Dickson 1986), or hafted for scraping and cutting use. Cores and blank/preforms (33 percent of the assemblage) are by-products of chipped stone tool manufacture, primarily discards from the production of dart points, and the relatively high proportions of cores and blank/preforms indicate that the manufacture of bifacial tools was a principal concern of the lithic technological activity during the Late Archaic/Early Ceramic occupation. The presence of a few arrowpoint preforms also indicates that these types of tools were being made as well as discarded at the site during the Early Caddoan period. Groundstone tools, principally hammerstones, manos, pitted stones, and metates, were made from local quartzites and sandstones available in gravel beds or outcrops in the Cooper Lake area. The low frequency of groundstone implements (1.1 percent) in Midden 1 is matched by that in all other areas of the site, except for Block $E$ on the slopes of the North rise (see below). This suggests that the bulk processing of plants for food was not an important activity during either the Late Archaic/Early Ceramic or Early and Middle Caddoan occupations, as is also indicated by the relatively low density of FCR at the Hurricane Hill site, or that bone and wood tools were more frequently used for this task along with ceramic vessels.

The chipped stone and groundstone tool assemblage from Blocks D and $\mathrm{E}$ on the North rise consists of 703 specimens (see Tables 8-2 and 8-3), including 190 cores and blank/preforms. Most of the tools derive from levels 2-5, the Primary Midden, but cultural materials (lithic debris, bifacial tool fragment, and two retouched pieces) extended to depths of $90 \mathrm{~cm}$ bs in Block E (see Table 8-3). The Early Caddoan period components and tools are basically confined to the upper $20-30 \mathrm{~cm}$ of the deposit (note the vertical distribution of arrowpoint preforms in Tables 8-2 and 8-3) but constitute only a small percentage of the overall tool assemblage: about 7 percent of the bifacial tools are arrowpoints, and another 1-2 percent are arrowpoint preforms.

Dart points comprise over 28 percent of the total tooll assemblage from this part of the Primary Midden, mainly in an Early Ceramic to Late Archaic context (estimated to date from ca. 1200-2800 B.P., although calibrated radiocarbon dates from the Primary Midden range from A.D. 59-449; see Chapter 7, this volume). Cores and blank/preforms are well-represented in all levels, but also occur most frequently in the Early Ceramic and Late Archaic deposits. Groundstone tools, however, are predominantly associated with the later occupations (i.e., $0-30 \mathrm{~cm}$ ), although they only account for 4.5 percent $(n=14)$ of the tools in those levels. Below $30 \mathrm{~cm}$ bs, groundstone tools represent 1.5 percent of the tool assemblage in the Late Archaic/Early Ceramic component. 
One of the major differences between the lithic assemblages on the North and South rises is the substantial variation in the relative density of tools and debris. On the North rise in Block A, tools occur at a density of 23.8 per $\mathrm{m}^{2}$ and lithic debris at densities of about $1,200 \mathrm{per}^{2}$ (the lithic debris densities employing the 1/4-inch fraction is ca. 370 pieces per $\mathrm{m}^{2}$ ). Tooll densities on the South rise average only 6.9 chipped and groundstone tools per $\mathrm{m}^{2}$, and lithic debris densities are a relatively meager $264 \mathrm{per} \mathrm{m}^{2}$ (with the 1/4-inch fraction sample, the lithic debris density is 186 pieces per $\mathrm{m}^{2}$, twice as low as in Block A).

Midden Caddoan lithic tools and debris concentrate in levels 1-3, but especially between 0-20 cm bs. A relatively undisturbed Late Archaic to Early Ceramic period component(s) underlies the two Middle Caddoan structures on the South rise (i.e., levels 4-7, or 30-70 cm bs), except where it is penetrated by pit and post features. Peaks in lithic tools and debris in level 5 (see Table 8-4), and the higher densities of FCR (see discussion below, and Appendix XII), appear to mark either an "occupational surface" or, more likely, the natural downward movement of artifacts on the relatively depositionally stable rise (e.g., Bruseth and Martin 1987:13-14) that were primarily derived from these earlier, pre-Caddoan period occupations.

There is a higher relative occurrence of Middle Caddoan period lithic tools on the South rise in Blocks B/C and F than on the North rise. Arrowpoints account for 25 percent of the bifacial tools from these blocks, and arrowpoint preforms comprise another 0.8 percent of the tools (see Table 8-4). In Block A, arrowpoint preforms amount to 0.5 percent of the tool assemblage (see Table 8-1). Moreover, the Middle Caddoan tools are vertically restricted almost exclusively to levels $1-3 \mathrm{~B}(0-30 \mathrm{~cm}$ below the surface). High frequencies of cores and blank/preforms and the relatively high densities of tools and debris in the Middle Caddoan period deposits of Block B (see Figure 4-4) may be indicative of a relatively localized Caddoan lithic reduction area situated in an extra-mural context, not a midden, along the north wall of the structures. Otherwise, these types of tool by-products are apparently more common in the Early Ceramic/Late Archaic zones, where they account for 34-37 percent of the tools in deposits between 30-50 cm bs (see Table 8-4). The few groundstone tools from the South rise are confined almost exclusively to the Late Archaic/Early Ceramic deposits, with the exception of a few celts in shallow Middle Caddoan or surface contexts. Dart points are also abundant, representing more than 13 percent of the tools from the South rise, and 70 percent of the completed bifacial tools in the assemblage as a whole (see Table 8-4).

A relatively small tool sample ( $\mathrm{n}=50$, as well as 16 blank/preforms and 9 cores) was recovered from the Southwest rise (Table 8-5). Nevertheless, it is an important one because it represents an almost totally undiluted sample of Late Archaic to Early Ceramic period lithic artifacts from an occupation dated between ca. 1000 B.C. and A.D. 300 (see Chapter 7, this volume). The only exceptions are three arrowpoints from Feature 68 (a Middle Caddoan period extended burial).

Blank/preforms and dart points are the most frequent chipped stone tools. Dart points account for 40 percent of the tools recovered on the Southwest rise from the midden deposits or in features such as cremations, secondary bundle burials, and other pits (see Table 8-5), and they occur in roughly equal proportions in both contexts: 35 and 46 percent in features and midden, respectively. Blank/preforms and cores are common in the midden, as are the retouched and utilized pieces, while a knife, scrapers, and bifacial tool fragments are more abundant in feature contexts (see Table 8-5). None of the tools found in burial and cremation feature contexts appear to have been deliberately placed in the burial pits, but rather they probably represent artifacts from the midden that became incorporated into the burial fill.

A single chipped and polished hematite axe was recovered below the Late Archaic/Early Ceramic period midden, as were two expanding stem dart points. These probably constitute part of the stone tool assemblage associated with an Late Archaic to Middle Archaic occupation (cf. Story 1990:Figure 32) sparsely represented in deposits below the Southwest rise midden. 
Table 8-5. Lithic tool and debris frequencies for the Southwest rise

\begin{tabular}{|c|c|c|c|}
\hline Tool Type & Feature Fill & Midden & Totals \\
\hline Arrowpoints & $3^{*}$ & - & 3 \\
\hline Dart points & 9 & 11 & 20 \\
\hline Gary var. Camden & 2 & - & 2 \\
\hline Gary var. LeFlore & 2 & 3 & 5 \\
\hline Gary var. Gary & 4 & 4 & 8 \\
\hline other Gary & - & 1 & 1 \\
\hline Rectangular stem & 1 & 1 & 2 \\
\hline Expanding stem & - & $2 * *$ & 2 \\
\hline Knive & 1 & - & 1 \\
\hline Scrapers & 2 & - & 2 \\
\hline Notch & - & 1 & 1 \\
\hline Biface Tool Fragment & 7 & 4 & 11 \\
\hline Retouched pieces & 1 & 3 & 4 \\
\hline Utilized flakes & 3 & 4 & 7 \\
\hline Hematite axe & - & $1 * *$ & 1 \\
\hline Lithic Debris & 396 & 4593 & 4989 \\
\hline Cores & 4 & 5 & 9 \\
\hline Local debris & 368 & 4043 & 4411 \\
\hline Probable local & 24 & 18 & 42 \\
\hline Non-local & - & 31 & 31 \\
\hline Probable non-local & - & 23 & 23 \\
\hline Indeterminate & - & 473 & 473 \\
\hline Fire-cracked Rock & 417 & 234 & 651 \\
\hline SUM & 847 & 4859 & 5706 \\
\hline
\end{tabular}

* Associated with the Middle Caddoan use of the rise (Features 68 and 75)

** Recovered below the Southwest rise midden

\section{Projectile Points}

Dart points and arrowpoints were classified according to morphological criteria, primarily the shape of the hafting element, the position and orientation of the barbs and tangs, and the placement of notches. Other data important in the projectile point classifications included the presence of grinding (lateral and basal), their overall thickness (particularly in the case of the Gary type [cf. Schambach 1982]), and the neck or stem width (see Appendices VIA and VIB). 
A total of 701 classifiable projectile points was present in the assemblage, 85 percent $(n=595)$ in 24 dart point classes and the remaining 15 percent $(n=106)$ in 11 arrowpoint classes (Figure 8-2).

Furthermore, 85 percent of the dart points and arrowpoints were recovered in the block excavations or on the Southwest rise, with the remainder from a variety of contexts (mainly surface collections and backhoe trench backdirt; see Appendix VIII). Tables 8-6 and 8-7 present more specific information on the relative frequencies of the different projectile point classes by block excavation area or natural rise, as well as by depth below surface.
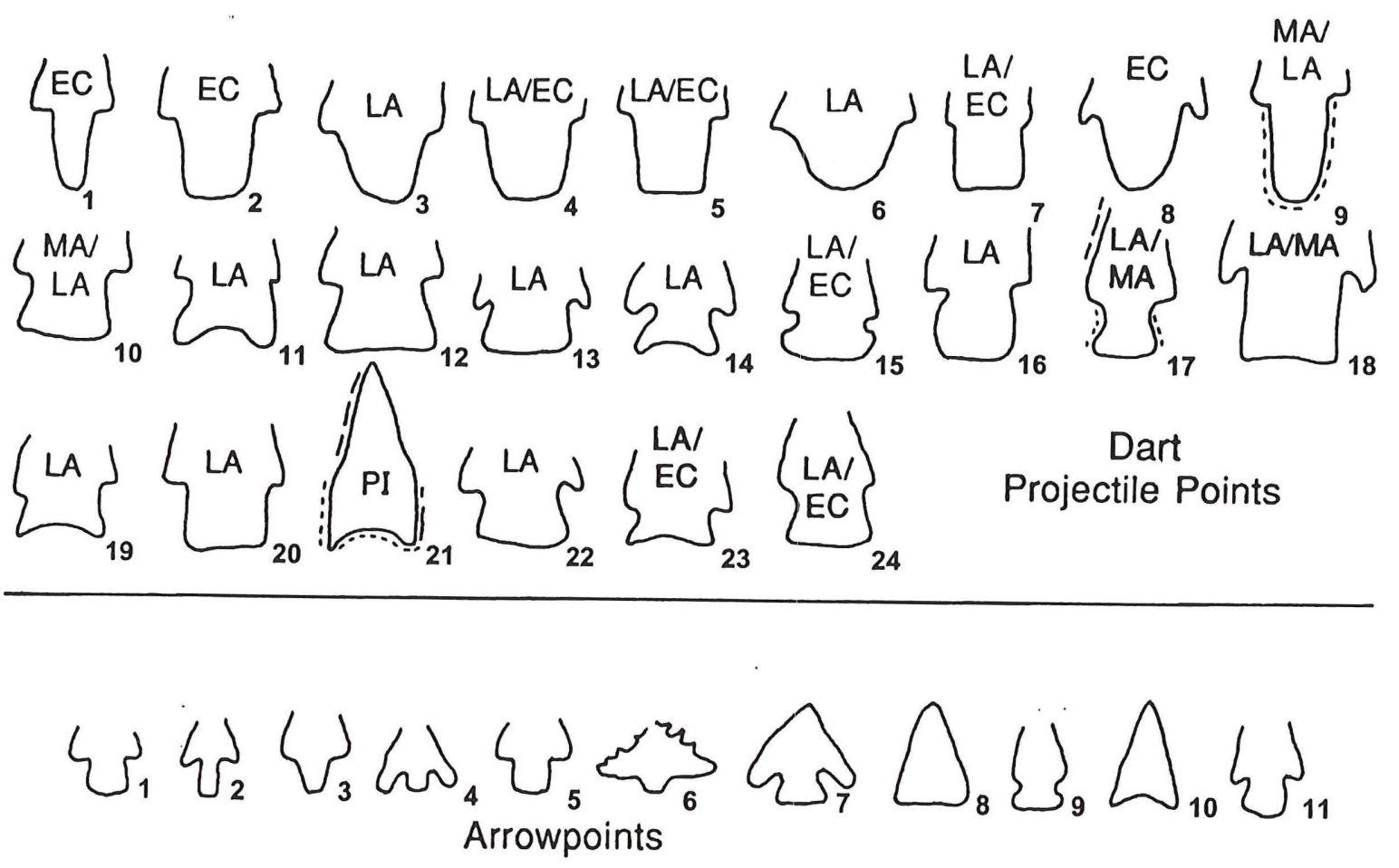

Figure 8-2. Projectile point classes: a, dart points; b, arrowpoints.

Among the Hurricane Hill dart points, there appear to be five distinct groups based on their apparent age and morphological form (see Collins 1995; Fields et al. 1997:Figures 26-28; Schambach 1982; Story 1990:Figure 32; Turner and Hester 1993). The first group includes Paleoindian lanceolate specimens (Class 21); the 2nd group Middle to Late Archaic darts (ca. 3300-4000+ years ago) with expanding or rectangular stems and lateral grinding (classes 09, 12, 17, and 18); the 3rd group includes Late Archaic thick contracting stem (Class 06) and expanding stem forms (classes 14 and 24) estimated to date from ca. 2400-3300 years ago; the 4th group is comprised of slightly thinner and narrower contracting stem forms (classes 02 and 03 ) and various expanding stem-shouldered specimens, including classes 10-13 and 22) and is estimated to date from ca. 2400-1700 years ago; and the 5th dart point group includes a thin and narrow contracting stem class (Class 01), a shallow side-notched class (Class 15), and several narrowstemmed darts, including classes 04, 05, 07, and 16 (see Figure 8-2). One class (Class 23) may also belong to the 4th group, based on similar morphology. Classes 19 and 20 are Late Archaic in age, and their use may have extended from as early as the 3rd group to the 4th group, or even later based on the occurrence of Class 20 dart points in Early Ceramic or Woodland period contexts at Cooper Lake (Fields et al. 1997:4243 and Table 4). The mean and standard deviation of blade and haft width and length, as well as thickness measurements are included in Table 8-8. As can be seen in Table 8-8, dart points of non-local raw materials are rare in the Hurricane Hill collection from Blocks A, D, E, and B/C, occurring only in regularity in the contracting stem Class 03 (comprising 1.9-4.5 percent in three of the four blocks), and many of the dart point classes (i.e., classes $08,09,10,15,16,17,18,20,21,22$, and 23) from these contexts are exclusively on local raw materials. 
Table 8-6. Relative frequencies of dart point classes $^{\mathrm{a}}$.

\begin{tabular}{|c|c|c|c|c|c|c|}
\hline \multirow[b]{2}{*}{ Class } & \multirow[b]{2}{*}{ Block A } & \multicolumn{2}{|c|}{ North Rise } & \multicolumn{2}{|l|}{ South Rise } & \multirow[b]{2}{*}{ Area B } \\
\hline & & Block D & Block E & Block B/C & SW Rise & \\
\hline 1 & 18.8 & 10.8 & 12.3 & 7.8 & 10.0 & - \\
\hline 2 & $10.9^{\circ}$ & 7.2 & 4.4 & 12.5 & 10.0 & \\
\hline $\begin{array}{l}3 \\
4\end{array}$ & 25.1 & 33.7 & 46.5 & 35.9 & & 60.0 \\
\hline $\begin{array}{l}4 \\
5\end{array}$ & $\begin{array}{l}3.4 \\
3.4\end{array}$ & 1.2 & 2.6 & 23 & - & \\
\hline 6 & $\begin{array}{l}1.4 \\
14.3\end{array}$ & 12.0 & 8.8 & 15.6 & 20.0 & 20.0 \\
\hline 7 & 2.9 & 2.4 & - & 0.8 & $=$ & \\
\hline 8 & 4.0 & 4.8 & 5.3 & 4.7 & 5.0 & 20.0 \\
\hline 9 & 0.6 & 6.0 & 0.9 & 3.1 & - & - \\
\hline 10 & 1.7 & 2.4 & - & 1.6 & - & - \\
\hline 11 & 2.3 & & 0.9 & - & - & - \\
\hline 12 & 3.4 & 3.6 & 0.9 & 4.7 & - & - \\
\hline 13 & 2.3 & 1.2 & 1.8 & 1.6 & - & - \\
\hline 14 & 1.1 & - & 0.9 & - & 5.0 & - \\
\hline 15 & 0.6 & - & 1.8 & 3.9 & - & - \\
\hline 16 & 0.6 & - & - & - & - & - \\
\hline 17 & 1.7 & 2.4 & 2.6 & 2.3 & - & - \\
\hline 18 & 0.6 & 2.4 & 0.9 & 0.8 & 5.0 & - \\
\hline 19 & 1.7 & 1.2 & 3.5 & - & - & - \\
\hline 20 & 0.6 & 3.6 & 1.8 & 2.3 & 5.0 & - \\
\hline 21 & & 2.4 & 0.9 & - & 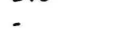 & - \\
\hline 22 & - & 1.2 & - & - & - & - \\
\hline 23 & - & - & 2.6 & - & - & - \\
\hline 24 & - & - & - & - & - & \\
\hline Totals & 175 & 83 & 114 & 128 & 20 & 5 \\
\hline
\end{tabular}

a Does not include 82 other dart points from the Hurricane Hill site, from the following contexts: Historic Locality 1 ( $n=4$ ) or from the general surface $(n=19)$, shovel tests $(n=4)$, scraped areas $(n=5)$, backhoe trenches $(n=19)$, isolated $1 \times 1 m$ units $(n=9)$, and features $(n=22)$ not contained within the blocks, the Southwest Rise, or Area B. See Appendix VIII.

Table 8-7. Relative frequencies of arrowpoint classes $^{\text {a }}$

\begin{tabular}{|c|c|c|c|c|c|}
\hline & & North Rise & & South Rise & \\
\hline Class & Block A & Block D & Block E & Block B/C & SW Ris \\
\hline 1 & 25.7 & 11.1 & - & 17.4 & - \\
\hline 2 & 20.0 & 22.2 & 16.7 & 23.9 & - \\
\hline 3 & 11.4 & 11.1 & - & 23.9 & 33.3 \\
\hline 4 & 2.9 & - & - & 4.3 & 33.3 \\
\hline 5 & 20.0 & 22.2 & 16.7 & 21.7 & - \\
\hline 6 & 14.3 & - & 50.0 & - & 33.3 \\
\hline 7 & 2.9 & 11.1 & 16.7 & 2.2 & - \\
\hline 8 & - & - & - & 2.2 & - \\
\hline 9 & - & 11.1 & - & 2.2 & - \\
\hline 10 & 2.9 & - & - & 2.2 & - \\
\hline 11 & - & 11.1 & - & - & - \\
\hline Totals & 35 & 9 & 6 & 46 & 3 \\
\hline
\end{tabular}

\footnotetext{
${ }^{a}$ Does not include 8 other arrowpoints from the following areas at Hurricane Hill: Historic Locality 1 ( $\left.n=3\right)$, or from the general surface $(n=1)$ and features $(n=4)$ not contained within the blocks or the Southwest (SW) rise. See Appendix VIII.
} 
Table 8-8. Dart point measurements.

\begin{tabular}{|c|c|c|c|c|c|c|c|c|}
\hline Area & Class & $\mathrm{BL}^{*}$ & BW & $\mathrm{HL}$ & NW & HW & $\mathrm{TH}$ & $\%$ Non-Local \\
\hline Block A & 01 & $23.7 \pm 4.0$ & $20.5 \pm 3.2$ & $15.4 \pm 1.2$ & $12.8 \pm 1.0$ & $12.8 \pm 1.0$ & $6.9 \pm 0.7$ & 6.1 \\
\hline Block D & 01 & $24.7 \pm 6.5$ & $19.0 \pm 3.3$ & $14.5 \pm 1.5$ & $13.4 \pm 2.0$ & $13.4 \pm 2.0$ & $7.1 \pm 0.6$ & 0.0 \\
\hline Block E & 01 & $30.3 \pm 3.4$ & $21.4 \pm 3.6$ & $16.7 \pm 1.7$ & $14.2 \pm 1.1$ & $14.2 \pm 1.1$ & $7.4 \pm 1.5$ & 0.0 \\
\hline Block B/C & 01 & $31.4 \pm 3.7$ & $21.4 \pm 4.7$ & $14.9 \pm 1.4$ & $12.8 \pm 1.6$ & $12.8 \pm 1.6$ & $7.3 \pm 0.6$ & 0.0 \\
\hline Block A & 02 & $26.2 \pm 7.3$ & $22.9 \pm 4.0$ & $13.2 \pm 2.0$ & $15.6 \pm 2.1$ & $15.6 \pm 2.1$ & $7.2 \pm 1.1$ & 0.0 \\
\hline Block D & 02 & $23 \pm 3.3$ & $24.8 \pm 3.8$ & $12.2 \pm 1.5$ & $16.0 \pm 2.3$ & $16.0 \pm 2.3$ & $7.5 \pm 0.7$ & 0.0 \\
\hline Block E & 02 & $24.5 \pm 1.5$ & $23.5 \pm 2.0$ & $12 \pm 3.5$ & $14.4 \pm 2.1$ & $14.4 \pm 2.1$ & $6.8 \pm 1.0$ & 20.0 \\
\hline Block B/C & 02 & $29.4 \pm 3.3$ & $24.9 \pm 3.0$ & $11.7 \pm 2.8$ & $14.8 \pm 1.9$ & $14.8 \pm 1.9$ & $7.6 \pm 1.6$ & 0.0 \\
\hline Block A & 03 & $33.7 \pm 6.2$ & $28.1 \pm 4.0$ & $14.6 \pm 2.3$ & $17.4 \pm 2.3$ & $17.4 \pm 2.3$ & $7.9 \pm 1.2$ & 4.5 \\
\hline Block D & 03 & $25.8 \pm 6.2$ & $27.0 \pm 5.9$ & $15.5 \pm 1.6$ & $17.7 \pm 2.1$ & $17.7 \pm 2.1$ & $7.8 \pm 0.9$ & 0.0 \\
\hline Block E & 03 & $27.7 \pm 5.1$ & $26.9 \pm 4.3$ & $14.5 \pm 2.0$ & $16.7 \pm 2.3$ & $16.7 \pm 2.3$ & $7.7 \pm 1.1$ & 1.9 \\
\hline Block B/C & 03 & $32.4 \pm 4.9$ & $30.7 \pm 5.5$ & $14.3 \pm 2.0$ & $17.3 \pm 2.0$ & $17.3 \pm 2.0$ & $7.7 \pm 1.2$ & 2.2 \\
\hline Block A & 04 & $25.6 \pm 5.4$ & $18.2 \pm 1.4$ & $13 \pm 1.3$ & $13.3 \pm 1.6$ & $13.3 \pm 1.6$ & $8.2 \pm 0.6$ & 33.3 \\
\hline Block D & 04 & 39 & 22 & - & 14 & 14 & 8 & 0.0 \\
\hline Block E & 04 & 29 & $22.3 \pm 4.2$ & $16 \pm 2$ & $14.7 \pm 1.6$ & $15.5 \pm 1.5$ & $8.7 \pm 0.4$ & 0.0 \\
\hline Block A & 05 & $27.3 \pm 3.5$ & $20.8 \pm 2.0$ & $14.5 \pm 1.7$ & $12.5 \pm 1.0$ & $12.5 \pm 1.0$ & $7.0 \pm 0.3$ & 0.0 \\
\hline Block D & 05 & 30 & 18 & 9 & 11 & 12 & 7 & 0.0 \\
\hline Block E & 05 & 41 & 14 & 12 & 11 & 11 & 8 & 100.0 \\
\hline Block B/C & 05 & - & - & $20.5 \pm 5.5$ & 15 & 16 & $9.5 \pm 0.5$ & 0.0 \\
\hline Block A & 06 & $32.8 \pm 7.3$ & $27.8 \pm 4.7$ & $15.9 \pm 3.4$ & $20.6 \pm 3.8$ & $20.6 \pm 3.8$ & $8.4 \pm 1.2$ & 4.0 \\
\hline Block D & 06 & $37.3 \pm 3.1$ & $30.0 \pm 8.0$ & $17.0 \pm 3.6$ & $23.9 \pm 3.3$ & $23.9 \pm 3.3$ & $9.2 \pm 1.1$ & 0.0 \\
\hline Block E & 06 & $28.7 \pm 3.6$ & $28.9 \pm 5.6$ & $14.5 \pm 3.0$ & $20.6 \pm 3.5$ & $20.6 \pm 3.5$ & $7.5 \pm 1.4$ & 0.0 \\
\hline Block B/C & 06 & $32.0 \pm 3.0$ & $29.3 \pm 4.8$ & $14.8 \pm 3.8$ & $20.3 \pm 3.1$ & $20.3 \pm 3.1$ & $9.1 \pm 1.1$ & 0.0 \\
\hline Block A & 07 & $25.5 \pm 8.5$ & $16.5 \pm 1.1$ & $13.5 \pm 1.5$ & $11.8 \pm 0.8$ & $11.8 \pm 0.8$ & $7.0 \pm 0.8$ & 20.0 \\
\hline Block D & 07 & 29 & $18 \pm 3$ & $13.5 \pm 2.5$ & $14 \pm 2$ & $14.5 \pm 1.5$ & 8 & 0.0 \\
\hline Block B/C & 07 & - & 15 & 10 & 11 & 11 & 6 & 0.0 \\
\hline Block A & 08 & $31.3 \pm 5.8$ & $27.2 \pm 2.6$ & $14.7 \pm 2.9$ & $14.9 \pm 1.3$ & $14.9 \pm 1.3$ & $8.3 \pm 2.0$ & 0.0 \\
\hline Block D & 08 & $30 \pm 5.0$ & $28.5 \pm 2.5$ & $15 \pm 2.7$ & $20.5 \pm 3.3$ & $20.5 \pm 3.3$ & $7.3 \pm 1.3$ & 0.0 \\
\hline Block E & 08 & $41.5 \pm 6.5$ & $38.0 \pm 6.0$ & $15 \pm 1$ & $18.4 \pm 2.8$ & $18.4 \pm 2.8$ & $7.5 \pm 1.5$ & 0.0 \\
\hline Block B/C & 08 & $31.7 \pm 7.6$ & 40 & $12.3 \pm 1.8$ & $15.6 \pm 1.1$ & $15.6 \pm 1.1$ & $6.5 \pm 0.7$ & 0.0 \\
\hline Block A & 09 & - & 28 & 25 & 16 & 16 & 13 & 0.0 \\
\hline Block D & 09 & $24.7 \pm 2.2$ & $17.3 \pm 1.3$ & $20.2 \pm 3.0$ & $14 \pm 0.8$ & $14 \pm 0.8$ & $8.2 \pm 1.0$ & 0.0 \\
\hline Block E & 09 & - & - & 20 & 12 & 12 & 6 & 0.0 \\
\hline Block B/C & 09 & $27.5 \pm 4.5$ & $21.5 \pm 4.0$ & $22.0 \pm 1.5$ & $14.8 \pm 2.8$ & $14.8 \pm 2.8$ & $8.0 \pm 1.5$ & 0.0 \\
\hline Block A & 10 & $30.5 \pm 11.5$ & $17.0 \pm 0.7$ & $13.0 \pm 2.0$ & $12.7 \pm 0.4$ & $14 \pm 0.7$ & $8 \pm 1.3$ & 0.0 \\
\hline Block D & 10 & 51 & 25 & 13 & 15 & 17 & $8.5 \pm 2.5$ & 0.0 \\
\hline Block B/C & 10 & $35.5 \pm 5.5$ & $22.5 \pm 0.5$ & $14.5 \pm 0.5$ & $12 \pm 1$ & $14 \pm 1$ & $9.5 \pm 0.5$ & 0.0 \\
\hline Block A & 11 & - & - & 11 & $14 \pm 2$ & $17 \pm 1$ & $5.5 \pm 1$ & 50.0 \\
\hline Block E & 11 & - & - & - & 14 & 15 & $\cdot$ & 0.0 \\
\hline Block A & 12 & $28.0 \pm 8.7$ & $21.4 \pm 2.9$ & $11.8 \pm 2.5$ & $14 \pm 1.3$ & $15 \pm 1.4$ & $7.5 \pm 1$ & 0.0 \\
\hline Block D & 12 & 32 & 29 & $12.5 \pm 2.5$ & $17 \pm 2$ & $19 \pm 2$ & $8 \pm 0.7$ & 0.0 \\
\hline Block E & 12 & 33 & 25 & 15 & 17 & 19 & 11 & 0.0 \\
\hline Block B/C & 12 & $23.0 \pm 3.3$ & $22.2 \pm 1.0$ & $10.7 \pm 2.1$ & $15.7 \pm 1.7$ & $17.6 \pm 1.7$ & $7.3 \pm 0.8$ & 16.7 \\
\hline
\end{tabular}


Table 8-8. Dart point measurements, cont.

\begin{tabular}{|c|c|c|c|c|c|c|c|c|}
\hline Area & Class & $\mathrm{BL}^{*}$ & BW & $\mathrm{HL}$ & NW & HW & $\mathrm{TH}$ & $\%$ Non-Local \\
\hline Block A & 13 & 39 & $25.3 \pm 1.8$ & $10.8 \pm 2.7$ & $15.3 \pm 2.8$ & $15.3 \pm 2.4$ & $7.8 \pm 1.3$ & 0.0 \\
\hline Block D & 13 & - & - & 9 & - & - & 8 & 0.0 \\
\hline Block E & 13 & 36 & 25 & $13 \pm 1$ & $17 \pm 1$ & $18.5 \pm 1.5$ & $9.0 \pm 1.0$ & 0.0 \\
\hline Block B/C & 13 & $37.5 \pm 1.5$ & 30 & $8.5 \pm 0.5$ & $13.5 \pm 0.5$ & 14 & $6.5 \pm 1.5$ & 50.0 \\
\hline Block A & 14 & 20 & $26 \pm 2$ & $9.5 \pm 1.5$ & $12.0 \pm 1$ & $17 \pm 4$ & $6.5 \pm 0.5$ & 50.0 \\
\hline Block E & 14 & - & - & 11 & 14 & 20 & 6 & 0.0 \\
\hline Block A & 15 & 22 & 21 & 13 & 16 & 19 & 10 & 0.0 \\
\hline Block E & 15 & 34 & - & $12.5 \pm 0.5$ & $15.5 \pm 0.5$ & $18 \pm 1$ & $10 \pm 1$ & 0.0 \\
\hline Block B/C & 15 & 17 & $19.4 \pm 1.9$ & $12.5 \pm 2.3$ & $14.6 \pm 1.7$ & $18.0 \pm 2.7$ & $7.8 \pm 1.3$ & 0.0 \\
\hline Block A & 16 & - & - & 23 & 18 & 21 & - & 0.0 \\
\hline Block A & 17 & $28.3 \pm 1.6$ & $19.3 \pm 1.1$ & $14.7 \pm 1.8$ & $14.0 \pm 0.7$ & $15.7 \pm 0.9$ & $7.7 \pm 0.4$ & 0.0 \\
\hline Block D & 17 & $32 \pm 1$ & $18.5 \pm 0.5$ & $15 \pm 2$ & $15 \pm 1$ & $17.5 \pm 0.5$ & $7.5 \pm 0.5$ & 0.0 \\
\hline Block E & 17 & $33 \pm 1$ & $19 \pm 2$ & $13.3 \pm 2.2$ & $14.7 \pm 2.4$ & $17 \pm 1.3$ & $7.5 \pm 1.0$ & 0.0 \\
\hline Block B/C & 17 & $33.0 \pm 1.0$ & $18.3 \pm 0.4$ & $14 \pm 2$ & $15 \pm 1.3$ & $16.0 \pm 0.7$ & $7.3 \pm 0.4$ & 0.0 \\
\hline Block A & 18 & - & - & 17 & 21 & 22 & 9 & 0.0 \\
\hline Block D & 18 & 35 & $33.5 \pm 5.5$ & $15.5 \pm 0.5$ & $17 \pm 3$ & $18 \pm 2$ & 11 & 0.0 \\
\hline Block E & 18 & - & - & 16 & 15 & 16 & 9 & 0.0 \\
\hline Block B/C & 18 & 34 & 26 & 13 & 19 & - & 8 & 0.0 \\
\hline Block A & 19 & $21 \pm 1$ & $19.5 \pm 0.5$ & 8.0 & $15.7 \pm 3.8$ & $21.0 \pm 5.3$ & $6.7 \pm 0.4$ & 33.3 \\
\hline Block D & 19 & 36 & 15 & 10 & 12 & - & 8 & 0.0 \\
\hline Block E & 19 & $25.3 \pm 5.6$ & $18 \pm 0.5$ & $13.3 \pm 1.3$ & $13.5 \pm 1.3$ & $17 \pm 1.3$ & $7.5 \pm 1.0$ & 0.0 \\
\hline Block A & 20 & - & 23 & 17 & 17 & 17 & 11 & 0.0 \\
\hline Block D & 20 & 46 & $26 \pm 3$ & $20.7 \pm 4.4$ & $18.3 \pm 1.8$ & $18.3 \pm 1.8$ & $9.7 \pm 2.2$ & 0.0 \\
\hline Block E & 20 & - & $25 \pm 2$ & $17.5 \pm 4.5$ & $16 \pm 1$ & $18 \pm 1$ & $9 \pm 1$ & 0.0 \\
\hline Block B/C & 20 & - & $27.5 \pm 0.5$ & $15.0 \pm 2.7$ & $18.0 \pm 1.7$ & $18.0 \pm 1.7$ & $9.7 \pm 1.1$ & 0.0 \\
\hline Block D & 21 & 33 & $18.5 \pm 0.5$ & 15 & 18 & $20 \pm 2$ & 7 & 0.0 \\
\hline Block E & 21 & 40 & - & - & - & - & 7 & 0.0 \\
\hline Block D & 22 & - & 24 & 10 & 14 & 18 & 7 & 0.0 \\
\hline Block E & 23 & 27 & $28 \pm 3.3$ & $11.0 \pm 0.7$ & $16.0 \pm 1.3$ & 20 & $7.7 \pm 0.4$ & 0.0 \\
\hline
\end{tabular}

* measurements in millimeters

$\mathrm{BL}=$ blade length; $\mathrm{BW}=$ blade width; $\mathrm{HL}=$ haft length; $\mathrm{NW}=$ neck width; $\mathrm{HW}=$ haft length; $\mathrm{TH}=$ thickness

The only Paleoindian projectile point class represented in the sample $(n=4)$ is a lanceolate, beveled form with lateral and basal grinding (Class 21 dart point). This form somewhat resembles the Plainview type, probably the most common Paleoindian point type found in collections on the North and South Sulphur rivers (Carley n.d.; Preston 1972, 1974), as well as the lanceolate variety of Dalton point (Johnson 1989a). In fact, Morse's (1997:Figure 3.3 and 3.4) analysis of Dalton points from the Sloan site cemetery in Arkansas suggests that the Hurricane Hill lanceolates are beveled and unbeveled Dalton points, as well as biface preforms (see Bradley 1997:Figure 4.1b). The recovery of these lanceolates points to some utilization of the site at ca. 10,000 B.P. (cf. Anderson 1996a, 1996b; Holliday 1997; Holliday et al. 1985; Johnson 1989a).

Possible Middle to Late Archaic forms are represented by the Class 09 (Wells), Class 12 (Lange), Class 17 (Yarbrough), and Class 18 (Bulverde) dart points. The Wells points have long and narrow contracting stems with basal and lateral grinding, while the Lange forms have an expanding stem with a flat 
base, and are shouldered rather than barbed or notched (see Figure 8-2). The distinctive Yarbrough forms have parallel to expanding stems, a convex base, with lateral and basal grinding, and blade beveling. Bulverde points have parallel to slightly expanding stems, a slightly concave to flat base, and small barbs. Of the Middle to Late Archaic points from Hurricane Hill, only a single Lange point from Block B/C was made of non-local raw materials (see Table 8-8).

Based on the frequency of impact fractures--ranging between 16.7-100 percent of the points from the different blocks--the Class 09, 12, 17, and 18 forms were used as projectiles (Table 8-9). They were probably also used as knives and cutting tools, since most of the points have resharpened, serrated, and/or beveled blades. By resharpening, serrating, and/or beveling the tool's blade edge, "the knapper was able to extend the life span of a knive [or point] through more resharpening stages...[s]errations were advantageous because (1) the cutting edge was saw-toothed and (2) the worn-down serrations themselves could be used as the platform for the new edge" (Morse 1997:20).

Table 8-9. Relative frequency of grinding, resharpening, serrating, beveling, and impact fractures in dart point classes.

\begin{tabular}{|c|c|c|c|c|c|c|c|}
\hline Area & Class & BG* & LG & RS & $\mathrm{S}$ & BV & IF \\
\hline Block A & 01 & - & $3.0+$ & 84.8 & 33.3 & 18.2 & 9.1 \\
\hline Block D & 01 & - & 11.1 & 100.0 & 55.5 & 33.3 & - \\
\hline Block E & 01 & - & 7.1 & 78.6 & 42.9 & 21.4 & - \\
\hline Block B/C & 01 & - & 10.0 & 100.0 & 30.0 & 10.0 & - \\
\hline Block A & 02 & - & 10.5 & 84.2 & 5.3 & - & 21.1 \\
\hline Block D & 02 & - & 16.7 & 100.0 & 33.3 & 16.7 & 16.7 \\
\hline Block E & 02 & - & 20.0 & 80.0 & 60.0 & 40.0 & - \\
\hline Block B/C & 02 & - & 12.5 & 68.8 & - & - & - \\
\hline Block A & 03 & 4.5 & 6.8 & 81.8 & 11.4 & 11.4 & 15.9 \\
\hline Block D & 03 & - & 7.1 & 82.1 & 35.7 & 7.1 & - \\
\hline Block E & 03 & - & 3.8 & 75.5 & 49.1 & 17.0 & 5.6 \\
\hline Block B/C & 03 & 4.3 & 4.3 & 60.9 & 6.5 & 4.3 & 8.7 \\
\hline Block A & 04 & - & - & 100.0 & 16.7 & 16.7 & 16.7 \\
\hline Block D & 04 & - & - & 100.0 & 100.0 & - & - \\
\hline Block E & 04 & - & - & 66.7 & 66.7 & - & - \\
\hline Block A & 05 & 16.7 & 16.7 & 100.0 & 50.0 & 16.7 & - \\
\hline Block D & 05 & - & - & 100.0 & - & 100.0 & - \\
\hline Block E & 05 & - & - & 100.0 & 100.0 & - & - \\
\hline Block B/C & 05 & - & - & - & - & - & - \\
\hline Block A & 06 & 4.0 & 4.0 & 60.0 & - & 12.0 & 4.0 \\
\hline Block D & 06 & - & - & 20.0 & 30.0 & - & 10.0 \\
\hline Block E & 06 & - & - & 60.0 & 30.0 & - & 20.0 \\
\hline Block B/C & 06 & 5.0 & 5.0 & 55.0 & 15.0 & - & - \\
\hline Block A & 07 & 20.0 & 60.0 & 60.0 & 40.0 & 20.0 & - \\
\hline Block D & 07 & - & 50.0 & 50.0 & 100.0 & 50.0 & - \\
\hline Block B/C & 07 & - & - & 100.0 & - & - & - \\
\hline Block A & 08 & - & 28.6 & 57.1 & 28.6 & 14.3 & - \\
\hline Block D & 08 & 25.0 & 50.0 & 75.0 & 75.0 & - & - \\
\hline Block E & 08 & - & 16.7 & 66.7 & 16.7 & - & 16.7 \\
\hline Block B/C & 08 & - & - & 83.3 & 33.3 & - & 16.7 \\
\hline
\end{tabular}


Table 8-9. Relative frequency of grinding, resharpening, serrating, beveling, and impact fractures in dart point classes, cont.

\begin{tabular}{|c|c|c|c|c|c|c|c|}
\hline Area & Class & $\mathrm{BG}^{*}$ & LG & RS & $S$ & BV & IF \\
\hline Block A & 09 & - & - & 100.0 & - & - & 100.0 \\
\hline Block D & 09 & 40.0 & 80.0 & 100.0 & 40.0 & 40.0 & \\
\hline Block E & 09 & - & - & 100.0 & - & - & 100.0 \\
\hline Block B/C & 09 & - & 75.0 & 75.0 & - & - & - \\
\hline Block A & 10 & - & 33.3 & 100.0 & 33.3 & 33.3 & - \\
\hline Block D & 10 & - & - & 50.0 & 50.0 & - & - \\
\hline Block B/C & 10 & 50.0 & 50.0 & 50.0 & - & - & 50.0 \\
\hline Block A & 11 & 25.0 & 25.0 & 25.0 & - & - & 25.0 \\
\hline Block E & 11 & 100.0 & 100.0 & - & - & - & - \\
\hline Block A & 12 & - & 16.7 & 50.0 & - & 16.7 & - \\
\hline Block D & 12 & - & - & 66.7 & 66.7 & - & 33.3 \\
\hline Block E & 12 & - & - & 100.0 & 100.0 & 100.0 & - \\
\hline Block B/C & 12 & 16.7 & 33.3 & 83.3 & 16.7 & 33.3 & 16.7 \\
\hline Block A & 13 & 50.0 & 50.0 & 75.0 & 25.0 & 25.0 & 25.0 \\
\hline Block D & 13 & - & - & 100.0 & 100.0 & - & - \\
\hline Block E & 13 & 100.0 & 50.0 & 50.0 & - & 50.0 & - \\
\hline Block B/C & 13 & - & - & 100.0 & - & 50.0 & - \\
\hline Block A & 14 & - & - & 50.0 & - & - & - \\
\hline Block E & 14 & - & - & 100.0 & - & - & 100.0 \\
\hline Block A & 15 & - & - & 100.0 & - & - & - \\
\hline Block E & 15 & - & - & 100.0 & 100.0 & 50.0 & 50.0 \\
\hline Block B/C & 15 & - & - & 40.0 & 40.0 & 20.0 & 20.0 \\
\hline Block A & 16 & 100.0 & 100.0 & - & - & - & 100.0 \\
\hline Block A & 17 & 66.7 & 66.7 & 66.7 & 33.3 & 33.3 & - \\
\hline Block D & 17 & 100.0 & 100.0 & 100.0 & 100.0 & 50.0 & - \\
\hline Block E & 17 & 33.3 & 100.0 & 33.3 & 100.0 & 33.3 & - \\
\hline Block B/C & 17 & 33.3 & 66.7 & 100.0 & 100.0 & 66.7 & 33.3 \\
\hline Block A & 18 & - & 100.0 & - & - & - & - \\
\hline Block D & 18 & 50.0 & - & 100.0 & 50.0 & - & 50.0 \\
\hline Block E & 18 & - & - & - & - & - & - \\
\hline Block B/C & 18 & - & - & - & - & 100.0 & - \\
\hline Block A & 19 & 33.3 & 33.3 & 33.3 & - & - & - \\
\hline Block D & 19 & - & - & - & 100.0 & 100.0 & - \\
\hline Block E & 19 & 25.0 & 75.0 & 75.0 & 50.0 & 100.0 & - \\
\hline Block A & 20 & - & - & - & - & - & - \\
\hline Block D & 20 & 33.3 & 66.7 & 33.3 & 66.7 & - & - \\
\hline Block E & 20 & - & 50.0 & 50.0 & - & 50.0 & - \\
\hline Block D & 21 & 100.0 & 50.0 & 100.0 & 50.0 & 100.0 & - \\
\hline Block E & 21 & - & - & 100.0 & - & 100.0 & - \\
\hline
\end{tabular}


Table 8-9. Relative frequency of grinding, resharpening, serrating, beveling, and impact fractures in dart point classes, cont.

\begin{tabular}{llllllll}
\hline Area & Class & BG* & LG & RS & S & BV & IF \\
\hline Block D & 22 & 100.0 & 100.0 & 100.0 & 100.0 & - & - \\
Block E & 23 & - & 33.3 & 66.7 & 66.7 & - & - \\
\hline
\end{tabular}

* BG=basal grinding; LG=lateral grinding; $\mathrm{RS}=$ resharpened; $\mathrm{S}=$ serrated; $\mathrm{BV}=$ beveled; $\mathrm{IF}=$ impact fracture + proportion of specimens in particular class for particular block; i.e., 28/33 Class 01 dart points from Block A are resharpened $=84.8$ percent

These types are not common on the site, but the highest frequencies occurred uniformly in Block D on the North rise (see Table 8-6), where they account for 14.4 percent of the darts. Their vertical distribution in that block was between 30 and $70 \mathrm{~cm}$ bs. This is below Midden 1, either in the lower levels of the Primary Midden or deeper (see discussion below, and Appendix VIII). The best distributed diagnostic of the Middle to Late Archaic period dart points is Class 17 (Yarbrough). These comprise between 1.7-2,6 percent of the classifiable dart points from the North rise block excavations $(n=372)$ and 2.3 percent of the dart points from the South rise (see Table 8-6). On the South rise, the possible Middle to Late Archaic diagnostics were recovered only in levels 4 and $5,30-50 \mathrm{~cm}$ bs, stratigraphically below the Middle Caddoan house structures and midden deposits. In Block A on the North rise, the Yarbrough forms (Class 17) occurred in the lower Primary Midden. Outside of Midden 1, on the North rise, however, these forms are distributed between 40 and $60 \mathrm{~cm}$ bs, beneath the Primary Midden.

As noted above, Late Archaic projectile point classes estimated to date between ca. 3300-240 years ago are well represented in the Hurricane Hill collections. Identified types include Class 06 (Gary var. Gary), Class 14 (Edgewood), Class 19 (Fairland), Class 20 (Dawson), and Class 24 (Ellis). Class 23 is also included among the Late Archaic diagnostics from Hurricane Hill, based on similarities in hafting elements and overall blade and stem shape with the other identified types (i.e., slightly expanding stem and concave base and definite shoulders), although no type identification is offered. From Prewitt's (1995) projectile point distributional data in Texas, these Late Archaic forms occur from South Texas through Northeast Texas (Figure 8-3a) (and on into Southeast Oklahoma and southwestern Arkansas), but as Fields (1995a:323) has pointed out, the most common types "occur widely across eastern Texas but not beyond to the west, [and] indicates that there was sufficient interaction among groups who lived in the eastern part of the state to lead to some degree of uniformity in dart...point styles."

The most common Late Archaic form is Class 06, a broad contracting stemmed Gary type form with a convex base, and lacking barbs or tangs (see Figure 8-2). The Class 06 dart is most abundant in Blocks A and B/C on the North and South rises (see Table 8-6), as well as on the Southwest rise and Area B. This type is thick, with a wide haft or neck (see Table 8-8) fully consistent with the Gary var. Gary variety defined by Schambach (1982:Tables 7.2 and 7.4). According to Schambach (1982), the thickness mode of this variety ranges from $10-11 \mathrm{~mm}$, with a modal stem width of $22-23 \mathrm{~mm}$. The second most common form is Class 20 (Dawson), a straight-stemmed point with a straight base and shoulders. They were most common in Blocks $\mathrm{B} / \mathrm{C}$ and $\mathrm{D}$, occurring primarily in subsurface contexts below the Early and Middle Caddoan middens and structures (see Appendix VIII). A Class 20 point and a Class 14 form (a corner-notched Edgewood with a concave base and distinct barbs) were also recovered in Zone IIIa below the midden deposit on the Southwest rise (see Chapter 5, this volume).

As with the Middle to Late Archaic dart points, this group of Late Archaic points was primarily manufactured from local lithic raw materials (see Table 8-8). The few darts on non-local materials include classes 06, 14, and 19, all in Block A deposits on the North rise. Lower frequencies of these darts actually have impact fractures (see Table 8-9), suggesting a decline use of finished bifaces for projectiles, and a corresponding increase in their use for cutting and scraping based on significant proportions of these tools with resharpening, serrating, and/or blade beveling. 


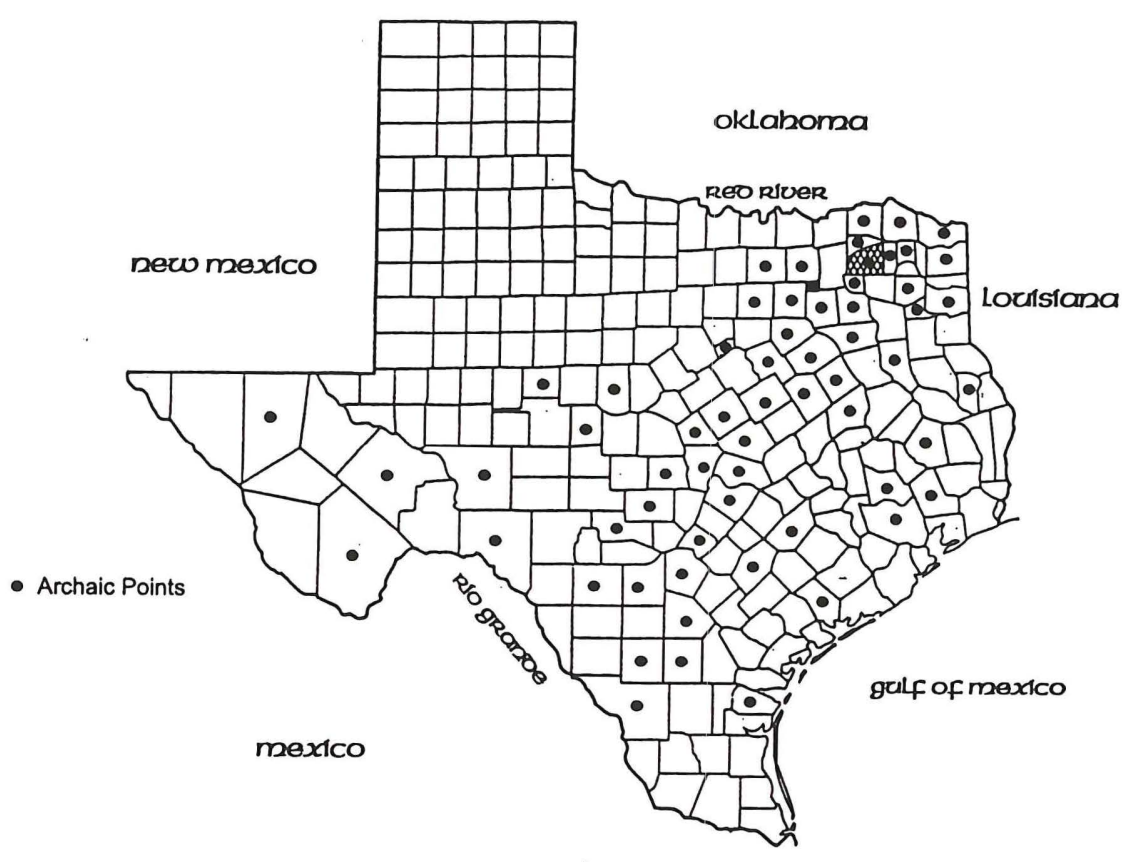

A

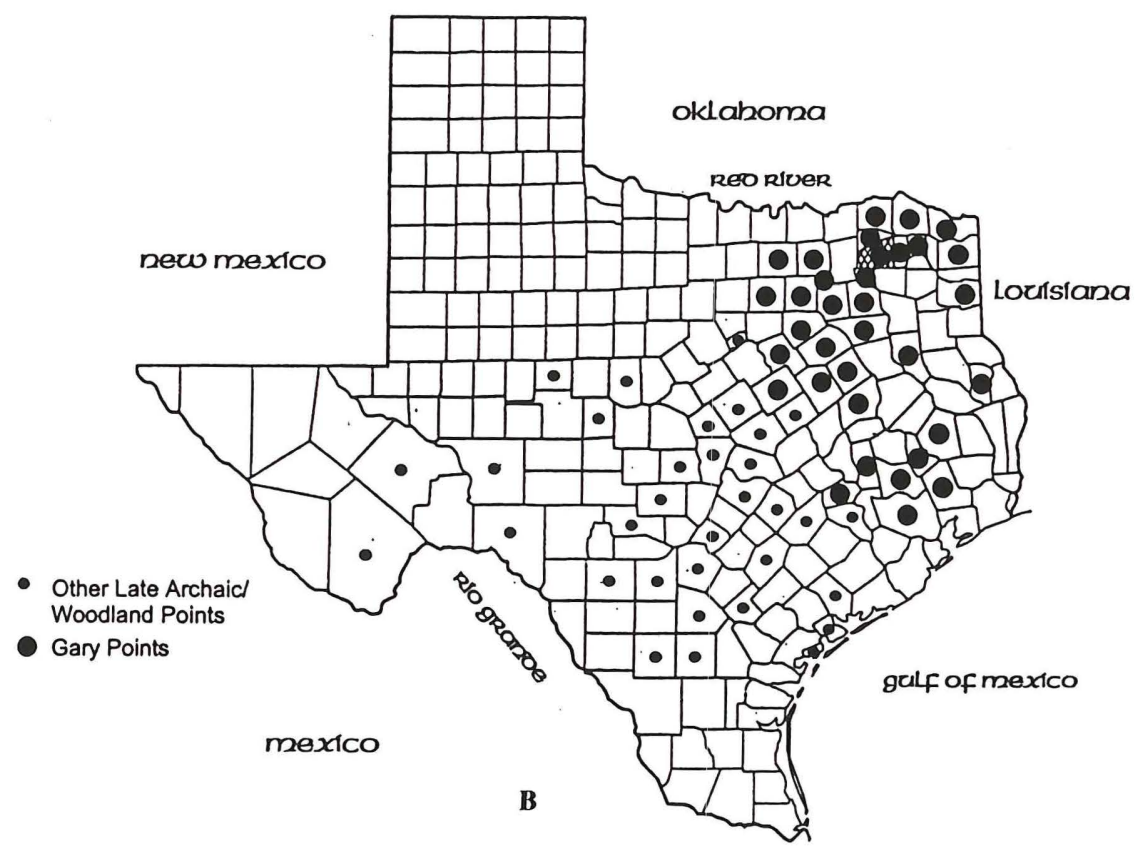

Figure 8-3. Distributions of dart points in Texas (after Prewitt 1995): a, classes 06. 09, 12, 14, 17, 18, 21, and 24; b, Classes 01, 02, 03, 04, 05, 07, 10, 11, 12, 13, 15, 16, 19, 20, and 22. 
A number of the dart points date to both the Late Archaic and Early Ceramic periods. Forms occurring in both periods include Class 02 (Gary var. LeFlore), 03 (Gary var. LeFlore), Class 10 (Williams), Class 11 (Fairland IV, see Rohrbaugh et al. [1971] and Wyckoff [1984.] for a discussion of the character and age of this narrow expanding stem/concave base dart), Class 13 (Marshall), and Class 22 (Marcos). Of these, the Gary var. LeFlore form, dated at 1700-2400 B.P. by Schambach (1982), was the most common form in all contexts on the North and South rises (see Table 8-6), particularly in Block E (50.9 percent of the 114 dart points), as well as on the Southwest rise and Area B (see Appendix I). The older, and thicker, broader, Gary var. Gary, however, was most common in the Southwest rise midden and the Late Archaic/Early Ceramic component on the South rise, where it accounts for 15.6-20.0 percent of the dart points in these contexts, compared to 45.0-48.4 percent of the dart points that are var. LeFlore forms. Compared to the Gary points, the other forms are minor components in all block and area assemblages.

Of these Late Archaic-Early Ceramic dart points, non-local raw materials were not commonly used in bifacial tool manufacture, with the exception of Class 03. Table 8-8 indicates that 1.9-4.5 percent of this dart point class from Blocks $\mathrm{A}, \mathrm{E}$, and $\mathrm{B} / \mathrm{C}$ is on non-local raw materials; none of the Class 03 darts from Block D are from non-local sources. Single examples of the Williams (from Block A) and Marshall (from Block B/C) types are also on non-local lithics. The dart points in this group were used as projectiles, particularly the Gary var. LeFlore form, where 5.6-21.1 percent of the Class 02 and 03 specimens from the North and South rises have impact fractures (see Table 8-9). The relative frequency of blade resharpening, serration, and/or blade beveling among the darts also indicate they were multi-functional tools.

Dart points associated with the Early Ceramic period occupation of the site (ca. 1700-1200 years ago) are Classes 01, 04, 05, 07, 08, 15, and 16 (see Figure 8-2). Class 01 has a narrow pointed base and the general thickness and stem width characteristics of the Gary var. Camden form (see Table 8-8). The var. Camden specimens from Hurricane Hill have neck widths that range between 12.8-14.2 mm and are 6.9-7.4 $\mathrm{mm}$ in thickness (see Table 8-8).

Class 08 dart points have the shape and size of the Gary var. LeFlore, but it also has definite barbs, which the var. LeFlore examples lack (cf. Schambach 1998:Figure 44). The Kent type (Classes 04, 05, and 07), forms with narrow parallel stems, flat to slightly convex bases, and no definite shoulder, occurred in each of the North and South Rise excavations, accounting for 3.1-9.8 percent (Blocks B/C and A, respectively) of the dart points (see Table 8-6). The Class 15 (Ensor) and 16 (Darl?) darts comprise only 1.2-3.9 percent of the projectile points, 2-15 times less frequent than the contracting stem forms of presumed Early Ceramic age.

The Class 08 Gary form is present in comparable but low frequencies in each excavation area at Hurricane Hill (between 4.7-5.3 percent), and comprises 20 percent of the dart points in the Early Ceramic component in Area B (see Table 8-6). On the South rise, the Class 08 dart point is only predominant in levels deeper than $30 \mathrm{~cm}$ bs. However, the Class 01 (Gary var. Camden) points were more frequent than the Class 08 Gary point in all contexts, particularly in certain levels of Midden 1 where the materials had become apparently mixed with the later Early Caddoan occupation. The Gary var. Camden (Class 01) points represent 52-56 percent of the Early Ceramic period projectile points in the North rise blocks excavations, further indicating (as suggested by the radiocarbon dates, see Chapter 7, this volume) that the upper levels of the Primary Midden (Zone III, see Chapter 5, this volume) were deposited during much of the Early Ceramic period, particularly between A.D. 100-450. On the South rise, the Class 01 Gary accounts for only 42 percent of the darts, with a higher percentage of Class 08 and Class 15 darts (see Table 8-6). This may suggest that the Early Ceramic period component on the South rise dates to the latter part of the period, after ca. A.D. 500.

Non-local raw materials among the Early Ceramic dart point classes are restricted to 6.1 percent of the Gary var. Camden darts from Block A, and four (13.8 percent) Kent points from Blocks A and E (see Table 8-8). The Gary and Kent points are resharpened and serrated and used as cutting tools, and impact fractures are present in these classes only in the Block A dart point assemblage (see also below). The Ensor and Darl types were clearly used as projectiles--with impact fracture percentages ranging from 20-100 percent on the North and South rises (see Table 8-9), and the Ensor may also have been used as a cutting tool because of the high relative frequencies (between 20-100 percent) of resharpening, serration, and beveling among this dart point class. 
Both the Late Archaic-Early Ceramic and Early Ceramic dart point groups are widely distributed from South Texas to the northern part of East Texas (see Figure 8-3b). The Gary point in particular is best represented in Prewitt's (1995) distributional data in the eastern part of the state, indicating "localized interaction spheres in the northern...parts of the region" (Fields et al. 1997:86), and in adjoining parts of northwestern Louisiana, southeastern Oklahoma, and southwestern Arkansas.

\section{Arrowpoints}

Arrowpoints were recovered from all areas of the site except for Area B on the western slope of the upland landform, which appears from the projectile points found there to be a relatively discrete Early Ceramic period deposit (see Appendix I). Nevertheless, arrowpoints and arrowpoint preforms occur in low frequencies by comparison with the Middle and Late Archaic and Early Ceramic period dart points at the Hurricane Hill site. Arrowpoint-to-dart point ratios on the North, South, and Southwest rises are as follows: North Rise, Block A, 1:5.0; North Rise, Block D, 1:9.2; North Rise, Block E, 1:19.0; South Rise, Block B/C, 1:2.8; Southwest Rise, 1:6.7. As expected, the Block A North rise Early Caddoan midden and Block B/C Middle Caddoan period structural deposits had the highest relative percentages of arrowpoints in excavated contexts, as well as the greatest numbers of arrowpoint fragments. This is consistent with the fact that substantial Early and Middle Caddoan period archaeological deposits were present in these areas of the site. Table 8-10 provides relevant mean and standard deviation measurement data for the arrowpoint classes, as well as information on the relative proportions of non-local lithic raw materials in each of the classes.

Table 8-10. Arrowpoint measurements.

\begin{tabular}{|c|c|c|c|c|c|c|c|c|}
\hline Area & Class & $\mathrm{TH}^{*}$ & $\mathrm{BL}$ & BW & $\mathrm{HL}$ & HW & NW & $\%$ Non-Local \\
\hline Block A & 01 & $3.11 \pm 0.39$ & $12 \pm 2$ & $12.57 \pm 1.35$ & $5.78 \pm 0.91$ & $8.00 \pm 0.67$ & $6.89 \pm 0.39$ & 0.0 \\
\hline Block D & 01 & 1.00 & - & 18.00 & 6.00 & 9.00 & 7.00 & 0.0 \\
\hline Block B/C & 01 & $3.38 \pm 0.63$ & $15.5 \pm 1.5$ & $16.3 \pm 1.1$ & $5.63 \pm 0.56$ & $7.38 \pm 1.07$ & $6.50 \pm 1.00$ & 0.0 \\
\hline Block A & 02 & $3.71 \pm 0.82$ & $19 \pm 6$ & $12.8 \pm 1.04$ & $7.43 \pm 1.22$ & $5.86 \pm 1.06$ & $5.71 \pm 1.18$ & 14.3 \\
\hline Block D/E & 02 & $3.3 \pm 0.43$ & $14 \pm 1$ & $12.5 \pm 1.5$ & $6.33 \pm 1.11$ & $5 \pm 0.67$ & $5 \pm 0.67$ & 0.0 \\
\hline Block B/C & 02 & $3.45 \pm 0.58$ & $19 \pm 2.33$ & $12.75 \pm 1.19$ & $5 \pm 1$ & $4.8 \pm 0.68$ & $4.82 \pm 0.63$ & 27.3 \\
\hline Block A & 03 & $4.5 \pm 1$ & $18 \pm 2$ & $14.5 \pm 0.95$ & $6.5 \pm 1$ & $6 \pm 0.5$ & $6 \pm 0.5$ & 0.0 \\
\hline Block D & 03 & 6 & - & 14 & - & - & - & 100.0 \\
\hline Block B/C & 03 & $4.27 \pm 0.74$ & $17.33 \pm 3.3$ & $14.3 \pm 2.5$ & $6.18 \pm 1.47$ & $7.54 \pm 1.59$ & $7.54 \pm 1.59$ & 9.1 \\
\hline Site & 04 & $3.67 \pm 0.89$ & $16.33 \pm 2.44$ & $14.0 \pm 0.67$ & $2.67 \pm 0.44$ & $4.25 \pm 0.75$ & $4.25 \pm 0.75$ & A: $0.0 ; B / C: 50.0$ \\
\hline Block A & 05 & $3.29 \pm 0.41$ & $15.00 \pm 3.60$ & $12.2 \pm 1.04$ & $5.14 \pm 1.06$ & $5.71 \pm 0.41$ & $5.71 \pm 0.41$ & 0.0 \\
\hline Block D/E & 05 & $3.67 \pm 0.44$ & $14 \pm 1$ & $14 \pm 2$ & $5.67 \pm 0.89$ & $6.33 \pm 1.11$ & $6.33 \pm 1.11$ & 0.0 \\
\hline Block B/C & 05 & $3.6 \pm 0.48$ & $15.25 \pm 1.31$ & $13.67 \pm 1.78$ & $5.8 \pm 0.84$ & $6.0 \pm 0.6$ & $6.0 \pm 0.6$ & 10.0 \\
\hline Block A & 06 & $3.6 \pm 0.48$ & $13.75 \pm 1.75$ & $15.4 \pm 2.88$ & $4.2 \pm 1$ & $8.5 \pm 1.5$ & $8.5 \pm 1.5$ & 20.0 \\
\hline Block E & 06 & 3.0 & $16.0 \pm 2.0$ & 13.0 & 5.0 & $6.0^{-}$ & $6.0^{-}$ & 0.0 \\
\hline Site & 07 & $3.0 \pm 0.4$ & $15.8 \pm 4.2$ & $16 \pm 2$ & $3.75 \pm 0.87$ & $6.75 \pm 1.25$ & $5.80 \pm 0.32$ & $\begin{array}{l}\mathrm{A}: 0.0 ; \mathrm{D} / \mathrm{E}: 50.0 \\
\mathrm{~B} / \mathrm{C}: 0.0\end{array}$ \\
\hline Block B/C & 08 & 3.0 & 21.0 & 15.0 & - & . & - & 0.0 \\
\hline Site & 09 & $3.5 \pm 0.5$ & $10.5 \pm 2.5$ & 9.0 & $6.5 \pm 0.5$ & $8.0 \pm 1.0$ & $6.0 \pm 1.0$ & D:0.0; \\
\hline Site & 10 & $3.67 \pm 0.44$ & $18.0 \pm 1.0$ & $12.67 \pm 1.11$ & $6.67 \pm 1.11$ & $10.33 \pm 0.89$ & $10.33^{2} \pm 0.89$ & $\mathrm{~A}: 0.0 ; \mathrm{B} / \mathrm{C}: \mathrm{C} .0$ \\
\hline Site & 11 & $2.67 \pm 0.44$ & $16.0 \pm 1.0$ & $12.33 \pm 0.89$ & - & . & - & $\begin{array}{l}D: 0.0 \\
B / C: 1(00.0\end{array}$ \\
\hline Site & 12 & 4.0 & 25.0 & - & 7.0 & 8.0 & 8.0 & 0.0 \\
\hline
\end{tabular}

measurements in millimeters

TH=thickness; $\mathrm{BL}=$ =blade length; $\mathrm{BW}=$ =blade width; $\mathrm{HL}=$ haft length; $\mathrm{HW}=$ haft width; $\mathrm{NW=neck}$ width 
The arrowpoints from the Hurricane Hill site represent a stylistically diverse sample that is the product of two (or three, if the Late Caddoan arrowpoints constitute a distinct component) temporally distinct occupations (see Figure 8-2 and Table 8-7). In aggregate, however, the arrowpoints indicate that the site was occupied several different times from the Early Caddoan to Late Caddoan periods, but principally between ca. A.D. 1000-1400.

As with the dart points, the most common arrowpoints from the Hurricane Hill site are types that are distributed primarily in eastern Texas, but mainly north of the Sabine River (Figure 8-4). The Perdiz (Class 03) and Scallom (Class 07) types, however, also have a wide distribution across Central and South Texas, which Fields (1995a:323) suggests may be evidence for "increased interaction with groups who lived to the west during parts of the Late Prehistoric period." However, Perdiz points are a noticeably abundant arrowpoint type in several recently excavated Middle Caddoan components in the Sabine River drainage (Perttula and Cruse 1997; Walters et al. 1998; Rogers n.d.), as they are in ca. A.D. 1350-1500 components in the Big Cypress Creek basin (see Thurmond 1990; Perttula 1992; Turner 1978), instead pointing to an increased north-south interaction during the Middle Caddoan period.

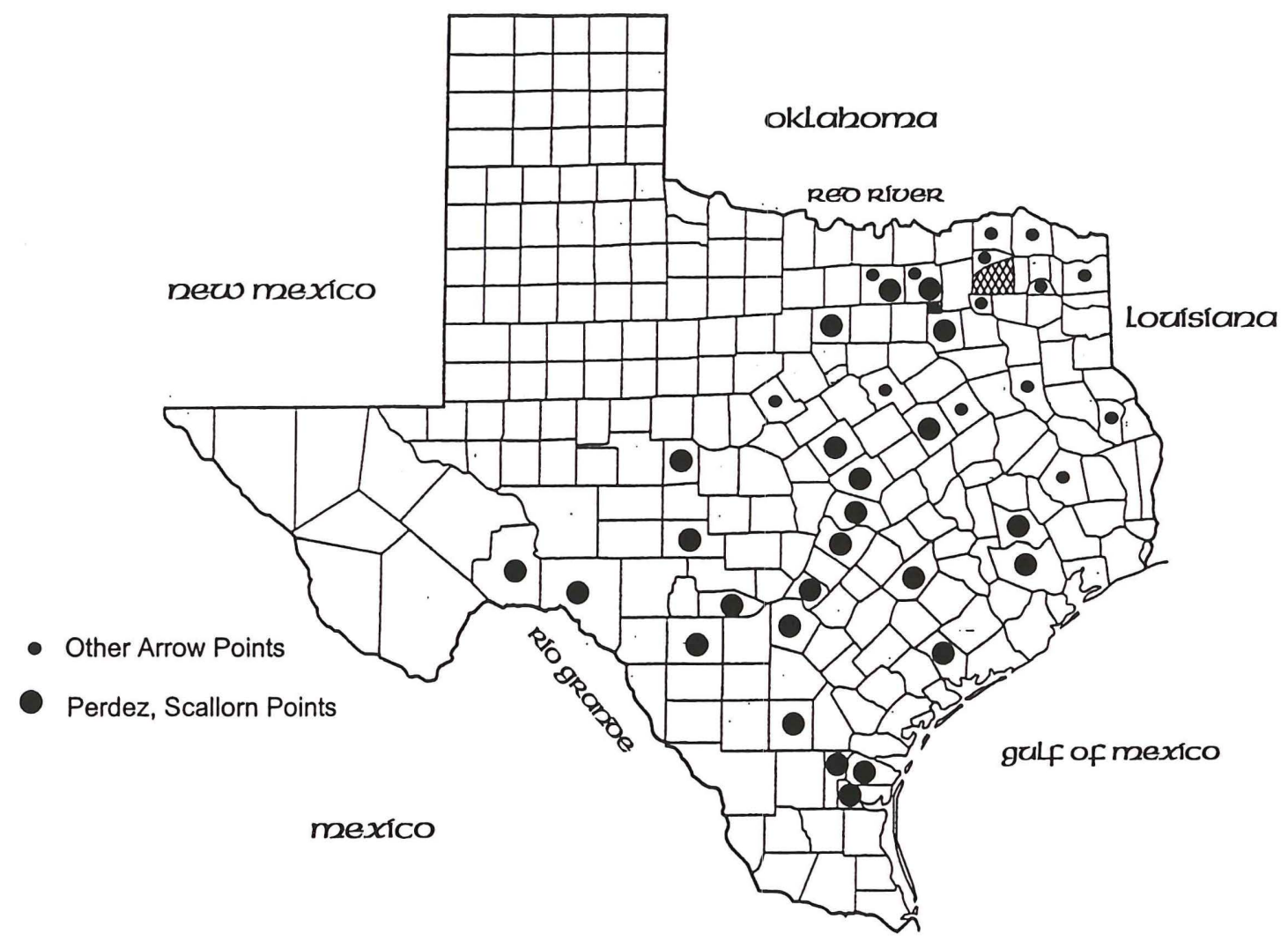

Figure 8-4. Distribution of arrowpoints in Texas (after Prewitt 1995).

Temporal evidence from the Richland/Chambers Reservoir in the Trinity River basin in eastern Texas indicated that Scallorn (Class 07) and Steiner (Class 06) arrowpoints occurred in deposits there dating between A.D. 700 and A.D. 900 (McGregor and Bruseth 1987a:Figure 15-2). Archaeological evidence from several other sites at Cooper Lake, however, suggests that arrowpoints are absent in deposits that predate A.D. 800 (Fields et al. 1997:43), but Fields et al. (1997) go on to state that "the atlatl and dart were used along with the bow and arrow during at least the early part of the period [ca. A.D. 800-1000]." 
The most common arrowpoint forms in Early Caddoan contexts reported by Fields et al. (1997:47) include the Colbert, Steiner, and Catahoula forms, with lesser frequencies of the Alba, Friley, and Scallorn types. At Hurricane Hill, these classes (with the exception of the Catahoula type, which is absent at the site) were found almost exclusively on the North rise, particularly in the lower levels of Midden 1 and in Block $E$ off the crest of the rise Over 66 percent of the arrowpoints from Block $E$ (albeit a sample of four arrowpoints) are either Scallorn (Class 07) or Steiner (Class 06) forms, but their relative frequencies range only between 2.2 percent and 17.2 percent in the other blocks (see Table 8-7). About 16 percent of the Scallorn and Steiner arrowpoints were made on non-local lithic raw materials (see Table 8-10), all on the North rise.

The Alba type (Class 05) has a lengthy period of use in northeastern Texas, but appears to have been particularly common in use between A.D. 1000 and A.D. 1200 (e.g., Baskin 1981; McGregor and Bruseth 1987a, 1987b), the Early Caddoan period. The Alba has a broad, straight stem with a flat base, and a straight and pointed tang (see Figure 8-2).

Between 16.7 percent and 22.2 percent of the arrowpoints recovered from the different blocks belong to the Alba type (see Table 8-7). In other Cooper Lake Early Caddoan contexts, they comprise only 3-12 percent of the arrowpoints, with the highest percentage from the L. O. Ray site (41DT21) (Fields et al. 1997:Table 4). Baskin (1981:280) also notes that in certain instances at the George C. Davis site, in deposits apparently post-dating A.D. 1200, Alba points co-occur with Perdiz (Class 03) and Hayes (Classes 11) forms, or intergrade stylistically with them (cf. Johnson 1989b:197), indicating a temporal continuity in arrowpoint styles. Therefore, while it is possible that the occurrence of the Alba type at the site may be better indicative of an Early Caddoan period occupation, and this can be corroborated by the radiocarbon dates from Block A (see Table 7-1), it is also possible that it is also a later form assignable to the earlier part of the Middle Caddoan period (i.e., Structure B on the South rise), where it is also common (see Table 8-7). Approximately 5 percent of the Alba points from Hurricane Hill are made of non-local lithics.

Early to Middle Caddoan period arrowpoint forms include Colbert (Class 01), Bonham (Class 02), Reed (Class 09), and Hayes (Class 11) types. These Early to Middle Caddoan arrowpoint forms comprise between 40-55 percent of the arrowpoints in Blocks A, B/C, and D, but only 16.7 percent in Block $E$. The highest representation is in Block D (see Table 8-7), although the sample includes only five arrowpoints. In Blocks A and B/C, the Colbert (Class 01) form is the most abundant, as it is in the majority of the Early Caddoan sites discussed by Fields et al. (1997:47), while the Bonham (Class 02) type is the most common form in Middle Caddoan contexts, apparently along with the Reed type. About 11.9 percent of these Early to Middle Caddoan arrowpoints have been manufactured from non-local lithic raw materials, most notably the Bonham points (see Table 8-10). Non-local raw materials for arrowpoints are also better represented in Block $B / C$ contexts than on the North rise.

The recovery of a few plain and brushed shell-tempered pottery from Blocks $A$ and $B / C$ suggested that a Late Caddoan period occupation had occurred at the Hurricane Hill site (see Chapters 7 and 9, this volume). The A.D. $1540 \pm 60$ TL date from one of the sherds in Block B/C (see Table 7-2) was also intriguing in this regard. Thus, the recovery of later Caddoan arrowpoint styles at Hurricane Hill was not unexpected. Possible Late Caddoan forms identified include Bassett (Class 04), Fresno (Class 08), and Maud (Class 10) types, along with the possible Perdiz forms (Class 03). The Bassett and Perdiz points appear to be most common in ca. A.D. 1300-1500 contexts in Northeast Texas, where they occur in both defined Middle and Late Caddoan phases, including the Bossier, Whelan, and Titus phases. From recent radiocarbon dating (Perttula 1998b, 1998e) and further ceramic analyses from sites in the Sabine, Cypress, and Red River (see Girard 1998) basins, the Bossier and Whelan phases actually temporally overlap with the latter part of the Middle Caddoan period, as it has been defined by Story (1990) to extend to ca. A.D. 1400. Thus, in terms of their temporal context, the Bassett and Perdiz points at Hurricane Hill may date both before and after A.D. 1400. The abundance of Class 03 arrowpoints in Block B/C suggests that they primarily are associated with the Middle Caddoan residential occupation on the South rise, rather than with a transitory Late Caddoan use of the site. The evidence is equivocal for the Class 04 Bassett points, as only three have been recovered from Blocks $A$ and $B / C$ (see Table 8-7).

The Class 03 points do also bear a resemblance to projectile points (Type X) from the Manton Miller site (41DT1) that were recovered in deposits dominated by Alba and Catahoula-like forms (Johnson 1962:Figure 29pp-rr and Table 4). At Hurricane Hill, these forms (Class 03), however, have narrow 
contracting stems with rounded bases, are thick in cross-section relative to the length of the blades (see Table 8-10), and there are also small barbs on the blades.

Almost 16 percent of these Middle to Late Caddoan period arrowpoints are of non-local raw materials (see Table 8-10), about the same proportions as the ca. A.D. 800-1000 arrowpoints from the North rise, and 30 percent higher in frequency than the suite of Early-Middle Caddoan arrowpoints from the site as a whole, and several times more common than was the case among the Early Caddoan Alba arrowpoints on either the North or South rise. The non-local lithic materials are also more abundant on the South rise than they are in Block A on the North rise.

The triangular arrowpoints, Class 08 (Fresno) and 10 (Maud), are of Late Caddoan age. The few examples on the North and South rises are made exclusively on local raw materials.

\section{Lithic Debris}

Lithic debris from the Hurricane Hill site was collected employing two different recovery techniques. The first technique was the screening of soil matrix through $1 / 4$-inch hardware cloth. A total of 60,405 pieces of lithic debris was recovered by this method from the excavation blocks and the investigations at the Southwest rise (Table 8-11). In this assemblage, pieces were separated into large or small debris (large: $>1.5 \times 1.5 \mathrm{~cm}$ and small: $<1.5 \times 1.5 \mathrm{~cm}$ ) and then were categorized by the presence (cortical) or absence (interior piece) of cortex on the dorsal surface. Chunks of lithic debris (i.e., irregular pieces without clear flake morphology, a singular striking platform, or a termination) were also tabulated to give some indication of the nature of the reduction process. Finally, the lithic debris was then categorized as either quartzite or chert (including all siliceous materials other than quartzite) to rapidly detect trends in raw material use across the site, or within particular deposits (see Appendix XIA).

Table 8-11. Frequencies of coarse-screened lithic debris by size and cortex.

\begin{tabular}{lllllll}
\hline & & \multicolumn{2}{c}{ Large $^{\mathrm{a}}$} & \multicolumn{2}{c}{ Small } \\
Provenience & Interior & Cortical & Chunk & Interior & Cortical & Total \\
\hline North Rise & & & & & \\
Block A & 3,572 & 7,006 & 865 & 4,171 & 2,618 & 1,164 \\
$\begin{array}{l}\text { Block D } \\
\text { Block E }\end{array}$ & 1,282 & 2,174 & 304 & 2,027 & 1,232 \\
South Rise & & 2,420 & 346 & 1,521 & 1,026 & 6,486 \\
Block B/C & 5,286 & 9,754 & 1,107 & & & \\
Southwest & 540 & 1,064 & 89 & 6,085 & 3,976 & 26,208 \\
Rise & 540 & & 529 & 306 & 2,528 \\
\hline Total & 11,853 & 22,418 & 2,711 & 14,333 & 9,090 & 60,405 \\
\hline
\end{tabular}

a $>1.5 \times 1.5 \mathrm{~cm}$

b $<1.5 \times 1.5 \mathrm{~cm}$

More detailed raw material identifications were completed for the lithic debris recovered by means of the second technique, the fine screening or flotation of soil matrix (in the case of approximately 90 percent of Block A-extension and all of Block F, each $1 \times 1 \mathrm{~m}$ unit was screened through 1/16-inch hardware cloth) (see Appendix XIB). In this analysis phase, lithic debris recovered by either of these methods (i.e., flotation or fine screening) was examined in more detail by size, the relative percentage of dorsal cortex present, and the raw material (Table 8-12). This sample, which totaled 61,202 pieces (including lithic debris from the Southwest rise), was selected for more detailed considerations because the fine-screening 
procedures were more likely to recover a representative sample of the lithic debris sizes, particularly the small flakes, than the coarse-screening technique (e.g., Fladmark 1982; Shott 1994).

Table 8-12. Relative frequencies of cortex and size data for a selected sample of lithic debris recovered from fine-screening or flotation.

\begin{tabular}{|c|c|c|c|c|c|c|}
\hline \multirow[b]{2}{*}{$\%$ Cortex } & \multirow[b]{2}{*}{ Block A } & \multicolumn{2}{|c|}{ North Rise } & \multicolumn{2}{|c|}{ South Rise } & \multirow[t]{2}{*}{ Southwest Rise } \\
\hline & & Block D & Block E & Block B/C & Block F & \\
\hline \multicolumn{7}{|c|}{ Large $(>1.5 \times 1.5 \mathrm{~cm})$} \\
\hline $\begin{array}{c}0 \% \\
1-25 \% \\
26-50 \% \\
51-75 \% \\
76-100 \%\end{array}$ & $\begin{array}{l}9.8 \\
5.8 \\
3.0 \\
2.1 \\
3.1\end{array}$ & $\begin{array}{l}13.6 \\
8.0 \\
4.7 \\
3.4 \\
3.7\end{array}$ & $\begin{array}{l}17.5 \\
9.2 \\
5.2 \\
3.5 \\
4.4\end{array}$ & $\begin{array}{l}17.0 \\
8.7 \\
4.3 \\
2.9 \\
4.3\end{array}$ & $\begin{array}{l}3.5 \\
1.9 \\
1.1 \\
0.7 \\
0.6\end{array}$ & $\begin{array}{l}5.6 \\
5.1 \\
2.8 \\
2.2 \\
2.2\end{array}$ \\
\hline \multicolumn{7}{|c|}{ Small $(<1.5 \times 1.5 \mathrm{~cm})$} \\
\hline $\begin{array}{c}0 \% \\
1-25 \% \\
26-50 \% \\
51-75 \% \\
76-100 \%\end{array}$ & $\begin{array}{l}72.7 \\
1.7 \\
0.7 \\
0.5 \\
0.6\end{array}$ & $\begin{array}{l}60.6 \\
2.5 \\
1.0 \\
0.6 \\
0.9\end{array}$ & $\begin{array}{l}53.5 \\
3.3 \\
1.4 \\
0.8 \\
1.2\end{array}$ & $\begin{array}{l}59.1 \\
1.7 \\
0.8 \\
0.5 \\
0.7\end{array}$ & $\begin{array}{l}90.0 \\
0.9 \\
0.6 \\
0.2 \\
0.6\end{array}$ & $\begin{array}{l}80.2 \\
1.8 \\
0.6 \\
0.5 \\
0.3\end{array}$ \\
\hline Totals & 30,862 & 6,518 & 7,452 & 10,599 & 1,173 & 3,542 \\
\hline
\end{tabular}

In the initial sample based on the 1/4-inch fraction, several trends are apparent. As expected, large debris predominates in all contexts. Cortical pieces account for 48.0-54 percent of the debris in each block or excavation area, indicating the occurrence of initial tool reduction (e.g., Peter and McGregor 1987:199; McGregor 1997c), as well as reliance on the abundant local Uvalde gravels. It is assumed that this source of knappable lithic raw material was used during all phases of site occupation. Chunks consistently account for 3.5-5 percent of the debris and also reflect a continuity in basic reduction processes: the reduction of relatively small upland gravels (see Table 8-11). Local quartzites (Ogallala and coarse-grained varieties) account for the majority of the debris (see below).

The lithic debris sample from the fine screening and flotation samples also indicates the basic similarity in the size of the pieces and amount of cortex present on each between the different areas of the site (see Table 8-12), with the exception of Block F, where large pieces of lithic debris are rare by comparison with small non-cortical lithic debris. Because of the higher frequency of small debris recovered by the fine-screening methods, large debris accounts for 23.8-39.8 percent of the assemblages in the block excavations, as compared to 60-70 percent in the 1/4-inch sample (see Table 8-11). Cortical pieces are less common in these lithic debris sample, and of those with cortex, those pieces with only 1-25 percent dorsal cortex are best represented. The relatively high frequency of lithic debris, most of it small, with little cortex probably is indicative of an emphasis on internal core reduction (Peter and McGregor 1987:199; McGregor 1997c). Prentiss (1998:647) further suggests that high numbers of flakes and flake fragments are particularly abundant in lithic reduction activities associated with prepared core and biface reduction, as well as with the reduction of fine-grained lithic raw materials (such as the Ogallala quartzite in the local gravels). Shott (1994) and Patterson (1990) have noted the same relationship, wherein high percentages of small flakes are obtained during bifacial reduction activities.

The largest relative percentage of dorsal cortex pieces with 51-100 percent cortex is from Block E (see Table 8-12), representing 9.9 percent of the large and small pieces of lithic debris in the sample. In other areas of the site, the percentage of dorsal cortex pieces with 51-100 percent cortex ranges from lows of 
2.1 percent and 5.2 percent in Block $F$ and the Southwest rise, respectively, to between 6.3-8.6 percent in Blocks $A, D$, and $B / C$ on both rises. This may suggest that the initial stages of reduction were more common on the North rise during Late Archaic/Early Ceramic and Early Caddoan periods than elsewhere at the site. As was discussed above, the Late Archaic/Early Ceramic components at Hurricane Hill have considerable numbers of cores, non-tool bifacial blank/preforms, and discarded broken bifacial tools (principally dart points).

The sample from Block $F$ is composed primarily of small (92.3 percent), non-cortical (93.5 percent) pieces of lithic debris (see Table 8-12), probably from a heightened emphasis on biface reduction from flake blanks. This particular assemblage is significant because it seems to represent a relatively discrete post-AD 1350 Middle Caddoan occupation.

\section{Patterns of Raw Material Use}

Even though the Hurricane Hill site occupies a landform that is covered by knappable Uvalde gravels, the occupants of the site did not totally rely upon this local resource for tool stone. For reasons of mobility, exchange, or the variability in availability of raw materials (e.g., McGregor 1987:188; Perttula 1984), at certain times in the prehistory of northeastern Texas the use of non-local lithic raw materials was much higher than at other times. In particular, Paleoindian, Early Archaic, and some Late Prehistoric Caddoan groups made significant use of non-local lithic materials (e.g., Fields 1995a; Meltzer 1987; McGregor 1987; Perttula 1984).

A wide variety of lithic raw materials has been identified from the Hurricane Hill site (Table 8-13). Based on information on lithic sources by Mallouf (1976), Banks $(1984,1990)$, and Banks and Winter (1975), as well as inspection of the Uvalde gravels at Hurricane Hill and other locales at Cooper Lake, the lithic raw materials have been divided into four groups: (1) local, (2) probably local, (3) probably nonlocal, and (4) non-local. The identification of probably non-local and non-local raw materials, most of which derive from Ouachita Mountain sources in southeastern Oklahoma and were available in Red River gravels in northeastern Texas (e.g., Banks 1984:Figure 3.6) east of the Boggy River (and particularly abundant downstream from the mouth of the Kiamichi River), was facilitated by a large collection of western Ouachita Mountain lithic raw material types from gravel and archaeological contexts in Atoka County, Oklahoma and McCurtain County, Oklahoma (see Banks 1990; McGuff 1993; Perttula 1994a; Perttula et al. 1998).

Table 8-13. Identified lithic raw material types ${ }^{\mathrm{a}}$

\section{Local}

Ogallala Quartzite

Other Quartzite (coarse-grained)

Petrified Wood

\section{Probably Local}

\section{Chalcedony}

Yellow Chert

Red Chert (not thermally altered)

Ochre

\section{Probably Non-local}

\author{
Jasper \\ Gray Chert (w/tan cortex) \\ Siltstone
}

\author{
Sandstone \\ Ferruginous Sandstone
}

Tan Chert
Hematite
Limestone
White, Fossiliferous Chert

White, Non-fossiliferous Chert

White Chert (w/chalky cortex) 
Table 8-13. Identified lithic raw material types, cont. ${ }^{\text {a }}$

\section{Non-local}

\author{
Novaculite \\ Siliceous Shale (non-black) \\ Black Siliceous Shale \\ Vein Quartz \\ WoodfordChert \\ Big Fork Chert (green) \\ Black Chert (Big Fork Chert)
}

\author{
Quartzitic Sandstone \\ Johns Valley Chert \\ Spanish Fort Quartzite \\ Black Chert (with fossil inclusions) \\ Frisco Chert (?) \\ Obsidian
}

a From Banks 1984, 1990; Mallouf 1976; Perttula 1984

At Hurricane Hill, the use of non-local raw materials was apparently much less than at many other Caddoan sites in northeastern Texas (see Briggs and Malone 1970; Perttula 1984), but the relative frequencies of non-local raw materials is quite comparable to other Caddoan lithic assemblages at Cooper Lake (see discussion in Fields et al. 1997). In fact, Fields et al. (1997:Figure 42) document a regular decrease in the use of non-local raw materials for the manufacture of projectile points from the Late Archaic (16 percent non-local) to the Woodland (3-8 percent), Early Caddoan (0-7 percent), and Late Caddoan (1 percent) periods at Cooper Lake.

In general, between 1-7 percent of the tools and debris from each site context at Hurricane Hill were made of non-local or probably non-local raw materials (Figure 8-5), with the highest percentage of non-local tools and debris from Block B/C on the South rise. The lithics from Blocks D and E have the lowest proportions of non-local tools (about 3 percent) and lithic debris (about 1-2 percent).

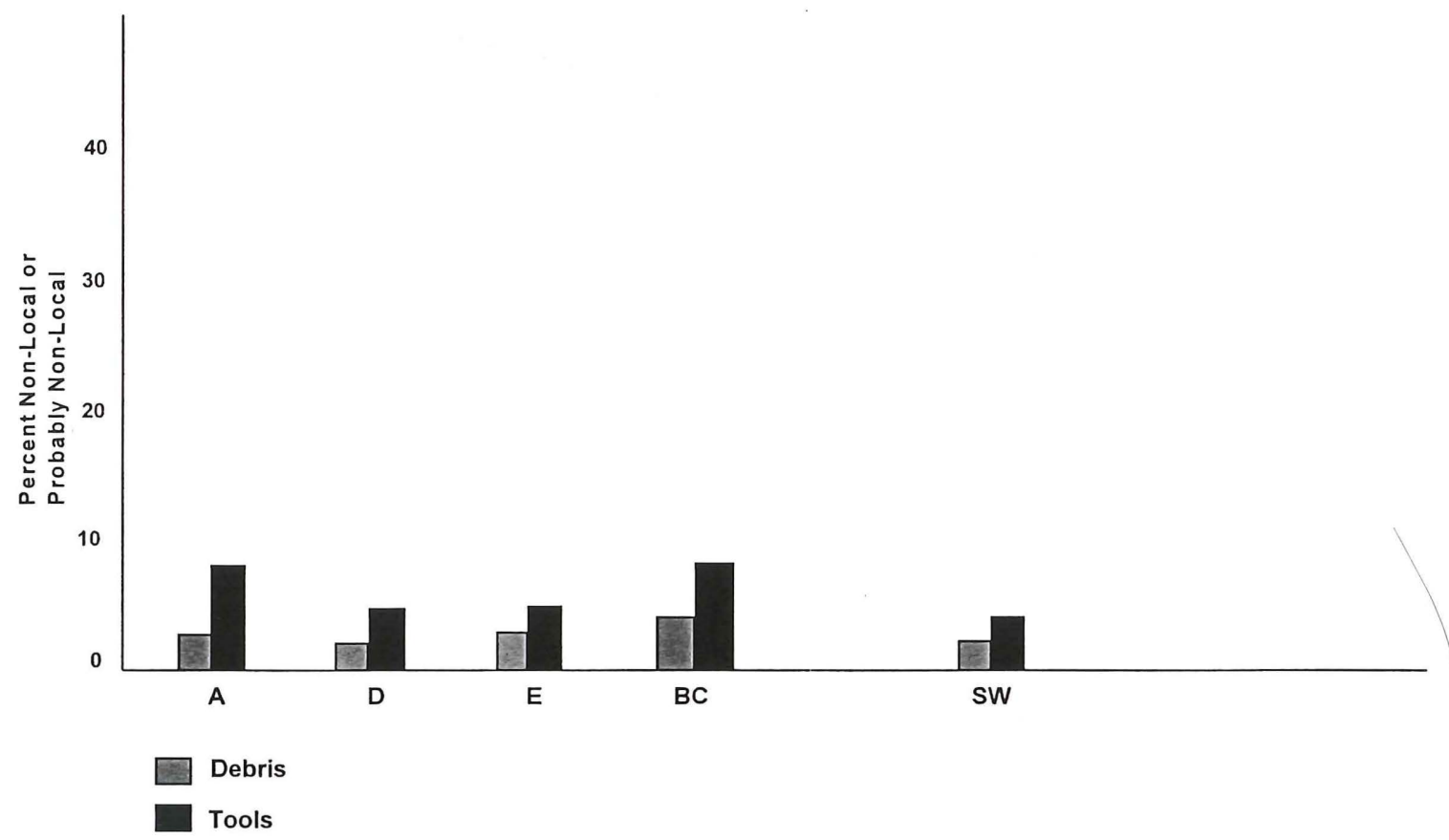

Figure 8-5. Use of non-local lithic raw materials in the lithic debris and tools at Hurricane Hill. 
The lithic debris is predominantly of Ogallala quartzite and a coarse-grained quartzite (referred to as "other quartzite"). Ogallala quartzite accounts for between 70-80 percent of the lithic debris, and the coarsegrained quartzite another 7-17 percent of the large lithic debris samples. Petrified wood ranks a distant third among the local sources (Table 8-14), probably a reflection of the poor knapping quality (e.g., Girard 1995) and low availability of this siliceous material in comparison with the coarse- and fine-grained quartzites in the upland gravels. Among the probable local raw materials, a non-heat-treated red chert and a yellow chert are most common, followed by a tan chert and chalcedony (see Table 8-14). All of these materials are available in upland gravel sources in the vicinity of the Hurricane Hill site, and in many other intefluvial gravel deposits in the region.

Table 8-14. Frequencies of local and non-local raw material types for a selected sample of debris recovered from fine screening or flotation.

\begin{tabular}{lllll}
\hline Raw Material & Block A & $\begin{array}{l}\text { North Rise } \\
\text { Block D }\end{array}$ & Block E & Block B/C Rise \\
\hline
\end{tabular}

Local

Ogallala Quartzite Other Quartzite

Petrified Wood

Ferruginous Sandstone

$\begin{array}{ll}23,496 & 5,029 \\ 3,556 & 873 \\ 128 & 34 \\ 53 & 8\end{array}$

5,710
1,020
73
21

7,780
1,614
97
10

941
79
4
2

3,179
792
70
2

Probably Local

$$
\begin{aligned}
& \text { Chalcedony } \\
& \text { Yellow Chert } \\
& \text { Red Chert } \\
& \text { Tan Chert }
\end{aligned}
$$

$\begin{array}{ll}27 & 5 \\ 98 & 15 \\ 180 & 14 \\ 67 & 8\end{array}$

Probably Non-local

$\begin{array}{lllllll}\text { Jasper } & 23 & 8 & 25 & 11 & - & 6 \\ \text { Gray Chert } & 253 & 27 & 40 & 86 & 13 & 9 \\ \text { Siltstone } & - & - & - & 1 & - & 5 \\ \text { White Chert (w/fossils) } & 43 & 6 & 14 & 13 & - & 3 \\ \text { White Chert (w/o fossils) } & - & - & - & - & \end{array}$

Non-local

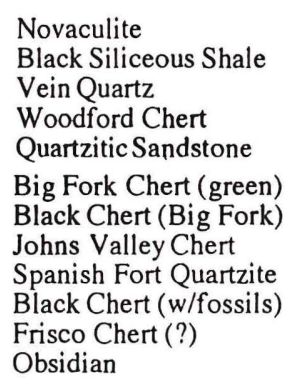

$\begin{array}{ll}22 & 35 \\ - & 4 \\ 1 & 2 \\ 5 & 5 \\ - & - \\ 1 & 4 \\ 4 & 11 \\ 3 & - \\ - & - \\ - & - \\ - & -\end{array}$

95
1
5
11
-
6
12
-
-
-
-
-

6
9
-
5
3 3

\begin{tabular}{llllllll}
\hline Total $\cdots$ & 30,862 & 6,518 & 7,453 & 10,599 & 1,173 &. & 4,598 \\
\hline
\end{tabular}


The non-local or probably non-local lithic debris in Block A on the North rise accounts for almost 2 percent of the total sample from this block (see Table 8-14). The most common non-local or probably non-local lithic raw material types are a gray chert (e.g., Banks 1984:88) from the John's Valley shale formation in the western Ouachita Mountains, and novaculite.

A previous study of lithic raw materials identified the gray chert as originating from Ozark Mountains chert deposits (Perttula 1984), when in fact these cherts appear to be from gravel aggregates in Ouachita Mountains sources (see Banks 1990). Thus, both the gray chert and novaculite materials are available in Red River gravels about $100 \mathrm{~km}$ north of the site, downstream from where Muddy Boggy Creek and the Kiamichi River enter the Red River. Cliff et al. (1996a, 1996d) also have noted the presence of novaculite in Bowie gravels along the interfluve between the Red and Sulphur rivers, well downstream and to the east from the Hurricane Hill site. However, in either Early Ceramic, Early Caddoan, and Middle Caddoan period contexts at Hurricane Hill, these non-local materials probably were obtained through mechanisms of exchange or trade with other groups, rather than by direct procurement (which may have been the case during much of the Archaic, since aboriginal populations were relatively mobile), because by that time aboriginal Caddoan populations in Northeast Texas were relatively sedentary and had definite territorial boundaries, and would have been able to control access and procurement of these raw materials.

Except in terms of absolute numbers or percentages, the archaeological deposits in Blocks B/C and $F$ on the South rise as a whole and Blocks D and $E$ on the North rise do not differ significantly in the types of non-local raw materials represented in the lithic debris assemblages. Only 2-3 percent of the debris is of non-local origin, and in Block $F$ the percentage of non-local materials is 1.6 percent, primarily represented by the gray chert (see Table 8-14) whose source is the southern and western Ouachita Mountains.

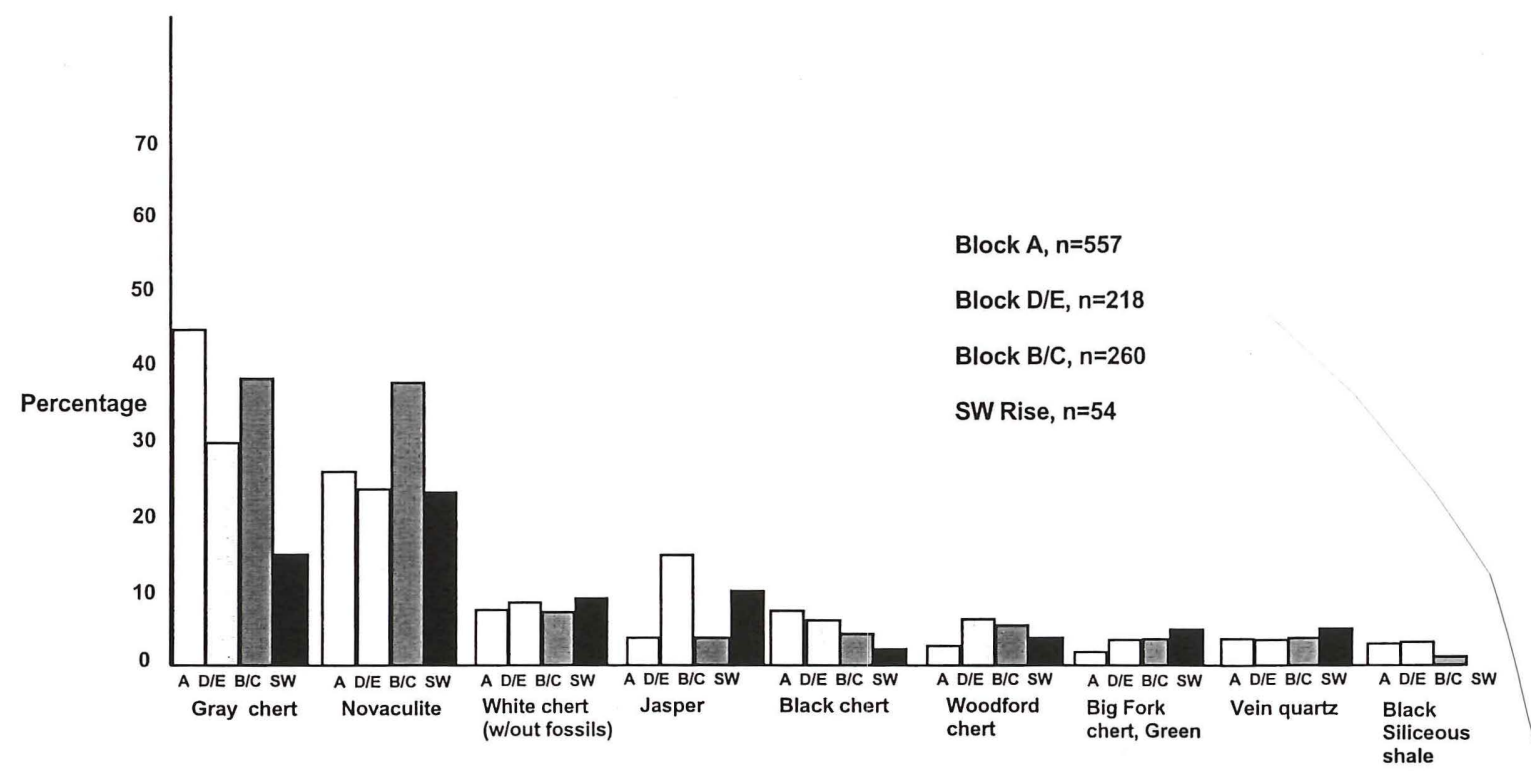

Figure 8-6. Use of probably non-local and non-local lithic raw materials in the lithic debris, depicting the nine most common non-local materials.

The most common non-local and probable non-local lithic raw materials among the lithic debris in all contexts at Hurricane Hill are gray chert and novaculite, with proportions ranging between 17-45 percent from the North, South, and Southwest rises (Figure 8-6). The gray chert was predominant on the North rise, while novaculite was most abundant in the Block B/C lithic debris, accounting for 38 percent of the sample of non-local debris (see Figure 8-6 and Table 8-14). Seven other non-local lithic raw materials are consistently represented in the lithic debris samples, listed in the order of their relative frequency: white 
chert (without fossil inclusions); jasper; black Big Fork chert; Woodford chert; Big Fork green chert; vein quartz; and black siliceous shale. The proportions of these non-local raw materials are generally comparable from one part of the site to another, with the exception of higher frequencies of jasper (11-16 percent) in Block D and E on the North rise and in midden deposits and features on the Southwest rise, and slightly higher amounts of Big Fork green chert on the Southwest rise (see Figure 8-6).

On the Southwest rise, in an Late Archaic-Early Ceramic period midden and feature deposit, nonlocal and probable non-local lithic raw materials only account for 1.2 percent of the lithic debris assemblage (see Table 8-14). Novaculite and gray chert are again the most common types, although the variety of lithics of non-local origin is impressive, numbering 12 different kinds, including several lithic raw materials not represented in the larger lithic debris samples from the block excavations (i.e., Spanish Fort quartzite [Dan McGregor, 1997 personal communication] and a possible Frisco chert from upstream on the Red River, and a black chert with fossils from an unknown source).

Tools made from non-local raw materials (including probable non-local sources) comprise 1.8-16.7 percent of the assemblages from the different areas of the site (Table 8-15). North rise assemblages, particularly those from Blocks D and E that sampled Late Archaic and Early Ceramic occupational deposits in the PrimaryMidden or below it, have lesser amounts of non-local materials (between 1.8-2.1 percent) than do the South rise components, where probable non-local and non-local raw materials comprise 4.6 percent of the tools (see Table 8-15). This is probably related to the increased use of non-local materials from the Ouachita Mountains and Red River gravels for the manufacture of arrowpoints and certain types of retouched pieces/flake tools during the Middle Caddoan period occupation on the South rise (see below). The raw material type preferred for those tools at that time was white novaculite (usually not heat-treated), followed by jasper (Figure 8-7). Although there are a wide variety of colors of novaculite in Ouachita Mountain sources, including black, gray, green, orange, and brown (cf. Etchieson 1998), the creamy white novaculite was clearly preferred for tool manufacture during the Middle Caddoan period occupation at Hurricane Hill. In Blocks D and E, Big Fork chert, the green variety (Mallouf 1976:49), is a relatively common non-local material for tools (especially in Blocks D and E), as is the gray chert on the North rise. The preference for non-local raw materials from Red River basin sources to the north is matched by the appearance of Red River Caddoan ceramics in the sample of sherds subjected to instrumental neutron activation analysis from Early and Middle Caddoan contexts at Hurricane Hill (see Neff et al., Chapter 10, this volume).

Table 8-15. Relative Frequencies of Local and Non-Local Lithic Raw Materials for Tools*

$\begin{array}{llllll}\text { Provenience } & \text { N } & \text { Local } & \begin{array}{l}\text { Probably } \\ \text { Local }\end{array} & \begin{array}{l}\text { Probably } \\ \text { Non-local }\end{array} & \text { Non-local }\end{array}$

North Rise

$\begin{array}{lllllll}\text { Block A } & 1166 & 88.7 & 2.1 & 2.0 & 2.1 & 4.7 \\ \text { Block D } & 319 & 91.0 & 1.2 & 0.6 & 1.2 & 6.0 \\ \text { Block E } & 384 & 90.7 & 1.2 & 0.5 & 1.6 & 6.0\end{array}$

South Rise

$\begin{array}{lrrrccc}\text { Block B/C } & 962 & 88.6 & 2.2 & 1.8 & 2.8 & 4.6 \\ \text { Block F } & 6 & 66.6 & - & 16.7 & - & 16.7 \\ \text { SW Rise } & 65 & 81.7 & 4.5 & 1.5 & 1.5 & 10.8\end{array}$

IND=indeterminate

* Includes cores and bifacial preforms 


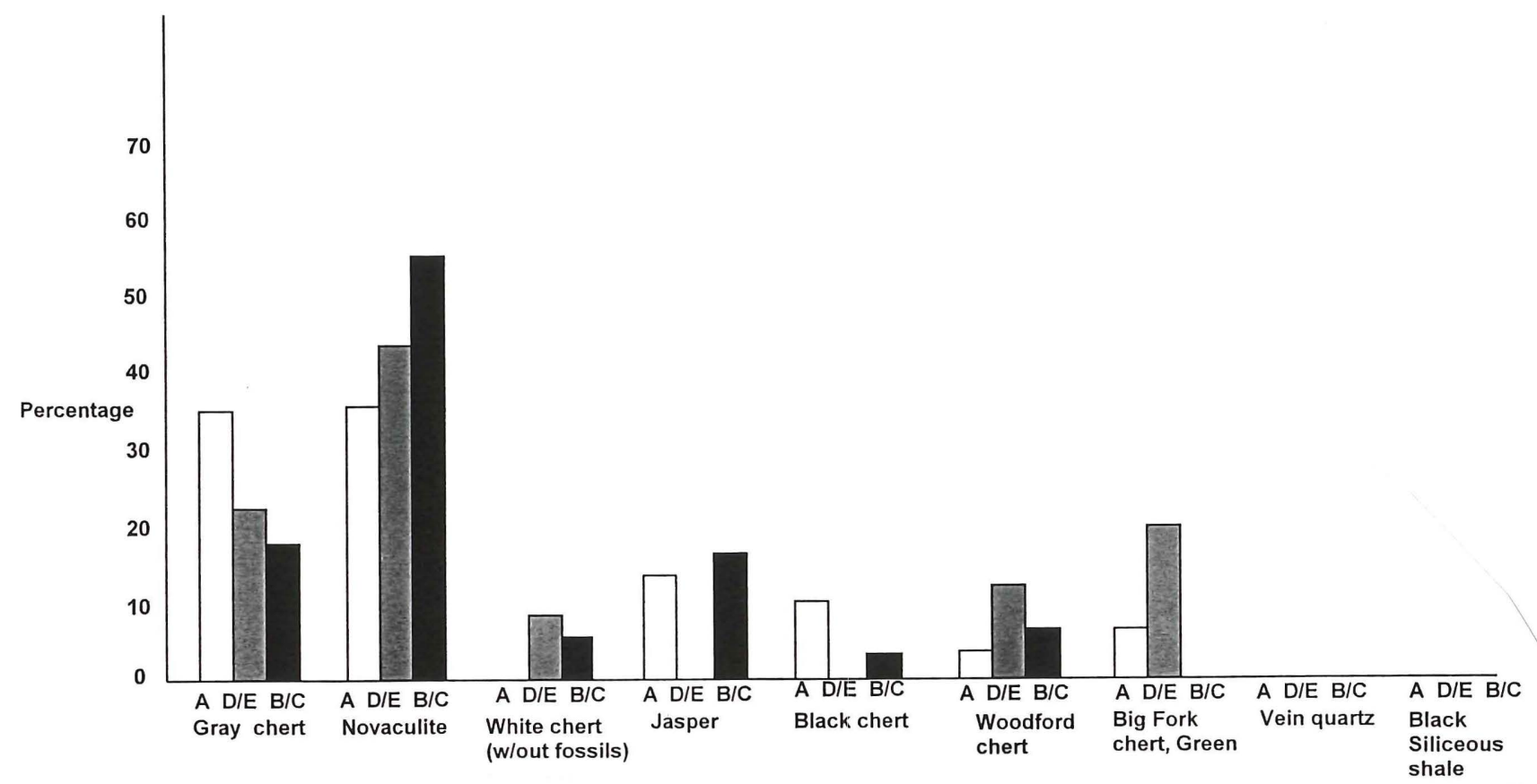

Figure 8-7. Use of probably non-local and non-local lithic raw materials in the tools from the North and South rises.

Non-local raw materials were used for many different types of tools at the site (Table 8-16). It is particularly well represented among Late Archaic and Early Ceramic period dart points from the North rise, bifacial fragments from completed tools, retouched pieces, and arrowpoints. In an attempt to gauge temporal trends in raw material use at Hurricane Hill, the percentages of non-local materials were examined for dart points and arrowpoints, the most diagnostic of the stone artifacts. Proportionally, however, more arrowpoints were made from non-local materials than were the earlier dart point types. This is particularly the case with the stone tools on the South rise and Block D on the North rise, where 15.2 and 28.6 percent, respectively, of the non-local tools were arrowpoints (many of white novaculite) as compared to only 6.5 percent of the non-local tools that were dart points from the South rise, and none of the dart points from Block D (see Table 8-16). Other Block B/C Middle Caddoan tools--such as drills/perforators and unifacial scrapers--were also more commonly made on non-local raw materials there than elsewhere at the site.

These trends among principally the projectile points suggest an increasing utilization of stone raw material types from the Red River gravels and the Ouachita Mountains during the Middle Caddoan period occupation at Hurricane Hill, compared with the Late Archaic/Early Ceramic and Early Caddoan components. It also indicates a divergence in the temporal trend noted by Fields et al. (1997:Figure 42) in the percentage of projectile points made of non-local materials from Late Archaic to Late Caddoan occupations at Cooper Lake, although their sample of occupations did not contain any that dated to the Middle Caddoan period.

Nevertheless, the relative frequency of non-local materials at the Hurricane Hill site, as well as at Copper Lake sites in general, appears to be quite low compared to lithic assemblages from the upper Sabine River basin, the Jewett Mine area in the Post Oak Savanna, and the middle Trinity River dating to the same periods (Fields 1995a:Figure 17; McGregor 1987:Table 16-4; Bruseth and Perttula 1981:Table 6-9; Perttula 1984). The non-local materials that were present at Copper Lake sites were primarily Red River gravels that were distributed or brought into the Cooper Lake area during the Late Archaic, Early Ceramic, and Early-Middle Caddoan periods, and that through time the use of such non-local raw materials continually decreased--with the notable exception of the Middle Caddoan period occupation at Hurricane Hill, where contact and interaction with Caddoan groups in the Red River basin reached a florescence. However, higher frequencies of these materials were obtained and utilized by other groups farther to the south and east in 
Northeast Texas. In summary, the abundant local Uvalde gravels continued to be the primary source of lithic raw materials during each temporal period at Hurricane Hill.

Table 8-16. Relative frequencies of tools manufactured from non-local lithic raw materials.

\begin{tabular}{|c|c|c|c|c|}
\hline \multirow[b]{2}{*}{ Tool Types } & \multirow[b]{2}{*}{ Block A } & \multicolumn{2}{|c|}{ North Rise } & \multirow{2}{*}{$\begin{array}{l}\text { South Rise } \\
\text { Block B/C and F }\end{array}$} \\
\hline & & Block D & Block E & \\
\hline Dart Points & 25.0 & - & 42.9 & 6.5 \\
\hline Arrowpoints & 4.2 & 28.6 & - & 15.2 \\
\hline $\begin{array}{l}\text { Arrowpoint } \\
\text { preform }\end{array}$ & - & 14.3 & - & - \\
\hline Biface Fragments & 14.6 & 28.6 & 14.3 & 21.7 \\
\hline Drills/Perforators & - & - & - & 2.2 \\
\hline Scrapers & 4.2 & - & - & 6.5 \\
\hline Retouched Pieces & 50.0 & 28.6 & 42.9 & 47.8 \\
\hline $\begin{array}{l}\text { Total No. of Tools } \\
\text { of Non-Local }\end{array}$ & & & & \\
\hline Raw Material & 48 & 7 & 7 & 46 \\
\hline
\end{tabular}

A lithic raw material obtained from great distances was obsidian (see Table 8-14). Two small ( $<1$ $\mathrm{cm}$ in length and width) interior or non-cortical flakes of obsidian were recovered on the North rise. One, from Block A, was in an Early Caddoan midden deposit (ca. A.D. 900/1000-1200), and the other, from Block E, may have been from the same occupation, based on its relative depth (Unit 93, 20-30 cm bs). Although these specimens have not been analyzed to determine their source, due to their small size, the closest obsidian source is in northern New Mexico along the Rio Grande and in the Jemez Mountains (e.g., Newman and Nielsen 1985).

\section{North Rise Assemblages, Blocks $\mathbf{D}$ and $\mathbf{E}$}

The production of bifaces and bifacial tools was an important aspect of the lithic technological strategies employed by the prehistoric occupants of the Hurricane Hill site. Hayden et al. (1996:22-26) point out that the strategy of biface manufacture can be traced to their multi-functionality and portability, an economy of raw material use, and a design for repeated resharpenings. At Hurricane Hill, the reduction of bifaces from cobbles and large pebbles appears to have been clearly geared towards the production of projectile points, and perhaps an occasional stemmed or unstemmed knife (see Appendix X), based on the frequency of dart points in each Late Archaic/Early Ceramic component, and the reduction trajectory, thickness, and shape of the discarded blank/preforms (cf. Johnson 1995:170-171).

Dart points are well-distributed in the Block D and E archaeological deposits, particularly between 20-60 cm bs (Tables 8-17 and 8-18). They account for about 28 percent of the tools, blank/preforms, and cores from these areas (see Tables 8-2 and 8-3). In contrast, the few arrowpoints $(n=15)$ from both blocks occur to a maximum depth of $40 \mathrm{~cm}$ bs, but 67 percent are present between $0-20 \mathrm{~cm}$ bs. 
Table 8-17. Distribution of arrow and dart points in Block D.

\begin{tabular}{|c|c|c|c|c|c|}
\hline Class & lv. 1 & lv. 2 & lv. & lv. & lv. 5 \\
\hline
\end{tabular}

\section{ARROW POINTS}

\begin{tabular}{llllllllll}
01 & - & - & - & - & - & - & - & 1 & 1 \\
02 & - & 1 & 1 & - & - & - & - & - & 2 \\
03 & - & 1 & - & - & - & - & - & - & 1 \\
05 & - & - & 2 & - & - & - & - & - & 1 \\
07 & - & 1 & - & - & - & - & - & - & 1 \\
09 & - & 1 & - & - & - & - & - & - & 1 \\
11 & - & 1 & - & - & - & - & - & \\
\hline \multirow{2}{*}{ Total Arrows } & - & 5 & 3 & - & - & - & - & 1 & 9 \\
\hline
\end{tabular}

\section{DART POINTS}

\begin{tabular}{|c|c|c|c|c|c|c|c|c|c|}
\hline 01 & 1 & 1 & - & 4 & 1 & 1 & - & 1 & 9 \\
\hline 02 & 1 & 2 & 1 & 1 & - & 1 & - & - & 6 \\
\hline 03 & - & 3 & 4 & 12 & 5 & 2 & 2 & - & 28 \\
\hline 04 & - & - & - & - & 1 & - & - & - & 1 \\
\hline 05 & - & - & - & 1 & - & - & - & - & 1 \\
\hline 06 & - & 2 & - & 3 & 2 & 2 & 1 & - & 10 \\
\hline 07 & - & - & 1 & - & - & 1 & - & - & 2 \\
\hline 08 & - & 1 & - & 1 & - & 1 & 1 & - & 4 \\
\hline 09 & - & 1 & - & 1 & 1 & - & 2 & - & 5 \\
\hline 10 & - & - & - & 1 & - & 1 & - & - & 2 \\
\hline 12 & - & 1 & - & 1 & - & 1 & - & - & 3 \\
\hline 13 & - & - & - & - & 1 & - & - & - & 1 \\
\hline 17 & - & 1 & - & - & - & 1 & - & - & 2 \\
\hline 18 & - & - & - & 1 & - & 1 & - & - & 2 \\
\hline 19 & - & - & - & - & - & - & 1 & - & 1 \\
\hline 20 & - & - & - & - & 1 & 2 & - & - & 3 \\
\hline 21 & - & - & - & 1 & 1 & - & - & - & 2 \\
\hline 22 & - & - & - & - & - & - & - & 1 & 1 \\
\hline Total Darts & 2 & 12 & 6 & 27 & 13 & 14 & 7 & 2 & 83 \\
\hline
\end{tabular}

Table 8-18. distribution of arrow and dart points in Block $\mathbb{E}$.

$\begin{array}{llllllllll}\text { Class } & \text { lv. } 1 & \text { lv. } 2 & \text { 1v. } 3 & \text { 1v. } 4 & \text { 1v. } 5 & \text { 1v. } 6 & \text { 1v. } 7 & \text { Features } & \text { Total }\end{array}$

\section{ARROW POINTS}

$\begin{array}{llllllllll}02 & 1 & - & - & - & - & - & - & - & 1 \\ 05 & - & 1 & - & - & - & - & - & - & 1 \\ 06 & - & 2 & - & 1 & - & - & - & - & 3 \\ 07 & - & 1 & - & - & - & - & - & - & 1\end{array}$


Table 8-18, distribution of arrow and dart points in Block $\mathbb{E}$, cont.

\begin{tabular}{llllllllll}
\hline Class & 1v. 1 & 1v. 2 & 1v. 3 & 1v. 4 & 1v. 5 & 1v. 6 & 1v. 7 & Features & Total \\
\hline Total Arrows & 1 & 4 & - & 1 & - & - & - & - & 6 \\
\hline
\end{tabular}

\section{DART POINTS}

\begin{tabular}{|c|c|c|c|c|c|c|c|c|c|}
\hline 01 & 1 & 3 & 3 & 3 & - & 1 & - & 3 & 14 \\
\hline 02 & 2 & 1 & - & - & - & 2 & - & - & 5 \\
\hline 03 & - & 10 & 13 & 11 & 10 & 5 & 2 & 2 & 53 \\
\hline 04 & - & 1 & 2 & - & - & - & - & - & 3 \\
\hline 05 & - & 1 & - & - & - & - & - & - & 1 \\
\hline 06 & 1 & 1 & 1 & 2 & 3 & 1 & 1 & - & 10 \\
\hline 08 & - & - & 4 & - & 1 & 1 & - & - & 6 \\
\hline 09 & - & - & - & 1 & - & - & - & - & 1 \\
\hline 11 & - & 1 & - & - & - & - & - & - & 1 \\
\hline 12 & - & - & - & 1 & - & - & - & - & 1 \\
\hline 13 & - & 1 & 1 & - & - & - & - & - & 2 \\
\hline 14 & - & - & - & 1 & - & - & - & - & 1 \\
\hline 15 & - & 1 & 1 & - & - & - & - & - & 2 \\
\hline 17 & - & - & - & - & 1 & - & - & 2 & 3 \\
\hline 18 & - & - & - & - & - & - & 1 & - & 1 \\
\hline 19 & - & - & 2 & - & 1 & - & 1 & - & 4 \\
\hline 20 & - & - & 2 & - & - & - & - & - & 2 \\
\hline 21 & - & - & 1 & - & - & - & - & - & 1 \\
\hline 23 & - & - & 1 & - & 1 & - & 1 & - & 3 \\
\hline Total Darts & 4 & 20 & 31 & 19 & 17 & 10 & 6 & 7 & 114 \\
\hline
\end{tabular}

Among the dart points, the contracting stem Gary forms are most abundant in both blocks (Figures 8-8 and 8-9a), especially the var.LeFlore (classes 02 and 03) specimens that are estimated to date ca. 1700-2400 B.P., spanning portions of the Late Archaic/Early Ceramic period (this is the temporal interval that Cliff [1998] describes as the Terminal Archaic), and these contracting stem points (see Figures 8-8a:1, 4; 8-8b:1-5; and 8-9a:1-9, 14) occur throughout the archaeological deposits (see Tables 8-17 and 818). Middle to Late Archaic point types (such as Wells, Yarbrough, Bulverde, and Marshall) comprise only 5-14 percent of the dart points, being more common in Block D (Figure 8-10a-b), and they tend to occur deeper in the Primary Midden, or below these deposits (see Figure 8-9b:3-4), on the North rise, while Early Ceramic (classes 01, 04, 05, 07, 15, and 16; see Figure 8-8a:3 and Figure 8-9a:10, 12-13) and Late Archaic forms (such as classes $06,14,19,20$, and 23) are also well-represented in both block excavations.

The dart points from Blocks $\mathrm{D}$ and $\mathrm{E}$ are generally resharpened (71.9-75.9 percent), serrated (45.648.2 percent), and beveled (16.9-21.1 percent) (see for example, Figure 8-8b:4 and Figure 8-10a:1-3), along with relatively low frequencies of points with impact fractures (Table 8-19). Clearly, the dart points from this part of the North rise were multi-functional tools that were repeatedly resharpened along their blade edges. The high numbers of discarded points with serrations (2-3 times higher than in the Late Archaic/Early Ceramic components in Blocks $A$ and $B / C$ ) implies that efforts to extend the use-life of the points/knives were more extensive here than in other site contexts. The Block D points also have relatively high frequencies of basal and lateral grinding, and these attributes tend to occur on the Middle to Late Archaic point forms, such as the distinctively beveled Yarbrough type (Class 17; see Figure 8-9b:4). 


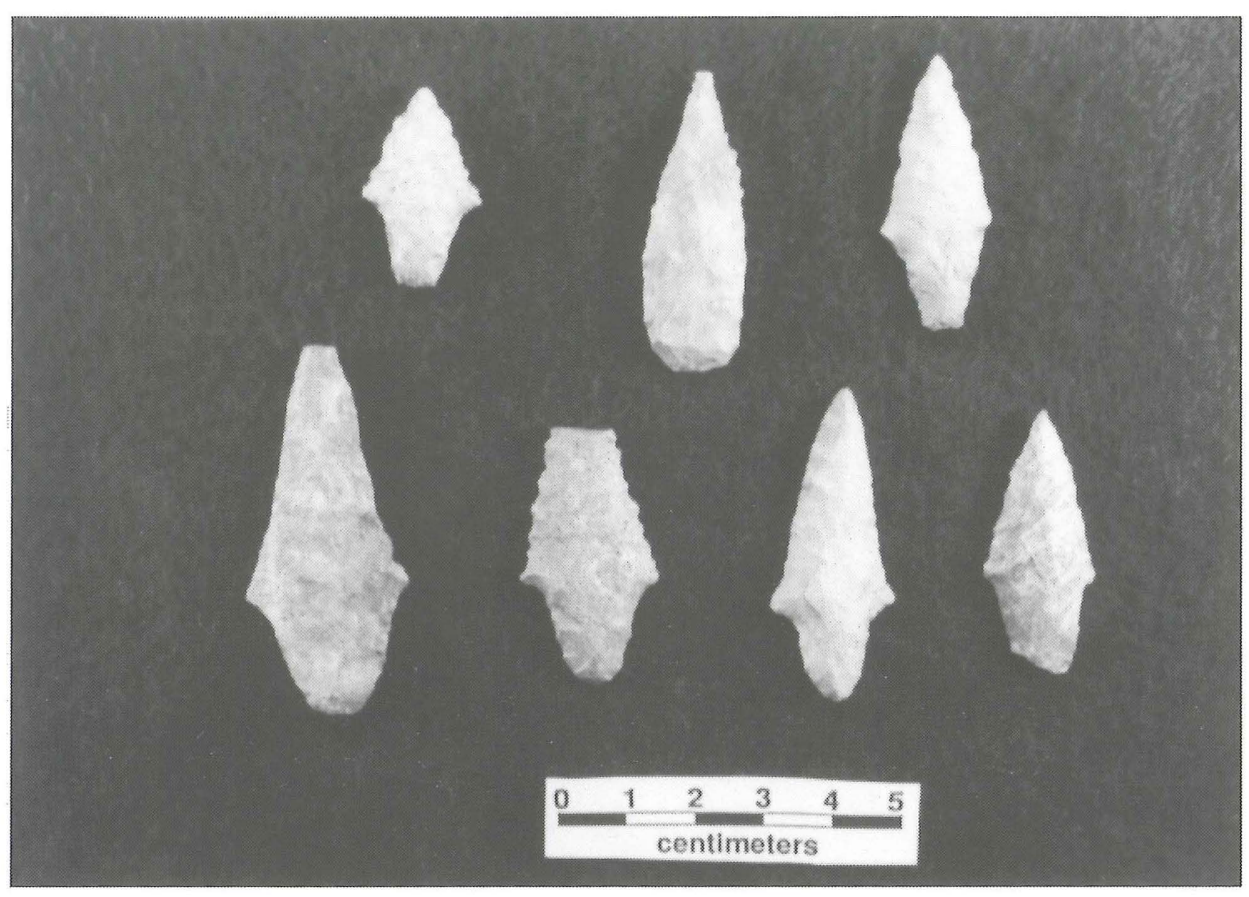

A

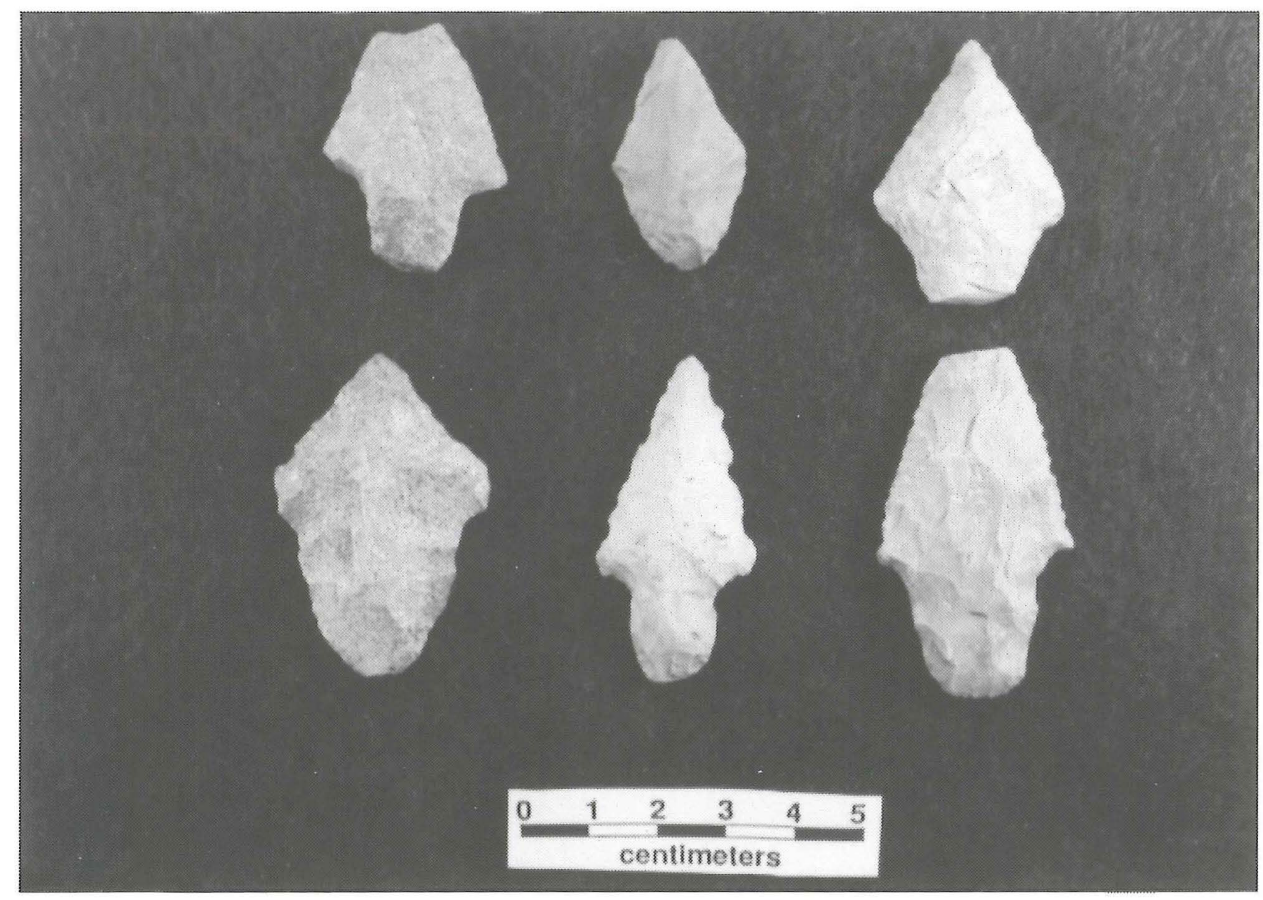

$B$

Figure 8-8. Dart Points, Block D: a, Class 01 (No. 3, 5-7), Class 02 (No. 1), Class 03 (No. 4), Class 09 (No. 2); b. Class 02 (No. 1, 3), Class 03 (No. 2, 45), and Class 08 (No. 6). Provenience: a-1 (81-1), a-2 (S38E26, 55-60 $\mathrm{cm})$ a-3 (S26E27, $54 \mathrm{~cm}), a-4$ (S32E27, $40 \mathrm{~cm}), a-5$ (S35E25, $40 \mathrm{~cm}), a-6(80-5 B), a-7$ (87-2), b-1 (87-2), b-2 (S36E29, $29 \mathrm{~cm}), \mathrm{b}-3$ (S36E25, $40 \mathrm{~cm}), \mathrm{b}-4$ (87-5), b-5 (S39E29, $30 \mathrm{~cm}), \mathrm{b}-6$ (S29E27, 30-35 cm) 


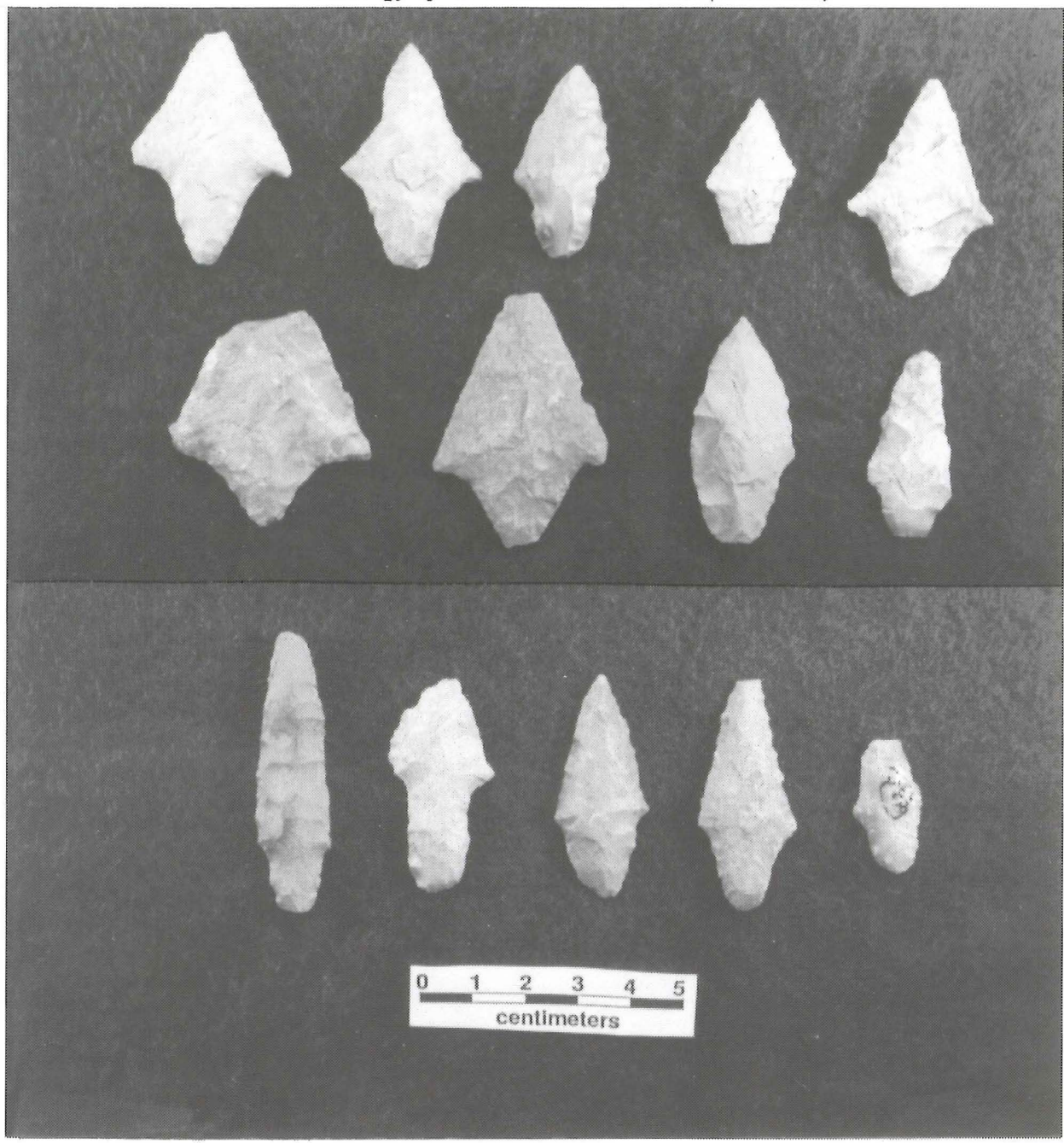

$A$

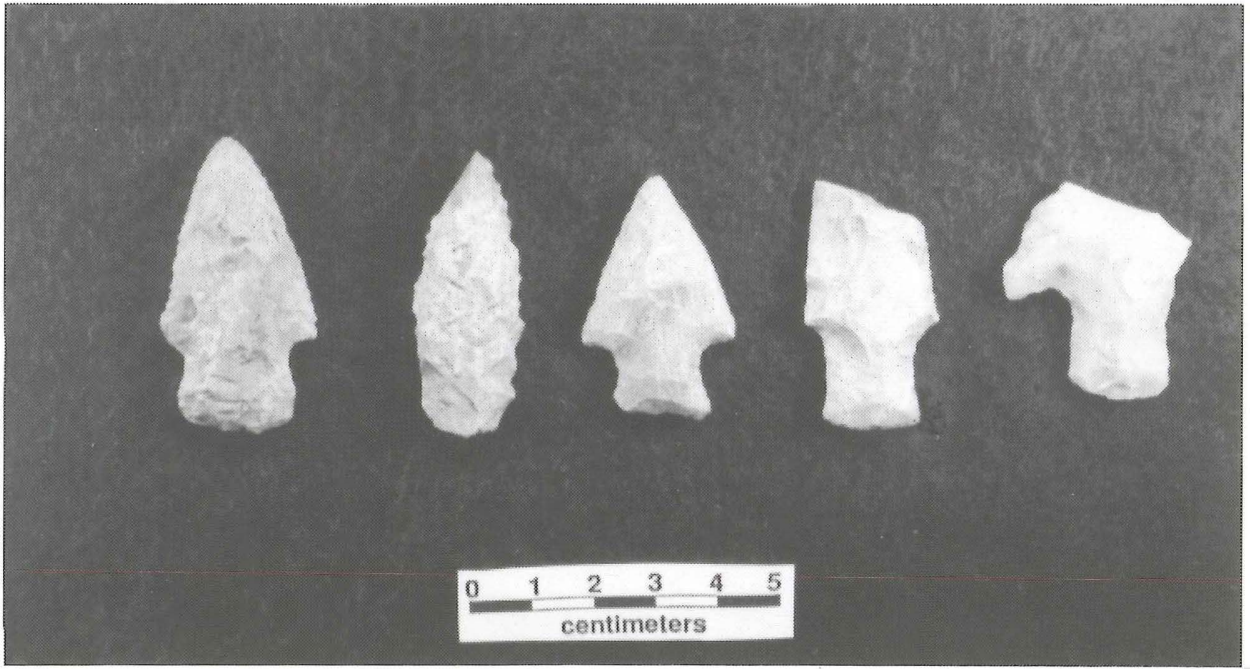

$B$

Figure 8-9. Dart Points, Block E: a, Class 01 (No. 12, 13), Class 02 (No. 2, 9), Class 03 (No. 1, 3-8, 13), Class 05 (No. 10), and Class 09 (No. 11); b, Class 08 (No. 2), Class 12 (No. 1), Class 17 (No. 4), Class 18 (No. 5), and Class 23 (No. 3). Provenience: a-1 (S33E22, $50 \mathrm{~cm}), a-2(S 30 E 21,60 \mathrm{~cm}), a-3(90-5 \mathrm{~A}), \mathrm{a}-4$ (S35E20, 34-36 cm), a-5 (24-6), a-6 (S29E20, $52 \mathrm{~cm}$ ), a-7 (24-6), a-8 (S33E20, $45 \mathrm{~cm}), a-9$ (92-1), a-10 (S27E17, $15 \mathrm{~cm})$, a-11 (91-4), a-12 (S36E20, $38 \mathrm{~cm}), a-13$ (S36E21, $10 \mathrm{~cm}), a-14(93-4), b-1(\mathrm{~S} 24 \mathrm{E} 17,32 \mathrm{~cm}), b-2(\mathrm{~S} 29 \mathrm{E} 18,30 \mathrm{~cm}), b-3$ (S32E20, $70 \mathrm{~cm}), \mathrm{b}-4(\mathrm{~S} 29 \mathrm{E} 16,45 \mathrm{~cm}), \mathrm{b}-5(\mathrm{~S} 32 \mathrm{E} 20,70 \mathrm{~cm})$ 


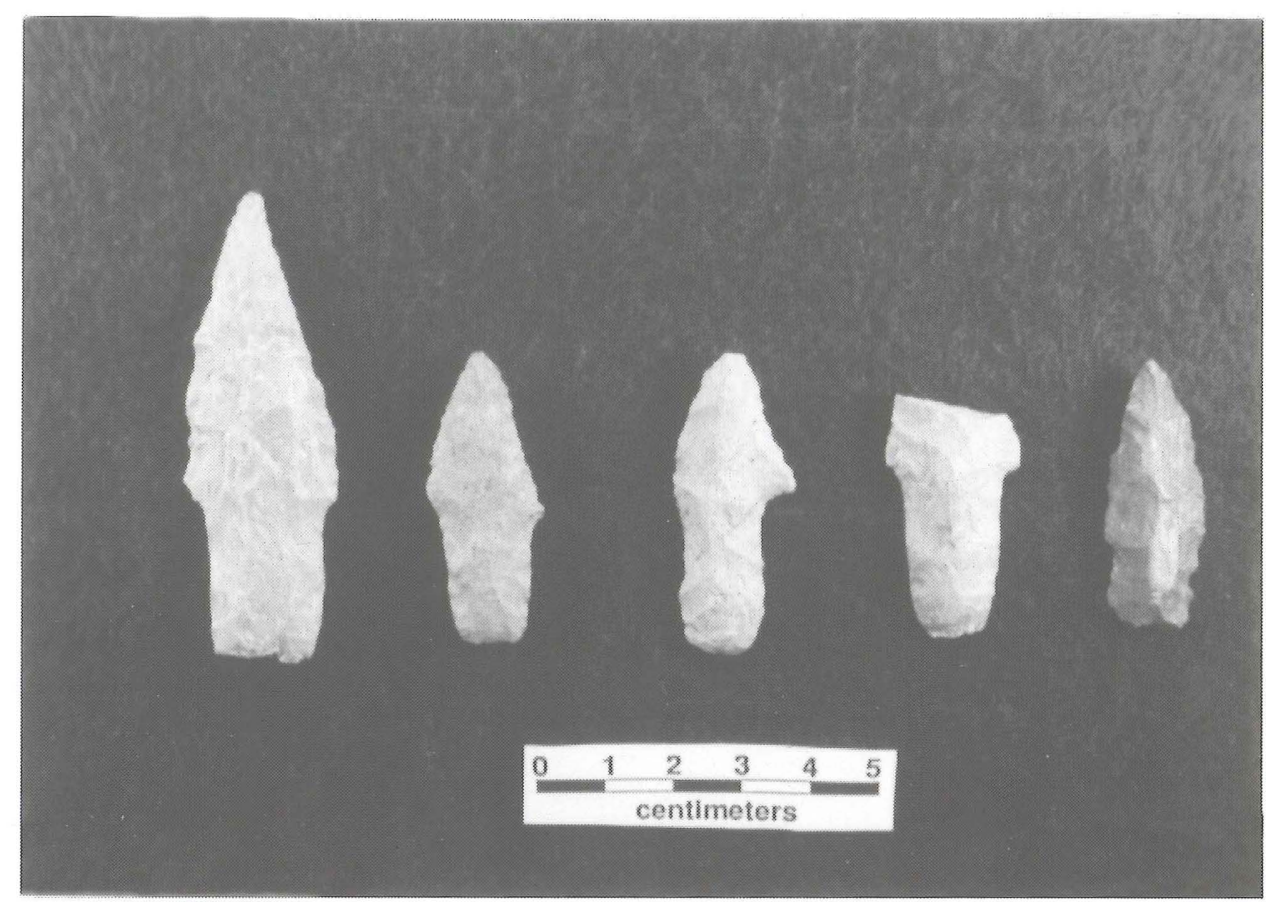

A

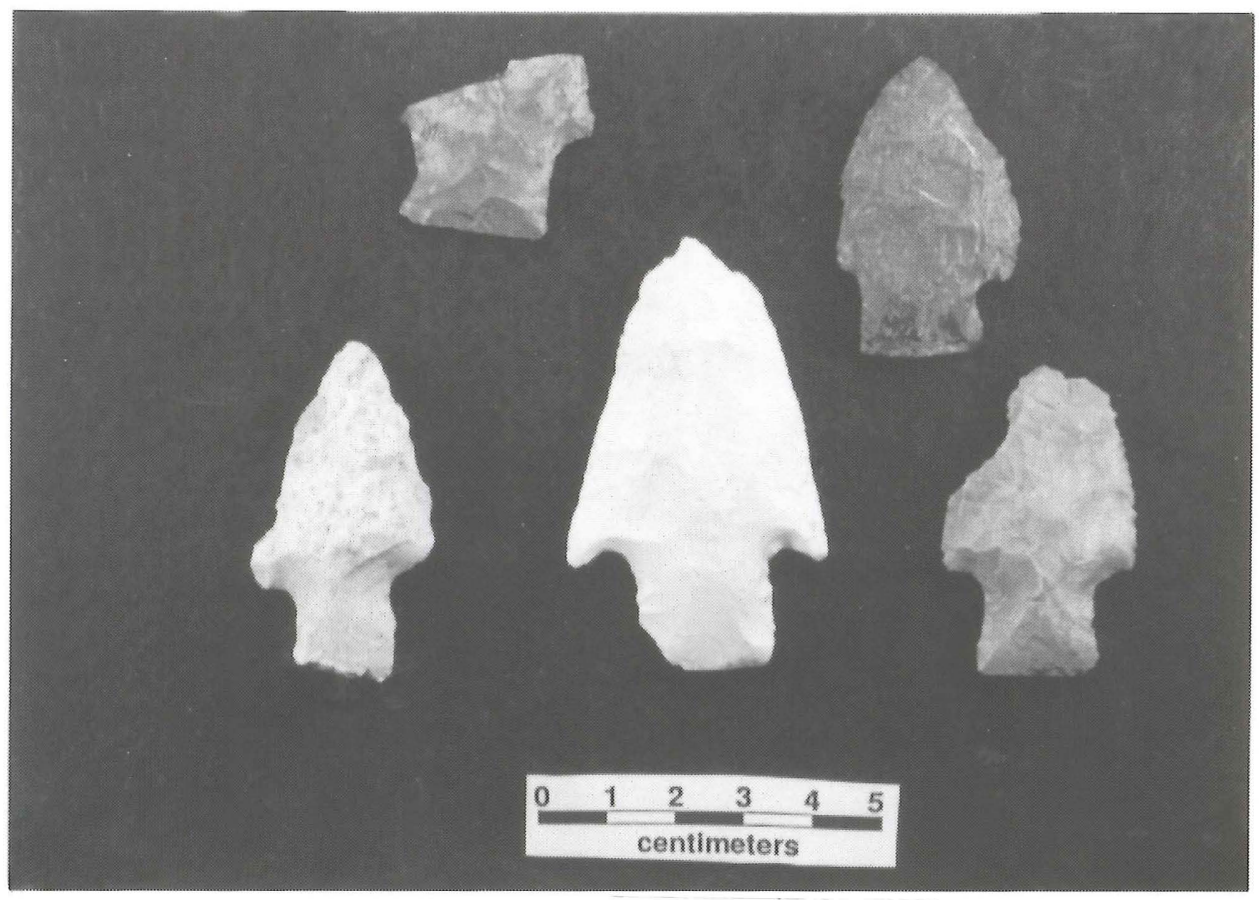

$B$

Figure 8-10. Late Archaic Style Dart Points, Block D: a, Class 07 (No. 5), Class 09 (No. 2-4), Class 20 (No. 1); b, Class 12 (No. 1-2, 5), Class 18 (No. 3-4). Provenience: a-1 (S35E27, $60 \mathrm{~cm}$ ), a-2 (88-4), a-3 (87-2A), a-4 (S36E28, $43 \mathrm{~cm}$ ), a-5 (S36E26, $53 \mathrm{~cm}), \mathrm{b}-1$ (S36E27, $20 \mathrm{~cm})$, b-2 (S39E29, $35 \mathrm{~cm}), \mathrm{b}-3$ (S35E28/29, $52 \mathrm{~cm}), \mathrm{b}-4$ (S30E29, $38 \mathrm{~cm}), \mathrm{b}-5(\mathrm{~S} 28 \mathrm{E} 30,54 \mathrm{~cm})$ 
Table 8-19. Dart Point Beveling, Resharpening, Grinding, and Impact Fractures

\begin{tabular}{|c|c|c|c|c|c|c|c|}
\hline Area & $\begin{array}{l}\text { Basal } \\
\text { Grind. }\end{array}$ & $\begin{array}{l}\text { Lateral } \\
\text { Grind. }\end{array}$ & Resharpened & Serrated & Beveled & $\begin{array}{l}\text { Impact } \\
\text { Fract. }\end{array}$ & $\mathrm{N}$ \\
\hline \multicolumn{8}{|c|}{ NORTH RISE } \\
\hline Block A & $6.9 *$ & 13.1 & 74.9 & 16.0 & 12.6 & 11.4 & 175 \\
\hline Block D & 12.0 & 20.5 & 75.9 & 48.2 & 16.9 & 4.8 & 83 \\
\hline Block E & 4.4 & 13.2 & 71.9 & 45.6 & 21.1 & 7.9 & 114 \\
\hline \multicolumn{8}{|c|}{ SOUTH RISE } \\
\hline Block B/C & 4.7 & 10.9 & 64.1 & 13.3 & 7.8 & 6.3 & 128 \\
\hline \multicolumn{8}{|c|}{ SOUTHWEST } \\
\hline RISE & 0.0 & 0.0 & 75.0 & 75.0 & 10.0 & 0.0 & 20 \\
\hline
\end{tabular}

* Percentage

Blocks $\mathrm{D}$ and $\mathrm{E}$ have a diversity of arrowpoint forms, with classes 02 (Bonham), 05 (Alba), 06 (Steiner), and 07 (Scallorn) represented by two or more specimens (Figure 8-11a:1, 3, 6 and Figure 8-12:3, 5-8). The latter three forms best represent the Early Caddoan stone tool use of the North rise. The frequency of arrowpoint preforms also suggests that arrowpoints were manufactured on the site during the Early Caddoan occupation. A single triangular arrowpoint from Block D (see Figure 8-11a:2) hints at a transitory Late Caddoan use of the North rise.

Shaped flake tools are outnumbered by projectile points 15.3:1 and 24:1 in Blocks D and E. The most common shaped flake tools are notches/spokeshaves and adzes; the latter appears to be a Late Archaic to Early Ceramic tool form based on its distribution across the Hurricane Hill site (Table 8-20). Expedient retouched and utilized flakes, on the other hand, are abundant in both Late Archaic/Early Ceramic and Early Caddoan assemblages from Blocks $\mathrm{D}$ and $\mathrm{E}$, with projectile point-expedient flake tool ratios of 1.2:1 and 1.3:1, respectively. Unilateral and bilateral utilized flakes are the primary expedient tools in both blocks (see Figure 8-11b:1-2, 4-6, 8); distal and distal/lateral utilized flakes are also well-represented in the blocks (see Figure 8-11b:3, 7), while retouched flake tools are more common in all excavation levels in Block E (Table 8-21).

In Blocks D and E, ovoid blank/preforms (Figure 8-13a:2 and Figure 8-14a:1-2, 4-6) range from 5.1-25.1+ $\mathrm{mm}$ in thickness, with the thickest pieces (i.e., those more than $20.1 \mathrm{~mm}$ ) representing the initial stages of biface manufacture, and the thinnest the final stages of biface manufacture (see Figure 814a:2; this particular blank/preform is one of the few from the site made from non-local raw materials, a Big Fork chert, green variety). The distribution of blank/preforms in each thickness class suggests that all stages of biface knapping occurred in these areas of the site (Figure 8-15). The Block D blank/preforms differ from all other areas of the site in that the largest proportions of blanks (60 percent) range from 5.1-10 $\mathrm{mm}$ in thickness, compared to less than 30 percent of the blank/preforms on the North, South, and Southwest rises. Clearly, the knapping and subsequent discarding of near-finished bifaces was a common activity in Block D during the Late Archaic/Early Ceramic and Early Caddoan periods. By contrast, in Block $\mathrm{E}$, thicker blank/preforms (ranging from 10.1-15.0 $\mathrm{mm}$ in thickness) were more frequently being knapped, and presumably broken and discarded during attempts at thinning the specimens. 


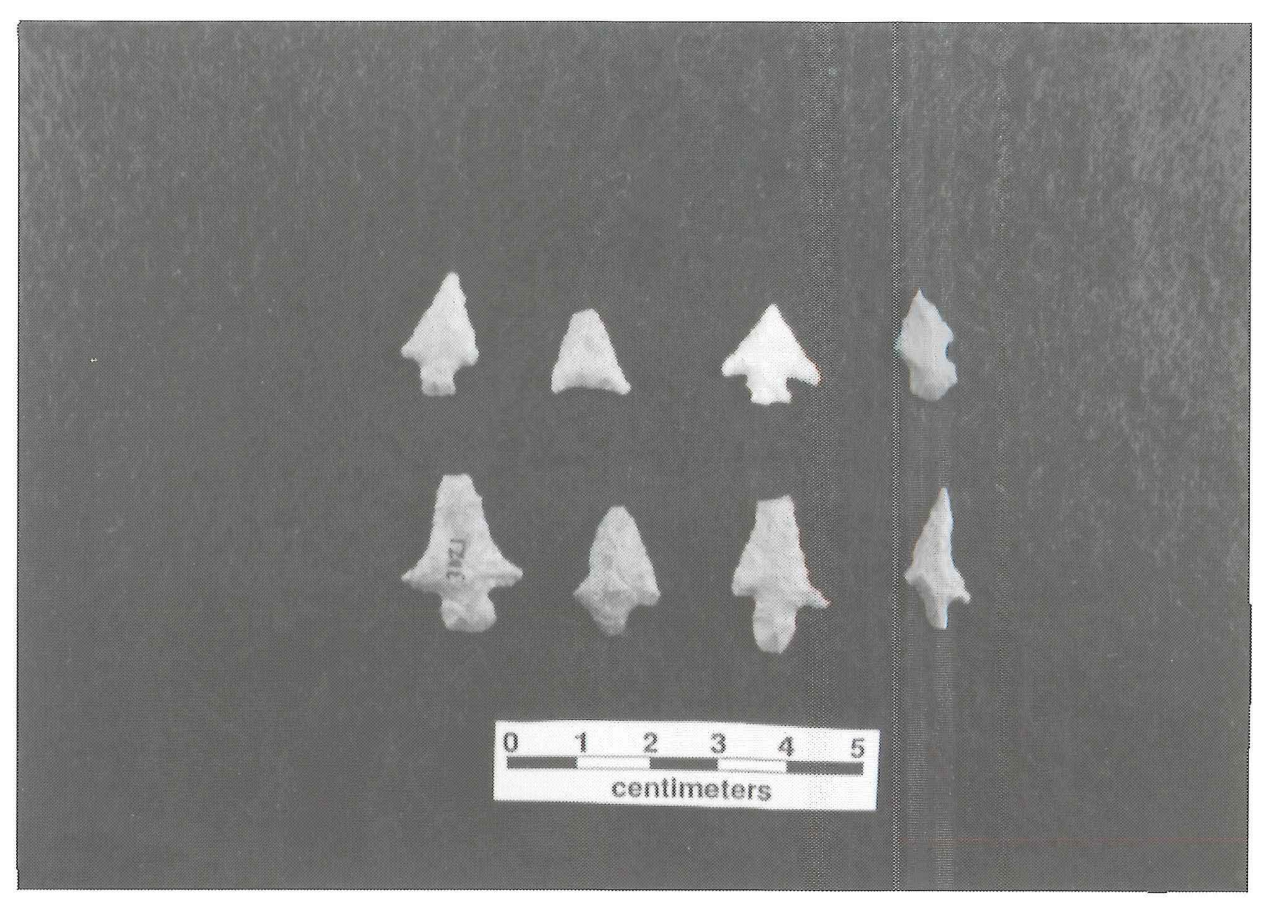

A

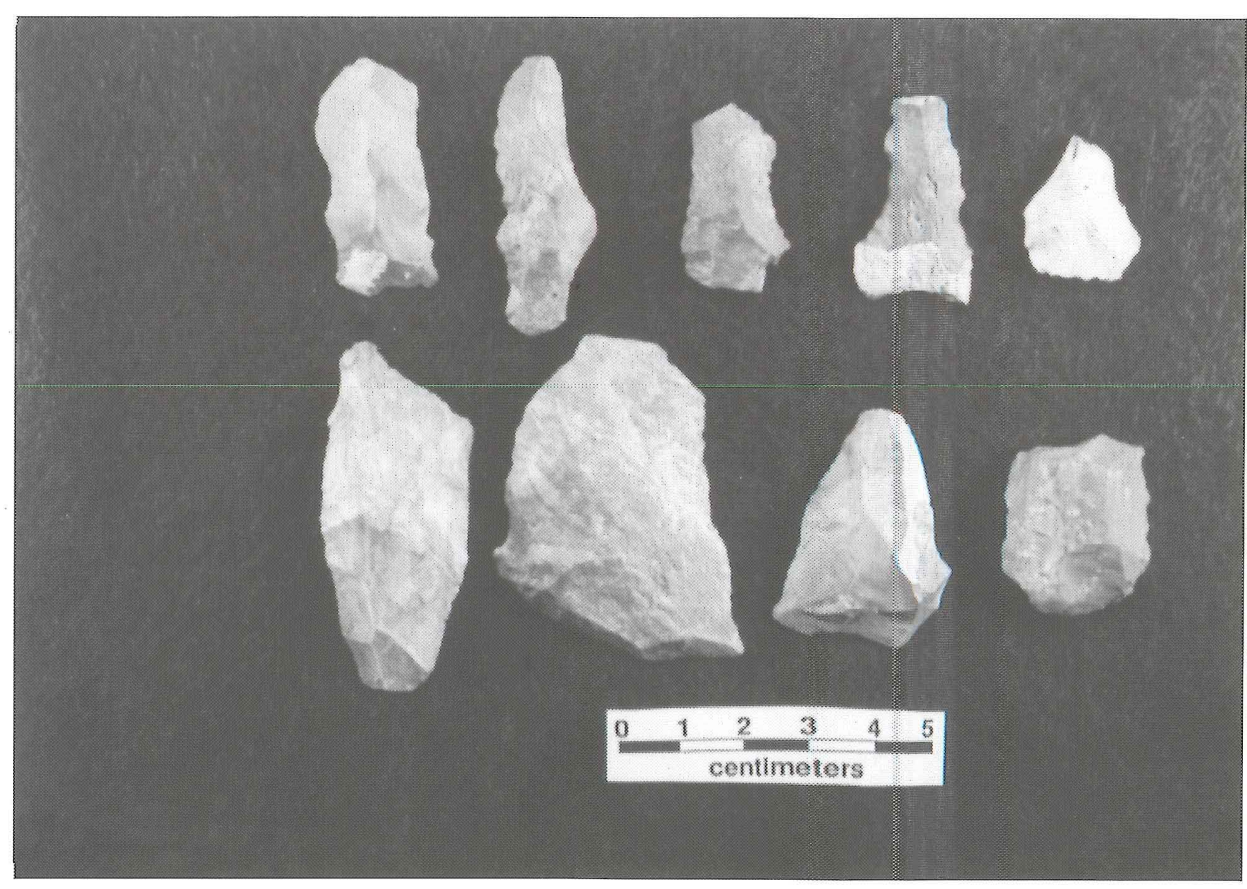

$B$

Figure 8-11. Arrow Points and Flake Tools, Block D: a, Class 01 (No. 5), Class 02 (No. 7-8), Class 05 (No. 1, 6), Class 07 (No. 3), Class 09 (No. 4), Class 10 (No. 2); b, utilized flake (No. 1-2, 4,6, 8), distal/lateral utilized flake (No. 3, 7), bilateral utilized flake (No. 5), indeterminate bifacial tool (No. 9). Provenience: a-1 (78-3), a-2 (832A), a-3 (S34E25, $15 \mathrm{~cm}), a-4$ (77-2), a-5 (80-5A), a-6 (79-3), a-7 (75-2), a-8 (S30E26, profile 40), b-1 (79-4), b2 (S34E26, $50 \mathrm{~cm}), \mathrm{b}-3(87-3), \mathrm{b}-4(87-3), \mathrm{b}-5$ (75-UID), b-6 (S34E26, $40 \mathrm{~cm}), \mathrm{b}-7$ (S34E26, $60 \mathrm{~cm}), \mathrm{b}-8$ (87-4), b-9 (81-5). 


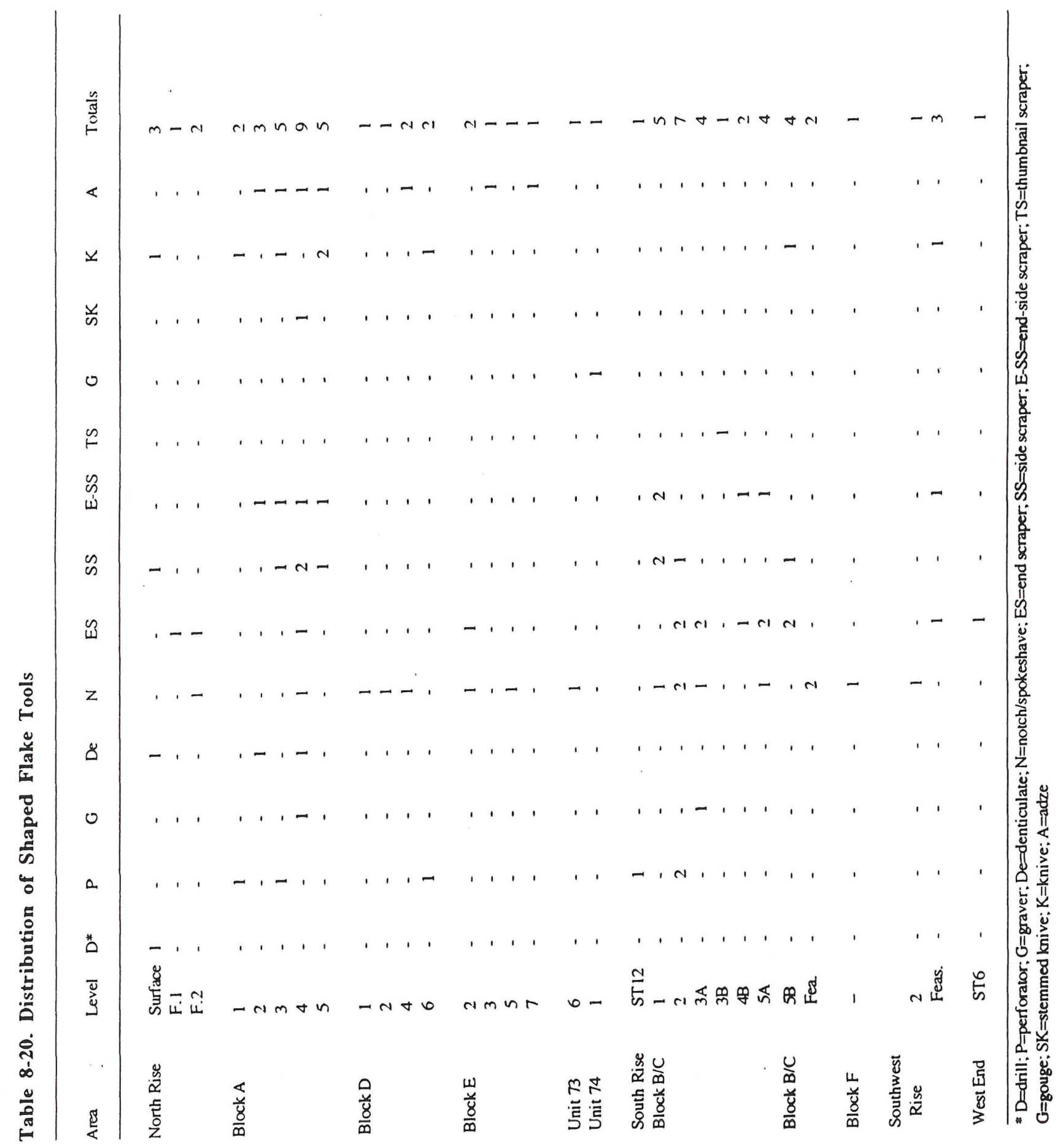




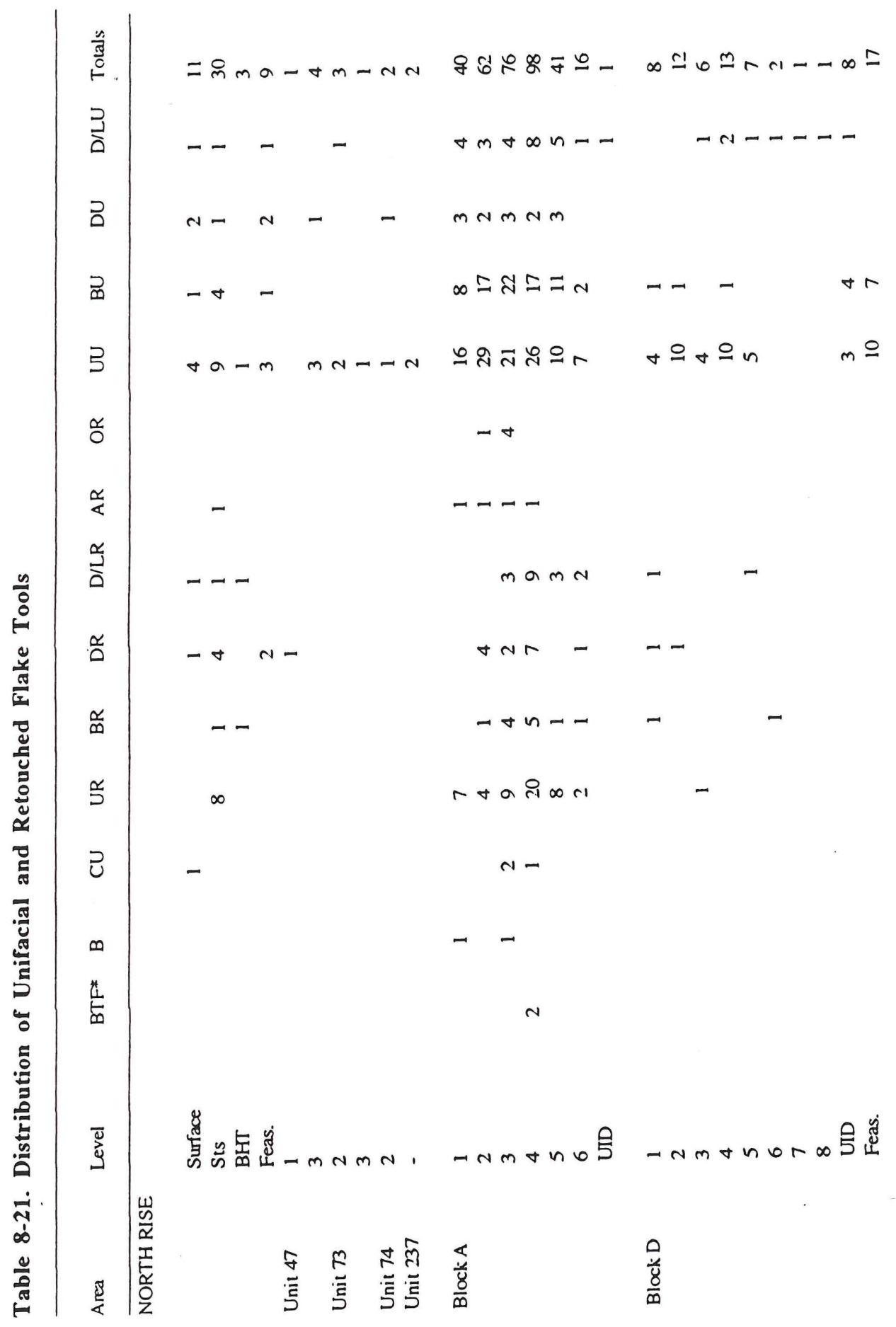




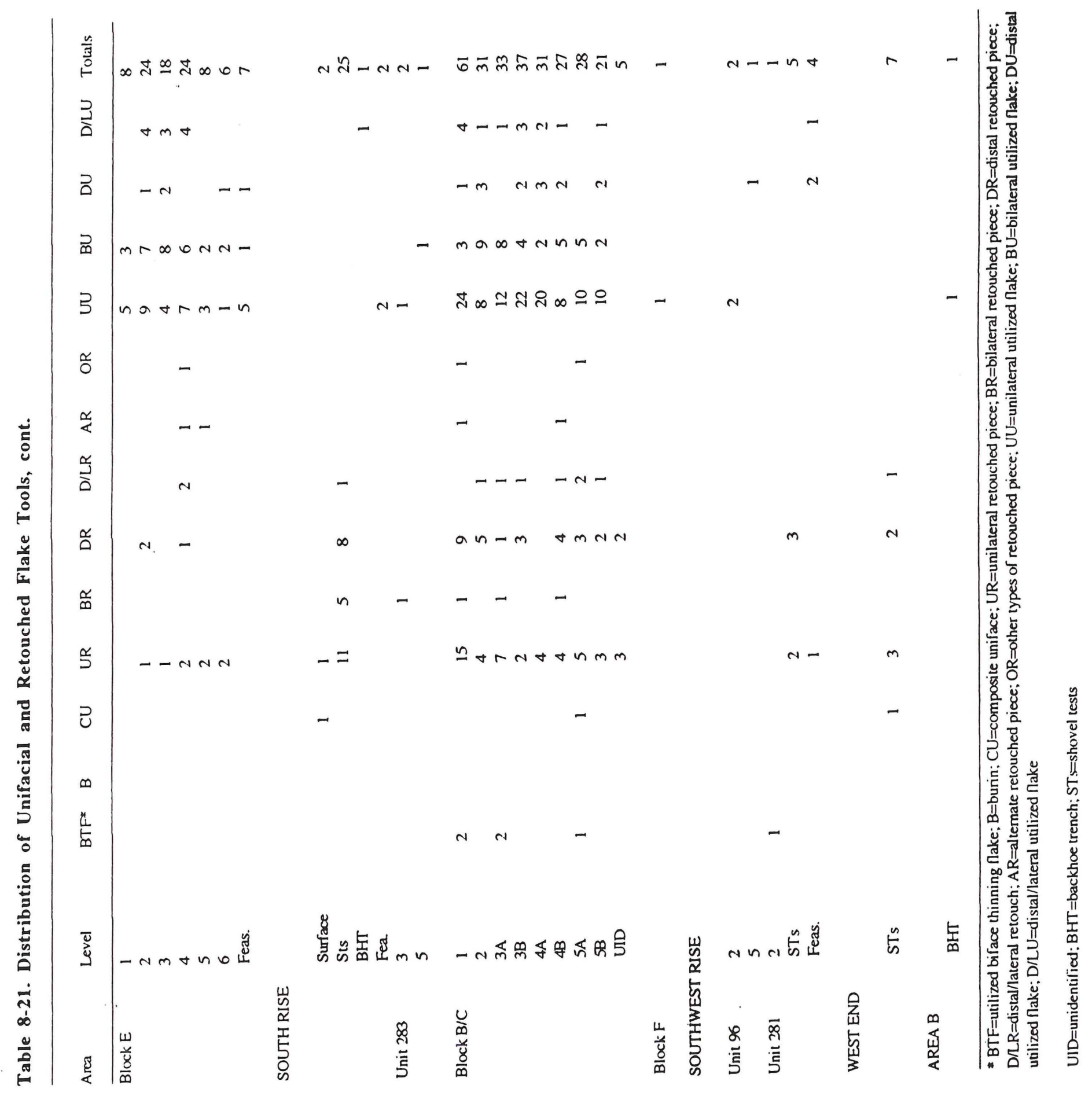




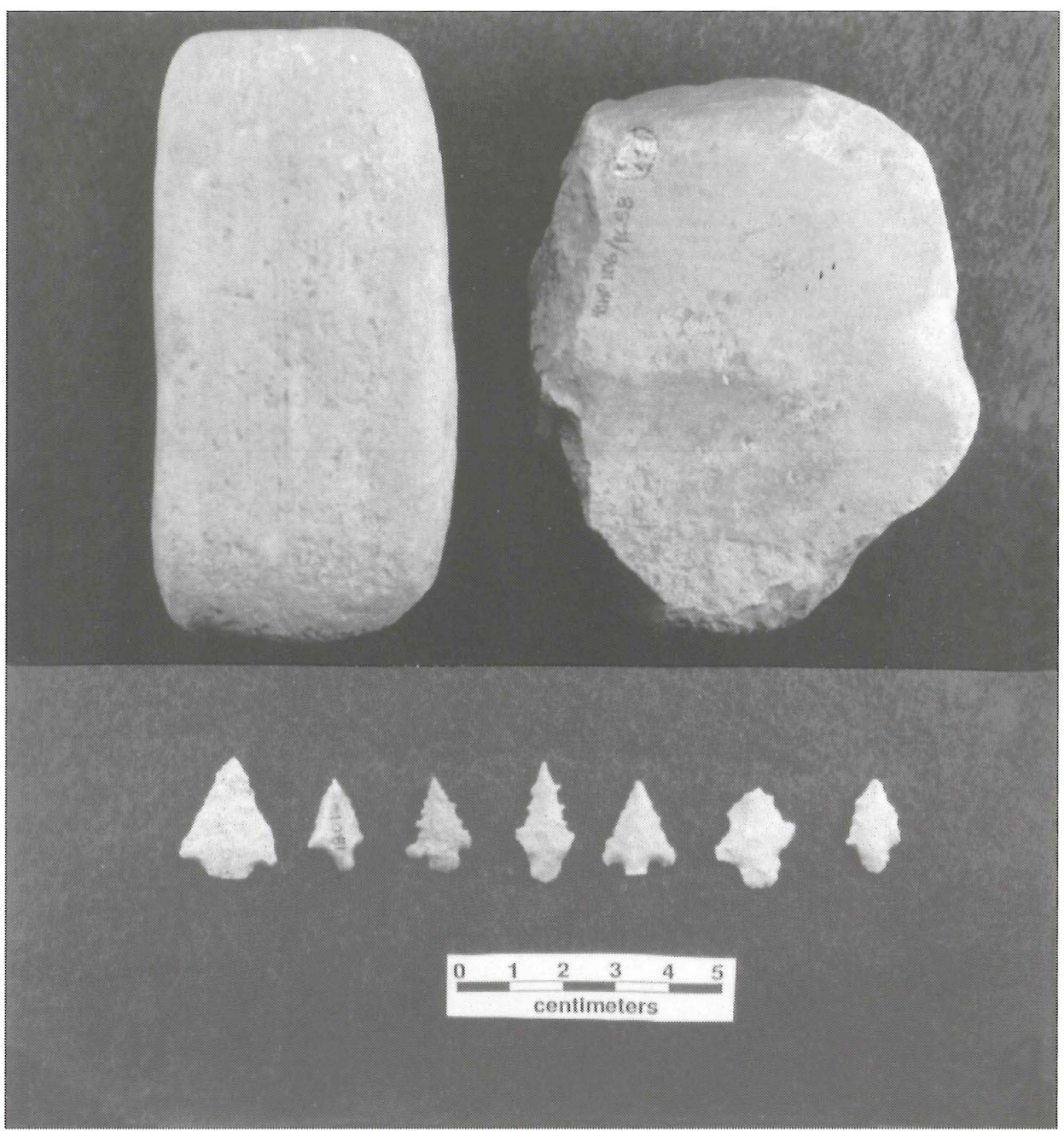

Figure 8-12. Arrowpoints and groundstone tools, Block E: 1, mano; 2, bifacial mano; 3, 5-6, Class 06; 4, Class 02; 7, Class 07; 8, Class 05; 9, Class 01. Provenience: 1, S27E18, $20 \mathrm{~cm}$; 2, S24E20, $38 \mathrm{~cm}$; 3 , 94-3A; 4, 92-1; 5, 24-4; 6, 23-2; 7, S36E19, $17 \mathrm{~cm} ; 8$, 92-2; 9, BHT 39.

As with the blank/preforms, cores are more abundant in apparent Late Archaic/Early Ceramic contexts in Blocks D and E (see Figure 8-13a:1, 3-6 and Figure 8-14a:3 and b:3), as the highest frequencies of cores occur from 30-60 cm bs (Table 8-22). This is not surprising given the overall emphasis on production of large bifaces for tools and tool blanks at those times in the Cooper Lake sites (Fields et al. 1997:71). Besides core fragments and tested cobbles, multiple platform flake cores and opposed platform cores (i.e., flakes were removed from platforms on opposing sides of a cobble mass) occur frequently in both Late Archaic/Early Ceramic and Early Caddoan contexts, while bifacial (including one of a poor quality petrified wood; see Figure 8-14b:3) and discoidal cores are less frequent in the same contexts. Single platform and globular cores are present only in Late Archaic/Early Ceramic deposits (see Table 8-22); the latter two kinds of cores are absent from the South and Southwest rises. 


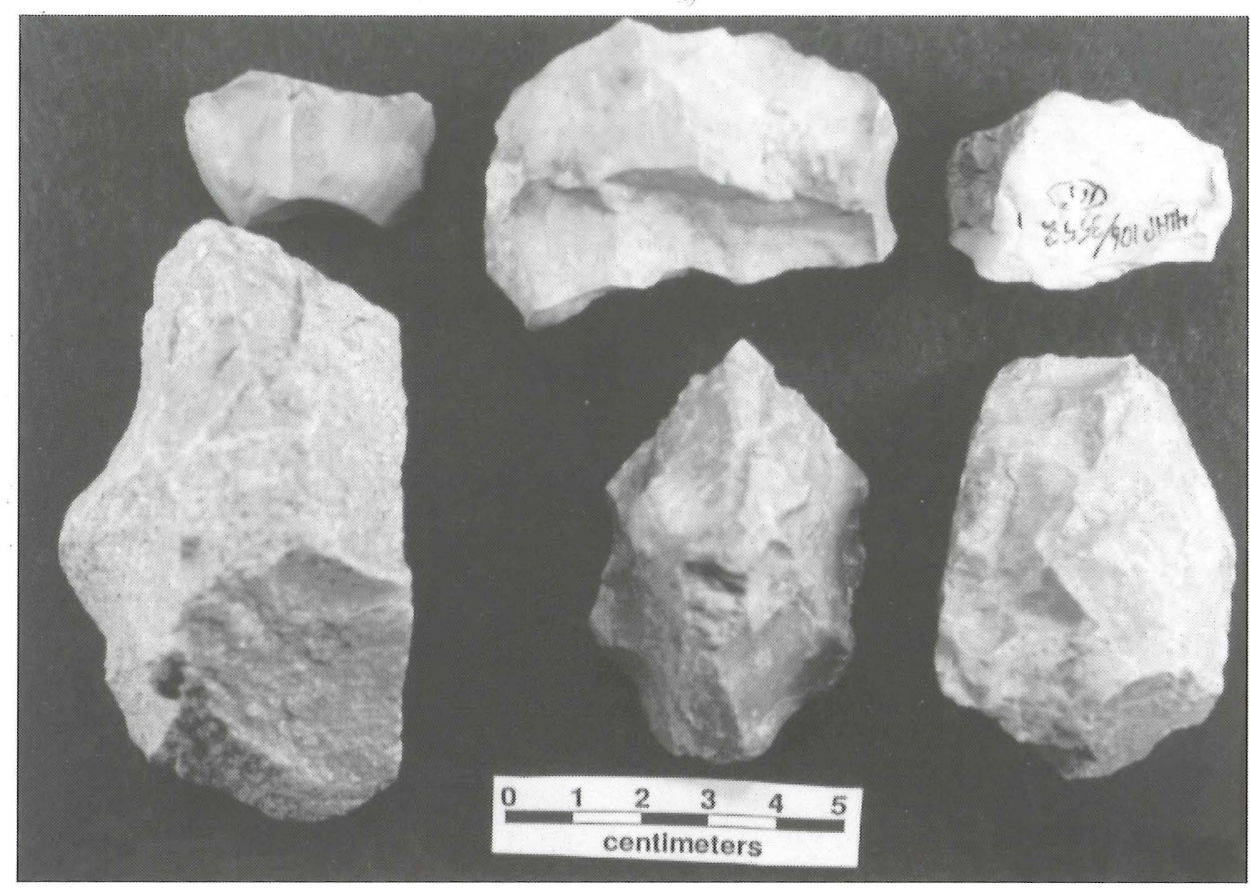

A

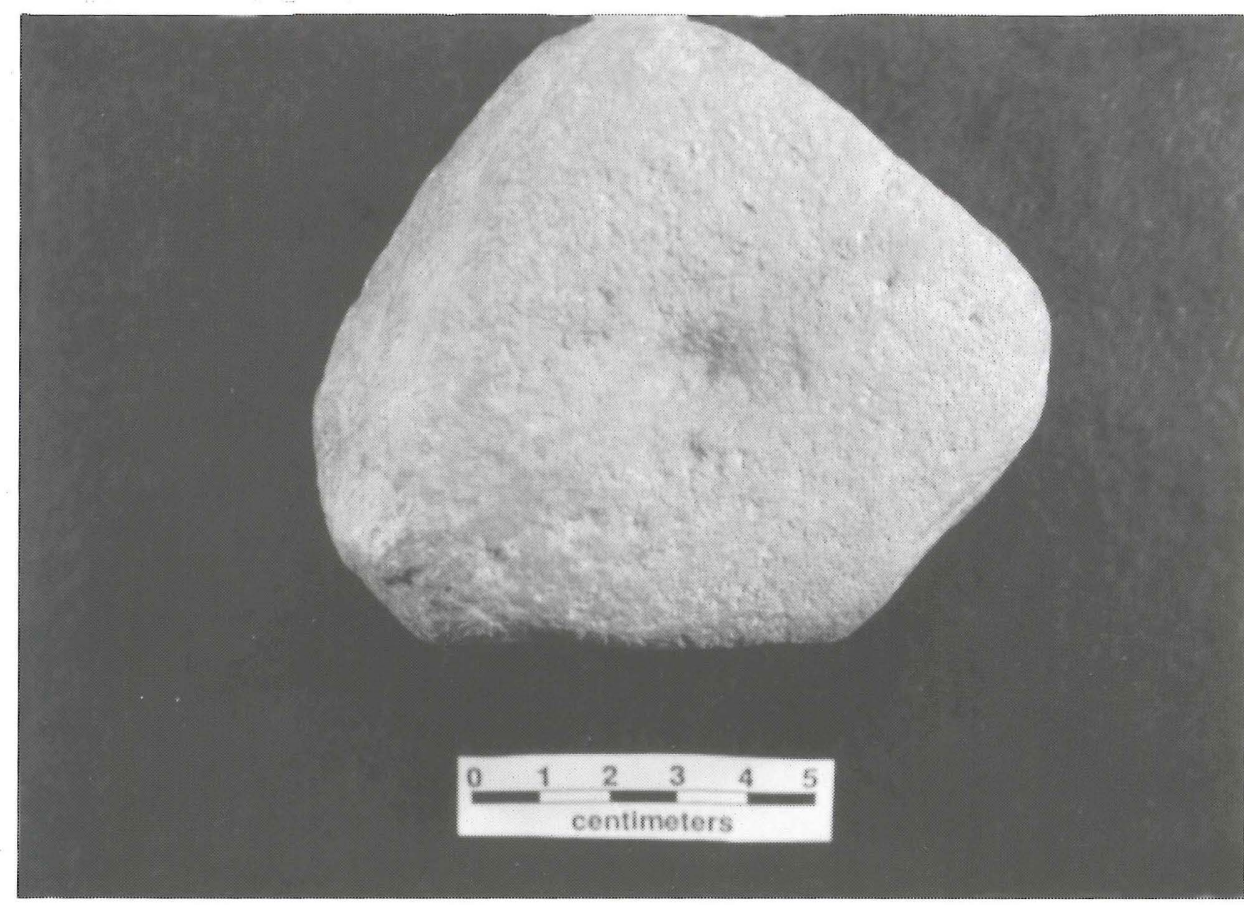

$B$

Figure 8-13. Cores, Blank-Preforms, and Groundstone, Block D: a, opposed platform core (No. 1, 3-4), multiple platform core (No. 5-6), blank-preform (No. 2); b, pitted stone (No. 1). Provenience: a-1 (82-2), a-2 (82-1), a-3 $(87-4), a-4$ (79-2), a-5 (87-5), a-6 (85-2), b-1 (S27E27, $25 \mathrm{~cm})$ 


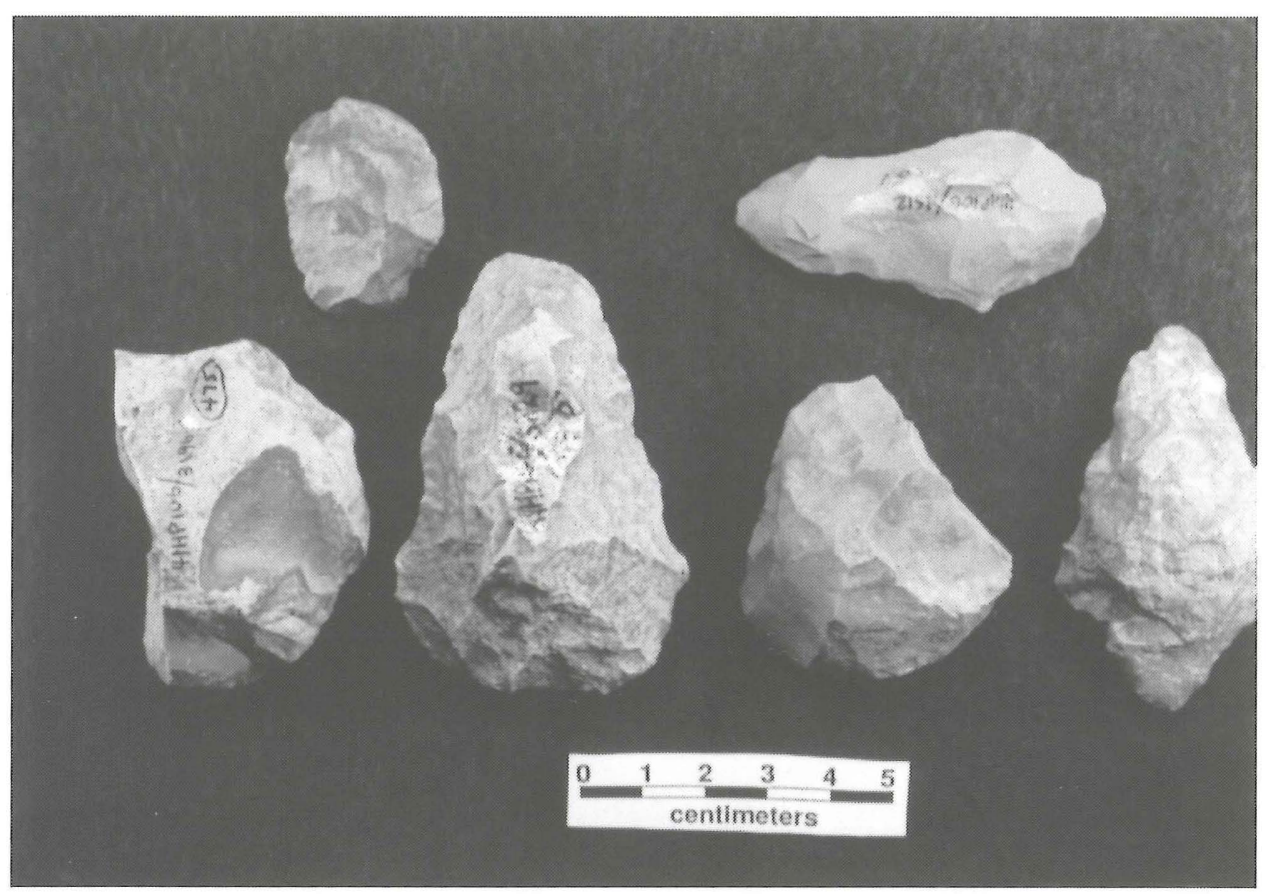

A

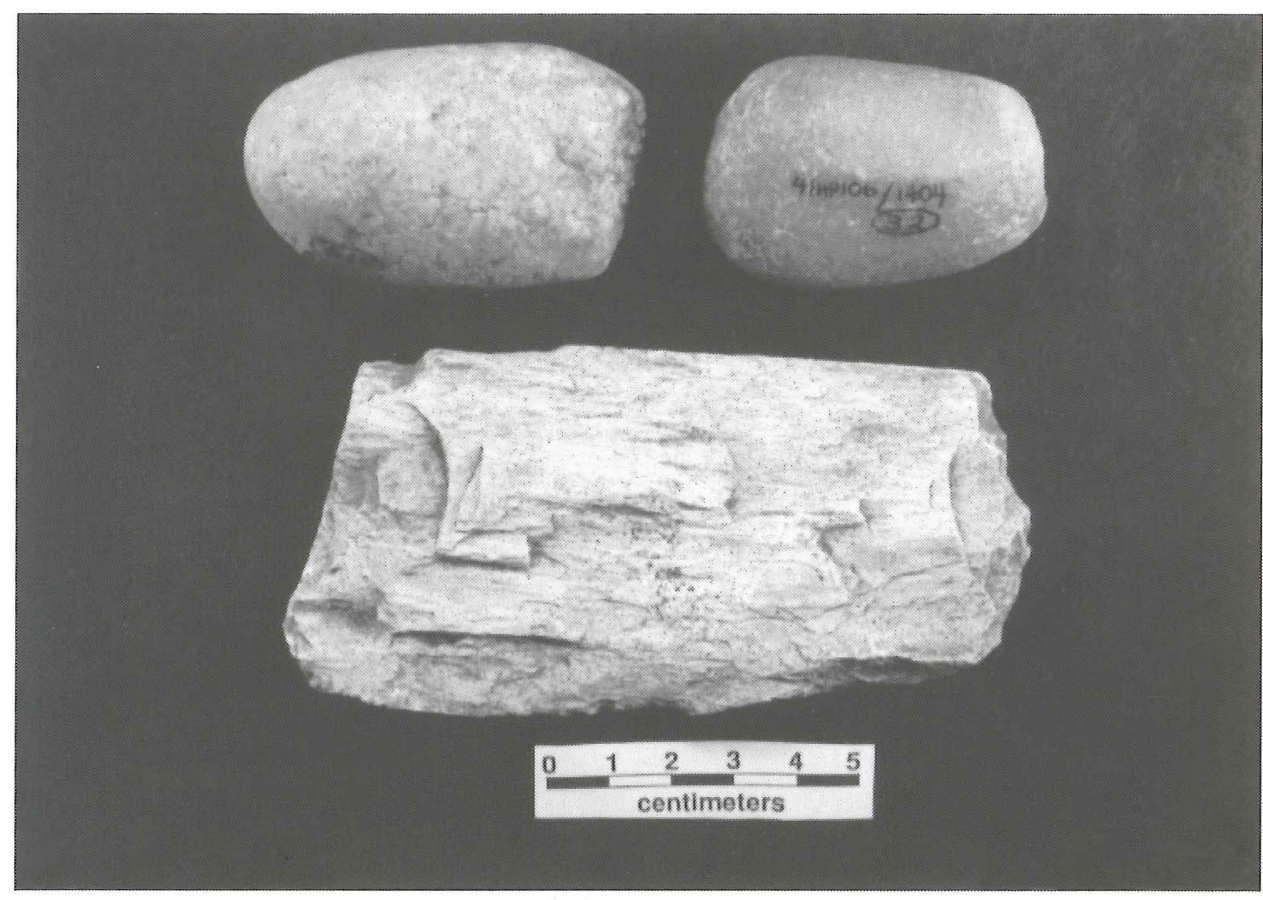

Figure 8-14. Cores, Blank-Preforms, and Hammerstones, Block E: a, blank-preforms (No. 1-2, 4-6), multiple platform core (No. 3); b, hammerstones (No. 1-2), bifacial core (No. 3). Provenience: a-1 (92-1), a-2 (S29E20. 55-60 cm), a-3 (94-4), a-4 (91-3A), a-5 (24-6), a-6 (S24E21, $30 \mathrm{~cm}), \mathrm{b}-1$ (S37E21, $30 \mathrm{~cm}), \mathrm{b}-2$ (S32E18, $35 \mathrm{~cm})$, b-3 (91-2) 


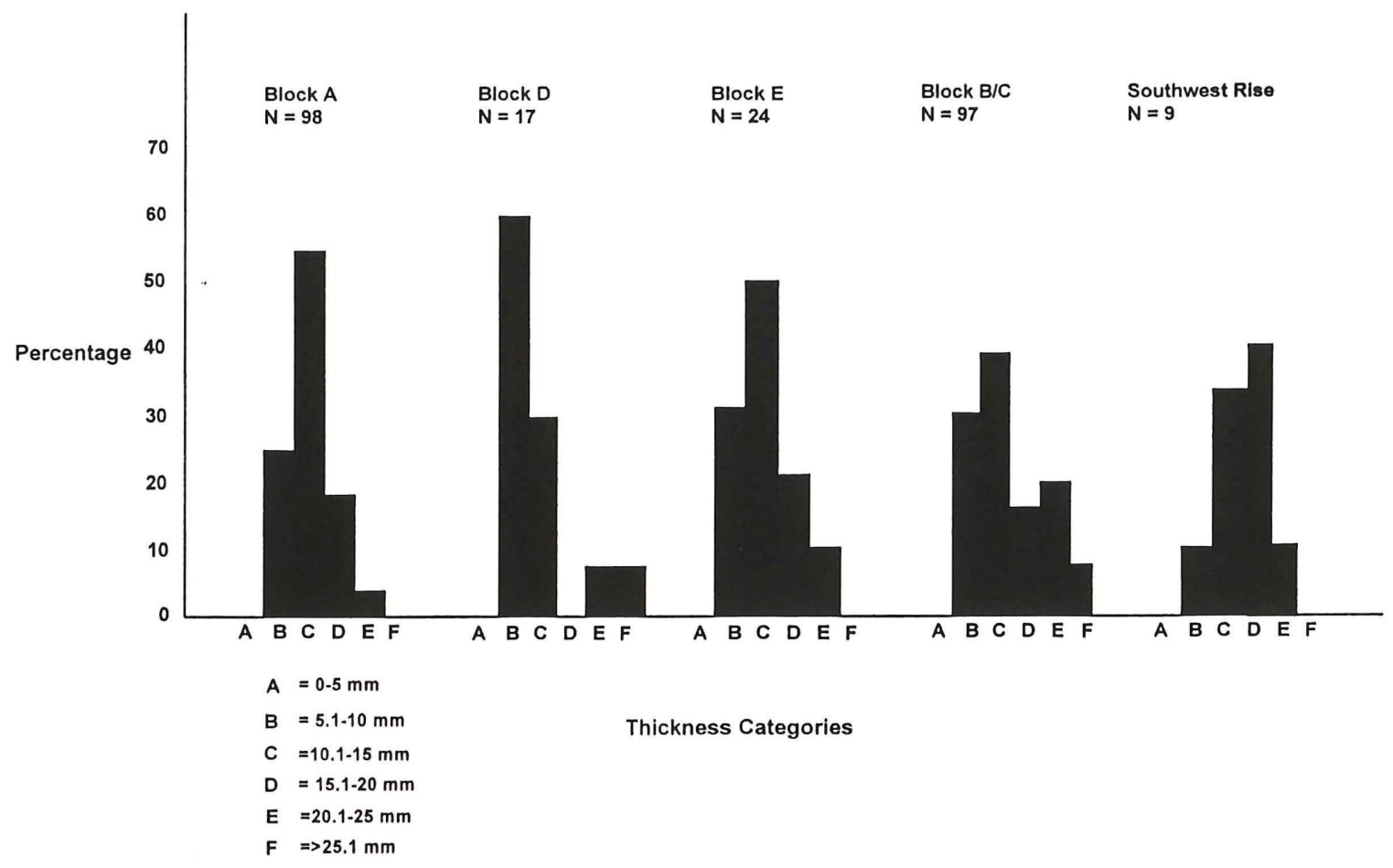

Figure 8-15. Blank-preform thickness intervals.

Table 8-22. Distribution of cores.

\begin{tabular}{lllllllllllll} 
Area & Level & MPF* & $\mathrm{D}$ & $\mathrm{SPF}$ & $\mathrm{BC}$ & $\mathrm{OP}$ & $\mathrm{GL}$ & $\mathrm{TC}$ & $\mathrm{CF}$ & Total \\
\hline
\end{tabular}

\section{NORTH RISE}

$\begin{array}{lllllllllll}\text { Block A } & 1 & 2 & - & - & 1 & 1 & - & 1 & 5 & 10 \\ \text { Block D } & 1 & 3 & - & - & - & 1 & - & - & 2 & 6 \\ \text { Block E } & 1 & - & - & - & - & - & - & - & - & 0 \\ \text { Block A } & 2 & 6 & 1 & - & 2 & 1 & - & 2 & 25 & 37 \\ \text { Block D } & 2 & 1 & - & - & - & 3 & - & - & - & 4 \\ \text { Block E } & 2 & - & - & - & 1 & 2 & - & - & 3 & 6 \\ \text { Block A } & 3 & 1 & 1 & - & 4 & 4 & - & 6 & 15 & 31 \\ \text { Block D } & 3 & 1 & - & - & - & - & - & - & 1 & 2 \\ \text { Block E } & 3 & 3 & - & - & - & - & - & 1 & 2 & 6 \\ \text { Block A. } & 4 & 9 & - & - & 2 & 3 & 1 & 2 & 28 & 45 \\ \text { Block D } & 4 & 1 & - & 1 & - & 5 & - & - & - & 7 \\ \text { Block E } & 4 & 2 & - & - & - & 3 & - & - & 9 & 14 \\ & & & & & & & & & & \\ \text { Block A } & 5 & 11 & 1 & 5 & 1 & 3 & 1 & 2 & 18 & 42 \\ \text { Block D } & 5 & 1 & - & - & - & 1 & - & - & 2 & 4 \\ \text { Block E } & 5 & - & - & 1 & 1 & 1 & - & - & 4 & 7\end{array}$


Table 8-22. Distribution of cores, cont.

\begin{tabular}{lllllllllll}
\hline Area & Level & MPF* & D & SPF & BC & OP & GL & TC & CF & Total \\
\hline Block A & 6 & 4 & - & - & - & 1 & - & - & 5 & 10 \\
Block D & 6 & 4 & - & - & - & - & - & - & - & 4 \\
Block E & 6 & 1 & - & - & - & 2 & - & 1 & 6 & 9 \\
& 7 & - & - & - & 1 & - & - & - & 1 & 2 \\
Block A & 7 & - & - & - & - & - & - & - & - & 0 \\
Block D & 7 & - & - & - & - & - & - & - & - & 0 \\
Block E & 7 & & & & & & & & & \\
& & & & & & & & & &
\end{tabular}

North Rise

Subtotal

$\begin{array}{lllllllll}50 & 3 & 7 & 13 & 31 & 2 & 15 & 126 & 247 \\ 20.2 & 1.2 & 2.8 & 5.3 & 12.6 & 0.8 & 6.1 & 51.0 & \end{array}$

Percent

$20.2-1.2-2.8$

SOUTH RISE

Block B/C

$\begin{array}{llll}1 & 2 & - & - \\ 2 & 6 & - & - \\ 3 & 1 & - & - \\ 4 & 5 & - & - \\ 5 & 3 & - & -\end{array}$

$-2$

$2 \quad-\quad 1$

$11 \quad 16$

4

28

$4 \quad-\quad 2 \quad 5$

19

23

$5 \quad 10$

26

2

$\begin{array}{lllll}2 & - & 1 & 14 & 20\end{array}$

South Rise

Subtotal

$17 \quad 0 \quad 0 \quad 6$

19

Percent

$17.0 \quad 0.0$

0.0

6.0

19.0

0

$10 \quad 48$

100

Percent

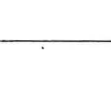

\section{SOUTHWEST \\ RISE}

Percent

$\begin{array}{lll}1 & - & - \\ 11.1 & 0.0 & 0.0\end{array}$

\footnotetext{
* $\mathrm{MPF}=$ multiple platform flake; $\mathrm{D}=$ discoidal; $\mathrm{SPF}=$ single platform flake; $\mathrm{BC}=$ bifacial core; $\mathrm{OP}=$ opposed; $\mathrm{GL}=$ globular; $\mathrm{TC}=$ tested cobble; $\mathrm{CF}=$ core fragment
}

Non-local lithic raw materials occur in only low densities on the North rise, in either Late Archaic/Early Ceramic PrimaryMidden or Early Caddoan contexts. However, the vertical distribution of tools made from non-local materials (i.e., more than 75 percent are present between $0-20 \mathrm{~cm}$ bs), and the types of tools of these materials (i.e., arrowpoints and arrowpoint preforms and retouched pieces), indicate that most of them are associated with the Early Caddoan component (Figure 8-16). Only 1.5 percent of the dart points ( $\mathrm{n}=197)$ from Blocks $\mathrm{D}$ and $\mathrm{E}$, and one of the blank/preforms, are made of non-local materials, compared to 13.3 percent of the arrowpoints $(n=15)$ and 9.1 percent of the 11 arrowpoint preforms. Two of 
the indeterminate bifacial tools from $40-50 \mathrm{~cm}$ bs, in Late Archaic/Early Ceramic period contexts, are on non-local materials (gray chert and white fossiliferous chert).

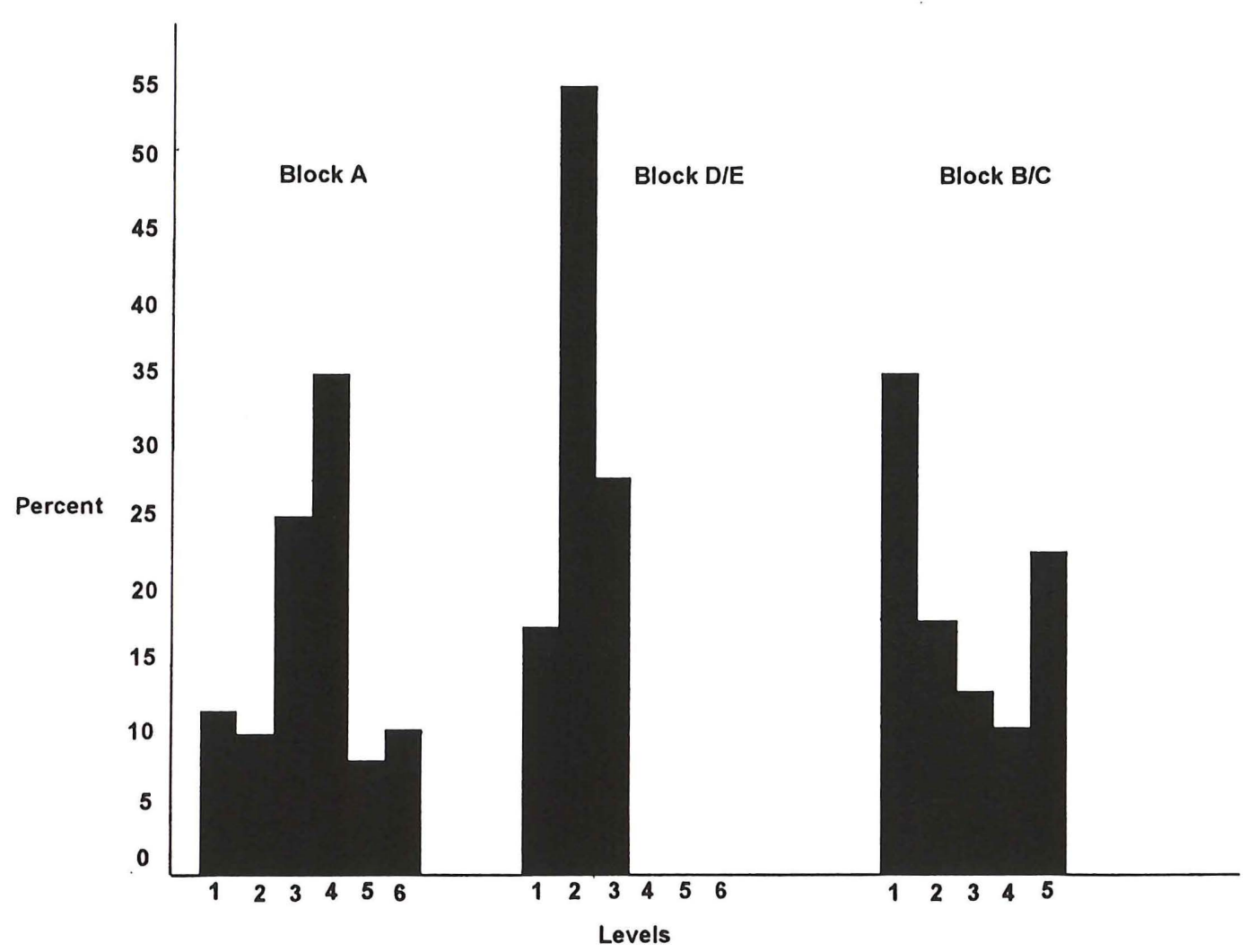

Figure 8-16. Distribution of non-local tools by depth in blocks.

Novaculite is the preferred non-local raw material for tools, accounting for more than 42 percent of the Block D and E sample of tools made of non-local lithics. Gray chert (21 percent) and Big Fork chert, green variety (21 percent) are also abundant. Jasper is noticeably scarce compared to the non-local tool samples from Block A and Block B/C, where it comprises between 13-16 percent of the non-local tools, suggesting differences in procurement.

By comparison with the other areas at Hurricane Hill, the archaeological deposits in Blocks D and E contain proportionally more ground stone tools (about 3 percent); in Block E, in particular, ground stone tools comprise 3.8 percent of the tools. The most abundant ground stone tools include metates and small quartzite hammerstones (see Figure 8-14b:1-2), along with two manos (see Figure 8-12:1-2) and a pitted stone (see Figure 8-13b; see also Appendix X). Local quartzites were the preferred raw material for the ground stone tools. Fourteen of the 19 ground stone tools are from $0-30 \mathrm{~cm}$ bs, and are probably associated with the Early Caddoan deposits in Middens 1 and 2. The remainder were from deeper archaeological deposits, including two hammerstones and a mano from $50-60 \mathrm{~cm}$ bs, and these can be associated with the Late Archaic/Early Ceramic Primary Midden.

From the lithic debris collected in the 1/4-inch screen samples discussed above, both Blocks D and $\mathrm{E}$ are characterized by high percentages of large cortical flakes, as are the archaeological deposits in the other areas of the Hurricane Hill site (Figure 8-17). Fine-screen and flotation samples are more discriminating, sorting the lithic debris assemblages into two groups: (a) Blocks D, E, and B/C; and (b) Blocks A and F and 
the Southwest rise. In the case of Blocks D and E, the lithic debris contains higher proportions of large flakes (30-40 percent) and lesser amounts of non-cortical flakes (70-75 percent) (see Figure 8-17), suggesting an emphasis on biface reduction from core and larger bifacial blank/preforms. Fine-screen samples from Block E (see Appendix XVI) further indicate the relatively consistent focus of this reduction strategy throughout the Late Archaic and Early Ceramic period occupations on the North rise (Figure 8-18).

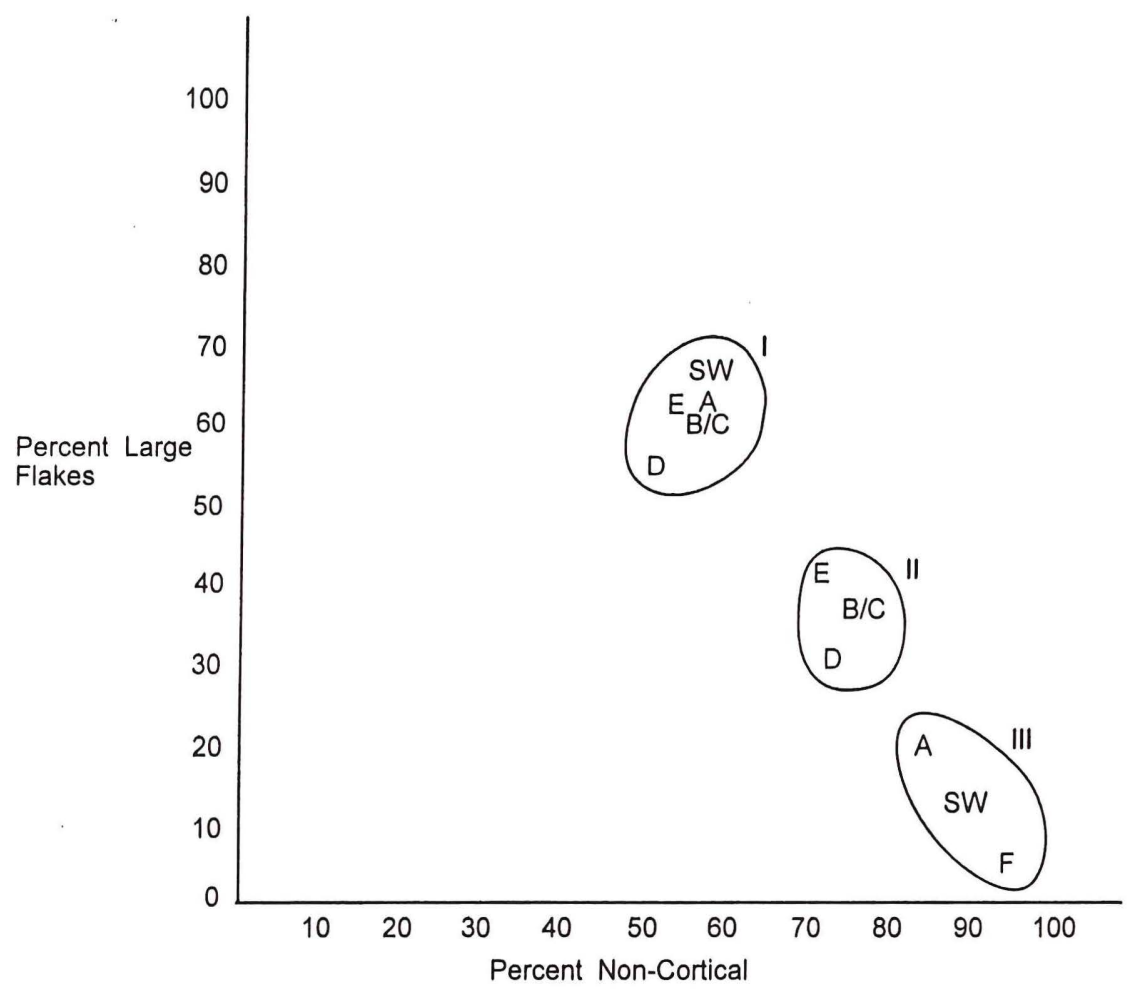

Figure 8-17. Percentage of large flakes and non-cortical flakes in 1/4-inch, fine-screen, and flotation samples (see Tables 8-8 and 8-9). Group I, 1/4-inch screen sample, and Groups II and III, fine-screen and flotation samples.

More than 2800 fire-cracked rocks of coarse-grained quartzite and sandstone (FCR) weighing 72.7 $\mathrm{kg}$ were recovered in the Block D and E excavations in the Primary Midden and Midden 2 deposits, more than 58 percent of which by weight were from four features (Tables 8-23 and 8-24), particularly Feature 31, a shallow basin filled with FCR. In non-feature contexts, FCR was most abundant between $10-40 \mathrm{~cm}$ bs. The overall FCR density was 2.7-3.6 $\mathrm{kg}$ per $\mathrm{m}^{2}, 2-20$ times higher here in the Primary Midden than in Late Archaic/Early Ceramic, Early Caddoan, or Middle Caddoan contexts elsewhere at Hurricane Hill.

The ratio of the number of FCR to FCR weight from Blocks D and E ranges from 0.0124 (Block E) to 0.0416 (Block D), indicating that the FCR from Block D were more than three times larger in weight on average than they were from Block E. Considering the number/weight relationships of the FCR in midden deposits only, the average weight of the FCR ranges from $.0126-.0132 \mathrm{~kg}$. These average FCR weights are consistent with the FCR weights from Block A and the Southwest rise, but considerably larger than the FCR from the predominantly Middle Caddoan occupation on the South rise: 
Mean Size of FCR $(\mathrm{kg})$

Block A

Block D

Block E

Block B/C

Southwest rise
0.0114

0.0416

0.0124

0.0064

0.0118
FCR Density $/ \mathrm{m}^{2}$
1.6
3.6
2.7
0.2
1.0

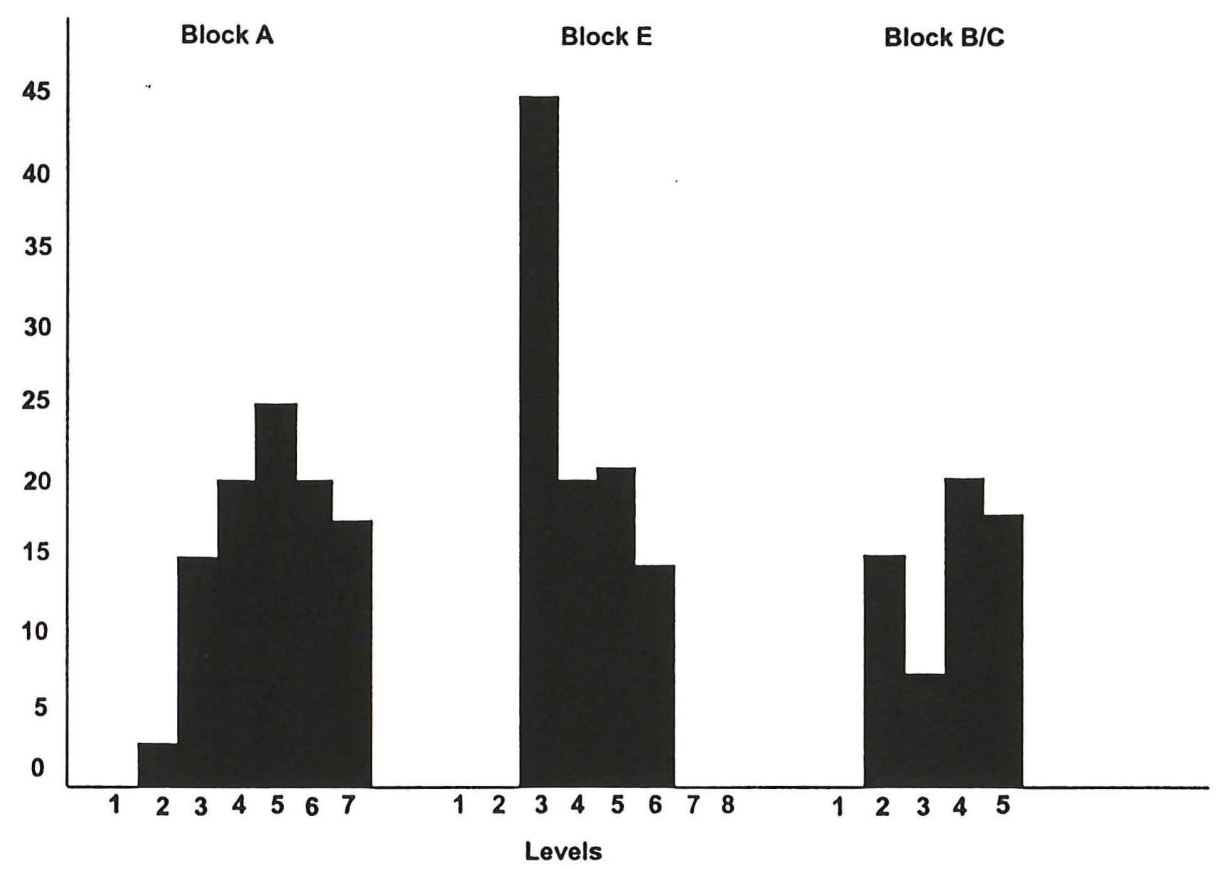

Percent of Large Flakes

Figure 8-18. Percentage of large flakes by level in Blocks $A, E$, and $B / C$ from fine-screen samples (see Appendix XVI). Block A, n=2848; Block E, $n=469$; Block B/C, $n=1699$.

Table 8-23. Weight and frequency of daub, burned clay, and fire-cracked rock, Block D

\begin{tabular}{|c|c|c|c|c|c|c|}
\hline Provenience & Daub (g) & Daub (\#) & Burned Clay (g) & Burned Clay (\#) & $\mathrm{FCR}(\mathrm{kg})$ & FCR (\#) \\
\hline $\begin{array}{l}\text { Iv. } 1 \\
\text { Iv. } 2 \\
\text { lv. } 3 \\
\text { Iv. } 4 \\
\text { Iv. } 5 \\
\text { Iv. } 6 \\
\text { Iv. } 7 \\
\text { Iv. } 8 \\
\text { Iv. } 9\end{array}$ & $\begin{array}{l}2.8 \\
10.2 \\
1.3 \\
8.7 \\
1.7 \\
8.4 \\
-1.0 \\
--\end{array}$ & $\begin{array}{l}1 \\
12 \\
4 \\
26 \\
8 \\
12 \\
-- \\
2 \\
--\end{array}$ & $\begin{array}{l}63.2 \\
73.5 \\
31.2 \\
129.8 \\
54.9 \\
49.1 \\
-- \\
-- \\
--\end{array}$ & $\begin{array}{l}18 \\
54 \\
30 \\
72 \\
59 \\
54 \\
-- \\
-- \\
--\end{array}$ & $\begin{array}{l}1.4 \\
4.0 \\
2.4 \\
2.1 \\
1.7 \\
0.7 \\
1.7 \\
+ \\
--\end{array}$ & $\begin{array}{l}115 \\
229 \\
201 \\
190 \\
189 \\
91 \\
39 \\
4 \\
--\end{array}$ \\
\hline $\begin{array}{l}\text { Fea. } 31 \\
\text { Fea. } 32 \\
\text { Fea. } 33 \\
\text { Fea. } 49 \\
\text { Fea. } 98\end{array}$ & $\begin{array}{l}-- \\
-- \\
0.1 \\
-- \\
--\end{array}$ & $\begin{array}{l}-- \\
-- \\
1 \\
-- \\
--\end{array}$ & $\begin{array}{l}- \\
2.0 \\
4.1 \\
-- \\
--\end{array}$ & $\begin{array}{l}-- \\
6 \\
3 \\
-- \\
--\end{array}$ & $\begin{array}{l}39.0 \\
+ \\
0.7 \\
+ \\
+\end{array}$ & $\begin{array}{l}195 \\
2 \\
39 \\
1 \\
1\end{array}$ \\
\hline Iv. $99 *$ & 2.5 & 6 & 13.0 & 15 & 0.2 & 14 \\
\hline Totals & 36.7 & 72 & 420.8 & 311 & 54.1 & 1300 \\
\hline
\end{tabular}

* miscellaneous provenience (wall and floor troweling and scrapings, etc.) 
Table 8-24. Weight and frequency of daub, burned clay, and fire-cracked rock, Block $\mathbf{E}$.

\begin{tabular}{|c|c|c|c|c|c|c|}
\hline Provenience & $\operatorname{Daub}(\mathrm{g})$ & Daub (\#) & Burned Clay (g) & Burned Clay (\#) & $\mathrm{FCR}(\mathrm{kg})$ & FCR (\#) \\
\hline $\begin{array}{l}\text { lv. } 1 \\
\text { lv. } 2 \\
\text { Iv. } 3 \\
\text { lv. } 4 \\
\text { lv. } 5 \\
\text { lv. } 6 \\
\text { Iv. } 7 \\
\text { Iv. } 8\end{array}$ & $\begin{array}{l}3.3 \\
6.7 \\
3.3 \\
8.3 \\
6.1 \\
0.4 \\
-- \\
--\end{array}$ & $\begin{array}{l}2 \\
21 \\
10 \\
16 \\
16 \\
2 \\
-- \\
--\end{array}$ & $\begin{array}{l}129.6 \\
44.1 \\
70.5 \\
120.2 \\
131.0 \\
178.7 \\
-- \\
--\end{array}$ & $\begin{array}{l}88 \\
70 \\
86 \\
84 \\
137 \\
64 \\
-- \\
--\end{array}$ & $\begin{array}{l}0.5 \\
2.2 \\
5.4 \\
3.4 \\
2.9 \\
2.5 \\
+ \\
+\end{array}$ & $\begin{array}{l}56 \\
336 \\
289 \\
281 \\
254 \\
109 \\
1 \\
6\end{array}$ \\
\hline $\begin{array}{l}\text { Fea. } 22 \\
\text { Fea. } 24 \\
\text { Fea. } 25 \\
\text { Fea. } 35\end{array}$ & $\begin{array}{l}-- \\
-- \\
-- \\
23.5\end{array}$ & $\begin{array}{l}-- \\
-- \\
- \\
6\end{array}$ & $\begin{array}{l}5.7 \\
3.5 \\
26.5\end{array}$ & $\begin{array}{l}\ddot{5} \\
2 \\
25\end{array}$ & $\begin{array}{l}+ \\
0.5 \\
+ \\
1.2\end{array}$ & $\begin{array}{l}9 \\
24 \\
10 \\
127\end{array}$ \\
\hline Totals & 51.6 & 73 & 709.8 & 561 & 18.6 & 1502 \\
\hline
\end{tabular}

The generally small size of the FCR from the different excavated contexts, as well as the low spatial density of FCR across the site, first suggests that the FCR is a product of multiple cooking events that reduced the coarse-grained quartzite and sandstone cobbles to small pieces and spalls (see Leach et al. 1998). Second, Ellis' (1997:63 and Tables 3 and 6) discussion of cooking technologies using heated rocks further suggests that several kinds of cooking and heating facilities may have been employed at Hurricane Hill, primarily parching, stone boiling, and steaming of foods using small stones. In an experiment conducted by Leach et al. (1998) employing 26 limestone rocks weighing an average of $3.5 \mathrm{~kg}$ each, two cooking events reduced the average weight of the FCR to $0.42 \mathrm{~kg}, 10-60$ times larger by weight than the FCR from any of the excavated contexts at Hurricane Hill. Even given likely differences in the availability and size of naturally occurring rock between the limestone employed by Leach et al. (1998) and the quartzite and sandstone from local gravels at Hurricane Hill, it is apparent that the FCR from Hurricane Hill has been well reduced in size from numerous cooking events.

Daub is rare in the Block D and E excavations, totaling only 145 pieces weighing $88.3 \mathrm{~g}$ (see Tables 8-23 and 8-24). Oxidized pieces of burned clay, however, are abundant, particularly in the lower depths of the PrimaryMidden. More than $1130 \mathrm{~g}$ of burned clay pieces were found in the deposits, and these are considered by-products of the burning of clay in the soil surrounding features (probably shallowly buried) utilized for the heating and cooking of plant and animal foods.

\section{North Rise Assemblages, Block A}

Dart points account for 15 percent of the tools, blank/preforms, and cores from Block A on the North rise, compared to 28 percent elsewhere on the rise. The darts are well-distributed throughout the archaeological deposits, particularly between $10-50 \mathrm{~cm}$ bs (Table 8-25); 70 percent of the dart points occur in the 20-60 $\mathrm{cm}$ levels in Midden 1 and the PrimaryMidden. The arrowpoints $(\mathrm{n}=35)$ occur to a maximum depth of $40 \mathrm{~cm}$ bs, but 77 percent are present between $10-30 \mathrm{~cm}$ bs. 
Table 8-25. Distribution of Arrow and Dart Points in Block $\mathbf{A}$

$\begin{array}{llllllllll}\text { Class } & \text { lv. } 1 & \text { lv. } 2 & \text { lv. } 3 & \text { lv. } 4 & \text { lv. } 5 & \text { lv. } 6 & \text { lv. } 7 & \text { IND } & \text { Total }\end{array}$

\section{ARROW POINTS}

$\begin{array}{llllllllll}01 & 2 & 5 & 1 & 1 & - & - & - & - & 9 \\ 02 & 1 & 6 & - & - & - & - & - & - & 7 \\ 03 & - & 2 & 1 & 1 & - & - & - & - & 4 \\ 04 & - & 1 & - & - & - & - & - & - & 1 \\ 05 & - & 3 & 2 & 2 & - & - & - & - & 7 \\ 06 & - & 2 & 3 & - & - & - & - & - & 5 \\ 07 & - & - & 1 & - & - & - & - & - & 1 \\ 10 & 1 & - & - & - & - & - & - & - & 1\end{array}$

$\begin{array}{llllllllll}\text { Total Arrows } & 4 & 19 & 8 & 4 & - & - & - & - & 35\end{array}$

\section{DART POINTS}

\begin{tabular}{|c|c|c|c|c|c|c|c|c|c|}
\hline 01 & 6 & 6 & 12 & 5 & 4 & - & - & - & 33 \\
\hline 02 & 1 & 5 & 5 & 2 & 5 & 1 & - & - & 19 \\
\hline 03 & 2 & 7 & 12 & 10 & 8 & 3 & - & 2 & 44 \\
\hline 04 & 1 & 1 & 1 & 2 & 1 & - & - & - & 6 \\
\hline 05 & - & 1 & 2 & 2 & 1 & - & - & - & 6 \\
\hline 06 & - & 8 & 4 & 3 & 6 & 3 & 1 & - & 25 \\
\hline 07 & - & 1 & 1 & 3 & - & - & - & - & 5 \\
\hline 08 & - & 2 & - & 2 & 3 & - & - & - & 7 \\
\hline 09 & - & - & - & 1 & - & - & - & - & 1 \\
\hline 10 & 1 & 1 & 1 & - & - & - & - & - & 3 \\
\hline 11 & 1 & - & - & 2 & 1 & - & - & - & 4 \\
\hline 12 & - & 2 & 2 & 2 & - & - & - & - & 6 \\
\hline 13 & - & 2 & - & 1 & 1 & - & - & - & 4 \\
\hline 14 & - & - & - & 1 & 1 & - & - & - & 2 \\
\hline 15 & - & - & - & 1 & - & - & - & - & 1 \\
\hline 16 & - & - & - & 1 & - & - & - & - & 1 \\
\hline 17 & - & - & - & 1 & 2 & - & - & - & 3 \\
\hline 18 & - & 1 & - & - & - & - & - & - & 1 \\
\hline 19 & - & - & - & 2 & - & 1 & - & - & 3 \\
\hline 20 & - & - & - & - & - & - & - & 1 & 1 \\
\hline Dart Totals & 12 & 37 & 40 & 41 & 33 & 8 & 1 & 3 & 175 \\
\hline
\end{tabular}

IND=indeterminate level

Among the dart points, the contracting stem Gary forms are most abundant, as they represent 71 percent of the large Block A sample ( $n=175)$. The var. LeFlore (classes 02 and 03) specimens have the highest frequencies, followed by the var. Camden (Class 01) and var. Gary (Class 06). Each of the contracting stem point varieties occur throughout the archaeological deposits (see Table 8-25), but in a rough stratigraphic order based on the assumed age of the Gary point varieties (see discussion in Schambach 1998), with the var. Camden form most common in the uppermost midden deposits (Figure 8-19a:1-2, 8-9 and Figure 8-20:3-4); the highest percentages of the var. LeFlore form occur in levels 3 (42.5 percent of the points; Figure 8-21:1-2, 4, 8, 12, and 14) and levels 5 (39 percent); and level 5 has the highest percentage of var. Gary points (Figure 8-22b:10). Narrow straight-stemmed Early Ceramic Kent points (classes 04, 05, and 07) are also relatively popular (see Figure 8-19a:7 and Figure 8-21:10-11), accounting for 9.7 percent of 


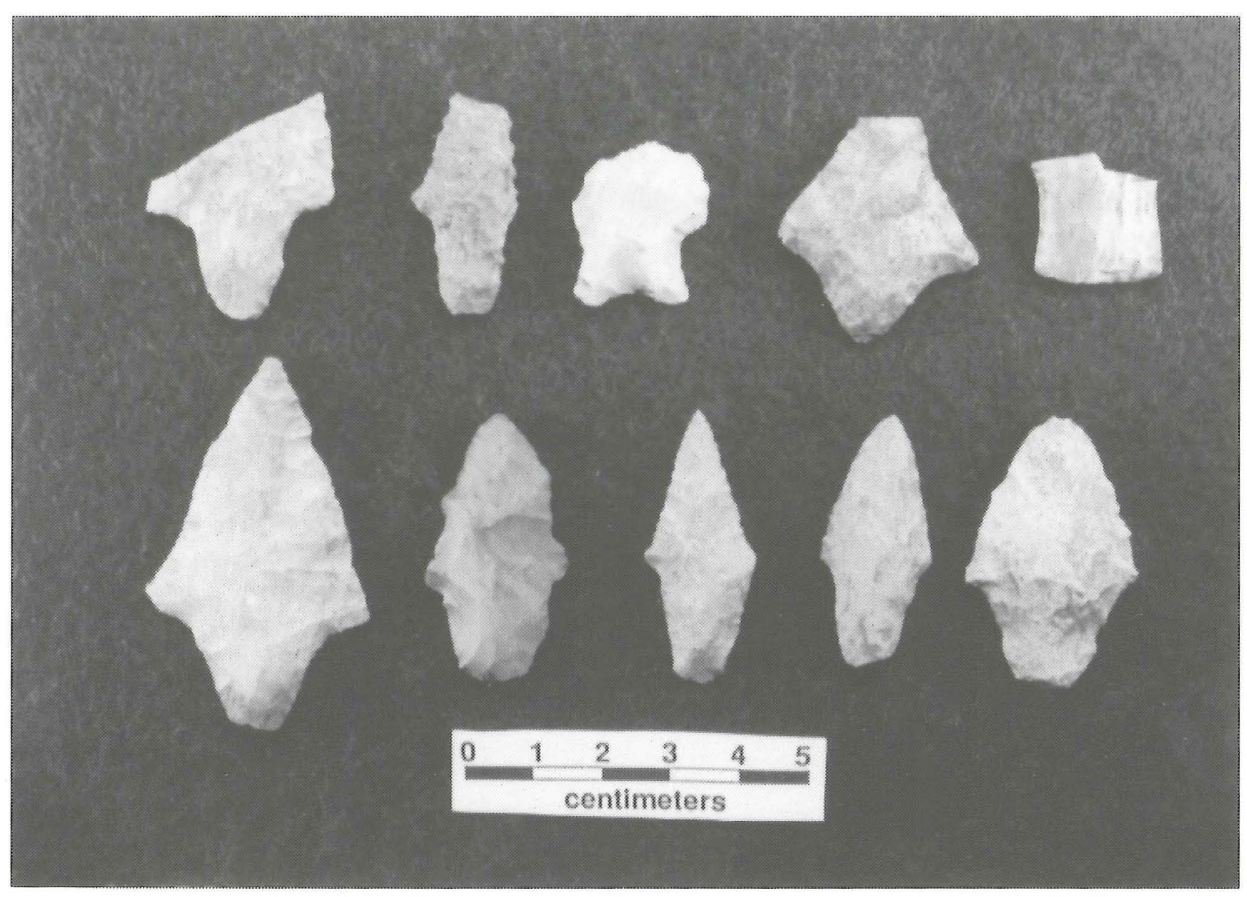

A

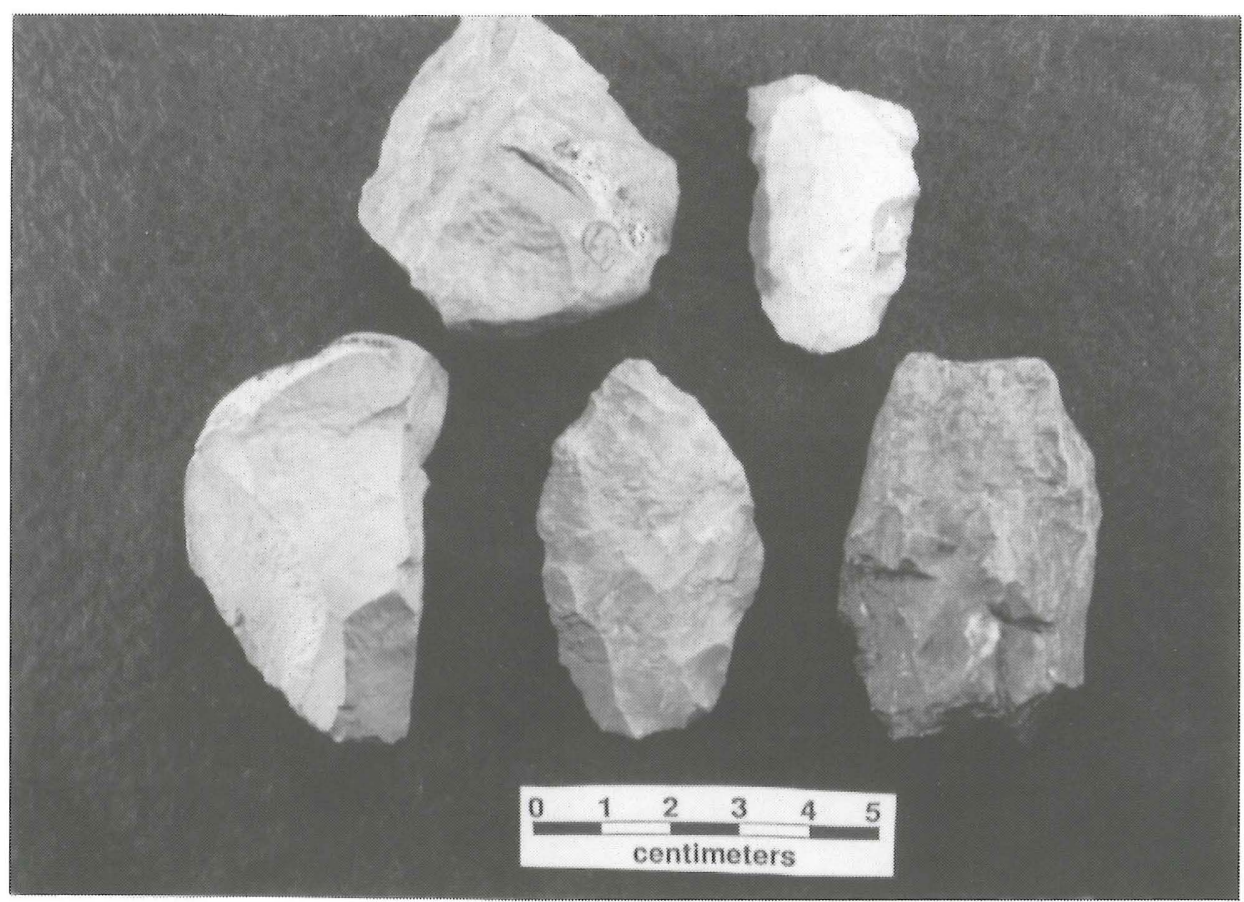

B

Figure 8-19. Dart Points, Bifaces, and Cores, Block A, levels 1 and 2: a, Class 01 (No. 1-2, 8-9), Class 02 (No. 6. 10), Class 03 (No. 4), Class 04 (No. 7), Class 11 (No. 3), unidentified expanding stem (No. 5); b, indeterminate bifacial tool (No. 2), knive (No. 4), multiple platform core (No. 5), core fragments (No. 1, 3). Provenience: a-1 (34-1), a-2 (36-1), a-3 (31-1), a-4, a-8 (35-1), a-5 (43-1), a-6 (41-2), a-7, a-10 (44-1), a-9 (25-1), b-1, b-4 (26-1), b-2, b-5 (32-1), b-3 (43-1) 


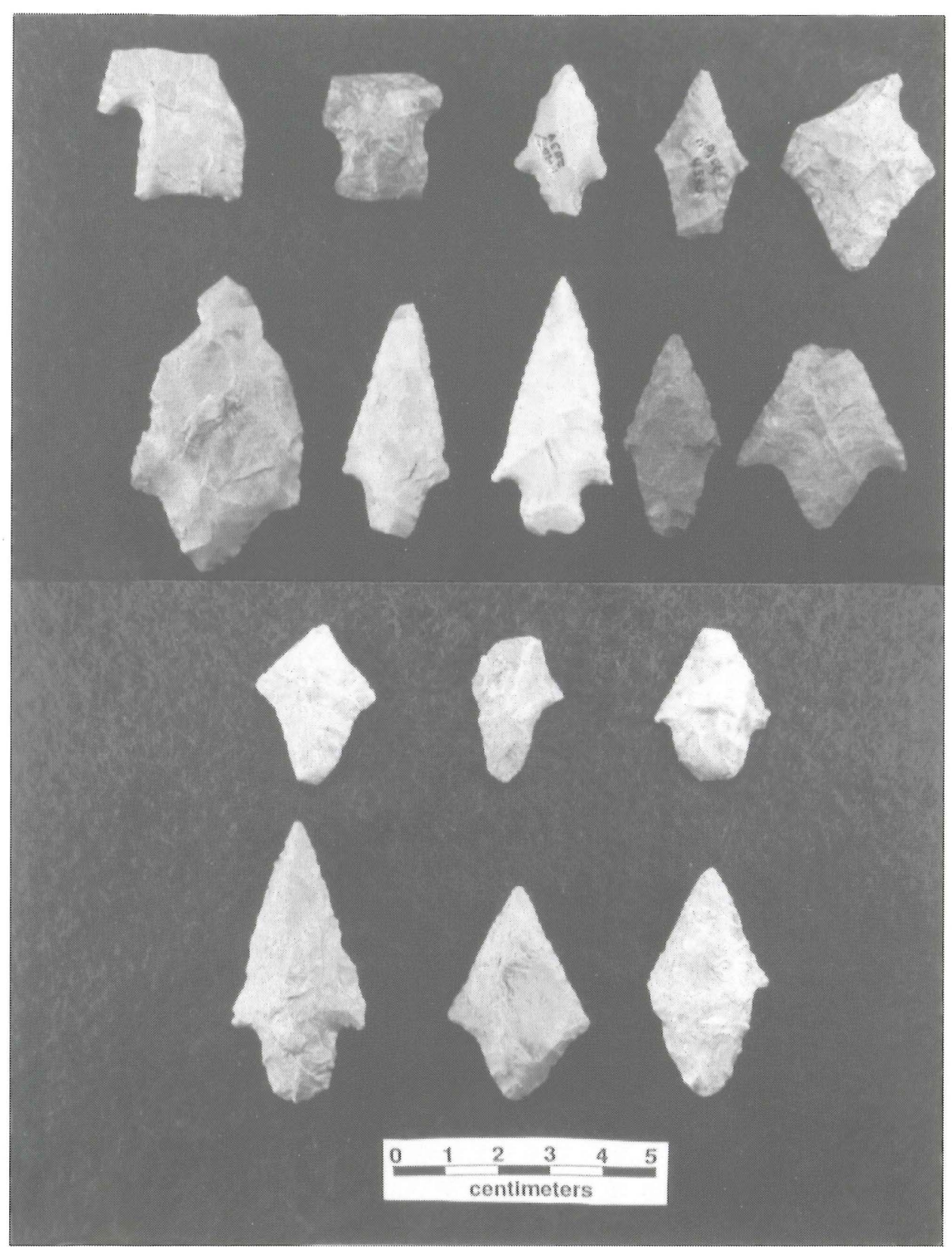

Figure 8-20. Dart Points, Block A, level 2: Class 01 (No. 3-4, 9, 11-12), Class 02 (No. 7, 13), Class 03 (No. 5-6, 15-16), Class 08 (No. 10, 14), Class 12 (No. 2), Class 13 (No. 8), Class 18 (No. 1). Provenience: 1, 4 (252-2A), 2, 6 (246-2), 3 (242-5A), 5 (249-2B), 7 (244-2B), 8 (256-2B), 9 (248-2A), 10 (255-2A), 11 (34-2), 12 (32-2), 13 $(43-2), 14(35-2), 15(29-2), 16(42-2)$ 


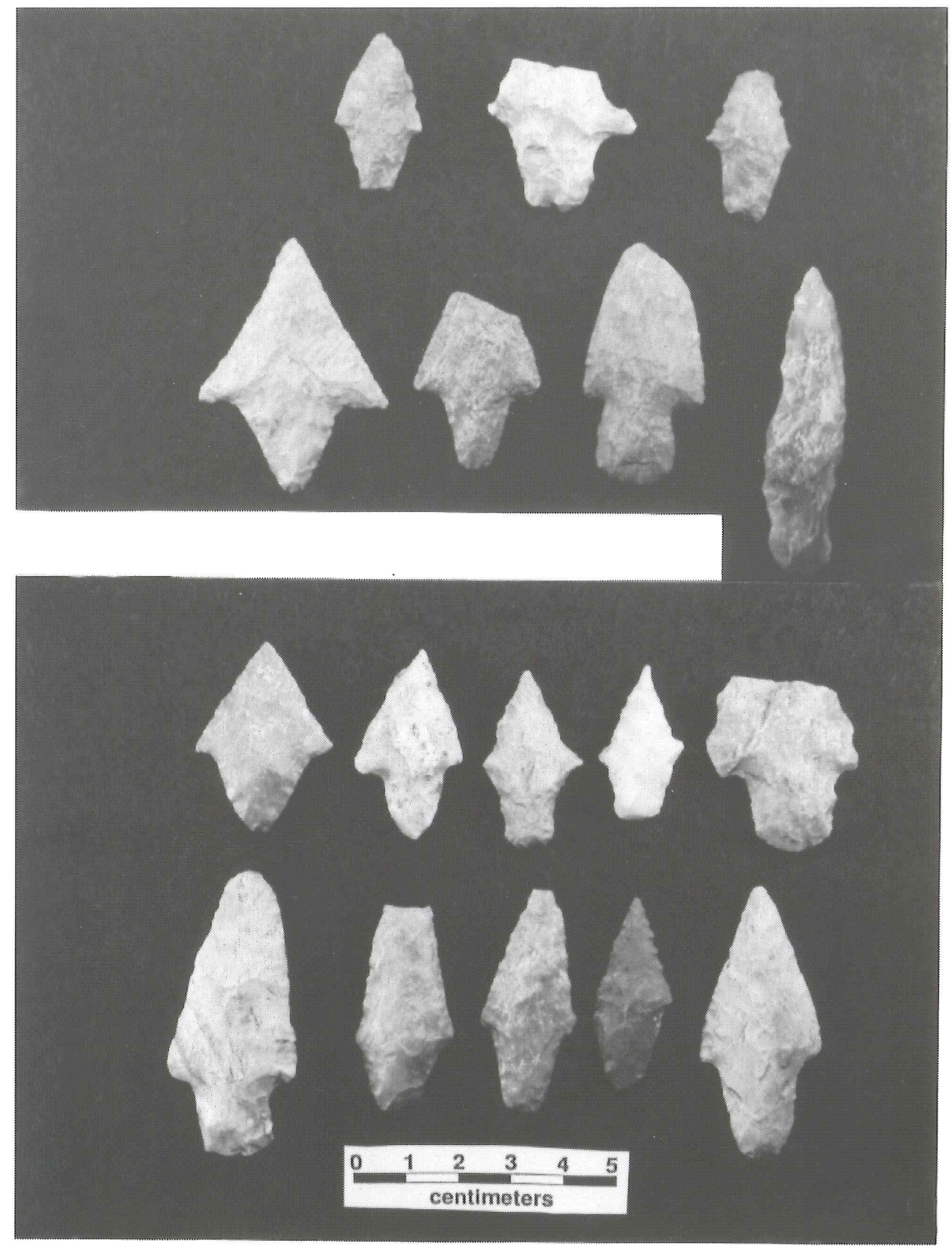

Figure 8-21. Dart Points, Block A, level 3: Class 01 (No. 3, 5, 9, 15-17), Class 02 (No. 1-2), Class 03 (No. 4, 8 , 12, 14), Class 05 (No. 10), Class 07 (No. 11), Class 10 (No. 6-7), Class 12 (No. 13). Provenience: 1 (257-3B), 2 (240-3A), 3 (249-3A), 4 (136-141, 4), 5 (244-3B), 6(108-113, 5A), 7 (256-3B), 8 (39-3), 9 (44-3), 10,12 (373), $11(42-3), 13(38-3), 14(30-3), 15,17(34-3), 16(41-3)$ 


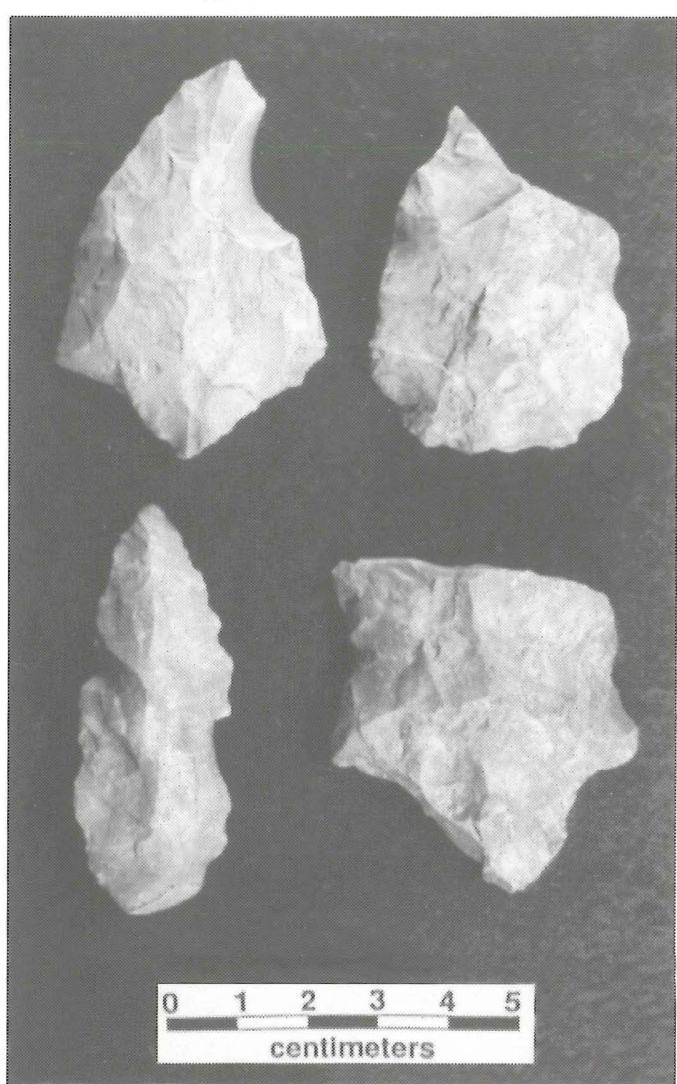

$A$

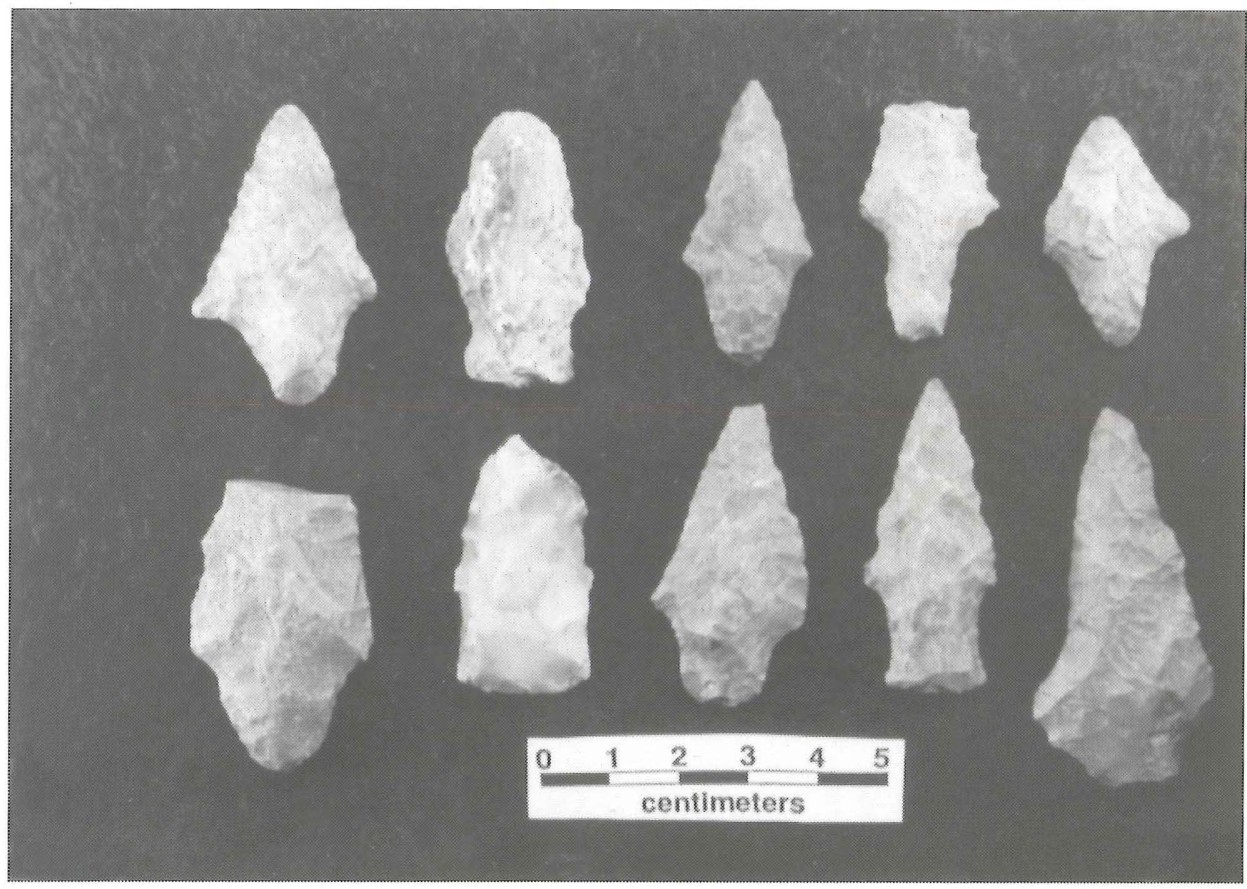

$B$

Figure 8-22. Blank-Preforms, and Dart Points, Block A and E, level 5: a, blank-preforms

(No. 1-4); b, Class 01 (No. 3, 5), Class 03 (No. 1, 6, 8), Class 05 (No. 4), Class 06 (No. 10), Class 13 (No. 7), Class 17 (No. 2, 9). Provenience: a-1, a-2 (38-5), a-3 (23-5), a-4 (37-5), b-1, b-3, b-5, b-7 (27-5), b-2 (29-5), b-4, b-6 (31-5), b-8 (26-5), b-9 (37-5), b-10 (45-5) 
the Block A dart points, but classes 15 (Figure 8-23:8) and 16 are represented by single specimens found between $30-40 \mathrm{~cm}$ bs (see Table $8-25$ ).

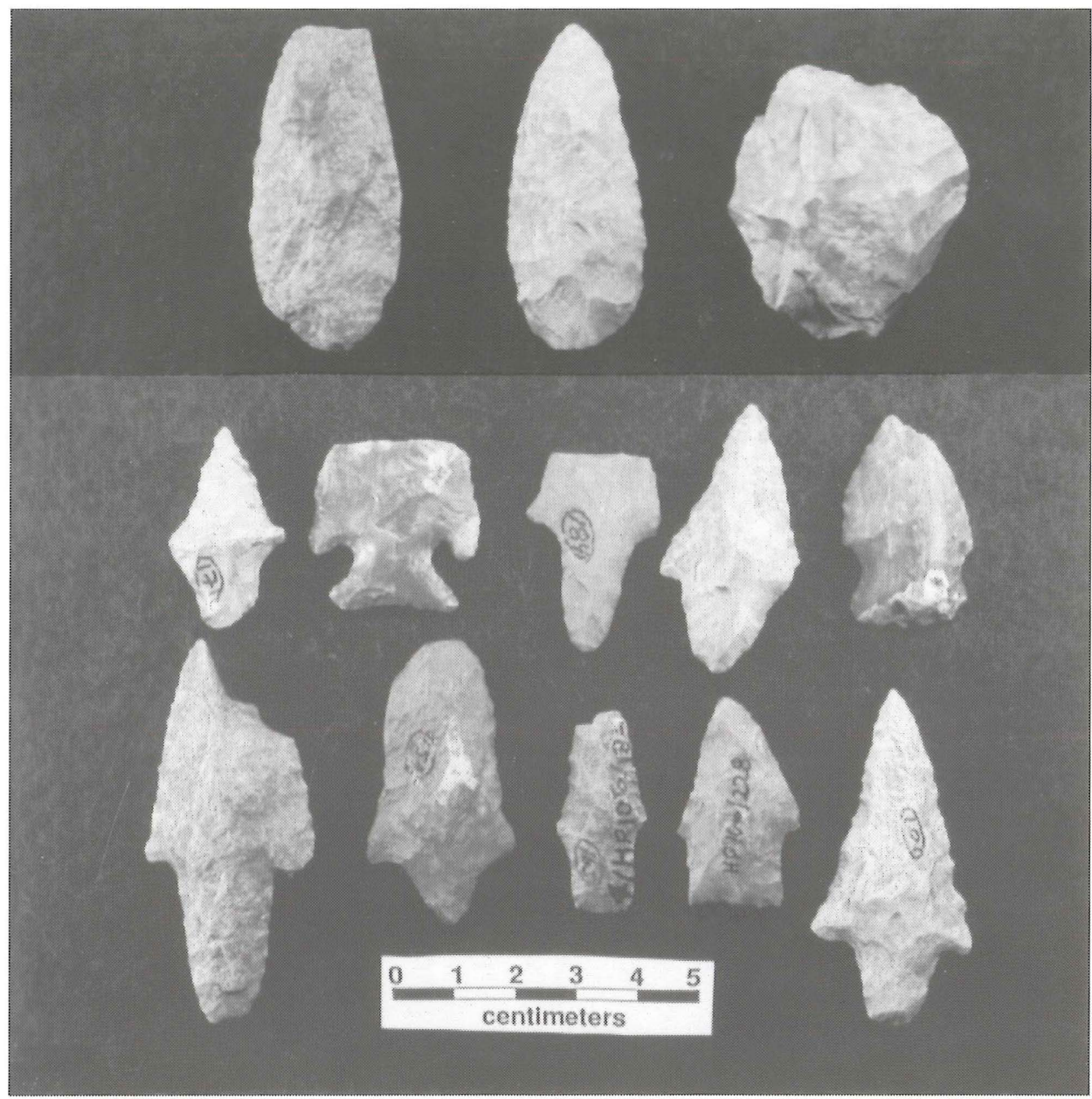

Figure 8-23. Blank-preforms and dart points, Block A and E: 1-3, blank-preforms; 4, Class 04; 5, Class 14; 6 , Class $01 ; 7,10,13$, Class 03; 8, Class 15; 9, Class 09; 11, Class 07; 12, Class 12. Provenience: 1, 43$4 ; 2,34-4 ; 3,41-4 ; 4,31-4 ; 5,13,34-4 ; 6,12,32-4 ; 7,11,29-4 ; 8-9,45-4 ; 10,24-4$.

Middle to Late Archaic point types ( $\mathrm{n}=11$ ) comprise about 6 percent of the dart points, with a little over half of them found below 30-40 $\mathrm{cm}$ bs (see Figure 8-20:1, Figure 8-22b:2, 9 and Figure 8-23:9). Late Archaic styles (classes 06, 14, 19, and 20) are also poorly represented in the block excavations--amounting to only 7 percent of the darts (see Figure 8-23:5)--particularly compared to the dart point forms estimated to date from the latter part of the Late Archaic and the earlier portion of the Early Ceramic period (see discussion of projectile points, above). This particular group of dart points, which includes the aforementioned Gary var. LeFlore points as well as Williams, Fairland IV, Lange, Marshall, and Marcos types (see Figure 8-19a:3, Figure 8-20:2, 8, Figure 8-21:6, 13, and Figure 8-23:12), amounts to 46 percent of the Block A dart point sample; by comparison, the cluster of Block A Early Ceramic dart point types previously discussed totals 30 percent.

The dart points from Block A are generally resharpened (74.9 percent), but have considerably lower relative frequencies of serrated (16.0 percent), and beveled (12.6 percent) edges, along with relatively high frequencies of points with impact fractures (see Table 8-19 and Figure 8-22b:7, a heat-treated novaculite Marshall point from $40-50 \mathrm{~cm}$ bs with a broad impact fracture on the blade). While the incidence of 


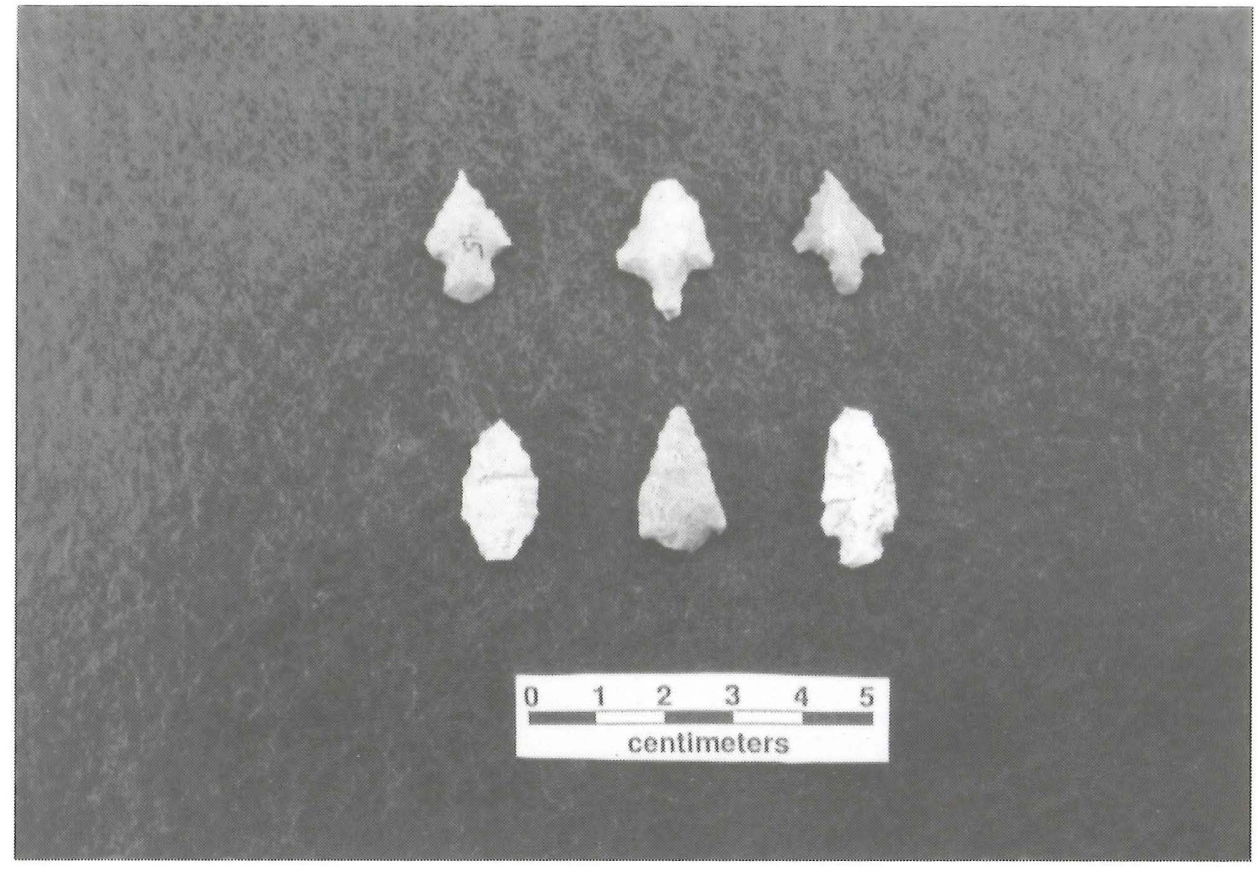

A

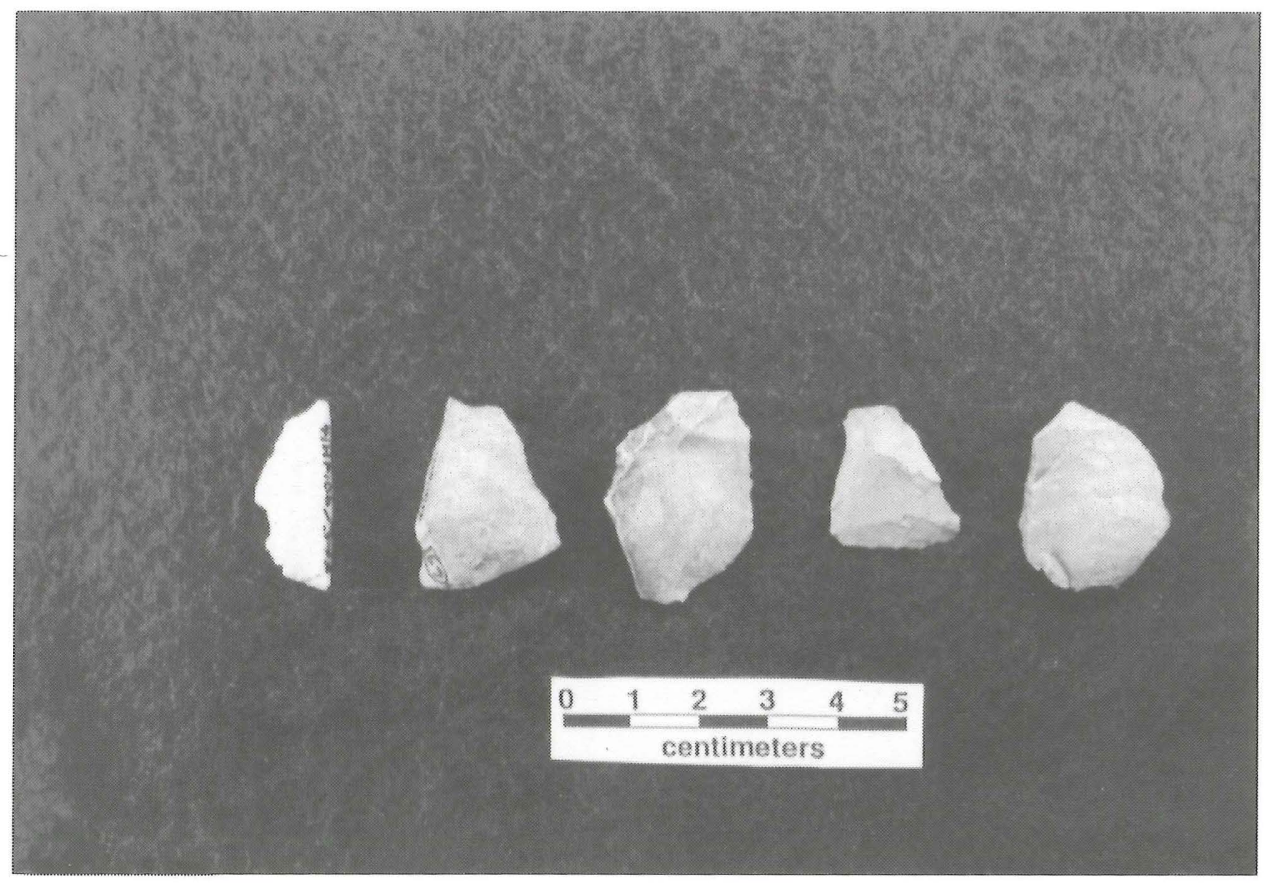

B

Figure 8-24. Arrowpoints and Flake Tools, Block A, levels 1-2: a, Class 01 (No. 1, 6), Class 02 (No. 3), Class 03 (No. 2), unidentified (No. 5), preform (No. 4); b, unilateral retouched piece (No. 3), alternate retouched piece (No. 1), distal retouched piece (No. 2, 4), distal/lateral retouched piece (No. 5). Provenience: a-1, 4 (29-1), a- 2 (41-2), a-3 (39-1), a-5 (32-1), a-6 (26-1), b-1 (36-2), b-3 (36-1), b-4 (30-1), b-5 (25-1) 
resharpening in the dart points from this part of the North rise suggests that the points were multifunctional tools that were repeatedly resharpened along their blade edges, the low numbers of discarded points with serrations (2-3 times lower than in the Late Archaic/Early Ceramic components in Blocks D and E) implies that efforts to extend the use-life of the points/knives were less extensive here in Late Archaic and Early Ceramic times than in other site contexts, and thus more dart points were apparently used strictly for projectiles. The Block A points have intermediate frequencies of basal and lateral grinding and, when present, these attributes tend to occur on the few Middle to Late Archaic point forms, such as the distinctively beveled Yarbrough type (see Figure 8-22:9).

Block A has a diversity of Early Caddoan arrowpoint forms, with classes 01 (Colbert), 05 (Alba), and 06 (Steiner) each represented by five to nine specimens (see Table 8-25). Figures 8-24 to 8-26 illustrate the range in arrowpoint styles in the upper $30 \mathrm{~cm}$ of the Midden 1 deposit on the North rise. The Class 02 arrowpoints (see Figure 8-25a:1-2, 8, 10, and 12) are also common, accounting for 20 percent of the arrows. The former three forms best represent the Early Caddoan stone tool use of the North rise. The frequency of arrowpoint preforms (see Figure 8-24a:4 and Figure 8-25b:6) also suggests that arrowpoints were manufactured on site during this occupation. The single Late Caddoan triangular arrowpoint was found in the first level in Midden 1.

Shaped flake tools in Block $\mathrm{A}(\mathrm{n}=24)$ are outnumbered by projectile points $8.8: 1$, and are thus 2-3 times more abundant than they are in nearby Blocks $\mathrm{D}$ and $\mathrm{E}$. The vertical distribution of shaped flake tools indicates that these kinds of tools are much more frequent in Late Archaic/Early Ceramic period contexts than they are in the Early Caddoan occupation, given projectile point/shaped flake tool ratios of 14.4:1 for the deposits between $0-20 \mathrm{~cm}$ bs and a ratio of $5.9: 1$ for the deposits from $30-60 \mathrm{~cm}$ bs (see Table 8-20). The most common shaped flake tools are side scrapers, end-side scrapers, bifacial knifes (see Figure 819b:2), and small adzes (Figure 8-27:4, 6, 8); the latter, including one of novaculite from $30-40 \mathrm{~cm} \mathrm{bs,}$ appears to be exclusively a Late Archaic to Early Ceramic tool form based on its distribution across the Hurricane Hill site (see Table 8-20). Early Caddoan shaped tools may include perforators and denticulates.

Expedient retouched and utilized flakes are abundant in both Late Archaic/Early Ceramic (see Figure 8-27:1-3, 5, 7, 9-10 and Figure 8-28:1, 5-9) and Early Caddoan assemblages from Block A (see Figure 8-24b, Figure 8-25b:1-5, and Figure 8-26:9-13, 15-16, 18-19), with projectile point-expedient flake tool ratios of 0.5:1 $(30-60 \mathrm{~cm}$ bs) and $0.7: 1(0-20 \mathrm{~cm} \mathrm{bs})$, respectively. Unilateral and bilateral utilized flakes are the primary expedient tools; distal and distal/lateral utilized flakes are also well-represented in both components in the block, while retouched flake tools (particularly unilateral and distal/lateral retouched pieces) are more common in the deeper excavation levels in Block A (see Table 8-21). Composite unifaces (i.e., unifacial tools with retouched and use-worn edges; see Figure 8-26:17) and bifacial thinning flakes with use wear (see Figure 8-26:15) also appear to represent Late Archaic/Early Ceramic flake tools.

The distribution of Block A blank/preforms in each thickness class suggests that all stages of biface knapping occurred in this part of the site (see Figure 8-15). The largest proportion of the Block A blank/preforms occur in the thicker blank/preform classes (with 55 percent ranging from 10.1-15.0 mm in thickness, and another 19 percent between 15.1-25 $\mathrm{mm}$ in thickness). This thickness data indicates that the majority of the ovoid blank/preforms were being knapped, and presumably broken, during initial and intermediate attempts at thinning the cobbles and larger pebbles of local quartzites, chert, and hematite (Figure 8-29:8-9, Figure 8-30:2, 4, 6-7, 10, and Figure 8-31:6-8), rather than during the final shaping and finishing of blank/preforms noted in Block D, although final and relatively thin blank-preforms are present in Late Archaic/Early Ceramic period contexts (see Figure 8-22a:1-4 and Figure 8-23:1-2). 


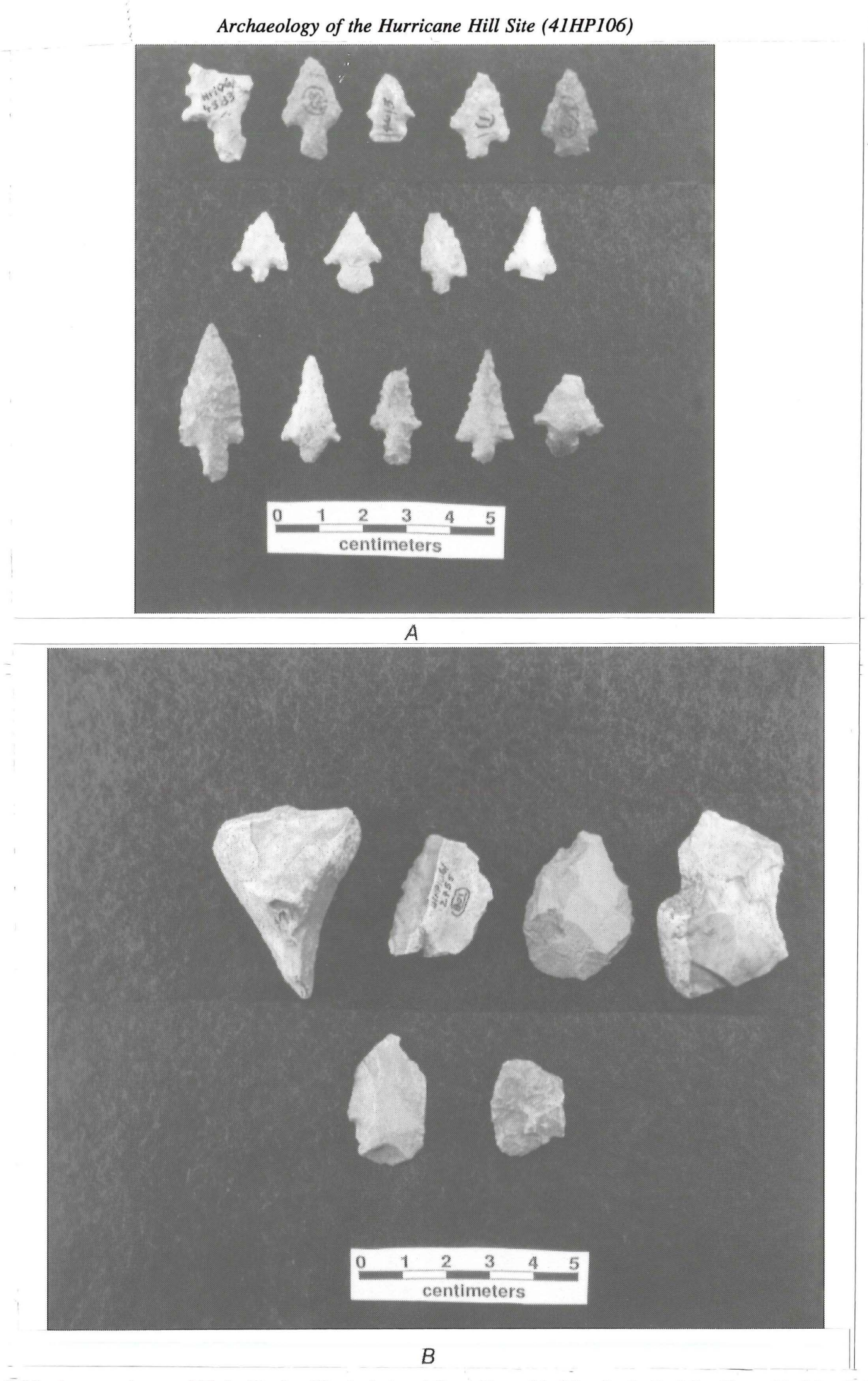

Figure 8-25. Arrowpoints and Flake Tools, Block A, level 2: a, Class 01 (No. 3, 5, 7, 14), Class 02 (No. 1-2, 8, 10, 12), Class 04 (No. 6), Class 05 (No. 4, 13), Class 06 (No. 11), unidentified (No. 9); b, distal utilized flake (No. 1, 3), distal retouched piece (No. 2), bilateral utilized flake (No. 45), arrowpoint preform (No. 6). Provenience: a-1 (252-2A), a-2 (249-2A), a-3 (257-2A), a-4 (246-2), a-5 (244-2B), a-6 (38-2), a-7, a-10 (45-2), a8, a-11 (27-2), a-9 (32-2), a-12 (39-2), a-13 (40-2), a-14 (36-2), b-1 (257-2), b-2 (242-2), b-3 (253-2), b-4 (2502), b-5 (35-2), b-6 (40-Fea. 4) 


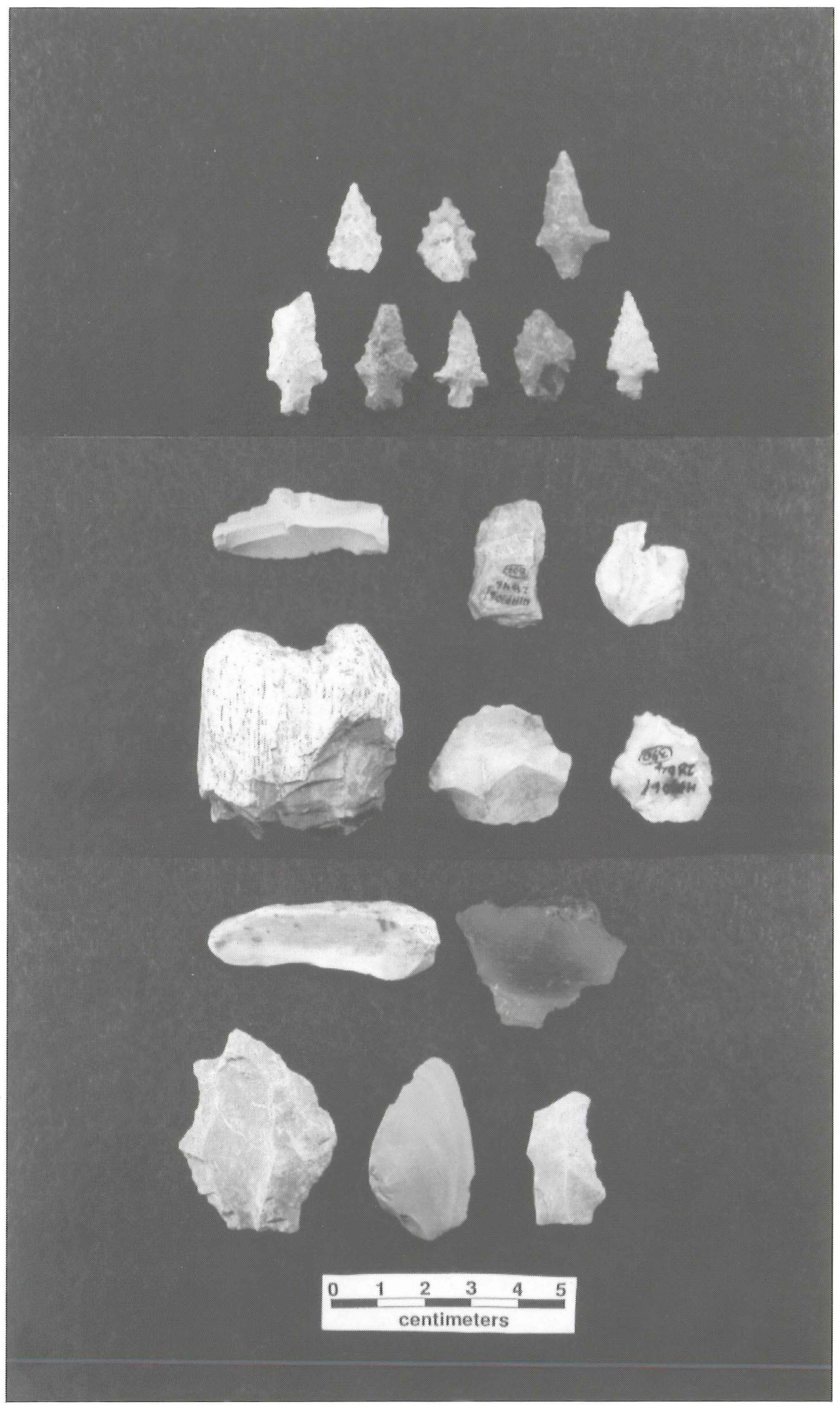

Figure 8-26. Arrowpoints and Flake Tools, Block A, level 3: Class 01 (No. 5), Class 02 (No. 4), Class 03 (No. 3 ), Class 05 (No. 6, 8), Class 06 (No. 1-2, 7), bilateral utilized blade (No. 9, 13), distal/lateral utilized flake (No. 10. 16), unilateral retouched piece (No. 11, 12, 18-19), end-side scraper (No. 14), utilized bifacial thinning flake (No. 15, 17). Provenience: 1 (UID unit-3), 2, 18 (37-3), 3 (28-3), 4 (44-2), 5 (40-Fea. 4), 6 (32-3), 7 (27-3), 8 (36-3), 9 (243-3), 10 (239-3), 11 (256-3), 12 (241-3), 13 (249-3), 14 (240-3), 15 (30-3), 16-17, 19 (40-3) 


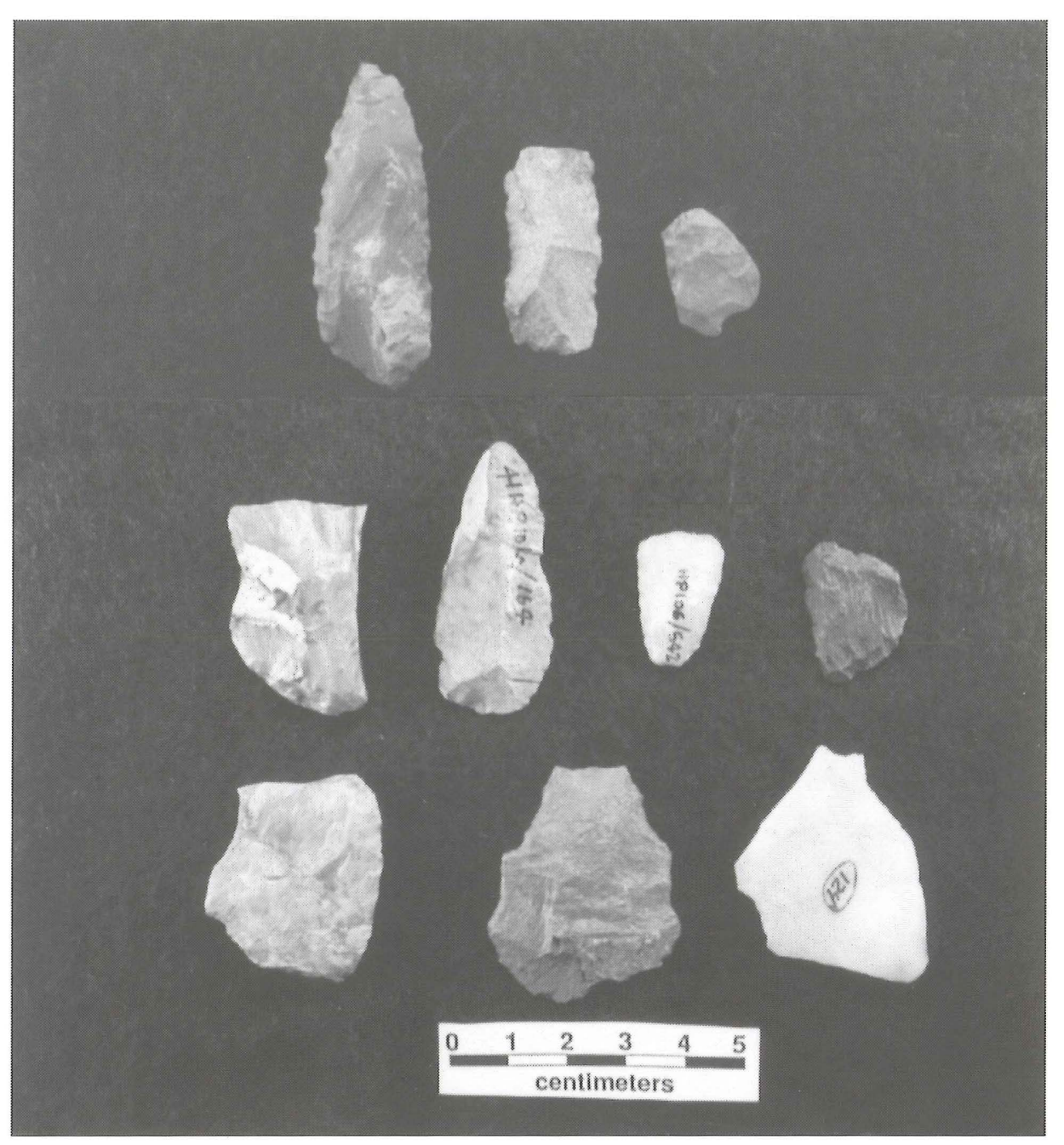

Figure 8-27. Flake tools, Block A, level 4: distal/lateral utilized flakes (No. 1, 2); unilateral retouched piece (No. 3, 5, 9); bilateral retouched piece (No. 10); end-side scraper (No. 4); small adze (No. 6); distal retouched piece (No. 7); side scraper (No. 8). Provenience: 1 (238-4), 2 (239-4), 3 (244-4), 4-5 (28-4), 6 (37-4), 7-8 (31-4), 9 (45-4), 10 (41-4).

Cores are more abundant in what are probably Late Archaic/Early Ceramic contexts in Block A on the North rise, as the highest frequencies of cores occur from $30-50 \mathrm{~cm}$ bs (see Table 8-22), but cores are also present in significant numbers in Early Caddoan contexts. This reflects the emphasis on production of large bifaces for tools and tool blanks at the Hurricane Hill site. Besides core fragments (see Figure 8-19b:1, 3) and tested cobbles (Figure 8-32:2), multiple platform flake cores (see Figure 8-29:7 and Figure 8-31:1, 34) and opposed platform cores (see Figure 8-30:3,9) occur in both Late Archaic/Early Ceramic and Early Caddoan contexts in Block A, as they do in Blocks D and E, while bifacial and discoidal cores are less frequent in the same contexts. Single platform and globular cores are present only in Late Archaic/Early Ceramic deposits (see Table 8-22). 


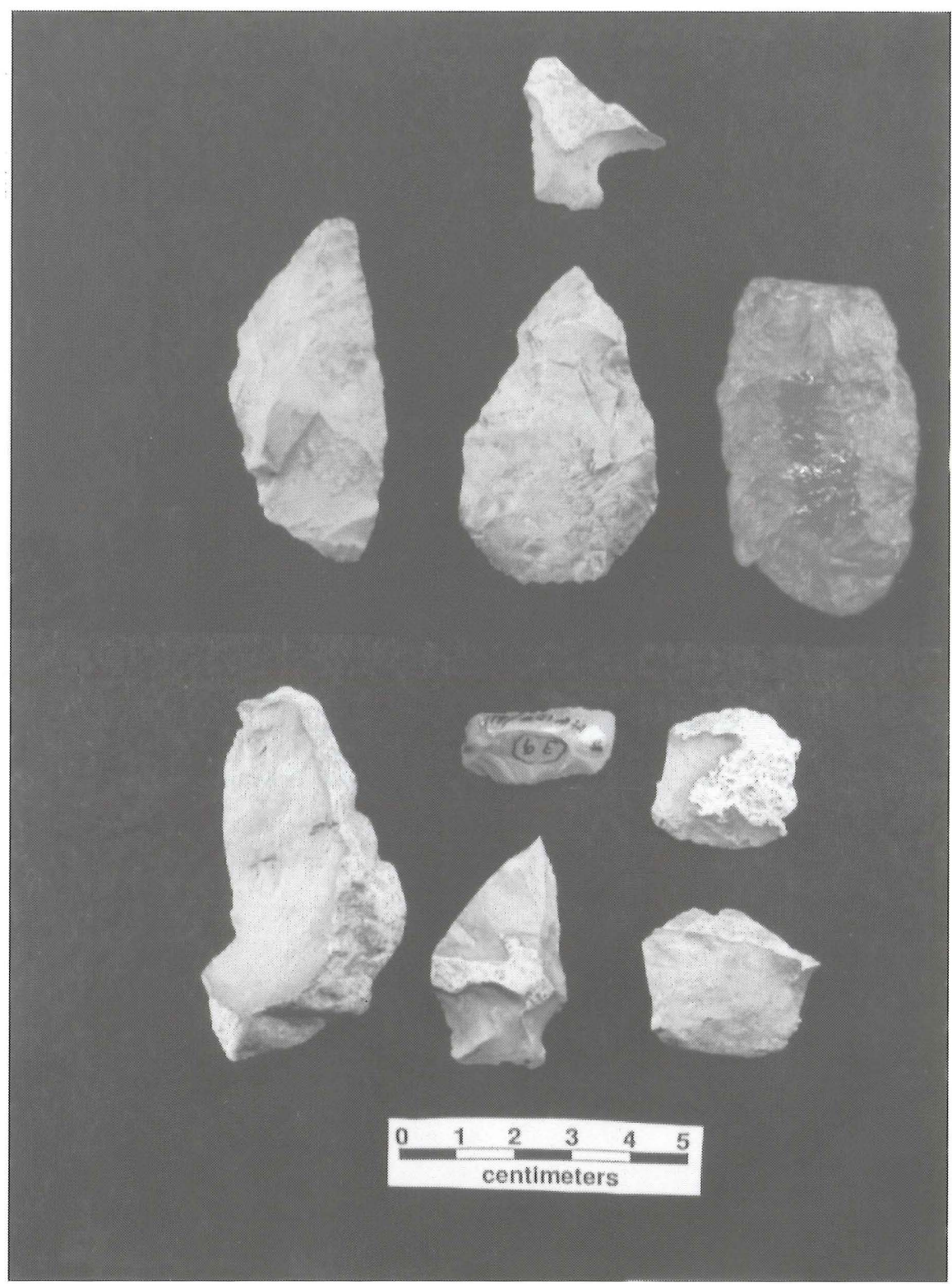

Figure 8-28. Flake Tools and Blank-Preforms, Block A, level 5: blank-preforms (No. 3-4), indeterminate bifacial tool (No. 2), bilateral utilized flake (No. 1), unilateral retouched piece (No. 5-6, 9), distal utilized flake (No. 7), distal/lateral retouched piece (No. 8). Provenience: 1-2 (242-5), 3 (241-5), 4 (257-5), 5-7 (29-5), 8 (26-5), 9 (415). 


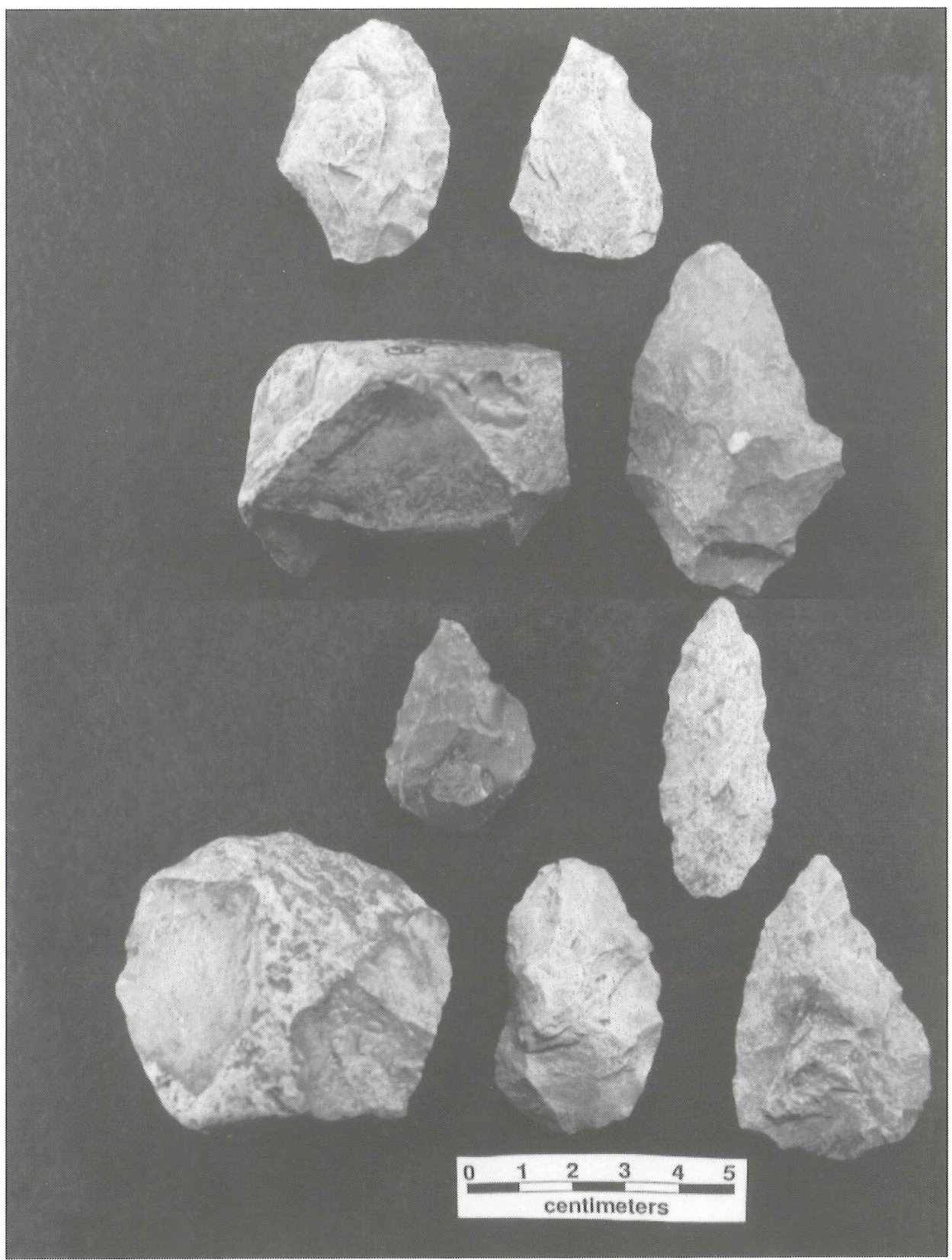

Figure 8-29. Cores and blank-preforms, Block A, level 2: blank-preforms (No. 1-2, 4-6, 8-9); multiple platform core (No. 7); core fragment (No. 3). Provenience: 1 (25-2), 2 (36-2), 3 (30-2), 4 (38-2), 5 (248-2), 6 (243-2), 7, 9 (253-2), 8 (257-2). 


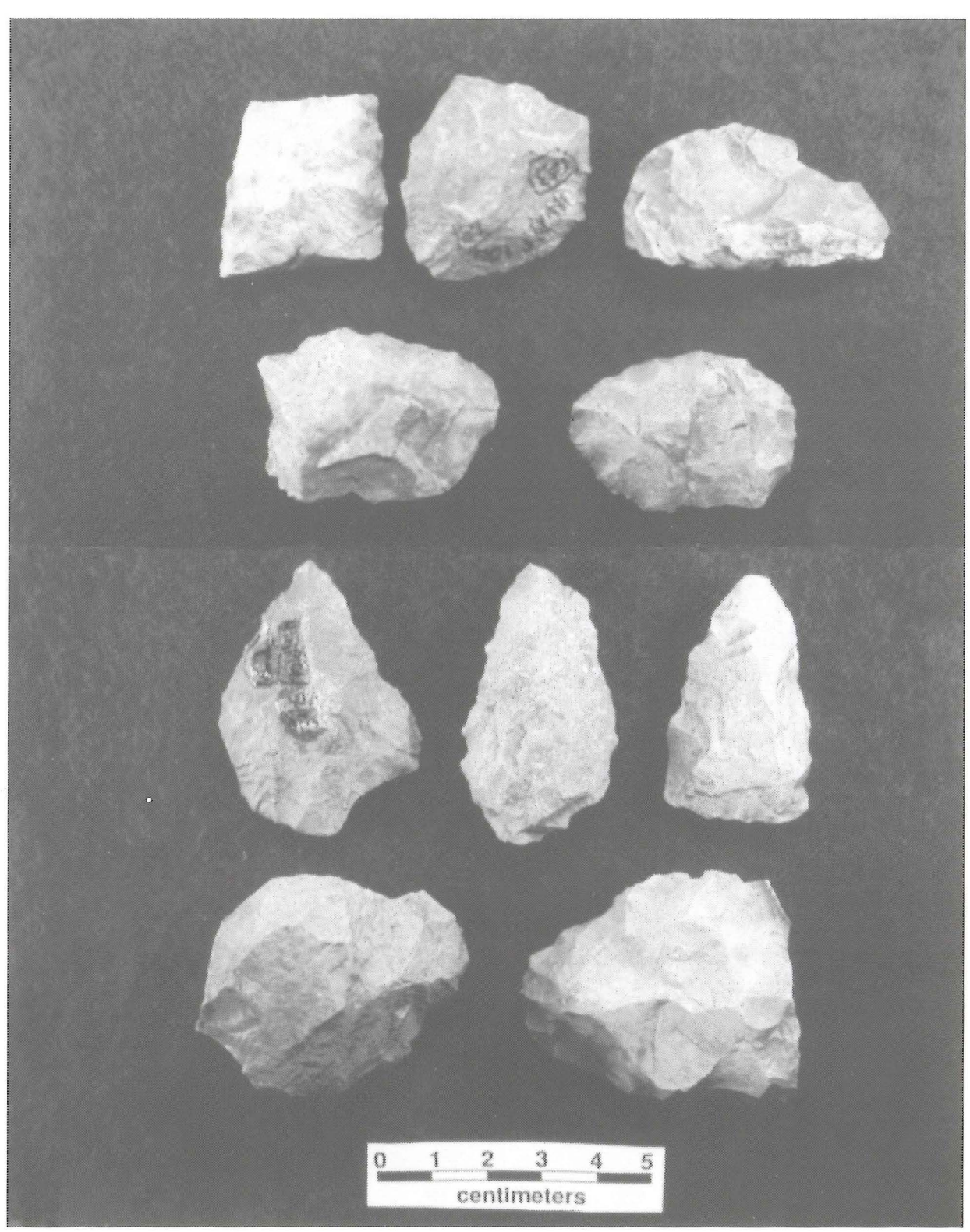

Figure 8-30. Cores, blank-preforms, and bifacial tools, Block A, level 3: blank-preforms (No. 2, 4, 6-7, 10); indeterminate bifacial tool (No. 1); bifacial knife (No. 5); Adze (No. 8); opposed platform core (No. 3, 9). Provenience: 1 (32-3), 2 (29-3), 3-4 (27-3), 5 (36-3), 6 (255-3), 7, 10 (256-3), 8 (238-3), 9 (251-3). 


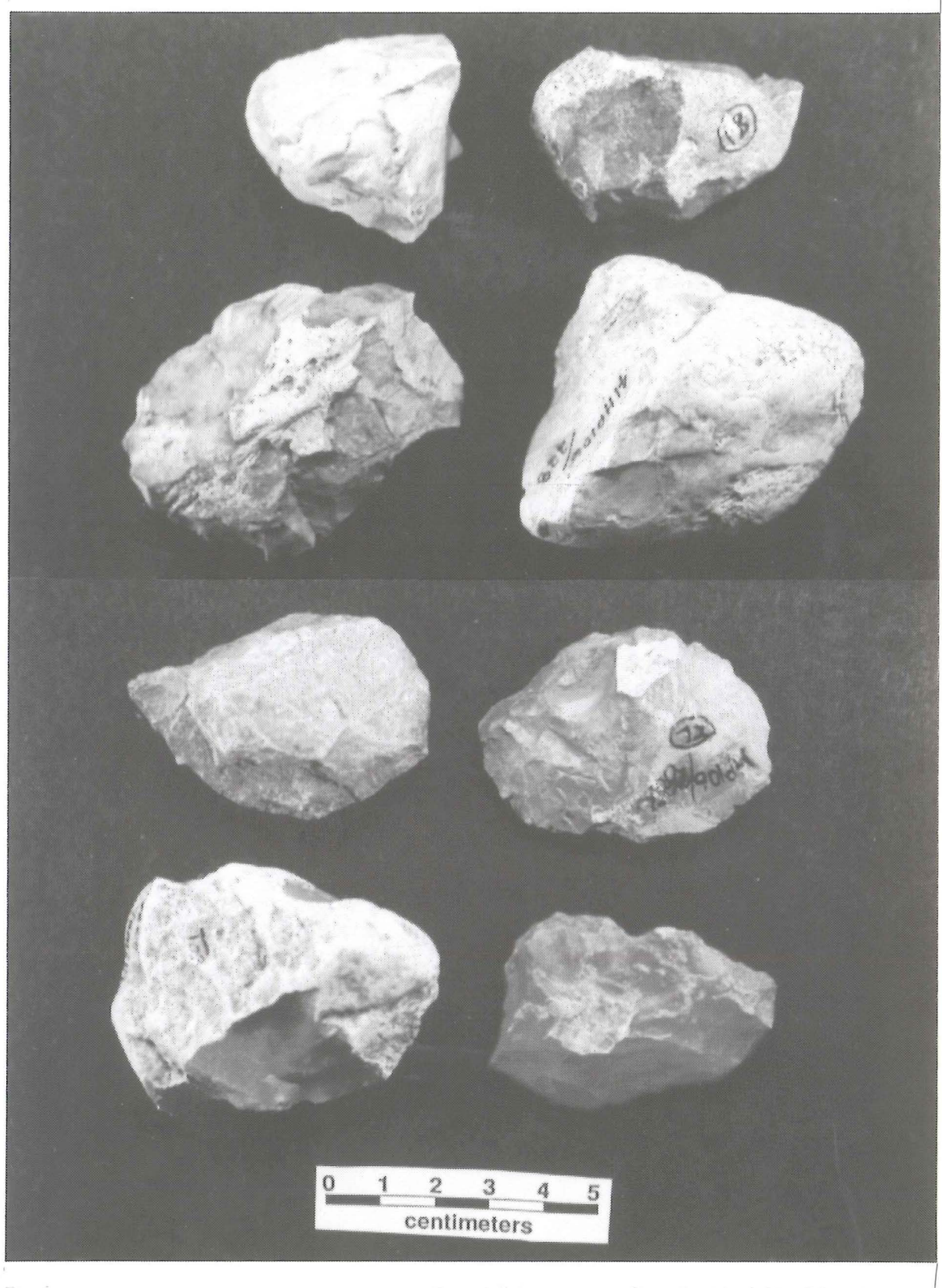

Figure 8-31. Cores and blank-preforms, Block A, levels 4 and 7: blank-preforms (No. 5-6, 8); tested cobble (No. 7); multiple platform core (No. 1, 3-4); single platform core (No. 2). Provenience: 1 (36-4), 2 (40-4), 3 (43-4), 4 (32-4), 5 (257-4), 6 (240-4), 7 (247-7A0, 8 (245-4). 


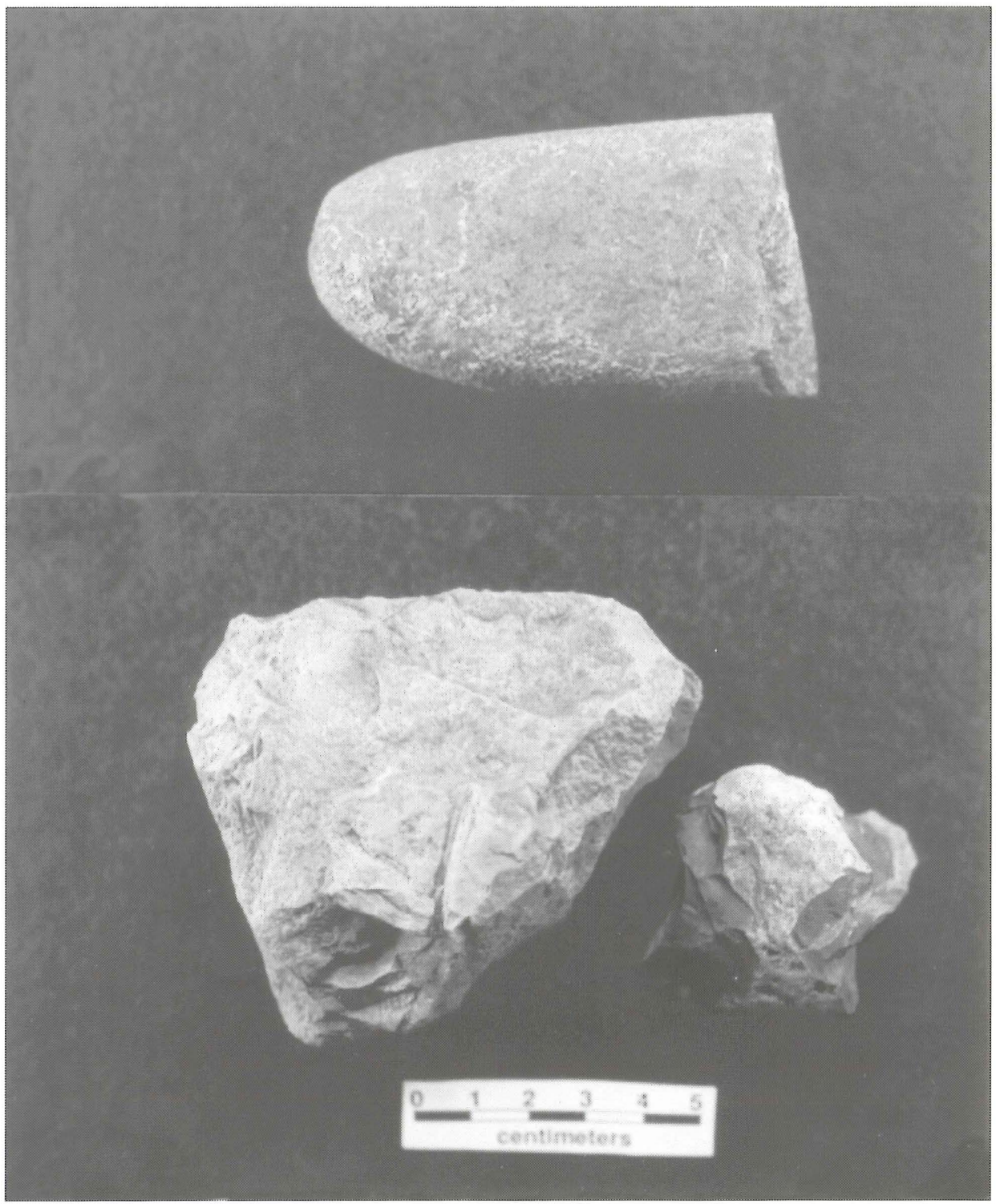

Figure 8-32. Celts and cores, Block A: celt (No. 1), opposed platform core (No. 2), multiple platform core (No. 3). Provenience: 1 (244-3), 2 (35-4), 3 (40-2).

Non-local lithic raw materials occur in both Late Archaic/Early Ceramic Primary Midden and Early Caddoan contexts in Block A on the crest of the North rise. A unimodal peak in the vertical distribution of tools made from non-local materials (i.e., more than 61 percent are present between $20-40 \mathrm{~cm}$ bs), and the types of tools of these materials (i.e., dart points, arrowpoints, blank/preforms, indeterminate bifacial tools, scrapers, and retouched pieces), indicate that they are associated with both the Late Archaic/Early Ceramic and Early Caddoan components (see Figure 8-16).

However, non-local tools are better represented in the Late Archaic/Early Ceramic period deposits. Midden deposits between $20-40 \mathrm{~cm}$ contain the following tools $(n=24)$ made of non-local materials: eight dart points, nine retouched pieces, five utilized flakes, one end scraper, and one end-side scraper. In deposits between 0-20 cm, non-local tools $(\mathrm{n}=9)$ include one arrowpoint, four utilized flakes, a retouched piece, and three dart points. 
In fact, the vertical distribution of non-local tools in Block A suggests a declining temporal use of non-local raw materials after the Late Archaic/Early Ceramic period occupation, similar to the pattern of raw material use detected by Fields et al. (1997:Figure 42) from a number of sites at Cooper Lake. About 7 percent of the dart points $(n=175)$ from Block $A$ are made of non-local materials, compared to 5.7 percent of the arrowpoints $(n=35)$ and none of the six arrowpoint preforms. Three of the indeterminate bifacial tools and a single blank/preform from $30-60 \mathrm{~cm}$ bs, in Late Archaic/Early Ceramic period contexts, are on nonlocal materials (two of gray chert, and one each of novaculite and Big Fork chert).

Novaculite and gray chert are the two preferred non-local raw materials for tools, both accounting for more than 35 percent of the Block A sample of tools made of non-local lithics. Jasper is noticeably abundant compared to the non-local tool samples from Blocks $\mathrm{D}$ and $\mathrm{E}$ (where it is absent), as it comprises 12.5 percent of the non-local tools, suggesting differences in procurement through time and by occupation area; jasper also is a common non-local material in Block B/C on the South rise, also in a Late Archaic/Early Ceramic context. Big Fork chert--black and green varieties--comprise 14.6 percent of the nonlocal tools in Block A.

The Block A lithic debris from the 1/4-inch sample is characterized by high percentages of large cortical flakes, as are the archaeological deposits in the other areas of the Hurricane Hill site (see Figure 817). Fine-screen and flotation samples indicate that the Block $A$ lithic debris in aggregate resembles the samples from Block F and the Southwest rise. In these areas, the lithic debris contains lower proportions of large flakes (5-25 percent) than in Blocks D, E, and B/C and much higher amounts of non-cortical flakes (80-90+ percent) (see Figure 8-17). This suggests a change in emphasis from biface reduction from core and larger bifacial blank/preforms to the production of tools from smaller blank/preforms, probably many of which began from flakes rather than cores. Fine-screen samples from Block A (see Appendix XVI) point to the change in reduction strategies having occurred between the Late Archaic/Early Ceramic period and Early Caddoan occupations on the North rise (see Figure 8-18), based on the high proportions of large flakes in Primary Midden deposits (i.e., levels 4-7).

Approximately 1.2 percent of the Block A tools are ground stone tools. The most abundant ground stone tools include manos, hammerstones, and pitted stones, as well as two metates and a celt from 20-30 cm bs (see Figure 8-32:1; see also Appendix X). Outside of Block A on the North rise and Block D, manos (either unifacial or bifacial) or pitted stones are uncommon, suggesting that certain grinding and pounding activities were spatially (and perhaps temporally) concentrated in Midden 1. Local quartzites were the preferred raw material for all the ground stone tools, with the exception of one mano and pitted stone made from a dense ferruginous sandstone and the celt from a gray siltstone.

Eleven of the 13 ground stone tools are from depths of $10-40 \mathrm{~cm}$ bs in Midden 1 or just beneath that zone, and are likely associated with the Early Caddoan component in Midden 1. Only one hammerstone was found in deeper archaeological deposits, between $40-45 \mathrm{~cm}$ bs, and this can be associated with the Late Archaic/Early Ceramic PrimaryMidden.

Over 5900 fire-cracked rocks of coarse-grained quartzite and sandstone (FCR) weighing $68.3 \mathrm{~kg}$ were recovered in the Block A excavations in the Primary Midden and Midden 1 deposits, more than 94 percent of which by weight were from midden rather than feature contexts (Table 8-26). The FCR was most abundant between $20-50 \mathrm{~cm}$ bs, generally considered to be Late Archaic/Early Ceramic contexts. The overall FCR density was $1.6 \mathrm{~kg}$ per $\mathrm{m}^{2}, 2$ times lower than in the Primary Midden deposits outside of Block A on the North rise.

The ratio of the number of FCR to FCR weight from Block A is 0.0114 (i.e., the mean weight of a piece of FCR is $0.0114 \mathrm{~kg}$ ). Considering the number/weight relationships of the FCR in these midden deposits to the Primary Midden deposits sampled in Blocks D and E, the average FCR weights are consistent between the two different contexts (and with the Southwest rise), but larger than the FCR from the predominantly Middle Caddoan occupation on the South rise. This suggests that the FCR is a product of multiple cooking events that reduced the coarse-grained quartzite and sandstone cobbles to small pieces and spalls (see Leach et al. 1998). 
Table 8-26. Weight and frequency of daub, burned clay, and fire-cracked rock, Block A and Block A extension.

\begin{tabular}{|c|c|c|c|c|c|c|}
\hline Provenience & Daub (g) & Daub (\#) & Burned Clay (g) & Burned Clay (\#) & FCR $(\mathrm{kg})$ & FCR (\#) \\
\hline $\begin{array}{l}\text { Surface } \\
\text { lv. } 1 \\
\text { Iv. } 2 \\
\text { lv. } 3 \\
\text { lv. } 4 \\
\text { lv. } 5 \\
\text { Iv. } 6\end{array}$ & $\begin{array}{l}-- \\
79.3 \\
406.2 \\
270.0 \\
138.9 \\
55.4 \\
23.6\end{array}$ & $\begin{array}{l}-- \\
219 \\
1376 \\
794 \\
259 \\
93 \\
29\end{array}$ & $\begin{array}{l}0.2 \\
802.5 \\
3353.6 \\
1782.3 \\
1097.7 \\
484.0 \\
61.4\end{array}$ & $\begin{array}{l}2 \\
911 \\
4367 \\
2133 \\
932 \\
400 \\
102\end{array}$ & $\begin{array}{l}+ \\
4.3 \\
8.9 \\
11.2 \\
25.4 \\
11.5 \\
1.4\end{array}$ & $\begin{array}{l}4 \\
425 \\
1274 \\
1363 \\
1551 \\
1082 \\
175\end{array}$ \\
\hline $\begin{array}{l}\text { Fea. } 4 \\
\text { Fea. } 34 \\
\text { Fea. } 96 \\
\text { Fea. } 104\end{array}$ & $\begin{array}{l}42.6 \\
148.2 \\
-- \\
--\end{array}$ & $\begin{array}{l}150 \\
18 \\
-- \\
--\end{array}$ & $\begin{array}{l}482.1 \\
206.8 \\
-- \\
--\end{array}$ & $\begin{array}{l}614 \\
52 \\
-- \\
--\end{array}$ & $\begin{array}{l}0.5 \\
3.7 \\
+ \\
+\end{array}$ & $\begin{array}{l}64 \\
7 \\
1 \\
1\end{array}$ \\
\hline Totals & 1164.2 & 2938 & 8280.8 & 9516 & 68.3 & 5985 \\
\hline
\end{tabular}

Both daub and burned clay pieces are common in the Block A excavations in Midden 1, weighing $1164.2 \mathrm{~g}$ and $8280.8 \mathrm{~g}$, respectively (see Table 8-26). The daub and burned clay are particularly abundant between $0-40 \mathrm{~cm}$ bs, and in Features 4 and 34, and these are primarily considered by-products of the burning of clay in the soil surrounding features (probably shallowly buried) utilized for the heating and cooking of plant and animal foods. Unlike the daub from Structures A and B on the South rise, the distribution of the daub from Block A suggests it is not from the clay plastering or lining of structure walls, but clay with grass and stick impressions obtained from clay-lined hearths and cooking features that were outside of the Early Caddoan period Structure D.

\section{South Rise Assemblages, Blocks B/C}

Dart points account for 13 percent of the tools, blank/preforms, and cores from Block B/C on the South rise, compared to a range of 15-28 percent in Blocks A, D, and E on the North rise, and more than 30 percent (although the sample is small) in middens and features on the Southwest rise. However, the darts are well-distributed throughout the archaeological deposits on the relatively stable South rise--around and under the Middle Caddoan structures--particularly in levels $3(20-30 \mathrm{~cm}$ bs) and $5(40-50 \mathrm{~cm} \mathrm{bs})$ (Table 8-27). More than 96 percent of the arrowpoints $(\mathrm{n}=46)$ occur between $0-30 \mathrm{~cm}$ bs, and they are particularly wellrepresented in surficial (i.e., $0-10 \mathrm{~cm}$ bs) contexts (see Table 8-27). The two arrowpoints from level 5 were probably moved downward in the deposit as a result of the aboriginal excavation of pits and posts during the Middle Caddoan period construction and use of several structures on the South rise.

Among the 128 Block B/C dart points, the contracting stem Gary forms are most abundant, especially the var.LeFlore (classes 02 and 03) specimens that are estimated to date ca. 1700-2400 B.P. These two point classes (Figure 8-33:3-11, 13-14, 16, Figure 8-34:1-3, 6-7, 9-10, and Figure 8-35:1-3, 7, 12) account for 48 percent of the dart points, and with the other Late Archaic/Early Ceramic point forms (classes 10 and 13; see Figure 8-33:2 and Figure 8-34:6), as a group they represent 56 percent of the dart point sample from the South rise. By comparison, these Late Archaic/Early Ceramic point forms from Block A amount to 45.7 percent of the darts (see Table 8-25). These relatively broad contracting stem points occur throughout the archaeological deposits (see Tables 8-27), with the highest relative frequencies (55-56 percent) between $20-40 \mathrm{~cm}$ bs. 
Table 8-27. Distribution of Arrow and Dart Points in Block $\mathbb{B} / \mathrm{C}$

\begin{tabular}{lllllllll}
\hline Class & lv. 1 & lv. 2 & lv. 3 & 1v. 4 & 1v. 5 & Features & IND & Total \\
\hline
\end{tabular}

\section{ARROW POINTS}

\begin{tabular}{lllllllll}
01 & 3 & 5 & - & - & - & - & - & 8 \\
02 & 5 & 4 & 1 & - & 1 & - & - & 11 \\
03 & 5 & 1 & 4 & - & 1 & - & - & 11 \\
04 & 2 & - & - & - & - & - & - & 2 \\
05 & 5 & 2 & 3 & - & - & - & - & 10 \\
07 & - & 1 & - & - & - & - & - & 1 \\
08 & 1 & - & - & - & - & - & - & 1 \\
09 & 1 & - & - & - & - & - & - & 1 \\
10 & - & 1 & - & - & - & - & - & 46 \\
\hline \multirow{2}{*}{ Total Arrows } & 22 & 14 & 8 & - & 2 & - & - & \\
\hline
\end{tabular}

\section{DART POINTS}

$\begin{array}{lllllllll}01 & - & 4 & 4 & - & 2 & - & - & 10 \\ 02 & 2 & 2 & 8 & 3 & 1 & - & - & 16 \\ 03 & 4 & 10 & 13 & 6 & 10 & 2 & 1 & 46 \\ 05 & 1 & - & 1 & 1 & - & - & - & 3 \\ 06 & - & 7 & 8 & 2 & 3 & - & - & 20 \\ 07 & 1 & - & - & - & - & - & - & 6 \\ 08 & - & - & 2 & - & 4 & - & - & 4 \\ 09 & 1 & - & - & 1 & 2 & - & - & 2 \\ 10 & - & - & - & - & 2 & - & - & 2 \\ 12 & 2 & - & - & - & 3 & 1 & - & 5 \\ 13 & - & 1 & - & 1 & - & - & - & 1 \\ 15 & - & - & 1 & 1 & 3 & - & - & 3 \\ 17 & - & 1 & - & 1 & 1 & - & - & 128 \\ 18 & - & - & - & - & 1 & - & - & \\ 20 & - & 1 & 1 & - & 1 & - & & \end{array}$

IND=indeterminate level

Middle to Late Archaic point types comprise about 11 percent of the dart points (see Figure 834:12-13 and Figure 8-35:10,13,17), and they are found predominantly between $30-50 \mathrm{~cm}$ bs, in deposits underneath the Middle Caddoan structures (see Table 8-27). Late Archaic forms (classes 06 and 20), including the thick and broad contracting stem Gary var. Gary form (see Figure 8-34:4-5 and Figure 8-35:5, 20), are well-represented in the block excavations, accounting for 18 percent of the darts, and these occur mainly between $10-30 \mathrm{~cm}$ bs (in mixed contexts). Furthermore, Early Ceramic period Gary var. Camden, Kent, and Ensor dart points (Figure 8-36:21, 26-27; see also Figure 8-33:12, 16), amounting to about 15 percent of the dart point sample, also are not apparently distributed in anything like a consistent vertical (i.e., percentage stratigraphy [Lyman et al. 1998:243]) or stratigraphic order in the Block B/C excavations.

The dart points from Blocks $\mathrm{B} / \mathrm{C}$ are commonly resharpened (64.1 percent), although less frequently than in the North and Southwest rise dart point assemblages, and they are infrequently serrated (13.3 percent) or beveled (7.8 percent). Furthermore, there is a low frequency of points with impact fractures (see Table 8-19). The regularity in which dart points from the South rise were resharpened along their blade 


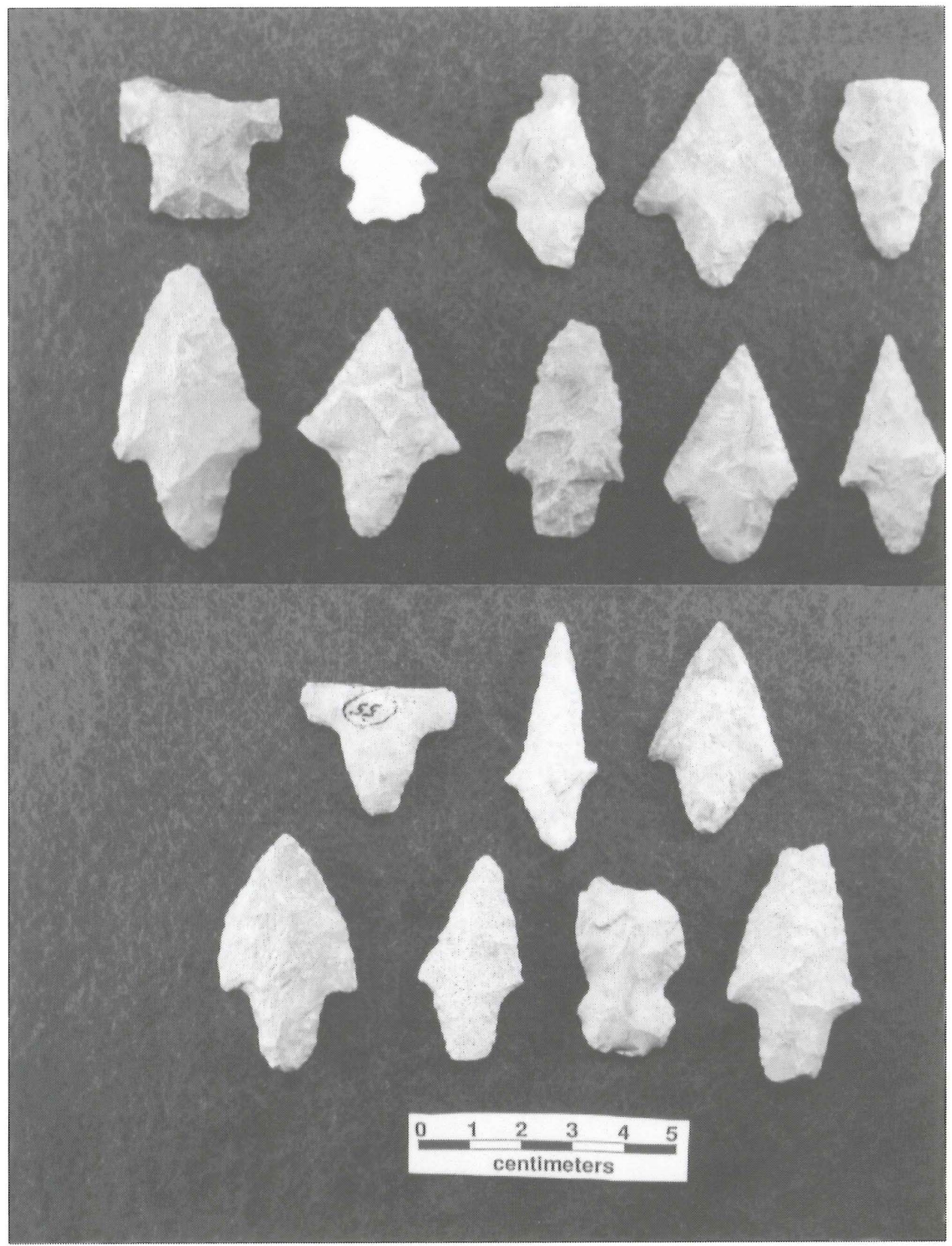

Figure 8-33. Dart Points, Block B/C, level 3: Class 01 (No. 12), Class 02 (No. 3, 7-8, 10-11, 15, 17), Class 03 (No. 4-6, 9, 13-14), Class 10 (No. 2), Class 15 (No. 16), Class 20 (No. 1). Provenience: 1 (133-3B), 2 (106-3B), 3 (110-3B), 4 (124-3B), 5 (175-3B), 6 (112-3B), 7 (143-3B), 8 (62-3B), 9 (149-3B), 10 (120-3B), 11 (156-3B), 12 (105-3B), 13 (163-3A), 14 (133-3A), 15 (136-3A), 16 (134-3A), 17 (109-3A) 


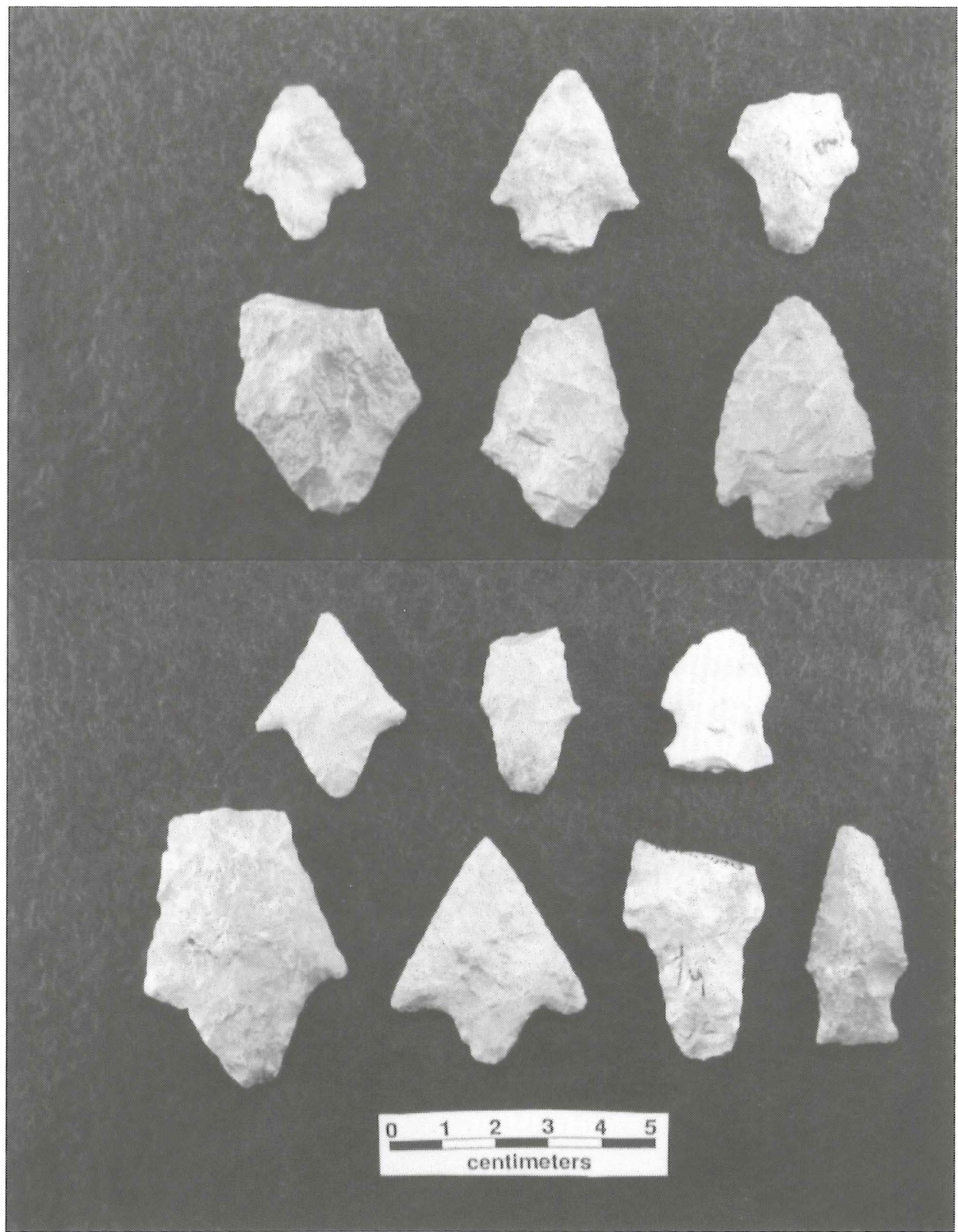

Figure 8-34. Dart Points, Block B/C, level 4: Class 02 (No. 1-3, 8), Class 03 (No. 7, 10-11), Class 06 (No. 4-5), Class 09 (No. 12), Class 13 (No. 6), Class 15 (No. 9), Class 17 (No. 13). Provenience: 1 (142-4A), 2 (105-4A), 3 (158-4A), 4 (144-4A), 5 (171-4A), 6 (67-4A), 7 (65-4B), 8, 10 (108-113-4A/4B), 9 (205-4B), 11 (169-4B), 12 (52-4B), 13 (Zone $2 / 3$ ) 


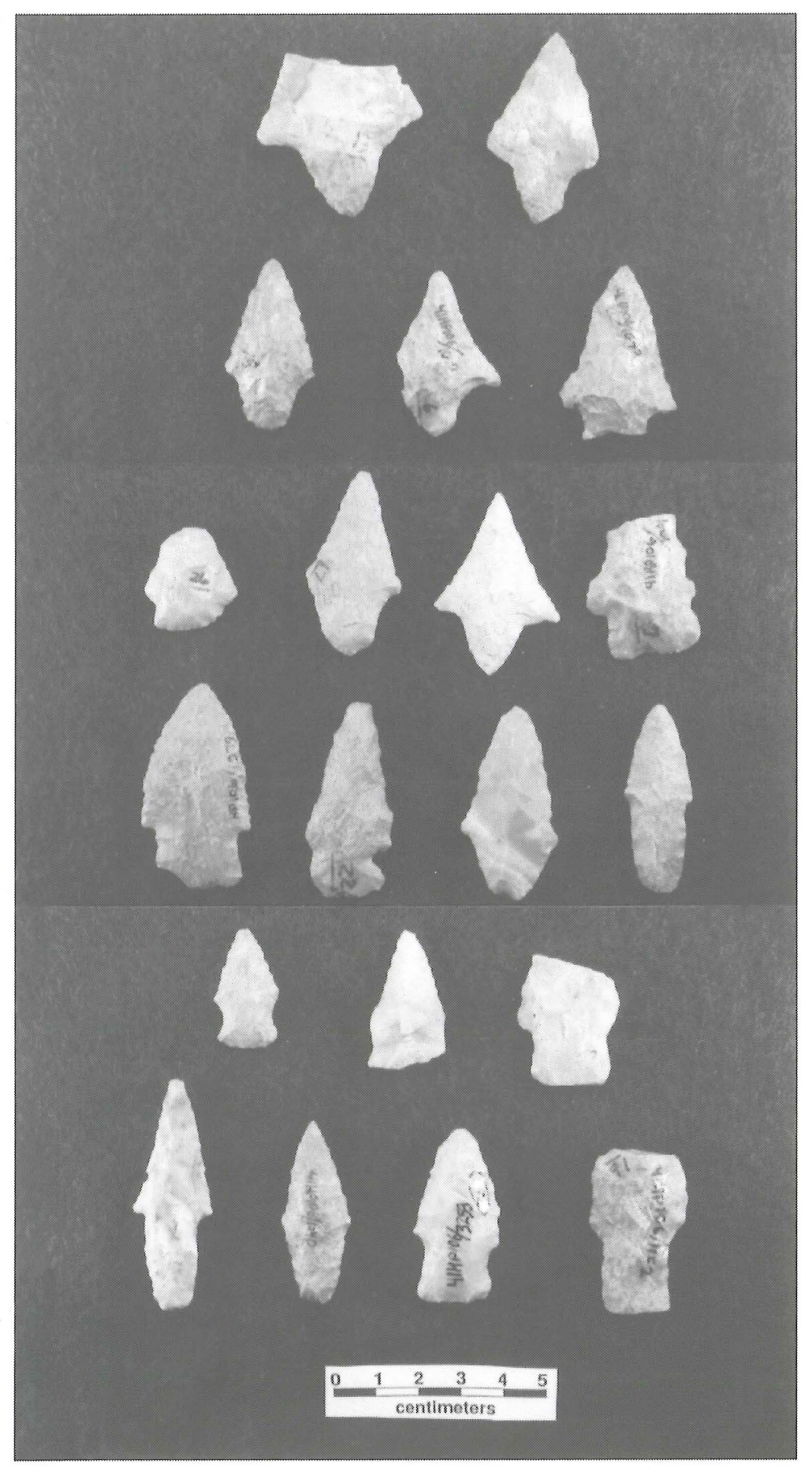

Figure 8-35. Dart Points, Block B/C, level 5: Class 01 (No. 8, 18), Class 03 (No. 1-3, 7, 12), Class 06 (No. 5), Class 08 (No. 4), Class 09 (No. 13, 17), Class 12 (No. 6, 9, 16, 19), Class 15 (No. 11, 14-15), Class 18 (No. 10), Class 20 (No. 20). Provenience: 1 (65-5B), 2 (173-5B), 3 (57-5B), 4 (55-5B), 5, 16 (59-5B), 6 (48-5A), 7 (57$5 \mathrm{~A}), 8(192-5 \mathrm{~A}), 9(59-5 \mathrm{~A}), 10$ (55-5A), 11 (56-5A), 12 (133-5A), 13 (116-5A), 14 (174-5B), 15 (101-5B), 17 (143-5B), 18 (55-5B), 19 (175-5B), 20 (49-5B) 


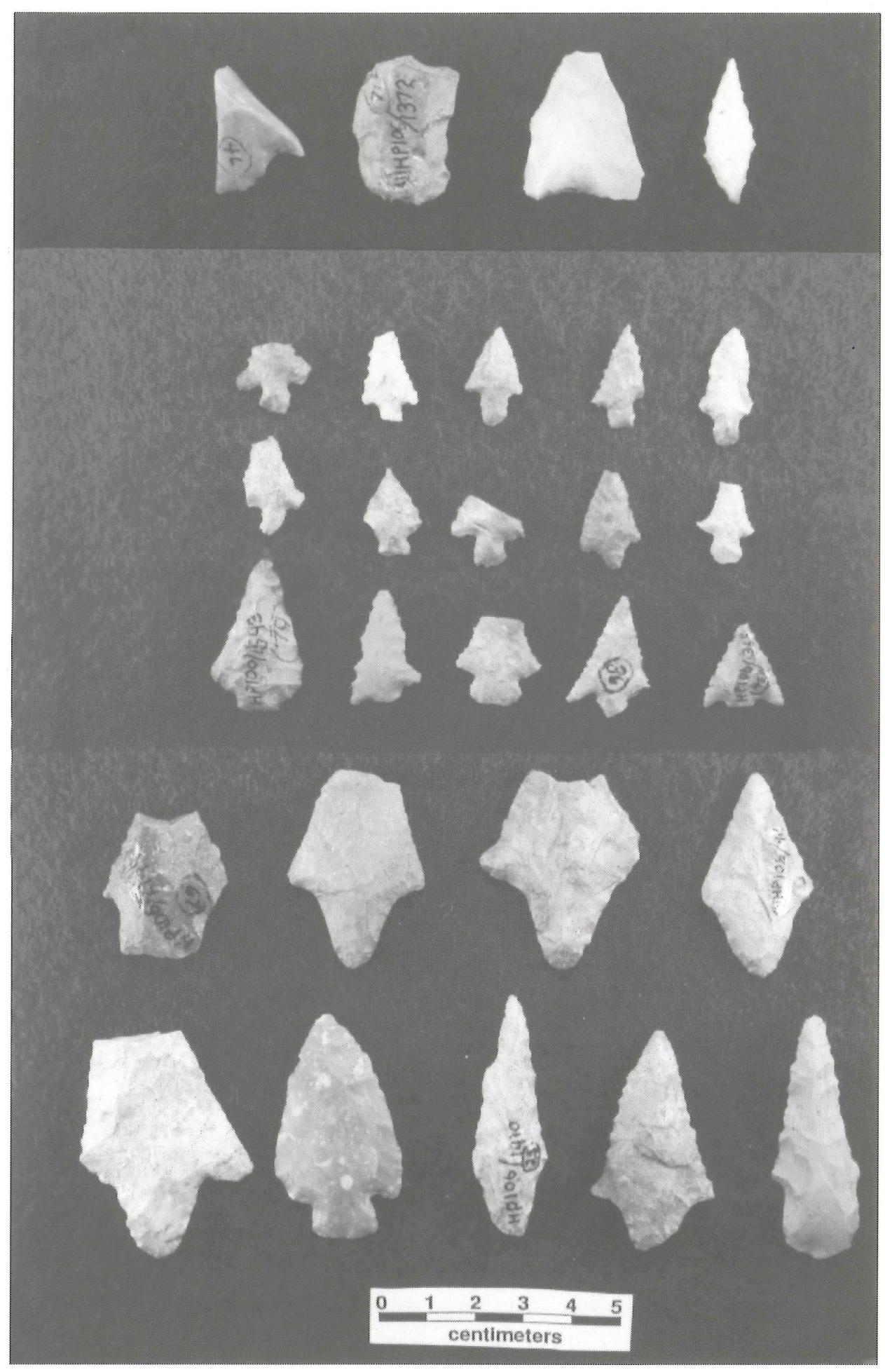

Figure 8-36. Flake Tools, Arrowpoints, and Dart Points, Block B/C, level 2: notch (No. 1), distal utilized flake (No. 2), distal/lateral retouched piece (No. 3), unifacial perforator (No. 4), arrowpoints: Class 01 (No. 5, 11-12, 14, 17), Class 02 (6-7, 9-10), Class 03 (No. 13), Class 05 (No. 8), Class 07 (No. 19), unidentified (No. 15-16, 18), dart points: Class 01 (No. 21, 26-27), Class 03 (No. 23-24), Class 13 (No. 25), Class 17 (No. 28 ), Class 20 (No. 20). Provenience: 1 (167-2), 2, 7 (174-2), 3, 18, 22 (234-2), 4 (71-2), 5 (99-2), 6 (68-2), 8 (184-2), 9 (1362), 10 (137-2B), 11 (187-2B), 12 (105-2), 13 (231-2), 14 (58-2), 15 (176-2B), 16, 20 (141-2), 17 (120-2B), 19 (188-2), 21 (197-2), 23 (59-2), 24 (113-2A), 25, 28 (55-2), 26 (133-2), 27 (111-2A) 
edges suggests that they were multi-functional tools, but like the darts from Block A, the low numbers of discarded points with serrations (more than three times lower than in the Late Archaic/Early Ceramic components in Blocks D and E) implies that efforts to extend the use-life of the points/knives were much less extensive here than in other site contexts. The points were apparently used more often as projectiles than as multi-functional tools. The Block $\mathrm{B} / \mathrm{C}$ points also have low amounts of basal and lateral grinding (see Table 8-19).

There is an impressive diversity of arrowpoint forms in the Middle Caddoan component in Block $\mathrm{B} / \mathrm{C}$ on the South rise. Classes 02 (Bonham), 03 (Perdiz), 05 (Alba), and 01 (Colbert) are represented by eight or more specimens (Figure 8-37a:1-2, 4-8, 10, 12-14, 16-17 and Figure 8-38b; see also Figure 836:5-14, 17), and between them they account for 87 percent of the arrowpoints (see Table 8-25). Although the Bonham and Perdiz (as well as Class 04, the Bassett type; see Figure 8-37a:11, 15) points are thought to be diagnostic of the Middle Caddoan period occupation at Hurricane Hill, there is no stratigraphic separation between them and the Colbert and Alba types, more common between ca. A.D. 900-1300 at Cooper Lake Caddoan sites (Fields et al. 1997). The few arrowpoint preforms from the South rise also suggests that arrowpoints were manufactured on site during the Middle Caddoan period.

Shaped flake tools $(n=29)$ in Block $B / C$ on the South rise are particularly well-represented compared to the Late Archaic/Early Ceramic and Early Caddoan components on the North rise. They are only outnumbered by projectile points $6: 1$, a ratio about 2-4 times greater than in Blocks D and E, and comparable to the Late Archaic/Early Ceramic tool assemblage in Block A on the crest of the North rise. They are also more abundant on the South rise in Late Archaic/Early Ceramic period contexts than they are in Middle Caddoan contexts, based on projectile point/shaped flake tool ratios of 4.9:1 $(30-50 \mathrm{~cm} \mathrm{bs})$ and 6.1:1 (0-20 cm bs), respectively (see Table 8-20).

The most common shaped flake tools are end scrapers, notches/spokeshaves, and end-side scrapers; (see Table 8-20). The notch/spokeshave flake tool (see Figure 8-36:1) appears to be restricted primarily to the Middle Caddoan component, while the scrapers occur in both occupations (Figure 8-39a:3). Other possible Middle Caddoan flake tools include unifacial perforators of novaculite (see Figure 8-36:4) and drills (see Figure 8-37b:2).

Expedient retouched and utilized flakes are also quite abundant in both Late Archaic/Early Ceramic and Middle Caddoan assemblages from Block $\mathrm{B} / \mathrm{C}$, with projectile point-expedient flake tool ratios of 0.4:1 $(30-50 \mathrm{~cm} \mathrm{bs})$ and $0.8: 1(0-20 \mathrm{~cm} \mathrm{bs})$, respectively. Unilateral and bilateral utilized flakes, as well as unilateral retouched pieces, are the primary expedient tools in both components (see Figure 8-37b:1, 3, Figure 8-38a:1-2, 4-7, and Figure 8-39:2, 5); distal and distal/lateral utilized flakes and retouched pieces are also well-represented (see Figure 8-36:2-3, Figure 8-38a:3, and Figure 8-39a:1, 4. In general, retouched flake tools are somewhat more common in the Middle Caddoan excavation levels in Block B/C (see Table 8-21), where they represent 32-44 percent of the expedient tools. In deposits between $30-50 \mathrm{~cm}$ bs, retouched pieces comprise between 13-41 percent of the expedient tools. One of the more interesting retouched pieces in the Late Archaic/Early Ceramic component is a unifacial non-cortical flake tool of novaculite apparently with corner tangs or notches (Figure 8-40:2). It has retouch and use wear along the lateral and distal edges. Analysis by Saner and Tomka (1998:32) of the use wear of a number of unifacial corner-tang artifacts (which they date between 1000 B.C.-A.D. 700, contemporaneous with the Late Archaic/Early Ceramic period components at Hurricane Hill) suggests they "were used for cutting soft and perhaps fibrous materials."

The distribution of Block B/C blank/preforms in each thickness class, including blank/preforms more than $25.1 \mathrm{~mm}$ in thickness, suggests that all stages of biface knapping occurred in this part of the Hurricane Hill site, probably during both components (see Figure 8-15). The largest proportion of the Block B/C blank/preforms occur in the thinner blank/preform classes (with 30 percent ranging from 5.1-10 $\mathrm{mm}$ in thickness, and 37 percent ranging from 10.1-15.0 mm in thickness; Figure 8-41:4, 7), but 33 percent are between 15.1-25 mm in thickness (Figure 8-42:3, 5-6, 10-11 and Figure 8-43:1, 7, 9, 11; see also Figure 8-39b:2, 5-6). The thickness ranges may indicate that the blank/preforms were being knapped, and presumably broken, during initial, intermediate, and final attempts at thinning the cobbles and larger pebbles of local quartzites, rather than during the final shaping and finishing of blank/preforms noted in Block D, and the initial and intermediate blank/preform reduction in Blocks $\mathrm{A}$ and $\mathrm{E}$ on the North rise (see above). 

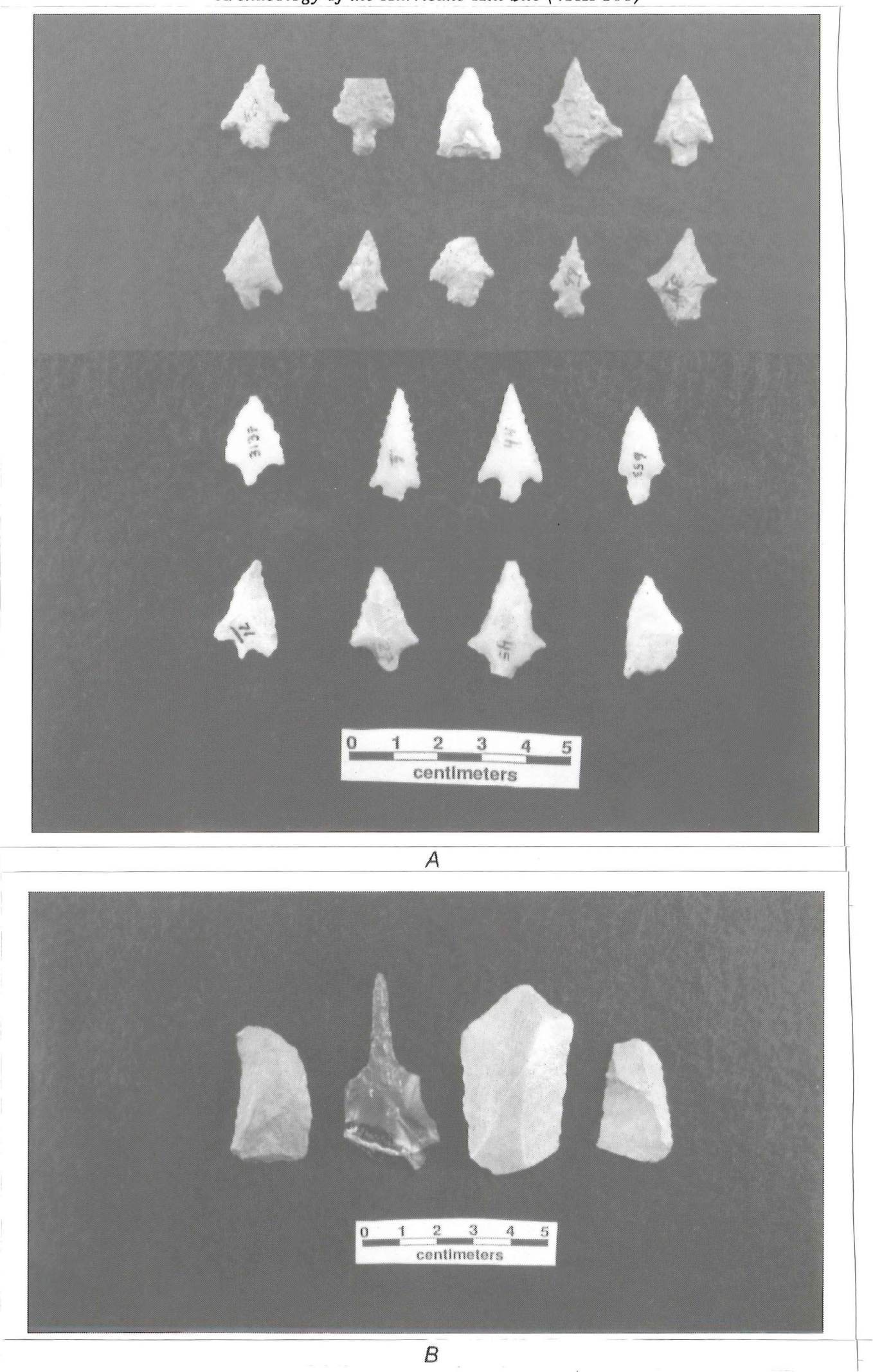

Figure 8-37. Arrowpoints and Flake Tools, Block B/C, Surface and level 1: a, Class 01 (No. 6, 8), Class 02 (No. 2 , 12-14), Class 03 (No. 4, 10, 17), Class 04 (No. 11, 15), Class 05 (No. 1, 5, 7, 16), Class 08 (No. 3), Class 09 (No. 9), unidentified (No. 18); b, bilateral retouched piece (No. 1, 3), drill (No. 2), side scraper (No. 4). Provenience: a-1 (106-1), a-2, a-9, a-15 (213-1), a-3, a-14 (51-1), a-4 (123-1), a-5 (109-1), a-6 (116-1), a-7 (491), a-8 (135-1), a-10 (53-1), a-11 (148-1), a-12 (48-1), a-13, a-17 (115-1), a-16 (50-1), a-18 (56-1), b-1, b-2, b$3, \mathrm{~b}-4$ (Surface, South rise) 


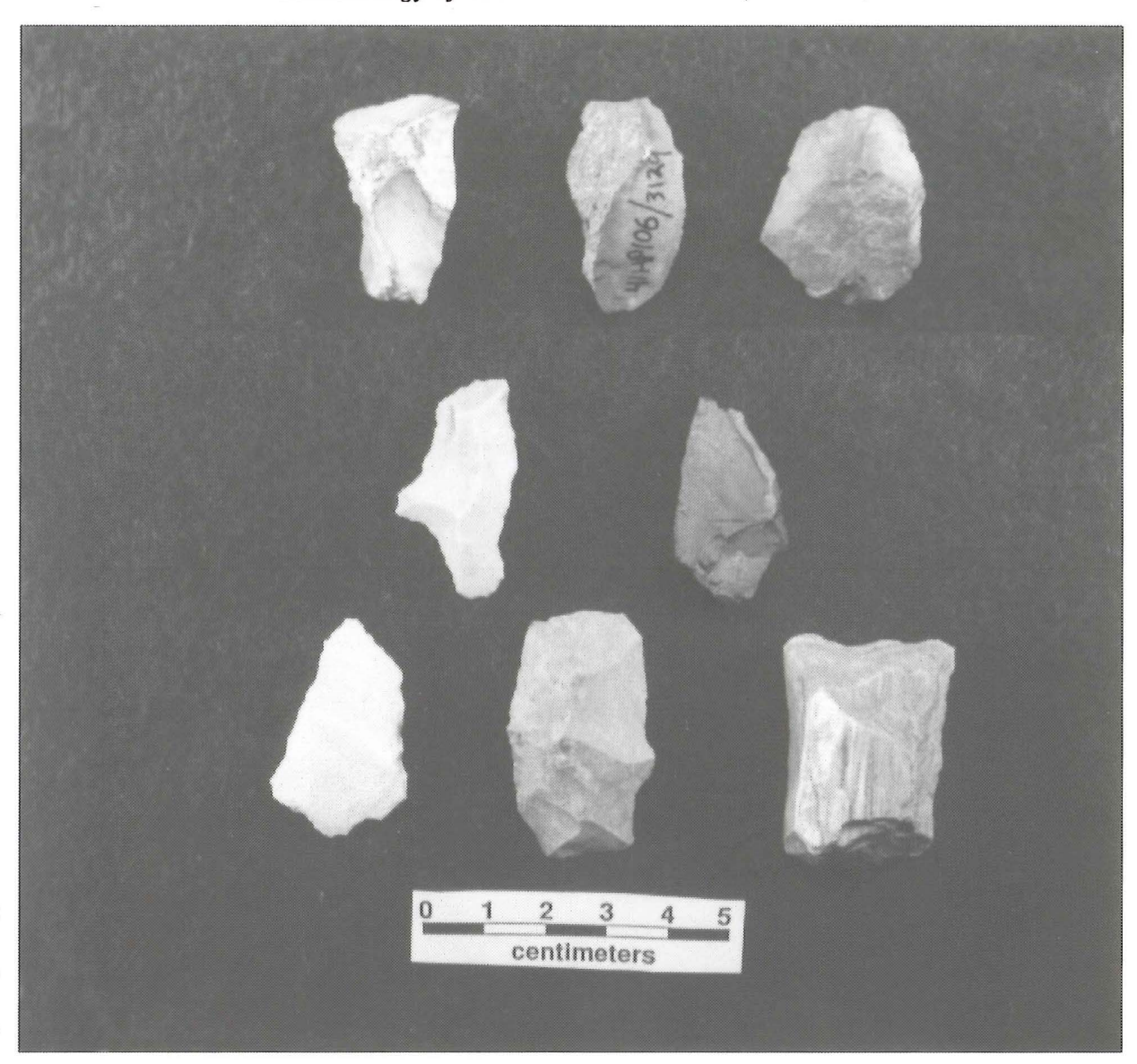

A

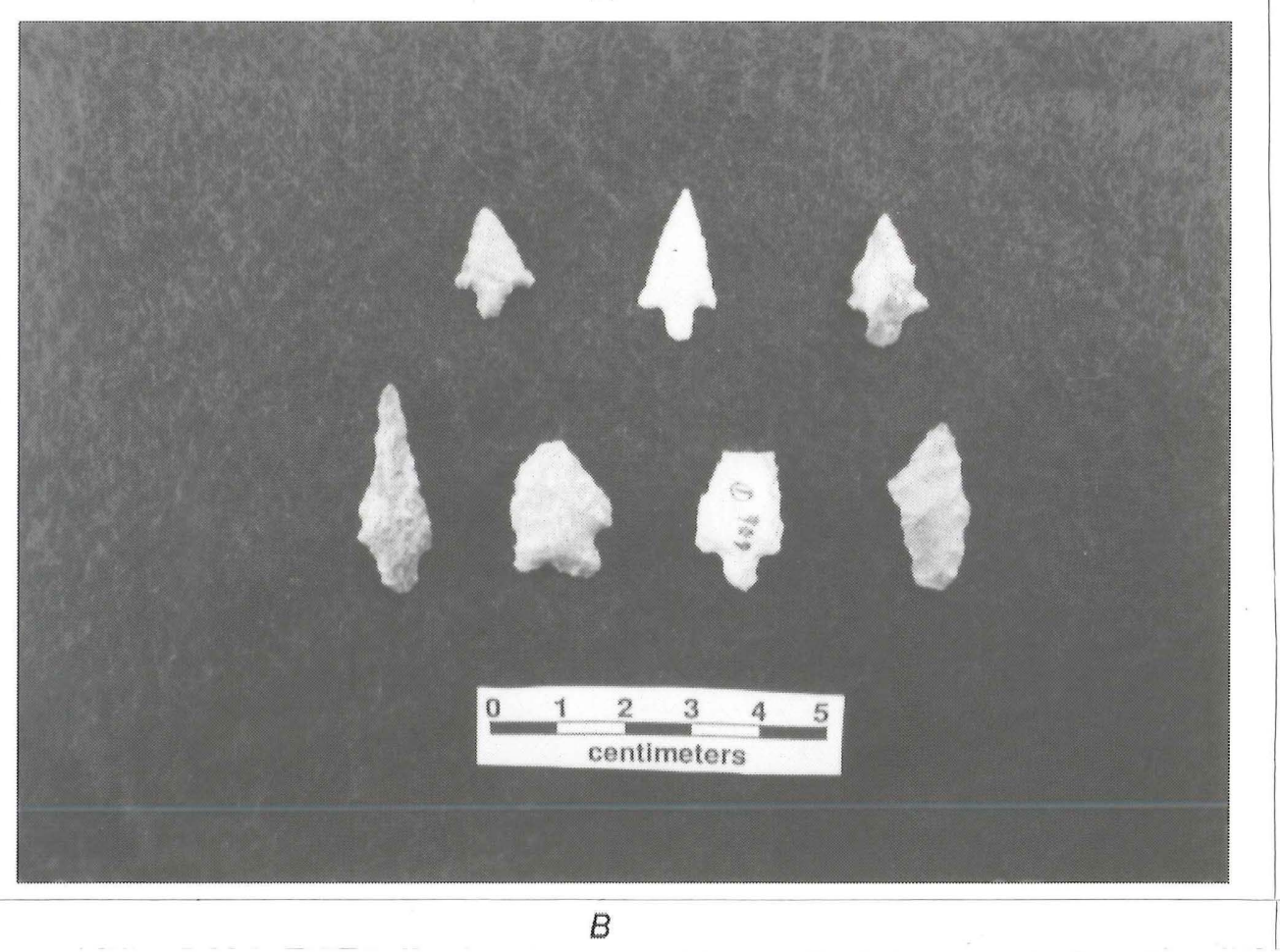

Figure 8-38. Flake Tools and Arrowpoints, Block B/C, level 3: a, utilized flake (No. 1, 5), unilateral retouched piece (No. 2, 6), distal/lateral utilized flake (No. 3), bilateral utilized flake (No. 4, 7), end scraper (No. 8); b, Class 02 (No. 2), Class 03 (No. 1, 4, 7), Class 05 (No. 3, 5-6). Provenience: a-1 (106-3B), a-2 (170-3B), a-3 (114-3B), a-4 (126-3A), a-5 (114-3A), a-6 (222-3A), a-7, a-8 (112-3A), b-1 (60-3A), b-2 (192-3A), b-3 (68-3A), b-4 (140$3 A), b-5(133-3 A), b-6(58-3 A), b-7$ (97-3A) 


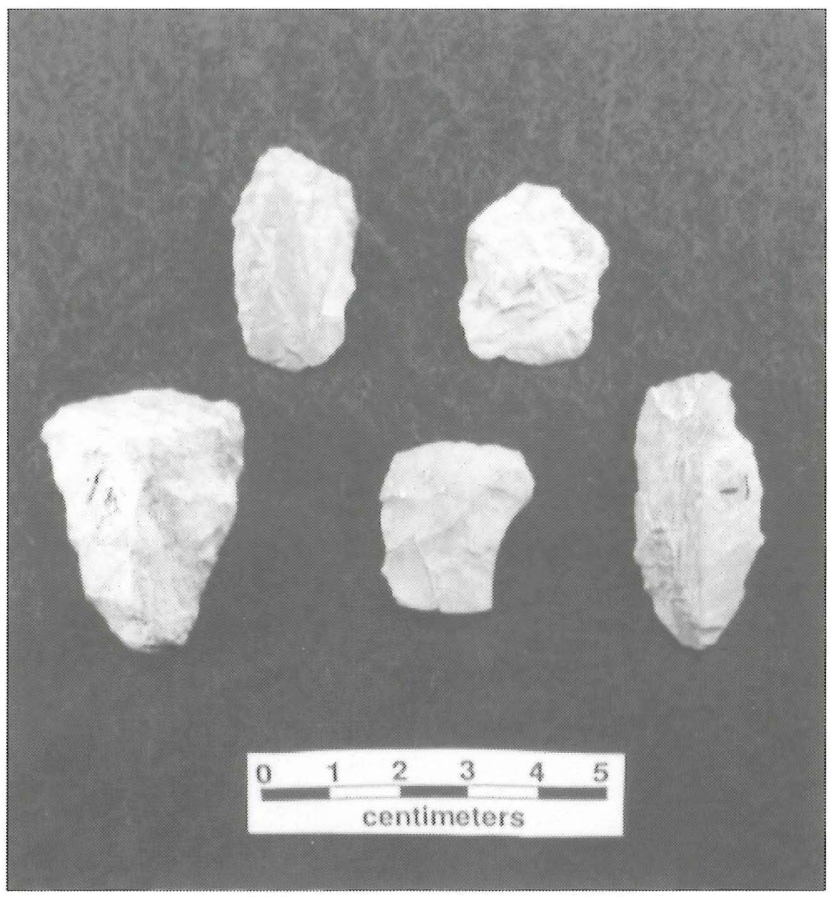

A

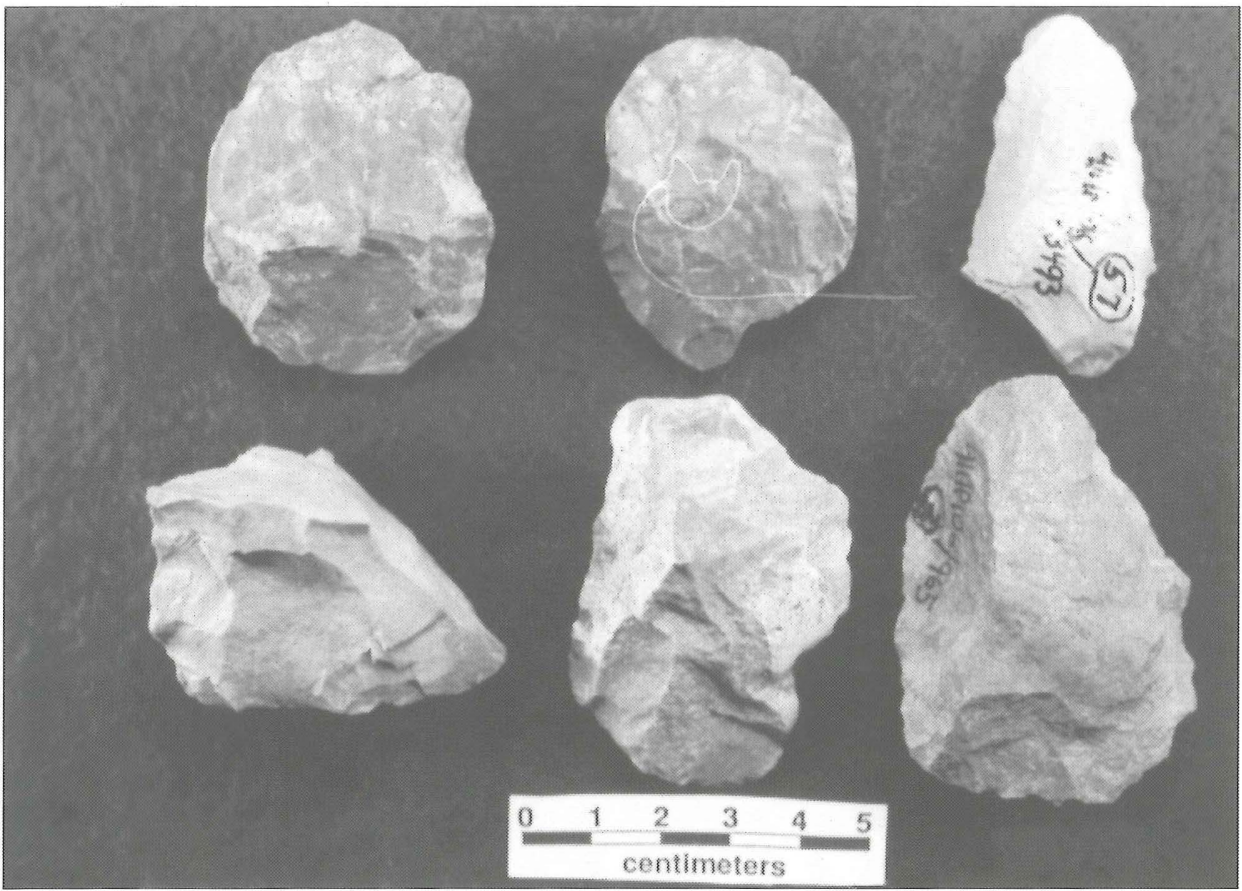

B

Figure 8-39. Cores, Blank-Preforms, and Flake Tools, Block B/C: a, distal/lateral utilized flake (No. 1, 4), utilized flake (No. 2), end-side scraper (No. 3), unilateral retouched piece (No. 5); b, blank-preform (No. 2-3, 6), multiple platform core (No. 1, 5), core fragment (No. 4). Provenience: a-1 (114-4B), a-2 (120-4B), a-3 (52-4), a-4 (106-4B), a-5 (51-4), b-1 (116-4A), b-2 (160-4A), b-3 (133-4A), b-4 (173-4A), b-5 (105-4A), b-6 (48-4A) 


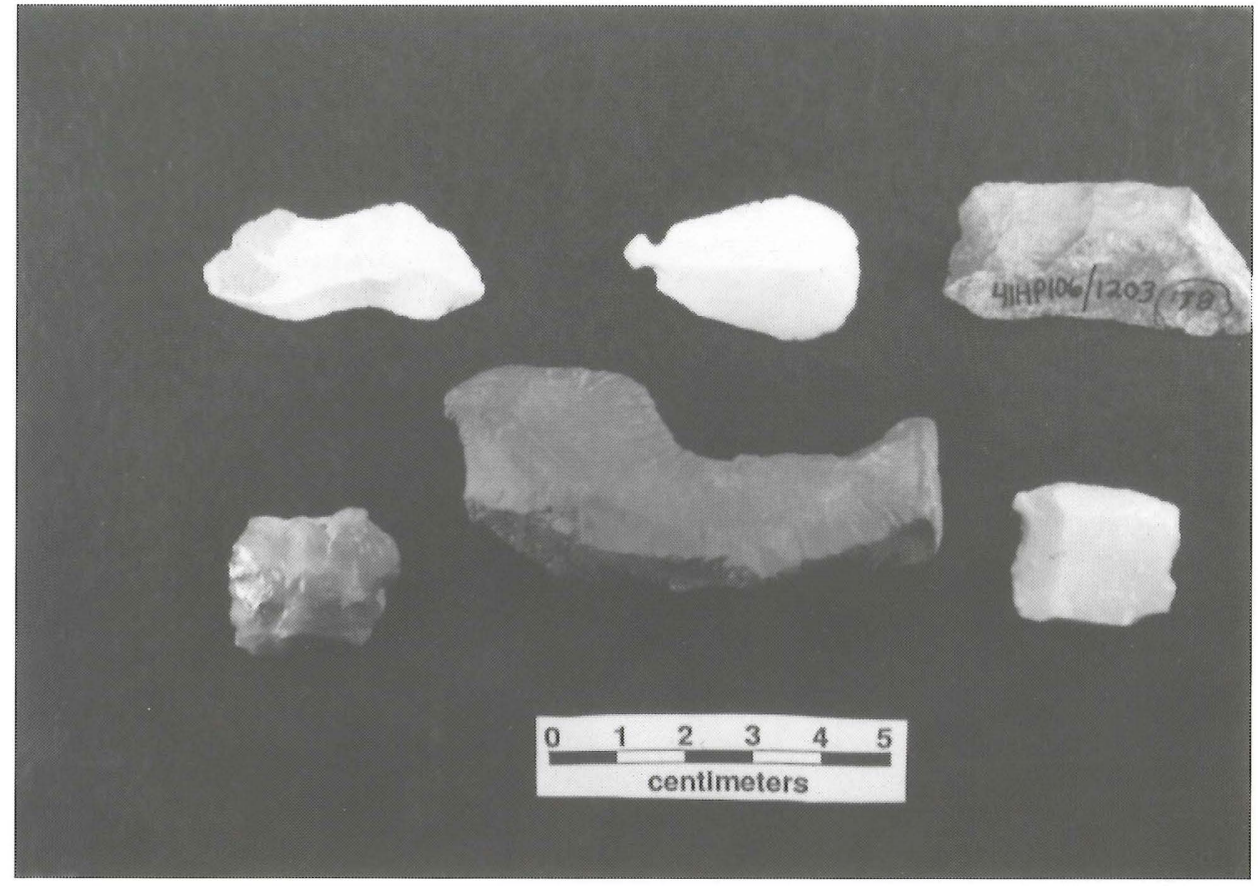

Figure 8-40. Flake tools and pigment stone, Block B/C, level 5: pigment stone (No. 5); utilized flake (No. 3); bilateral utilized flake (No. 1); composite uniface (No. 2); bifacial thinning flake with used edge (No. 4); distal/lateral utilized flake (No. 6). Provenience: 1 (142-5B), 2 (174-5A), 3 (63-5B), 4 (55-5A), 5 (107-5A), 6 (243-2B).

Cores are present in generally comparable amounts in both Late Archaic/Early Ceramic and Middle Caddoan contexts in Block B/C on the South rise; the highest frequencies of cores occur between $20-30 \mathrm{~cm}$ bs and 40-50 cm bs (see Table 8-22), but cores are also present in significant numbers in Middle Caddoan contexts. This reflects the production of both large and small bifaces for tools and tool blanks at the Hurricane Hill site. Besides core fragments (see Figure 8-41:2-3 and Figure 8-42:4, 12) and tested cobbles, which account for 58 percent of the Block B/C cores, multiple platform flake cores and opposed platform cores occur in both Late Archaic/Early Ceramic (see Figure 8-39b:1, 5 and Figure 8-41:1) and Middle Caddoan contexts (see Figure 8-43:2, 6, 8, 10, 12), while bifacial cores are apparently restricted to the earlier use of the South rise (see Table 8-22).

Non-local lithic raw materials occur in both Late Archaic/Early Ceramic and Midden Caddoan contexts in Block B/C. There is a bimodal peak in the vertical distribution of tools made from non-local materials, with 38 percent of the non-local tools found between $0-10 \mathrm{~cm}$ bs, and 22 percent found between $40-50 \mathrm{~cm}$ bs (see Figure 8-16). The types of tools made of these materials (i.e., dart points, arrowpoints, blank/preforms, indeterminate bifacial tools, scrapers, and retouched pieces), indicate that non-local raw materials were used in both the Late Archaic/Early Ceramic and Middle Caddoan components.

Non-local tools are particularly well represented in the Middle Caddoan period deposits. This includes the following tools made of non-local materials: seven arrowpoints, a perforator, seven retouched pieces, and one end scraper, almost all made on novaculite (see Figure 8-37:11-18). In Late Archaic/Early Ceramic period deposits between $30-50 \mathrm{~cm}$ bs, non-local tools include two dart point, three utilized flakes, two retouched pieces, a composite unifacial tool, one end scraper, and one side scraper. 
Figure 8-41. Cores, blank-preforms, and flake tools, Block B/C, level 3: blank-preforms (No. 4, 6-7); opposed platform core (No. 1); core fragments (No. 2-3); bilateral utilized flake (No. 5); distal/lateral utilized flake (No. 8). Provenience: 1 (182-3A), 2 (123-3A), 3 (101-3A), 4, 8 (126-3B), 5 (196-3B), 6 (1333B), 7 (68-3B).

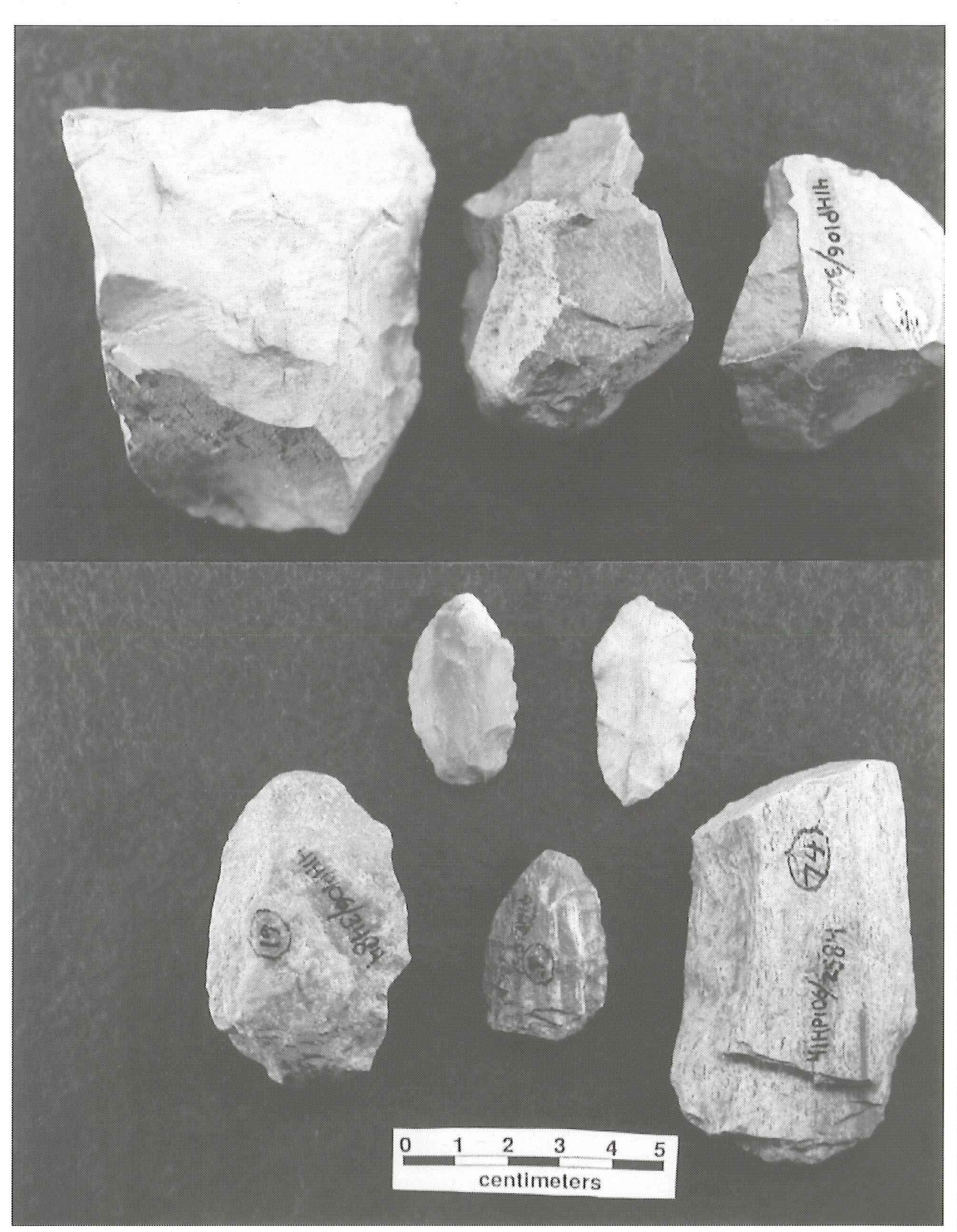




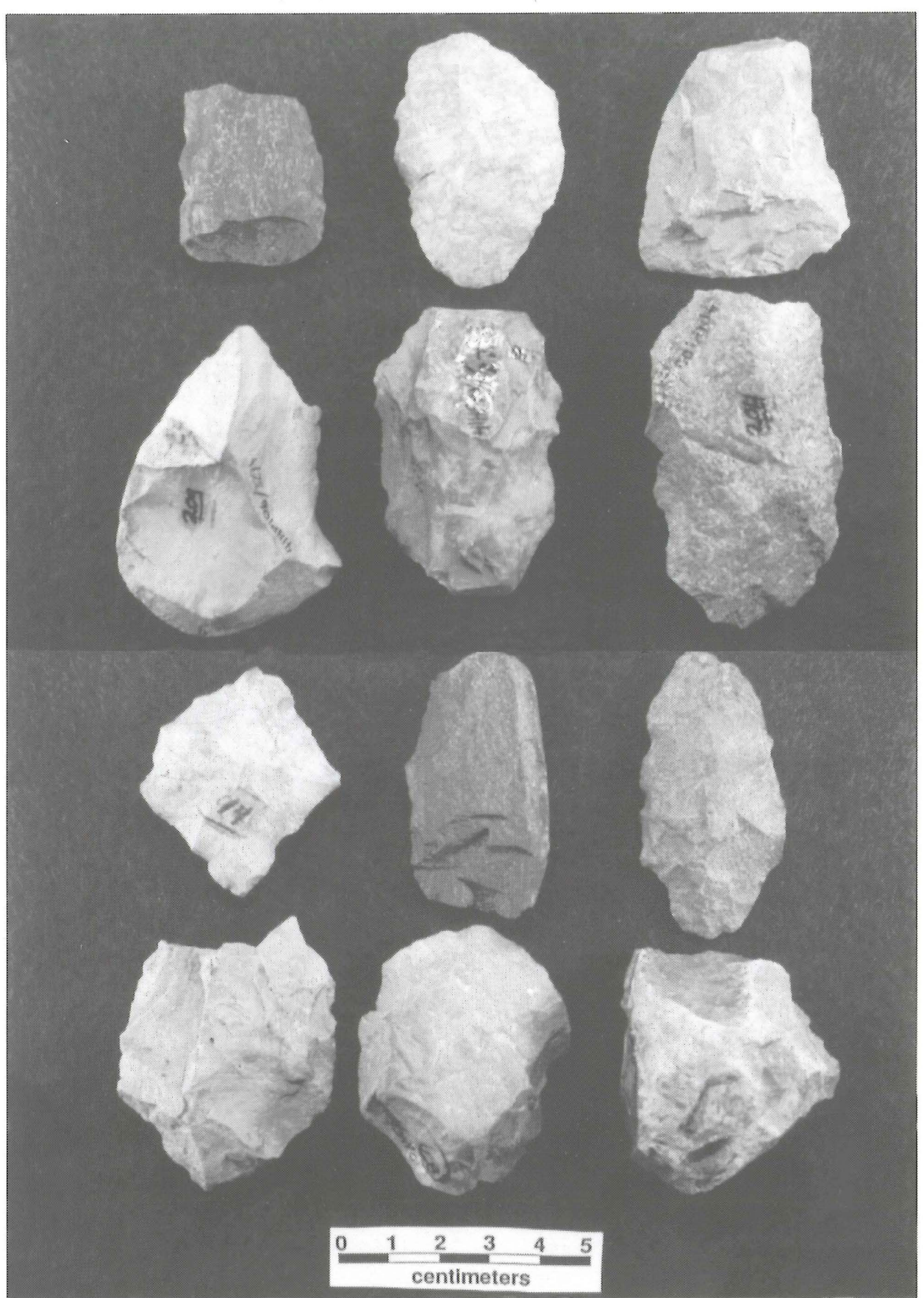

Figure 8-42. Cores, Blank-Preforms, and Knive, Block B/C, level 5: blank-preforms (No. 1, 3, 5-11), knive (No. 2), core fragments (No. 4, 12). Provenience: 1 (63-5B), 2 (186-5B), 3 (136-141-5B), 4 (129-5B), 5 (134-5B), 6 (105-5B), 7 (52-5A), $8(192-5 \mathrm{~A}), 9-10(106-5 \mathrm{~A}), 11(116-5 \mathrm{~A}), 12(54-5 \mathrm{~A})$ 

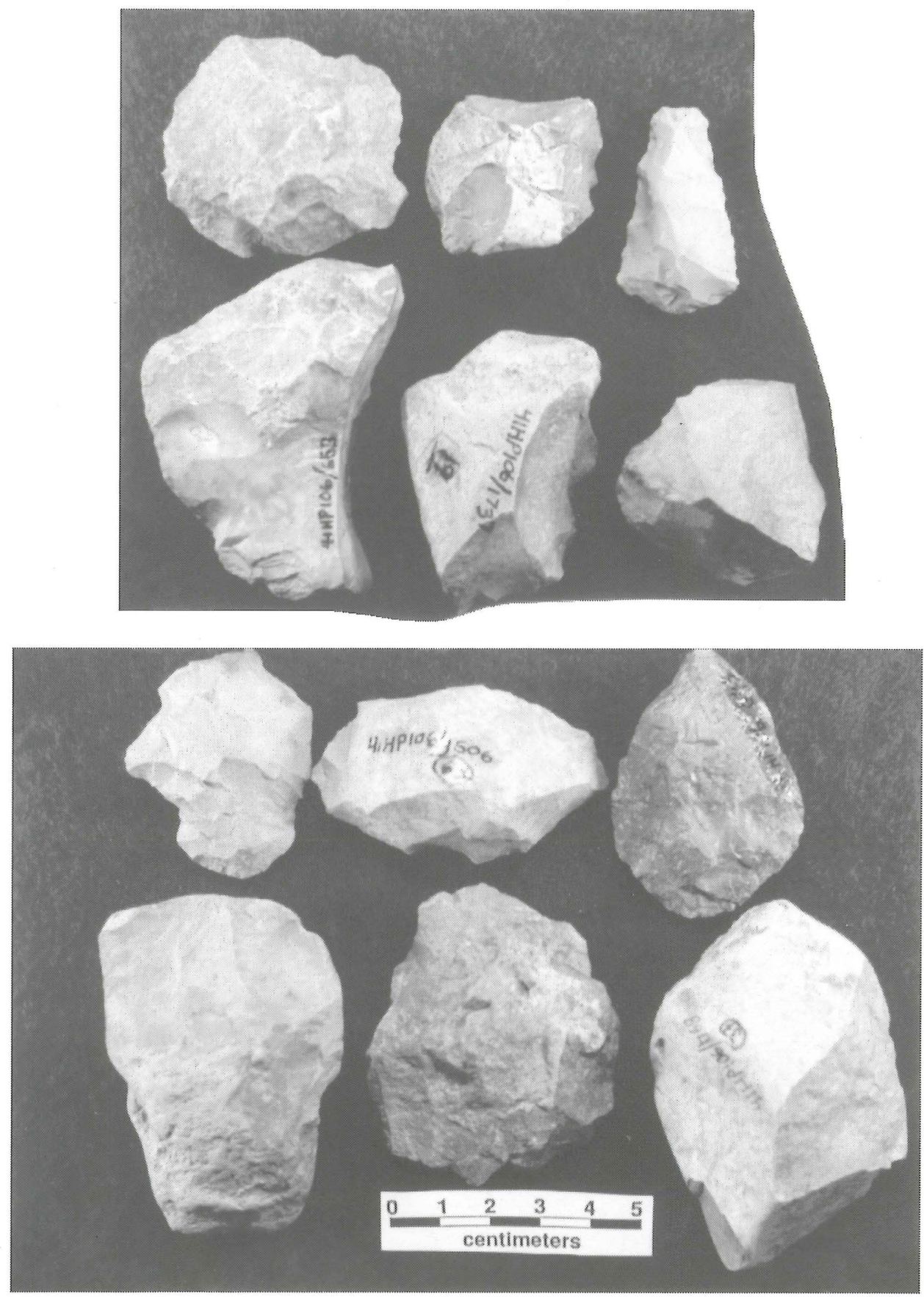

Figure 8-43. Cores, Blank-Preforms, Biface, and Flake Tool, Block B/C, levels 1-2: multiple platform core (No. 6,8 ), opposed platform core (No. 2, 10), core fragment (No. 4), blank-preform (No. 1, 7, 9, 11), bifacial gouge (No. 3), unilateral retouched piece (No. 5). Provenience: 1 (163-1), 2 (121-1), 3 (57-1), 4 (51-1), 5 (98-1), 6 (1291), 7 (221-2), 8 (142-2), 9 (55-2), 10 (127-2), $11(222-2), 12(124-2)$ 
The vertical distribution of non-local tools in Block B/C suggests an increased Middle Caddoan use of non-local raw materials after the Late Archaic/Early Ceramic period occupation. This differs from the pattern of raw material use detected by Fields et al. (1997:Figure 42) from a number of sites at Cooper Lake where there is a gradual decline in non-local raw material use from the Late Archaic and Woodland periods through the Early and Late Caddoan period. About 2.3 percent of the dart points $(n=128)$ from Block $B / C$ are made of non-local materials, compared to 15.2 percent of the arrowpoints $(n=46)$. Other tool classes with a significant use of non-local materials include perforators (50 percent), end and side scrapers (50 percent), unilateral retouched pieces (12.5 percent), and bilateral utilized flakes (10.5 percent).

Novaculite is the most common non-local raw material for tools on the South rise, accounting for more than 54 percent of the Block B/C sample of tools made of non-local lithics. Jasper is also noticeably abundant compared to the non-local tool samples from Blocks D and E (where it is absent), as it comprises 16 percent of the non-local tools (mainly in Late Archaic/Early Ceramic contexts), suggesting differences in procurement through time and by occupation area; jasper also is a common non-local material in Block A on the North rise, also in a Late Archaic/Early Ceramic context. White chert and Woodford chert comprise 9.1 percent of the non-local tools in Block $\mathrm{B} / \mathrm{C}$, compared to 2.1 percent in Block $\mathrm{A}$, and 14.3 percent in Blocks D and E.

The Block B/C lithic debris from the 1/4-inch sample is characterized by high percentages of large cortical flakes, as are the archaeological deposits in the other areas of the Hurricane Hill site (see Figure 817). Fine-screen and flotation samples indicate that the Block $B / C$ lithic debris in aggregate resembles the samples from Blocks D and $\mathrm{E}$ on the North rise. In these areas, the lithic debris contains higher proportions of large flakes (30-40 percent) than in Blocks A, F, and the Southwest rise, as well as much lower amounts of non-cortical flakes (70-80 percent) (see Figure 8-17). This suggests an emphasis in the Block B/C lithic debris on biface reduction from core and larger bifacial blank/preforms. However, further examination of fine screen samples from the top to the bottom of the archaeological deposits in Block B/C (see Appendix XVI), as well as from fine-screen and flotation samples in the Block $\mathrm{F}$ midden, also suggests that the production of tools from smaller blank/preforms was important, probably many of which began from flakes rather than large cores. Fine-screen samples from Block B/C point to the change in reduction strategies having occurred between the Late Archaic/Early Ceramic period and Middle Caddoan occupations (see Figure 8-18), based on the high proportions of large flakes in the Late Archaic/Early Ceramic deposits (i.e., levels 4-5), and the much higher frequencies of small flakes (most of which are non-cortical) in the upper Middle Caddoan deposits.

Only 10 or approximately 1.1 percent of the Block B/C tools are ground stone implements; three other groundstone tools were found in the Block F investigations. These include two celts, two metate, and six hammerstones (Figure 8-44; see Appendix X). There is also a large chunk of red ochre, found between $40-50 \mathrm{~cm}$ bs, with numerous scratches and cuts on several edges (see Figure 8-40:5), suggesting it was cut with a tool to obtain pieces for pigment. The other groundstone celt, a small and heavily reworked tool with a steep bit, was found in Block F (see Figure 8-44:4), in midden deposits associated with the Middle Caddoan structures on the South rise. Local quartzites were the preferred raw material for the hammerstones as well as the bifacial mano from Block $F$, and the metates were made from a local dense sandstone, while the celts were manufactured from Ouachita Mountains raw materials (probably obtained in the Red River gravels; see Ferring 1969; Banks 1984, 1990; Banks and Winter 1975), including a quartzitic sandstone and a gray siltstone.

Except for the five hammerstones and the ochre pigment stone recovered between $35-50 \mathrm{~cm}$ bs, beneath the Middle Caddoan structures, that are part of the Late Archaic/Early Ceramic lithic assemblage, the remaining ground stone tools are from depths that can be associated with the Middle Caddoan occupation of the South rise. The prevalence of celts and metates in this component indicate the relative importance of wood-working, tree clearing, and plant food grinding activities at the site during this time; metates were also abundant in Block $E$ on the North rise in Early Caddoan contexts. 


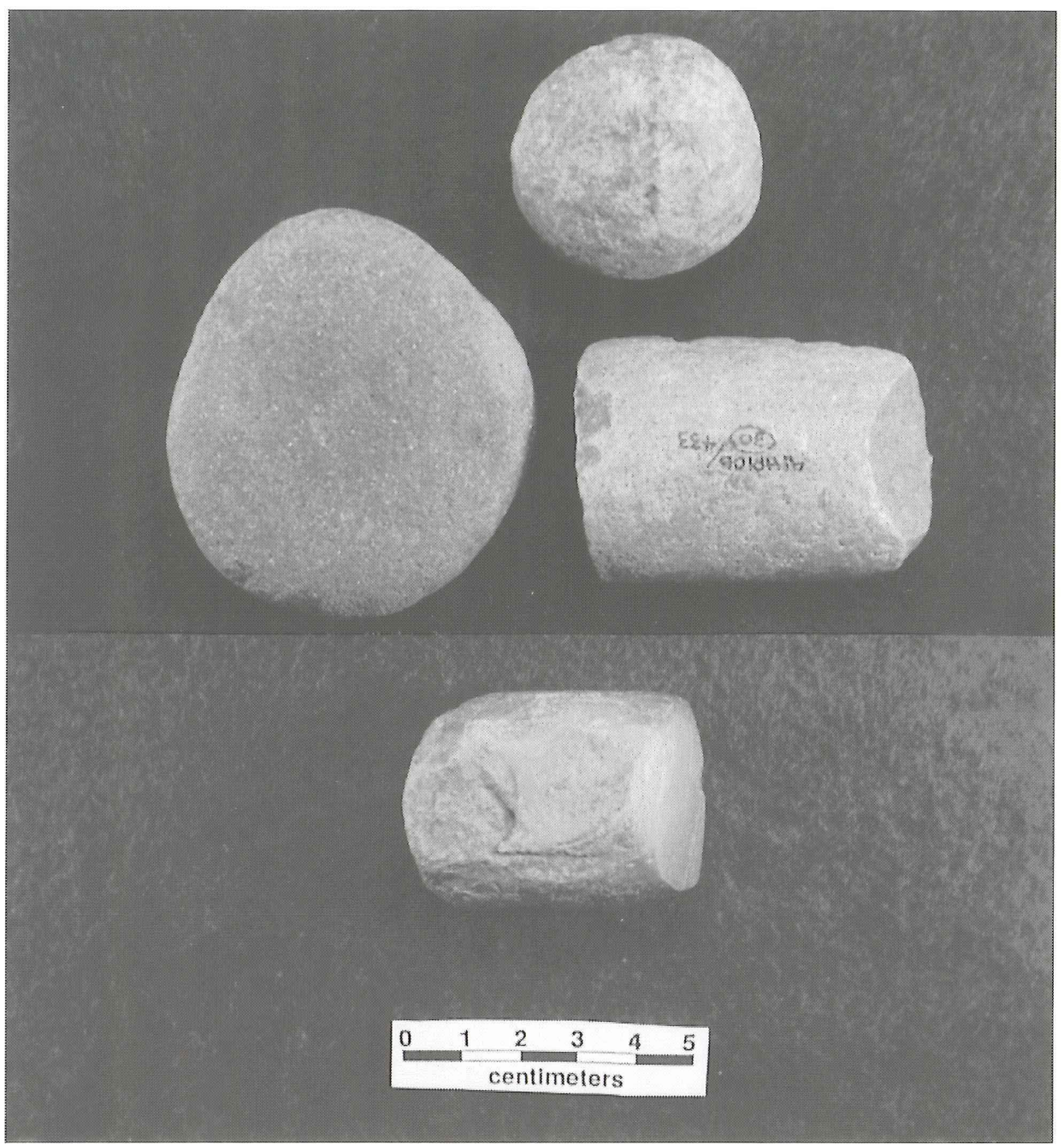

Figure 8-44. Groundstone tools, South rise and Block F: hammerstone (No. 1), mano/pitted stone (No. 2), celt (No. 3-4). Provenience: 1-3 (surface), 4 (276-1).

As with many other Middle to Late Caddoan components in Northeast Texas, fire-cracked rocks (FCR) are relatively scarce compared to ceramic sherds. This appears to be related to temporal changes in cooking and heating technologies, where hot rock cooking (e.g., Black et al. 1997) of plant and animal foods was replaced by the cooking and heating of foods (including different sorts of foods, such as maize) in ceramic vessels built with a sophisticated technology designed to withstand thermal shocks and continual reheating. With this change in cooking technology, hot rocks were not a necessary cooking apparatus, and their use diminished in direct proportion to the intensity with which ceramic vessels were employed for cooking (see related discussion in Fields [1995a:318]).

About 4050 pieces of FCR of coarse-grained quartzite and sandstone weighing $25.9 \mathrm{~kg}$ were recovered in the Block B/C excavations, more than 98 percent of which by weight were from general habitation deposits rather than feature contexts (Table 8-28). By weight and number, the FCR was most abundant between $20-50 \mathrm{~cm}$ bs either inside or outside the Middle Caddoan structures, in what are generally

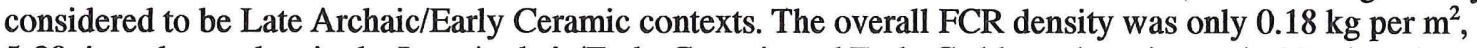
5-20 times lower than in the Late Archaic/Early Ceramic and Early Caddoan deposits on the North and Southwest rises. 
Table 8-28. Weight and frequency of daub, burned clay, and fire-cracked rock, Block $\mathbf{B} / \mathbf{C}$.

\begin{tabular}{|c|c|c|c|c|c|c|}
\hline Provenience & Daub (g) & Daub (\#) & Burned Clay (g) & Burned Clay (\#) & FCR (kg) & FCR (\#) \\
\hline $\begin{array}{l}\text { lv. } 1 \\
\text { Iv. } 2 \\
\text { Iv. 3A } \\
\text { lv. 3B } \\
\text { Iv. 4A } \\
\text { Iv. 4B } \\
\text { Iv. 5A } \\
\text { Iv. 5B } \\
\text { Iv. 6A } \\
\text { Iv. 6B }\end{array}$ & $\begin{array}{l}344.9 \\
320.1 \\
87.8 \\
85.9 \\
26.5 \\
39.9 \\
15.8 \\
8.2 \\
1.3 \\
1.2\end{array}$ & $\begin{array}{l}362 \\
454 \\
205 \\
146 \\
62 \\
50 \\
29 \\
18 \\
4 \\
3\end{array}$ & $\begin{array}{l}1293.1 \\
1573.7 \\
649.2 \\
581.6 \\
250.2 \\
263.7 \\
254.9 \\
207.3 \\
17.6 \\
1.2\end{array}$ & $\begin{array}{l}1423 \\
1417 \\
569 \\
446 \\
214 \\
170 \\
162 \\
109 \\
21 \\
2\end{array}$ & $\begin{array}{l}2.1 \\
4.6 \\
2.1 \\
3.0 \\
3.0 \\
1.9 \\
2.0 \\
6.3 \\
+ \\
0.5\end{array}$ & $\begin{array}{l}789 \\
770 \\
415 \\
391 \\
345 \\
357 \\
327 \\
508 \\
2 \\
16\end{array}$ \\
\hline $\begin{array}{l}\text { Fea. } 3 \\
\text { Fea. } 5 \\
\text { Fea. } 8 \\
\text { Fea. } 12 \\
\text { Fea. } 20 \\
\text { Fea. } 29 \\
\text { Fea. } 38\end{array}$ & $\begin{array}{l}12.7 \\
-- \\
1.7 \\
0.1 \\
-- \\
-- \\
--\end{array}$ & $\begin{array}{l}6 \\
-- \\
4 \\
2 \\
-- \\
-- \\
--\end{array}$ & $\begin{array}{l}39.5 \\
569.8 \\
8.2 \\
0.1 \\
16.8 \\
-- \\
3.5\end{array}$ & $\begin{array}{l}15 \\
202 \\
7 \\
1 \\
1 \\
\ddot{1}\end{array}$ & $\begin{array}{l}0.2 \\
+ \\
0.2 \\
+ \\
+ \\
+ \\
+\end{array}$ & $\begin{array}{l}38 \\
10 \\
13 \\
1 \\
3 \\
8 \\
4\end{array}$ \\
\hline Iv. $99^{*}$ & 3.4 & 8 & 23.5 & 18 & + & 20 \\
\hline Totals & 949.5 & 1353 & 5793.5 & 4778 & 25.9 & 4057 \\
\hline
\end{tabular}

* miscellaneous provenience (backhoe scrapings, floor troweling, etc.)

The ratio of the number of FCR to FCR weight from Block B/C is 0.0064 (i.e., the mean weight of a piece of FCR is $0.0064 \mathrm{~kg}$ ). Considering the number/weight relationships of the FCR in these deposits to the Primary Midden deposits sampled in Blocks D and E on the North rise, the average FCR weights are much smaller than the FCR from the predominantly Late Archaic/Early occupations on the North rise where FCR was more abundant, and the FCR pieces were much larger. This suggests that the FCR on the South rise is a product of many more cooking events when compared to the remainder of the site, and these cooking events extensively reduced the coarse-grained quartzite and sandstone cobbles to very small pieces and spalls.

Both daub and burned clay pieces are common in the Block B/C excavations in Midden 1, weighing $949.5 \mathrm{~g}$ and $5793.5 \mathrm{~g}$, respectively (see Table 8-28). The daub and burned clay are particularly abundant between 0-30 cm bs, and in Features 3 and 5. In general, the daub and burned clay from nonfeature contexts on the South rise are primarily considered to be pieces of clay-plastered wall and thatch. The impressed daub specimens appear to be pieces of clay with the impressions of narrow-bladed grasses and sticks used for thatching on the house walls.

Unlike the daub from the North rise, the distribution of the daub and burned clay from Block B/C was concentrated inside and just outside of Structures A and B, perhaps where the walls of one of the structures collapsed after they were abandoned (the depths of the recovered daub and burned clay suggest they are associated with the later Structure A; see discussion in Chapter 7). The burned clay in and around Feature 5, the central hearth, is heavily oxidized pieces of clay without grass and stick impressions that are fragments of the clay-lined hearths, as well as fragments from cooking features and midden deposits that were dumped in Feature 3 (Burial 3) when it was aboriginally backfilled.

\section{Southwest Rise}

Dart points comprise about 41 percent of the chipped stone tools from the Southwest rise, and they are found in both midden and feature contexts (see Table 8-5). Samples of flake tools and various bifacial tools and tool fragments from Features 59, 62, 67, 75, and 76 are illustrated in Figure 8-45. 

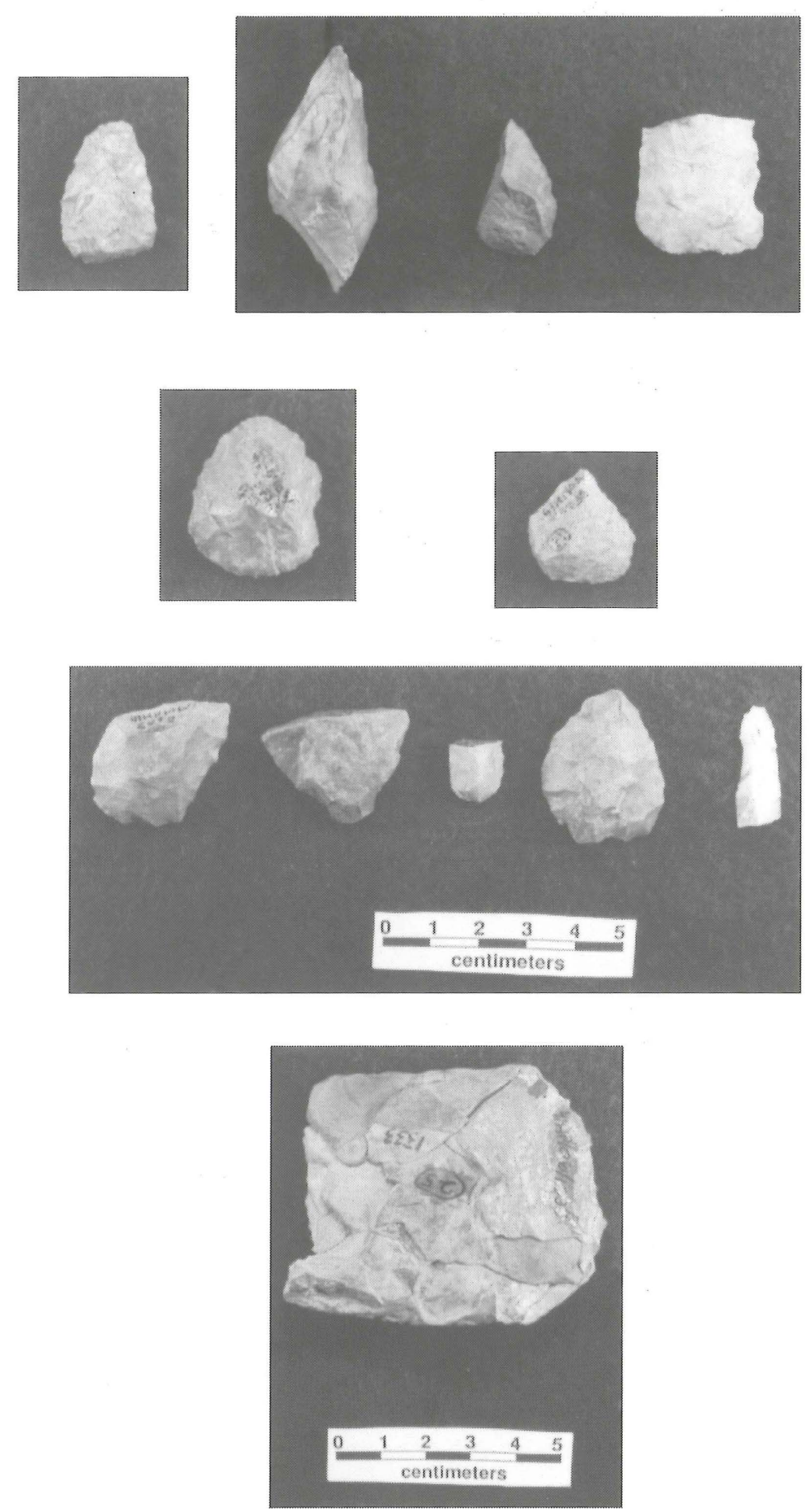

Figure 8-45. Southwest Rise Tools: adze (No. 1), indeterminate biface (No. 2-4, 7), end-side scraper (No. 5), dart point base (No. 6, 9), blank-preform (No. 8, 10), unilateral retouched piece (No. 11), axe (No. 12). Provenience: 1 (Fea. 59), 2-4 (Fea. 62), 5 (Fea. 67), 6 (Fea. 75), 7-11 (Fea. 76), 12 (BHT 46) 
The dart points are dominated by contracting stem Gary type points that date from the Late Archaic to the earlier part of the Early Ceramic period--principally var. Gary and var. LeFlore--along with rectangular and expanding stem Late Archaic forms in and below the midden deposit. The occurrence of var. Camden Gary points only in feature contexts (i.e., burials) suggests that at least a few of the pit features were dug after the midden had been previously built up.

Most of the dart points have been resharpened and serrated, and although the dart point sample is small $(n=20)$, none of them have impact fractures or stem grinding (see Table 8-19). These pointed bifacial tools from midden and feature contexts must have been multi-function tools, and probably used more as cutting tools than as projectiles, given the absence of impact fractures.

The only arrowpoints on the Southwest rise are from a presumed Middle Caddoan extended burial (Feature 68). These may represent grave goods, as such tools are otherwise absent from the midden deposits on the rise that were used for burial fill.

Shaped flake tools are relatively common in the small chipped stone tool assemblage from the Southwest rise, with a projectile point to shaped flake tool ratio of 5:1. The shaped flake tools include one notch/spokeshave from a midden context, and two scrapers and a bifacial knife from features (see Figure 845:1, 5 and Table 8-20). Expedient retouched and utilized flakes are also abundant, with a projectile pointexpedient flake tool ratio of 1.5:1, comparable to the tool assemblages from Blocks D and E. Distal utilized flakes and retouched pieces are the primary expedient tools, along with unilateral retouched and utilized flakes (see Figure 8-45:11). A distinctive expedient tool in the Southwest rise--and also in Late Archaic/Early Ceramic contexts on the North $(n=2)$ and South $(n=5)$ rises--is a bifacial thinning or billet flake (cf. Johnson 1995:136 and Figure 44b) with purposeful use wear on one flake edge (see Table 8-21).

Tools made on non-local raw materials are rare on the Southwest rise (3.4 percent), but the sample of tools is low (see Table 8-5). These non-local tools include one unilateral retouched piece and an indeterminate bifacial tool fragment.

There are 16 bifacial preforms and 11 indeterminate bifacial tool fragments from midden and feature contexts on the Southwest rise (see Figure 8-45:2-4, 7-8, 10). The bifacial preforms range from 6.5-21.0 $\mathrm{mm}$ in thickness, with the majority between 15.1-20 mm in thickness (see Figure 8-15), suggesting the prevalence of initial reduction of cobbles and pebbles for bifacial tools during the Late Archaic/Early Ceramic occupation; by contrast, in the other Late Archaic/Early Ceramic components on the North and South rises, technological efforts were directed more towards secondary (with thicknesses between 10.1-15 $\mathrm{mm}$ ) and final (5.1-10 mm thickness) core-biface reduction. All of the preforms and 91 percent of the bifacial tool fragments are on locally available quartzites. The nine cores from the Southwest rise are dominated by bifacial cores (see Table 8-22), further highlighting the emphasis here on initial bifacial tool reduction activities that is also denoted by the thick blank preforms.

The lithic debris in fine-screen and flotation samples is predominantly small and non-cortical (see Figure 8-17). While this suggests that the production of tools from smaller blank/preforms was important, probably many of which began from flakes rather than large cores, there is no evidence to indicate a temporal change in reduction strategies as postulated between the Late Archaic/Early Ceramic period and Early-Middle Caddoan occupations (see Figure 8-18) on the North and South rises. Perhaps during the Late Archaic/Early Ceramic period use of the Southwest rise, either smaller-sized pieces of raw material were preferred or available for tools (which seems dubious given the abundance of raw materials on the landform), or that many of the pieces of lithic debris are the product of heightened tool resharpening and maintenance activities. This appears to be borne out by the high proportions of resharpened and serrated dart points on the Southwest rise (see Table 8-19), as well as the ratio of tools to lithic debris (1:249) compared to ratios of 1:126 and 1:112 in Block D and E, respectively.

Only one ground stone tool is present in the small tool assemblage from the Southwest rise, a ground and polished fragment of a hematite axe (see Figure 8-45:12). The axe fragment was found in situ in BHT 46, below the Late Archaic/Early Ceramic midden deposits that cover the rise. Story (1990:Figure 32) indicates that such tools date from as early as ca. 2000 B.C., the beginning of the Late Archaic period, in Northeast Texas. 
Fire-cracked rocks of coarse-grained quartzite and sandstone were found in midden and feature contexts across the Southwest rise; 21 separate features on the rise contain FCR in amounts between traces to $2.0 \mathrm{~kg}$ (Table 8-29). More than 60 percent of the FCR by weight were Late Archaic/Early Ceramic feature contexts. While the sample of FCR from excavated contexts is small, the overall estimated FCR density was $1.03 \mathrm{~kg}$ per $\mathrm{m}^{2}, 2-3$ times lower than in the Primary Midden deposits outside of Block A on the North rise.

Table 8-29. Weight and frequency of daub, burned clay, and fire-cracked rock, Southwest rise.

\begin{tabular}{|c|c|c|c|c|c|c|}
\hline Provenience & Daub (g) & Daub (\#) & Burned Clay (g) & Burned Clay (\#) & FCR (kg) & FCR (\#) \\
\hline $\begin{array}{l}\text { Unit } 96 \\
\text { Unit } 281 \\
\text { Unit } 282 \\
\text { BHT } 45 / 46\end{array}$ & $\begin{array}{l}1.0 \\
-- \\
-- \\
--\end{array}$ & $\begin{array}{l}5 \\
-- \\
-- \\
--\end{array}$ & $\begin{array}{l}132.8 \\
24.7 \\
3.8 \\
--\end{array}$ & $\begin{array}{l}242 \\
4 \\
7 \\
--\end{array}$ & $\begin{array}{l}1.9 \\
0.5 \\
0.7 \\
+\end{array}$ & $\begin{array}{l}134 \\
19 \\
78 \\
3\end{array}$ \\
\hline $\begin{array}{l}\text { Fea. 15 } \\
\text { Fea. 16 } \\
\text { Fea. } 59 \\
\text { Fea. 60 } \\
\text { Fea. 61 } \\
\text { Fea. 62 } \\
\text { Fea. 63 } \\
\text { Fea. 64 } \\
\text { Fea. 65 } \\
\text { Fea. 66 } \\
\text { Fea. } 68 \\
\text { Fea. 69 } \\
\text { Fea. 70 } \\
\text { Fea. 71 } \\
\text { Fea. 73 } \\
\text { Fea. 74 } \\
\text { Fea. 75 } \\
\text { Fea. 76 } \\
\text { Fea. } 77 \\
\text { Fea. } 81 \\
\text { Fea. } 82 \\
\text { Fea. } 90 \\
\text { Fea. } 91\end{array}$ & $\begin{array}{l}-- \\
-- \\
-- \\
- \\
- \\
- \\
- \\
- \\
7.5 \\
- \\
1.5 \\
- \\
- \\
- \\
0.1 \\
- \\
- \\
- \\
- \\
- \\
- \\
- \\
0.4\end{array}$ & $\begin{array}{l}-- \\
-- \\
-- \\
-- \\
-- \\
-- \\
-- \\
- \\
18 \\
-- \\
4 \\
-- \\
-- \\
-- \\
1 \\
-- \\
-- \\
-- \\
-- \\
-- \\
-- \\
-- \\
2\end{array}$ & $\begin{array}{l}-- \\
-- \\
1.6 \\
-- \\
-- \\
5.2 \\
5.9 \\
11.0 \\
123.1 \\
-- \\
95.6 \\
-- \\
1.6 \\
-- \\
-- \\
3.0 \\
3.9 \\
460.3 \\
-- \\
-- \\
0.6 \\
-- \\
4.1\end{array}$ & $\begin{array}{l}-- \\
-1 \\
-- \\
-- \\
3 \\
9 \\
34 \\
955 \\
-- \\
137 \\
-- \\
2 \\
-- \\
-- \\
2 \\
6 \\
53 \\
-- \\
-- \\
3 \\
-- \\
4\end{array}$ & $\begin{array}{l}0.5 \\
+ \\
0.5 \\
+ \\
+ \\
0.4 \\
+ \\
0.8 \\
-- \\
+ \\
0.2 \\
+ \\
0.2 \\
+ \\
+ \\
+ \\
+ \\
2.0 \\
+ \\
+ \\
+ \\
+ \\
+\end{array}$ & $\begin{array}{l}4 \\
2 \\
21 \\
1 \\
7 \\
32 \\
14 \\
59 \\
- \\
7 \\
46 \\
1 \\
15 \\
1 \\
13 \\
10 \\
7 \\
157 \\
5 \\
2 \\
7 \\
1 \\
12\end{array}$ \\
\hline Totals & 10.5 & 30 & 877.2 & 1462 & 7.7 & 651 \\
\hline
\end{tabular}

The ratio of the number of FCR to FCR weight from Block A is 0.0118 (i.e., the mean weight of a piece of FCR is $0.0118 \mathrm{~kg}$ ). Considering the number/weight relationships of the FCR in these feature and midden deposits to the Primary Midden deposits sampled in Blocks D and E, and the Midden 1 and Primary Midden contexts in Block A, the average FCR weights are consistent between the North and Southwest rises, suggesting a comparable use intensity, but the FCR weights are larger than the FCR from the predominantly Middle Caddoan occupation on the South rise. This suggests that the FCR on the Southwest rise is a product of comparable kinds of multiple cooking events that reduced the coarse-grained quartzite and sandstone cobbles to small pieces and spalls.

Daub is scarce in feature and midden contexts on the Southwest rise. Only 4 features and one $1 \mathrm{x} 1$ $\mathrm{m}$ unit had daub, and it is only abundant by weight and number in Feature 65, one of the smaller cremations in the Late Archaic/Early Ceramic period cemetery. This particular feature also had considerable burned clay pieces (123.1 g) (see Table 8-29). Both the daub and burned clay from this cremation may be the product of in situ heating of grasses, sticks, and logs in a cremation pit, or more likely simply the refuse of cooking and heating events in the midden that was dumped in the cremation pit when it was backfilled. 
Burned clay pieces are common on the Southwest rise, particularly in feature contexts, weighing $877.2 \mathrm{~g}$ (see Table 8-29). The burned clay is particularly abundant in Features 65, 68, and 76, where the burned clay comprises 77 percent by weight of the burned clay pieces from the entire rise excavations; the considerable amount of burned clay from Unit 96 (see Table 8-29) is probably from Feature 18, another cremation pit excavated into the midden deposits. These pieces are primarily considered by-products of the burning of clay in the midden soil surrounding features (probably shallowly buried basins, such as the Feature 76 hearth) utilized for the heating and cooking of plant and animal foods, and then the subsequent use of midden sediments to fill the feature pits. Unlike the daub from Structures A and B on the South rise, the distribution of the daub from the Southwest rise suggests it is not from the clay plastering or lining of structure walls, but clay with grass and stick impressions obtained from clay-lined hearths and cooking features.

\section{Other Lithic Artifacts}

Two other unique lithic artifacts were recovered in the excavations at the Hurricane Hill site. The first is a $2.1 \times 1.4 \times 0.9 \mathrm{~cm}$ piece of galena that has been ground and shaped into a rectangular cube. The piece was recovered about $20 \mathrm{~cm}$ bs in Unit 56 of Block B/C, outside the Middle Caddoan period Structure A on the South rise. Galena frequently occurs in certain types of civic-ceremonial Caddoan sites, such as Spiro (Brown 1983; Walthall 1981) and George C. Davis (Baskin 1981), but it is not commonly found in small habitation sites like Hurricane Hill. Galena in Caddoan sites usually derives from source areas in the Ozark Highlands (Potosi, central Missouri, and Tri-state locales), particularly in the Potosi formations in southeastern Missouri, about $700 \mathrm{~km}$ northeast of the Cooper Lake area (Brown 1983:Table 3).

The final piece is a rounded, tube-shaped sandstone item that exhibits the initial stages of drilling at either end in a manner analogous to the manufacture of shell and bone beads (see discussion of the shell bead from Block $E$ in Chapter 11). The piece is $22.5 \mathrm{~mm}$ long and $12 \mathrm{~mm}$ wide. The drilled holes, only shallow $(<4 \mathrm{~mm})$ depressions at either end of the piece, have a diameter of $5 \mathrm{~mm}$. The piece was discarded before the holes were completed. The shaped sandstone artifact was recovered from Early Caddoan period deposits in Block A (Unit 249, between 20 and $25 \mathrm{~cm}$ bs).

\section{Summary of the Lithic Assemblages}

A substantial assortment of chipped and ground stone tools, lithic debris, and fire-cracked rock has been recovered from the Archaic (principally Late Archaic), Early Ceramic, and Caddoan (both Early and Middle) occupations on the North, South, and Southwest rises at the Hurricane Hill site. The lithic assemblages from the different areas and components share several characteristics, including:

(a) an abundance of cores, blank/preforms, and bifacial tools, indicating a general emphasis on biface tool production;

(b) considerable amounts of lithic debris from tool manufacturing activities during each occupation;

(c) the use of large numbers of expedient flake tools, apparently for a variety of domestic tasks (cf. Odell 1998), but conversely the use of lesser numbers of shaped tools (although they are relatively more frequent in the Late Archaic/Early Ceramic components in Block $\mathrm{A}$ and Block B/C and the Middle Caddoan component in Block B/C);

(d) the use of the bow and arrow of diverse styles in occupations after ca. A.D. 900;

(e) a dearth of groundstone tools and hammerstones;

(f) the reliance on local upland gravels as a raw material source for chipped and groundstone tools; and 
(g) the occasional use of non-local lithic raw materials from Red River gravels (originating in the western Ouachita Mountains), principally novaculite, gray chert, jasper, and Big Fork chert.

Fields et al. (1997:68-74) examine the variability in Cooper Lake Archaic, Early Ceramic (or Woodland), and Caddoan lithic assemblages in several respects, including the proportions of shaped tools and unmodified lithic debris; the percentages of projectile points, manufacture-related chipped stone artifacts (i.e., cores and blank-preforms), and other chipped stone tools; and through a use-intensity index, namely the "total number of shaped and expedient chipped stone tools $/ \mathrm{m}^{2}$ of manual excavations/primary occupation span in millennia" (Fields et al. 1997:72). This summary will close with a comparison of the Hurricane Hill site lithic assemblages and other Cooper Lake sites with respect to these attributes.

First, the analysis of the numerical relationship of shaped tools and lithic debris by Fields et al. (1997:Figure 40) defined two patterns: (1) an Archaic and Woodland pattern with a high amount of lithic debris relative to shaped tools, and (2) an Early Caddoan trajectory where "shaped tools tend to be relatively frequent" compared to total numbers of lithic debris. Fields et al. (1997:70) suggest that the latter pattern relates to either a heightened focus on tool use/discard compared to tool manufacture, off-site tool manufacture, or that the Early Caddoan occupations were "long lived...implying greater ranges of activities."

Turning to the most discrete Hurricane Hill tool and lithic debris data from the Southwest rise, Late Archaic/Early Ceramic components from Block A (i.e., deposits between $30-50 \mathrm{~cm}$ bs) and Block B/C (i.e., $30-50 \mathrm{~cm}$ bs), the Early Caddoan component from Block A (i.e., deposits between 0-20 cm bs), and the Middle Caddoan component from Block B/C (i.e., deposits between 0-20 cm bs), each assemblage conforms to the Archaic and Woodland pattern with high amounts of lithic debris relative to shaped tools (ratios between 20-90 pieces of lithic debris per tool. It is suspected the reason each of the components from Hurricane Hill display this tool-debris relationship is because of the raw material-rich setting of the occupations on a large upland gravel source. Thus, no raw material economizing activities were necessary (see discussion in Odell 1996:62-63 and Figure 8), tools were generally made as needed (not necessarily in advance of use), and conservation practices would not have been emphasized that would have prolonged tool use and maintenance.

In their examination of the percentages of projectile points, other tools, and manufacture-related items (what they refer to as non-tool bifaces and preforms; we have categorized these lithic artifacts as blank-preforms) among Archaic, Woodland, and Caddoan sites at Cooper Lake, Fields et al. (1997:68 and Figure 39) note very little temporal differentiation in the proportions of these chipped stone artifacts. They suggest this is because the components being studied have "comparably broad ranges of procurement, processing, and manufacture/maintenance activities." The analysis of the Hurricane Hill chipped stone artifacts supports the lack of temporal differentiation in lithic artifact assemblages, in that there are few differences between the Late Archaic/Early Ceramic, Early Caddoan, and Middle Caddoan components in the relative percentages of projectile points (between 18-33 percent, but with considerable differences in sample sizes), other tools (25-33 percent, including completed but fragmentary bifacial tools), and non-tool blankpreforms (42-53 percent). Where Hurricane Hill differs from the other Cooper Lake sites discussed by Fields et al. (1997) is that the latter sites have generally higher proportions of projectile points (particularly in the Early Caddoan period) but lower proportions of other tools. The proportions of blank-preforms in the Cooper Lake sites examined by Fields et al. (1997:Table 7) range from 43 percent in the Middle Archaic; 49 percent in the Late Archaic; 45-58 percent in the Woodland components; 39-58 percent for the Early Caddoan components; and 42 percent in the Late Caddoan assemblage.

Finally, the use-intensity index developed by Fields et al. (1997:74 and Figure 41) suggests there were significant temporal "changes in how frequently sites were occupied and how long the individual occupations lasted, ranging from short-term (albeit still residential) and infrequent use during the middle Archaic period to at least seasonal (and longer in some cases), multi-generational occupation during the early and middle Caddoan periods." Fields et al. (1997:74) also suggest a decreasing use-intensity in the Late Caddoan period, which they argue "implies an increase in logistical mobility over the early Caddoan period." 
The use-intensity indices for the Late Archaic/Early Ceramic, Early Caddoan, and Middle Caddoan components at Hurricane Hill support these broad changes, in that the use-intensity indices for the Late Archaic/Early Ceramic components on the North (Block A) and South rise range from lows of 0.87 (Block B/C) to 5.07 (Block A), implying relatively short-term use, while the Early Caddoan use-intensity index increases to 15.34, and the Middle Caddoan use-intensity index is 8.33. Based on the presence of middens, various features, and several structures, there is no doubt that the Early and Middle Caddoan components at Hurricane Hill were relatively lengthy residential occupations. Nevertheless, a comparison of the useintensity indices suggests that Hurricane Hill was less intensively used than other Late Archaic (index value=10), Early Ceramic (index values=10-20), Early Caddoan (index value=25-60), and Late Caddoan (index value $=30$ ) components at Cooper Lake. 



\title{
CHAPTER 9, THE CADDOAN CERAMIC ARTIFACTS FROM HURRICANE HILL
}

\author{
Timothy K. Perttula, with a contribution by Sergio A. Iruegas
}

This chapter first discusses the analysis of the prehistoric Caddoan ceramics from the Hurricane Hill site. Over 8,800 sherds have been analyzed from the site, the largest prehistoric Caddoan ceramic assemblage recovered from any Caddoan site at Cooper Lake (Cliff and Perttula 1995; Fields et al. 1997), and detailed descriptions and attribute analyses of the decorated and plain sherds are presented in Appendices VII and VIII. A second part of Chapter 9 considers the petrographic analysis of 14 sherds from the North and South rises to characterize the paste composition (including clay composition, mineral inclusions, and temper selection differences) of the Early and Middle Caddoan ceramics from the site, and also includes a comparative discussion on the petrographic analysis of Caddoan ceramics from selected Northeast Texas sites in the Sulphur River, Cypress Creek, and Sabine River drainage basins. Chemical variations in the Hurricane Hill ceramics are discussed in Chapter 10 by Hector Neff, James W. Cogswell, and Michael D. Glascock (see also Cogswell et al. 1998a).

The framework of the ceramic analysis was a paradigmatic classification (e.g., Dunnell 1971, 1986) in which dimensions and attributes of surface treatments, temper types, decoration types, and decorative elements were selected for class definitions and the sorting of the plain and decorated sherds (see Miller 1986:77-96; Perttula et al. 1988). Information concerning sherd location, rim shape, lip profile, vessel form, base shape, and type were also recorded during the analysis to provide nominal, or qualitative, data regarding the morphological characteristics of the sherds from the different block assemblages on the North and South rises. (Table 9-1).

Table 9-1. Ceramic attributes.

\begin{tabular}{|c|c|c|}
\hline \multicolumn{3}{|l|}{ Artifact Class: } \\
\hline $\begin{array}{l}01 \mathrm{Rim} \\
02 \mathrm{Rim} / \text { Body } \\
03 \mathrm{Body}\end{array}$ & $\begin{array}{l}04 \text { Body/Base } \\
05 \text { Base } \\
06 \text { Appendage }\end{array}$ & $\begin{array}{l}07 \mathrm{Rim} / \text { Appendage } \\
08 \text { Indeterminate }\end{array}$ \\
\hline $\begin{array}{l}\text { Type of Decoration: } \\
01 \text { None } \\
02 \text { Incised } \\
03 \text { Punctated } \\
04 \text { Engraved } \\
05 \text { Brushed } \\
06 \text { Trailed } \\
07 \text { Incised/Punctated } \\
08 \text { Punctated/Appliqued }\end{array}$ & $\begin{array}{l}09 \text { Appliqued } \\
10 \text { Incised/Appliqued } \\
11 \text { Excised } \\
12 \text { Impressed } \\
13 \text { Incised/Engraved } \\
14 \text { Pinched } \\
15 \text { Engraved/Punctated } \\
16 \text { Impressed/Punctated }\end{array}$ & $\begin{array}{l}17 \text { Trailed/Brushed } \\
18 \text { Engraved/Brushed } \\
19 \text { Punctated/Noded } \\
20 \text { Punctated/Brushed } \\
21 \text { Noded } \\
22 \text { Incised/Brushed } \\
23 \text { Incised/Punctated/Brushed }\end{array}$ \\
\hline $\begin{array}{l}\text { Decorative Element: } \\
\text { 000 None } \\
001-095 \text { (see Figures 9-2 }\end{array}$ & $\begin{array}{l}999 \text { Indeterminate } \\
\text { ugh 9-7) }\end{array}$ & \\
\hline $\begin{array}{l}\text { Location of Decoration: } \\
\text { 00 None/Indeterminate } \\
\text { 01 Rim } \\
\text { 02 Rim/Body }\end{array}$ & $\begin{array}{l}03 \text { Lip } \\
04 \text { Body } \\
05 \text { Body/Base }\end{array}$ & $\begin{array}{l}06 \text { Base } \\
07 \text { Appendage } \\
08 \text { Interior }\end{array}$ \\
\hline
\end{tabular}

Surface Treatment:

00 Indeterminate

01 None

02 Smoothed Interior

03 Smoothed Interior/Exterior

04 Smoothed Exterior

05 Scraped Interior
06 Scraped Exterior 07 Scraped Interior/Exterior

08 Burnished Interior

09 Burnished Exterior

10 Burnished Interior/Exterior

11 Polished Interior
12 Polished Exterior

13 Polished Interior/Exterior

14 Slipped Interior

15 Slipped Exterior

16 Slipped Interior/Exterior 
Table 9-1. Ceramic attributes, cont.

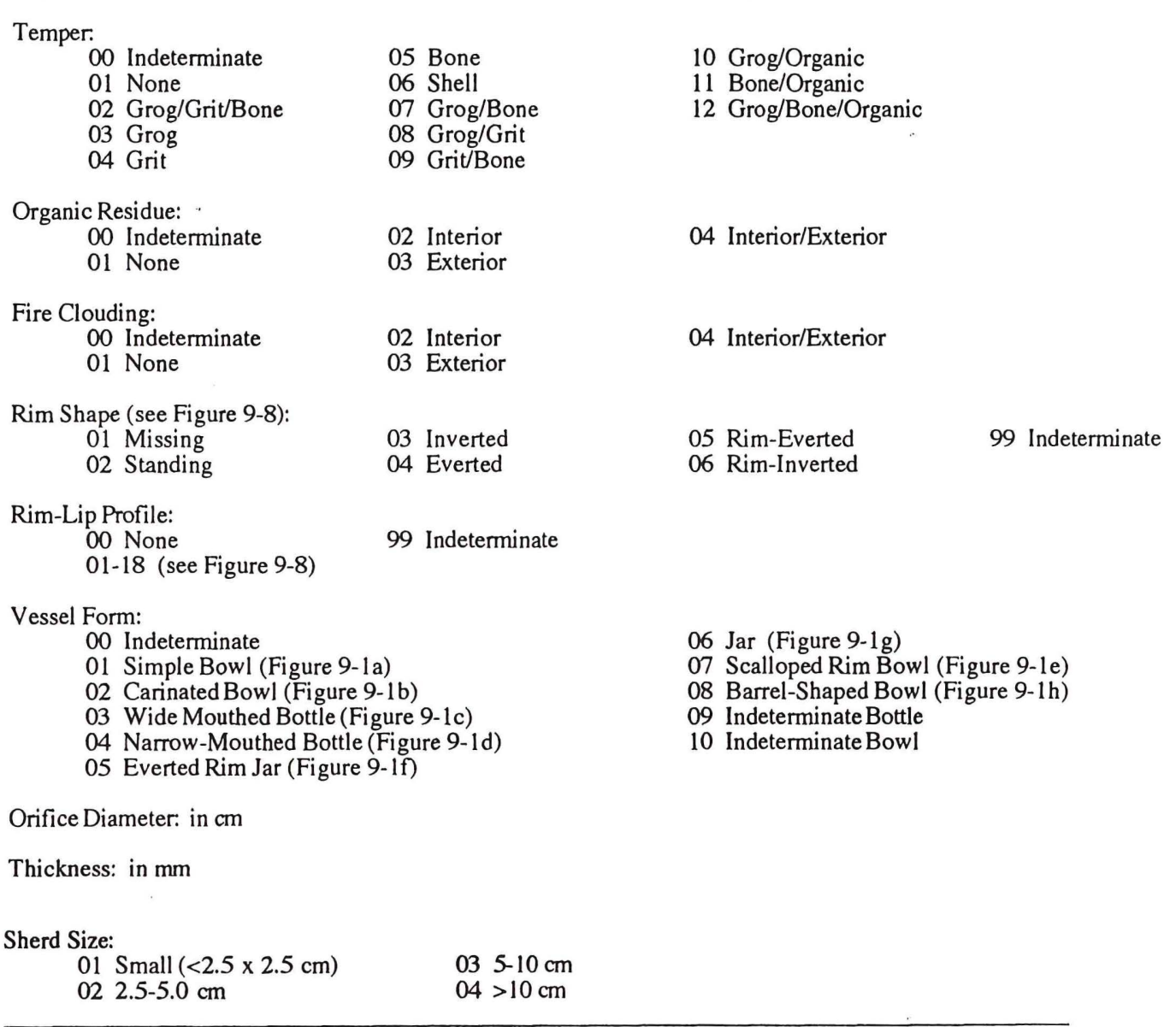

We also examined sherd size because it is informative about the preservation and contextual condition of the ceramics from the Hurricane Hill site. Differences in sherd size between various site areas relates fragmentation to specific actions, such as modern plow disturbances, and to depositional and formation processes in the archaeological record (e.g., Schiffer 1987:276-278). Data on surface treatment and color are also useful in these respects since some variations in these can be related to sherd erosion and to the overall preservation of the archaeological deposits (e.g., Bruseth and Perttula 1981:73-74).

Thickness and orifice diameter are continuous data that are considered necessary for measuring or estimating vessel size and strength (cf. Braun 1985), as well as for determining minimum numbers of vessels (MNV) when they are combined with the paradigmatic classes. Cross-mends, of which there are several hundred examples from the site, are also important in the determination of MNVs, and in assessing the depositional context and integrity of the ceramics within the various component deposits. The analyses of these data will be presented in the specific discussions below of the ceramic assemblages from the different components at the Hurricane Hill site.

Lastly, information about the vessel type, the placement of decoration on the rim and/or body of the vessel, and the type of decorative element provides more specific data on the stylistic variability present in the Caddoan ceramic assemblages from the Hurricane Hill site. Eight different vessel forms and one type of long-stemmed Red River pipe (see discussion below), are represented in the ceramic assemblage (Figure 9-1). It is possible that a small amount of the ceramics from the Southwest rise, Area B (see also Appendix I), and the North rise represent Early Ceramic or Woodland period wares, based on their 
archaeological context and dates from features and midden deposits (see Chapter 7, this volume). They occur in very low densities in such contexts, however, and are not readily distinguishable in temper, thickness, or decoration from the Early and Middle Caddoan period wares from the North and South rises. It appears to be the case that the use of ceramics by Early Ceramic or Woodland period groups in the upper and middle Sulphur River basins was minimal in comparison with contemporaneous Woodland or Fourche Maline period groups on the Red River in southwestern Arkansas and northeastern Texas (see McGregor 1997b; Bruseth 1998; Schambach 1982, 1998), or with Mossy Grove groups in the Neches-Angelina River basins in deep East Texas (see Story 1990; Fields 1995b).

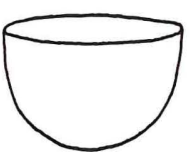

a.

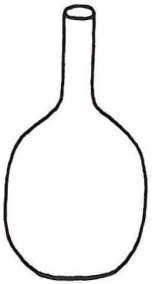

d.

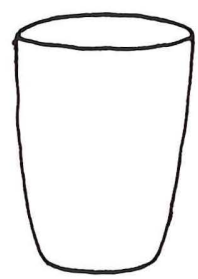

g.

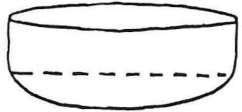

b.

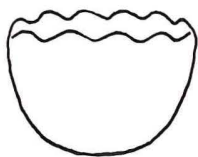

e.

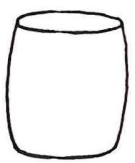

h.

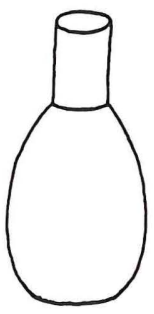

c.

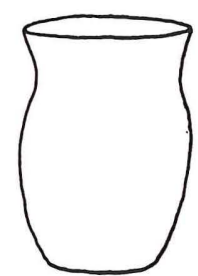

f.

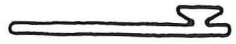

i.

Figure 9-1. Vessel and pipe forms represented at Hurricane Hill: a, simple bowl; b, carinated bowl; c, widemouthed bottle; d, narrow-mouthed bottle; e, scalloped rim bowl; f, everted rim jar; g, vertical rim jar; $h$, barrel-shaped bowl; i, long-stemmed Red River pipe.

\section{Overview of the Hurricane Hill Ceramics}

Inspired by the scheme initially outlined by Plog (1980:47-50), and further developed following analyses of Caddoan ceramics from sites in the Cooper Lake Basin (Cliff and Perttula 1995), the Cypress Creek basin (Perttula 1998c), and the Sabine River basin (Perttula 1998d), the analysis of the ceramics focused on the recognition and definition of unique decorative elements, along with the attribute analysis of both plain and decorated sherds. A total of 95 decorative elements have been defined in the ceramic assemblages at the Hurricane Hill site (Figures 9-2 to 9-7). At this stage, however, the identified decorative elements represent a combination of primary and secondary units (in the sense employed by Plog [1980]) because distributional studies have not been completed to determine the overall character of the decorative 
elements or to distinguish which portions of the decorative elements can actually be considered primary or secondary units.
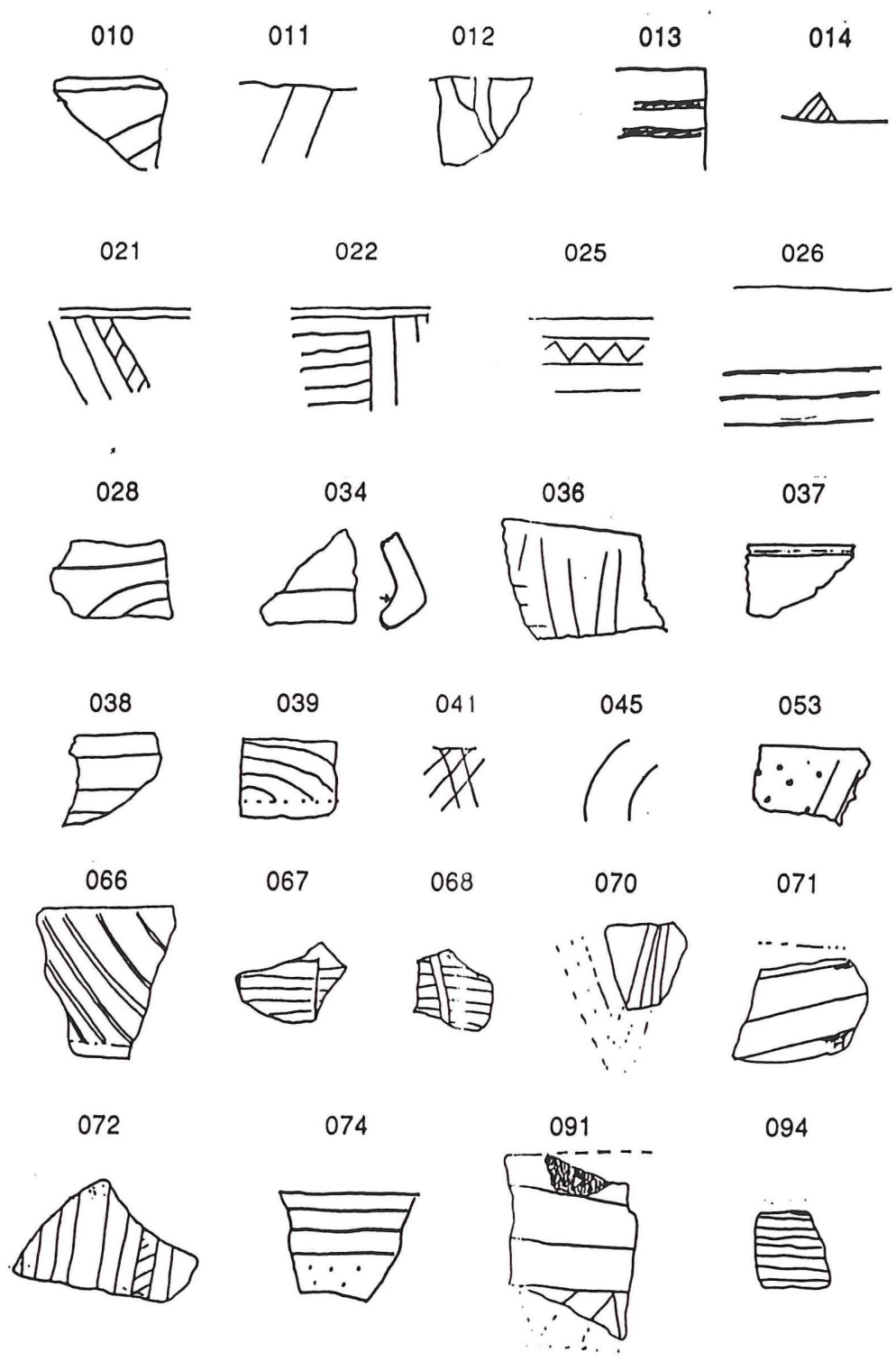

094

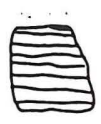

Figure 9-2. Engraved ceramic decorative elements \#010-\#014, \#021, \#022, \#025, \#026, \#028, \#034, \#036\#039, \#041, \#045, \#053, \#066-\#068, \#070-\#072, \#074, \#091, and \#094. 

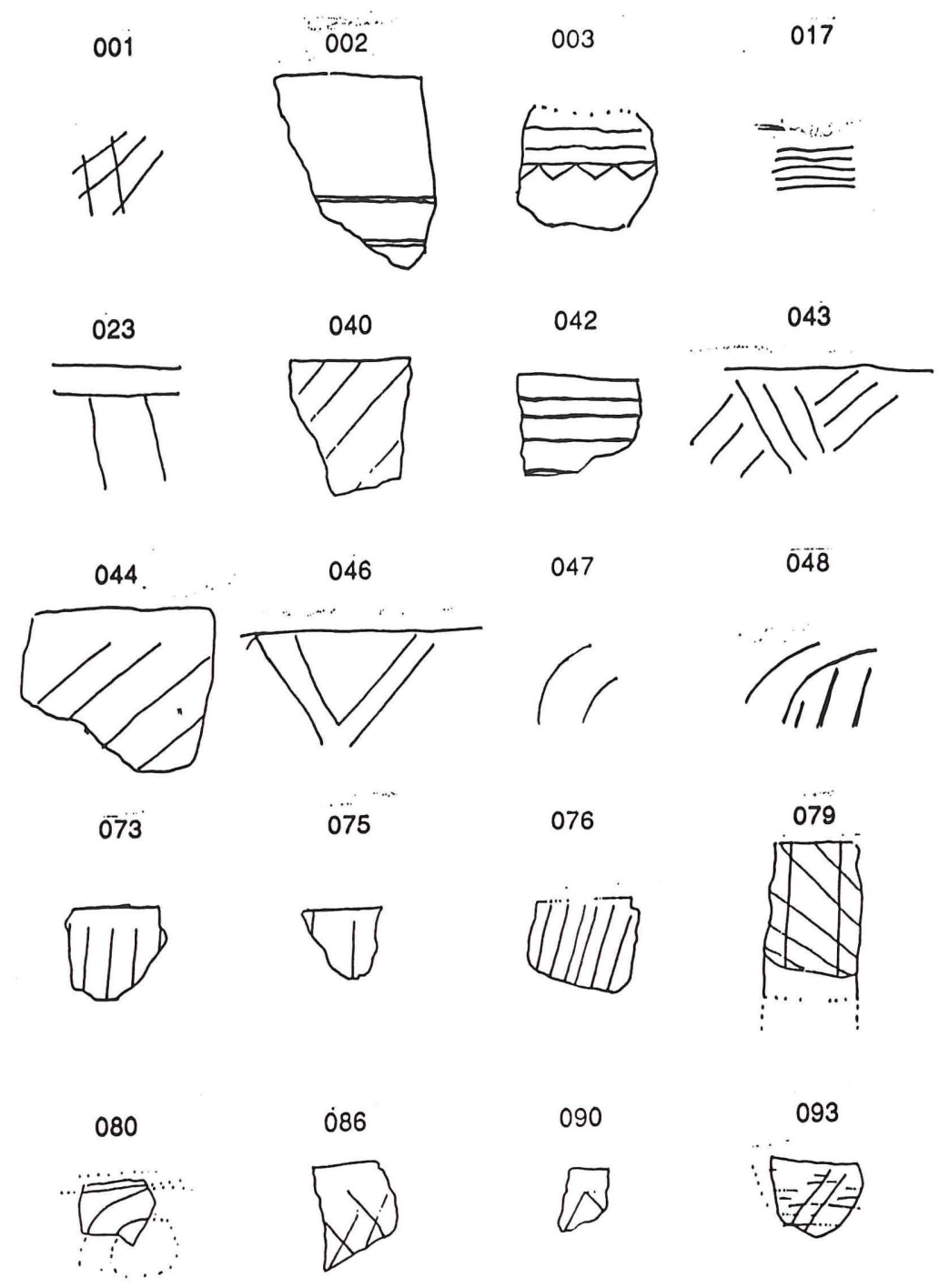

Figure 9-3. Incised, incised-brushed, and incised-appliqued ceramic decorative elements: a, incised, \#001, $\# 002, \# 017, \# 023, \# 040, \# 042, \# 043, \# 044, \# 046, \# 047, \# 048$, \#073, \#075, \#076, \#079, \#80, and \#090; b, incised-brushed, \#086, \#093; c, incised-appliqued, \#003.

The majority of the ceramic assemblage is from Block A on the North rise, deriving from the Early Caddoan Midden 1 deposits, and from the Middle Caddoan period Structures A and B and associated midden deposits on the South rise in Block B/C (Table 9-2). Over 80 percent of the ceramics from the Hurricane Hill site were found in the upper $30 \mathrm{~cm}$ of the archaeological deposits on the two rises, particularly between $10-30 \mathrm{~cm}$ bs. In Block A excavations, for example, over 66 percent of the decorated and rim sherds were recovered between $10-30 \mathrm{~cm}$ bs, and less than 8 percent were found at depths greater than 40 $\mathrm{cm}$ bs (Figure 9-8). More than 80 percent of the Block $\mathrm{D}$ and $\mathrm{E}$ rim and decorated sherds were found between $0-40 \mathrm{~cm}$, with the highest frequencies between $30-40 \mathrm{~cm}$ bs. A similar distribution of rim and decorated sherds is documented in Block $\mathrm{B} / \mathrm{C}$ on the South rise, with less than 17 percent of the sherds found below $30 \mathrm{~cm}$ bs. The sherds found below $30-40 \mathrm{~cm}$ bs in each excavated context appear to be sherds that through bioturbation have been displaced into earlier archaeological materials, or were in pit and post features that could not be discerned in lower levels during the excavations. 


\begin{tabular}{|c|c|c|c|}
\hline 004 & 005 & 015 & 019 \\
\hline $0_{0}^{0}$ & $\because \because \because \cdots$ & $0_{0}^{\circ}$ & 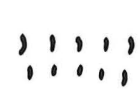 \\
\hline
\end{tabular}
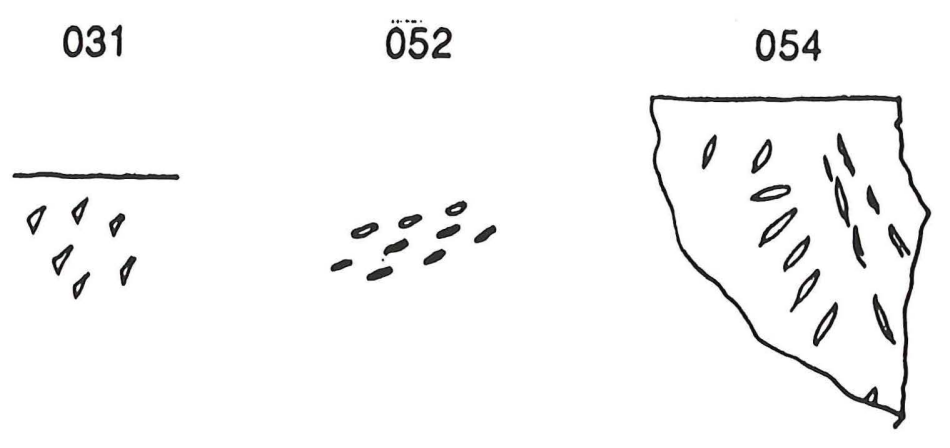

059

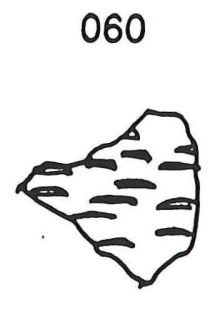

061
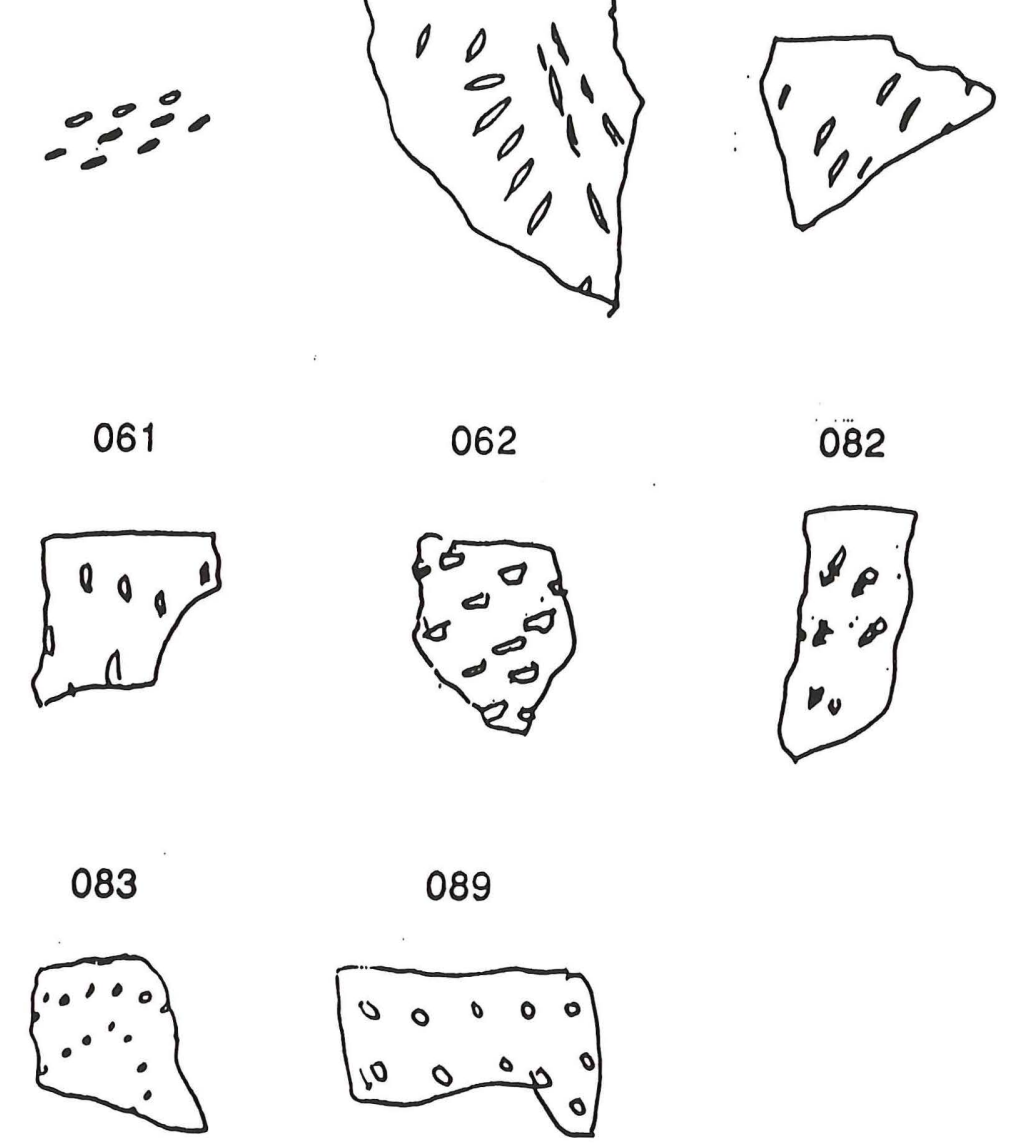

Figure 9-4. Punctated ceramic decorative elements \#004, \#005, \#015, \#019, \#031, \#052, \#054, \#059-\#062, \#082, \#083, and \#089. 
a.
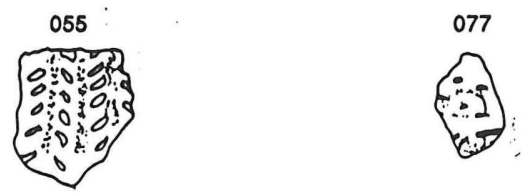

b.

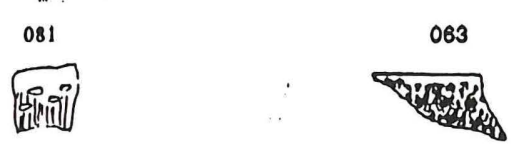

c.

$\underline{085}$

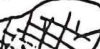

N1

Figure 9-5. Punctated-appliqued, punctated and noded, brushed-punctated, impressed-punctated, and incisedpunctated-brushed ceramic decorative elements: a, punctated-appliqued, \#055; b, punctated-noded, \#077; c, brushed-punctated, \#081; d, impressed-punctated, \#063; e, incised-punctated-brushed, \#085.
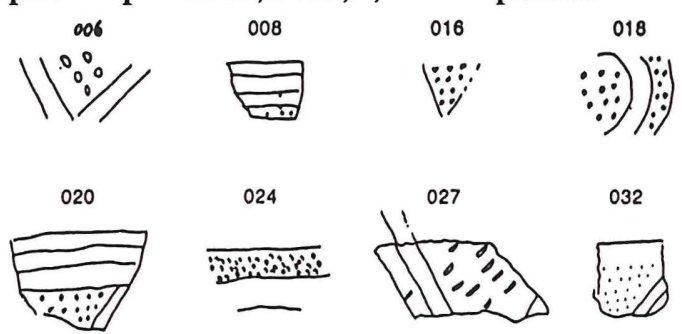

032
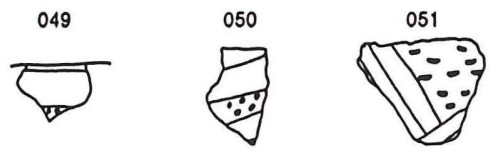

056
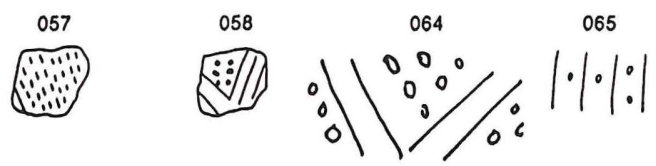

078

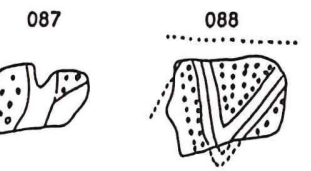

Figure 9-6. Incised-punctated ceramic decorative elements \#006, \#008, \#016, \#018, \#020, \#024, \#027, \#032, \#049-\#051, \#056-\#058, \#064, \#065, \#078, \#087, and \#088. 
a.

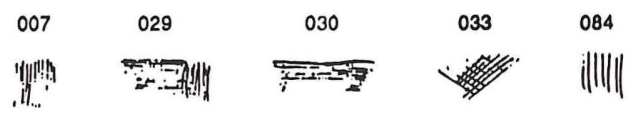

b.
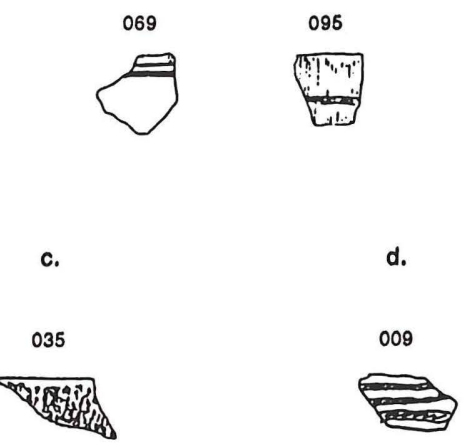

Figure 9-7. Brushed, brushed-trailed-impressed, impressed, and trailed ceramic decorative elements: a, brushed, \#007, \#029, \#030, \#033, and \#084; b, brushed-trailed, \#069 and \#095; c, impressed, \#035; d, trailed, \#009.

Table 9-2. Relative Frequencies and Densities for the Ceramic Assemblages from the North, South, and Southwest Rises

\begin{tabular}{|c|c|c|c|c|}
\hline Provenience & $\mathrm{N}$ & $\begin{array}{c}\text { Decorated } \\
\text { Rim/Body Rim }\end{array}$ & $\begin{array}{l}\text { Plain } \\
\text { Slipped }\end{array}$ & $\begin{array}{l}\text { Body/ } \\
\text { Base }\end{array}$ \\
\hline
\end{tabular}

$\begin{array}{crlllll}\text { North Rise } & & & & & & \\ \text { Block A } & 2660 & 10.2^{\mathrm{a}} & 6.3 & 1.0 & 79.2 & 63 \\ \text { Block D } & 205 & 2.4 & 1.5 & 0.5 & 95.6 & 14 \\ \text { Block E } & 202 & 3.0 & 3.0 & 0.0 & 94.0 & 29\end{array}$

South Rise

$\begin{array}{lrrrrrl}\text { Block B/C } & 5060 & 6.1 & 4.6 & 0.6 & 89.4 & 36 \\ \text { Block F } & 13 & 7.7 & 0.0 & 0.0 & 92.3 & 6.5\end{array}$

Southwest Rise ${ }^{b}$

$\begin{array}{lllllll}\text { Units/Fea. } & 27 * & 7.4 & 3.7 & 3.7 & 85.2 & 6.5\end{array}$

Area B
Units
$\begin{array}{ll}12 & 0.0\end{array}$
$\begin{array}{lll}0.0 & 0.0 & 100.0\end{array}$
10.0

a The decorated rim/body sherds from Block A are over-represented because decorated sherds from selected finescreen and flotation samples were analyzed but the plain body/base sherds from those samples were not tabulated. b This includes 12 sherds from Unit 96, 2 sherds from Unit 282, 1 sherd from Feature 65, 2 sherds from Feature 68, 9 sherds from Feature 76, and 1 sherd from Feature 92.

* Perttula (1995b:143 and Table 4) incorrectly listed the ceramics total from the Southwest rise as 21 sherds, and Story (1990:Table 72) incorrectly tabulated 48 sherds from the rise. Most of these are actually from the Middle Caddoan occupation centered on the South rise. 


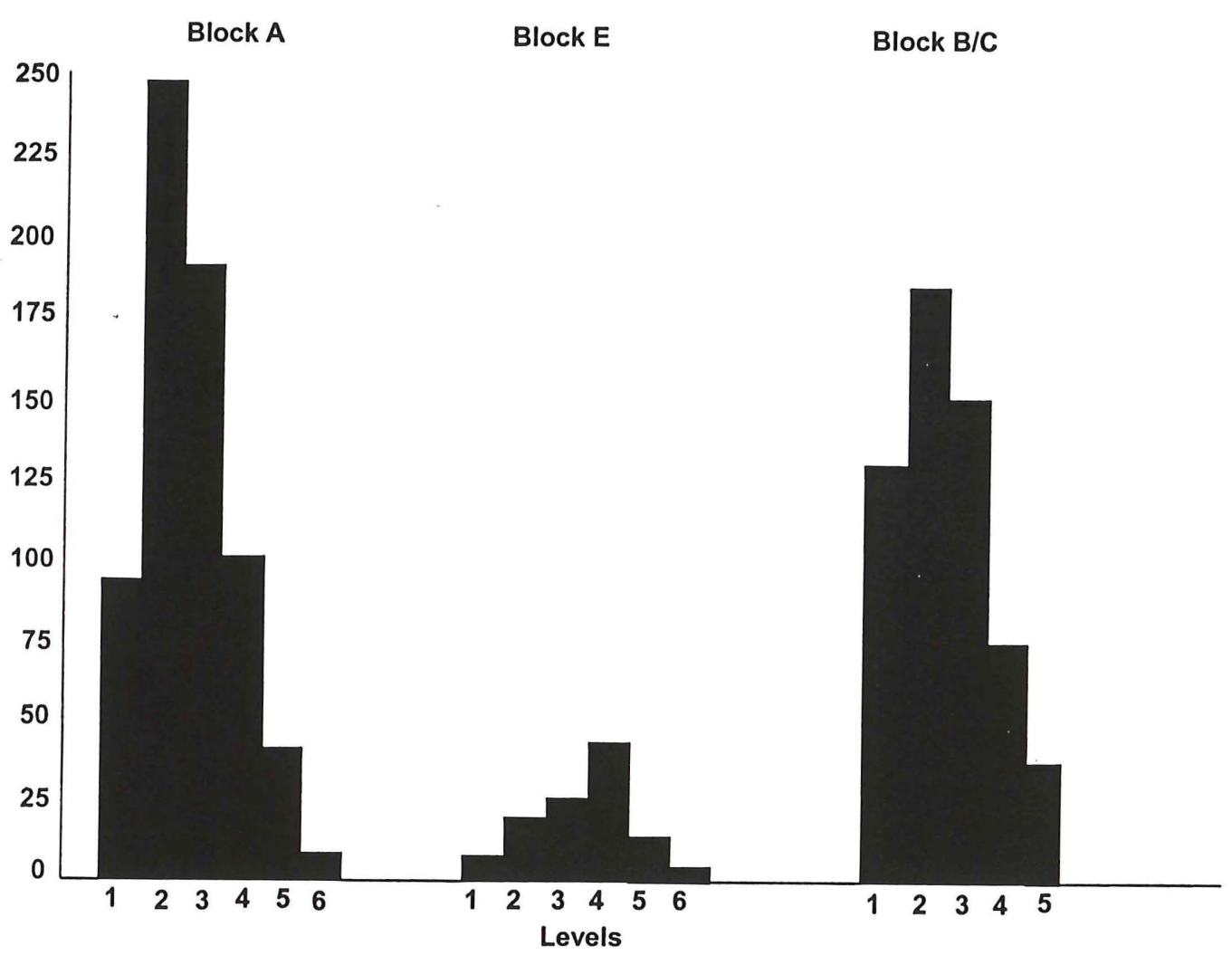

Number of Decorated and Rim Sherds

Figure 9-8. Frequency of decorated sherds and rim sherds by block and level.

In general, the ceramic assemblage is characterized by a low frequency of decorated sherds, whether the decoration is on the rim, body, or rim/body; roughly 5 percent of the sherds are decorated. Many plain sherds (probably from bowls and bottles) are present, and less than 1 percent of the sherds are from hematite-rich red-slipped vessels (bowls and bottles). The highest density of sherds occurs in Block A (63 sherds $/ \mathrm{m}^{2}$ ), followed by Blocks B/C, E, and D with densities between 14-36 sherds $/ \mathrm{m}^{2}$. The Block D assemblage also has the lowest percentage ( 2.4 percent) of decorated body and rim sherds at the site. Thus, it is difficult to characterize the Block D ceramic assemblage temporally, although the presence of Caddoan Structure D and its proximity to Midden 1 (in Block A) seem to be good associational evidence that the ceramics from Blocks $\mathrm{A}$ and $\mathrm{D}$ are contemporaneous.

Grog, grog/bone, and grog/grit/bone were the primary temper types in the ceramic assemblages (Table 9-3), with smaller amounts of grit-tempered pottery. The shell-tempered wares may represent a small Late Caddoan ceramic assemblage, based on the presumption that the use of shell tempering in Northeast Texas generally (meaning the lower Sulphur and the Red River basin [Bruseth 1998; Cliff 1997], and the Cooper Lake area specifically (Cliff and Perttula 1995; Fields et al. 1993, 1997), is a Late Caddoan phenomena. By ca. A.D. 1400 in the middle Red River area, for example, Caddoan ceramic assemblages have 90-95 percent shell-tempered wares (Bruseth 1998). At the 15th-16th century Peerless Bottoms site (41HP175) at Cooper Lake, 41 percent of the 1947 sherds had shell tempering (Fields et al. 1997:Table 5). Otherwise, based on the tempering materials and the range of ceramic decorative styles, the Hurricane Hill ceramics represent Early and Middle Caddoan period assemblages. Cliff's (1995) analysis of the Thomas site (41DT80) suggests that burnished grit-tempered LeFlore Plain sherds (cf. Brown 1971) occur in Early and Middle Caddoan contexts in the Cooper Lake basin, and a few such sherds are present at Hurricane Hill. 
Table 9-3. Temper Data for Base and Body Sherds

\begin{tabular}{|c|c|c|c|c|c|c|}
\hline \multirow[b]{2}{*}{ Temper } & \multicolumn{2}{|c|}{ Base Sherds } & \multicolumn{2}{|c|}{ Body Sherds } & \multirow[b]{2}{*}{ Total } & \multirow{2}{*}{$\begin{array}{l}\text { Percent } \\
\text { of Total }\end{array}$} \\
\hline & $\mathrm{N}$ & $\%$ & $\mathrm{~N}$ & $\%$ & & \\
\hline Bone & 7 & 3.0 & 441 & 6.0 & 448 & 5.9 \\
\hline Grog/Bone & 39 & 16.9 & 1104 & 15.1 & 1143 & 15.1 \\
\hline Grog/Grit & 10 & 4.3 & 339 & 4.6 & 349 & 4.6 \\
\hline Grog/Grit/Bone & 11 & 4.8 & 526 & 7.2 & 537 & 7.1 \\
\hline Grit & - & - & 105 & 1.4 & 105 & 1.4 \\
\hline Grog & 164 & 71.0 & 4676 & 63.9 & 4840 & 64.1 \\
\hline Grit/Bone & - & - & 65 & 0.9 & 65 & 0.9 \\
\hline Shell & - & - & 20 & 0.3 & 20 & 0.3 \\
\hline Other & - & - & 25 & 0.3 & 25 & 0.3 \\
\hline None & - & - & 17 & 0.2 & 17 & 0.2 \\
\hline Total & 231 & & 7318 & & 7549 & \\
\hline
\end{tabular}

Given the differences in sample size between the blocks, changes across the site in the temper types used do not appear to have great temporal significance (Table 9-4). The use of bone as a temper is more common in Middle Caddoan contexts (30.4 percent) than it is in Early Caddoan contexts on the North rise (26.4 percent), but the proportional differences are not significant. Functional parameters (e.g., vessel forms) of the assemblage, looking at correlations between functional attributes and temper selection patterns, will be considered further on. Elevated percentages of grog/grit-tempered vessels in blocks D and E (i.e., between 7.4-18.9 percent), which apparently are from relatively thick coarse-tempered utility wares, may indicate differing patterns of ceramic refuse accumulation around Structures $\mathrm{D}$ and $\mathrm{E}$ than is reflected in Midden 1, or conversely that earlier ceramic sherds are present on the North rise outside of the Early Caddoan midden deposits; it may simply be a product of the small ceramic sample size in blocks D and E. The Early Caddoan Midden 1 deposit on the North rise contained a wider variety of vessel types and sherds.

Table 9-4. Relative Frequencies of Temper Types for Plain Base and Body Sherds

\begin{tabular}{lllllll}
\hline Temper & $\begin{array}{l}\text { Block A } \\
(\mathrm{n}=2107)\end{array}$ & $\begin{array}{l}\text { Block D } \\
(\mathrm{n}=196)\end{array}$ & $\begin{array}{l}\text { Block E } \\
(\mathrm{n}=190)\end{array}$ & $\begin{array}{l}\text { Block B/C } \\
(\mathrm{n}=4522)\end{array}$ & $\begin{array}{l}\text { Block F } \\
(\mathrm{n}=13)\end{array}$ & $\begin{array}{l}\text { SW Rise } \\
(\mathrm{n}=23)\end{array}$ \\
Grog & 68.9 & 52.0 & 63.7 & 62.8 & 46.2 & 43.5 \\
Grog/Bone & 14.4 & 15.4 & 17.9 & 14.4 & 15.4 & 47.8 \\
Grog/Grit/Bone & 6.3 & 6.6 & 2.6 & 8.5 & - & - \\
Bone & 5.4 & 3.6 & 5.8 & 6.5 & 7.7 & 8.7 \\
Grog/Grit & 2.4 & 18.9 & 7.4 & 4.8 & 7.7 & - \\
Grit & 1.1 & 1.5 & 1.1 & 1.5 & 7.7 & - \\
Grit/Bone & 0.3 & 1.5 & 1.6 & 1.0 & - & - \\
Grog/Organic & 0.4 & 0.5 & - & 0.2 & - & - \\
Shell & 0.5 & - & - & 0.1 & 15.4 & - \\
None & 0.2 & - & - & 0.2 & - & -
\end{tabular}

The grit-, shell-, grit/bone-, and grog/organic-tempered sherds represent a distinctive component of the ceramic assemblage because they are generally thinner (ca. 4-6 $\mathrm{mm}$ ) than the other types of tempered wares (ca. 7-8 mm). However, only 2.3-3.5 percent of the samples from any block or rise belong to this group of sherds. The grit- tempered wares include unslipped bowl forms with primarily incised/punctated, 
punctated, trailed, and excised decorations. Crockett Curvilinear Incised decorative elements (see Figure 9-6) and horizontal incised elements are predominant styles with this ware. Shell-tempered wares include only brushed or plain pottery. Grit-bone-tempered wares from the North and South rises are commonly slipped and engraved with motifs common to the Early and Middle Caddoan periods. Grog/organic-tempered pottery is also more frequently slipped than other temper classes, but decorative elements include punctated, corncob-impressed, and brushed designs. As discussed above, only the shell-tempered wares are believed to represent a probable later Caddoan ceramic component at Hurricane Hill (albeit a small one), based on the common manufacture of shell-tempered ceramics along the Red River and the lower Sulphur River after ca. A.D. 1300-1400 (Bruseth 1998; Cliff 1997), and at Cooper Lake after ca. A.D. 1400. The other low artifact frequency wares are apparently expressions of the increased variability in temper selection in both the Early and Middle Caddoan period ceramic assemblages on parts of the site.

The relative frequencies of temper types for base sherds are similar to those for the body sherds (see Table 9-3). However, the base-to-body ratios vary significantly within the temper groups. That may indicate differences in the size of the vessel body relative to the base, as well as the difficulty in identifying base sherds in certain cases (i.e., when the base is not noticeably thicker than the body or when sherd sizes are small). Base-to-body ratios for various temper types range from 1:28 to 1:63: Grog/bone, 1:28.3; Grog, 1:28.5; Grog/grit, 1:33.9; Grog/grit/bone; 1:47.8; Bone, 1:63.0. The base to body ratios suggest that bonetempered wares probably had the largest vessel sizes, followed by the grog-grit-bone wares.

Identified base shapes include disk and circular types, although only 6.1 percent of the sherds could be so categorized (Table 9-5). Excluding the indeterminate base types, over 98 percent of the base sherds are flat; the others are rounded and are probably from bottles.

Table 9-5. Ceramic attribute data for a selected sample of base sherds by temper type.

\begin{tabular}{|c|c|c|c|c|c|c|c|}
\hline \multirow[t]{2}{*}{$\begin{array}{l}\text { Base Shape/ } \\
\text { Temper }\end{array}$} & \multicolumn{2}{|l|}{ Flat } & \multicolumn{2}{|c|}{$\begin{array}{l}\text { Base Type } \\
\text { Rounded }\end{array}$} & \multicolumn{2}{|c|}{ Indeterminate } & \multirow{2}{*}{$\begin{array}{l}\text { Totals/ } \\
\text { Percent }\end{array}$} \\
\hline & $\mathrm{N}$ & Percent & $\mathrm{N}$ & Percent & $\mathrm{N}$ & Percent & \\
\hline \multicolumn{8}{|l|}{$\begin{array}{l}\text { Grog Temper: } \\
\text { Disk }\end{array}$} \\
\hline $\begin{array}{l}\text { Disk } \\
\text { Circular }\end{array}$ & $\begin{array}{l}1 \\
7\end{array}$ & $\begin{array}{l}1.2 \\
8.3\end{array}$ & - & & - & & $\begin{array}{l}1 / 0.6 \\
7 / 4.3\end{array}$ \\
\hline Indeterminate & 76 & 90.5 & 2 & 100.0 & 77 & 100.0 & $155 / 95.1$ \\
\hline \multicolumn{8}{|c|}{ Grog/Bone Temper: } \\
\hline & 2 & 11.1 & - & - & - & - & \\
\hline $\begin{array}{l}\text { Circular } \\
\text { Indeterminate }\end{array}$ & 14 & $\begin{array}{l}11.1 \\
77.8\end{array}$ & - & 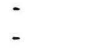 & $\overline{21}$ & 100.0 & $\begin{array}{l}2 / 5.1 \\
35 / 89.7\end{array}$ \\
\hline \multicolumn{8}{|c|}{ Grog/Grit/Bone Temper: } \\
\hline Circular & 2 & 40.0 & - & - & - & & $2 / 18.2$ \\
\hline Indeterminate & 3 & 60.0 & - & - & 6 & 100.0 & $9 / 81.8$ \\
\hline $\begin{array}{l}\text { Grog/Grit Temper } \\
\text { Indeterminate }\end{array}$ & 4 & 100.0 & - & - & 6 & 100.0 & $10 / 100.0$ \\
\hline $\begin{array}{l}\text { Bone Temper. } \\
\text { Indeterminate }\end{array}$ & & 1000 & & & 5 & & 71000 \\
\hline & & & & & & & \\
\hline Total & 113 & 49.1 & 2 & & 115 & 50.0 & 230 \\
\hline
\end{tabular}

The sample of sherds from Hurricane Hill is large compared with other excavated sites at Cooper Lake (e.g., Doehner and Larson 1978; Doehner et al. 1978; Martin 1997a, 1997b; Cliff 1995; Fields et al. 1997). However, the assemblage is comprised primarily of size 1 sherds as a result of plowing and grubbing activities. These sherds are less than $2.5 \mathrm{~cm}$ in length and width (see Table 9-1). Consequently, 
the assemblage discussions below are influenced to an unknown degree by fragmentation and weathering processes. Only in the lower levels of Midden 1 are the larger size 2 and 3 sherds (see Table 9-1) relatively common, indicating the better preservation of discarded sherds in this thicker trash deposit.

These modern disturbances are also reflected in the low percentage of sherds with visible interior/exterior surface treatments, such as burnishing and polishing. In addition, the preservation of organic residues on the sherds is rare (Table 9-6). Only 0.6-1.1 percent of the analyzed sherds from Blocks $\mathrm{A}$ and $\mathrm{B} / \mathrm{C}$ had preserved organic residues from the charring of plant remains during cooking and heating activities (see Hally 1983, 1986; Skibo 1992). Body polishing is equally infrequent (0.9-1.2 percent). About 10-13 percent of the sherds from Blocks $A$ and $B / C$ exhibit some form of exterior or interior treatment, primarily smoothing and burnishing (e.g., Rye 1981), but polished and scraped surfaces are also represented. Fireclouding was noted on 5.3-5.7 percent of the sherd sample, indicating that the firing atmosphere was difficult to control in open fires when the ceramics were manufactured (see Rye 1981:120).

Table 9-6. Relative Frequencies of Surface Treatments for Sherd Samples from Blocks $A$ and $B / C$

$\begin{array}{lll}\text { Surface Treatment } & \begin{array}{l}\text { Block A } \\ (\mathrm{n}=1076)\end{array} & \begin{array}{l}\text { Block B/C } \\ (\mathrm{n}=685)\end{array}\end{array}$

Smoothed Exterior

Smoothed Interior

Scraped Exterior

Scraped Interior

Burnished Exterior

Burnished Interior

Polished Exterior

Polished Interior

Organics on Exterior

Organics on Interior

Fireclouds on Exterior

Fireclouds on Interior

Fireclouds on Both Surfaces

None
5.3

5.3

1.9

2.0

5.3

3.8

0.8

0.1

0.5

0.6

5.3

2.4

2.6

64.1
5.5

3.5

0.7

0.4

4.8

3.4

0.6

0.6

0.6

5.7

1.7

2.2

70.3

Over 690 decorated sherds (rim and body) are present at the Hurricane Hill site. In the assemblages with more than 40 decorated sherds (i.e., Blocks $A$ on the North rise and B/C on the South rise), incised, punctated, incised/punctated, and engraved decorated types are the major classes (Table 9-7). Blocks A and $\mathrm{B} / \mathrm{C}$ are quite similar in the relative frequencies of these major decorated types (90.2-91 percent), except that in Block B/C the frequency of engraved sherds is slightly higher, and the incidence of rim and body punctation is correspondingly lower (see Table 9-7). Brushing on vessel bodies accounts for 3-6-4.0 percent of the assemblages in both areas, and probably constitutes a distinct portion of the Middle Caddoan period ceramics from Hurricane Hill. The only other decorative types that occur on both the North and South rises are trailing and incised/brushed sherds (see Table 9-7), while appliqued, trailed/brushed, engraved/brushed, the punctated/noded (Maxey Noded Redware), and the punctated/brushed types are specific to the Middle Caddoan component on the South rise. 
Table 9-7. Relative frequencies for ceramic decorative types.

\begin{tabular}{|c|c|c|c|c|c|c|}
\hline \multirow[b]{2}{*}{ Type of Decoration } & \multirow[b]{2}{*}{ A } & \multicolumn{2}{|c|}{ North Rise } & \multicolumn{2}{|c|}{ South Rise } & \multirow[b]{2}{*}{ SW Rise } \\
\hline & & D & $E$ & $\mathrm{~B} / \mathrm{C}$ & $\mathrm{F}$ & \\
\hline $\begin{array}{l}\text { Incised } \\
\text { Punctated } \\
\text { Engraved } \\
\text { Incised/Punctated } \\
\text { Brushed } \\
\text { Slipped } \\
\text { Appliqued } \\
\text { Trailed/Brushed } \\
\text { Punctated/Noded } \\
\text { Punctated/Brushed } \\
\text { Noded } \\
\text { Excised } \\
\text { Trailed } \\
\text { Engraved/Punctated } \\
\text { Incised/Brushed } \\
\text { Incised/Punctated/Brushed } \\
\text { Impressed } \\
\text { Pinched } \\
\text { Impressed/Punctated } \\
\text { Punctated/Appliqued } \\
\text { Incised/Appliqued }\end{array}$ & $\begin{array}{l}32.6 \\
26.3 \\
13.0 \\
15.2 \\
3.3 \\
5.2 \\
- \\
- \\
- \\
- \\
- \\
- \\
1.5 \\
0.4 \\
0.7 \\
0.4 \\
0.4 \\
0.4 \\
0.4 \\
0.4 \\
-\end{array}$ & $\begin{array}{l}45.0 \\
25.0 \\
20.0 \\
10.0 \\
- \\
- \\
- \\
- \\
- \\
- \\
- \\
- \\
- \\
- \\
- \\
- \\
- \\
- \\
- \\
- \\
-\end{array}$ & $\begin{array}{l}17.6 \\
41.2 \\
17.6 \\
5.9 \\
5.9 \\
- \\
- \\
- \\
- \\
- \\
- \\
- \\
- \\
- \\
- \\
- \\
- \\
- \\
- \\
5.9 \\
5.9\end{array}$ & $\begin{array}{l}30.5 \\
20.8 \\
18.2 \\
12.3 \\
4.2 \\
8.1 \\
0.6 \\
0.6 \\
1.0 \\
0.3 \\
0.6 \\
0.4 \\
0.6 \\
1.0 \\
0.6 \\
- \\
- \\
- \\
- \\
- \\
-\end{array}$ & $\begin{array}{l}- \\
- \\
- \\
- \\
- \\
- \\
- \\
- \\
- \\
- \\
- \\
- \\
- \\
- \\
- \\
- \\
- \\
- \\
-\end{array}$ & $\begin{array}{l}- \\
- \\
- \\
66.7 \\
- \\
33.3 \\
- \\
- \\
- \\
- \\
- \\
- \\
- \\
- \\
- \\
- \\
- \\
- \\
- \\
- \\
-\end{array}$ \\
\hline TOTALS & 270 & 20 & 17 & 308 & 1 & 3 \\
\hline
\end{tabular}

Table 9-8 tabulates the frequencies of each of the different decorative elements. In comparing the relative frequency of decorative elements across the site, the same general range of designs are apparent on the North and South rises, but there are significant differences in the specific decorative elements present in these two areas. The sample from Blocks D and $\mathrm{E}$ are too small to adequately characterize stylistically or temporally, although the one decorated sherd with an identifiable element (\#060) from Block D is a well represented decorative element in Block A on the North rise (see Table 9-8).

Among the engraved sherds, diagnostic decorative elements on both rises include decorative element \#011 (see Figure 9-2), with parallel sets of diagonal engraved lines on carinated bowls and simple bowls; it is the most common engraved decorative element on the South rise. Related decorative elements consist of engraved pendant triangles, either pendant from the rim (decorative element \#014) or pendant from horizontal engraved lines above the carination on carinated bowls (decorative element \#025). This decorative element is well-represented in the North rise ceramics (see Table 9-8). Engraved "ladders" (decorative elements \#021 and \#072) are also present in the assemblage. These decorative elements may on first glance be from Poynor Engraved (Suhm and Jelks 1962:Plate 62e). However, this is an unlikely attribution based on spatial and temporal data on the Hurricane Hill ceramics and the apparent localized manufacture of Poynor Engraved vessels in post-A.D. 1400 Frankston and Allen phase contexts in the Neches-Angelina River basins (cf. Fields 1995b). It is more likely that the engraved "ladders" simply represent a decorative element now known to be consistently present in Middle Caddoan period ceramic assemblages throughout East Texas (Middlebrook and Perttula 1997; Perttula 1998d). Curvilinear engraved elements from bowls and bottles (see Figure 9-2) are present in both block excavation areas, although they are more common in Early Caddoan contexts on the North rise. Finally, horizontal engraved designs (decorative element \#038) may represent the Hickory Engraved type.

Of the incised specimens, decorative elements \#001, \#040, and \#043 were well represented on both the North and South rise ceramics, along with a few sherds with curvilinear elements (i.e., \#047, \#048, and \#080) exclusively on the North rise. Horizontal incised sherds (\#017 and \#042) are present on both rises 
(see Figure 9-3). These decorative elements compare closely to Canton Incised, Crockett Curvilinear Incised, Dunkin Incised, and Davis Incised types, which are common in ca. A.D. 900-1300 (Early and Middle Caddoan period) contexts at other Cooper Lake excavated sites (Fields et al. 1997; Cliff and Perttula 1995). The Canton Incised is represented by cross-hatched (decorative element \#001) and diagonal designs (decorative elements \#040, 044, etc.), as well as a combination of zoned punctated-incised elements (see below), while the hachured incised elements (\#043 and \#046) are probably from a late form of Dunkin Incised (cf. Jelks 1961; Webb 1983).

Punctated designs are represented by rows of fingernail punctations, of various shapes (see Figure 9-4), on the bodies of some vessels (probably the incised and incised-punctated Canton Incised utility ware jars). It also occurs on rims as the sole decorative element (i.e., \#031, \#054, \#059, \#061, and \#082); these kinds of punctated sherds are found most frequently on the North rise. The most common decorative elements on both the North and South rises are \#004, \#005, and \#015, parallel rows of punctations made with a tool, cane, and fingernails, respectively (see Figure 9-4), on the body of utility wares. A red-slipped and punctated and noded variety of Maxey Noded Redware (decorative element \#019) (Suhm and Jelks 1962:Plate 51b, d) was present in low frequencies $(n=4)$ only on the South rise (see also punctated-noded decorative element \#077 in Figure 9-5), and one sherd was recovered from the fill of Hearth 5A.

Common Incised/Punctated elements include Canton Incised (decorative elements \#006, \#027, \#051, etc), Crockett Curvilinear Incised (\#018 and \#087), and zoned punctations (decorative elements \#016 and \#020, and possibly also \#008 and \#024) that are identified as Pennington Punctated-Incised (see Figure 9-6). Decorative element \#088 appears to be a "hybrid between Crockett and Pennington Punctated-Incised" (Fields et al. 1997:51). Canton Incised appears to be the most frequent type of incised-punctated jar decoration on utility wares. Crockett Curvilinear Incised, Pennington Punctated-Incised, and Davis Incised are restricted to the fine ware bowls and carinated bowls, principally in the North rise ceramics.

Table 9-8. Frequencies of decorative elements.

Decorative
Element $\quad$ Block A $\begin{aligned} & \text { North Rise } \\ & \text { Block D Block E }\end{aligned} \quad \begin{aligned} & \text { South Rise } \\ & \text { Block B/C Block F SW Rise }\end{aligned}$

\begin{tabular}{|c|c|c|c|c|c|c|}
\hline \multicolumn{7}{|c|}{ Engraved } \\
\hline 010 & 1 & - & - & 3 & - & - \\
\hline 011 & 3 & - & 1 & 11 & - & - \\
\hline 012 & - & - & - & 1 & - & - \\
\hline 014 & - & - & - & 3 & - & - \\
\hline 021 & - & - & - & 3 & - & - \\
\hline 022 & 1 & - & - & 1 & - & - \\
\hline 025 & 3 & - & 1 & - & - & - \\
\hline 026 & 2 & 2 & - & - & - & - \\
\hline 028 & - & - & - & 2 & - & - \\
\hline 034 & 1 & - & - & - & - & - \\
\hline 036 & 1 & - & - & - & - & - \\
\hline 037 & 1 & - & - & 1 & - & - \\
\hline 038 & 2 & - & - & 3 & - & - \\
\hline 039 & 2 & - & - & - & - & - \\
\hline 041 & 1 & - & - & 2 & - & - \\
\hline 045 & 2 & - & - & - & - & - \\
\hline 066 & - & - & - & 2 & - & - \\
\hline 067 & - & - & - & 1 & - & - \\
\hline 068 & - & - & - & 2 & - & - \\
\hline 070 & - & - & - & 1 & - & - \\
\hline 071 & - & 1 & - & - & - & - \\
\hline 072 & 1 & - & - & 1 & - & - \\
\hline 091 & - & - & - & 1 & - & - \\
\hline 094 & - & - & - & 2 & - & - \\
\hline \multicolumn{7}{|c|}{ Engraved/Punctated } \\
\hline 053 & 1 & - & - & - & - & - \\
\hline 074 & - & - & - & 3 & - & - \\
\hline \multicolumn{7}{|c|}{ Excised } \\
\hline
\end{tabular}


Table 9-8. Frequency of decorative elements, cont.

\begin{tabular}{|c|c|c|c|c|c|c|}
\hline $\begin{array}{l}\text { Decorative } \\
\text { Element }\end{array}$ & Block A & $\begin{array}{l}\text { North Rise } \\
\text { Block D }\end{array}$ & Block E & $\begin{array}{l}\text { South Rise } \\
\text { Block B/C }\end{array}$ & Block F & SW Rise \\
\hline \multicolumn{7}{|l|}{ Incised } \\
\hline 001 & 6 & 1 & - & 4 & - & - \\
\hline 017 & - & - & - & 2 & - & - \\
\hline 023 & 1 & - & - & 1 & - & - \\
\hline 040 & 2 & - & - & 5 & - & - \\
\hline 042 & 2 & - & - & 2 & - & - \\
\hline 043 & 5 & - & - & 1 & - & - \\
\hline 044 & 2 & - & - & 2 & - & - \\
\hline 046 & $\overline{1}$ & - & - & 3 & - & - \\
\hline 047 & 2 & - & - & - & - & - \\
\hline 048 & 1 & - & - & - & - & - \\
\hline 073 & - & - & - & 1 & - & - \\
\hline 075 & 1 & - & - & 1 & - & - \\
\hline 076 & - & - & - & 2 & - & - \\
\hline 079 & - & 1 & - & 1 & - & - \\
\hline 080 & - & - & - & 1 & - & - \\
\hline 090 & - & - & - & 1 & - & - \\
\hline \multicolumn{7}{|c|}{ Incised/Appliqued } \\
\hline 003 & - & - & 1 & - & - & - \\
\hline \multicolumn{7}{|c|}{ Incised/Brushed } \\
\hline 086 & - & - & - & 1 & - & - \\
\hline 093 & - & - & - & 1 & - & - \\
\hline \multicolumn{7}{|l|}{ Punctated } \\
\hline 004 & 3 & 2 & 4 & 8 & - & - \\
\hline 005 & 4 & - & 1 & 7 & - & - \\
\hline 015 & 11 & - & - & 13 & - & - \\
\hline 019 & - & - & - & 4 & - & - \\
\hline 031 & 1 & - & - & 3 & - & - \\
\hline 052 & 1 & - & - & - & - & - \\
\hline 054 & 2 & - & - & - & - & - \\
\hline 059 & 4 & - & - & - & - & - \\
\hline 060 & 9 & 2 & 2 & - & - & - \\
\hline 061 & 1 & - & - & 3 & - & - \\
\hline 062 & 8 & - & - & - & - & - \\
\hline 082 & 1 & - & - & - & - & - \\
\hline 083 & 1 & - & - & 1 & - & - \\
\hline 089 & - & - & - & 1 & - & - \\
\hline
\end{tabular}


Table 9-8. Frequency of decorative elements, cont.

\begin{tabular}{|c|c|c|c|c|c|c|}
\hline $\begin{array}{l}\text { Decorative } \\
\text { Element }\end{array}$ & Block A & $\begin{array}{l}\text { North Rise } \\
\text { Block D }\end{array}$ & Block E & $\begin{array}{l}\text { South Rise } \\
\text { Block B/C }\end{array}$ & Block F & SW Rise \\
\hline \multicolumn{7}{|c|}{ Punctated/Appliqued } \\
\hline 055 & 1 & - & - & - & - & - \\
\hline \multicolumn{7}{|c|}{ Punctated/Noded } \\
\hline 077 & - & - & $\cdot$ & 3 & - & - \\
\hline \multicolumn{7}{|c|}{ Puncated/Brushed } \\
\hline 081 & & - & - & 1 & - & - \\
\hline \multicolumn{7}{|c|}{ Impressed/Punctated } \\
\hline 063 & 1 & - & - & - & - & - \\
\hline \multicolumn{7}{|c|}{ Incised/Punctated/Brushed } \\
\hline 085 & 1 & - & - & - & - & - \\
\hline \multicolumn{7}{|c|}{ Incised/Punctated } \\
\hline 006 & - & - & - & 4 & - & - \\
\hline 008 & 2 & - & - & 2 & - & - \\
\hline 016 & 3 & - & - & 3 & - & - \\
\hline 018 & 5 & - & - & 1 & - & - \\
\hline 020 & 2 & - & - & - & - & - \\
\hline 027 & 3 & - & - & 4 & - & 1 \\
\hline 032 & $\overline{2}$ & - & - & - & - & - \\
\hline $\begin{array}{l}049 \\
050\end{array}$ & $\begin{array}{l}2 \\
1\end{array}$ & $\begin{array}{l}- \\
-\end{array}$ & - & $\begin{array}{l}- \\
-\end{array}$ & - & - \\
\hline 051 & 2 & - & - & 1 & - & - \\
\hline 056 & 2 & - & - & - & - & - \\
\hline 057 & 3 & - & - & - & - & - \\
\hline 058 & 1 & - & - & - & - & - \\
\hline 064 & - & - & - & 1 & - & - \\
\hline 065 & - & - & - & 1 & - & - \\
\hline 087 & 1 & - & - & - & - & - \\
\hline 088 & - & - & - & 1 & - & - \\
\hline \multicolumn{7}{|c|}{ Trailed/Brushed } \\
\hline 069 & - & - & - & 1 & - & - \\
\hline 095 & - & - & - & 1 & - & - \\
\hline \multicolumn{7}{|l|}{ Impressed } \\
\hline 035 & 1 & - & $\cdot$ & - & - & - \\
\hline \multicolumn{7}{|l|}{ Trailed } \\
\hline 009 & 2 & - & - & 2 & - & - \\
\hline \multicolumn{7}{|l|}{ Brushed } \\
\hline 007. & 6 & - & 1 & 3 & - & - \\
\hline $\begin{array}{l}029 \\
030\end{array}$ & $\overline{1}$ & - & 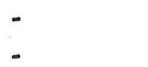 & $\begin{array}{l}1 \\
2\end{array}$ & 5 & - \\
\hline 033 & 1 & - & - & 4 & - & - \\
\hline 084 & 1 & - & - & 1 & - & - \\
\hline Total & 133 & 9 & 11 & 151 & 0 & 1 \\
\hline
\end{tabular}


Brushed pottery on both the North and South rises includes parallel brushing (probably vertical in orientation on the vessel body, see element \#084) and diagonal or overlapping brushing (\#033) on the bodies of utility vessels or jars (see Figure 9-7). On the North rise, a number of the brushed sherds are shell-tempered and probably relate to a later Late Caddoan use of the rise. The other non-shell-tempered brushed sherds, however, appear to clearly belong with the Middle Caddoan period ceramic assemblage (cf. Middlebrook and Perttula 1997:7; Thurmond 1988). Brushed-incised sherds are found only in the South rise ceramic assemblage (see Figure 9-3). Punctated/appliqued (\#055), impressed/punctated (\#063), and corncobimpressed (decorative element \#035) designs on sherds are also included with the Early Caddoan period ceramic sample on the North rise, while the trailed and trailed-brushed sherds are present in both the Early and Middle Caddoan assemblages (see Table 9-8). Corncob-impressed sherds similar to decorative element \#035 and \#063) have been found at the Spoonbill site (41WD109) in Early to Middle Caddoan period deposits associated with a small hamlet (Bruseth and Perttula 1981) in the Lake Fork Creek drainage of the Sabine River basin.

Although plain red-slipped pottery is very uncommon in the ceramic assemblages at Hurricane Hill (see Table 9-2), several plain rim sherds from Blocks $\mathrm{A}$ and $\mathrm{B} / \mathrm{C}$ indicate that bowls with only a red slip (interior and exterior slips) are present in Early and Middle Caddoan contexts. This pottery can be classified as Sanders Plain (e.g., Brown 1971:164, 1996:401). The low frequency (0.5-1.0 percent) of slipped sherds at the site contrasts with other northeastern Texas Caddoan assemblages dating to this period (Ferring and Perttula 1987:442) in the middle Red, upper Cypress, and upper Sabine River basins (Perttula 1997b; Nelson and Turner 1997; Perttula and Cruse 1997), where red-slipped sherds may amount to more than 10 percent of the decorated sherds, but is consistent with other Early and Middle Caddoan ceramic assemblages at Cooper Lake. Fields et al. (1997:Table 5), for instance, report that 0.7-2.6 percent of the sherds from the Tick, Spike, Luna, Spider's Knoll, L. O. Ray, 41DT63, Thomas, and Doctor's Creek sites were redslipped.

Ceramic rim shape (e.g., Brown 1971, 1996) and rim-lip profiles are shown in Figure 9-9. Summary tables of rim shapes and lip profiles are presented in Tables 9-9 and 9-10, respectively. Standing rims (i.e., straight or direct) dominate the plain and decorated rims in all collections, but everted (i.e., inclining outward) and rim-folded exterior shapes comprise 8.1-14.8 percent of the rims (see Table 9-9). These rim shapes tend to be associated with decorative elements, such as engraved scrolls, punctated/appliquéd elements, and cross-hatched incising (probably Maydelle Incised), or with undecorated rim sherds.

Table 9-9. Relative Frequencies of Rim Shapes for Block $A$ and Block B/C Rim Sherds

\begin{tabular}{|c|c|c|c|c|c|c|}
\hline \multirow[t]{2}{*}{$\bar{R}$ im Shape } & \multicolumn{3}{|c|}{ Block A } & \multicolumn{3}{|l|}{ Block B/C } \\
\hline & Decorated & Plain & Sum & Decorated & Plain & Sum \\
\hline Standing & 83.3 & 89.6 & 87.6 & 89.8 & 91.9 & 91.0 \\
\hline Rim-Folded interior & 1.9 & - & 0.6 & - & - & 0.0 \\
\hline Rim-Folded exterior & 11.1 & 7.8 & 8.9 & 7.4 & 8.1 & 7.9 \\
\hline Everted & 3.7 & 1.7 & 2.4 & 2.8 & - & 1.1 \\
\hline Inverted & - & 0.9 & 0.6 & - & - & 0.0 \\
\hline $\mathrm{N}$ & 54 & 115 & 169 & 108 & 160 & 268 \\
\hline
\end{tabular}


Rim Shape

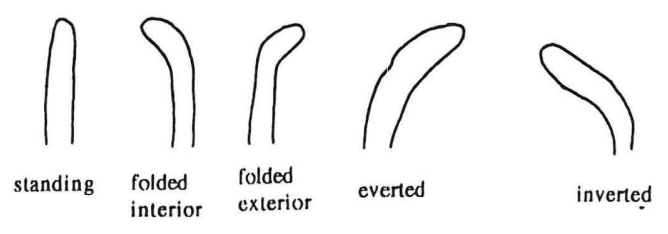

RIM-LIPPROFLE

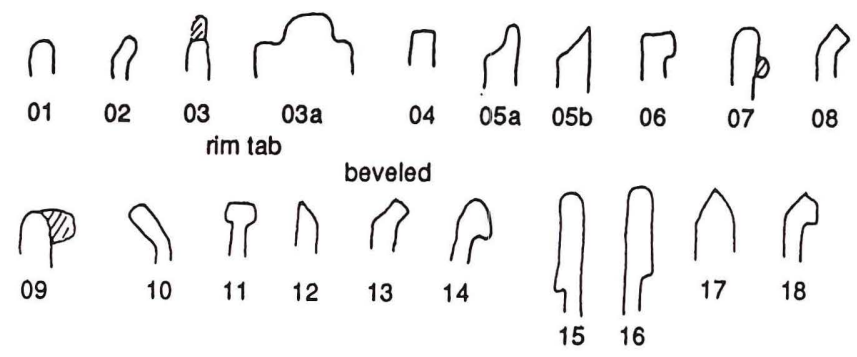

Figure 9-9. Rim shape and rim-lip profile.

Table 9-10. Relative frequencies of rim-lip profiles from the North and South rises.

North Rise

Block A Blocks D/E

Lip Profile ${ }^{a}$
South Rise

Block B/C

\begin{tabular}{llll}
\hline & & & \\
01 & 45.7 & 42.9 & 55.0 \\
02 & 5.5 & 23.8 & 7.4 \\
03 & - & - & - \\
04 & 25.2 & 23.8 & 19.4 \\
05 & 4.7 & 4.8 & 2.6 \\
06 & 6.3 & - & 5.4 \\
07 & - & - & 0.4 \\
08 & 2.4 & - & 0.9 \\
09 & - & - & 0.4 \\
10 & - & - & 0.4 \\
11 & 3.1 & 4.8 & 1.3 \\
12 & 0.8 & - & 1.3 \\
13 & - & - & 0.9
\end{tabular}


Table 9-10. Relative frequencies of rim-lip profiles from the North and South rises, cont.

North Rise

Block A Blocks D/E
South Rise

Block B/C

Lip Profile ${ }^{a}$

\begin{tabular}{|c|c|c|c|}
\hline 14 & 6.2 & - & 3.1 \\
\hline 15 & - & - & - \\
\hline 16 & - & - & 0.4 \\
\hline 17 & - & - & 0.4 \\
\hline 18 & - & - & 0.4 \\
\hline $\mathrm{N}$ & 127 & 21 & 229 \\
\hline
\end{tabular}

${ }^{a}$ See Figure 9-9.

Rim-lip profiles illustrate the same trends as the rim shapes. Specifically, the majority of the lips are rounded (31.6-50.5 percent) or flat (19.4-36.8 percent). A small number have rolled or folded lips (Classes \#02, \#08, \#13, \#14, \#18) that have been associated in the past with Late Caddoan occupations in Northeast Texas (e.g., Bruseth and Perttula 1981:7; Bruseth and Martin 1987:110), but recent analyses of Middle Caddoan ceramic assemblages in Northeast Texas (e.g., Middlebrook and Perttula 1997; Perttula 1998d) indicate that rolled or folded rims are also present in ca. A.D. 1200-1400 contexts. Indeed, most of these kinds of rim-lip profiles are present in the South rise rim sherds (see Table 9-10). At Hurricane Hill, most of the rolled or folded lips are plain, but decorative element \#037, the engraved "ladders," engraved elements \#010 and \#011, brushing designs, and possible Maydelle Incised cross-hatched designs are apparent in the small rim sample (see Appendix VIII). A few of the rim sherds also have tabs or nodes (see Figure 99), from both Early and Middle Caddoan contexts.

Decorated sherds recovered from the Southwest rise consist of one rim sherd (Feature 76) and one body sherd (Scraped Area 11). Both are incised and punctated (see Table 9-7), including one with decorative element \#032 (see Figure 9-6). A plain grog-tempered and red-slipped (Sanders Plain?) sherd from Feature 68, along with an arrowpoint) probably denotes a Middle Caddoan affiliation for this extended burial, but Feature 76 is considered to date to the Early Ceramic or Woodland period, dating before A.D. 800, based on the dart projectile point assemblage and series of radiocarbon dates from the Southwest rise (see Chapters 7 and 8). The few plain sherds from this rise include grog- and grog/bone tempered wares (see Table 9-4).

Block $\mathrm{F}$ has only a very small sample of sherds derived from two $1 \mathrm{x} 1 \mathrm{~m}$ units excavated at two corners of the block on the South rise. The percentage of shell temper (15.4 percent) and the stratigraphic position of the Feature 9 midden in the block (see Chapter 5) suggest that the midden accumulated towards the latter part of the Middle Caddoan period occupation associated with Structures A and B on the South rise. The discussion of decorative elements, lip profiles, and rim shapes presented above does suggest that post-A.D. 1400 ceramic sherds do occur on the North and South rises in low numbers, primarily in a plow zone context (i.e., postdating the primary components).

\section{North Rise Assemblages, Blocks $\mathbf{D}$ and $\mathbf{E}$}

There are 37 decorated sherds and 21 plain rim sherds from Blocks D and E on the North rise. Incised and punctated decorations are predominant, incised sherds from Block D (45 percent of the 20 decorated sherds) and punctated sherds (41.2 percent) from Block $E$ (see Table 9-7). This disparity is probably due to the small sample sizes from each block, because the decorative elements represented in both collections are quite comparable between the two blocks. 
Among the punctated sherds, decorative elements include tool, cane, and fingernail-punctated parallel rows--either on the body and/or the rim--with tool punctations the most common decorative element (\#004). Incised-punctated sherds contain closely-spaced rows of fingernail punctations (element \#060) within incised zones; these are from jars with burnished interior and smoothed exterior surfaces. Incised sherds have cross-hatched elements (\#001), along with a rim from Block D with incised vertical panels overlain by widely-spaced diagonal incised lines (\#079; see Figure 9-3); this particular decorative element is also present in the South rise ceramics. A rather unique incised sherd from Block $E$ has a set of incised or impressed triangles below a series of crimped rim coils (decorative element \#003); a similar impressed triangle motif is represented by decorative element \#025, with horizontal engraved or incised lines (made when the vessel was leather-hard), in sherds from Blocks A and E (Figure 9-10c-d). These decorative elements appear to be one of the more distinctive Early Caddoan ceramic styles in the North rise collections, as similar sherds are absent from the South rise (see Table 9-8).

The engraved sherds with recognizable decorative elements include the previously mentioned horizontal engraved sherd with impressed triangles from Block E, a diagonal engraved rim (\#011), two horizontal engraved or leather-hard incised rims (decorative element \#026) from large bowls or barrel-shaped jars where the lines begin well down the rim (Figure 9-11f and Figure 9-12b), and another with part of a scroll and excised motif (decorative element \#071) from Block D; the latter resembles Ripley Engraved (see Figure 9-2). Decorative element \#026 is virtually the same in layout as element \#002 in the incised sherds, except in the case of the latter, the vessel was not leather-hard before it was decorated. This particular engraved element is present at the Hurricane Hill site only on the North rise, and along with the impressed triangle motifs previously discussed, appear to be the most distinctive styles in the Early Caddoan ceramics from the North rise. Fields et al. (1997:Figure 29) illustrate a vessel form with a comparable incised rim, and the body has a curvilinear incised-punctated motif.

Of the 30 rim sherds, 21 (70 percent) are from plain vessels. The ratio of plain to decorated rims is about the same as the Block A ceramic assemblage, but more than 10 percent higher than is the case with the Middle Caddoan ceramics from the South rise, where apparently more vessels had decorations than in Early Caddoan contexts.

The majority of the plain rims are direct or standing (57 percent), with four other direct rims that were folded to the exterior (see Figure 9-9). Only one rim (4.8 percent) was everted. Rim-lip profiles are rounded (01) and flat (02), with another example that has an interior bevel (05; also well-represented in the Block A rims) and one that has a flanged rim-lip profile (011); the latter is a relatively rare rim-lip profile at the Hurricane Hill site (see Table 9-10).

Available information on the size of the Early Caddoan ceramic vessels from the Block D and E excavations, from the orifice diameter of the larger rim sherds, suggests that the vessels were generally and uniformly large, ranging from $21-32 \mathrm{~cm}$ in diameter (analyses of orifice diameters in other Caddoan contexts indicates that orifice diameter closely correlates to vessel height and volume; see Perttula [1998c]). Although there are few measurable rim sherds from the Block A ceramics, none of the few rim sherds from that context or from Block B/C on the South rise had orifice diameters greater than $26 \mathrm{~cm}$. Plain vessels-apparently simple bowls--had a mean orifice diameter of $27 \pm 4 \mathrm{~cm}$, including a large portion of a plain bowl from Feature 53 between the North and South rises (Figure 9-13) while the engraved (element \#026) and incised (\#002) rim sherds were from vessels (either bowls or barrel-shaped jars) with orifice diameters of $27 \pm 1 \mathrm{~cm}$ and $24 \mathrm{~cm}$, respectively.

The single sherd with instrumental neutron activation analysis (INAA) data from Block D is a cross-hatched incised (\#001) sherd of the Canton Incised type tempered with grog (see Neff et al., this volume). The chemical compositional data indicates that it was manufactured from local clays, and can be assigned to the Hurricane-1 group. 

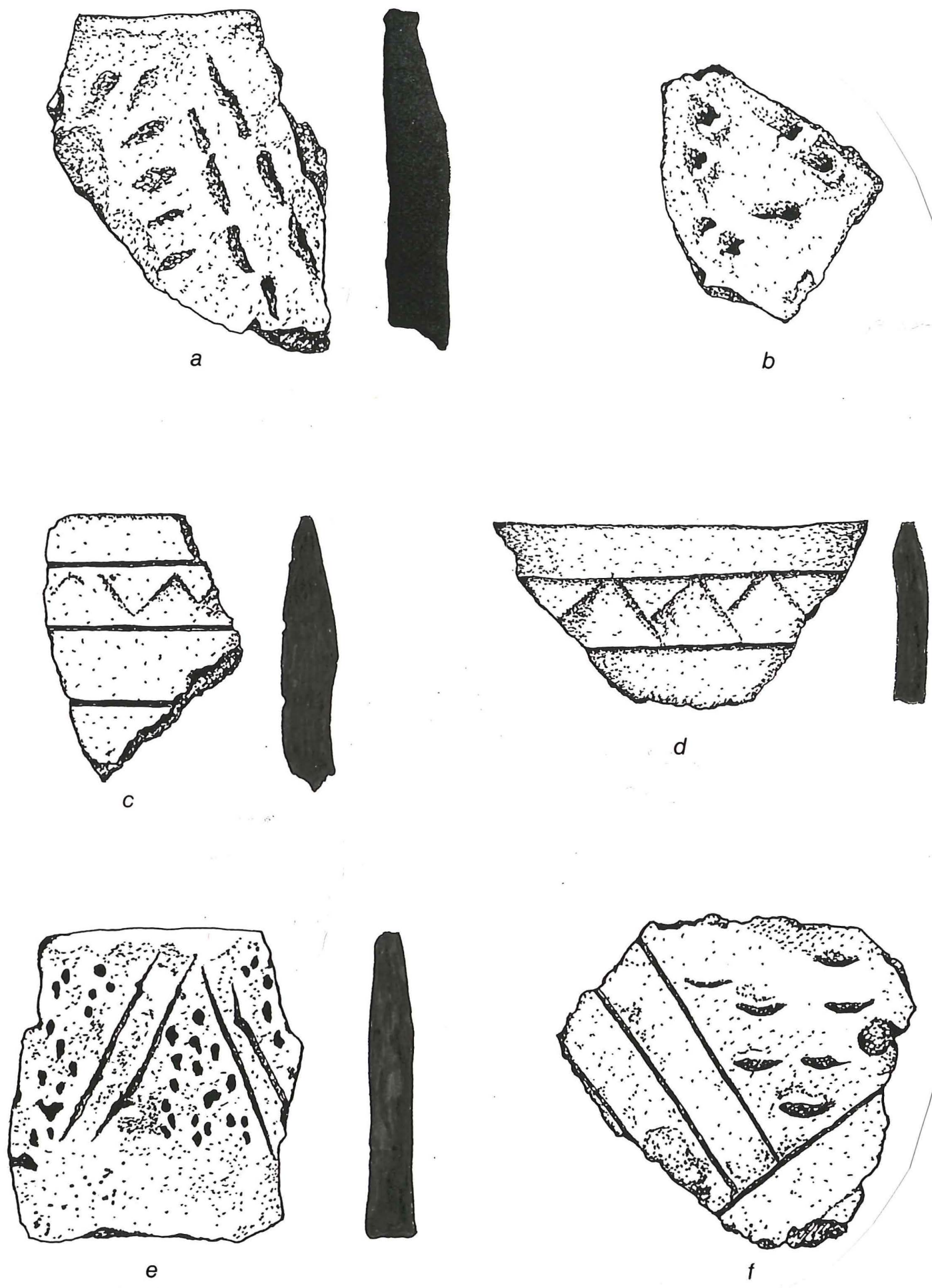

Figure 9-10. Punctated, engraved-impressed triangle, and incised-punctated sherds from the North rise: a-b, punctated; c-d, engraved-impressed triangle (\#025); e-f, incised-punctated. Provenience: a, 32-2; b, 32-5; c, S34E20, 37 cm; d, 257-6A; e, Fea. 2; f, 257-4B. 


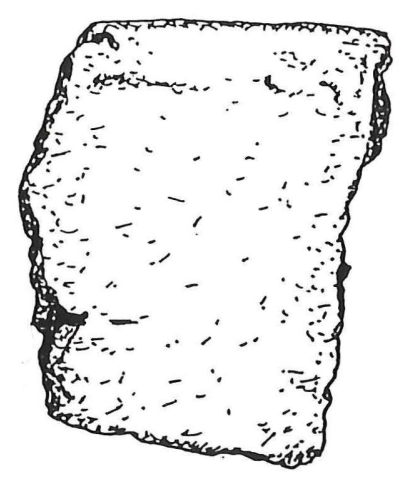

a

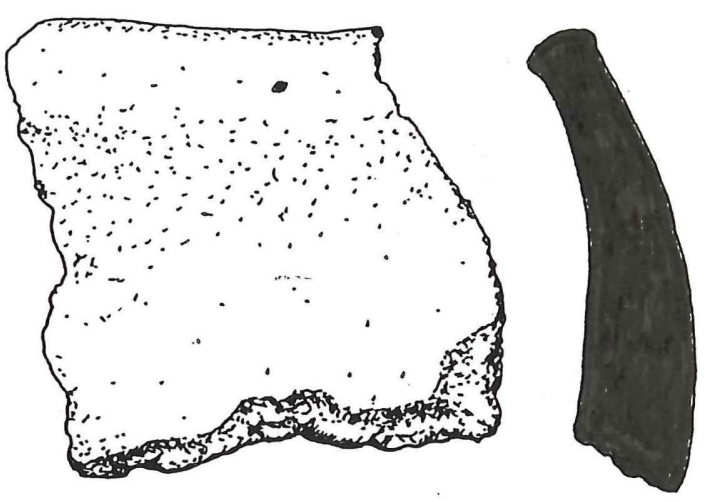

C

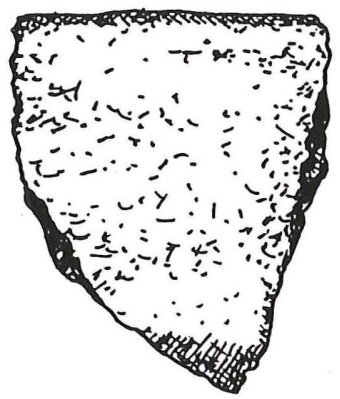

e
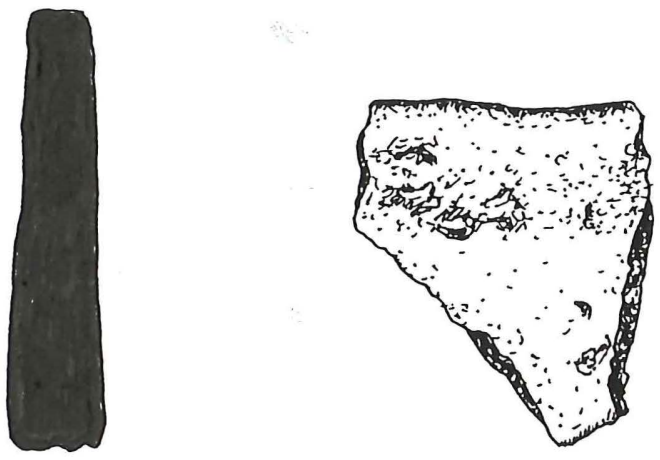

$b$

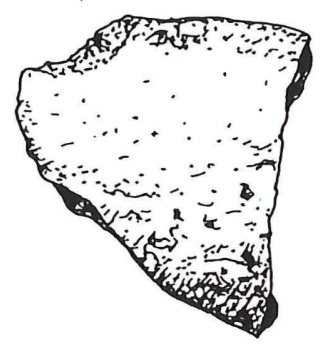

$d$
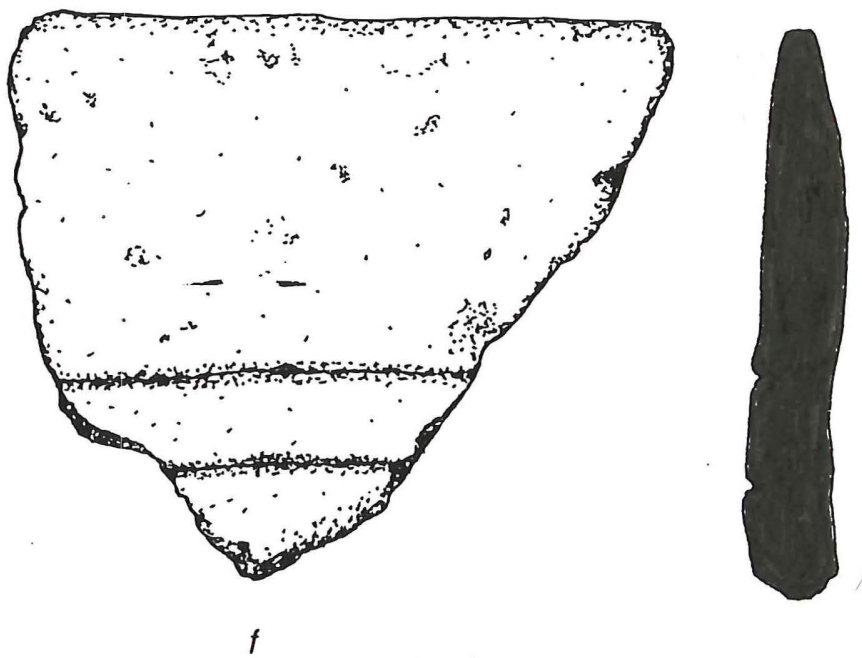

Figure 9-11. Plain and engraved rims from the North rise: a-e, plain rims; f, engraved rim, element \#26. Provenience: a, ST 4; b, 29-1; c, 34-3; d, 31-2; e, BHT 32; f, S36E33. 

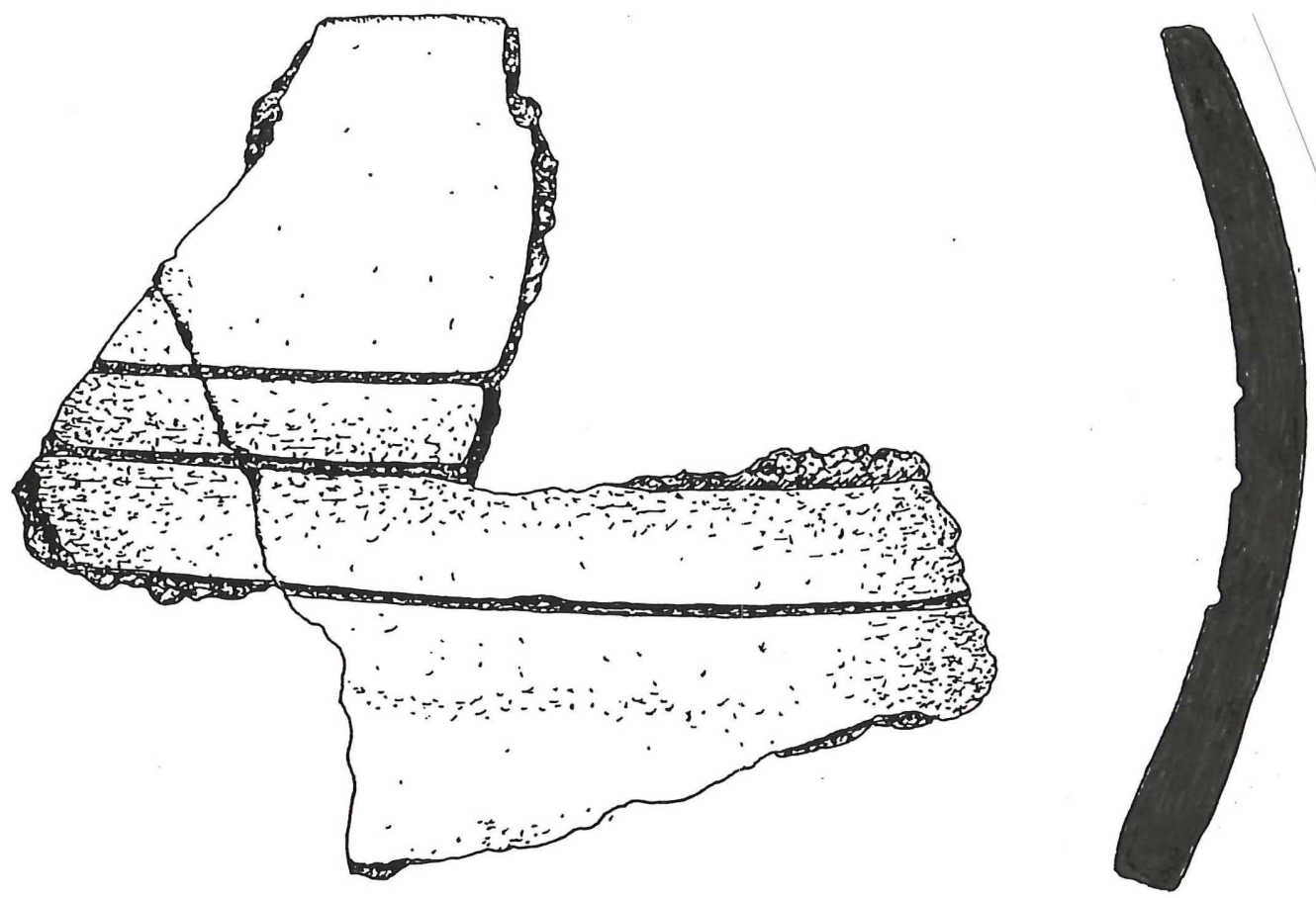

a

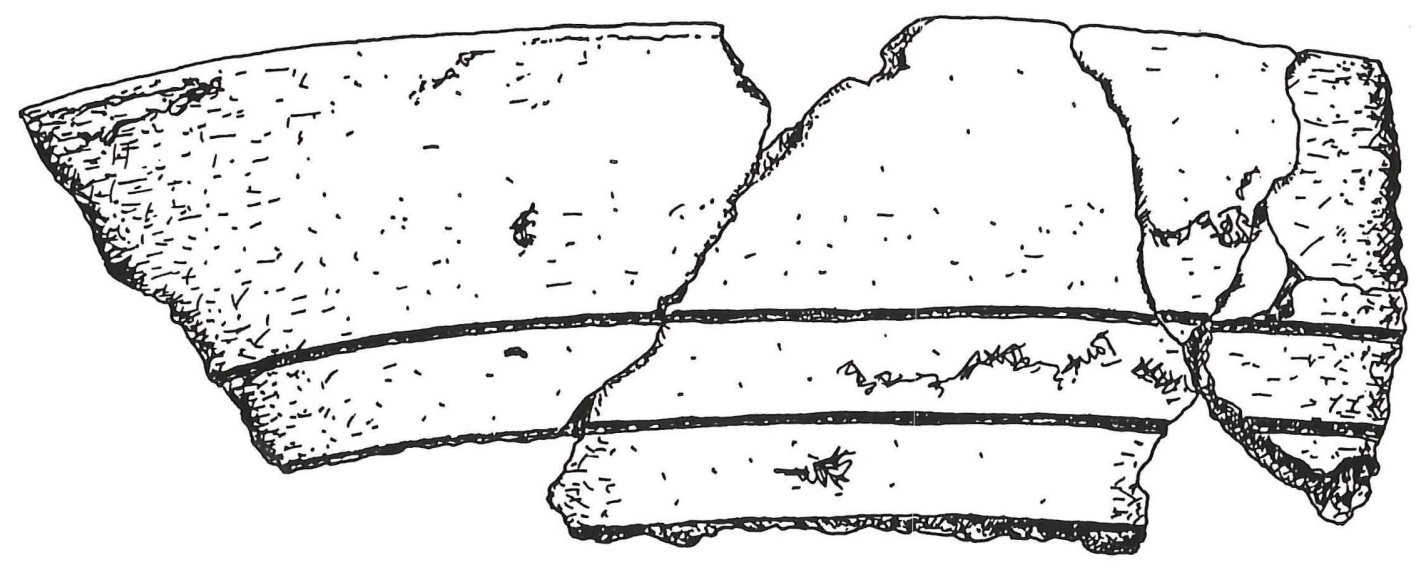

b

Figure 9-12. Engraved sherds from the North rise, element \#026. Provenience: a, 25-6; b, 81-2. 


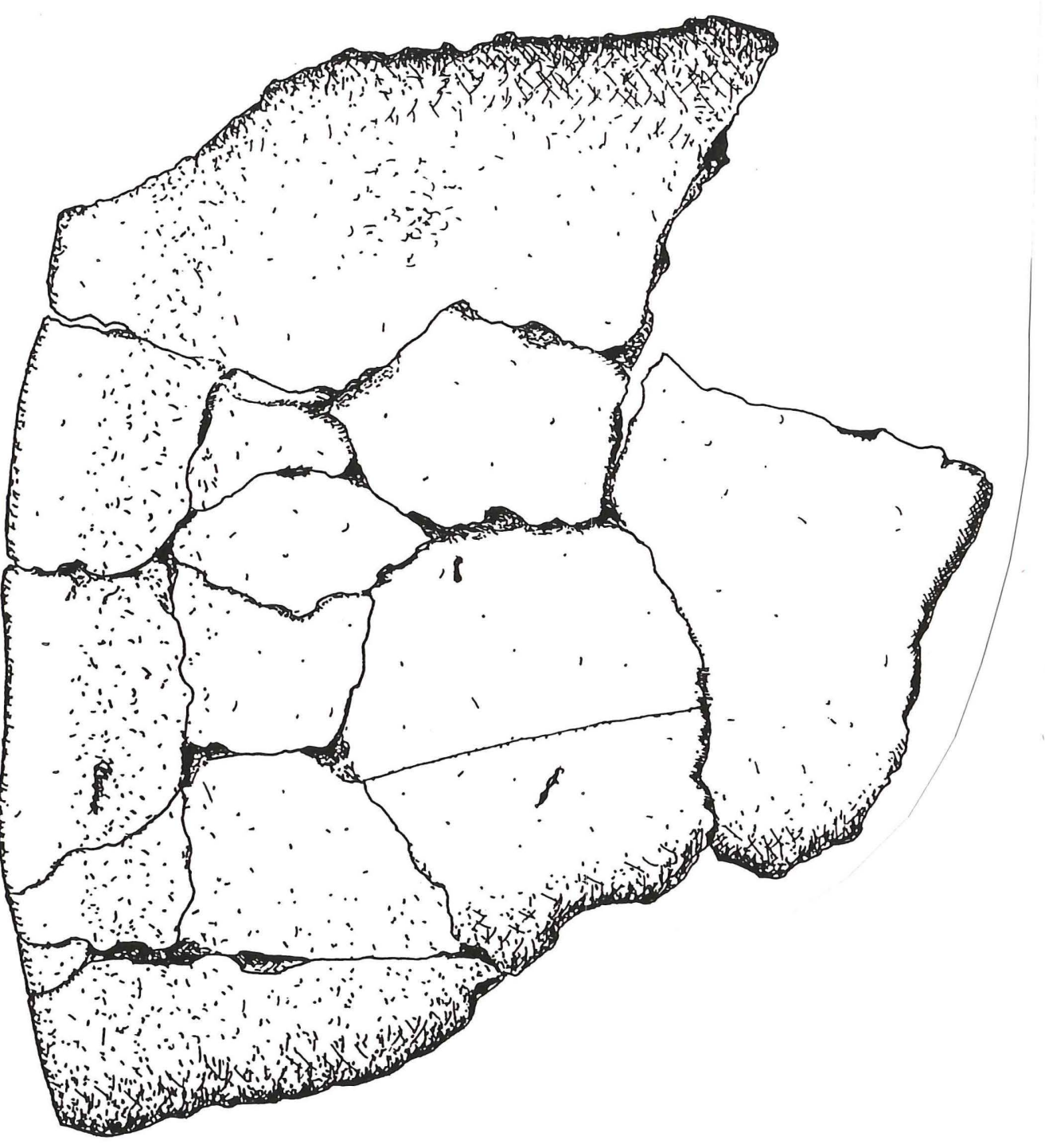

Figure 9-13. Plain vessel section from Feature 53, Scrape Area 3. 


\section{North Rise Assemblages, Block A}

There are 270 decorated rim and body sherds from Block A (see Table 9-7), and approximately 49 percent of these sherds have an identifiable decorative element (see Table 9-8). There are also 127 plain rims in the assemblage (see Figure 9-10a-e). The ratio of decorated rims to plain rims is 1:2.4, and 71 percent of the 180 rims are from plain or undecorated vessels.

The most common decorative methods in the North rise ceramics are incised (32.6 percent), punctated (26.3 percent), incised-punctated (15.2 percent), and engraved (13.0 percent), and these four methods account for 87.1 percent of the decorated sherd assemblage. Other common decorative methods include slipped ( 5.2 percent) and brushed ( 3.3 percent), about half of which are tempered with crushed mussel shell and are thought to represent a Late Caddoan occupation on the North rise (see Chapter 7, this volume). In terms of rank ordering, the most popular decorative elements include several sorts of fingernail punctations (\#015, \#059, \#060, and \#062), cross-hatched incised (\#001), parallel brushed (\#007), hachured incised (\#043), curvilinear incised-punctated (\#018, Crockett Curvilinear Incised), and cane punctations (\#005).

The incised sherds from the North rise are dominated by cross-hatched (\#001) and hachured or opposed diagonal (\#043) decorative elements (see Figure 9-3), with a small assortment of diagonal (\#040, \#044), chevron (\#046) and horizontal (\#042) incised decorations on the rims of jars and bowls. Curvilinear incised decorative elements (\#047 and \#048) comprise 13 percent of the identifiable incised elements in the North rise assemblage, compared to less than 4 percent in the later South rise ceramics (see below).

Among the punctated sherds, more than 65 percent are represented by parallel rows of fingernailpunctated decorative elements on the rim and body (\#015, \#059, \#060, and \#062) (see Figure 9-4). Fingernail punctations were also used to create opposed diagonal rows of punctations on vessel rims (see Figure 9-10a). Rows of tool (see Figure 9-10b) and cane punctations are also present on vessel rims and bodies, comprising 11 and 13 percent of the punctated sherds, respectively.

The most common incised-punctated decorative element on the North rise is a curvilinear incised motif with cane-punctated zones (\#018, Figure 9-14d; see also decorative element \#087, a partial scroll of Crockett Curvilinear Incised [Suhm and Jelks 1962:Plate 16d]), followed by punctation-filled (tool and fingernail) incised triangles or chevrons (\#016, \#027, \#051, and \#057) (see Figures 9-10e-f and 9-14a, c). Another distinctive set of incised-punctated sherds have at least three horizontal incised lines on the rim, with a lower zone of cane punctations created by diagonal and/or curvilinear incised lines offset from the rim (see Figure 9-6, decorative elements \#008 and \#020). Related decorative elements include parallel incised lines filled with a band of cane punctations (\#050; see Figure 9-14b).

There are 14 different engraved decorative elements present in the 22 engraved sherds from the North rise ceramic assemblage with an identifiable element (see Table 9-8). No one engraved element accounts for more than 14 percent of the engraved sherds, and the two most common decorative elements are diagonals on the rim (\#011, see Figure 9-14e-f), opposed diagonals (see Figure 9-14g), and horizontal engraved or leather-hard incised lines with impressed triangles (\#025; see Figure 9-10c-d); the INAA analyses discussed below suggest the latter sherds were manufactured among Caddoan groups living on the middle reaches of the Red River (Cogswell et al. 1998a). Other common engraved elements in this Early Caddoan ceramic assemblage include deep horizontal engraved lines set well down the rim (\#026; see Figures 9-11f and 9-12a), closely-spaced horizontal engraved lines beginning immediately below the lip (\#038, possibly Hickory Engraved), engraved concentric semi-circles on a carinated bowl form (\#039), and a curvilinear motif (\#045) on bowls. Another North rise sherd has an engraved line on the vessel interior, and one distinctive rim sherd has diagonal engraved or leather-hard lines creating a triangular zone of small cane punctations (\#053, see Figure 9-2).

The few brushed sherds from the North rise include both shell $(n=4)$ and non-shell-tempered $(n=5)$ wares. The shell-tempered sherds have parallel and overlapping decorative elements (\#07 and \#33), probably on the bodies of jars, with the parallel brushing being most common. Parallel brushed sherds are also predominant in the non-shell-tempered sherds, along with horizontal (on the rim) and vertical decorative elements (see Figure 9-7 and Table 9-8). 
Archaeology of the Hurricane Hill Site (41HP106)

268
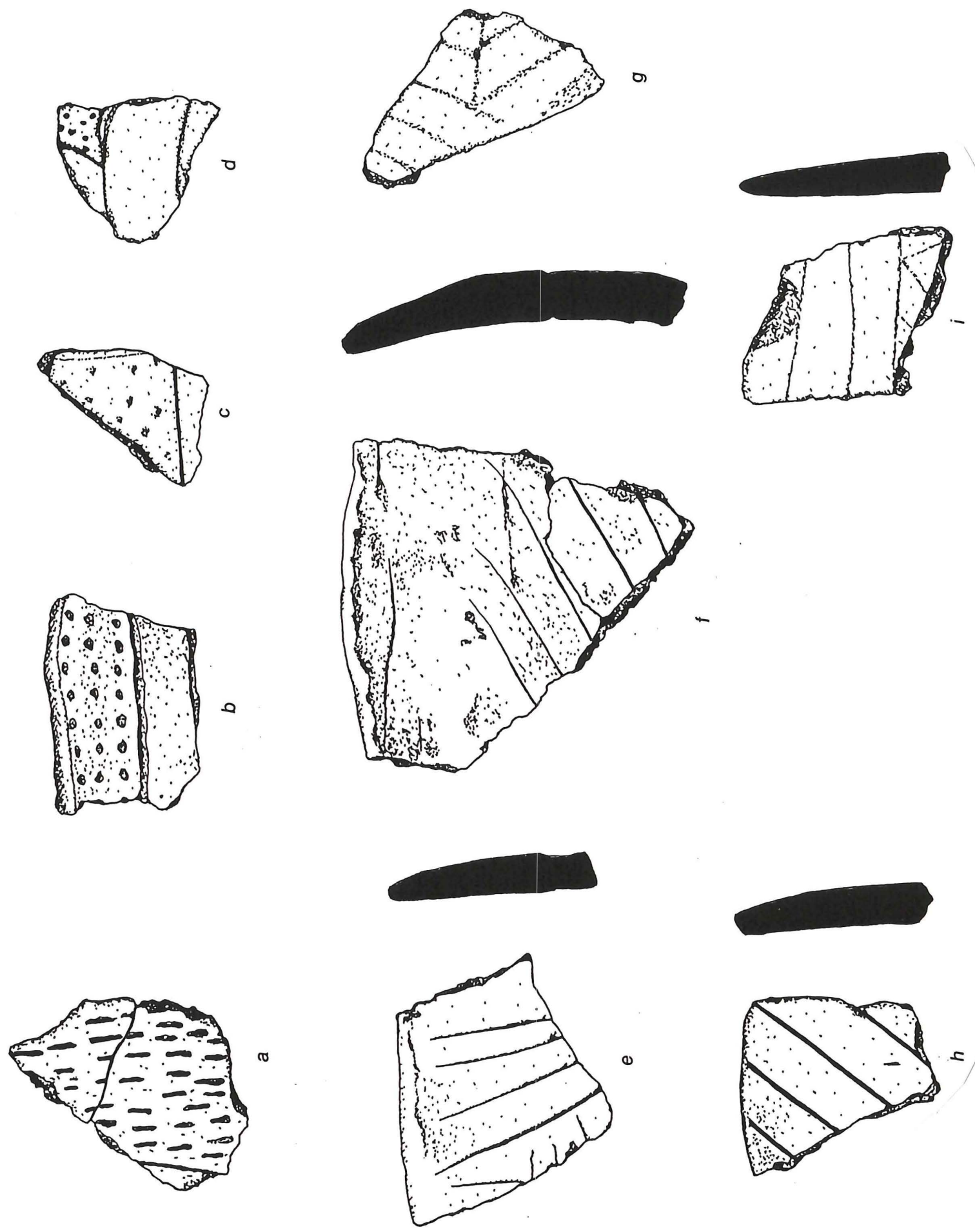

Figure 9-14. Incised-punctated and engraved sherds from the North rise: a-d, incised-punctated; e-i, engraved. Provenience: a, 29-2/44-2; b, 259-6A; c, 32-3; d, 257-5B; e, 32-1; f, 38-1; g, 37-3; h, 29-4; i, ST 11, historic locality 1. 
Rounding out the Early Caddoan ceramic assemblage are a few decorated sherds with punctatedappliqued (\#055, see Figure 9-5), corn cob impressed (\#035, see Figure 9-7), corn cob impressed-punctated (\#063), incised-punctated-brushed (\#085), and horizontally trailed (\#009, see Figure 9-7) decorative elements. Together, these decorative elements comprise only 4.5 percent of the identifiable decorative elements from the North rise (see Table 9-8).

A variety of rim and rim-lip profiles (see Figure 9-9) are documented in the North rise ceramic assemblage. The overwhelming majority ( $>91$ percent) of the rims are direct (see Figure 9-14a), with a few others being folded either to the exterior (see Figure 9-14b) or interior (see Figure 9-14d), and about 2 percent have everted rims (see Figure 9-14c); one rim from BHT 32 (between the North and South rises) has a direct rim with an interior thickened rim-lip profile (see Figure 9-14e). In general, rim-lip profiles are rounded (see Table 9-10) or flat--accounting for 70.9 percent of the rim sherds--with a number of others that have rolled, flanged, or beveled rim-lip profiles.

The INAA data (see Neff et al., Chapter 10, this volume) for the Block A ceramics include analyses of 19 sherds. Of these sherds, 26 percent appear to be from Caddoan vessels that have been made outside the upper Sulphur River basin, including 21 percent from the middle Red River (the Red River group, based on a series of 36 Early-Late Caddoan sherds from the Mound Prairie area in Red River County, Texas; see Perttula et al. n.d.) and 5 percent from either the Cypress Creek or Sabine River basins to the south (the Titus group, based on +100 sherds from Middle to Late Caddoan sites in the Cypress Creek and Sabine River drainages; see Neff et al. 1998; Rogers n.d.); another 26 percent of the INAA sherds cannot be assigned to a chemical group with the presently available chemical data (Cogswell et al. 1998a). The other 47 percent of the sherds are from vessels manufactured from local clays (i.e., the Hurricane-1 group).

The Hurricane-1 group sherds have a diversity of decorative methods and elements along with a variety of tempers, indicating that the character of the local ceramic technology and stylistic choices during the Early Caddoan occupation at Hurricane Hill was well developed; one shell-tempered sherd indicates that the Late Caddoan occupants of the site also made ceramics using local clays. Represented in the decorated sherds are three incised (hachured, curvilinear, and diagonal elements), two punctated (fingernail punctations in horizontal and vertical rows), two engraved (diagonal and vertical-horizontal elements; see Figure 9-14e-f, h), one incised-punctated (incised chevron with fingernail-punctated zones; see Figure 9-10e-f), and an overlapping brushed (decorative element \#033) sherd with shell-tempering. The other Hurricane-1 group sherds are tempered with grog-grit-bone, grog $(n=6)$, and grog-bone.

Among the four Red River group sherds are three that are incised with various decorative elements, and a fourth with either horizontal incised or engraved lines and impressed triangles (decorative element \#025; see Figure 9-10d). As previously mentioned, this particular decorative element is one of the more common ceramic styles in the Early Caddoan ceramic assemblage at Hurricane Hill. The other incised sherds include one with closely spaced horizontal lines (decorative element \#042), a Crockett Curvilinear Incised sherd (decorative element \#018; see Figure 9-6), and another horizontal incised sherd of undetermined decorative element. They are tempered with grog, grog-bone $(\mathrm{n}=2)$, and grog-grit. The one Titus group sherd is a plain red-slipped sherd tempered with grit and bone.

The ungrouped sherds include a fingernail punctated (decorative element \#062) specimen, another that is cane punctated (\#083), a curvilinear engraved rim (decorative element \#039), a cross-hatched incised sherd, and a fifth sherd with a fine-line incised and zoned-punctated decoration. The ungrouped sherds may or may not have been made from local clays (Cogswell et al. 1998a). Temper classes represented are grog-gritbone, grog ( $=2)$, grog-grit, and grit-bone.

Six of the decorated sherds subjected to INAA have decorative elements that are among the nine best-represented styles in the Early Caddoan ceramic assemblage on the North rise: decorative elements $\# 001, \# 018, \# 043, \# 059, \# 060$, and \#062 (see Table 9-8). Three of these sherds are from the Hurricane-1 group, two others from the ungrouped sherds (suggesting that the ungrouped sherds are probably also from relatively local clays, but a different clay source than the Hurricane-1 group), and one from the non-local Red River group.

Orifice diameter data is available from only three rim sherds in this Block A ceramic assemblage. Two are from small plain and trailed vessels with orifice diameters of 6.0 and $9.0 \mathrm{~cm}$, respectively. The 
other is an engraved or leather-hard incised sherd (decorative element \#025) from a bowl or carinated bowl with a $22.0 \mathrm{~cm}$ orifice diameter.

Sherd refitting data from Block A indicate that there has been little movement $(<4 \mathrm{~m}$ spatially and $20 \mathrm{~cm}$ vertically) of the ceramic pieces once they were discarded in the midden, with one notable exception. A conjoin of two plain rims from a bowl was found in Unit 238, 15-20 cm bs, in the Midden 1 deposits and $12 \mathrm{~m}$ away in Unit $81,10-20 \mathrm{~cm}$, in Block D (Figure 9-15). Otherwise, the refitted sherds are concentrated in the western portion of the Midden 1 deposits excavated in Block A.
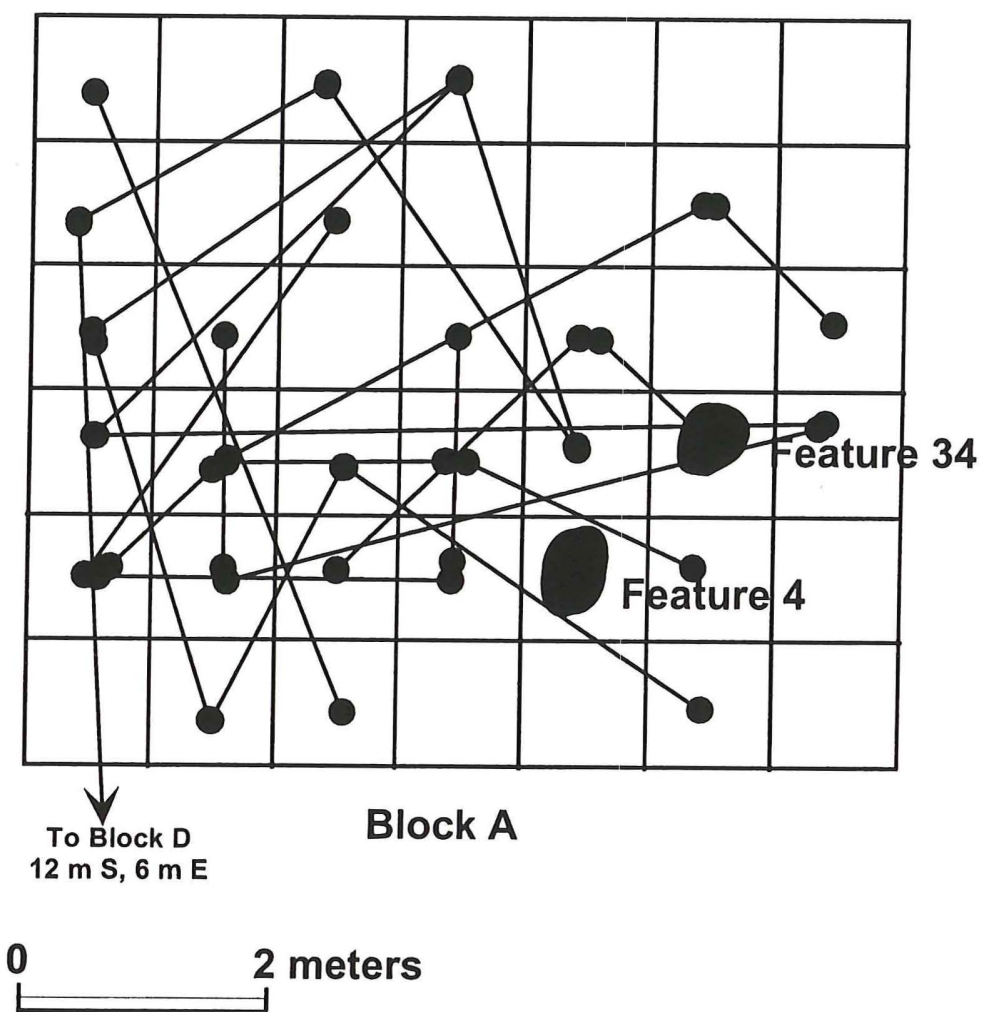

Figure 9-15. Distribution of refitted sherds from Block A on the North rise.

Of the 27 refitted sherd examples from Block A, 37 percent were conjoined with sherds from the same excavation level, principally level $2(10-20 \mathrm{~cm} \mathrm{bs})$. Another 48 percent of the refitted sherds were conjoined with sherds in the level immediately above or below it; again, the majority of these sherds were recovered in level 2, the densest part of the Midden 1 deposit. There are only two examples of refitted sherds where the conjoins were separated by more than $20 \mathrm{~cm}$ of midden deposits, including two sherds of a probable Crockett Curvilinear Incised bowl from level $1(0-10 \mathrm{~cm})$ and $5 B(45-50 \mathrm{~cm})$, and engraved sherds (element \#025, see Figure 9-2) from levels 1 and 4A $(30-35 \mathrm{~cm})$.

\section{South Rise Assemblage, Blocks B and C}

There are 308 decorated sherds in the Middle Caddoan period ceramic assemblage from the South rise. As with the Early Caddoan ceramics discussed above, incised, punctated, engraved, and incisedpunctated sherds represent the principal types of decoration on the South rise, amounting to 81.8 percent of the decorated sherds (see Table 9-7). However, the relative proportions of incised, punctated, and incisedpunctated sherds in Blocks $B$ and $C$ are each 3-5 percent lower in frequency than in the North rise 
assemblage, while engraved sherds are 5.2 percent more abundant in Middle Caddoan contexts. Red slipped sherds and brushed sherds are also more common on the South rise than they are on the North rise, comprising 8.1 and 4.2 percent, respectively, of the South rise decorated ceramics. Three of the red slipped sherds are plain rims with grog and grog-bone tempering, which can be identified as Sanders Plain (cf. Brown 1971, 1996). The remainder of the decorated sherds consist of small amounts of trailed, appliqued, excised, engraved-punctated, trailed-brushed, punctated-noded, punctated-brushed, noded, and incised-brushed specimens, each accounting for between 0.3-1.0 percent of the assemblage as a whole. In addition to the decorated rim and body sherds, there are 232 plain rim sherds in the South rise ceramics. The decorated-plain rim ratio is $1: 2.4$, and approximately 71 percent of the rims are from plain vessels.

The engraved sherds are the most distinctive of the decorated sherds from the South rise. The most common decorative elements include diagonal, cross-hatched, and diagonal-horizontal engraved rim motifs (Figure 9-16d-e, g, i-j), engraved pendant triangles (\#014, see Figure 9-2), and engraved ladders (see Figure 9-16b). In particular, engraved decorative element \#011 (see Figure 9-2) is the most common, representing 23 percent of the engraved sherds with recognizable elements. Varieties of the diagonal engraving include three sherds with an additional engraved line below the lip (\#011), a haphazardly engraved set of diagonal to curvilinear lines (\#012), broad line diagonals on the rim (\#066, see Figure 9-16g), and an engraved chevron (\#070). The engraved pendant triangle motif (\#014 and \#091) is represented by four sherds from carinated bowls, with the engraved triangles pendant from a horizontal engraved line at the base of the carination (cf. Suhm and Jelks 1969:Plate 69e, i). There are several sherds with engraved ladders, with the ladders parallel to sets of diagonal engraved lines (see Figure 9-16b), along with engraved sherds with sets of vertical engraved lines creating a panel filled with horizontal engraved lines (decorative elements \#022, \#67, and \#68, see Figure 9-2 and Figure 9-16c).

Both horizontal (\#038 and \#094) and cross-hatched engraved sherds are present in the South rise ceramic assemblage, and one distinctive decorative element includes closely-spaced horizontal engraved lines above a zone of small cane punctations (\#074); except for the engraving, the decorative motif is identical to incised-punctated element \#008 (see Figure 9-6), also present on both the North and South rises. Curvilinear engraved sherds are rare in comparison to the North rise, with only two sherds with a curvilinear and horizontal motif (\#028), rather than concentric circles and semi-circles.

Another distinctive decorative element in the South rise ceramics is Maxey Noded Redware (see decorative element \#019 on Figure 9-4 and decorative element \#077 on Figure 9-16a). These particular redslipped sherds--none of which are shell-tempered--appear to represent two different varieties, one with rows of nodes and vertically-set fingernail punctations (see Figure 9-16a) between the nodes, and the other with at least two parallel rows of small fingernail punctations around the upper body of red-slipped bottles. Both varieties are present as whole vessels at the Sanders site (Krieger 1946:Plate 29b-c; Suhm and Jelks 1962:Plate 51a-d), as well as in whole vessels and sherds from other middle Red River Caddoan sites (e.g., Perino 1995; Perttula 1995c, 1997b).

Diagonal, chevron, cross-hatched, and zoned punctated-incised rim and body sherds belong primarily to Canton Incised jars and deep bowls (Figure 9-17a-b, d, g) (Inexplicably, Schambach [n.d.:Figure 4] has reclassified Canton Incised as Avoyelles Punctated var. Canton, and sorts out hachured and cross-hatched varieties as Mazique Incised and Harrison Bayou Incised defined by Phillips [1970] for the lower Mississippi Valley, and also considered Red River types by Schambach [n.d.:36]). This includes decorative elements \#006, \#016, \#027, \#051, and \#058 (see Figure 9-6). The chevron incised element, the most common incised-punctated decoration, has both large tool and fingernail punctations (see Figure 9$17 \mathrm{~g}$ ) and small cane punctations (see Figure 9-17f). Some of the incised and punctated sherds may be stylistic hybrids of Crockett Curvilinear Incised and Pennington Punctated-Incised (see Figure 9-17e-f), as noted in Early Caddoan contexts (i.e., as late as A.D. 1300) at Cooper Lake (Fields et al. 1997:Figure 29). 


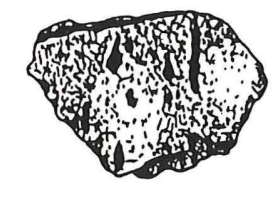

a

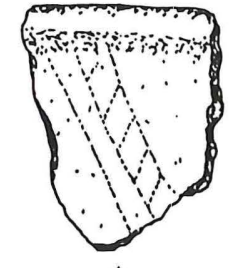

b
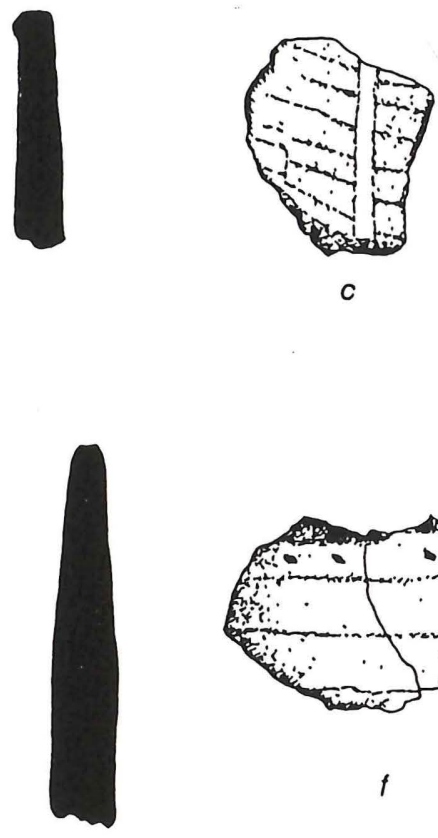

c

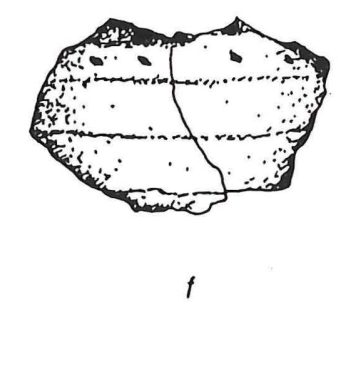

$f$
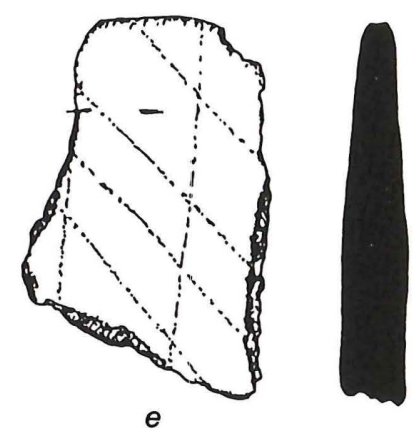
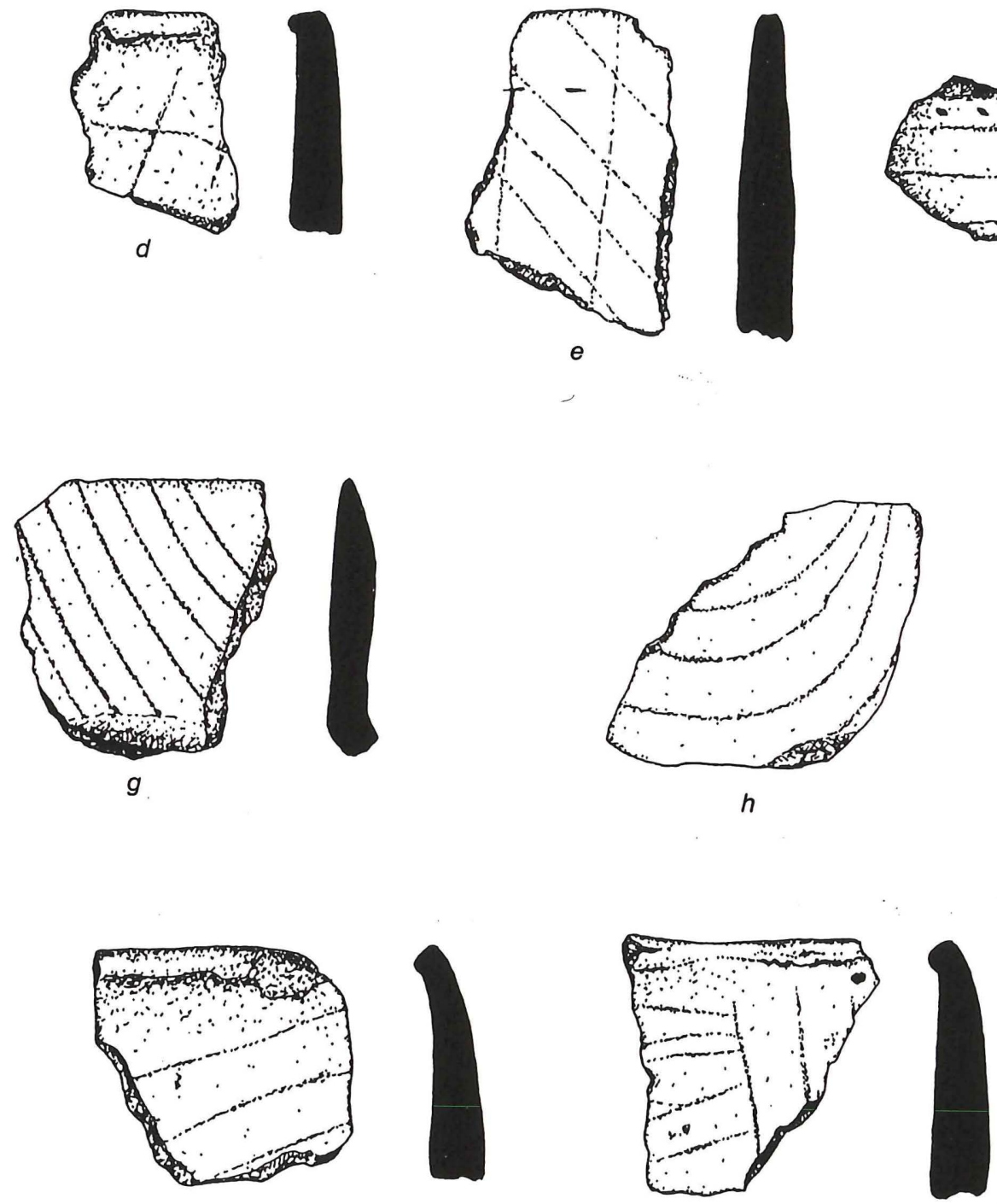

i

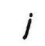

Figure 9-16. Punctated-noded, engraved, and engraved-punctated sherds from the South rise: a, Maxey Noded Redware; b-e, g-j, engraved; f, engraved-punctated. Provenience: a, 173-4A; b, 59-1; c, 115-2; d, 63-2; e, 184-2; f, 174-2; g, 68-3A; h, 223-3A; i, 68-3B; j, 60-5B, Feature 12. 


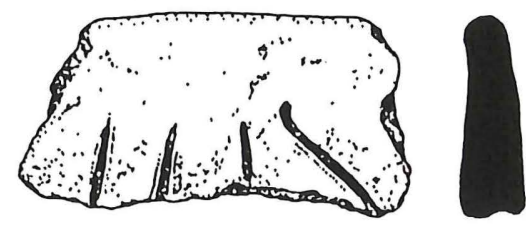

a

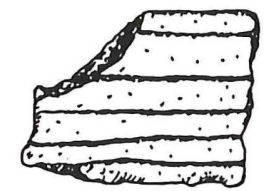

c
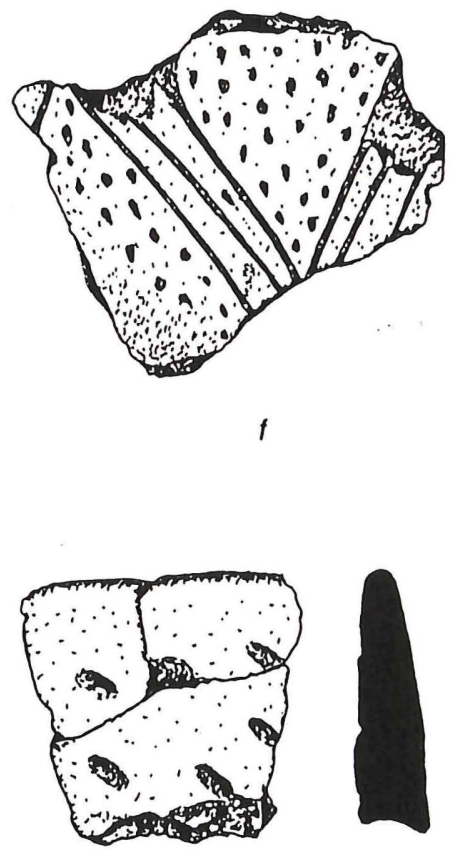

$h$
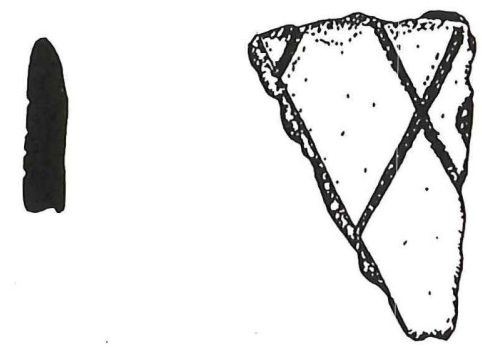

d

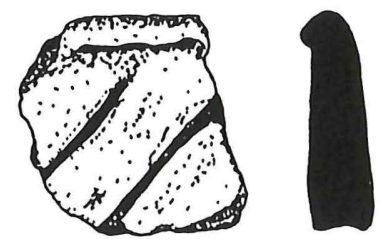

b

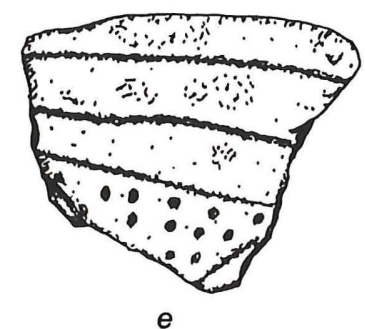

e
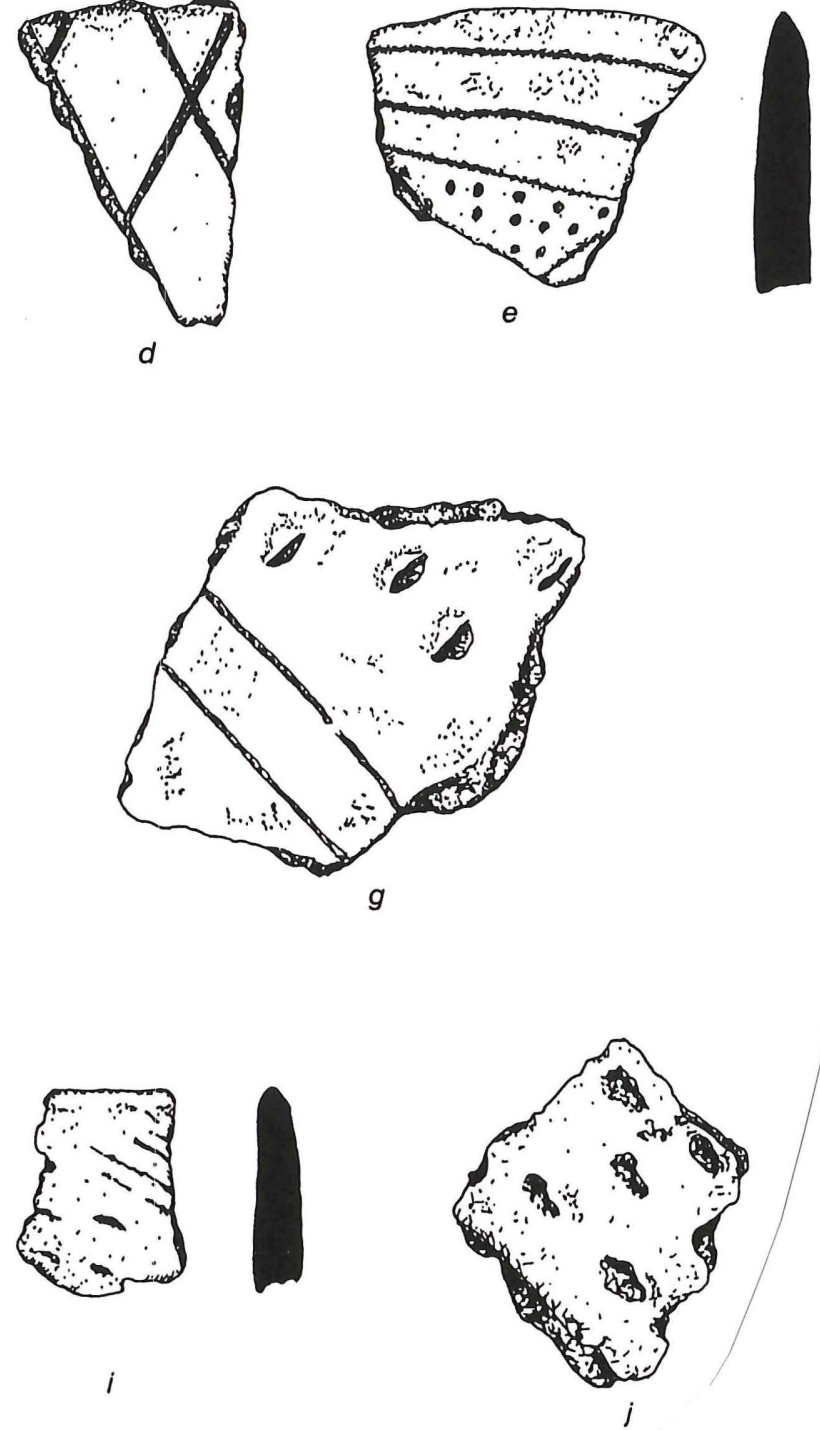

Figure 9-17. Incised, incised-punctated, and punctated sherds from the South rise: a-d, incised; e-g, incisedpunctated; h-j, punctated. Provenience: a, 192-5A; b, 111-2; c, 113-3B; d, 66-2; e, BHT 38; f, 196-2B; g, $109-1 ; \mathrm{h}, 66-1 ; \mathrm{i}, 52-3 \mathrm{~B} ; \mathrm{j}, 168-2$. 
Among the incised sherds, narrow and widely-spaced diagonal and cross-hatched decorative elements are well-represented in Block B/C, along with incised chevrons (decorative element \#046) (see Figure 9-3 and Figure 9-17a-b, d); hachured incised sherds are rare, while they are relatively common on the North rise. Curvilinear incised decorative elements, also present on the North rise, are absent in the South rise ceramics, although one sherd has a horizontal and curvilinear incised decoration on a rim (\#080, see Figure 9-3). Horizontal (see Figure 9-17c) and vertical incised rims comprise 22 percent of the incised sherds, and one rim sherd has vertical panels that are intersected by diagonal incised lines (\#079, see Figure 9-3).

The punctated sherds include tool, cane, and fingernail punctated specimens, placed in rows or diagonals on the rim and body of utility vessels (see Figure 9-17h-j); one sherd (decorative element \#083) has cane punctations placed in a curvilinear motif (see Figure 9-4). Tool and cane-punctated sherds are more common in Middle Caddoan contexts--comprising 33 and 22 percent, respectively, of the punctated sherds-than they are in Early Caddoan contexts on the North rise, where fingernail punctated sherds represent about 65 percent of the sample. In the Block B/C ceramic assemblage, however, fingernail-punctated sherds amount to 44 percent of the punctated sherds.

The brushed sherds, only one of which is shell-tempered, include parallel, overlapping, and vertical brushed elements on vessel bodies, along with two rims with horizontal brushing (decorative element \#030). Brushing also occurs in combination with punctated, incised, and trailed decorations on utility wares, whereas such decorative elements are absent from the earlier Caddoan ceramics on the North rise. The punctated-brushed sherd has rows of fingernail punctations at the rim-body juncture, with parallel-vertical brushing on the vessel body (\#081), while the incised-brushed sherds have horizontal brushing on a vessel rim that has been cut through with either cross-hatched or diagonal incised lines (\#086 and \#093, see Figure 9-3). This form of incised-brushing is different from the incised-brushed sherds seem in Late Caddoan contexts in Northeast Texas, where either the utility vessel body has parallel brushed-incised lines on it, the rim has a brushed decoration on it while the body has been incised, or conversely, the rim is incised and the body has brushing marks (see Perttula 1998c). The two trailed-brushed sherds have either parallel brushed and trailed lines (of uncertain orientation) or vertical brushing on the vessel rim with trailed lines cutting through the brush marks (decorative elements \#069 and \#095). There are also two horizontal trailed rims.

Most of the plain vessel rims are from unburnished grog, grit, and grog-bone-tempered bowls and jars with direct or standing rims (Figure 9-18). Folded-exterior and everted rims account for only 8.9 percent of the rim shapes, not much different than in the Early Caddoan rims discussed above. Rim-lip profiles (see Figure 9-9), however, are different between the North and South rises in that rounded profiles (on either direct or folded exterior rims) are more common in the latter ceramic assemblage (62.9 percent), and there is a much wider range of rim-lip profiles (i.e., 16 shapes on the South rise compared to only nine shapes on the North rise; see Table 9-10). Flat, beveled, and flanged rim-lip profiles are more abundant in Early Caddoan contexts than they are in the later ceramics, while exterior thickened, interior-exterior beveled, and beveled-rolled lip profiles are present only in the Middle Caddoan ceramic rims. Also present only in the Middle Caddoan ceramics from the South rise are rims with exterior nodes (rim-lip shapes 07 and 09 on Figure 9-9).

The INAA data (see Neff et al., Chapter 10, this volume) for the Block B/C ceramics on the South rise include analyses of 20 sherds. Of these sherds, 20 percent appear to be from Caddoan vessels that have been made outside the upper Sulphur River basin, all from the middle Red River (the Red River group, based on a series of 36 Early-Late Caddoan sherds from the Mound Prairie area in Red River County, Texas; see Perttula et al. n.d.); another 30 percent of the INAA sherds from Block B/C cannot be assigned to a chemical group with the presently available chemical data (see Neff et al., Chapter 10, this volume; Cogswell et al. 1998a). The other 50 percent of the sherds are from vessels manufactured from local clays (i.e., the Hurricane-1 group). 
Figure 9-18. Plain rims from the South rise. Provenience: a, 134-3A; b, e, Surface; c, 170-5A; d, 53-4B; f, 66-1.
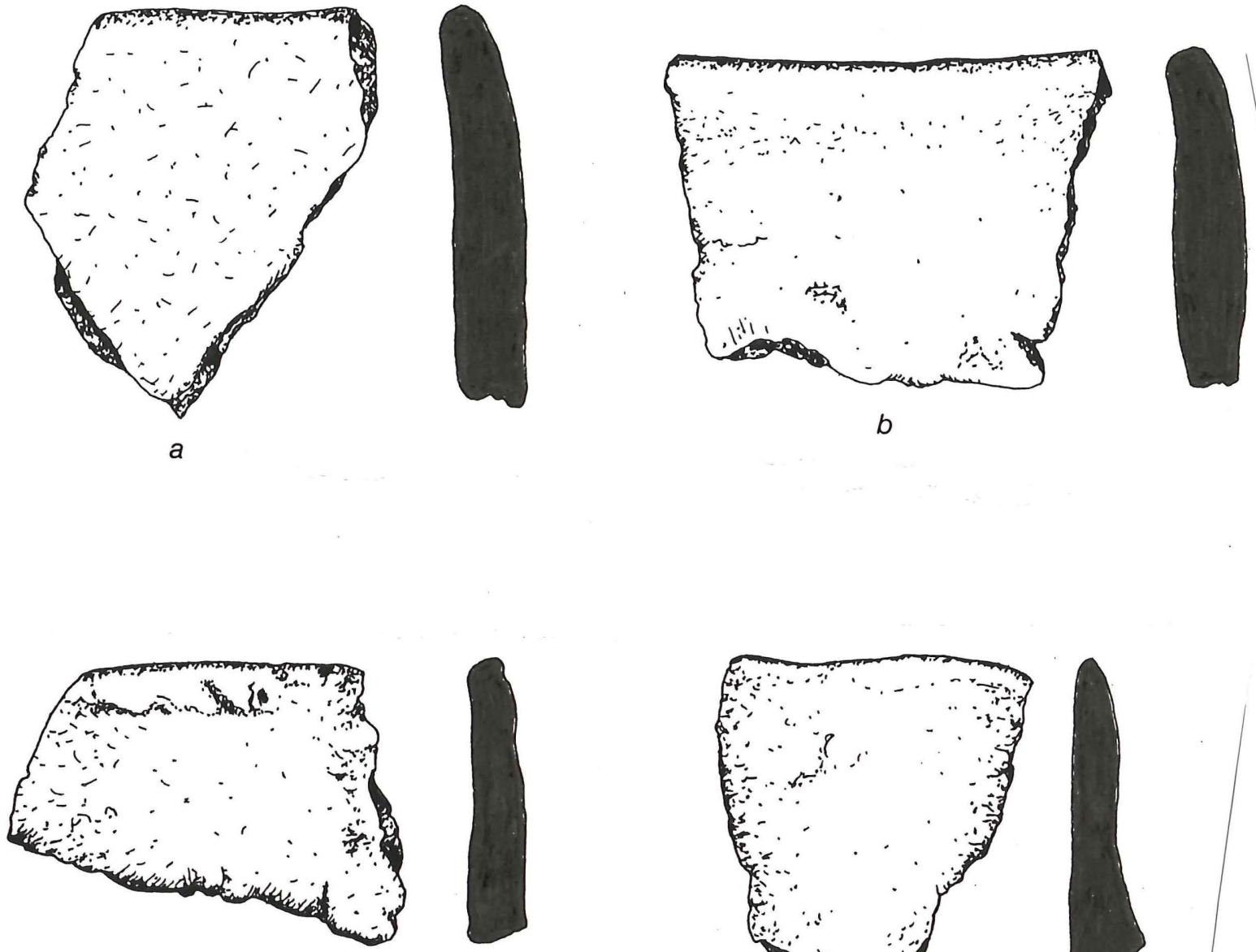

c
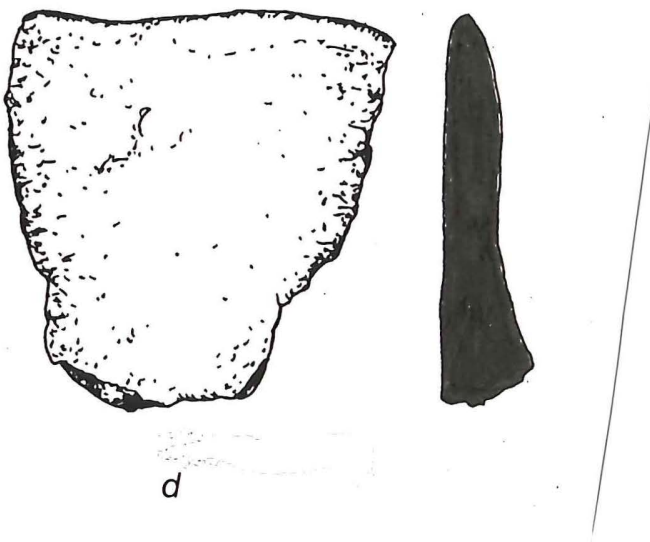

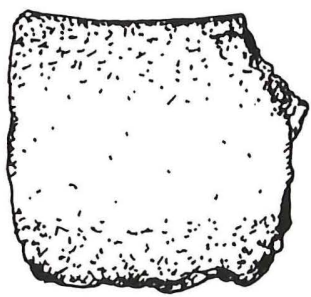

e
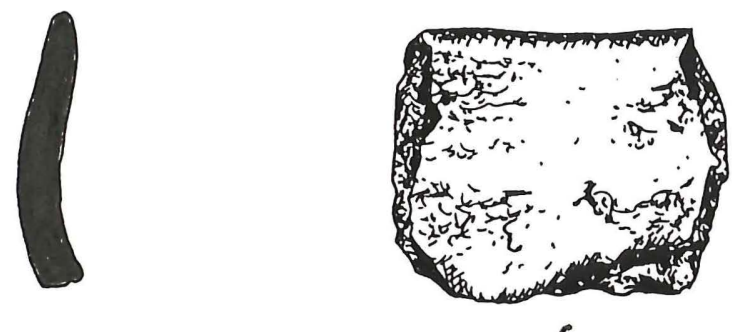

$f$

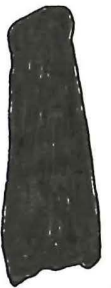


Like the Block A Early Caddoan ceramics, the Hurricane-1 group sherds from the Middle Caddoan ceramic assemblage on the South rise have a wide diversity of decorative methods and elements along with a variety of tempers, along with rims from plain vessels, indicating that the technological and stylistic character of the local ceramics during the Middle Caddoan occupation at Hurricane Hill was well developed. In addition to two Hurricane-1 plain rims (tempered with grog and bone), represented in the decorated sherds are three incised (cross-hatched and two sherds with diagonal elements), two punctated (fingernail and tool punctations in horizontal and vertical rows), one engraved (diagonal and horizontal elements; see Figure 916j), one thick incised-punctated (incised chevron with fingernail-punctated zones), and a parallel or vertical brushed (decorative element \#007) sherd with grog-grit-tempering. The other Hurricane-1 group sherds are tempered with grog $(n=6)$, grit, bone, and grog-grit.

Among the four Red River group sherds from the South rise, one has fingernail punctations (decorative element \#015), another has a zoned incised-punctated decoration with cane punctates, the third is diagonal incised, and the final sherd has a diagonal engraved element. They are tempered with grog and groggrit $(n=3)$.

The six ungrouped sherds include a grog-tempered Maxey Noded Redware (decorative element \#077) specimen (contrary to Schambach's [n.d.:80) hypothesis that all Maxey Noded Redware is shell-tempered), a sherd with an engraved ladder element (\#021; see Figure 9-16b), a diagonal incised rim (decorative element \#076), and three plain rim sherds. The ungrouped sherds may or may not have been made from local clays (Cogswell et al. 1998a), but they clearly are not Arkansas River valley trade wares as Schambach (n.d.:32) has asserted for the Maxey Noded Redware. Temper classes represented are grog, grit $(\mathrm{n}=2)$, grog-grit-bone, and grog-bone $(\mathrm{n}=2)$.

Four of the South rise decorated sherds subjected to INAA have decorative elements that are among the 10 best-represented styles in the Middle Caddoan ceramic assemblage in Block B/C: decorative elements \#001, \#015, and \#040 (see Table 9-8). Three of these sherds are from the Hurricane-1 group, and the other is from the non-local Red River group.

Nine Block B/C rim sherds, including four plain rims, were sufficiently large to accurately determine the vessel orifice diameter. Vessel orifice diameters range from $3.5-25.0 \mathrm{~cm}$, and fall readily into three size classes: small (orifice diameters $<9 \mathrm{~cm}$ ), medium $(13-18 \mathrm{~cm}$ ), and large $(>22 \mathrm{~cm}$ ). The small orifice vessels are simple plain bowls and wide-mouth bottles, while the medium-sized vessels included a plain bowl and a punctated (decorative element \#089) bowl. Three of the four large vessels have engraved designs (elements \#010, \#011, and \#022) on the rims of bowls and carinated bowls, and the other is a plain and relatively thick-walled jar. Excluding the bottles, the mean orifice diameter of the vessel rim sherds from Block $\mathrm{B} / \mathrm{C}$ is $19.3 \pm 5.7 \mathrm{~cm}$, which is significantly smaller than the vessels from Block $\mathrm{D}$ and $\mathrm{E}$ on the North rise.

The sherd refitting data from the South rise excavations suggest that most of the sherds represent vessels broken inside Structures A and B, and either swept to the outside structure walls, or discarded immediately outside the structure entrance (Figure 9-19). The conjoins are more widely separated in space than was the case in the concentrated Early Caddoan trash midden deposits on the North rise, and there are several examples of conjoins that are 6-8 $\mathrm{m}$ apart (see Figure 9-19). Most of the refitted sherds are concentrated in the southeastern part of Block $B / C$, just inside or outside the extended entranceway to Structure B, the earlier of the two Middle Caddoan period structures on the South rise.

There are 28 refitted sherd examples from Block B/C. About 40 percent of these were conjoined with sherds from the same excavation level, principally in levels $3 \mathrm{~A}(20-25 \mathrm{~cm})$ and $3 \mathrm{~B}(25-30 \mathrm{~cm} \mathrm{bs})$, at the same depth as the floors of the two structures. Another 36 percent of the refitted sherds were conjoined with sherds in the level immediately above or below it, with the majority of these sherds being recovered in level 3A. One incised sherd (decorative element \#076, see Figure 9-3) from Feature 26 (a small pit feature inside the structure) was conjoined with three others about 1-2 $\mathrm{m}$ to the northeast, lying near the southeastern structure wall of Structure B (see Figure 9-19). Two other sherds found in level 3A were refitted with sherds recovered from the disturbed surface of the block excavations, and there were only three examples of refitted sherds where the conjoins were separated by more than $20 \mathrm{~cm}$ of archaeological deposits. This includes two grog-tempered red-slipped body sherds from level $2(10-20 \mathrm{~cm})$ and $5 B(45-50$ 
$\mathrm{cm})$ in adjoining units, and three plain rim sherds from levels $1,4 \mathrm{~A}(30-35 \mathrm{~cm})$, and $4 \mathrm{~B}(35-40 \mathrm{~cm})$ in units from 1-3 m apart.

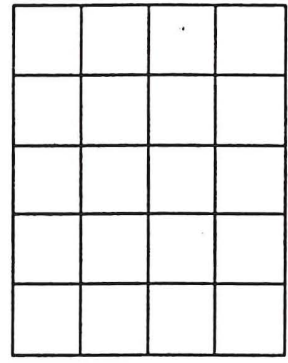

Block F

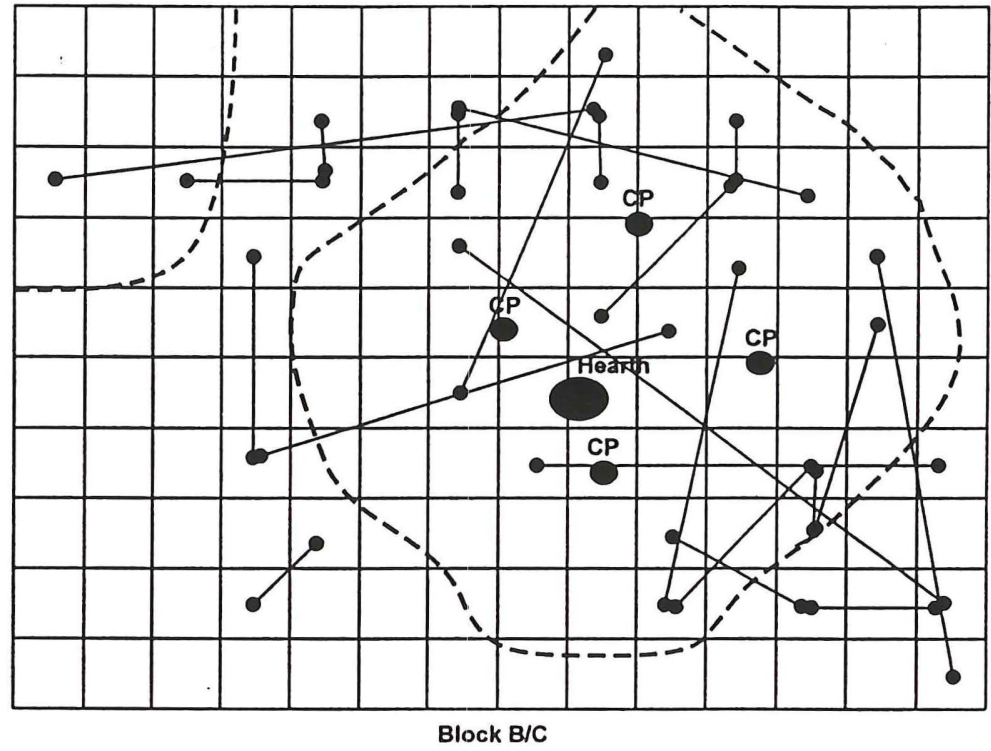

2 moters

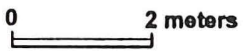

Figure 9-19. Distribution of refitted sherds from Block B/C on the South rise.

\section{Southwest Rise}

There are only three decorated sherds from the Southwest rise, one each from features 68, 76, and 92 (see Appendix V). Feature 68 also has several arrowpoints, and the red-slipped body sherd (grog-bone tempered) from the feature fill suggests that it is part of the Middle Caddoan period occupation centered on the South rise at Hurricane Hill. The other two decorated sherds appear to be associated with the Early Ceramic or Woodland period component on the Southwest rise based on their recovery from features belonging to that component (see Chapter 7, this volume).

These two sherds have incised-punctated decorations, only one of which (from Feature 76) has a definable decorative element (\#032); this incised-punctated decorative element is found only on the Southwest rise. The element includes at least two diagonal incised lines, possibly part of a chevron motif, with at least five parallel rows of small cane punctations (see Figure 9-6).

\section{Summary of the Ceramic Assemblages}

Essentially, the ceramics from the Hurricane Hill site are primarily plain wares tempered with grog, bone, grit, and various combinations of these inclusions, as between ca. 65-70 percent of the rim sherds from the Early and Middle Caddoan period assemblages on the North and South rises, respectively, are undecorated. The undecorated vessels were made in several sizes, but appear to consist primarily of simple bowls, bottles, and jars used for cooking, serving, and holding liquids. 


\section{Block A}

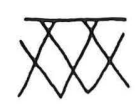

a.

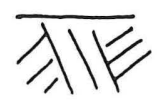

b.

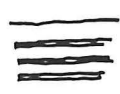

h.

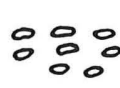

c.

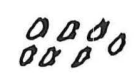

d.

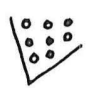

j.

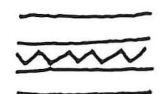

e.

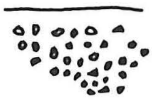

k.

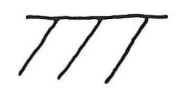

f.

g.<smiles>c1ccc2ccccc2c1</smiles>

i.

\section{Block B/C}

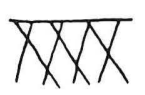

a.

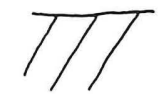

b.

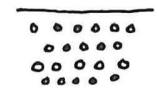

c.

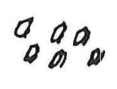

d.

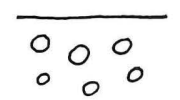

e.<smiles>C1CC2CCCC(C1)C2</smiles>

f.

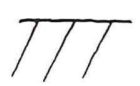

g.

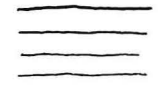

h.

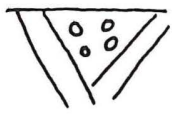

I.

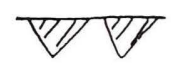

i.

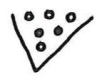

m.

\section{Block D/E}

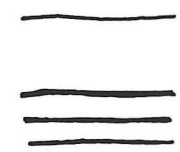

b.

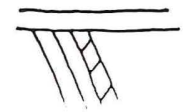

j.

k.

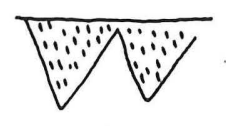

I.

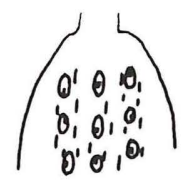

n.

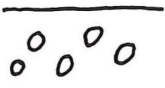

a.

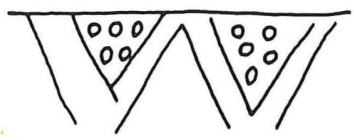

C.

Figure 9-20. Differences and Similarities between the Blocks in Ceramic Decorative elements. Block A: a, crosshatched incised; b, hachured incised; c-d, fingernail punctated; e, engraved with impressed triangles; f, diagonal engraved; g, parallel brushed; h, horizontal engraved; II, curvilinear incised-punctated; $j$, 1 , zoned incisedpunctated; k, corncob-impressed. Block B/C: a, cross-hatched incised; b, diagonal incised; c, e, cane punctated; d, fingernail punctated; f, n, Maxey Noded Redware; g, diagonal engraved; h, horizontal engraved; I, engraved pendant triangles; $j$, engraved ladder; $k$, overlapping brushed; $1-\mathrm{m}$, zoned incised-punctated. Block D/E: a, cane punctation; b, horizontal engraved; $c$, incised-punctated. 
The decorated vessels from Hurricane Hill had primarily incised, punctated, engraved, and incisedpunctated designs, and a few vessels may have had only a red hematite-rich slip on interior and exterior surfaces, while others had brushed bodies and rims, or a combination of brushed, punctated, incised, appliqued, and trailed utility ware vessels. Although the same decorative methods are represented in both ceramic assemblages and there are considerable commonalities in the utility wares between both the Early and Middle Caddoan ceramic assemblages (especially in the predominance of cross-hatched and diagonal incised decorations and the use of fingernail punctations), there are differences in the relative proportions of decorative methods and in the presence/absence of particularly distinctive decorative elements (Figure 9-20) that appear to have both stylistic and temporal implications. The Middle Caddoan period component, for example, has certain distinctive ceramic stylistic attributes--including (a) red-slipped punctated and punctated-noded Maxey Noded Redware, (b) engraved ladders, and (c) engraved pendant triangle elements--that are not present in the Early Caddoan ceramics from the North rise, while the Early Caddoan ceramics from the North rise (including Blocks D and E) include (a) engraved or leather-hard horizontal engraved rims with impressed triangles, (b) Crockett Curvilinear Incised, and (c) horizontal incised and engraved rims with the incised/engraved lines placed well down the rim, that are not represented in the Middle Caddoan ceramics on the South rise (see Figure 9-20).

The INAA data suggests that the majority of the ceramics from Hurricane Hill were made from local clays. Nevertheless, non-locally manufactured wares (principally from the middle reaches of the Red River, about 50 miles to the north, but including one grog-tempered red-slipped sherd from either the Big Cypress Creek or Sabine River basins to the south) also constitute a significant component (20-25 percent) of the decorated ceramics from the site during both Early and Middle Caddoan times, and these include a variety of incised, punctated, engraved, and incised-punctated decorative elements.

\title{
The Petrographic Analysis of Caddoan Ceramics from the Hurricane Hill Site (41HP106), Hopkins County, Texas
}

\author{
Sergio A. Iruegas
}

\section{Introduction}

The microscopic petrography of Caddoan ceramics from the Hurricane Hill site (41HP106), Hopkins County, Texas, is the principal focus of this part of Chapter 9. Fourteen sherds collected from Block A on the North rise and Block B/C on the South rise were selected for the analysis of the paste composition of the Early and Middle Caddoan ceramics from the site. Petrographic analysis concentrated on the optical identification of tempering agents, mineral inclusions, and clay slips. A minimum point-count of 200 per thin section was completed to facilitate statistical comparisons of paste composition, and minimize statistical variation (Pettijohn et al. 1987:520). The temper and grain count data were grouped into similar types of inclusions for comparisons with chemical characterization studies by the University of Missouri Research Reactor (see Neff et al., Chapter 10, this volume) to begin to assess intra- and intercommunity paste variation in A.D. 1000-1400 Caddoan ceramics at this one community in the upper Sulphur River basin.

The purpose in pursuing the petrographic analysis of sherds from Early and Middle Caddoan period components at the site is two-fold in that: (1) it will provide specific information on changes, if any, in the paste compositional variability of the Caddoan ceramics from the site over time, as well as (2) detect distinct paste compositional varieties (some likely to be of non-local character) that may be associated with specific types of vessel forms, decorative elements, and/or a combination of both variables. The sherd petrographic sampling strategy focused on a diverse assortment of decorated sherds and/or rim forms with different decorative elements from two temporally distinct components across the site.

As discussed earlier in this report, the Hurricane Hill site is located on a prominent upland landform along the South Sulphur River astride the dam embankment for Cooper Lake. It is a large multicomponent prehistoric site, but the Caddoan occupations (middens, pit features, burials, portions of five Caddoan structures, and a large material culture assemblage) were concentrated over about two acres along the western side of the upland ridge. Block excavations recovered about 3000 Caddoan sherds from an Early Caddoan component dated between ca. A.D. 1000-1200 on the North rise. Petrographic sherds samples 1 
through 20 derive from various midden and feature contexts in this component, and samples 4, 5, 7-10, and 20 discussed herein are from the North rise. Block B/C is some $40-50$ meters south of Block A. It extensively sampled a Middle Caddoan period domestic component dated (with seven radiocarbon dates and a single archaeomagnetic date) between ca. A.D. 1250-1375 (see Chapter 7, this volume). Petrographic sherd samples 21 through 40 are associated with this occupation, and they are primarily associated with two overlapping rectangular structures; samples 22-24, 29-31, and 38 were analyzed from the South rise Middle Caddoan component.

\section{Methodology}

The thin-sections were prepared by Spectrum Petrographics, Inc. (Winston, Oregon) through a series of steps that involved cutting a clean level face on the sherd sample with a diamond saw, and impregnating the samples with an epoxy resin to hold the grain particles in places. Samples were then mounted on a standard glass slide $1 \times 4$ inches in size with an adhesive and ground to a thickness of ca. 0.03 $\mathrm{mm}$. To prevent scratches, the thin-section samples were protected with a thin cover glass. Heinrich (1956), Orton et. al. (1993:140-144), Rice (1987:376-379), and Shepard (1971:139-140) offer detailed descriptions of thin-section preparation and petrography procedures

The analysis was conducted on an Olympus $\mathrm{BH} 2$ petrographic microscope with rotating stage and its IC-10 lens, and thin section samples were photographed on 100 ASA film using the microscope's C35DA-2 mounted camera. All components (void, matrix, and grains) were point-counted under cross-hairs in transect intervals of $0.5 \mathrm{~mm}$ over a rectangular grid measuring $10 \times 20 \mathrm{~mm}$, with a total of 200 pointcounts per thin section. Minerals and/or temper particles observed with a 10X Rupen hand lens, but not observed under the microscope, are also included in the discussion of the analyses.

\section{Results of the Petrographic Analysis}

Prior to analysis of the thin-section point counts, a microscopic preview of each sample was conducted to determine the detrital composition of the ceramics. Table 9-11 summarizes the ceramic types represented in the thin-sectioned sherds, voids (or pores), matrix, and grain point-counts. The percentage frequency of detrital grains (quartz, micrite, calcite, feldspar, and hematite) and temper inclusions is presented in Table 9-12. It should be noted that calcite and shell temper are difficult to distinguish depending on the orientation of the shell temper in the thin-section sample; in cases where shell temper was observed with a 10X Rupen hand lens in the sherd sample, a note is made within the table. Because staining for K-feldspar (orthoclase or microlene) was not part of the thin section preparation, all feldspars were counted under one identification column. Comments regarding different feldspars are included in the sample descriptions. The following is a summary and description of the thin-section samples according to the two paste groups.

Table 9-11. Ceramic attributes of decoration, voids, matrix, and temper.

\begin{tabular}{cllcrrr}
\hline Sample \# & \multicolumn{1}{c}{ Sherd Attributes } & Block & Lot \# & Void & Matrix & Grain \\
& & & & & \\
\hline \hline 4 & red slipped & $\mathrm{A}$ & 588 & $6 \%$ & $52 \%$ & $28 \%$ \\
5 & incised-punctated & $\mathrm{A}$ & 4941 & $15 \%$ & $64 \%$ & $13 \%$ \\
7 & incised-punctated & $\mathrm{A}$ & 5428 & $1 \%$ & $45 \%$ & $27 \%$ \\
8 & engraved & $\mathrm{A}$ & 3785 & $11 \%$ & $51 \%$ & $16 \%$ \\
9 & engraved & $\mathrm{A}$ & 4836 & $13 \%$ & $52 \%$ & $6 \%$ \\
10 & engraved & $\mathrm{A}$ & 489 & $8 \%$ & $52 \%$ & $4 \%$ \\
20 & punctated & $\mathrm{A}$ & 5646 & $5 \%$ & $51 \%$ & $19 \%$ \\
22 & diagonal engraved & $\mathrm{B} / \mathrm{C}$ & 3926 & $5 \%$ & $51 \%$ & $12 \%$ \\
23 & brushed & $\mathrm{B} / \mathrm{C}$ & 4845 & $7 \%$ & $64 \%$ & $17 \%$ \\
24 & red slipped bottle & $\mathrm{B} / \mathrm{C}$ & 4129 & $11 \%$ & $67 \%$ & $7 \%$ \\
29 & engraved (ladder) & $\mathrm{B} / \mathrm{C}$ & 4717 & $4 \%$ & $58 \%$ & $9 \%$ \\
30 & diagonal engraved & $\mathrm{B} / \mathrm{C}$ & 646 & $6 \%$ & $57 \%$ & $24 \%$ \\
31 & diagonal engraved rim & $\mathrm{B} / \mathrm{C}$ & 2679 & $7 \%$ & $34 \%$ & $17 \%$ \\
38 & plain rim & $\mathrm{B} / \mathrm{C}$ & 2401 & $5 \%$ & $37 \%$ & $19 \%$ \\
\hline
\end{tabular}


Table 9-12. Grain characteristics.

\begin{tabular}{|c|c|c|c|c|c|c|c|c|c|c|}
\hline \multirow[t]{2}{*}{ Group } & \multirow[t]{2}{*}{ Sherd \# } & \multicolumn{3}{|c|}{ Grains } & \multirow[b]{2}{*}{$\mathrm{F}$} & \multirow[b]{2}{*}{$\mathrm{H}$} & \multicolumn{3}{|c|}{ Temper } & \multirow[b]{2}{*}{$S$} \\
\hline & & $\mathrm{QTZ}^{*}$ & M & $\mathrm{C}$ & & & QTZ & B & G & \\
\hline \multicolumn{11}{|l|}{1} \\
\hline & $\begin{array}{l}8 \\
9 \\
20 \\
23 \\
24 \\
29 \\
30 \\
38\end{array}$ & $\begin{array}{l}11 \% \\
2 \% \\
2 \% \\
7 \% \\
2 \% \\
2 \% \\
10 \% \\
2 \%\end{array}$ & $\begin{array}{l}2 \% \\
1 \% \\
0 \% \\
0 \% \\
0 \% \\
3 \% \\
4 \% \\
2 \%\end{array}$ & $\begin{array}{l}0 \% \\
0 \% \\
0 \% \\
0 \% \\
0 \% \\
0 \% \\
1 \% \\
1 \%\end{array}$ & $\begin{array}{l}1 \% \\
0 \% \\
11 \% \\
7 \% \\
1 \% \\
1 \% \\
2 \% \\
10 \%\end{array}$ & $\begin{array}{l}2 \% \\
3 \% \\
6 \% \\
3 \% \\
4 \% \\
3 \% \\
7 \% \\
4 \%\end{array}$ & $\begin{array}{l}3 \% \\
0 \% \\
1 \% \\
4 \% \\
0 \% \\
0 \% \\
0 \% \\
3 \%\end{array}$ & $\begin{array}{l}0 \% \\
7 \% \\
0 \% \\
0 \% \\
0 \% \\
0 \% \\
0 \% \\
0 \%\end{array}$ & $\begin{array}{l}21 \% \\
25 \% \\
24 \% \\
20 \% \\
15 \% \\
25 \% \\
13 \% \\
36 \%\end{array}$ & $\begin{array}{l}0 \% \\
0 \% \\
0 \% \\
8 \% \\
0 \% \\
0 \% \\
0 \% \\
0 \%\end{array}$ \\
\hline \multicolumn{11}{|l|}{2} \\
\hline & $\begin{array}{l}4 \\
5 \\
7 \\
10 \\
22 \\
31\end{array}$ & $\begin{array}{l}7 \% \\
12 \% \\
15 \% \\
1 \% \\
4 \% \\
11 \%\end{array}$ & $\begin{array}{l}8 \% \\
0 \% \\
9 \% \\
0 \% \\
0 \% \\
4 \%\end{array}$ & $\begin{array}{l}0 \% \\
0 \% \\
0 \% \\
0 \% \\
1 \% \\
2 \%\end{array}$ & $\begin{array}{l}13 \% \\
1 \% \\
3 \% \\
3 \% \\
7 \% \\
0 \%\end{array}$ & $\begin{array}{l}0 \% \\
0 \% \\
0 \% \\
0 \% \\
0 \% \\
0 \%\end{array}$ & $\begin{array}{l}2 \% \\
0 \% \\
4 \% \\
0 \% \\
3 \% \\
3 \%\end{array}$ & $\begin{array}{l}9 \% \\
0 \% \\
0 \% \\
5 \% \\
0 \% \\
0 \%\end{array}$ & $\begin{array}{l}3 \% \\
8 \% \\
22 \% \\
31 \% \\
20 \% \\
36 \%\end{array}$ & $\begin{array}{l}0 \% \\
0 \% \\
0 \% \\
0 \% \\
9 \% \\
0 \%\end{array}$ \\
\hline
\end{tabular}

* $\mathrm{QTZ}=$ quartz; $\mathrm{M}=$ micrite; $\mathrm{C}=$ calcite; $\mathrm{F}=$ feldspar; $\mathrm{H}=$ hematite; $\mathrm{B}=$ bone; $\mathrm{G}=$ grog; $\mathrm{S}=$ shell

For purposes of this study, temper was limited to bone, shell (crushed mussels), grog (crushed pottery), and deliberately added quartz grains recognized by their low sphericity and high angularity compared to the naturally occurring quartz grains that are rounded with smoother edges. Non-plastics include deliberate and indeterminate materials in the paste (Rice 1987:411), including the aforementioned tempers and "particulate matter of some size." Bone inclusions are burned and crushed, and are sub-rounded and angular in shape (cf. Ferring and Perttula 1987). Grog temper inclusions are present in three colors: gray, yellow, and dark reddish-brown. The latter is likely from fragments of low-fired ceramic vessels. Shell temper has a distinctive high angularity due to the crushing process before levigation in the clay. Prior macroscopic examination of the sherd samples indicated that Sample 23 (a brushed sherd, see Table 9-11) contained shell temper; however, shell temper inclusions were also noted in the Sample 22 thin section (a diagonal engraved sherd), although the macroscopic examination of this sherd detected no shell temper.

All of the thin section samples contained grog inclusions (ranging from 3-36 percent), and more than 70 percent of the samples had grog in the 20 percentile range. About 57 percent of the sample had deliberately added crushed quartz temper, and 29 percent of the thin sectioned sherds had burned bone temper inclusions.

After the petrographic analysis of the thin section samples was completed, results indicated that the samples can be divided into two groups based on clay matrix color and grain inclusions. The first group (Group 1, $\mathrm{n}=8$ ) has a light brownish-tan clay matrix with hematite detrital grains, and the remaining six (Group 2) have a dark brown clay matrix without hematite detrital grains. Based on the color of the clay matrix alone, it appears that Group 1 thin section samples (representing 71 percent of the South rise sherds but only 43 percent of the North rise sherds) are from well-fired ceramic vessels probably fired in an oxidizing environment (cf. Teltser 1993). Conversely, the dark brown color of the Group 2 thin sectioned sherds indicate they were from ceramic vessels probably fired at a lower temperature and/or in a reducing or low oxygen environment. 


\section{Group 1}

Sample 8

The light brown clay matrix of this sample is characterized by hematitic stains and grains ( 2 percent) with slightly oriented shredded voids or pores (11 percent point-count). Quartz grains have high and low sphericity with angular to sub-angular edges; three percent of these inclusions are deliberately added and 11 percent are naturally occurring in the paste. Compared to the size of these grains (averaging $0.06 \times 0.04$ $\mathrm{mm}$ ), grog inclusions are very large--almost $0.5 \mathrm{~mm}$ to $1 \mathrm{~mm}$ in size (Figure 9-21a)--and account for 21 percent of the clay matrix. The grog inclusions are well-defined in the light brownish-tan hematitic-stained clay matrix.

\section{Sample 9}

The naturally occurring and moderately sorted detrital quartz grains with low sphericity and subangular to subrounded edges comprise 2 percent of the clay matrix, along with 13 percent oriented shredded voids or pores. The light brownish-tan clay matrix has hematite stains and small rounded grains (3 percent), with trace amounts of plagioclase laths and micritic grains. Yellow grog inclusions (15 percent) are well defined and large, nearly $1 \mathrm{~mm}$ in size (Figure 9-22a). As in the previous sample, grayish grog inclusions are also present in the paste. Together, these two kinds of grog inclusions comprise 25 percent of the clay matrix While there is no deliberately added crushed shell or quartz inclusions, burned bone fragments (see Figure 9-22a) have been added to the paste (7 percent). Petrographic analysis indicates a sedimentary terrain source for the clay.

\section{Sample 20}

Three medium-sized (averaging $0.83 \times 0.50 \mathrm{~mm}$ ) dark reddish-brown and yellow grog inclusions comprise 24 percent of the clay matrix in Sample 20 (see Figure 9-22b), a punctated sherd. The yellow grog fragment $(0.75 \times 0.40 \mathrm{~mm})$ is very poorly defined and has blended into the clay matrix through diagenesis. Hematite grains (6 percent of the point-count) are embedded in the clay matrix, along with detrital quartz grains ( 3 percent, including 1 percent deliberately added as a temper) that have low sphericity with subangular edges. The hematitic-stained clay matrix and natural inclusions are consistent with a sedimentary terrain.

\section{Sample 23}

The core of this sample is a light yellowish-brown hematitic-stained matrix (64 percent pointcount) characterized by poorly sorted sand grains (7 percent) with high and low sphericity with sub-angular to rounded edges. Deliberately added detrital quartz inclusions comprise 4 percent of the matrix. There is a noticeable large $(0.90 \times 0.50 \mathrm{~mm})$ dark reddish-brown grog inclusion with poorly defined boundaries in Sample 23. It should be noted that a fragment of crushed mussel shell was previewed macroscopically, but is not included in the thin section sample. Accordingly, the presence of this temper is listed in Table 9-12 as 1 percentage point lower ( 8 percent) than the percentage of shell temper observed in the thin section for Sample 22 (see below). The analysis of this sample indicates a sedimentary terrain as the source of the clay.

\section{Sample 24}

The well-oriented shredded void structure (11 percent point-count) throughout the clay matrix (67 percent point-count) of Sample 24, a red-slipped sherd from a bottle, is indicative of a montmorillionite clay source. The matrix is comprised of large $(0.4 \times 1.0 \mathrm{~mm})$ dark reddish-brown grog inclusions and 2 percent detrital quartz grains. Four percent of the clay matrix is comprised of rounded hematite grains. A sedimentary environment is indicated by the void structure and natural inclusions of this sample. 

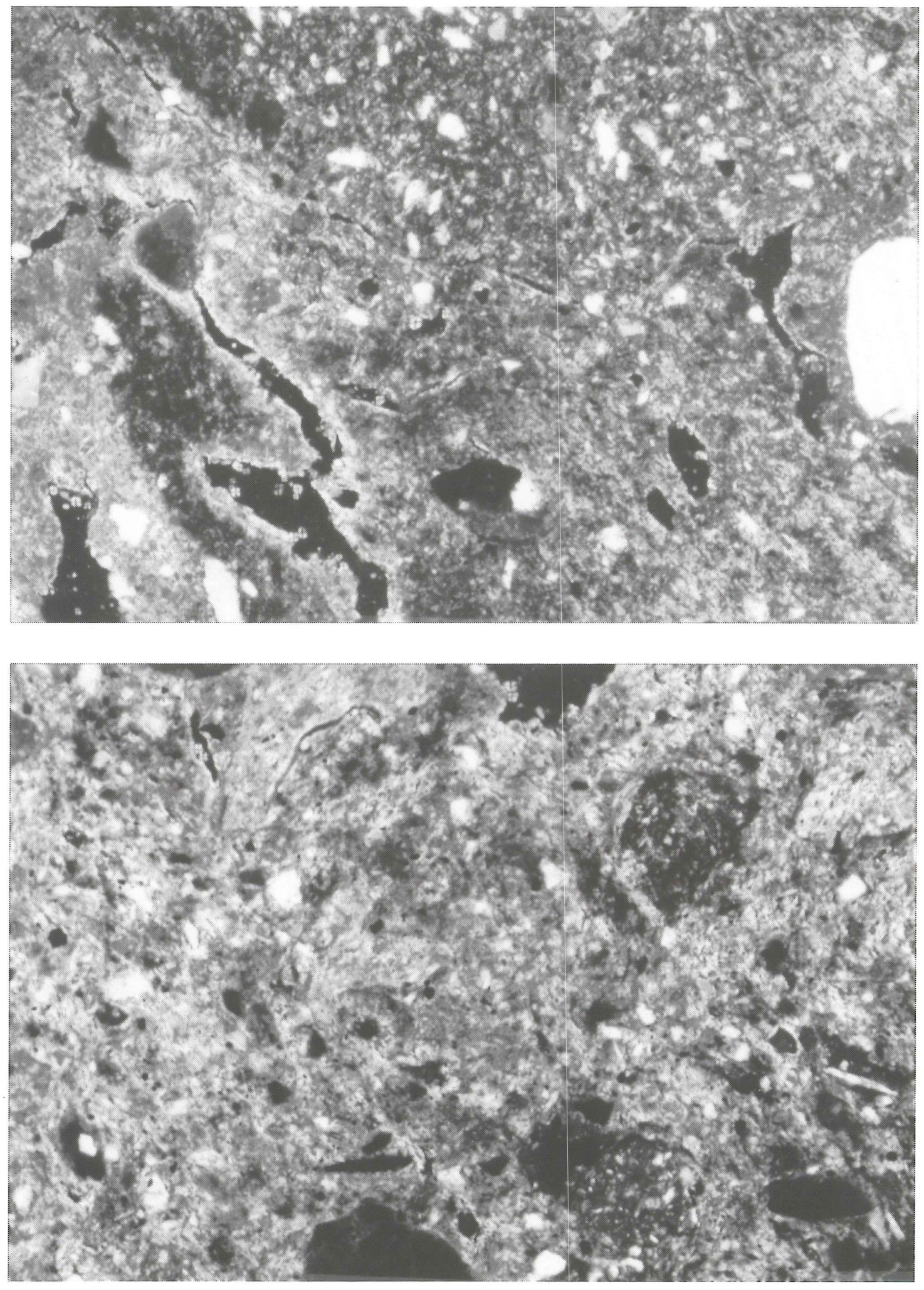

Figure 9-21. Group 1 Thin Sections: a, Sample 8, hematite-stained light brown clay matrix with detrital quartz inclusions and large gray grog inclusions; b, Sample 30, light reddish-brown hematite-stained clay matrix with poorly sorted detrital quartz grains and small yellow and reddish-brown grog inclusions. 

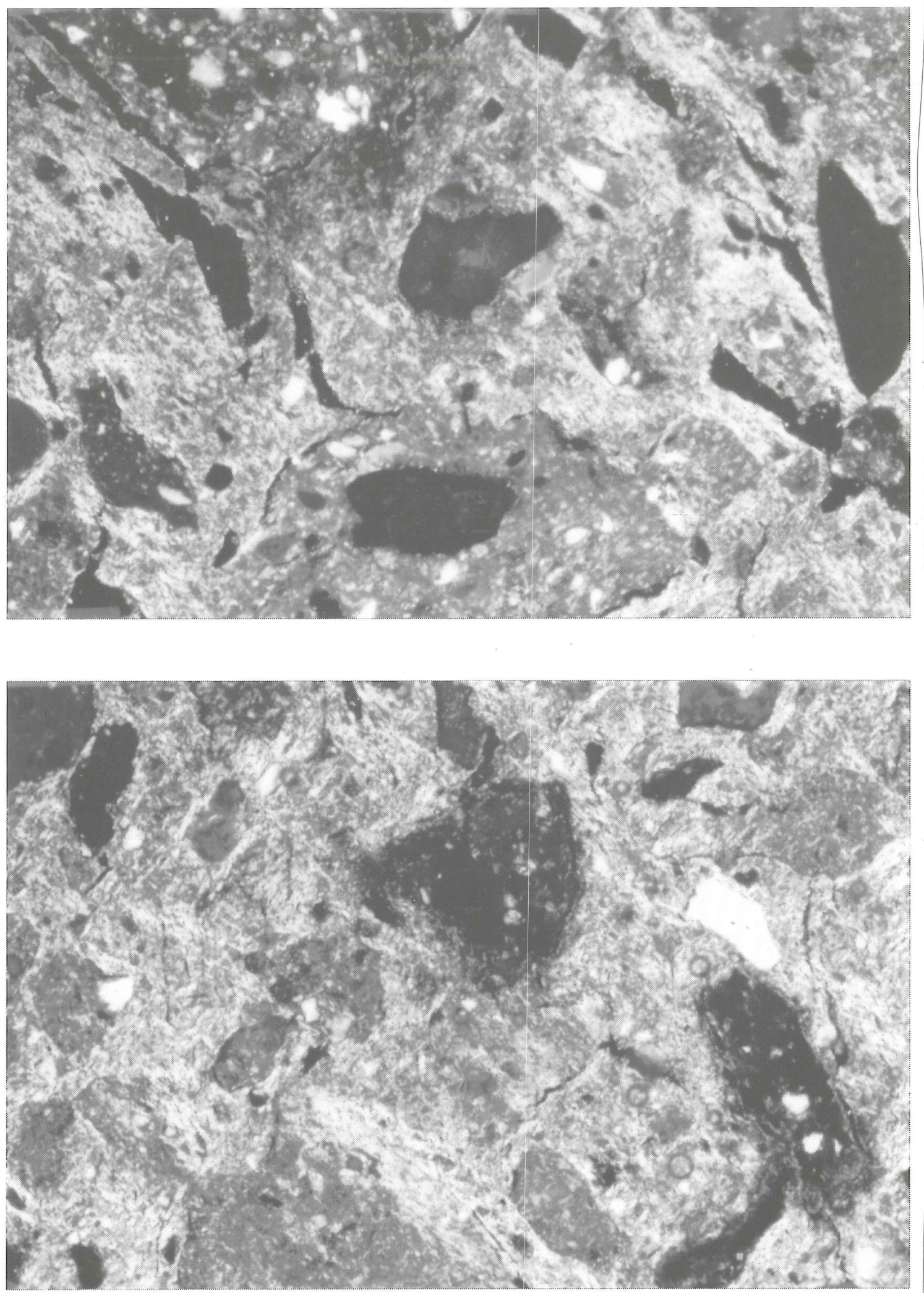

Figure 9-22. Group 1 Thin Sections: a, Sample 9, light brownish-tan clay matrix embedded with hematite, moderately sorted quartz grains, burned bone, and yellow and gray grog; b, Sample 20, dark reddish-brown grog inclusions embedded in a light brownish-tan clay matrix. Hematite and quartz detrital grains appear red and white under polarized light. 
The clay matrix of this sample is characterized by a brown reddish-tan core that comprised 58 percent of the paste. Oriented shredded voids or pores comprise 8 percent of the hematitic-stained clay matrix, with rounded hematite grains ( 3 percent) staining the matrix. Dark reddish-brown grog inclusions amount to 25 percent of the matrix, and they average $0.70 \times 0.44 \mathrm{~mm}$ in size, with low sphericity and angular to sub-angular edges. Two percent of the matrix is comprised of well-sorted detrital quartz grains. Analysis of this sample indicates a sedimentary terrain as the source of the clay.

Sample 30

Fifty-seven percent of Sample 30 is a light brownish-red hematitic-stained clay matrix (see Figure 9-21b). The poorly sorted detrital grains include 10 percent quartz, 7 percent hematite, 4 percent micrite, 1 percent calcite, and 2 percent feldspars. Six percent of the matrix is comprised of oriented shredded voids. The small rounded, high and low sphericity, dark reddish-brown grog inclusions (average size of $0.40 \times 0.45$ $\mathrm{mm}$ ) comprise 13 percent of the clay matrix. These inclusions, along with the detrital grains, suggest a sedimentary terrain clay source.

Sample 38

The core of this sample has a brownish clay matrix ( 37 percent point-count) with poorly sorted detrital quartz grains ( 5 percent point-count, 3 percent of which comprise a deliberately added temper), and 36 percent dark reddish-brown and yellow grog inclusions. Also included in the matrix is 2 percent micrite, 1 percent calcite, and 10 percent feldspars. The detrital quartz grains are very angular to angular and exhibit low sphericity. The intraclastic detrital grains and the clay matrix indicate a sedimentary terrain for the clay source.

\section{Group 2}

Sample 4

This thin-section sample shows a dark reddish-brown core with a thin red-slip coating $(<0.03 \mathrm{~mm})$ on its exterior surface, with detrital quartz grains $(<0.01 \mathrm{~mm}$ in size) embedded throughout the matrix. The matrix is characterized by very angular to angular quartz grains (average size of $0.07 \times 0.05 \mathrm{~mm}$ ) with low sphericity ( 2 percent point-count); these grains, along with micrite, calcite, and feldspars, are very poorly sorted. Burned bone temper (Figure 9-23a) and 3 percent gray grog inclusions are also present in the matrix. The detrital grains and clay matrix indicate a sedimentary terrain clay source for Sample 4.

Sample 5

A very dark brown clay matrix characterizes the core of this sample. The voids (15 percent) have an oriented shredded structure that is indicative of a montmorillionite clay (Heinrich 1956:128). Embedded in the matrix-rich sherd sample (64 percent) are poorly sorted and low sphericity quartz grains that are angular to subangular as the dominate paste constituent (12 percent) compared to 1 percent feldspar. Eight percent of the clay matrix is composed of a gray grog temper. The grain inclusions and the montmorillionite type voids also indicate a sedimentary environment for the clay source of this vessel.

\section{Sample 7}

The core of this sample is very dark brown in color. The matrix ( 45 percent point-count) is characterized by 22 percent well-defined yellow grog inclusions, 15 percent poorly sorted quartz grains (Figure 9-24), and 4 percent deliberately added quartz temper. Small amounts of micrite and feldspars are also present. The grog inclusions have high sphericity and are angular to sub-angular compared to the quartz temper grains, as the latter have a low sphericity with sub-angular to angular edges. The clay matrix and detrital grains again suggest a sedimentary environment for the clay source. 

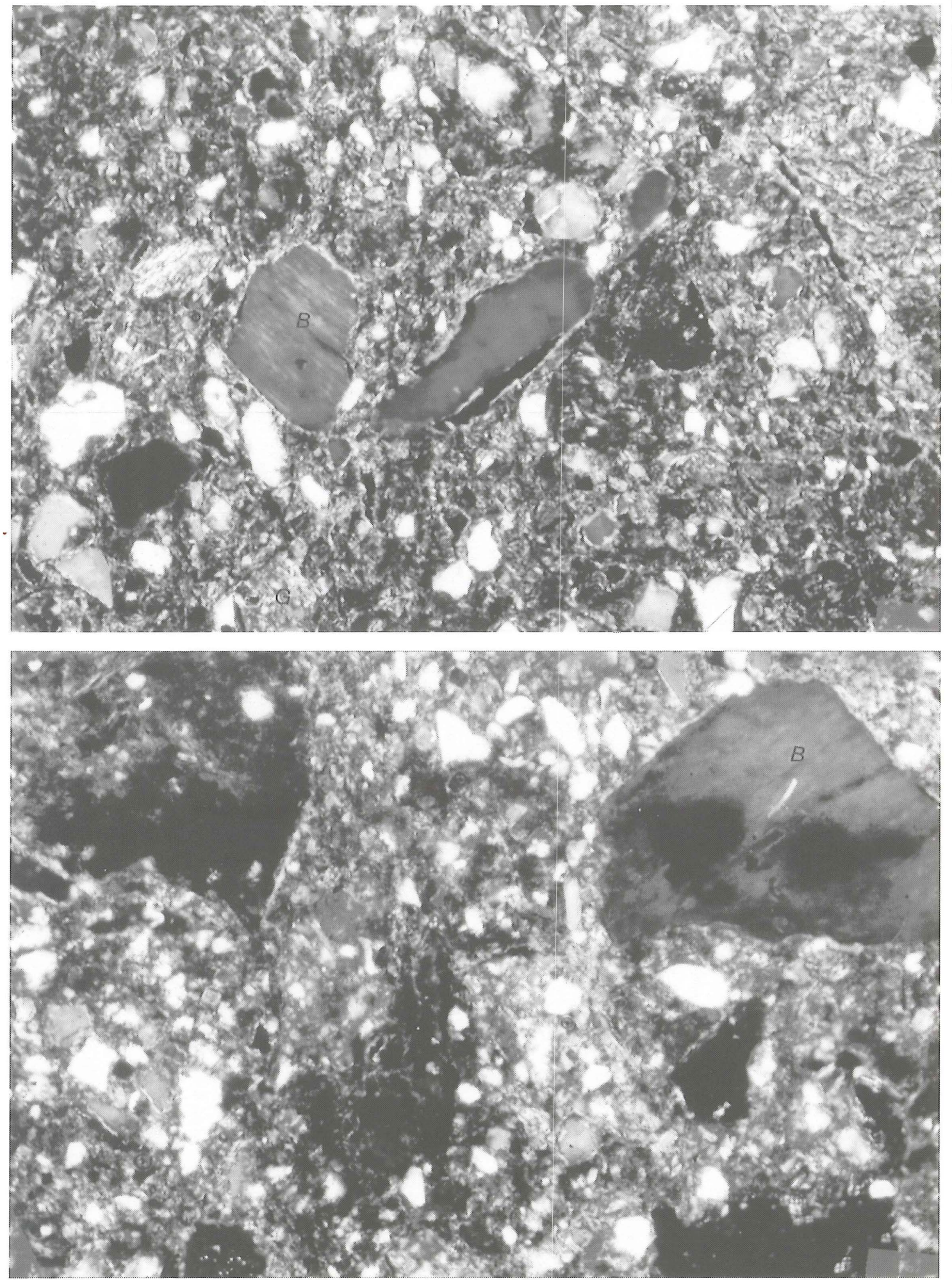

Figure 9-23. Group 2 Thin Sections: a, Sample 4, detrital mineral grains viewed under polarized light. Naturally occurring and deliberately added quartz inclusions appear white to dark gray throughout the clay matrix. Burned bone appears on left side of photograph; $b$, Sample 31, well-sorted detrital quartz grains and burned bone temper. 


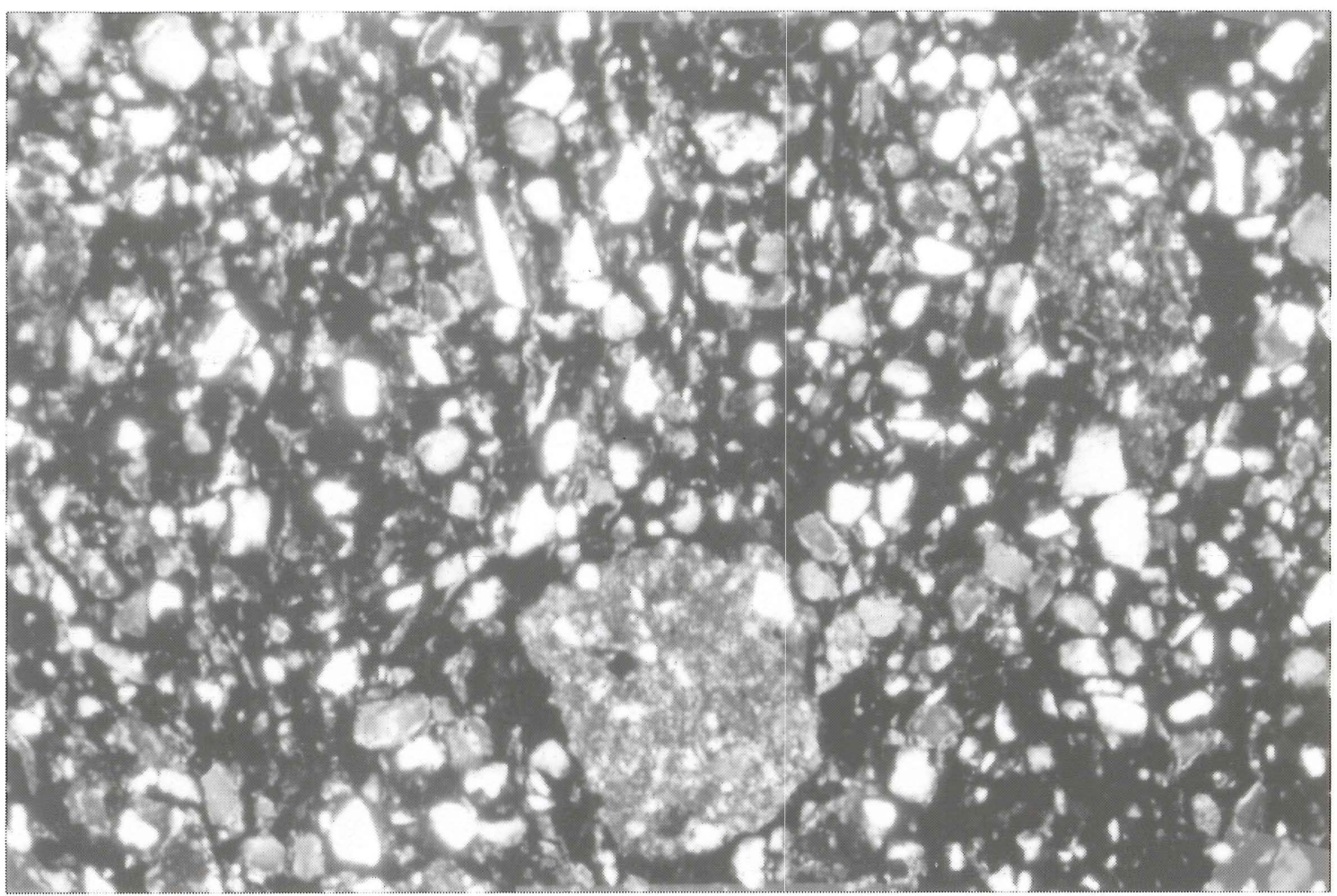

Figure 9-24. Group 2 Thin Sections, Sample 7. This sample has poorly sorted detrtital quartz grains embedded in the dark reddish-brown clay matrix, with well-defined yellow grog inclusions.

\section{Sample 10}

The hematite-stained clay matrix of this sample is a very dark brown with a well-oriented shredded void structure ( 8 percent point-count) (Figure 9-25a). It is characterized by trace amounts of quartz and feldspar and well-defined large gray and yellow grog inclusions (31 percent) measuring $0.86 \times 0.53 \mathrm{~mm}$ and $1.23 \times 0.40 \mathrm{~mm}$, respectively. Five percent of the clay matrix is composed of burned bone temper The matrix and the voids indicate a sedimentary terrain.

\section{Sample 22}

This sample has a dark brown core with hematitic stains that characterize the clay matrix. Welloriented shredded void structure ( 5 percent of the point counts) is evident throughout the matrix. Four percent poorly-sorted detrital quartz grains comprise the matrix along with three percent angular quartz temper inclusions. Twenty percent of the matrix are gray grog inclusions ranging in size from $0.70 \times 0.40$ $\mathrm{mm}$ to $0.75 \times 0.48 \mathrm{~mm}$. Crushed mussel shell (with low sphericity and very angular edges) is also present (see Figure 9-25b), measuring $1.0 \times 0.5 \mathrm{~mm}$ in size. Other intraclastic grains include 1 percent calcite and 7 percent feldspars; trace amounts of hematite grains were present but did not fall under the cross-hairs of the point counts. The sub-rounded intraclastic grains have a high sphericity and indicate the clay source material comes from a sedimentary environment. 

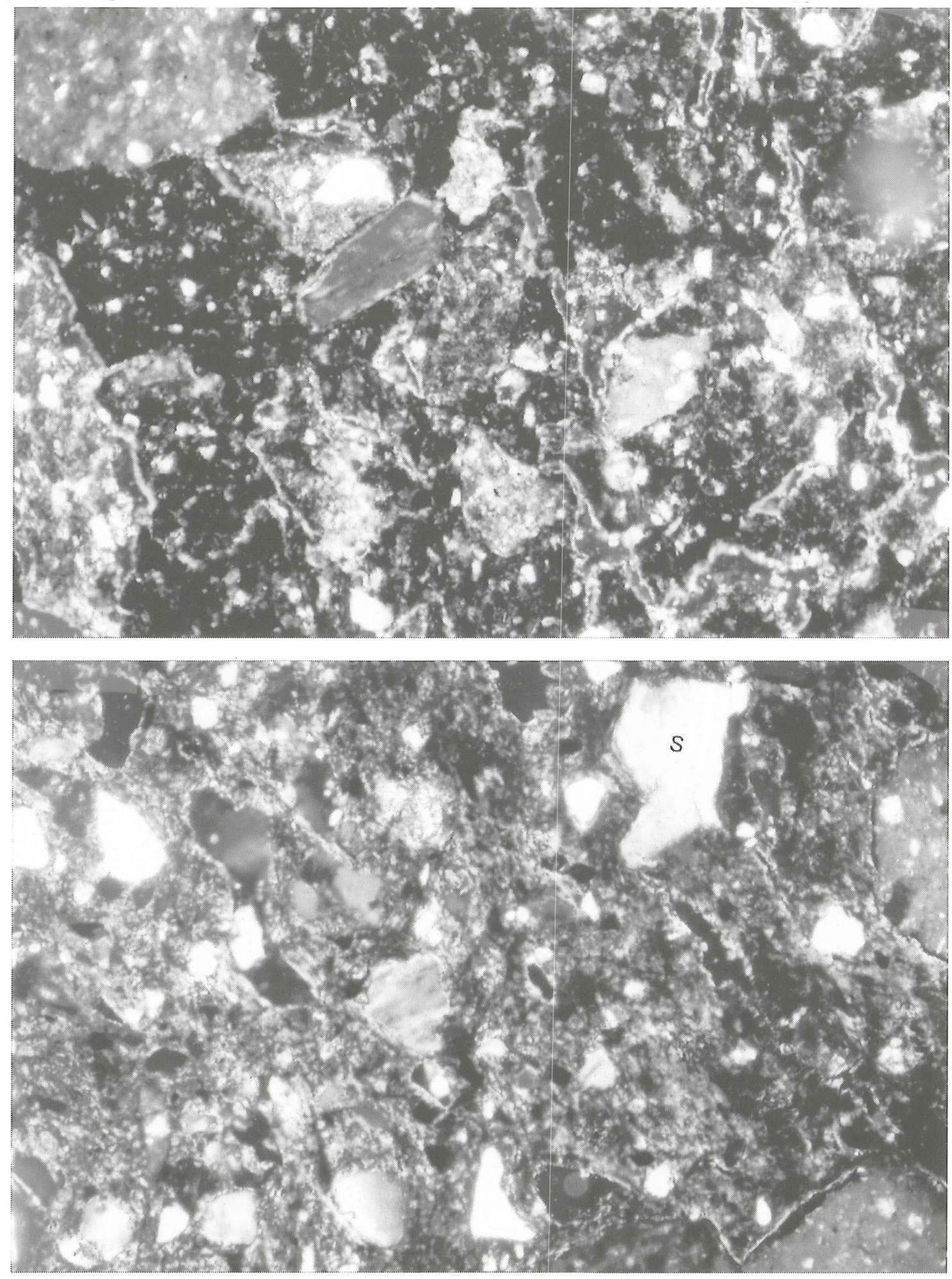

Figure 9-25. Group 2 Thin Sections: a, Sample 10, well-oriented shredded void structures throughout the dark reddish-brown clay matrix with gray and yellow grog inclusions and burned bone; b, Sample 22, large angular crushed mussel shell fragment embedded in a dark reddish-brown clay matrix rich in quartz detrtital grains and gray grog inclusions. 
Sample 31

The hematitic-stained clay matrix ( 34 percent point-count) of this sample is comprised of large $(1.0 \times 0.90 \mathrm{~mm})$ dark reddish-brown grog inclusions as well as large fragments of burned bone temper $(1.10$ x $0.86 \mathrm{~mm}$ in size) (see Figure 9-23b). Poorly sorted detrital quartz grains make up 11 percent of the matrix; these grains are sub-angular and have a low sphericity. Three percent of the quartz grains are considered a deliberately added temper. The voids ( 7 percent point-count) are subangular and also show an oriented shredded structure. These characteristics, along with the intraclastic grains, indicate a sedimentary context for the clay used in the manufacture of the vessel from which this sherd came.

\section{Summary}

A total of 14 sherd samples from Early and Middle Caddoan period components at the Hurricane Hill site (41HP106) were selected for ceramic petrography. The intent of the petrographic analysis was to provide specific information on any changes in the paste compositional variability of the Caddoan ceramics from the site over time, as well as detect distinct paste compositional varieties (some likely to be of nonlocal character, based in part on the INAA analyses conducted by Neff et al., this volume) that may be associated with specific types of vessel forms, decorative elements, and/or a combination of both variables.

The Hurricane Hill site is underlain by Cretaceous limestone/dolomite-rich formations (Malicse 1994:267). Thin section samples of local manufactured pottery would be indicative of the local limestone clay sources. Likewise, imported ceramic thin section samples would not reflect the local geology of the Hurricane Hill site or the South Sulphur River basin. Clay matrices of all the sherd samples indicate a sedimentary geologic depositional environment that is consistent with expected clay sources in the upper Sulphur River basin.

Except for the diagonal engraved rim (sherd sample \#31) from Middle Caddoan contexts with high proportions of grog temper (36 percent; see Table 9-12) and the lowest clay matrix point counts (see Table 9-11) in the site sample, distinct paste compositional varieties associated with specific engraved decorative elements are consistent over time, even though engraved sherds are present in both Groups 1 and 2. Oriented shredded void structures and similar percentage counts of the clay matrix with temper grains indicate that the same ferruginous (hematitic-stained) limestone Montmorillonite clay source may have been utilized by the Caddoan potters at Hurricane Hill over time when making vessels with engraved decoration. Sherd samples $\# 8$, \#9, \#10, \#22, \#29, and \#30 with engraved decoration (from both Blocks $A$ and B/C) had clay matrices classified as mud-supported intraclastic wackestones. The point-counts of the clay matrices are in the 50 percentile, with the temper inclusions ranging from a low of 13 percent (\#30) to as high as 36 percent (\#10). If the engraved sherds other than the diagonal engraved examples are considered, the percentile ranges become more focused: matrix (51-52 percent), temper (24-36 percent), and intraclastic grains (4-16 percent). With more information regarding vessel forms, this engraved decorative petrographic data may or may not indicate further similarities of the compositional make-up of these thin-section sherd samples. In the case of incised-punctated decorative elements, there are no distinct paste compositional varieties evident in the sherd samples, although both sherds are assigned to Group 2. The red-slipped sherds have low percentages of grog temper, but differ in their paste porosity, clay matrix, and grain composition.

Regarding the first objective of this study, specific information on change in the paste compositional variability of the Caddoan ceramics from the site over time is evident in the fact that two compositionally distinct groups (Groups 1 and 2) are defined from the thin section analysis. Both groups of clay matrices are present during both the Early and Middle Caddoan period components, as well as deliberately added quartz, bone, and grog tempers; Group 1 sherds are, however, more common in Middle Caddoan contexts, while Group 2 sherds are better represented in the Early Caddoan ceramics from the North rise. Crushed mussel shell temper is present only in the Middle Caddoan ceramics, although both Group 1 and 2 samples have one thin-sectioned sherd with shell temper, indicating little change in paste composition choices even as temper selection preferences changed from Early to Middle Caddoan times. Although naturally occurring, calcite grains are also only present in the later Caddoan component.

As for distinctive paste compositional differences associated with decorative elements, incisedpunctated and red-slipped ceramics from the Early Caddoan period component do not have crushed mussel shell added as temper. They are also more porous, contain more non-plastic grain inclusions, and have 
lower amounts of grog temper added to the paste than do the Middle Caddoan period ceramic samples:

\section{Early Caddoan}

$\begin{array}{lll}\text { pores } & 8.7 \% & 6.4 \% \\ \text { matrix } & 52.4 \% & 52.6 \% \\ \text { grains } & 16.1 \% & 15.0 \% \\ \text { grog temper } & 19.1 \% & 23.6 \%\end{array}$

\section{Middlle Caddoan}

$6.4 \%$

Further petrographic analysis of Caddoan ceramics with larger samples of sherds with a variety of decorative elements and different temporal periods is necessary to propose more definitive statements about the ceramic practices and preferences (both functional and stylistic) of the prehistoric Caddoan peoples in Northeast Texas. 


\section{Regional Comparisons in Paste Composition from Petrographic Analyses}

\section{Timothy K. Perttula}

The petrographic analysis of ceramic sherds from Caddoan prehistoric archaeological sites has become more commonplace in the last decade, as archaeologists have become more concerned with the functional and technological characteristics of the ceramics made by Caddoan peoples, along with their continued interest in the stylistic attributes of the pottery (Perttula et al. 1995). While not an exhaustive list, Table 9-13 indicates that more than 340 ceramic sherds from 33 prehistoric Caddoan sites (and one Caddoan trade sherd from a Central Texas Toyah phase [ca. A.D. 1300-1700) site) have been subjected to petrographic analysis. Most of the petrographic samples have been from Caddoan sites in the Sabine and Sulphur River drainages in Northeast Texas, along with the Arkansas River basin in eastern Oklahoma, and the Big Cypress Creek basin in Northeast Texas (Figure 9-26). This work has been designed to obtain detailed microscopic information on the paste of ceramics--i.e., including the composition and quantity of non-plastic inclusions, clay matrix, pore spaces, and temper selection--across much of the Caddoan area to seek insights into changes in the use of clay resources over time and space as well as intra- and interregional differences in manufacturing traditions (see Reese-Taylor 1995a).

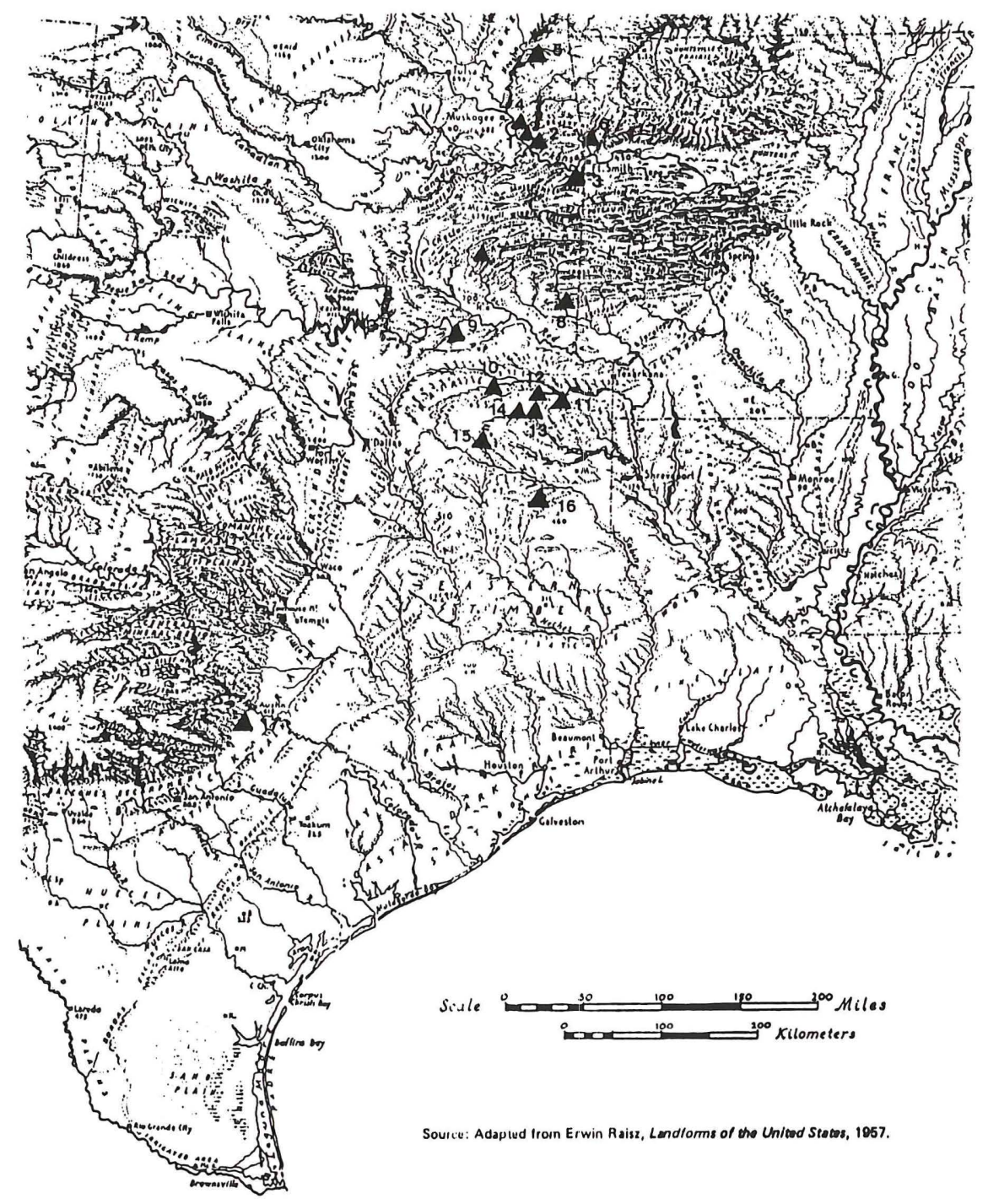

Figure 9-26. Location of Caddoan sites with ceramic petrographic data. Site clusters 1-17 are keyed to Table 9-13. Note that site 17 is a Toyah phase site in Central Texas with Caddoan trade ceramics. 
Table 9-13. Available petrographic data from Caddoan sites.

Sites

Arkansas River Basin

1. 34SQ11 (Horton)

2. 34SQ13 (Fine)

3. $34 \mathrm{LF} 46$ (Spiro)

34LF46 (Spiro)

34LF46 (Spiro)

4. 34MS52 (Cat Smith)

Southern Ozarks

5. 34CK43 (Brackett)

6. 34SQ12 (Parris Mound)

10

29

$\underline{\text { Ouachita Mountains }}$

7. 34AT220 (Kafka)

1

8. 34MC54 (E. Johnson)

3

$\underline{\text { Red River }}$

9. 41LR2 (T.M. Sanders)

4

Sulphur River

10. 41HP106 (Hurricane Hill)

14

10

11. $41 \mathrm{BW} 553$

12. 41 TT670
Ferring and

Perttula 1987

Reference

Ferring and

Perttula 1987

Ferring and

Perttula 1987

Ferring and

Perttula 1987

Porter 1971

Swenson 1989

Ferring and

Perttula 1987

Swenson 1989

Swenson 1989

Ferring and Perttula 1987

Ferring and Perttula 1987

Iruegas, this volume

Ennes and Cliff 1997

Ennes and Cliff 1997 
Table 9-13. Available petrographic data from Caddoan sites, cont.

\begin{tabular}{|c|c|c|}
\hline Sites & No. of Thin-Sections & Reference \\
\hline 13. 41TT392 & 3 & $\begin{array}{l}\text { Reese-Taylor } \\
\text { 1995b }\end{array}$ \\
\hline 41TT396 & 3 & $\begin{array}{l}\text { Reese-Taylor } \\
\text { 1995b }\end{array}$ \\
\hline 41TT399 & 3 & $\begin{array}{l}\text { Reese-Taylor } \\
1995 \mathrm{~b}\end{array}$ \\
\hline $41 \mathrm{TT} 400$ & 3 & $\begin{array}{l}\text { Reese-Taylor } \\
1995\end{array}$ \\
\hline 41TT406 & 2 & $\begin{array}{l}\text { Reese-Taylor } \\
1995 \mathrm{~b}\end{array}$ \\
\hline 41TT409 & 3 & $\begin{array}{l}\text { Reese-Taylor } \\
\text { 1995b }\end{array}$ \\
\hline 41TT572 & 4 & Switek 1997 \\
\hline $41 \mathrm{TT} 577$ & 3 & Switek 1997 \\
\hline 41TT591 & 1 & Switek 1997 \\
\hline $41 \mathrm{TT} 593$ & 2 & Switek 1997 \\
\hline 41TT601 & 2 & $\begin{array}{l}\text { Reese-Taylor } \\
\text { 1995b }\end{array}$ \\
\hline 41TT653 (Ear Spool) & 4 & Switek 1997 \\
\hline \multicolumn{3}{|l|}{ Big Cypress Bayou } \\
\hline 14. 41 TT550 (Mockingbird) & 16 & $\begin{array}{l}\text { Skokan and } \\
\text { Perttula } 1998\end{array}$ \\
\hline 41TT550 (Mockingbird) & 2 & $\begin{array}{l}\text { Reese-Taylor } \\
1993\end{array}$ \\
\hline $41 \mathrm{TT} 370$ & 1 & $\begin{array}{l}\text { Reese-Taylor } \\
1993\end{array}$ \\
\hline 41TT372 & 1 & $\begin{array}{l}\text { Reese-Taylor } \\
1993\end{array}$ \\
\hline $41 \mathrm{TT} 372$ & 13 & $\begin{array}{l}\text { Reese-Taylor } \\
1995 b, 1997\end{array}$ \\
\hline \multicolumn{3}{|l|}{ Sabine River } \\
\hline 15. 41 WD482 (Taddlock) & 2 & $\begin{array}{l}\text { Ferring and } \\
\text { Perttula } 1987\end{array}$ \\
\hline
\end{tabular}


Table 9-13. Available petrographic data from Caddoan sites, cont.

Sites No. of Thin-Sections Reference

41WD109 (Spoonbill)

16. 41 RK214 (Oak Hill)

41RK214 (Oak Hill)

41RK215

41RK216

41RK342

Central Texas Prairie/ Colorado River

17. 41HY209-T (Mustang Branch)
1

6

124

4

3

21

$1^{*}$
Ferring and

Perttula 1987

Reese-Taylor

1994

Switek 1998b

Reese-Taylor 1994

Reese-Taylor 1994

Switek 1998a

Reese-Taylor et al. 1995

* Poynor Engraved in a non-Caddoan Toyah phase context

In this discussion, the focus is on the results of petrographic analyses of ceramic sherds from two Middle Caddoan sites in the middle Sabine River basin (Switek 1998a, 1998b); a Middle Caddoan site (41TT372) and Late Caddoan site (41TT550) in the central part of the Big Cypress Creek basin (ReeseTaylor 1995b, 1997; Switek 1997; Skokan and Perttula 1998); Early, Middle, and Late Caddoan ceramics from sites in the Sulphur River drainage, including sites on East Piney Creek and White Oak Bayou (Ennes and Cliff 1997; Switek 1997); and the Early and Middle Caddoan ceramic samples from the Hurricane Hill site discussed above (Table 9-14).

Table 9-14. Paste Composition of Sherds from Sellected Caddoan Sites in Northeast Texas.

\begin{tabular}{|c|c|c|c|c|c|c|c|c|}
\hline Constituents & $\begin{array}{l}\text { 41RK } \\
342\end{array}$ & $\begin{array}{l}\text { 41RK } \\
214\end{array}$ & $\begin{array}{l}41 T T \\
372\end{array}$ & $\begin{array}{l}41 T T \\
550\end{array}$ & $\begin{array}{l}41 T T \\
653\end{array}$ & $\begin{array}{l}41 B W \\
553\end{array}$ & $\begin{array}{l}41 \mathrm{TT} \\
670\end{array}$ & $\begin{array}{l}\text { Hurricane } \\
\text { Hill }\end{array}$ \\
\hline $\begin{array}{l}\text { Non-plastics } \\
\text { Matrix } \\
\text { Pore space } \\
\text { Quartz } \\
\text { Feldspar } \\
\text { Grog } \\
\text { Bone } \\
\text { Hematite } \\
\text { Shell }\end{array}$ & $\begin{array}{l}41.8^{*} \\
48.9 \\
9.2 \\
20.0 \\
+ \\
11.4 \\
25.8 \\
2.2 \\
0.0\end{array}$ & $\begin{array}{l}48.0 \\
41.1 \\
10.9 \\
20.4 \\
+ \\
15.2 \\
1.3 \\
7.7 \\
0.0\end{array}$ & $\begin{array}{l}32.0 \\
58.9 \\
4.5 \\
18.7 \\
1.7 \\
12.6 \\
3.4 \\
7.5 \\
0.0\end{array}$ & $\begin{array}{l}37.5 \\
48.4 \\
12.2 \\
22.0 \\
0.1 \\
8.7 \\
2.5 \\
1.5 \\
0.0\end{array}$ & $\begin{array}{l}38.4 \\
50.3 \\
11.4 \\
19.8 \\
1.5 \\
9.5 \\
1.3 \\
3.3 \\
0.0\end{array}$ & $\begin{array}{l}28.0 \\
57.2 \\
14.8 \\
10.7 \\
0.1 \\
6.7 \\
2.5 \\
0.9 \\
3.3\end{array}$ & $\begin{array}{l}28.5 \\
61.6 \\
9.9 \\
9.7 \\
1.8 \\
7.5 \\
5.0 \\
0.6 \\
0.0\end{array}$ & $\begin{array}{l}40.1 \\
52.5 \\
7.4 \\
6.3 \\
4.3 \\
21.4 \\
1.5 \\
2.3 \\
1.2\end{array}$ \\
\hline
\end{tabular}

${ }^{*}$ percentage

$+=$ trace amounts

It is immediately apparent from Table 9-14 that the paste composition of Caddoan ceramics from Northeast Texas archaeological sites is diverse, both in terms of the temper selection choices as well as the primary constituents in the clay matrix. Grog is the most abundant temper inclusion, with the highest proportions in the Hurricane Hill collection (particularly in Middle Caddoan contexts, see above), followed 
by the two Middle Caddoan period sites in the Sabine River basin, and the Middle Caddoan period ceramics from 41TT372 on Tankersley Creek in the Big Cypress Creek drainage.

The choice of grog--either finely or coarsely crushed--as a temper by Caddoan potters may have had both technological and stylistic properties. The addition of grog in the paste slows the oxidation process of the ceramic vessels, creating darker-colored vessels in the reducing environment, while allowing them to be fired longer, with more control, and producing a harder ceramic (Rice 1987:354; Teltser 1993:532, 540). Thus, the addition of grog (particularly if it is finely crushed) contributes to the vessel's ability to withstand heat-related stresses, as well as increases its flexural strength (Rice 1987:362; O'Brien et al. 1994:281). Such vessels would also have better thermal conductivity.

Bone temper is ubiquitous, albeit in low frequencies, in Northeast Texas Caddoan ceramics, except at 41RK342, where it comprises 25.8 percent of the clay matrix in that assemblage (see Table 9-14). Switek (1998b) suggests that the use of bone temper would have been "useful in increasing the plasticity and drying and firing characteristics of the clay." Only Middle to Late Caddoan ceramics from the middle and upper reaches of the Sulphur River drainage, including the Hurricane Hill site, have shell temper inclusions.

The consistent proportion of voids or pores in the Northeast Texas ceramics (4.5-14.8 percent of the point counts), in combination with the percentage of clay matrix, point to similar and/or shared technological traditions in the manufacture of these Caddoan vessels. The types of pores present in a vessel's paste affect its permeability. A vessel designed to hold liquids will perform best if its porosity is low. Specifically, these pore data indicate that the Caddoan potters in the Sulphur, Big Cypress, and Sabine basins were mixing and kneading the clay paste in a comparable manner to produce vessels with consistent pore spaces, which in turn relates to the production of serviceable vessels that can be successfully heated, reheated, and cooled without easily cracking, suffering from cumulative thermal fatigue, and maintaining their impermeability.

Non-plastics range from 28.0-48.0 percent of the clay matrix in the ceramic samples, and the proportions of non-plastics correlate with river/creek river basin locations. The lowest proportions of nonplastics in the clay matrix are found in the Early-Late Caddoan ceramics from the middle and lower reaches of the Sulphur River drainage (e.g., Ennes and Cliff 1997), the three Titus County sites in the Hayes, Tankersley, and East Piney creek drainages share comparable proportions (32,0-38.4 percent), as do the Sabine River basin Middle Caddoan sites, with 41.8-48.0 percent non-plastics. Hurricane Hill falls between the Hayes-Tankersley-East Piney creeks and Sabine River basin ceramic samples. Clay matrix groups (see Table 9-14) have the same spatial-temporal relationships among the eight ceramic assemblages, as do the proportions of quartz grains.

Detrital grains of feldspar are the most abundant in clay pastes in Sulphur River basin Caddoan ceramics, particularly at the Hurricane Hill site in the upper Sulphur River basin. The frequency of feldspar in the clay paste of the Hurricane Hill ceramics, and from other Northeast Texas Caddoan sites (see ReeseTaylor 1995a, 1997), has manufacturing and functional implications. Feldspars occur as fine grains in a clay and enhance a vessel's ability to sinter (i.e., the melting and fusing of paste constituents) during firing, resulting in a vessel having a dense, hard body, and a reduced porosity (Rice 1987:96). This appears to have contributed to the distinctive characteristic of the Hurricane Hill ceramics in that they have a very low porosity and an abundance of grog temper. The combination of the two non-plastics appears to have been a more than adequate technological solution to making useful, hard, and relatively low-porosity vessels in Early and Middle Caddoan times at the site.

Plotting the frequency of feldspar in the petrographic samples from west to east along the Sulphur River basin indicates that it is most common in the upper basin, and steadily decreases in frequency in the clay matrix (or is depleted) of sherd samples in the middle (41TT670) and lower (41BW553) reaches of the Sulphur River basin. This suggests that the clay sources selected by the Caddoan occupants of the Hurricane Hill site were from sedimentary sources with relatively immature arkosic sands or sandstone, which would be expected in upper basin sedimentary deposits, and that the clay sources down basin were from sedimentary sources with a mature quartz sand or sandstone. In the other Caddoan ceramic assemblages, the parent material for the clay matrix appears to have been a mature quartz sand or sandstone because the feldspars occur in frequencies less than 1.7 percent (see Table 9-14). 
The same east-west (or northwestern to southeastern) trends in depletion of rare earths and minerals have been detected in neutron activation analyses of Northeast Texas Caddoan sherd samples by Cogswell et al. (1998a:7):

...average rainfall increases slightly from north to south in the project area [Northeast Texas]. Increased precipitation may cause alkali elements such as sodium [or alkali feldspar] to be preferentially leached from raw clays or from pottery deposited in the ground, thus causing the observed trend of dilution of alkali elements in pottery from north to south. Second, while the Sulphur and Sabine rivers, which flow through Hopkins, Titus, and Rusk counties, start in the predominantly marly deposits of the Taylor formation and work through predominantly limestones and sandstones in the area (Stone 1937), the clay deposits in the more northerly Hopkins and Titus counties (Macon 1979) are characterized by kaolin, a mineral that is generally depleted in rare earths, while the clays in Rusk County to the south are characterized by Montmorillonite, a mixedlayer clay that generally contains comparatively higher amounts of rare earths. Pottery made from kaolins from Hopkins and Titus counties would presumably be depleted in rare earth elements compared to Montmorillonite-rich pottery produced in Rusk County.

The proportions of hematite in the clay paste of the Sulphur River basin samples are also depleted from west to east, and it is an abundant natural inclusion in the middle Sabine River ceramics (41RK214 and 41RK342), as well as 41TT372 in the Tankersley Creek area of the Big Cypress Creek basin (see Table 9-14). Sherds with very high proportions (>20-40 percent) of hematite inclusions in the Big Cypress Creek ceramic samples have been suggested to represent vessels manufactured outside of the local area, probably in the "hematite-rich" Sabine River basin (see Reese-Taylor 1995a, 1995b).

Quartz inclusions in the paste have distinct regional proportions: the Sulphur River basin samples range from 6.3-10.7 percent; the Hayes-Tankersley-East Piney Creek ceramics have quartz ranges between 18.7-22.0 percent; and the middle Sabine River ceramic samples have quartz grain proportions of 20.0-20.4 percent (see Table 9-14). Not too surprisingly, therefore, the proportions of quartz in the clay paste are also generally inversely related to the proportions of clay matrix in the ceramics, as well as to the amount of non-plastics. The differing proportions of quartz in the ceramic petrographic samples across the Northeast Texas region suggest that the clays from each of the Caddoan sites in different river/creek basins were collected from different sources, but that the sources within each of the river/creek basins are more similar to each other (given east-west trends in depletion of minerals and age differences in sand/sandstone deposits) than they are to clay sources in adjoining river/creek basins. Thus, it appears to be the case that the ceramics from the various sites are generally being made from local clay resources with distinctive mineral and temper characteristics. Nevertheless, the existence of east-west trends in mineral depletion and interregional differences in non-plastics appear to be sufficient, given robust sample sizes for the petrographic analyses, to be able to detect anomalous clay matrix groups in a sample of sherds and hence infer that particular sherds in an assemblage may be from non-local Caddoan manufacturing and clay sources. Consequently, it is recommended that petrographic analysis of samples routinely be conducted of decorated Caddoan ceramics of known age from Caddoan sites to be excavated and studied in the future in Northeast Texas. The relatively consistent proportions of minerals and non-plastic inclusions in the Hurricane Hill site ceramic petrographic samples do not clearly suggest that any of the 14 sherds are from vessels not made from local clay sources (see Iruegas, this chapter), although the absence of hematite in the Group 2 sherds, and the low ( $<1$ percent) proportions of feldspar in Samples 5 and 31, combined with the low amount of grog temper in Sample 5 (see Table 9-12), hint that the latter two sherds may have been made from clay sources downstream from Hurricane Hill, along the middle reaches of the Sulphur River basin.

\section{Ceramic Pipes}

A total of 42 clay pipe sherds were recovered from the Hurricane Hill site. Although many of the sherds are quite small ( $<2 \mathrm{~cm}$ in length or width), the larger fragments are identified as Red River longstemmed pipes as defined by Hoffman (1967) from Caddo sites in southwestern Arkansas, northwestern Louisiana, and southeastern Oklahoma. The long-stemmed pipe style has also been found on a number of Caddo sites in northeastern Texas (Fritz 1975; Mallouf 1976; Bruseth and Perttula 1981; Story 1981, ed.). Examples of recovered specimens from the North rise (Figure 9-27a) and the South rise (Figure 9-27b-h) are illustrated below, and provenience data are provided in Tables 9-15 and 9-16. 


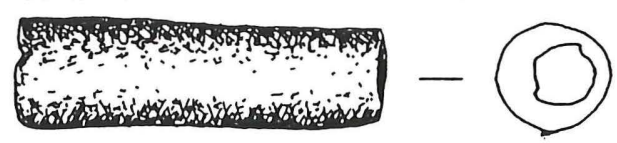

a

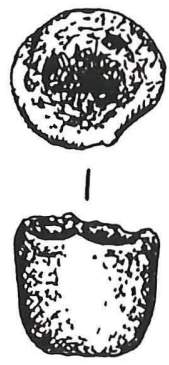

b

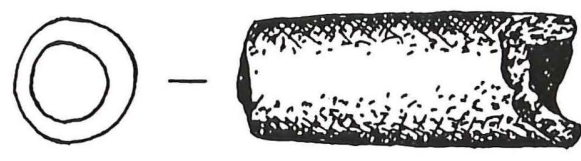

$c$

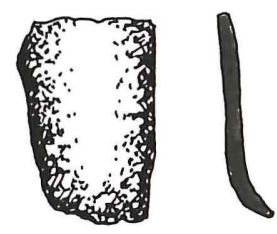

$f$

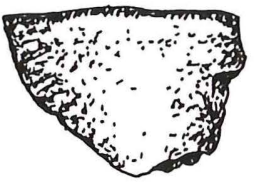

$g$
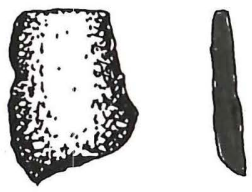

d
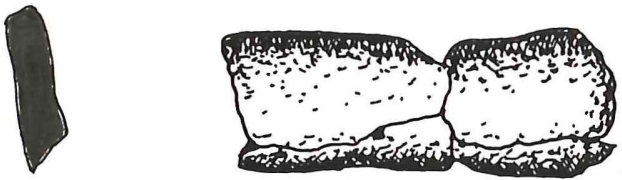

$h$

Figure 9-27. Pipe sherds from Hurricane Hill: a, c, h, stem; b, butt end; d-g, bowls. Provenience: a, 2523 A; b, 148-2; c, 142-3B; d, 68-2; e, 62-3B; f, surface, South rise; g, 173-3A; h, 108-2A.

The eight specimens from Block A include four bowl fragments and four stem fragments (one proximal, two medial, and another sherd that was broken along the attachment to the bowl). The pipes appear to have been burnished and/or polished after manufacture, and one (see Figure 9-27a) is covered with a hematite-derived red slip. The one measurable bowl fragment is $20.5 \mathrm{~mm}$ in height. Diameters of the stem fragments range between 9.0 and $10.2 \mathrm{~mm}$, with an average of $9.6 \pm 0.6 \mathrm{~mm}$. Stem hole diameters average $5.5 \pm 0.5 \mathrm{~mm}$, with a range of $5-6 \mathrm{~mm}$. These fall within the range of the Graves Chapel and Haley varieties of Red River pipes, which are dated by Hoffman (1967, 1983:Figure 2) from between A.D. 1100 and A.D. 1400; the Graves Chapel variety is about 100 years earlier than the Haley variety. All the fragments are characterized by a fine sandy paste. In addition, 75 percent $(n=6)$ have small inclusions of crushed bone. This is consistent with other samples of Red River pipes from Northeast Texas (e.g., Bruseth and Perttula 1981:Table 5-11; Mallouf 1976:275). 
Table 9-15. Frequencies of pipe fragments from Blocks $B / C$ and $F$ on the South rise.

\begin{tabular}{llcll}
\hline Provenience & Bowl & Bowl/Stem & Stem & Total \\
\hline Level 1 & 7 & - & 1 & 8 \\
Level 2 & 3 & 3 & 7 & 13 \\
Level 3A & 1 & - & 2 & 3 \\
Level 3B & 3 & - & 3 & 6 \\
Level 4A & - & - & $2^{\mathrm{a}}$ & 1 \\
Level 5A & - & - & $1 \mathrm{~b}$ & 33 \\
\hline Total & 14 & 3 & 16 & \\
\hline
\end{tabular}

${ }^{a}$ Stain 12 (center post), Structure B

${ }^{b}$ Feature 101

Table 9-16. Frequencies of pipe fragments from Block $A$ on the North rise.

$\begin{array}{llll}\text { Provenience } & \text { Bowl } & \text { Bowl/Stem } & \text { Stem }\end{array}$

$\begin{array}{lllll}\text { Level 1 } & 1 & - & - & 1 \\ \text { Level 2 } & 2 & - & 1 & 3 \\ \text { Level 3 } & - & - & 3 & 3 \\ \text { Level 4 } & 1 & - & - & 1\end{array}$

Total

Pipe fragments were distributed throughout Block A, but were concentrated in the vicinity of Features 4 and 34, extramural hearths located near the top of the Early Caddoan Midden 1 deposit (Figure 928). Presumably, these pipe sherds are fragments of pipes used by smokers during outside heating and cooking activities.

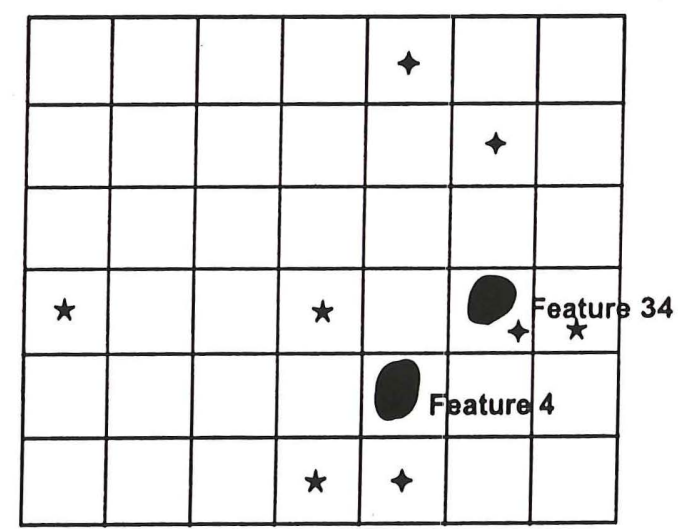

Block A

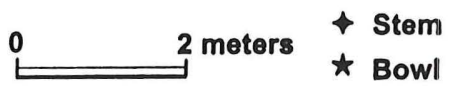

Figure 9-28. Distribution of pipe sherds in Block A. 
estimated to have taken place at approximately A.D. 1000-1200 (see Chapter 7 , this volume), is $1-2$ centuries older than the Middle Caddoan occupation (ca. A.D. 1250-1375) in Block B/C.

Two of the larger Block B/C long-stemmed pipe stem fragments (see Figure 9-27h) have a coarser paste with bone and grog inclusions. These are among the thicker specimens in the Hurricane Hill assemblage. Mallouf (1976:275) describes a similar group of thick, bone/grog-tempered long-stemmed pipe sherds from Mound B at the A. C. Mackin site (41LR39) in Lamar County, Texas. They derived from a context postdating A.D. 1210-1280 (e.g., Mallouf 1976:Table 2), and thus are contemporaneous with the Middle Caddoan occupation on the South rise at Hurricane Hill.

The pipe sherds from the South rise were primarily distributed within the two Middle Caddoan period structures (Figure 9-30). In particular, both bowl and stem sherds were found along the outer margins of the structures, mainly to the north of the central hearth, 2-4 m from the central hearth, probably where the broken pipe sherds were swept when the central floor area was kept clean. About 20 percent of the pipe sherds were found outside the structure walls, and the majority of these were outside the western walls of the structure, in the vicinity of the possible Structure C arbor/ramada (see Figure 9-30).

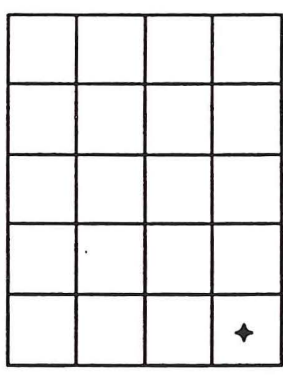

Block F
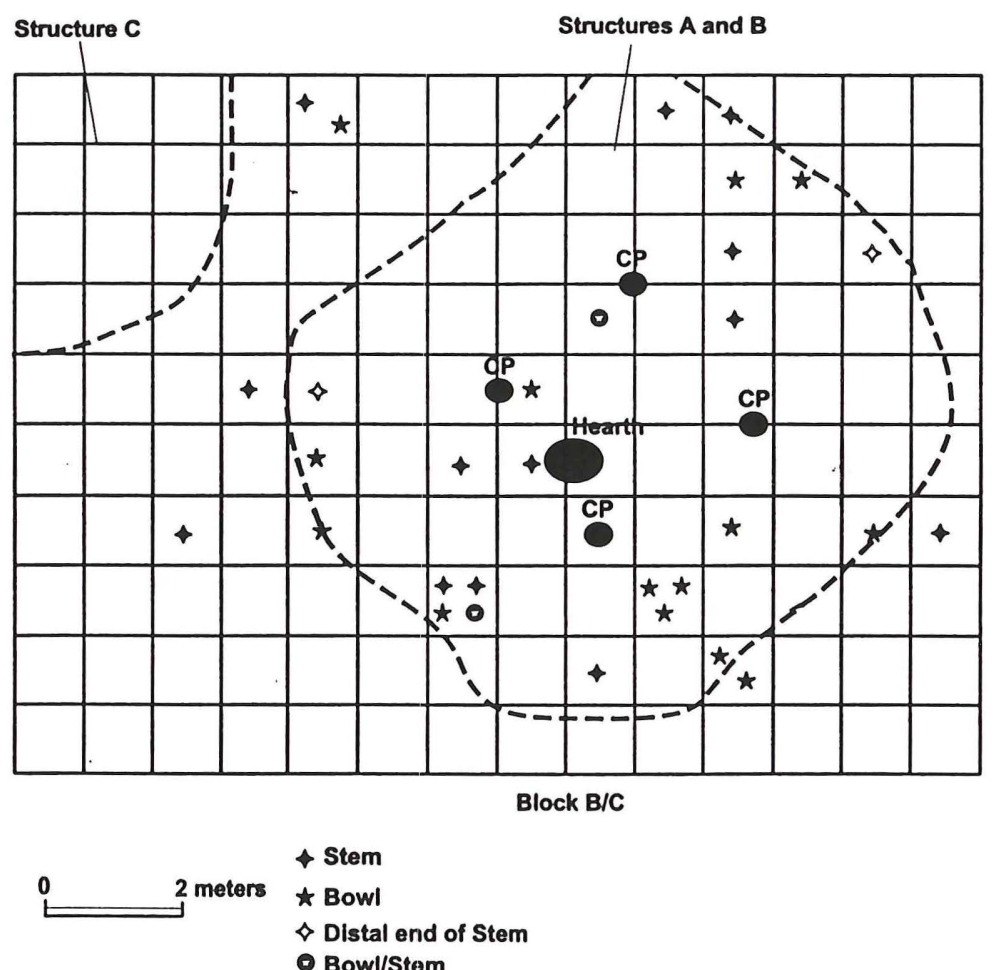

Figure 9-30. Distribution of pipe sherds in Block B/C.

The final pipe specimen from the Hurricane Hill site is a pipe bowl fragment that was recovered from Shovel Test \#17 during the Phase I investigations. This shovel test was located between the North and South rises (see Figure 4-5). It has paste, temper, and surface treatment characteristics similar to the fragments from both Blocks $\mathrm{A}$ and $\mathrm{B} / \mathrm{C}$, and is probably culturally associated with them.

\section{Miscellaneous Clay Items}

Nine other clay artifacts were recovered from the Hurricane Hill site that illustrate additional uses of clay by its Caddoan inhabitants. Some also represent by-products of the manufacture of ceramic vessels. 
Sections of clay coils were found in Blocks A and B/C on the North and South rises, respectively (Table 917). Only two had temper, a coarse grog. The coil fragments from Block $B / C$ are uniformly less than 2.0 $\mathrm{cm}$ in length or width and exhibit shallow impressions from an unidentified type of plant material. The Block A coil is $53 \mathrm{~mm}$ long and $9.5 \mathrm{~mm}$ wide (Figure 9-31a).

Table 9-17. The distribution of other clay items.

\begin{tabular}{|c|c|c|c|}
\hline \multirow[b]{2}{*}{ Types } & \multicolumn{2}{|c|}{ North Rise } & \multirow{2}{*}{$\begin{array}{l}\text { South Rise } \\
\text { Block B/C }\end{array}$} \\
\hline & Block A & Block E & \\
\hline Clay ball & - & 1 & - \\
\hline $\begin{array}{l}\text { Clay with basket } \\
\text { impressions }\end{array}$ & 1 & - & 1 \\
\hline Clay coils & 1 & - & 5 \\
\hline $\begin{array}{l}\text { Sherd with drilled } \\
\text { hole }\end{array}$ & 1 & - & - \\
\hline
\end{tabular}

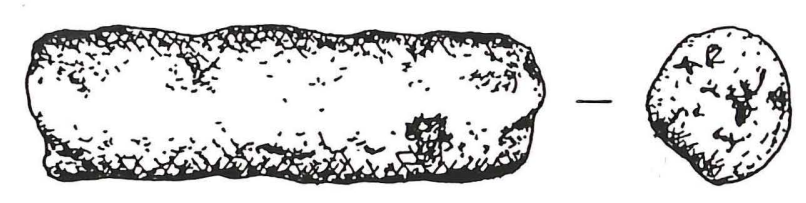

a

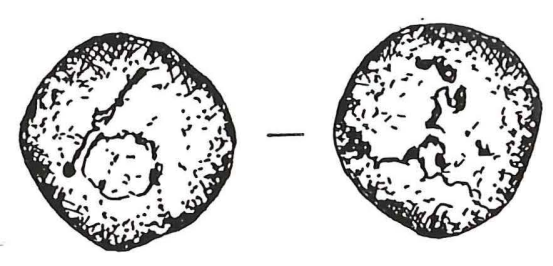

$b$
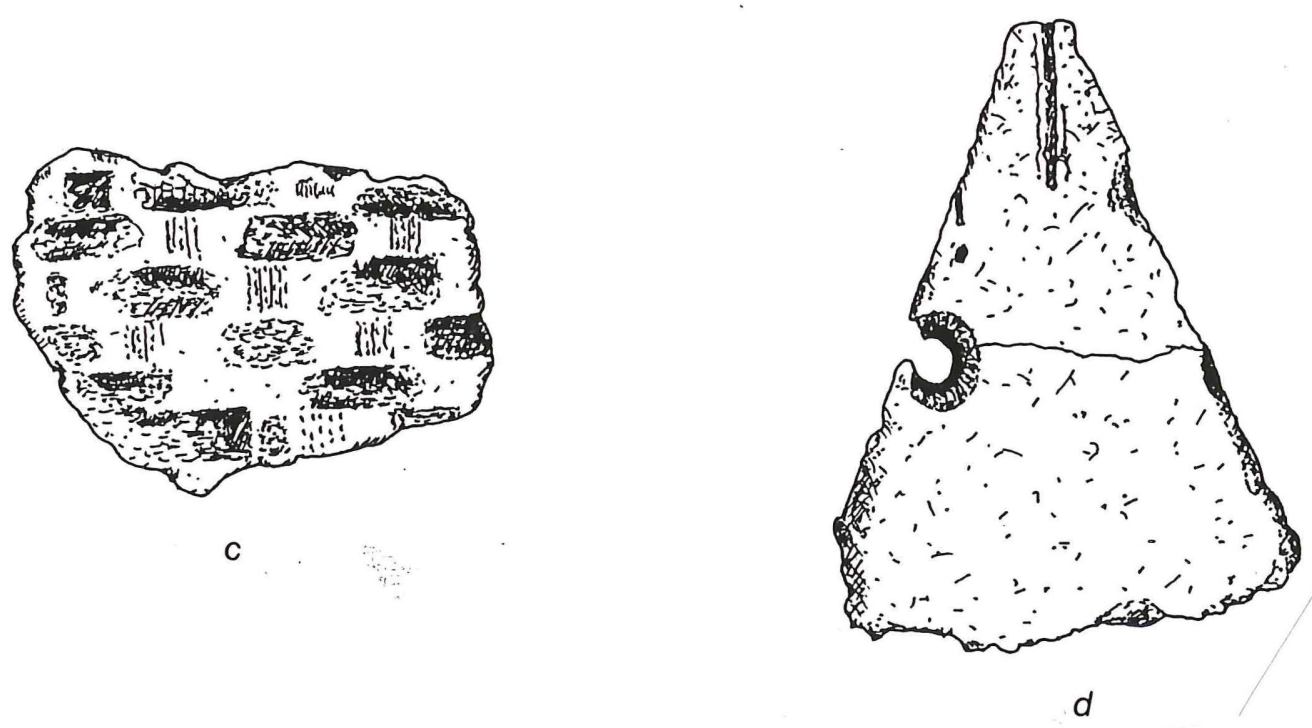

Figure 9-31. Miscellaneous clay items: a, clay lump/coil; b, clay ball; c, basketry impression on fired clay; d, sherd with drilled hole. Provenience: a, 242-3A; b, 91-2; c, 50-3A; d, ST 4, North rise. 
The clay with basketry impressions has preserved a negative image of a split cane (Arundinaria gigantea) basket made either by twilling or coiling techniques (see Brown 1976:1-13). These types of baskets probably had flat, square bases and a bowl shape. Occasionally, ceramic vessels were likely made within the cane baskets, and as a result, basket impressions were preserved on selected sherds when they were fired. The Block A specimen exhibits four cane splints to the inch, and the Block B/C specimen exhibits five cane splints to the inch (see Figure 9-31c). The plaiting exhibited on the latter specimen consists of each weft passing over one warp, then under a warp, producing a simple pattern common in Native American baskets made in the Southeastern U.S. (e.g., Brown 1976:2). The specimen from Block $\mathrm{A}$ is too small to determine the plaiting.

One decorated body sherd from the North rise has a drilled hole (see Figure 9-31d). The hole may have been for repair of this particular vessel, since it was placed below the rim (apparent from the remnant of an incised decoration above the hole), rather than from use as a "spindle whorl." The latter sherds usually consist of one to several large drilled holes placed in the thick base of a broken pottery vessel.

The last item is a clay ball that was found in an Early Caddoan period context in Unit 91 (Block E) between $10-20 \mathrm{~cm}$ bs. The clay ball is about $20 \mathrm{~mm}$ in diameter and slightly flattened on one side (see Figure 9-31b), Root and grass impressions are visible, and the ball has been fired in an oxidizing environment to a bright orange color. The use of this particular clay artifact is problematic, but it is unlikely that it functioned as a heating material, as was the case in certain parts of the lower Mississippi valley during prehistoric times (e.g., Webb 1982). It is much smaller than clay balls in Poverty Point assemblages. 


\title{
CHAPTER 10, COMIPOSITIONAL ANALYSIS OF CADDOAN CERAMICS FROM NORTHEAST TEXAS
}

\author{
Hector Neff, James W. Cogswell, and Michael D. Glascock
}

\section{Introduction}

Caddoan ceramics from the Hurricane Hill site (41HP106), Hopkins County, Texas, and the Mockingbird site (41TT550) in Titus County, Texas, have been analyzed by neutron activation analysis (NAA) at the University of Missouri Research Reactor Center (MURR). The sample consists of 40 sherds from Hurricane Hill, submitted by Timothy K. Perttula, along with 10 specimens from the Mockingbird site (41TT550), which were submitted by Elizabeth Skokan, then with Espey, Huston \& Associates, Inc. (see Neff et al. 1998; Skokan and Perttula 1998). These chemical compositional data are placed within a broader Caddoan context by comparison with analytical data from previously reported Caddoan ceramics (Steponaitis et al. 1996).

\section{Background}

The Hurricane Hill site is a multi-component prehistoric site located along the South Sulphur river in Hopkins County, Northeast Texas. Excavations during 1986-1987 yielded a large quantity of Caddoan ceramics and other occupational debris from two distinct Caddoan contexts, one (Block A, North rise) dated to between ca. A.D. 1000-1200 (Early Caddoan period), and the other (Block B/C, South rise) dated to between ca. A.D. 1250-1375 (Middle Caddoan period). The main questions motivating the NAA study of the ceramic assemblage are: (1) are there shifts in clay source usage over time (from the Early to Middle Caddoan period?; and (2) are source-related compositional groups associated non-randomly with specific forms or ceramic decorative elements from either of the components that can be attributed to local vs. nonlocal manufacturing sources (see Chapter 9 , this volume)?

The Mockingbird site (41TT550) is a Titus phase Caddo cemetery site at the headwaters of Hayes Creek in the Big Cypress Creek drainage basin, about $50 \mathrm{~km}$ east of Hurricane Hill. The cemetery was used between about A.D. 1430-1600 (Perttula and Nelson 1998). The 10 sampled ceramics were associated with eight separate burials in the cemetery. Incorporating these analyses into the Hurricane Hill study broadens the study's geographic and chronological coverage. ${ }^{1}$

The geographic perspective of this study is broadened further by incorporating data from 22 Caddoan specimens analyzed as part of a study of large-scale patterns in the chemical composition of Mississippian pottery (Steponaitis et al. 1996). Ten ceramic specimens come from the Great Bend region, about $100 \mathrm{~km}$ northeast of Hurricane Hill, along the Red River in extreme southwestern Arkansas. Three specimens are from the Natchitoches region, about $300 \mathrm{~km}$ southeast of Hurricane Hill, along the Red River in western Louisiana. Another nine ceramic specimens are from the Spiro region, about $230 \mathrm{~km}$ north of Hurricane Hill, along the Arkansas River in eastern Oklahoma.

The Great Bend and Natchitoches specimens all manifest a generalized western chemical compositional profile associated with the smectite and illite clays of the Western Gulf clay-mineral province (Steponaitis et al. 1996:Figure 4). Three of the Spiro specimens also conform to the western compositional profile, but the remaining six ungrouped sherds are inferred to represent local production within the Arkansas River valley, which is within the Ouachita-Ozark clay-mineral province. Incorporating these analyses into the present study helps generate a more comprehensive picture of ceramic compositional variation within the Caddoan area, and provides a basis for evaluating the probability that non-local sources are represented among the analyzed ceramics from the Hurricane Hill site. 


\section{Sample Preparation}

Ceramic specimens were prepared for NAA using standard MURR procedures. Sherd surfaces and all adhering soil were first removed with a silicon carbide burr. Burred samples were then washed with deionized water and allowed to dry in air. Finally, the cleaned sherds were crushed in an agate mortar to yield a fine powder. Part of each specimen was retained, unpowdered, for the MURR archive of analyzed ceramic fabrics.

The powder samples were oven-dried at 100 degrees $C$ for 24 hours. Portions of approximately 200 mg were weighed and placed in small polyvials used for short irradiations. At the same time, another 200 $\mathrm{mg}$ of each sample were weighed into high-purity quartz vials used for long irradiations. Along with the unknown samples, reference standards of SRM-1633a (coal fly ash) and SRM-688 (basalt rock) were similarly prepared, as were quality control samples (i.e., standards treated as unknowns) of SRM-278 (obsidian rock).

\section{Irradiation and Gamma-Ray Spectroscopy}

Neutron activation analysis of ceramics at MURR, which consists of two irradiations and a total of three gamma counts, constitutes a superset of the procedures used at most other laboratories (Glascock 1992; Neff 1992). As discussed in detail by Glascock (1992), a short irradiation is carried out through the pneumatic tube irradiation system.

Samples in the polyvials are sequentially irradiated, two at a time, for five seconds at a neutron flux of $8 \times 10^{13} \mathrm{n} / \mathrm{cm}^{2} / \mathrm{s}$. The 720 -second count yields gamma spectra containing peaks for the following short-lived elements: Aluminum (Al), Barium (Ba), Calcium (Ca), Dysprosium (Dy), Potassium (K), Manganese (Mn), Sodium (Na), Titanium (Ti), and Vanadium (V). The samples in quartz vials are subjected to a 24-hour irradiation at a neutron flux of $5 \times 10^{13} \mathrm{n} / \mathrm{cm}^{2} / \mathrm{s}$. This long irradiation is analogous to the single irradiation utilized at most other laboratories. After the long irradiation, samples decay for seven days, then are counted for 2,000 seconds (the "middle count") on a high-resolution germanium detector coupled to an automatic sample changer. The middle count yields determinations of seven medium half-life elements, namely Arsenic (As), Lanthanum (La), Lutetium (Lu), Neodymium (Nd), Samarium (Sm), Uranium (U), and Ytterbium (Yb). After an additional three- or four-week decay, a final count of 10,000 seconds is carried out on each sample. The latter measurement yields the following 17 long half-life elements: Cerium (Ce), Cobalt (Co), Chromium (Cr), Cesium (Cs), Europium (Eu), Iron (Fe), Hafnium (Hf), Nickel (Ni), Rubidium (Rb), Antimony (Sb), Scandium (Sc), Strontium (Sr), Tantalum (Ta), Terbium (Tb), Thorium (Th), Zinc (Zn), and Zirconium (Zr).

Elemental concentration data from the two irradiations and three counts (a total of 33 elements) are assembled into a single tabulation and stored in a dBASE III file. This is linked to descriptive information available for each sample (see Appendix III).

The Caddoan ceramic analyses reported previously (Steponaitis et al. 1996) were analyzed for medium- and long-lived isotopes at the National Bureau of Standards (now the National Institute of Standards and Technology, or NIST) through a collaborative program with the Smithsonian Institution's Conservation Analytical Laboratory (CAL); analytical conditions are reported elsewhere (Steponaitis et al. 1996). The NIST data were calibrated with the MURR data using conversion factors obtained from multiple analyses of a homogeneous check standard (Ohio Red Clay) analyzed in both laboratories. Data for the short-lived isotopes of $\mathrm{Al}, \mathrm{Ba}, \mathrm{Ca}, \mathrm{Dy}, \mathrm{K}, \mathrm{Mn}, \mathrm{Na}, \mathrm{Ti}$, and $\mathrm{V}$ for these specimens were obtained more recently at MURR, using the analytical procedures outlined above.

\section{Quantitative Analysis of the Chemical Data}

The analyses at MURR described above produced elemental concentration values for 33 elements. The elements $\mathrm{Nd}, \mathrm{Ni}$, and $\mathrm{Zr}$ were not determined in the 22 specimens analyzed at NIST, and so were eliminated from consideration. $\mathrm{Ca}$ and $\mathrm{Sr}$ were also eliminated from consideration because some of the specimens from Hurricane Hill were shell-tempered, and shell dramatically enriches both $\mathrm{Ca}$ and $\mathrm{Sr}$ concentrations, making them unreliable for source analysis. Sr determinations have large analytical errors in NAA anyway, which limits their usefulness even for the non-shell tempered specimens. Several of the 
shell-tempered specimens analyzed at NIST had calcium concentrations in excess of 10 percent, a concentration that implies sufficient calcium carbonate from shell temper to dilute substantially the concentrations of other elements. This shell temper-related dilution was counteracted using a correction introduced by Blackman (Steponaitis et al. 1996; see also Cogswell et al. 1998b).

The remaining analytical data for 28 elements were transformed to log base 10 values. This transformation compensates for the differences in magnitude between major elements, such as $\mathrm{Al}$ and $\mathrm{Fe}$, on one hand and trace elements, such as the rare earth or lanthanide elements, on the other hand. In addition, for highly skewed data, such as many of the trace elements, log-transformation yields a more nearly normal distribution.

The goal of quantitative analysis of the chemical data is to recognize compositionally homogeneous groups within the analytical database. Based on the "provenance postulate" (Weigand et al. 1977), such groups are assumed to represent geographically restricted sources or source zones. The location of sources or source zones may be inferred by comparing the unknown groups to knowns (i.e., source raw materials); by indirect means such as the "criterion of abundance" (Bishop et al. 1982); or by arguments based on geological and sedimentological characteristics (e.g., Steponaitis et al. 1996).

Hypotheses about source-related subgroups in the compositional data can be derived from noncompositional information (e.g., the archaeological context, decorative attributes, etc.), or from application of pattern-recognition techniques to the chemical data. In the present study, most of the analyses are from a single site (Hurricane Hill), so hierarchical cluster analysis and principal components analysis (PCA) are used to recognize the initial groups. One seldom-exploited strength of PCA, discussed recently by Baxter (1992) and Neff (1994), is that it can be applied as a simultaneous R-and Q-mode technique, with both variables (elements) and objects (individual analyzed samples) displayed on the same set of principal component reference axes. When attention is directed to the first two principal components, the twodimensional plot of element coordinates is the best possible two-dimensional representation of the correlation or variance-covariance structure in the data. Likewise, the plot of object coordinates is the best two-dimensional representation of Euclidean relations among the objects in log-concentration space (if the PCA was based on the variance-covariance matrix), or standardized log-concentration space (if the PCA was based on the correlation matrix). Displaying objects and variables on the same plots makes it possible to observe the contributions of specific elements to group separation, and to observe the distinctive shapes of the various groups. These variable interrelationships can then be observed directly through bivariate elemental concentrations plots.

Hypothetical groups suggested by pattern-recognition (cluster analysis, PCA, and inspection of bivariate plots) can be evaluated further and refined with multivariate statistics based on Mahalanobis distance (Bieber et al. 1976; Bishop and Neff 1989; Harbottle 1976; Sayre 1975). Mahalanobis distance (or generalized distance) is expressed as:

$$
\mathrm{D}^{2} \mathrm{y}, \mathrm{x}=[\mathrm{y}-\mathrm{X}] \mathrm{t}_{\mathrm{x}}[\mathrm{y}-\mathrm{X}]
$$

where $\mathrm{y}$ is $1 \mathrm{x} \mathrm{m}$ array of logged elemental concentrations for the individual point of interest, $\mathrm{X}$ is the $\mathrm{n} \mathrm{X}$ $m$ data matrix of logged concentrations for the group to which the point is being compared with $X$ being its $1 \times \mathrm{m}$ centroid, and $\mathrm{I}_{X}$ is the inverse of the $\mathrm{m} \times \mathrm{m}$ variance-covariance matrix of group $\mathrm{X}$. Because

Mahalanobis distance takes into account variances and covariances in the multivariate group, it is analogous to expressing distance from a univariate mean in standard deviation units. Like standard deviation units, Mahalanobis distances can be converted into probabilities of group membership for each individual specimen (e.g., Bieber et al. 1976; Bishop and Neff 1989; Harbottle 1976). For relatively small sample sizes, it is appropriate to base probabilities on Hotelling's $\mathrm{T}^{2}$, which is a multivariate extension of the univariate Student's t.

As is common in provenance research, even the largest group in the present study has fewer specimens than variables. To effect a reduction in dimensionality, we use the first eight principal components, which subsume over 86 percent of the variance in the data (Table 10-1), to calculate Mahalanobis distances from the group centroids. We consider this approach to dimensionality reduction preferable to eliminating a large number of elements from consideration. Even with the reduction in 
dimensionality, specimen-to-variate ratios remain small, and this causes Mahalanobis distance-based probabilities of group membership to fluctuate dramatically depending upon whether or not each specimen is assumed to be a member of the group to which it is being compared. Harbottle (1976) calls this phenomenon "stretchability." Cross-validation or "jackknifing," in which each specimen is removed from a group before calculating its probability of membership, helps counteract such inflated probabilities for small groups (Baxter 1994; Leese and Main 1994), and is used in all the comparisons discussed below.

Table 10-1. Principal Components Analysis of correlation matrix of Caddo area data set $(n=72)$

\begin{tabular}{rrrr} 
Component & Eigenvalue & \%Variance & $\begin{array}{r}\text { Cumulative } \\
\text { \%Variance }\end{array}$ \\
\cline { 2 - 3 } 2 & 11.423 & 40.796 & 40.796 \\
3 & 4.928 & 17.602 & 58.397 \\
4 & 2.123 & 7.583 & 65.980 \\
5 & 1.913 & 6.830 & 72.810 \\
6 & 1.574 & 5.621 & 78.431 \\
7 & 0.926 & 3.306 & 81.736 \\
8 & 0.811 & 2.898 & 84.634 \\
9 & 0.635 & 2.267 & 86.901 \\
10 & 0.612 & 2.186 & 89.087 \\
11 & 0.465 & 1.661 & 90.748 \\
12 & 0.449 & 1.605 & 92.353 \\
13 & 0.411 & 1.468 & 93.820 \\
14 & 0.293 & 1.048 & 94.867 \\
15 & 0.226 & 0.806 & 95.674 \\
16 & 0.217 & 0.776 & 96.450 \\
17 & 0.170 & 0.607 & 97.057 \\
18 & 0.149 & 0.532 & 97.588 \\
19 & 0.134 & 0.477 & 98.066 \\
20 & 0.111 & 0.398 & 98.464 \\
21 & 0.102 & 0.363 & 98.827 \\
22 & 0.083 & 0.298 & 99.125 \\
23 & 0.067 & 0.241 & 99.365 \\
24 & 0.059 & 0.211 & 99.576 \\
25 & 0.037 & 0.133 & 99.709 \\
26 & 0.029 & 0.102 & 99.811 \\
27 & 0.024 & 0.087 & 99.897 \\
28 & 0.015 & 0.054 & 99.951 \\
& 0.014 & 0.049 & 100.000
\end{tabular}

\section{Results}

Appendix III contains descriptive and compositional data for the 40 Caddoan specimens analyzed from the Hurricane Hill site. Table 10-1 summarizes the PCA of the correlation matrix of the data set, which consists of the 50 Northeast Texas specimens (Hurricane Hill and Mockingbird) plus the 22 specimens from neighboring regions reported previously (Steponaitis et al. 1996). Table 10-2 lists the analyzed Northeast Texas specimens and their compositional affiliations, and Table 10-3 gives similar information for the previously-reported analyses. PCA biplots of principal components 1 and 2 (Figure 101), and principal components 1 and 3 (Figure 10-2) illustrate the basic inter-object similarities together with the structure of inter-element correlations in the data set. Specific compositional differences among the subgroups also may be inferred from this plot, as discussed below. 
Table 10-2. Hurricane Hill and Titus County analyses.

\begin{tabular}{|c|c|c|c|c|c|c|}
\hline \multirow[t]{8}{*}{$\begin{array}{l}\text { Compositional } \\
\text { Group }\end{array}$} & $\frac{\text { Anld }}{\text { TKP001 }}$ & $\frac{\text { Lot }}{1577}$ & $\begin{array}{l}\text { Reglon } \\
\text { Hopkins Cty, } \\
\text { Texas }\end{array}$ & $\begin{array}{l}\text { Slte } \\
\text { Hurricane } \\
\text { Hill }\end{array}$ & $\frac{\text { Prov }}{\text { Block A }}$ & $\begin{array}{l}\text { Description } \\
\text { Cross-hatched incised }\end{array}$ \\
\hline & TKP003 & 435 & $\begin{array}{l}\text { Hopkins Cty, } \\
\text { Texas }\end{array}$ & $\begin{array}{l}\text { Hurricane } \\
\text { Hill }\end{array}$ & Block A & Diagonalilncised \\
\hline & TKP004 & 4167 & $\begin{array}{l}\text { Hopkins Cty, } \\
\text { Texas }\end{array}$ & $\begin{array}{l}\text { Hurricane } \\
\text { Hill }\end{array}$ & Block A & Curvilinear incised \\
\hline & TKP006 & 5601 & $\begin{array}{l}\text { Hopkins Cty, } \\
\text { Texas }\end{array}$ & $\begin{array}{l}\text { Hurricane } \\
\text { Hill }\end{array}$ & Block A & Punctated rim \\
\hline & TKP007 & 446 & $\begin{array}{l}\text { Hopkins Cty, } \\
\text { Texas }\end{array}$ & $\begin{array}{l}\text { Hurricane } \\
\text { Hill }\end{array}$ & Block A & Diagonal incised \\
\hline & TKP010 & 229 & $\begin{array}{l}\text { Hopkins Cty, } \\
\text { Texas }\end{array}$ & $\begin{array}{l}\text { Hurricane } \\
\text { Hill }\end{array}$ & Block A & Sanders Engraved \\
\hline & TKP014 & 461 & $\begin{array}{l}\text { Hopkins Cty, } \\
\text { Texas }\end{array}$ & $\begin{array}{l}\text { Hurricane } \\
\text { Hill }\end{array}$ & Block A & $\begin{array}{l}\text { Diagonal incised-zoned } \\
\text { punctated }\end{array}$ \\
\hline & TKP016 & 532 & $\begin{array}{l}\text { Hopkins Cty, } \\
\text { Texas }\end{array}$ & $\begin{array}{l}\text { Hurricane } \\
\text { Hill }\end{array}$ & Block A & Brushed \\
\hline \multirow[t]{13}{*}{ Hurricane-1 } & TKP016 & 586 & $\begin{array}{l}\text { Hopkins Cty, } \\
\text { Texas }\end{array}$ & $\begin{array}{l}\text { Hurricane } \\
\text { Hill }\end{array}$ & Block A & Punctated \\
\hline & TKP020 & 5459 & $\begin{array}{l}\text { Hopkins Cty, } \\
\text { Texas }\end{array}$ & $\begin{array}{l}\text { Hurricane } \\
\text { Hill }\end{array}$ & Block A & Engraved \\
\hline & TKP022 & 2699 & $\begin{array}{l}\text { Hopkins Cty, } \\
\text { Texas }\end{array}$ & $\begin{array}{l}\text { Hurricicane } \\
\text { Hill }\end{array}$ & Block B/C & Punctated, thick-walled \\
\hline & TKP023 & 2950 & $\begin{array}{l}\text { Hopkins Cty, } \\
\text { Texas }\end{array}$ & $\begin{array}{l}\text { Hurricane } \\
\text { Hill }\end{array}$ & Block B/C & Brushed \\
\hline & TKP026 & 4130 & $\begin{array}{l}\text { Hopkins Cty, } \\
\text { Texas }\end{array}$ & $\begin{array}{l}\text { Hurricane } \\
\text { Hill }\end{array}$ & Block B/C & Fingernail punctated \\
\hline & TKP027 & 4717 & $\begin{array}{l}\text { Hopkins Cty, } \\
\text { Texas }\end{array}$ & $\begin{array}{l}\text { Hurricane } \\
\text { Hill }\end{array}$ & Block B/C & $\begin{array}{l}\text { Thick-walled } \\
\text { incised-punctated }\end{array}$ \\
\hline & TKP030 & 871 & $\begin{array}{l}\text { Hopkins Cty, } \\
\text { Texas }\end{array}$ & $\begin{array}{l}\text { Hurricane } \\
\text { Hill }\end{array}$ & Block B/C & Diagonal engraved \\
\hline & TKP032 & 3349 & $\begin{array}{l}\text { Hopkins Cty, } \\
\text { Texas }\end{array}$ & $\begin{array}{l}\text { Hurricane } \\
\text { Hill }\end{array}$ & Block B/C & Cross-hatched incised \\
\hline & TKP034 & 4541 & $\begin{array}{l}\text { Hopkins Cty, } \\
\text { Texas }\end{array}$ & $\begin{array}{l}\text { Hurricane } \\
\text { Hill }\end{array}$ & Block B/C & Diagonal incised \\
\hline & TKP036 & 2049 & $\begin{array}{l}\text { Hopkins Cty, } \\
\text { Texas }\end{array}$ & $\begin{array}{l}\text { Hurricane } \\
\text { Hill }\end{array}$ & Block B/C & Diagonal incised \\
\hline & TKP038 & 3937 & $\begin{array}{l}\text { Hopkins Cty, } \\
\text { Texas }\end{array}$ & $\begin{array}{l}\text { Hurricane } \\
\text { Hill }\end{array}$ & Block B/C & Plain rim \\
\hline & TKP039 & 1948 & $\begin{array}{l}\text { Hopkins Cty, } \\
\text { Texas }\end{array}$ & $\begin{array}{l}\text { Hurricane } \\
\text { Hill }\end{array}$ & Block B/O & Plain rim \\
\hline & TKP002 & 528 & $\begin{array}{l}\text { Hopkins Cty, } \\
\text { Texas }\end{array}$ & $\begin{array}{l}\text { Hurricane } \\
\text { Hill }\end{array}$ & Block A & Cunvilinear incised \\
\hline \multirow[t]{10}{*}{ Hurricane-2 } & TKP012 & 494 & $\begin{array}{l}\text { Hopkins Cty, } \\
\text { Texas }\end{array}$ & $\begin{array}{l}\text { Hurricane } \\
\text { Hill }\end{array}$ & Block A & $\begin{array}{l}\text { Curvilinear } \\
\text { incised-punctated }\end{array}$ \\
\hline & TKP013 & 5673 & $\begin{array}{l}\text { Hopkins Cty, } \\
\text { Texas }\end{array}$ & $\begin{array}{l}\text { Hurricane } \\
\text { Hill }\end{array}$ & Block A & Horizontal incised \\
\hline & TKP019 & 548 & $\begin{array}{l}\text { Hopkins Cty, } \\
\text { Texas }\end{array}$ & $\begin{array}{l}\text { Hurricane } \\
\text { Hill }\end{array}$ & Block A & $\begin{array}{l}\text { Horizontal incised with } \\
\text { impressed triangles }\end{array}$ \\
\hline & TKP021 & 1638 & $\begin{array}{l}\text { Hopkins Cty, } \\
\text { Texas }\end{array}$ & $\begin{array}{l}\text { Hurricane } \\
\text { Hill }\end{array}$ & Block B/C & Plain rim, thickened \\
\hline & TKP024 & 3137 & $\begin{array}{l}\text { Hopkins Cty, } \\
\text { Texas }\end{array}$ & $\begin{array}{l}\text { Hurricane } \\
\text { Hill }\end{array}$ & Block B/C & Maxey Noded Redware \\
\hline & TKP025 & 2392 & $\begin{array}{l}\text { Hopkins Cty, } \\
\text { Texas }\end{array}$ & $\begin{array}{l}\text { Hurricane } \\
\text { Hill }\end{array}$ & Block B/C & Cane-punctated rim \\
\hline & TKP028 & 846 & $\begin{array}{l}\text { Hopkins Cty, } \\
\text { Texas }\end{array}$ & $\begin{array}{l}\text { Hurricane } \\
\text { Hill }\end{array}$ & Block B/C & Zoned incised-punctated \\
\hline & TKP031 & 3441 & $\begin{array}{l}\text { Hopkins Cty, } \\
\text { Texas }\end{array}$ & $\begin{array}{l}\text { Hurricane } \\
\text { Hill }\end{array}$ & Block B/C & Diagonal engraved \\
\hline & TKP033 & 3955 & $\begin{array}{l}\text { Hopkins Cty, } \\
\text { Texas }\end{array}$ & $\begin{array}{l}\text { Hurricane } \\
\text { Hill }\end{array}$ & Block B/C & Diagonal incised rim \\
\hline & TKP035 & 4541 & $\begin{array}{l}\text { Hopkins Cty, } \\
\text { Texas }\end{array}$ & $\begin{array}{l}\text { Hurricane } \\
\text { Hill }\end{array}$ & Block B/C & Diagonal incised \\
\hline
\end{tabular}

\begin{tabular}{|c|c|c|c|c|}
\hline \multirow{2}{*}{$\begin{array}{l}\text { Primary } \\
\text { Temper } \\
\text { clay }\end{array}$} & \multirow{2}{*}{$\begin{array}{l}\text { Secondary } \\
\text { Temper }\end{array}$} & \multirow{2}{*}{$\begin{array}{l}\text { Trace } \\
\text { Temper }\end{array}$} & \multicolumn{2}{|c|}{$\begin{array}{l}\text { Ref. Group Probabilities" } \\
\text { Hurricane-1 Hurricane-2 }\end{array}$} \\
\hline & & & 33.352 & 2.153 \\
\hline sandy clay & & & 43.248 & 3.173 \\
\hline clay & & & 41.554 & 3.364 \\
\hline clay & & limonite & 8.458 & 2.556 \\
\hline clay & limonite & sand & 79.744 & 0.975 \\
\hline clay & sand & & 55.084 & 1.361 \\
\hline clay & bone & & 61.035 & 1.604 \\
\hline shell & & & 1.976 & 0.389 \\
\hline clay & bone & & 21.593 & 1.644 \\
\hline clay & & & 26.300 & 1.740 \\
\hline sandy clay & & & 99.403 & 1.996 \\
\hline clay & & & 47.735 & 1.907 \\
\hline clay & bone & & 24.071 & 0.922 \\
\hline clay & & & 58.093 & 1.908 \\
\hline clay & & & 32.459 & 2.880 \\
\hline clay & & & 45.535 & 2.181 \\
\hline clay & & limonite & 69.985 & 3.387 \\
\hline clay & & & 65.607 & 2.007 \\
\hline clay & bone & & 70.114 & 0.533 \\
\hline clay & sand & bone & 96.031 & 1.619 \\
\hline clay & limonite & sand & 0.627 & 49.213 \\
\hline clay & & & 0.349 & 68.526 \\
\hline clay & limonite & bone & 0.247 & 57.980 \\
\hline clay & sand & bone & 0.422 & 44.393 \\
\hline sand & & & 0.480 & 46.101 \\
\hline clay & & bone? & 5.318 & 17.251 \\
\hline clay & bone & & 0.009 & 96.548 \\
\hline clay & & & 0.007 & 82.492 \\
\hline clay & bone & limonite & 0.152 & 24.937 \\
\hline clay & sand & bone? & 0.008 & 50.618 \\
\hline clay & bone & & 0.021 & 39.877 \\
\hline
\end{tabular}


Table 10-2. Hurricane Hill and Titus County analyses, cont.

\begin{tabular}{|c|c|c|c|c|c|c|c|c|c|c|c|}
\hline \multirow[t]{3}{*}{$\begin{array}{l}\text { Compositional } \\
\text { Group }\end{array}$} & $\frac{\text { Anld }}{\text { TKP011 }}$ & $\frac{\text { Lot }}{138}$ & $\begin{array}{l}\frac{\text { Reglon }}{\text { Hopkins Cty, }} \\
\text { Texas }\end{array}$ & $\begin{array}{l}\text { Site } \\
\text { Hurricane } \\
\text { Hill }\end{array}$ & $\frac{\text { Prov }}{\text { Block A }}$ & $\begin{array}{l}\text { Descriptlon } \\
\text { Cross-hatched incised }\end{array}$ & $\begin{array}{l}\text { Primary } \\
\text { Temper } \\
\text { clay }\end{array}$ & $\begin{array}{l}\text { Secondary } \\
\text { Temper } \\
\text { sand }\end{array}$ & $\begin{array}{l}\text { Trace } \\
\text { Temper }\end{array}$ & \multicolumn{2}{|c|}{$\begin{array}{l}\text { Ref. Group Probabillites" } \\
\begin{array}{cc}\text { Hurricane-1 } & \text { Hurricane-2 } \\
0.041 & 2.550\end{array}\end{array}$} \\
\hline & TKP017 & 103 & $\begin{array}{l}\text { Hopkins Cty, } \\
\text { Texas }\end{array}$ & $\begin{array}{l}\text { Hurricane } \\
\text { Hill }\end{array}$ & Block A & Fine-line incised-punctated & clay & bone & sand & 5.934 & 12.246 \\
\hline & TKP018 & 4852 & $\begin{array}{l}\text { Hopkins Cty, } \\
\text { Texas }\end{array}$ & $\begin{array}{l}\text { Hurricane } \\
\text { Hill }\end{array}$ & Block A & Small punctated & fine sand & clay & & 1.266 & 2.048 \\
\hline \multirow[t]{4}{*}{ Unassigned } & TKP029 & 2699 & $\begin{array}{l}\text { Hopkins Cty, } \\
\text { Texas }\end{array}$ & $\begin{array}{l}\text { Hurricane } \\
\text { Hill }\end{array}$ & Block B/C & Engraved ladder & clay & & & 0.009 & 2.738 \\
\hline & TKP037 & 3044 & $\begin{array}{l}\text { Hopkins Cty, } \\
\text { Texas }\end{array}$ & $\begin{array}{l}\text { Hurricane } \\
\text { Hill }\end{array}$ & Block B/C & Plain rim & & clay & & 0.002 & 13.781 \\
\hline & TKP040 & 377 & $\begin{array}{l}\text { Hopkins Cty, } \\
\text { Texas }\end{array}$ & $\begin{array}{l}\text { Hurricane } \\
\text { Hill }\end{array}$ & Block B/C & Plain rim & clay & bone & & 0.000 & 1.377 \\
\hline & TKP005 & 626 & $\begin{array}{l}\text { Hopkins Cty, } \\
\text { Texas }\end{array}$ & $\begin{array}{l}\text { Hurricane } \\
\text { Hill }\end{array}$ & Block A & Punctated & clay & & sand & 0.069 & 0.978 \\
\hline \multirow[t]{5}{*}{ Unassigned } & TKP008 & 3783 & $\begin{array}{l}\text { Hopkins Cty, } \\
\text { Texas }\end{array}$ & $\begin{array}{l}\text { Hurricane } \\
\text { Hill }\end{array}$ & Block A & Curvilinear engraved & clay & & sand & 0.002 & 7.387 \\
\hline & TKP009 & 4603 & $\begin{array}{l}\text { Hopkins Cty, } \\
\text { Texas }\end{array}$ & $\begin{array}{l}\text { Hurricane } \\
\text { Hill }\end{array}$ & Block A & Red-slipped & clay & sand & bone & 0.075 & 1.003 \\
\hline & F10V11 & & $\begin{array}{l}\text { Titus Cty., } \\
\text { Texas }\end{array}$ & $41 T \pi 550$ & Feat. 10 & & sand & & & 0.022 & 0.846 \\
\hline & F10V12 & & $\begin{array}{l}\text { Titus Cty.. } \\
\text { Texas }\end{array}$ & $41 T T 550$ & Feat. 10 & & sand & clay & bone? & 0.003 & 2.564 \\
\hline & F1V4 & & $\begin{array}{l}\text { Titus Cty., } \\
\text { Texas }\end{array}$ & $41 \pi T 550$ & Feat. 1 & & sand & & & 0.009 & 0.395 \\
\hline \multirow[t]{7}{*}{ Titus } & F3V3 & & $\begin{array}{l}\text { Titus Cty., } \\
\text { Texas }\end{array}$ & $41 T T 550$ & Feat. 3 & & sand & clay & & 0.117 & 0.558 \\
\hline & $\mathrm{F} 4 \mathrm{~V} 3$ & & $\begin{array}{l}\text { Titus Cty.. } \\
\text { Texas }\end{array}$ & $41 T T 550$ & Feat. 4 & & clay & & sand & 1.593 & 2.143 \\
\hline & F5V1 & & $\begin{array}{l}\text { Titus Cty., } \\
\text { Texas }\end{array}$ & $41 T T 550$ & Feat. 5 & & clay & bone & & 0.013 & 0.753 \\
\hline & $\mathrm{F} 6 \mathrm{~V} 2$ & & $\begin{array}{l}\text { Titus Cty., } \\
\text { Texas }\end{array}$ & $41 \pi 550$ & Feat. 6 & & clay & & & 0.006 & 6.370 \\
\hline & F 712 & & $\begin{array}{l}\text { Titus Cty.. } \\
\text { Texas }\end{array}$ & $41 T \pi 550$ & Feat. 7 & & clay & sand & bone & 0.002 & 0.419 \\
\hline & F9V1 & & $\begin{array}{l}\text { Titus Cty., } \\
\text { Texas }\end{array}$ & $41 T T 550$ & Feat. 9 & & clay & sand & bone & 0.006 & 3.480 \\
\hline & F9V11 & & $\begin{array}{l}\text { Titus Cty., } \\
\text { Texas }\end{array}$ & $41 T T 550$ & Feat. 9 & & sand & clay & bone & 0.001 & 0.396 \\
\hline
\end{tabular}


Table 10-3. Other compositional analyses from the Caddo area

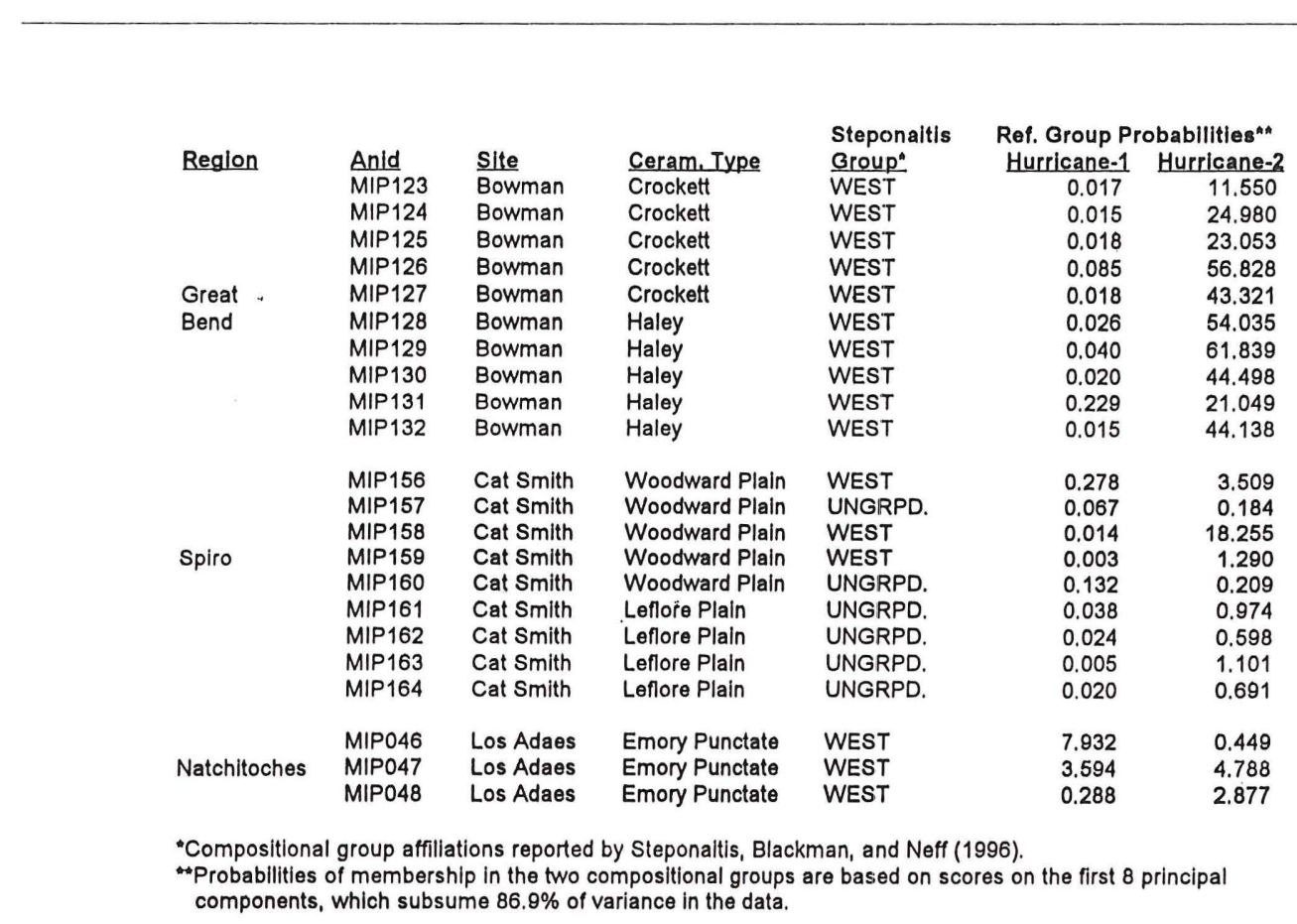

\section{Compositional Groups}

The Northeast Texas ceramic specimens fall into three distinct groups. Ceramic specimens from the Hurricane Hill site partition into two separate compositional groups, Hurricane-1 and Hurricane-2 (nine specimens from the site remain ungrouped, as shown in Table 10-2). The 10 ceramic specimens from the Mockingbird site comprise a third compositional group, which is designated the Titus group. A fourth compositional group shown in Figures 10-1 and 10-2 includes all 10 NAA analyses from the Great Bend region. The labels "Northeast Texas" and "Red River" on Figures 10-1 and 10-2 indicate the inferred production zones for the four groups; the bases for these inferences are discussed in greater detail in the following section.

Mahalanobis distances of individual specimens in the data set to the centroids of the two largest groups (Hurricane-1 and Hurricane-2) were calculated using scores on the first eight principal components of the total data sets (see Tables 10-2 and 10-3). Posterior classifications for the two reference groups are 100 percent correct (see Table 10-2). And, with one exception, all of the Titus County ceramic specimens fall outside a 5 percent probability cutoff for membership in both reference groups. "Unassigned" status indicates either that the Mahalanobis distance calculations and inspection of PCA and elemental concentration plots identified the specimen as marginal to all groups, or that assignment to one of the groups would have blurred the group's distinctiveness from other groups. Comparison of analyses from elsewhere in the Caddoan area to the Hurricane Hill reference groups (see Table 10-3) suggests some clear patterns of resemblance, which can be exploited for inferring provenance (see below). 


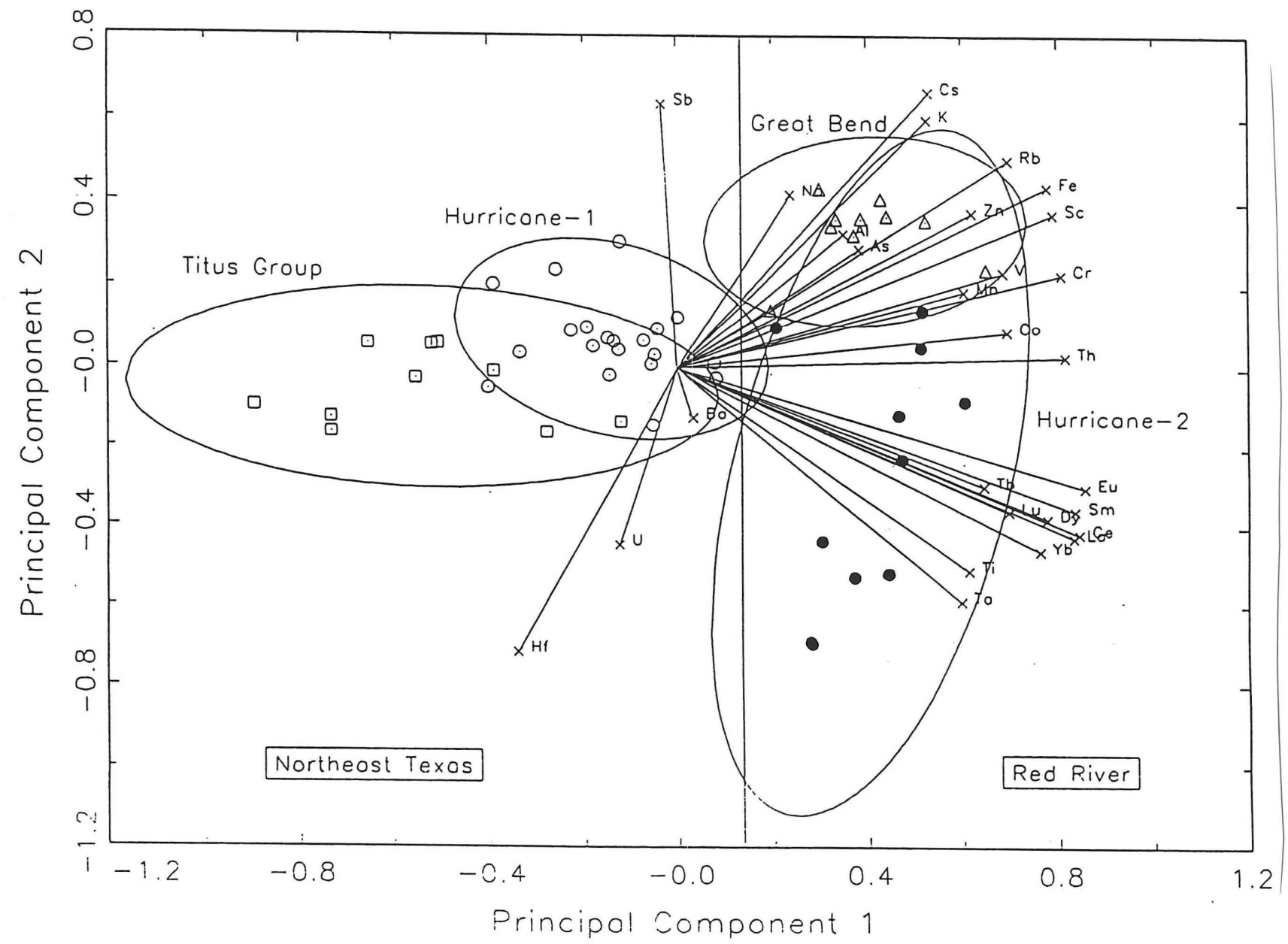

Figure 10-1. PCA biplot of principal components 1 and 2 of the Northeast Texas data set. Ellipses represent 90 percent confidence level for membership in the four reference groups. Vectors connect the origin with the coordinates of each element.

\section{Compositional Groups}

The Northeast Texas ceramic specimens fall into three distinct groups. Ceramic specimens from the Hurricane Hill site partition into two separate compositional groups, Hurricane-1 and Hurricane-2 (nine specimens from the site remain ungrouped, as shown in Table 10-2). The 10 ceramic specimens from the Mockingbird site comprise a third compositional group, which is designated the Titus group. A fourth compositional group shown in Figures 10-1 and 10-2 includes all 10 NAA analyses from the Great Bend region. The labels "Northeast Texas" and "Red River" on Figures 10-1 and 10-2 indicate the inferred production zones for the four groups; the bases for these inferences are discussed in greater detail in the following section.

Mahalanobis distances of individual specimens in the data set to the centroids of the two largest groups (Hurricane-1 and Hurricane-2) were calculated using scores on the first eight principal components of the total data sets (see Tables 10-2 and 10-3). Posterior classifications for the two reference groups are 100 percent correct (see Table 10-2). And, with one exception, all of the Titus County ceramic specimens fall outside a 5 percent probability cutoff for membership in both reference groups. "Unassigned" status indicates either that the Mahalanobis distance calculations and inspection of PCA and elemental concentration plots identified the specimen as marginal to all groups, or that assignment to one of the groups would have blurred the group's distinctiveness from other groups. Comparison of analyses from 
elsewhere in the Caddoan area to the Hurricane Hill reference groups (see Table 10-3) suggests some clear patterns of resemblance, which can be exploited for inferring provenance (see below).

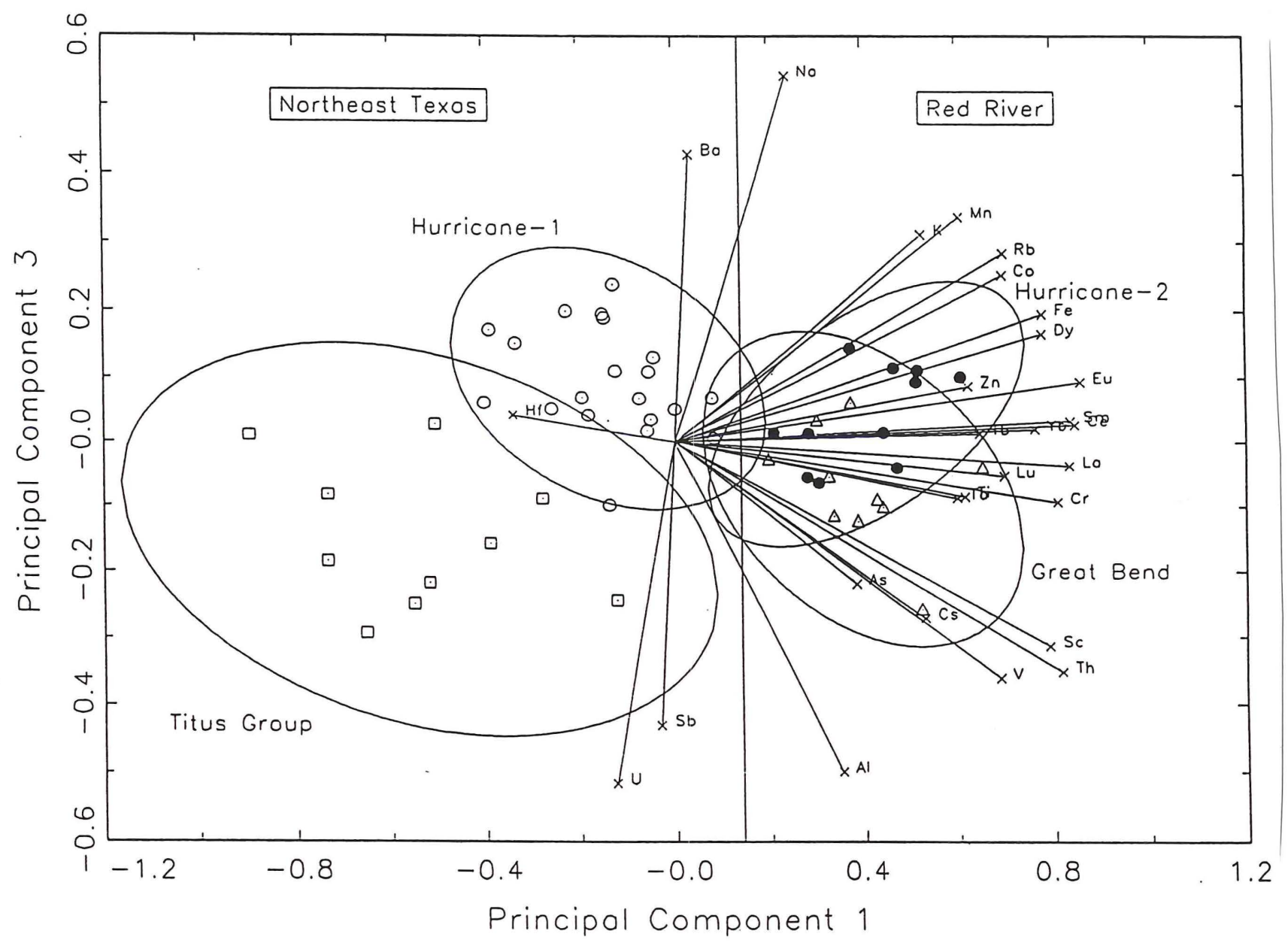

Figure 10-2. PCA biplot of principal components 1 and 3 of the Northeast Texas data set. Ellipses represent 90 percent confidence level for membership in the four reference groups. Vectors connect the origin with the coordinates of each element.

The compositional basis of the group separation shown in Figures 10-1 and 10-2 can be inferred from the variable configurations. Most obviously, the Red River groups (Hurricane-2 group and Great Bend) tend to be enriched in a large number of elements compared to the Northeast Texas groups (Hurricane-1 and Titus). A bivariate plot of Lanthanum ( $\mathrm{La}$ ) and Chromium (Cr) (Figure 10-3) clearly depicts the enrichment-dilution relationship, and separates the Red River from the Northeast Texas groups even more effectively than the PCA plot.

Figures 10-1 and 10-2 also indicate the compositional basis of group separation within the Red River and Northeast Texas regions. Differentiation of Great Bend and Hurricane- 2 groups along component 2 (see Figure 10-1) is due to higher Antimony ( $\mathrm{Sb}$ ) in the Red River group combined with higher Tantalum (Ta) in the Hurricane-2 group, and this is confirmed by a bivariate plot of these two elements (Figure 10-4). Similarly, Figure 10-2 indicates that enriched Sodium (Na) and Rubidium (Rb) in the Hurricane-1 group serves to differentiate it from the Titus County group, and this is confirmed by a bivariate plot (Figure 105). 


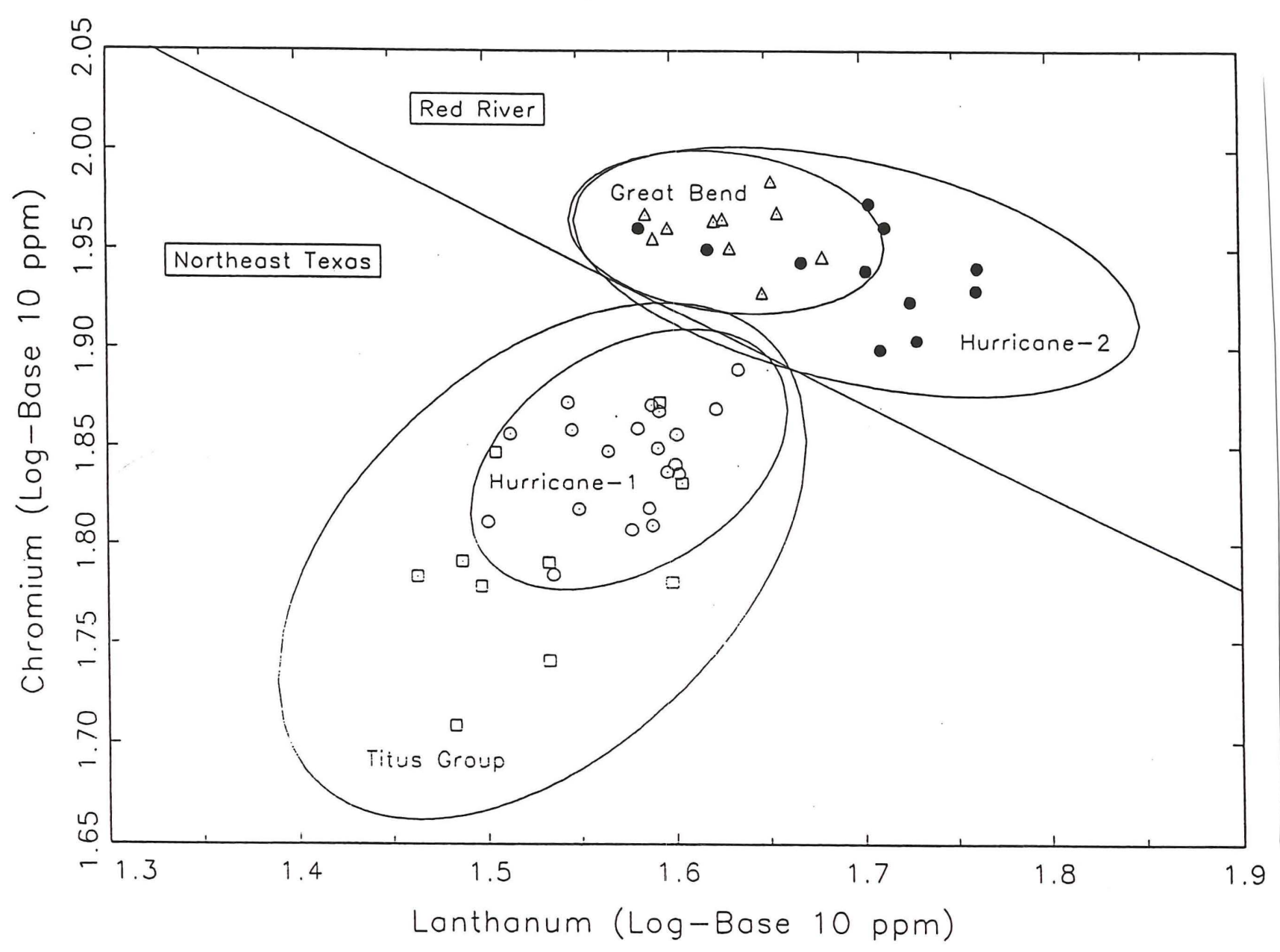

Figure 10-3. Plot of logged elemental concentrations of lanthanum and chromium in the four reference groups. Ellipses represent 90 percent confidence level for membership in the four reference groups.

\section{Production Zones}

Because raw materials have not yet been sampled, inferences of production zones for the compositional groups described above have to be indirect. Three of the groups, Hurricane-1, Titus County, and Great Bend, can be linked provisionally to production zones based on the criterion of abundance:

Hurricane-1 includes more than half of the assignable ceramic specimens from the Hurricane Hill site; the Titus group includes all of the analyzed ceramic sherds from the Mockingbird site; and the Great Bend group includes all of the analyzed specimens from the Bowman site in the Great Bend region. At a broader geographic scale, the 30 analyzed ceramics in the Hurricane-1 and Titus groups all manifest a relatively diluted composition (see Figure 10-3), which, based on its dominance in the two sampled assemblages from Northeast Texas, would seem to characterize the area lying just at the edge of the Mississippi River drainage basin, south and west of the Great Bend of the Red River. 


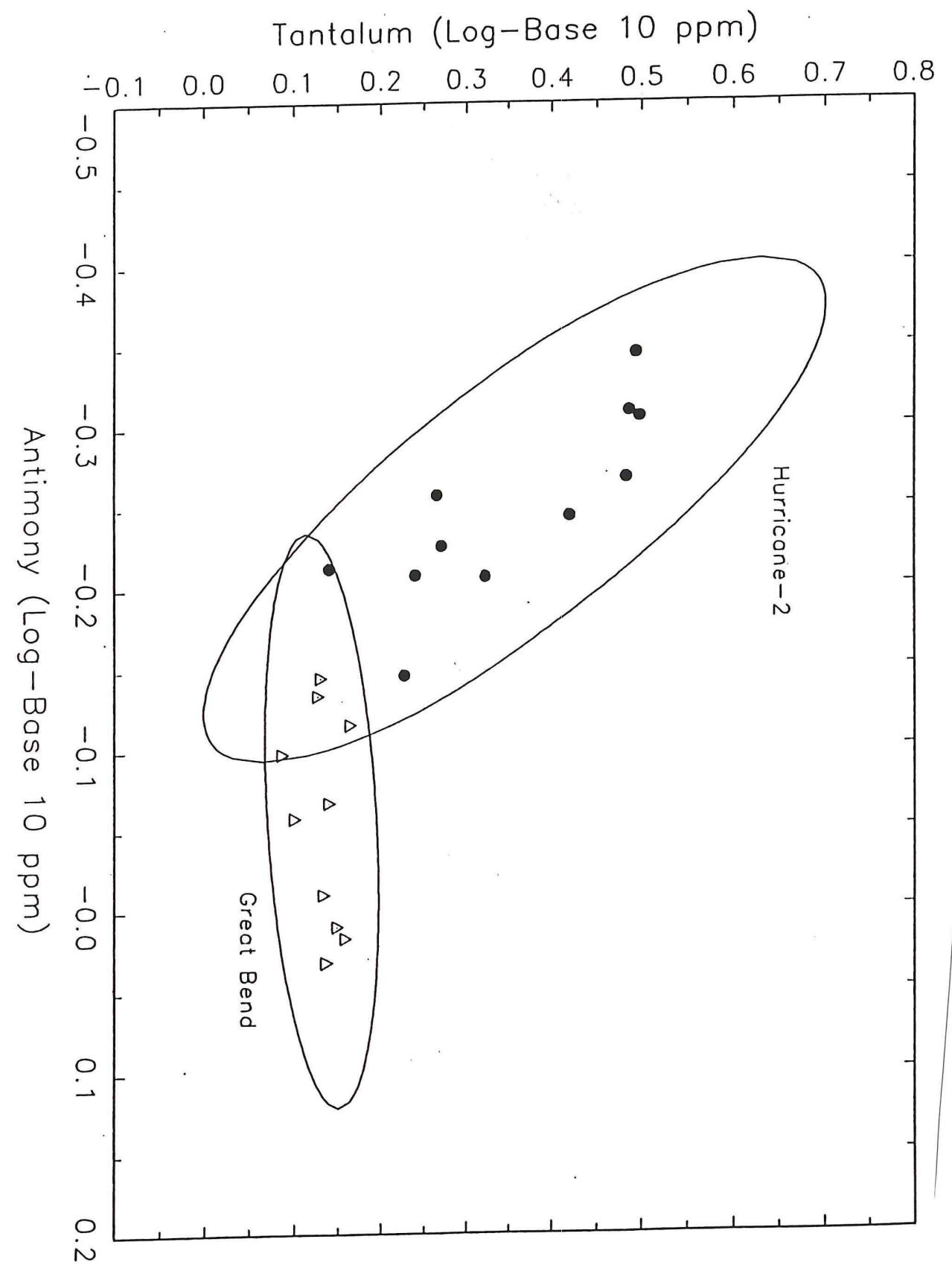

Figure 10-4. Plot of logged elemental concentrations of antimony and tantalum in the Great Bend and Hurricane-2 reference groups. Ellipses represent 90 percent confidence level for membership in the groups. 


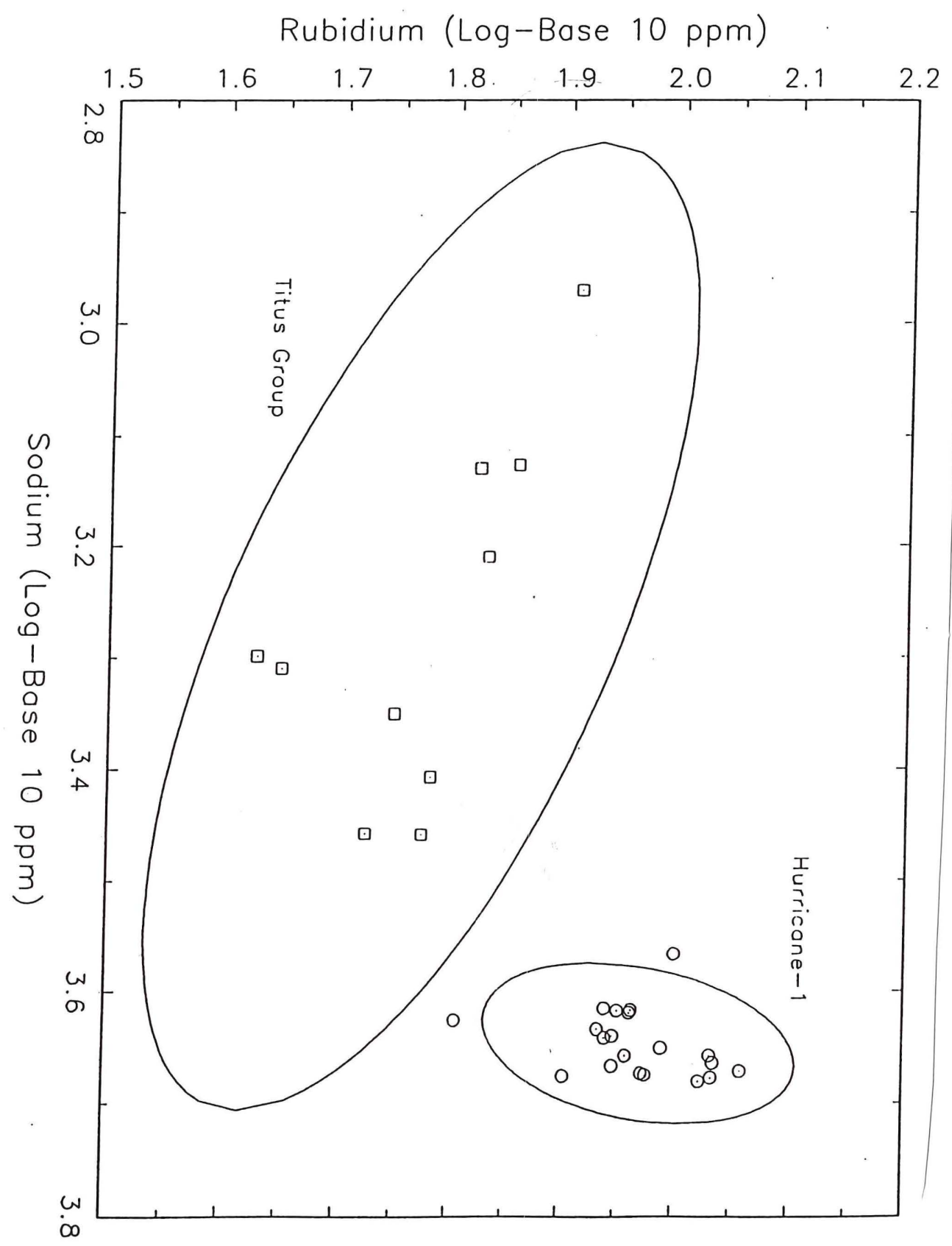

Figure 10-5. Plot of logged elemental concentrations of sodium and reubidium in the Titus and Hurricane-1 reference groups. Ellipses represent 90 percent confidence level for membership in the groups. 
Provenance of the Hurricane-2 group can be inferred from the similarity of its compositional profile to that of pottery from sites along the Red and Arkansas rivers. Mahalanobis distance-based probabilities shown in Table 10-3 indicate that all 10 Great Bend specimens exceed the 10 Percent p-value for membership in the Hurricane-2 group. That is, the Bowman site analyses (Great Bend region) seem to represent a subset of the compositions subsumed by the Hurricane- 2 group. In accord with this view, Figure 10-1, Figure 10-2, and Figure 10-3 all depict the Great Bend group as contained within the range of variation of the Hurricane-2 group, at the "enriched" extreme of compositional variation in the analyzed sample. Therefore, since the dominant compositions in the Northeast Texas assemblages show a relatively diluted composition, whereas the dominant compositions along the Red River (judging from the Bowman site) are relatively enriched, we hypothesize that enriched compositions in general (including Hurricane-2) pertain to the lower Mississippi River basin, of which the Red River drainage forms the western limit.

As discussed by Steponaitis et al. (1996), the western portion of the lower Mississippi River basin is characterized by a distinctive, high-smectite clay mineral assemblage, and pottery derived from this region shows sufficient compositional similarity to be subsumed within a single regional group (the Western group). The Great Bend analyses are all within this group, as are the three Natchitoches region ceramic specimens, and three of nine specimens from the Spiro region (see Table 10-3). The fact that all but one of these Western group members exceed a 1 percent cutoff level for membership in the Hurricane- 2 group (see Table 10-3) provides a further link between the Hurricane-2 group and the high-smectite clays of the western Mississippi basin.

The three Natchitoches specimens require special comment, because both their Mahalanobis distance-related probabilities (see Table 10-3) and the various views of the data presented here (Figures 10-6 to 10-8), suggest dual affiliation with both the Hurricane-1 group (Northeast Texas) and the Hurricane-2 (Red River/Western Gulf clay provinces) compositional profiles. Natchitoches is about $120 \mathrm{~km}$ downstream from the Red and Sulphur rivers confluence in the Great Bend of the Red River. The Sulphur River drains part of Northeast Texas, and forms the very edge of the Mississippi River basin, so it is not surprising that sediments downstream from its confluence with the Red River would show some resemblance to Northeast Texas clays. Interestingly, while the Red River as a whole is a high-smectite drainage, Louisiana portions below the Great Bend are lower in smectite, and there is a pocket of high-kaolinite sediments in the immediate Natchitoches area (Potter et al. 1975:Figures 6 and 8). The Natchitoches ceramic analyses thus form something of a bridge between the diluted, western (Northeast Texas) and the enriched, eastern (lower Mississippi basin) compositional profiles represented in this study by the Hurricane-1 and Hurricane-2 groups, respectively.

Six specimens from the Spiro region are not included in the generalized Western group of Steponaitis et al. (1996), and these also require some comment. It was suggested in the earlier study by Steponaitis et al. (1996) that these ceramic specimens pertain to the Ouachita-Ozark clay-mineral province, which lies to the north and west of the Western Gulf province. Although affiliation with the Hurricane-1 group is not sustained by Mahalanobis distances calculated on the first eight principal components (see Table 10-3), these specimens tend to fall within the ranges of variation of the Northeast Texas groups, Hurricane-1 and Titus (see Figures 10-6 to 10-8). While it is remotely possible that these similarities indicate a common origin for Hurricane-1, Titus, and Spiro pottery (perhaps along the Arkansas River in eastern Oklahoma or, alternatively, in Northeast Texas), we suspect instead that it reflects broader patterns of similarity in clays across the two regions. The diluted compositions of the ungrouped Spiro, Titus, and Hurricane-1 ceramic specimens are more consistent with a highly weathered, kaolinite-rich clay-mineral assemblage rather than the smectite-illite-kaolinite association of the Western Gulf (represented in this study by the Hurricane-2 and Great Bend groups). Therefore, we tentatively suggest that the residual clays of Northeast Texas resemble the high-kaolinite residual clays of the Ouachita-Ozark clay-mineral province. Analysis of raw clays, additional analysis of pottery, and a more careful consideration of broad patterns of clay-mineral occurrence (along the lines presented by Steponaitis et al. [1996]) would help clarify these issues.

The nine specimens that were left unassigned in this study can be attributed provisionally to the Northeast Texas or Red River groups based on their position in principal component space (see Figures 10 6 and 10-7), or on the Lanthanum-Chromium plot (see Figure 10-8). The relatively diluted compositional profiles of sherds TKP005, TKP009, TKP011, TKP018, and TKP029 link them best with Northeast 
Texas, while the more enriched profiles of sherds TKP008, TKP017, TKP037, and TKP040 links them best with the Red River valley or other parts of the western lower Mississippi basin.

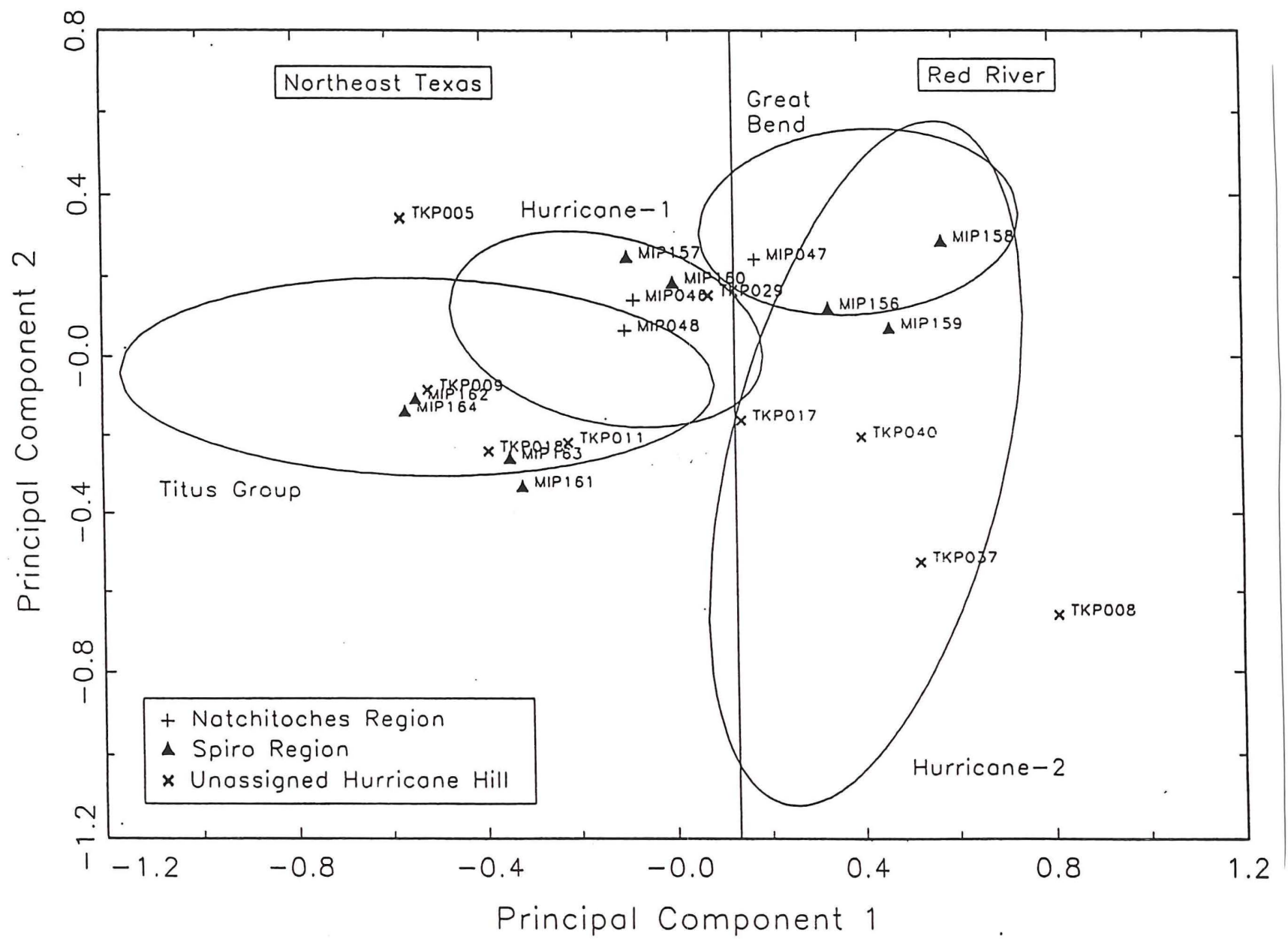

Figure 10-6. Principal components 1 and 2 of the Northeast Texas data set (same as Figure 10-1) showing the unassigned, Natchitoches, and Spiro region specimens plotted along with 90 percent ellipses for the four reference groups.

\section{Association of Chemical Composition with Other Attributes}

Table 10-2 contains some basic descriptive data on the ceramic samples from the Hurricane Hill and Mockingbird sites that might be expected to correlate with compositional groupings. The non-local Hurricane-2 group has more Middle Caddoan period ceramics (35 percent) than it does Early Caddoan period sherds (20 percent), but the overall pattern of association of compositional group (Hurricane-1 versus Hurricane-2) with chronological divisions is not statistically significant. Similarly, although certain decorative features seem to be confined to one group or the other, no strong patterns of association can be discerned. 


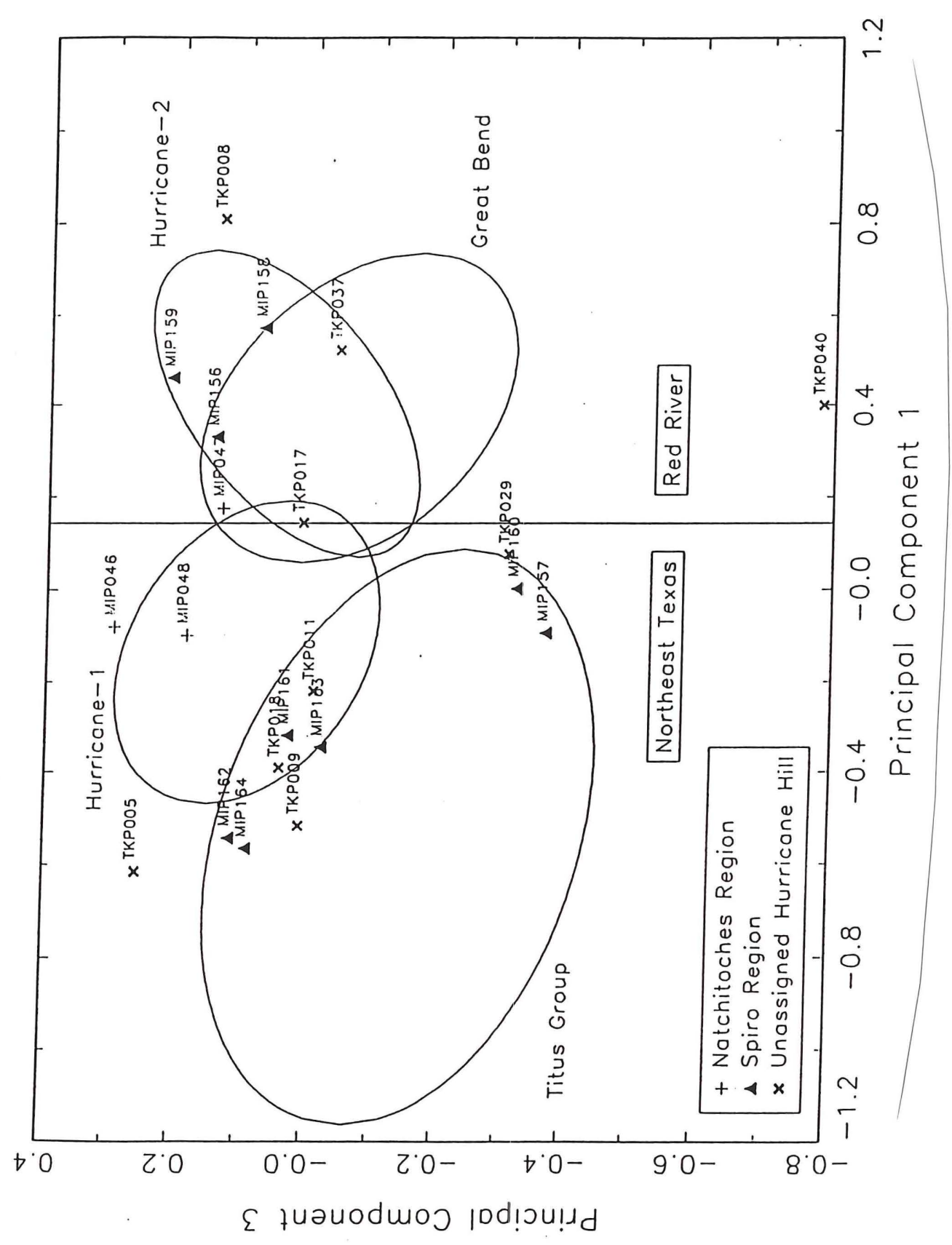

Figure 10-7. Principal components 1 and 3 of the Northeast Texas data set (same as Figure 10-2) showing the unassigned, Natchitoches, and Spiro region specimens plotted along with 90 percent ellipses for the four reference groups. 


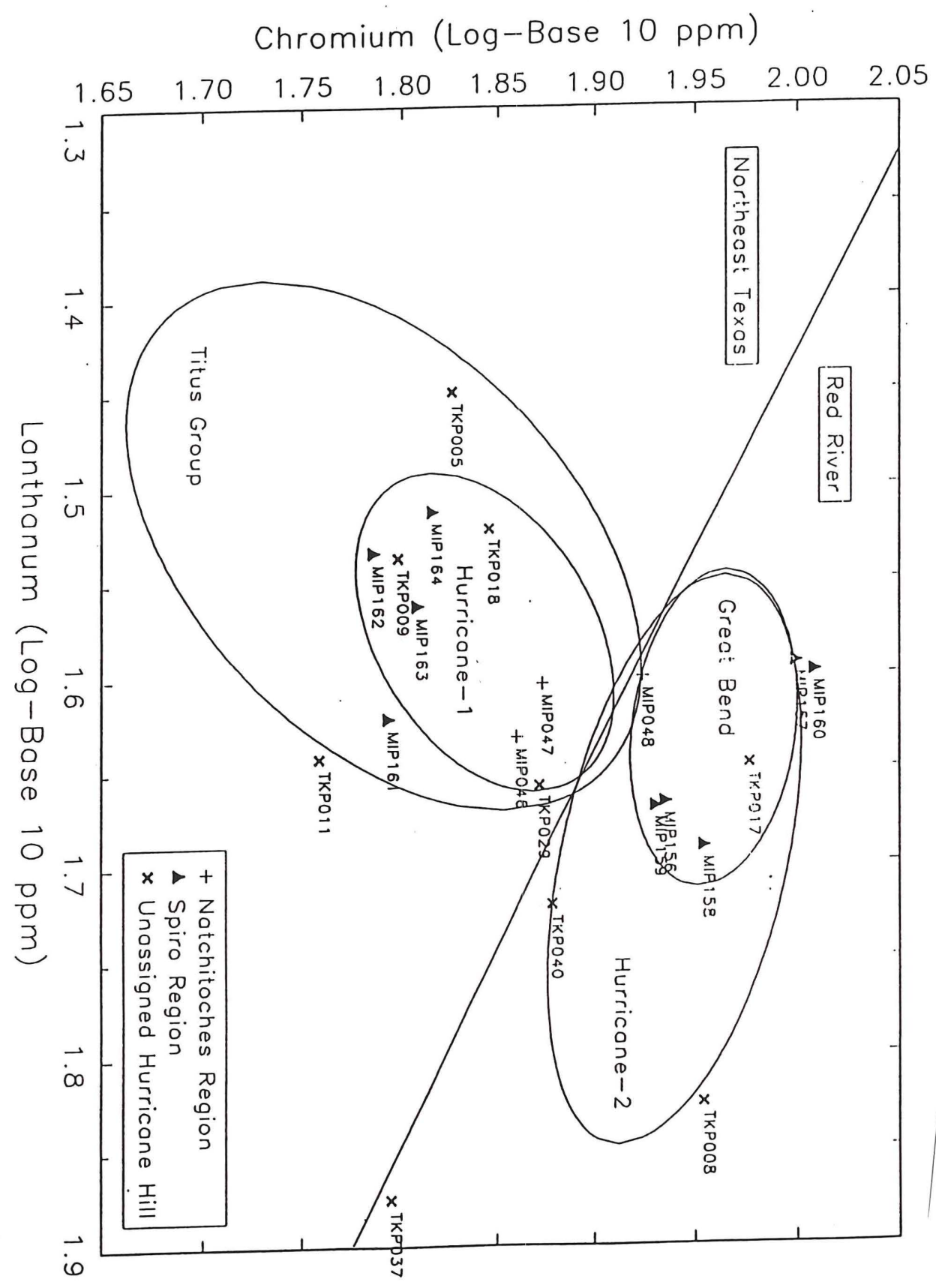

Figure 10-8. Bivariate plot of lanthanum and chromium concentrations (same as Figure 10-3) showing the unassigned, Natchitoches, and Spiro region specimens plotted along with 90 percent ellipses for the four reference groups. 
For the most part, the non-plastic characteristics observed under low-power microscopic examination by James Cogswell at MURR show little in the way of clear patterning (see Table 10-2). The mix of primary and secondary tempers in the three compositional groups reinforces the view that the groups represent distinct clay sources or source zones rather than the alternative interpretation that they represent differential paste preparation.

The Late Caddoan period cemetery assemblage from the Mockingbird site differs in several respects from the Early and Middle Caddoan period assemblages from Hurricane Hill (see Neff et al. 1998). First, the analyzed ceramics all appear to pertain to a single compositional group, and they are inferred to have been produced locally. Second, Titus group specimens more frequently have sand as the primary or secondary temper, and the sand tends to be dominated by clear quartz grains. The sandier texture of specimens in this group may help explain their extreme improverishment in many elements (see Figures 10-1, 10-2, 10-3, and 10-5), since quartz (relatively pure $\mathrm{SiO}_{2}$ ) dilutes the elements measured by NAA.

\section{Conclusions}

This study demonstrates that the Early and Middle Caddoan period ceramics from the Hurricane Hill site come from at least two distinct source zones, one of which is arguably non-local in origin. More specifically, we believe that ceramics in the Hurricane-2 group originate somewhere north or northeast of Hurricane Hill, perhaps along the Red River, while specimens in the Hurricane-1 group originate somewhere closer to the site (if not from the site itself). So far as we can determine, the imports do not differ from the local ceramics other than chemically: both the Early and Middle Caddoan period ceramic assemblages have both local and non-local ceramics, and there are no obvious decorative characteristics in the analyzed samples that consistently distinguish local from non-local wares.

As pointed out previously, additional analysis of ceramics and raw materials from Northeast Texas and other parts of the Caddoan area would clarify the compositional relationships discussed here. Two projects are currently underway from samples in and near the Caddoan area: Marvin Jeter (University of Arkansas) has recently submitted 85 sherds and 15 clays from southeastern Arkansas for analysis at MURR, and a number of sherds have been submitted from the Oak Hill Village site (41RK214) in Northeast Texas by Robert M. Rogers (Espey, Huston \& Associates, Inc.). These studies will improve our understanding of chemical variation within the Western Gulf clay-mineral province, which we believe is the source zone for the non-local ceramics at Hurricane Hill. Additional sampling in western Arkansas, eastern Oklahoma, and Northeast Texas should be encouraged as well.

\section{Ackmowledgments}

The research reported here was funded by grants from the National Science Foundation (DBS9102016). The authors are indebted to Cynthia Hays and Sergio Herrera for able assistance with sample preparation and various other analytical tasks.

\section{Editor's Footnote}

Preliminary INAA of ceramic sherds from the Oak Hill Village site (41RK214) by Neff (1998) led to the assignment of two previously unassigned sherds (TKP009 and TKP011) from Hurricane Hill to the Titus compositional group. Both the Titus and Hurricane-1 groups appear to "represent ceramic raw materials procured along the Sulphur River drainage...Hurricane-1 would seem to represent a more westerly (upstream) composition while Titus would seem to represent a more easterly (downstream) composition along the Sulphur River drainage" (Neff 1998:2). Final analyses of compositional affiliation determined that TKP009, a red-slipped and grog-bone tempered sherd, is assigned to the Titus chemical group, but TKP011, a cross-hatched incised sherd, is ungrouped (Cogswell et al. 1998a:Table 1). Also, the Hurricane-2 group is now part of the Red River group better defined from analyses of Early-Late Caddoan sherds from Red River County, Texas, including the Holdeman (41RR11), Roitsch (41RR16), and Salt Well Slough (41RR204) sites (Perttula et al. n.d.). 



\section{CHAPTER 11, BONE TOOLS FROM HURRICANE HILL}

Bonnie C. Yates

Bone as a medium for sharpness, pressure, puncture, and probe is superior to wood or stone in its versatility and ease of manufacture. A deer's ulna is a prime example. The thin, tapering shaft needs little shaping to form a functional tool, and the proximal end provides a handle replete with "finger notch" (Figure 11-1). As the shaft is broken from use, its form and function can be changed. An ulna tool with a flat blunted tip is usually the final tool form of a deer ulna. This form may have been used as a pressure flaker for lithic tools (Jelks 1961:33; Parmalee and Opperman 1983:68).

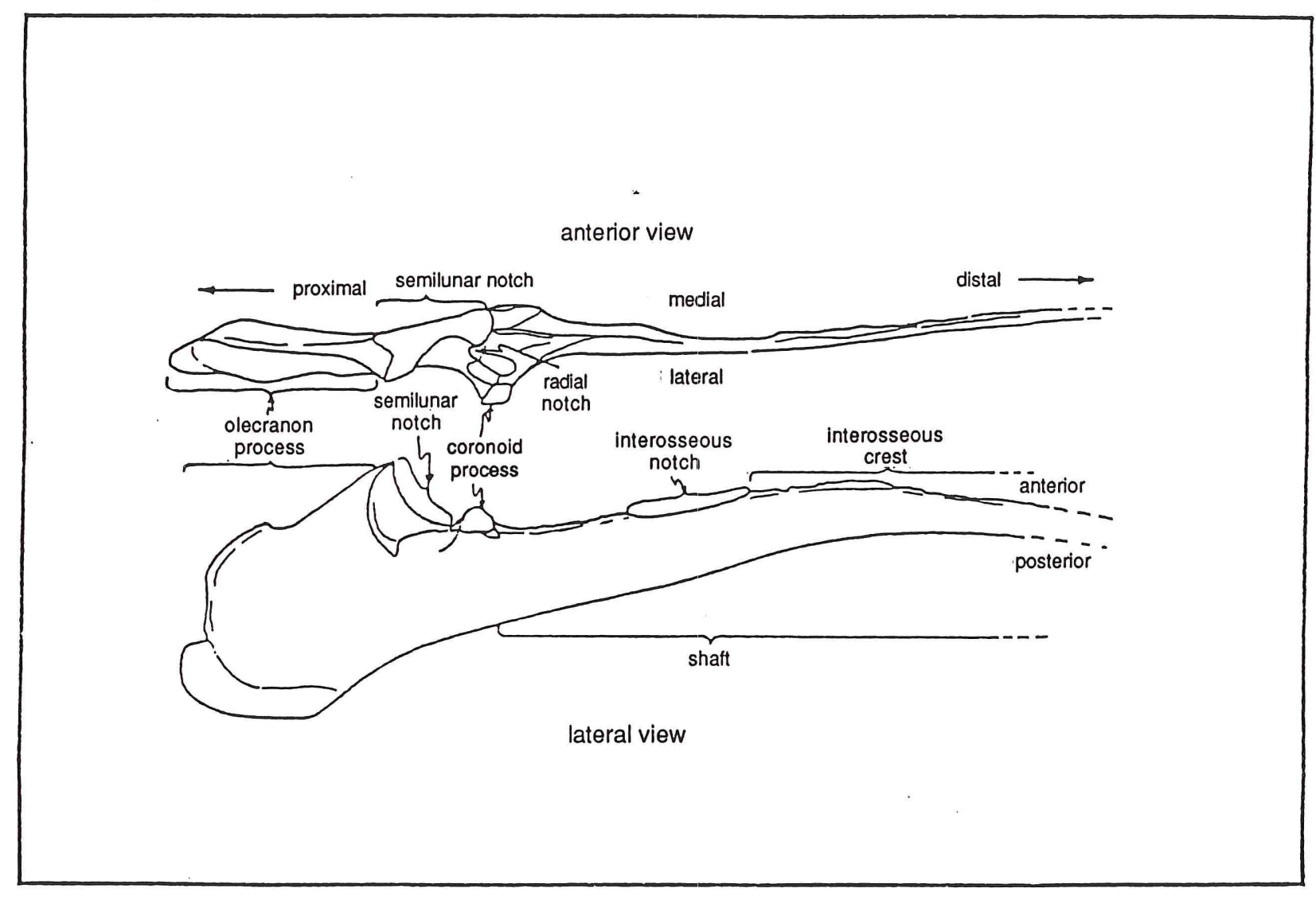

Figure 11-1. Landmarks on right deer ulna.

The worked proximal ulna from the Hurricane Hill site (Figure 11-2e) is enigmatic because it is apparently a preform instead of a tool remnant. The proximal end did not serve as a handle or base. The lower shaft of the element was removed by the ring-and-snap method for some other use. Evidence of shaft shaping in the form of random longitudinal striations appears just distal to the coronoid notch and continues down the shaft to the deep grooves that remain from an aborted ring cut, as well as the remnant of the successful groove. The recovered specimen is an adult deer's right ulna that had been discarded as manufacturing debris. If it ever served as a handle, it was used in an earlier modified form. No isolated 

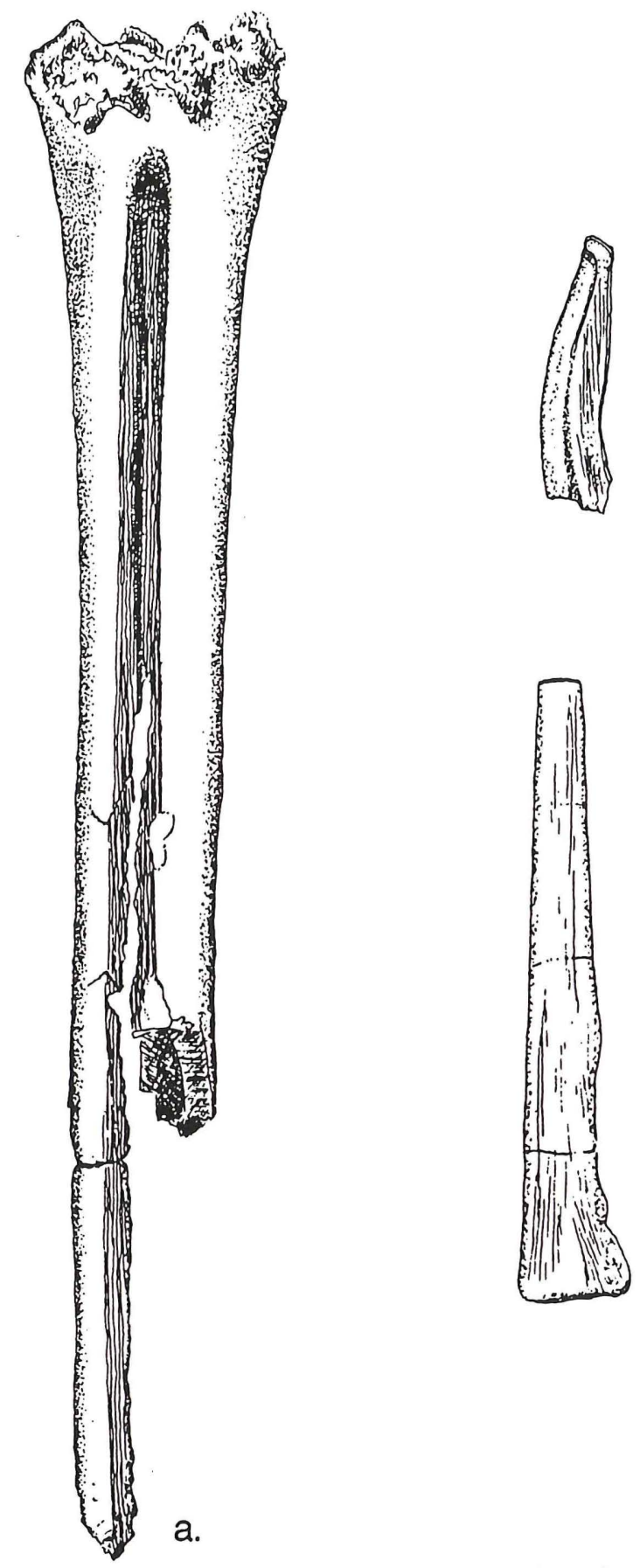

b.

C.
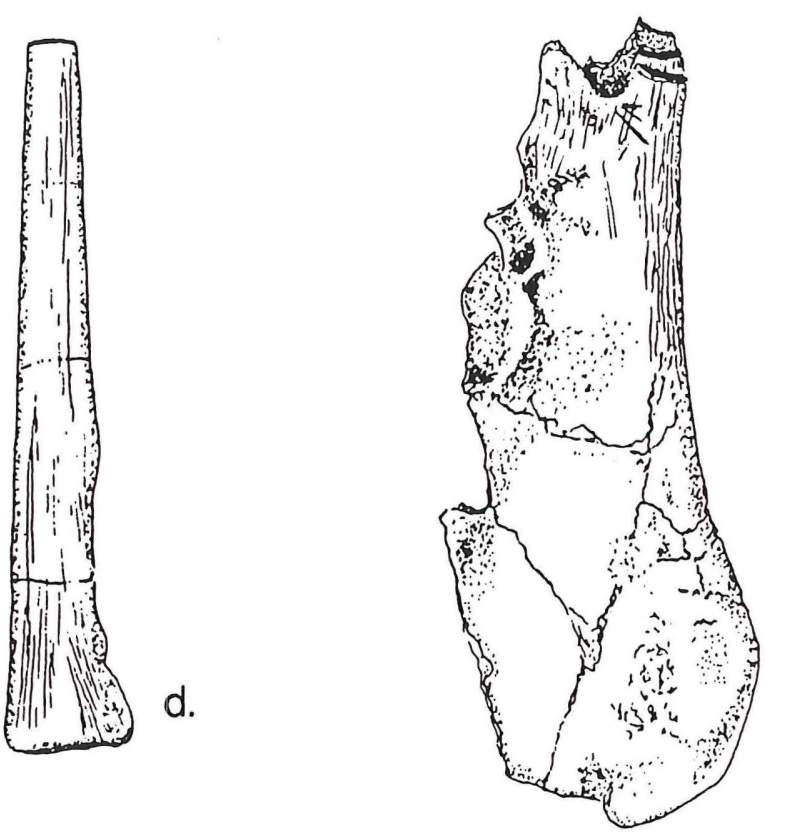

Figure 11-2. Bone tools from Hurricane Hill: a, deer metapodial blank/preform (Type A); b, worked beaver incisor (Type X); c, ring-and-snap platform (Type G); d, metapodial tool (Type X); e, deer ulna platform (Type G). 
fragment that could have been the missing, snapped-off working section was recognized in the bone tool assemblage from Hurricane Hill.

This assemblage of 59 specimens yielded only this one ulna tool. The majority are unclassifiable awls and other shapes of worked bone (Table 11-1). Deer metapodials, tibia, antler, and a beaver tooth are identified skeletal elements chosen for tool fabrication. However, almost 70 percent of the assemblage is made up of very small $(<2.5 \mathrm{~cm})$, burned fragments of shaped bone.

Table 11-1. Bone Artifacts from Hurricane Hill

$\begin{array}{lll}\text { Type* } & \text { Description } & \text { Total }\end{array}$

$\begin{array}{lll}\text { A } & \text { Preforms } & 1 \\ \text { G } & \text { Ring-and-snap preforms } & 6\end{array}$

B

D

E

F

$\mathrm{H}$

I

$\mathbf{J}$

$\mathrm{K}$

$\mathbf{L}$

$\mathbf{M}$

$\mathrm{N}$

O

$\mathbf{P}$

Q

R

S

$X$
$Y$
$Z$

Large Mammal Bone Awls

Split metapodial, distal end retained 0

Split metapodial, proximal end retained 2

Splinter awls $\quad 3$

Awl tips 0

Element unknown, basal fragment 0

Ulna, proximal end retained 0

Ulna shaft fragments 1

Spatulate tips 0

Unclassifiable awl fragments $\quad 8$

Ornaments/Special Function

Engraved/decoratedfragments 1

Bone tubes, "beads" 1

Fishing/Hunting Implements

Engraved shafts, points, both ends worked 0

Fishhook fragments 5

Fishhooks 3

Stone-Knapping/Hide-Working Tools (see also I-K)

Partially altered antler tine $\quad 6$

Completely altered antler tine $\quad 0$

Miscellaneous

Beaver jaw/incisor 1

Bird and small mammal bone 1

Unclassifiable worked bone fragments $\quad 20$

Total

* Adapted from Beach and Causey (1984) after Kidder(1932)

All modified bone was segregated when identified during attribute coding procedures of the faunal analysis. Butcher-marked bone was examined and returned to the provenience bag. Bones altered as tools were repackaged for separate analysis. The 59 specimens were then separated into categories based loosely on Kidder's (1932) scheme for bone artifacts from Pecos, New Mexico, and an adaptation of this scheme by 
Beach and Causey (1984) for Arroyo Hondo, New Mexico. Although this general scheme was formulated and used successfully for bone tool assemblages from Puebloan sites, its simplicity, based on function (assumed) and form (observed), makes it appropriate for the organization of bone artifacts from any site/cultural affiliation.

Function, although assumed in many cases, provides the first level of distinction because that is precisely what is interesting about the artifacts. Functional groupings used for this analysis are: (1) awls, (2) ornaments/special functions, (3) hunting/fishing implements, (4) stone-knapping/hide-working tools, and (5) miscellaneous. Alphabet letters are assigned to various types within each group; these types are based on anatomical element and manufactured form. Evidence of manufacture and use are identified as cuts, scratches, grooves, nicks, striations (striae), and polish. Old breaks, burning patterns, and dimensions of the tool remnants are each considered in the determination of function (Appendix XIII).

\section{Awls}

Awls are pointed objects used to perforate softer materials (meats, leather, fibers, clays) or to rub into or against other substances (i.e., wood, stone).

\section{Ornament/Special Fulnction}

Bone fragments of any shape can be decorated, but such special treatment is usually reserved for personal adornment (e.g., bodkins, hair pins, headdress decoration). Other types placed in this group are musical instruments (e.g., flutes and rasps), undecorated bone beads, and drilled teeth and bone which were also used for personal adornment (none of the latter types occurs in this sample).

\section{Hunting/Fishing Implements}

Double-pointed bone shafts, atlatl weights, and fishhooks are examples of this group. However, only fishhooks and fishhook fragments (Figure 11-3a-d, f-h) are present in this sample. Some "awl" fragments may actually be parts of composite fishhooks as described by Stewart (1977:33-45).

\section{Stone-Knapping/Hide-Working Tools}

Because of the interest in lithic technology and ethnographic accounts of bone used on stone, this group includes bone artifacts possibly used to reduce or resharpen stone tools. Some overlap probably occurs with ulna "awls" in that they can be reshaped into a rounded end suitable for use as pressure flakers. Antler can also be used as a pressure flaker or a billet. No hide-working tools, such as tibia fleshers, were recorded in the Hurricane Hill bone tools.

\section{Miscellaneous}

Bone artifacts made from species other than large mammals and unclassifiable worked bone constitute this group.

\section{Bone Artifact Descriptions}

Under the classification system presented in Table 11-1, two types (A and G) are tool preforms. A complete metatarsal from an immature deer (see Figure 11-2a) is the single example of what Beach and Causey (1984:197) and Harrell (1978) call a bone tool preform (Type A). The specimen has been deeply scored by a stone tool down the middle of the anterior and posterior faces where there exist natural longitudinal depressions. The posterior wall had been completely perforated almost down the entire length of the bone, while less than half of the anterior groove had been broken through. The resulting marks are identical to many fragments found at other sites in the Cooper Lake project area (Yates 1997), indicating at least local continuity in the fabrication of metapodial tools. The specimen from Hurricane Hill was found in Block A, Unit 247, having been discarded probably as a result of failure during fabrication. Three segments of this bone were found in three successive 5-cm levels ( $30-45 \mathrm{~cm} \mathrm{bs})$, distal end down, in the lower midden deposits. 


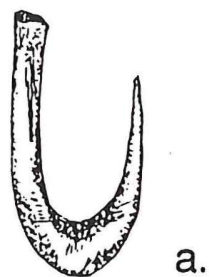

a.

d.
1]

e.

b.
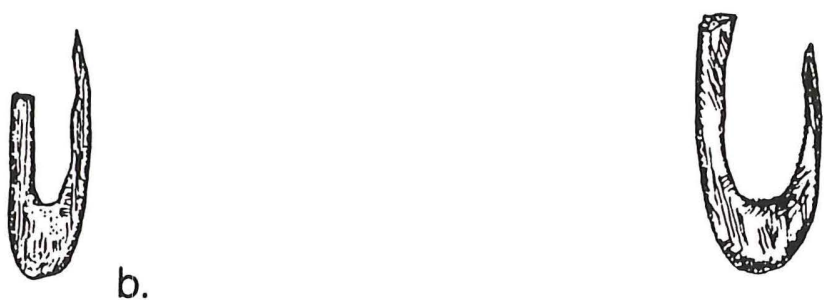

C.

g.

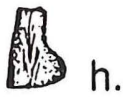

Figure 11-3. Fishhook fragments: a-c, bone fishhooks (Type Q); d, fishhook fragment (Type P); e, incised bone fragment (Type M); f-h, fishhook fragments (Type P). 
The Type $\mathrm{G}$ preform category includes the above-mentioned ulna (see Figure 11-2e) and five fragments that exhibit ring-and-snap breaks. One (G:1) is a shaft fragment from a deer-sized long bone (see Figure 11-2c), other than an ulna, that shows traces of preparation on the interior as well as exterior surfaces of the bone. Another specimen (G:6), possibly a bead preform, exhibits ring-and-snap marks on both ends of a small animal long bone. The remaining specimens in this category are small fragments with ring-and-snap breaks. Two of the five are burned.

No unbroken awls were recovered. The fragmentary awl remnants were placed in four categories (Types D, E, J, and L) for ready comparison with bone tools from other sites (Lawson, Thomas, and Doctors Creek in the Cooper Lake reservoir area that were analyzed by Southern Methodist University (see Yates 1997). Metapodial tool fragments that incorporate the altered proximal end as a base (Type D) (see Figure 11-2d) constitute the most complete of the awl fragments. Type E tools are tips of scarcely modified long bone splinter tools shaped to a conical point. Type $\mathbf{J}$ is the only remnant of an ulna tool shaft and it is burned. The remaining awl fragments are eight small $(<2 \mathrm{~cm})$ tool shafts. All of these Type $\mathrm{L}$ pieces are burned and many are also broken longitudinally.

Since the term awl is generally construed to mean a puncturing implement, the charring and calcination observed on these specimens may have resulted from their being discarded into a fire pit. Bone tools with a similar "awl" morphology but functioning as bone points, hide pegs, hair pins, etc., could also have been burned upon disposal in a fire. If, however, they were used as skewers or pokers, the burning may have been a direct result of use in fire. Unfortunately, they are too small and fragmentary to discern an exact function.

There are two fragments listed in the ornamental group (Type $M$ and N). One (Type $M$ ) is a tiny $(<0.5 \mathrm{~cm})$ chip of bone with three parallel grooves across its longest axis (see Figure 11-3e). A trace of the medullary cavity is revealed on its interior surface, and it appears to be from a small or medium-sized animal, possibly a rabbit or bird. Two of the grooves could be ring-and-snap marks because they occur at the broken edges. The third or central groove, however, appears to be strategically placed midway between the others and does not extend all the way across the bone as do the others. Furthermore, this central groove is superimposed over a smoothed (i.e., prepared) surface, suggesting ornamentation instead of fabrication. It may be a decorated bone bead fragment like the one listed as Type $\mathrm{N}$. This specimen, Type $\mathrm{N}$, was found in a unit about a meter away in the next 5-cm level below the Type $\mathrm{M}$ specimen. It is made from a medium to large bird bone and exhibits longitudinal striae as well as ring-and-snap marks. It is broken lengthwise and may never have been completed. Both of these specimens are burned.

The most outstanding group of bone artifacts from Hurricane Hill, at least from the standpoint of completeness and workmanship, is the fishhook category (Types P and Q). Two nearly complete fishhooks and five fishhook fragments were recovered from excavation units $3 \mathrm{~m}$ north and south of Feature 34 in Block A. These specimens (see Figure 11-3a-d and f-h) are completely shaped, oval or flat in cross-section, with their widest/thickest portion relegated to the curved area of the hook design. The two more complete fishhooks (Q:1 and Q:2) (see Figure 11-3a, c) were both recovered from Unit 244, level 3a (20-25 cm) on the North rise, and are flat in cross-section and unburned. The third fishhook $(\mathrm{Q}: 3)$ (see Figure 11-3b) comes from Unit 174, level 2, in Block B/C on the South rise. It is oval in cross-section and burned.

The fragments (Type P) (see Figure 11-3d, f-d) are all from the thick, curved part of the implement, which may reflect the fact that this part is what distinguishes a fishhook; broken fragments from other areas on this type of artifact would be indistinguishable from broken awl fragments. Only one (P:1) is unburned, and it is also unusual in that it is not made from a compact bone preform. This fragment appears to have been manufactured from a hollow long bone shaft of a small animal.

Six pieces of partially modified antler are recorded. Four are tine tips, one is a basal beam section, and one is little more than a chip (R:5) covered on the exterior with deep longitudinal scoring marks (shallower than grooves but deeper than striations). The basal section ( $R: 1)$ is smoothed and rounded on the broad end and terminates in a jagged hinged break at the other. It is broken lengthwise revealing a fresh break at one edge, but an old, deliberately rounded area forms the opposite edge. It may have functioned as a handle. Two of the tips are only minimally altered but exhibit many nicks and scratches that suggest their short-term use as implements. The other two have been blunted and also have longitudinal striae radiating 
from the terminae. All of these modified antler fragments are burned, and all but one (R:4) were recovered from Block A.

The miscellaneous group consists of a beaver tooth implement (X) (see Figure 11-2b), an extensively scratched fragment of a large bird bone (Y), and 20 worked deer-size bone that do not fit any of the foregoing types. Each of the last type $(Z)$ is highly fragmented, but all exhibit striations, or polish, or shaping indicative of worked bone. Notable here are: (1) a worked section of a right tibia crest in which the broken edges have been smoothed; (2) a highly burnished section of a long bone shaft that retains a broken edge that has been flattened and exhibits longitudinal striae; and (3) a radius (?) splinter covered with multiple wavy striations and rounded edges. These specimens are too fragmentary or atypical to permit functions to be assigned.

\section{Discussion}

As indicated above, the majority of worked bone ( 86 percent) was recovered from units in Block $\mathrm{A}$. This is due in part to the fine screening of soil excavated in this part of the site, as well as the better preservation of animal bone in the North rise midden deposits. The hearths located there (Features 4 and 34) formed foci of activities in which bone tools figured prominently. Figure 11-4 presents the distribution of bone artifacts in Block $A$. The eight tool fragments occurring outside this block are associated with features located inside the two structures in Block $B / C(n=6)$ or are from the northern half of Block $D(n=2)$, also within the North rise midden. All bone tools are associated with Early and/or Middle Caddoan period components at Hurricane Hill.

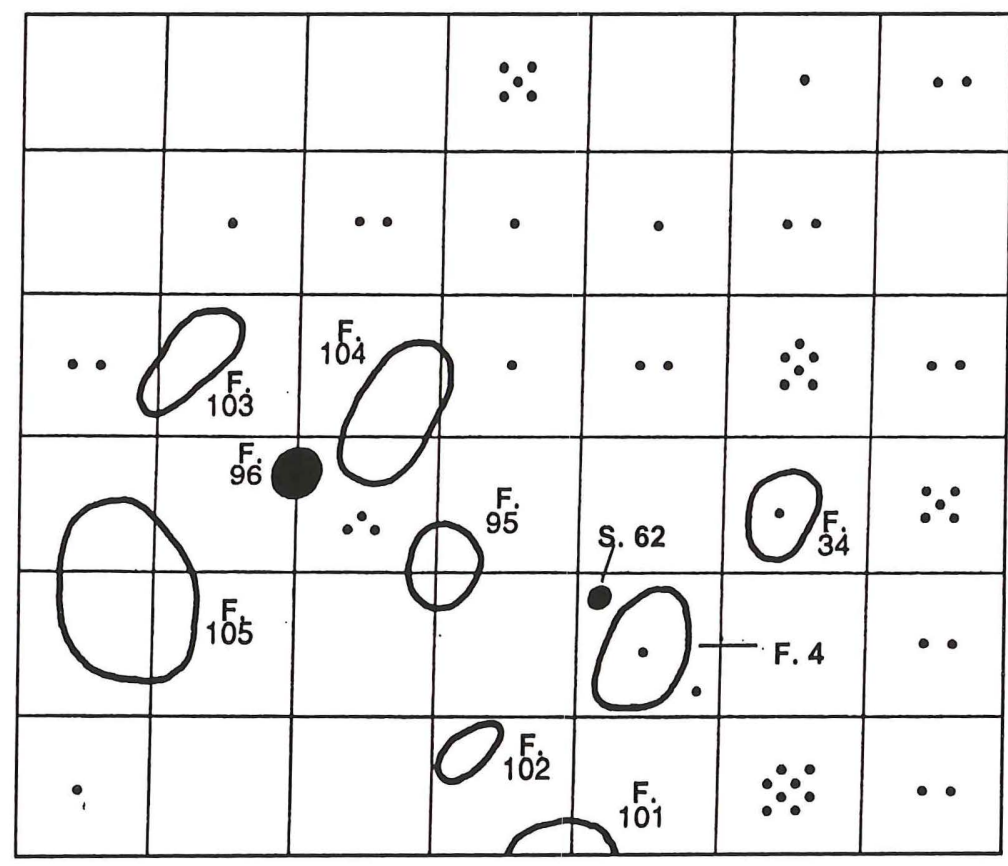
- Bone Tool
- Feature
Posthole

Figure 11-4. Distribution of bone tools in Block $A$ on the North rise.

In comparison with bone artifacts from other Caddoan sites in the Cooper Lake area, those from Hurricane Hill are significant in two regards. First, few other sites in the project area have reported bone fishhooks. From previous investigations at Cooper Lake (Johnson 1962; Hyatt et al. 1974; Butler 1975; 
Henderson 1978a, 1978b) and other Caddoan site reports (Jelks 1961; Johnson 1962; Byrd 1978; Butler 1981; Parmalee and Bogan 1981; Henderson 1982; Parmalee and Opperman 1983), fishhooks were reported only from the Cox and Spider Knoll sites, Early Caddoan components at Cooper Lake (Fields et al. 1994:107), and the Roden site, a Late Caddoan period site just across the Red River from the Sam Kaufman or Arnold Roitsch site (Parmalee and Bogan 1981:89). Outside the region, bone fishhooks have been reported from contemporary Wichita or Plains Village components at places such as Hog Creek in Bosque and Coryell counties, Texas (Harrell 1978), and in Kansas at the Pottorff site (Wedel 1959:Plate 61c) and Smoky Hill sites (Brown 1982:102).

Brown (1982:104) offers a five-step manufacturing process for bone fishhooks:

1. a flat, oblong section of bone is cut from a longitudinally split bone;

2. a small hole is drilled at one end [or both];

3. the center of the bone blank is cut away by grooving from the drilled hole[s] down the length of the blank to form a ring of bone with walls of roughly equal thickness;

4. the oblong ring is grooved and snapped at two points on the opposing long arms of the ring; and

5. the resulting fishhook preform is ground to the desired shape (i.e., length of haft, hafting groove, and point).

Guilday et al. (1962:78) suggest a method of fishhook manufacture from deer phalanges in which the toe bone is drilled and scored longitudinally until it can be split into two halves. The medullary cavity is open, thereby forming a blank that approximates a ring of bone with very thick wall remnants at the proximal and distal ends. One side wall is broken away in such a manner that it leaves a small tang which forms the point of the hook.

Neither type of fishhook blank was recognized in the Hurricane Hill material. Each of the more complete fishhooks (Type Q) (see Figure 11-3a-c) measures about $2.3 \mathrm{~cm}$ in total length, with pointed tangs that measure about $2 \mathrm{~cm}$. The hafting arms are each broken, and the curved portions measure about 6 mm wide. The width of the curved portion is critical to the strength of the hook. Even though the hooks are large by modern standards, they "would have been unsuited for taking very large fish" (Fowler 1972:16). Only small fish vertebrae were recovered in the faunal assemblage from this site.

Secondly, the bone artifacts from Hurricane Hill are notable for their lack of certain tool types that are ubiquitous at other contemporaneous sites. The virtual absence of ulna awls is striking. Even worked ulna shafts and spatulate tool tips are uncommon or nonexistent here, whereas they are quite numerous at the other Cooper Lake sites (Henderson 1978a, 1978b; Yates 1997) and at nearby Lake Fork sites (Butler 1981). Metapodial awls are likewise underrepresented.

In conclusion, the bone technology at Hurricane Hill was clearly advanced in workmanship and diversity (fourteen different types are recorded); however, for the extent of the area excavated, bone tools are not particularly numerous $(\mathrm{n}=59)$ when compared to the 149 bone tools from Thomas (41DT80), 187 from Arnold (41HP102), and 209 from Doctors Creek (41DT124) recovered from mostly coarse-screened samples. Furthermore, the specimens from Hurricane Hill are more fragmented and of generally smaller size fragments. If fine-screening techniques had not been used, this sample would surely be even smaller in total number recovered. 


\title{
CHAPTER 12, HUMAN SKELETAL REMAINS: PATHOLOGICAL AND DIETARY/NUTRITIONAL ASPECTS
}

\author{
H. Gill-King
}

\section{Introduction}

Native American skeletal remains were recovered from 22 separate burials: 7 extended burials, six bundle burials (including one of questionable provenience, Burial 18), and nine cremations; several of the possible bundle burial features contained only morphologically nondescript human skeletal fragments obtained by flotation. While none of the burials contained obvious grave goods, a few radiocarbon dates, their spatial context, and the general character of the burial pit fill indicate that all the extended burials date to the Early and Middle Caddoan periods, while the bundle burials and cremations date to the Late Archaic and/or Early Ceramic periods (see Chapter 7, this volume).

Although the size and condition of the sample prohibits statistically reliable demographic generalizations, it is possible to determine whether the individuals studied conform to the picture of overall cultural adaptations developed by others (see Burnett 1990; Burnett and Harmon 1997; Wilson and Steele 1997) for the Caddoan area in a comparable time frame. Since morphological assessments are severely limited by the condition of the remains, this analysis focuses on nutrition and diet and, to a lesser extent, pathological features of the individuals recovered. This approach provides some insight into the manenvironment relationship and adds to the corpus of biological knowledge of the prehistoric Caddo and their ancestors.

\section{Condition of the Human Materials}

The condition of the remains, viewed as a sample, is poor, owing to repeated wetting and drying, root damage, and a generally humid environment. The pale, manila-colored bone tissue is dry and brittle, having lost much of its organic component, and the most painstaking attempt to remove the bone from soil results in the crumbling of the bones. In some features, fragments of long bones several centimeters in length are intact and cross sections of diaphyses may be discerned, but only in rare instances are articulations preserved. Some of the larger fossae (e.g., glenoid and acetabulum) have fared slightly better and can be analyzed for developmental and degenerative changes. No complete crania are preserved, although a few large fragments (approximately $70 \times 80 \mathrm{~mm}$ ) allow inspection of sutural status, vascular markings, cross-sectional development of the tables and diploe, and occasional pathologies. Assessment of the vertebrae is not possible since only fragments of laminae are preserved. The ribs are similarly fragmented, and there are no costochondral margins available for age analysis.

As expected, dental remains have fared slightly better with respect to preservation, although no complete dentitions were recovered. Many teeth are broken or missing postmortem; however, those that remain affirm characteristics or wear and pathology noted in other Caddo skeletal analyses (see especially Brues 1959; Butler 1969; Loveland 1980; Burnett and Harmon 1997; Wilson and Steele 1997).

\section{Morphological Considerations}

Diagnoses of sex and age are, of necessity, presumptive. In almost all instances, the attribution of sex is based on size and robusticity criteria alone (Stewart 1979:85-96). Age determination is based upon: (1) dental development and/or attrition (Cottone and Standish 1981:80), (2) status of cranial sutures (Krogman 1978:80-82), and (3) cortical development and/or decline, except where otherwise noted. Accordingly, age of the Hurricane Hill skeletal remains is designated as "infant," "subadult," "young adult," "mid-life adult," or "senescent adult." Table 12-1 summarizes the age and sex of the burials from which minimal interpretations are possible (the age and sex determinations incorporate the results of further analyses conducted by the University of Arkansas in the mid-1990s [see Appendix XVIII). 
Table 12-1. Burials (not including cremations) by age, sex, and burial no. ${ }^{\text {a }}$

\begin{tabular}{llll}
\hline Age & Male & Female & Unknown \\
\hline Infant & & & \\
Subadult & - & - & - \\
& B5 & - & B4A \\
& & & B4B \\
Young Adult & B2 & & B15B \\
Mid-life Adult & B1 & - & B20 \\
& B18A & B6 & - \\
Senescent Adult & B3 & B14 & - \\
& B13 & & \\
& B18B & & \\
& & &
\end{tabular}

a Use of "A" or "B" denotes more than one individual in a feature

b This is a disturbed burial (Burial 18) with questionable provenience, and it was not assigned a feature number.

The assessment of Caddoan dental morphology is based upon the recovery of 61 intact permanent teeth and four deciduous elements from Burials 4A and 4B (Feature 35). A surprisingly good set of observations is possible despite the small sample. Table 12-2 lists the available dentition by feature.

Table 12-2. Dentition available by feature.

\begin{tabular}{|c|c|c|c|c|c|c|c|c|c|c|c|c|c|c|c|c|}
\hline \multirow[b]{2}{*}{ Burial } & \multirow[b]{2}{*}{ M3 } & \multicolumn{5}{|c|}{ Right } & \multicolumn{10}{|c|}{ Left } \\
\hline & & M2 & M1 & P4 & P3 & C & I2 & I1 & I1 & I2 & $\mathrm{C}$ & P3 & P4 & M1 & M2 & M3 \\
\hline \multicolumn{17}{|c|}{ Maxillary } \\
\hline 1 & & & $X$ & $X$ & $X$ & $X$ & $X$ & $X$ & $X$ & $X$ & $X$ & & & & & \\
\hline 2 & & & & & & & $X$ & $X$ & $X$ & X & & & & & $X$ & $X$ \\
\hline $4 \mathrm{~A}$ & & X & X & & & & & & & & & & & & $X$ & \\
\hline $4 \mathrm{~B}$ & & & & & & & & & & & & & & $X$ & $X$ & \\
\hline $18 \mathrm{~A}$ & $X$ & $X$ & & & & & $X$ & X & $X$ & $X$ & & & & $X$ & $X$ & \\
\hline $18 \mathrm{~B}$ & & & & & & & & $\mathrm{X}$ & $X$ & & & & & & & \\
\hline \multicolumn{17}{|c|}{ Mandibular } \\
\hline 1 & & & & & & & & & & & & & & $\mathrm{X}$ & $X$ & $\mathrm{X}$ \\
\hline 2 & & & & & & & & & & & & & $X$ & & & \\
\hline 3 & & X & & & & & & & & & & & & & & \\
\hline $4 \mathrm{~A}$ & & $X$ & $X$ & $X$ & $X$ & $X$ & $X$ & & & & & & & $X$ & $X$ & \\
\hline 5 & & & $X$ & & & & & & & & & & $X$ & $X$ & & \\
\hline 13 & & & & & & & & & & & & & & $X$ & $X$ & $X$ \\
\hline $18 \mathrm{~A}$ & & $X$ & & $\mathbf{X}$ & $X$ & & & $X$ & $X$ & $X$ & $X$ & $X$ & & & & \\
\hline 18B & & & & & & & & & & & & $X$ & & & $X$ & $X$ \\
\hline
\end{tabular}


The most notable feature of the dental sample is a form of lingual to buccal sloping attrition seen only in the adult males (the left $\mathrm{M}_{1}, \mathrm{M}_{2}$, and $\mathrm{M}_{3}$ of Burial 13 [Feature 68], the right $\mathrm{M}_{2}$ of Burial 3 [Feature 3], and the left $\mathrm{M}_{1}$ and $\mathrm{M}_{2}$ of Burial 1 [Feature 1]). This wear pattern has been observed on other skeletal remains, and has been interpreted as resulting from chronic chewing of vegetation (e.g., "quid"-like masses) (King 1969). Elemental analysis of such teeth, often discolored a dark reddish-brown, reveal extremely high levels of strontium ( $\mathrm{Sr}$ ) and iron ( $\mathrm{Fe})$. Both the attrition pattern and the trace elemental data may also be the result of the accessory use of the teeth in pulling plant fibers through the clenched jaw at a slightly downward angle (Pedersen 1952:170-178). The occlusal edges of the maxillary central incisors in Burials 1 and 2, and individuals B18A and B18B (Burial 18), as well as the right $I_{1}$ and left $I_{1}$ and $I_{2}$ (individual B18A), are worn flat. This exposed the secondary dentin. This may be part of a complex related to the wear pattern seen on the cheek teeth.

One unusual instance affords an opportunity to assess rates of wear on cheek teeth. Burial 4A (Feature 35) has a fully occluded six-year molar (M1) adjacent to an almost occluded 12-year molar (M2). Allowing one year for the first tooth (M1) to move into occlusal position, it is possible to gauge approximately five years of wear by comparison with the crown on the adjacent, more recent molar (M2) (Figures 12-1 and 12-2). In all instances, the pattern of attrition is comparable to that observed in other contemporaneous Caddo samples (Goldstein 1948:63-82; Lovejoy 1985:37). Moderate shoveling is observable on all available central and lateral incisors for Burials 1 and 2 and individuals B18A and B18B.

Temporomandibular joints are available for some individuals (individual B18A and Burial 4A, Burial 4B, and Burial 13). The wear (i.e., some flattening of the condyle) exhibited by Burial 13 is more like that observed in individuals whose diets contain a larger amount of meat (Petit, 1987 personal communication). Since the population is presumed to rely principally on plant foods (see Dietary and Nutritional Features, below), this observation may be evidence for the accessory use of teeth in some routine task.

\section{Skeletal and Dental Pathology}

In general, the skeletal pathology of the assemblage is comparable to that in other contemporaneous Caddoan bioarchaeological samples (Goldstein 1957; Butler 1969; Buikstra and Fowler 1975:79-97; Wilson and Steele 1997). Pathological features are described by category. Inferences about the overall population pattern of disease by age or sex are not reasonable; however, the entities noted are useful for comparison. Table 12-3 summarizes general categories of disease with subtypes noted in the sample. The following discussion proceeds by category with reference to affected individuals. No instances of congenital or true developmental anomalies were noted in the Hurricane Hill remains.

\section{Infection}

Second to dental caries, infections of the cranium are the most frequent in the Hurricane Hill bioarchaeological sample, and in some instances, these may be the direct result of hematogenous export from dental abscesses. Severe mastoiditis is present in Burial 18A, a mid-life adult (bilaterally), Burial 4A (child or subadult), Burial 2 (young adult male, the right side only), and Burials 3 and 13 (both old or senescent males, the right side in each). The lesions are small $(2-3 \mathrm{~mm})$ crypts with remodeled borders and give the petra a moth-eaten appearance. In the case of Burial 18A, the left mastoid process is badly deteriorated and the lesion penetrates to the interior of the skull. The margins of this lesion are rounded and grainy, indicating the chronic nature of the infection. Burial 3, an old Caddoan male, has a perforating abscess of the squama above the right mastoid process. The abscess has penetrated into the auditory meatus. 


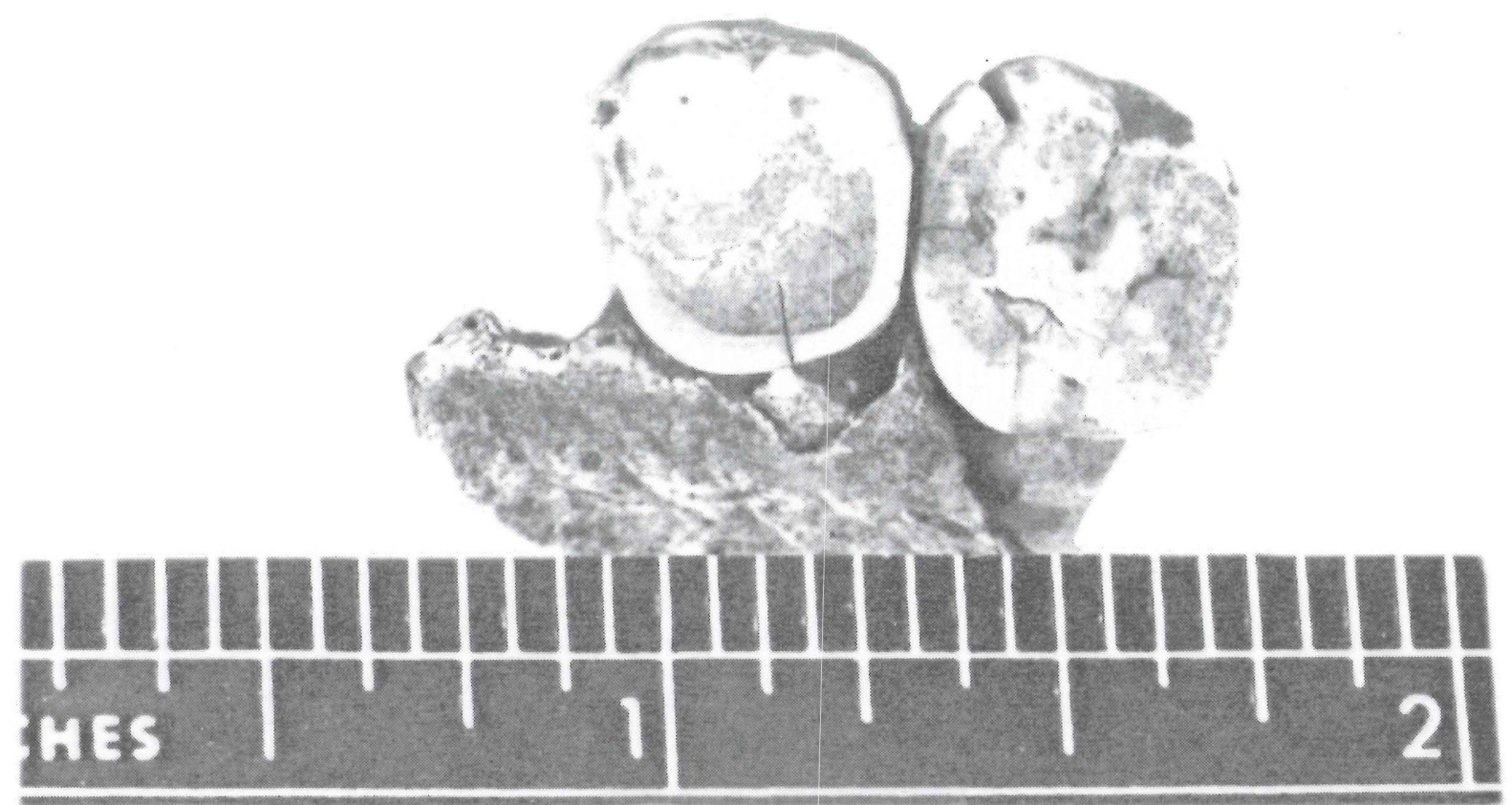

Figure 12-1. Burial 4, individual (B) from Feature 35. Six-year molar is fully occluded and worn adjacent to 12-year molar (not yet occluded).

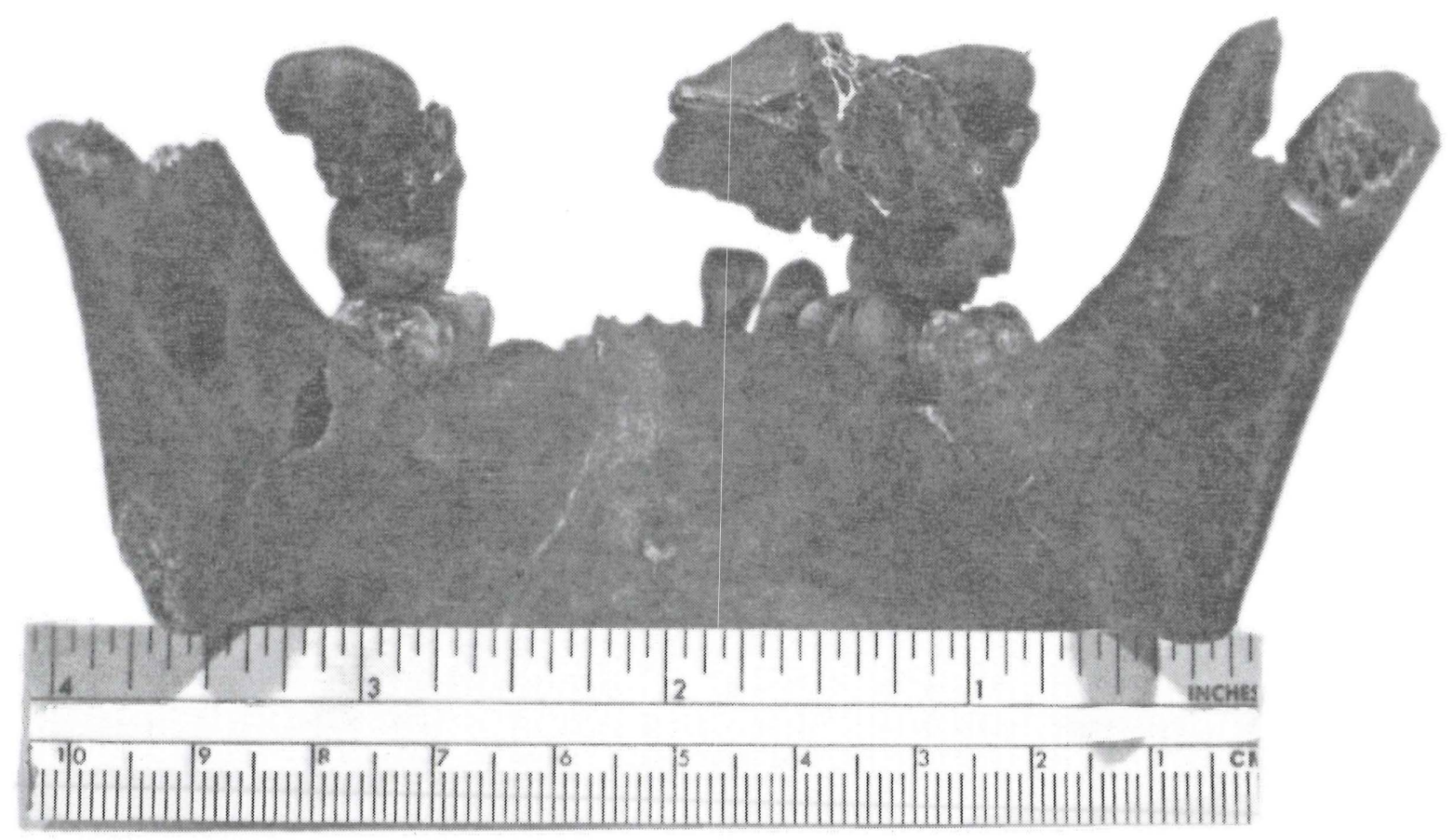

Figure 12-2. Burial 3, Feature 3. 
Table 12-3. Instances of observed pathologies by category and location.

Disorder Individual(s)

Infection:

Mastoiditis

Caries (see Dental Pathology)

Sphenoid Sinus

Frontal Sinus

Periostitis

Metabolism/Nutrition:

Senescent Anemia

Iron Deficiency Anemia

(presumptive)

Endosteal Sclerosis

(parathyroid etiology?)

Growth Arrest Lines

Neoplasia:

Button Osteoma (solitary myeloma?)

B6

Degeneration/Trauma:

Depression Fracture

Joint Injury (hyperextension)

Dental Wear (see text)

Osteoarthritis

B5
B2, B3, B4A, B13, B18A

B5

B1

B13
B3, B15B (?)

B1, B4A

B15A

Burial 5, a Middle Caddoan period subadult male, displays new, reactive bone in the left sphenoid sinus which is enlarged. Since the corresponding maxilla is absent, this infection cannot be attributed conclusively to a molar root abscess. Reactive bone is also visible in the right frontal sinus of Burial 1.

The only noted instance of long bone involvement (Burial 13) is a periosteal inflammation on the proximal left tibia beneath the insertions of the sartorius, gracilis, and semitendinosus muscles. The lesion consists of two confluent nodules of bone, $12 \times 8 \mathrm{~mm}$ in size, with a stippled appearance. This type of lesion often occurs as a result of repeated traumatization or overuse accompanied by low grade, chronic infection (Zimmerman and Kelley 1982:49).

\section{Metabolism/Nutrition}

Rather than force a distinction between two sets of clinical entities that are often confused without the benefit of individual history, these categories are combined for discussion here. In addition, interplay between these two categories of disease has been acknowledged in the discipline (Aegerter and Kirkpatrick 1968:280; Steinbock 1976:234-236).

Neither the senescent Burial 15A female (of probable Early Ceramic age), nor the middle-aged female in Burial 6 (on the South rise), exhibits the cortical thinning on the long bones that is typical of endocrine osteoporosis (Price and Wilson 1982:707-708). The older female may have suffered from chronic anemia as evidenced by a slightly thickened diploe in the frontal fragments and similar thickening of the spongiosa of a dorsal right iliac crest. Whether these represent compensatory hyperplasia of erythropoetic marrow cannot be determined because of lack of comparison with the same sites in other females. 
An old male (Burial 5) also exhibits a thickened diploe of the frontal bone accompanied by porotic hyperostosis (Angel 1966a:760; Lallo et al. 1977:471-485) in two adjacent frontal fragments. An area of approximately 8 square centimeters in size is affected by the pathology.

The most exotic osteopathology observed in the sample was noted in a senescent male (Burial 3, of Middle Caddoan age, on the South rise). The mid-portion of the right femoral shaft is spirally fractured, revealing thickened cortices that have generated a chalky bone plug, $17 \mathrm{~cm}$ long (determined radiographically), completely occluding the medullary cavity. Underlying this is a sclerosed endosteum with dense cord-like ridges (Figure 12-3). A $9 \mathrm{~cm}$ long segment of the opposite femur exhibits the same endosteal pattern, but without radiographic evidence of the plug (Figure 12-4). The extra bone is nonstructural. The cortices are 0.9-1.2 cm thick, although the outside diameter of the shaft appears normal ( $\mathrm{AP}=2.9 \mathrm{~cm}$ and $\mathrm{LAT}=2.4 \mathrm{~cm}$ at midshaft). A similar pathology, without the bone plug, is noted in the right tibial midshaft of Burial 15B, a subadult of Early Ceramic period age. Speculation concerning the possibility of a familial parathyroid syndrome with resulting failure of osteoclasis may be unavoidable (Ortner and Putschar 1985:344), except the burials are separated by hundreds of years.

Several instances of Harris' Lines (Aegerter and Kirkpatrick 1968:31) are present in the Hurricane Hill Caddoan burials (Burial 1, right proximal tibia; Burial 6, left distal tibia). In one young Caddoan individual (Burial 4B, left distal tibia) from the North rise, these correlate with enamel wrinkling on the right $\mathrm{I}^{1}$ and $\mathrm{I}^{2}$ and left $\mathrm{I}^{1}$ (Figures 12-5 and 12-6). Radiographs of the left distal tibia of Burial 4B show the most proximal arrest line to be $13 \mathrm{~cm}$ from the distal articular surface, while the most distal line is $2 \mathrm{~cm}$ from the articular surface. The placement of these lines corresponds roughly to ages 4 through 9 . Dentally, the individual in Burial 4B is estimated to have been 9-11 years of age at death. This, together with the dental evidence, suggests a series of nutritional or disease stresses, or some combination of both, occurred between 4 and 11 years of age that may have been sufficiently severe to contribute to this individual's early demise. The dietary picture of this individual (see below) does not seem significantly different from the other individuals in the Hurricane Hill sample. It is, therefore, more likely that the growth arrest lines represent protracted bouts with disease rather than chronic caloric deprivation.

\section{Neoplasia}

The only occurrence of neoplasm observed in this sample was a single "button osteoma," 12.7 $\mathrm{mm}$ in diameter, on a left frontal fragment of Burial 6, a middle-aged Caddoan female. The absence of any vertebral bodies prevents correlation of this event with a systemic process--such as multiple myeloma--that has a predilection for females of this age group (Sodeman and Sodeman 1974:137).

\section{Degeneration/Trauma}

The Hurricane Hill burials have a low incidence of trauma and degenerative processes, although this is likely a product of the small number of burials recovered from the site and the extremely poor condition of the recovered bones. Most of the observed degenerative effects are in the dental tissues (see Dental Pathology, below).

One middle-aged Early Caddoan male (Burial 1) exhibits lipping and eburnation of the right glenoid fossa and "shallowing" and lipping of the right acetabulum. This individual also has a bone "pile-up" on the lateral facet of the left patella that articulates with the lateral femoral condyle. There is a similarly remodeled point in apposition near the insertion of the rectus femoris muscle. The two events together are consistent with a hyperextension injury. 


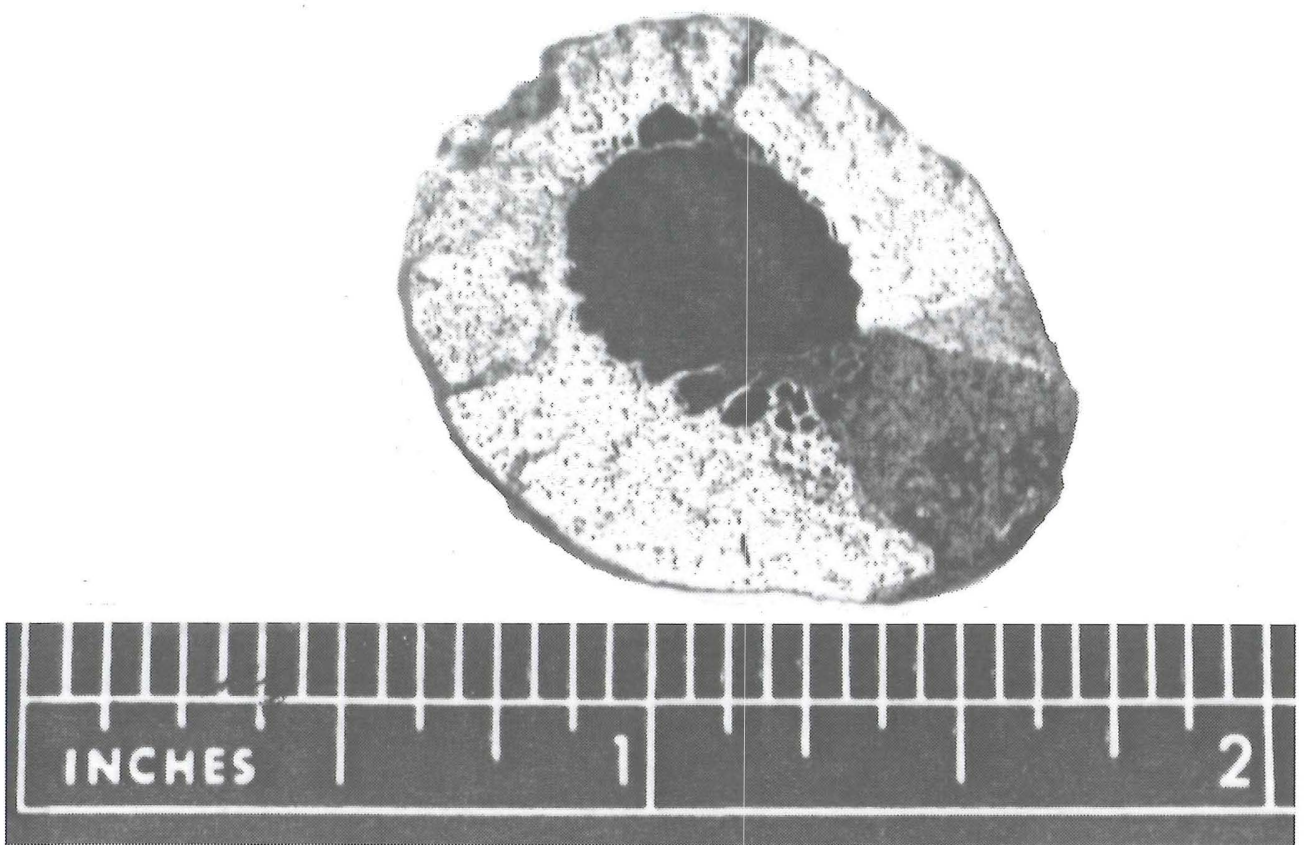

Figure 12-3. Burial 3, note excessive cortical thickening and hyperactive endosteum (i.e., thick cord-like character).

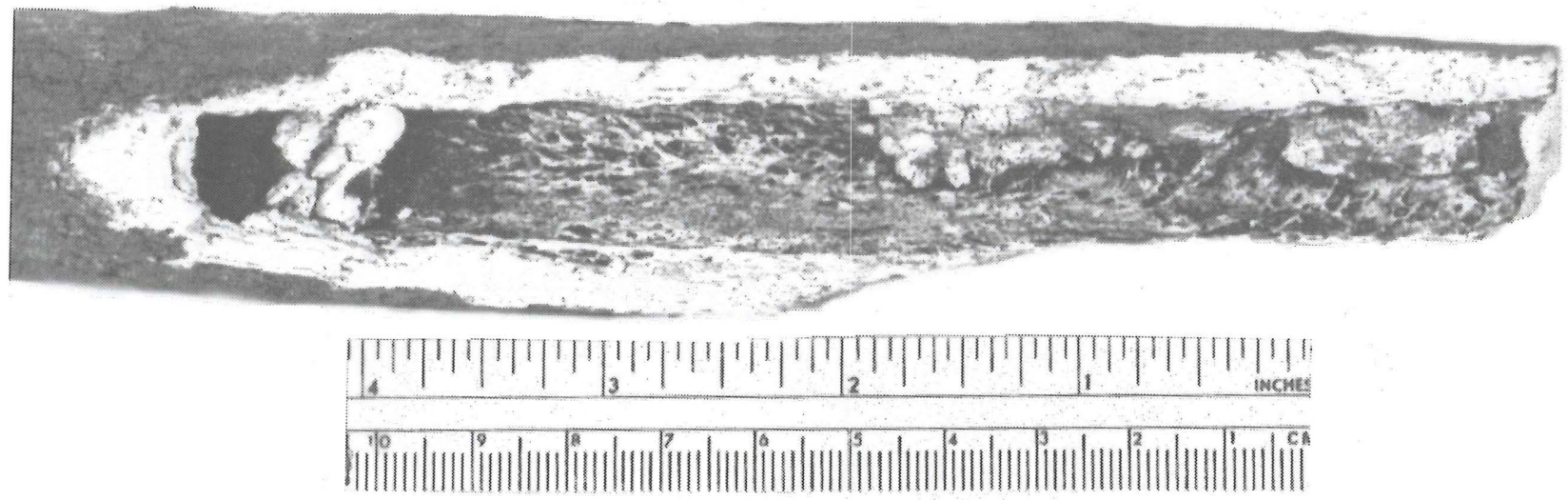

Figure 12-4. Burial 3, Feature 3. Long bone with endosteal nodules and hyperactive endosteum. 


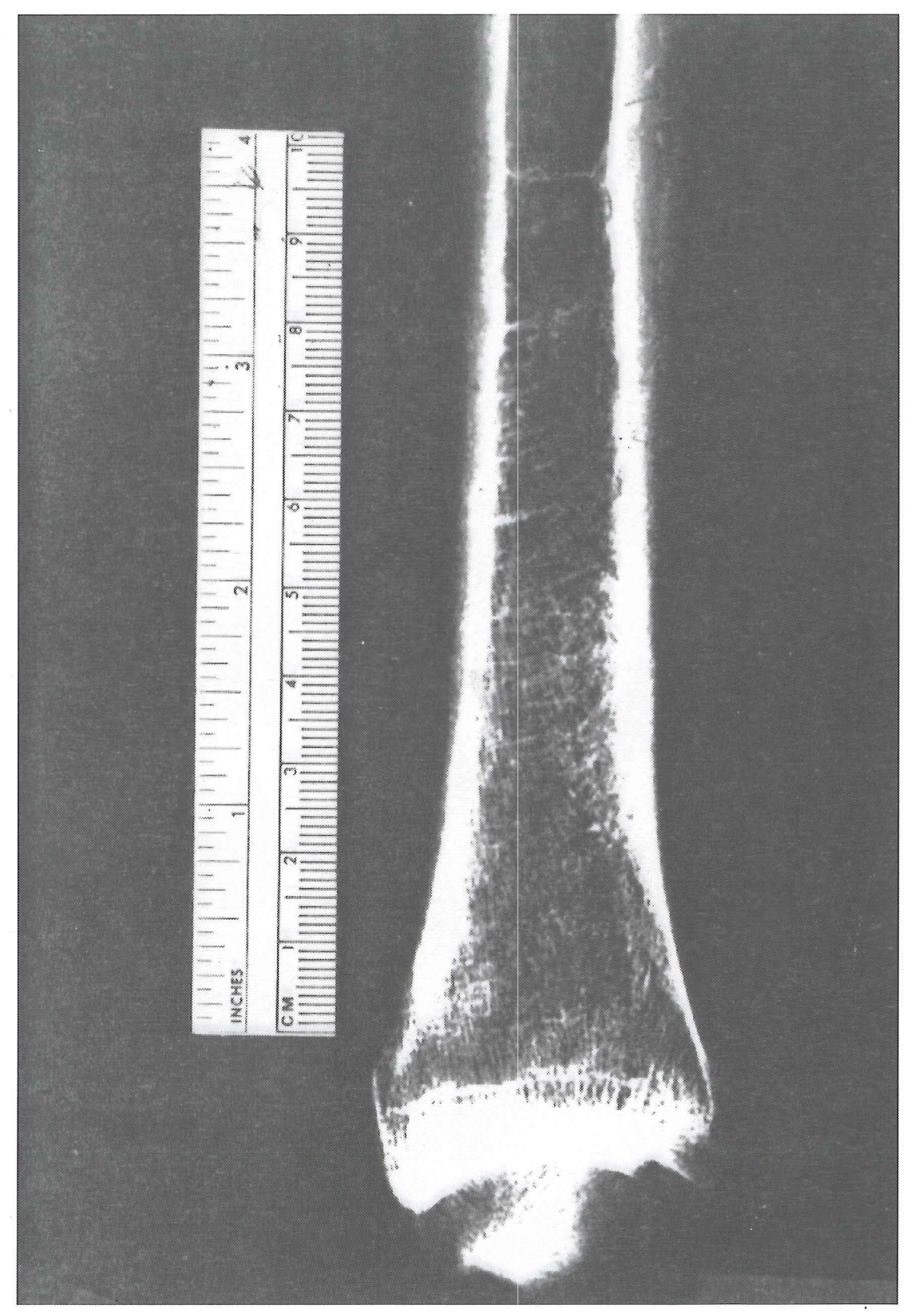

Figure 12-5. Growth arrest lines from bone of Burial 4B. Several growth arrest lines correlating roughly to age $4-9$ years. 

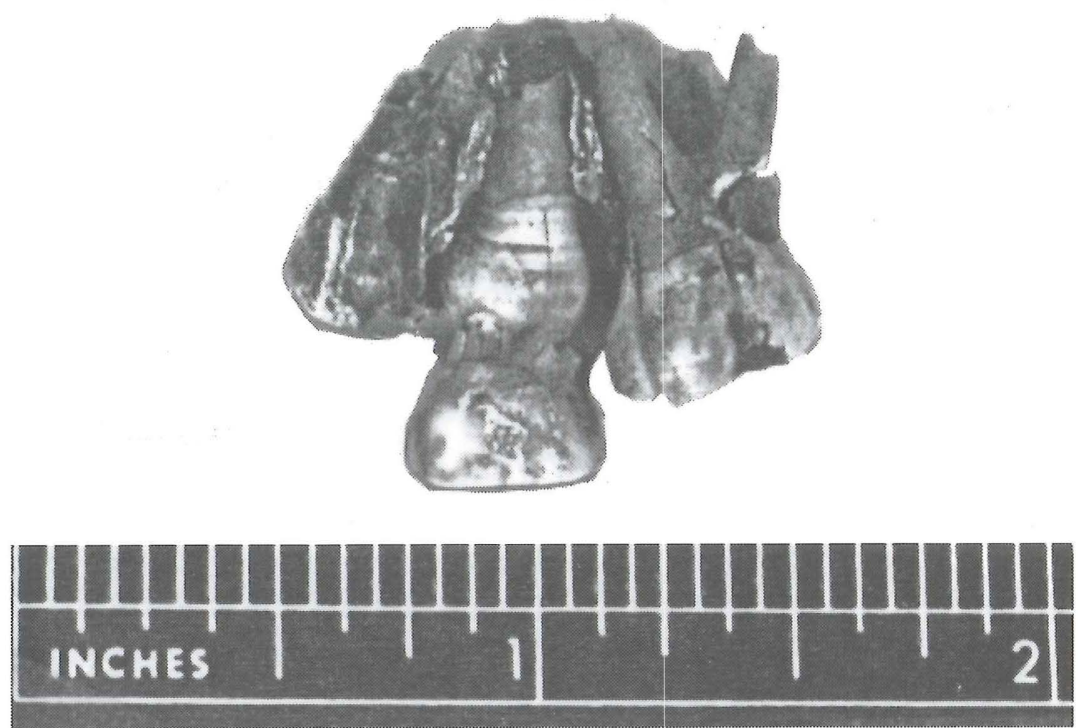

Figure 12-6. Enamel lines in dentition of Burial 4B. Note six or seven enamel lines in permanent second premolar, which is displacing deciduous molar.

An old Middle Caddoan male (Burial 3) has arthritic features similar to Angel's throwing complex, "os acromiale" (Angel 1966b:3). The right distal acromion process is roughened and thickened, and the right ulnar and radial midshafts of this individual have prominent interosseous borders and supinator and pronator insertions.

Two instances of trauma are noted. The first of these is an $18 \times 16 \mathrm{~mm}$ round depression fracture with completely healed margins on a right parietal fragment near bregma from the Middle Caddoan Burial 13. Burial 6, a Middle Caddoan female (see Neoplasia above) bears a pair of incised ("hack") marks on the dorsum of the mid-femoral shaft (side undetermined). These markings, $58 \mathrm{~mm}$ apart, were made diagonally from below to above. It is speculated that the marks were made as a step in the reduction of the bone, possibly preparatory to cremation or other disposal, since no stone tools capable of a full cortical thickness cut through a fleshed thigh were recovered in association with the burial (i.e., the flesh was removed or deteriorated before the cuts were made). The occurrence of two incisions so closely spaced rules against battle wounds. The margins of these incisions show no healing and are definitely not animal or exhumation artifacts.

\section{Dental Pathology}

Varieties of dental pathology noted in the sample of 61 permanent whole teeth are listed in Table 12-4. In general, wear patterns are consistent with a diet containing silicates (see Dietary and Nutritional Features, below).

The lateral attrition pattern in the cheek teeth may be associated with accessory use of the mouth as a tool or with a chronic chewing habit, as noted above. This feature probably inhibits occlusal caries in some instances but also presages disease resulting from exposure of the pulp cavity in others. Alveolar resorption is seen primarily in the anterior mandibular dentition of Burials $1,4 \mathrm{~A}$, and $18 \mathrm{~A}$, and with one example in a molar (Burial 5). This is viewed as a step in the direction of periodontal disease, especially in the front teeth where the gumline is constantly traumatized. Dental calculus is absent throughout the sample and premortem loss is surprisingly rare, with only three instances noted in Burial 2 and Burial 18A. There is no evidence of temporomandibular joint arthritis in the complete joints recovered, Burial 13 notwithstanding (see Morphological Considerations, above). 
Table 12-4. Dental pathology by feature and tooth.

\begin{tabular}{|c|c|c|c|c|c|c|c|c|c|c|c|c|c|c|c|c|}
\hline \multirow[b]{2}{*}{ Feature } & \multirow[b]{2}{*}{ M3 } & \multirow[b]{2}{*}{ M2 } & \multirow[b]{2}{*}{$\mathrm{M} 1$} & \multicolumn{2}{|c|}{ Right } & \multirow[b]{2}{*}{ c } & \multirow[b]{2}{*}{12} & \multirow[b]{2}{*}{11} & \multirow[b]{2}{*}{11} & \multicolumn{3}{|c|}{ Left } & \multirow[b]{2}{*}{ P4 } & \multirow[b]{2}{*}{$\mathrm{M} 1$} & \multirow[b]{2}{*}{ M2 } & \multirow[b]{2}{*}{ M3 } \\
\hline & & & & P4 & P3 & & & & & 12 & C & P3 & & & & \\
\hline Maxillary: & & & & & & & & & & & & & & & & \\
\hline $\begin{array}{c}1 \\
2 \\
4 \mathrm{~A}\end{array}$ & & & $\mathrm{~A} / \mathrm{M}$ & & & $\mathrm{T}$ & $\begin{array}{l}\mathrm{R} / \mathrm{P} \\
\mathrm{D}\end{array}$ & $\begin{array}{l}\mathrm{R} / \mathrm{P} \\
\mathrm{D}\end{array}$ & D & D & L & & & & $\begin{array}{l}\mathrm{M} \\
\mathrm{M}\end{array}$ & M \\
\hline $\begin{array}{l}4 \mathrm{~B} \\
18 \mathrm{~A} \\
18 \mathrm{~B}\end{array}$ & L & M & & & & D & $\begin{array}{l}D \\
D\end{array}$ & $\begin{array}{l}\mathrm{M} \\
\mathrm{D}\end{array}$ & & & & & & M & & E \\
\hline \multicolumn{17}{|c|}{ Mandibular. } \\
\hline $\begin{array}{l}1 \\
2 \\
3\end{array}$ & & $M$ & & & & & & & & & & & D & & $\mathrm{C} / \mathrm{M}$ & \\
\hline $4 \mathrm{~A}$ & & $\mathrm{E} / \mathrm{M}$ & $C / E$ & & & & $\mathrm{R} / \mathrm{P}$ & $\mathrm{R}$ & & & & & & & M & \\
\hline $\begin{array}{l}5 \\
13\end{array}$ & & & $M / R$ & & & & & & & & & & & $\mathrm{~A} / \mathrm{M}$ & $E$ & \\
\hline $18 \mathrm{~A}$ & & & M & & & & & L & & & & $\mathrm{R}$ & & & & \\
\hline $18 \mathrm{~B}$ & & & & & & & & & & & & & & & M & \\
\hline
\end{tabular}

Key: $A=a b s c e s s ; C=$ occlusal caries; $D=$ =secondary dentin exposed; $E=$ =pulp chamber exposed; $L=$ premortem loss; $M=$ use artifact; $\mathrm{P}$-periodontal membrane disease; $\mathrm{R}=$ al veolar resorption; $\mathrm{T}$ =peg-shaped tooth

\section{Dietary and Nutritional Features}

The late J. Lawrence Angel often encouraged a distinction between "diet" and "nutrition," noting that many analysts use these terms almost interchangeably in analyses of skeletal remains from archaeological sites. For present purposes, "diet" refers to what people eat, while "nutrition" signifies the metabolic fate of ingested foodstuffs and their adaptive value as revealed by good skeletal development and maintenance. In this analysis, diet and nutrition are evaluated according to the following criteria:

$\underline{\text { Diet }}$

(1) dental wear patterns;

(2) trace mineral evaluation by energy dispersive $\mathrm{X}$-ray fluorescence (EDX) of $\mathrm{Fe}, \mathrm{Cu}, \mathrm{Sn}, \mathrm{Sr}$;

(3) ratios of stable isotopes of carbon and nitrogen; and

(4) assessment of the temporomandibular joint surfaces

\section{$\underline{\text { Nutrition }}$}

(1) cortical development;

(2) thickness of basilar skull fragments;

(3) dental enamel lines;

(4) Harris' lines; and

(5) cross-sectional shape of femora and tibiae

Several questions are sometimes raised concerning diet in prehistoric populations: (1) What are the relative proportions of plants and animals consumed? (2) Within the plant component of the diet, what is the mix of cultigens and wild plants? (3) Is there evidence of sexual dimorphism or age-related variation in the proportions of these nutrient sources? (4) Does the diet amount to adequate nutrition? Improved understanding of photosynthesis and of the metabolic fates of stable isotopes of carbon and nitrogen from plant and animal dietary sources has provided partial answers to the first two questions. The small number 
of burials from Hurricane Hill precludes adequate statistical treatment of the third and fourth questions, although, with this caveat, a few inferences may be worthwhile concerning diet and nutrition.

Table 12-5 presents the results of stable carbon and nitrogen analyses of human remains from seven burials, five of Caddoan age (Burials 1,2, 4A, 4B, and 13), one of probable Early Ceramic age (Burial 15), and one of unknown age (Burial 18A; Editor's Note: It is unfortunate that the samples selected for isotope analyses were done by King without consultation with the Principal Investigator or Project Director, as the selection of Burial 18A remains for this analysis was inappropriate because of the burial's unknown provenience and unknown age). The stable isotope ratios are presented in mils (o/oo) of sample per mil of standard for stable isotopes of carbon and nitrogen, using both bone gelatin and bone apatite. The carbon from carbohydrate sources is expressed in the hard calcium hydroxyapatite portion of bone, while carbon and nitrogen from animal dietary sources is bound in the collagen or gelatin fraction. Apatite and gelatin (collagen) fractions were subjected to mass spectrograplaic analysis to determine the ratios of stable isotopes of each element.

Table 12-5. Stable isotope ratios from bone gelatin and Hydroxyapatite.

\begin{tabular}{|c|c|c|c|c|}
\hline Feature & Burial & ${ }^{13} \mathrm{C}$ gelatin (o/oo) & $15_{\mathrm{N}}$ gelatin $(\mathrm{o} / \mathrm{oo})$ & ${ }^{13} \mathrm{C}$ apatite (o/oo) \\
\hline 1 & 1 & -16.5 & +8.9 & -9.6 \\
\hline 2 & 2 & -15.3 & +8.9 & -7.4 \\
\hline 35 & $4 \mathrm{~A}$ & -15.3 & +9.0 & -8.8 \\
\hline 35 & $4 \mathrm{~B}$ & -17.6 & +8.4 & -10.2 \\
\hline 68 & 13 & -15.2 & +9.2 & -7.3 \\
\hline 77 & 15 & -15.0 & +9.1 & -8.7 \\
\hline- & $18 \mathrm{~A}$ & -17.6 & +7.6 & -10.3 \\
\hline
\end{tabular}

$\mathrm{R}_{\text {sample }}-\left[\left(\mathrm{R}_{\text {sample }} / \mathrm{R}_{\text {standard }}\right)-1\right] \times 1000$

${ }^{13} \mathrm{C} /{ }^{12} \mathrm{C}$ standard is $\mathrm{PDB}$

$15_{\mathrm{N}} / 4_{\mathrm{N}}$ standard is atmospheric nitrogen

Van der Merwe (1982), DeNiro (1985), and many others have established isotopic ratios for various plants and animals that comprise ranges of different paleodiets. Control populations with wellestablished dietary regimes are used for comparisons with archaeological skeletal samples. In general, C3 and C4 plants in East Texas settings are non-cultigens (most species of plants, as well as most animals that consume these foods, except perhaps for bison [Huebner 1991]) and cultigens (maize), respectively. Their carbon and nitrogen isotopic ratios may be traced from the original plant and animal sources, whether terrestrial or marine, up through one or more trophic levels and ultimately to human bone, where they act as dietary signatures.

Figure 12-7 (adapted from Krueger 1985) presents the stable isotope data from Table 12-5 translated to a dietary nomogram. The seven individuals represented had diets that were relatively high in $\mathrm{C4}$ plant and/or animal foods. The stable isotope ratios for carbon suggest that between 25 and 40 percent of the plants consumed appear to have been C4 photosynthesizers (i.e., maize). Figure 12-8 consists of a series of isotopic "zones" that are probability areas expressing the likelihood of specific dietary sources of the ratios. The cluster of values for the Hurricane Hill site is similar to that of upper Amazon huntergatherer populations moving toward becoming agriculturists (Krueger 1985:9-11). 


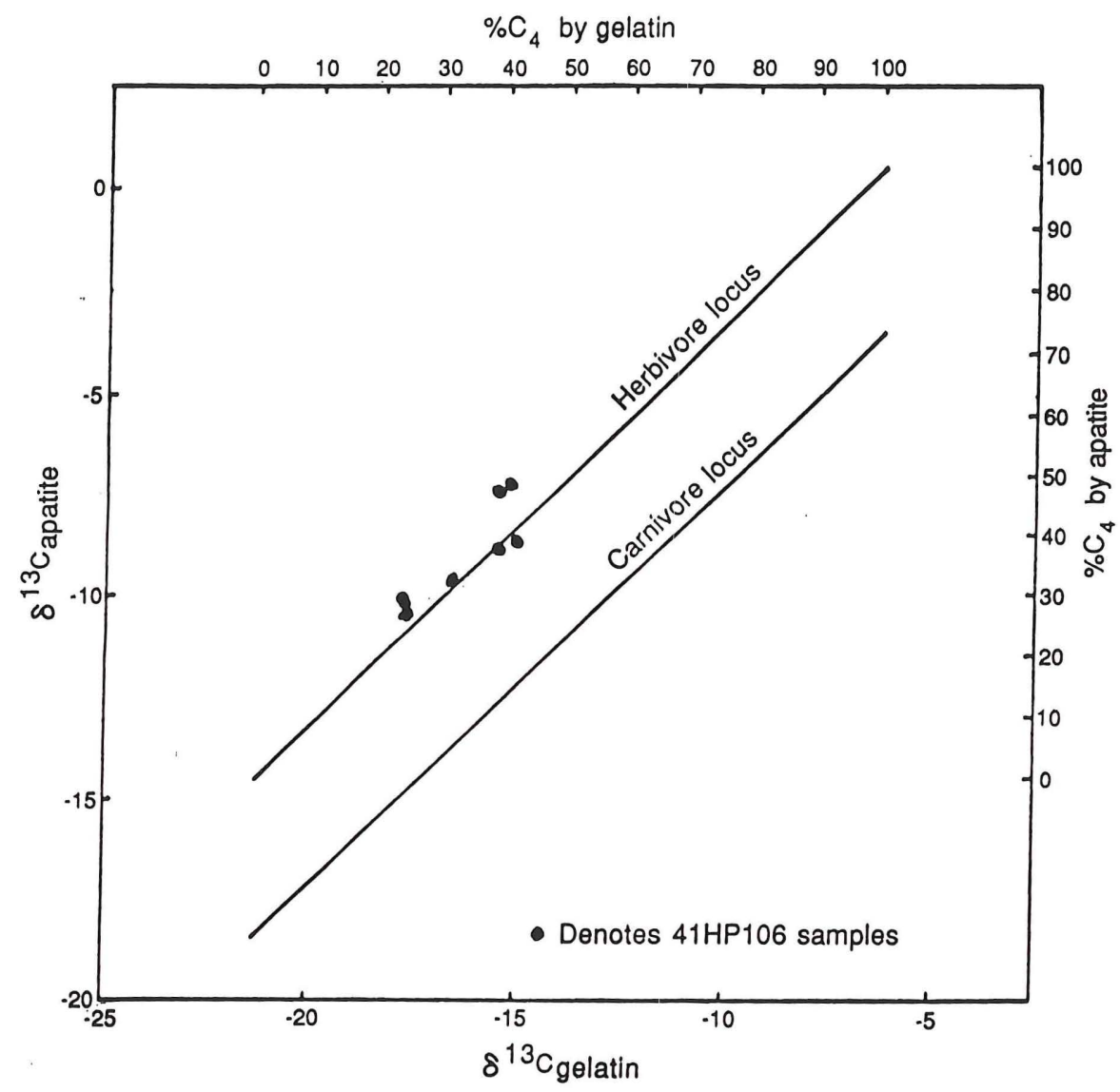

Figure 12-7. Dietary nomogram.

All of the Hurricane Hill burials, except one individual (Burial $18 \mathrm{~A}$ ), are too high in ${ }^{15} \mathrm{~N}$ for them to be considered pure herbivores. This indicates that meat supplementation was present, amounting to at least a few percent of the bulk diet. This is confirmed by the semi-quantitative analysis of the trace metals $\mathrm{Zn}^{++}$and $\mathrm{Cu}^{++}$by energy dispersive X-Ray analysis (Gilbert 1975:146-155; Lambert 1983:409-414). These elements are metabolically blocked by plants and are, therefore, indicators of meat in the diet.

For the analysis, morphologically nondescript bone grind was weighed and molded into 1 cubic cm acrylic blocks containing $1 \mathrm{gm}$ of bone. These were polished on one surface to reduce beam scatter during assay. Runs were made at $10 \mathrm{KEV}$ for 100 seconds per sample. The results are given in Table 12-6, and suggest a population making the dietary transition from no consumption of cultigens to at least some cultigen consumption. Burial 4A, whose tibial radiographs and dentition showed marked growth arrest, has the lowest intake of animal protein. The diet includes a significant supplement of animal protein, probably on the order of at least several percent of the bulk diet. Most of the meat was of C3 plant origin, implying that humans and game animals were utilizing the plant menu somewhat differently.

As noted earlier, these dietary data are consistent with the type and degree of dental attrition in the sample. Likewise, the temporomandibular surfaces are smooth (with one exception), and typical of a diet high in plant fiber and silicates. 


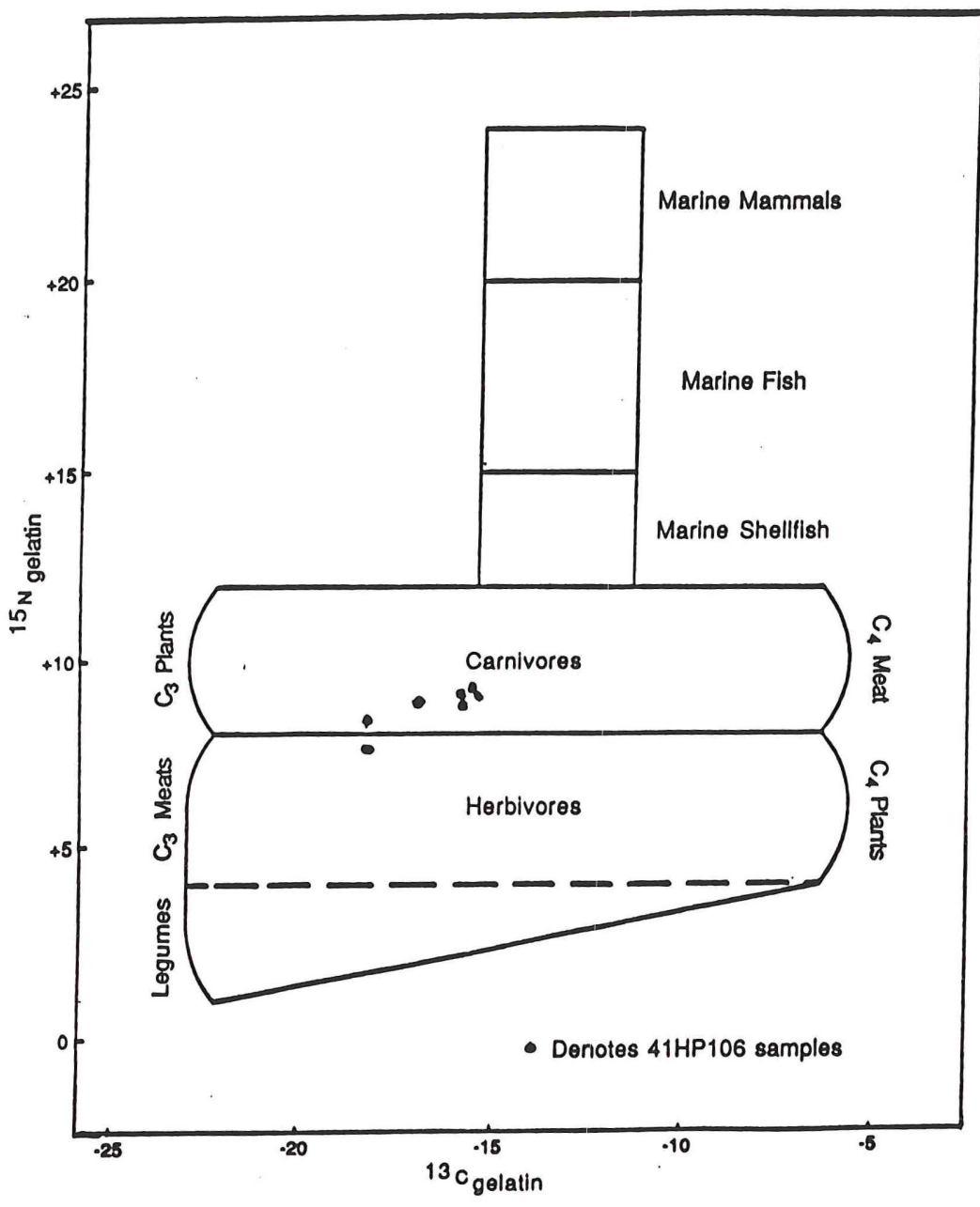

Figure 12-8. Isotopic probability zones of dietary sources.

Table 12-6. Frequencies of Zinc and Copper in selected human skeletal remains.

\begin{tabular}{ccc}
\hline Burial & ${\text { Zinc }(\mathrm{Zn})^{\mathrm{a}}}^{\mathbf{a}}$ & ${\text { Copper }(\mathrm{Cu})^{\mathbf{a}}}^{\mathrm{a}}$ \\
\hline & 16 & 1 \\
2 & 9 & 1 \\
$4 \mathrm{~A}$ & 11 & 0 \\
$4 \mathrm{~B}$ & 6 & 1 \\
13 & 9 & 1 \\
15 & 12 & 1 \\
$18 \mathrm{~A}$ & 19 & 2 \\
Control $1^{\mathrm{b}}$ & 22 & 0 \\
Control $2^{\mathrm{b}}$ & 6 & 1 \\
\hline
\end{tabular}

\footnotetext{
a Parts per million

b 1 = modern American autopsy sample, 2 = bovine
} 
Basilar skull fragments are of normal thickness, indicating good perinatal nutrition (Angel 1982:297), as are the cortices. The pathological exceptions may be explained by the fact that trace metal values and isotopic ratios reflect a lifetime of nutrition, while the observed anatomical features are developmentally isolated in time. Thus, while the overall picture is one of an apparently adequate diet, there have clearly been instances of dietary compromise. There is no indication of a sexual or developmental bias in the distribution of calories to individuals in the sample. In addition, there is no evidence to suggest differences in the distribution of calories by source (e.g., males or children eating more animal protein). It should be emphasized that the stable isotope ratios and trace mineral assays represent diet over the entire lifespan. Caloric shortages or short-term shifts in dietary emphasis cannot be determined by these techniques. Indeed, an individual who has succumbed to starvation might show an adequate overall dietary picture by these criteria. These data are best evaluated against morphological indicators of nutritional stress, such as those previously noted in Burials $1,4 \mathrm{~A}$, and 5 .

Overall, these results imply that the Hurricane Hill individuals suffered no unusual dietary stresses. The ultimate test of nutritional adaptation, a decrease in morbidity and mortality accompanied by increased lifespan, can only be made with a population large enough to calculate demographic life tables (examples of this approach include demographic assessments of the prehistoric Arikara by Ubelaker [1978:95] and Merchant and Ubelaker [1977:61-72]).

\section{Cremations}

Nine of the burial features from the Hurricane Hill site are cremations (Table 12-7). Most of these features are small, "posthole"-appearing pits, but several others are pits more than $1 \mathrm{~m}$ in diameter. Although some are grouped together (see Chapter 6), most are solitary and vary in depth. While the extended burials are correlated with Early to Middle Caddoan period temporal contexts (i.e., A.D. 10001400), all of the cremation features, and the bundle burials, appear to be associated with Late Archaic to Early Ceramic period occupations at Hurricane Hill (ca. 800 B.C.-A.D. 800).

The absence of complete burials from the Early Ceramic period occupation and the only extended burials in the Early-Middle Caddoan components certainly indicate a change in mortuary practices over time. Both the Early Ceramic and Caddoan burial features contain single and multiple individuals, though multiple individuals ( $>2-3$ minimum numbers of individuals; see Appendix XVIII) appear to be more common in the cremations. For instance, the Burial 7 (Feature 25) cremation had at least two individuals, including one subadult on the basis of a deciduous incisor and an adult female. Burial 11 (Feature 64) contains an adult's calcined femoral midshaft that was burned in "wet" condition (i.e., in the flesh) along with an older adult and a juvenile, while Burial 8 (Feature 55) had the cremated remains of two adults, one of whom was male. Finally, Burial 12 (Feature 65) contained the cremated remains of an adult and a child. From this information on age and sex, adults, subadults, and children of both sexes were cremated at the Hurricane Hill site.

In general, the cremation pits contain large amounts of burned bone fragments (ca. $10 \mathrm{~g}$ to $>8$ $\mathrm{kg}$ ). This also suggests that several individuals' cremated remains were co-interred in 44 percent of the cremation features. With the exception of the Burial 11 (Feature 64) cremation, it is impossible to discern whether the bones were routinely burned in the flesh or macerated first. One piece of evidence suggests that some attempt might have been made to deflesh bone prior to burning (Burial 6, although this is probably unrelated to the process of cremation used during Late Archaic/Early Ceramic times because Burial 6 dates to the Middle Caddoan period). The bones, all of which were burned "green" (i.e., fresh) appear to have been subjected to a temperature range of $700-900^{\circ} \mathrm{F}$ on the basis of their texture and color (Trotter and Peterson 1955:350-355). 
Table 12-7. Cremations.

\begin{tabular}{|c|c|c|c|c|}
\hline Feature/Burial & Condition & Weight(g) & Ochre & Individuals \\
\hline 25/B7 & calcined/charred & 1436 & ++ & $\begin{array}{c}\text { several } \\
(>2 \mathrm{MNI})^{\mathrm{a}}\end{array}$ \\
\hline 55/B8 & calcined & 1180 & - & $\begin{array}{r}\text { several } \\
(>2 \mathrm{MNI})\end{array}$ \\
\hline 60/B9 & calcined & 121 & - & one \\
\hline 63/B10 & calcined/charred & 171 & - & one \\
\hline 64/B11 & calcined/charred & $2500+$ & - & $\begin{array}{c}\text { several } \\
(>3 \mathrm{MNI})^{\mathrm{a}}\end{array}$ \\
\hline 65/B12 & light brown/charred & 8078 & - & $\begin{array}{c}\text { several } \\
(>2 \mathrm{MNI})^{\mathrm{a}}\end{array}$ \\
\hline $81 / \mathrm{B} 16$ & yellow/orange & 10 & + & one \\
\hline 90/B17 & yellow & 250 & - & one \\
\hline 18/B19 & calcined & NA & - & one \\
\hline
\end{tabular}

a Includes at least one subadult

+ presence of ochre

++ ochre is abundant

Two of the cremation features (Burials 7 and 16) contain burned bone that has been covered with ochre (see Table 12-7). The ochre is oxidized, suggesting the possibility that the cremation deposits reflect multiple episodes of burning. Certainly the stratified cremated deposits in Burial 7 indicate multiple episodes of burning for one feature (see Chapter 6 , this volume).

\section{Summary}

Despite the many limitations of the skeletal sample, it is possible to conclude that the population of Hurricane Hill was not significantly different in its overall level of biological adaptedness from contemporaneous Caddoan groups (see Wilson and Steele 1997). Comparisons with other Caddoan populations must be restricted to features of diet/nutrition, and skeletal and dental pathology.

Other limitations on comparisons have less to do with the skeletal remains themselves than with a lack of systematic chemical assessment of diet at the time in other Caddoan samples. This situation has changed since the early 1990s (see discussion in Chapter 16, this volume) Future bioarchaeological analyses will profit from the increased use of trace and isotopic evidence, and correlation of these with standardized radiography where samples permit. As these practices become commonplace, a more comprehensive picture of biological adaptation in the Caddo and their ancestors will be achieved. 



\title{
CHAPTER 13, VERTEBRATE FAUNA FROM HURRICANE HILL
}

\author{
Bonnie C. Yates \\ Introduction
}

The excavations at Hurricane Hill resulted in the retrieval of approximately 50,000 pieces of vertebrate bone from several different parts of the site. Of these, about 12 percent was identified to the taxonomic level of class or lower (e.g., family, genus, or species). All classes of vertebrates are represented, although mammals are clearly dominant. Table 13-1 presents the identified taxa, the number of identified specimens (NISP) for each, the percentage of each taxon in the total composition, and minimum number of individuals (MNI) for those vertebrates identified to the family, genus, or species level.

Table 13-1. Vertebrate fauna recovered from Hurricane Hill

\begin{tabular}{|c|c|c|c|c|}
\hline Taxon & Habitat ${ }^{a}$ & NISP $^{b}$ & Percent $^{\mathrm{c}}$ & M \\
\hline \multicolumn{5}{|l|}{ FISHES $(\mathrm{n}=367)$} \\
\hline Lepisosteus osseus (longnose gar) & A & 1 & .01 & 1 \\
\hline$\overline{\text { Lepisosteus sp. (gar) }}$ & A & 18 & .30 & 1 \\
\hline cf. Noturus sp. (madtomcatfish) & A & 2 & .03 & 1 \\
\hline Ictalurus sp. (cf. channel catfish) & A & 45 & .86 & 3 \\
\hline Amia Calva (bowfin) & A & 17 & .33 & 1 \\
\hline cf. Anguilla rostrata (eel) & A & 1 & .01 & 1 \\
\hline Aplodinotus grunniens (drum) & A & 2 & .03 & 1 \\
\hline cf. Micropterus salmoides (largemouthbass) & A & 1 & .01 & 1 \\
\hline Lepomis sp.(sunfish) & A & 2 & .03 & 1 \\
\hline cf. Lepomis gulosus (warmouth) & A & 1 & .01 & 1 \\
\hline cf. Pomoxis annularis (white crappie) & A & 1 & .01 & 1 \\
\hline Centrarchidae (bass/sunfish) & A & 13 & .25 & - \\
\hline Osteichthyes (indet. fishes) & A & 263 & 5.06 & - \\
\hline
\end{tabular}

AMPHIBIANS $(\mathrm{n}=32)$

Rana catesbiana (bullfrog)

cf. Rana utricularia (southern leopard frog)

cf. Scaphiopus holbrooki (spadefoot toad)

Anura (toads/frogs)

$\begin{array}{ll}\text { A } & 4 \\ \text { A } & 1 \\ \text { W } & 2 \\ \text { A B } & 25\end{array}$

.07

.01

.03

$\begin{array}{lll}\text { A, B } & 25 & .48\end{array}$

REPTILES $(\mathrm{n}=1121)$

Chelydra serpentina (snapping turtle)

Pseudemys scripta (red-eared slider)

Terrapene sp. (box turtle)

Terrapene ornata (ornate box turtle)

Kinosterni dae (musk/mudturtles)

Kinosternon cf. subrubrum (eastern mudturtle)

Graptemys cf. kohnii (Miss. mapturtle)

Testudines (indet. turtles)

$\begin{array}{llll}\text { A } & 2 & .03 & 1 \\ \text { A } & 8 & .15 & 1 \\ \text { W, B } & 144 & 2.77 & 4 \\ \text { W, G } & 1 & .01 & 1 \\ \text { A } & 20 & .38 & 2 \\ \text { A } & 1 & .01 & 1 \\ \text { A } & 1 & .01 & 1 \\ - & 904 & 17.40 & -\end{array}$

Colubridae (non-poisonous snakes)

cf. Diadophis punctatus (ringneck)

Viperidae (poisonous snakes)

Serpentes (indet. snakes)

$\begin{array}{ll}\mathrm{V} & 4 \\ \mathrm{~W} & 1\end{array}$

$\begin{array}{ll}\mathrm{W} & 1 \\ \mathrm{~V} & 7\end{array}$

Anolis carolinensis (green anole)

W, B

18

.07

.07
.01

.13

.34

.01

$\mathrm{MNI}^{\mathrm{d}}$ 
Table 13-1. Vertebrate fauna recovered from Hurricane Hill, cont.

\begin{tabular}{|c|c|c|c|c|}
\hline Taxon & Habitat $^{\mathrm{a}}$ & NISP $^{\mathrm{b}}$ & Percent $^{c}$ & $\mathrm{MNI}^{\mathrm{d}}$ \\
\hline cf. Crotaphytus & $\mathrm{W}$ & 1 & .01 & 1 \\
\hline cf. Şinella lateralis (ground skink) & W & 1 & .01 & 1 \\
\hline Cnemidophorus sexlineatus (6-lined racerunner) & WE, G & 1 & .01 & 1 \\
\hline$\overline{\text { Lacertilia (indet.lizards) }}$ & - & 6 & .10 & - \\
\hline \multicolumn{5}{|l|}{ BIRDS $(n=68)$} \\
\hline Anas acuta (pintail) & A & 1 & .01 & 1 \\
\hline cf. Accipiter cooperii & W & 1 & .01 & 1 \\
\hline Falconiformes (hawk sp.) & - & 1 & .01 & - \\
\hline Meleagris gallopavo (wild turkey) & WE & 31 & .56 & 2 \\
\hline Tympanuchus sp.(prairie chicken) & G & 1 & .01 & 1 \\
\hline Colinus virginianus (bobwhite) & WE, G & 1 & .01 & 1 \\
\hline Ardea herodias (great blue heron) & A & 1 & .01 & 1 \\
\hline Passeriformes (perching bird) & - & 3 & .05 & 1 \\
\hline Aves (indet. birds) & - & 28 & .51 & - \\
\hline \multicolumn{5}{|l|}{ MAMMALS ( $\mathrm{n}=3606)$} \\
\hline Didelphis virginiana (opossum) & W & 5 & .09 & 1 \\
\hline Cryptotis parva (least shrew) & W, G & 3 & .05 & 1 \\
\hline Scalopus aquaticus (eastern mole) & $\mathrm{s}$ & 4 & .07 & 2 \\
\hline Lasiurus cf. borealis (red bat) & W & 1 & .01 & 1 \\
\hline Sylvilagus floridanus (cottontail) & WE & 583 & 10.62 & 12 \\
\hline Sylvilagus aquaticus (swamp rabbit) & B & 12 & .21 & 1 \\
\hline Lepus californicus (jackrabbit) & G & 5 & .09 & 1 \\
\hline Lagomorpha (swamp/jack) & - & 76 & 1.38 & $=$ \\
\hline Scuirus cf. niger (fox squirrel) & $B, W$ & 95 & 1.73 & 2 \\
\hline$\overline{\text { Scuirus }}$ carolinensis (gray squirrel) & $\mathrm{B}, \mathrm{W}$ & 2 & .03 & 1 \\
\hline Geomys bursarius (pocket gopher) & $\mathrm{s}$ & 319 & 5.80 & 23 \\
\hline Perognathus hispidus (pocket mouse) & G & 1 & .01 & 1 \\
\hline Castor canadensis (beaver) & A & 10 & .19 & 1 \\
\hline cf. Oryzomys palustris (rice rat) & A & 1 & .01 & 1 \\
\hline Peromyscus sp. (white-footed mice) & $\mathrm{V}$ & 12 & .21 & 3 \\
\hline Sigmodon hispidus (cotton rat) & G, WE & 12 & .21 & 1 \\
\hline Neotoma floridana (wood rat) & $\mathrm{B}, \mathrm{W}$ & 4 & .07 & 1 \\
\hline Microtus sp.(vole) & V & 45 & .86 & 8 \\
\hline Rodentia (rodents) & $\mathrm{V}$ & 344 & 6.62 & - \\
\hline Canidae (dogs) & $\mathrm{V}$ & 3 & .05 & 1 \\
\hline Urocyon cinereoargenteus (gray fox) & V & 2 & .03 & 1 \\
\hline Procyon lotor (raccoon) & $\mathrm{B}, \mathrm{W}$ & 22 & .42 & 2 \\
\hline Mephitis mephitis (striped skunk) & $\mathrm{V}$ & 1 & .01 & 1 \\
\hline cf. Felis concolor (cougar) & V & 1 & .01 & 1 \\
\hline Odocoileus virginianus (white-tailed deer) & WE & 747 & 24.75 & 15 \\
\hline Antilocapra americana (pronghorn) & G & 1 & .01 & 1 \\
\hline cf. Cervus elaphus (wapiti) & WE & 1 & .01 & 1 \\
\hline Artiodactyla (bos/bison/elk) & $\mathrm{V}$ & 4 & .07 & - \\
\hline Artiodactyla (goat/pronghorn) & $\mathrm{V}$ & 1 & .01 & - \\
\hline Mammalia (large sp.) & - & 307 & 5.91 & - \\
\hline Mammalia (mediumsp.) & - & 203 & 3.90 & - \\
\hline Mammalia (small sp.) & - & 240 & 4.62 & - \\
\hline Total Identified Bone & & 5194 & 100.00 & 124 \\
\hline
\end{tabular}

${ }^{a}$ Preferred habitat (Davis 1974; Ernst and Barbour 1972; Robbins et al. 1966; Schmidly 1983):

$\mathrm{A}=$ aquatic (rivers, swamps, marshes)

$\mathrm{B}=$ bottomlands (riparian habitats)

$\mathrm{G}=$ grasslands (brush, prairies) 
$S=$ sandy soils (alluvium)

$\mathrm{V}=$ various (more than one habitat)

$\mathrm{W}=$ woodlands (deciduous or pine forests)

$\mathrm{WE}=$ wooded edges (openmeadows, parkland)

$\mathrm{b}_{\mathrm{NISP}}=$ Number of identified specimens

${ }^{\mathrm{c}}$ Percent of identified fauna

$\mathrm{d}_{\mathrm{MNI}}=$ Minimum number of individuals

The methods used to conduct this zooarchaeological analysis are standard identification techniques using comparative skeletal material, which in this case is housed at the Institute of Applied Sciences at the University of North Texas. All bone was sorted and washed and originally quantified by screen size. Potentially identifiable bone was separated and identified to the lowest possible taxonomic level and recorded for computer encoding. Attributes of skeletal element, portion of element, side of body, and age were noted; aspects of the condition (state of burning, taphonomy, modification) of the bone were also noted.

From these tabulations, NISP was calculated and MNI was estimated using adapted methods from Grayson (1984), Chaplin (1971), and Ziegler (1973). Although the data were collected and organized by provenience (unit and level), the present analysis is concerned with the assemblage as a whole, reflecting the fauna associated with the Early and Middle Caddoan periods components. These data are on file at the Institute of Applied Sciences and with the contracting agency as stipulated in the Scope of Work (see also Appendix XIV).

Several assumptions are in operation when analyzing faunal materials from archaeological sites. Because of differential destruction, the faunal assemblage can never precisely reflect the relative proportion of species used by a site's inhabitants (Davis 1984:113). Therefore, bone counts such as NISP provide only an indication of broad trends in prehistoric subsistence strategies. It is also assumed that a representational sample was collected from the site. In the case of Hurricane Hill, samples were collected from a variety of features, outlying areas, and block excavations, and thereby assuring an expansive coverage of the site. Lastly, one assumes that the animals are associated with the archaeological materials with which they are found, unless obvious intrusion is indicated.

Preservation factors play a crucial role in how the faunal assemblage is interpreted. The potential for identification is directly affected by variable preservation, as is their horizontal and vertical distribution. Preservation of bone in the middens was good, probably due to the normal $\mathrm{pH}$ of the soil matrix (pH 4.8). Calcium carbonate encrustation was not a problem, but some of the bones were stained, root-etched, and in some cases, decorticated--a process in which the inner compact bone is weakened and the outer cortex separates from the inner core. Decortication is a type of exfoliation coined to describe deterioration of some unburned bones that otherwise are undamaged. This phenomenon is being investigated as a diagenetic soil process to determine the possible causes and conditions under which it occurs. Otherwise, gnawing by rodents and carnivores has caused the greatest frequency of damage noted in the faunal remains.

Heavier clay content in some portions of the site caused damage to coarse-screened material due to unavoidable breakage during water screening. The majority of the material in the unidentified fraction, however, are small fragments of large mammal bone exhibiting fresh breaks that probably occurred during this processing. Fine-screen and flotation samples fared better, and this facilitated the accumulation of a sizable collection of microfaunas.

\section{Environmental Reconstruction}

The animals represented in this assemblage are typical of the eastern extremes of the Texan biotic province as described by Blair (1950), in which faunas of the Southeastern temperate forests reach their western limits. The Texan biotic province is an immense ecotone where eastern mesic forms coexist with western xeric forms brought together by the interdigitation of streamside forestlands with parklands or grasslands. This ecotonal character allows for optimal exploitation of a diversity of animal and plant life. This diversity is reflected by the species list from Hurricane Hill.

Table 13-1 also indicates the preferred habitat of the animals represented in the samples. Aquatic species are quite numerous, but their contribution to the meat diet of the site's inhabitants is difficult to 
assess because the bones of small fishes and amphibians do not preserve well and because of the complexity in interpreting and quantifying turtle remains. Woodland animals, including creek bottomland denizens, are the most numerous, while grassland animals are fairly rare. For example, no bison bones were identified, and pronghorn is represented by only one tooth specimen. These two grassland herbivores may have added substantial amounts of meat to the occupants' diet, but the osteological evidence would not likely become part of the archaeological record if the animals were killed and thoroughly butchered at a location distant to the site (i.e., the Schlepp effect, Daly 1969; Perkins and Daly 1968:104). On the other hand, with such abundance and variety of game as an ecotone provides, the hunters would not need to go very far afield to procure meat.

Another animal that is conspicuous by its absence is bear. Bear bones are surprisingly rare in faunal lists for any Caddoan sites (prehistoric or historic), and yet the importance of bear for its meat, fat, and teeth is well documented in the ethnographic record (Swanton 1911:67-69, 1942:137,157; LePage du Pratz 1774:248). It may be that because bear prefer heavily forested areas, the Schlepp effect is again affecting the archaeological record, and that only bear meat and fat were returned to the site from hunting trips to forests farther east.

Taken as a whole, the animals from the Hurricane Hill archaeological deposits indicate that the woodland edges were hunted most extensively by its Caddoan occupants. These areas are niches for deer, rabbit, and turkey. Considering the geographic location of the site and the absence of osteological traits for mule deer, the species of deer represented in this assemblage is considered to be Odocoileus virginianus or white-tailed deer. Three species of rabbits have been identified from the site, but it is the Eastern cottontail, Sylvilagus floridanus, that prefers the woodland edge habitat and is represented by at least 12 individuals. The most frequent avian remains are from turkey, another edge dweller, and in this case is probably represented by the Eastern wild turkey, Meleagris gallopavo silvestris. According to Schorger (1966:45), the western limit of this turkey is dependent on rainfall, and that it "does not appear to occur where the anmual rainfall is below 25 inches."

White-tailed deer is the taxon with the highest NISP and undoubtedly this species provided the most meat protein. Medium-size mammals are not particularly abundant; however, those that are represented (opossum, fox, raccoon, and skunk) are omnivores that inhabit various niches and tend to compete with the human hunters for certain foods. The value of these medium-size mammals is their pelts, which in winter become luxuriant and more highly prized than at other seasons. The small animals and rodents are from a wider variety of habitats and are well represented. While it cannot be demonstrated that each individual rodent was deposited at the site as meal refuse, some are burned, and most are present as a singular element in a given provenience instead of as isolated carcasses resulting from natural taphonomic events.

These small animals and rodents were obviously available and certainly edible. Rodents such as squirrels, woodrats, and pocket gophers can weigh as much as one kilogram in live weight, and many of these bones have been found burned in this assemblage. Smaller rodents such as rice rat, cotton rat, voles, and mice may be intrusive to the midden deposits; however, human coprolite studies from drier sites in South Texas have documented the presence of bones and hair from small mammals such as these (e.g., Williams-Dean 1978).

Small animals also provide clues to the nature of the surrounding environment. Using two small animals as examples: the mutually exclusive presence of a woodland lizard (green anole) and a lizard that prefers more open habitat (six-lined racer) indicates that the site was probably situated in a location where a variety of habitats was accessible. Many rodents species are restrictive in habitat requirements, and although it is sometimes not possible to identify rodents to the species or subspecies level in order to qualify which habitat is suggested by their presence, zooarchaeological investigations can contribute to zoogeography. For example, the voles have very specific habitat needs, and some species have been used to track paleoenvironmental changes through time (Semken 1983; Semken and Falk 1987). At Hurricane Hill, most of the teeth of microtines all compare better to the prairie vole (Microtus ochrogaster), a grassland species that is now extirpated from much of East Texas (Schmidly 1983:306).

The abundance of aquatic forms in the faunal remains suggests the proximity of the site to water, and the high NISP and MNI of woodland-edge species suggest heavy exploitation of that habitat. Grassland species are rare and may reflect utilization of pockets of prairie grasses interspersed within the woodlands 
and bottomlands. A General Land Office description of the site area in 1840 (Chapter 2, this volume) confirms the above environmental reconstruction, which is based solely on the natural history of identified fauna found in association with archaeological materials at Hurricane Hill.

\section{Distribution of Faunal Remains}

Midden 1 on the North rise yielded the majority of identifiable bone $(n=5,012)$. This material is associated with Structures D and $E$ just a few meters south of the midden. Within the midden, two features (Features 4 and 34) appear to be focal points for the clustering of deer bone. The deer bone is not directly associated with the two hearths, but rather it is found surrounding the hearths as if when the hearths were used, the meat on the bone was cooked, and the inedible bone elements were tossed aside. Two of the bone fishhooks were also found in the periphery of Feature 34 (see Chapter 11, this volume, Bone Artifacts). Fish bone also clusters around that feature and others in the block.

The larger block excavation at the South rise (Block B/C) only produced 266 identified animal bones. This rather paltry amount of bone suggests a different treatment of the food refuse from the structures there than what was seen at the North rise. Either the bone was deposited in an area outside our excavations, or it was deposited in areas in which the soil conditions accelerated the deterioration of the osseus remains (e.g., low moist areas). The distribution (see Figures 7-16 and 7-17) of bone from this rise shows that the bone was scattered around the central hearth area, and extended in concentrations near where the entrances to the two superimposed structures would have been.

Vertically, the bone is concentrated in the upper $30 \mathrm{~cm}$ of each rise. Fully 62 percent of the identified bone comes from the first $30 \mathrm{~cm}$ of the North rise in Midden 1. Table 13-2 gives the identified bone counts for each level by excavation block.

Table 13-2. Number of identified bones in each excavation block.

\begin{tabular}{|c|c|c|c|c|c|}
\hline \multirow[t]{2}{*}{ Levels } & \multicolumn{3}{|c|}{ Blocks } & \multirow[b]{2}{*}{$\mathrm{E}$} & \multirow[b]{2}{*}{ Total } \\
\hline & A & $\mathrm{B} / \mathrm{C}$ & $\mathrm{D}$ & & \\
\hline 1 & 38 & 9 & 2 & 1 & 50 \\
\hline 2 & 1070 & 95 & 5 & 4 & 1174 \\
\hline 3 & 1266 & 83 & 12 & 7 & 1368 \\
\hline 4 & 1111 & 37 & 9 & 3 & 1160 \\
\hline 5 & 929 & 19 & 19 & 7 & 974 \\
\hline 6 & 444 & 20 & 2 & - & 466 \\
\hline 7 & - & - & 2 & 2 & 4 \\
\hline Total & 4858 & 263 & 51 & 22 & 5194 \\
\hline
\end{tabular}

\section{Behavioral Inferences}

\section{Seasonality}

The faunal remains indicate that the site was occupied during all seasons of the year. Mixing of the material in the middens and the overlapping of structures prohibit segregation of the bones into discrete assemblages that would allow exact seasonality determination by occupation episode. Furthermore, those assemblages would lack the sample sizes necessary to make any behavioral determinations with certainty. 
However, inferences may be made concerning which faunas were exploited during each season. For example, the centrarchid fish found in the assemblage would probably have been taken during the spring spawning runs. The three young fawns were killed during the summer before they reached six months of age. The pintail duck could have been taken either in its spring or fall migration through the area. Lastly, a deer cranium with a shed antler pedicle indicates a late winter kill. The rest of the animals on the species list would have been available all year.

\section{Hunting/Fishing Practices}

The presence of many small animals in this collection suggests that entire families participated in procuring meat. Deer hunting is generally considered the domain of the male member of a group, but if all of the taxa represented here were consumed, most likely the women and children obtained the small animals in passive hunting techniques. These techniques abound in ethnographic literature for a variety of American Indian tribes, but can only be used with caution in extrapolating behavior to the Early/Middle Caddoan occupants of the Hurricane Hill site. Nevertheless, while the precise methods may differ among tribes, some generalities may be made. For example, Ohiyesa, a Sioux, (Eastman 1974) recalls that the play of young Indian boys was in emulation of the hunting skills of their fathers. They used bow strings, sinew, or horsehair to make snares to catch small animals, such as rabbits, squirrels, gophers, and birds (Eastman 1974:42-44).

Fish were trapped in basketry cages, speared, or caught by hand after being driven into the shallows. Swanton (1942:138) recounts from Henri Joutel's 1687 diary that the Caddo used a kind of trot line to which:

...other little lines are fastened along the entire length about a foot apart. At the end of each line is a fish-hook upon which they put a little piece of hominy dough or a little piece of meat. With these they do not fail to catch fishes weighing more than fifteen to twenty pounds.

It is not known if all of the hooks used in this way were curved like the ones recovered from Hurricane Hill or if they were used as part of composite bone hooks; that is, bone points hafted to wooden shanks (Figure 13-1). Turtles are another type of animal that could have been taken by any member of a household. The terrestrial box turtle may be encountered almost anywhere along wooded edges and requires no special hunting paraphernalia. Aquatic turtles are quick to swim away if threatened when basking, but can be trapped in fishing weirs and nets. From the faunal evidence, turtles formed an important resource in the subsistence economy of the site inhabitants. Turtle shell was ubiquitous from all blocks. Although the MNI is not very impressive per species, it was observed that many different species could be found in a single provenience among only a handful of shell fragments. Therefore, it is concluded that the quantity of turtle shell is not merely a factor of breakage of a few carapaces, but rather that many more individuals were consumed than the MNIs indicate. Burning patterns amongst the turtle shell debris further indicate that the carapaces, of box turtles especially, were used as hearth vessels.

Terrestrial birds such as turkey, prairie chicken, and bobwhite quail indicate exploitation of the grassy areas along the edges of the woods. By virtue of meat weight, the wild turkey is of greater economic importance. Wild turkey is represented by only two individuals, but more individuals are suggested by the many large bird long bone fragments in the unidentified flotation and fine-screen fractions. Schorger (1966:377-381) describes a variety of methods used by North American Indians to hunt turkeys that included the use of snares, circular drives into pens or trees, blowguns, lures and decoys. In the ethnographic accounts of Caddoan animal food uses written by Europeans and cited by Swanton (1942:135), "bustards" are usually interpreted to be turkeys, but no method of hunting is explicated.

White-tail deer is the unequaled meat staple represented in this sample. Edible meat weight estimates (Table 13-3) indicate that 86 percent of the total amount of meat represented by the faunal remains was contributed by deer. Bones of deer are found in nearly every provenience, and at least $15 \mathrm{MNI}$ are recorded. The MNI for deer is based on 12 right astragali, a dense and durable ankle bone, and three fawns aged at death at less than six months old. Based on edible meat weight estimates (White 1953), these deer would have provided about 1500 pounds of venison. This is somewhat misleading because it is based on the combined proveniences at the site. Most likely, many more deer are actually represented in the faunal assemblage than can be estimated using the traditional and conservative MNI methods. 
Throat Gorges

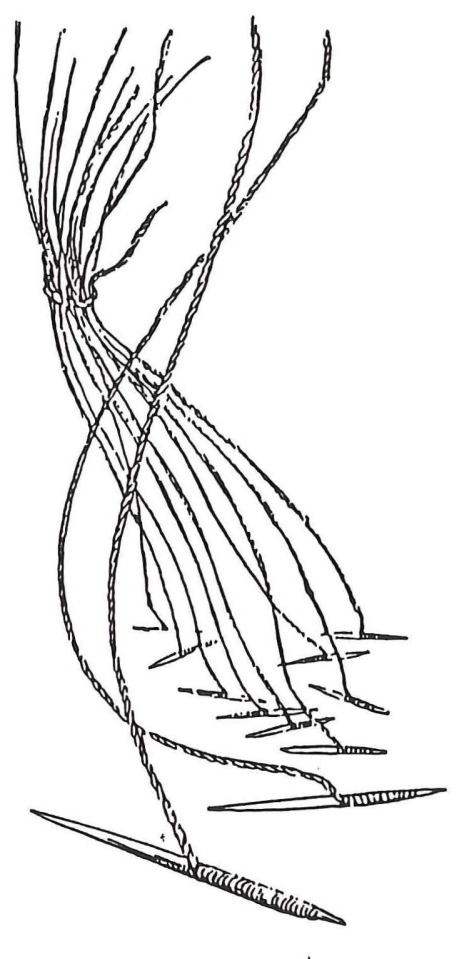

Miscellaneous Hooks

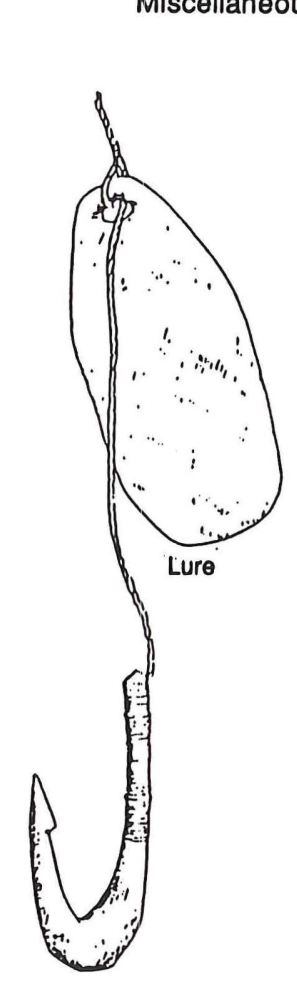

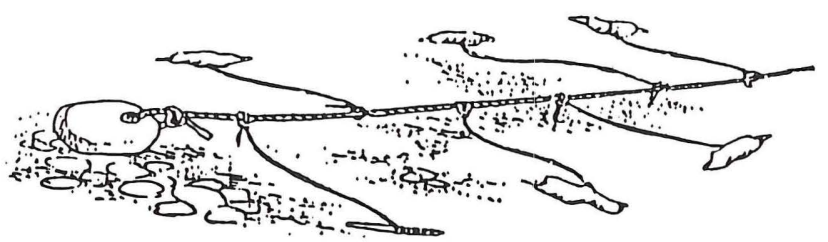

Figure 13-1. Types of aboriginal fishing apparatus (from Stewart 1977).

Butchering marks were observed on many deer bones from the assemblage, and they conform to typical skinning, dismembering, and filleting loci on a carcass. Skinning marks were found on phalanges and across the shafts of metapodials. Marks are present at the foreleg joint, indicating disarticulation of the humerus and radio-ulna, and at the hindleg joint on the distal femur and proximal shaft of the tibia. Filleting marks occur on neural spines of the vertebrae but are not recorded on typical loci on the scapular spine or shafts of long bones. Transverse marks across the posterior shaft of the calcaneum were noted, and these have been suggested by Binford (1981:119) to be cuts made to insert a rope or gambrel between the bone and the strong tendon at that location in order to hang the carcass for further processing. 
Table 13-3. Dietary Contribution of Major Species.

\begin{tabular}{llccc}
\hline Taxon & MNI & $\begin{array}{l}\text { Edible } \\
\text { Meat Wt }\end{array}$ & $\begin{array}{l}\text { Total } \\
\text { Yield }\end{array}$ & Percent \\
\hline White-tailed deer & 15 & 36.32 & 544.80 & 85.95 \\
Pronghorn & 1 & 36.32 & 36.32 & 5.73 \\
Cottontail & 12 & .91 & 10.92 & 1.72 \\
Wild turkey & 3 & 3.86 & 11.58 & 1.83 \\
Raccoon & 2 & 3.86 & 7.72 & 1.22 \\
Beaver & 1 & 9.08 & 9.08 & 1.43 \\
Swamp/Jackrabbit & 2 & 2.59 & 5.18 & 0.82 \\
Pocket gopher & 23 & 0.17 & 3.91 & 0.62 \\
Gray fox & 1 & 2.27 & 2.27 & 0.36 \\
Fox/Gray squirrel & 3 & 0.68 & 2.04 & 0.32 \\
\hline & & & & \\
Total & 63 & & & \\
\end{tabular}

\section{Dog Burial}

Feature 37 on the South rise contained the poorly preserved remains of a dog, probably a domestic pet. Discovered only after extensive damage had occurred to the bones, very little bone from the dog was available for analysis. Portions of the maxilla, mandible, and various long bone shaft fragments were recorded. Unfortunately, none of the remains were complete enough to measure. Even the canine teeth were so badly preserved that it was impossible to surmise the age of the individual. Its remains were recovered from a shallow pit southeast of the superimposed Middle Caddoan period structures on the South rise.

Dog burials are commonplace in Caddoan sites. They have been recorded at the Arnold site (41HP102) (Henderson 1978a) and at the Manton Miller site (41DT2) (Johnson 1962) in the Cooper Lake reservoir area. Isolated canid remains have been reported at Cox (41HP105) (Hyatt et al. 1974:53; Butler 1975:64), and from the excavations by SMU at Thomas (41DT80), Lawson (41HP78), and Doctor's Creek (41DT124) (Yates 1997). Outside the project area, contemporary and later Caddoan dog burials are known from such sites as Mahaffey (34CH1) (Perino and Bennett 1978:12), Steck (41WD529) (Butler and Perttula 1981:123), Arnold Roitsch and Bob Williams (41RR16) (Perttula et al. n.d.; Perino 1983), DeShazo (Henderson 1982), and many other Caddoan sites in Northeast Texas described by A. T. Jackson (Wilson and Jackson 1930; Jackson 1932).

\section{Conclusions and Inter-site Comparisons}

Previous zooarchaeological investigations at Cooper Lake vary in scope and treatment but generally are in agreement concerning the overall species composition and resource utilization of Caddoan groups living in the area. Barbara H. Butler studied samples from early excavations at Cox, Thomas, and Lawson by Hyatt and co-workers in 1970-1972 (Hyatt et al. 1974) and again in 1973 at Manton Miller and Cox (Hyatt and Doehner 1975). Jerry Henderson examined an enormous quantity of bone from the Arnold site $(n=83,408)$ and from Spike $(n=26,700)$, as well as smaller samples from the Tick (41DT6) and Luna (41DT52) sites (Doehner et al. 1978; Doehner and Larson 1978). Both did admirable work in reconstructing the resource base of animal protein from the Sulphur River valley as reflected in the vertebrate faunal remains.

The present study of faunal remains from Hurricane Hill fully corroborates their findings. The species lists from the larger samples are very similar, including deer as the staple dietary contributor and with an occasional occurrence of pronghorn, gray fox, and beaver. Rodents and non-mammalian species complement the subsistence regimes in much the same composition (Table 13-4). 
Table 13-4. Intersite Comparisom of Minimum Number of Individual Vertebrates ${ }^{\text {a }}$ from Selected Sites at Cooper Lake.

\begin{tabular}{|c|c|c|c|c|c|c|}
\hline Taxon & Hurricane Hill & 1 Arnold & Miller & Cox & Luna & Spike \\
\hline White-tailed Deer & 15 & 126 & 22 & 24 & 8 & 4 \\
\hline Cottontail & 12 & 72 & 8 & 6 & 5 & 8 \\
\hline Pocket Gopher & 23 & 48 & - & 1 & 2 & 6 \\
\hline Swamp Rabbit & 1 & 16 & - & - & - & 1 \\
\hline Jack Rabbit & 1 & 5 & 1 & - & 1 & 2 \\
\hline Opossum & 1 & 17 & 1 & 1 & - & 1 \\
\hline Raccoon & 2 & 50 & 10 & 8 & 1 & 5 \\
\hline Fox/Gray Squirrel & 3 & 38 & - & 3 & 1 & 3 \\
\hline Beaver & 1 & 7 & - & 2 & 1 & 1 \\
\hline Gray Fox & 1 & 9 & - & 1 & 1 & - \\
\hline Skunk & 1 & 4 & 1 & 2 & - & 1 \\
\hline Mink & - & 2 & 2 & 3 & 1 & - \\
\hline Bobcat & - & 1 & - & - & - & - \\
\hline Dog/Coyote & 1 & 13 & 1 & 2 & - & 1 \\
\hline Vole & 8 & - & - & 1 & - & 3 \\
\hline Cotton Rat & 1 & 7 & - & 1 & 1 & 1 \\
\hline Woodrat & 1 & - & - & 1 & - & - \\
\hline Ground Squirrel & - & 1 & - & - & - & - \\
\hline Pocket Mouse & 1 & 4 & - & - & - & 1 \\
\hline \multicolumn{7}{|l|}{ White-footed } \\
\hline Mouse & 3 & 4 & - & - & - & 1 \\
\hline Pronghorn & 1 & 1 & - & - & 1 & - \\
\hline Bison/Cattle & - & - & - & - & $1 ?$ & $1 ?$ \\
\hline Wild Turkey & 3 & 56 & $8 ?$ & 2 & 2 & 4 \\
\hline Prairie Chicken & 1 & - & - & - & - & - \\
\hline Quail & 1 & - & - & - & - & - \\
\hline Duck/Grebe & 1 & - & - & - & - & - \\
\hline Box Turtle & 4 & 1 & - & 6 & 2 & 6 \\
\hline
\end{tabular}

aselected species based on MNI abundance at Hurricane Hill and other sites at Cooper Lake. Zooarchaeological data for the Arnold, Cox, Luna, and Spike sites were taken from Henderson (1978b), and that from the MantonMiller site were taken from Johnson (1962).

Exceptions to this comparability exist in isolated occurrences of bird and snake species and a few mammals, namely mink, 13-lined ground squirrel, and bobcat. These species occur at Arnold, along with mink at the Cox site, but not at Hurricane Hill.

The conclusions reached by these previous investigators are reflected in the present study:

1. the faunal subsistence base is similar throughout the Cooper Lake area during the Early to Middle Caddoan settlement of the area;

2. three local environmental zones were exploited: aquatic, forest, and grassland; and

3. the greatest reliance was on game that frequented the edges of the wooded areas. 



\title{
CHAPTER 14, ANALYSIS OF THE MOLLUSCAN REMAINS FROM THE HURRICANE HILL SITE
}

\author{
Laurie S. Zimmerman
}

\section{Introduction}

Freshwater bivalves have been utilized by prehistoric and historic populations in Texas for millennia as food resources, tools, ornaments, grave goods, and more recently as a ceramic temper or aplastic. A sample of 446 bivalves recovered from the Hurricane Hill site (41HP106), in Hopkins County, Texas, is analyzed in order to address questions regarding diet, ecology, and cultural practices for the indigenous Caddoan populations that occupied the site from approximately A.D. 1050 to A.D. 1400.

\section{Faunal Identification}

\section{Methods}

Identification of the invertebrate faunal remains was determined by using keys (Burch 1973; Murray and Leonard 1962; Parmalee 1967; Read 1954; Starrett 1971), and then comparing the archaeological specimens to comparative taxa housed at the Zooarchaeological Research Collection in the Department of Anthropology at Texas A\&M University. In addition, specimens were also compared with published photographs, drawings (Burch 1973; Littleton 1979; Murray and Leonard 1962; Parmalee 1967; Starrett 1971), and guides illustrating the geographic distribution of Texas fauna (Strecker 1931). Identifications were made on the basis of structural features, and then the specimens were assigned to the lowest taxonomic level. A 10X hand lens and a binocular microscope were employed to examine beak sculpture as well as modified or potentially modified specimens, such as shucking, notching, cut marks, gnawing, or incising.

According to Strecker (1931), there are 59 species of bivalves that have been identified from 12 river systems in Texas (including the Red, Sabine, Neches, San Jacinto, Buffalo, Trinity, Brazos, Colorado, Guadalupe, San Antonio, Nueces, and Rio Grande). This diversity is not reflected in the present freshwater bivalve sample from the South Sulphur River. This may be attributed to either taphonomy or sample size. First, taphonomic factors affect the condition of the shell so that diagnostic morphological features may be masked; for the present study, fragmentation of specimens and weathering of beak morphology or surface sculpture resulted in more conservative taxonomic assignments. Second, the sample size is small; therefore, interpretations such as diversity, cultural preferences for particular taxa, or environmental inferences should be tempered with this knowledge.

For the present analysis, the classification scheme adopted was one developed by Burch (1973). Taxonomic changes have occurred since Burch's (1973) publication, however, and this study reflects those changes in nomenclature (see Neck 1987:III-2).

\section{Computer Coding}

All invertebrate data were recorded using a modified version of a computer coding and tabulation system originally developed by Shaffer and Baker (1992). Information was coded on raw data sheets and then entered into dBase III + . For each provenience, specimens were sorted by taxon. Each specimen was coded for the following information: block, lot, unit, level, quantity, taxon, element, portion of element, side, burning, comments, and modification (i.e., drilled/perforated, incised/grooved, polished, or notched). Appendix XIX provides pertinent details for individual bivalve specimens at the Hurricane Hill site.

\section{Quantitative Techniques}

Invertebrate material was quantified using the number of identified specimens (NISP) and the minimum number of individuals (MNI) (see Grayson [1984] for a discussion of the limitations of MNI and NISP). For this study, the presence of an umbo was the criterion used for defining an individual; the umbo 
is the projecting portion on or above the hinge line of the shell (Moore et al. 1952:403-404). Umbo fragments were divided into right and left components; those umbo fragments that were too eroded to side were also quantified. The MNI was calculated by dividing by two the number of umbo fragments which could not be sided; the result was then added to the side containing the greater number of specimens. The NISP calculation was quantified by counting umbo fragments, pseudocardinal and lateral tooth fragments, and unidentifiable fragments.

\section{Structure of the Assemblage}

The invertebrate assemblage consisted of 446 bivalve specimens recovered from three different areas of the site: Block A and Block A extension ( $n=254$ and $n=164$, respectively) on the North rise, Block $B / C$ $(n=8)$ on the South rise, and Block D $(n=20)$ on the North Rise, but south of Block A (see Chapter 4, this volume). Table 14-1 summarizes the NISP $(n=446)$ and MNI $(n=148)$ for the Hurricane Hill site.

Table 14-1. Number of Identified Specimens and Minimum Number of Individuals for each taxon recovered from the Hurricane Hill site.

$\begin{array}{llll}\text { Taxon } & \text { Common Name } & \text { NISP } & \text { MNI } \\ \text { Invertebrata Total } & & 446 & \\ & & & \\ \text { Bivalvia } & \text { Bivalves } & 7 & \\ \text { Unionacea } & \text { Freshwater mussel } & 303 & \\ \text { Amblemidae } & \text { Three-ridge } & 26 & 9 \\ \text { Amblema plicata } & \text { Maple-leaf } & 18 & 5 \\ \text { Quadrula apiculata* } & \text { Maple-leaf } & 3 & \\ \text { Quadrula of. apiculata } & \text { Muadrula of. houstonensis } & 5 & 1 \\ \text { Quadrula sp. } & \text { Quadrula } & 2 & \\ \text { Quanidae } & & 1 & \\ \text { Unionilinae } & & 31 & 7 \\ \text { Lampsilina } & 22 & 2 \\ \text { Lampsilis teres } & \text { Sand shell } & 10 & \\ \text { Lampsilis cf. hydiana } & \text { Fat mucket } & 2 & 4 \\ \text { Lampsilis sp. } & & 9 & 1 \\ \text { Toxolasma texasensis } & \text { Liliput shell } & 6 & \\ \text { Rangia sp. } & \text { Rangia } & 1 & \end{array}$

"Quadrula apiculata and Quadrula cf. apiculata have been combined in calculating the MNI.

Approximately 13 percent (57 specimens) of the bivalve remains from the assemblage could be assigned to the level of genus. Close inspection of Table 14-1 clearly shows that the bivalve assemblage from Hurricane Hill consisted primarily of four species: the Threeridge mussel (Amblema plicata); the Yellow sandshell (Lampsilis teres); the Southern mapleleaf (Quadrulaapiculata); and the Texas liliput shell (Toxlasma texasensis). Other taxa recovered and identified to the specific level included the Louisiana fatmucket (Lampsilis cf. hydiana), the Smooth pimpleback (Quadrulahoustonensis), and rangia (Rangia sp.).

Tables 14-2 through 14-5 summarize the NISP and MNI for each block excavation. Block A and Block A extension not too surprisingly reflect similar patterns as those observed for the overall site in terms of the diversity of taxa, as 94 percent of the bivalves were recovered from these adjoining blocks on the North rise. The small sample size of both Block B/C and Block D make a direct comparison untenable. 
Table 14-2. Number of Identified Specimens and Minimum Number of Individuals for each taxon recovered from Block $A$.

\begin{tabular}{|c|c|c|c|}
\hline Taxon & Common Name & NISP & MNI \\
\hline Invertebrata Total & & 254 & \\
\hline $\begin{array}{l}\text { Unionacea } \\
\text { Amblemidae }\end{array}$ & Freshwater mussel & $\begin{array}{l}190 \\
12\end{array}$ & \\
\hline Amblema plicata & Three-ridge & 8 & 5 \\
\hline Quadrula apiculata* & Maple-leaf & 3 & 4 \\
\hline Quadrula cf. apiculata & Maple-leaf & 3 & \\
\hline Quadrula cf. houstonensis & & 2 & 1 \\
\hline Unionidae & & 3 & \\
\hline Lampsilinae & & 18 & \\
\hline Lampsilis teres & Sand shell & 10 & 7 \\
\hline Lampsilis sp. & & 4 & \\
\hline Toxolasma texasensis & Lilliput shell & 1 & 1 \\
\hline
\end{tabular}

"Quadrula apiculata and Quadrula cf. apiculata have been combined in calculating the MNI.

Table 14-3. Number of Identified Specimens and Minimum Number of Individuals for each taxon recovered from Block $A$ extension.

Invertebrata Total
Unionacea
Amblemidae
Amblema plicata
Quadrula cf. apiculata
Quadrula sp.
Unionidae
Lampsilinae
Lampsilis cf. hydiana
Lampsilis sp.
Toxolasma texasensis

Common Name
Freshwater mussel
Three-ridge
Maple-leaf
Quadrula
Fat mucket
Lilliput shell

NISP

MNI

164

97

13

$10 \quad 5$

2

25

4

2

5

5
2

2

3

Table 14-4. Number of Identified Specimens and Minimum Number of Individuals for each taxon recovered from Block $B / C$.

\begin{tabular}{llll} 
Taxon & Common Name & NISP & MNI \\
\hline Invertebrata Total & & 8 & \\
Bivalvia & Bivalves & 7 & 2 \\
Rangia sp. & Rangia & 1 & 1 \\
\hline
\end{tabular}


Table 14-5. Number of Identified Specimens and Minimum Number of Individuals for each taxon recovered from Block $\mathbb{D}$.

\begin{tabular}{llll}
\hline Taxon & Common Name & NISP & MNI \\
\hline Invertebrata Total & & 20 & \\
Unionacea & Freshwater mussel & 16 & \\
Amblemidae & & 1 & 1 \\
Unionidae & & 3 & 1 \\
\hline
\end{tabular}

\section{Burned Shell}

Burning was systematically assessed for the Hurricane Hill bivalve assemblage. Approximately 49 specimens (11 percent) exhibited burning. There were 26 burned umbo fragments, nine tooth (pseudocardinal or lateral) fragments, and 14 unidentified fragments. Taxonomic identifications of burned specimens included: 43 specimens assigned to Unionacea, three specimens assigned to Amblemidae, and three specimens assigned to Unionidae. From a spatial perspective, Block A had 24 (9.5 percent of the NISP from the block) burned specimens, Block A extension had 23 (14 percent of the block NISP), and Block D had two (10 percent of the NISP) burned fragments. Only one umbo fragment found in association with a clay hearth (Block A, Feature 4) exhibited burning.

\section{Modified Shell}

Six shell specimens recovered from Hurricane Hill had the shell sharply truncated posterior to the umbo. The margin appeared to be modified or cut from the exterior to the interior; on some specimens, a lip occurred on the interior portion of the valve, and on another specimen, a lip occurred on both the exterior and interior portions. Examination of the cut surface did not reveal striations or any evidence that the shells may have been utilized. Furthermore, the specimens did not exhibit drilling or notching that may have suggested the shells were employed in ornamental and/or decorative functions.

The shells were found in Block A or Block A extension on the North rise. Table 14-6 summarizes the provenience data, taxonomic information, a brief description of the prevailing truncation pattern observed on the shell, and measurements for the modified specimens. Measurements represent the maximum length (measured from the anterior margin to the posterior margin) and maximum height (measured from the dorsal margin to the ventral margin). All measurements were taken with digital calipers.

\section{Glochidia}

Fish serve as hosts for the parasitic or glochidium stage of freshwater mussels. Certain species of mussels require a specific host fish, whereas other species use several fishes as hosts (Baker 1928:13). The length of time which the glochidia remain embedded can vary from one week to six weeks (Parmalee 1967).

The importance of this stage to zooarchaeological research is that it can potentially aid in the identification of fish remains, because certain species are host specific. Even if a species is not hostspecific, a list of potential hosts can still be constructed that can aid the faunal analyses. Furthermore, host fish may provide further insights into changes in environmental conditions. 
Table 14-6. Provenience information and measurements for modified freshwater taxa recovered from the Hurricane Hill site.

\begin{tabular}{||l|l|l|l|l|l||}
\hline \hline Block & Lot & Taxon & Side & $\begin{array}{l}\text { Length } \\
(\mathrm{mm})\end{array}$ & $\begin{array}{l}\text { Height } \\
(\mathrm{mm})\end{array}$ \\
\hline A & 540 & Lampsilinae & left & 29.57 & 22.08 \\
\hline A & 542 & Lampsilinae & left & 31.38 & 20.27 \\
\hline A & 588 & Lampsillinae & left & 34.35 & 26.76 \\
\hline A & 590 & Unionidae & right & 16.58 & 17.91 \\
\hline A extension & 2142 & Lampsills sp. & right & 31.96 & 24.11 \\
\hline $\begin{array}{l}\text { A } \\
\text { extension }\end{array}$ & 4197 & $\begin{array}{l}\text { Amblema } \\
\text { pllcata }\end{array}$ & left & 25.46 & 41.86 \\
\hline
\end{tabular}

A540: This specimen exhibits two cut surfaces which intersect at right angles. The umbo is absent; only a portion of the lateral tooth is present.

A542: This specimen is cut perpendicular to the hinge, posterior to the umbo. This first cut separates the lateral tooth from the umbo. A second cut occurs which would be parallel to the ventral edge; this second cut surface forms a right angle with the first cut surface. The interior surface is smooth; there is a slight lip on the exterior surface.

A588: This specimen exhibits two cut surfaces which intersect at right angles. The first cut surface is perpendicular to the hinge, posterior to the umbo. This cut essentlally removes the lateral tooth. The second cut surface is parallel with the ventral edge.

A590: This specimen exhibits a similar modification pattern as those described. The first cut surface is perpendicular to the hinge line, removing the umbo. Only the pseudocardinal teeth are present; the second cut surface is parallel with the ventral edge. The two cut surfaces form a right angle. Slight lipping occurs on the interior surface.

A extension 2142:

This specimen exhibits two cut surfaces. The first cut surface is perpendicular to the hinge, bisecting the umbo. The second cut is parallel to the ventral edge, forming a right angle with the first cut surface.

A extension 4197:

This specimen differs from the previous pattern. There is one cut surface which occurs posterior to the umbo; however, the measurement representing the height (the distance from the dorsal to the ventral margin) exceeds the length.

Table 14-7 summarizes those species of fish that have been documented as hosts for species of freshwater mussels recovered from the Hurricane Hill site. Based on the freshwater mussels identified from Hurricane Hill, and host requirements, crappies and longnose gar were present in the South Sulphur River during the Caddoan occupation of the site, along with probably the shortnose gar, the alligator gar, green sunfish, orange-spotted sunfish, and large mouth bass. Gar have been documented as host fish for the Threeridge and Yellow sandshell mussels, and sunfish have been documented as host fish for the Threeridge, Yellow sandshell, and Texas liliput mussels. Only the gar, large mouth bass, and sunfish were represented in the faunal assemblage from Hurricane Hill (see Yates, Chapter 13, this volume). Gar and sunfish have also been documented from the Tick and Spike sites on the South Sulphur River (Yates 1993:312).

\section{Harvesting Patterns}

The invertebrate taxa recovered from Block A, Block A extension, and Block D on the North rise could have been easily procured by the Caddoan occupants from freshwater habitats, such as the nearby South Sulphur River. The bivalves recovered from Block B on the South rise, however, included the one brackish water taxon, Rangia sp. There are two species of rangia that have been found in archaeological 
contexts in Texas: Rangia cuneata (common rangia) and Rangia flexuosa (brown rangia). The latter taxon prefers higher salinities than the former. Although the common rangia is commonly characterized as a brackish water taxon (Andrews 1981), its occurrence in coastal fresh waters, river-influenced areas, and lakes has been documented (Hopkins 1970; Howells et al. 1996:161). In estuarine contexts, the co-occurrence of common rangia and Glebula rotundata (round pearlshell) has been reported by Parker et al. (1984).

Table 14-7. Reported fish hosts for freshwater mussels recovered from the Hurricane Hill site.

\begin{tabular}{|c|c|c|}
\hline Mussel Taxon & Fish Host(s) & Reference(s) \\
\hline $\begin{array}{l}\text { Quadrula apiculata } \\
\text { (Southern mapleleaf) }\end{array}$ & Unreported & Howells et al.1996:106 \\
\hline $\begin{array}{l}\text { Quadrula houstonensis } \\
\text { Smooth pimpleback }\end{array}$ & Unreported & Howells et al. 1996:113 \\
\hline $\begin{array}{l}\text { Amblema plicata } \\
\text { (Threeridge) }\end{array}$ & $\begin{array}{l}\text { Shortnose gar (Lepisosteus platostomus); } \\
\text { northern pike (Esox lucius), highfin carpsucker (Carpiodes } \\
\text { velifer), white bass (Morone chrysops), rock bass } \\
\text { (Ambloplites rupestris), green sunfish (Lepomis cyanellus), } \\
\text { bluegill (Lempomis macrochirus), pumpkinseed (Lepomis } \\
\text { gibbosus), warmouth (Lepomis gulosus), white crappie } \\
\text { (Pomoxis annularis), black crappie (Pomoxis } \\
\text { nigromaculatus), largemouth bass (Micropterus salmoides), } \\
\text { sauger (Stizostedion canadense), yellow perch (Perca } \\
\text { flavescens), channel catfish (Ictalurus punctatus), and } \\
\text { flathead catfish (Pylodictis olivaris). }\end{array}$ & $\begin{array}{l}\text { Coker et al. 1921; Howard } \\
\text { and Anson 1922; Baker } \\
\text { 1928; Stein 1968; Fuller } \\
\text { 1978). }\end{array}$ \\
\hline $\begin{array}{l}\text { Toxolasma texasensis } \\
\text { (Texas lilliput) }\end{array}$ & $\begin{array}{l}\text { Warmouth (Lepomis gulosus) and longear sunfish (Lepomis } \\
\text { megalotis). }\end{array}$ & Stern and Felder 1978 \\
\hline $\begin{array}{l}\text { Lampsilis hydiana } \\
\text { (Louisiana fatmucket) }\end{array}$ & Unreported & Howells et al. 1996:66 \\
\hline $\begin{array}{l}\text { Lampsilis teres } \\
\text { (Yellow sandshell) }\end{array}$ & $\begin{array}{l}\text { Primarily the longnose gar (Lepisosteus osseus); other hosts } \\
\text { include: alligator gar (Lepisosteus spatula), shortnose gar } \\
\text { (Lepisosteus platostomus), green sunfish (Lepomis } \\
\text { cyanellus), orangespotted sunfish (Lepomis humilis), } \\
\text { largemouth bass (Micropterus salmoides), black crappie } \\
\text { (Pomoxis nigromaculatus), white crappie (Pomoxis } \\
\text { annularis), shovelnose sturgeon (Scahpirhynchus } \\
\text { platorynchus), and warmouth (Lepomis gulosus). }\end{array}$ & $\begin{array}{l}\text { Baker 1928; Oesch 1984; } \\
\text { Surber } 1913\end{array}$ \\
\hline $\begin{array}{l}\text { Rangia sp. } \\
\text { (Rangia) }\end{array}$ & $\begin{array}{l}\text { This taxon does not have a glochidial stage and does not } \\
\text { require a fish host. }\end{array}$ & Howells et al. 1996:161 \\
\hline
\end{tabular}

The occurrence of rangia at Hurricane Hill is problematic from both a dietary and ecological perspective. Along the Upper Texas Coast, the common rangia represented a major dietary resource for aboriginal populations (Aten 1983; Steele 1987), resulting in shell-bearing midden deposits located in estuarine settings. In sharp contrast, Hurricane Hill is an inland site, situated near the South Sulphur River, and not far from tall grass prairie habitat. Even though Rangia sp. have been documented from freshwater contexts, the specimen recovered from Hurricane Hill was probably procured near an estuarine setting, rather than from the South Sulphur River. If the South Sulphur River or its environs were a source of this dietary resource, then it would be expected that a greater amount of shell refuse would be present. Indeed, the paucity of Rangia sp. may suggest that the source of the rangia was not close. Of course, this assumes that rangia shells were not preserved, traded, affected by differential preservation, or cultural preferences.

\section{The South Sulphur River Habitat}

Assuming that the invertebrate taxa from the Hurricane Hill site had been procured from the South Sulphur River, some generalizations may be made concerning the energy regime, substrate, and depth of the river during the period of occupation spanning ca. A.D. 1050 to A.D. 1400. Reconstructions based on 
archaeological assemblages must be tempered with the knowledge, however, that the full range of taxa may not be represented due to both taphonomic and cultural factors.

It appears to be the case that the South Sulphur River 600-900 years ago was similar to its present system. It is a freshwater meandering river system, characterized by shallow zones called riffles and deeps called pools (Ritter 1978). These microzones would be favorable habitats for mussels requiring differing energy, substrate, or depth requirements. For example, taxa such as Amblema plicata (Threeridge)and Quadrulaapiculata(Southern mapleleaf) may be found in deeper waters; furthermore, these two mussel taxa prefer sand and gravel substrates. On the other hand, taxa such as Toxolasma texasensis (Texas liliput) and Lampsilis hydiana (Louisiana fat mucket) prefer sluggish, low-energy areas with mud bottoms.

Since freshwater mussels require fish hosts for their reproductive cycle, fish taxa such as gar and sunfish would have been present in the South Sulphur River 600-900 years ago. The presence of Lampsilis hydiana (Louisiana fat mucket) does suggest that in the past, if drought conditions had existed, they were not of a long enough duration to have had an impact on the mussel population. The Louisiana fat mucket is intolerant to drought conditions, whereas the Three ridge can burrow in the sediment to withstand a drought.

In summary, the freshwater musssl taxa from Hurricane Hill preferred substrates ranging from mud to gravel. Shifting sands appear to have been one limiting factor for the freshwater mussel taxa. Specific ecological data for each species are included in the following taxonomic section.

Phylum MOLLUSCA (Molluses)

\title{
Taxonomy
}

\author{
Class Pelecypoda \\ OrderSchizodonta \\ Superfamily Unionacea \\ Family Amblemidae
}

QuadrulaapiculatalQuadrulacf. apiculata

\section{Material: $\mathrm{NISP}=\mathbf{8}, \mathrm{MNI}=5$}

This species of freshwater mussel is found in Block A and Block A extension on the North rise. The NISP and MNI calculations combine the values for both Quadrulaapiculata and Quadrulacf. apiculata. The shell is quadrate to oval in outline. Small pustules cover the exterior portion of the shell. Triangular pseudocardinal teeth can be observed on the interior portion of the valve. Between the lateral tooth and the umbo is a wide area called the interdentum. There is a white nacreous layer on the interior of the valve. Parmalee (1967) reported that species of Quadrula can be found in most sediment types with the exception of pure mud. Read (1954:47) reported that this taxon is found in abundance in fairly deep water with a sand substrate.

Material: $\mathrm{NISP}=2, \mathrm{MNI}=1$

\section{Quadrulacf. houstonensis}

This species of freshwater mussel was recovered only in Block A. The shell is rounded to quadrate in outline. The specimens observed from this sample did not possess knobs or pustules. The pseudocardinal teeth are triangular in outline. Comparative specimens exhibit a yellow to light brown epidermis. Although this can be a diagnostic feature, this cannot be discerned on the archaeological specimens in the Hurricane Hill assemblage because of poor preservation. This taxon has been recovered from depths approximating one meter, and from substrates composed of gravel (Read 1954:46).

\section{Material: $\mathrm{NISP}=18, \mathrm{MNI}=9$}

\section{Amblema plicata}

This freshwater mussel is present in Block A and Block A extension deposits. It represents one of the predominant taxa recovered from the site. The predominance, however, may also be attributed to morphological characteristics that are more resistant to weathering. The shell is elongated, and ranges from quadrate to sub-rhomboidal. The exterior surface is covered with ridges which are parallel with the posterior ridge; the left valve consists of two divergent pseudocardinal teeth; the right valve consists of one single, thick serrated, triangular, large pseudocardinal tooth. Parmalee (1967:26) documented that this taxon reaches 
its greatest abundance in sand and gravel substrates, with water depths ranging from one to three feet. Sixteen different taxa represent host fish for the glochidia of the three ridge (Baker 1928:74-75; Coker et al. 1921; Fuller 1978; Howard and Anson 1922; Stein 1968). The taxa that have been documented as host fish are listed in Table 14-7.

\author{
Order Schizodonta \\ Family Unionidae \\ Subfamily Lampsilinae
}

\title{
Material: NISP $=6, \mathrm{MNI}=4$
}

\section{Toxolasma texasensis}

This species of freshwater mussel was found only in Block A and Block A extension. It is one of the major taxa characterizing the Hurricane Hill bivalve assemblage. The shell is elliptical in outline with a smooth exterior, with adult shell lengths usually not exceeding $5 \mathrm{~cm}$ (Read 1954). The inner portion contains two small slanted pseudocardinal teeth lying below the umbo. The lateral tooth is elongated, and extends to the end of the hinge line. The characteristic nacreous layer is present on the inner portion of the shell. Toxolasma may inhabit shallow mud banks, shallow ponds, or sluggish streams (Read 1954:43; Starrett 1971:331). Host fish for the Texas liliput are the warmouth (Lepomis gulosus) and longear sunfish (Lepomis megalotis) (Stern and Felder 1978).

\section{Material: $\mathrm{NISP}=10, \mathrm{MNI}=7$}

\section{Lampsilis teres}

Recovered in Block A, this species of freshwater mussel is one of the more common taxa at Hurricane Hill. The shell is large, elongated, thick, and moderately inflated. The anterior end is rounded, while the posterior end can be truncated. The dorsal and ventral margins are straight and nearly parallel. On the left valve, the pseudocardinal teeth are serrated; serrations are also present on the lateral teeth. Lampsilis teres is adversely affected by siltation (Starrett 1971:334). The fish host for the yellow sand-shell is the longnose gar (Lepisosteus osseus). Other possible fish hosts are the shortnose gar (Lepisosteus platostomus); alligator gar (Lepisosteus spatula); green sunfish, orange spotted sunfish; large mouth bass; white crappie; and black crappie (Baker 1928:267). The primary host fish for the yellow sandshell is the longnose gar (Oesch 1984). Other fish taxa which serve as hosts are listed in Table 14-7.

\section{Material: NISP $=2, \mathrm{MNI}=2$}

\section{Lampsilis cf. hydiana}

This freshwater mussel species was found in the Block A extension excavations on the North rise. The shell varies in thickness depending on the environment; shells tend to be thick and heavy in large rivers. The beak sculpture consists of six to 10 double-looped bars. On the left valve, the pseudocardinal teeth are divergent, elongated, and triangular; the two lateral teeth are straight. Specimens have been collected from substrates composed of pebbles or on top of hard clay bottoms (Read 1954:44).

\author{
OrderEulamellibranchia \\ Superfamily Mactracea \\ Family Mactridae
}

Material: $\mathrm{NISP}=1, \mathrm{MNI}=1$

$$
\text { Rangia sp. }
$$

The archaeological specimen from Block B/C assigned to this genus represents a brackish water taxon. There are two species of rangia which have been recovered from archaeological contexts in Texas: common rangia (Rangiacuneata) and brown rangia (Rangia flexuosa).

The common rangia is characterized by a diagnostic lateral tooth which extends almost to the ventral margin, and a distinct pallial sinus (Andrews 1981:112). The brown rangia is characterized by a short lateral tooth, an indistinct pallial sinus, and a keeled posterior slope (Andrews 1981:112). The specimen from Hurricane Hill could not be assigned to a more specific taxonomic level because the posterior portion of the shell was broken, making it difficult to determine the length of the lateral tooth; furthermore, the condition of the specimen was such that the other characteristics could not be readily discerned. Both taxa prefer brackish water habitats, although the brown rangia is associated with higher salinities (Andrews 1971). 
Rangia populations are found in estuaries with salinities that seldom exceed $18 \mathrm{ppt}$ (Hoese 1973; Swingle and Bland 1974). Bedford (1972) and O'Heeron (1966) concluded that the upper salinity boundary for Rangia in the natural environment was imposed by predation and competition, rather than a physiological limitation, although further research is warranted. 



\title{
CHAPTER 15, MACROBOTANICAL REMAINS FROM A NORTHEAST TEXAS LATE ARCHAIC TO MIDDLE CADDOAN SITE: HURRICANE HILL (41HP106), HOPKINS COUNTY
}

\author{
S. Eileen Goldborer and Timothy K. Perttula, with contributions by \\ Marie E. Brown and Gary M. Crites
}

\section{Introduction}

The paleobotanical analyses reported on here represent the study of more than 275 flotation samples from distinct feature, midden, and structure contexts at the Hurricane Hill site (see Appendix XX). The initial analyses of the charred plant remains were undertaken by Brown and Crites (1990); their results are incorporated in Chapter 15 where pertinent. The senior author completed the remainder of the paleobotanical analyses between 1995 and 1998, and Goldborer and Perttula collaborated in the project-wide and region-wide consideration of the Hurricane Hill paleobotanical remains that concludes this chapter.

More than 17,000 liters of matrix were processed by flotation (see Table 4-3) from the Hurricane Hill site. The vast majority of that matrix was derived from the excavation of features, Block A-extension midden deposits, and sediments from Middle Caddoan period houses in Block B/C during Phases III and IV excavations. Because of budgetary limitations and the volume of the materials recovered from flotation, an initial sample (826.5 liters) of eight features and 23 midden and house-floated deposits from the North and South rises, respectively, was submitted to Dr. Gary Crites of the University of Tennessee for identification of the carbonized plant remains and wood charcoal. Flotation samples were submitted from features and particular units where paleobotanical remains were expected to occur, based on the presence of wellpreserved faunal materials, pockets of ash and charcoal, and their overall context (Table 15-1).

Table 15-1. List of Initial Sample Contexts Analyzed by Crites.

$\begin{array}{llll}\text { Block A } & \text { Block B/C } & \text { Block D } & \text { Block E }\end{array}$

\begin{tabular}{lccr}
\hline Unit 36 & Unit 61 & Feature 32 & Feature 25 \\
Unit 245 & Unit 172 & &
\end{tabular}

Feature $4 \quad$ Feature $5 \mathrm{~A} / \mathrm{B}$

Feature $34 \quad$ Feature 12

Feature 38

Feature 39

Further analyses of another 246 flotation samples were completed by Eileen Goldborer (see Appendix XX). These were small samples, each generally containing less than 7 grams of charred materials by volume. In order to assess the potential for preserved paleobotanical data from such small samples, a preliminary scan of 97 flotation samples was undertaken, and 47 samples from the initial group were chosen for full sorting; all scanned samples having charred maize or seeds were included in that group. In addition, the other 149 unscanned flotation samples were also fully sorted. All charred and uncharred materials were sorted from the flotation soil matrix. Carbonized plant remains present in the samples included wood charcoal, hickory (Carya sp.) and walnut (Juglans nigra) shell, seeds, and maize cupules (Zea mays ssp. mays). Numerous samples contained fresh seeds. Uncharred pecan (Carya illinoensis), acorn (Quercus sp.), and branchlet fragments of juniper (Juniperus sp.) were also present in a few samples. The results of these analyses are discussed below. 


\section{Laboratory Methods}

The flotation samples analyzed by Crites were placed in a nested series of standard geologic screens ( $2 \mathrm{~mm}, 1 \mathrm{~mm}$, and $500 \mathrm{ym}$ ) and gently shaken to sort by general fragment size. All charred plant material retained in the $2 \mathrm{~mm}$ screen was sorted into class designations (i.e., nut remains, wood charcoal, and maize) and weighed. Nut remains were weighed by genus. Maize was weighed by plant part (i.e., cupule, kernel, and glume). Wood fragments were weighed as one sample component. Materials retained in the $1 \mathrm{~mm}$ and $500 \mathrm{ym}$ screens, as well as in the catch basin under the screens, were scanned for the presence of seeds, fleshy fruit fragments, maize, etc. If present, these items were removed, identified, and weighed by genus/species. Any other remaining material was weighed as one sample component (i.e., residue) and the presence of nut genera, wood, etc., was noted on laboratory analysis forms with a "P" if present.

The flotation samples analyzed by Goldborer were scanned or sorted under a binocular microscope (7X to $45 \mathrm{X}$ ). Scanned flotation samples were generally not weighed, but the largest of such samples was weighed to determine a maximum weight. A separation of materials was not done for those samples. On the other hand, all flotation samples that were fully sorted were weighed. Those samples were passed through geological sieves ( $4 \mathrm{~mm}, 2 \mathrm{~mm}, 1 \mathrm{~mm}$, and $0.5 \mathrm{~mm}$ mesh) when needed to facilitate sorting. Charcoal and nutshell below $1 \mathrm{~mm}$ in size were not removed from the soil matrix, while all other materials were removed, regardless of size.

A comparative collection and standard identification manuals (Delorit 1970; Martin and Barkley 1973; Montgomery 1977) were used to identify the seeds. In a few cases, the condition of the charcoal was such that wood source identifications were attempted using a binocular microscope up to $100 \mathrm{X}$ magnification. A comparative collection, and standard references (Core et al. 1979; Dimbleby 1967), were employed to make the wood identifications.

\section{Results of the Paleobotanical Analyses}

\section{Wood Charcoal}

Charcoal was present in 51.6 percent of the flotation samples (see Appendix XX), although the amount of charcoal in each sample was generally small. Only a few samples $(\mathrm{n}=18)$ had more than $1 \mathrm{~g}$ of charcoal, mainly from feature contexts on the North and South rises. Attempts to identify the wood sources of the charcoal were hindered by its small size and fragile condition, but a few pieces of charcoal were identified by source. One piece from Block B/C (Unit 155, level 3A) is American elm (Ulmus americana). American elm is a common native tree in floodplain settings in the region around the site (Elias 1980:236237; Simpson 1988:334). Hickories and oaks can occur in either floodplain or upland environments (Elias 1980:275-291, 310-385). Charred fragments from the Southwest rise and Block B/C (Unit 172, $14 \mathrm{~cm}$ bs) are oak, while hickory was identified in Block A (Unit 40, level 2).

Most of the material in the light fraction examined by Crites was modern grass stems, and almost all of the heavy fraction consisted of rocks, soil, modern grass parts, and some clay/daub. Only 96.01 grams of carbonized plant material was recovered (Brown and Crites 1990) from the initial samples, of which 75.1 grams (78.1 percent) was charcoal (Editor's Note: An attempt was made in 1996 to have Crites return the carbonized plant materials for reexamination by Goldborer, as well as for possible radiocarbon analyses, but Crites had unfortunately lost the material sometime between 1988 and 1996). Given the volume of flotation, the paucity of preserved prehistoric plant remains was considered striking by Crites. Subsequent flotation analyses of several other Archaic, Early Ceramic, and Caddoan sites in the upper and middle Sulphur River basin, however, has also shown that paleobotanical remains are relatively sparse (e.g., Crane 1993, 1997; Dering 1992, 1993, 1994; Borojevic 1995, 1996; Fritz 1995; Holloway 1997). Taking the site as a whole, more than 781 grams of carbonized plant remains were recovered from the Hurricane Hill flotation samples (see Appendix XX), charcoal comprising approximately 76 percent of the sample, and charred nutshells almost 24 percent; cultigens represented less than 0.5 percent of the plant remains.

\section{Nutshells}

Approximately 21 percent of the charred plant remains examined by Crites (Brown and Crites 1990) were nutshell fragments. He identified at least three nut genera: Carya (hickory), Corylus (hazelnut), 
and Quercus (acorn) (Table 15-2). If any of the nut fragments identified as Juglandaceae (hickory and walnut) were Juglans (walnut), then four genera were represented in the Crites sample.

Table 15-2. Weights ${ }^{a}$ of Identified Nut Remains

\begin{tabular}{|c|c|c|c|c|}
\hline & Carya & Juglandaceae & Juglans Corylus Quercus & Total \\
\hline Provenience & (Hickory) & $\begin{array}{l}\text { (Hickory/ } \\
\text { Walnut) }\end{array}$ & Walnut (Hazelnut) (Acorn) & Weight \\
\hline
\end{tabular}

North Rise, Block A:
87.85
0.75
$\begin{array}{lll}1.0 & 0.02 & 0.03\end{array}$
89.65

North Rise, Block D:

$\begin{array}{llllll}17.66 & 0.01 & 0.0 & 0.03 & 0.01 & 17.71\end{array}$

North Rise, Block E:

$\begin{array}{llllll}9.40 & 0.05 & 0.0 & 0.00 & 0.00 & 9.45\end{array}$

NORTH RISE,

SUBTOTAL

114.91

0.81

$\begin{array}{lll}1.0 & 0.05 & 0.04\end{array}$

116.81

South Rise, Block B/C:
49.16
12.10
0.0
$0.39 \quad 0.33$
61.98

South Rise, Block F:
0.1
0.00
0.0
$0.00 \quad 0.00$
0.10

SOUTH RISE,

SUBTOTAL

49.26

12.10

0.0

$0.39 \quad 0.33$

62.08

SOUTHWEST RISE

5.7

0.00

0.0

$0.00 \quad 0.00$

5.70

$\begin{array}{lllllll}\text { Total } & 169.87 & 12.91 & 1.0 & 0.44 & 0.37 & 184.59\end{array}$

a In grams

Thick hickory nutshell was observed in all of the flotation samples that were only scanned by Goldborer, along with one fragment of charred acorn. Two types of charred nutshell, thick hickory and black walnut, were distinguished in the fully sorted flotation samples. While 92.6 percent of those samples had hickory, only three samples (1.2 percent) contained walnut. All of the charred walnut shells came from the Block A or Block A extension midden deposits (see Table 15-2), but they amount to less than 1 percent by weight.

Historically, nuts were important food resources that could be eaten raw or dried and preserved for later use. However, to use them requires some processing costs, in terms of collecting, hulling, shelling, and additional processing (e.g., the removal of tannic acid from acorns or parching for later storage), prior to consumption (see Keene 1981:54-75; Gardner 1997a:165-167; Talalay et al. 1984). Processing costs would also be increased because nut meats only account for approximately 25-65 percent of the total nut weight (Keene 1981:Table 3.2); therefore, large amounts of nuts must be harvested in order to produce a usable 
quantity of nut meats. For example, $100 \mathrm{lb}$. of hickory nuts would be necessary to extract one gallon of oil (Hudson 1976:301).

Southeastern Indians extracted oil for cooking and seasoning from acorns, hickory nuts, and walnuts, with that from hickory nuts being preferred (Hudson 1976:301). The nuts, including the shells, were crushed in a mortar and then boiled in water. The oil rose to the top and was skimmed off, while the shells sank to the bottom. Large quantities of shell fragments were a by-product of this process.

When whole, or nearly whole, nut meats were desired, quantities of nutshell fragments were also generated by the shelling process. To facilitate extraction, the nuts were heated in an oven or over a fire. This helped to dry the shell, making it easier to crack. "Then the nuts were cracked lightly en masse and the nut meat was winnowed from the shell" (Keene 1981:73). This was a time-consuming process, as indicated in the experiments conducted by Talalay et al. (1984:356). They estimated that it would take 2 hours of collecting and processing to obtain a kilogram of hickory nut meat. It was easier to pulverize whole nuts and make use of the resulting nut powder, then spitting out the shell (Gardner 1997a:166). However, black walnuts are very difficult to crush.

The identified nut assemblage from Hurricane Hill is dominated by Hickory (Carya), accounting for about 92 percent by weight in the site paleobotanical assemblage as a whole (see Table 15-2). Ripe nuts of this family are available for harvest in September and October. Acorns (Quercus) are also available at this time, but they amount to less than 0.3 percent of the nutshells by weight; they are found on both the North and South rises in Caddoan contexts. Hazelnuts (Corylus), however, are ripe in late summer (i.e., AugustSeptember). About 89 percent of the charred hazelnut is from the Middle Caddoan component on the South rise (see Table 15-2).

The Native American exploitation of nuts as a food resource has a long tradition in North America, dating from as early as the Paleoindian period. Each type of nut provides some nutrients essential for the maintenance of a healthy diet. Hickory nuts, walnuts, and hazelnuts are high energy foods, functioning primarily as fat and protein sources. According to Gardner (1997a:162), "hickories are a relatively good source of essential amino acids. The nuts are superior to both maize and acorns as a source of nine of the ten essential amino acids." Acorns are, however, much higher in carbohydrates but lower in fat and protein than hickory, and contain much more fat per 100 grams than does maize (Asch et al. 1972:10, 25 and Table 5; Keene 1981:Table 5.4; Gardner 1997a:Figures 8.1-8.2).

The dominance of hickory nutshells in the Hurricane Hill paleobotanical remains probably indicates that hickory mast was extensively exploited and processed in the fall during the site occupation, presumably as a source of fat, protein, and carbohydrates. The poor preservability of acorn in the archaeological record precludes an accurate assessment of its importance as a food resource, but it too was probably an important food resource. Gardner (1997a:171-172) also suggests that hickory and acorn nuts were probably most important as a stored food commodity (and they were easily stored by parching them over heated stones in shallow pit features) for the lean late winter and early spring months when "other resources would have been harder to come by."

\section{Cultigens}

One rind fragment of Cucurbita (squash) was found (Feature 12) and a total of $1.07 \mathrm{~g}$ of maize was recovered in the few flotation samples analyzed by Crites. The maize and Cucurbita remains were recovered from the central hearths (Feature 5A/B) and from, or near, the large interior pits associated with Structures $A$ and $B$, the Middle Caddoan period houses on the South rise. In the additional samples examined by Goldborer, remains of maize were present in six of the seven block areas at Hurricane Hill and Scraped Area 10 on the South rise; it was absent on the Southwest rise, and most common on the North rise in Early Caddoan midden deposits. All told, 3.74+ grams of charred maize cupules, kernels, and glumes were recovered in the Hurricane Hill flotation analyses. Twenty-seven or 9.7 percent of the flotation samples contained charred maize.

Table 15-3 provides the measurements and means for all maize cupules (no kernels were recovered) studied by Goldborer. This includes 51 whole cupules and 143 cupule fragments. The cupule structure is the hardest part of the cob; therefore, it often survives in the archaeological record. The cupule spans the 
approximate width of two kernels and, even when charred, may offer clues to the type of corn that was grown and used by the Caddoan peoples at Hurricane Hill.

Table 15-3. Maize Cupule Measurements.

\begin{tabular}{lllll}
\hline \multirow{2}{*}{ Provenience } & Weight & \multicolumn{2}{c}{ Cupules } & Whole Cupules \\
& $(\mathrm{g})$ & Fragments & Whole & Width* Internode**
\end{tabular}

Block A and A Extension

$\begin{array}{ll}\text { 239, lv. 2A } & <0.1 \\ \text { 239, lv. 4A } & <0.1 \\ \text { 241, lv. 3A } & <0.1 \\ \text { 244, lv. 2B } & <0.1 \\ \text { 244, lv. 3B } & 0.1\end{array}$

244, lv. 4A

$<0.1$

249, lv. $2 A$

0.1

$249,1 v .3 \mathrm{~A}<0.1$

250,1 v. $3 \mathrm{~A}<0.1$

251, 1v. 2B $<0.1$

252, lv. 3B $<0.1$

256, lv. $4 \mathrm{~A}$

0.1

$256,1 v .4 B$

$<0.1$

1

12

1

1

$-$

1

9

1

259, 1v. 7A

0.5

13

\begin{tabular}{|c|c|c|}
\hline 1 & 6.2 & 2.1 \\
\hline - & - & - \\
\hline - & - & - \\
\hline 1 & 8.4 & 3.3(c)\# \\
\hline 6 & & \\
\hline a & 6.3 & - \\
\hline b & 4.8 & 1.5 \\
\hline c & 5.1 & - \\
\hline d & 5.0 & - \\
\hline e & 5.5 & 2.0 \\
\hline f & 6.3 & 1.5 \\
\hline - & - & - \\
\hline 1 & 5.6 & 3.2(c)\# \\
\hline - & - & - \\
\hline 1 & 44 & 1 \\
\hline - & $\begin{array}{l}-7.7 \\
-\end{array}$ & $\begin{array}{l}2.1 \\
-\end{array}$ \\
\hline 1 & 4.9 & 1.1 \\
\hline 4 & & \\
\hline a & 6.0 & 1.6 \\
\hline b & 7.1 & 2.0 (c)\# \\
\hline$c(a)+$ & 6.6 & 3.1(c)\# \\
\hline $\begin{array}{l}c(b)+ \\
13\end{array}$ & 5.8 & \\
\hline $\mathrm{a}(\mathrm{a})+$ & 5.8 & 3.1(c)\# \\
\hline$a(b)+$ & 5.8 & 2.0 \\
\hline b & 5.7 & 2.8 \\
\hline c & 5.6 & - \\
\hline d & 6.2 & 2.9 \\
\hline e & 5.7 & 2.7 \\
\hline f & 5.8 & 3.2(c)\# \\
\hline g & 5.5 & 2.2 \\
\hline h & 5.0 & 3.3(c)\# \\
\hline $\mathrm{i}$ & 5.9 & 2.8 \\
\hline j & 5.4 & - \\
\hline k & 5.6 & 2.8 \\
\hline 1 & 5.8 & 3.1(c)\# \\
\hline
\end{tabular}

Block D

77, 1v. 3B

$<0.1$

1

N. RISE

TOTALS

1.8

57

28

25 
Table 15-3. Maize Cupule Measurements, cont.

\begin{tabular}{|c|c|c|c|c|c|c|}
\hline \multirow[t]{2}{*}{ Provenience } & \multirow{2}{*}{$\begin{array}{l}\text { Weight } \\
\text { (g) }\end{array}$} & \multicolumn{2}{|c|}{ Cupules } & \multicolumn{2}{|c|}{ Whole Cupules } & \multirow[t]{2}{*}{ G } \\
\hline & & Fragments & Whole & Width* & Internode** & \\
\hline \multicolumn{7}{|l|}{ Block B/C } \\
\hline $58,1 \mathrm{v} .2$ & 0.10 & 2 & - & - & - & \\
\hline 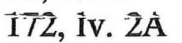 & $0 \hat{.1} 5$ & $\hat{Z}$ & - & - & - & \\
\hline 172, lv. $3 \mathrm{~A}$ & 0.23 & $10^{n}$ & - & - & - & \\
\hline 172, Iv. 4B & 0.06 & $I^{\kappa}$ & - & - & - & \\
\hline 172, lv. 5B & 0.02 & 1 & - & - & - & \\
\hline Fea. 5 & 0.01 & I & - & - & - & \\
\hline Fea. 12 & 0.09 & 5 & - & - & - & 1 \\
\hline \multirow[t]{3}{*}{ Fea. 36} & 0.10 & - & $\overline{2}$ & & & \\
\hline & & & a & 4.3 & $2+$ & 2 \\
\hline & & & b & 4.3 & $2+$ & \\
\hline Fea. 38 & 0.42 & $21^{\wedge}$ & - & - & - & \\
\hline Fea. 39 & 0.06 & 3 & - & - & - & \\
\hline
\end{tabular}

Block F

$<0.1$

1

$1 \quad 4.4 \quad 1.2$

Scrape Area 10

Fea. 89

0.70

80

20

a $\quad 5.3 \quad 1.0$

$\begin{array}{lll}\text { b } & 4.3 & 0.8\end{array}$

c $5 . \overline{6} \quad$ I.0

d $\quad 7.6 \quad 1.0$

e $\quad 4 . \overline{9} \quad \overrightarrow{1} . \overline{0}$

f $\quad 5.0 \quad 1.5$

$\begin{array}{lll}\text { g } & 3.3 & 1.0\end{array}$

$\begin{array}{lll}\mathrm{h} & 3.9 & 1.2\end{array}$

$\begin{array}{lll}\text { I } & 3.7 & 0.8\end{array}$

$\begin{array}{lll}\mathrm{j} & 4.0 & 0.7\end{array}$

$\begin{array}{llll}\overline{\mathrm{k}} & 3 . \overline{3} & 1 . \overline{3} & 1\end{array}$

$\begin{array}{llll}1 & 4.3 & 0.8 & 1\end{array}$

m $\quad 3.2 \quad 0.5$

$\begin{array}{llll}\text { n } & 4.5 & 0.9 & 1\end{array}$

$\begin{array}{llll}\mathrm{o} & 4.0 & 1.1 & \\ \mathrm{p} & 3.2 & 1.0 & 2\end{array}$

$\begin{array}{llll}\mathrm{p} & 3.2 & 1.0 & 2 \\ \mathrm{q}(1) \sim & 4.5 & 2.7(\mathrm{c}) \# & 2\end{array}$

$\mathrm{q}(2) \sim \quad 5.1 \quad 2.8(\mathrm{c}) \# \quad 2$

q(3) $\begin{array}{lll}5.0 & \text { İ.1 } & 2\end{array}$

SOUTH RISE

TOTAIS

1.94

127

23

22

* In mm $\quad$ ** Thickness in mm (a)+ and (b)+ are attached cupules

(c)\# indicates cupule has second attached cupule or associated lower glume intact. An internode measurement taken under these circumstances is probably more accurate than one taken from a single cupule.

$\hat{n}$ Includes kerneî fragments

$\sim$ Multiple cupules attached in either an axial or radial line 
Fourteen (51.9 percent) of the flotation samples with maize came from Early Caddoan Block A and Block A extension flotation samples on the North rise, one flotation sample from Block D had less than 0.1 grams of maize, and the remainder came from Middle Caddoan period house, midden, and feature contexts on the South rise. The combined Block A/Block A extension excavations also had the greatest amount (64.5 percent) of corn by weight. One feature sample (Fea. 89, Scraped Area 10) with maize on the South rise, however, had 18.8 percent of the corn by weight from the site.

While most of the maize is made up of individual cupules, three sets of attached, adjacent cupules were also recovered. The multi-cupule sets include two sets of two cupules and one of three. The cupules in these sets adjoin along an axial (vertical) line. The set of three cupules had a fourth whole cupule and a cupule fragment that were attached radially (horizontally).

In addition, 47 whole or partial glumes were preserved with attached cupules, 25 from Block A/A extension and 22 from the South rise (see Table 15-3). Morphologically, a lower and upper glume surrounds each corn kernel. Glume characteristics may also provide information about the corn type (Wellhausen et al. 1952:32-33). Glumes are more fragile than cupules, and are less likely to be recovered in archaeological contexts. Eight unattached, partial, glumes were recovered from the one feature sample with maize on the Southwest rise.

Intact cobs were not recovered in the flotation samples to confirm row numbers. However, all of the cupules at Hurricane Hill are much wider than they were thick. Kernels and cupules that have this shape are considered to be indicative of 8-rowed Eastern Complex or Northern Flint maize (Cutler and Blake 1973; Galinat 1985:261-263; Jones and Fonner 1954:107). While Eastern Complex corn has a low average row number, usually eight, 10 or occasionally 12-rowed corn sometimes occurs as well (Brown and Anderson 1947:1-28; Jones and Fonner 1954:107; Wagner 1986:115). A mixing of 8- and 10-rowed condition may even occur on the same cob (Galinat 1970:222; Wagner 1986:120).

Maiz de Ocho is the term applied to the 8-rowed corn that was spread out of the Southwest into the Plains and Northeast U.S. (Galinat and Gunnerson 1963; Galinat 1985:264-268; Mangelsdorf 1974:113). The ratio of cupule width (w) to internode length (I), which approximates kernel thickness, is greater than 1.0 in Maiz de Ocho (Galinat 1985:261-263). Where the w/i ratio could be determined for Hurricane Hill cupules, it was greater than 1.0.

The internode length measurement can be expected to be more accurate where two adjoining cupules, or the entire alicole (cupule and associated spikelets) length is preserved. Such circumstances were noted for nine cupules in the Hurricane Hill maize assemblage. For these cupules, the mean cupule width and internode lengths were 5.84 and 3.09, respectively, producing a $1.89 \mathrm{w} / \mathrm{i}$ ratio. Among single cupules the internode lengths were smaller, making the w/i ratio appear higher than it probably is.

\section{Distribution of Maize across the Hurricane Hill site}

None of the 15 Block A flotation samples analyzed by Goldborer or Crites contained maize (see Appendix XX). By contrast, maize was relatively abundant in the Block A extension investigations, being present in 17.1 percent of the 82 flotation samples from this context. A significant percentage of the maize was present in one sample from level 7A (from a probable pit extending below the midden) in Unit 259, however. The 13 whole cupules had a width range of 4.4-6.2 $\mathrm{mm}$, with a mean of $5.59 \mathrm{~mm}$. The internode length range was $2.0-3.3 \mathrm{~mm}$, with a mean of $2.75 \mathrm{~mm}$. However, the internode mean was $3.17 \mathrm{~mm}$ when only the four cupules with an adjacent attached cupule, or the associated lower glumes for a cupule, were present. Four additional cupules were 90-95 percent complete, and were counted as fragments. Based on the preserved portions of those fragments, an original charred range for those fragments is projected at 5.7-6.0 $\mathrm{mm}$; this falls within the measured range for the whole cupules from Block A.

The remaining 15 whole cupules are from only seven proveniences, and 10 of them occur in just two excavation contexts (Unit 244, level 3B and Unit 256, level 4B) (see Table 15-3). The whole cupules have a width range of 4.8 to $8.4 \mathrm{~mm}$, with a mean of $5.96 \mathrm{~mm}$. The internode length range is $1.1-3.3 \mathrm{~mm}$, with a mean of $2.11 \mathrm{~mm}$. However, as with the cupules from the Unit 259 pit, when only cupules with the most complete alicoles were considered, the internode mean rose to $3.2 \mathrm{~mm}$. 
Some 10 percent of the 124 Block B/C, F, and South rise feature samples contained charred maize (see Appendix X). These samples included 23 whole cupules and 127 fragments. The whole cupules $(n=20)$ from Feature 89 had a width range of 3.2-7.6 mm, with a mean of 4.51. The whole cupules from Feature 36 were $4.3 \mathrm{~mm}$ in width, with internode lengths of $2 \mathrm{~mm}$, while the single cupule from Block F consisted of a small cupule ( $\mathrm{w}=4.2 \mathrm{~mm}$ and $\mathrm{I}=1.2 \mathrm{~mm}$ ) and a cupule fragment (see Table 15-3).

A single Block D sample had maize (4 percent of the flotation samples), but Block E had no maize in the 17 flotation samples with paleobotanical remains. The Block D cupule fragment is probably associated with the Early Caddoan midden deposits on this part of the North rise. None of the 15 flotation samples from the Southwest rise contained maize. The flotation sample contexts are either Woodland or Late Archaic in age.

The flotation samples analyzed by both Crites and Goldborer document the relatively low occurrence of cultivated plants at the Hurricane Hill site, particularly the apparently limited use of maize. These data are generally consistent with the paleobotanical findings from the Thomas (Cliff 1995), Lawson (Martin 1997a), Doctors Creek (Martin 1997b), Peerless Bottoms (Fields et al. 1993), and Spider Knoll (Fields et al. 1994) sites where low amounts of maize were recovered from Early and Late Caddoan components (see Crane 1997; Dering 1993, 1994). Percentage ubiquity values for maize ranged between 019 percent for the flotation samples for these sites. As suggested by McGregor (1997a), maize probably did not comprise a major portion of the diet of peoples living in the Cooper Lake area during the period from ca. A.D. 900-1300/1400, and likely never was a primary food source for the Caddoan groups living in the upper Sulphur River basin.

However, squash was relatively abundant in the latter contexts, whereas it was rare at Hurricane Hill. In samples analyzed by Crane $(1993,1997)$, squash rind was present in 50-71.4 percent of the Early Caddoan period flotation samples at the Lawson, Doctors Creek, and Thomas sites, and in 100 percent of the Early Ceramic samples from 41HP137. Squash was also present in low amounts in Early and Late Caddoan contexts at the Spike, Spider Knoll, and Peerless Bottoms sites (Dering 1993, 1994).

\section{Charred Seeds}

Generally, only charred seeds from prehistoric archaeological sites are considered to be associated with the archaeological deposits. However, charred seeds may occur in the archaeological record as "seed rain" or from direct or indirect use (Minnis 1981:145), but prehistoric seeds used by man, or attached to another utilized plant part, are more likely to become exposed to fire in a cultural context. Table 15-4 provides information on the charred seeds recovered from the Hurricane Hill site.

Table 15-4. Charred Seeds.

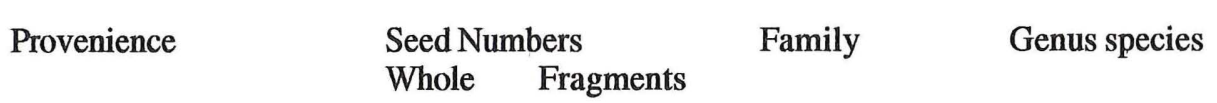

Block $\mathrm{A}$ and $\mathrm{A}$ extension

$35,1 v .5$

$41,1 \mathrm{v} .2$

239 , lv. 2B

$241,1 v .3 A$

$242,1 v .2 A$

242, lv. $2 B$

$244,1 v .3 B$

$247,1 v$. 3B

$247,1 v$. $4 \mathrm{~A}$

$248,1 v$. 2 A
1

1

2

1

1

1

1

1

1

1
Liliaceae

Unidentified

Compositae

Unidentified

Vitaceae

Polygonaceae

Unidentified

Gramineae

Vitaceae

Vitaceae

$1 \quad$ Vitaceae

Vitaceae

\section{Polygonatum biflorum}

Helianthus sp.

Vitis sp.

Polygonum sp.

Vitis sp.

Vitis sp.

Vitis sp.

Vitis sp. 
Table 15-4. Charred Seeds, cont.

\begin{tabular}{|c|c|c|c|c|}
\hline \multirow[t]{2}{*}{ Provenience } & \multicolumn{2}{|c|}{ Seed Numbers } & \multirow[t]{2}{*}{ Family } & \multirow[t]{2}{*}{ Genus species } \\
\hline & Whole & Fragments & & \\
\hline $248,1 v .2 B$ & 1 & & Vitaceae & Vitis sp. \\
\hline 255, lv. $3 \mathrm{~A}$ & & 1 & Unidentified & \\
\hline $259,1 \mathrm{v} .4 \mathrm{~A}$ & 1 & & Unidentified & \\
\hline $259,1 v .5 B$ & 1 & & Vitaceae & Vitis sp. \\
\hline \multicolumn{5}{|l|}{ Block B/C } \\
\hline $54,1 v .3 A$ & 1 & & Anacardiaceae & Rhus sp. \\
\hline $97,1 v \cdot 2 A$ & 1 & & Cupressaceae & Juniperus sp. \\
\hline 112, lv. $3 \mathrm{~A}$ & 1 & & Anacardiaceae & Rhus sp. \\
\hline \multicolumn{5}{|l|}{ Block E } \\
\hline \multirow[t]{4}{*}{$93,1 v .2 A$} & 3 & & Vitaceae & Vitis sp. \\
\hline & 2 & & Polygonaceae & Polygonum sp. \\
\hline & 1 & & Rosaceae & Rosa sp. \\
\hline & 1 & & Unidentified & \\
\hline
\end{tabular}

Two of the Block A samples contained the remains of charred seeds. The one identified seed was Solomon's-seal (Polygonatum biflorum) (see Table 15-4). The Solomon's-seal berry, which is inedible (Peterson 1977:76), would have been present on the plant in summer (Correll and Johnston 1979:407; Forey 1990:200). The berry could have been attached to a plant dug for its edible root, available at any time of year (Peterson 1977:76; Steyermark 1963:442). Several sources also indicate that Solomon's-seal had medicinal uses among some Native Americans (Krochmal and Krochmal 1984:175; Vogel 1970:102, 213).

Twelve of the Block A extension samples had whole seeds or fragments of charred seeds. Eight of the whole seeds were wild grape (Vitis sp.). Various varieties of wild grapes would have been available from August to November (Correll and Johnston 1979:1017-1021). The seeds of this easily attainable seasonal food are often recovered from archaeological sites in the region. Maize accompanied the wild grape in one sample (see Appendix XX). One grass seed similar to Agrostis sp. or bentgrass (Martin and Barkley 1973:11 and Plate 16), one knotweed (Polygonum sp.), and one sunflower kernel (Helianthus sp.) also occurred in the samples. These three are starchy or oily seed types with high nutritional values (Earle and Jones 1962:221-250; Jones and Earle 1966:127-255). All three are known to have been used by historic Indian groups (Cheatham and Johnston 1995; King 1984a; Yanovsky 1936:1-83). According to Cheatham and Johnston 1995:178-179), the bentgrass rhizomes were applied to wounds to promote healing, and that drinking a rhizome concoction could relieve digestive disorders. One $3 \mathrm{~mm}$ long whole seed associated with the grass in Unit 242, level 2B is unidentified.

Only three (2.4 percent) of the Block B/C samples contained charred seeds (see Table 15-4). Two of the seeds are sumac (Rhus sp.), and one is juniper (Juniperus sp.). Both of these types of berries would have been available in the late summer through the fall months (Vines 1982:10-18, 301-307). Sumac berries were used either to make a lemonade-like beverage or were eaten by Native Americans (Yanovsky 1936:4041). The berries of local juniper species were generally unlikely to have been consumed for food (Elias and Dykeman 1990:194), though one ethnographic account suggests Juniperus virginiana berries might occasionally have been eaten (Carlson and Jones 1939:527). However, they may have been ingredients in medicine, or have been attached to branches whose leaves had medicinal use (Vogel 1970:289-290); they may have had other uses as well, perhaps in arbor building (King 1984a:55). 
None of the 25 Block D flotation samples had charred seeds. A single sample (Unit 77, level 3B; the same flotation sample that contained a charred maize cupule fragment) had two unidentified charred buds, $3 \mathrm{~mm}$ and $5 \mathrm{~mm}$ in length.

Only a single Block E sample contained charred seeds, and it had seven seeds (see Table 15-4). Three were wild grape, two others were knotweed, and one was a wild rose (Rosa sp.). The rose hip is an edible fruit. The unidentified seventh seed has a $2 \mathrm{~mm}$ length. Three fragments of charred juniper branchlets also occur in this sample. $(\mathrm{n}=15)$.

No charred seeds were found in any of the samples from Block F $(n=2)$ or the Southwest rise

\section{Uncharred Seeds}

More than 49 percent (and 1126 uncharred seeds) of the samples had fresh seeds, approximately 4.1 uncharred seeds/sample. Uncharred fragments of juniper branchlets were also present in a few samples.

Uncharred seeds are generally considered to be modern contaminants because they have a poor chance of long-term preservation (Minnis 1981:143-150). Modern species might, however, indicate environmental and resource differences between the prehistoric and modern site setting. Uncharred seed taxa are listed in Table 15-5.

Table 15-5. Uncharred Seed Types

\begin{tabular}{lll} 
Family & Genus species & Common Name \\
\hline Amaranthaceae & Amaranthus sp. & Pigweed \\
cf. Boraginaceae & Carex sp. & Borage \\
Cyperaceae & Scirpus sp. & Sedge \\
& Scleria sp. & Bulrush \\
Euphorbiaceae & Croton capitatus & Scleria \\
& Croton sp. & Doveweed \\
Fagaceae & Quercus sp. & Spurge \\
Gramineae & Panicum sp. & Oak \\
& Paspalum sp. & Grass \\
& Setaria sp. & Grass \\
Juglandaceae & Carya illinoensis & Grass \\
Leguminosae & Centrosema virginianum & Pecan \\
Passifloraceae & Passifloraincarnata & Butterfly pea \\
Polygonaceae & Polygonum sp. & Passion-flower \\
Ulmaceae & Celtis sp. & Knotweed \\
Umbelliferae & Daucus sp. & Hackberry \\
Vitaceae & Parthenocissus sp. & Wildcarrot \\
& Vitis sp. & Virginia creeper \\
Unidentified A & & Grape \\
Unidentified B & & \\
& & \\
\hline
\end{tabular}

\section{Discussion}

The macrobotanical data from the Hurricane Hill site comes from Late Archaic, Woodland/Early Ceramic, Early Caddoan, and Middle Caddoan archaeological deposits. The archaeobotanical assemblages for the respective components at the site reflect a continuation of wild plant food reliance during the Late Archaic and Woodland periods, modified by the adoption of a limited amount of horticulture in the later Caddoan occupations (dating between ca. A.D. 1000-1400). This discussion examines the degree to which 
changes in plant food use might have occurred, based on the Hurricane Hill data viewed in conjunction with Cooper Lake and other Caddoan macrobotanical assemblages (cf. Fields et al. 1997; Perttula 1990b, 1996). In addition, identification of the maize type at Hurricane Hill is considered in more detail.

\section{Late Archaic and Early Ceramic components}

Fifteen sampled features on the Southwest rise date either to the Late Archaic (Fea. 64, 1000-890 B.C. at 1-sigma) or to a terminal Archaic-early Early Ceramic period occupation dated by radiocarbon assays to 300 B.C.-A.D. 230; the 42 samples from Blocks D and $E$ on the North rise principally relate to an Early Ceramic component in the Primary Midden. The flotation sample from the dated Late Archaic feature did not contain any plant materials other than a trace of wood charcoal. Similarly scant paleobotanical data were recovered in the samples from the Early Ceramic-age features, almost exclusively hardwood nutshells (Table $15-6)$.

Table 15-6. Summary of plant remains by component.

\begin{tabular}{|c|c|c|c|c|c|c|c|c|}
\hline $\begin{array}{l}\text { Component/ } \\
\text { Age }\end{array}$ & $\begin{array}{l}\text { Sample } \\
\text { Wt. }\end{array}$ & $\begin{array}{l}\text { Charcoal } \\
\text { Wt. }\end{array}$ & Maize (g) & Cucurbit & Nutshell & $\begin{array}{l}\text { Maize/ } \\
\text { Nutshell } \\
\text { ratio* }\end{array}$ & $\begin{array}{l}\text { Samples } \\
\text { with } \\
\text { Maize** }\end{array}$ & $\begin{array}{l}\text { Samples } \\
\text { with } \\
\text { Charred seeds ** }\end{array}$ \\
\hline $\begin{array}{l}\text { Late Archaic/ } \\
\text { Early Ceramic, } \\
\text { Southwest Rise, } \\
1007 \text { BC-AD } 232\end{array}$ & 11.80 & 4.90 & 0.00 & 0.00 & 5.70 & 0.0 & 0.0 & 0.0 \\
\hline $\begin{array}{l}\text { Early Ceramic, } \\
\text { North Rise } \\
\text { AD } 59-449\end{array}$ & 46.79 & 3.65 & $<0.1+$ & 0.00 & 27.16 & + & 2.4 & 2.4 \\
\hline $\begin{array}{l}\text { Early Caddoan, } \\
\text { North Rise } \\
\text { AD 1000-1200 }\end{array}$ & 153.62 & 18.77 & 1.8 & 0.00 & 89.65 & 2.0 & 14.6 & 12.5 \\
\hline $\begin{array}{l}\text { Middle Caddoan, } \\
\text { South Rise } \\
\text { AD 1248-1394 }\end{array}$ & 1024.91 & 565.66 & 1.94 & $<0.1$ & 62.08 & 3.2 & 9.7 & 2.4 \\
\hline
\end{tabular}

* Maize/Nutshell Ratio=Maize Wu/Nutshell Wt. X 10

** Percentage

+ Likely associated with Early Caddoan Middens 1 and 2

Even the common use of mast from hardwood trees for food or for the use of the wood fuel is barely substantiated by the dearth of botanical remains from Hurricane Hill (about 35 grams of plant foods). One charred oak fragment was identified in the scan of wood charcoal. Small amounts of hickory and acorn nutshell were also present in the samples. These findings, although not as diverse, are nevertheless consistent with assemblages from other generally contemporaneous components in the Cooper Lake study area (Fields et al. 1997:Table 11).

The Archaic components at the Finley Fan site (41HP159) produced hickory and tuberous roots (cf. Pediomelum) (Crane 1993; Fields et al. 1997; Gadus et al. 1992; Jurney et al. 1993; Jurney and Bohlin 1993). A clearly defined Early Ceramic period component at 41HP137, about $1 \mathrm{~km}$ from Hurricane Hill, yielded both hickory, pecan, and acorn, as well as cultivated squash rind and tuberous root and rhizome (cf. Pediomelum) fragments (Fields et al. 1997; Crane 1997). The botanical remains recorded for other Cooper Lake Early Ceramic components also included native seeds of wild fruit and legumes, as well as nuts and tuberous root fragments (Fields et al. 1997:Table 11). At 41DT59, Middle Archaic, Late Archaic, and 
Terminal Archaic-Early Ceramic components contained minuscule amounts of hickory/walnut nutshell (0.07 grams), acorn (0.01 grams), and possible tubers (0.02 grams) (Borojevic 1995; Cliff et al. 1995).

The presence of tuberous roots in Archaic (at least as early as the Middle Archaic period) and Early Ceramic period components suggests the existence of a long tradition of their use among Native Americans in the Cooper Lake area. Tuberous roots have also been documented in contexts that date between ca. 350 B.C.-A.D. 150 at the Unionville site (41CS151), Area C, downstream along the middle reaches of the Sulphur River basin (see Borojevic 1996; Cliff et al. 1996b). Such root use as food and medicine is well documented among historic Native American groups (Ford 1986; King 1984a). At least five scurfy pea or Pediomelum (Psoralea) species produce edible tuberous roots or rootstocks (rhizomes) (Harrington 1967:206; Tull 1987:87). Three of these have been reported in Texas (Correll and Johnston 1979:812, 815816). Prairie turnip (Psoraleaesculenta) is particularly well documented as a food among Native Americans (Kindscher 1987:184-189). Reid (1977:325) has suggested that Psoraleaesculenta may have even been reseeded when harvested. Attitudes associated with the encouragement of wild plants such as edible tubers certainly could have played a role in leading to the adoption of squash horticulture. The appearance of cultivated squash within the Cooper Lake area (and indeed in Northeast Texas generally) is currently believed to date to the early part of the Early Ceramic period (Fields et al. 1997).

\section{Early Caddoan component}

Macrobotanical remains from the Hurricane Hill Early Caddoan period component are more diverse than those of the Archaic and Early Ceramic samples (see Table 15-6). Less variation in species were documented in the Hurricane Hill plant materials than was the case at several of the other Early Caddoan period components at Cooper Lake (Crane 1993, 1997; Fields et al. 1997:81-82 and Table 11), however, probably due to differences in preservation conditions between the sites. The same general categories of wild plants, however, appear to be represented at Hurricane Hill, with the exception of tuberous roots and squash.

The multi-seasonal, multi-environmental nature of Early Caddoan plant exploitation at Hurricane Hill generally coincides with the paleobotanical evidence from other Cooper Lake sites. The addition of maize to squash horticulture has been well substantiated in the Cooper Lake area during this period, although at no site of this age is maize abundant. Maize is present in 7.7 percent of the 41 flotation samples from the Thomas site (41DT80); 7.7 percent of the 26 samples from Spider Knoll (Dering 1994); and 19.1 percent of the 26 samples at Doctors Creek (41DT124), but is absent in Early Caddoan deposits at Tick, Spike, and 41DT59 (Dering 1993; Borojevic 1995).

While the paleobotanical data for Hurricane Hill indicates the addition of cultivated plant species in Early Caddoan subsistence practices, there is no macrobotanical evidence for any significant reliance on them in this era. Stable isotope data on Early Caddoan skeletal remains, however, suggests that these populations may have consumed more than just minor amounts of maize (see Chapter 12, this volume; see also discussion in Wilson and Steele 1997:234). Indeed, throughout much of the Caddoan area, paleobotanical, isotopic, and bioarcheological data strongly suggest that cultivated maize was not the primary food source for Caddoan peoples at this time (see discussion in Crane 1997; Fields et al. 1997; Perttula 1990b, 1996; Rose et al. 1998).

\section{Wild Plant Resources}

Botanical evidence from other Cooper Lake sites suggests that wild plant procurement for Early Caddoan groups focused on various hardwood nuts, fruits, starchy and oily seeds, and roots (Fields et al. 1997:32, 80). The first three categories of wild plant materials are also preserved at Hurricane Hill, and the fourth category may also be represented.

Hardwood nutshells are the most ubiquitous plant class at the Hurricane Hill site. Hazelnut, as well as hickory, walnut, and acorn were recovered in the flotation samples. Edible fruits are represented by seeds of wild rose and grape. Grass, knotweed, and sunflower at Hurricane Hill duplicate some of the starchy and oily seeds that have been found at other Cooper Lake sites (Fields et al. 1997:81-82 and Table 11).

At various other Cooper Lake sites, and in all components from the Archaic through the Late Caddoan period, fragments of a tuberous root or rootstock (rhizome) have been identified in flotation 
samples (Fields et al. 1997:20-21, 80-81 and Table 11). Ubiquity values in Early Caddoan contexts range from 20-90 percent for these tubers (Crane 1993, 1997; Dering 1994).

Roots and stem modifications--including rhizomes, tubers, corms, and bulbs--can be considered together as a group. The major nutritional component of all these plant structures is starchy carbohydrates. Numerous historic accounts for extensive Native American use of underground plant structures indicate similar technologies for recovering (digging), preparation (chopping, peeling, and pounding), cooking (boiling and roasting), and storage (drying) (Harrington 1967:155-227; Kindscher 1987; Palmer 1871:404428). In addition, the major nutritional component of all these structures is starchy carbohydrates.

While no edible underground plant parts were directly recovered from Hurricane Hill, the charred inedible seed of a Solomon's-seal berry could represent the use of the plant's root. The edible rootstock of Solomon's-seal can be eaten year-round (Peterson 1977:76). However, like Psoralea (Kindscher 1987:187), this rootstock is probably best when dug up after blooming has ended, when its starch content would be greatest. In that case, acquisition would have been most likely to occur in the summer while berries were on the plant.

Archaeological preservation of underground plant parts will correspond to how the resource was processed and used (Pearsall 1989:169). Historically, the Iroquois are reported to have eaten Solomon's-seal root raw, cooked, or pounded into flour (Bye 1970; Waugh 1916). Other Native American groups also used the pulverized rootstock medicinally (Erichsen-Brown 1979:340-342). Such processing is more likely to leave the discarded seed charred and preserved rather than the rootstock itself.

\section{Resource Areas and Seasonality}

The macrobotanical materials recovered in the Early Caddoan period component at Hurricane Hill suggest wild plant procurement from moist floodplain and upland woods, open woods or woody edges, thickets, and perhaps prairie habitats. An emphasis, however, seems to have been the open woodland-woods edge-and thicket plants. Based simply on periods of availability for the charred seeds and nutshells recovered at Hurricane Hill, plants and plant foods were gathered in the spring through the fall, and perhaps in the winter (Figure 15-1).

The occurrence of hickory, walnut, and oak document riparian and/or upland woods in the vicinity of the site during the Early Caddoan period. Walnut, however, is intolerant of shade, and prefers natural openings or the woodland edge (Kaylor and Randall 1931:6). Various acorn and hickory species, as well as walnut, are available between September and November. Hazelnut would have matured in July and August (Vines 1960:145), slightly earlier than the other nuts. The shrubs that produce the filberts occur as thickets in the open areas of woods or at the woodland-prairie margin (Kindscher 1987:100; Talalay et al. 1984:340).

Both wild rose and grape species of Northeast Texas have similar habitats, namely along streams and in open woods and thickets (Correll and Johnston 1979:754-755, 1017-1021; McCoy 1980:5, 27; Steyermark 1963:849, 852). Two local native wild rose species (Rosa setigera and $R$. carolina) extend their range into the prairie, but require moist soils (Loughmiller and Loughmiller 1984:211; McCoy 1980:5; Steyermark 1963:849). The hips of these Rosa species ripen in the early fall, but remain attached through the winter (McCoy 1980:5). Depending on the species, wild grapes generally mature from August through November (Correll and Johnston 1979:1017-1021; Vines 1960:712-731).

The starchy or oily seed types represented at Hurricane Hill include grass (cf. Agrostis sp.), knotweed, and sunflower. The native bentgrass species of Texas seem to grow as perennials in moist conditions along streams or in open woods, and spring-flowering species seed in the spring, while the fallflowering species seed in the late fall (Cheatham and Johnston 1995:176; Correll and Johnston 1979:143144; Gould 1978:13). Both spring (Agrostis hyemalis) and autumn (Agrostis perennans) bentgrass occur in Northeast Texas (Cheatham and Johnston 1995:177). Native knotweeds/smartweeds generally occur in moist or wet open areas, and various species seed between February and November (Correll and Johnston 1979:520-526). Sunflower species grow in open habitats, but require a variety of soil and moisture conditions to thrive. Three common species (Helianthus hirsutus, H. annuus, and H. mollis) currently grow in East Texas. Of these, the Rough sunflower ( $H$. hirsutus) is more likely to be found in moist soils of open woods, or to extend its range west along streams (Enquist 1987:228). The other two species tolerate 
drier soils along stream banks or in prairies (Ajilvsgi 1984:123; Loughmiller and Loughmiller 1984:62-63; Enquist 1987:228-229). The achenes would ripen in the late summer or fall (Enquist 1987:228-229; Peterson 1977:88).

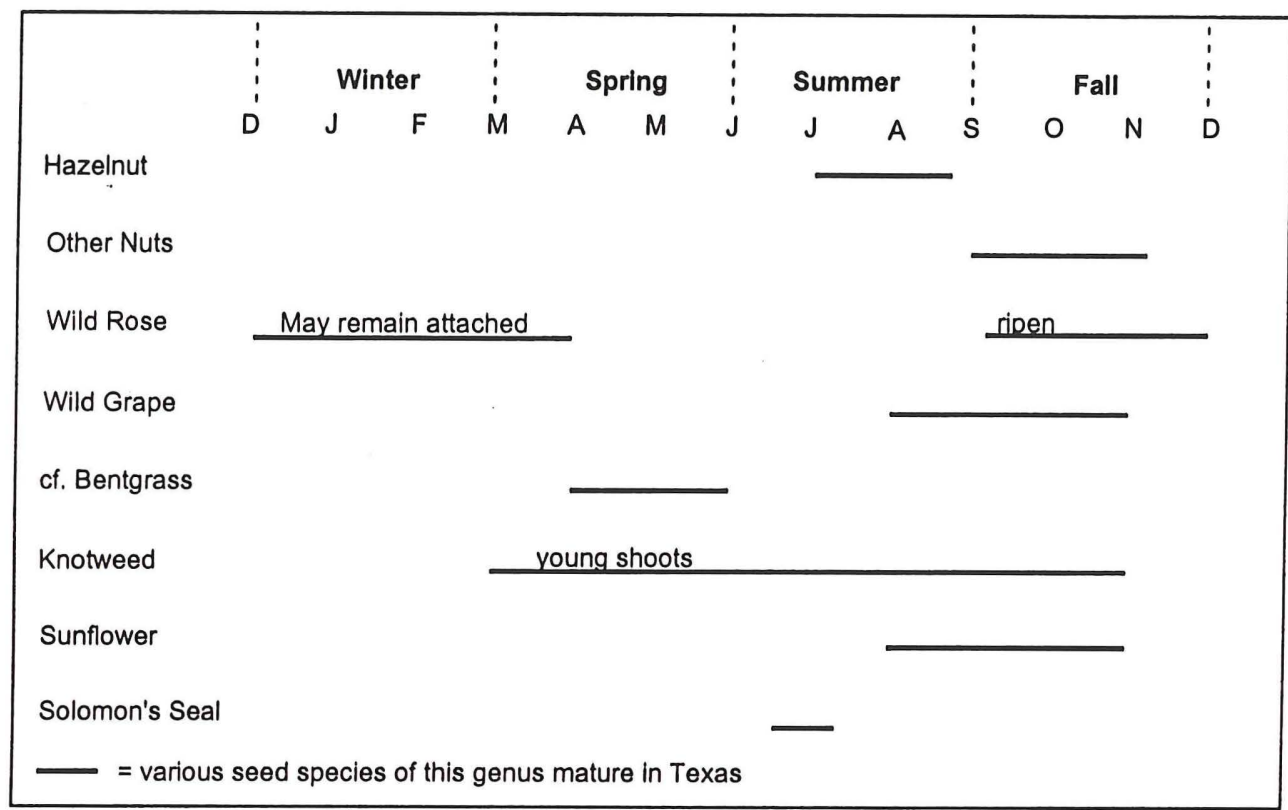

Figure 15-1. General seasonal availability for charred wild plants represented at the Hurricane Hill site.

The Solomon's-seal occurs along wooded stream edges, moist, rich soils on wooded slopes, and in thickets (Ajilvsgi 1984:65; Correll and Johnston 1979:407; Steyermark 1963:442). In Texas, blooming ends in May (Correll and Johnston 1979:407), so that the mature berries would be formed by early summer.

\section{Cultivated Plants}

Both squash and maize have been recovered in Caddoan contexts at Hurricane Hill. The squash was associated with the Middle Caddoan period component on the Southern rise, while maize was found with both the Early and Middle Caddoan occupations on the North (Block A, Block A extension, and selected samples from Block D) and South (Block B/C and Block F) rises.

The Cucurbita was identified by Crites in the initial analysis of flotation samples; unfortunately, no additional squash materials were present in the flotation samples from Goldborer's study. Cucurbita are very vulnerable to numerous environmental and cultural processes that generally prevent botanical materials from being recovered in open archaeological sites (Cowan 1997:64-65). Therefore, the amount of squash utilization may very well be underrepresented at Hurricane Hill compared to many of the other Caddoan sites at Cooper Lake.

Maize, on the other hand, preserves better than most botanical materials (Wetterstrom 1978:239). Traces of corn may be left even after the shelling and grinding of kernels (Wetterstrom 1978:239). Cobs do not readily decompose, and generally provide a fuel source that increases the likelihood that some remains will be charred and preserved. The quantity and ubiquity of maize at a site are much better indicators of its use and subsistence importance than would be the case for the readily destroyed squash or beans.

Only 14.6 percent of the flotation samples in Early Caddoan period contexts on the North rise had maize remains (see Table 15-6). Only 1.8 grams of corn were recovered in these samples, and most of that came from a single feature sample in Unit 259. By actual cupule count, most of the maize was distributed between Unit 259 and two others (Unit 256, 1v. 4B and Unit 244, 1v. 3B) in the Block A extension. Considering the durability of maize, the small quantity, and low percentage of corn in the numerous 
samples suggest that there was little use and no dependence on this foodstuff at Hurricane Hill during this period. This finding is consistent with paleobotanical samples from Cooper Lake and elsewhere in the Sulphur River basin at this time, but contrasts with well-documented post-A.D. 1200 paleobotanical assemblages from Northeast Texas Caddoan sites such as Oak Hill Village (41RK214; J. Phil Dering, 1998 personal communication); Roitsch (41RR16) and Spoonbill (41WD109) (Fritz 1992; Goldborer 1995; Perttula et al. 1983), and many other Caddoan sites in Arkansas, Louisiana, and Oklahoma, such as Cedar Grove (King 1984b; Trubowitz 1984); Hardman (Early 1993; Fritz 1993); McLelland (Gardner 1997b; Kelley 1997); Roden (see Perttula 1990b); and Spiro (Fritz 1982, 1989). Here, maize is ubiquitous in flotation and feature contexts, with percent ubiquity values ranging from 50-100 percent; these sites also have cultivated bean and/or squash.

Hurricane Hill lies between and slightly west of the Roitsch (middle Red River) and Spoonbill (upper Sabine River basin) sites. An analysis of feature ubiquity for maize from the latter two sites (58 and 83 percent, respectively) suggests that it was in common use after ca. A.D. 1200; stable carbon isotope values on A.D. 1300-1500 human skeletal remains from the Roitsch site also are indicative of the common use of maize as a food resource (see Perttula 1996). "Common use," meaning it occurs in 50 percent or more of the analyzed features, certainly suggests some measure of reliance (e.g., Johannessen 1984:203). The current botanical evidence from the Early Caddoan component at Hurricane Hill, and at other Early Caddoan sites at Cooper Lake, does not indicate any major reliance on maize, but rather supports the hypothesis that corn was a dietary supplement. In an analysis of paleobotanical remains from Early and Middle Caddoan sites downstream from Hurricane Hill on the Sulphur River, Fritz (1995:I-7) commented that "maize is not as abundant as one might expect for maize-dependent agriculturists...the low frequencies of maize relative to nutshell in these middens is consistent with an interpretation of relatively late [after A.D. 1400] agricultural intensification in Northeast Texas."

Despite apparent differences in the reliance on maize between these sites, the type of corn at Hurricane Hill appears very similar to that at Roitsch and various other Caddoan sites (Ford 1997; Fritz 1989:73-75, 1992:6-8; Goldborer 1988:18, 1995:6-9, 17-18, 1997:3; Jones 1949). The maize found at all of these sites is small with generally low average row numbers (although row numbers appear to increase through time at many Caddoan sites to the point where cob row numbers average greater than 11-12 rows [Perttula 1990b]), and a cupule width/internode ratio of more than 1 . These combined characteristics suggest a small type of Maiz de Ocho (Bird and Dobbs 1986:94-95; Cutler and Blake 1973; Galinat 1970:220, 1985:261-263; Wagner 1986:115-119). Yet, the type affiliation for the small maize recovered at many Caddoan sites many not be so unambiguous.

Small maize from the George C. Davis site, Cherokee County, Texas (occupied between ca. A.D. 900-1300 [Story 1997]) was previously defined as a Northern Flint type (Jones 1949). Re-examination of the Davis site maize indicates that, while it is possibly a small type of Maiz de Ocho, another origin is also possible (Galinat and Gunnerson 1963:132-133; Yarnell 1964). Maiz de Ocho is characterized as having eight or 10 rows, or occasionally, 12 rows. However, when row number could be established for the small maize from Caddoan sites, it has ranged from eight to 16 rows, yet cupules may be wider than thick (Blake 1994:43; Early 1988:134). Ford (1997:107) found a predominance of Eastern Complex corn among the maize remains from the 1968-1970 excavations at the Davis site, but acknowledges that several 14-rowed cobs could represent another type.

In discussing archaeological maize from the Vosburg site in Minnesota, Bird and Dobbs (1986:94) described a small Eastern Eight-row corn with eight to 10 rows and cupules 5.5-8.5 mm in width. Midwest Twelve Row is defined as having the same small cupule size range, but with 10-16 rows (Bird and Dobbs 1986:94). Cupule size of the small Caddoan maize generally falls into this range. Early Caddoan maize cupules from the Hurricane Hill site do not exceed $8.4 \mathrm{~mm}$ in width.

Cob shape and dimensions, which are important in defining maize types, have usually not been attainable from Caddoan maize remains. Whether the small maize variety at Hurricane Hill and other Caddoan sites represents an Eastern Complex maize, a type with a different origin, or several types, remains unresolved (Bird and Dobbs 1986:94-95; Ford 1997:107; Galinat and Gunnerson 1963:132-133; Yarnell 1964:114). 
Regardless of the origin of the small maize prevalent in Caddoan archaeological sites, it could be the same kind as the "little corn" described in 17th and 18th century historic accounts of the Caddo peoples (Swanton 1942, 1979). Spanish missionaries in the early 1700s noted "little corn" grown by the Hasinai Caddo in the Neches-Angelina river basins in Northeast Texas (Swanton 1942:129). An early season small corn type, which was planted in April and harvested by the end of May, seems to have been widely available in the Southeast U.S. during historic times (Swanton 1942:129, 1979:274, 290). Fritz (1990a:4-7) has speculated that a few cobs from rockshelters in Northwest Arkansas may represent the historically described "little corn." The rockshelters are located at the northern limits of what is considered the Caddoan area (Fritz 1986:40-41). One directly dated cob has a radiocarbon age of A.D. 1300 (Fritz 1986:74, 1990a:6). Among these cobs, row number and cupule width give the impression of an Eastern Complex maize, but cob and shank dimensions are not characteristic of that type (Fritz 1986:5-7). This situation demonstrates the problems with actually determining what "type" of corn the small Caddoan maize is.

If the small maize being recovered in Northeast Texas archaeological sites is synonymous with the historic "little corn," its initial appeal may have been its early maturity. The historic accounts indicate that "little corn" was harvested between the middle and end of May (Swanton 1942:129, 1979:274). Late spring can be a stressful period for a hunter-gatherer society because winter food stores may be low or depleted, and the abundance of summer and fall foods has yet to be established. In an environment where seasonal foods are sufficient to meet subsistence needs in other periods, a plant that offers a high carbohydrate product and matures opportunely so as to augment the diminished food supply of late spring should have a high probability of usage.

These circumstances, combined with any existing favorable attitudes toward encouraging wild plants or gardening squash, would further favor the adoption of the carbohydrate-rich maize. For huntergatherers with no other periods of food stress, a small, late-spring maturing maize used as a supplemental food would be sufficient to meet their needs. At such a level of use, maize could be expected to enter the archaeological record, but without leaving much of a substantial record. The paleobotanical record at Hurricane Hill for the Early Caddoan period conforms to such an expectation.

\section{Middlle Caddoan period}

The numerous flotation samples from the Middle Caddoan period component on the South rise at Hurricane Hill (see Appendix XX) included only a small amount of paleobotanical material, primarily hickory nutshell, maize in low amounts, squash, and a few charred seeds (see Table 15-6). The presence of American elm charcoal and hickory nutshell among the paleobotanical remains reflects the continued use of floodplain or flanking upland woods as resources for food and fuel.

Two sumac seeds and one juniper seed were among the few charred plant remains from the South rise. The sumac seeds are probably Rhus glabra. Smooth sumac can grow in a variety of soil conditions, but usually occurs along streams and woodland margins (Elias 1980:803). The juniper seed probably represents the common Eastern Red Cedar (Juniperus virginiana). Eastern Red Cedar is very adaptable to either wet or dry soil conditions, so that its presence is not a good indicator of a specific resource area. Both sumac and juniper species have mature fruit in the fall. Sumac fruit may remain attached through the winter. However, the combined presence of sumac, juniper, and hickory probably attests to plant food gathering during the fall months.

Less than 10 percent of the Block B/C and Block F samples from the Middle Caddoan component included maize. In contrast to the Early Caddoan plant remains, that are fairly well-distributed in midden deposits on the North rise, most of the maize in the Middle Caddoan period assemblage is found in pit features. Percent ubiquity values for maize in Middle Caddoan flotation samples from features is 35.3, compared to only 5.6 percent in non-pit feature contexts (see Table 15-2 and Appendix XX). This suggests that there were different means of processing, disposing, and storing of maize between Early and Middle Caddoan times. Cucurbita remains were recovered in a pit from within the younger of the two superimposed structures in Block B/C.

Whole cupules ranged from 3.2-7.6 mm in width. The mean width of $4.49 \mathrm{~mm}$ for the Middle Caddoan period maize at Hurricane Hill is slightly less than that of $5.78 \mathrm{~mm}$ for the Early Caddoan botanical materials. All cupules are wider than thick. These small cupules are generally within the width 
ranges of cupules from other Middle Caddoan and Late Caddoan McCurtain phase (ca. A.D. 1300-1700) sites (Blake 1994:43-49; Fritz 1992:13 and Table 3; Goldborer 1997:3). Historical records indicate that a larger, late season maize was planted by the Hasinai following the "little corn" harvest (Swanton 1942:129). Evidence for a larger variety at prehistoric Caddoan sites, however, has not been forthcoming (e.g., Blake 1994:43-49; Early 1988:134; Fritz 1989:73-75, 1992:6-8 and Table 3; Goldborer 1988:18, 1995:6-9, 29 and Table 5, 1977:2-3; Jones 1949; Weber 1973).

Based on ubiquity values, then, the Middle Caddoan period component at Hurricane Hill indicates only the supplemental use of a small, low row-numbered maize in the subsistence system. Maize is equally sparse in several Middle Caddoan period components in the White Oak Creek Mitigation area downstream from Cooper Lake (see Cliff and Hunt 1995; Fritz 1995; Holloway 1997; Largent et al. 1997).

\section{Summary}

The analysis of more than 275 flotation samples have provided macrobotanical data from Late Archaic, Early Ceramic, Early Caddoan, and Middle Caddoan period components at the Hurricane Hill site. The botanical assemblages for these components, although affected by differences in context and conditions of preservation, indicate some diachronic continuity and change in plant use over approximately 2 millennia.

The use of hardwood trees for food and fuel is noted for both the Late Archaic and Early Ceramic period paleobotanical data, and the only economic plant resources present include hardwood nuts used for their meat and oil. Squash and tubers are absent. A more diverse wild plant assemblage is present in the Early Caddoan period occupation at Hurricane Hill. Macrobotanical remains suggest that native plant procurement for this period focused on hardwood nuts (mainly hickory), wild fruits, starchy and oily seeds, and possibly roots. These data support the pattern of plant food use seen in other Cooper Lake sites (Crane 1997; Fields et al. 1997), and other sites in the middle reaches of the Sulphur River basin. Wild plants were apparently procured from riparian and upland woods, thickets, and possibly prairie habitats. The emphasis, however, at the Hurricane Hill site appears to have been on open woodland or woodland edge and thicket plants. Botanical evidence for seasonality supports plant use and procurement during at least the spring, summer, and fall months.

Cultivated squash is documented in a Early Ceramic period context at nearby 41HP137 (McGregor 1997b), and is also present in some quantity in Late Archaic and Early Caddoan components elsewhere at Cooper Lake (see summaries in Crane 1997; Fields et al. 1997). At Hurricane Hill, however, squash was recovered only in the Middle Caddoan period occupation, while maize has been found in roughly comparable amounts for both the Early Caddoan and Middle Caddoan period components. While the paleobotanical evidence confirms the use of cultigens, it does not indicate any major reliance on either corn or squash at the site. Rather, the data supports a view that maize and/or squash were dietary supplements in Early and Middle Caddoan subsistence systems in the upper Sulphur River basin.

The small amount of botanical data gleaned for the Middle Caddoan occupation indicates a continued focus on floodplain and upland woods to procure native plants. There is insufficient botanical data to confirm plant use in any season except the fall. While there is evidence that maize and squash cultivation continued at Hurricane Hill during this period, it was probably still a minor subsistence component, although perhaps slightly more abundant based on the feature ubiquity values.

Measurements of maize cupules at Hurricane Hill seem to indicate the presence of a small Eastern 8-rowed corn during both the Early and Middle Caddoan periods. While this correlates with paleobotanical data from several other assemblages throughout the Caddoan area, the issue of maize type among these groups is still largely unresolved. Most evidence for maize type among Caddoan sites is generated from kernel and cupule measurements. Direct observations of other factors such as row number and cob shape, that might help clarify type identifications, are rare. Where row number has been directly established for small corn from Caddoan archaeological sites, it has sometimes been greater than the eight to 12-rows that characterize Eastern 8-rowed maize. This suggests that "type" identifications of maize may be a very complex issue in this region. 
A possible relationship between the small maize indicated at Hurricane Hill and the "little corn" of historic accounts of the Caddo peoples is plausible. The lack of archaeological evidence for the larger corn planted as a second crop, reported in historical documents, at least suggests that a "little corn" variety may have a more important link to the prehistoric Caddoan groups. Maize types, and the relationship of corn and its adoption into Caddoan subsistence strategies, are important issues that warrant further scrutiny. 


\title{
CHAPTER 16, PREHISTORIC SETTLEMENT AND CULTURAL LIFEWAYS AT THE HURRICANE HILL SITE: SUMMARY AND CONCLUSIONS
}

\author{
Timothy K. Perttula
}

This final report presents the various results, thoughts, and speculations of the many authors and the present editor about the prehistoric archaeological information gathered from the 1986-1987 archaeological investigations at the Hurricane Hill site (41HP106), located on the dam embankment rightof-way for Cooper Lake. The site is located on a large upland landform overlooking the South Sulphur River, and covers about 21 acres. Our first encounter with the site came during the recording of it during the September 1986 cultural resources survey of the dam embankment (Perttula 1988a); at that time the site was being cleared, grubbed, and bulldozed by U.S. Army Corps of Engineers, Fort Worth District (COE-Ft. Worth) contractors in preparation for the construction of the Cooper Lake dam. Inexplicably, the site had been missed during the original Southern Methodist University survey of Cooper Lake in 1970 (Hyatt and Skinner 1971). When we identified and recorded the Hurricane Hill site, large amounts of prehistoric archaeological materials were visible on the disturbed surface of the site over this large area, and rumors abounded from concerned local citizens that human skeletal remains had been exposed during the construction clearing contract. Subsequent findings proved these rumors to be true.

Due to the perseverance of the Cultural Resources Section of the COE-Ft. Worth District, once the site was identified, however, dam construction activities were diverted from the site area while initial assessments of site integrity and research significance were conducted during the survey investigations by the University of North Texas. Although the upper $10-20 \mathrm{~cm}$ of the archaeological deposit had been disturbed by the clearing and construction activities, it was apparent at the completion of this initial work (dubbed, imaginatively enough, Phase I) that the site contained new and valuable prehistoric archaeological information about the Early Ceramic and Early-Middle Caddoan period settlements and use of the Cooper Lake area, and clearly warranted additional consideration before it was to be destroyed by dam construction. Following the recommendations made in the survey report (Perttula 1988a:123-124), a multi-phase program of archaeological investigations was subsequently conducted at the site at the behest of the COE-Ft. Worth, under emergency conditions, to mitigate the adverse effects upon it by construction of the Cooper Lake dam.

From a research perspective, our work concentrated on a ca. $6,000 \mathrm{~m}^{2}$ area (1.5 acres) at the western end of the site itself where the best-preserved and most interesting prehistoric archaeological deposits had already been located during pedestrian survey and intensive shovel testing. At the completion of the work more than a year later, over 37 percent of that area had been excavated either by hand or by machine (using a backhoe and gradall) in an attempt to locate and define prehistoric Caddoan structural remains, Late Archaic/Early Ceramic and Caddoan midden deposits, and prehistoric cemeteries and burial areas dating to Late Archaic/Early Ceramic, Early Caddoan, and Middle Caddoan periods. It was due at least in part to the concern of the COE-Fort Worth District that all prehistoric human burials be located and excavated from the right-of-way, prior to the renewal of construction activities--along with the expressed concerns of the Caddo Tribe of Oklahoma that prehistoric burials not be further damaged by construction-that contributed to the extensive areal investigations that were conducted at the site, although the opportunity to define intra-site community and settlement patterning for the Late Archaic/Early Ceramic and Caddoan occupations was also seized upon as a guiding framework for the research effort.

\section{Highlights of the Research}

This archaeological work provided an excellent opportunity to examine significant portions of both the Late Archaic/Early Ceramic and Early-Middle Caddoan period deposits on several natural rises on the landform as part of the investigation of intra-site patterning and site structure in Northeast Texas prehistory. Another research avenue which was exploited was the recovery of well-preserved ecofactual (i.e., animal 
bones and plant remains, including charred maize) remains on the North rise, from which a substantial Early Caddoan faunal assemblage was retrieved. Plant remains were less well preserved, but analysis of the extensive flotation remains from midden and feature fills does illustrate the use of maize, squash, nuts, seeds, and roots by either the Late Archaic/Early Ceramic and Caddoan groups that lived at Hurricane Hill. The plant and animal remains from the Caddoan components suggest that the Caddoan inhabitants of the site lived there year-round, perhaps for as long as a generation or two (based on the superposition of Structures A and B on the South rise during the Middle Caddoan period) during each component. On the other hand, during the Late Archaic/Early Ceramic periods, the Hurricane Hill site may have been used as a residential camp during certain seasons of the year rather than year-round.

The study of lithic raw materials and chipped and ground stone artifacts provided a massive data set to examine concerning the use and procurement of local and non-locally available stone in this part of the western Gulf Coastal Plain (e.g., Banks 1990; Perttula 1984). Although local Uvalde gravel sources (composed primarily of fine-grained and coarse-grained quartzites, petrified wood, and several different colors of small chert pebbles) were the predominant material selected for tool manufacture and use during all periods when the site was occupied, materials from Southeast Oklahoma (i.e., the western Ouachita Mountains), Red River gravels (also deriving from western Ouachita Mountain sources), Missouri, and New Mexico were documented in the collections. The obsidian from New Mexico was apparently collected through long-distance trade by the Early Caddoan inhabitants of the site.

Ceramics are typically rather uncommon at other Cooper Lake sites (see Fields et al. 1997) in comparison to lithic tools and debris, but the intensive investigations at Hurricane Hill recovered over 8,800 sherds from across the site, as well as a small number of fragments of several long-stemmed Red River pipes. The decorated sherds during both the Early and Middle Caddoan period occupations share stylistic elements with contemporaneous Caddoan groups downstream on the Sulphur River, and to the north on the Red River. Radiocarbon and archaeomagnetic dates from feature and midden deposits, and (less confidently) thermoluminescence dates on a number of sherds, indicates that the Caddoan archaeological record at the site dates primarily between A.D. 900/1000-1400, with two relatively discrete components of different age on the North (ca. A.D. 900/1000-1200) and South (ca. A.D. 1200-1400) rises. Consequently, the large sample of decorated and plain ceramics from relatively restricted temporal contexts at Hurricane Hill has provided a much-needed data base to better investigate the character of Early and Middle Caddoan period ceramics in the upper Sulphur River basin (see Perttula 1997c), as well as for adjoining parts of Northeast Texas (e.g., Story 1988; Thurmond 1988; Cliff 1997; Middlebrook and Perttula 1997).

Petrographic and instrumental neutron activation analysis (INAA) of a sample of $\mathbf{4 0}$ sherds from the two Caddoan components suggest that the majority of the ceramic vessels--both plain and decorated-used at Hurricane Hill were manufactured locally from nearby clay sources. The local manufacture of the Hurricane Hill ceramics, in combination with many shared stylistic and decorative elements, implies (at least to my mind) close social interaction between the Caddoan groups living at Hurricane Hill and Caddo populations to the north and east, as well as probably to the south (e.g., Fields et al. 1994, 1997). However, between 20-25 percent of the sherds subjected to INAA have chemical compositions similar to Northeast Texas Red River and Titus group sherds (Cogswell et al. 1998a) from Early-Late Caddoan contexts along the middle reaches of the Red River north of the Hurricane Hill site or Middle-Late Caddoan contexts in the Big Cypress Creek and Sabine River drainages. The prevalence of Red River group sherds in both Early and Middle Caddoan components at the site seems to nicely corroborate the increased use of Red River gravels--particularly novaculite, gray chert, and jasper--in the same time periods.

Clusters of features were recorded on three different parts of the site, the North rise, the South rise, and the Southwest rise. The bulk of the more than 230 features are Early and Middle Caddoan period pits, posts, or other cultural disturbances related to the apparent year-round habitation by small groups of Caddoan peoples on the two natural rises. Portions of at least five Caddoan structures were recorded on the North and South rises, and one or two of these may be arbors or ramadas associated with the residences. At any one time, however, none of the households appear have been contemporaneously occupied during the Caddoan use of the site, and it is estimated that a maximum of 10-20 people lived at the Hurricane Hill site at any one time during the A.D. 1000-1400 period. Later, post-A.D. 1400 materials have been recovered in very small amounts from the site (a few shell-tempered sherds and triangular arrowpoints), and they seem to document a more transitory non-residential utilization of the landform/site area (perhaps for hunting and/or food processing activities) since no definite features or burials can be associated with them. This is 
consistent with broader regional patterns of Late Caddoan settlement in the western portions of the Post Oak Savanna in Northeast Texas (Fields 1995a; Fields et al. 1997; Perttula 1995a), where Late Caddoan residential settlements were situated to the south and north or a substantial way downstream ( $>30$ miles) from Hurricane Hill.

The Early and Middle Caddoan period occupations lasted sufficiently long that considerable areas of trash midden had accumulated in proximity to the structures, particularly on the North rise, to the northwest of Structure D. One of the structures on the South rise was rebuilt (or built over the area of a decayed, abandoned house), and several individuals had died and been buried there. These persons were placed in pits in midden deposits, or outside the walls of the structures, with the exception of one individual who was buried in a sub-floor pit. None of these Caddoan individuals had any grave goods. Faunal remains from the Early Caddoan component indicate that all environmental habitats in the vicinity were exploited, especially the forest edge. Wild and cultivated plant foods were apparently also consumed during both the Early and Middle Caddoan occupations, although the proportions of cultivated plant foods are dwarfed in the flotation samples--as they are in other Cooper Lake Caddoan sites--by charred nutshells of hickory and acorn. Nevertheless, the flotation samples do document an increased ubiquity of maize in the Middle Caddoan component, but the ubiquity is considerably lower than in contemporaneous Middle Caddoan contexts in the Sabine River drainage, however (see Dering 1998). Certainly the arable loam soils at Hurricane Hill would have been amenable to the use of slash-and-burn cultivation strategies by Caddoan horticulturists.

An earlier occupation (or occupations) was also identified in most areas of the site that predates the Early and Middle Caddoan period occupations, one by at least 500-1000 years. This occupation took place during the Late Archaic and Early Ceramic periods, between ca. 2800 and 1200 years ago, based on radiocarbon dating (the radiocarbon dates suggest the occupations ended about 1500 years ago) and temporally diagnostic projectile points. Midden deposits of this age on the North and Southwest rises do indicate that these people were at least living at the site during several seasons of the year, but they are not considered to have had a sedentary settlement system because permanently maintained structures of this age have not been located at any Late Archaic/Early Ceramic component at Cooper Lake, including Hurricane Hill, and year-round seasonal indicators in plant or animal remains are lacking. Nevertheless, an impressive body of information was obtained on some aspects of Late Archaic/Early Ceramic period life at Hurricane Hill.

Of singular importance is an Late Archaic to Early Ceramic period cemetery on the Southwest rise. This cemetery, which covered about a $90 \mathrm{~m}^{2}$ area, was completely exposed and excavated during the final Phase IV investigations at the site. Interments in the cemetery were both secondary cremations and probably bundle burials, although these were poorly preserved. The cemetery's centerpoint was a large secondary cremation that contained the remains of several individuals, and which was apparently used during at least four different episodes; the other cremations and bundle burials were dispersed around that feature (Feature 64). Many of the interments originated in Late Archaic/Early Ceramic period midden deposits on the Southwest rise, but others were outside of the midden boundaries. None of the burials contained any apparent grave good offerings, although the relative frequency of projectile points in the cremation fill is much higher than in the midden deposits, and there are heat-fractured artifacts in the cremation fill.

In addition to these primary archaeological components at the site, Hurricane Hill was the focus of intermittent use extending back to about 10,000 years ago, but with a heightened use beginning about 5000-6000 years ago. The primary components at the site appear to have occurred during more mesic intervals in the regional paleoenvironmental reconstruction (Figure 16-1). Undoubtedly Hurricane Hill's forested setting overlooking the South Sulphur River Valley, mesic climatic conditions along the prairiesavanna ecotone, the abundance of knappable lithic materials, the presence of sandy, arable soils, and its prominent landform were contributing factors in the long period of use by prehistoric peoples living in Northeast Texas. 


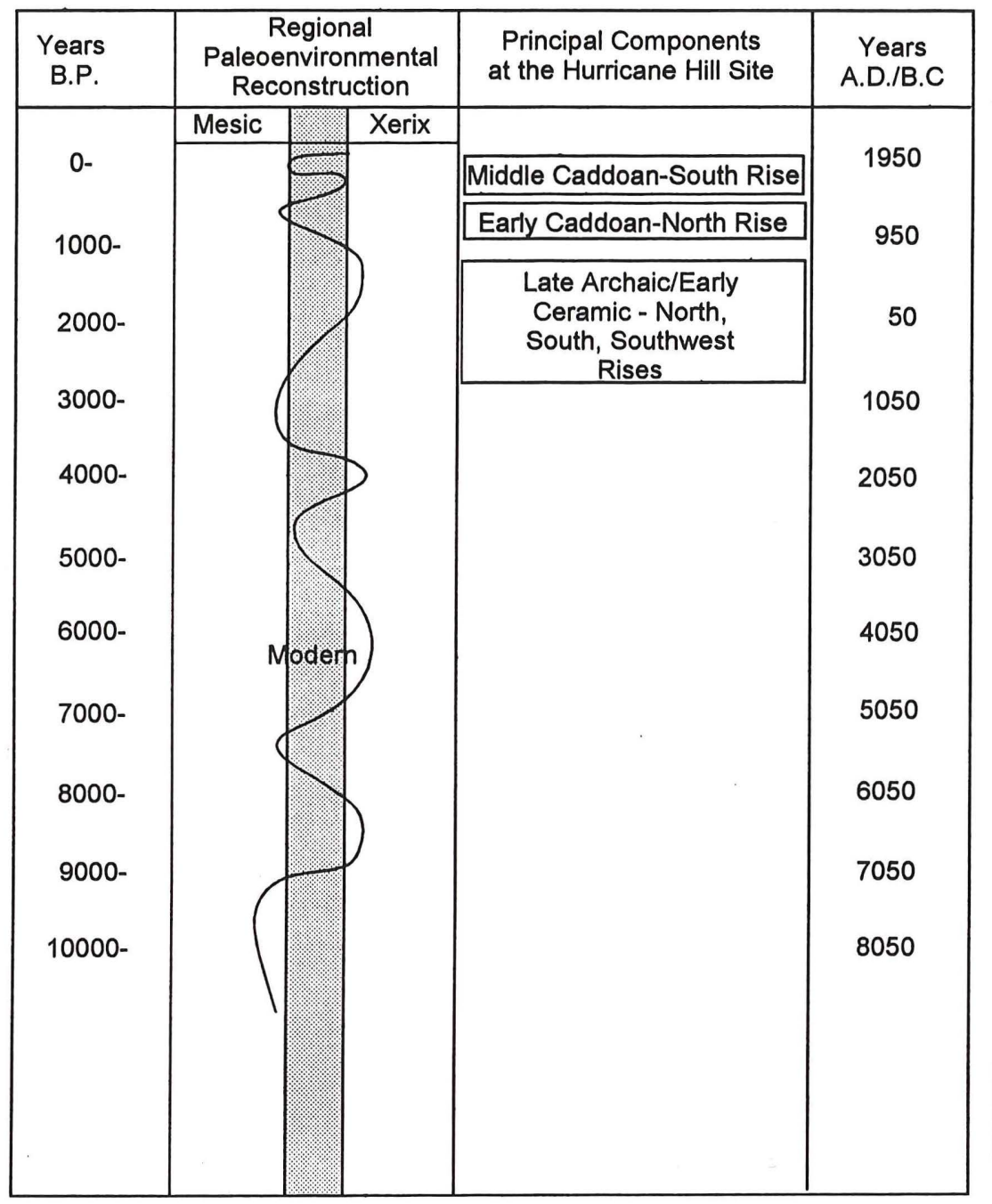

Figure 16-1. Principal components at Hurricane Hill and regional paleoenvironmental conditions.

\section{A Broader View}

Fields et al. (1997:85-93) have provided an excellent summary discussion of the prehistoric archaeological record at Cooper Lake, particularly the archaeology of the Late Archaic, Early Ceramic (or Woodland), and Early Caddoan periods at Cooper Lake and how it compares with the prehistory elsewhere in Northeast Texas. It is not necessary to duplicate their findings here. Rather, the task of this final section of the report is to take a broader archaeological view of the character of the primary components at Hurricane Hill (i.e., the Late Archaic/Early Ceramic, Early Caddoan, and Middle Caddoan) for the purpose of considering the site's place in the prehistoric native history of the southern Caddoan area.

\section{Late Archaic/Early Ceramic Period}

Probably the most important culture change that marks the Late Archaic to Early Ceramic period archaeological record in Northeast Texas is an increased residential sedentism marked by sites with evidence of longer duration occupations, at least in certain places (see Story 1990), likely associated with both an increasing population size and the development of distinct territories. Early Ceramic period sites are common in the region, and apparently quite common in much of the Sulphur River basin (see Perttula et 
al. 1993; Story 1990). This increased sedentism does not appear to have been uniformly associated with either the development of horticultural economies, although squash is reported from several sites at Cooper Lake dating to this temporal interval, complex mortuary or ritual practices (such as the mound crematoria on the Red River), or with the introduction of ceramics and/or the bow and arrow, although such technologies are adopted during the earlier and later parts of the Early Ceramic or Woodland period across much of the region. It is suspected that increasing population sizes through the natural long-term growth of adaptively successful hunter-gatherer bands contributed more to shape the character of Early Ceramic period societies than any other single cultural change.

The archaeological evidence from the Hurricane Hill site, and the many other Early Ceramic or Woodland period components at Cooper Lake (see Fields et al. 1997:86-88), represent some of the more extensive information available on the nature of these relatively sedentary hunter-gatherers in the region. The more intensively occupied residential sites have midden deposits with an abundance of lithic tools and debris and fire-cracked rock features, and there are smaller camps apparently used for the procurement and processing of plant, animal, and raw material resources. The residential sites contain burials, but lack structures or other evidence for year-round or multi-seasonal use, and only the Hurricane Hill site contains a cemetery. This particular cemetery sits on the edge of a prominent hill, and contains cremations and bundle burials, none with grave goods.

Cremations are reported from Late Archaic to post-A.D. 1200 contexts in the Caddoan area, including sites such as Jonas Short, J. E. Galt, Jaggers, L. A Hale, Boxed Springs, and 41RK215 in Texas (see Jackson 1934b; Martin 1997a; Rogers et al. 1994; Story 1990; Thurmond 1990), the Johnny Ford and Mineral Springs sites in southwestern Arkansas (Bohannon 1973; Stewart 1993), and several small earthen mounds along the Red River in southwestern Arkansas and northwestern Louisiana (Schambach 1982:145146, 1996, 1997a; Webb 1984). Furthermore, there are various contemporaneous sites in the Post Oak Savanna and Blackland Prairie and North central and East central Texas that also have cremations (Bruseth and Martin 1987; Fields and Klement 1995; Peter et al. 1988).

The burial practice of cremations at Hurricane Hill is much like those described from the contemporaneous Johnny Ford site (3LA5), an Early Fourche Maline village (ca. 200 B.C.-A.D. 300) in the Great Bend area of the Red River valley. This suggests the existence of similar belief systems among aboriginal groups in the Red River and Sulphur River basins. Schambach (1996:36) describes the burials at Johnny Ford as occurring in a "cremation cemetery," and he further suggests that everyone in the village may have been cremated, using the bluff edge crematoria at mound sites such as Cicero Young and Bellevue (Schambach 1997a:57). No such mound crematoria have been reported in the upper Sulphur River basin, however, and it is likely the deceased at Hurricane Hill were processed for cremation or bundle burials in or near the residential settlements.

The cremations themselves at the Johnny Ford site were marked by small, shallow pits $(20-60 \mathrm{~cm}$ in diameter) filled with varying amounts of calcined human bones that were found in a midden deposit, and they lacked grave goods. In at least one feature (Fea. 32), the cremation pit had three discrete deposits of calcined bone representing multiple individuals (Stewart 1993:Figure 3-8). Several cremation features at Hurricane Hill also had multiple deposits of human bone from a number of individuals, including children and adults. The cremation and burial together of children and adults stands in contrast to Binford's (1971:21-22) findings that children in egalitarian societies were frequently buried in private family space (i.e., in pits under houses) while adults were buried in the community's public space, and is also in opposition to the better-understood and diverse mortuary practices documented for later Caddoan groups in the region where children and adults were concerned.

\section{Social Aspects of the Cemetery}

Carr's (1995) analysis of the social, philosophical-religious, and circumstantial, and physical characteristics of mortuary practices among hunter-gatherers, horticultural tribes, petty hierarchies, and paramount chiefdoms is illuminating with respect to the defining features of the Late Archaic/Early Ceramic cemetery at Hurricane Hill. As discussed previously, the spatially discrete cemetery is comprised of both single and multiple cremations and small pits with bundle burials (see Chapter 6 , this volume). 
Pertinent aspects of the Hurricane Hill cemetery include the following attributes (see Carr 1995:Table IIII):

$$
\begin{aligned}
& \frac{\text { body preparation }}{\text { body treatment }} \\
& \text { no. of individuals } \\
& \text { grave location } \\
& \frac{\text { overall energy }}{\text { expenditure }} \\
& \frac{\text { regional location }}{\frac{\text { relative to }}{\text { settlement }}} \\
& \frac{\text { cemetery formally }}{\text { demarcated }}
\end{aligned}
$$

\author{
sprinkling bones with pigments \\ cremation; bundling of bones prior to \\ funeral \\ single and multiple individuals in \\ graves \\ in midden/community life-space \\ not all burials similar \\ near/visible \\ Yes
}

In general, following Carr's (1995:Table IV) analyses, particularly the mortuary practices of hunter-gatherers (as were the Late Archaic/Early Ceramic populations at Hurricane Hill), the determining variables contributing to the character of Hurricane Hill mortuary practices include: "beliefs about the nature of the soul;" "beliefs or myths about universal orders and their symbols;" "age as a social position;" and "vertical social position in life." In other words, the mortuary practices used by the Hurricane Hill folk reflects primarily social and religious beliefs of their (and related) specific social group(s), rather than ecological factors or "death and physical requirements" (see Carr 1995:Table XII).

The identification of a formally bounded cemetery area at Hurricane Hill is consistent with the existence and settlement of a distinctive social group (i.e., kinship or residence group) of affiliated individuals in residence at the site and the local vicinity during the latter part of the Late Archaic and the early part of the Early Ceramic period (cf. Carr 1995:182). That children and adults were buried together in the cemetery using the same mortuary practices further suggests that these Late Archaic/Early Ceramic populations had an egalitarian social organization. In fact, the determining variables mentioned above are apparently the most common among egalitarian societies in locating a cemetery within a local settlement and community (Carr 1995:Table XXI). At the broader scope, the establishment of the cemetery itself clearly correlates with an increasing sedentism in the upper Sulphur River basin, and in the broader West Gulf Coastal plain region.

\section{Early Caddoan Period}

There are several interrelated processes that took place that apparently led to the full development around A.D. 800-900 of the prehistoric Caddoan tradition from their Early Ceramic or Woodland period ancestors. This includes: (1) an increased sedentism; (2) the expanding reliance on tropical cultigens in local economic systems; (3) the development of elite social positions within Caddoan communities as well as within regional social and political spheres of Caddoan society; and (4) the rise and elaboration of more complex social and political symbols of authority, ritual, and ceremony focusing on the construction, dismantling, remodeling, and continued use of earthen mounds (see Jeter et al. 1989; Rogers 1991, 1995a, 1995b; Schambach 1996; Story 1990). The available archaeological evidence indicates that the early growth and elaboration of Caddoan culture is not synchronous with the development of Caddoan agricultural economies (i.e., based on the intensive consumption of maize, beans, and squash), which seem to have intensified around and after ca. A.D. 1300-1400 (see Perttula 1990b, 1996:313-322), also significantly about the time the Hurricane Hill site was abandoned as a residential site.

Needless to say, this combination of cultural changes does not characterize the Caddoan archaeology at Cooper Lake. The archaeological record supports increased sedentism and some use of cultigens after about A.D. 900 , but there is no evidence for mound construction, elaborate burials of the social elite, or the construction of structures for public rituals during the Caddoan occupation of the upper Sulphur River basin. Much has been written recently about the nature of the Caddoan archaeology there, particularly in how apparently different and less socially complex the Caddoan societies were in the upper 
Sulphur River basin by comparison with the main Caddoan polities and communities along the Red River to the north and east, and the Sabine and Big Cypress drainages to the south (see Fields et al. 1997; Story 1990). I do agree that there are considerable differences in social complexity between the prehistoric Caddoans in the upper Sulphur River basin and those Caddoan groups living along the Red River in Texas, Arkansas, and Louisiana. However, there are also significant cultural and social differences between the latter Early Caddoan groups and other contemporaneous Caddoan communities living in the Piney Woods, the Ouachita Mountains, and the West Gulf Coastal Plain, for instance. This diversity in cultural adaptations and the evolution of distinct Caddo lifeways warrants further consideration, for the recognition of the variability that existed among the prehistoric Caddoan peoples at different times and places as a whole is basic to understanding the dynamic of how Caddoan societies evolved, floresced, and changed between about A.D. 900 and A.D. 1600. Cooper Lake:

Fields et al. (1997:89) nicely summarize the character of the Early Caddoan period archaeology at

The...early Caddoan sites have middens containing abundant faunal remains...the data indicate an increase in the intensity of site use over the Woodland period, and this probably reflects continued increases in population densities, occupations of relatively long duration, and frequent reuse. The sites were used for broad ranges of procurement, processing, and maintenance activities, and the possibility of ephemeral structures at several suggests that they may have been used as seasonal campsites. Only one site...has yielded concrete evidence for year-round (or maybe multiseasonal) occupations, however.

That one site is Hurricane Hill, and the most substantial occupation there occurred during the Middle Caddoan period, after ca. A.D. 1200 (see discussion below).

The Early Caddoan period occupation of Hurricane Hill was residential, with several structures, midden deposits, as well as burial features (but no organized cemeteries), and stable isotope analyses and paleobotanical remains suggest that the prehistoric Caddoan occupants of the site cultivated and consumed small amounts of maize (see also Wilson and Steele 1997:233). The occupation was more intensive and of longer duration than was the Late Archaic/Early Ceramic period component, reflecting broader regional and temporal trends in site use. The lithic and ceramic data further indicate that the Early Caddoans at Hurricane Hill interacted with their Caddoan neighbors to the north along the middle reaches of the Red River.

\section{A Question of Affiliation}

Throughout this report, the term "Caddoan" has been used to refer to the ca. A.D. 900/1000-1200 and A.D. 1200-1400 archaeological components on the North and South rises at the Hurricane Hill site. The term "Caddoan," or "Southern Caddoan" (cf. Story 1990:322), is meant to imply that the prehistoric occupants of the Hurricane Hill site were culturally and socially affiliated with the ancestors of the Southern Caddoan-speaking groups, namely the Kadohadacho on the middle Red River, the Hasinai-Hainai (or Neches-Angelina tribes), and the Natchitoches. This likely cultural and social affiliation is based on evidence of interaction between the Cooper Lake inhabitants and Caddoan groups living on the middle Red River, downstream on the Sulphur River, and to the south in the Big Cypress Creek drainage over at least a 500 year period, evidence of settlement and population continuity (e.g., Fields et al. 1997:92), shared ceramic styles, local Cooper Lake ceramic manufacture based on the use of the regional Caddoan stylistic traditions, as well as trade in lithic raw materials, tools, and ceramic vessels.

While it is argued that the question of Cooper Lake Caddoan cultural affiliations is reasonably clear, this does not mean that the cultural and social adaptations of the Caddoan inhabitants of the upper Sulphur River basin was the same as other prehistoric Caddoan groups. In fact, Caddoan cultural adaptations across the Caddoan area from north to south and east to west are diverse:

Although these [Caddoan] occupations share a number of broad cultural patterns, probably even including ritual symbolism...it is becoming increasingly evident that the Caddoan tradition embraces much diversity...This diversity can be seen in the material assemblages, sequences of development, and biological adaptive efficiency (Story 1990:320). 
Thus, it is argued that the Caddoan archaeology of the Cooper Lake area represents a culturally distinctive Caddoan occupation, not one that is necessarily biologically or culturally different or composed of unrelated peoples. This is contrary to the recent off-hand suggestions of Bruseth (1998:Figure 3-4) and Shafer (Brewington et al. 1995:15) that the post A.D. 900 archaeological record in the Cooper Lake area is not affiliated with Caddoan groups. Bruseth (1998) dubs the archaeology "Undesignated Non-Caddoan."

One need only consider the bioarchaeological evidence reviewed by Rose et al. (1998; see also Burnett and Harmon 1997; Wilson and Steele 1997) to appreciate the fact that populations in different parts of the Caddoan area were basically on evolutionary trajectories that were regionally divergent and locally variable. Further archaeological investigations in the Sulphur River basin--and indeed throughout Northeast Texas and the remainder of the Caddoan area--along with close scrutiny of the archaeological and bioarchaeological record should show that the evolution of distinct Caddoan lifeways and cultural adaptations was diachronically and spatially quite diverse. As Fields et al. (1997:93) note, the key is to carry out "thoughtful and critical comparative studies of regions and the relationships between regions."

\section{The Middle Caddoan Period}

There appear to be broad regional patterns in the character of the archaeological record of prehistoric Caddoan groups living in Northeast Texas and Northwest Louisiana in the Middle Caddoan period (ca. A.D. 1200-1400). Middlebrook and Perttula (1997:7) have noted that "diversity is the hallmark of the Middle Caddoan period archaeological record," and they suggest that this reflects the dynamics of social changes that were occurring "within and between Caddoan groups that reaches a culmination during that time."

Although sets of related spatio-temporal archeological units or phases are recognized in the Middle Caddoan period across Northeast Texas and northwestern Louisiana, phase identifications and taxonomic assignments have proven to be of little utility when discussing the cultural affiliations of most of the Middle Caddoan groups that lived in the region. For instance, the Middle Caddoan sites in the lower Sulphur River area appear to be related to the Haley phase defined in the Great Bend area of the Red River, but Cliff (1997) considers the lower Sulphur River groups to be part of a distinctive Middle Caddoan period ceramic and cultural tradition around A.D. 1300. Such is probably also the case with the apparent stylistic and ceramic affiliations (weak though they may be) of sites along the middle Red River and upper Sulphur and Sabine River basins to the Sanders phase (however poorly defined), at most suggesting that these components of the Middle Caddoan period date from about A.D. 1100-1350, and shared similar ceramic styles, but probably little else in a taxonomic sense. Additionally, Nelson and Turner (1997), and Robert L. Turner (1997), suggest that some probable Middle Caddoan sites in the Cypress Creek drainage were previously subsumed within the Whelan phase (e.g., Thurmond 1990), which is considered by Thurmond to be a Late Caddoan construct; clearly, the place of the Whelan phase archeological record warrants further consideration in light of the ceramic stylistic diversity seen in the Big Cypress Creek basin after ca. A.D. 1200. Middlebrook (1997) has pointed out that useful taxonomic units for the Middle Caddoan period sequence south of the Sabine River do not exist, and Corbin and Hart (1998:75) have argued that the ceramics from the Washington Square Mound "although showing strong ties with the Haley phase of the Great Bend area of the Red River, constitute a regionally distinct Middle Caddoan horizon in south-central East Texas."

In general, then, referring to existing Middle Caddoan period taxonomic units is useful in making temporal linkages (based mainly on ceramic styles) between groups of sites in different basins and areas within Northeast Texas and northwestern Louisiana. However, these temporal linkages should imply nothing more than that, provided "that convenient blocks of time do simply not become reified as cultural entities with assumed prehistoric Caddoan socio-cultural meaning" (Middlebrook and Perttula 1997:2).

Caddoan settlement patterns during the Middle Caddoan period, and the distribution of Middle Caddoan period components (see Middlebrook and Perttula 1997:Figure 1), are apparently diverse from one stream drainage or basin to another across Northeast Texas. The meaning of this variability in Caddoan settlement is probably complex, but most likely relates to differences in prehistoric Caddoan demographic patterns and population distributions in this part of the Caddoan area, as well as the permanent settlement of well-watered forested savanna and Pineywoods habitats. 
From what is known of the distribution of multiple mound centers, they are found in Middle Caddoan period times only in the largest river basins, such as the Red River and Sabine River basins. Even along the Red River, however, multiple mound centers are apparently less common in the Middle Caddoan period than they were several hundred years earlier (cf. Schambach 1996). These public and sacred community centers may occur in association with large communities or residential settlements (villages or hamlets) and have non-mound cemeteries, some rather substantial in size (see Perino 1995). The smaller mounds, and this is best exemplified by the archeological record in the middle and upper Sabine River basin, are more widely dispersed in the valleys of the major streams and in uplands along smaller tributary streams (as at the Oak Hill Village). These sites contain house structures, middens, and cemeteries.

Middle Caddoan period settlement on the lower Sulphur River are primarily dispersed hamlets in the uplands, and on old natural levees in major and minor drainages. These residential sites contain house structures (sometimes overlapping), ramadas/arbors, middens, and cemeteries. Large settlements, according to Cliff (1997), appear to be absent in the lower Sulphur. In the middle and upper Sulphur River basin, small residential sites such as Hurricane Hill are the principal kind of Middle Caddoan settlement, and these settlements contain evidence of structures, middens, extra-mural features and activity areas, and small cemeteries.

Both small and large settlements occur along major and minor tributaries in the Big Cypress Creek drainage. Three Middle Caddoan period mound sites with single mounds are noted in the western part of the basin, but none are known to the east. There are a number of cemeteries in the Big Cypress Creek basin dating to this period that apparently were not situated immediately adjacent to a village or farmstead site (see Turner 1997), and thus they may represent the development of spatially distinct burial areas for extended communities (perhaps presaging the more widespread development of community cemeteries after about A.D. 1500 in the Titus phase; see Perttula and Nelson 1998).

In the upper and middle Sabine River basin, there are apparently a number of large communities (covering from 2-3 hectares) as well as mound centers that are located along primary tributaries, and sometimes near their headwaters, but not along the Sabine River itself (with the exception of the HudnallPirtle site, which may primarily have been settled prior to the Middle Caddoan period). Because of the extensive hand and machine excavations, the Oak Hill village (41RK214) in the middle Sabine River basin is the premier example of the larger communities that existed at this time, but there is little doubt that comparable villages exist elsewhere in the region. Despite the size of the settlement at the Oak Hill Village site, however, there was no associated cemetery; the same may be said for the community at the George C. Davis site. By contrast, along the middle Red River, the larger communities typically contain large household cemeteries

The few Middle Caddoan period sites in the Angelina River basin include an important multiple mound center (Washington Square), as well as villages along levees and high terraces with trash middens, house structures, and few burials or small cemeteries. The George C. Davis mound center and large village, situated to the west in the Neches River drainage, continued to be occupied until ca. A.D. 1300, the first half of the Middle Caddoan period (Story 1997, 1998). The distribution of contemporaneous villages and settlements is not known, and it may be the case that such settlements are absent. Story (1997:64) suggests that the decline seen in the elaborateness of mortuary practices after A.D. 1200 at George C. Davis may be a response to population declines after that time.

The development of agricultural economies (including the cultivation of maize, beans, and squash) among the prehistoric Caddo people appears to have taken root in the Middle Caddoan period, and this appears to have a great deal to do with the overall character of Middle Caddoan social and cultural practices in Northeast Texas and beyond (cf. Schambach 1996:41). Nevertheless, the amount of maize and other cultigens recovered in archeological excavations from features and middens is still quite small except for the findings at Oak Hill Village and a few other Middle Caddoan sites, including George C. Davis (Jones 1949; Ford 1997); maize is ubiquitous at Oak Hill, however (Dering 1998). Recently, the completion of stable carbon isotope and bioarcheological studies of skeletal remains from Caddoan populations has helped to document the importance of maize in the diet around A.D. 1250 to A.D. 1300, and the changing nature of the subsistence economy, "from a generalized hunting and gathering economic base, with little horticulture, to a substantial horticultural economy with less emphasis on hunting and gathering" (Schambach 1996:41). 
Maize may have been a greater component of the diet of Caddoan people on the middle Red River than was the case among contemporaneous Middle Caddoan populations to the south, and C12/C13 stable isotope values of -10.0 to -12.9 o/oo from the Sanders site (Wilson and Cargill 1993) support this notion. A stable isotope value of -14.6 o/oo from a burial at the Coker Mound (41CS1), dated to cal AD 13001435, along with a caries rate of 3.0 (Derrick 1997), indicates that the individual had a diet based on a significant contribution of $\mathrm{C} 4$ plants, primarily maize. Comparable stable isotope values from contemporaneous Caddoan individuals in Red River and Ouachita River populations suggest that some of the lower Sulphur River Caddo groups had the same diet as Caddoan neighbors living along the Red River in Northwest Louisiana and Southwest Arkansas, and in the Ouachita River drainage of Southwest Arkansas. Lee's (1997:176) bioarchaeological analysis of Middle to Late Caddoan burials from the HatchelMitchell-Moores complex on the Red River concludes that the:

...health of the Caddo people...was good. The well-healed fractures, the low to moderate severity of arthritis, mild anemia, and periostitis, imply a fairly successful adaptation...The cranial modeling and enthesopathies suggest that the Caddo traveled long distances, perhaps for marriage and trade.

Bioarchaeological studies of Caddoan populations in Northeast Texas also support the importance of maize in the diet for some, if not all, Middle Caddoan populations, with the intensification of maize production and consumption becoming more prevalent between ca. A.D. 1300-1400 (Perttula 1996:321). Higher rates of caries by ca. A.D. 1400 in series from northwestern Louisiana, the middle Ouachita River basin, and the Great Bend of the Red River suggest, moreover, that Caddo populations in the major streams or heartland of the Caddoan area utilized more maize than other Caddo populations (see Burnett 1990, 1993; Perttula 1996; Rose et al. 1998). The paleobotanical findings in the upper and middle Sabine River basin, and the paleobotanical evidence from Oak Hill Village (see Dering 1998), also suggest that maize may have been more commonly grown and used there after A.D. 1300. By contrast, low caries rates in the skeletal remains from Mound C at George C. Davis (1.2 caries/per individual, with 2.0 caries/individual a generally accepted measure of a significant consumption of maize; see Wilson [1995:Table 1] and Rose et al. [1998:115]), suggest that this Caddoan population was not dependent on maize agriculture.

Many Middle Caddoan period sites bear evidence of the frequent procurement and use of hardwood nuts, along with maygrass, tubers, and other wild plants. Deer were a major meat and protein resource for Middle Caddoan hunters, and there is only very limited evidence of bison hunting, and much of this comes from the poorly studied Sanders site on the Red River. Many small mammals--such as rabbit, opossum, and raccoon--have also been recovered from Middle Caddoan period middens. Fish, reptiles, and birds are also present in these Caddoan faunal assemblages, and could have been important supplemental subsistence resources during portions of the year (see Perttula 1996:318-319).

Ceremonial mound centers built and used during the Middle Caddoan period are present in most of the major river basins in Northeast Texas and Northwest Louisiana, although none are known in the upper Sulphur River basin. Particularly high numbers of these mound centers, with both single and multiple mound groupings and including sub-structural, platform, and mortuary types, characterize the archeological record in the Red River and Sabine River basins. This is probably a reflection of more extensive domestic settlements and population densities there than elsewhere in the general region, as well as a reflection of differences in social complexity between Middle Caddoan groups across the Caddoan area.

Schambach (1996:40-41) suggests that there was a significant change in mound ceremonialism ca. A.D. 1250 to A.D. 1300 in the Caddoan area that is related to major changes in religion and social organization. He argues that this change "was not so much a loss of ceremonialism in public life as it was a change of emphasis from individual-oriented ceremonialism to public building-oriented ceremonialism...the major mounds of the Late Caddo era [dating after A.D. 1300] contain the remains of important buildings rather than important people." Schambach (1996:41) illustrates these mound ceremonial practices by discussing the Ferguson site in the Little Missouri River drainage in southwestern Arkansas. There, the main mound (Mound A) contained the remains of 10 structures, five of which were superimposed on the south platform, and were square with extended entranceways (Schambach 1996:Figure 5.11). The structures or temples were deliberately destroyed, burned, and buried by sand. Although not explicitly discussed by Schambach, the deliberate and regular destruction of these temples was not 
apparently accompanied by the burial of a leader or member of the elite. In an earlier discussion, however, Schambach (1972:7) notes that the death of an adult individual "triggered the house-burning-mound building ritual" in Mound B at the Ferguson site. The graves contained multiple individuals (two and three individuals in two burials) with "plentiful, if not elaborate, offerings": 11-25 vessels per burial, arrowpoint quivers, a potter's kit, and other items.

In general, the changes noted by Schambach (1996) appear to be borne out in the archaeological record across Northeast Texas and surrounding locales, in that mound centers constructed after ca. A.D. 1200 (with the exception of burial mounds at Sanders, Coker, and Washington Square, if not others) principally were built to cap important public buildings rather than to serve as burial tumuli. Nevertheless, Schambach's (1996) analyses do overlook the integral fact that the basic purpose of such Early and Middle Caddoan mounds as Mounds A and B at George C. Davis, built and constructed between ca. A.D. 900-1200, was also to cap ceremonial or public structures that had been deliberately destroyed; Mound A also had public structures on the platform (see Story 1997, 1998). The episodes of structure destruction and capping at George C. Davis appears to correlate with the death and entombment of important personages in Mound $\mathrm{C}$ at the site, however.

The Fasken, Roitsch, and Sanders sites are important middle Red River civic-ceremonial centers that had mounds that were apparently built and used during the Middle Caddoan period; the mound at the Harling site appears to have been erected over a Middle Caddoan residential component. At the Sanders site, one of the mounds was used as a burial place for the social elite (Hamilton 1997), while those at Fasken and Roitsch were either platforms for special-purpose structures or served to cap buried structures. To the south, however, Cliff (1997) commented that there are no certain Middle Caddoan mound centers in the lower Sulphur River basin of Texas, but at least three mound sites (with multiple mounds) are present in the Great Bend area of the Red River that have Middle Caddoan period components (Haley, Hatchel, and Cabe; the initial mound stages at the Battle Mound may have been constructed during the Middle Caddoan Haley phase). Furthermore, there are other single lower basin mounds that may have Middle Caddoan period components, including Coker (Perttula et al. 1997), reported to have a massive burial deposit with a Haley Engraved vessel in one of the mounds.

Three mound centers are located in the Big Cypress Creek basin (Hale, Keith, and Davis-McPeak [41UR4/99]), and there are a number of substructural mounds, including the single mound in Structure Group B at the Oak Hill Village, on north and south-flowing tributaries of the Sabine River in the upper and middle parts of the basin. Although there are a few unknown Caddoan mounds in the Neches River basin (see Perttula 1993b), the Washington Square Mound site (Corbin and Hart 1998) represents the only identified Middle Caddoan mound center south of the Sabine River basin other than the venerable George C. Davis site (Story 1997, 1998).

The site had three mounds, including one with shaft tombs, with burials containing an abundance of grave good offerings. At George C. Davis, the post-A.D. 1200 mound shaft tombs were smaller than the earlier tombs within Mound C, contained fewer grave goods (1-2 vessels, celts, and clay pigment), and they were placed along the flanks of Mound C. Story (1997:64) attributes this decline in the complexity of mortuary practices to changes in ceremonial behavior brought on by population declines in the community. The radiocarbon dating of the Washington Square and George C. Davis sites hints at the possibility that the Washington Square Mound center began to flourish about the time the George C. Davis site was diminishing in power and social authority, after ca. A.D. 1250. This suggests that the Caddoan community that built and used the Washington Square Mound site--more advantageously located eastward at the nexus of north-south and east-west aboriginal trails--achieved pre-eminence at the expense of the long-lasting (400 years) polity on the Neches River. The George C. Davis site was abandoned by the early 14th century.

Small cemeteries, probably family cemeteries associated with residences, have been documented from several Middle Caddoan sites in Northeast Texas, particularly between the Sabine River and the Red River where Caddoan population densities may have been higher. The few Middle Caddoan burials from Hurricane Hill appear to be part of such a family cemetery associated with the South rise residential settlement.

Much less common during Middle Caddoan times are large cemeteries with 20 or more individuals (e.g., the Turbeville site [41WD20] and 41HS144), or mortuary mounds (e.g., Haley, Coker, Washington 
Square, or the Stage V burials at George C. Davis). Double interments and a multiple internment in a shallow shaft grave at the Charlie Crews site (41WD371) demonstrate that mortuary practices were diverse in non-mound contexts as well during the Middle Caddoan period, although the majority of the burials are single interments (usually of adults). Individuals were generally placed in an extended supine position, but with their heads either oriented east, southeast, or south rather than consistently in the same position (as is seen in Late Caddoan contexts).

Cremations appear to be rare from Middle Caddoan period sites, although one possible cremation has been mentioned from 41RK215 in the middle Sabine River basin (Rogers et al. 1994), as well as from at least one mound burial at the Mineral Springs site in southwestern Arkansas (see Bohannon 1973). Ceramic vessels, arrowpoints, and clay pipes were placed with most interred individuals, although the extended burials at the Hurricane Hill site in the upper Sulphur River basin lacked grave goods. Other special kinds of grave goods that have been placed with Caddo peoples at death, as at the Tyson site (cf. Middlebrook 1994) included ear spools or similar objects (of stone or bone), marine shell columnella and olivella beads, carved shell inlays, mussel shells, bird bone flageolets, deer ulna awls, and deer antler. The study of Middle Caddoan period mortuary practices could provide important insights into social, gender, or age differences in burial treatment among different Middle Caddoan groups, and to broader questions of Caddoan social diversity.

Ceramic assemblages from Middle Caddoan period sites are apparently stylistically diverse. In general, there is a broad dichotomy in Middle Caddoan period ceramic assemblages between those to the west that are (a) dominated by plain wares (and high plain/decorated sherd ratios), some red-slipping, rectilinear and curvilinear motifs in the engraved, incised, and incised-punctated ceramics, and little to no brushed utility vessels (as at Hurricane Hill), and (b) those to the east towards the Great Bend of the Red River that have ceramic assemblages with abundant brushed pottery (and low plain/decorated sherd ratios), engraved scrolls and circles and other curvilinear decorative elements, less plainwares, and little to no redslipped vessels. It is probable that this east-west division in ceramic styles reflects basic and underlying differences in ethnic affiliation and interaction between Caddo populations during the Middle Caddoan period (if not also earlier and later in time). Interestingly, a similar east-west division has been noted by Derrick and Wilson (1997:143) in cranial modeling styles among the Caddo, and they suggest that "geographical distance from east to west may have played an important role in ethnic affinity." Given these findings, it is reasonable to conclude that the Hurricane Hill Caddoan population was ethnically and stylistically affiliated with western Caddoan groups.

Assemblages from Middle Caddoan sites from the upper Sabine River basin northward to the middle reaches of the Red River basin fall into the first group. They have some number of plain red slipped vessels (usually bowls and carinated bowls with grog and grog-bone tempering), suggesting a broad affiliation with the Caddoan occupations on the middle Red River (but see Schambach 1995, 1997b, n.d.), or at least with ceramic traditions where plain ware vessels were important. The spatial extent of the Caddoan groups making this sort of pottery is much too broad to be subsumed within a single phase-particularly one as poorly defined as the Sanders phase--but it is clear that these western Caddo groups shared a ceramic tradition and probably maintained relatively close social and kinship ties and interaction. Other sorts of ceramics that may characterize the Middle Caddoan period in these areas include Sanders Plain, Sanders Engraved, Canton Incised, and rarely Maxey Noded Redware, along with Crockett Curvilinear Incised and Hickory Engraved (probably found in contexts predating ca. A.D. 1300, as at the Spider Knoll site [41DT11] at Cooper Lake; see Fields et al. 1997).

Middle Caddoan ceramic designs and vessel forms for the Great Bend Caddo groups include such defined types as Haley Complicated Incised, Haley Engraved, Red River pipes of the Haley variety, Pease Brushed-Incised, Maddox Engraved, and Sinner Linear Punctated. After ca. A.D. 1300, there appear to exist broad similarities in ceramic styles between the Great Bend Middle Caddoan groups and contemporaneous societies in East Texas (i.e., Hart 1982; Corbin and Hart 1998), suggesting affiliations and considerable interaction after this time. There is a diversity in ceramic assemblages and decorative styles, along with amalgamations of diverse styles-decorative elements, that increases over time, and this is a particularly notable trend in the middle Sabine and Angelina River basins.

Certain engraved motifs are characteristic of Middle Caddoan period ceramic assemblages throughout most of East Texas. This includes: pendant triangles (with small triangles being excised, and 
larger ones having cross-hatching), pendant spirals, ladders, branches, ribbons or bands with closely spaced parallel lines or cross-hatching, zones of diagonal lines or large cross-hatching, negative S-shaped scrolls, vertical scrolls, circles, concentric circles, semi-circles (occasionally offset across parallel lines), small circles with radiant lines ("sunbursts"), circles and crosses, and engraved rattlesnakes/serpents.

Among the vessel forms are simple bowls, carinated bowls, neckless bottles, ollas, globular and elongated (some shouldered or four cornered) bottles with medium to long necks, beaker-shaped jars, and globular jars with everted rims. At George C. Davis, the vessel forms in the latest shaft tombs (dating from the late 13th to the early 14th century) are "more characteristic of Late Caddoan rather than Early Caddoan ceramics" (Story 1997:57) in that the bottles have shouldered bodies and outflaring necks. Neck-banded rims are occasionally seen on jars in Middle Caddoan period sites in the upper Sabine (Perttula, Skiles, and Yates 1993) and Neches river basins, and scalloped rims, rim tabs, lugs, and strap handles are present in many Middle Caddoan period ceramic assemblages; lip notching is a notable lip treatment in the upper Sabine River basin. Interior thickened rims are present on some bowl and carinated bowl rims, and these rims may have engraved or incised decorations.

While a few thermoluminescence dates on ceramic sherds have been obtained from possible Middle Caddoan period sites in the upper Sabine and Sulphur River basins (i.e., Perttula et al. 1987; see Chapter 7, this volume), and the archaeomagnetic dating of one feature at Hurricane Hill has also been performed, the great majority of absolute dates for the Middle Caddoan period are from calibrated radiocarbon dates on charcoal, charred nutshells, and maize. In the last few years, oxidizable carbon ratio (OCR) dates have also been obtained from a few Middle Caddoan period sites. At present, some 154 radiocarbon and 11 OCR dates have been obtained from Middle Caddoan period sites in the region (see compilations in Perttula 1998a, 1998e).

The largest number of the 520+ radiocarbon dates from East Texas sites fall in the Middle Caddoan period, followed by the Early Caddoan period (ca. A.D. 1000-1200). Although the number of dates for this period of time is probably inflated to some degree by the extensive series of dates from this period from the George C. Davis site ( $\mathrm{n}=48$, or 31 percent of the Middle Caddoan period sample), it does appear to be the case that dated Middle Caddoan period occupations are rather commonplace throughout much of the region. Caddoan settlements were widely distributed throughout Northeast Texas and Northwest Louisiana.

Using calibrated ages and age mid-points of 1-sigma calibrated age ranges, the largest number of Caddoan radiocarbon dates fall within the A.D. 1201-1300 interval. Examining the same radiocarbon data, but at 25 year intervals, fluctuations in the number of radiocarbon dates suggest peaks in the occupational history of the region in the 25 year intervals between A.D. 1201-1225 and A.D. 1226-1250, the early part of the Middle Caddoan period (Perttula 1998a:Figure 4).

In conclusion, the Middle Caddoan period in Northeast Texas is a time of great change, increasing population sizes and densities, diverse social arrangements and mortuary practices, and of innovations in ceramic styles and forms. It was only a few years ago--outside of the Great Bend area of the Red River--that the Middle Caddoan period archeological record was considered to be relatively obscure, and was usually overlooked in work that seemed to be concentrated on the more spectacular Early Caddoan mound sites and the extensive Late Caddoan mounds and community cemeteries known in certain parts of the Caddoan area.

It is known now, however, that Middle Caddoan period societies were vibrant and dynamic societies, societies developing new traditions in settlement, subsistence, and interaction that set them apart from the societies that came before, and others that were then to follow. The distinctiveness of the Middle Caddoan period can probably be traced to the development and flowering of many independent social communities across the Caddoan area at that time. This is a development that is firmly linked to the intensification of maize agriculture among these self-sufficient Caddo communities (see Perttula 1996; Schambach 1996), loosening the long-standing ties between the public and ritual, and the secular and residential, at least at the regional scale. Instead, the ritual and secular relationships were embodied in the small and single mounds and public structures that characterized many communities, such as the Oak Hill Village. As Sabo (1998:172-173) concludes, such communities "consisted of matrilineally organized communities of human and spiritual beings." Ultimately, then, the archaeological record of the ca. A.D. 1200-1400 Middle Caddoan period, including that of the small residential occupation on the South rise at 
the Hurricane Hill site, is key to understanding the long development of, and changes in, the prehistoric traditions and native history of the Caddoan peoples.

\section{Final Thoughts}

Only within the last few years have the right opportunities occurred in Northeast Texas archaeological research and cultural resource management undertakings where it has been possible conduct the type of extensive and expansive excavations that were completed under emergency conditions at the Hurricane Hill site in 1986 and 1987. This would include residential sites such as Bird Point Island (Bruseth and Martin 1987) at the Richland-Chambers Reservoir in the Trinity River basin, Oak Hill Village (41RK214) (Cruse 1995; Rogers n.d.) at the Oak Hill Mine in the Sabine River basin, Rookery Ridge (41UR133) (Parsons 1998) at Lake Gilmer in the Little Cypress Creek basin, the Pilgrim's Pride site (41CP304) on Big Cypress Creek (Perttula 1999), and the Ear Spool (41TT653) (Galan n.d.) at the Monticello B-2 Mine in the White Oak Creek basin. Such opportunities are few and far between, and they need to be seized without hesitation, if we are to contribute new and important information on the native history of the aboriginal inhabitants of eastern Texas.

As Dee Ann Story (1990:336) has noted, it is fair to state that with the exception of these recently examined sites, and others like Deshazo (Story 1982, 1995) and George C. Davis (Story 1997, 1998) in the Neches-Angelina river basin in deep East Texas, Caddoan residential sites in Northeast Texas:

have not been adequately investigated. In the case of the habitation only sites, most excavations have been too limited to permit accurate characterization of the settlement size and structure, and sometimes even its history of use...As a result, the most fundamental building blocks of the Caddoan settlement system--the household and community--are poorly understood.

Although our work at Hurricane Hill raised more questions than we could answer, much less questions that we were able to consider thoroughly, we learned some things about the Caddoan peoples (and their ancestors) that we did not know before. We have had a peek into the past, and it is hoped that the information contained in this report, warts and all, can contribute to a better understanding of prehistoric lifeways in this part of Northeast Texas and the Caddoan Area. 


\section{REFERENCES CITED}

Aegerter, E. and J. A. Kirkpatrick

1968 Orthopedic Diseases: Physiology, Pathology, and Radiology. 3rd Edition. W. B. Saunders, Philadelphia.

Aitken, M. J.

1985 Thermoluminescence Dating. Academic Press, London.

Ajilvsgi, G.

1984 Wildflowers of Texas. Shearer Publishing, Fredericksburg, Texas.

Anderson, D. G.

1996a Models of Paleoindian and Early Archaic Settlement in the Lower Southeast. In The Paleoindian and Early Archaic Southeast, edited by D. G. Anderson and K. E. Sassaman, pp. 29-57. University of Alabama Press, Tuscaloosa.

1996b Approaches to Modeling Regional Settlement in the Archaic Period Southeast. In Archaeology of the Mid-Holocene Southeast, edited by K. E. Sassaman and D. G. Anderson, pp. 157-176. University Press of Florida, Gainesville.

Anderson, D. G., D. W. Stahle, and M. K. Cleaveland

1995 Paleoclimate and the Potential Food Resources of Mississippian Societies: A Case Study from the Savannah River Valley. American Antiquity 60(2):258-286.

Andrews, J.

1971 Sea Shells of the Texas Coast. University of Texas Press, Austin.

1981 Texas Shells: A Field Guide. University of Texas Press, Austin.

Angel, J. L.

1966a Anemias, Malarias, and Marshes in the Prehistoric Eastern Mediterranean. Science 153:760-763.

1966b Early Skeletons from Tranquility, California. Contributions to Anthropology 2(1). Smithsonian Institution, Washington, D.C.

1982 A New Measure of Growth Efficiency: Skull Base Height. American Journal of Physical Anthropology 58:297-305.

Asch, N. B., R. I. Ford, and D. L. Asch

1972 Paleoethnobotany of the Koster Site: The Archaic Horizons. Reports of Investigations No. 24. Illinois State Museum, Springfield.

Aten, L. E.

1983 Indians of the Upper Texas Coast. Academic Press, New York.

Bailey, G. L., D. K. Boyd, and C. B. Bousman

1991 Archeological Survey of the City Lakes Area and Geomorphological and Magnetometer Surveys, Cooper Lake Project, Delta and Hopkins Counties, Texas. Technical Reports No. 11. Prewitt and Associates, Inc., Austin. 
Baker, F. C.

1928 The Fresh Water Mollusca of Wisconsin. Part II, Pelecypoda. Bulletin 70. Wisconsin Geological and Natural History Survey, Madison.

Banks, L. D.

1984 Lithic Resources and Quarries. In Prehistory of Oklahoma, edited by R. E. Bell, pp. 65-95. Academic Press, New York.

1990 From Mountain Peaks to Alligator Stomachs: A Review of Lithic Sources in the TransMississippi South, the Southern Plains, and Adjacent Southwest. Memoir \#4. Oklahoma Anthropological Society, Norman.

Banks, L. D., and J. Winter

1975 The Bentsen-Clark Site, Red River County, Texas: A Preliminary Report. Special Publication No. 2. Texas Archeological Society, San Antonio.

Banks, W. J.

1986 Interview of Wilbur J. Banks, Cooper, Texas, by Timothy K. Perttula on September 24, 1986.

Baskin, B. J.

1981 Lithic and mineral artifacts. In Archeological Investigations at the George C. Davis Site, Cherokee County, Texas: Summers of 1979 and 1980, edited by D. A. Story, pp. 239-320. Occasional Papers No. 1. Texas Archeological Research Laboratory, The University of Texas at Austin.

Baxter, M. J.

1992 Archaeological uses of the biplot--a neglected technique? In Computer Applications and Quantitative Methods in Archaeology, 1991, edited by G. Lock and J. Moffett, pp. 141-148. BAR International Series S577, Cambridge. Tempvs Reparatvm, Archaeological and Historical Associates, Oxford.

1994 Stepwise Discriminant Analysis in Archaeometry: a Critique. Journal of Archaeological Science 21:659-666.

Beach, M. A. and C. S. Causey

1984 Bone Artifacts from Arroyo Hondo Pueblo. In The Faunal Remains from Arroyo Hondo Pueblo, New Mexico, edited by R. U. Long and A. H. Harris, pp. 187-225. Arroyo Hondo Archaeological Series, No 5. School of American Research Press, Santa Fe.

Bedford, W. B.

1972 The Physiological Ecology of the Estuarine Clam Rangiacuneata (Gray). Unpublished Ph.D. dissertation, Department of Biology, Texas A\&M University, College Station.

Bell, M.

n.d. Titus County site forms. Texas Archeological Research Laboratory, The University of Texas at Austin.

Bieber, A. M., Jr., D. W. Brooks, G. Harbottle, and E. V. Sayre

1976 Application of Multivariate Techniques to Analytical Data on Aegean Ceramics. Archaeometry 18:59-74.

Binford, L. R.

1971 Mortuary Practices: Their Study and their Potential. In Approaches to the Social Dimensions of MortuaryPractices, edited by J. A. Brown, pp. 6-29. Memoirs No. 25. Society for American Archaeology, Washington, D.C. 
1978 Dimensional Analysis of Behavior and Site Structure: Learning from an Eskimo Hunting Stand. American Antiquity 43:330-361.

1980 Willow Smoke and Dogs' Tails: Hunter-Gatherer Settlement Systems and Archaeological Site Formation. American Antiquity 45:1-20.

1981 Bones: Ancient Men and Modern Myths. Academic Press, New York.

1982 The Archaeology of Place. Journal of Anthropological Archaeology 1:5-31.

1983a Working at Archaeology. Academic Press, New York.

1983b Long Term Land Use Patterns: Some Implications for Archaeology. In Lulu Linear Punctated: Essays in Honor of George Irving Quimby, edited by R. C. Dunnell and D. K. Grayson, pp. 2753. Anthropological Papers No. 72. Museum of Anthropology, University of Michigan, Ann Arbor.

Bird, R. M. and C. A. Dobbs

1986 Archaeological Maize from the Vosburg Site (21FA2), Fairbault County, Minnesota. The Missouri Archaeologist 47:85-105.

Bishop, R. L. and H. Neff

1989 Compositional Data Analysis in Archaeology. In Archaeological Chemistry IV, edited by R. O. Allen, pp. 576-586. Advances in Chemistry Series 220. American Chemical Society, Washington, D.C.

Bishop, R. L., R. L. Rands, and G. R. Holley

1982 Ceramic Compositional Analysis in Archaeological Perspective. In Advances in Archaeological Method and Theory, Volume 5, edited by M. B. Schiffer, pp. 275-330. Academic Press, New York.

Black, S. L., L. W. Ellis, D. G. Creel, and G. T. Goode

1997 Hot Rock Cooking on the Greater Edwards Plateau: Four Burned Rock Midden Sites in West Central Texas. 2 Vols. Studies in Archeology 22, Texas Archeological Research Laboratory, The University of Texas at Austin, and Archeology Studies Program, Report 2, Environmental Affairs Department, Texas Department of Transportation, Austin.

Blair, W. F.

1950 The Biotic Provinces of Texas. Texas Journal of Science 2:93-117.

Blake, L.

1994 Analysis of Rowland Clark Site Corn. Journal of Northeast Texas Archaeology 4:43-49.

Bohannon, C. F.

1973 Excavations at the Mineral Springs Site, Howard County, Arkansas. Research Series No. 5. Arkansas Archeological Survey, Fayetteville.

Bollaert, W.

1850 Observations on the Indian Tribes in Texas. London Ethnological Society Journal, Vol. 2, London.

Bolton, H. E.

1987 The Southern Hasinais. Edited by R. Magnaghi. University of Oklahoma Press, Norman. 
Borojevic, K.

1995 Analysis of Archeobotanical Remains from Site 41DT59 in the Cooper Lake Area, Delta County, Texas. In Archeological Test Excavations at Two Prehistoric Sites (41DT59 and 41DT247) at Cooper Lake, Delta County, Texas, 1994, by M. B. Cliff, M. M. Green, S. M. Hunt, and D. Shanabrook, pp. I-1 to I-15. Miscellaneous Report of Investigations Number 90. Geo-Marine, Inc., Plano.

1996 Analysis of Archeobotanical Remains from Area C, 41CS151. In Excavations at 41CS151, Area C, White Oak Creek Mitigation Area (WOCMA), Cass County, Texas, by M. B. Cliff, M. M. Green, S. M. Hunt, D. Shanabrook, and D. E. Peter, pp. F-1 to F-15. White Oak Creek Mitigation Area Archeological Technical Series, Report of Investigations Number 4. Geo-Marine, Inc., Plano.

Bousman, C. B.

1998 Paleoenvironmental Change in Central Texas: The Palynological Evidence. Plains Anthropologist 43(164):201-219.

Bousman, C. B. and D. O. Brown

1998 Setting the Stage: Previous Paleoclimatic Research in Texas and Surrounding Areas. Plains Anthropologist 43(164):105-109.

Bousman, C. B., M. B. Collins, and T. K. Perttula

1988 Quaternary Geomorphology at Cooper Lake: A Framework for Archeological Inquiry. Report of Investigations No. 55. Prewitt and Associates, Inc., Austin.

Bradley, B. A.

1997 Sloan Site Biface and Projectile Point Technology. In Sloan: A Paleoindian Dalton Cemetery in Arkansas, by D. F. Morse, pp. 53-57. Smithsonian Institution Press, Washington, D.C.

Braun, D. P.

1985 Ceramic Decorative Diversity and Illinois Woodland Regional Interaction. In Decoding Prehistoric Ceramics, edited by B. A. Nelson, pp. 128-153. Southern Illinois University Press, Carbondale.

1988 The Social and Technological Roots of "Late Woodland." In Interpretations of Culture Change in the Eastern Woodlands during the Late Woodland Period, edited by R. W. Yerkes, pp. 17-38. Occasional Papers in Anthropology No. 3. Department of Anthropology, Ohio State University, Columbus.

Brewington, R. L., J. E. Dockall, and H. J. Shafer

1995 Archaeology of 41MX5: A Late Prehistoric Caddoan Hamlet in Morris County, Texas. Reports of Investigations No. 1. Center for Environmental Archaeology, Texas A\&M University, College Station.

Briggs, A. K. and J. Malone

1970 An Archaeological Survey of the Texarkana Reservoir Enlargement Area. Archaeological Survey Report 7. Texas Historical Survey Committee and Texas Water Development Board, Austin.

Brown, D. E., F. Reichenbacher, and S. E. Franson

1998 A Classification of North American Biotic Communities. University of Utah Press, Salt Lake City.

Brown, D. O.

1998 Late Holocene Climates of North-Central Texas. Plains Anthropologist 43(164):157-172. 
Brown, J. A.

1971 Pottery Vessels. Spiro Studies, Vol. 3. University of Oklahoma Research Institute, Norman.

1976 The Artifacts. Spiro Studies, Vol. 4. The Stovall Museum of Science and History, University of Oklahoma, and the University of Oklahoma Research Institute, Norman.

1983 Spiro Exchange Connections Revealed by Sources of Imported Raw Materials. In Southeastern Natives and Their Pasts, edited by D. G. Wyckoff and J. L. Hofman, pp. 129-162. Studies in Oklahoma's Past No. 11. Oklahoma Archeological Survey, Norman.

1996 The Spiro Ceremonial Center: The Archaeology of Arkansas Valley Caddoan Culture in Eastern Oklahoma. Memoirs Number 29. 2 Vols. Museum of Anthropology, University of Michigan, Ann Arbor.

Brown, $\mathrm{M}$.

1982 Cultural Behavior as Reflected in the Faunal Assemblages from Three Smoky Hill Sites. Unpublished Master's thesis, Department of Anthropology, University of Kansas, Lawrence.

Brown, M. and G. M. Crites

1990 Paleobotanical Analyses. In The Hurricane Hill Site (41HP106): Excavations at Cooper Lake, Hopkins County, Texas, edited by T. K. Perttula, pp. 271-274. Second draft. Institute of Applied Sciences, University of North Texas, Denton.

Brown, W. L. and E. Anderson

1947 The Northern Flint Corns. Annals of the Missouri Botanical Garden 34:1-28.

Brues, A. M.

1959 Skeletal Material from the Morris Site, Ck-39. Bulletin of the Oklahoma Anthropological Society 7:63-70.

Bruseth, J. E.

1998 The Development of Caddoan Polities along the Middle Red River Valley of Eastern Texas and Oklahoma. In The Native History of the Caddo: Their Place in Southeastern Archeology and Ethnohistory, edited by T. K. Perttula and J. E. Bruseth, pp. 47-68. Studies in Archeology 30. Texas Archeological Research Laboratory, The University of Texas at Austin.

Bruseth, J. E. and W. A. Martin (editors)

1987 The Bird Point Island and Adams Ranch Sites: Methodological and Theoretical Contributions to North Central Texas Archaeology. Richland Creek Technical Series, Vol. II. Archaeology Research Program, Institute for the Study of Earth and Man, Southern Methodist University, Dallas.

Bruseth, J. E. and T. K. Perttula

1981 Prehistoric Settlement Patterns at Lake Fork Reservoir. Texas Antiquities Permit Series No. 2. Archaeology Research Program, Southern Methodist University, Dallas, and Texas Antiquities Committee, Austin.

Bruseth, J. E., L. M. Raab, and D. E. McGregor

1987 Late Holocene Paleoecology of the Prairie Margin of Texas. In Introduction to the Richland Creek Archaeological Project: Environmental Background and Cultural Setting, edited by J. E. Bruseth and R. W. Moir, pp. 29-47. Richland Creek Technical Series, Volume I. Archaeology Research Program, Institute for the Study of Earth and Man, Southern Methodist University, Dallas. 
Bryant, V. M. and R. G. Holloway

1985 A Late-Quaternary Paleoenvironmental Record of Texas: An Overview of the Pollen Evidence. In Pollen Records of Late-Quaternary North American Sediments, edited by V. M. Bryant and R. G. Holloway, pp. 39-70. American Association of Stratigraphic Palynologists Foundation, Dallas.

Buikstra, J. E. and D. Fowler

1975 Osteological Studies of Human Skeletal Materials from the Bentsen-Clark Site. In The BentsenClark Site, Red River County, by L. D. Banks and J. Winter, pp. 79-92. Special Publication No. 2. Texas Archeological Society, San Antonio.

Burch, J. B.

1973 Freshwater Unionacean Clams (Molluscs: Pelecypoda) of North America. Biota of Freshwater Ecosystems Identification Manual No. 11. Environmental Protection Agency, Washington, D.C.

Bureau of Economic Geology

1979 Geologic Atlas of Texas, Texarkana Sheet. Bureau of Economic Geology, University of Texas, Austin.

Burnett, B. A.

1990 The Bioarcheological Synthesis of the eastern portion of the Gulf Coastal Plain. In The Archeology and Bioarcheology of the Gulf Coastal Plain, by D. A. Story, J. A. Guy, B. A. Burnett, M. D. Freeman, J. C. Rose, D. G. Steele, B. W. Olive, and K. J. Reinhard, pp. 385-418. Research Series No. 38. Arkansas Archeological Survey, Fayetteville.

1993 Adaptive Efficiency of Arkansas Populations. In Caddoan Saltmakers in the Ouachita Valley: The Hardman Site, edited by A. M. Early, pp. 187-223. Research Series No. 43. Arkansas Archeological Survey, Fayetteville.

Burnett, B. A. and A. Harmon

1997 Descriptive Osteology of 41DT80, 41DT124, and 41HP78. In Archaeological Investigations at Cooper Lake, Delivery Order Numbers 2, 3 \& 4, 1987: Cultural Resource Studies for Cooper Lake, Hopkins and Delta Counties, Texas, by D. E. McGregor, M. M. Green, D. H. Jurney, W. A. Martin, R. W. Moir, and J. W. Saunders, pp. 603-642. 2 Vols. Archaeology Research Program, Southern Methodist University, Dallas. Final report submitted to U.S. Army Corps of Engineers, Ft. Worth District, Contract Number DACW63-87-D-0017.

Butler, B. H.

1969 Analysis of Human Skeletal Remains. In Archaeological Investigations at the Sam Kaufman Site, edited by S. A. Skinner, R. K. Harris, and K. M. Anderson, pp. 115-136. Contributions in Anthropology No. 5. Department of Anthropology, Southern Methodist University, Dallas.

1975 Faunal Remains. In Archeological Research at Cooper Lake, Northeast Texas, 1973, by R. Hyatt and K. Doehner, pp. 61-66. Contributions in Anthropology No. 15. Department of Anthropology, Southern Methodist University, Dallas.

1981 Bone Artifact Analysis. In Prehistoric Settlement Patterns at Lake Fork Reservoir, by J. E. Bruseth and T. K. Perttula, pp. 147-148. Texas Antiquities Permit Series No. 2. Archaeology Research Program, Southern Methodist University, Dallas, and Texas Antiquities Committee, Austin.

Butler, B. H. and T. K. Perttula

1981 Subsistence Analysis. In Prehistoric Settlement Patterns at Lake Fork Reservoir, by J. E. Bruseth and T. K. Perttula, pp. 117-125. Texas Antiquities Permit Series No. 2. Archaeology Research Program, Southern Methodist University, Dallas, and Texas Antiquities Committee, Austin. 
Bye, R. A., Jr.

1970 The Ethnobotany and Economic Botany of Onondaga County, New York. Master's thesis, Harvard University, Cambridge.

Byrd, C. L.

1971 Origin and History of the Uvalde Gravel of Central Texas. Baylor Geological Studies Bulletin No. 20. Baylor University, Waco.

Byrd, K. M.

1980 Zooarchaeological Analysis of the Hanna Site: An Alto Focus Occupation in Louisiana. Louisiana Archaeology 5:235-265.

Cahen, D., L. H. Keeley, and F. L. Van Noten

1979 Stone Tools, Tool Kits, and Human Behavior in Prehistory. Current Anthropology 20:661-683.

Carley, D.

n.d. Evidence of Early Man in Northeast Texas. Preliminary report submitted to the Texas Historical Commission. Ms. on file, Division of Antiquities Protection, Texas Historical Commission, Austin.

Carlson, G. G. and V. H. Jones

1939 Some Notes on Uses of Plants by the Comanche Indians. Papers of the Michigan Academy of Science, Arts, and Letters 25:517-542.

Carr, C.

1985 Alternative Models, Alternative Techniques: Variable Approaches to Intrasite Spatial Analysis. In For Concordance in Archaeological Analysis, edited by C. Carr, pp. 302-473. Westport Publishers, Inc., Kansas City.

1995 Mortuary Practices: Their Social, Philosophical-Religious, Circumstantial, and Physical Determinants. Journal of Archaeological Method and Theory 2(2):105-200.

Casselberry, S. E.

1974 Further Refinement of Formulae for Determining Population from Floor Area. World Archaeology 6(1):117-124.

Chaplin, R. E.

1971 The Study of Animal Bones from Archaeological Sites. Seminar Press, New York.

Cheatham, S. and M. C. Johnston

1995 The Useful Wild Plants of Texas, the Southeastern and Southwestern United States, the Southern Plains, and Northern Mexico, Volume 1. Useful Wild Plants, Inc., Austin.

Cheatwood, G.

1988 Notes on the Stratigraphic Position of Archaeological Remains in the Sulphur River Valley, Red River County, Texas. In Quaternary Geomorphology at Cooper Lake: A Framework for Archeological Inquiry, by C. B. Bousman, M. B. Collins, and T. K. Perttula, pp. 143-145. Report of Investigations No. 55. Prewitt and Associates, Inc., Austin. 
Cliff, M. B.

1995 Archaeological Investigations at 41DT80: The Thomas Site. In Archaeological Survey of Cooper Lake, Delivery Order Number 4, 1989: Cultural Resource Studies for Cooper Lake, Hopkins and Delta Counties, Texas, by D. H. Jurney, D. E. McGregor, W. A. Martin, M. Green, R. W. Moir, M. B. Cliff, and J. W. Saunders, pp. 165-274. Archaeology Research Program, Southern Methodist University, Dallas. Draft report submitted to U.S. Army Corps of Engineers, Ft. Worth District, Contract DACW63-87-D-0017.

1997 The Middle Caddoan Period in the Lower Sulphur River Area. Journal of Northeast Texas Archaeology No. 9:9-16.

1998 Not With a Bang, but a Whimper: The End of the Archaic in Northeast Texas. Journal of Northeast Texas Archaeology 11:100-107.

Cliff, M. B. (editor)

1994 Cultural Resources Survey of a Portion of the White Oak Creek Mitigation Area (WOCMA), Bowie, Cass, and Morris Counties, Texas: 1990-1992. White Oak Creek Mitigation Area Archeological Technical Series, Report of Investigations Number 2. Geo-Marine, Inc., Plano.

Cliff, M. B. and D. L. Beene

1997 White Oak Creek Wildlife Management Area: Historic Properties Management Plan. Geo-Marine, Inc., Plano.

Cliff, M. B., and S. M. Hunt

1995 Cultural Resources Testing of Three Sites within the Moist Soils Management Area (MSMA) of the White Oak Creek Mitigation Area (WOCMA), Cass County, Texas. White Oak Creek Mitigation Area Archeological Technical Series, Report of Investigations, Number 3. Geo-Marine, Inc., Plano.

1998 Intensive Pedestrian Survey at Lake O' the Pines and Wright Patman Lake, Bowie, Cass, and Marion Counties, Texas: 1997. Miscellaneous Report of Investigations No. 154. Geo-Marine, Inc., Plano.

Cliff, M. B. and T. K. Perttula

1995 Preliminary Ceramic Typology for Cooper Lake. In Archeological Survey of Cooper Lake, Delivery Order Number 4, 1989: Cultural Resource Studies for Cooper Lake, Hopkins and Delta Counties, Texas, by D. H. Jurney, D. E. McGregor, W. A. Martin, M. Green, R. W. Moir, M. B. Cliff, and J. W. Saunders, pp. 573-612. Archaeology Research Program, Southern Methodist University, Dallas. Draft submitted to U.S. Army Corps of Engineers, Ft. Worth District, Contract DACW63-87-D-0017, Delivery Order Number 4.

Cliff, M. B. and D. E. Peter (editors)

1988 Test Excavations at Sites $41 B$ W182 and 41BW183, Red River Army Depot, Bowie County, Texas. RRAD/LSAAP Archeological Technical Series, Report of Investigations Number 1. GeoMarine, Inc., Plano.

1992 Cultural Resources Survey of the Moist Soils Management Area, White Oak Creek Mitigation Area (WOCMA), Cass County, Texas. White Oak Creek Mitigation Area Archeological Technical Series, Report of Investigations Number 1. Geo-Marine, Inc., Plano.

1994 Cultural Resources Survey of 2,226 Hectares within the Red River Army Depot and Lone Star Army Ammunition Plant, Bowie County, Texas. RRAD/LSAAP Archeological Technical Series, Report of Investigations Number 4. Geo-Marine, Inc., Plano. 
Cliff, M. B., M. M. Green, S. M. Hunt, and D. Shanabrook

1995 Archeological Test Excavations at Two Prehistoric Sites (41DT59 and 41DT247) at Cooper Lake, Delta County, Texas, 1994. Miscellaneous Report of Investigations No. 90. Geo-Marine, Inc., Plano.

Cliff, M. B., S. M. Hunt, D. Pleasant, R. Proctor, and H. B. Ensor

1996a Cultural Resources Survey of 600 Acres at Wright Patman Lake, Bowie and Cass Counties, Texas. Miscellaneous Report of Investigations No. 108. Geo-Marine, Inc., Plano.

Cliff, M. B., M. M. Green, S. M. Hunt, D. Shanabrook, and D. E. Peter

1996b Excavations at 41CS151, Area C, White Oak Creek Mitigation Area (WOCMA), Cass County, Texas. White Oak Creek Mitigation Area Archeological Technical Series, Report of Investigations, Number 4. Geo-Marine, Inc., Plano.

Cliff, M. B., D. White, S. M. Hunt, D. Pleasant, and G. Shaw

1996c Cultural Resources Survey of 5,000 Acres within the White Oak Creek Mitigation Area (WOCMA), Bowie, Morris, and Titus Counties, Texas: 1993-1994. White Oak Creek Mitigation Area Archeological Technical Series, Report of Investigations Number 5. Geo-Marine, Inc., Plano.

Cliff, M. B., S. M. Hunt, M. M. Green, D. E. Peter, and F. D. Kent

1996d Cultural Resources Survey of 1,342 Hectares (3,317 Acres) within the Red River Army Depot and Lone Star Army Ammunition Plant, Bowie County, Texas. RRAD/LSAAP Archeological Technical Series, Report of Investigations Number 5. Geo-Marine, Inc., Plano.

Cogswell, J. W., H. Neff, and M. D. Glascock

1998a Chemical Variation in Northeastern Texas Ceramics. MS on file, University of Missouri Research Reactor, University of Missouri, Columbia.

1998b Analysis of Shell-Tempered Pottery Replicates: Implications for Provenance Studies. American Antiquity 63(1):63-72.

Coker, R. E., A. F. Shira, H. W. Clark, and A. D. Howard

1921 Natural History and Propagation of Freshwater Mussels. United States Bureau of Fisheries Bulletin (Document 893) 37:75-181.

Colby, G. R.

1997 Analysis of Dental Abscess Formation in a Texas Hunter-Gatherer and a Texas Agricultural Population. Bulletin of the Texas Archeological Society 68:179-189.

Collins, M. B.

1988 Fluvial Geoarchaeology of Walnut and Mountain Creek Valleys. In Late Holocene Prehistory of the Mountain Creek Drainage, edited by D. E. Peter and D. E. McGregor, pp. 259-275. Joe Pool Lake Archaeological Project, Vol. 1, Archaeology Research Program, Southern Methodist University, Dallas.

1995 Forty Years of Archeology in Central Texas. Bulletin of the Texas Archeological Society 66:361400.

Collins, M. B. and C. B. Bousman

1993 Quaternary Environments and Archeology in Northeastern Texas. In Archeology in the Eastern Planning Region, Texas: A Planning Document, edited by N. A. Kenmotsu and T. K. Perttula, pp. 49-67. Cultural Resource Management Report 3. Department of Antiquities Protection, Texas Historical Commission, Austin. 
Cook, S. L.

1972 Prehistoric Demography. McCaleb Module in Anthropology 16. Addison-Wesley, Reading, Massachusetts.

Corbin, J. E. and J. P. Hart

1998 The Washington Square Mound Site: A Middle Caddo Mound Complex in South Central East Texas. Bulletin of the Texas Archeological Society 69:47-78.

Core, H. A., W. A. Cote, and A. C. Day

1979 Wood Structure and Identification. Syracuse University Press, Syracuse, New York.

Correll, D. S. and M. C. Johnston

1979 Manual of the Vascular Plants of Texas. University of Texas at Dallas.

Cottone, J. A. and S. M. Standish (editors)

1981 Outline of Forensic Dentistry. Medical Publishers, Chicago.

Council of Texas Archeologists

1987 Guidelines (Performance, Curation, and Reports). Austin, Texas.

Cowan, C. W.

1997 Evolutionary Change Associated with the Domestication of Cucurbita pepo: Evidence from Eastern Kentucky. In People, Plants, and Landscapes: Studies in Paleoethnobotany, edited by K. J. Gremillion, pp. 63-85. University of Alabama Press, Tuscaloosa.

Crane, C. J.

1982 Plant Utilization at Spoonbill, an Early Caddo Site in Northeast Texas. Midcontinental Journal of Archaeology 7:81-97.

1993 Archaeobotanical Analysis. In Archaeological Survey of Cooper Lake, Delivery Order Number 7 , 1989: Cultural Resource Studies for Cooper Lake, Hopkins and Delta Counties, Texas, by D. H. Jurney, J. Bohlin, S. E. Linder-Linsley, S. C. Caran, and D. R. Pedler, pp. 453-458. Archaeology Research Program, Southern Methodist University, Dallas.

1997 Archaeobotanical Remains. In Archaeological Investigations at Cooper Lake, Delivery Order Numbers 2, 3, \& 4, 1987: Cultural Resource Studies for Cooper Lake, Hopkins and Delta Counties, by D. E. McGregor, M. M. Green, D. H. Jurney, W. A. Martin, R. W. Moir, and J. W. Saunders, pp. 717-728. Archaeology Research Program, Southern Methodist University, Dallas. Final report submitted to U.S. Army Corps of Engineers, Ft. Worth District, Contract Number DACW63-87-D-0017.

Creel, D. G.

1996 Hatchel-Mitchell Site. In The New Handbook of Texas, Vol. 3, edited by R. Tyler, pp. 504-505. Texas State Historical Association, Austin.

Cruse, J. B.

1994 Archaeological Investigations at a Middle Caddoan Village Site (41RK214) in Rusk County, Texas. Paper presented at the 65th Texas Archeological Society Meeting, Lubbock.

1995 Archaeology at the Oak Hill Village Site: A Caddoan Settlement in Rusk County. Heritage 13(1):10-14. Texas Historical Foundation, Austin.

Cutler, H. C. and L. W. Blake

1973 Plants from Archaeological Sites East of the Rockies. Missouri Botanical Garden, St. Louis. 
Daly, $P$.

1969 Approaches to Faunal Analysis in Archaeology. American Antiquity 34:146-153.

Darwin, R. L., C. R. Ferring, and B. B. Ellwood

1990 Geoelectric Stratigraphy and Subsurface Evaluation of Quaternary Stream Sediments at the Cooper Basin, Northeast Texas. Geoarchaeology 5(1):53-79.

Davis, D. D.

1984 Comparative Aspects of Late Prehistoric Faunal Ecology at the Sims Site. Louisiana Archaeology 11:111-138.

Davis, E. M.

1979 The First Quarter Century of the Texas Archeological Society. Bulletin of the Texas Archeological Society 50:159-194.

Davis, W. B.

1974 The Mammals of Texas. Bulletin 41. Texas Parks and Wildlife Department, Austin.

Delorit, R. J.

1970 An Illustrated Taxonomy Manual of Weed Seeds. Agronomy Publications, River Falls, Wisconsin.

DeNiro, M. J.

1985 Postmortem Preservation and Alteration of in vivo Bone Collagen Ratios: Implications for Paleodietary Analysis. Nature 317:806-809.

Dering, J. P.

1992 Analysis of Macrobotanical Remains from 41DT11, 41DT21, and 41DT63. In Archeological Investigations at 41DT11, 41DT21, 41DT50, 41DT54, and 41DT63 at Cooper Lake, Delta County, Texas, by E. F. Gadus, R. C. Fields, and C. B. Bousman, pp. 113-119. Reports of Investigations No. 86. Prewitt and Associates, Inc., Austin.

1993 Macrobotanical Analysis of Samples from Four Woodland and Caddoan Period Sites in the Cooper Lake Area of the Upper Sulphur River. In Excavations at the Tick, Spike, Johns Creek, and Peerless Bottoms Sites, Cooper Lake Project, Delta \& Hopkins Counties, Texas, by R. C. Fields, E. F. Gadus, L. W. Klement, C. B. Bousman, and J. B. McLerran, pp. 335-355. Reports of Investigations No. 91. Prewitt and Associates, Inc., Austin.

1994 Analysis of the Plant Remains. In Excavations at the Spider Knoll Site, Cooper Lake Project, Delta County, Texas, by R. C. Fields, E. F. Gadus, L. W. Klement, and K. M. Gardner, pp. 161173. Reports of Investigations No. 96. Prewitt and Associates, Inc., Austin.

1998 Archaeobotanical Evidence for Middle Caddoan Agriculture and Wild Plant Use at 41RK214. MS on file, PBS \& J, Inc., Austin.

Derrick, S. M.

1997 A Study in Frustration: Analysis of Human Remains Removed from the Coker Mound Site (41CS1). Journal of Northeast Texas Archaeology No. 9:21-29.

Derrick, S. M. and D. E. Wilson

1997 Cranial Modeling as an Ethnic Marker among the Prehistoric Caddo. Bulletin of the Texas Archeological Society 68: 139-146. 
Dickinson, S. D.

1941 Certain Vessels from the Clements Place, an Historic Caddo Site. Bulletin of the Texas Archeological and Paleontological Society 13:117-132.

Dickson, D. B.

1986 The Atlatl Assessed: A Review of Recent Anthropological Approaches to Prehistoric North American Weaponry. Bulletin of the Texas Archeological Society 56:1-38.

Dimbleby, G. W.

1967 Plants and Archaeology. Baker, London.

Dobyns, H. F.

1983 Their Number Became Thinned: Native American Population Dynamics in Eastern North America. The University of Tennessee Press, Knoxville.

Dockall, H. D.

1995 Analysis of Human Skeletal Remains. In Archaeology of 41MX5: A Late Prehistoric Caddoan Hamlet in Morris County, Texas, by R. L. Brewington, J. E. Dockall, and H. J. Shafer, pp. 6570. Reports of Investigations No. 1. Center for Environmental Archaeology, Texas A\&M University, College Station.

Doehner, K. and R. E. Larson

1978 Archaeological Research at the Proposed Cooper Lake, Northeast Texas, 1974-1975. Research Report No. 108. Archaeology Research Program, Southern Methodist University, Dallas.

Doehner, K., D. Peter, and S. A. Skinner

1978 Evaluation of the Archaeology at the Proposed Cooper Lake. Research Report No. 114. Archaeology Research Program, Southern Methodist University, Dallas.

Duffield, L. F.

1959 Archeological Reconnaissance at Cooper Reservoir, Delta and Hopkins Counties, Texas, February, 1959. Submitted to the National Park Service by the Texas Archeological Salvage Project, The University of Texas at Austin.

Dunnell, R. C.

1971 Systematics in Prehistory. Free Press, New York.

1986 Methodological Issues in Americanist Artifact Classification. In Advances in Archaeological Method and Theory, Vol. 9, edited by M. B. Schiffer, pp. 149-207. Academic Press, New York.

Earle, F. R. and Q. Jones

1962 Analyses of Seed Samples from 113 Plant Families. Economic Botany 16(4):221-250.

Early, A. M.

1988 Standridge: Caddoan Settlement in a Mountain Environment. Research Series No. 29. Arkansas Archeological Survey, Fayetteville.

Early, A. M. (editor)

1993 Caddoan Saltmakers in the Ouachita Valley: The Hardman Site. Research Series No. 43. Arkansas Archeological Survey, Fayetteville.

Eastman, C. A.

1974 Indian Scout Craft and Lore. Reprinted. Dover Publications, New York. Originally published in 1914 by Little, Brown and Co., Boston. 
East Texas State University

1971 An Environmental Inventory and Survey of the Sulphur River Basin. East Texas State University, Commerce.

Elias, T. S.

1980 The Complete Trees of North America: Field Guide and Natural History. Times Mirror Magazines, New York.

Elias, T. S. and P. A. Dykeman

1990 Edible Wild Plants: A North American Field Guide. Sterling Publishing Company, New York.

Ellis, L. W.

1997 Hot Rock Technology. In Hot Rock Cooking on the Greater Edwards Plateau: Four Burned Rock Midden Sites in West Central Texas, by S. L. Black, L. W. Ellis, D. G. Creel, and G. T. Goode, pp. 43-81. 2 Vols. Studies in Archeology 22, Texas Archeological Research Laboratory, The University of Texas at Austin, and Archeology Studies Program, Report 2, Environmental Affairs Department, Texas Department of Transportation, Austin.

Ennes, M. J., with contributions by M. B. Cliff

1997 Petrographic Analysis of Prehistoric Ceramics Recovered from Sites 41BW553 and 41TT670. In Cultural Resources Testing of Two Sites within the White Oak Creek Wildlife Management Area, Bowie and Titus Counties, Texas, by F. B. Largent, Jr., D. L. Beene, M. B. Cliff, and S. M. Hunt, pp. G-1 to G-22. White Oak Creek Mitigation Area Archeological Technical Series, Report of Investigations No. 6. Geo-Marine, Inc., Plano.

Enquist, $M$.

1987 Wildflowers of the Texas Hill Country. Lone Star Botanical, Austin.

Erichsen-Brown, C.

1979 Medicinal and Other Uses of North American Plants. Dover Publications, New York.

Ernst, C. H., and R. W. Barbour

1972 Turtles of the United States. University of Kentucky Press, Lexington.

Etchieson, $\mathrm{M}$.

1998 Prehistoric Novaculite Quarries in the Ouachita Mountains. Paper presented at the 1998 Caddo Conference, Arkadelphia, Arkansas.

Ewers, J. C. (editor)

1969 The Indians of Texas in 1830 by Jean Louis Berlandier. Smithsonian Institution Press, Washington, D.C.

Feathers, J. K.

1997 The Application of Luminescence Dating in American Archaeology. Journal of Archaeological Method and Theory 4(1):1-66.

Ferring, C. R.

1969 Pecked and Ground Stone. In Archaeological Investigations at the Sam Kaufman Site, Red River County, Texas, edited by S. A. Skinner, R. K. Harris, and K. M. Anderson, pp. 83-95. Contributions in Anthropology No. 5. Department of Anthropology, Southern Methodist University, Dallas. 
1984 Intrasite Spatial Patterning: Its Role in Settlement-Subsistence System Analysis. In Intrasite Spatial Analysis in Archaeology, edited by H. J. Hietala, pp. 106-116. Cambridge University Press, Cambridge.

1986 Late Quaternary Geology and Environments of the Upper Trinity Basin. In An Assessment of the Cultural Resources in the Trinity River Basin, Dallas, Tarrant, and Denton Counties, Texas, edited by B. C. Yates and C. R. Ferring, pp. 32-112. Institute of Applied Sciences, North Texas State University, Denton. Submitted to U.S. Army Corps of Engineers, Ft. Worth District.

1987 Geoarchaeology of Site 41CO141: A Late Holocene Locality in the Upper Trinity Basin, Cooke County, Texas. In Test Excavations at 41CO141, Ray Roberts Reservoir, Cooke County, Texas, edited by D. J. Prikryl and B. C. Yates, pp. 19-52. Contributions in Archaeology No. 4. Institute of Applied Sciences, North Texas State University, Denton.

1994 McGee Creek in Regional Paleoenvironmental Context. In Past Environments and Prehistory at McGee Creek Reservoir, Atoka County, Oklahoma, edited by C. R. Ferring, pp. 29-43. McGee Creek Archaeological Project Reports, Volume V, Part 4. Institute of Applied Sciences, University of North Texas, Denton.

1995 Middle Holocene Environments, Geology, and Archaeology in the Southern Plains. In Archaeological Geology of the Archaic Period in North America, edited by E. A. Bettis III, pp. 2135. Special Paper 297. Geological Society of America, Boulder.

1997 Geoarchaeological Investigations at Cooper Lake. In Archaeological Investigations at Cooper Lake, Delivery Order Numbers 2, 3, \& 4, 1987: Cultural Resource Studies for Cooper Lake, Hopkins and Delta Counties, Texas, by D. E. McGregor, M. M. Green, D. H. Jurney, W. A. Martin, R. W. Moir, and J. W. Saunders, pp. 685-706. Archaeology Research Program, Southern Methodist University, Dallas. Final report submitted to U.S. Army Corps of Engineers, Ft. Worth District, Contract DACW-63-87-D-0017.

Ferring, C. R., and L. A. Allen

1987 Frequency and Attribute Data for Lithic Artifacts from Site 41CO141. In Test Excavations at 41CO141, Ray Roberts Reservoir, Cooke County, Texas, edited by D. J. Prikryl and B. C. Yates, pp. 125-131. Contributions in Archaeology No. 4. Institute of Applied Sciences, North Texas State University, Denton.

Ferring, C. R., and T. K. Perttula

1987 Defining the Provenance of Red-Slipped Pottery from Texas and Oklahoma by Petrographic Methods. Journal of Archaeological Science 14:437-456.

Ferring, C. R., and D. Peter

1987 Geoarchaeology of the Dyer Site, A Prehistoric Occupation in the Western Ouachitas, Oklahoma. Plains Anthropologist 32:351-366.

Ferring, C. R. and B. C. Yates

1996 Holocene Geoarchaeology and Prehistory of the Ray Roberts Lake Area, North Central Texas. Institute of Applied Sciences, University of North Texas, Denton.

Fields, R. C.

1987 Excavations at the Alley Road Site (41LN149B) and the Harris Hole Site (41LN30), Jewett Mine Project, Leon County, Texas. Reports of Investigations No. 61. Prewitt and Associates, Inc., Austin. 
1989 Survey and Testing along Boone Creek, Louisiana Army Ammunition Plant, Webster Parish, Louisiana. Reports of Investigations No. 64. Prewitt and Associates, Inc., Austin.

1995a The Archeology of the Post Oak Savannah of East Central Texas. Bulletin of the Texas Archeological Society 66:301-330.

1995b Analysis of Native-Made Ceramics. In The Deshazo Site, Nacogdoches County, Texas, Volume 2: Artifacts of Native Manufacture, edited by D. A. Story, pp. 173-232. Studies in Archeology 21. Texas Archeological Research Laboratory, The University of Texas at Austin.

Fields, R. C. (editor)

1990 Excavations at the Charles Cox, Lambs Creek Knoll, and Buffalo Branch Sites, Jewett Mine Project, Leon and Freestone Counties, Texas. Reports of Investigations No. 70. Prewitt and Associates, Inc., Austin.

Fields, R. C. and K. M. Gardner

1991 Mitigation Plan for the Cooper Lake Project, Delta and Hopkins Counties, Texas. Submitted to the U.S. Army Corps of Engineers, Fort Worth District by Prewitt and Associates, Inc., Austin.

Fields, R. C. and L. W. Klement

1995 Excavations at the Cottonwood Springs Site, Jewett Mine Project, Leon County, Texas. Report of Investigations No. 102. Prewitt and Associates, Inc., Austin.

Fields, R. C. and S. A. Tomka

1993 Hunter-Gatherer Mobility in Northeast Texas, 10,000-200 B.C. In Archeology in the Eastern Planning Region, Texas: A Planning Document, edited by N. A. Kenmotsu and T. K. Perttula, pp. 69-95. Cultural Resource Management Report 3. Texas Historical Commission, Department of Antiquities Protection, Austin.

Fields, R. C., M. E. Blake, and K. W. Kibler

1997 Synthesis of the Prehistoric and Historic Archeology of Cooper Lake, Delta and Hopkins

Counties, Texas. Reports of Investigations No. 104. Prewitt and Associates, Inc., Austin.

Fields, R. C., D. K. Boyd, C. B. Bousman, and J. B. McLerran

1991 Review of Cultural Resources Investigations at Cooper Lake, Delta and Hopkins Counties, Texas. Prewitt and Associates, Inc., Austin.

Fields, R. C., E. F. Gadus, and L. W. Klement

1994 The Peerless Bottoms Site: A Late Caddoan Component at Cooper Lake, Hopkins County, Texas. Bulletin of the Texas Archeological Society 65:55-114.

Fields, R. C., E. F. Gadus, L. W. Klement, and K. M. Gardner

1994 Excavations at the Spider Knoll Site, Cooper Lake Project, Delta County, Texas. Reports of Investigations No. 96. Prewitt and Associates, Inc., Austin.

Fields, R. C., E. F. Gadus, L. W. Klement, C. B. Bousman, and J. B. McLerran

1993 Excavations at the Tick, Spike, Johns Creek, and Peerless Bottoms Sites, Cooper Lake Project, Delta \& Hopkins Counties, Texas. Reports of Investigations No. 91. Prewitt and Associates, Inc., Austin.

Fisher, W. L.

1965 Rock and Mineral Resources of East Texas. Report of Investigations No. 54. Bureau of Economic Geology, The University of Texas at Austin. 
Fladmark, K. R.

1982 Microdebitage Analysis: Initial Considerations. Journal of Archaeological Science 9:205-220.

Flores, D. L. (editor)

1985 Journal of an Indian Trader: Anthony Glass and the Texas Trading Frontier, 1790-1810. Texas A \& M University Press, College Station.

Ford, R. I.

1997 Preliminary Report on the Plant Remains from the George C. Davis Site, Cherokee County, Texas, 1968-1970 Excavations. Bulletin of the Texas Archeological Society 68:104-107.

Ford, R. I. (editor)

1986 An Ethnobiology Source Book: The Use of Plants and Animals by American Indians. Garland Publishing, Inc., New York.

Forey, P.

1990 American Nature Guides: Wild Flowers. Gallery Books, W. H. Smith Publishers, Inc., New York.

Foster, W. C. (editor)

1998 The La Salle Expedition to Texas: The Journal of Henri Joutel 1684-1687. Texas State Historical Association, Austin.

Fowler, W. S.

1972 Bone Implements: How They Were Used. Bulletin of the Massachusetts Archaeological Society 33(1-2):12-19.

Fox, D. E.

1983 Traces of Texas History: Archaeological Evidence of the Past 450 Years. Corona Publishing Company, San Antonio.

Fritz, G. J.

1975 Analysis of Ceramic Pipes, Ear Ornaments, and Effigies from the George C. Davis Site. Master's thesis, Department of Anthropology, The University of Texas at Austin.

1982 Analysis of Plant Remains from the Spiro Site, 34Lf-46, LeFlore County, Oklahoma. In Spiro Archaeology: 1980 Research, by J. D. Rogers, pp. 201-213. Studies in Oklahoma's Past No. 9. Oklahoma Archeological Survey, Norman.

1986 Prehistoric Ozark Agriculture: The University of Arkansas Rockshelter Collections. Unpublished Ph.D. dissertation, Department of Anthropology, The University of North Carolina at Chapel Hill.

1989 Evidence of Plant Use from Copple Mound at the Spiro Site. In Contributions to Spiro Archaeology: Mound Excavations and Regional Perspectives, edited by J. D. Rogers, D. G. Wyckoff, and D. A. Peterson, pp. 65-87. Studies in Oklahoma's Past No. 16. Oklahoma Archeological Survey, Norman.

1990a Dent Corn, Little Corn and Flint Corn from Ozark Rockshelters: Myth, Speculation, and Reality. Paper presented at the "Corn and Culture" Conference, Minneapolis, Minnesota.

1990b Multiple Pathways to Farming in Precontact Eastern North America. Journal of World Prehistory 4:387-435. 
1992 Archaeobotanical Remains from Five Sites on the Red River, Northeast Texas. Report submitted to the Department of Antiquities Protection, Texas Historical Commission, Austin.

1993 Archeobotanical Analysis. In Caddoan Saltmakers in the Ouachita Valley: The Hardman Site, edited by A. M. Early, pp. 159-168. Research Series No. 43. Arkansas Archeological Survey, Norman.

1994 The Value of Archaeological Plant Remains for Paleodietary Reconstruction. In Paleonutrition: The Diet and Health of Prehistoric Americans, edited by K. D. Sobolik, pp. 21-33. Occasional Paper No. 22. Center for Archaeological Investigations, Southern Illinois University at Carbondale.

1995 Macrobotanical Remains from Testing of Sites 41CS150, 41CS151, and 41CS155/156. In Cultural Resources Testing of Three Sites within the Moist Soils Management Area (MSMA) of the White Oak Creek Mitigation Area (WOCMA), Cass County, Texas, by M. B. Cliff and S. M. Hunt, pp. I-1 to I-9. White Oak Creek Mitigation Area Archeological Technical Series, Report of Investigations Number 3. Geo-Marine, Inc., Plano.

1997 A Three-Thousand Year-Old Cache of Crop Seeds from Marble Bluff, Arkansas. In People, Plants, and Landscapes: Studies in Paleoethnobotany, edited by K. J. Gremillion, pp. 42-62. University of Alabama Press, Tuscaloosa.

1999 Gender and the Early Cultivation of Gourds in Eastern North America. American Antiquity 64(3):417-429.

Fuller, S. L. H.

1978 Fresh-water Mussels (Unionidae) of the Upper Mississippi River: Observations at Selected Sites within the 9-Foot Channel Navigation Project on Behalf of the U.S. Army Corps of Engineers. Academy of Natural Sciences, Philadelphia.

Gadus, E. F., R. C. Fields, and C. B. Bousman

1992 Archeological Investigations at 41DT11, 41DT21, 41DT50, 41DT54, and 41DT63 at Cooper Lake, Delta County, Texas. Reports of Investigations No. 86. Prewitt and Associates, Inc., Austin.

Gadus, E. F., R. C. Fields, C. B. Bousman, S. A. Tomka, and M. A. Howard 1992 Excavations at the Finley Fan Site (41HP159), Cooper Lake Project, Hopkins County, Texas. Report of Investigations No. 78. Prewitt and Associates, Inc., Austin.

Gadus, E. F., R. C. Fields, L. W. Klement, C. B. Bousman, M. A. Howard, and K. M. Gardner 1991 Testing, Revisitation, and Evaluation of Selected Sites at Cooper Lake, Delta and Hopkins Counties, Texas. Reports of Investigations No. 81. Prewitt and Associates, Inc., Austin.

Gaither, S., T. K. Perttula, and G. Cheatwood

1991 The Cheatwood Place (41RR181), a Midden Mound along Little Mustang Creek, Red River County, Texas. Caddoan Archeology Newsletter II (No. 2):21-28.

Galan, V.

n.d. Untitled Technical Report on Excavations at the Ear Spool Site (41TT653). PBS \& J, Inc., Austin.

Galinat, W. C.

1970 Maize from the Blain Site. In Blain Village and the Fort Ancient Tradition in Ohio, by O. H. Prufer and O. C. Shane, III, pp. 219-226. Kent State University Press, Kent, Ohio. 
1985 Domestication and Diffusion of Maize. In Prehistoric Food Production in North America, edited by R. I. Ford, pp. 245-278. Anthropological Papers No. 75. Museum of Anthropology, University of Michigan, Ann Arbor.

Galinat, W. C. and J. H. Gunnerson

1963 Spread of Eight-Rowed Maize from the Southwest to the Central Plains. Massachusetts Agricultural Experiment Station, Monograph Series 1:1-16.

Gardner, P. S.

1997a The Ecological Structure and Behavioral Implications of Mast Exploitation Strategies. In People, Plants, and Landscapes: Studies in Paleoethnobotany, edited by K. J. Gremillion, pp. 161-178. University of Alabama Press, Tuscaloosa.

1997b Plant Remains. In Two Caddoan Farmsteads in the Red River Valley: The Archeology of the McLelland and Joe Clark Sites, edited by D. B. Kelley, pp. 109-120. Research Series No. 51. Arkansas Archeological Survey, Fayetteville.

Gilbert, R. I.

1975 Trace Element Analysis of Three Skeletal Amerindian Populations at Dickson Mounds. Ph.D. dissertation, Department of Anthropology, University of Massachusetts, Amherst.

Gilmore, K. and N. Hoffrichter

1964 Preliminary Investigations of the L. O. Ray Site, Delta County, Texas. The Record, Newsletter of the Dallas Archeological Society 19(1):3-17.

Girard, J. S.

1995 The Chipped Stone Collection: Technological, Functional, and Typological Analyses. In The Deshazo Site, Nacogdoches County, Texas, Volume 2: Artifacts of Native Manufacture, edited by D. A. Story, pp. 33-156. Studies in Archeology 21. Texas Archeological Research Laboratory, The University of Texas at Austin.

1998 Caddoan Settlement in the Red River Floodplain: Perspectives from the Willow Chute Bayou Area, Bossier Parish, Louisiana. Louisiana Archaeology 22:143-162.

Glascock, M. D.

1992 Characterization of archaeological ceramics at MURR by neutron activation analysis and multivariate statistics. In Chemical Characterization of Ceramic Pastes in Archaeology, edited by H. Neff, pp. 11-26. Prehistory Press, Madison, Wisconsin.

Goldborer, S. E.

1988 Botanical Materials from the Bohannon (34HU61) and Ashland (34HU62) Sites. MS on file, Oklahoma Conservation Commission, Norman.

1995 More Macrobotanical Materials from Three Sites along the Red River, Northeast Texas: Ray (41LR135), Fasken (41RR14), and Roitsch (41RR16). MS on file, Division of Antiquities Protection, Texas Historical Commission, Austin.

1997 Botanical Remains from Redwine (41SM193), Smith County, Texas. Report submitted to Mark Walters and Patti Haskins, Tyler, Texas.

Goldschmidt, W. R.

1935 A Report on the Archeology of Titus County in East Texas. Bulletin of the Texas Archeological and Paleontological Society 7:89-99. 
Goldstein, M. S.

1948 Dentition of Indian Crania from Texas. American Journal of Physical Anthropology 6:63-84.

1957 Skeletal Pathology of the Early Indians of Texas. American Journal of Physical Anthropology 15:299-307.

Good, C. E.

1982 Analysis of Structures, Burials, and Other Cultural Features. In The Deshazo Site, Nacogdoches County, Texas, Vol. 1, edited by D. A. Story, pp. 51-110. Texas Antiquities Permit Series No. 7. Texas Antiquities Committee, Austin.

Gould, F.

1975 The Grasses of Texas. Texas A\&M University Press, College Station.

1978 Common Texas Grasses: An Illustrated Guide. Texas A\&M University Press, College Station.

Grayson, D. K.

1984 Quantitative Zooarchaeology: Topics in the Analysis of Archaeological Faunas. Academic Press, New York.

Green, M. M., D. E. Peter, and D. K. Shepard

1996 Friendship: An African-American Community on the Prairie Margin of Northeast Texas. Miscellaneous Report of Investigations No. 81. Geo-Marine, Inc., Plano.

Guilday, J. E., P. W. Parmalee, and D. P. Tanner

1962 Aboriginal Butchering Techniques at the Eschelman site (36LA12), Lancaster County, Pennsylvania. Pennsylvania Archaeologist 32:59-83.

Guy, J. A.

1988 A History of Archeological Research within the West Gulf Coastal Plain. Unpublished Master's thesis, Department of Anthropology, The University of Texas at Austin.

1990 Previous Archeological Investigations. In The Archeology and Bioarcheology of the Gulf Coastal Plain, by D. A. Story, J. A. Guy, B. A. Burnett, M. D. Freeman, J. C. Rose, D. G. Steele, B. W. Olive, and K. J. Reinhard, pp. 27-130. 2 Vols. Research Series No. 38. Arkansas Archeological Survey, Fayetteville.

Hally, D. J.

1983 The Interpretive Potential of Pottery from Domestic Contexts. Midcontinental Journal of Archaeology 8:163-196.

1986 The Identification of Vessel Function: A Case Study from Northwest Georgia. American Antiquity 51:267-295.

Hamilton, D. L.

1997 Observations on Caddoan Burial Practices at the Sanders Site (41LR2). Bulletin of the Texas Archeological Society 68:115-134.

Harbottle, G.

1976 Activation Analysis in Archaeology. Radiochemistry 3:33-72. 
Harrell, L.

1978 Bone Tools from Hog Creek. MS on file, Institute of Applied Sciences, University of North Texas, Denton.

Harrington, H. D.

1967 Edible Native Plants of the Rocky Mountains. University of New Mexico Press, Albuquerque.

Harris, R. K.

1955 A Flexed Burial, Site 19C5-15, Delta County, Texas. The Record, Newsletter of the Dallas Archeological Society 14(2):8-10.

Harris, R. K., I. M. Harris, and M. P. Miroir

1980 The Atlanta State Park Site in Northeastern Texas. Louisiana Archaeology 6:231-241.

Hart, J. P.

1982 An Analysis of the Aboriginal Ceramics from the Washington Square Mound Site, Nacogdoches County, Texas. M.A. thesis, Department of Anthropology, Northeast Louisiana University, Monroe.

Hatzenbuehler, $\mathbf{R}$.

1949 An Indian Burial, Hopkins County, Texas. The Record, Newsletter of the Dallas Archeological Society 7(10):34-36.

1950 Preliminary Report Site 19C3-5. The Record, Newsletter of the Dallas Archeological Society 8(6):24-26.

1951 A Preliminary Report on Site 19C3-1 in Hopkins County, Texas. The Record, Newsletter of the Dallas Archeological Society 9(4):16-17.

1953 A Flexed Burial, Delta County, Texas. The Record Newsletter of the Dallas Archeological Society 11(4):16-17.

Hayden, B., N. Franco, and J. Spafford

1996 Evaluating Lithic Strategies and Design Criteria. In Stone Tools: Theoretical Insights into Human Prehistory, edited by G. H. Odell, pp. 9-45. Plenum Press, New York.

Heartfield, Price, and Greene, Inc.

1982a A Cultural Resources Survey of Portions of Harts Bluff Ranch in Connection with Corps of Engineers Permit No. SWF-81-Titus-396. Heartfield, Price, and Greene, Inc., Monroe, Louisiana. Submitted to U.S. Army Corps of Engineers, Ft. Worth District.

1982b A Cultural Resources Survey of High Site Probability Locations Which Will Be Affected by Proposed Levee Construction within Angelina Farms, Red River County, Texas. Heartfield, Price, and Greene, Inc., Monroe, Louisiana. Submitted to Angelina Farms, Inc., Houston.

Heinrich, E. W.

1956 Microscopic Petrography. McGraw-Hill Series in the Geological Sciences. McGraw-Hill Book Company, Inc., New York.

Heinrich, P. V.

1986 Geomorphology of Seven Sites at the Jewett Mine Project. In National Register Assessments of Archeological and Historical Resources at the Jewett Mine, Leon County, Texas, by R. C. Fields, S. V. Lisk, J. M. Jackson, M. D. Freeman, and G. L. Bailey, pp. 189-223. Reports of Investigations No. 48. Prewitt and Associates, Inc., Austin. 
Henderson, J.

1978a The Vertebrate Fauna. In Archaeological Research at the Proposed Cooper Lake, Northeast Texas, 1974-1975, by K. Doehner and R. E. Larson, pp. 99-114. Research Report No. 108.

Archaeology Research Program, Southern Methodist University, Dallas.

1978b Faunal Analyses. In Evaluation of the Archaeology at the Proposed Cooper Lake, edited by K. Doehner, D. Peter, and S. A. Skinner. Research Report No. 114. Archaeology Research Program, Southern Methodist University, Dallas.

1982 Faunal Analysis. In The Deshazo Site, Nacogdoches County, Texas, Vol. 1, edited by D. A. Story, pp. 131-158. Texas Antiquities Permit Series No. 7. Texas Antiquities Committee, Austin.

Hietala, H. (editor)

1984 Intrasite Spatial Analysis in Archaeology. Cambridge University Press, New York.

Hoese, H. D.

1973 Abundance of the Low Salinity Clam, Rangiacuneata, in Southwestern Louisiana. Proceedings of the National Shellfisheries Association 63:99-106.

Hoffman, M. P.

1967 Ceramic Pipe Style Chronology along the Red River Drainage in Southwestern Arkansas. The Arkansas Archeologist 8(1):4-14.

1983 Changing Mortuary Patterns in the Little River Region, Arkansas. In Southeastern Natives and Their Pasts, edited by D. G. Wyckoff and J. L. Hofman, pp. 163-182. Studies in Oklahoma's Past No. 11. Oklahoma Archeological Survey, Norman.

Hofman, J. L.

1986 Vertical Movement of Artifacts in Alluvial and Stratified Deposits. Current Anthropology 27(2):163-171.

Holliday, V. T.

1997 Paleoindian Geoarchaeology of the Southern High Plains. University of Texas Press, Austin.

Holliday, V. T., E. Johnson, H. Haas, and R. Stuckenrath

1985 Radiocarbon Ages from the Lubbock Lake Site, 1981-1984. Plains Anthropologist 30:277-292.

Holloway, R. G.

1994 Ferndale Bog: A Record of Late Pleistocene-Holocene Climate and Vegetational Change. In Past Environments and Prehistory at McGee Creek Reservoir, Atoka County, Oklahoma, edited by C. R. Ferring, pp. 9-27. McGee Creek Archaeological Project Reports, Volume V, Part 4. Institute of Applied Sciences, University of North Texas, Denton.

1997 Analysis of Prehistoric Macrobotanical Remains Recovered from Sites 41BW553 and 41TT670. In Cultural Resources Testing of Two Sites within the White Oak Creek Wildlife Management Area, Bowie and Titus Counties, Texas, by F. B. Largent, Jr., D. L. Beene, M. B. Cliff, and S. M. Hunt, pp. F-1 to F-15. White Oak Creek Mitigation Area Archeological Technical Series, Report of Investigations No. 6. Geo-Marine, Inc., Plano.

Hopkins, S. H.

1970 Studies on the Brackish Water clams of the genus Rangia in Texas. Proceedings of the National Shellfisheries Association 60:5-6. 
Howard, A. D. and B. J. Anson

1922 Phases in the Parasitism of Unionidae. Journal of Parasitology 9:70-84.

Howells, R. G., R. W. Neck, and H. D. Murray

1996 Freshwater Mussels of Texas. Texas Parks and Wildlife Department, Austin.

Huebner, J. A.

1991 Late Prehistoric Bison Populations in Central and Southern Texas. Plains Anthropologist 36(137):343-358.

Hudson, C.

1976 The Southeastern Indians. University of Tennessee Press, Knoxville.

1986 Hernando De Soto in the Caddo Area. Paper presented at the 28th Caddo Conference, Little Rock.

1997 Knights of Spain, Warriors of the Sun: Hernando de Soto and the South's Ancient Chiefdoms. University of Georgia Press, Athens.

Humphrey, J, D, and C, R, Ferring

1994 Stable Isotopic Evidence for Latest Pleistocene and Holocene Climatic Change in North-Central Texas, QuaternaryResearch 41;200-213.

Hunt, S, M, and M, B, Cliff

1998 Intensive Pedestrian Survey of 1,260 Acres at Lake O' the Pines and Wright Patman Lake, Bowie and Marion Counties, Texas; 1997, Miscellaneous Report of Investigations No, 160, Geo-Marine, Inc., Plano.

Hyatt, R. D. and K. Doehner

1975 Archaeological Research at Cooper Lake, Northeast Texas, 1973. Contributions in Anthropology No. 15. Department of Anthropology, Southern Methodist University, Dallas.

Hyatt, R. D. and S. A. Skinner

1971 Archaeological Resources of the Cooper Reservoir, Texas. Department of Anthropology, Southern Methodist University, Dallas. Submitted to the National Park Service, Denver.

Hyatt, R. D., B. H. Butler, and H. P. Mosca

1974 Archaeological Research at Cooper Lake, 1970-1972. Contributions in Anthropology 12. Department of Anthropology, Southern Methodist University, Dallas.

Jackson, A. T.

1931 Department of Anthropology Field Notebook No. 3 for 1931: April 17, 1931 (Tom N. Cole or Mustang Creek Site). MS on file, Texas Archeological Research Laboratory, The University of Texas at Austin.

1932 Dog burial (?). Goode Hunt Farm. Notes from unpublished report. Ms. on file Texas Archeological Research Laboratory, The University of Texas at Austin.

1933 Some Pipes of East Texas. Bulletin of the Texas Archeological and Paleontological Society 5:6986.

1934a Burial Site and Midden, Bert W. Davis Plantation. Ms. on file, Texas Archeological Research Laboratory, The University of Texas at Austin. 
1934b Trenching of an Earth Mound, L. A. Hale Farm, 2 1/2 Miles South of Winfield, Titus County, Texas (Near Edge of Franklin County), Trenched May 11, 1934, to May 28, 1934. MS on file, Texas Archeological Research Laboratory, The University of Texas at Austin.

1938 Fire in East Texas Burial Rites. Bulletin of the Texas Archeological and Paleontological Society 10:77-113.

Jelks, E. B.

1961 Excavations at Texarkana Reservoir, Sulphur River, Northeastern Texas. River Basin Survey Papers No. 21, Bulletin No. 179. Bureau of American Ethnology, Smithsonian Institution, Washington, D.C.

Jeter, M. D., J. C. Rose, I. Williams, Jr., and A. M. Harmon

1989 Archeology and Bioarcheology of the Lower Mississippi Valley and Trans-Mississippi South in Arkansas and Louisiana. Research Series No. 37. Arkansas Archeological Survey, Fayetteville.

Johannessen, S.

1984 Paleoethnobotany. In American Bottom Archaeology, edited by C. J. Bareis and J. W. Porter, pp. 197-214. University of Illinois Press, Urbana.

Johnson, L., Jr.

1962 The Yarbrough and Miller Sites of Northeastern Texas, with a Preliminary Definition of the La Harpe Aspect. Bulletin of the Texas Archeological Society 32:141-284.

1987 A Plague of Phases: Recent Sociocultural Taxonomy in Texas Archeology. Bulletin of the Texas Archeological Society 57:1-26.

1989a Great Plains Interlopers in the Eastern Woodlands in Late Paleoindian Times: The Evidence from Oklahoma, Texas, and Areas Close By. Report Series No. 36. Office of the State Archeologist, Texas Historical Commission, Austin.

1989b Classification of Stone Projectile Points by a Small Texan Folk Community: A Case Study. The Texas Journal of Science 41(2):193-203.

1995 Past Cultures and Climates at the Jonas Terrace Site, 41 ME29 of Medina County, Texas. Office of the State Archeologist Report 40. Texas Department of Transportation and Texas Historical Commission, Austin.

Jones, G. T., C. Beck, and D. K. Grayson

1983 Artifact Class Richness and Sample Size in Archaeological Surface Assemblages. In Lulu Linear Punctated: Essays in Honor of George Irving Quimby, edited by R. C. Dunnell and D. K. Grayson, pp. 55-73. Anthropological Papers No. 72. Museum of Anthropology, University of Michigan, Ann Arbor.

Jones, G. T. and R. Leonard (editors)

1989 Quantifying Diversity in Archaeology. Cambridge University Press, Cambridge.

Jones, Q. and F. R. Earle

1966 Chemical Analyses of Seeds II: Oil and Protein Content of 759 Species. Economic Botany 20:127-155. 
Jones, V. H.

1949 Maize from the Davis Site: Its Nature and Interpretation. In The George C. Davis Site, Cherokee County, Texas, by H. P. Newell and A. D. Krieger, pp. 241-249. Memoirs No. 5. Society for American Archaeology, Menasha, Wisconsin.

Jones, V. H. and R. L. Fonner

1954 Plant Materials from Sites in the Durango and La Plata Areas, Colorado. In Basketmaker II Sites Near Durango, Colorado, by E. H. Morris and R. F. Burgh, pp. 93-115. Publication 604. Carnegie Institution of Washington, Washington, D.C.

Jordan, T. G.

1973 Pioneer Evaluation of Vegetation in Frontier Texas. Southwestern Historical Quarterly 76:233254.

1981 Trails to Texas: Southern Roots of Western Cattle Ranching. University of Nebraska Press, Lincoln.

Jurney, D. H.

1987 Biotic Resources of the Prairie Margin of Texas at the Time of Pre-Euro-American Settlement. In Introduction to the Richland Creek Archaeological Project: Environmental Background and Cultural Setting, edited by J. E. Bruseth and R. W. Moir, pp. 49-54. Richland Creek Technical Series, Vol. I. Archaeology Research Program, Institute for the Study of Earth and Man, Southern Methodist University, Dallas.

1997 Summary of Historic Archaeology: Results of the 1987 Field Season. In Archaeological Investigations at Cooper Lake, Delivery Order Numbers 2, 3, \& 4, 1987: Cultural Resource Studies for Cooper Lake, Hopkins and Delta Counties, Texas, by D. E. McGregor, M. M. Green, D. H. Jurney, W. A. Martin, R. W. Moir, and J. W. Saunders, pp. 517-527. 2 Vols. Archaeology Research Program, Southern Methodist University, Dallas. Final report submitted to U.S. Army Corps of Engineers, Ft. Worth District, Contract DACW63-87-D-0017.

Jurney, D. H. and J. Bohlin

1993 Archaeological Survey of Cooper Lake, Delivery Order Number 6, 1989: Cultural Resource Studies for Cooper Lake, Hopkins and Delta Counties, Texas. Archaeology Research Program, Southern Methodist University, Dallas.

Jurney, D. H., J. Bohlin, S. E. Linder Linsley, S. C. Caran, and D. R. Pedler

1993 Archaeological Survey of Cooper Lake, Delivery Order Number 7, 1989: Cultural Resource Studies for Cooper Lake, Hopkins and Delta Counties, Texas. Archaeology Research Program, Southern Methodist University, Dallas.

Kaylor, J. F. and L. R. Randall

1931 Methods of Collecting, Stratifying and Planting Black Walnuts in Indiana. Publication 104. Indiana Department of Conservation.

Keene, A. S.

1981 Prehistoric Foraging in a Temperate Forest. Academic Press, New York.

Kelley, D. B. (editor)

1997 Two Caddoan Farmsteads in the Red River Valley: The Archeology of the McLelland and Joe Clark Sites. Research Series No. 51. Arkansas Archeological Survey, Fayetteville. 
Kelley, D. B., D. G. Hunter, P. S. Gardner, D. C. Weinand, A. Tine, and L. L. Tieszen

1996 The McLelland and Joe Clark Sites: Protohistoric-Historic Caddo Farmsteads in the Red River Valley of Northwest Louisiana. Southeastern Archaeology 15(1):81-102.

Kelly, R. L.

1995 The Foraging Spectrum: Diversity in Hunter-Gatherer Lifeways. Smithsonian Institution Press, Washington, D.C.

Kidder, A. V.

1932 The Artifacts of Pecos. Papers of the Phillips Academy Southwestern Expedition No. 6. Yale University Press, New Haven.

Kindscher, $\mathrm{K}$.

1987 Edible Wild Plants of the Prairie. University Press of Kansas, Lawrence.

King, F. B.

1984a Plants, People, and Paleoecology. Scientific Papers, Volume XX. Illinois State Museum, Springfield.

1984b Plant Remains from the Cedar Grove (3LA97) and Sentell (3LA128) Sites. In Cedar Grove: An Interdisciplinary Investigation of a Late Caddo Farmstead in the Red River Valley, edited by N. L. Trubowitz, pp. 207-210. Research Series No. 23. Arkansas Archeological Survey, Fayetteville.

King, H. G.

1969 Unpublished Energy Dispersive X-Ray Data on Dentition at X41RR1, Sam Kaufman Site, Texas. MS on file with the author.

Kotter, S. M., R. Rogers, R. Taylor, K. Reese-Taylor, and W. P. Glander

1993 Archaeological Investigation within the Monticello B-2 First Five-Year Disturbance Area, Titus County, Texas. Document No. 920013. Espey, Huston \& Associates, Inc., Austin.

Krieger, A. D.

1946 Culture Complexes and Chronology in Northern Texas with Extension of Puebloan Datings to the Mississippi Valley. Publication No. 4640. University of Texas, Austin.

Krochmal, A. and C. Krochmal

1984 A Field Guide to Medicinal Plants. Times Books, New York.

Krogman, W. M.

1978 The Human Skeleton in Forensic Medicine. C. C. Thomas, Springfield, Illinois.

Kroll, E. M. and T. D. Price (editors)

1991 The Interpretation of Archaeological Spatial Patterning. Plenum Press, New York.

Krueger, H. W.

1985 Models for Carbon and Nitrogen Isotopes in Bone. Krueger Enterprises, Inc., Cambridge, Massachusetts.

Kuchler, A. W.

1964 Potential Natural Vegetation of the Conterminous United States. Special Publication 36. American Geographical Society, New York.

Lallo, J., G. J. Armelagos, and R. P. Mensforth 
1977 Role of Diet, Disease, and Physiology in the Origin of Porotic Hyperostosis. Human Biology 49:471-485.

Lambert, L. R.

1983 Microprobe Analysis of Elemental Distribution in Excavated Human Femurs. American Journal of Physical Anthropology 62:409-423.

Lane, G. L.

1977 Soil Survey of Hopkins and Rains Counties, Texas. United States Department of Agriculture, Soil Conservation Service, in cooperation with Texas Agricultural Experiment Station, Temple.

Largent, F. B., Jr., D. L. Beene, M. B. Cliff, and S. M. Hunt

1997 Cultural Resources Testing of Two Sites within the White Oak Creek Wildlife Management Area, Bowie and Titus Counties, Texas. White Oak Creek Mitigation Area Archeological Technical Series, Report of Investigations No. 6. Geo-Marine, Inc., Plano.

Leach, J. D., D. L. Nickels, B. K. Moses, and R. Jones

1998 A Brief Comment on Estimating Rates of Burned Rock Discard: Results from an Experimental Earth Oven. La Tierra 25(3):42-50.

Lebo, S. A.

1988 The Tucker (41DT104) and Sinclair (41DT105) Cemeteries of Delta County, Texas: An Archaeological and BioarchaeologyPerspective. Institute of Applied Sciences, University of North Texas, Denton. Submitted to the U.S. Army Corps of Engineers, Ft. Worth District, Contract No. DACW63-85-D-0066.

Lee, C.

1997 Paleopathology of the Hatchel-Mitchell-Moores Sites, Bowie County, Texas. Bulletin of the Texas Archeological Society 68:161-177.

Leese, M. N. and P. L. Main

1994 The efficient computation of unbiased Mahalanobis distances and their interpretation in archaeometry. Archaeometry 36:307-316.

LePage du Pratz, A. S.

1774 The History of Louisiana. Facsimile reprint (1975), edited by J. G. Tregle, Jr. Louisiana State University Press, Baton Rouge.

Linder-Linsley, S. E. and L. D. Lindsay

1997 Cultural Resources Survey 1996: Wright Patman Lake and Lake O' the Pines, Bowie, Cass, and Marion Counties, Texas. LL Consultants, Dallas and Atlanta, Texas.

Littleton, T. G.

1979 The Distribution and Abundance of the Freshwater Mussels (Bivalvia: Unionacea) of the Navasota River, Texas. Unpublished Master's Thesis, Department of Biology, Texas A\&M University, College Station.

Long, J. K.

n.d. Hopkins County site forms. On file, Texas Archeological Research Laboratory, The University of Texas at Austin.

Loughmiller, C. and L. Loughmiller

1984 Texas Wildflowers. University of Texas Press, Austin. 
Lovejoy, C. O.

1985 Multifactorial Determination of Skeletal Age at Death. American Journal of Physical Anthropology 68:1-14.

Loveland, C. J.

1980 The Skeletal Biology of the Caddo Indians of the Kaufman-Williams Site, Red River County, Texas. Ph.D. dissertation, Department of Anthropology, University of Tennessee, Knoxville.

Lyman, R. L., S. Wolverton, and M. J. O'Brien

1998 Seriation, Superposition, and Interdigitation: A History of Americanist Graphic Depictions of Culture Change. American Antiquity 63(2):239-261.

Macon, J. W.

1979 Mineral Resources of Texas. Bureau of Economic Geology, The University of Texas at Austin.

Malicse, A.

1994 A Petrographic Analysis of Ceramics from Four Texas Missions. In Texas Beyond the Periphery: An Archaeological Study of the Spanish Missions During the 18th Century, by S. B. Carlson, pp. 248-269. Unpublished Ph.D. dissertation, Department of Anthropology, Texas A\&M University, College Station.

Mallouf, R. J.

1976 Archeological Investigations at Proposed Big Pine Lake, 1974-1975, Lamar and Red River Counties, Texas. Archeological Survey Report No. 18. Office of the State Archeologist, Texas Historical Commission, Austin.

Mandel, R. D.

1987 Geomorphological Investigations. In Buried in the Bottoms: The Archaeology of Lake Creek Reservoir, Montgomery County, Texas, by L. C. Bement, R. D. Mandel, J. F. de la Teja, D. K. Utley, and S. A. Turpin, pp. 4-1 to 4-41. Research Report 97. Texas Archeological Survey, The University of Texas at Austin.

Mangelsdorf, P. C.

1974 Corn: Its Origin, Evolution, and Involvement. Belknap Press, Cambridge.

Martin, A. C. and W. D. Barkley

1973 Seed Identification Manual. University of California Press, Berkeley,

Martin, W. A.

1997a Archaeological Investigations at 41HP78: The Lawson Site. In Archaeological Investigations at Cooper Lake, Delivery Order Numbers 2, 3, \& 4, 1987: Cultural Resource Studies for Cooper Lake, Hopkins and Delta Counties, Texas, by D. E. McGregor, M. M. Green, D. H. Jurney, W. A. Martin, R. W. Moir, and J. W. Saunders, pp. 363-428. 2 Vols. Archaeology Research Program, Southern Methodist University, Dallas. Final Report submitted to U.S. Army Corps of Engineers, Ft. Worth District, Contract DACW63-87-D-0017.

1997b Archaeological Investigations at 41DT124: The Doctors Creek Site. In Archaeological Investigations at Cooper Lake, Delivery Order Numbers 2, 3, \& 4, 1987: Cultural Resource Studies for Cooper Lake, Hopkins and Delta Counties, Texas, by D. E. McGregor, M. M. Green, D. H. Jurney, W. A. Martin, R. W. Moir and J. W. Saunders, pp. 271-340. 2 Vols. Archaeology Research Program, Southern Methodist University, Dallas. Final report submitted to U.S. Army Corps of Engineers, Ft. Worth District, Contract DACW63-87-D-0017. 
McCoy, D.

1980 Roadside Wild Fruits of Oklahoma. University of Oklahoma Press, Norman.

McGregor, D.E.

1987 Lithic Raw Material Utilization. In Hunter-Gatherer Adaptations along the Prairie Margin: Site Excavations and Synthesis of Prehistoric Archaeology, edited by D. E. McGregor and J. E. Bruseth, pp. 185-195. Richland Creek Technical Series, Vol. III. Archaeology Research Program, Institute for the Study of Earth and Man, Southern Methodist University, Dallas.

1988 The Archaeological Potential of Holocene Alluvial Sites in North Central Texas: An Example from Richland/Chambers Reservoir. The Record 42(3):3-11. Fiftieth Anniversary Edition, Dallas Archeological Society, Dallas.

1997a Summary of Prehistoric Archaeology Results: The 1987 Field Season. In Archaeological Survey of Cooper Lake, Delivery Order Number 4, 1989: Cultural Resource Studies for Cooper Lake, Hopkins and Delta Counties, Texas, by D. E. McGregor, M. M. Green, D. H. Jurney, W. A. Martin, R. W. Moir, and J. W. Saunders, pp. 437-446. 2 Vols. Archaeology Research Program, Southern Methodist University, Dallas. Final report submitted to U.S. Army Corps of Engineers, Ft. Worth District, Contract DACW63-87-D-0017.

1997b Archaeological Investigations at 41HP137. In Archaeological Survey of Cooper Lake, Delivery Order Number 4, 1989: Cultural Resource Studies for Cooper Lake, Hopkins and Delta Counties, Texas, by D. E. McGregor, M. M. Green, D. H. Jurney, W. A. Martin, R. W. Moir, and J. W. Saunders, pp. 347-367. Archaeology Research Program, Southern Methodist University, Dallas. Final report submitted to U.S. Army Corps of Engineers, Ft. Worth District, Contract DACW6387-D-0017.

1997c Lithic Technological Analysis. In Archaeological Survey of Cooper Lake, Delivery Order Number 4, 1989: Cultural Resource Studies for Cooper Lake, Hopkins and Delta Counties, Texas, by D. E. McGregor, M. M. Green, D. H. Jurney, W. A. Martin, R. W. Moir, and J. W. Saunders, pp. 561-572. Archaeology Research Program, Southern Methodist University, Dallas. Final report submitted to U.S. Army Corps of Engineers, Ft. Worth District, Contract DACW63-87-D-0017.

McGregor, D. E. and J. E. Bruseth

1987a Artifact Chronology. In Hunter-Gatherer Adaptations along the Prairie Margin: Site Excavations and Synthesis of Prehistoric Archaeology, edited by D. E. McGregor and J. E. Bruseth, pp. 171184. Richland Creek Technical Series, Vol. III. Archaeology Research Program, Institute for the Study of Earth and Man, Southern Methodist University, Dallas.

McGregor, D. E. and J. E. Bruseth (editors)

1987b Hunter-Gatherer Adaptations along the Prairie Margin: Site Excavations and Synthesis of Prehistoric Archaeology. Richland Creek Technical Series, Vol. III. Archaeology Research Program, Institute for the Study of Earth and Man, Southern Methodist University, Dallas.

McGregor, D. E. and D. H. Jurney

1997 Survey and Testing Methodology. In Archaeological Investigations at Cooper Lake, Delivery Order Numbers 2, 3, \& 4, 1987: Cultural Resource Studies for Cooper Lake, Hopkins and Delta Counties, Texas, by D. E. McGregor, M. M. Green, D. H. Jurney, W. A. Martin, R. W. Moir, and J. W. Saunders, pp. 25-29. Archaeology Research Program, Southern Methodist University, Dallas. Final Report submitted to U.S. Army Corps of Engineers, Ft. Worth District, Contract DACW63-87-D-0017. 
McGregor, D. E. and W. A. Martin, with contributions by T. K. Perttula

1997 Site Descriptions of Tested Prehistoric Sites. In Archaeological Investigations at Cooper Lake, Delivery Order Numbers 2, 3, \& 4, 1987: Cultural Resource Studies for Cooper Lake, Hopkins and Delta Counties, Texas, by D. E. McGregor, M. M. Green, D. H. Jurney, W. A. Martin, R. W. Moir, and J. W. Saunders, pp. 31-126. Archaeology Research Program, Southern Methodist University, Dallas. Final Report submitted to U.S. Army Corps of Engineers, Ft. Worth District, Contract DACW63-87-D-0017.

McGregor, D. E., M. M. Green, D. H. Jurney, W. A. Martin, R. W. Moir, and J. W. Saunders

1997 Archaeological Investigations at Cooper Lake, Delivery Order Numbers 2, 3, \& 4, 1987; Cultural Resource Studies for Cooper Lake, Hopkins and Delta Counties, Texas. Archaeology Research Program, Southern Methodist University, Dallas. Final Report submitted to U.S. Army Corps of Engineers, Ft. Worth District, Contract DACW63-87-D-0017.

McGuff, P. R.

1993 Initial Site Testing, McGee Creek Project, Atoka County, Oklahoma. McGee Creek Archaeological Project Reports, Vol. 2. Institute of Applied Sciences, University of North Texas, Denton.

McKinley, M. A. and J. E. Bruseth

1978 The Invertebrate Fauna. In Archaeological Research at Proposed Cooper Lake, Northeast Texas, 1974-1975 by K. Doehner and R. E. Larson. pp. 95-98. Research Report No. 108. Archaeology Research Program, Southern Methodist University, Dallas.

Meltzer, D. J.

1987 The Clovis Paleoindian Occupation of Texas: Results of the Texas Clovis Fluted Point Survey. Bulletin of the Texas Archeological Society 57:27-68.

Meltzer, D. J. and B. D. Smith

1986 Paleoindian and Early Archaic Subsistence Strategies in Eastern North America. In Foraging, Collecting, and Harvesting: Archaic Period Subsistence and Settlement in the Eastern Woodlands, edited by S. W. Neusius, pp. 3-31. Occasional Paper No. 6. Center for Archaeological Investigations, Southern Illinois University, Carbondale.

Merchant, V. L. and D. H. Ubelaker

1977 Skeletal Growth of the Protohistoric Arikara. American Journal of Physical Anthropology 46(1):61-72.

Middlebrook, T.

1994 An Update of Archaeological Investigations at the Tyson Site (41SY92). Journal of Northeast Texas Archaeology No. 3:1-36.

1997 The Caddoan Occupation of the Attoyac and Angelina River Basins in the Middle Caddoan Period. Journal of Northeast Texas Archaeology 10:36-40.

Middlebrook, T. and T. K. Perttula

1997 The Middle Caddoan Period in East Texas: A Summary of the Findings of the East Texas Caddoan Research Group. Journal of Northeast Texas Archaeology No. 9:1-8.

Miller, J. E.

1986 The Myers Mound: Salvage Excavations at a Caddo II Site in Southwest Arkansas. The Arkansas Archeologist 23/24:67-127. 
Minnis, P. E.

1981 Seeds in Archaeological Sites: Sources and Some Interpretive Problems. American Antiquity 46(1):143-152.

Moir, R.W., D. E. McGregor, and D. H. Jurney

1997 Introduction, Scope, and Archaeological Background. In Archaeological Investigations at Cooper Lake, Delivery Order Numbers 2, 3, \& 4, 1987: Cultural Resource Studies for Cooper Lake, Hopkins and Delta Counties, Texas, by D. E. McGregor, M. M. Green, D. H. Jurney, W. A. Martin, R. W. Moir, and J. W. Saunders, pp. 1-24. Archaeology Research Program, Southern Methodist University, Dallas. Final Report submitted to U.S. Army Corps of Engineers, Ft. Worth District, Contract DACW63-87-D-0017.

Montgomery, F. H.

1977 Seeds and Fruits of Plants of Eastern Canada and Northeastern United States. University of Toronto Press, Toronto.

Moore, R. C., C. G. Lalicker, and A. F. Fischer

1952 Invertebrate Fossils. McGraw-Hill Book Company, Inc., New York.

Moorman, E. H., and E. B. Jelks

1952 Appraisal of the Archeological Resources of the Cooper Reservoir, Delta and Hopkins Counties, Texas. River Basin Surveys, Austin Office. Smithsonian Institution, Washington, D.C.

Morse, D. F.

1997 Sloan: A Paleoindian Dalton Cemetery in Arkansas. Smithsonian Institution Press, Washington, D.C.

Murray, H. D. and A. B. Leonard

1962 Handbook of Unionid Mussels in Kansas. Miscellaneous Publications No. 28. Department of Zoology and State Biological Survey, The University of Kansas, Lawrence.

Naroll, R.

1962 Floor Area and Settlement Population. American Antiquity 27:587-589.

Neck, R.

1987 Appendix III: Analysis of 1982 Molluscan Fauna. In Archeology at Aquilla Lake: 1978-1982 Investigations, Volume III, compiled by D. O. Brown, pp. III-1 to III-13. Research Report 81. Texas Archeological Survey, The University of Texas at Austin.

Neff, $\boldsymbol{H}$.

1992 Introduction. In Chemical Characterization of Ceramic Pastes in Archaeology, edited by H. Neff, pp. 1-10. Prehistory Press, Madison, Wisconsin.

1994 RQ-mode Principal Components Analysis of Ceramic Compositional Data. Archaeometry 36:115130.

1998 April 1, 1998 Letter to Robert Rogers, Espey, Huston \& Associates, Inc., Austin.

Neff, H., J. W. Cogswell, and M. D. Glascock

1998 Compositional Analysis of Caddoan Ceramics from the Mockingbird Site (41TT550) in Northeast Texas. In Analysis of the Titus Phase Mortuary Assemblage at the Mockingbird Site (“Kahbakayammaahin”), 41TT550, by T. K. Perttula, M. Tate, H. Neff, J. W. Cogswell, M. D. Glasscock, E. Skokan, S. Mulholland, R. Rogers, and B. Nelson, pp. 255-272. Document No. 970849. Espey, Huston \& Associates, Inc., Austin. 
Nelson, B. and T. K. Perttula

1997 Documenting the Looting of Early, Middle, and Late Caddoan Cemeteries in Northeast Texas. In The Steward: Collected Papers on Texas Archeology, Vol. 4:3-14. Office of the State Archeologist, Texas Historical Commission, Austin.

Nelson, B. and M. Turner

1997 Middle Caddoan Sites in the Cypress Creek Drainage Basin. Journal of Northeast Texas Archaeology, No. 10:1-11.

Newell, H. P. and A. D. Krieger

1949 The George C. Davis Site, Cherokee County, Texas. Memoirs No. 5. Published jointly by the Society for American Archaeology and the University of Texas, Menasha, Wisconsin.

Newman, J. R. and R. L. Nielsen

1985 Initial Notes on the X-Ray Fluorescence Sourcing of Northern New Mexico Obsidians. Journal of Field Archaeology 12:377-383.

O'Brien, M. J., T. D. Holland, R. J. Hoard, and G. L. Fox

1994 Evolutionary Implications of Design and Performance Characteristics of Prehistoric Pottery. Journal of Archaeological Method and Theory 1(3):259-304.

O'Connell, J. F.

1987 Alyawara Site Structure and its Archaeological Implications. American Antiquity 52:74-108.

O’Heeron, M. K., Jr.

1966 Some Aspects of the Ecology of Rangiacuneata (Gray). Unpublished Master's of Science Thesis, Department of Biology, Texas A\&M University, College Station.

Odell, G. H.

1996 Economizing Behavior and the Concept of "Curation." In Stone Tools: Theoretical Insights into Human Prehistory, edited by G. H. Odell, pp. 51-80. Plenum Press, New York.

1998 Investigating Correlates of Sedentism and Domestication in Prehistoric North America. American Antiquity 63(4):553-571.

Oesch, R. D.

1984 Missouri Naiades: A Guide to the Mussels of Missouri. Missouri Department of Conservation, Jefferson City.

Ortner, D. J. and W. G. J. Putschar

1985 Identification of Pathological Conditions in Human Skeletal Remains. Contributions in Anthropology No. 26. Smithsonian Institution, Washington, D.C.

Orton, C., P. Tyers, and A. Vince

1993 Pottery in Archaeology. Cambridge Manuals in Archaeology. Cambridge University Press, Cambridge, England

Palmer, E.

1871 Food Products of the North American Indians. Annual Report of the Commissioner of Agriculture, pp. 404-428. House Executive Document, 3rd Session, 41st Congress, Serial Set No. 1461.

Washington, D.C. 
Parish, C. and T. K. Perttula

1996 Historic Lifeways in the Cedar Creek Community, Delta County, Cooper Lake Area. Special Publication No. 3. Friends of Northeast Texas Archaeology, Pittsburg, Texas.

Parker, R. S., C. T. Hackney, and M. F. Vidrine

1984 Ecology and Reproductive Strategy of a South Louisiana Mussel, Glebula rotundata (Lamarck) (Unionidae: Lampsilini). Freshwater Invertebrate Biology 3:53-58.

Parmalee, P. W.

1967 The Fresh-Water Mussels of Illinois. Popular Science Series, Vol. 8. Illinois State Museum, Springfield.

Parmalee, P. W. and A. E. Bogan

1981 Animal Remains from the Roden Site (Mc-215), McCurtain County, Oklahoma. In Archaeological Investigations at the Roden Site (Mc-215), McCurtain County, Oklahoma, by G. Perino, pp. 87-94. Potsherd Press No. 1, Museum of the Red River, Idabel, Oklahoma.

Parmalee, P. W. and A. F. Opperman

1983 Animal Remains from the Bob Williams Site, Red River, County, Texas. In Archaeological Research at the Bob Williams Site (41RR16), Red River County, Texas, by G. Perino, pp. 79-84. Potsherd Press, Museum of the Red River, Idabel, Oklahoma.

Parsons, M.

1998 41UR133: A Late Caddo Hamlet at Lake Gilmer. CRM News \& Views 10(1):16-19. Archeology Division, Texas Historical Commission, Austin.

Patterson, L. W.

1990 Characteristics of Bifacial Reduction: Flake Size Distribution. American Antiquity 55(3):550-558.

Pearce, J. E.

1920 Early work in East Texas. MS on file, Texas Archeological Research Laboratory, The University of Texas at Austin.

1932 The Archaeology of East Texas. American Anthropologist 34:670-687.

Pearsall, D. M.

1989 Paleoethnobotany: A Handbook of Procedures. Academic Press, New York.

Pederson, P. O.

1952 Some Dental Aspects of Anthropology. Dental Record London 72:170-178.

Perino, G.

1983 Archaeological Research at the Bob Williams Site (41RR16), Red River County, Texas. Museum of the Red River, Idabel, Oklahoma.

1995 The Dan Holdeman Site (41RR11), Red River County, Texas. Journal of Northeast Texas Archaeology, No. 6:3-65.

Perino, G. and W. J. Bennett

1978 Archaeological Investigations at the Mahaffey Site, CH-1 Hugo Reservoir, Choctaw Co., Oklahoma. Museum of the Red River, Idabel, Oklahoma. Submitted to U.S. Army Corps of Engineers, Tulsa District, Contract No. DACW56-77-C-0129. 
Perkins, D., Jr. and P. Daly

1968 A Hunters' Village in Neolithic Turkey. Scientific American 219(5):97-106.

Perttula, T. K.

1984 Patterns of Prehistoric Lithic Raw Material Utilization in the Caddoan Area: The Western Gulf Coastal Plain. In Prehistoric Chert Exploitation -- Studies from the Midcontinent, edited by B. M. Butler and E. E. May, pp. 129-148. Occasional Paper No. 2. Center for Archaeological Investigations, Southern Illinois University, Carbondale.

1988a Cultural Resources Survey at Cooper Lake, Delta and Hopkins Counties, Texas. Institute of Applied Sciences, North Texas State University, Denton. Submitted to the U.S. Army Corps of Engineers, Ft. Worth District, Contract No. DACW63-85-D-0066.

1988b Cultural Setting. In Test Excavations at Sites 41BW182 and 41BW183, Red River Army Depot, Bowie County, Texas, edited by M. B. Cliff and D. E. Peter, pp. 11-25. RRAD/LSAAP Archeological Technical Series, Report of Investigations Number 1. Geo-Marine, Inc., Plano.

1989a The James Franks Site (41DT97): Excavations at a Mid-Nineteenth Century Farmstead in the South Sulphur River Valley, Cooper Lake Project, Texas. Contributions in Archaeology No. 7. Institute of Applied Sciences, University of North Texas, Denton.

1989b Test Excavations at Three Late Nineteenth/Early Twentieth Century Farmsteads at Cooper Lake, Delta and Hopkins Counties, Texas. Contributions in Archaeology No. 8. Institute of Applied Sciences, University of North Texas, Denton.

1989c The Paleoindian Archaeological Record in Northeast Texas: Evidence from Avocational Collecting Activities. Current Research in the Pleistocene 6:19-21.

1989d Contact and Interaction between Caddoan and European Peoples: The Historic Archaeological and Ethnohistorical Records. Ph.D. dissertation, Department of Anthropology, University of Washington, Seattle.

1989e Prehistoric Cultural Materials from 41DT88 and 41HP106, Historical Localities \#1 and \#2. In Test Excavations at Three Late 19th/Early 20th Century Farmsteads at Cooper Lake, Delta and Hopkins Counties, Texas, by T. K. Perttula, pp. 117-132. Contributions in Archaeology No. 8. Institute of Applied Sciences, University of North Texas, Denton.

1990a The Hurricane Hill Site (41HP106): Excavations at Cooper Lake, Hopkins County, Texas. Second draft. Contributions in Archaeology No. 9. Institute of Applied Sciences, University of North Texas, Denton.

1990b Historic Context: The Evolution of Agricultural Societies in Northeast Texas before A.D. 1600. 2 Parts. Final Report on file, Texas Historical Commission, Austin.

1992 "The Caddo Nation": Archaeological and Ethnohistoric Perspectives. University of Texas Press, Austin.

1993a The Development of Agriculture in Northeast Texas before A.D. 1600. In Archeology in the Eastern Planning Region, Texas: A Planning Document, edited by N. A. Kenmotsu and T. K. Perttula, pp. 121-146. Cultural Resource Management Document 3. Texas Historical Commission, Department of Antiquities Protection, Austin. 
1993b Mound Sites in Northeast Texas and Northwest Louisiana. In Archeology in the Eastern Planning Region, Texas: A Planning Document, edited by N. A. Kenmotsu and T. K. Perttula, pp. 251252. Cultural Resource Management Report 3. Texas Historical Commission, Austin.

1994a Excavations at the Quince Site (34AT134), Atoka County, Oklahoma. McGee Creek Archaeological Project Reports, Volume V, Part 2. Institute of Applied Sciences, University of North Texas, Denton.

1994b Caddoan Mound Sites in the Sabine River Basin of Northeast Texas. Caddoan Archeology Newsletter IV(4):4-19.

1995a The Archeology of the Pineywoods and Post Oak Savanna of Northeast Texas. Bulletin of the Texas Archeological Society 66:331-359.

1995b Early Ceramic Settlement in Northeast Texas: Archeological Investigations of the Hurricane Hill Site (41HP106), Cooper Lake. In Advances in Texas Archeology: Contributions from Cultural Resource Management, Volume 1, edited by J. E. Bruseth and T. K. Perttula, pp. 131-154. Cultural Resource Management Report 5. Department of Antiquities Protection, Texas Historical Commission, Austin.

1995c A Reconsideration of the Chronological and Cultural Placement of the Mortuary Remains and Grave Goods from the Dan Holdeman Site. Journal of Northeast Texas Archaeology, No. 6:67-87.

1996 Caddoan Area Archaeology Since 1990. Journal of Archaeological Research 4(4):295-348.

1997a Radiocarbon Dates from the Hurricane Hill Site (41HP106). In Synthesis of the Prehistoric and Historic Archeology of Cooper Lake, Delta and Hopkins Counties, Texas, by R. C. Fields, M. E. Blake, and K. W. Kibler, pp. 171-176. Reports of Investigations No. 104. Prewitt and Associates, Inc., Austin.

1997b The Archaeology of the Middle Caddoan Period in the Middle Red River Valley of Northeast Texas. Journal of Northeast Texas Archaeology No. 10:47-51.

1997c Middle Caddoan Period Archaeology in the Upper Sulphur River Basin. Journal of Northeast Texas Archaeology No. 10:41-46.

1998a A Compendium of Radiocarbon and Oxidizable Carbon Ratio Dates from Archaeological Sites in East Texas, with a Discussion of the Age and Dating of Select Components and Phases.

Radiocarbon 39(3):305-342.

1998b Late Caddoan Societies in the Northeast Texas Pineywoods. In The Native History of the Caddo: Their Place in Southeastern Archeology and Ethnohistory, edited by T. K. Perttula and J. E. Bruseth, pp. 69-90. Studies in Archeology 30. Texas Archeological Research Laboratory, The University of Texas at Austin.

1998c Analysis of the Decorated Ceramics from the Ear Spool Site (41TT653). MS on file, PBS \& J, Inc., Austin.

1998d The Decorated Ceramics from the Oak Hill Village Site (41RK214), Rusk County, Texas. PBS \& J, Inc., Austin.

1998e Radiocarbon and Oxidizable Carbon Ratio Dates from Archaeological Sites in East Texas, Part II. Journal of Northeast Texas Archaeology 11:66-90. 
1999 Preliminary Report on the Data Recovery Investigations at the Pilgrim's Pride Site (41CP304), Walker Creek Project, Camp County, Texas. Archeological and Environmental Consultants, Austin.

Perttula, T. K. and J. E. Bruseth

1983 Early Caddoan Subsistence Strategies, Sabine River Basin, East Texas. Plains Anthropologist 28(99):9-21.

1995 Trade and Exchange in Eastern Texas, 1100 B.C.-A.D. 800. In "Exchange in the Lower Mississippi Valley and Contiguous Areas in 1100 B.C.," edited by J. L. Gibson. Louisiana Archaeology 17:93-121.

Perttula, T. K. and J. B. Cruse

1997 The Caddoan Archaeology of the Sabine River Basin during the Middle Caddoan Period. Journal of Northeast Texas Archaeology No. 9:30-37.

Perttula, T. K., and S. A. Lebo

1987 Current Research: North Texas State University. Southeastern Archaeological Conference Newsletter 29(2):36-37.

Perttula, T. K. and B. Nelson

1998 Titus Phase Mortuary Practices in the Northeast Texas Pineywoods and Post Oak Savanna. In Analysis of the Titus Phase Mortuary Assemblage at the Mockingbird Site (“Kahbakayammaahin"), 41TT550, by T. K. Perttula, M. Tate, H. Neff, J. W. Cogswell, M. D. Glasscock, E. Skokan, S. Mulholland, R. Rogers, and B. Nelson, pp. 328-401. Document No. 970849. Espey, Huston \& Associates, Inc., Austin.

Perttula, T. K., C. J. Crane, and J. E. Bruseth

1983 A Consideration of Caddoan Subsistence. Southeastern Archaeology 1(2):89-102.

Perttula, T. K., B. D. Skiles, and B. C. Yates

1993 The Carlisle Site (41WD46), a Middle Caddoan Occupation on the Sabine River, Wood County, Texas. Notes on Northeast Texas Archaeology, No. 1:34-62.

Perttula, T. K., R. R. Turbeville, and B. D. Skiles

1987 New Thermoluminescence and Radiocarbon Dates from the upper Sabine River Basin, East Texas. Texas Archeology 31(2):7-9.

Perttula, T. K., M. Turner, and B. Nelson

1997 A Radiocarbon Date from the Coker Mound (41CS1). Journal of Northeast Texas Archaeology No. 9:17-20.

Perttula, T. K., J. E. Bruseth, N. A. Kenmotsu, and W. A. Martin

1995 Archeological Testing at the Cabe Mounds (41BW14), Bowie County, Texas. Cultural Resource Management Report 8. Department of Antiquities Protection, Texas Historical Commission, Austin.

Perttula, T. K., R. C. Fields, J. E. Corbin, and N. A. Kenmotsu

1993 The Emergence of Sedentism in the Northeast Texas Archeological Region, ca. 500 B.C. to A.D. 1000. In Archeology in the Eastern Planning Region, Texas: A Planning Document, edited by N. A. Kenmotsu and T. K. Perttula, pp. 97-120. Cultural Resource Management Report 3. Texas Historical Commission, Austin. 
Perttula, T. K., S. Gaither, C. A. Pegues, and R. L. Cast

1988 Prehistoric and Historic Cultural Materials from the Mill Race Creek Project Area. In Archeological Survey along Mill Race Creek and Tributaries, Wood County, Texas: 1987-1988, by T. K. Perttula and K. K. Gilmore, pp. 297-342. Contributions in Archaeology No. 6. Institute of Applied Sciences, University of North Texas, Denton.

Perttula, T. K., D. J. Prikryl, B. Nelson, and R. L. Cast

1998 Archeological Survey of the Broken Bow Lake Shoreline and the Relocation of Nine Previously Recorded Sites, McCurtain County, Oklahoma. Report of Investigations No. 7. Archeological \& Environmental Consultants, Austin.

Perttula, T. K., M. R. Miller, R. A. Ricklis, D. J. Prikryl, and C. Lintz

1995 Prehistoric and Historic Aboriginal Ceramics in Texas. Bulletin of the Texas Archeological Society 66:175-235.

Perttula, T. K., B. D. Skiles, M. B. Collins, M, C. Trachte, and F. Valdez, Jr.

1986 "This Everlasting Sand Bed": Cultural Resources Investigations at the Texas Big Sandy Project, Wood, and Upshur Counties, Texas. Reports of Investigations No. 52. Prewitt and Associates, Inc., Austin.

Perttula, T.K. , J. E. Bruseth, N. A. Kenmotsu, D. J. Prikryl, L. Banks, J. Smith, N. G. Reese, S. A. Iruegas, and W. A. Martin

n.d. Archeological Investigations on the Red River and Tributaries: Summary of the Findings of the 1991 and 1992 Texas Archeological Society Field School in Red River and Lamar Counties,

Texas. MS in preparation.

Peter, D. E.

1987 Flotation Methodology. In The Bird Point Island and Adams Ranch Sites: Methodological and Theoretical Contributions to North Central Texas Archaeology, edited by J. E. Bruseth and W. A. Martin, p. 293. Richland Creek Technical Series, Vol. II. Archaeology Research Program, Institute for the Study of Earth and Man, Southern Methodist University, Dallas.

Peter, D. E., M. B. Cliff, and J. T. Abbott, with contributions by T. K. Perttula

1990 Research Design for Cultural Resources Investigations at the White Oak Creek Mitigation Area, Bowie, Cass, Morris, and Titus Counties, Texas. Geo-Marine, Inc., Plano.

Peter, D. E. and M. B. Cliff (editors)

1990a Intensive Archeological Survey and Archival Investigations at the Red River Army Depot and Lone Star Army Ammunition Plant, Bowie County, Texas. RRAD/LSAAP Archeological Technical Series, Report of Investigations, Number 2. Geo-Marine, Inc., Plano.

1990b Cultural Resources Survey of Historic Sites at the Lone Star Army Ammunition Plant, Bowie County, Texas. RRAD/LSAAP Archeological Technical Series, Report of Investigations Number 3. Geo-Marine, Inc., Plano.

Peter, D. E., M. B. Cliff, and S. M. Hunt, with contributions by M. Collins, S. Gaither, T. K. Perttula, and N. Reese

1991 Red River Army Depot and Lone Star Army Ammunition Plant Cultural Resource Management Plan. Geo-Marine, Inc., Plano. 
Peter, D. E. and D. E. McGregor

1987 Lithic Reduction Systems and Interassemblage Variability: Problems of Recognition. In HunterGatherer Adaptations along the Prairie Margin: Site Excavations and Synthesis of Prehistoric Archaeology, edited by D. E. McGregor and J. E. Bruseth, pp. 197-228. Richland Creek Technical Series, Vol. III. Archaeology Research Program, Institute for the Study of Earth and Man, Southern Methodist University, Dallas.

Peter, D. E., D. E. McGregor, J. R. Newman, B. C. Yates, G. W. Rutenberg, G. J. Fritz, and J. E. Bruseth

1988 Site 41DL184. In Late Holocene Prehistory of the Mountain Creek Drainage, edited by D. E. Peter and D. E. McGregor, pp. 99-125. Joe Pool Lake Archaeological Project, Volume I. Archaeology Research Program, Institute for the Study of Earth and Man, Southern Methodist University, Dallas.

Peterson, L. A.

1977 A Field Guide to Edible Wild Plants of Eastern and Central North America. Houghton Mifflin Company, Boston.

Pettijohn, F. J., P. E. Potter, and R. Siever

1987 Sand and Sandstone. Springer-Verlag, New York.

Phillips, P.

1970 Archaeological Survey in the Lower Yazoo Basin, Mississippi, 1949-1955. 2 Parts. Papers of the Peabody Museum of Archaeology and Ethnology, Vol, 60. Peabody Museum of Archaeology and Ethnology, Harvard University, Cambridge.

Plog, S.

1980 Stylistic Variation in Prehistoric Ceramics. Cambridge University Press, New York.

Porter, J. W.

1971 Thin-Section Identifications of Spiro Sherds. In Spiro Studies, Volume 3: Pottery Vessels, by J. A. Brown, pp. 244-246. First Part of the Third Annual Report of Caddoan Archaeology - Spiro Focus Research. Stovall Museum of Science and History, University of Oklahoma and The University of Oklahoma Research Institute, Norman.

Potter, P. E., D. Heling, N. F. Shimp, and W. Van Wie

1975 Clay mineralogy of modern alluvial muds of the Mississippi River Basin. Bulletin du Centre de Recherches de Pau 9(2):353-389.

Prentiss, W. C.

1998 The Reliability and Validity of a Lithic Debitage Typology: Implications for Archaeological Interpretation. American Antiquity 63(4):635-650.

Preston, N. E.

1972 Multiple Paleo Finds in Hunt County, Texas. Missouri Archaeological Society Newsletter, October 1972:6-8.

1974 Waco Sinkers in Association with Paleo-Indian Artifacts. The Record, Newsletter of the Dallas Archeological Society 30(4):4-5.

Prewitt, E. R.

1975 Bayou Loco: Investigations and Speculations. Paper presented at the 1975 Caddo Conference. 
1995 Distributions of Typed Projectile Points in Texas. Bulletin of the Texas Archeological Society 66:83-173.

Price, S. A. and L. M. Wilson

1982 Pathophysiology. 2nd Edition. McGraw-Hill, New York.

Prikryl, D. J.

1990 Lower Elm Fork Prehistory: A Redefinition of Cultural Concepts and Chronologies along the Trinity River, North-Central Texas. Report 37. Office of the State Archeologist, Texas Historical Commission, Austin.

Raisz, E.

1957 Landforms of the United States. 6th edition. Cambridge, Massachusetts.

Ramenofsky, A. F. and P. Galloway

1997 Disease and the Soto Entrada. In The Hernando de Soto Expedition: History, Historiography, and "Discovery" in the Southeast, edited by P. Galloway, pp. 259-279. University of Nebraska Press, Lincoln.

Read, L. B.

1954 The Pelecypoda of Dallas County, Texas. Field and Laboratory22(2):35-52.

Reese-Taylor, K.

1993 Petrographic Analysis of Caddo Ceramics from Titus County, Northeast Texas. In Archaeological Investigation within the Monticello B-2 First Five-Year Disturbance Area, Titus County, Texas, by S. M. Kotter, R. Rogers, R. Taylor, K. Reese-Taylor, and W. P. Glander, pp. A-1 to A-13. Document No. 920013. Espey, Huston \& Associates, Inc., Austin.

1994 Petrographic Analysis of Caddoan Ceramics from Rusk County, Texas. In National Register Testing at Eight Archaeological Sites within the Oak Hill 2,280-Acre Study Area, Rusk County, Texas, by R. Rogers, E. Foster, and K. Reese-Taylor, pp. B-1 to B-15. Document No. 930169. Espey, Huston \& Associates, Inc., Austin.

1995a Evidence of Resource Procurement and Manufacturing Techniques in Caddoan Ceramic Assemblages from the Sabine, Cypress, and Sulphur River Drainage Basins, Rusk and Titus Counties, Texas. Journal of Northeast Texas Archaeology No. 5:9-27.

1995b Petrographic Analysis of Ceramics. In National Register Testing of Ten Sites in the Monticello B2 Surface Mine, Titus County, Texas, by M. A. Nash, S. M. Kotter, K. V. Reese-Taylor, E. A. Skokan, E. R. Foster, R. M. Rogers, and W. P. Glander, pp. C-1 to C-13. Document No. 930529. Espey, Huston \& Associates, Inc., Austin.

1997 Petrographic Analysis of Ceramics. In Data Recovery Excavations at Site $41 T 7372$ in the Tankersley Creek Watershed, Monticello B-2 Surface Mine, Titus County, Texas. Document No. 940608. Espey, Huston \& Associates, Inc., Austin.

Reese-Taylor, K., J. Hageman, and R. A. Ricklis

1995 Preliminary Paste Analyses of Ceramic Samples from the Mustang Branch Site (41HY209) and Barton Site (41HY202). In Archaic and Late Prehistoric Human Ecology in the Middle Onion Creek Valley, Hays County, Texas, by R. A. Ricklis and M. B. Collins, pp. 549-568. 2 Vols. Studies in Archeology 19. Texas Archeological Research Laboratory, The University of Texas at Austin. 
Reid, K. C.

1977 Psoraleaesculenta as a Prairie Resource: An Ethnographic Appraisal. Plains Anthropologist 22(78), Part 1:321-327.

Ressel, D.

1979 Soil Survey of Lamar and Delta Counties, Texas. United States Department of Agriculture, Soil Conservation Service, in cooperation with Texas Agricultural Experiment Station, Temple.

Rice, P.M.

1987 Pottery Analysis: A Sourcebook. University of Chicago Press, Chicago.

1996 Recent Ceramic Analysis: 1. Function, Style, and Origins. Journal of Archaeological Research 4(2):133-163.

Ritter, D.

1978 Process Geomorphology. Wm. C. Brown Company Publishers, Dubuque, Iowa.

Robbins, C. S., B. Bruun, A. Singer, and H. S. Zim

1966 Birds of North American. Golden Press, New York.

Rogers, J. D.

1991 Patterns of Change on the Western Margin of the Southeast, A.D. 600-900. In Stability, Transformation, and Variation: The Late Woodland Southeast, edited by M. S. Nassaney and C. R. Cobb, pp. 221-248. Plenum Press, New York.

1995a The Archaeological Analysis of Domestic Organization. In Mississippian Communities and Households, edited by J. D. Rogers and B. D. Smith, pp. 7-31. University of Alabama Press, Tuscaloosa.

1995b Dispersed Communities and Integrated Households: A Perspective from Spiro and the Arkansas Basin. In Mississippian Communities and Households, edited by J. D. Rogers and B. D. Smith, pp. 81-98. University of Alabama Press, Tuscaloosa.

Rogers, R. M.

n.d. Untitled Technical Report on Oak Hill Village (41RK214) Excavations. PBS \& J, Inc., Austin.

Rogers, R., E. Foster, K. Reese-Taylor, G. Rutenberg, M. Nash, J. Hageman, and D. Jurney

1994 National Register Testing at Eight Archaeological Sites within the Oak Hill 2,280-Acre Study Area, Rusk County, Texas. Document No. 930169. Espey, Huston \& Associates, Inc., Austin.

Rohrbaugh, C. L., R. J. Burton, S. S. Burton, and L. J. Rosewitz

1971 Hugo Reservoir I. Archaeological Site Report No. 22. Oklahoma River Basin Survey, University of Oklahoma, Norman.

Rose, J. C.

1984 Bioarchaeology of the Cedar Grove Site. In Cedar Grove: An Interdisciplinary Investigation of a Late Caddo Farmstead in the Red River Valley, edited by N. L. Trubowitz, pp. 227-256. Research Series No. 23. Arkansas Archeological Survey, Fayetteville.

Rose, J. C., M. P. Hoffman, B. A. Burnett, A. M. Harmon, and J. E. Barnes

1998 Skeletal Biology of the Prehistoric Caddo. In The Native History of the Caddo: Their Place in Southeastern Archeology and Ethnohistory, edited by T. K. Perttula and J. E. Bruseth, pp. 123136. Studies in Archeology 30. Texas Archeological Research Laboratory, The University of Texas at Austin. 
Rye, O. S.

1981 Pottery Technology: Principles and Reconstruction. Taraxacum Inc., Washington, D.C.

Sabo, G., III

1998 The Structure of Caddo Leadership in the Colonial Era. In The Native History of the Caddo: Their Place in Southeastern Archeology and Ethnohistory, edited by T. K. Perttula and J. E. Bruseth, pp. 159-174. Studies in Archeology 30. Texas Archeological Research Laboratory, The University of Texas at Austin.

Saner, B., Jr. and S. A. Tomka

1998 Unifacial Corner-Tang Artifact Report: An Investigation of an Unusual and Rarely Reported Lithic Tool. La Tierra 25(3):24-36.

Sayre, E. V.

1975 Brookhaven Procedures for Statistical Analyses of Multivariate Archaeometric Data. Brookhaven National Laboratory Report BNL-23128. Brookhaven National Laboratory, New York.

Schambach, F. F.

1972 Preliminary Report on the 1972 Excavations at the Ferguson Site (3HE63). The Arkansas Archeologist 13(1-2):1-13.

1982 An Outline of Fourche Maline Culture in Southwest Arkansas. In Arkansas Archeology in Review, edited by N. L. Trubowitz and M. D. Jeter, pp. 132-197. Research Series No. 15. Arkansas Archeological Survey, Fayetteville.

1983 The Archeology of the Great Bend Region in Arkansas. In Contributions to the Archeology of the Great Bend Region of the Red River Valley, Southwest Arkansas, edited by F. F. Schambach and F. Rackerby, pp. 1-11. Research Series No. 22. Arkansas Archeological Survey, Fayetteville.

1995 A Probable Spiroan Entrepot in the Red River Valley in Northeast Texas. Caddoan Archeology Newsletter 6 (No. 1):9-25.

1996 Mounds, Embankments, and Ceremonialism in the Trans-Mississippi South. In Mounds, Embankments, and Ceremonialism in the Midsouth, edited by R. C. Mainfort and R. Walling, pp. 36-43. Research Series No. 46. Arkansas Archeological Survey, Fayetteville.

1997a The Development of the Burial Mound Tradition in the Caddo Area. Journal of Northeast Texas Archaeology No. 9:53-72.

1997b Continuing the Discussion of the Spiroans and their Entrepots: A Reply to Brook's Critique of my New Paradigm for the Archeology of the Arkansas Valley. Caddoan Archeology 7 (No. 4):1746.

1998 Pre-Caddoan Cultures in the Trans-Mississippi South: A Beginning Sequence. Research Series No. 53. Arkansas Archeological Survey, Fayetteville.

n.d. Spiroan Traders, the Sanders Site, and the Plains Interaction Sphere: A Reply to Bruseth, Wilson, and Perttula. MS on file with the author.

Schambach, F. F. and J. E. Miller

1984 A Description and Analysis of the Ceramics. In CedarGrove: An Interdisciplinary Investigation of a Late Caddo Farmstead in the Red River Valley, edited by N. L. Trubowitz, pp. 109-170.

Research Series No. 23. Arkansas Archeological Survey, Fayetteville. 
Schambach, F. F., N. L. Trubowitz, F. Rackerby, E. T. Hemmings, W. F. Limp, and J. E. Miller

1983 Test Excavations at the Cedar Grove site (3LA97): A Late Caddo Farmstead in the Great Bend region, Southwest Arkansas. In Contributions to the Archeology of the Great Bend Region, edited by F. F. Schambach and F. Rackerby, pp. 90-129. Research Series No. 22. Arkansas Archeological Survey, Fayetteville.

Schiffer, M. B.

1972 Archaeological Context and Systemic Context. American Antiquity 37:156-165.

1983 Toward the Identification of Formation Processes. American Antiquity 48:675-706.

1987 Formation Processes of the Archaeological Record. University of New Mexico Press, Albuquerque.

Schmidly, D. J.

1983 Texas Mammals East of the Balcones Fault Zone. Texas A\&M University Press, College Station.

Schorger, A.W.

1966 The Wild Turkey, Its History and Domestication. Oklahoma State University Press, Stillwater.

Schrire, C.

1995 Digging Through Darkness: Chronicles of an Archaeologist. University Press of Virginia, Charlottesville.

Scurlock, J. D.

1962 The Culpepper Site, A Late Fulton Aspect Site in Northeast Texas. Bulletin of the Texas Archeological Society 32:285-316.

Sellards, E. H., W. S. Adkins, and F. B. Plummer

1932 The Geology of Texas. Bulletin 3232. The University of Texas, Austin.

Semken, H. A., Jr.

1983 Holocene Mammalian Biogeography and Climate Change in the Eastern and Central United States. In Late Quaternary Environments of the United States, Vol. 2. The Holocene, edited by H. E. Wright, Jr., pp. 182-207. University of Minnesota Press, Minneapolis.

Semken, H. A., Jr. and C. R. Falk

1987 Late Pleistocene/Holocene Mammalian Faunas and Environmental Changes on the Northern Plains of the United States. In Late Quaternary Mammalian Biogeography and Environments of the Great Plains and Prairies, edited by R. W. Graham, H. A. Semken, Jr., and M. A. Graham, pp. 176-313. Scientific Papers Vol. 22. Illinois State Museum, Springfield.

Shaffer, B. S. and B. W. Baker

1992 A Vertebrate Faunal Analysis Coding System: With North American Taxonomy and dBase Support Programs and Procedures (Version 3.3). Technical Report 23. Museum of Anthropology, University of Michigan, Ann Arbor.

Shepard, A. O.

1971 Ceramics for the Archaeologist. Carnegie Institution of Washington, Washington D.C.

Shott, M. J.

1994 Size and Form in the Analysis of Flake Debris: Review and Recent Approaches. Journal of Archaeological Method and Theory 1(1):69-110. 
Sierzchula, M. C., M. J. Guccione, R. H. Lafferty III, and M. T. Oates

1995 Archeological Investigations in the Great Bend Region, Miller County, Arkansas, Levee Items 2 and 3. Report 94-5. Mid-Continental Research Associates, Inc., Springdale, Arkansas.

Simpson, B. J.

1988 A Field Guide to Texas Trees. Texas Monthly Press, Austin.

Skibo, J. M.

1992 Pottery Function: A Use-Alteration Perspective. Plenum Press, New York.

Skinner, S. A., R. K. Harris, and K. M. Anderson (editors)

1969 Archaeological Investigations at the Sam Kaufman Site, Red River County, Texas. Contributions in Anthropology No. 5. Department of Anthropology, Southern Methodist University, Dallas.

Skokan, E. and T. K. Perttula

1998 The Petrographic Analysis of ceramic Thin-Sections from the Mockingbird Site (41TT550), Titus County, Texas. In Analysis of the Titus Phase Mortuary Assemblage at the Mockingbird Site (“Kahbakayammaahin"), 41TT550, by T. K. Perttula, M. Tate, H. Neff, J. W. Cogswell, M. D. Glasscock, E. Skokan, S. Mulholland, R. Rogers, and B. Nelson, pp. 273-288. Document No. 970849. Espey, Huston \& Associates, Inc., Austin.

Slaughter, B. H., and B. R. Hoover

1963 Sulphur River Formation and the Pleistocene Mammals of the Ben Franklin Local Fauna. Journal of the Graduate Research Center 31(3):132-148. Southern Methodist University, Dallas

1965 An Antler Artifact from the Late Pleistocene of Northeastern Texas. American Antiquity 30:351352.

Smith, B. D.

1978 Prehistoric Patterns of Human Behavior: A Case Study in the Mississippi Valley. Academic Press, New York.

Smith, F. T.

1995 The Caddo Indians: Tribes at the Convergence of Empires, 1542-1854. Texas A\&M University Press, College Station.

Sodeman, W. A. and W. A. Sodeman, Jr.

1974 Pathologic Physiology: Mechanisms of Disease. W. B. Saunders, Philadelphia.

Southern Methodist University (SMU)

1987 Preliminary Research Design, Cooper Lake Project. Archaeology Research Program, Southern Methodist University, Dallas. Submitted to U.S. Army Corps of Engineers, Ft. Worth District, Contract DACW63-87-D-0017.

Stafford, C. R.

1985 The Campbell Hollow Archaic Occupations: A Study of Intrasite Spatial Structure in the Lower Illinois Valley. Research Series, Vol. 4. Center for American Archaeology, Kampsville Archaeological Center, Kampsville.

Stahle, D. W.

1996 The Hydroclimatic Application of Tree-Ring Chronologies. In Tree Rings, Environment and Humanity: Proceedings of the International Conference, Tucson, Arizona, 17-21 May 1994, edited by J. S. Dean, D. M. Meko, and T. W. Swetnam, pp. 119-126. Radiocarbon, Department of Geosciences, The University of Arizona, Tucson. 
Stahle, D. W. and M. K. Cleaveland

1988 Texas Drought History Reconstructed and Analyzed from 1698 to 1980. Journal of Climate 1:5974.

1992 Reconstruction and Analysis of Spring Rainfall over the Southeastern U.S. for the Past 1000 Years. Bulletin of the American Meteorological Society 73:1947-1961.

1993 Southern Oscillation Extremes Reconstructed from Tree Rings of the Sierra Madre Occidental and southern Great Plains. Journal of Climate 6:129-140.

1994 Tree-Ring Reconstructed Rainfall over the Southeastern U.S.A. during the Medieval Warm period and Little Ice Age. Climatic Change 26:194-212.

1995 Texas Paleoclimatic Data from Daily to Millenial Time Scales. In The Changing Climate of Texas: Predictability and Implications for the Future, edited by J. Norwine, J. R. Giardino, G. R. North, and J. B. Valdes, pp. 49-69. GeoBooks, College of Geosciences and Maritime Studies, Texas A\&M University, College Station.

Stahle, D. W., M. K. Cleaveland, and J. G. Hehr

1985 A 450-Year Drought Reconstruction for Arkansas, United States. Nature 316:530-532.

Starrett, W. C.

1971 A Survey of the Mussels (Unionacea) of the Illinois River: A Polluted Stream. Natural History Survey Division, Volume 30, No. 5. State of Illinois Department of Registration and Education, Urbana.

Steele, D. G.

1987 Utilization of Marine Mollusks by Inhabitants of the Texas Coast. Bulletin of the Texas Archeological Society 58:215-248.

Steely, S.

1986 Six Months from Tennessee. Hennington Publishing Company, Wolfe City, Texas.

Stein, C. B.

1968 Studies in the Life History of the Naiad, Amblema plicata (Say, 1817). Annual Reports of the American Malacological Union 35:46-47.

Steinbock, R. T.

1976 Paleopathological Diagnosis and Interpretation: Bone Diseases in Ancient Human Populations. C. C. Thomas, Springfield, Illinois.

Stephenson, R. L.

1950 Archeological Survey of Texarkana Reservoir, Bowie and Cass Counties, Texas. River Basin Surveys, Austin Office. Smithsonian Institution, Washington, D.C.

Steponaitis, V., M. J. Blackman, and H. Neff

1996 Large-scale Compositional Patterns in the Chemical Composition of Mississippian Pottery. American Antiquity 61(3):555-572.

Stern, E. M. and D. L. Felder

1978 Identification of Fish Hosts for Four Species of Freshwater Mussels (Bivalvia: Unionidae). American Midland Naturalist 100:233-236. 
Stewart, $\mathrm{H}$.

1977 Indian Fishing: Early Methods on the Northwest Coast. University of Washington Press, Seattle.

Stewart, J. H.

1993 The Johnny Ford Site (3LA5): An Early Fourche Maline Site in Southwest Arkansas. M.A. thesis, Department of Anthropology, The University of Arkansas, Fayetteville.

Stewart, T. D.

1979 Essentials of Forensic Anthropology. C. C. Thomas, Springfield, Illinois.

Steyermark, J. A.

1963 Flora of Missouri. Iowa State University Press, Ames.

Stone, G. W. (editor)

1937 Geologic Map of Texas. Department of the Interior, U.S. Geological Survey, Washington, D.C.

Story, D. A.

1981 An Overview of the Archaeology of East Texas. Plains Anthropologist 26(92);139-156.

1985 Adaptive Strategies of Archaic Cultures of the West Gulf Coastal Plain. In Prehistoric Food Production in North America, edited by R. I. Ford, pp. 19-56. Anthropological Papers No. 75. Museum of Anthropology, University of Michigan, Ann Arbor.

1988 Caddoan Archaeology. Paper presented at the 30th Caddo Conference, Dallas.

1990 Cultural History of the Native Americans. In The Archeology and Bioarcheology of the Gulf Coastal Plain, by D. A. Story, J. A. Guy, B. A. Burnett, M. D. Freeman, J. C. Rose, D. G. Steele, B. W. Olive, and K. J. Reinhard, pp. 163-366. 2 Vols. Research Series No. 38. Arkansas Archeological Survey, Fayetteville.

1997 1968-1970 Archeological Investigations at the George C. Davis Site, Cherokee County, Texas. Bulletin of the Texas Archeological Society 68:1-113.

1998 The George C. Davis Site: Glimpses into Early Caddoan Symbolism and Ideology. In The Native History of the Caddo: Their Place in Southeastern Archeology and Ethnohistory, edited by T. K. Perttula and J. E. Bruseth, pp. 9-43. Studies in Archeology 30. Texas Archeological Research Laboratory, The University of Texas at Austin.

Story, D. A. (editor)

1981 Archeological Investigations at the George C. Davis Site, Cherokee County, Texas: Summers of 1979 and 1980. Occasional Papers No. 1. Texas Archeological Research Laboratory, The University of Texas at Austin.

1982 The Deshazo Site, Nacogdoches County, Texas: Vol. 1. Texas Antiquities Permit Series No. 7. Texas Antiquities Committee, Austin.

1995 The Deshazo Site, Nacogdoches County, Texas, Volume 2: Artifacts of Native Manufacture. Studies in Archeology 21. Texas Archeological Research Laboratory, The University of Texas at Austin.

Strecker, J.

1931 The Distribution of Naiades or Pearly Fresh-water Mussels of Texas. Bulletin 2. Baylor University Museum, Waco. 
Strickland, R. W.

1937 Anglo-American Activities in Northeastern Texas, 1803-1845. Unpublished Ph.D. dissertation, Department of History, The University of Texas at Austin.

Stuiver, M. and P. J. Reimer

1993 Extended ${ }^{14} \mathrm{C}$ Data Base and Revised CALIB 3.0 ${ }^{14} \mathrm{C}$ Age Calibration Program. Radiocarbon 35(1):215-230.

Suhm, D. A., and E. B. Jelks

1962 Handbook of Texas Archeology: Type Descriptions. Texas Archeological Society Special Publication 1 and Texas Memorial Museum Bulletin 4, The University of Texas at Austin.

Surber, $\mathrm{T}$.

1913 Notes on the Natural Hosts of Fresh-water Mussels. Bulletin of the U.S. Bureau of Fisheries (Document 778) 32:110-116.

Swanton, J. R.

1911 Indian Tribes of the Lower Mississippi Valley and Adjacent Coast of the Gulf of Mexico. Bulletin 43. Bureau of American Ethnology, Smithsonian Institution, Washington, D.C.

1939 Final Report of the United States De Soto Expedition Commission. House Report No. 71. Submitted to the 76th Congress, 1st Session, Washington, D.C.

1942 Source Material on the History and Ethnology of the Caddo Indians. Bulletin 132. Bureau of American Ethnology, Smithsonian Institution, Washington, D.C.

1979 The Indians of the Southeastern United States. Smithsonian Institution Press, Washington, D.C.

Swenson, F. E.

1989 Preliminary Studies in the Use of Petrographic and Proton Induced X-Ray Emission Analysis (PIXE). In Contributions to Spiro Archeology: Mound Excavations and Regional Perspectives, edited by J. D. Rogers, D. G. Wyckoff, and D. A. Peterson, pp. 177-186. Studies in Oklahoma's Past No. 16. Oklahoma Archeological Survey, Norman.

Swingle, H. A. and D. G. Bland

1974 Distribution of the Estuarine Clam Rangiacuneata Gray in Coastal Waters of Alabama. Alabama Marine Resource Bulletin 10:9-16.

Switek, E. S.

1997 Results of the Petrographic Analysis of Ceramics from Sites 41TT572, 41TT577, 41TT591, 41TT593, and 41TT653, Titus County, Texas. In National Register Testing of Seven Sites in the Monticello B-2 Surface Mine, Titus County, Texas, by V. Galan, R. Rogers, T. K. Perttula, and E. S. Switek, pp. C-1 to C-12. Document No. 971085. Espey, Huston \& Associates, Inc., Austin.

1998a Results of the Petrographic Analysis of Ceramics from Site 41RK342, Rusk County, Texas. In National Register Testing of Five Cultural Resources Sites in the Oak Hill D-III Permit Area, Rusk County, Texas, by D. L. Sherman, M. A. Nash, T. K. Perttula, G. S. Greene, E. A. S. Switek, and R. M. Rogers, pp. E-1 to E-11. Document No. 971091. Espey, Huston \& Associates, Inc., Austin.

$1998 \mathrm{~b}$ Results of the Petrographic Analysis of Ceramics from 41RK214, Rusk County, Texas. MS on file, PBS \& J, Inc., Austin. 
Talalay, L., D. R. Keller, and P. J. Munson

1984 Hickory Nuts, Walnuts, Butternuts, and Hazelnuts: Observations and Experiments relevant to their Aboriginal Exploitation in Eastern North America. In Experiments and Observations on Aboriginal Wild Plant Food Utilization in Eastern North America, edited by P. J. Munson, pp. 338-359. Prehistory Research Series VI(2). Indiana Historical Society, Indianapolis.

Teltser, P. A.

1993 An Analytic Strategy for Studying Assemblage-Scale Ceramic Variation: A Case Study from Southeast Missouri. American Antiquity 58(3):530-543.

Thoms, A. V.

1993 The Brazos Valley Slopes Archaeological Project: Cultural Resources Assessments for the Texas A\&M University Animal Science Teaching and Research Complex, Brazos County, Texas. Reports of Investigations No. 14. Archaeological Research Laboratory, Texas A\&M University, College Station.

Thurmond, J. P.

1985 Late Caddoan Social Group Identifications and Sociopolitical Organization in the Upper Cypress Basin and Vicinity, Northeastern Texas. Bulletin of the Texas Archeological Society 54:185-200.

1988 Caddoan Archaeology -- Its Present Status and Future Directions: A Perspective from Northeast Texas. Paper presented at the 30th Caddo Conference, Dallas.

1990 Archeology of the Cypress Creek Drainage Basin, Northeastern Texas and Northwestern Louisiana. Studies in Archeology 5. Texas Archeological Research Laboratory, The University of Texas at Austin.

Trotter, M. and R. R. Peterson

1955 Ash Weight of Human Skeletons in Percent of Dry, Fat-Free Weight. Anatomical Record 123:341-368.

Trubowitz, N. L. (editor)

1984 Cedar Grove: An Interdisciplinary Investigation of a Late Caddo Farmstead in the Red River Valley. Research Series No. 23. Arkansas Archeological Survey, Fayetteville.

Tucker, G. C.

1994 Archeological Investigations at Site 41BW422. Cultural Resource Management News \& Views 6(1):6. Texas Historical Commission, Austin.

Tull, D.

1987 A Practical Guide to Edible and Useful Plants. Texas Monthly Press, Austin.

Turner, E. S. and T. R. Hester

1993 A Field Guide to Stone Artifacts of Texas Indians. 2nd Edition. Gulf Publishing Company, Houston.

Turner, R. L.

1978 The Tuck Carpenter Site and Its Relation to Other Sites within the Titus Focus. Bulletin of the Texas Archeological Society 49:1-110.

1992 Prehistoric Mortuary Remains at the Tuck Carpenter Site, Camp County, Texas. Studies in Archeology 10. Texas Archeological Research Laboratory, The University of Texas at Austin. 
1997 Observations on Four Probable Middle Caddo Cemeteries in Camp and Upshur Counties. Journal of Northeast Texas Archaeology No. 10:12-35.

Ubelaker, D. H.

1978 Reconstruction of Demographic Profiles from Ossuary Skeletal Samples: A Case Study from the Tide Water Potomac. Contributions to Anthropology No. 18. Smithsonian Institution, Washington, D.C.

U.S. Department of Agriculture

1975 Soil Taxonomy: A Basic System of Soil Classification for Making and Interpreting Soil Surveys. Agriculture Handbook No. 436. Soil Conservation Service, U.S. Department of Agriculture, Washington D.C.

Van der Merwe, $N$.

1982 Carbon Isotopes, Photosynthesis, and Archeology. American Scientist 70:596-606.

Villa, P.

1982 Conjoinable Pieces and Site Formation Processes. American Antiquity 47:276-290.

Vines, R. A.

1960 Trees, Shrubs, and Woody Vines of the Southwest. University of Texas Press, Austin.

1982 Trees of North Texas. University of Texas Press, Austin.

Vogel, V. J.

1970 American Indian Medicine. University of Oklahoma Press, Norman.

Wagner, G. E.

1986 The Corn and Cultivated Beans of the Fort Ancient Indians. The Missouri Archaeologist 47:107136.

Walters, M., P. Haskins, D. H. Jurney, S. E. Goldborer, and T. K. Perttula

1998 Archaeological Investigations at the Redwine Site (41SM193), Smith County, Texas. Journal of Northeast Texas Archaeology 11:1-38.

Walthall, J. A.

1981 Galena and Aboriginal Trade in Eastern North America. Scientific Paper No. 17. Illinois State Museum, Springfield.

Wandsnider, L.

1996 Describing and Comparing Archaeological Spatial Structures. Journal of Archaeological Method and Theory 3(4):319-384.

Waugh, F. W.

1916 Iroquois Foods and Food Preparation. Memoirs 86, Anthropological Series 12. Canadian Department of Mines, Ottawa.

Webb, C. H.

1959 The Belcher Mound, A Stratified Caddoan Site in Caddo Parish, Louisiana. Memoirs No. 16. Society for American Archaeology, Salt Lake City.

1982 The Poverty Point Culture. 2nd edition. Geoscience and Man 27. Louisiana State University Press, Baton Rouge. 
1983 The Bossier Focus Revisited: Montgomery I, Werner, and Other Unicomponent Sites. In Southeastern Natives and Their Pasts: A Collection of Papers Honoring Dr. Robert E. Bell, edited by D. G. Wyckoff and J. L. Hofman, pp. 183-240. Studies in Oklahoma's Past No. 11. Oklahoma Archeological Survey, Norman.

1984 The Bellevue Focus: A Marksville-Troyville Manifestation in Northwestern Louisiana. Louisiana Archaeology 9:251-274.

Webb, C. H., J. L. Shiner, and E. W. Roberts

1971 The John Pearce Site (16CD56): A San Patrice Site in Caddo Parish, Louisiana. Bulletin of the Texas Archeological Society 42:1-49.

Weber, J. C.

1973 The Hays Mound, 3CL6, Clark County, South Central Arkansas. Final report submitted to the Southeast Region, National Park Service by the Arkansas Archeological Survey, Fayetteville.

Wedel, M. M.

1978 LaHarpe's 1719 Post on the Red River and Nearby Caddo Settlements. Bulletin No. 30. Texas Memorial Museum, Austin.

Wedel, W. R.

1959 An Introduction to Kansas Archeology. Bureau of American Ethnology Bulletin 174. Smithsonian Institution, Washington, D.C.

Weigand, P. C., G. Harbottle, and E. V. Sayre

1977 Turquoise Sources and Source Analysis: Mesoamerica and the Southwestern U.S.A. In Exchange Systems in Prehistory, edited by T. K. Earle and J. E. Ericson, pp. 15-34. Academic Press, New York.

Wellhausen, E. J., L. M. Roberts, and E. Hernandez X. in collaboration with P. C. Mangelsdorf

1952 Races of Maize in Mexico. Bussey Institution, Harvard University, Cambridge.

Wetterstrom, W. E.

1978 Plant Remains from Mesilla and El Paso Phase Sites of the Hueco Bolson: A Preliminary Report on Plant Foods. In Settlement Patterns of the Western Hueco Bolson, by M. E. Whalen, pp. 230240. Publications in Anthropology No. 6. El Paso Centennial Museum, The University of Texas at El Paso.

Whallon, $\mathbf{R}$.

1984 Unconstrained Clustering for the Analysis of Spatial Distributions in Archaeology. In Intrasite Spatial Analysis in Archaeology, edited by H. J. Hietala, pp. 142-177. Cambridge University Press, Cambridge.

White, T. E.

1953 A Method of Calculating the Dietary Percentage of Various Food Animals Utilized by Aboriginal Peoples. American Antiquity 18:396-398.

White, W. D., Jr., S. M. Hunt, and M. B. Cliff

1995 Cultural Resources Survey of 1,290 Acres at Wright Patman Lake, Bowie and Cass Counties, Texas. Miscellaneous Report of Investigations No. 99. Geo-Marine, Inc., Plano.

Williams-Dean, G.

1978 Ethnobotany and Cultural Ecology of Prehistoric Man in Southwest Texas. Unpublished Ph.D. dissertation, Department of Botany, Texas A\&M University, College Station. 
Wilson, A. M., and A. T. Jackson

1930 Field Notes: Work Done at Indian Sites, Wood Co., Texas. Department of Anthropology Field Notebooks, Book 1. MS on file, Texas Archeological Research Laboratory, The University of Texas at Austin.

Wilson, D.

1995 Dental Paleopathologies in the Sanders Site (41LR2) Population from Lamar County, Texas. Journal of Northeast Texas Archaeology 5:29-59.

1997 Dental Paleopathology in the Sanders (41LR2) and Mitchell (41BW4) Populations from the Red River Valley, Northeast Texas. Bulletin of the Texas Archeological Society 68:147-159.

Wilson, D. and D. Cargill

1993 Stable Isotope Analysis from the Sanders Site (41LR2). Caddoan Archeology Newsletter IV (No. 3):3.

Wilson, D. and D. G. Steele

1997 Analysis of Human Remains from Cooper Lake. In Synthesis of the Prehistoric and Historic Archeology of Cooper Lake, Delta and Hopkins Counties, Texas, by R. C. Fields, M. E. Blake, and K. W. Kibler, pp. 177-244. Reports of Investigations No. 104. Prewitt and Associates, Inc., Austin.

Winchell, F., J. C. Rose, and R. W. Moir

1992 Bioanthropological Investigation of Nineteenth Century Burials at Site 41DT105: Cultural Resource Studies for Cooper Lake, Delta County, Texas. Archaeology Research Program, Southern Methodist University, Dallas.

1995 Health and Hard Times: A Case Study from the Middle to Late Nineteenth Century in Eastern Texas. In Bodies of Evidence: Reconstructing History through Skeletal Analysis, edited by A. L. Grauer, pp. 161-172. Wiley-Liss, New York.

Wyckoff, D. G.

1984 The Foragers: Eastern Oklahoma. In Prehistory of Oklahoma, edited by R. E. Bell, pp. 119-160. Academic Press, New York.

Yanovsky, E.

1936 Food Plants of North American Indians. Miscellaneous Publication No. 237. U.S. Department of Agriculture, Washington, D.C.

Yarnell, R. A.

1964 Aboriginal Relationships Between Culture and Plant Life in the Upper Great Lakes Region. Anthropological Papers No. 23. Museum of Anthropology, University of Michigan, Ann Arbor.

Yates, B. C.

1993 Zooarcheology of Four Woodland/Caddoan Sites at Cooper Lake. In Excavations at the Tick, Spike, Johns Creek, and Peerless Bottoms Sites, Cooper Lake Project, Delta \& Hopkins Counties, Texas, by R. C. Fields, E. F. Gadus, L. W. Klement, C. B. Bousman, and J. B. McLerran, pp. 307-334. Reports of Investigations No. 91. Prewitt and Associates, Inc., Austin. 
1997 Vertebrate Faunal Remains. In Archaeological Investigations at Cooper Lake, Delivery Order Numbers 2, 3, \& 4, 1987: Cultural Resource Studies for Cooper Lake, Hopkins and Delta Counties, Texas, by D. E. McGregor, M. M. Green, D. H. Jurney, W. A. Martin, R. W. Moir, and J. W. Saunders, pp. 643-683. Archaeology Research Program, Department of Anthropology, Southern Methodist University, Dallas.

Ziegler, A. C.

1973 Inferences from Prehistoric Faunal Remains. Addison-Wesley Module in Anthropology No. 43. Addison-Wesley Publishing Co., Inc., Reading, Massachusetts.

Zimmerman, M. R. and M. A. Kelley

1982 Atlas of Human Paleopathology. Praeger, New York. 